\title{
Estudios ambientales
}

\section{Tercera edición}

César NAVA ESCUDERO

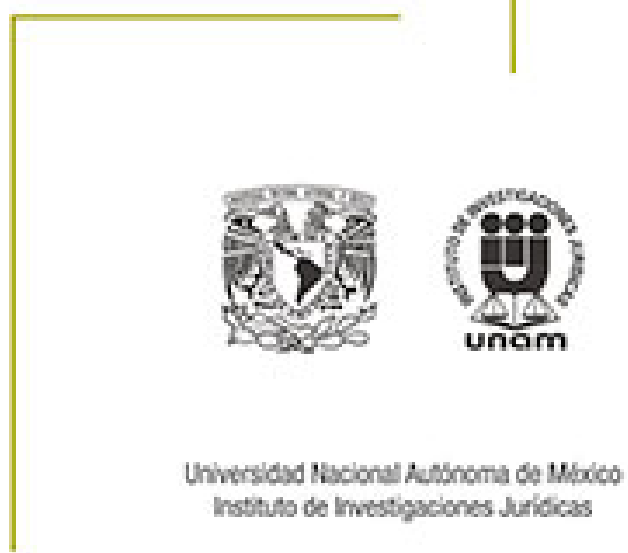


ESTUDIOS AMBIENTALES 


\title{
INSTITUTO DE INVESTIGACIONES JURÍDICAS
}

Serie Doctrina Jurídica, núm. 602

\section{COORDINACIÓN EDITORIAL}

\author{
Lic. Raúl Márquez Romero \\ Secretario Técnico
}

Lic. Wendy Vanesa Rocha Cacho

Jefa del Departamento de Publicaciones

Isidro Saucedo

Ricardo Hernández Montes de Oca

Cuidado de la edición

Isidro Saucedo

Formación en computadora

Ricardo Hernández Montes de Oca

Apoyo editorial

Mauricio Ortega Garduño

Elaboración de portada 


\section{CÉSAR NAVA ESCUDERO}

\section{ESTUDIOS \\ AMBIENTALES}

Tercera edición
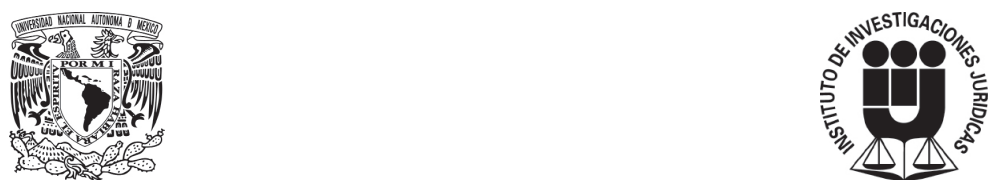

UNIVERSIDAD NACIONAL AUTÓNOMA DE MÉXICO INSTITUTO DE INVESTIGACIONES JURÍDICAS

MÉXICO, 2018 
Primera edición: 15 de junio de 2009

Segunda edición: 10 de agosto de 2011

Tercera edición: 11 de junio de 2018

DR (C 2018, Universidad Nacional Autónoma de México

\section{INSTITUTO DE INVESTIGACIONES JURÍDICAS}

Circuito Maestro Mario de la Cueva s/n Ciudad de la Investigación en Humanidades Ciudad Universitaria, 04510 Ciudad de México

Impreso y hecho en México

ISBN electrónico: 978-607-30-0622-4 
A mi madre, Eva Escudero Morales A mi padre, Alfonso Nava Negrete ${ }^{\dagger}$ Gracias por tantos años de cariño y apoyo

A mis hermanos, Alfonso y Oscar, quienes siguen creyendo - al igual que yoque es posible transformar a los seres humanos para construir un mundo mejor 
A todos aquellos que son incapaces de trabajar según la naturaleza, los veo como espíritus enfermizos, en los que me niego a creer...

Joan Miró

Montroig, agosto de 1918

Cómo voy a creer / dijo el fulano que el mundo se quedó sin utopías

Mario BenedetTI

El amor, las mujeres y la vida 
CONTENIDO

Nota del autor a la primera edición. . . . . . . . . XXIII

Nota del autor a la segunda edición $\ldots \ldots \ldots$ XXV

Nota del autor a la tercera edición . . . . . . . . . . XXVII

Prólogo a la primera edición . . . . . . . . . . . XXIX Héctor FIX-FIERRO

PRIMERA PARTE

\section{ESTUDIOS AMBIENTALES EN MATERIA CONSTITUCIONAL}

La primera reforma constitucional ambiental del nuevo milenio: el acceso de los pueblos indios a los recursos naturales. . . . 3

I. Introducción . . . . . . . . . . . . . . . . . 3

II. Constitución y medio ambiente . . . . . . . . . . 4

III. Antecedentes de la reforma constitucional de $2001 \ldots$. . 10

IV. Recursos naturales y pueblos indios . . . . . . . . . . . . 17

V. Conclusiones . . . . . . . . . . . . . . 20 
De los derechos indígenas ambientales o del porqué existen preceptos constitucionales virtuales . . . . . . . . . .

I. Introducción ． . . . . . . . . . . . . . . . . . 23

II. Derechos indígenas y ambiente: el punto de encuentro . 24

III. El acceso al uso y disfrute preferente de los recursos naturales. . . . . . . . . . . . . . 37

IV. Reflexión final . . . . . . . . . . . . . . 44

El turismo sustentable en la Constitución . . . . . . . . . . 45

I. Sobre lo sustentable . . . . . . . . . . . . . . . 45

II. Sobre el turismo . . . . . . . . . . . . . . . . . . 54

III. Sobre el turismo sustentable . . . . . . . . . . . . . . 63

IV. Reflexión final . . . . . . . . . . . . . . . . . . 74

El artículo 27 en materia de aguas . . . . . . . . . . 75

I. Delimitación conceptual . . . . . . . . . . . . . . 75

II. Régimen constitucional: del texto original al texto vigente 79

III. Régimen legal . . . . . . . . . . . . . . . . . 86

IV. Aguas continentales . . . . . . . . . . . . . . . 91

V. Aguas marinas . . . . . . . . . . . . . . . . 102

La cláusula de interpretación conforme en el caso del derecho a un ambiente sano en México . . . . . . . . . . . . . . 113

I. La cláusula de interpretación conforme . . . . . . . . 113

II. Las normas internas relativas al derecho a un ambiente sano: la Constitución y las leyes . . . . . . . . . . .

III. Las normas externas relativas al derecho a un ambiente sano: los tratados internacionales. . . . . . . . . . . 
Evolución constitucional ambiental. Análisis abreviado . . . . .

I. Introducción ． . . . . . . . . . . . . . . . . 133

II. Antecedentes: conservación de los recursos naturales . . 134

III. El comienzo: contaminación ambiental y salubridad . . 136

IV. El ambiente y su protección desde una óptica integral. . 139

V. El derecho al ambiente y el desarrollo sustentable. . . . 145

VI. Conclusión: ¿más derechos, más sustentabilidad? . . . . 151

SEGUNDA PARTE

\section{ESTUDIOS AMBIENTALES EN MATERIA INTERNACIONAL}

El principio de precaución en el derecho internacional ambiental

I. Introducción ～. . . . . . . . . . . . . . 157

II. Orígenes y terminología . . . . . . . . . . . . . . . . . . . 158

III. Significado . . . . . . . . . . . . . . . . . . . . 162

IV. Conclusiones . . . . . . . . . . . . . . . . 166

La seguridad de la biotecnología: la normatividad internacional vis-à-vis la regulación nacional mexicana. . . . . . . . . 167

I. Introducción ． . . . . . . . . . . . . . . . 167

II. Antes y durante Río de Janeiro . . . . . . . . . . . . . 169

III. De Río de Janeiro a Cartagena de Indias y Kuala Lumpur 176

IV. El caso mexicano: dispersión y parsimonia reguladora . 183

V. Conclusiones . . . . . . . . . . . . . . . . . . . . 197 
Guía mínima para la enseñanza del derecho internacional ambiental en México . . . . . . . . . . . . . . . . . . . . 201

I. Introducción ． . . . . . . . . . . . . . . . . . 201

II. Orígenes: ¿qué es y cuándo nace? . . . . . . . . . . . . 202

III. Instrumentos internacionales soft y hard law . . . . . 207

IV. Principios fundamentales del derecho internacional ambiental. . . . . . . . . . . . . . 211

V. El caso mexicano. Tratados ambientales y acuerdos interinstitucionales ambientales . . . . . . . . . . . . . 214

VI. Conclusiones . . . . . . . . . . . . . . . . . 222

Los acuerdos interinstitucionales ambientales . . . . . . . 227

I. Introducción ． . . . . . . . . . . . . . . 227

II. Reflexión primera: fundamento jurídico . . . . . . . . . 228

III. Reflexión segunda: características . . . . . . . . . . 230

IV. Reflexión tercera: naturaleza jurídica . . . . . . . . . 233

V. Reflexión cuarta: aspectos sobre su constitucionalidad . 236

VI. Conclusión . . . . . . . . . . . . . . . . . . . . 239

Turismo internacional de playa y cambio climático en México 241

I. Introducción . . . . . . . . . . . . . . . . . . . 241

II. Turismo internacional y destinos de playa . . . . . . . . 242

III. Cambio climático: ¿alguien duda todavía de su existencia? . . . . . . . . . . . . . 255

IV. Un maridaje de tres: turismo, playas y cambio climático 261

V. Reflexiones finales . . . . . . . . . . . . . . . 269 
México ante la COP-16. Entre la simulación climática y la incertidumbre jurídica. . . . . . . . . . . . . . .

I. Preliminar: el calentamiento del sistema climático en nuestro planeta es inequívoco . . . . . . . . . . . . . . . 273

II. Kyoto, Copenhague y Cancún: ¿común denominador de la decepción? . . . . . . . . . . . . . .

III. La simulación climática: "candil de la calle y oscuridad de su casa" . . . . . . . . . . . . . . . . 281

IV. La incertidumbre jurídica: ¿qué ley tendremos? . . . . . 293

V. Epílogo . . . . . . . . . . . . . 300

El Acuerdo de París. Predominio del soft law en el régimen climático . . . . . . . . . . . . . . . 303

I. Introducción ． . . . . . . . . . . . . . . 303

II. Sobre los tratados y la naturaleza de sus normas. . . . . 304

III. El soft law en el derecho internacional ambiental . . . . 314

IV. El Acuerdo de París: reincidencia del soft law en el régimen climático. . . . . . . . . . . . . 322

V. Reflexión final . . . . . . . . . . . . . . . . 334

TERCERA PARTE

\section{ESTUDIOS AMBIENTALES EN MATERIA ATMOSFÉRICA}

Debate ambiental y contaminación atmosférica urbana: los casos de Londres y la Ciudad de México . . . . . . . . . . 339

I. Introducción . . . . . . . . . . . . . . . . . . 339

II. El debate ambiental: la distinción norte-sur . . . . . . . 341

III. Centros urbanos y contaminación del aire: la magnitud del problema . . . . . . . . . . . . . 
IV. Londres. . . . . . . . . . . . . . . . . . 355

V. Ciudad de México . . . . . . . . . . . . . . . . . 368

VI. Conclusión . . . . . . . . . . . . . . . . . . . 386

Hacia un derecho atmosférico ambiental . . . . . . . . 389

I. Introducción ． . . . . . . . . . . . . . . . . 389

II. Derecho atmosférico . . . . . . . . . . . . . . . . 390

III. Derecho atmosférico como norma . . . . . . . . . . . 396

IV. Derecho atmosférico como ciencia. . . . . . . . . . . 401

V. Conclusión: ¿derecho atmosférico ambiental? . . . . . 406

De homo sapiens a homo automobilis: revisitando la gestión de la calidad del aire en la Ciudad de México . . . . . . . . . . .

I. Introducción . . . . . . . . . . . . . . . . . 409

II. La Ciudad de México en 2000: la segunda mega-ciudad en el mundo. . . . . . . . . . . . . . . . . . . .

III. La gestión de la calidad del aire en la Ciudad de México revisitada . . . . . . . . . . . . . . 417

IV. Hacia una mega-ciudad de automóviles . . . . . . . . 426

V. Conclusión . . . . . . . . . . . . . . . . . . 437

Exclusión ambiental en la Zona Metropolitana del Valle de México. Visiones antropocéntricas para mejorar la calidad del aire

I. Introducción ． . . . . . . . . . . . . . . . . . 441

II. Ambiente y exclusión . . . . . . . . . . . . . . . . . 442

III. La ética antropocéntrica . . . . . . . . . . . . . . . . . . . . . . . . 448

IV. La calidad del aire en la ZMVM . . . . . . . . . . . . 453

V. Régimen atmosférico de protección ambiental: ¿y dónde quedó el medio natural? . . . . . . . . . . . . . 466

VI. Reflexión final . . . . . . . . . . . . . . . . . . . 472 
El Hoy No Circula . . . . . . . . . . . . . . . . . 475

I. Primer engomado. . . . . . . . . . . . . . . . 475

II. Segundo engomado. . . . . . . . . . . . . . . . 477

III. Tercer engomado . . . . . . . . . . . . . . . . . . . . . . . . . . . . . . . . . . . . .

IV. Cuarto engomado. . . . . . . . . . . . . . . . . . . . . 483

V. Quinto engomado. . . . . . . . . . . . . 485

CUARTA PARTE

\section{ESTUDIOS AMBIENTALES DIVERSOS}

Indicadores y retos para el desarrollo urbano sustentable . . . .

I. Introducción . . . . . . . . . . . . . . . .

II. Indicadores o criterios para un desarrollo urbano sustentable. . . . . . . . . . . . . . 492

III. El escenario: los retos y dilemas . . . . . . . . . . . . . . . . . . . 493

IV. Las tendencias: el hoy y el mañana. . . . . . . . . . . . 494

Visita a Laguna Verde . . . . . . . . . . . . . . . . . . 497

La regulación jurídica de la desalación de agua en México: lo bueno, lo malo y lo más malo del periodo 2001-2006 . . . .

I. Introducción ． . . . . . . . . . . . . . . . . 501

II. La idea de la desalación . . . . . . . . . . . . . . . 502

III. Agua y desalación en México . . . . . . . . . . . . 507

IV. Lo bueno, lo malo y lo más malo de la regulación jurídica en el periodo 2001-2006. . . . . . . . . . . . . . 513

V. Reflexiones finales . . . . . . . . . . . . . 518 
Agua y desalación en México: del engaño al oscurantismo jurídico . . . . . . . . . . . . . . .

I. Introducción ． . . . . . . . . . . . . . . . . . 521

II. El agua: ¿asunto de seguridad nacional? . . . . . . . . . 523

III. El camino que se recorrió para que el agua se convirtiera en un asunto de seguridad nacional . . . . . . . . . .

IV. La desalación: ¿medida urgente de seguridad nacional? .

V. El camino que se recorrió para que la desalación no se convirtiera en una medida urgente de seguridad nacional

VI. Reflexión final: del engaño al oscurantismo jurídico. . .

Tres frases para la construcción de argumentos legales en la aplicación de la legislación ambiental. . . . . . . . . . . .

I. Sobre uno de los consejos de Don Quijote. . . . . . . . 541

II. Sobre Einstein, Dios y una vieja paradoja . . . . . . . . 545

III. Sobre la verdad incómoda de Carlos Fuentes . . . . . . 550

IV. Conclusión . . . . . . . . . . . . . . . . 555

Institucionalizar la capacitación jurídico-ambiental en México

I. Introducción ～. . . . . . . . . . . . . 557

II. Capacitación jurídico-ambiental: significado y alcances. $\quad 558$

III. El derecho ambiental en México . . . . . . . . . . . . . 561

IV. Tipología del derecho ambiental normativo . . . . . . . 564

V. Capacitado y capacitador, ¿por dónde empezar? . . . . . 581

VI. Cuatro breves conclusiones. . . . . . . . . . . . . 587 
QUINTA PARTE

\section{ESTUDIOS AMBIENTALES EN HOMENAJES Y CONMEMORACIONES}

La privatización de las zonas costeras en México . . . . . . . .

I. Nota introductoria: ¿se privatizan nuestras zonas costeras?

II. Nota conceptual primera: delimitación y terminología . 593

III. Nota conceptual segunda: conceptos jurídicos costeros .

IV. Nota breve que describe la situación actual: importancia, legislación y administración pública . . . . . . . . .

V. Nota que identifica dos procesos privatizadores: concesiones y desincorporaciones . . . . . . . . . . . . .

VI. Nota que concluye y se pregunta: legislar y privatizar, ¿es esa la cuestión? . . . . . . . . . . . . . . .

VII. Nota que es adicional a la nota que concluye . . . . . .

Palabras de reconocimiento al doctor Héctor Fix-Zamudio por sus cincuenta años de labor científica (1956-2006) . . . . . .

El Quijote y Sancho Panza en la legislación ambiental mexi-

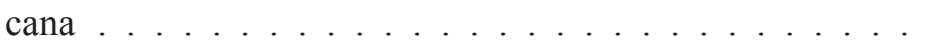

I. Preliminar: un maestro y dos personajes ficticios . . . .

II. El consejo del Quijote, la respuesta de Sancho Panza, y lo que debemos saber sobre las pragmáticas . . . . . . .

III. El legado cervantino en la legislación ambiental mexicana

IV. Epílogo: dice un refrán anónimo que "de necios es huir del consejo". . . . . . . . . . . . . . .

Diálogos en cronología. A 75 años de la fundación del Instituto de Investigaciones Jurídicas . . . . . . . . . . . . . . . . 
Historias anti-ambientales de un pasado reciente. El sexenio 20062012 que se fue . . . . . . . . . . . . . . . 679

I. Introducción . . . . . . . . . . . . . . . . . . . 679

II. Historias anti-ambientales . . . . . . . . . . . . . 680

III. Guerra y ambiente: incongruencia presidencial . . . . . 689

IV. Si se es aficionado a los toros, no se puede ser ambientalista . . . . . . . . . . . . . . 696

V. Reflexión final . . . . . . . . . . . . . . . . 704

\section{SEXTA PARTE}

\section{VOCES EN DICCIONARIOS}

Cambio climático (marco jurídico internacional) . . . . . . . 709

Conflictos socio-ambientales . . . . . . . . . . . . 713

Derecho al medio ambiente . . . . . . . . . . . 717

Derecho atmosférico . . . . . . . . . . . . . 721

Derechos de los animales. . . . . . . . . . . . . . 727

Derecho del cambio climático . . . . . . . . . . . . . 733

Derecho internacional ambiental . . . . . . . . . . . . 737 
SÉPTIMA PARTE

\section{BIBLIOGRAFÍA Y APÉNDICE}

Bibliografía . . . . . . . . . . . . . 743

I. Libros y revistas . . . . . . . . . . . . . . . . . . . 743

II. Fuentes electrónicas . . . . . . . . . . . . . . . . . 768

III. Otras fuentes . . . . . . . . . . . . . . . . . . . . . 777

Apéndice ......................... 793

I. Tratados y otros instrumentos internacionales . . . . . . . 793

II. Legislación nacional . . . . . . . . . . . . . . . . 798 
Esta obra forma parte del acervo de la Biblioteca Jurídica Virtual del Instituto de Investigaciones Jurídicas de la UNAM

\section{NOTA DEL AUTOR A LA PRIMERA EDICIÓN}

Me parece sumamente delicado que en los albores del siglo XXI haya todavía quien se atreva a negar la existencia de una crisis ambiental planetaria y a sostener, por consiguiente, que el derecho ambiental no es tan importante como otras disciplinas jurídicas tradicionales. Quienes anquilosan su pensamiento con semejantes ideas ignoran el hecho de que con o sin su aval intelectual de cualquier manera nos enfrentamos a un fenómeno sin precedentes en la historia de la humanidad. Pero convencer a los cornucopianos (abogados o no) de que sus idílicas crónicas sobre un crecimiento ilimitado son obsoletas, y de que su soberbia y superioridad sobre el mundo natural deben terminar, no es sencillo. Tampoco es fácil persuadir a estudiantes y estudiosos del derecho de que el dilema de la crisis ambiental no es falso, y que por lo tanto, el desarrollo de la ciencia y la norma iusambientalista son indispensables para inducir el comportamiento humano hacia una cultura de respeto y convivencia armónica con el ambiente.

Por todo lo anterior, y como todavía se está permitido soñar y creer en utopías, pienso que una de las batallas más importantes que han de librarse para desarrollar esa cultura es la de fomentar un proceso de concienciación ambiental que exige, entre otras cosas, la difusión de ideas y conceptos con sustento científico. Es por esto que he decidido reunir en una sola obra una serie de trabajos realizados durante el período 19982008 que se encuentran dispersos en libros y revistas que no siempre son fáciles de conseguir. Se trata de 17 escritos (dos de ellos traducidos por mí del inglés al español) que en sus líneas plasman reflexiones de experiencias adquiridas en la investigación (teórica y empírica), la docencia, y la práctica profesional burocrática.

Con esta obra espero contribuir no sólo a dar una mayor divulgación a diversos temas jurídico-ambientales con el objetivo último de fortalecer ése proceso de concienciación, sino a combatir a los únicos y verdaderos enemigos de la crisis ambiental de nuestros días: la ignorancia (que supone arrogancia o estrechez de pensamiento), la corrupción (que supone 
Esta obra forma parte del acervo de la Biblioteca Jurídica Virtual del Instituto de Investigaciones Jurídicas de la UNAM

la aceptación de la cultura de la ilegalidad), y la impunidad (que supone la mezquindad y complicidad humanas).

Mi más amplia gratitud a todas aquellas personas que de diversas maneras han contribuido a la conformación de este libro; no podría mencionarlas a todas por tratarse de una nota de indispensable brevedad. Sin embargo, hago expreso mi agradecimiento a dos invaluables abogados. En primer lugar, al doctor Diego Valadés, quien con su amplia visión de jurista ha creído desde siempre en mis líneas de investigación, su apoyo institucional fue indispensable para iniciarme como investigador en el Instituto de Investigaciones Jurídicas de la UNAM. En segundo lugar, y no por ello menos importante, al doctor Héctor Fix-Fierro por haber aceptado prologar este libro y por otorgarme cuanto apoyo académico le he solicitado, su interés por lo ambiental es genuino.

En lo estrictamente personal, quiero compartir con mis lectores que este año de 2008 celebro 15 años de dedicarme ininterrumpidamente a las cuestiones ambientales, 10 de haber obtenido el grado de doctor por la London School of Economics and Political Science de la Universidad de Londres, Inglaterra, y 40 de haber nacido. Suman todas ellas razones suficientes que impulsaron aún más mi decisión de realizar una antología de estudios ambientales. 
Esta obra forma parte del acervo de la Biblioteca Jurídica Virtual del Instituto de Investigaciones Jurídicas de la UNAM

\section{NOTA DEL AUTOR A LA SEGUNDA EDICIÓN}

La primera edición de este libro apareció en junio de 2009 y su presentación se llevó a cabo en septiembre de ese mismo año en el Auditorio "Dr. Héctor Fix-Zamudio" del Instituto de Investigaciones Jurídicas de la UNAM. Transcurridos casi dos años desde su publicación, dicha edición se agotó.

Aunque inesperada, esta noticia me animó a preparar cuanto antes una segunda edición en la que se incluyeran otros trabajos ya publicados. Por lo que incorporé un par de estudios sobre legislación ambiental en México intitulados "Tres frases para la construcción de argumentos legales en la aplicación de la legislación ambiental" y "El Quijote y Sancho Panza en la legislación ambiental mexicana", un escrito que aborda el tema de la capacitación ambiental denominado "Institucionalizar la capacitación jurídico-ambiental en México", y un artículo en el que fijo mi postura a priori en relación con la cumbre sobre cambio climático celebrada en Cancún a finales de 2010 bajo el título de "México ante la COP-16. Entre la simulación climática y la incertidumbre jurídica".

Agradezco nuevamente el apoyo del doctor Héctor Fix-Fierro para la elaboración de esta segunda edición.

Ciudad Universitaria, México, junio de 2011 
Esta obra forma parte del acervo de la Biblioteca Jurídica Virtual del Instituto de Investigaciones Jurídicas de la UNAM

\section{NOTA DEL AUTOR A LA TERCERA EDICIÓN}

Presento a la comunidad universitaria la tercera edición de Estudios ambientales, con un cambio significativo respecto de sus dos antecesoras: he decidido sistematizar todos los trabajos aquí reunidos. Lo anterior, no sólo por el aumento en número de escritos que se incorporan sino también por el incremento en la diversificación de los temas ambientales abordados. Entre artículos en revistas impresas y electrónicas, capítulos de libros, ensayos para homenajes y conmemoraciones, así como voces en diccionarios jurídicos, ahora suman 36 estudios elaborados durante el periodo 1998-2017.

Esta nueva edición se encuentra dividida en siete partes. La primera agrupa trabajos ambientales en materia constitucional; la segunda, en materia internacional y la tercera, en materia atmosférica. La cuarta parte reúne estudios diversos; la quinta, escritos elaborados para homenajes y conmemoraciones, y la sexta voces realizadas para dos diccionarios jurídicos mexicanos. La séptima parte recoge toda la bibliografía (clasificada en libros y revistas, fuentes electrónicas y otras fuentes) e incluye dos apéndices: uno sobre tratados e instrumentos internacionales y el otro sobre legislación nacional.

Agradezco al doctor Pedro Salazar Ugarte, director del Instituto de Investigaciones Jurídicas de nuestra máxima casa de estudios, y al licenciado Raúl Márquez Romero, titular de la Secretaría Técnica del propio Instituto, por todo el apoyo brindado para que Estudios ambientales continúe incomodando a ignorantes, corruptos y farsantes, y siga fortaleciendo al mismo tiempo el proceso de concienciación ambiental entre mis amables lectores.

Ciudad Universitaria, México, mayo de 2018 
Esta obra forma parte del acervo de la Biblioteca Jurídica Virtual del Instituto de Investigaciones Jurídicas de la UNAM

\section{PRÓLOGO A LA PRIMERA EDICIÓN}

Es para mí motivo de gran satisfacción escribir unas breves líneas como prólogo a este libro de César Nava Escudero, amigo y apreciado colega en el Instituto de Investigaciones Jurídicas de la UNAM.

Este libro reúne un total de quince ensayos del periodo 1998-2008, en su mayoría publicados previamente, que abordan problemas muy diversos del derecho ambiental, desde el cambio climático hasta el régimen jurídico de las playas de nuestro país, pasando por la desalación del agua y la contaminación atmosférica en las zonas urbanas. Completan este volumen un breve texto sobre una visita a la planta nuclear de Laguna Verde, las palabras que el autor dedicó a Héctor Fix-Zamudio en sus cincuenta años de labor científica, así como una extensa bibliografía y dos apéndices que compendian las principales normas nacionales e internacionales en materia ambiental.

El libro de César Nava Escudero constituye una aportación muy significativa, no sólo por la importancia creciente que tienen los problemas y desafíos que enfrenta la sociedad humana globalizada en su relación con el ambiente, sino también porque entre nosotros la bibliografía jurídica en materia ambiental sigue siendo relativamente escasa. En el campo académico, cabe al Instituto de Investigaciones Jurídicas el honor de haber sido una de las primeras instituciones en abordar y promover los temas del derecho ambiental. Recordamos así que, en 1974, el Instituto organizó, de manera conjunta con la Asociación Internacional de Ciencias Jurídicas y la UNESCO, el "Coloquio sobre la Protección Jurídica del Medio Ambiente en los Países en Desarrollo", cuyos trabajos fueron publicados por el propio Instituto, en 1976, en un volumen editado por Ignacio Carrillo Prieto y Raúl Nocedal, intitulado Legal Protection of the Environment in Developing Countries. Mencionamos también, entre otras obras importantes, el libro del profesor Lucio Cabrera Acevedo, uno de los juristas mexicanos pioneros en esta disciplina, que el Instituto publicó en 1981 bajo el título El derecho de protección al ambiente en México. El libro de César Nava Escudero continúa esta tradición, pues 
Esta obra forma parte del acervo de la Biblioteca Jurídica Virtual del Instituto de Investigaciones Jurídicas de la UNAM

hasta donde puedo apreciar, son pioneros algunos de los ensayos incluidos en el volumen, pues abordan cuestiones de gran actualidad que todavía no habían sido examinadas en términos académicos.

Permítaseme ahora intentar una sistematización de los ensayos reunidos en el volumen, con el propósito de ofrecer unos breves comentarios desde la perspectiva de un lego interesado. Me parece que los ensayos se pueden agrupar en cinco grandes temas: $a$ ) el desarrollo sustentable urbano y la contaminación atmosférica; $b$ ) las normas y los acuerdos internacionales de naturaleza ambiental; $c$ ) el régimen jurídico de las zonas costeras del país; $d$ ) los problemas jurídicos relacionados con el agua, $\mathrm{y}$ e) la relación entre los pueblos indígenas y el ambiente.

El primer bloque apuntado comprende cuatro ensayos: "Indicadores y retos para el desarrollo urbano sustentable"; "Debate ambiental y contaminación atmosférica urbana: los casos de Londres y la Ciudad de México"; "Hacia un derecho atmosférico ambiental", y "De homo sapiens a homo automobilis: la gestión de la calidad del aire en la Ciudad de México revisitada". Desde que el ser humano se volvió sedentario y empezó a establecer asentamientos permanentes, ha sido inevitable la alteración del ambiente en los lugares en donde se han ubicado estos asentamientos. Pensemos simplemente en la necesidad de la tala cuando los asentamientos se establecen en zonas boscosas. Sin embargo, la civilización tecnológica moderna, que es un fenómeno esencialmente urbano y más o menos reciente, ha llevado a los extremos la alteración y la degradación del ambiente, lo cual es particularmente visible en las megalópolis, como la Ciudad de México, respecto de la contaminación atmosférica. Los ensayos de César Nava Escudero nos ofrecen una visión muy informada del problema; nos plantean una perspectiva de cuál puede ser la estructuración de temas jurídicos centrales de lo que él llama un "derecho atmosférico ambiental", y nos recuerdan que es el automóvil el elemento que establece un principio de comunidad entre ciudades tan diversas como pueden ser las de Londres y México y que en la solución de los problemas ambientales causados por los automóviles, y no en la reducción de la movilidad de los seres humanos, está el futuro sustentable de los centros urbanos.

El segundo grupo de ensayos incluye los siguientes cuatro trabajos: "El principio de precaución en el derecho internacional ambiental"; "La seguridad de la biotecnología: la normatividad internacional vis-à-vis la 
Esta obra forma parte del acervo de la Biblioteca Jurídica Virtual del Instituto de Investigaciones Jurídicas de la UNAM

regulación nacional mexicana"; "Guía mínima para la enseñanza del derecho internacional ambiental en México", y "Los acuerdos interinstitucionales ambientales". Resulta un lugar común señalar que, dado que los problemas ambientales tienden a no respetar fronteras nacionales, no será posible solucionar jurídicamente los problemas del ambiente sin incorporar los esfuerzos de la comunidad internacional, los cuales deben traducirse en normas de igual nivel, conformando el derecho internacional ambiental. Lo que ya no resulta trivial y requiere, en cambio, esfuerzos importantes de los juristas, es el modo en que los distintos planos jurídicos - el interno y el internacional, que incluye los ámbitos regionalesdeben articularse y reforzarse mutuamente. Como señala el propio autor, el derecho internacional ambiental ejerce una doble influencia sobre el derecho interno, al ser uno de los principales factores propulsores de la normatividad interna y al generar un efecto de armonización de los derechos nacionales. Sin embargo, la cesura que separa el ámbito jurídico nacional del internacional —y así también lo apunta Nava - les permite a los estados comprometerse internacionalmente, sin que esos compromisos se plasmen cabalmente en disposiciones internas, lo cual introduce nuevas dificultades y complejidades en la regulación ambiental. Por lo que se refiere al movimiento en dirección contraria, podemos suponer que en algunos ámbitos los derechos nacionales puedan estar más avanzados que la normatividad internacional y que, por ello, sean fuente también de innovación y cambio en ese plano, pero entonces sucede que las negociaciones internacionales que hacen posible su incorporación en el derecho internacional ambiental enfrentan toda clase de dilaciones y obstáculos, ante la existencia de intereses aparentemente inconciliables entre los estados y la ausencia de una autoridad central mundial que los armonice. Creo que ese puede ser el tema implícito común en los trabajos de este grupo de ensayos.

En tercer lugar podemos agrupar los siguientes dos trabajos: "La privatización de las zonas costeras en México" y "Turismo internacional de playa y cambio climático en México". El primer trabajo destaca por hacer una contribución notable a un tema descuidado en nuestra doctrina jurídica, no obstante que fácilmente comprueba su importancia, debido a la extensión, la riqueza y la variedad de las zonas costeras de nuestro país. Desafortunadamente, no es sorprendente el paradójico diagnóstico que hace: por un lado, la existencia de un conjunto muy complejo de nor- 
Esta obra forma parte del acervo de la Biblioteca Jurídica Virtual del Instituto de Investigaciones Jurídicas de la UNAM

mas y disposiciones jurídicas, de diverso nivel y proveniencia que, por el otro lado, presentan lagunas e inconsistencias importantes. Por ello, al mismo tiempo que insiste en la conveniencia de contar con una ley particular para la regulación de las zonas costeras, nos pone en guardia sobre los inconvenientes de una política de privatización que no esté guiada por criterios racionales de utilidad social. El segundo ensayo está muy ligado a las preocupaciones del primero y constituye una aportación a un campo del derecho que, al menos desde el punto de vista doctrinal, está muy descuidado también en nuestro país: el derecho del turismo. Nuevamente, a pesar de la importancia que tiene el turismo de playa para la economía de México, ni la regulación positiva ni la correspondiente reflexión jurídica están a la altura de los desafíos que enfrentamos en esta materia. El ensayo de Nava Escudero no sólo contribuye a la reflexión (jurídica) sobre el turismo (con muy útiles datos sobre su importancia social y económica), sino que pretende vincular, como lo señala el mismo autor, el turismo internacional de playa en nuestro país con dos peligros específicos que derivan del cambio climático: los huracanes y la elevación del nivel del mar. El problema ya ha sido advertido tanto a nivel internacional como nacional; pero en este último caso, como apunta el autor, el gobierno mexicano no ha tomado todavía medidas jurídicas claras para la adaptación climática del sector turístico costero. Sin poner en duda que dichas medidas sean necesarias y posibles, éste es quizá un ámbito en donde el derecho encuentra claros límites, pues, al menos en el corto plazo, la afluencia turística a nuestro país seguirá siendo muy vulnerable a fenómenos naturales difícilmente controlables, como el cambio climático o las epidemias, o a fenómenos sociales complejos que no han podido resolverse, como la delincuencia y la inseguridad.

El cuarto conjunto de ensayos abarca los tres títulos siguientes: "Comentarios al artículo 27 constitucional en materia de aguas"; "La regulación jurídica de la desalación de agua en México: lo bueno, lo malo y lo más malo del periodo 2001-2006”, y “Agua y desalación en México: del engaño al oscurantismo jurídico". Para nadie es un secreto que el tema del agua incrementa su importancia en la misma medida en que los recursos hídricos disponibles disminuyen por efecto del cambio climático, la contaminación y la degradación ambientales, así como por el desperdicio humano. Por si los problemas que lo aquejan fueran pocos, nuestro país enfrenta una situación cada vez más difícil en la materia, lo cual conduce 
Esta obra forma parte del acervo de la Biblioteca Jurídica Virtual del Instituto de Investigaciones Jurídicas de la UNAM

necesariamente a la revalorización del agua como elemento indispensable para el sostenimiento de la vida. En el primer ensayo, el autor nos presenta la regulación constitucional de las aguas en nuestro país a la luz de los conceptos y debates doctrinales que ha suscitado, particularmente en el campo del derecho administrativo. Entiendo que la principal aportación de este ensayo es la exploración sistemática de la vertiente ambiental de este tema que tradicionalmente se ha abordado sólo desde la perspectiva patrimonial. Los otros dos trabajos se ocupan de una de las opciones que la tecnología ofrece actualmente para aumentar el acceso al agua para usos humanos: la desalación. Nava Escudero critica aquí que se haya declarado al agua como asunto de "seguridad nacional" sin que esta declaratoria se haya traducido en ningún cambio significativo en las normas o las políticas públicas y sin un encauzamiento jurídico explícito de las posibilidades tecnológicas a las que antes se hizo referencia.

En el quinto tema incluimos dos ensayos: "La primera reforma constitucional ambiental del nuevo milenio: el acceso de los pueblos indios a los recursos naturales" y "De los derechos indígenas ambientales o del por qué existen preceptos constitucionales virtuales". En estos ensayos, el autor, en forma similar a otros trabajos del libro, busca establecer un vínculo explícito entre un tema de otra proveniencia jurídica (los derechos indígenas) con los aspectos ambientales, en este caso ejemplificados por los recursos naturales, a los cuales se hizo referencia en los proyectos e iniciativas que condujeron a la aprobación de la llamada "ley indígena" de 2001. Sin calificar las bondades que pueda tener para los pueblos indígenas de nuestro país, le parece al autor que esta reforma constitucional presenta deficiencias que la convierten en "virtual", es decir, en inoperante, respecto a la preferencia que se pretendió establecer para los pueblos y comunidades indígenas en el acceso a los recursos naturales de su hábitat.

Que César Nava Escudero haya decidido reunir en este volumen varios de sus trabajos aparecidos en publicaciones dispersas ha sido una decisión feliz y oportuna, porque permite apreciar con claridad las cualidades que lo distinguen como investigador: acucioso y preciso; capaz para el razonamiento jurídico; pendiente de los temas de frontera en su disciplina, al mismo tiempo que explora las vertientes ambientales de algunos tópicos que provienen de otras ramas jurídicas; por último, se revela también como crítico pero no radical (lo que no siempre ocurre 
Esta obra forma parte del acervo de la Biblioteca Jurídica Virtual del Instituto de Investigaciones Jurídicas de la UNAM

entre los ambientalistas). En suma, tiene el lector en sus manos un volumen bien escrito que llevará tanto al especialista como al lego a aprender y a reflexionar sobre los desafíos más urgentes que enfrenta la sociedad humana, y su derecho, en los umbrales del siglo XXI. Para el Instituto de Investigaciones Jurídicas es motivo de satisfacción y orgullo hacer una contribución académica más al desarrollo y perfeccionamiento de nuestro ordenamiento jurídico ambiental de la mano de César Nava Escudero.

Héctor FIX-FIERRO 
Esta obra forma parte del acervo de la Biblioteca Jurídica Virtual del Instituto de Investigaciones Jurídicas de la UNAM

\section{LA PRIMERA REFORMA CONSTITUCIONAL AMBIENTAL DEL NUEVO MILENIO: EL ACCESO DE LOS PUEBLOS INDIOS A LOS RECURSOS NATURALES*}

\section{INTRODUCCIÓN}

Común es ya entre la comunidad ius-ambientalista de México el uso de la expresión "régimen constitucional ambiental" o "régimen ambiental constitucional". La razón no es menor: en los últimos treinta años se han reformado diversos artículos de nuestra carta magna en los que se ha insertado la variable ambiental en su acepción moderna. El mundo jurídico de lo constitucional ambiental no se compone, sin embargo, sólo de preceptos constitucionales recientes, existen preceptos anteriores a la irrupción de lo ambiental que son actualmente referentes obligados en cualquier estudio de la parte ambiental de nuestra Constitución. Uno de esos casos es precisamente el de los recursos naturales.

Este trabajo tiene por objeto analizar la primera reforma constitucional ambiental del siglo XXI cuyo contenido se refiere a los recursos naturales. Se trata de uno de los muchos preceptos que forman parte integral de la reforma en materia de derechos y cultura indígena de 2001 derivada de los Acuerdos de San Andrés Larráinzar celebrados el 16 de febrero de 1996 entre el Ejército Zapatista de Liberación Nacional y el gobierno federal. En lo particular, nos enfocaremos a comentar sobre el acceso preferente de los pueblos y comunidades indígenas al uso y disfrute de los recursos naturales según lo establecido en el artículo 2o., apartado A, fracción VI, de nuestra ley fundamental y sobre la relación que este precepto guarda con la Ley de la Comisión de Concordia y Pacificación que fue elaborada y presentada en noviembre de 1996.

* Publicado en Serna de la Garza, José María (coord.), Derecho comparado AsiaMéxico. Culturas y sistemas jurídicos comparados, México, UNAM, Instituto de Investigaciones Jurídicas, 2007. 
Esta obra forma parte del acervo de la Biblioteca Jurídica Virtual del Instituto de Investigaciones Jurídicas de la UNAM

Para ubicar esta reforma en materia de derechos y cultura indígena en el ámbito de lo ambiental, haremos una revisión sucinta de los artículos constitucionales más importantes vinculados a las cuestiones ambientales. De esta manera y después de describir brevemente los antecedentes de la reforma de 2001, podremos analizar el significado de dicha reforma y conocer más de cerca si ésta recogió o no lo pactado en los acuerdos de San Andrés y/o si incorporó en lo conducente el texto contenido en la propuesta elaborada por los miembros de la Comisión de Concordia y Pacificación.

\section{CONSTITUCIÓN Y MEDIO AMBIENTE}

En sentido amplio, la parte ambiental en nuestra Constitución comprende: a) preceptos que expresamente mencionan cuestiones ambientales y/o de equilibrio ecológico o que sin hacerlo están íntimamente vinculados a ellas; $b$ ) preceptos sobre recursos naturales (con tratamiento general y particular), y $c$ ) preceptos sobre materias con repercusiones ambientales evidentes. En un intento por tipificar lo anterior, podemos referirnos a cinco grandes categorías que no son de ningún modo excluyentes sino por el contrario, complementarias: ${ }^{1}$

\section{Preceptos constitucionales que de manera expresa se refieren a la} cuestión ambiental y/o a la expresión equilibrio ecológico ${ }^{2}$

Esta primera categoría abarca disposiciones de reciente inclusión en nuestra Constitución ya que lo ambiental como concepto constitucional nace en nuestro país apenas a principios de la década de los setenta del siglo pasado vinculado a la idea de la prevención y combate a la conta-

1 La clasificación que aquí proponemos tiene cierto fundamento en las reflexiones que al respecto realiza Brañes, Raúl, Manual de derecho ambiental mexicano, 2a. ed., México, Fundación Mexicana para la Educación Ambiental-Fondo de Cultura Económica, 2000, pp. 65 y ss. Para otra clasificación, se recomienda acudir a Carmona Lara, María del Carmen, Derechos en relación con el medio ambiente, 2a. ed., México, Cámara de Diputados, LVIII Legislatura-UNAM, 2001, quien esquematiza los artículos constitucionales relacionados con el ambiente en tres principios: $i$ ) principios que consagran derechos; $i$ ) principios fundamentales, y iii) principios que establecen atribuciones.

2 En nuestro sistema jurídico la idea de "protección al ambiente" ha estado acompañada en muchas ocasiones de la idea de "preservar y restaurar el equilibrio ecológico". 
Esta obra forma parte del acervo de la Biblioteca Jurídica Virtual del Instituto de Investigaciones Jurídicas de la UNAM

minación. En efecto, la primera vez que de manera expresa nuestra carta magna incorpora un término relacionado a la cuestión ambiental fue en 1971 a través de una reforma a la fracción XVI, base cuarta, del artículo 73 en la que se otorgan "atribuciones legislativas y ejecutivas" al Consejo de Salubridad General para legislar y establecer medidas en materia de prevención y combate a la contaminación ambiental. ${ }^{3}$

En orden cronológico, las modificaciones más importantes que al respecto ha sufrido nuestro texto constitucional bajo este rubro desde esa fecha son las siguientes:

i) 1971 - Artículo 73, fracción XVI, base cuarta: prevención y combate a la contaminación ambiental. ${ }^{4}$

ii) 1983 - Artículo 25, párrafo sexto: sujeción del uso de los recursos productivos que hagan los sectores social y privado a la idea de cuidar tanto su conservación como el medio ambiente (i.e. protección ambiental en su conjunto). ${ }^{5}$

iii) 1987 - Artículo 27, párrafo tercero (segunda parte): medidas necesarias para la preservación y restauración del equilibrio ecológico. ${ }^{6}$

iv) 1987 - Artículo 73, fracción XXIX-G: distribución de competencias en materia de protección al ambiente y de preservación y restauración del equilibrio ecológico. ${ }^{7}$

3 Es importante señalar que existe cierta discusión respecto a si esta norma constitucional otorga al Consejo de Salubridad General y no al Congreso de la Unión facultades legislativas y administrativas en esta y otras materias. Si bien no es contundente el hecho de que sea el consejo quien tenga dichas facultades, de serlo se podría estar contraviniendo el principio de división de poderes en nuestro sistema constitucional. Para mayor abundamiento sobre esta discusión inserta en el tema ambiental, recomendamos acudir a Brañes Ballesteros, Raúl, op. cit., nota 1, pp. 81 y 82, y a González Márquez, José Juan y Cancino Aguilar, Miguel Ángel, "La distribución de competencias en materia ambiental", en González Márquez, José Juan, Derecho ambiental, México, Universidad Autónoma Metropolitana, 1994, p. 32.

4 Publicada en el Diario Oficial de la Federación el 6 de julio de 1971.

5 Publicada en el Diario Oficial de la Federación el 3 de febrero de 1983.

6 Publicada en el Diario Oficial de la Federación el 10 de agosto de 1987.

7 Publicada en el Diario Oficial de la Federación el 10 de agosto de 1987. Es ya conocida entre la comunidad jurídico-ambiental la discusión que existe sobre el significado de este artículo en torno a si se trata o no de un verdadero sistema de concurrencia (o coincidencia) de competencias y si de serlo —o aún no siéndolo— se trata de facultades legislativas o sólo administrativas (coordinación de los tres órdenes de gobierno). Para que los lectores conozcan sobre la diversidad de interpretaciones que 
Esta obra forma parte del acervo de la Biblioteca Jurídica Virtual del Instituto de Investigaciones Jurídicas de la UNAM

v) 1993 - Artículo 122, fracción IV, inciso g, y 1996 - mismo artículo, apartado $\mathrm{C}$, base primera, fracción $\mathrm{V}$, inciso j: preservación del medio ambiente y protección ecológica como facultad para legislar del órgano local legislativo. ${ }^{8}$

vi) 1993 - Artículo 122, fracción IX, y 1996 - mismo artículo, apartado $\mathrm{G}$, párrafo primero: suscripción de convenios para la creación de comisiones metropolitanas en materia de protección al ambiente y preservación y restauración del equilibrio ecológico. ${ }^{9}$

vii) 1999 - Artículo 4o., párrafo quinto, y 2001 - mismo artículo, párrafo cuarto: derecho de las personas a un medio ambiente adecuado para su desarrollo y bienestar. ${ }^{10}$

\section{Preceptos constitucionales que sin referirse de manera expresa} a la cuestión ambiental se encuentran intimamente vinculados a la misma

En esta segunda categoría, se incluyen aquellos temas que tienen relación estrecha con lo ambiental y que son la salud, la sustentabilidad del

existen sobre el alcance de esta norma se recomienda acudir a Aceves, Carla D., Bases fundamentales de derecho ambiental mexicano, México, Porrúa, 2003, pp. 108 y 109; Arrieta Lerdo de Tejada, Gustavo, "La descentralización o federación ambiental en México", Derecho Ambiental y Ecología, México, año 1, núm. 3, octubre-noviembre de 2004, pp. 5-9; Baqueiro Rojas, Edgard, Introducción al derecho ecológico, México, Oxford University Press-Harla, 1997, p. 6; Brañes, Raúl, op. cit., nota 1, pp. 87-90; Carmona Lara, María del Carmen, Ley General del Equilibrio Ecológico y la Protección al Ambiente. Comentarios y concordancias, México, Procuraduría Federal de Protección al Ambiente-UNAM, Instituto de Investigaciones Jurídicas, 2003, pp. 22-24; González Márquez, José Juan y Cancino Aguilar, Miguel Ángel, op. cit., nota 3, pp. 3237, y Vázquez García, Aquilino, "El federalismo en materia ambiental”, Memorias del Primer Encuentro Internacional de Derecho Ambiental, México, Instituto Nacional de Ecología-Secretaría de Medio Ambiente y Recursos Naturales-Programa de las Naciones Unidas para el Medio Ambiente, 2003, pp. 602 y 603.

8 Publicada en el Diario Oficial de la Federación el 25 de octubre de 1993 donde se señalaba como facultad para legislar en dicha materia a la Asamblea de Representantes del Distrito Federal, y el 22 de agosto de 1996 donde dicha facultad corresponde ahora a la Asamblea Legislativa del Distrito Federal.

9 Publicada en el Diario Oficial de la Federación el 25 de octubre de 1993 en la fracción IX del artículo 122, para quedar inalterada, posteriormente, con una reforma del 22 de agosto de 1996 y quedar en el mismo artículo 122 pero ahora en el apartado G, párrafo primero.

10 Publicada en el Diario Oficial de la Federación el 28 de junio de 1999. 
Esta obra forma parte del acervo de la Biblioteca Jurídica Virtual del Instituto de Investigaciones Jurídicas de la UNAM

desarrollo y la conservación y mejoramiento del hábitat. Los preceptos más relevantes son los siguientes:

i) 1983 - Artículo 4o. párrafo cuarto, y 2001 - mismo artículo, párrafo tercero: derecho de las personas a la protección de la salud. ${ }^{11}$

ii) 1999 - Artículo 25 párrafo primero: garantía para que el desarrollo nacional (corresponde al Estado su rectoría) sea integral y sustentable. ${ }^{12}$

iii) 2001 - Artículo 2o. apartado A, fracción V: conservación y mejoramiento del hábitat de y por los pueblos y comunidades indígenas. ${ }^{13}$

iv) 2001 - Artículo 2o. apartado B, fracción VII: obligación de las autoridades para apoyar las actividades productivas y el desarrollo sustentable de las comunidades indígenas. ${ }^{14}$

\section{Preceptos constitucionales que se refieren de manera general a los recursos naturales}

En esta categoría encontramos en términos cronológicos la primera disposición constitucional relativa a cuestiones ambientales al referirse a diversos aspectos de los recursos naturales, entre otros, a su conservación, aprovechamiento, cuidado y acceso. En efecto, desde su promulgación en febrero de 1917, nuestra carta magna recogió la idea de que la nación tendría en todo tiempo el derecho de regular el aprovechamiento de los recursos naturales (denominados textualmente elementos naturales) susceptibles de apropiación para cuidar de su conservación. Desde sus inicios, la norma constitucional ha supeditado el aprovechamiento de los recursos naturales a una modalidad que si bien en aquella época no se consideraba como precepto ambiental por no existir tal idea o concepto, ahora se incluye como tema central para los estudiosos del derecho am-

11 Publicada en el Diario Oficial de la Federación el 3 de febrero de 1983 como cuarto párrafo y años después, el 14 de agosto de 2001 para quedar como tercer párrafo. Las disposiciones constitucionales sobre salud son muchas y muy diversas, aquí sólo citamos la que constituye un derecho de los mexicanos.

12 Publicada en el Diario Oficial de la Federación el 28 de junio de 1999.

13 Publicada en el Diario Oficial de la Federación el 14 de agosto de 2001.

14 Idem. 
Esta obra forma parte del acervo de la Biblioteca Jurídica Virtual del Instituto de Investigaciones Jurídicas de la UNAM

biental: la conservación de los recursos naturales. ${ }^{15}$ La primera reforma constitucional de tipo ambiental del siglo veintiuno se refiere precisamente a cuestiones generales sobre los recursos naturales en relación con el acceso que para su uso y disfrute preferente tienen los pueblos y comunidades indígenas. Éstos son los preceptos en cuestión:

i) 1917 - Artículo 27, párrafo tercero (primera parte): conservación de los recursos naturales.

ii) 1917 - Artículo 27, párrafo tercero (tercera parte): medidas para evitar la destrucción de los recursos naturales.

iii) 1917- Artículo 27, párrafo sexto, y 1960 - mismos artículo y párrafo: explotación, uso o aprovechamiento de los recursos naturales por particulares o sociedades mediante concesiones. ${ }^{16}$

iv) 2001 - Artículo 2o., apartado A, fracción VI: acceso al uso y disfrute preferente de los recursos naturales por los pueblos y comunidades indígenas. ${ }^{17}$

\section{Preceptos constitucionales que se refieren de manera particular a los recursos naturales}

Existen disposiciones constitucionales que aluden de manera específica pero dispersa a diversos recursos naturales, como por ejemplo, tierras, aguas continentales (superficiales y del subsuelo), aguas marinas, atmósfera, bosques, minerales, salinas, etcétera. Si bien es cierto que a cada uno de estos recursos naturales aplica en lo conducente lo que en términos generales se establece en algunos de los artículos arriba señalados, su tratamiento constitucional no se agota en ellos. Es decir, cada recurso

15 En este sentido, Carla Aceves nos explica, que el Constituyente de 1917 tuvo la visión de incluir una disposición que se preocupara de la preservación de los recursos naturales de los mexicanos, aunque fuera con un afán de preservar ciertas fuentes de riqueza, es decir, para conservar la "gallina de los huevos de oro"; situación que dista mucho - como enfatiza la misma autora - del actual concepto conservacionista del ambiente, véase Aceves, Carla D., op. cit., nota 7, p. 176.

16 Publicada en el Diario Oficial de la Federación el 20 de enero de 1960. En el texto original de 1917 se estableció el otorgamiento de concesiones a particulares o sociedades para la explotación de los elementos (naturales) de los que se tratara con la condición de que se establecieran trabajos regulares para dicha explotación.

17 Publicada en el Diario Oficial de la Federación el 14 de agosto de 2001. 
Esta obra forma parte del acervo de la Biblioteca Jurídica Virtual del Instituto de Investigaciones Jurídicas de la UNAM

natural en lo particular tiene un tratamiento específico en nuestra Constitución que va desde el aspecto patrimonialista (derechos de propiedad) y los medios y/o modalidades a los que estarán sujetos para su explotación, uso y aprovechamiento, hasta los entes públicos que participan en su gestión como es el caso de los municipios en aguas (potable y residual) y suelo (utilización), así como lo es también el de la Asamblea Legislativa del Distrito Federal para legislar en el uso del suelo.

\section{Preceptos constitucionales que se refieren a materias que tienen evidentes repercusiones en el ambiente o en los recursos naturales}

Advierte Raúl Brañes que al lado de disposiciones constitucionales que aluden a la protección del ambiente (en su conjunto) se encuentran aquéllas que se refieren a determinadas actividades que pueden generar efectos ambientales, como por ejemplo las actividades industriales. ${ }^{18}$ En efecto, existen preceptos constitucionales que no se consideran propiamente dentro de lo ambiental (como objeto de estudio o de regulación), pero que tienen de cualquier modo repercusiones ambientales evidentes, como lo relativo no sólo a las actividades industriales sino también a las comerciales, productivas, deportivas, turísticas, culturales, etcétera. Ya en otras ocasiones hemos hecho hincapié sobre la importancia y utilidad que tiene el incluir semejantes materias o actividades dentro de la cuestión ambiental: como se hizo a propósito en un artículo sobre derecho internacional ambiental. ${ }^{19}$ Ahora hacemos lo mismo para conformar esta quinta y última categoría.

Pensamos que todo este conglomerado de disposiciones constitucionales distribuidas en cinco categorías bien puede conformar lo que se denomina régimen constitucional ambiental o régimen ambiental constitucional.

18 Brañes, Raúl, op. cit., nota 1, pp. 65 y 66.

19 Véase Nava Escudero, César, "Guía mínima para la enseñanza del derecho internacional ambiental en México", Boletín Mexicano de Derecho Comparado, México, nueva serie, año XXXVIII, núm. 113, mayo-agosto de 2005, p. 819. 
Esta obra forma parte del acervo de la Biblioteca Jurídica Virtual del Instituto de Investigaciones Jurídicas de la UNAM

\section{ANTECEDENTES DE LA REFORMA CONSTITUCIONAL DE 2001}

El tema central que analizamos en este artículo se encuentra en la tercera categoría según la tipificación que hemos intentado en un sentido amplio de la parte ambiental en la Constitución. Se trata de un precepto que se refiere de manera general a los recursos naturales y que constituye la primera de las reformas ambientales que se han hecho a nuestra carta magna en este milenio que comienza: el acceso de los pueblos y comunidades indígenas al uso y disfrute preferente de los recursos naturales consagrado en el artículo 2o., apartado A, fracción VI.

Los comentarios que podamos realizar respecto a este artículo constitucional tienen como base el hecho de que su contenido forma tan solo una parte pequeña de una reforma aún mayor en materia de derechos y cultura indígenas. De aquí que sea necesario repasar los antecedentes más importantes sobre la llamada reforma indígena para luego adentrarnos en el significado y alcance del precepto constitucional mencionado. He aquí el preámbulo de la reforma constitucional de 2001.

1) El 17 de noviembre de 1983 nace en las montañas del sureste mexicano el Ejército Zapatista de Liberación Nacional (EZLN) conformado por un grupo caracterizado por la tradición de las guerrillas latinoamericanas de los setenta, grupo de vanguardia, con ideología marxista-leninista y que lucha por la transformación del mundo a través de la llegada al poder en una dictadura del proletariado. ${ }^{20} \mathrm{Du}-$ rante los siguientes diez años, el EZLN se enfrenta al pensamiento indígena produciendo un choque entre dos ideologías: una joven (de finales del siglo XIX, nacimiento del marxismo) y una vieja (de varios siglos atrás, desde la formación de la cultura maya). Este choque entre una vanguardia político-militar y una forma política de resistencia (en colectivo), se traduce para 1993 en un zapatismo que no tiene que ver con el entonces zapatismo de $1983 .{ }^{21}$

20 Subcomandante Insurgente Marcos, "Unas palabras sobre nuestro pensamiento", Crónicas intergalácticas: EZLN. Primer Encuentro Intercontinental por la Humanidad y contra el Neoliberalismo, México, Planeta Tierra, 1996, pp. 65 y 66.

21 Ibidem, pp. 67 y 68. En este sentido, Vázquez Montalbán señala que en su origen se dio el encuentro de la tradición de la resistencia indígena con la teoría del "foquismo" revolucionario guevarista, superviviente del triunfo sandinista y de la permanencia de la 
Esta obra forma parte del acervo de la Biblioteca Jurídica Virtual del Instituto de Investigaciones Jurídicas de la UNAM

2) El 1o. de enero de 1994, el EZLN irrumpe en el escenario público y al grito de ¡Ya basta! se levanta en armas en contra del gobierno del entonces presidente constitucional de los Estados Unidos Mexicanos Carlos Salinas de Gortari y toma control de cuatro municipios cercanos a la Selva Lacandona: San Cristóbal de las Casas, Altamirano, Ocosingo y Las Margaritas, en el estado de Chiapas. Tras doce días de enfrentamientos entre el ejército mexicano y el EZLN, y ante la presión nacional e internacional de suspender la contraofensiva militar y encontrar una salida negociada, el presidente Salinas de Gortari declara unilateralmente el cese al fuego. ${ }^{22}$ En voz de los propios zapatistas, en 1994 nace el zapatismo armado que habría de convertirse en algo nuevo a la hora que se encuentra al llamado zapatismo civil en México y el resto del mundo. ${ }^{23}$ Desde ese 1o. de enero el discurso zapatista incorpora la variable ambiental (aunque no expresamente en aquélla ocasión) referida a los recursos (riquezas) naturales. ${ }^{24}$

3) Después de casi dos años de que el EZLN se levantara en armas en contra del gobierno federal, ${ }^{25}$ y ya como presidente constitucional de los Estados Unidos Mexicanos Ernesto Zedillo Ponce de León, se firman el 16 de febrero de 1996 los Acuerdos de San Andrés (también conocidos como Acuerdos de San Andrés Larráinzar o Acuerdos de San Andrés Sacamch'en) sobre derechos y cultura indígenas. Los Acuerdos de San Andrés (ASA) — correspondientes a la primera de cinco mesas de diálogo para alcanzar la paz en Chiapas y

Revolución cubana. Véase Vázquez Montalbán, Manuel, Marcos: el señor de los espejos, Madrid, Aguilar, 1999, p. 69.

22 Castells, Manuel, "The Power of Identity", The Information Age: Economy, Society and Culture, 2a. ed., Oxford, Inglaterra, Blackwell, vol. II, 2004, p. 76.

23 Subcomandante insurgente Marcos, op. cit., nota 20, p. 68.

24 En la Primera Declaración de la Selva Lacandona, en la que se hace manifiesta la declaración de guerra, se giraron órdenes a las fuerzas militares del EZLN para que se suspendiera el saqueo de las riquezas naturales en los lugares controlados por el propio EZLN.

25 Lo sucedido durante este periodo se encuentra documentado en la gran cantidad de noticias y artículos plasmados en periódicos nacionales que recogieron y analizaron tanto las informaciones gubernamentales como los comunicados del grupo rebelde. Para una mirada rápida de lo acontecido durante esa época desde la óptica de una periodista que recopiló información y vivencias de la realidad dentro y fuera del zapatismo, se recomienda Muñoz Ramírez, Gloria, EZLN: 20 y 10, el fuego y la palabra, México, La Jornada-Revista Rebeldía, 2005. 
Esta obra forma parte del acervo de la Biblioteca Jurídica Virtual del Instituto de Investigaciones Jurídicas de la UNAM

materializados en diversos documentos -26 fueron firmados por las dos partes en conflicto: tanto el EZLN como el gobierno federal. Ahí se plasmó por consenso un marco en el que se habría de establecer el reconocimiento en la Constitución de los derechos de los pueblos indios; tanto sus derechos individuales, de personas, como sus derechos colectivos, de pueblos (no poblados). ${ }^{27}$ En términos políticos, la firma de los ASA significó en su momento el resultado de una sola etapa en el largo y esperado proceso de diálogo y negociación entre ambas partes que habría de continuarse. En este sentido se ha señalado lo siguiente:

... los ASA son, por una parte, el producto parcial de una amplia negociación entre el gobierno federal y el EZLN, y por la otra, las directrices a partir de las cuales esas mismas partes deberían continuar negociando a efecto de alcanzar la llamada "paz digna" en Chiapas. ${ }^{28}$

4) Meses después, en septiembre de ese mismo año, una de las partes, el EZLN, suspendió la negociación con el gobierno federal al argumentar que el propio gobierno no había cumplido su compromiso de legislar sobre lo ya acordado en San Andrés. ${ }^{29}$ Para destrabar el conflicto, la Comisión de Concordia y Pacificación (Cocopa) - creada en 1995 e integrada por los partidos políticos representados en el Poder Legislativo- elaboró un proyecto de iniciativa de reforma constitucional que trataría de recoger los compromisos adoptados en los Acuerdos de San Andrés. En un procedimiento avalado por las partes en conflicto para llegar a un proyecto final que sería enviado al Congreso de la Unión en caso de que fuera aceptado por las mismas, la Cocopa presentó el 29 de noviembre de 1996 dicha iniciativa a la que se le conoce comúnmente como

26 Véase para conocer a detalle el contenido de estos documentos: Hernández Navarro, Luis y Vera Herrera, Ramón (comps.), Acuerdos de San Andrés, México, Era, 1998, y Cossío Díaz, José Ramón, Los problemas del derecho indígena en México, México, Comisión Nacional de los Derechos Humanos, 2002.

27 Hernández Navarro, Luis y Vera Herrera, Ramón, “Al margen y en el centro", en Hernández Navarro, Luis, y Vera Herrera, Ramón (comps.), op. cit., nota anterior, p. 9.

28 Cossío Díaz, José Ramón, op. cit., nota 26, p. 46.

29 Hernández Navarro, Luis, "Constitución y derecho indígena: el alcance de la norma", Revista del Senado de la República, México, vol. 4, núm 11, abril-junio de 1998, p. 141. 
Esta obra forma parte del acervo de la Biblioteca Jurídica Virtual del Instituto de Investigaciones Jurídicas de la UNAM

la "ley Cocopa" o la "iniciativa de ley de la Cocopa". ${ }^{30}$ Pocos días después, el EZLN aceptaba los términos en lo que se habría redactado jurídicamente la propuesta de la Cocopa pero no así el gobierno federal quien la rechazara en enero de $1997 .{ }^{31}$ Durante los años siguientes, se presentaron ante el congreso diversas iniciativas de ley sobre la materia, como la del propio presidente Ernesto Zedillo que fue desde luego rechazada por el EZLN, ${ }^{32}$ una del Partido Acción Nacional y otra más del Partido Verde Ecologista de México.

5) En su discurso de toma de posesión como presidente constitucional de los Estados Unidos Mexicanos el 1o. de diciembre de 2000, Vicente Fox Quesada señaló:

Hermanos de las comunidades y pueblos indígenas, permítanme dirigirme a ustedes de manera especial:

Como presidente de México asumo responsablemente el compromiso de crear condiciones que hagan posible la participación permanente de todos y cada uno de ustedes, de sus comunidades y pueblos, en la construcción de los marcos legales que garanticen, dentro del Estado nacional, el ejercicio pleno de su autonomía y su libre determinación en la unidad nacional.

¡Nunca más un México sin ustedes!

En México y en Chiapas hay un nuevo amanecer.

En Chiapas, serán las acciones — no las palabras huecas - el eje vertebral de una nueva política federal y presidencial que conduzca a la paz.

Fue mi palabra empeñada enviar al Congreso de la Unión, como iniciativa de Ley, el documento elaborado por la Cocopa que sintetiza el espíritu de los Acuerdos de San Andrés. Y éste será el primer acto de mi gobierno en referencia al Congreso.

30 Claro está que es necesario advertir que esta propuesta no era en estricto sentido una iniciativa de ley por no ser en ese entonces un proyecto legislativo terminado ni tampoco porque no se trataba de una iniciativa de ley, sino de una iniciativa de reforma constitucional. Véase en este sentido a Rabasa Gamboa, Emilio, "Las falacias sobre la reforma indígena: sus aciertos y desaciertos”, Derecho y Cultura, México, vol. 1, núm. 3, primavera-verano de 2001, pp. 66 y 67. Como se verá más adelante, esta situación habría de cambiar desde el momento en que el presidente Fox "haría suya" la propuesta de la Cocopa para enviarla al Congreso de la Unión como iniciativa del Ejecutivo Federal.

31 Moguel, Julio, “Legislar sobre el tema indígena: ¿callejón sin salida?”, Revista del Senado de la República, México, vol. 4, núm 11, abril-junio de 1998, p. 27.

32 Hernández Navarro, Luis, op. cit., nota 29, p. 141. 
Esta obra forma parte del acervo de la Biblioteca Jurídica Virtual del Instituto de Investigaciones Jurídicas de la UNAM

Al día siguiente, el 2 de diciembre, el Comité Clandestino Revolucionario Indígena - Comandancia General del Ejército Zapatista de Liberación Nacional- emitió un comunicado (firmado por el subcomandante insurgente Marcos) en el que establecía que el EZLN reiteraba su disposición al diálogo y a la negociación pacíficos para llegar al fin de la guerra y construir una paz justa y digna con los pueblos indios de México. En dicho comunicado, el EZLN demandó del nuevo gobierno federal tres señales concretas que acreditaran su disposición al diálogo y a la negociación; entre esas tres señales se encontraba la del cumplimiento de los ASA, en concreto la transformación en ley de la iniciativa elaborada por la Cocopa. ${ }^{33}$ Ese mismo día, el EZLN le envió una carta al presidente Vicente Fox demandando el cumplimiento de esas señales para la reanudación del diálogo, aquí la parte relativa al mismo:

... Señor Fox: durante más de seis años su antecesor, Zedillo, fingió voluntad de diálogo y nos hizo la guerra. Escogió el enfrentamiento y perdió. Ahora usted tiene la oportunidad de elegir.

Si elige la vía del diálogo sincero, serio y respetuoso, simplemente demuestre con hechos su disposición. Tenga la seguridad de que tendrá una respuesta positiva de los zapatistas. Así podrá reiniciarse el diálogo y, pronto, empezará a construirse la paz verdadera.

En el comunicado público que le anexamos, el EZLN da a conocer la demanda de una serie de señales mínimas por parte del Ejecutivo federal. Si éstas se dieran, todo estaría listo para volver al diálogo.

Lo que estará en juego no es si nosotros nos oponemos a lo que usted representa y lo que usted significa para nuestro país. En esto no debe haber duda: nosotros somos sus contrarios. Lo que estará en juego es si esta oposición se da por canales civiles y pacíficos, o si debemos continuar alzados en armas y con el rostro cubierto hasta conseguir lo que buscamos, que no es otra cosa, señor Fox, que democracia, libertad y justicia para todos los mexicanos.

33 Comité Clandestino Revolucionario Indígena, Comandancia General del Ejército Zapatista de Liberación Nacional, Comunicado, México, 2 de diciembre de 2000, http:// www.ezln.org/documentos/2000/20001202c.e-s.htm. En este comunicado se establece que las otras dos señales serían la liberación de todos los zapatistas presos en cárceles de Chiapas y otros estados y la desmilitarización (retiro y cierre) de 7 de las 259 posiciones del ejército federal en diversos puntos geográficos de Chiapas. 
Esta obra forma parte del acervo de la Biblioteca Jurídica Virtual del Instituto de Investigaciones Jurídicas de la UNAM

Pocos días después, en cumplimiento a su discurso de toma de protesta, el 5 de diciembre de ese año, el presidente Vicente Fox envía al Senado de la República la ley Cocopa como una iniciativa del Ejecutivo Federal. ${ }^{34}$

6) El 25 de abril de 2001, el Senado de la República aprueba un dictamen de ley sobre la iniciativa de ley de la Cocopa enviada por el Ejecutivo Federal y la remite a la Cámara de Diputados. Sólo tres días después, el 28 de ese mismo mes y año, los diputados aprueban el dictamen de ley enviado por el Senado; al día siguiente, el 29 de abril, el EZLN emite un comunicado en el que rechaza dicho dictamen argumentando que traiciona los ASA en lo general y a la iniciativa de ley de la Cocopa en lo particular en puntos sustanciales. Señala el EZLN en ese comunicado lo siguiente:

29 de abril de 2001

Al pueblo de México:

A los pueblos y gobierno del mundo: Hermanos y hermanas:

El EZLN ha tomado conocimiento de la reforma constitucional sobre derechos y cultura indígenas recientemente aprobada en el Congreso de la Unión. Esta es nuestra posición:

PRIMERO. La reforma constitucional aprobada en el Congreso de la Unión no responde en absoluto a las demandas de los pueblos indios de México, del Congreso Nacional Indígena, del EZLN, ni de la sociedad civil nacional e internacional que se movilizó en fechas recientes.

SEXTO. El EZLN formalmente desconoce esta reforma constitucional sobre derechos y cultura indígenas. No retoma el espíritu de los Acuerdos de San Andrés, no respeta la "Iniciativa de la Ley de la Cocopa", ignora por completo la demanda nacional e internacional de reconocimiento de los derechos y la cultura indígenas, sabotea el incipiente proceso de acercamiento entre el gobierno federal y el EZLN, traiciona las esperanzas de una solución negociada de la guerra en Chiapas, y revela el divorcio total de la clase política respecto de las demandas populares. ${ }^{35}$

34 Ceceña, Ana Esther, "El reconocimiento de los derechos y cultura indígenas y la incompetencia del sistema político mexicano", Derechos indígenas y los Acuerdos de San Andrés, México, s.f., http://www.ezln.org/-san_andres/.

35 Comité Clandestino Revolucionario Indígena, Comandancia General del Ejército Zapatista de Liberación Nacional, Comunicado, México, 29 de abril de 2001, http://www. ezln.org/documentos/2001/ezln010429b.es.htm. 
Esta obra forma parte del acervo de la Biblioteca Jurídica Virtual del Instituto de Investigaciones Jurídicas de la UNAM

A los pocos días, se inicia el proceso de aprobación del dictamen en los congresos estatales y después de algunos meses, el 3 de agosto de 2001, se promulga el decreto por el que se reforman varios artículos de la Constitución. Dicho decreto de reformas constitucionales se publica en el Diario Oficial de la Federación el 14 de agosto de ese mismo año.

7) A raíz de la entrada en vigor de la llamada reforma constitucional indígena de 2001, se promueven controversias constitucionales en su contra ante la Suprema Corte de Justicia de la Nación (SCJN), en las que se argumenta, entre otras, la violación a las normas que rigen el procedimiento de reformas a la Constitución por parte del órgano reformador de la misma. ${ }^{36}$ Es hasta los primeros días de septiembre de 2002 que la SCJN falla en contra de las reclamaciones presentadas declarando la improcedencia de más de 320 controversias bajo el argumento de no tener facultad de control sobre los actos del llamado órgano reformador de la Constitución. ${ }^{37}$ Fueron ocho los ministros de nuestro máximo tribunal que se declararon incompetentes para revisar el cumplimiento del procedimiento de reforma constitucional sosteniendo además que las controversias constitucionales sólo proceden en contra de actos o disposiciones generales contrarias a la Constitución, es decir, actos propiamente dichos, leyes y reglamentos (federales, locales y municipales) pero no de las reformas o adiciones constitucionales ni del proceso que les dé origen. ${ }^{38}$

8) A principios de 2006 último año de gobierno del presidente Vicente Fox - el diálogo entre el EZLN y el gobierno federal es inexistente, y el conflicto iniciado en 1994 aún no se ha resuelto.

36 Véase Espinoza Sauceda, Guadalupe, Los pueblos indignos ante la coyuntura de las controversias constitucionales y posibles escenarios, México, 14 de mayo de 2002, http://www.ciepac.org/procesodepaz/contges0502.htm.

37 Véase Centro de Derechos Humanos, "Miguel Agustín Pro Juárez", Cronología narrativa. Proceso de la Reforma Constitucional en materia indígena, México, s.f., http:// www.centroprodh.org.mx/especiales/cronología_indigena/CRONOLOGÍAINDIGENA. htm.

38 González Galván, Jorge Alberto, "La Corte y los indígenas", Boletín Mexicano de Derecho Comparado, México, nueva serie, año XXXVI, núm. 107, mayo-agosto de 2003, p. 732. 
Esta obra forma parte del acervo de la Biblioteca Jurídica Virtual del Instituto de Investigaciones Jurídicas de la UNAM

\section{RECURSOS NATURALES Y PUEBLOS INDIOS}

Dos son las interrogantes que nos formulamos en el análisis del contenido de la reforma constitucional de 2001. Primero, si lo plasmado en el texto de la Constitución tiene la misma redacción que la ley Cocopa. Segundo, en caso de que no sea así (y aún siéndolo), cuál es el significado y alcance del precepto constitucional y qué tan alejado o cercano está tanto de la propuesta de la ley Cocopa como del espíritu de lo pactado entre el EZLN y el gobierno federal en los ASA. Nos preguntamos, entonces, ¿qué sucedió para el caso del acceso de las comunidades y pueblos indígenas a los recursos naturales?

Primero. Nos interesa esclarecer si lo que está plasmado textualmente en nuestra Constitución respecto al acceso a los recursos naturales por los pueblos y comunidades indígenas corresponde a lo señalado en la iniciativa de ley que mandara el Ejecutivo Federal al Congreso (i. e. la ley Cocopa de 1996). Transcribimos ambos textos, comenzando por el vigente precepto constitucional en su artículo 2o., apartado A, fracción VI:

Artículo 2o....

A. Esta Constitución reconoce y garantiza el derecho de los pueblos y las comunidades indígenas a la libre determinación y, en consecuencia, a la autonomía para:

VI. Acceder, con respeto a las formas y modalidades de propiedad y tenencia de la tierra establecidas en esta Constitución y a las Leyes de la materia, así como a los derechos adquiridos por terceros o por integrantes de la comunidad, al uso y disfrute preferente de los recursos naturales de los lugares que habitan y ocupan las comunidades, salvo aquellos que corresponden a las áreas estratégicas, en términos de esta Constitución. Para estos efectos las comunidades podrán asociarse en términos de ley.

Por su lado, la propuesta contenida en la ley Cocopa señala lo siguiente en su artículo 4o., párrafo segundo, fracción V:

Artículo 4o.

Los pueblos indígenas tienen el derecho a la libre determinación y, como expresión de ésta a la autonomía como parte del Estado mexicano para: 
Esta obra forma parte del acervo de la Biblioteca Jurídica Virtual del Instituto de Investigaciones Jurídicas de la UNAM

V. Acceder de manera colectiva al uso y disfrute de los recursos naturales de sus tierras y territorios, entendidos éstos como la totalidad del hábitat que los pueblos indígenas usan u ocupan, salvo aquellos cuyo dominio directo corresponde a la Nación.

De la simple lectura de estos párrafos se desprende claramente que la redacción de los textos entre uno y otro es distinta. No hay duda sobre ello. Y no sólo eso, el actual texto constitucional se ubica en el artículo 2o. que contempla dos apartados (cada uno con diversas fracciones) mientras que la ley Cocopa intentaba modificar el artículo 4o. constitucional. Como se verá más adelante, sin embargo, no todo lo redactado en el vigente texto constitucional se separa de la ley Cocopa.

Segundo. Debemos señalar que en los encabezados aquí transcritos tanto de la ley Cocopa como del texto constitucional, el derecho a la libre determinación de los pueblos y comunidades indígenas (y su autonomía) para acceder al uso y disfrute de los recursos naturales está reconocido por el Estado. ${ }^{39} \mathrm{Si}$ bien el debate que gira en torno a estos dos conceptos - libre determinación y autonomía - es muy amplio y sin embargo no pretendemos de manera alguna agotarlo en este artículo, basta con señalar que ambos textos concibieron la posibilidad de establecer derechos a los pueblos y comunidades indígenas para el uso y disfrute de los recursos naturales. Un segundo punto que tratamos se refiere a la manera en la que los grupos y comunidades indígenas habrán de acceder a los recursos naturales. En efecto, mientras que la ley Cocopa establece textualmente que dicho acceso habría de ser de manera colectiva, el texto constitucional elimina esa posibilidad. Esta situación deriva en lo siguiente: se está ante una negativa al carácter colectivo de acceso que tienen los pueblos y comunidades indígenas y por lo tanto es aceptable argumentar que existe un alejamiento de lo redactado en la ley Cocopa. El que sea o no benéfico para los pueblos y comunidades indígenas (o que en su caso contravenga compromisos internacionales adquiridos por México) para que el acceso sea exclusivamente de manera colectiva podrá ponerse en tela de juicio, pero en definitiva eso no fue lo que recogió la ley Cocopa. Un tercer y último punto — quizá el más importante - radica en el sistema de preferencia que los pueblos y comunidades indígenas tienen sobre el acceso

39 En este sentido, véase González Galván, Jorge Alberto, "La reforma constitucional en materia indígena”, Cuestiones Constitucionales, México, núm. 7, juliodiciembre de 2002, p. 256. 
Esta obra forma parte del acervo de la Biblioteca Jurídica Virtual del Instituto de Investigaciones Jurídicas de la UNAM

de uso y disfrute a los recursos naturales, y las obligaciones y/o salvedades que deberán observar dentro de ese orden preferencial conforme lo establece la reforma de 2001. Es precisamente en este punto en el que aquéllos que sostienen que la reforma constitucional se apartó de lo pactado en los ASA y en la ley Cocopa encuentran suficientes argumentos para desvirtuar - al menos en materia de recursos naturales - el vigente texto constitucional. Curiosamente, pensamos que la propia ley Cocopa se apartó, a su vez, de lo pactado en los ASA.

Mientras que los ASA recogen la idea de un sistema preferencial de los pueblos y comunidades indígenas para el acceso a los recursos naturales, la ley Cocopa no establece con claridad dicho sistema. En efecto, lo pactado en los ASA señalaba una propuesta de reforma que incluyera lo siguiente: "En materia de recursos naturales, reglamentar un orden de preferencia que privilegie a las comunidades indígenas en el otorgamiento de concesiones para obtener los beneficios de la explotación y aprovechamiento de los recursos naturales".

Pero la ley Cocopa en este punto en particular es omisa. Al mismo tiempo, y de manera poco explicable, la reforma constitucional sí incluyó dicho sistema de preferencia en la ahora vigente fracción VI, apartado A del artículo 20.

No obstante lo anterior, debemos señalar lo siguiente: así como la ley Cocopa pareciera alejarse de lo pactado en los ASA, la reforma constitucional de 2001 (con todo y que establece un sistema preferencial) también se aleja. Efectivamente, si bien la ley Cocopa no recogió el orden preferencial estipulado en los ASA, aquélla sujetó el acceso de los pueblos indios (de manera colectiva) a los recursos naturales con una sola salvedad: no se podría tener dicho acceso cuando se tratara de recursos cuyo dominio directo correspondiera a la nación; sin embargo, la reforma constitucional, al mismo tiempo de establecer un sistema preferencial determina una serie de obligaciones y salvedades para actualizar dicho orden de preferencia que resulta no sólo en un texto que va más allá de los ASA sino de la propia ley Cocopa. Estas obligaciones o salvedades consagradas en nuestra Constitución son limitantes al acceso del uso y disfrute de los recursos naturales y son las siguientes:

a) Deberán respetar las formas y modalidades de propiedad y tenencia de la tierra establecidas en la Constitución y leyes de la materia. 
Esta obra forma parte del acervo de la Biblioteca Jurídica Virtual del Instituto de Investigaciones Jurídicas de la UNAM

b) Deberán respetar los derechos adquiridos por terceros o por integrantes de la comunidad.

c) Deberá tratarse de los lugares que habitan y ocupan las comunidades (y no los pueblos).

d) No podrán tener dicho acceso cuando se trate de áreas estratégicas

e) Para estos efectos, las comunidades (y no los pueblos) podrán asociarse en términos de ley.

De esta manera, podemos afirmar lo siguiente: $i$ ) subyace en la reforma constitucional de 2001 una aberración jurídica ya que por un lado, establece un orden preferencial (lo originalmente pactado en los ASA), pero por el otro, sujeta dicho orden a tales obligaciones y salvedades que desaparece de facto toda posibilidad que los pueblos indios tengan tal preferencia; ii) la situación anterior se traduce en una tergiversación del espíritu de los ASA cuya intención era verdaderamente privilegiar a los pueblos indios, y iii) la ley Cocopa y la reforma constitucional poco o nada tienen entre sí en este punto (y de hecho ambas contrarían lo pactado en los ASA) pues aquélla no establece un sistema preferencial de acceso y sin embargo limita el mismo sólo a una salvedad, y ésta sí establece dicho sistema, pero multiplica las limitaciones.

\section{CONCLUSIONES}

Si existe en la historia del México contemporáneo tema alguno que haya polarizado la opinión pública de manera tan radical, es sin duda alguna el relativo al levantamiento armado del Ejército Zapatista de Liberación Nacional el 1o. de enero de 1994 en contra del gobierno del entonces presidente Carlos Salinas de Gortari. Hay quienes lo han criticado, descalificado, vilipendiado, ignorado o despreciado; hay quienes por otro lado lo han apoyado, elogiado, aplaudido o endiosado. Existen todo tipo de argumentos y contra-argumentos para ir en su contra o para simpatizar con su causa. Es difícil no tomar postura cuando se discute sobre sus orígenes, su desarrollo, sus métodos de lucha, su historia, su palabra, su rebeldía. Se podrá estar a favor o en contra, pero cualquiera que sea la posición que se adopte, hay un hecho rotundamente innegable: la irrupción del EZLN trajo consigo - entre muchas otras cosas más - una de las discusiones jurídicas más trascendentales que haya tenido nuestro 
Esta obra forma parte del acervo de la Biblioteca Jurídica Virtual del Instituto de Investigaciones Jurídicas de la UNAM

país en los últimos años en materia de derechos y cultura indígenas. Estas discusiones no han estado exentas, por cierto, de incluir ciertos temas ambientales.

Tratándose de la reforma constitucional de 2001, el texto vigente consagró temas relacionados con el acceso "preferencial" al uso y disfrute de los recursos naturales; sin embargo, y al igual que con otros preceptos constitucionales ambientales, la norma constitucional fundamentó su existencia en cuestiones sobre derechos de propiedad y, en todo caso, en obligaciones, salvedades o si se quiere, modalidades a dicho acceso. Lo mismo aconteció con la redacción del texto presentada en la iniciativa de ley de la Cocopa. Ciertamente, la discusión jurídico-ambiental sobre los recursos naturales no excluye la disputa sobre su régimen patrimonial pero debemos insistir en que no debería agotarse en ella. En este sentido, pensamos que la parte ambiental de esta reforma quedó en mucho disecada en una discusión de corte patrimonialista, una vez más, como tradicionalmente se ha hecho en otras ocasiones con temas ambientales en nuestra carta magna. Si bien existe en el texto constitucional una referencia a los derechos que tienen los pueblos y comunidades indígenas sobre conservación y mejoramiento del hábitat de sus tierras (i.e. artículo 2o., apartado A, fracción V), es también francamente insuficiente. Estamos conscientes que el debate actual no versa sobre si existe y de qué manera la variable ambiental en la reforma constitucional, en la ley Cocopa o en los ASA, sino en determinar si lo establecido en la ley Cocopa se incorporó a la Constitución. Sin embargo, no dejamos de señalar que tanto la reforma constitucional como la ley Cocopa dejaron de establecer con mayor precisión temas relacionados al ambiente que se discutieron en San Andrés.

Uno de los aspectos centrales para que no se haya reanudado el diálogo entre el EZLN y el gobierno federal, radica en que la reforma constitucional de 2001 no recoge lo establecido en la ley Cocopa. En los textos aquí analizados ha quedado demostrado que así como existen algunas similitudes entre ambos, también hay diferencias que no son sólo de matiz; de hecho, diríamos que la reforma constitucional no sólo se aleja de lo establecido en la ley Cocopa sino que va más allá al establecer un orden preferencial no contemplado por esta y una serie de limitaciones al derecho de los pueblos y comunidades indígenas sobre el acceso al uso y disfrute de los recursos naturales. Debemos insistir en algo: la afirmación 
Esta obra forma parte del acervo de la Biblioteca Jurídica Virtual del Instituto de Investigaciones Jurídicas de la UNAM

que hacemos en este párrafo nada tiene que ver con el hecho de que la reforma constitucional de 2001 sea "buena" o "mala" para los pueblos indios. Se trata de señalar que, una vez hecho el análisis correspondiente, ni la reforma constitucional ni la ley cocopa se parecen, son diferentes en su redacción, contenido y alcance.

Por todo lo dicho anteriormente, podemos concluir lo siguiente. En primer lugar, la primera reforma constitucional ambiental de este siglo según lo establecido en el artículo 2o., apartado A, fracción VI se enmarca dentro de nuestra tipología como un precepto que se refiere de manera general a los recursos naturales; dicha reforma confirma la aseveración de que nuestro régimen constitucional ambiental continúa siendo fundamentalmente patrimonialista. En segundo lugar, la reforma de 2001 es una reforma que recoge parcialmente lo establecido en la ley Cocopa e incluso va más allá de la misma y de los propios ASA; por tanto, no se debe argumentar, al menos por lo que toca al acceso preferente de los pueblos y comunidades indígenas al uso y disfrute de los recursos naturales, que las demandas de una de las partes — las del EZLN — han sido cumplimentadas. Por último, consideramos que existen los suficientes elementos para creer que el conflicto que se ha originado en Chiapas está muy lejos de resolverse ante la forma en la que fue redactado y redimensionado el texto de la reforma constitucional de 2001. 
Esta obra forma parte del acervo de la Biblioteca Jurídica Virtual del Instituto de Investigaciones Jurídicas de la UNAM

\section{DE LOS DERECHOS INDÍGENAS AMBIENTALES \\ O DEL PORQUÉ EXISTEN PRECEPTOS CONSTITUCIONALES VIRTUALES*}

\section{INTRODUCCIÓN}

Indígenas y ambiente, ambiente e indígenas son dos caras de una misma moneda. En la actualidad, ambas categorías aparecen cual binomio inseparable ya sea como objeto de estudio dentro de disciplinas jurídicas (como el derecho indígena o el derecho ambiental), o como parte de la regulación dentro del ordenamiento jurídico mexicano (sea en un precepto constitucional, en el texto de una ley del Congreso de la Unión o en algún artículo de un tratado internacional). De la gran variedad de derechos que tienen los indígenas y que han sido reconocidos por nuestro sistema jurídico, destacan sin duda alguna los que se refieren a los temas ambientales, en particular, el relativo al acceso a los recursos naturales.

Este estudio tiene por objeto analizar el vínculo que existe entre los preceptos indígenas y los preceptos ambientales que se encuentran consagrados en la Constitución Política de los Estados Unidos Mexicanos, con especial énfasis en el tema de los derechos indígenas al acceso, uso y disfrute preferente de los recursos naturales según se establece en el artículo 2o., apartado A, fracción VI. De modo que se pretende demostrar que el precepto constitucional en el que se encuentra plasmado dicho derecho indígena ambiental es virtual. Esta aseveración se basa en dos razonamientos puntuales. Primero, porque de la lectura de dicha disposición no se desprende que sea real la existencia de tal derecho para una de las dos categorías conceptuales de pueblos indios que reconoce nuestra

* Publicado en Carmona Tinoco, Jorge Ulises y Hori Fojaco, Jorge M. (coords.), Derechos humanos y medio ambiente, México, Secretaría de Medio Ambiente y Recursos Naturales-UNAM, Instituto de Investigaciones Jurídicas, 2010. Este artículo se presentó como ponencia en el Seminario de Derechos Humanos y Medio Ambiente que se llevó a cabo el 27 y 28 de noviembre de 2007 y cuya organización estuvo a cargo de ambas instituciones. 
Esta obra forma parte del acervo de la Biblioteca Jurídica Virtual del Instituto de Investigaciones Jurídicas de la UNAM www.juridicas.unam.mx

carta magna: los pueblos indígenas. Segundo, porque si bien el precepto aludido sí se refiere a la otra categoría conceptual que reconoce la Constitución, i. e. la de las comunidades indígenas, lo hace en el marco de un sistema preferente que está sujeto a obstáculos o limitantes que hacen virtual el ejercicio del supuesto derecho de preferencia en el uso y disfrute de los recursos naturales.

\section{DERECHOS INDÍGENAS Y AMBIENTE: EL PUNTO DE ENCUENTRO}

\section{Los derechos indígenas de los pueblos y comunidades indígenas}

En la actualidad, nuestro sistema jurídico cuenta con una serie de preceptos constitucionales aplicables a los grupos o poblaciones indígenas de este país (tradicionalmente llamados pueblos indios), ${ }^{1}$ de entre los que

1 Existe cierto debate sobre cuál debe ser la correcta denominación de las poblaciones que habitaban y siguen habitando lo que ahora conforma el territorio mexicano, sobre todo porque es común que se utilice el término "indígena" como sinónimo de "indio". Véase, por ejemplo, el estudio que realiza Diego Valadés respecto a los derechos indígenas en el marco de nuestra Constitución. Valadés, Diego, "Los derechos indígenas y la renovación constitucional en México", en González Galván, Jorge Alberto (coord.), Constitución y derechos indigenas, México, UNAM, Instituto de Investigaciones Jurídicas, 2002, p. 16. Carlos Montemayor nos advierte que el uso de la palabra indio nos remite tanto a una confusión europea derivada de la creencia de Cristóbal Colón de haber llegado a costas asiáticas, al extremo oriente de la India, así como a una negación de su primera existencia (de su especificidad social y humana) y enfatiza: "A partir de la conquista se convirtió en el nombre del habitante que antes y siempre había vivido en este continente porque el concepto no provenía del sujeto mismo a quien se aplicaba, sino de la sociedad que lo conquistaba". De aquí que los indios de México, argumenta el autor, nunca han sido los indios de México sino pueblos que han tenido nombres precisos como purépechas, tzotziles, tojolabales, nahuas, mazahuas, yaquis, etcétera. Véase Montemayor, Carlos, Los pueblos indios de México. Evolución histórica de su concepto y la realidad social, México, Debolsillo, 2008, pp. 29-32. En este sentido, nosotros nos manifestamos por la idea de que es trascendental escuchar la voz misma de estos grupos y así conocer la forma políticamente correcta para referirnos a ellos y en su caso, estar preparados para sustituir o cambiar el uso de términos de forma pertinente. Recordemos que los grupos que se levantaron en armas el 1o. de enero de 1994, evento que ha sido el antecedente primero del actual texto constitucional en materia de derechos y cultura indígenas, han utilizado en voz de uno de sus combatientes, el subcomandante insurgente Marcos, los términos indígenas e indios de manera indistinta, lo que es posible corroborar en muchas de las decenas de comunicados y documentos emitidos desde su comandancia general. Tal es el caso de la última Declaración de la Selva Lacandona (la sexta de junio 
Esta obra forma parte del acervo de la Biblioteca Jurídica Virtual del Instituto de Investigaciones Jurídicas de la UNAM

destaca, sin lugar a dudas, el del reconocimiento de sus derechos según lo establecido en el artículo 2o. de la Constitución Política de los Estados Unidos Mexicanos. Dicha disposición, resultado de la reforma constitucional en materia de derechos y cultura indígenas según decreto publicado en el Diario Oficial de la Federación del 14 de agosto de 2001, se refiere expresamente a estos pueblos, grupos o poblaciones como "pueblos indígenas" y como "comunidades indígenas". ${ }^{2}$ La distinción que hace nuestra carta magna es de suma importancia ya que constituye el punto de partida para identificar que los titulares o sujetos de los derechos indígenas ( $i$.e. el ámbito personal de validez del precepto en cuestión) están determinados precisamente por estas dos categorías conceptuales. ${ }^{3}$ De manera tal que a partir de esta reforma es posible diferenciar no sólo lo que es un pueblo indígena de lo que es una comunidad indígena, sino lo que ambos son o representan respecto de lo que es un ejido y una comunidad como figuras agrarias. ${ }^{4}$

de 2005) que establece lo siguiente: "I. De lo que somos. Nosotros somos los zapatistas del EZLN... nosotros del EZLN somos casi todos puros indígenas de acá de Chiapas, pero no queremos luchar sólo por su bien de nosotros o sólo por el bien de los indígenas de Chiapas, o sólo por los pueblos indios de México...". Véase Comité Clandestino Revolucionario Indígena, Comandancia General del Ejército Zapatista de Liberación Nacional, Sexta Declaración de la Selva Lacandona, México, junio de 2005, http://www. ezln.org/documentos/2005/sexta.es.htm.

2 Antes de esta reforma la Constitución se refería a ellos sólo como pueblos indígenas tal y como quedó plasmado con la adición de un primer párrafo al artículo 4o. a través de una reforma constitucional publicada en el Diario Oficial de la Federación del 28 de enero de 1992 que a la letra establecía lo siguiente: "La Nación mexicana tiene una composición pluricultural sustentada originalmente en sus pueblos indígenas. La ley protegerá y promoverá el desarrollo de sus lenguas, culturas, usos, costumbres, recursos y formas específicas de organización social, y garantizará a sus integrantes el efectivo acceso a la jurisdicción del Estado. En los juicios y procedimientos agrarios en que aquéllos sean parte, se tomarán en cuenta sus prácticas y costumbres jurídicas en los términos que establezca la ley".

3 Para conocer sobre el debate que existe en relación con el problema de determinar si los sujetos de los derechos indígenas son de orden colectivo y/o individual, recomendamos acudir a Carbonell, Miguel, Los derechos fundamentales en México, México, Comisión Nacional de los Derechos Humanos-Porrúa-UNAM, Instituto de Investigaciones Jurídicas, 2005, pp. 1007 y ss.

4 Incluso, es posible encontrar en la legislación actual algunas disposiciones que establecen esta distinción, tal es el caso de la Ley General de Desarrollo Forestal Sustentable que por ejemplo en sus objetivos específicos así lo determina: "Artículo 3.- Son objetivos específicos de esta ley: XXIII. Contribuir al desarrollo socio-económico de 
Esta obra forma parte del acervo de la Biblioteca Jurídica Virtual del Instituto de Investigaciones Jurídicas de la UNAM

Ahora bien, es la propia Constitución la que en su artículo 2o. se encarga por un lado de definir lo que son tanto los pueblos indígenas como las comunidades indígenas, y por el otro la de establecer el listado de lo que constituyen los derechos indígenas.

En primer término, por lo que hace a la definición constitucional de pueblos indígenas, el artículo 2o. establece en sus párrafos segundo y tercero lo siguiente:

La Nación tiene una composición pluricultural sustentada originalmente en sus pueblos indígenas que son aquellos que descienden de poblaciones que habitaban en el territorio actual del país al iniciarse la colonización y que conservan sus propias instituciones sociales, económicas, culturales y políticas, o parte de ellas.

La conciencia de su identidad indígena deberá ser criterio fundamental para determinar a quiénes se aplican las disposiciones sobre pueblos indígenas.

Respecto al concepto de comunidades indígenas, el mismo artículo 2o. establece en su párrafo cuarto lo siguiente:

Son comunidades integrantes de un pueblo indígena, aquellas que formen una unidad social, económica y cultural, asentadas en un territorio y que reconocen autoridades propias de acuerdo con sus usos y costumbres.

Es conveniente apuntar que estas disposiciones constitucionales recogen en cierto sentido las definiciones que se han elaborado a nivel internacional en el Convenio 169 sobre Pueblos Indígenas y Tribales en Países Independientes (también conocido como convenio 169 de la OIT o convenio sobre pueblos indígenas y tribales) adoptado en Ginebra, Suiza, en junio de 1989 durante la Septuagésima Sexta Reunión de la Conferencia General de la Organización Internacional del Trabajo de la que México es parte contratante. ${ }^{5}$ Este tratado establece lo siguiente en su artículo 1o., numerales 1 y 2 dentro de la parte 1 , política general:

los pueblos y comunidades indígenas, así como de ejidatarios, comuneros, cooperativas, pequeños propietarios y demás poseedores de recursos forestales".

5 Este convenio fue aprobado por la Cámara de Senadores el 11 de julio de 1990, ratificado por el Ejecutivo Federal casi un mes después, el 13 de agosto de ése año y depositado ante el director general de la Organización Internacional del Trabajo el 5 de septiembre también de ese mismo año. El texto completo e íntegro (copia fiel y completa) 
Esta obra forma parte del acervo de la Biblioteca Jurídica Virtual del Instituto de Investigaciones Jurídicas de la UNAM

Artículo 1.

1. El presente Convenio se aplica:

a) a los pueblos tribales en países independientes, cuyas condiciones sociales, culturales y económicas les distingan de otros sectores de la colectividad nacional, y que estén regidos total o parcialmente por sus propias costumbres o tradiciones o por una legislación especial

b) a los pueblos en países independientes, considerados indígenas por el hecho de descender de poblaciones que habitaban en el país o en una región geográfica a la que pertenece el país en la época de la conquista o la colonización o del establecimiento de las actuales fronteras estatales y que, cualquiera que sea su situación jurídica, conservan todas sus propias instituciones sociales, económicas, culturales y políticas, o parte de ellas.

2. La conciencia de su identidad indígena o tribal deberá considerarse un criterio fundamental para determinar los grupos a los que se aplican las disposiciones del presente Convenio.

En segundo término, y por lo que concierne a los derechos indígenas que establece el citado artículo 2o., la Constitución parte del aserto de reconocer y garantizar el derecho de los pueblos y comunidades indígenas a la libre determinación, y en consecuencia, a la autonomía para ejercer una serie de derechos expresamente mencionados dentro del marco de los principios generales que rigen la Constitución. Estos derechos, consagrados en el apartado A del artículo en cuestión, se refieren de manera sucinta a decidir sobre sus formas internas de convivencia y organización social, económica, política y cultural; aplicar sus propios sistemas de regulación y solución de conflictos internos; elegir a sus autoridades o representantes según sus normas, procedimientos y prácticas tradicionales garantizando la participación de la mujer en condiciones de equidad; preservar y enriquecer sus lenguas, conocimientos y demás elementos que conformen su cultura e identidad; conservar y mejorar el hábitat y preservar la integridad de sus tierras; acceder al uso y disfrute preferente de los recursos naturales; elegir en municipios con población indígena representantes ante los ayuntamientos; acceder a la jurisdicción del Estado mexicano y ser asistidos por intérpretes y defensores que conozcan su lengua y cultura.

de este tratado internacional puede consultarse en el Diario Oficial de la Federación del 24 de enero de 1991 (día, mes y año en el que fue publicado). 
Esta obra forma parte del acervo de la Biblioteca Jurídica Virtual del Instituto de Investigaciones Jurídicas de la UNAM

Es importante mencionar que los pueblos y comunidades indígenas tienen, además de los ya aludidos, otros derechos indígenas. Nos referimos en primer lugar a aquéllos derechos que se derivan del propio texto constitucional (y a los que podríamos denominar derechos indígenas ampliados $)^{6}$ en virtud de la remisión expresa que éste hace para que el reconocimiento de los derechos de los pueblos y comunidades indígenas se haga en las Constituciones y leyes locales. En segundo lugar, se encuentran aquellos derechos indígenas que están diseminados en diversas disposiciones de nuestra legislación federal. Tercero, son también derechos indígenas los que fueron establecidos en favor de estos grupos en las legislaciones locales antes de la reforma del 14 de agosto de 2001 y los cuales habrán de seguir vigentes siempre y cuando no contraríen como es lógico suponer- los principios básicos respectivos de nuestra Constitución. ${ }^{7}$ Por último, existen otros derechos indígenas — que quizá

6 Existe una tesis aislada de noviembre de 2002 de la Suprema Corte de Justicia de la Nación que ha distinguido entre derechos mínimos (que son los que consagra el texto del artículo 2o. constitucional) y los que denominamos derechos ampliados (que son los que habrán de reconocerse en las legislaciones de los congresos locales). El texto de dicha tesis establece lo siguiente: DERECHOS DE LOS INDÍGENAS. LOS ESTABLECIDOS EN LA CONSTITUCión Política de los ESTAdos Unidos MEXICANOS PUEDEN SER AMPLIADOS POR LAS LEGISLATURAS LOCALES DENTRO DEL MARCO DE AQUÉLLA. El artículo 1o. de la Constitución federal establece que las garantías que otorga no podrán restringirse ni suspenderse, sino en los casos y con las condiciones que ella misma establece, de lo que deriva que ninguna ley secundaria puede limitar las disposiciones constitucionales correspondientes; sin embargo, sí son susceptibles de ser ampliadas por el legislador ordinario, ya sea federal o local, en su reglamentación, al pormenorizar la norma constitucional que prevea el derecho público subjetivo a fin de procurarse su mejor aplicación y observancia. En consecuencia, los congresos locales, al legislar sobre la materia indígena y regular las instituciones relativas, en términos de lo dispuesto en el artículo 2o. de la Constitución Política de los Estados Unidos Mexicanos, deben hacerlo bajo el criterio de que los que se otorgan en ella a la población indígena son derechos mínimos que deben ser respetados para garantizar su efectividad, pero que pueden ser ampliados para imprimir las características propias que mejor expresen las situaciones y aspiraciones de sus pueblos indígenas, siempre que tal ampliación se realice sin vulnerar el marco constitucional al que dichos derechos se encuentran sujetos. Tesis 2a. CXXXIX/2002, Semanario Judicial de la Federación y su Gaceta, Novena Época, t. XVI, noviembre de 2002, p. 446. Nota: conforme al artículo 192, segundo párrafo, de la Ley de Amparo, esta tesis no es apta para integrar jurisprudencia. Texto obtenido en http://www.juridicas.unam.mx/ infjur/leg/jrs/jrsVer.htm?idt $=7967$.

7 Acudimos nuevamente a una tesis aislada de la Suprema Corte de Justicia de la Nación que establece: DERECHOS DE LOS INDÍGENAS. LOS ESTABLECIDOS EN LAS LEGISLACIONES LOCALES EN FAVOR DE ELLOS NO FUERON LIMITADOS POR LAS REFORMAS A LA 
Esta obra forma parte del acervo de la Biblioteca Jurídica Virtual del Instituto de Investigaciones Jurídicas de la UNAM

\begin{abstract}
no sean en estricto sentido derechos sino simples enunciados o disposiciones en materia indígena- que son los que se establecen explícitamente en el apartado B del mismo artículo 2o. constitucional. ${ }^{8}$
\end{abstract}

CONSTITUCIÓN FEDERAL EN LA MATERIA, VIGENTES A PARTIR DEL QUINCE DE AGOSTO DE DOS MIL UNO. Las reformas en materia indígena a la Constitución Política de los Estados Unidos Mexicanos, mediante decreto publicado en el Diario Oficial de la Federación el catorce de agosto de dos mil uno, en vigor a partir del día siguiente conforme a su artículo primero transitorio, dejan a las entidades federativas la regulación jurídica relativa al reconocimiento de los pueblos y comunidades indígenas, por lo que sólo están sujetas a las definiciones y criterios generales que al respecto se establecen, a la estructuración legal de las características de libre determinación y autonomía que mejor expresen las situaciones y aspiraciones de los pueblos indígenas de cada entidad, al postulado básico de unidad e indivisibilidad nacional y a que la autonomía se ejerza dentro del marco constitucional, ello en virtud de que el artículo 40 de la Constitución Federal consigna la unión del pueblo mexicano en una Federación establecida de acuerdo con sus principios fundamentales, de manera tal que cualquier norma contraria a los principios de unidad e indivisibilidad de la Nación Mexicana serían contrarios al Pacto Federal, además de que el numeral 133 de la propia Ley Fundamental prevé el principio de supremacía constitucional mediante el cual las Constituciones y leyes locales deben ser acordes con el Ordenamiento Supremo. En ese tenor, los derechos establecidos en favor de los pueblos y comunidades indígenas, así como de los indígenas en lo individual, deben ser considerados como mínimos a garantizarse por los Estados en la regulación y organización jurídica que al efecto realicen en sus Constituciones y leyes respectivas, razón por la cual los derechos que tales entidades federativas pudieran haber establecido con anterioridad a favor de los indígenas, no pueden considerarse limitados por los derechos consagrados en las normas constitucionales referidas, pues estos últimos sólo son derechos mínimos a satisfacer, a no ser que fueran contrarios a los postulados básicos de unidad e indivisibilidad nacional y de no sujeción al marco constitucional, caso en el cual serían contrarios, desde su origen y no en virtud de las reformas, a la Carta Magna, o bien, que los derechos que en tales legislaciones se hubieran previsto no sean los que mejor expresen las situaciones y aspiraciones de los pueblos indígenas de la entidad, lo que no constituye una limitante a tales derechos, sino una exigencia de que se ajusten a la realidad social. Tesis 2a. CXL/2002, Semanario Judicial de la Federación y su Gaceta, Novena Época, t. XVI, noviembre de 2002, p. 446. Nota: conforme al artículo 192, segundo párrafo, de la Ley de Amparo, esta tesis no es apta para integrar jurisprudencia. Texto obtenido en $h t t p: / / w w w$. juridicas.unam.mx/infjur/leg/jrs/jrsVer.htm?idt $=7968$.

8 Existe la duda sobre si los preceptos contenidos en este apartado B constituyen en realidad derechos indígenas y si aluden al mismo tiempo a otro tipo de disposiciones que no tienen el rango de verdaderos mandatos constitucionales. En este sentido, Miguel Carbonell señala que, sin estar del todo claro, lo establecido en ese apartado parece tratarse por su redacción de "tareas públicas que obligan a los órganos de los tres niveles de gobierno a desarrollar políticas encaminadas a mejorar la situación social y económica de los indígenas". Y añade que se trata en todo caso de medidas o previsiones gubernamentales (recomendaciones si acaso) más propios de la legislación secundaria que de la 
Esta obra forma parte del acervo de la Biblioteca Jurídica Virtual del Instituto de Investigaciones Jurídicas de la UNAM

Desde luego, los indígenas de este país gozan de todos esos otros derechos que están reconocidos y garantizados por nuestra carta magna (que son aquéllos de los que también gozan todos los mexicanos) pero que no debemos considerarlos propiamente como derechos indígenas.

\section{El punto de encuentro}

Contiene el ordenamiento jurídico mexicano ciertas disposiciones en materia de derechos indígenas que están vinculadas a la materia ambiental. Este punto de convergencia, que no es otra cosa más que la existencia de derechos de pueblos y comunidades indígenas con contenido ambiental, genera conceptualmente lo que hemos de llamar derechos indigenas ambientales.

Claro está que para conocer cuáles son esos derechos indígenas ambientales es necesario determinar a través de una tipología preestablecida lo que puede ser considerado como ambiental. ${ }^{9}$ Para ello, debemos partir

de la normativa constitucional. Véase, para mayor detalle, Carbonell, Miguel, op. cit., nota 3 , pp. 1021, 1033 y 1034 .

9 Ya hemos intentado en otros trabajos construir clasificaciones a través de ciertos criterios que nos auxilien en la comprensión de todo aquello que puede considerarse como ambiental. Lo hicimos desde el área de lo internacional-ambiental para señalar que los temas que pertenecen a lo jurídico-internacional-ambiental serán $a$ ) aquéllos que se discutan en los foros ambientales; $b$ ) los que tengan repercusiones ambientales evidentes, y c) los que perteneciendo tradicionalmente a otros foros de discusión internacional se hayan incorporado con el paso del tiempo a un todo ambiental. Véase Nava Escudero, César, "Guía mínima para la enseñanza del derecho internacional ambiental en México", Boletín Mexicano de Derecho Comparado, México, nueva serie, año XXXVIII, núm. 113, mayo-agosto de 2005, p. 819. También lo hicimos desde el área de lo constitucionalambiental y expusimos en aquélla ocasión que la parte ambiental en nuestra carta magna comprende: a) preceptos que expresamente mencionan cuestiones ambientales y/o de equilibrio ecológico o que se encuentran íntimamente vinculados a la cuestión ambiental; b) preceptos que se refieren de manera general y/o particular a los recursos naturales, y c) preceptos sobre materias con repercusiones ambientales evidentes. Véase Nava Escudero, César, "La primera reforma constitucional ambiental del nuevo milenio: el acceso de los pueblos indios a los recursos naturales”, en Serna de la Garza, José María (coord.), Derecho comparado Asia-México, México, UNAM, Instituto de Investigaciones Jurídicas, 2007, pp. 424 y ss. La tipología que ahora intentamos establecer sigue en mucho los criterios utilizados en la elaboración de las clasificaciones anteriores que no tienen otro propósito sino el de establecer desde la disciplina jurídica o sub-especialización jurídica de la que se trate la posibilidad de determinar lo que abarca la materia ambiental. Debemos enfatizar desde ahora que estas tipologías no deben ser vistas como sistemas 
Esta obra forma parte del acervo de la Biblioteca Jurídica Virtual del Instituto de Investigaciones Jurídicas de la UNAM

en primer lugar de la idea lógica de que todo precepto o norma que de manera expresa haga mención a la voz ambiente será entonces una disposición ambiental (incluyendo desde luego la expresión equilibrio ecológico que es utilizada en toda la legislación respectiva). En segundo lugar, serán ambientales aquéllas disposiciones que sin estar dentro de la clasificación anterior se encuentren vinculadas íntimamente a lo ambiental y/o que formen parte indiscutible de los debates o discursos ambientales (como lo relativo por ejemplo a la salud, la sustentabilidad del desarrollo y la conservación y mejoramiento del hábitat). Tercero, serán consideradas también como ambientales aquellas disposiciones que se refieran ya sea de manera general o particular a los recursos naturales, sin perjuicio de que dichas disposiciones pertenezcan a su vez a otros campos de estudio y/o regulación según se trate (como lo pueden ser las relativas a las aguas marinas que son objeto de estudio y regulación del derecho del mar). El que un recurso natural caiga o no dentro de la esfera de lo ambiental dependerá desde el punto de vista científico de lo que queramos que sea o abarque el objeto de estudio del derecho ambiental, y desde el punto de vista normativo de lo que la legislación mexicana determine y/o excluya en su caso como tal. Finalmente, adquieren el rango de ambiental aquellas materias que tienen repercusiones evidentes en el ambiente y/o en los recursos naturales (como las actividades industriales, comerciales, turísticas, etcétera).

En suma, estaremos en presencia de derechos indígenas ambientales cuando las disposiciones que versen sobre los derechos indígenas de estos pueblos y comunidades se encuentren en los siguientes supuestos:

i) Que hagan mención expresa al ambiente.

ii) Que se ocupen de temas o conceptos ligados estrechamente al campo de lo ambiental.

iii) Se refieran a los recursos naturales de manera genérica (y de manera particular cuando así se determine).

iv) Se trate de áreas con evidentes repercusiones en lo ambiental.

rígidos o camisas de fuerza que impidan futuros avances en la sistematización del derecho ambiental o disciplinas jurídicas afines a ella a través de clasificaciones semejantes o innovadoras. 
Esta obra forma parte del acervo de la Biblioteca Jurídica Virtual del Instituto de Investigaciones Jurídicas de la UNAM

Ahora bien, una vez establecido un criterio para determinar lo que puede considerarse como ambiental, el punto de encuentro entre los derechos indígenas y las cuestiones ambientales puede originarse tanto desde la normativa indígena (al incorporar los supuestos ambientales arriba mencionados) como desde la normativa ambiental (al insertar lo relativo a los derechos indígenas y hablar propiamente de derechos ambientales indígenas). Así, como derechos indígenas ambientales o derechos ambientales indígenas, las disposiciones respectivas se localizan tanto en instrumentos jurídicos internacionales (de hard y de soft law) como nacionales (en la Constitución o en algunas leyes del Congreso de la Unión).

Algunos ejemplos podrán dar cuenta de lo anterior. En su dimensión internacional desde el campo de lo indígena y como instrumento vinculante o de derecho duro (hard law) podemos mencionar el citado convenio 169 de la OIT. En él, el punto de encuentro lo encontramos en diversas disposiciones que de manera expresa se refieren al ambiente, ${ }^{10} \mathrm{a}$ los recursos naturales ${ }^{11} \mathrm{y}$ a temas o conceptos estrechamente vinculados

10 El contenido expreso sobre lo ambiental se encuentra en diversos preceptos jurídicos que abarcan el numeral 1 del artículo 4o. al establecer que "1. Deberán adoptarse las medidas especiales que se precisen para salvaguardar las personas, las instituciones, los bienes, el trabajo, las culturas y el medio ambiente de los pueblos interesados"; los numerales 3 y 4 del artículo 7o. que establecen que: “3. Los gobiernos deberán velar por que, siempre que haya lugar, se efectúen estudios, en cooperación con los pueblos interesados, a fin de evaluar la incidencia social, espiritual y cultural y sobre el medio ambiente que las actividades de desarrollo previstas puedan tener sobre esos pueblos. Los resultados de estos estudios deberán ser considerados como criterios fundamentales para la ejecución de las actividades mencionadas; 4. Los gobiernos deberán tomar medidas, en cooperación con los pueblos interesados, para proteger y preservar el medio ambiente de los territorios que habitan", y el artículo 32 que establece que: "los gobiernos deberán tomar medidas apropiadas, incluso por medio de acuerdos internacionales para facilitar los contactos y la cooperación entre pueblos indígenas y tribales a través de las fronteras, incluidas las actividades en las esferas económica, social, cultural, espiritual y del medio ambiente".

11 Destacan los numerales 1 y 2 del artículo 15 que al efecto establecen: " 1 . Los derechos de los pueblos interesados a los recursos naturales existentes en sus tierras deberán protegerse especialmente. Estos derechos comprenden el derecho de esos pueblos a participar en la utilización, administración y conservación de dichos recursos. 2. En caso de que pertenezca al Estado la propiedad de los minerales o de los recursos del subsuelo, o tenga derechos sobre otros recursos existentes en las tierras, los gobiernos deberán establecer o mantener procedimientos con miras a consultar a los pueblos interesados, a fin de determinar si los intereses de esos pueblos serían perjudicados y en qué medida, 
Esta obra forma parte del acervo de la Biblioteca Jurídica Virtual del Instituto de Investigaciones Jurídicas de la UNAM

a lo ambiental como es el caso de la salud. ${ }^{12}$ Otro ejemplo lo constituye la recientemente aprobada Declaración de las Naciones Unidas sobre los Derechos de los Pueblos Indígenas, instrumento jurídico no vinculante o de derecho suave (soft law). En esta declaración se establecen de manera expresa pocas pero importantes disposiciones relacionadas con el ambiente, ${ }^{13}$ un número amplio de enunciados sobre recursos naturales tanto de manera genérica como específica ${ }^{14}$ y una muy variada normativa vinculada a la materia de salud y otros temas relacionados. Desde el área de lo ambiental mencionamos el Convenio sobre Diversidad Biológica de 1992,15 instrumento jurídico vinculante que inserta el contenido indígena

antes de emprender o autorizar cualquier programa de prospección o explotación de los recursos existentes en sus tierras. Los pueblos interesados deberán participar siempre que sea posible en los beneficios que reporten tales actividades, y percibir una indemnización equitativa por cualquier daño que puedan sufrir como resultado de esas actividades".

12 Mencionamos, entre otras más, los numerales 1 y 2 del artículo 25: “1. Los gobiernos deberán velar porque se pongan a disposición de los pueblos interesados servicios de salud adecuados o proporcionar a dichos pueblos los medios que les permitan organizar y prestar tales servicios bajo su propia responsabilidad y control, a fin de que puedan gozar del máximo nivel posible de salud física y mental; 2 . Los servicios de salud deberán organizarse, en la medida de lo posible, a nivel comunitario. Estos servicios deberán planearse y administrarse en cooperación con los pueblos interesados y tener en cuenta sus condiciones económicas, geográficas, sociales y culturales, así como sus métodos de prevención, prácticas curativas y medicamentos tradicionales".

13 Se establece en el numeral 1 del artículo 29 lo siguiente: "1. Los pueblos indígenas tienen derecho a la conservación y protección del medio ambiente y de la capacidad productiva de sus tierras o territorios y recursos. Los Estados deberán establecer y ejecutar programas de asistencia a los pueblos indígenas para asegurar esa conservación y protección, sin discriminación alguna".

14 Mencionamos los ejemplos del artículo 25 que dispone: "Los pueblos indígenas tienen derecho a mantener y fortalecer su propia relación espiritual con las tierras, territorios, aguas, mares costeros, y otros recursos que tradicionalmente han poseído u ocupado y utilizado de otra forma y a asumir las responsabilidades que a ese respecto les incumben para con las generaciones venideras", y el numeral 1 del artículo 31: "1. Los pueblos indígenas tienen derecho a mantener, controlar, proteger y desarrollar su patrimonio cultural, sus conocimientos tradicionales, sus expresiones culturales tradicionales y las manifestaciones de sus ciencias, tecnologías y culturas, comprendidos los recursos humanos y genéticos, las semillas, las medicinas, el conocimiento de las propiedades de la fauna y la flora, las tradiciones orales, las literaturas, los diseños, los deportes y juegos tradicionales, y las artes visuales e interpretativas. También tienen derecho a mantener, controlar, proteger y desarrollar su propiedad intelectual de dicho patrimonio cultural, sus conocimientos tradicionales y sus expresiones culturales tradicionales".

15 El texto completo e íntegro (copia fiel y completa) del Convenio sobre la Diversidad Biológica adoptado en Río de Janeiro, Brasil en junio de 1992, puede consultarse en 
Esta obra forma parte del acervo de la Biblioteca Jurídica Virtual del Instituto de Investigaciones Jurídicas de la UNAM

a temas ligados con lo ambiental como lo es el de la conservación y utilización sostenible de la diversidad biológica por las comunidades indígenas (aunque valdría la pena comentar que de la lectura de esta disposición no queda del todo claro que se trate en estricto sentido de un derecho). ${ }^{16}$ Como ejemplos de instrumentos no vinculantes mencionamos por un lado la Declaración de Río sobre el Medio Ambiente y el Desarrollo, y por el otro la Agenda 21 o Programa 21, ambos emanados de la Conferencia de las Naciones Unidas sobre el Medio Ambiente y el Desarrollo celebrada en Río de Janeiro, Brasil, en 1992. En el primer caso, se establece en el principio 22 el papel que tienen los grupos indígenas con el ambiente y con el desarrollo sustentable (se trata de un enunciado a modo de guía o lineamiento más que de un derecho propiamente), ${ }^{17}$ y para el segundo, se crea todo un capítulo - el número 26 (la Agenda 21 está conformada por 40 capítulos) - en el que se vincula el reconocimiento y fortalecimiento de las poblaciones y comunidades indígenas a temas expresos sobre el ambiente, los recursos naturales y el desarrollo sustentable (aquí se alude a los derechos de los indígenas como derechos humanos, se enfatiza en la importancia de plasmarlos en la legislación doméstica de los países y se invoca la trascendencia del convenio 169 de la OIT y la Declaración Universal de los Pueblos Indígenas y Tribales en ese entonces todavía no aprobada). ${ }^{18}$

el Diario Oficial de la Federación del 7 de mayo de 1993 (día, mes y año en el que fue publicado).

16 Establece el inciso j del artículo 8o. lo siguiente: “Artículo 8. Conservación in situ. Cada Parte Contratante, en la medida de lo posible y según proceda: j) Con arreglo a su legislación nacional, respetará, preservará y mantendrá los conocimientos, las innovaciones y las prácticas de las comunidades indígenas y locales que entrañen estilos tradicionales de vida pertinentes para la conservación y la utilización sostenible de la diversidad biológica y promoverá su aplicación más amplia, con la aprobación y la participación de quienes posean esos conocimientos, innovaciones y prácticas, y fomentará que los beneficios derivados de la utilización de esos conocimientos, innovaciones y prácticas se compartan equitativamente".

17 Señala el principio 22 de la declaración de Río lo siguiente: "Las poblaciones indígenas y sus comunidades, así como otras comunidades locales, desempeñan un papel fundamental en la ordenación del medio ambiente y en el desarrollo debido a sus conocimientos y prácticas tradicionales. Los Estados deberían reconocer y apoyar debidamente su identidad, cultura e intereses y hacer posible su participación efectiva en el logro del desarrollo sostenible".

18 Se establece al inicio del capitulo 26 lo siguiente: “26.1. Las poblaciones indígenas y sus comunidades han establecido una relación histórica con sus tierras y suelen ser, 
Esta obra forma parte del acervo de la Biblioteca Jurídica Virtual del Instituto de Investigaciones Jurídicas de la UNAM

En su dimensión nacional, lo indígena y lo ambiental convergen, como ya lo hemos señalado, en el artículo 2o. constitucional. En él se establecen derechos indígenas relativos tanto a temas que se encuentran estrechamente vinculados con lo ambiental (tal es el caso de la conservación y mejoramiento del hábitat y de la preservación de la integridad de sus tierras) como a temas sobre recursos naturales de manera genérica (en particular, el acceso al uso y disfrute preferente de los recursos naturales). Aunque existen otros preceptos constitucionales donde prevalece la duda si estamos o no frente a derechos indígenas, en definitiva se trata de preceptos indígenas con contenido ambiental; el tema que se encuentra estrechamente vinculado a lo ambiental dentro de la normativa indígena en este sentido se refiere al de la sustentabilidad, en concreto a la obligación de las autoridades para apoyar las actividades productivas y el desarrollo sustentable de las comunidades indígenas a través de acciones que "permitan alcanzar la suficiencia de sus ingresos económicos, la aplicación de estímulos para las inversiones públicas y privadas que propicien la creación de empleos, la incorporación de tecnologías para incrementar su propia capacidad productiva, así como para asegurar el acceso equitativo a los sistemas de abasto y comercialización". ${ }^{19}$

En las leyes nacionales se han desarrollado algunos de estos preceptos constitucionales desde las ópticas indígena y ambiental. Así, por ejemplo, encontramos ciertas disposiciones indígenas (aunque no se trate en estricto rigor de derechos sino de principios) vinculadas a los recursos

en general, descendientes de los habitantes originales de esas tierras. En el contexto del presente capítulo, se sobreentiende que el término "tierras" abarca el medio ambiente de las zonas que esas poblaciones ocupan tradicionalmente. Las poblaciones indígenas y sus comunidades representan un porcentaje importante de la población mundial. Durante muchas generaciones han acumulado conocimientos científicos tradicionales holísticos de sus tierras, sus recursos naturales y el medio ambiente. Las poblaciones indígenas y sus comunidades habrán de disfrutar a plenitud de los derechos humanos y las libertades fundamentales sin trabas ni discriminación. Su posibilidad de participar plenamente en las prácticas de desarrollo sostenible en sus tierras ha tendido a verse limitada como resultado de factores de índole económica, social e histórica. Habida cuenta de la relación recíproca existente entre el medio natural y su desarrollo sostenible y el bienestar cultural, social, económico y físico de las poblaciones indígenas, en las actividades nacionales e internacionales encaminadas a lograr un desarrollo ecológicamente racional y sostenible se debería reconocer, promover y fortalecer el papel de las poblaciones indígenas y sus comunidades, y darle cabida". El documento completo puede consultarse en http:// www.un.org/esa/sustdev/documents/agenda21/spanish/agenda21spchapter $26 . \mathrm{htm}$.

${ }^{19}$ Véase el artículo 2o., apartado B, fracción VII, de nuestra carta magna. 
Esta obra forma parte del acervo de la Biblioteca Jurídica Virtual del Instituto de Investigaciones Jurídicas de la UNAM

naturales, tal y como sucede con la Ley de la Comisión Nacional para el Desarrollo de los Pueblos Indígenas. ${ }^{20}$ Algo semejante ocurre desde la óptica de lo ambiental en la que encontramos diversas disposiciones —algunas relativas a derechos- que permiten identificar el punto de encuentro entre lo indígena y lo ambiental. Son los casos concretos de la Ley de Bioseguridad de Organismos Genéticamente Modificados que incorpora el derecho de consulta y participación que tienen los pueblos y comunidades indígenas para los casos en que se liberen organismos genéticamente modificados en las zonas donde se encuentren asentados, ${ }^{21}$ y de la Ley General del Equilibrio Ecológico y Protección al Ambiente que establece que para la preservación y aprovechamiento sustentable de la flora y fauna silvestre habrán de tomarse en cuenta el conocimiento tradicional y la participación de los pueblos indígenas. ${ }^{22}$

También encontramos disposiciones en las que se mezclan diversas áreas temáticas. Tal es el caso de la Ley de Desarrollo Rural Sustentable que desarrolla desde la óptica de lo agrario o rural los derechos de los pueblos indígenas - pero sin mencionar a las comunidades indígenas-

20 En este sentido, la ley establece en su artículo 3o., fracción IV, que la Comisión Nacional para el Desarrollo de los Pueblos Indígenas - cuyo objeto es el de llevar acciones como la de orientar, coordinar, promover, apoyar, fomentar, dar seguimiento y evaluar programas, proyectos, estrategias, etcétera, para el desarrollo integral y sustentable de los pueblos y comunidades indígenas - se rige bajo el siguiente principio "Fomentar el desarrollo sustentable para el uso racional de los recursos naturales de las regiones indígenas sin arriesgar el patrimonio de las generaciones futuras". Esta ley fue publicada en el Diario Oficial de la Federación el 21 de mayo de 2003.

21 Es la Comisión Intersecretarial sobre Bioseguridad de los Organismos Genéticamente Modificados (Cibiogem) — cuyo objeto es el de formular y coordinar las políticas de la administración pública federal relativas a la bioseguridad de los organismos genéticamente modificados - la encargada de actualizar estos derechos indígenas tal y como lo dispone el párrafo tercero del artículo 108 que al efecto establece: "La Cibiogem, además, realizará los estudios y las consideraciones socioeconómicas resultantes de los efectos de los OGMs que se liberen al ambiente en el territorio nacional, y establecerá los mecanismos para realizar la consulta y participación de los pueblos y comunidades indígenas asentadas en las zonas donde se pretenda la liberación de OGMs, considerando el valor de la diversidad biológica”. Esta ley fue publicada en el Diario Oficial de la Federación el 18 de marzo de 2005.

22 La ley que aquí se cita establece en su artículo 79, fracción X, lo siguiente: “Artículo 79.- Para la preservación y aprovechamiento sustentable de la flora y fauna silvestre, se considerarán los siguientes criterios: X.- El conocimiento biológico tradicional y la participación de las comunidades; así como los pueblos indígenas en la elaboración de programas de biodiversidad de las áreas en que habiten". 
Esta obra forma parte del acervo de la Biblioteca Jurídica Virtual del Instituto de Investigaciones Jurídicas de la UNAM

en la utilización y apropiación de la biodiversidad y de los recursos genéticos. ${ }^{23}$

\section{EL ACCESO AL USO Y DISFRUTE PREFERENTE DE LOS RECURSOS NATURALES}

En el apartado anterior se hizo mención a los diferentes contenidos ambientales de los derechos indígenas y de otras disposiciones en la normativa indígena, que se encuentran consagrados en nuestra Constitución. Aparece entre ellos el tema que abordamos en este apartado: el derecho a acceder al uso y disfrute preferente de los recursos naturales.

\section{Historia clínica}

Cualquier análisis histórico que se haga en México en relación con los derechos indígenas sobre los recursos naturales desde el texto constitucional vigente debe comenzar por una fecha - célebre para unos, desastrosa para otros - en la que se dio a conocer por vez primera en la arena pública el Ejército Zapatista de Liberación Nacional (EZLN): el 1o. de enero de 1994. En efecto, al conflicto iniciado a partir de ese año entre este grupo armado (mayoritariamente indígena) y el gobierno federal se le atribuyen los orígenes de los actuales preceptos indígenas sobre recursos naturales.

Dichos preceptos, que como ya hemos mencionado, forman parte integral de una reforma más amplia en materia de derechos y cultura indígenas llevada a cabo en 2001 a nuestra Constitución, tuvieron como base los Acuerdos de San Andrés (ASA) celebrados en 1996 entre las dos partes en conflicto. La revuelta en Chiapas emerge así como antecedente primerísimo en el análisis de los derechos indígenas a lo que se conoce ahora como el acceso al uso y disfrute preferente de los recursos natu-

23 Esta ley establece expresamente en su artículo 176 que: "Los núcleos agrarios, los pueblos indígenas y los propietarios podrán realizar las acciones que se admitan en los términos de la presente Ley, de la Ley General del Equilibrio Ecológico y la Protección al Ambiente, Ley General de Vida Silvestre y de toda la normatividad aplicable sobre el uso, extracción, aprovechamiento y apropiación de la biodiversidad y los recursos genéticos". La ley fue publicada en el Diario Oficial de la Federación el 7 de diciembre de 2001 . 
Esta obra forma parte del acervo de la Biblioteca Jurídica Virtual del Instituto de Investigaciones Jurídicas de la UNAM

rales consagrado en el artículo 2o., apartado A, fracción VI, de nuestra Constitución.

En el recuento histórico sobre este tema debemos mencionar los tres documentos más importantes e influyentes del texto constitucional arriba aludido. Estos son:

i) Los Acuerdos de San Andrés Larráinzar (firmados el 16 de febrero de 1996 entre el EZLN y el gobierno federal).

ii) La iniciativa de ley de la Comisión de Concordia y Pacificación conocida comúnmente como "ley Cocopa" (elaborada y presentada por representantes legislativos de los tres partidos políticos mayoritarios en noviembre de 1996).

iii) El decreto respectivo que reforma diversos artículos de la Constitución y que contiene el texto constitucional actual del artículo 2o., apartado A, fracción VI, desde 2001.

La parte relativa al tema específico que nos ocupa (i. e. los derechos indígenas a los recursos naturales) es la siguiente:

i) Acuerdos de San Andrés Larráinzar: ${ }^{24}$

II.6.- Se propone al Congreso de la Unión y a las legislaturas de los estados...

d) acceder de manera colectiva al uso y disfrute de los recursos naturales, salvo aquellos cuyo dominio directo corresponda a la Nación;

III.6.- Se debe buscar el reconocimiento, en el sistema jurídico mexicano, federal y estatal, del derecho de los pueblos indígenas al uso sostenible $\mathrm{y}$ a todos los beneficios derivados del uso y aprovechamiento de los recursos naturales de los territorios que ocupan o utilizan de alguna manera para que, en un marco de desarrollo global, se supere el atraso económico y el aislamiento, lo que implica también un aumento y reorientación del gasto social.

24 Para mayor referencia sobre el contenido de estos acuerdos, véase González, Dolores, "Implicaciones de la reforma sobre derechos indígenas aprobada en el Congreso", Cuadro comparativo entre los derechos del Convenio 169 de la OIT, la iniciativa Cocopa, los Acuerdos de San Andrés y el dictamen de reforma constitucional aprobado por el Senado de la República el 25 de abril de 2001, México, Centro de Derechos Humanos Miguel Agustín Pro Juárez, A.C.-SERAPAZ, 17 de mayo de 2001, http://www.centropro dh.org.mx. 
Esta obra forma parte del acervo de la Biblioteca Jurídica Virtual del Instituto de Investigaciones Jurídicas de la UNAM

IV.2.- Los distintos niveles de gobierno e instituciones del Estado mexicano no intervendrán unilateralmente en los asuntos y decisiones de los pueblos y comunidades indígenas, en sus organizaciones y forma de representación y en sus estrategias vigentes de aprovechamiento de los recursos.

IV.3.- Sustentabilidad. Es indispensable y urgente asegurar la perduración de la naturaleza y la cultura en los territorios de los pueblos indígenas. Se impulsará el reconocimiento, en la legislación, del derecho de los pueblos y comunidades indígenas a recibir la indemnización correspondiente, cuando la explotación de los recursos naturales que el Estado realice, ocasione daños en su hábitat que vulneren su reproducción cultural...

V.1.- Por ello, proponemos que estas reformas deberán contener, entre otros, los siguientes aspectos generales:

c) En materia de recursos naturales, reglamentar un orden de preferencia que privilegie a las comunidades indígenas en el otorgamiento de concesiones para obtener los beneficios de la explotación y aprovechamiento de los recursos naturales;

\section{ii) Ley Cocopa: ${ }^{25}$}

\section{Artículo 4o...}

Los pueblos indígenas tienen el derecho a la libre determinación y, como expresión de ésta a la autonomía como parte del Estado mexicano para:

V.- Acceder de manera colectiva al uso y disfrute de los recursos naturales de sus tierras y territorios, entendidos éstos como la totalidad del hábitat que los pueblos indígenas usan u ocupan, salvo aquellos cuyo dominio directo corresponde a la Nación;

iii) Decreto de reformas a la Constitución de 2001:26

Artículo 2o...

A. Esta Constitución reconoce y garantiza el derecho de los pueblos y las comunidades indígenas a la libre determinación y, en consecuencia, a la autonomía para:

25 Véase Ejército Zapatista de Liberación Nacional, Reformas constitucionales propuestas de la Comisión de Concordia y Pacificación, 29 de noviembre de 1996, México, Ejército Zapatista de Liberación Nacional, s.f., http://www.ezln.org/san_andres/coco pa961129-sp.html.

26 El texto que se transcribe se puede consultar en la Constitución Política de los Estados Unidos Mexicanos vigente. 
Esta obra forma parte del acervo de la Biblioteca Jurídica Virtual del Instituto de Investigaciones Jurídicas de la UNAM

VI. Acceder, con respeto a las formas y modalidades de propiedad y tenencia de la tierra establecidas en esta Constitución y a las Leyes de la materia, así como a los derechos adquiridos por terceros o por integrantes de la comunidad, al uso y disfrute preferente de los recursos naturales de los lugares que habitan y ocupan las comunidades, salvo aquellos que corresponden a las áreas estratégicas, en términos de esta Constitución. Para estos efectos las comunidades podrán asociarse en términos de ley.

Como es fácil advertir, existen similitudes y discrepancias entre los tres textos transcritos. Detectamos al menos cuatro diferencias que vale la pena mencionar aunque sea de manera sucinta. Primero, en materia de preferencia mientras que por un lado los ASA y el decreto de 2001 sí establecen un orden preferencial y no así la ley Cocopa, por el otro, dicha preferencia en el decreto aludido determina una serie de limitantes o salvedades que ponen en duda la factibilidad de actualizar este derecho indígena. Segundo, si bien tanto en los ASA como en la ley Cocopa se habla del concepto de territorios (la ley Cocopa incluye la voz tierras), el texto constitucional no lo hace y se refiere en cambio a los lugares que habitan y ocupan los indígenas. Tercero, mientras que la ley Cocopa establece textualmente que el acceso a los recursos naturales habría de ser de manera colectiva, nuestra Constitución en la parte respectiva elimina esa posibilidad. Por último, aunque el encabezado del apartado A del artículo 2o. constitucional se refiera tanto a pueblos como a comunidades indígenas cuando les reconoce y garantiza el derecho a la libre determinación $\mathrm{y}$, en consecuencia, a la autonomía, omite la referencia a pueblos y deja sólo el de comunidades; mientras tanto, los ASA aluden a ambos y la ley Cocopa en el texto respectivo se refiere expresamente a pueblos y no a comunidades.

De manera tal que la reforma de 2001 es una reforma que recoge parcialmente lo establecido en los ASA y en la ley Cocopa, e incluso discrepa de la esencia de muchas disposiciones establecidas en ambos documentos. De aquí que la reforma desde este punto de vista no sea otra cosa sino el reflejo de una historia sobre un conflicto (entre el EZLN y el Estado mexicano) que no termina por resolverse. Es, en el mejor de los casos, una reforma inacabada que ni siquiera supo plasmar en sus líneas las aspiraciones legítimas de los pueblos indios de este país a sus recursos naturales. 
Esta obra forma parte del acervo de la Biblioteca Jurídica Virtual del Instituto de Investigaciones Jurídicas de la UNAM

\section{Razonamientos sobre lo que constituye} un precepto constitucional virtual

Aunque los ASA y la ley Cocopa hayan sido la base sobre la que se redactó el texto constitucional vigente, la distancia que éste guarda con su antecesoras deriva en implicaciones jurídicas importantes. El contenido que aparece en el precepto constitucional actual se traduce en que los derechos indígenas sobre los recursos naturales fundamentados en la idea del reconocimiento, garantía y acceso preferente de los pueblos y comunidades indígenas son en sí mismos virtuales. Es decir, el derecho indígena ambiental de acceso preferente a los recursos naturales que se establece en nuestra Constitución tiene una existencia aparente, no real.

La afirmación anterior se sustenta en dos reflexiones fundamentales. Primero, se alude al hecho de que el encabezado del apartado A donde se encuentra la fracción que estamos analizando (i.e. la fracción VI) comienza por reconocer y garantizar en el marco de la libre determinación, y en consecuencia, a la autonomía, una serie de derechos de los dos sujetos identificados por la propia Constitución como los titulares de los mismos: los pueblos y comunidades indígenas; sin embargo, la fracción VI no se refiere de manera expresa en ningún momento a uno de esos dos sujetos, esto es, a los pueblos indígenas.

Por lo que en principio se trata sólo de un derecho de las comunidades indígenas (que como veremos más adelante está sujeto asimismo a una serie de limitantes). Esto crea cierta confusión puesto que si bien la disposición en cuestión se refiere a las comunidades (y no a los pueblos) el encabezado del apartado sí habla de ambos conceptos. De cualquier modo, esto implica que el acceso al uso y disfrute preferente de los recursos naturales está diseñado sólo a nivel comunitario negando de esta manera la dimensión (cultural y de mayor amplitud) de los pueblos indígenas como sujetos de sus propios derechos. ${ }^{27}$

Segundo, al confrontar los textos de los ASA y de la ley Cocopa con el texto del artículo 2o., apartado A, fracción VI, detectamos una serie de supuestos - a los que en otra ocasión hemos llamado salvedades o limitantes -28 que parecieran estar dirigidos a confundir y/o dificultar el ejercicio del derecho indígena ambiental basado en la idea de una preferencia

27 Véase, en este sentido, González, Dolores, op. cit., nota 24.

28 Véase Nava Escudero, César, "La primera reforma constitucional ambiental del nuevo milenio: el acceso de los pueblos indios a los recursos naturales", cit., nota 9, p. 439. 
Esta obra forma parte del acervo de la Biblioteca Jurídica Virtual del Instituto de Investigaciones Jurídicas de la UNAM

reconocida y garantizada para las comunidades indígenas (recordemos que la existencia de ése derecho para pueblos indígenas es virtual). Estas cinco limitantes se refieren a lo siguiente:

1) Se deberán respetar las formas y modalidades de propiedad y tenencia de la tierra establecidas en la Constitución y leyes de la materia. Esta idea pretende ignorar que una de las causas que originó el conflicto está vinculado precisamente a las cuestiones agrarias. Esto que es en sí mismo muy grave, rompe con cualquier intento de otorgar preferencia a los indígenas ante problemas preexistentes de este tipo.

2) Se deberán respetar los derechos adquiridos por terceros o por integrantes de la comunidad. Es claro que el legislador privilegió lo ya otorgado, es decir, los derechos ya adquiridos por quienes preceden en todo momento a cualquier pretensión indígena. Esto que desde luego es una forma de conservar un statu quo jurídico preestablecido (o algunos dirían el Estado de derecho) redunda en hacer irreal la idea misma de preferencia. ${ }^{29}$

3) Deberá tratarse de los lugares que habitan y ocupan las comunidades. Aquí existen dos situaciones distintas. La primera se refiere a la enorme vaguedad y confusión que significa el lugar que habiten $\mathrm{u}$ ocupen los indígenas. Subyace en esta disposición el no querer reconocer el ámbito espacial de validez de la normativa indígena en un territorio. Segundo, al hacer mención expresa sólo de las comunidades, se elimina de plano - habremos de reiterar- el concepto de pueblos.

4) No podrán tener dicho acceso cuando se trate de áreas estratégicas. En esta limitante, el legislador tuvo mucho cuidado en no dejar que fueran los propios indígenas los que pudieran beneficiarse de recursos naturales que desde luego podrían representar grandes ganancias económicas desde cualquier actividad que se llegara a realizar. Sin decirlo, la reforma constitucional protege intereses de gran capital.

29 De manera tal que los titulares de actos administrativos como concesiones o asignaciones para el uso y disfrute de ciertos recursos naturales no sólo mantendrán sus derechos intactos sino que, en caso de que quisieran prorrogar dichos actos administrativos según sea el caso, tendrían en todo momento la posibilidad de hacerlo de manera preferente. 
Esta obra forma parte del acervo de la Biblioteca Jurídica Virtual del Instituto de Investigaciones Jurídicas de la UNAM

Para entender el alcance de esta disposición es necesario acudir al artículo 28 de nuestra carta magna donde se hace mención expresa de las áreas que se consideran como estratégicas en las que el Estado ejerce de manera exclusiva sus funciones sin que ello constituya un monopolio, como lo son el petróleo, los demás hidrocarburos, petroquímica básica, minerales radiactivos, etcétera. Pero el listado que da la Constitución no es el único que habrán de conocer bien los grupos indígenas en caso de que quisieran tener ese uso y disfrute de los recursos naturales, ya que el propio texto constitucional abre la posibilidad de que otros recursos naturales sean considerados como áreas estratégicas según lo llegara a señalar expresamente una ley que expida el Congreso de las Unión. No podemos cerrar los ojos al hecho de que es precisamente en la entidad federativa donde ha ocurrido el conflicto, $i$. e. el estado de Chiapas, donde se encuentran una gran cantidad de recursos naturales tan importantes como el petróleo, gas natural, uranio, entre otros.

5) Para todo lo anterior, las comunidades podrán asociarse en términos de ley. Este enunciado debe leerse conjuntamente con el último párrafo del apartado A en el que se establece que las comunidades indígenas son entidades de interés público y no entidades de derecho público o autoridades del propio Estado mexicano. De esta manera, las comunidades indígenas carecen de personalidad jurídica propia y son entidades sujetas a la tutela y protección del Estado, es decir, son órganos subordinados o tutelados por el Estado. ${ }^{30} \mathrm{Si}$ bien el que los indígenas fueran considerados como autoridades dentro del Estado mexicano ha sido una de las principales demandas de los pueblos indios que decidieron levantarse en armas, lo cierto es que las comunidades indígenas existen de manera aparente. En otras palabras, para que dichas comunidades dejen de ser virtuales es necesario que acrediten su personalidad jurídica ante la autoridad o instancia correspondiente. Cabe mencionar que el camino que deben recorrer las comunidades indígenas para que sean reconocidas como tales por las Constituciones y leyes locales es largo y complicado.

30 En ése sentido, véase González Galván, Jorge A., "La validez del derecho indígena en el derecho nacional", en Carbonell, Miguel y Pérez Portilla, Karla (coords.), Comentarios a la reforma constitucional en materia indígena, México, UNAM, Instituto de Investigaciones Jurídicas, 2002, p. 44. 
Esta obra forma parte del acervo de la Biblioteca Jurídica Virtual del Instituto de Investigaciones Jurídicas de la UNAM

\section{REFLEXIÓN FINAL}

Nos parece que el derecho indígena ambiental de acceso al uso y disfrute preferente de los recursos naturales establecido en el artículo 2o., apartado A, fracción VI, es un precepto constitucional virtual por dos razones.

Lo es en primer lugar en la medida en que si la propia Constitución reconoce que los sujetos de los derechos indígenas son los pueblos y las comunidades indígenas, y que la fracción que se refiere al acceso a los recursos naturales está dentro del apartado A cuyo encabezado reconoce y garantiza derechos de ambos conceptos, no debería quedar duda alguna de que dicha fracción aplica a ambos conceptos; sin embargo, de la lectura cuidadosa del texto constitucional se deriva que el derecho indígena ambiental sobre acceso a los recursos naturales es sólo de las comunidades indígenas y no de los pueblos indígenas.

Lo es en segundo lugar porque si el precepto en cuestión establece un sistema de preferencia para los indígenas en la actualización de ese derecho, no debieran existir tantos obstáculos o salvedades para su debido ejercicio. En efecto, detectamos al menos cinco limitantes de tal magnitud que desaparece de facto toda posibilidad de que los titulares de ese derecho indígena ambiental (que sólo son las comunidades indígenas) tengan realmente una preferencia sobre el uso y disfrute de los recursos naturales. 
Esta obra forma parte del acervo de la Biblioteca Jurídica Virtual del Instituto de Investigaciones Jurídicas de la UNAM

\section{EL TURISMO SUSTENTABLE EN LA CONSTITUCIÓN*}

\section{SOBRE LO SUSTENTABLE}

\section{Generalidades}

La palabra sustentable, como es utilizada en el contexto constitucional de nuestros días, se refiere a lo que entraña comúnmente la expresión desarrollo sustentable. Existe cierta discusión académica respecto a si el vocablo "sostenible" es el que debiera utilizarse en vez del de "sustentable", en virtud de que cada uno tiene un significado propio y se identifica con un discurso distinto. Pero con todo y que este debate encierre algún tipo de trascendencia para comprender lo que representa cada una de estas nociones, lo cierto es que a nivel internacional - particularmente en el seno de las Naciones Unidas - se ha preferido el de sostenible, y a nivel doméstico - en México - se ha privilegiado, tanto en nuestra carta magna como en nuestra legislación, el de sustentable. ${ }^{1}$

El concepto de desarrollo sustentable -empleado por vez primera en 1980 en la Estrategia Mundial de la Conservación — $^{2}$ se po-

* Publicado en Revista de la Facultad de Derecho de México, México, t. LXIII, núm. 260, julio-diciembre de 2013.

1 A lo largo de este trabajo se hará referencia a instrumentos internacionales, preceptos constitucionales, y leyes domésticas que corroboran esta distinción. Para una discusión sobre las diferencias entre "sostenibilidad" y "sustentabilidad", recomendamos Leff, Enrique, Saber ambiental: sustentabilidad, racionalidad, complejidad, poder, México, Siglo XXI-PNUMA-UNAM, 1998, pp. 19 y ss.

2 Es reiterada - aunque no absoluta - la afirmación entre diversos autores que tal instrumento internacional fue el que, en efecto, utiliza por primera vez el concepto de desarrollo sustentable, si bien con la particularidad de que el término sustentabilidad se concebía en términos fundamentalmente ecológicos y no económicos o de desarro1lo. Cfr., Jacobs, M., The Green Economy, Londres, Pluto, 1991, p. 58; McManus, Phil, "Sustainable Development", en Johnston, R. J. et al. (eds.), The Dictionary of Human Geography, 4a. ed., Malden, Blackwell, 2000, p. 812; y Soussan, John G., "Sustainable Development", en Mannion, A. M. y Bowlby, S. R. (eds.), Environmental Issues in the 1990s, Chichester, Wiley, 1992, p. 24. La Estrategia Mundial de la Conservación fue 
Esta obra forma parte del acervo de la Biblioteca Jurídica Virtual del Instituto de Investigaciones Jurídicas de la UNAM

pularizó y adquirió la forma y sentido que actualmente tiene a través de un documento al que se le conoce como Nuestro Futuro Común o Informe Brundtland, ${ }^{3}$ presentado en 1987. Este informe fue preparado por la Comisión Mundial sobre Medio Ambiente y Desarrollo a solicitud de la Asamblea General de la Organización de las Naciones Unidas con el propósito de formular una "agenda global para el cambio" en el marco de una serie de preocupaciones sobre diversos aspectos ambientales.

Aunque fueron muchos los temas que se abordaron en aquella ocasión, agrupando a un gran número de individuos y organizaciones participantes, ${ }^{4}$ el Informe Brundtland sentó las bases de discusión sobre el desarrollo sustentable. Si bien fueron numerosas las reflexiones y propuestas elaboradas por la Comisión Brundtland, habría que rescatar de todas ellas dos cuestiones sumamente trascendentales. Primero, se formuló una definición de desarrollo sustentable que ha sido citada en forma abrumadora por la literatura académica a la vez que aceptada de modo amplio por la comunidad internacional: "desarrollo que permita satisfacer las necesidades de las generaciones presentes, sin comprometer la capacidad de las generaciones futuras para satisfacer sus propias necesidades". ${ }^{5} \mathrm{Su}$ esencia supone lograr un balance entre la cuestión ecológico-ambiental, la dimensión sociocultural, y el desarrollo (y crecimiento) económicos. ${ }^{6}$

adoptada por la Unión Internacional para la Conservación de la Naturaleza y sus Recursos (UICN) fundada por la Organización de las Naciones Unidas en 1948 (ahora llamada Unión Mundial para la Naturaleza) en conjunto con el Fondo Mundial para la Naturaleza (WWF) y el Programa de las Naciones Unidas para el Medio Ambiente (PNUMA). Para mayor detalle, Colás Gil, Jaume (coord.), Diccionario ilustrado de ecología y medio ambiente, Barcelona, SPES Editorial, 2002, t. 2, pp. 343 y 344.

3 Se le llama Informe Brundtland porque quien presidió los trabajos para su elaboración fue la entonces primera ministra Noruega Gro Harlem Brundtland.

4 De manera visible, como lo señala el informe, por México participaron José Thiago Cintra, Rolando García, Omar Morrinez-Legerretta y Francisco Székely.

5 La definición primigenia fue presentada en idioma inglés, la cual reproducimos a continuación para darle al lector una idea de su sentido original: "sustainable development is development that meets the needs of the present without compromising the ability of future generations to meet their own needs". Véase World Commission on Environment and Development, Our Common Future, Oxford, Oxford University Press, 1987, p. 43.

6 Al respecto, se ha dicho que la idea misma de sustentabilidad es socialmente deseable, económicamente viable y ecológicamente sustentable. Hens, Luc, "The Rio Conference and Thereafter", en Bhaskar, Nath et al. (comps.), Sustainable Development, Bruselas, Vubpress, 1996, p. 98. 
Esta obra forma parte del acervo de la Biblioteca Jurídica Virtual del Instituto de Investigaciones Jurídicas de la UNAM

Sin embargo, no hay una explicación única sobre su contenido, y las deformaciones y diversas posturas sobre su significación, se han multiplicado. Las distorsiones, extensiones o reducciones que se han hecho, ya sea como resultado de traducciones a idiomas distintos al inglés, ${ }^{7}$ por virtud de una variedad de definiciones planteadas, ${ }^{8}$ o por la inconmensurabilidad de interpretaciones sobre sus alcances, ${ }^{9}$ han provocado que el desarrollo sustentable sea un concepto all-inclusive. ${ }^{10}$ Esto es, todo cabe en él y todo puede caracterizarse con él.

En un sentido, tiende puentes entre los discursos de los países del norte y del sur, acerca ideologías de izquierda y de derecha, permite vínculos interdisciplinarios entre diversos saberes, simpatiza con el ambientalismo, adjetiva actividades y fenómenos como lo hace con el turismo. En otro sentido, por la vaguedad que guarda su significado, falla en ofrecer una redefinición puntual para lograr un cambio en los patrones de crecimiento económico, y su uso y abuso sirve para enmascarar intereses privados y financieros contrarios a los temas de mayor preocupación en materia ambiental. Sin duda, el término se ha prostituido, y con esto, el discurso de políticos, organizaciones e individuos. Al invocarlo, farsantes, anti-ambientalistas, inconscientes y oportunistas se convierten en fariseos del saber ambiental.

La segunda cuestión es que la Comisión Brundtland instó a la Organización de las Naciones Unidas a convocar una gran conferencia en donde se abordaran los temas de ambiente y desarrollo. El resultado de esta

7 Esta situación ya habría sido detectada desde mediados de la década de los noventa del siglo pasado. Para algunos ejemplos, como el caso del búlgaro y el eslavo, acúdase a Nath, Bhaskar y Talay, Ilkden, "Man, Science, Technology and Sustainable Development", en Bhaskar, Nath et al. (comps.), op. cit., nota anterior, pp. 36 y 37.

8 Una buena discusión sobre si existe o no consenso en el significado de desarrollo sustentable, y para conocer sobre un buen número de definiciones, véase Pearce, David et al., Blueprint for a Green Economy, Londres, Earthscan, 1989.

9 Así lo enfatiza McManus, Phil, "Sustainable development", en Johnston, R. J. et al. (eds.), The Dictionary..., cit., p. 812. Este mismo autor ha identificado nueve posturas diferentes sobre el concepto de desarrollo sustentable que van, desde la formulada por la propia Comisión Brundtland, hasta las elaboradas por corrientes de pensamiento como el eco-feminismo, el eco-marxismo o el ambientalismo de libre mercado. Véase McManus, Phil, "Contested Terrains: Politics, Stories and Discourses of Sustainability", Environmental Politics, vol. 5, núm. 1, primavera de 1996, pp. 48-73.

10 Véase lo que al respecto hemos señalado en Nava Escudero, César, Ciencia, ambiente y derecho, México, UNAM, Instituto de Investigaciones Jurídicas, 2012, pp. 237 y 238 . 
Esta obra forma parte del acervo de la Biblioteca Jurídica Virtual del Instituto de Investigaciones Jurídicas de la UNAM

convocatoria fue la celebración de la Conferencia de las Naciones Unidas sobre el Medio Ambiente y el Desarrollo en Río de Janeiro, Brasil, en 1992. A partir de esta conferencia - también conocida como Cumbre de la Tierra- el concepto de desarrollo sustentable se consagró como un referente "obligado" en prácticamente toda discusión internacional sobre temas ambientales.

En efecto, no únicamente los instrumentos internacionales emanados de esta conferencia, ${ }^{11}$ y los que les han sucedido con los años, ${ }^{12}$ han hecho mención de la idea de la sustentabilidad, sino que las dos conferencias posteriores de seguimiento, i. e. las conocidas como Río+10 de 2002 y Río+20 de 2012, han llevado por título tal expresión. ${ }^{13}$ Aún más, la propia Corte Internacional de Justicia se ha referido a este concepto reconociendo su relevancia como norma emergente del derecho ambiental. Lo anterior, de manera específica en el caso paradigmático de GabcíkovoNagymaros con fallo de 25 de septiembre de 1997.14

11 Fueron cinco instrumentos jurídicos los que se refieren a la idea de la sustentabilidad: tres no vinculantes que incluyen la Declaración de Río sobre el Medio Ambiente y Desarrollo, la Agenda 21 (también conocida como Progama 21) y la Declaración Autorizada, sin Fuerza Jurídica Obligatoria, de Principios para un Consenso Mundial respecto de la Ordenación, la Conservación y el Desarrollo Sostenible de los Bosques de Todo Tipo (conocida como Principios Forestales), y dos vinculantes que son el Convenio sobre la Diversidad Biológica y la Convención Marco de las Naciones Unidas sobre el Cambio Climático.

12 Por ejemplo, podemos referirnos a los protocolos adoptados de los dos instrumentos jurídicos vinculantes emanados de la conferencia de Río. Por un lado, el Protocolo de Cartagena sobre Seguridad de la Biotecnología del Convenio sobre la Diversidad Biológica de 1997, y el Protocolo de Nagoya sobre Acceso a los Recursos Genéticos y Participación Justa y Equitativa en los Beneficios derivados de su Utilización al Convenio sobre la Diversidad Biológica de 2010. Por el otro, el Protocolo de Kyoto de la Convención Marco de las Naciones Unidas sobre el Cambio Climático de 1997.

13 Nos referimos, respectivamente, a la Cumbre Mundial sobre el Desarrollo Sostenible, celebrada en Johannesburgo, Sudáfrica, en agosto de 2002, y a la Conferencia de las Naciones Unidas sobre el Desarrollo Sostenible celebrada en Río de Janeiro, Brasil, en junio de 2012.

14 Se considera el primer caso propiamente ambiental que se somete a la jurisdicción de la Corte Internacional de Justicia (presentado el 2 de julio de 1993) a partir de un conflicto entre Eslovaquia y Hungría respecto a un proyecto para la construcción de presas, canales, plantas hidroeléctricas y otras obras sobre el Río Danubio orientadas a una mayor producción de electricidad, protección contra inundaciones del río, desarrollo de sistemas de riego, protección ambiental y mejoramiento de la navegación fluvial. Para un resumen sobre este caso recomendamos acudir a López-Bassols, Hermilo, Los nuevos desarrollos del derecho internacional público, 3a. ed., México, Porrúa, 2008, pp. 516- 
Esta obra forma parte del acervo de la Biblioteca Jurídica Virtual del Instituto de Investigaciones Jurídicas de la UNAM

Al convertirse lo sustentable en un epíteto inseparable del derecho internacional ambiental, muchos países la han adoptado en sus sistemas jurídicos, y México no ha sido la excepción a esta circunstancia. El ordenamiento jurídico mexicano de los últimos años ha evolucionado bajo la influencia del uso que realiza la comunidad internacional de este concepto, por lo que hoy es común encontrarlo en un sinnúmero de disposiciones jurídicas nacionales incluyendo, desde luego, a nuestra propia ley fundamental. Sobre esta última cuestión es correcto señalar que el proceso de constitucionalización de lo sustentable comenzó hacia finales de la década de los noventa del siglo pasado y se ha ido reafirmando en diversos preceptos a lo largo de varias reformas y adiciones a nuestra Constitución.

\section{Marco constitucional}

La primera inserción del concepto de desarrollo sustentable en la Constitución Política de los Estados Unidos Mexicanos, ocurrió en junio de 1999 con una adición ${ }^{15}$ al párrafo primero del artículo 25 . En ese año, se incluyó la voz sustentable dentro de lo que tradicionalmente se conoce como el marco regulatorio económico o capítulo económico de nuestra carta magna, el cual culminó su proceso de consolidación con una reforma ${ }^{16}$ amplia en febrero de 1983, con el reconocimiento de una economía mixta bajo rectoría estatal (donde el desarrollo nacional sería integral) con la participación de los sectores social y privado. ${ }^{17}$

De manera específica, la adición de 1999 implicó que dicha rectoría del desarrollo nacional (la cual corresponde al Estado mexicano), además de ser integral, ahora también sería sustentable. Dispone el citado párrafo primero del artículo 25 constitucional lo siguiente:

Artículo 25. Corresponde al Estado la rectoría del desarrollo nacional para garantizar que éste sea integral y sustentable, que fortalezca la soberanía

527. Desde luego, el caso completo puede obtenerse de la propia página de la Corte mencionada. Véase Gabčikovo-Nagymaros Project (Hungary/Slovakia), Judgement, I.C.J. Reports, 1997, consultado en marzo de 2013, www.icj-cij.org/docket/files/92/7375.pdf.

15 Publicada en el Diario Oficial de la Federación del 28 de junio de 1999.

16 Publicada en el Diario Oficial de la Federación del 3 de febrero de 1983.

17 Para mayor detalle, acúdase a Witker, Jorge, Curso de derecho económico, México, UNAM, Instituto de Investigaciones Jurídicas, 1989, pp. 45 y ss. 
Esta obra forma parte del acervo de la Biblioteca Jurídica Virtual del Instituto de Investigaciones Jurídicas de la UNAM

de la nación y su régimen democrático y que, mediante el fomento del crecimiento económico y el empleo y una más justa distribución del ingreso y la riqueza, permita el pleno ejercicio de la libertad y la dignidad de los individuos, grupos y clases sociales, cuya seguridad protege esta Constitución.

A su vez, el concepto del desarrollo nacional sustentable, como parte de las disposiciones económicas de nuestra ley fundamental, quedó relacionado con el sistema nacional de planeación democrática, contemplado en lo que ahora es el primer párrafo del apartado A del artículo 26 de la Constitución. De manera tal, que la planeación nacional (específicamente el Plan Nacional de Desarrollo sexenal y los programas gubernamentales sujetos obligatoriamente al propio Plan) están ligados constitucionalmente a lo sustentable.

A continuación los textos de los párrafos primero y segundo del apartado A del artículo 26, que al leerse de manera conjunta con el texto del artículo 25 constitucional, nos permiten entender el alcance que tuvo la reforma de junio de 1999.

Artículo 26.

A. El Estado organizará un sistema de planeación democrática del desarrollo nacional que imprima solidez, dinamismo, permanencia y equidad al crecimiento de la economía para la independencia y la democratización política, social y cultural de la nación.

Los fines del proyecto nacional contenidos en esta Constitución determinarán los objetivos de la planeación. La planeación será democrática. Mediante la participación de los diversos sectores sociales recogerá las aspiraciones y demandas de la sociedad para incorporarlas al plan y los programas de desarrollo. Habrá un plan nacional de desarrollo al que se sujetarán obligatoriamente los programas de la administración pública federal.

La segunda ocasión en la que se incluye de manera expresa la idea de la sustentabilidad en la Constitución, fue en agosto de 2001, en el artículo 2o., apartado B, fracción VII, como parte integral de una reforma amplia en materia de derechos y cultura indígenas. ${ }^{18}$ El desarrollo sustentable se in-

18 Recordemos que la reforma al artículo 2o. constitucional (publicada en el Diario Oficial de la Federación del 14 de agosto de 2001), fue resultado de una inconclusa y tergiversada interpretación de los legisladores de aquella época respecto a la esencia y 
Esta obra forma parte del acervo de la Biblioteca Jurídica Virtual del Instituto de Investigaciones Jurídicas de la UNAM

serta como una de las muchas obligaciones o "tareas" que las autoridades federales, estatales y municipales deberán cumplimentar o realizar con el objeto de que las comunidades indígenas alcancen: $i$ ) la suficiencia de sus ingresos económicos, ii) la aplicación de estímulos para inversiones públicas y privadas, iii) la incorporación de tecnologías, y $i v$ ) el acceso equitativo a los sistemas de abasto y comercialización. Aquí el texto vigente constitucional mencionado:

\section{Artículo 2...}

B. La Federación, los estados y los municipios, para promover la igualdad de oportunidades de los indígenas y eliminar cualquier práctica discriminatoria, establecerán las instituciones y determinarán las políticas necesarias para garantizar la vigencia de los derechos de los indígenas y el desarrollo integral de sus pueblos y comunidades, las cuales deberán ser diseñadas y operadas conjuntamente con ellos.

Para abatir las carencias y rezagos que afectan a los pueblos y comunidades indígenas, dichas autoridades, tienen la obligación de:

VII. Apoyar las actividades productivas y el desarrollo sustentable de las comunidades indígenas mediante acciones que permitan alcanzar la suficiencia de sus ingresos económicos, la aplicación de estímulos para las inversiones públicas y privadas que propicien la creación de empleos, la incorporación de tecnologías para incrementar su propia capacidad productiva, así como para asegurar el acceso equitativo a los sistemas de abasto y comercialización.

Como es fácil de observar, la reforma constitucional de 2001 privilegió la dimensión económica del desarrollo sustentable por sobre la eco-

espíritu de lo que contenían tanto la iniciativa de Ley Cocopa de 1996 (proyecto presentado por el Congreso de la Unión) como lo establecido en los Acuerdos de San Andrés Larráinzar de ese mismo año (redactados y acordados entre el Ejército Zapatista de Liberación Nacional y el gobierno federal que en un principio aceptó, pero que después rechazó). La importancia que tiene esta mención radica en que ya con un nuevo partido político en el poder y un congreso legislativo renovado para 2001, muchas de las propuestas fueron matizadas, rechazadas o simplemente ignoradas. Para una revisión sobre algunas cuestiones históricas de la reforma, particularmente vinculadas a ciertos temas ambientales, véase los que hemos escrito al respecto en Nava Escudero, César, Estudios ambientales, 2a. ed., México, UNAM, Instituto de Investigaciones Jurídicas, 2011, passim. 
Esta obra forma parte del acervo de la Biblioteca Jurídica Virtual del Instituto de Investigaciones Jurídicas de la UNAM

lógico-ambiental y la sociocultural en materia indígena. De hecho, se apartó diametralmente de uno de los dos textos que sirvieron de base para ella. Nos referimos a lo asentado en los Acuerdos de San Andrés Larráinzar de febrero de 1996 (el otro texto fue la iniciativa de ley Cocopa) que señalaba con claridad que los criterios de sustentabilidad que las autoridades debían de considerar, estarían vinculadas a las modalidades tradicionales de aprovechamiento de los recursos naturales practicados por pueblos y comunidades indígenas, así como a los mecanismos compensatorios o a la indemnización cuando el aprovechamiento de tales recursos por el Estado ocasionara daños en su hábitat y vulnerara su reproducción cultural. Es evidente que la dimensión ambiental que se sugería para el contenido de lo que ahora es el apartado B, fracción VII del artículo 2 quedó excluida. ${ }^{19}$

En agosto de 2007 se vuelve a incluir el concepto del desarrollo sustentable en nuestra Constitución ahora en relación con las facultades del Congreso de la Unión para expedir leyes sobre las sociedades cooperativas. Con una adición al artículo 73 fracción XXIX-N constitucional, se hace mención expresa sobre el hecho de que las leyes en cuestión habrán de establecer las bases para la concurrencia de la Federación, los estados y los municipios (y del Distrito Federal) en el ámbito de sus respectivas competencias en materia de fomento y desarrollo sustentable de la actividad cooperativa. ${ }^{20}$ Dispone el artículo citado lo siguiente:

Artículo 73. El Congreso tiene facultad:

XXIX-N Para expedir leyes en materia de constitución, organización, funcionamiento y extinción de las sociedades cooperativas. Estas leyes establecerán las bases para la concurrencia en materia de fomento y desarrollo sustentable de la actividad cooperativa de la Federación, estados y municipios, así como del Distrito Federal, en el ámbito de sus respectivas competencias.

19 Para tener una visión exacta de los documentos aludidos, pueden consultarse los textos íntegros en: Centro de Documentación sobre Zapatismo, Acuerdos de San Andrés - Reforma Aprobada en el 2001, México, Documentación histórica, CEDOZ, s. f., acceso en marzo de 2013, www.cedoz.org/site/content.php?doc $=720$.

20 Publicada en el Diario Oficial de la Federación del 15 de agosto de 2007. 
Esta obra forma parte del acervo de la Biblioteca Jurídica Virtual del Instituto de Investigaciones Jurídicas de la UNAM

Poco tiempo después, hacia finales de 2011, se añade un segundo párrafo a la fracción XX del artículo 27 constitucional para hacer expresa la cuestión de que el desarrollo rural integral también será sustentable. De esta manera, la idea de sustentabilidad quedó sujeta a lo establecido en el primer párrafo de esa misma fracción, que desde una reforma de febrero de 1983, señalaba que el Estado es el encargado de promover las condiciones para un desarrollo rural integral con el fin de crear empleo y garantizar a la población campesina tanto el bienestar como su participación e incorporación en el desarrollo nacional. El artículo 27 fracción $\mathrm{XX}$, párrafos primero y segundo vigentes, señalan lo siguiente:

\section{Artículo 27.}

XX. El Estado promoverá las condiciones para el desarrollo rural integral, con el propósito de generar empleo y garantizar a la población campesina el bienestar y su participación e incorporación en el desarrollo nacional, y fomentará la actividad agropecuaria y forestal para el óptimo uso de la tierra, con obras de infraestructura, insumos, créditos, servicio de capacitación y asistencia técnica. Asimismo, expedirá la legislación reglamentaria para planear y organizar la producción agropecuaria, su industrialización y comercialización, considerándolas de interés público.

El desarrollo rural integral y sustentable a que se refiere el párrafo anterior, también tendrá entre sus fines que el Estado garantice el abasto suficiente y oportuno de los alimentos básicos que la ley establezca.

Es fácil percatarse que esta disposición coincide con uno de los preceptos constitucionales arriba citados, particularmente, el que hace alusión al desarrollo nacional integral y sustentable (i. e. artículo 25, párrafo primero).

Por último, en febrero de 2012, se añade lo sustentable a nuestra carta magna en relación con el acceso y el uso de los recursos hídricos. Lo anterior, en el marco de lo que se conoce como el derecho humano al agua dentro del recientemente bautizado capítulo I. "De los derechos humanos y sus garantías", en el título primero de nuestra Constitución. Tal supuesto jurídico quedó plasmado en el párrafo sexto del artículo 4o., que a la letra señala:

Artículo 4o. 
Esta obra forma parte del acervo de la Biblioteca Jurídica Virtual del Instituto de Investigaciones Jurídicas de la UNAM

Toda persona tiene derecho al acceso, disposición y saneamiento de agua para consumo personal y doméstico en forma suficiente, salubre, aceptable y asequible. El Estado garantizará este derecho y la ley definirá las bases, apoyos y modalidades para el acceso y uso equitativo y sustentable de los recursos hídricos, estableciendo la participación de la Federación, las entidades federativas y los municipios, así como la participación de la ciudadanía para la consecución de dichos fines.

Un examen minucioso de esta adición, conduce a afirmar que el texto vigente contiene cierta contradicción conceptual. Por un lado, eleva a rango constitucional el derecho humano al agua, lo que supone en su acepción tradicional el acceso de todas las personas al agua independientemente de que ello signifique o no un beneficio económico. ${ }^{21}$ Por el otro, parece que el texto constitucional lo considera a su vez un sector vinculado a cuestiones económicas y de comercialización en virtud de referirse a él como un recurso hídrico, propio de un lenguaje utilizado en los procesos de mercado. ${ }^{22}$ Debió haberse utilizado la expresión "elemento natural", o en su caso, simplemente la de "aguas", como lo ha enfatizado desde hace muchas décadas (de hecho desde 1917) el artículo 27 de nuestra ley fundamental a propósito de los preceptos sobre la propiedad (originaria y derivada) de las aguas en este país.

\section{SOBRE EL TURISMO}

\section{Generalidades}

El turismo ha sido descrito de diversas maneras: como una actividad o fenómeno, que puede ser nacional, internacional o global, que implica aspectos económicos, comerciales, sociales, culturales y ambientales, además de que involucra lugares visitados y personas visitantes (deno-

21 Más detalles sobre los alcances que tiene el referirse a un derecho humano, y no a una necesidad humana, pueden obtenerse en Barlow, Maude y Clarke, Tony, Oro azul, trad. de Isidro Arias, Barcelona, Paidós, 2004, pp. 133-135.

22 Recomendamos la lectura de Valencia Mulkay, Miguel, "Hacia otra perspectiva jurídica del agua”, Derecho ambiental y ecología, México, año 2, núm. 11, febrero-marzo de 2006, pp. 17-22, en la que se hace un recuento sucinto sobre los significados de las diferentes formas de caracterizar jurídicamente al agua, ya sea como bien público, bien común, patrimonio común, res pública, recurso natural, etcétera. 
Esta obra forma parte del acervo de la Biblioteca Jurídica Virtual del Instituto de Investigaciones Jurídicas de la UNAM

minados comúnmente turistas) con propósitos distintos (i. e. ocio, placer, descanso, negocios, estudios, etcétera). La Organización Mundial del Turismo ${ }^{23}$ ha elaborado una definición tratando de englobar algunas de estas variables y se ha referido a él de la siguiente manera:

El turismo es un fenómeno social, cultural y económico relacionado con el movimiento de las personas a lugares que se encuentran fuera de su lugar de residencia habitual por motivos personales o de negocios/profesionales. Estas personas se denominan visitantes (que pueden ser turistas o excursionistas; residentes o no residentes) y el turismo tiene que ver con sus actividades, de las cuales algunas implican un gasto turístico.

Como tal, el turismo tiene efectos en la economía, en el entorno natural y en las zonas edificadas, en la población local de los lugares visitados y en los visitantes propiamente dichos. Debido a estos diversos impactos, la amplia gama y variedad de factores de producción requeridos para producir los bienes y servicios adquiridos por los visitantes y al amplio espectro de agentes involucrados o afectados por el turismo, es necesario adoptar un enfoque global del desarrollo, la gestión y la supervisión del turismo. Este enfoque es muy recomendable con miras a la formulación y puesta en práctica de políticas de turismo nacionales y locales, así como de acuerdos internacionales $u$ otros procesos en materia de turismo. ${ }^{24}$

En nuestro idioma, la palabra turismo aparece por vez primera en el Diccionario de la Real Academia Española de 1925, con dos acepciones: "Afición a viajar por gusto de recorrer un país" y "Organización de los medios conducentes a facilitar estos viajes". ${ }^{25}$ Así permaneció en las

23 Como su página web lo indica, la Organización Mundial del Turismo "es el organismo de las Naciones Unidas encargado de la promoción de un turismo responsable, sostenible y accesible para todos. La OMT, como principal organización internacional en el ámbito turístico, aboga por un turismo que contribuya al crecimiento económico, a un desarrollo incluyente y a la sostenibilidad ambiental, y ofrece liderazgo y apoyo al sector para expandir por el mundo sus conocimientos y políticas turísticas". Véase Organización Mundial del Turismo, Acerca de la OMT, www2.unwto.org/es/content/acera-de-laomt (acceso: marzo de 2013).

24 Definición obtenida de Organización Mundial del Turismo, Entender el turismo: glosario básico, http://media.unwto.org/es/content/entender-el-turismo-glosario-basico (acceso: marzo de 2013).

25 La voz turista aparece antes que la de turismo, lo que ocurre en la edición de 1914 y su definición fue "Viajero que recorre un país por distracción y recreo". Esta es la primera vez que aparece la palabra turista y desde entonces se mencionó que proviene del inglés, tourist. Esta definición cambia en la edición de 1925 a "Persona que recorre un 
Esta obra forma parte del acervo de la Biblioteca Jurídica Virtual del Instituto de Investigaciones Jurídicas de la UNAM

ediciones posteriores hasta la de 1970, donde se agregó, en suplemento, "automóvil de turismo". En 1989, cambió la segunda acepción a "Organización de los medios conducentes a facilitar los viajes de recreo". En la vigésima primera edición, la de 1992, se sustituyó la primera acepción por "Afición a viajar por placer", la segunda se modificó para quedar como se utilizó en el pasado, y se incluyó de manera expresa que turismo proviene del inglés tourism. ${ }^{26}$ Esto último quedó en la edición de 2001, la vigésima segunda, donde la primera acepción fue "Actividad o hecho de viajar por placer"; la segunda permaneció igual; se añadió "Conjunto de personas que realiza este tipo de viajes"; y se dejó "automóvil de turismo". ${ }^{27}$

En la actualidad, en los avances de la vigésima tercera edición, se confirma el origen inglés de la palabra, y las definiciones son "Actividad o hecho de viajar por placer"; "Conjunto de los medios conducentes a facilitar los viajes de turismo"; "Conjunto de personas que hace viajes de turismo"; "automóvil de turismo".

Pero la versión de que el surgimiento de este vocablo proviene del mundo anglosajón, como lo establece el Diccionario de la Real Academia Española, no es aceptada unánimemente. Al respecto, hay al menos tres visiones distintas:

Pues bien, en principio y en forma superficial podemos decir que el concepto de turismo surge del sajón antiguo Torn (Inglaterra). De esta forma, se desprendían los vocablos Torn-us (lo que da vueltas) y Torn-are (dar vueltas). Esa raíz implicaba una partida con regreso, y se utilizó durante el siglo XII en los viajes de descanso que emprendían los campesinos...

A mediados del siglo XVIII los nobles ingleses utilizaban el término Turn para denominar a los viajes que realizaban en búsqueda de educación y cultura. Se creía, por ese entonces, que los hombres (en formación) debían conducir viajes sobre distintos reinos para adquirir conocimientos que les serían útiles a la hora de gobernar. Esa forma de pensar, deriva del concepto de "Grand Tour" francés que pasara a la cultura inglesa a media-

país por distracción y recreo", y así quedo en ediciones subsecuentes hasta 2001 (edición vigésima segunda) donde se le definió como "Persona que hace turismo". Véase, Real Academia Española, Nuevo Tesoro Lexicográfico de la Lengua Española, 2010, http:// buscon-rae.es/ntlle/SrvltGUILoginNtlle (acceso: 26 de marzo de 2013).

26 Idem.

27 Véase Real Academia Española, Diccionario de la lengua española, 22a. ed., 2001. 
Esta obra forma parte del acervo de la Biblioteca Jurídica Virtual del Instituto de Investigaciones Jurídicas de la UNAM

dos del siglo XVII. Ya a comienzos del siglo XVIII, el término turn se deja de lado para adoptarse tour (también por influencia francesa).

En sajón, los sustantivos de origen del verbo son denominados con el sufijo -er (writ-er, Speak-er, etc.). Se presupone que aquel, el cual en el siglo XII, se desplazaba para luego volver a su punto de partida fuera llamado Torn-er. Siglos más tarde, durante la era de la burguesía (preferentemente entre el siglo XVIII y XIX) se sustituye el término er por el latín iste y griego isme, para luego en el siglo XX alcanzar la denominación de tourist(e) y la actividad que de su acción deriva bajo Tour-ism.

En castellano, ambos adquieren la denominación de Turismo y Turista en el mismo siglo; esta es la consideración de la escuela latina...

Pero no todos los investigadores piensan lo mismo, por ejemplo para la escuela semítica, cuyo exponente máximo es Arthur Houlot... el término turismo no deriva de la lengua latina sino del arameo antiguo. Según este autor, en este idioma se utilizaba el término Tur para los viajes, la exploración y el traslado de personas. Este vocablo se utiliza por primera vez, cuando Moisés inicia la expedición a las tierras de Canaán... Houlot piensa que el término Tur (de alguna u otra manera) se posicionó en las lenguas europeas latinas y sajonas de la misma forma.

No obstante, otra corriente (la escuela onomástica-inglesa) considera que el origen del concepto turismo no se encuentra en una raíz lingüística sino que está vinculado a un apellido de la aristocracia francesa - De la Tour- La prueba empírica a esta hipótesis se encuentra cuando Carlos $\mathrm{V}$ en 1516 firma un tratado de relaciones con Inglaterra. Al celebrar dicho convenio, el rey le entrega la exclusividad del transporte comercial a una familia aristócrata llamada De la Tour. De esta manera... esta familia organizó los primeros viajes de comerciantes ingleses al continente, hecho que marcó el principio del turismo como actividad orientada al desplazamiento comercial. $^{28}$

Más allá de las versiones que existen para determinar su origen, lo cierto es que las actividades que hoy caracterizamos bajo el nombre de turismo (i. e. ocio, placer, descanso, etcétera) se han practicado desde hace un buen número de años. A partir de cuándo ciertas actividades podrían ser consideradas "turismo" como ahora lo conocemos, es difícil de determinar. Por ejemplo, en épocas pasadas, en el mundo occidental, existían cierto tipo de vías, sitios o "servicios" para los viajeros o anti-

28 Korstanje, Maximiliano, Tratado turístico, versión electrónica, 2007, pp. 8 y 7 , www.eumed.net./libros/2007c/321/ (acceso: 26 de marzo de 2013). 
Esta obra forma parte del acervo de la Biblioteca Jurídica Virtual del Instituto de Investigaciones Jurídicas de la UNAM

guos turistas de aquellas épocas. Muestra de ello fueron en su momento los caminos y lugares de trabajo a lo largo y ancho del Imperio Romano, los monasterios que ofrecían alojamiento durante el medioevo, o las posadas de los siglos XVI, XVII y XVIII en Europa. ${ }^{29}$

¿Habremos de calificar los ejemplos anteriores de turismo? ¿Debiera mejor hablarse de viajes y no de turismo o, en su caso, de un remoto antecedente de lo que hoy llamamos turismo organizado? En realidad, no hay certeza absoluta sobre los orígenes del turismo, y sobre su formalización ciertamente no hay consenso entre los expertos. ${ }^{30}$ Pero lo que sí debe quedar claro es que el turismo de hoy en día involucra prácticamente a todas las naciones del planeta, es organizado (si bien a escalas diversas) y tiene impactos socioculturales, económico-políticos y ecológico-ambientales.

Es de suma trascendencia señalar que si bien el sector turismo genera muchos beneficios económicos y comerciales, éstos no siempre son equitativos para los propios países huéspedes o para determinado grupo de habitantes dentro de ellos. En este último sentido nos referimos a las comunidades locales o anfitrionas, los indígenas, los campesinos o simplemente los pobres, quienes acaban siendo desplazados de su territorio, marginados de modo social o explotados laboralmente. Frente a este escenario, en donde se benefician unos más que otros, hay que agregar que los daños ambientales en un buen número de destinos son cada vez mayores y más visibles. Y esto es así porque el turismo que se ha desarrollado en las últimas décadas en el mundo es, en general, masivo, y la esencia de este tipo de turismo no está precisamente orientada a la protección ambiental.

29 Véase France, Lesley, "Introduction", en France, Lesley (ed.), The Earthscan Reader in Sustainable Tourism, Londres, Earthscan, 1997, p. 4.

30 Ciertos autores han advertido sobre el error de equiparar el vocablo turismo al de viajes, porque equivocadamente se cree que "toda persona que viaja hace turismo". Según se argumenta, los viajes tienen un origen más antiguo que el turismo; de hecho, la actividad turística organizada habría comenzado a principios de la década de los treinta del siglo pasado, momento en el que el Estado inicia su interés por intervenir en su regulación. Cfr. Hernández-Mendible, Víctor Rafael, "La regulación de la actividad turística”, en Fernández Ruiz, Jorge y Santiago Sánchez, Javier (coords.), Régimen jurídico del turismo y de la zona maritimo-terrestre. Memoria del Congreso Internacional de Derecho Turístico, México, UNAM, Instituto de Investigaciones Jurídicas, 2009, pp. 373 y 374 . 
Esta obra forma parte del acervo de la Biblioteca Jurídica Virtual del Instituto de Investigaciones Jurídicas de la UNAM

Las preocupaciones de tipo social y ambiental han derivado no en $s u$ primir la actividad turística, pero sí en moldearla, adaptarla, corregirla o acotarla — según el término que se desee utilizar-. De aquí el surgimiento de expresiones como las de turismo alternativo o turismo sustentable; pero sobre esto hablaremos en el próximo apartado. Por ahora, habremos de concentrarnos en el proceso de constitucionalización del turismo en nuestro país.

\section{Marco constitucional}

La primera inserción del vocablo turismo de manera expresa en nuestra carta magna cuenta con una antigüedad de veinte años. En efecto, en 1993, se reformó por completo el artículo 122 constitucional para establecer que la Asamblea de Representantes del Distrito Federal tenía facultades para legislar en esta materia. ${ }^{31}$

Artículo $122 \ldots$

IV. La Asamblea de Representantes del Distrito Federal tiene facultades para:

g) Legislar en le ámbito local, en lo relativo al Distrito Federal en los términos del Estatuto de Gobierno en materias de: administración pública local... turismo y servicios de alojamiento...

Tres años después, se vuelve a reformar el artículo en cuestión: desaparece la Asamblea de Representantes y se crea la Asamblea Legislativa para ser ahora a ésta a la que le corresponde legislar en materia turística y de servicios de alojamiento, según lo establecido en la base primera, fracción V, inciso k) de la Constitución. ${ }^{32}$ Así reza desde entonces este precepto:

Artículo $122 \ldots$

BASE PRIMERA. Respecto a la Asamblea Legislativa:

...

V. La Asamblea Legislativa, en los términos del Estatuto de Gobierno, tendrá las siguientes facultades:

31 Publicada en el Diario Oficial de la Federación del 25 de octubre de 1993.

32 Publicada en el Diario Oficial de la Federación del 22 de agosto de 1996. 
Esta obra forma parte del acervo de la Biblioteca Jurídica Virtual del Instituto de Investigaciones Jurídicas de la UNAM

k) Regular la prestación y la concesión de los servicios públicos; legislar sobre los servicios de transporte urbano, de limpia, turismo y servicios de alojamiento, mercados, rastros y abasto, y cementerios;

De manera tal, que desde 1993, quedó establecido el precepto constitucional para que el órgano legislativo local en la Ciudad de México (antes Distrito Federal) pudiera legislar en turismo, lo que significó en su momento una excepción a la tendencia legislativa y doctrinal de considerar que la actividad turística gozaba de naturaleza federal. ${ }^{33}$ Vale la pena recordar que antes de las reformas de 1993 y 1996, y en los años siguientes hasta antes de que nuestra ley fundamental se reformara en 2003 — modificación a la que habremos de referirnos enseguida - se gestó cierto debate jurídico en torno a si las entidades federativas tenían o no facultad para legislar en materia turística dado que la Constitución no atribuía de manera expresa tal facultad al Congreso de la Unión. Lo anterior, en virtud de lo que establece el artículo 124 constitucional respecto a la competencia de los estados: "las facultades que no están expresamente concedidas por esta Constitución a los funcionarios federales, se entienden reservadas a los estados".

Eran dos las posturas identificadas (aunque no las únicas) en tal debate jurídico. Por un lado, la que consideraba que el turismo era federal en virtud de una interpretación extensiva de nuestra Constitución al artículo 73 fracción X por considerarla como una actividad eminentemente comercial, y por consiguiente, las leyes locales de los estados que se expidieran en la materia (salvo el Distrito Federal a partir de 1993) serían inconstitucionales. ${ }^{34}$ Y por el otro, la que señalaba que debido a que el turismo no estaba determinado como una atribución expresa del Congreso, los estados podían legislar sobre la materia, bajo el argumento de una supuesta actualización de las "facultades concurrentes" para este caso en particular. ${ }^{35}$

33 Véase Nava Negrete, Alfonso, "El turismo en las zonas arqueológicas de México", en Fernández Ruiz, Jorge y Santiago Sánchez, Javier (coords.), Régimen jurídico..., cit., p. 161.

34 Ibidem, pp. 159-161 y 163.

35 Al tenor de este debate se ha precisado lo siguiente: "Como se ha mencionado, asunto harto discutido es el de la competencia federal o estatal para legislar sobre el turismo. Al respecto, baste destacar que, por un lado, en nuestro país se ha adoptado el 
Esta obra forma parte del acervo de la Biblioteca Jurídica Virtual del Instituto de Investigaciones Jurídicas de la UNAM

La discusión quedó resuelta a través de una reforma a nuestra carta magna en 2003, en la que se adicionó un inciso más a la fracción XXIX del artículo 73 constitucional relativo a las facultades del Congreso de la Unión $^{36}$ para quedar de la siguiente manera:

Artículo 73. El Congreso tiene facultad:

XXIX-K Para expedir leyes en materia de turismo, estableciendo las bases generales de coordinación de las facultades concurrentes entre la Federación, estados, municipios y el Distrito Federal, así como la participación de los sectores social y privado.

Así, esta adición - que se erige como la tercera ocasión en la que hasta la fecha se ha incluido el vocablo turismo en nuestra Constitucióntuvo como propósito establecer de manera expresa la facultad para que el Congreso de la Unión expidiera una ley a través de la cual se precisaran "las bases generales de coordinación de las facultades concurrentes entre la Federación, los estados, los municipios y el Distrito Federal...". En consecuencia, y a partir de la creación de dicha ley (a la que años más tarde se le daría el nombre de Ley General de Turismo), ${ }^{37}$ las entidades federativas, ahora sí, contarían con un marco constitucional para expedir sus propias leyes locales. Claro está que si se publicaron leyes estatales en materia turística durante el periodo que va desde la reforma constitucional de 2003 a la expedición de la Ley en cuestión, habrían sido irre-

criterio de la interpretación extensiva de las facultades del Congreso de la Unión para regular al comercio (artículo 73, fracción X, de la Constitución Política de los Estados Unidos Mexicanos), incluyendo al turismo como una actividad comercial... Este criterio, se sustenta, a decir de sus defensores, en las facultades implícitas del Congreso de la Unión. Sin embargo, desde otro punto de vista, tomando en cuenta que la actividad turística no se encuentra señalada expresamente como facultad explícita del Congreso de la Unión, se ha llegado a interpretar que el turismo propicia facultades 'concurrentes' de la Federación y de los estados para legislar sobre la materia...”. Pujol Rosas, Rebeca F. y Torres Maldonado, Eduardo J., "El sistema constitucional, legal y reglamentario del turismo en México: una radiografía de la evolución institucional y la política legislativa turística", Anales de Jurisprudencia, México, Sexta Época, Segunda Etapa, núm. 247, septiembre-octubre de 2000, pp. 383 y 384.

36 Publicada en el Diario Oficial de la Federación del 29 de septiembre de 2003.

37 Publicada en el Diario Oficial de la Federación del 17 de junio de 2009. 
Esta obra forma parte del acervo de la Biblioteca Jurídica Virtual del Instituto de Investigaciones Jurídicas de la UNAM

gulares porque aquéllas tendrían que haber estado a lo que la propia ley turística estableciera en su texto. ${ }^{38}$

Si bien la discusión sobre las facultades para legislar en materia turística debió quedar resuelta, se ha advertido que no está del todo claro si el texto constitucional de referencia quiso establecer un régimen de "concurrencia", o bien un régimen de "coordinación". ${ }^{39}$ De aceptar esta distinción, hay que señalar que el contenido mismo de la Ley General de Turismo de 2009 no aclaró tal situación; por el contrario, la volvió aún más confusa.

Lo dicho en el párrafo anterior se explica porque dicha Ley se refiere a ambos regímenes al establecer en el artículo 2 fracción I, por un lado, que la Ley tiene por objeto "establecer las bases generales de coordinación de las facultades concurrentes entre el Ejecutivo federal, estados, municipios y el Distrito Federal...". Por el otro, en su artículo 1o. precisa que la aplicación de la Ley corresponde "en forma concurrente al Ejecutivo federal, por conducto de la Secretaría de Turismo, y en el ámbito de sus respectivas competencias a las dependencias y entidades de la administración pública federal, así como a los estados, municipios y el Distrito Federal". En artículos subsecuentes, la propia Ley establece las atribuciones que corresponden a cada uno de los cuatro órdenes de gobierno.

Queda así para el análisis una reflexión anterior a la expedición de la vigente Ley General de Turismo:

38 Nava Negrete, Alfonso, "El turismo en las zonas arqueológicas de México", en Fernández Ruiz, Jorge y Santiago Sánchez, Javier (coords.), Régimen jurídico..., cit., p. 163.

39 Para explicar la confusión que se da en materias como el turismo y el deporte, se hace la distinción, por un lado, de un régimen de "facultades concurrentes" donde existe un poder de dirección de la Federación que se traduce en su capacidad de expedir una ley que distribuya competencias entre los diferentes órdenes de gobierno, como sucede con las materias de educación, salubridad general, asentamientos humanos, así como de protección al ambiente y de preservación y restauración del equilibrio ecológico. Y por el otro, de un régimen asociado al concepto de "bases generales de coordinación", en donde no se otorga la facultad a la Federación para establecer en una ley la "concurrencia” respectiva, sino que sí se otorga a la Federación la facultad de expedir una ley, pero con el objeto de regular "aspectos formales o procedimentales para lograr la coherencia en el ejercicio de competencias propias a una materia, tal y como sucede con las materias de seguridad pública o de protección civil". Al respecto, véase Serna de la Garza, José María, El sistema federal mexicano. Un análisis jurídico, México, UNAM, Instituto de Investigaciones Jurídicas, 2008, pp. 152-159. 
Esta obra forma parte del acervo de la Biblioteca Jurídica Virtual del Instituto de Investigaciones Jurídicas de la UNAM

Cuando el legislador federal decida expedir... [la] ley, tendrá también que pronunciarse acerca del régimen constitucional que la nueva redacción del 73 fracción XXIX-K implica y, en consecuencia, tendrá que expedir ya sea una Ley General que establece las Bases de Coordinación en materia de Turismo (a la manera de la Ley General que establece las Bases de Coordinación del Sistema Nacional de Seguridad) o bien, una Ley General de Turismo (a la manera de las que existen en las... materias de asentamientos humanos, medio ambiente, salud y educación, entre otras).

De nuevo, creemos que la redacción de esta disposición induce a confusiones que se habrían evitado de haberse tenido más cuidado con los aspectos técnico-jurídicos de la estructura normativa de nuestro sistema federal. ${ }^{40}$

\section{SOBRE EL TURISMO SUSTENTABLE}

\section{Generalidades}

La expresión turismo sustentable es el resultado de la amalgama de dos nociones claramente identificables: por un lado, el turismo, y por el otro, la sustentabilidad. Es posible que ambos vocablos empezaran a entrelazarse conceptualmente hacia finales de la década de los ochenta y principios de la década siguiente del siglo pasado, cuando el desarrollo sustentable comenzaba a ser mencionado reiteradamente a nivel internacional (recordemos que a partir de 1987 este concepto se popularizó con el Informe Brundtland, el cual, por cierto, hizo alusión al turismo sólo de manera tangencial). Durante aquellos años, diversos eventos y documentos asociaban los temas ambientales a los turísticos pero no utilizaban la expresión turismo sustentable. ${ }^{41}$

\section{Ibidem, pp. 158 y 159.}

41 Tal fue el caso de la Declaración de la Haya sobre Turismo de 1989, cuyo Principio III vincula los temas ambientales con los turísticos al señalar en los numerales 1 y 2 lo siguiente: "1. La integridad del medio natural, cultural y humano es condición fundamental del desarrollo del turismo. Además, una gestión racional del turismo puede contribuir considerablemente a la protección y a la mejora del entorno físico y del patrimonio cultural, así como al aumento de la calidad de vida." "2. Habida cuenta de la existencia de esa relación intrínseca entre turismo y medio ambiente, convendría tomar medidas eficaces con los fines siguientes: a) informar y educar a los turistas nacionales e internacionales para que protejan, conserven y respeten el medio natural, cultural y humano de 
Esta obra forma parte del acervo de la Biblioteca Jurídica Virtual del Instituto de Investigaciones Jurídicas de la UNAM

En 1992, en el marco de la Conferencia de las Naciones Unidas sobre el Medio Ambiente y el Desarrollo, a la que ya hemos hecho referencia en este trabajo, se hizo presente la idea de incluir la temática del turismo en el instrumento que por excelencia abordó las cuestiones relativas a la sustentabilidad: la Agenda 21 o Programa 21. En efecto, la actividad turística quedó incorporada dentro de este instrumento no vinculante si bien privilegiando las expresiones "turismo ecológico", "turismo equilibrado", o "turismo ecológicamente racional", a la de turismo sustentable.

Por ejemplo, la Agenda 21 - considerado el plan de acción del desarrollo sustentable - estableció en la sección sobre conservación y gestión de los recursos cierto número de acciones que las naciones deberían de llevar a cabo para promover el turismo ecológico en la lucha contra la deforestación (capítulo 11), así como el turismo equilibrado en la ordenación de los ecosistemas frágiles, particularmente en zonas de montaña (capítulo 13). Adicionalmente, reconoció la importancia de integrar el turismo a programas sobre desarrollo sustentable y los impactos ocasionados por esta actividad, en todo lo relativo a los océanos, mares y zonas costeras (capítulo 17). La propuesta de un turismo ecológicamente racional quedó plasmada en la sección denominada "Medios de ejecución",

los lugares que visitan; b) promover una planificación integrada del desarrollo turístico que se fundamente en la noción de 'desarrollo duradero' enunciada en el Informe de la Comisión Mundial sobre el Medio Ambiente y el Desarrollo (Informe Brundtland) y en el informe sobre 'Perspectiva ambiental hasta el año 2000 y más adelante' del Programa de las Naciones Unidas Para el Medio Ambiente (PNUMA), documentos aprobados por la Asamblea General de las Naciones Unidas; c) determinar la capacidad de ocupación de los lugares visitados por los turistas y atenerse a ella, aunque a ese efecto haya que limitar el acceso a dichos lugares durante ciertos periodos o estaciones del año; d) proseguir el inventario de los lugares de interés turístico, creados por el hombre o por la naturaleza, que tienen especial importancia recreativa, deportiva, histórica, arqueológica, artística, cultural, religiosa, científica, social o técnica, y procurar que en los planes de desarrollo turístico se tengan en la debida cuenta la protección del medio ambiente y la necesidad de imbuir a los turistas, al sector turístico y a la población en general de la importancia de proteger el medio cultural y natural; e) fomentar el desarrollo de formas alternativas de turismo, que favorecen los contactos y la comprensión entre turistas y población local, preservan la identidad cultural y ofrecen a los turistas productos e instalaciones típicos y originales; f) garantizar la cooperación nacional e internacional necesaria con ese objeto entre el sector público y el sector privado". 
Esta obra forma parte del acervo de la Biblioteca Jurídica Virtual del Instituto de Investigaciones Jurídicas de la UNAM

dentro de lo que es el fomento de la educación, la capacitación y la toma de conciencia (capítulo 36). ${ }^{42}$

A partir de dicho instrumento internacional, se sucedieron en los años venideros una serie de documentos -incluyendo resoluciones de la Asamblea General de las Naciones Unidas y de la Organización Mundial del Turismo - que reafirmaron el vínculo entre ambas nociones, y empezaron a utilizar la expresión turismo sustentable. Ejemplos de esto son la Carta Mundial del Turismo Sostenible, de 1995, o el Código Ético Mundial Para el Turismo, de 1999. ${ }^{43}$

En 2002, se realizó la Cumbre Mundial sobre el Desarrollo Sostenible en Johannesburgo, Sudáfrica (también conocida como Río+10), y de ella surge el Plan de Aplicación de las Decisiones de la Cumbre Mundial sobre el Desarrollo Sostenible, donde se aborda también de manera expresa el tema del turismo sustentable. ${ }^{44}$ Lo anterior, en el marco del capítulo denominado "Protección y gestión de la base de recursos naturales del desarrollo económico y social". Como una medida para adoptarse por las naciones quedó establecido en este documento lo siguiente:

43. Promover el desarrollo sostenible del turismo, incluido el turismo no consuntivo y el turismo ecológico, teniendo en cuenta el espíritu del Año Internacional del Ecoturismo y del Año de las Naciones Unidas del Patrimonio Cultural, que se celebran en 2002, así como el espíritu de la Cumbre Mundial del Ecoturismo de 2002 y el Código Ético Mundial para el Turismo aprobado por la Organización Mundial del Turismo, a fin de aumentar los beneficios que las comunidades receptoras obtienen de los recursos que aporta el turismo, manteniendo al mismo tiempo la integridad cultural y

42 Para una lectura completa de la Agenda 21 y sus referencias al sector turismo recomendamos se acuda a la página electrónica siguiente: Organización de las Naciones Unidas, Programa 21, Departamento de Asuntos Económicos y Sociales, División de Desarrollo Sustentable, www.un.org/spanish/esa/sustdev/agenda21/agenda21toc.htm (acceso en abril 2103).

43 La Carta Mundial del Turismo Sostenible fue elaborada en el marco de la Conferencia Mundial de Turismo Sostenible realizada en Lanzarote, Islas Canarias, España. El Código Ético Mundial para el Turismo fue adoptado por la Asamblea General de la Organización Mundial del Turismo en Santiago de Chile el 1o. de octubre de 1999. Véase Mota Flores, Ventura Enrique, "Apuntes sobre la ordenación jurídica del turismo", en Fernández Ruiz, Jorge y Santiago Sánchez, Javier (coords.), Régimen jurídico..., cit., pp. 18 y ss.

44 El otro documento aprobado por resolución de la Cumbre fue la Declaración de Johannesburgo sobre el Desarrollo Sostenible. 
Esta obra forma parte del acervo de la Biblioteca Jurídica Virtual del Instituto de Investigaciones Jurídicas de la UNAM

ambiental de dichas comunidades y aumentando la protección de las zonas ecológicamente delicadas y del patrimonio natural. Promover el desarrollo sostenible del turismo y el fomento de la capacidad en ese ámbito para contribuir al fortalecimiento de las comunidades rurales y locales. ${ }^{45}$

Tras el progresivo aumento durante los primeros años del nuevo milenio de eventos e instrumentos internacionales que harían referencia al turismo sustentable, en 2012 se llevó a cabo la Conferencia de las Naciones Unidas sobre el Desarrollo Sostenible (Río+20), en Río de Janeiro, Brasil, donde se aprobó el documento intitulado "El futuro que queremos". En su 123a. sesión plenaria del 27 de julio de 2012, la Asamblea General de las Naciones Unidas hizo suyo este documento mediante Resolución $66 / 288$. Este instrumento internacional, no vinculante, reitera la importancia del turismo sustentable al referirse a él en el rubro de lo que denomina "Esferas temáticas y cuestiones intersectoriales". A continuación lo que en dos párrafos se señala al respecto:

\section{Turismo sostenible}

130. Ponemos de relieve que el turismo bien concebido y bien gestionado puede hacer una contribución importante a las tres dimensiones del desarrollo sostenible, tiene vínculos estrechos con otros sectores y puede crear empleo decente y generar oportunidades comerciales. Reconocemos la necesidad de apoyar las actividades de turismo sostenible y la creación de capacidad conexa que permitan crear conciencia ambiental, conservar y proteger el medio ambiente, respetar la fauna y la flora silvestres, la diversidad biológica, los ecosistemas y la diversidad cultural, y aumentar el bienestar y mejorar los medios de vida de las comunidades locales apoyando las economías locales y el medio humano y natural en su conjunto. Pedimos que se preste más apoyo a las actividades de turismo sostenible y

45 Para llevar a cabo tal aspiración, este documento no vinculante señala que se tendrán que adoptar diferentes medidas, como aumentar la cooperación internacional, las inversiones extranjeras directas y las asociaciones con los sectores privado y público; formular programas que fomenten el ecoturismo y que habiliten a las comunidades autóctonas y locales para beneficiarse del propio ecoturismo, aumentar la protección ambiental, los recursos naturales y el patrimonio cultural, etcétera. Este documento se puede consultar en Organización de las Naciones Unidas, Informe de la Cumbre Mundial sobre el Desarrollo Sostenible, Johannesburgo (Sudáfrica), 26 de agosto a 4 de septiembre de 2002, Naciones Unidas, 2002, Nueva York, www.un.org/spanish/conferences/wssd/ doconf.htm (acceso: abril de 2013). 
Esta obra forma parte del acervo de la Biblioteca Jurídica Virtual del Instituto de Investigaciones Jurídicas de la UNAM

de creación de capacidad en esa esfera en los países en desarrollo a fin de contribuir al logro del desarrollo sostenible.

131. Alentamos el fomento de las inversiones en el turismo sostenible, incluidos el ecoturismo y el turismo cultural, lo cual puede consistir, entre otras cosas, en crear empresas pequeñas y medianas y facilitar el acceso a recursos financieros por medios con las iniciativas de microcréditos para las comunidades pobres, indígenas y locales de zonas con gran potencial ecoturístico. A este respecto, subrayamos la importancia de establecer, en caso necesario, directrices y reglamentos apropiados, de conformidad con las prioridades y leyes nacionales, para promover y apoyar el turismo sostenible. ${ }^{46}$

De las diversas definiciones y significados que se han elaborado sobre el turismo sustentable, rescatamos la que maneja actualmente la Organización Mundial del Turismo: "El turismo que tiene plenamente en cuenta las repercusiones actuales y futuras, económicas, sociales y medioambientales para satisfacer las necesidades de los visitantes, de la industria, del entorno y de las comunidades anfitrionas". ${ }^{47}$ Esta definición adopta, como era de esperarse, la esencia tripartita del desarrollo sustentable: la dimensión económica, la sociocultural y la ambiental. ${ }^{48}$ Asimismo, el propio organismo especializado de las Naciones Unidas explica que este concepto incluye a los diversos tipos de turismo, incluido el masivo.

Las directrices para el desarrollo sostenible del turismo y las prácticas de gestión sostenible se aplican a todas las formas de turismo en todos los tipos de destinos, incluidos el turismo de masas y los diversos segmen-

46 Véase para mayor información, Organización de las Naciones Unidas, Resolución aprobada por la Asamblea General, 66/288. El futuro que queremos, Naciones Unidas, 2012, fecha de acceso: 30 de abril de 2013, www.un.org/es/comun/docs/?symbol=A/ RES/66/288.

47 Organización Mundial del Turismo, Definición, Sustainable Development of Tourism, UNWTO, acceso: marzo de 2013, sdt.unwto.org/ex/content/definicion

48 Idem. Para la dimensión económica, el turismo sustentable debe asegurar actividades que sean viables a largo plazo, que los beneficios estén bien distribuidos, que se cuenten con oportunidades de empleo estable, obtención de ingresos y servicios para las comunidades huéspedes, y que se contribuya a la reducción de la pobreza. En lo sociocultural, se debe respetar la autenticidad de las comunidades anfitrionas así como conservar activos culturales, arquitectónicos, valores tradicionales, entre otros. Por lo que toca a la parte ambiental, se debe dar uso óptimo a los recursos ambientales manteniendo procesos ecológicos y conservando los recursos naturales y la diversidad biológica. 
Esta obra forma parte del acervo de la Biblioteca Jurídica Virtual del Instituto de Investigaciones Jurídicas de la UNAM

tos turísticos. Los principios de sostenibilidad se refieren a los aspectos medioambiental, económico y sociocultural del desarrollo turístico, habiéndose de establecer un equilibrio adecuado entre esas tres dimensiones para garantizar su sostenibilidad a largo plazo. ${ }^{49}$

Independientemente de las coincidencias que pudieran existir en los distintos foros internacionales (ambientales y turísticos) sobre el contenido del turismo sustentable, su origen y desarrollo se debe en muchos sentidos a una serie de preocupaciones particularmente socio-ambientales que la propia evolución de la actividad turística en el mundo ha traído consigo. Como dejamos entrever en el apartado anterior, dichas preocupaciones no han tenido como objetivo primordial suprimir las actividades turísticas, pero sí discutir sus impactos económicos, sociales y ambientales y, por lo tanto, actuar en consecuencia. De modo que se ha tratado de re-direccionar (moldear, adaptar, corregir o acotar) los alcances y la prestación misma de todos los servicios que abarca esta actividad a nivel mundial.

Es importante aclarar que el turismo sustentable no ha sido la única expresión que se ha utilizado para confrontar las evidentes preocupaciones socio-ambientales provenientes de aquellas naciones, organizaciones, comunidades, o grupos locales afectados, sobre todo si se considera que la gran mayoría de los problemas se ocasionan por tratarse de un fenómeno masivo. ${ }^{50}$ Un ejemplo de lo anterior es la creación de lo que se conoce con el nombre de turismo alternativo cuyo propósito, por decirlo de manera abreviada, es minimizar los costos ambientales, sociales, culturales y económicos, así como maximizar los beneficios para contrarrestar de esta manera los impactos negativos del turismo en masa. ${ }^{51}$ Quizá esta definición tenga algunos puntos de contacto con el significado mismo del turismo sustentable, pero ciertamente se distingue por centrarse en la cuestión masiva de esta actividad. Con todo, tal opción (que cuenta

49 Idem.

50 Al respecto, véase Wheeller, Brian, “Tourism's Troubled Times. Responsible Tourism is Not the Answer", en France, Lesley (ed.), The Earthscan Reader..., cit., pp. 61 y 62 .

51 El turismo alternativo (vis à vis el turismo masivo) se caracteriza por referirse al viajero y no al turista; al operador independiente y no al global; al hospedaje a escala pequeña y no a las cadenas hoteleras multinacionales; al desarrollo lento y controlado y no al desarrollo rápido y sin planeación, etcétera. Más detalles en France, Lesley, "Introduction", en France, Lesley (ed.), The Earthscan Reader..., cit., p. 15. 
Esta obra forma parte del acervo de la Biblioteca Jurídica Virtual del Instituto de Investigaciones Jurídicas de la UNAM

con variantes en su denominación) no ha sido unánimemente aceptada como una posible solución para combatir las consecuencias del turismo de masas. ${ }^{52}$

¿Existe alguna expresión genérica que englobe a todas aquellas variantes turísticas no masivas? ¿En ella se encuentra la del turismo sustentable, o es ésta el género de todos los tipos de turismo? Hay autores que nos alertan sobre lo confuso que resulta equiparar el turismo alternativo con el turismo verde, responsable, ecológico, soft, apropiado, de aventura o, incluso, sustentable. Aún más, dentro de cada una de éstas pueden agregarse subcategorías conceptuales con significados diferentes, que hacen más complejo el entendimiento del alcance de un determinado tipo de turismo, como sucede con el ecoturismo, que puede ser categoría o subcategoría al mismo tiempo.

Aun cuando nos hemos acostumbrado a él, el concepto de ecoturismo surge tardíamente a partir de la nueva conciencia ambiental de las décadas de los sesenta y setenta; sin embargo, dista mucho de ser claro, tanto en su significado como en su alcance. La denominación de este tipo de actividad tampoco es uniforme, ya que se habla de turismo ecológico, alternativo, natural, verde, rural, agroturismo o bioturismo, por ejemplo. Estos términos, sin embargo, se pueden diferenciar por sus objetivos, tipo de naturaleza con la que se tiene contacto, así como por la forma de aproximación que permite, o las actividades que pueden realizarse, las cuales son de diversa índole, como las de observación, deportivas, de aventura, etcétera..$^{53}$

Pero como ya hemos visto en párrafos anteriores, el uso del concepto turismo sustentable en comparación con otros vocablos (sobre todo los que se refieren al turismo no masivo), ha ganado terreno a nivel global tanto en foros ambientales como turísticos. Es muy probable que esto haya sido así porque para la comunidad internacional la idea de sustentabilidad no es algo que "amenace" los intereses económicos, comerciales y de desarrollo de las empresas trasnacionales y de las propias naciones;

52 Para una argumentación más profunda, Wheeller, Brian, “Tourism's Troubled Times. Responsible Tourism is Not the Answer", en France, Lesley (ed.), The Earthscan Reader..., cit., pp. 61 y ss.

53 Huerta Ochoa, Carla, "Ecoturismo y protección ambiental”, en Fernández Ruiz, Jorge y Santiago Sánchez, Javier (coords.), Régimen jurídico..., cit., p. 77. 
Esta obra forma parte del acervo de la Biblioteca Jurídica Virtual del Instituto de Investigaciones Jurídicas de la UNAM

su intrínseca flexibilidad y ambigüedad permite adjetivar a prácticamente cualquier tipo de actividad turística, sea masiva o no.

Si bien el turismo sustentable no debe equipararse con el turismo alternativo, se ha planteado con un enfoque diferente la posibilidad de que co-existan muchos "turismos", ya sea "alternativos" o "de masas", pero todos con niveles distintos de sustentabilidad. ${ }^{54}$ Desde luego, esta visión puede ser aprovechada maliciosamente para crear un doble discurso o una simulación a nivel programático y legal porque en aras de la sustentabilidad se puede maquillar el re-direccionamiento del turismo y no evitar los impactos negativos producidos en lo social y lo ambiental ante la llegada de miles y miles de turistas a destinos diversos.

Con todo, no debe quedar duda sobre el hecho de que la trascendencia a nivel global que ha tenido el vincular la actividad turística con el proceso de sustentabilidad, ha provocado que las naciones hayan incorporado la expresión turismo sustentable en sus ordenamientos jurídicos, ya sea a nivel constitucional y legal, o bien a sus políticas o programas de desarrollo.

\section{Marco constitucional}

Como ha quedado demostrado en este trabajo, los artículos constitucionales sobre la sustentabilidad y el turismo se caracterizan por tener un origen y evolución disímil. La antigüedad normativa de éste es un tanto mayor a la de aquélla, pero el vínculo terminológico entre ellos aún no existe de manera expresa en nuestra ley fundamental. De modo que cualquier intento por referirse al turismo sustentable desde una óptica constitucional deberá hacerse a través de un proceso de adminiculación entre distintos preceptos de nuestra carta magna.

Por lo anterior, es un tanto inexacto referirse lisa y llanamente a la existencia de un proceso de "constitucionalización" del turismo sustentable. Cuando una ley o un programa gubernamental busquen una base o fundamento constitucional para referirse a esa expresión, podrán acudir a uno o a varios de los diferentes preceptos enlistados en este ensayo (según la materia de que se trate), o bien, a otros artículos no referenciados aquí pero que tengan un vínculo con la sustentabilidad y/o con el turismo.

54 Véase France, Lesley, "Introduction", en France, Lesley (ed.), The Earthscan Reader..., cit., p. 15. 
Esta obra forma parte del acervo de la Biblioteca Jurídica Virtual del Instituto de Investigaciones Jurídicas de la UNAM

Por ejemplo, para el primer caso, cuando se discutan y elaboren los programas sobre turismo en el marco de la planeación democrática del desarrollo nacional, se deberá tener presente la cuestión de la sustentabilidad en virtud de que el desarrollo nacional es integral y sustentable de conformidad con lo que establece el artículo 25 párrafo primero en relación con el artículo 26 apartado A, párrafos primero y segundo de la Constitución..$^{55}$ No podría entenderse el diseño de un plan nacional en el que se abordaran las actividades turísticas sin que se les relacionara con lo sustentable. ${ }^{56}$ Se entendería, por lo dicho respecto al contenido y alcances de este concepto, que el desarrollo turístico nacional deberá incluir los aspectos económico-financieros, socioculturales, y ecológicoambientales. Fortalece esta reflexión el hecho de que el turismo ha sido considerado desde hace muchos años una actividad económica (y comercial) por excelencia y, por lo tanto, la actividad turística queda enmarcada dentro del capítulo económico de rectoría estatal, esto es, en el mismo artículo 25 constitucional al que ya nos hemos referido.

55 Es interesante comentar que no obstante quedara plasmado en 1999 el mandato constitucional para que el desarrollo nacional sea sustentable, algunos años antes de tal adición, ya se impulsaba la política del turismo sustentable a través de ciertos programas gubernamentales, particularmente con el Programa de Desarrollo del Sector Turismo 1995-2000 bajo el sexenio del ex presidente Ernesto Zedillo Ponce de León. Véase, Brañes, Raúl, Manual de derecho ambiental mexicano, 2a. ed., México, Fundación Mexicana para la Educación Ambiental-Fondo de Cultura Económica, 2000, p. 600. Conviene agregar a esto que el programa turístico que le precedió - i. e. el Programa Nacional de Modernización del Turismo 1991-1994 expedido durante el gobierno de Carlos Salinas de Gortari- utilizó la palabra "sostenido" para referirse al desarrollo turístico, señalando dos cuestiones que vale la pena rescatar. Primero, que se habría de "promover la formación de recursos humanos y la investigación básica y aplicada que permitan aumentar la calidad y el acceso de nuevas etapas y categorías de servicios y el desarrollo turístico sano, armónico y sostenido"; y segundo, que se habría de "propiciar que las empresas del sector, públicas, privadas y sociales se desempeñen con eficiencia y competitividad en los mercados nacionales e internacionales conformando una nueva cultura empresarial turística que enfrente corresponsablemente el reto que la modernidad impone al desarrollo comunitario", puntualizando además que "el desarrollo sostenido de la actividad turística precisa de la participación creciente de los sectores privado y social, de la modernización de las empresas del sector y que éstas se incorporen efectivamente al desarrollo económico y social de las regiones donde operen".

56 Para una discusión más profunda sobre esta cuestión, acúdase a Vallarta Plata, José Guillermo, “Turismo y desarrollo sustentable”, en Fernández Ruiz, Jorge y Santiago Sánchez, Javier (coords.), Régimen jurídico..., cit., pp. 673-711. 
Esta obra forma parte del acervo de la Biblioteca Jurídica Virtual del Instituto de Investigaciones Jurídicas de la UNAM

En concordancia con lo dicho en el párrafo anterior, el último Plan Nacional de Desarrollo (2007-2012) se refirió en el tema específico sobre el turismo a los tres pilares de la sustentabilidad, aunque le otorgó indebidamente demasiada importancia a la cuestión económica:

El sector debe ser reconocido como una pieza clave en el desarrollo económico del país. Asimismo, se debe garantizar que el crecimiento del sector respete los entornos naturales, culturales y sociales. Es justamente la riqueza de México en términos de una cultura, enorme diversidad climática, belleza orográfica, fauna y flora endémicas, y su sociedad vibrante y abierta lo que atrae y diferencia a nuestro país de otras naciones del mundo. ${ }^{57}$

Algo similar sucede a nivel legal porque la Ley General de Turismo vigente determina que tiene por objeto, entre otras cuestiones, establecer "las bases para la política, planeación y programación en todo el territorio nacional... bajo criterios de beneficio social, sustentabilidad, competitividad y desarrollo equilibrado de los estados, municipios y el Distrito Federal, a corto, mediano y largo plazo". La definición que esta Ley proporciona de turismo sustentable reproduce con cierta similitud elementos de la descripción conceptual que maneja la propia Organización Mundial del Turismo. ${ }^{58}$ La ley señala:

Artículo 3. Para los efectos de esta Ley, se entenderá por:

XIX. Turismo sustentable: Aquel que cumple con las siguientes directrices:

a) Dar un uso óptimo a los recursos naturales aptos para el desarrollo turístico, ayudando a conservarlos con apego a las leyes en la materia;

b) Respetar la autenticidad sociocultural de las comunidades anfitrionas, conservando sus atractivos culturales, sus valores tradicionales y arquitectónicos, y

c) Asegurar el desarrollo de las actividades económicas viables, que reporten beneficios socioeconómicos, entre los que se cuenten oportuni-

57 Véase Presidencia de la República, "2.8 Turismo", Plan Nacional de Desarrollo, 2007, pnd.calderon.presidencia.gob.mx/economia-competitiva-y-generadora-de-em pleos/turismo.html (acceso: 9 de mayo de 2013).

58 Véase lo que hemos señalado supra en este tenor en la nota 48 de pie de página en el presente trabajo. 
Esta obra forma parte del acervo de la Biblioteca Jurídica Virtual del Instituto de Investigaciones Jurídicas de la UNAM

dades de empleo y obtención de ingresos y servicios sociales para las comunidades anfitrionas, que contribuyan a mejorar las condiciones de vida.

Para el segundo caso, hay que enfatizar que el punto de partida constitucional de programas o leyes que aborden cuestiones sobre el turismo sustentable, podrán referirse a preceptos constitucionales de contenido ambiental. Lo anterior, porque el desarrollo sustentable, como hemos visto en apartados anteriores, no sólo tiene un componente ambiental esencial, sino que su origen y evolución ha tenido como base de discusión foros ambientales. Por ejemplo, la sustentabilidad del turismo está vinculada al equilibrio ecológico y la protección al ambiente en tanto que la Ley que regula estas materias - i. e. la Ley General del Equilibrio Ecológico y la Protección al Ambiente (en adelante, LGEEPA) — ${ }^{59}$ tiene por objeto propiciar el desarrollo sustentable.

Aunado a lo anterior, vale la pena comentar que la LGEEPA alude a las actividades turísticas en el marco de la regulación de las áreas naturales protegidas. Es el caso específico de la categoría denominada "Áreas de protección de recursos naturales", cuyas características incluyen, entre otras, el realizar precisamente turismo en ellas. En este sentido, la Ley señala lo siguiente:

\section{Artículo 53.}

En las áreas de protección de recursos naturales sólo podrán realizarse actividades relacionadas con la preservación, protección y aprovechamiento sustentable de los recursos naturales en ellas comprendidos, así como con la investigación, recreación, turismo y educación ecológica, de conformidad con lo que disponga el decreto que las establezca, el programa de manejo respectivo y las demás disposiciones jurídicas aplicables.

Hay que tomar nota de que la LGEEPA es reglamentaria del artículo 73 fracción XXIX-G que se refiere a la facultad del Congreso para legislar en materia de preservación y restauración del equilibrio ecológico y la protección al ambiente. Junto a éste, existen preceptos constitucionales que también integran la parte ambiental constitucional y que tendrían relación con lo sustentable y/o lo turístico, como lo son los artículos 2o., apartados A y B (en materia de pueblos y comunidades indígenas); 40.,

59 Publicada en el Diario Oficial de la Federación del 28 de enero de 1988. 
Esta obra forma parte del acervo de la Biblioteca Jurídica Virtual del Instituto de Investigaciones Jurídicas de la UNAM

párrafos quinto (derecho a un medio ambiente sano) y sexto (derecho al agua); 25, párrafo sexto (cuidado del ambiente); 27, párrafo tercero (preservación y restauración del equilibrio ecológico), entre otros.

Sustentabilidad, turismo, ambiente, están vinculados constitucionalmente de diversas maneras.

\section{REFLEXIÓN FINAL}

Aunque nuestra carta magna no establezca en su texto de manera explícita la expresión turismo sustentable, hay que recordar que la Constitución no es un catálogo de conceptos como para incorporarle cuanta figura jurídica aparezca en el mundo del derecho. Baste con señalar, que de la lectura de diversos artículos constitucionales relacionados con la sustentabilidad y el turismo, se infiere su existencia y, por lo tanto, el turismo sustentable podrá ser regulado por leyes secundarias, como sucede en la actualidad en los ordenamientos jurídicos de los sectores turístico y ambiental.

La sustentabilidad - ingentemente ambigua como concepto, ampliamente prostituida en el discurso político - adjetiva la actividad turística. Entonces, el turismo sustentable puede ser masivo o no, puede privilegiar lo económico sobre lo ambiental y, lo que es peor aún, puede tan sólo dosificar - pero no resolver - las verdaderas causas que motivaron la necesidad de su origen.

No debemos equivocarnos: el desarrollo del turismo en México debe ser paulatino en su crecimiento y respetuoso siempre de la naturaleza. Si queremos caracterizarlo de sustentable, deberá ser distributivo en lo económico, incluyente en lo social y, por supuesto, vigilante y protector de lo ambiental. 
Esta obra forma parte del acervo de la Biblioteca Jurídica Virtual del Instituto de Investigaciones Jurídicas de la UNAM

\section{EL ARTÍCULO 27 EN MATERIA DE AGUAS*}

\section{DELIMITACIÓN CONCEPTUAL}

Central en el estudio del régimen constitucional de las aguas es el texto del extenso artículo 27 de nuestra carta magna. Un análisis oportuno de su contenido y significado comienza por una precisión de tipo conceptual. El término aguas que aparece en este artículo debe entenderse con relación a dos expresiones diferentes que se utilizan, entre otros, para efectos doctrinales: las aguas continentales por un lado, y las aguas marinas por el otro. Las primeras comprenden tanto las aguas superficiales como las del subsuelo que se encuentran en la parte continental del territorio nacional. Las segundas abarcan las aguas en zonas marinas que forman parte del territorio nacional y las que se encuentran en zonas marinas donde la nación ejerce derechos de soberanía, jurisdicciones y otros derechos.

Desde el punto de vista doctrinal, ambas categorías conceptuales han sido analizadas por diversas disciplinas jurídicas según su objeto de estudio. Por lo que respecta a las aguas continentales, una de las más importantes por tradición ha sido el derecho administrativo, cuya gran aportación científico-jurídica radica en discutir el régimen patrimonial de las aguas como bienes del dominio público de la Federación (y por ello, sujetos a un régimen de derecho público), así como la de revisar los actos jurídicos que existen entre la administración pública y los particulares respecto a su explotación, uso, aprovechamiento, distribución, etcétera. ${ }^{1}$

* Publicado en Derechos del Pueblo Mexicano: México a través de sus Constituciones, 9a. ed., México, Miguel Ángel Porrúa-Cámara de Diputados-Suprema Corte de Justicia de la Nación-Senado de la República-Tribunal Electoral del Poder Judicial de la FederaciónInstituto Nacional Electoral-Comisión Nacional de los Derechos Humanos, vol. VII, sección tercera, Edición Conmemorativa Centenario de la Constitución de 1917, 2016.

1 Algunos ejemplos sobre esto lo constituyen Gabino, Fraga, Derecho administrativo, 22a. ed., México, Porrúa, 1982, pp. 364-367; Nava Negrete, Alfonso, Derecho administrativo mexicano, 3a. ed., México, Fondo de Cultura Económica, 2007, pp. 374 y ss. 
Esta obra forma parte del acervo de la Biblioteca Jurídica Virtual del Instituto de Investigaciones Jurídicas de la UNAM

De la rama jurídico-administrativa se han desprendido otras disciplinas que adoptan nuevos enfoques para explicar el tema que aquí analizamos. De manera muy significativa, y en primer término, mencionamos al derecho ambiental, que trata a las aguas generalmente como un elemento o recurso natural vital para la subsistencia del ser humano y demás seres vivos que cohabitan con él en este planeta. Es por lo anterior que esta disciplina hace énfasis en la necesidad de proteger a las aguas bajo criterios de regulación en cuanto a su cantidad (uso racional) y en cuanto a su calidad (mantenimiento de las condiciones naturales) y cuya contaminación y deterioro debe asimismo prevenirse y controlarse. ${ }^{2}$ En segundo lugar, aludimos al derecho de aguas, también considerado un desprendimiento del derecho administrativo y que transita de la mano con el derecho ambiental. Se refiere a las aguas continentales como "un recurso unitario, que se renueva a través del ciclo hidrológico" y que desde el punto de vista normativo, "regula con eficiencia y equidad la distribución, aprovechamiento, control y preservación del agua continental, en equilibrio con los ecosistemas basándose en un desarrollo integral y sustentable". ${ }^{3}$

Otra disciplina que aporta nuevas formas de pensar, entender y, en todo caso, establecer el objeto de estudio y regulación de las aguas continentales, es el denominado derecho de los energéticos, al que le interesa su uso y aprovechamiento como elementos básicos en la generación de energía, como ha sido a través de las hidroeléctricas. ${ }^{4}$ La hidroelectricidad es parte del estudio del derecho energético por su enorme aportación a la generación de energía sin que por ello se hayan dejado de puntualizar las consecuencias ambientales negativas de su desarrollo (tanto en los seres humanos, en otros seres vivos, y en los ecosistemas en general) por la

2 Al respecto, véase lo señalado en Brañes, Raúl, Manual de derecho ambiental mexicano, 2a. ed., México, Fundación Mexicana para la Educación Ambiental-Fondo de Cultura Económica, 2000, pp. 399 y ss.; Nava Escudero, César, Estudios ambientales, 2a. ed., México, UNAM, Instituto de Investigaciones Jurídicas, 2011, pp. 287 y ss.

3 Farías, Urbano, Derecho mexicano de aguas nacionales, México, Porrúa, 1993, pp. 10 y 11.

4 Nava Negrete, Alfonso, "Derecho de los energéticos", en Fernández Ruiz, Jorge (coord.), Derecho administrativo. Memoria del Congreso Internacional de Culturas y Sistemas Jurídicos Comparados, México, UNAM, Instituto de Investigaciones Jurídicas, 2005, pp. 143-146. 
Esta obra forma parte del acervo de la Biblioteca Jurídica Virtual del Instituto de Investigaciones Jurídicas de la UNAM

construcción de presas y el estancamiento de las aguas. ${ }^{5}$ El crecimiento de la extracción de hidrocarburos a través de una técnica conocida como fracturación hidráulica (en inglés, fracking) la cual requiere de cantidades considerables de agua, pone de relieve la importancia de binomio jurídico energía-agua. Lamentablemente, los países que han optado por impulsar esta actividad, como es el caso reciente de México, han minimizado los costosísimos y enormes impactos ambientales que de ella se derivan tanto en la sociedad como en la naturaleza, ${ }^{6}$ lo que se contrapone a los esfuerzos que la comunidad internacional realiza para enfrentar los problemas ambientales, particularmente por lo que corresponde al cambio climático.

Algo semejante ocurre con las aguas marinas, ya que son diversas las disciplinas jurídicas que desde enfoques distintos estudian su significado y alcances, según lo que establece el artículo 27 constitucional. Por tradición, ha sido el derecho internacional el que se ha ocupado de esto. Dentro de esta rama jurídica se ubica lo que en algún momento llegó a denominarse el derecho internacional de los espacios maritimos o propiamente derecho internacional del mar. ${ }^{7} \mathrm{Si}$ bien esta última expresión tuvo cierto predominio en el pasado, ${ }^{8}$ desde hace algunas décadas se hace referencia al derecho del mar, expresión también válida en el contexto internacional de las naciones y que ha sido considerada una rama del

5 Alertaba la doctrina jurídica sobre esto desde hace ya algunos años. Véase Martín Mateo, Ramón, Nuevo derecho energético, Madrid, Instituto de Estudios de Administración Local, 1982, p. 357.

6 Aunque no es una tendencia generalizada, algunos países han comenzado a prohibir en sus territorios el uso de esta técnica por razones de tipo ambiental. Por ejemplo, en la Unión Europea tales Estados miembros como Francia, Bulgaria e Italia han llevado a cabo medidas jurídicas en este sentido. No así Reino Unido y Polonia, países que defienden e impulsan el fracking. Más detalles en Sández Arana, Juan Diego, "La fracturación hidráulica en la Unión Europea: estado de la cuestión”, Documento Marco, Instituto Español de Estudios Estratégicos, Ministerio de Defensa, Gobierno de España, Boletín electrónico, núm. 18, 3 de noviembre de 2014, disponible en www.ieee.es

7 Sepúlveda, César, Derecho internacional, 20a. ed., México, Porrúa, 2000, pp. 463 y ss.

8 Véase Székely, Alberto, comentarios al artículo de Vargas, Jorge A., "Terminología sobre el derecho del mar", Boletín Mexicano de Derecho Comparado, México, nueva serie, año XIII, núm. 39, septiembre-diciembre de 1980, diponible en http://www.juridicas. unam.mx/publica/librev/rev/boletin/cont/39/bib/bib26.pdf. 
Esta obra forma parte del acervo de la Biblioteca Jurídica Virtual del Instituto de Investigaciones Jurídicas de la UNAM

derecho internacional público. ${ }^{9}$ Bajo la égida de dicha rama jurídica los especialistas en la materia han logrado en mucho determinar la evolución histórica de la regulación sobre el mar y a su vez distinguir el derecho del mar tradicional del "nuevo" derecho del mar cuyo añejo punto de partida se estima hacia la década de los cuarenta del siglo pasado. ${ }^{10} \mathrm{El}$ derecho del mar de nuestros días nos ha permitido comprender la regulación tanto de aquellas aguas en zonas marinas (incluso las zonas marinas terrestres ${ }^{11}$ sujetas a la jurisdicción nacional de los Estados, así como de las que se encuentran dentro de un régimen de jurisdicción internacional. ${ }^{12}$

Otras ramas jurídicas que también se han ocupado de estas zonas aunque se trate más bien de desprendimientos del derecho administrativo incluyen al derecho maritimo ${ }^{13}$ que se ha definido como un conjunto de acontecimientos, construcciones ideales o instituciones jurídicas en conexión con el mar o con los espacios marítimos, ${ }^{14}$ así como al derecho pesquero cuyo objeto de estudio radica en el régimen de propiedad que corresponde a las especies hidrobiológicas así como en el elemento agua en donde éstas viven sin menoscabo de la importancia de los instrumentos materiales y técnicos que se emplean para el desarrollo de la actividad pesquera. ${ }^{15}$

Así, se infiere de lo señalado con antelación que para el análisis del artículo 27 constitucional en materia de aguas se debe distinguir entre

9 Véase Székely, Alberto, Derecho del mar, México, UNAM, Instituto de Investigaciones Jurídicas, 1991, p. 7.

10 Gómez-Robledo Verduzco, Alonso, Temas selectos de derecho internacional, 2a. ed., México, UNAM, Instituto de Investigaciones Jurídicas, 1994, pp. 354 y 355; id., Derecho del mar, México, McGraw Hill-UNAM, Instituto de Investigaciones Jurídicas, 1997, p. 5; Székely, Alberto, ibidem, p. 15.

11 Como se verá más adelante, las zonas marinas se refieren de manera genérica tanto a espacios de aguas que se encuentran en esas zonas (como el mar territorial) como a los espacios terrestres subyacentes a las aguas marinas (como el lecho o subsuelo marinos).

12 Székely, Alberto, Derecho del mar, cit., p. 8.

13 Al parecer, el primer texto que en forma de libro aparece en México ocurre hacia finales de la década de los sesenta del siglo pasado: Cervantes Ahumada, Raúl, Derecho marítimo, México, Herrero, 1970.

14 Ibidem, p. 6; Salgado y Salgado, José Eusebio, "Derecho marítimo", Nuevo diccionario jurídico mexicano, México, Porrúa-UNAM, Instituto de Investigaciones Jurídicas, t. D-H, 2000, p. 1194.

15 Barragán, José, "Derecho pesquero”, Diccionario jurídico mexicano, 8a. ed., México, Porrúa-UNAM, Instituto de Investigaciones Jurídicas, t. D-H, 1995, p. 1025. 
Esta obra forma parte del acervo de la Biblioteca Jurídica Virtual del Instituto de Investigaciones Jurídicas de la UNAM

las que son continentales y las que son marinas. Si bien la Constitución no hace una diferenciación expresa de estos dos conceptos y por lo tanto ubi lex non distinguit, nec nos distinguere debemus, ${ }^{16}$ enfatizamos que esta división ha sido reconocida por una parte importante de la doctrina mexicana y es ideal para fines didácticos en la comprensión del texto constitucional aludido. Aún más, esta distinción se adopta comúnmente para cuestiones técnicas y de regulación normativa, ${ }^{17}$ lo que sucede claramente en nuestro país.

Dicho lo anterior, si pretendemos que el análisis de cada una de estas categorías conceptuales (o ambas) sea integral y de actualidad, es indispensable adoptar un enfoque tanto patrimonial como ambiental, puesto que es esto lo que esencialmente las caracteriza. Lo anterior, como resultado no sólo de una lectura cuidadosa del texto del artículo citado, sino del hecho contundente de que las leyes más importantes que han emanado o que tienen su fundamento constitucional en dicho precepto, son leyes patrimoniales $\mathrm{y} / \mathrm{o}$ ambientales.

\section{RÉGIMEN CONSTITUCIONAL: DEL TEXTO ORIGINAL AL TEXTO VIGENTE}

Partiendo de la idea de que el artículo 27 constitucional recoge dos conceptos distintos (aunque íntimamente vinculados entre sí: el de aguas continentales y el de aguas marinas), es necesario aclarar que no todo el texto de este precepto está relacionado con las aguas. En efecto, se regulan otros bienes nacionales - como los minerales o los hidrocarburos, entre otros - así como lo relativo al régimen patrimonial de las tierras, los cuales no forman parte del análisis que aquí se realiza.

Para las aguas continentales interesa referirnos principalmente a los párrafos primero, tercero, quinto y sexto, y para las aguas marinas a los párrafos quinto, sexto y noveno en relación con los párrafos primero, tercero y cuarto del artículo en cuestión. Es claro que aun dentro del texto de cada uno de estos párrafos mencionados, se debe identificar la parte que corresponde a las aguas, ya sean continentales y/o marinas, debido

16 Principio general del derecho que se significa que cuando la ley no distingue, nosotros no debemos distinguir.

17 Así se señala, por ejemplo, en Arenas Muñoz, José Antonio, Diccionario técnico y jurídico del medio ambiente, Madrid, McGraw Hill, 2000, p. 39. 
Esta obra forma parte del acervo de la Biblioteca Jurídica Virtual del Instituto de Investigaciones Jurídicas de la UNAM

a que en algunos de ellos se hace referencia a otros recursos naturales. El párrafo décimo y sus diversas fracciones relativas a las prescripciones sobre la capacidad para adquirir el dominio de las aguas de la nación, tiene relevancia para nuestra materia, pero ésta no será objeto central de análisis en el presente trabajo.

Ahora bien, hay que aclarar que el estudio constitucional de las aguas continentales y marinas no se agota en los párrafos del artículo 27 arriba mencionados. Es necesario acudir a otros preceptos que forman parte fundamental del marco constitucional de las aguas en su totalidad, como es el caso para las aguas continentales, por ejemplo, del artículo 73, fracción XVII (relativo a las facultades que tiene el Congreso de la Unión para expedir leyes sobre el uso y aprovechamiento de las aguas de jurisdicción federal) en relación con los artículos 124 y 115 (relativos a las facultades reservadas a los estados y a la Ciudad de México, así como a las funciones y servicios públicos a cargo de los municipios, respectivamente). A lo anterior hay que agregar, por supuesto, el precepto relativo al derecho al agua consagrado en el artículo 4o., párrafo sexto en relación con las disposiciones y principios que se establecen en el artículo 1o. en materia de derechos humanos.

También es el caso para las aguas marinas, por ejemplo, de los artículos 89 , fracción X (relativo a las facultades y obligaciones que tiene el presidente de la República para dirigir la política exterior y celebrar tratados internacionales) y 76, fracción I (relativo a las facultades exclusivas del Senado para analizar la política exterior del Ejecutivo federal y para aprobar los tratados internacionales celebrados por el mismo). A éstos hay que agregar los artículos 42, fracción $\mathrm{V}$ y 48 (relativo a que las aguas del mar territorial y las marinas interiores son, respectivamente, partes integrantes del territorio nacional, y dependen directamente del gobierno de la Federación).

Sin embargo, en esta ocasión, para el análisis del artículo 27 constitucional en aguas habremos de referirnos fundamentalmente a los párrafos primero, tercero, cuarto, quinto, sexto y noveno mencionados con antelación, y sólo cuando así lo amerite por su relevancia, a otros preceptos constitucionales. Por lo que a continuación transcribimos los párrafos correspondientes tanto en su versión original — la de 1917- como en 
Esta obra forma parte del acervo de la Biblioteca Jurídica Virtual del Instituto de Investigaciones Jurídicas de la UNAM

su versión actual — la de 2016. ${ }^{18}$ Las cursivas en los textos de referencia son nuestras con el objeto de identificar las disposiciones jurídicas pertinentes.

Párrafo primero. Comencemos por transcribir el primer párrafo del artículo 27 constitucional. En su texto original, se señalaba lo siguiente:

La propiedad de las tierras y aguas comprendidas dentro de los límites del territorio nacional, corresponde originariamente a la nación, la cual, ha tenido y tiene el derecho de transmitir el dominio de ellas a los particulares, constituyendo la propiedad privada.

Desde su redacción por vez primera para la Constitución de 1917 y hasta nuestros días, este artículo no ha sido modificado. El texto vigente establece lo siguiente:

La propiedad de las tierras y aguas comprendidas dentro de los límites del territorio nacional, corresponde originariamente a la nación, la cual ha tenido y tiene el derecho de transmitir el dominio de ellas a los particulares, constituyendo la propiedad privada.

Párrafo tercero. Contrario a lo que ha sucedido en el párrafo primero, el texto del párrafo tercero sí ha sufrido diversas modificaciones desde 1917. En ellas se han incluido aspectos patrimoniales y ambientales diversos en relación con las aguas. Así, se leía en los años revolucionarios este precepto constitucional:

La nación tendrá en todo tiempo el derecho de imponer a la propiedad privada las modalidades que dicte el interés público, así como el de regular el aprovechamiento de los elementos naturales susceptibles de apropiación, para hacer una distribución equitativa de la riqueza pública y para cuidar de su conservación. Con este objeto se dictarán las medidas necesarias para el fraccionamiento de los latifundios; para el desarrollo de la pequeña propiedad; para la creación de nuevos centros de población agrícola con las tierras y aguas que les sean indispensables; para el fomento de la agricultura y para evitar la destrucción de los elementos naturales y los daños que la propiedad pueda sufrir en perjuicio de la sociedad. Los pueblos, rancherías y comunidades que carezcan de tierras y aguas, o no

18 Los preceptos constitucionales transcritos corresponden al texto vigente hasta la última reforma publicada en el Diario Oficial de la Federación del 29 de enero de 2016. 
Esta obra forma parte del acervo de la Biblioteca Jurídica Virtual del Instituto de Investigaciones Jurídicas de la UNAM

las tengan en cantidad suficiente para las necesidades de su población, tendrán derecho a que se les dote de ellas, tomándolas de las propiedades inmediatas, respetando siempre la pequeña propiedad. Por tanto, se confirman las dotaciones de terrenos que se hayan hecho hasta ahora de conformidad con el Decreto de 6 de enero de 1915. La adquisición de las propiedades particulares necesarias para conseguir los objetos antes expresados, se considerará de utilidad pública.

El actual párrafo tercero establece lo siguiente:

La nación tendrá en todo tiempo el derecho de imponer a la propiedad privada las modalidades que dicte el interés público, así como el de regular, en beneficio social, el aprovechamiento de los elementos naturales susceptibles de apropiación, con objeto de hacer una distribución equitativa de la riqueza pública, cuidar de su conservación, lograr el desarrollo equilibrado del país y el mejoramiento de las condiciones de vida de la población rural y urbana. En consecuencia, se dictarán las medidas necesarias para ordenar los asentamientos humanos y establecer adecuadas provisiones, usos, reservas y destinos de tierras, aguas y bosques, a efecto de ejecutar obras públicas y de planear y regular la fundación, conservación, mejoramiento y crecimiento de los centros de población; para preservar y restaurar el equilibrio ecológico; para el fraccionamiento de los latifundios; para disponer, en los términos de la ley reglamentaria, la organización y explotación colectiva de los ejidos y comunidades; para el desarrollo de la pequeña propiedad rural; para el fomento de la agricultura, de la ganadería, de la silvicultura y de las demás actividades económicas en el medio rural, y para evitar la destrucción de los elementos naturales y los daños que la propiedad pueda sufrir en perjuicio de la sociedad.

Párrafo cuarto. El texto original de este párrafo no contemplaba en realidad referencias importantes sobre las aguas, salvo aquella en la que se señalaba que serían del dominio directo las salinas formadas directamente por las aguas marinas. El contenido de este párrafo en aquel entonces era el siguiente:

Corresponde a la nación el dominio directo de todos los minerales o substancias que en vetas, mantos, masas o yacimientos, constituyan depósitos cuya naturaleza sea distinta de los componentes de los terrenos, tales como los minerales de los que se extraigan metales y metaloides utilizados en la industria; los yacimientos de piedras preciosas, de sal de gema y las 
Esta obra forma parte del acervo de la Biblioteca Jurídica Virtual del Instituto de Investigaciones Jurídicas de la UNAM

salinas formadas directamente por las aguas marinas. Los productos derivados de la descomposición de las rocas, cuando su explotación necesite trabajos subterráneos; los fosfatos susceptibles de ser utilizados como fertilizantes; los combustibles minerales sólidos; el petróleo y todos los carburos de hidrógeno sólidos, líquidos o gaseosos.

Interesa este párrafo en la actualidad puesto que su texto se modificó para incorporar la regulación sobre ciertos aspectos vinculados a los recursos naturales en determinadas zonas marinas. El actual párrafo cuarto reza así:

Corresponde a la nación el dominio directo de todos los recursos naturales de la plataforma continental y los zócalos submarinos de las islas; de todos los minerales o substancias que en vetas, mantos, masas o yacimientos, constituyan depósitos cuya naturaleza sea distinta de los componentes de los terrenos, tales como los minerales de los que se extraigan metales y metaloides utilizados en la industria; los yacimientos de piedras preciosas, de sal de gema y las salinas formadas directamente por las aguas marinas; los productos derivados de la descomposición de las rocas, cuando su explotación necesite trabajos subterráneos; los yacimientos minerales u orgánicos de materias susceptibles de ser utilizadas como fertilizantes; los combustibles minerales sólidos; el petróleo y todos los carburos de hidrógeno sólidos, líquidos o gaseosos; y el espacio situado sobre el territorio nacional, en la extensión y términos que fije el derecho internacional.

Párrafo quinto. El párrafo quinto ha sido desde sus orígenes (prácticamente en su totalidad) fundamental para el entendimiento de la regulación de las aguas continentales y marinas. El texto originario establecía lo siguiente:

Son también propiedad de la nación las aguas de los mares territoriales en la extensión y términos que fija el derecho internacional; las de las lagunas y esteros de las playas; las de los lagos interiores de formación natural, que estén ligados directamente a corrientes constantes; las de los ríos principales o arroyos afluentes desde el punto en que brota la primera agua permanente hasta su desembocadura, ya sea que corran al mar o que crucen dos o más estados; las de las corrientes intermitentes que atraviesen dos o más estados en su rama principal; las aguas de los ríos, arroyos o barrancos, cuando sirvan de límite al territorio nacional o al de los estados; las aguas que se extraigan de las minas; y los cauces, lechos 
Esta obra forma parte del acervo de la Biblioteca Jurídica Virtual del Instituto de Investigaciones Jurídicas de la UNAM

o riberas de los lagos y corrientes anteriores en la extensión que fije la ley. Cualquiera otra corriente de agua no incluida en la enumeración anterior, se considerará como parte integrante de la propiedad privada que atraviese; pero el aprovechamiento de las aguas, cuando su curso pase de una finca a otra, se considerará como de utilidad pública y quedará sujeta a las disposiciones que dicten los estados.

A lo largo de su existencia, el párrafo quinto ha sido modificado en algunas ocasiones para quedar como sigue:

Son propiedad de la nación las aguas de los mares territoriales en la extensión y términos que fija el derecho internacional; las aguas marinas interiores; las de las lagunas y esteros que se comuniquen permanente o intermitentemente con el mar; las de los lagos interiores de formación natural que estén ligados directamente a corrientes constantes; las de los ríos y sus afluentes directos o indirectos, desde el punto del cauce en que se inicien las primeras aguas permanentes, intermitentes o torrenciales, hasta su desembocadura en el mar, lagos, lagunas o esteros de propiedad nacional; las de las corrientes constantes o intermitentes y sus afluentes directos o indirectos, cuando el cauce de aquéllas en toda su extensión o en parte de ellas, sirva de límite al territorio nacional o a dos entidades federativas, o cuando pase de una entidad federativa a otra o cruce la línea divisoria de la República; las de los lagos, lagunas o esteros cuyos vasos, zonas o riberas, estén cruzados por líneas divisorias de dos o más entidades o entre la República y un país vecino; o cuando el límite de las riberas sirva de lindero entre dos entidades federativas o a la República con un país vecino; las de los manantiales que broten en las playas, zonas marítimas, cauces, vasos o riberas de los lagos, lagunas o esteros de propiedad nacional, y las que se extraigan de las minas; y los cauces, lechos o riberas de los lagos y corrientes interiores en la extensión que fije la ley. Las aguas del subsuelo pueden ser libremente alumbradas mediante obras artificiales y apropiarse por el dueño del terreno, pero cuando lo exija el interés público o se afecten otros aprovechamientos, el Ejecutivo federal podrá reglamentar su extracción y utilización y aun establecer zonas vedadas, al igual que para las demás aguas de propiedad nacional. Cualesquiera otras aguas no incluidas en la enumeración anterior, se considerarán como parte integrante de la propiedad de los terrenos por los que corran o en los que se encuentren sus depósitos, pero si se localizaren en dos o más predios, el aprovechamiento de estas aguas se considerará 
Esta obra forma parte del acervo de la Biblioteca Jurídica Virtual del Instituto de Investigaciones Jurídicas de la UNAM

de utilidad pública, y quedará sujeto a las disposiciones que dicten las entidades federativas.

Párrafo sexto. También es importante transcribir el párrafo sexto que en su texto original establecía lo siguiente:

En los casos a que se refieren los dos párrafos anteriores, el dominio de la nación es inalienable e imprescriptible, y sólo podrán hacerse concesiones por el gobierno federal a los particulares o sociedades civiles o comerciales constituidas conforme a las leyes mexicanas, con la condición de que se establezcan trabajos regulares para la explotación de los elementos de que se trata, y se cumpla con los requisitos que prevengan las leyes.

El actual párrafo sexto señala lo siguiente:

En los casos a que se refieren los dos párrafos anteriores, el dominio de la nación es inalienable e imprescriptible y la explotación, el uso o el aprovechamiento de los recursos de que se trata, por los particulares o por sociedades constituidas conforme a las leyes mexicanas, no podrá realizarse sino mediante concesiones, otorgadas por el Ejecutivo federal, de acuerdo con las reglas y condiciones que establezcan las leyes, salvo en radiodifusión y telecomunicaciones, que serán otorgadas por el Instituto Federal de Telecomunicaciones. Las normas legales relativas a obras o trabajos de explotación de los minerales y substancias a que se refiere el párrafo cuarto, regularán la ejecución y comprobación de los que se efectúen o deban efectuarse a partir de su vigencia, independientemente de la fecha de otorgamiento de las concesiones, y su inobservancia dará lugar a la cancelación de éstas. El gobierno federal tiene la facultad de establecer reservas nacionales y suprimirlas. Las declaratorias correspondientes se harán por el Ejecutivo en los casos y condiciones que las leyes prevean. Tratándose de minerales radiactivos no se otorgarán concesiones. Corresponde exclusivamente a la nación la planeación y el control del sistema eléctrico nacional, así como el servicio público de transmisión y distribución de energía eléctrica; en estas actividades no se otorgarán concesiones, sin perjuicio de que el Estado pueda celebrar contratos con particulares en los términos que establezcan las leyes, mismas que determinarán la forma en que los particulares podrán participar en las demás actividades de la industria eléctrica. 
Esta obra forma parte del acervo de la Biblioteca Jurídica Virtual del Instituto de Investigaciones Jurídicas de la UNAM

Párrafo noveno. El contenido del texto del actual párrafo noveno se adicionó por vez primera como párrafo octavo del artículo 27 constitucional por decreto publicado en el Diario Oficial de la Federación del 6 de febrero de 1976. Antes de esta fecha, no existía el contenido que ahora transcribimos.

La nación ejerce en una zona económica exclusiva situada fuera del mar territorial y adyacente a éste, los derechos de soberanía y las jurisdicciones que determinen las leyes del Congreso. La zona económica exclusiva se extenderá a doscientas millas náuticas, medidas a partir de la línea de base desde la cual se mide el mar territorial. En aquellos casos en que esa extensión produzca superposición con las zonas económicas exclusivas de otros Estados, la delimitación de las respectivas zonas se hará en la medida en que resulte necesario, mediante acuerdo con estos Estados.

Con reforma a la Constitución según decreto publicado en el Diario Oficial de la Federación del 20 de diciembre de 2013, se recorrió íntegro el texto del párrafo octavo al párrafo noveno. De tal manera que el texto vigente de este párrafo ha permanecido sin modificación alguna desde 1976, siempre relacionado en su totalidad con las aguas marinas.

\section{RÉGIMEN LEGAL}

Dentro del sistema jurídico mexicano existen varias leyes expedidas por el Congreso de la Unión que se refieren a lo que establece el artículo 27 constitucional en materia de aguas. Algunas de estas leyes regulan párrafos completos o partes del artículo citado, es decir, son leyes reglamentarias; otras, se apoyan en artículos constitucionales distintos pero tienen alguna vinculación con el artículo 27 (y no por ello son de una jerarquía inferior).

Mientras que para las aguas continentales, las leyes reglamentarias por excelencia son la Ley de Aguas Nacionales y la Ley General de Bienes Nacionales, para el caso de las aguas o zonas marinas lo son la Ley Federal del Mar y también la Ley General de Bienes Nacionales ya referida. Junto a éstas, y de singular importancia, se encuentra la Ley General del Equilibrio Ecológico y la Protección al Ambiente. Aunque ésta no es explícitamente ley reglamentaria del artículo 27 en materia de aguas, sí 
Esta obra forma parte del acervo de la Biblioteca Jurídica Virtual del Instituto de Investigaciones Jurídicas de la UNAM

regula diversos aspectos sobre las aguas continentales y marinas, aunque bajo el marco de la preservación y restauración del equilibrio ecológico y la protección al ambiente. ${ }^{19}$

A continuación, presentamos los antecedentes de estas cuatro leyes (de 1917 a la fecha) comenzando por la Ley de Aguas Nacionales:

a) Ley sobre Irrigación con Aguas Federales (1926) 20

b) Ley de Aguas de Propiedad Nacional (1929) ${ }^{21}$

c) Ley de Aguas de Propiedad Nacional (1934) 22

d) Ley de Riegos (1946) 23

e) Ley Reglamentaria del Párrafo Quinto del Artículo 27 Constitucional en Materia de Aguas del Subsuelo (1956) ${ }^{24}$

f) Ley Federal de Aguas (1972) 25

19 El apoyo constitucional de la Ley General del Equilibrio Ecológico y la Protección al Ambiente no sólo se encuentra en el artículo 27 constitucional sino también en el artículo 73, fracción XXIX-G relativo a las facultades que tiene el Congreso de la Unión para expedir leyes que establezcan la concurrencia del gobierno federal, de los gobiernos de las entidades federativas, de los municipios, y de las demarcaciones territoriales de la Ciudad de México, en el ámbito de sus respectivas competencias, en materia de protección al ambiente y de preservación y restauración del equilibrio ecológico.

20 Publicada en el Diario Oficial de la Federación del 9 de enero de 1926. Esta Ley señalaba en su artículo 1o. transitorio que quedaban modificados (en lo que se opusieran) los preceptos relativos de la entonces vigente Ley de Aguas de Jurisdicción Federal de 13 de diciembre de 1910. Por cierto, la Ley de 1926 no abrogó a la de referencia de 1910.

21 Publicada en el Diario Oficial de la Federación del 7 de agosto de 1929. Esta Ley es la encargada de abrogar la Ley de Aguas de Jurisdicción Federal de 13 de diciembre de 1910, como se establece en su primer artículo transitorio.

22 Publicada en el Diario Oficial de la Federación del 31 de agosto de 1934. Como se anota en su artículo 1o. transitorio, se abroga la anterior Ley de Aguas de Propiedad Nacional de 1929.

23 Publicada en el Diario Oficial de la Federación del 31 de diciembre de 1946. Con esta Ley queda abrogada la Ley sobre Irrigación con Aguas Federales de 1926, según su artículo segundo transitorio.

24 Publicada en el Diario Oficial de la Federación del 31 de diciembre de 1956.

25 Publicada en el Diario Oficial de la Federación del 11 de enero de 1972. Esta Ley se encarga de abrogar la entonces vigente Ley de Aguas de Propiedad Nacional de 1934, la Ley de Riegos de 1946, y la Ley Reglamentaria de 1956, así como las leyes Federal de Ingeniería Sanitaria y la de Cooperación para Dotación de Agua Potable en Municipios. 
Esta obra forma parte del acervo de la Biblioteca Jurídica Virtual del Instituto de Investigaciones Jurídicas de la UNAM

g) Ley de Aguas Nacionales (1992) ${ }^{26}$

Al elevarse a rango constitucional el derecho humano al agua por decreto que reformó el artículo 4o. de nuestra carta magna, ${ }^{27}$ se estableció en el transitorio tercero que el Congreso de la Unión contaría con un plazo de 360 días para emitir una Ley General de Aguas, que abrogaría a la Ley de 1992. Han transcurrido más de cuatro años (contando el plazo otorgado al Congreso de la Unión) y aún no se expide tal Ley.

Para el caso de la Ley General de Bienes Nacionales, sus antecedentes legislativos (por cierto con el mismo nombre de la actual Ley) son los siguientes:

a) Ley General de Bienes Nacionales (1942) 28

b) Ley General de Bienes Nacionales (1969) ${ }^{29}$

c) Ley General de Bienes Nacionales (1982) ${ }^{30}$

d) Ley General de Bienes Nacionales (2004) ${ }^{31}$

Por lo que respecta a la Ley Federal del Mar, su único antecedente inmediato es una ley reglamentaria de 1976. Aquí los nombres de las dos leyes que han regulado el tema:

26 Publicada en el Diario Oficial de la Federación del 1 de diciembre de 1992. Establece en su artículo 2o. transitorio la abrogación de la Ley Federal de Aguas de 1972. La Ley de Aguas Nacionales de 1992 sufrió profundas modificaciones a través de un decreto por el que se reforman, adicionan y derogan diversas disposiciones publicado en el Diario Oficial de la Federación del 29 de abril de 2004. Al momento de escribir, la última reforma a la Ley publicada en el Diario Oficial de la Federación es de 24 de marzo de 2016.

27 Publicado en el Diario Oficial de la Federación del 8 de febrero de 2012.

28 Publicada en el Diario Oficial de la Federación del 3 de julio de 1942. En el artículo 6o. transitorio de esta Ley se establece que se abroga el Decreto de 18 de diciembre de 1902, antecedente inmediato de la misma.

29 Publicada en el Diario Oficial de la Federación del 30 de enero de 1969.

30 Publicada en el Diario Oficial de la Federación del 8 de enero de 1982. La ley establece en el artículo 2o. transitorio que se abroga la ley de 1969.

31 Publicada en el Diario Oficial de la Federación del 20 de mayo de 2004. El artículo 2o. transitorio establece que se abroga la anterior Ley de 1982. 
Esta obra forma parte del acervo de la Biblioteca Jurídica Virtual del Instituto de Investigaciones Jurídicas de la UNAM

a) Ley Reglamentaria del Párrafo Octavo del Artículo 27 Constitucional, relativo a la Zona Económica Exclusiva (1976) ${ }^{32}$

b) Ley Federal del Mar (1986) 33

Finalmente, la Ley General del Equilibrio Ecológico y la Protección al Ambiente ha tenido dos antecedentes muy importantes; aquí los mencionamos:

a) Ley Federal para Prevenir y Controlar la Contaminación Ambiental $(1971)^{34}$

b) Ley Federal de Protección al Ambiente (1982) 35

c) Ley General del Equilibrio Ecológico y la Protección al Ambiente $(1988)^{36}$

A todas las anteriores, se suman otras leyes que regulan distintas cuestiones sobre las aguas continentales y las aguas marinas:

a) Ley Orgánica de la Administración Pública Federal (1976) ${ }^{37}$

b) Ley Federal de Derechos $(1981)^{38}$

c) Ley General de Salud (1984) ${ }^{39}$

d) Ley de Contribución de Mejoras por Obras Públicas Federales de Infraestructura Hidráulica (1990) ${ }^{40}$

e) Ley Agraria (1992) ${ }^{41}$

32 Publicada en el Diario Oficial de la Federación del 13 de febrero de 1976.

33 Publicada en el Diario Oficial de la Federación del 8 de enero de 1986. En su artículo 2o. transitorio, la ley abroga la anterior ley reglamentaria del párrafo 8o. del artículo 27 constitucional de 1976.

34 Publicada en el Diario Oficial de la Federación del 23 de marzo de 1971.

35 Publicada en el Diario Oficial de la Federación del 11 de enero de 1982. Señala el artículo 2o. transitorio que se abroga la Ley Federal Para Prevenir y Controlar la Contaminación Ambiental de 1971.

36 Publicada en el Diario Oficial de la Federación del 28 de enero de 1988. En su artículo segundo transitorio se señala que queda abrogada la Ley Federal de Protección al Ambiente de 1982.

37 Publicada en el Diario Oficial de la Federación del 29 de diciembre de 1976.

38 Publicada en el Diario Oficial de la Federación del 31 de diciembre de 1981.

39 Publicada en el Diario Oficial de la Federación del 7 de febrero de 1984.

40 Publicada en el Diario Oficial de la Federación del 26 de diciembre de 1990.

41 Publicada en el Diario Oficial de la Federación del 26 de febrero de 1992. 
Esta obra forma parte del acervo de la Biblioteca Jurídica Virtual del Instituto de Investigaciones Jurídicas de la UNAM

f) Ley Minera (1992) 42

g) Ley de Puertos (1993) ${ }^{43}$

h) Ley General de Vida Silvestre (2000) ${ }^{44}$

i) Ley de Desarrollo Rural Sustentable $(2001)^{45}$

j) Ley Orgánica de la Armada de México (2002) ${ }^{46}$

k) Ley General de Desarrollo Forestal Sustentable (2003) ${ }^{47}$

1) Ley General para la Prevención y Gestión Integral de los Residuos $(2003)^{48}$

m) Ley de Navegación y Comercio Marítimos (2006) ${ }^{49}$

n) Ley General de Pesca y Acuacultura Sustentables (2007) ${ }^{50}$

ñ) Ley de Promoción y Desarrollo de los Bioenergéticos (2008) $)^{51}$

o) Ley General de Cambio Climático (2012) ${ }^{52}$

p) Ley de Vertimientos en las Zonas Marinas Mexicanas (2014) ${ }^{53}$

q) Ley de Hidrocarburos (2014) $)^{54}$

r) Ley de Energía Geotérmica (2014) 55

s) Ley de la Industria Eléctrica (2014) $)^{56}$

t) Ley de la Agencia Nacional de Seguridad Industrial y de Protección al Medio Ambiente del Sector Hidrocarburos (2014) ${ }^{57}$

u) Ley de Transición Energética (2015) ${ }^{58}$

42 Publicada en el Diario Oficial de la Federación del 26 de junio de 1992.

43 Publicada en el Diario Oficial de la Federación del 19 de julio de 1993.

44 Publicada en el Diario Oficial de la Federación del 3 de julio de 2000.

45 Publicada en el Diario Oficial de la Federación del 7 de diciembre de 2001. Publicada en el Diario Oficial de la Federación del 30 de diciembre de 2002. Publicada en el Diario Oficial de la Federación del 25 de febrero de 2003. Publicada en el Diario Oficial de la Federación del 8 de octubre de 2003. Publicada en el Diario Oficial de la Federación del 1o. de junio de 2006. Publicada en el Diario Oficial de la Federación del 24 de julio de 2007. Publicada en el Diario Oficial de la Federación del 1o. de febrero de 2008. Publicada en el Diario Oficial de la Federación del 6 de junio de 2012. Publicada en el Diario Oficial de la Federación del 17 de enero de 2014. Publicada en el Diario Oficial de la Federación del 11 de agosto de 2014. Publicada en el Diario Oficial de la Federación del 11 de agosto de 2014. Publicada en el Diario Oficial de la Federación del 11 de agosto de 2014. Publicada en el Diario Oficial de la Federación del 11 de agosto de 2014. 
Esta obra forma parte del acervo de la Biblioteca Jurídica Virtual del Instituto de Investigaciones Jurídicas de la UNAM

\section{AgUAS CONTINENTALES}

\section{Enfoque patrimonial}

Al centro de toda discusión sobre el tema de las aguas, según lo establecido en el artículo 27 constitucional, se encuentra el de su régimen patrimonial. Nos preguntamos entonces ¿quién o quiénes son o pueden ser los propietarios de las aguas continentales?

Como es de suponerse, existe cierto debate en torno al significado de lo que la Constitución estableció en 1917 en este sentido, y el cual se ha enriquecido a partir de los cambios o adiciones que ésta ha sufrido a lo largo de su existencia. El texto constitucional en sus párrafos correspondientes ha sido interpretado de diversas maneras y las opiniones que se han vertido (particularmente en relación con el concepto de dominio) hacen evidente la falta de consenso que existe entre juristas sobre el tema. No se trata aquí de elaborar un análisis exhaustivo de cada una de las posturas existentes; ${ }^{59}$ en realidad, presentamos lo que consideramos de mayor relevancia para los fines de este trabajo.

El punto de partida relativo al régimen patrimonial de las aguas continentales lo establece el párrafo primero del artículo 27 constitucional de donde se desprende que no sólo el Estado es el propietario de las aguas, sino que los particulares también pueden serlo. En efecto, por un lado, al Estado ${ }^{60}$ se le considera el propietario originario de las aguas, ya que la primera parte del párrafo al que se alude señala con claridad que co-

59 Para ello, remitimos a Farías, Urbano, Derecho mexicano..., cit., pp. 40 y ss., quien cita a diversos autores que han opinado sobre el tema. También sobre propiedad, y particularmente sobre dominio, recomendamos una serie de ensayos compilados por Antonio Azuela: Díaz y Díaz, Martín, Ensayos sobre la propiedad, México, UNAM, Instituto de Investigaciones Jurídicas, 2014, passim.

60 No es objeto de este artículo discurrir sobre las similitudes o disimilitudes conceptuales y de enfoque científico entre las nociones de Estado y Nación. Para los efectos del presente trabajo se hace uso indistinto de ambas sin que por ello dejemos de reconocer que diversos autores han tratado de precisar los elementos que las conforman. En este sentido, Carpizo, Jorge, "Nación", Diccionario jurídico mexicano, 8a. ed., México, Porrúa-UNAM, Instituto de Investigaciones Jurídicas, t. I-O, 1995, p. 2171, ha señalado que "el concepto de nación es más amplio que el de Estado porque el primero abarca muchos aspectos de la vida del hombre, mientras el segundo es el órgano creador y aplicador del derecho". Recomendamos al lector acudir para mayor abundancia sobre este tema a Tamayo y Salmorán, Rolando, "Estado", Enciclopedia 
Esta obra forma parte del acervo de la Biblioteca Jurídica Virtual del Instituto de Investigaciones Jurídicas de la UNAM

rresponde originariamente a la nación la propiedad de las aguas; de aquí que se hable de una propiedad originaria. Por el otro lado, es la misma nación la que puede — si así lo determina - crear o constituir la propiedad privada de las aguas, y de aquí que se pueda considerar a los particulares - aunque no sea común denominarlos así- como los propietarios derivados de las aguas.

Si aceptamos lo antes dicho, debemos entonces preguntarnos cuáles aguas pertenecen a uno y a otro. Para ello, acudimos al párrafo quinto del artículo 27 constitucional, que nos dice de manera expresa cuáles son las aguas propiedad de la nación de donde se deriva cuáles son las de propiedad de los particulares. De esta manera, el citado párrafo del artículo constitucional señala que son aguas propiedad de la nación -o lo que es lo mismo aguas nacionales - las siguientes:

a) las de las lagunas y esteros que se comuniquen permanente o intermitentemente con el mar;

b) las de los lagos interiores de formación natural que estén ligados directamente a corrientes constantes;

c) las de los ríos y sus afluentes directos o indirectos (desde el punto del cauce en que se inicien las primeras aguas permanentes, intermitentes o torrenciales, hasta su desembocadura en el mar, lagos, lagunas o esteros de propiedad nacional);

d) las de las corrientes constantes o intermitentes y sus afluentes directos o indirectos (cuando el cauce de aquéllas en toda su extensión o en parte de ellas, sirva de límite al territorio nacional o a dos entidades federativas, o cuando pase de una entidad federativa a otra o cruce la línea divisoria de la República);

e) las de los lagos, lagunas o esteros cuyos vasos, zonas o riberas, estén cruzados por líneas divisorias de dos o más entidades o entre la República y un país vecino, o cuando el límite de las riberas sirva de lindero entre dos entidades federativas o a la República con un país vecino;

jurídica mexicana, 2a. ed., México, Porrúa-UNAM, Instituto de Investigaciones Jurídicas, t. III, D-E, 2004, pp. 811-820. 
Esta obra forma parte del acervo de la Biblioteca Jurídica Virtual del Instituto de Investigaciones Jurídicas de la UNAM

f) las de los manantiales que broten en las playas, zonas marítimas, cauces, vasos o riberas de los lagos, lagunas o esteros de propiedad nacional;

g) las que se extraigan de las minas;

h) las de los cauces, lechos o riberas de los lagos y corrientes interiores en la extensión que fije la ley

i) las aguas del subsuelo

Este listado — como advierte Urbano Farías — ${ }^{61}$ es tan amplio y general que abarca prácticamente todas las aguas continentales (superficiales o del subsuelo) y aún así no es limitativo sino enunciativo. Por lo que a esta enumeración habrá que agregar, como lo señala el autor, aquellas aguas que sin estar precisadas con toda claridad en el listado del párrafo quinto se encuentran en depósitos o corren sobre bienes nacionales. El apoyo que encuentra Urbano Farías para afirmar lo anterior se encuentra precisamente en lo que establece la parte final del párrafo en comento, que señala que cualesquiera otras aguas no incluidas en la enumeración de referencia, serán parte integrante de la propiedad de los terrenos por los que corran o en los que se encuentren sus depósitos. Por lo tanto, si las aguas corren y se depositan sobre bienes nacionales entonces se considera que forman parte de dichos bienes y con ello se convierten en aguas nacionales.

Con lo señalado anteriormente, es posible determinar ahora cuáles son las aguas propiedad de los particulares. Para ello, debemos tener en mente que los particulares adquieren el dominio de las aguas bajo un régimen de excepción puesto que, como ya hemos señalado, prácticamente todas las aguas continentales son nacionales. De esta manera, los particulares podrán apropiarse de aquellas aguas que no se encuentren en el listado arriba señalado (esto es, en la primera parte del párrafo quinto) ni que corran o se encuentren en depósitos que sean bienes nacionales. Por lo tanto, para que los particulares se apropien de las aguas es menester que corran o se encuentren (sus depósitos) en terrenos que sean de su propiedad. ${ }^{62}$

61 Farías, Urbano, Derecho mexicano..., cit., p. 43.

62 Sobre este punto en particular Nava Negrete señala que las aguas propiedad de los particulares se rigen por el Código Civil de cada entidad federativa. Véase Nava Negrete, 
Esta obra forma parte del acervo de la Biblioteca Jurídica Virtual del Instituto de Investigaciones Jurídicas de la UNAM

De cualquier manera, la idea de "apropiación" por parte de los particulares no se refiere al tradicional concepto de un derecho de propiedad sobre un bien, en este caso, el de las aguas.

El quinto párrafo y la fracción I del artículo 27 constitucional no deja lugar a duda de que puede haber, por excepción, agua susceptible de apropiación de particulares, siempre y cuando no sean aguas nacionales, que por disposición constitucional y legal se deben mantener como tales. Sin embargo, tal adquisición o apropiación es en todo caso sui generis, en atención al recurso natural de que se trata. En realidad implica una titularidad del derecho para explotar, usar o aprovechar las aguas que están en un constante devenir y no una propiedad privada sobre un bien aprehensible, en el sentido tradicional. ${ }^{63}$

Por tanto, se trata más bien de un derecho de aprovechamiento (y de uso y explotación) que se obtiene mediante una concesión o permiso otorgados por el Ejecutivo Federal y por el que se habrá de pagar una contribución.

Mención especial merecen las aguas del subsuelo ya que durante mucho tiempo se ha debatido si son aguas propiedad de la nación o pueden ser aguas propiedad de los particulares. ${ }^{64}$ Esta discusión se deriva de la lectura del párrafo quinto del artículo 27 constitucional, ya que en él se señala que las aguas del subsuelo podrán ser apropiadas por el dueño del terreno en las zonas de libre alumbramiento, lo que se traduce en que, una vez extraídas o sacadas, si el dueño o propietario del suelo es particular entonces tendrá la propiedad sobre ellas. En otras palabras, pareciera que las aguas del subsuelo en zonas de libre alumbramiento dejan de ser aguas nacionales y pueden ser apropiadas por los particulares (con la variable desde luego de que cuando lo exija el interés público o se afecten otros aprovechamientos el Ejecutivo federal podrá reglamentar su extracción y utilización y aun establecer zonas vedadas). En el otro extremo, se ha afirmado que las aguas del subsuelo son simple y sencillamente de

\footnotetext{
Alfonso, "Aguas", Diccionario jurídico mexicano, 8a. ed., México, Porrúa-UNAM, Instituto de Investigaciones Jurídicas, t. A-CH, 1995, p. 130.

63 Farías, Urbano, Derecho mexicano..., cit., p. 45.

64 Se sugiere acudir a Brañes, Raúl, Manual de..., cit., pp. 418 y 419; Cervantes Ramírez, Francisco F., "De la Propiedad de las Aguas Nacionales", Lex, México, Suplemento Ecología, enero de 1999, pp. XVIII y XIX; Nava Negrete, Alfonso, Derecho administrativo..., cit., p. 427 y ss.
} 
Esta obra forma parte del acervo de la Biblioteca Jurídica Virtual del Instituto de Investigaciones Jurídicas de la UNAM

la exclusiva propiedad del gobierno federal, con todo y que la redacción del texto que por reforma constitucional publicada en el Diario Oficial de la Federación del 21 de junio de 1945 señalara que la propiedad de las aguas de subsuelo (tal y como ahora está en el texto vigente) son del propietario del terreno. ${ }^{65}$

Durante algunos años, la legislación secundaria en la materia - nos referimos en particular a la ley reglamentaria del párrafo quinto del artículo 27, la Ley de Aguas Nacionales - no fue de mucha utilidad para aclarar el punto antes mencionado. En efecto, al considerar a las aguas del subsuelo como aguas nacionales, las colocaba como bienes inalienables e imprescriptibles y, por lo tanto, para su uso, explotación o aprovechamiento por los particulares se requería de concesión. La propia Ley agregaba que tal explotación, uso o aprovechamiento de las aguas del subsuelo causaría las contribuciones fiscales correspondientes. Sin embargo, la Ley señalaba al mismo tiempo que las aguas del subsuelo podían ser alumbradas libremente sin que se necesitara concesión o asignación para ello (al menos que se tratara de zonas reglamentadas para su extracción y para su explotación, uso o aprovechamiento, o bien se tratara de zonas de veda o zonas de reserva); lo anterior suponía que en este caso estaríamos frente a aguas propiedad de los particulares. ${ }^{66}$

Sobre el punto anterior, hay que recordar que algunos doctrinarios han considerado que los bienes (nacionales) concesionables son inalienables, ${ }^{67}$ por lo que si se considerara que las aguas del subsuelo no son nacionales por esa excepción mencionada en el precepto constitucional, entonces perderían su carácter de inalienabilidad.

$\mathrm{Al}$ respecto, Urbano Farías sostenía que el verdadero sentido del artículo 27 constitucional es que las aguas del subsuelo son aguas nacionales que podrán aprovecharse libremente por el dueño del terreno en zonas de libre alumbramiento sin que por ello se estuviera en presencia de propiedad privada. Se trata tan sólo de aprovechamientos particulares de aguas en donde la adquisición o apropiación es, en todo caso, sui ge-

65 Nava Negrete, Alfonso, Derecho administrativo..., cit., nota anterior, p. 428.

66 Los detalles sobre el particular en Nava Escudero, César, Estudios ambientales..., cit., pp. 243 y ss. Aquí se encontrarán, adicionalmente, algunos criterios jurisprudenciales sobre el tema.

67 Gabino, Fraga, Derecho administrativo..., cit., p. 373. 
Esta obra forma parte del acervo de la Biblioteca Jurídica Virtual del Instituto de Investigaciones Jurídicas de la UNAM

neris, no hay necesidad de discutir su titularidad. ${ }^{68}$ Otros autores, como es el caso de Cervantes Ramírez, llegaron a argumentar que en realidad el agua que se extrae del subsuelo sí es susceptible de apropiación, pero lo que no es apropiable es la fuente (o sea el acuífero) de donde se extraen las aguas subterráneas. ${ }^{69}$

En la actualidad, el texto vigente de la Ley de Aguas Nacionales sigue considerando a las aguas del subsuelo como aguas nacionales (artículo 3o., fracción IV), donde el Ejecutivo federal es quien tiene la competencia para reglamentar el control de su extracción, explotación, uso o aprovechamiento, incluso las que hayan sido libremente alumbradas (artículo 6o.). Tal explotación, uso o aprovechamiento de las aguas del subsuelo no sólo causará las contribuciones fiscales correspondientes (artículo 18, último párrafo), sino que dichas aguas incluso las que hayan sido libremente alumbradas requerirán de concesión o asignación (artículo 42, fracción I). Para muchos, este enunciado parece contradecir lo que el precepto constitucional aludido establece.

Ahora bien, así como las aguas continentales pueden ser - por excepción- susceptibles de apropiación por los particulares conforme lo dicho anteriormente, también pueden pertenecer a los estados, los municipios y la Ciudad de México. Para determinar cuáles aguas podrán tener el carácter de estatales, municipales o de la Ciudad de México (incluso sociales en el caso de ejidatarios y comuneros) se debe atender a la última parte del párrafo quinto del artículo 27 constitucional. Esto es, tendrán ese carácter las aguas por las que corran o se encuentren sus depósitos según la propiedad de los terrenos, o como claramente señala Urbano Farías "en aplicación estricta [de la] norma, las aguas pueden ser parte integrante de la propiedad estatal, municipal, social... según donde se encuentren o transiten". ${ }^{70} \mathrm{El}$ texto constitucional aludido concluye estableciendo que si en ese caso se localizaren en dos o más predios, entonces el aprovechamiento de esas aguas se considerará de utilidad pública y quedará sujeto a las disposiciones que dicten las entidades federativas.

Concluyendo, se puede afirmar in genere que todas las aguas continentales (superficiales y subterráneas) son nacionales, donde el propietario originario es la nación. Las aguas nacionales son inalienables (es de-

\footnotetext{
68 Farías, Urbano, Derecho mexicano..., cit., pp. 45 y 46.

69 Cervantes Ramírez, Francisco F., "De la Propiedad...", cit.

70 Farías, Urbano, Derecho mexicano..., cit., p. 44.
} 
Esta obra forma parte del acervo de la Biblioteca Jurídica Virtual del Instituto de Investigaciones Jurídicas de la UNAM

cir, están fuera del comercio) e imprescriptibles, y su explotación, uso o aprovechamiento por los particulares requiere de concesión (o si se trata de un ente público, de asignación). Hay aguas que no tienen este carácter y por lo tanto son la excepción a la regla anterior. Dentro de los casos de excepción se encuentran aquellas aguas que los particulares pueden apropiarse en virtud de que se encuentran depositadas o corran en terrenos de su propiedad y que no estén dentro de una lista que establece el párrafo quinto del artículo 27 constitucional. El caso de las aguas del subsuelo requiere de un tratamiento especial, puesto que aun siendo consideradas constitucional y legalmente aguas nacionales al momento de ser alumbradas libremente la propia Constitución señala que podrán apropiarse por el dueño del terreno.

\section{Enfoque ambiental.}

Es innegable que la esencia del artículo 27 constitucional en materia de aguas continentales es patrimonialista. Sin embargo, al tiempo que son consideradas bienes nacionales, las aguas también son elementos o recursos naturales, y como tales, han encontrado significativo y creciente cobijo dentro del ordenamiento jurídico ambiental. Hay que aclarar que el estudio de las aguas continentales desde la óptica de lo ambiental no excluye la discusión sobre su régimen patrimonial. Al contrario, la discusión jurídico-ambiental sobre los recursos naturales en general y sobre las aguas en particular tiene una parte fundamental de argumentación y análisis sobre derechos de propiedad. El origen es que "las aguas se enmarcaron dentro de la propiedad de la nación y su aprovechamiento", ${ }^{71}$ y con el paso del tiempo y el desarrollo de la normativa ambiental, el régimen constitucional ambiental ha sido "eminentemente patrimonialista y... se fundamenta en el establecimiento de modalidades a la apropiación de los recursos naturales y en el régimen de bienes nacionales". ${ }^{72}$ Existe, entonces, un binomio constitucional patrimonio/ambiente de las aguas en este país.

71 Díaz y Díaz, Martín, Ensayos sobre..., cit., p. 522.

72 Carmona Lara, María del Carmen, Ley General del Equilibrio Ecológico y la Protección al Ambiente. Comentarios y concordancias, México, Procuraduría Federal de Protección al Ambiente-UNAM, Instituto de Investigaciones Jurídicas, 2003, p. 5. 
Esta obra forma parte del acervo de la Biblioteca Jurídica Virtual del Instituto de Investigaciones Jurídicas de la UNAM

En su análisis sobre el artículo 27 constitucional, Raúl Brañes sostiene que el texto de este precepto contiene tres principios relevantes desde la óptica ambiental, sin excluir, desde luego, la patrimonial: $i$ ) lo señalado en el párrafo primero relativo a la naturaleza de la propiedad originaria de tierras y aguas; ii) lo que establece el párrafo tercero relativo a la llamada función social de la propiedad privada, y iii) lo que se establece en ése mismo párrafo tercero respecto al derecho que tiene la nación de regular el aprovechamiento de los elementos naturales susceptibles de apropiación para obtener una distribución equitativa de la riqueza pública y cuidar su conservación. ${ }^{73}$

Si bien la discusión patrimonio/ambiente son dos caras de una misma moneda, es importante rescatar desde lo ambiental algunas cuestiones interesantes sobre las aguas en su calidad de recursos o elementos naturales.

En primer lugar, es necesario referirnos al texto constitucional de donde se desprende que las aguas continentales son recursos naturales. Como ya se dijo, el párrafo quinto se refiere a las aguas propiedad de la nación y de los particulares; el párrafo siguiente —el sexto - señala que en los casos a los que se refiere el párrafo antes citado, la explotación, uso, o aprovechamiento de los recursos (en este caso, las aguas) por los particulares o por sociedades constituidas por leyes mexicanas, no podrá realizarse sino mediante concesiones otorgadas por el Ejecutivo federal.

De esta primera correlación de párrafos en el artículo 27 se desprende que la Constitución considera a las aguas como recursos naturales. Lo anterior se complementa con lo que señala el párrafo tercero en el sentido de que la nación tiene en todo tiempo el derecho de imponer a la propiedad privada las modalidades que dicte el interés público, y regular, en beneficio social, el aprovechamiento de los elementos naturales susceptibles de apropiación para hacer una distribución equitativa de la riqueza pública y cuidar de su conservación. Para tal efecto - continúa el párrafo tercero- se dictarán medidas necesarias para establecer provisiones, usos, reservas y destinos de aguas a efecto de preservar y restaurar el equilibrio ecológico y para evitar su destrucción. Es claro que esas medidas que habrán de dictarse a efecto de evitar la destrucción de los elementos naturales (por el aprovechamiento que se haga bajo la idea de

73 Brañes, Raúl, Manual de..., cit., pp. 73-76. 
Esta obra forma parte del acervo de la Biblioteca Jurídica Virtual del Instituto de Investigaciones Jurídicas de la UNAM

una distribución equitativa donde se cuide de su conservación) incluyen a las aguas continentales.

En segundo lugar, la idea de regular el aprovechamiento de los elementos naturales para hacer una distribución equitativa de la riqueza pública y para cuidar de su conservación, así como la de evitar su destrucción, no es nueva. Es decir, estas dos ideas se consagraron en el texto constitucional original ${ }^{74} \mathrm{y}$, por lo tanto, se han incorporado como parte de las preocupaciones ambientales que dieron nacimiento al derecho ambiental en este país hacia finales de la década de los sesenta y principios de los setenta del siglo pasado. ${ }^{75}$ Hay que recordar que la intención del Constituyente de 1917 de introducir estas ideas era que los recursos naturales debían ser aprovechados según una racionalidad productiva (utilización racional) que considerara su conservación y evitara su destrucción. ${ }^{76}$ Actualmente, sería insuficiente referirse a las aguas nacionales sólo como bienes nacionales sin considerarlas dentro del marco de lo ambiental, que incluye no sólo su conservación, sino su preservación, protección, prevención, control de calidad y cantidad, control de su contaminación, deterioro, aprovechamiento sustentable, etcétera.

En tercer lugar, la idea del aprovechamiento de las aguas como elemento natural se encuentra vinculada a otros preceptos constitucionales que conforman todo un régimen constitucional ambiental. Dichos preceptos han ido incorporándose a la Constitución debido a la innegable importancia que ha adquirido la cuestión ambiental. Estas nuevas disposiciones constitucionales han modulado, enriquecido e insertado una forma distinta de entender y dar lectura al tema de las aguas como originalmente se había establecido en el texto de 1917.

Los vínculos que tienen las aguas continentales como recursos naturales con lo ambiental comprenden principalmente los siguientes preceptos

74 Se argumenta que estas ideas acuñadas desde el texto de 1917 confirma el carácter precursor de nuestra carga magna en la materia. Ibidem, p. 66.

75 Las preocupaciones ambientales o "crisis ambiental moderna" en aquellos años estuvo vinculada en países desarrollados a temas sobre el agotamiento de los recursos naturales, la contaminación del ambiente y su impacto en la salud humana, así como en países menos desarrollados a temas sobre supervivencia y desarrollo en ciertas regiones del mundo. Para mayor detalle sobre esto y la evolución del discurso ambiental de las últimas décadas, véase Nava Escudero, César, Urban Environmental Governance: Comparing Air Quality Management in London and Mexico City, Aldershot, Ashgate, 2001, pp. $12-18$.

76 Brañes, Raúl, Manual de..., cit., p. 77. 
Esta obra forma parte del acervo de la Biblioteca Jurídica Virtual del Instituto de Investigaciones Jurídicas de la UNAM

(la lista no es exhaustiva): el derecho a la protección de la salud (artículo 4o., párrafo tercero); el derecho a un medio ambiente sano para su desarrollo y bienestar (artículo 4o., párrafo quinto); el derecho al acceso, disposición y saneamiento de agua para consumo personal y doméstico en forma suficiente, salubre, aceptable y asequible (artículo 4o., párrafo sexto); la sustentabilidad vinculada al desarrollo nacional (artículo 25, párrafo primero) y al derecho humano al agua (artículo 4o., párrafo sexto); el cuidado del ambiente frente al uso de los recursos productivos de los sectores social y privado (artículo 25, párrafo séptimo); las medidas para prevenir y combatir la contaminación ambiental asociadas a la salubridad general (artículo 73, fracción XVI, base 4a.); la distribución de competencias en materia ambiental, esto es, la facultad que tiene el Congreso de la Unión para expedir leyes que establezcan la concurrencia del gobierno federal, de los gobiernos de las entidades federativas, de los municipios y de las demarcaciones territoriales de la Ciudad de México en materia de protección ambiental y preservación y restauración del equilibrio ecológico (artículo 73, fracción XXIX-G); entre otros.

En cuarto lugar, la Ley de Aguas Nacionales ha desarrollado una serie de conceptos vinculados a lo que se establece tanto en el artículo 27 en los párrafos ya mencionados, como en los preceptos constitucionales relacionados con éste. Así, es objeto de esta Ley — reglamentaria del artículo constitucional citado - regular la explotación, uso, aprovechamiento, distribución y control de las aguas nacionales así como la preservación de su cantidad y calidad para lograr su desarrollo integral sustentable. ${ }^{77}$ Por su parte, la Ley General del Equilibrio Ecológico y la Protección al Ambiente, introduce en su texto legal la idea del aprovechamiento sustentable y la prevención y control de la contaminación del agua y los ecosistemas acuáticos. ${ }^{78}$ Mientras que ésta considera que como criterio corresponde al Estado y a la sociedad el aprovechamiento sustentable del agua y la protección de los ecosistemas acuáticos y equilibrio de los elementos naturales que intervienen en el ciclo hidrológico (artículo 88, fracción I), aquélla reafirma que es tarea fundamental de ambos (Estado y sociedad) la preservación en cantidad y calidad y sustentabilidad del agua considerándola prioridad y asunto de seguridad nacional (artículo 14 , bis 5 , fracción I).

\footnotetext{
77 Véase el artículo 1o. de la Ley.

78 Véase los artículos 88-97 y 117-133 de esta Ley.
} 
Esta obra forma parte del acervo de la Biblioteca Jurídica Virtual del Instituto de Investigaciones Jurídicas de la UNAM

Por último, es importante mencionar que los contenidos y propósitos plasmados en el artículo 27 y demás artículos constitucionales relacionados en materia de aguas así como los de sus respectivas leyes reglamentarias -i. e. el aprovechamiento sustentable, la conservación, la distribución equitativa de la riqueza pública, el desarrollo equilibrado, el mejoramiento de las condiciones de vida rural y urbana, el uso racional, el control de la calidad y cantidad, la preservación y restauración del equilibrio ecológico, el control y la prevención de contaminación, así como la protección de los ecosistemas acuáticos y del ambiente in genere, entre otros - no siempre reflejan lo que verdaderamente sucede en diversas regiones del país. Los retos y dilemas que enfrentamos son enormes y muy delicados dadas las condiciones de disponibilidad variable (distribución inequitativa), grado de presión sobre el recurso (estrés hídrico, mayor extracción que recarga) y contaminación y deterioro o modificación (residuos, intrusión salina, etcétera).

Datos alarmantes incluyen, ${ }^{79}$ por ejemplo, el hecho de que el número de acuíferos sobrexplotados en la actualidad respecto a los de hace 15 años no haya disminuido (en 2001 se calculaban 104 de 653, hoy son 106). Aunado a esto, el grado de presión sobre el recurso es alto en las zonas centro, norte y noroeste del país (oscila entre 40 y $74 \%$ del volumen de agua concesionada y el agua renovable), y para el Valle de México es muy alto (alcanza casi 138\%, es decir, hay mucho más agua empleada que renovable). Las cifras de agua renovable per cápita en el país disminuirán a nivel nacional hacia el futuro; si bien algunas de las regiones hidrológico-administrativas en las que se divide territorialmente nuestro país para la gestión del agua no sufrirán un decremento significativo, otras sí lo experimentarán. ${ }^{80}$ Así, mientras que el decremento del agua renovable a nivel nacional irá de $3,982 \mathrm{~m}^{3} / \mathrm{hab} /$ año en 2013 a 3,430 para el 2030, en algunas regiones el agua renovable per cápita estará por debajo de los $1,000 \mathrm{~m}^{3} / \mathrm{hab} / \mathrm{año}$, escenario que es sumamente alarman-

79 Obtenidos de Comisión Nacional del Agua, Estadísticas del Agua en México. Edición 2014, México, Secretaría de Medio Ambiente y Recursos Naturales, Comisión Nacional del Agua, diciembre de 2014, passim.

80 Desde 1997 nuestro país está dividido en trece regiones hidrológico-administrativas: I Península de Baja California; II Noroeste; III Pacífico Norte; IV Balsas; V Pacífico Sur; VI Río Bravo; VII Cuencas Centrales del Norte; VIII Lerma-Santiago-Pacífico; IX Golfo Norte; X Golfo Centro; XI Frontera Sur; XII Península de Yucatán; XIII Aguas del Valle de México. 
Esta obra forma parte del acervo de la Biblioteca Jurídica Virtual del Instituto de Investigaciones Jurídicas de la UNAM

te. Esto ocurrirá en al menos tres regiones: Región I Península de Baja California, que irá de 1,165 m³/hab/año en 2013 a 907 en 2030; Región VI Río Bravo, que irá de $1,063 \mathrm{~m}^{3} / \mathrm{hab} / \mathrm{año}$ a 888 ; y la más inquietante Región XIII Aguas del Valle de México, que irá de $152 \mathrm{~m}^{3} / \mathrm{hab} / \mathrm{año}$ en 2013 a 137 en 2030.

\section{AGUAS MARINAS}

\section{Enfoque patrimonial}

Al igual que con las aguas continentales, debemos preguntarnos, ¿quién o quiénes son $-\mathrm{o}$ pueden ser- los propietarios de las aguas marinas?

Señalamos al principio de este trabajo que las aguas marinas se refieren tanto a las aguas en zonas marinas que forman parte del territorio nacional como a las que se encuentran en zonas marinas donde la nación ejerce derechos de soberanía, jurisdicciones y otros derechos. Si bien la Constitución en este artículo 27 no establece una lista de cuáles son consideradas aguas marinas (o al menos zonas marinas), sí lo hace su ley reglamentaria por excelencia: la Ley Federal del Mar. Esta Ley —reglamentaria de los párrafos cuarto, quinto, sexto, y antes octavo ahora noveno- establece en su artículo 3o. que las zonas marinas mexicanas son:

a) El mar territorial;

b) Las aguas marinas interiores;

c) La zona contigua;

d) La zona económica exclusiva;

e) La plataforma continental y las plataformas insulares;

f) Cualquier otra permitida por el derecho internacional.

De todas éstas, el párrafo quinto del artículo 27 constitucional sólo menciona a dos como propiedad de la nación:

a) las aguas de los mares territoriales, y

b) las aguas marinas interiores. 
Esta obra forma parte del acervo de la Biblioteca Jurídica Virtual del Instituto de Investigaciones Jurídicas de la UNAM

Consiste el mar territorial en una franja del mar adyacente a las costas nacionales (continentales o insulares) y a las aguas marinas interiores; tiene una anchura de 12 millas marinas (22,224 metros) que se miden a partir de las líneas de base normales o rectas, o una combinación de ellas. ${ }^{81}$ Las aguas marinas interiores son aguas de mar localizadas entre la costa o tierra firme (continental o insular), y las líneas de base normales o rectas, que sirven para medir el mar territorial. ${ }^{82}$

Estos dos tipos de aguas marinas están sujetas a lo que establece el párrafo sexto del artículo 27 constitucional en cuanto a que son inalienables e imprescriptibles y, por lo tanto, para su uso, explotación y aprovechamiento por particulares (o sociedades constituidas conforme a las leyes mexicanas) se requiere de concesión otorgada por el Ejecutivo federal..$^{83}$ Al ser ambas consideradas partes integrantes del territorio nacional (según lo establece la fracción $\mathrm{V}$ del artículo 42 de la Constitución) les aplica también lo que establece el párrafo primero del artículo 27 constitucional. Esto es, la propiedad de las aguas de los mares territoriales y las aguas marinas interiores que se encuentran comprendidas dentro de los límites del territorio nacional corresponden originariamente a la nación; ésta podría constituir la propiedad privada (derivada) y transmitir su dominio a los particulares, pero esto no ha tenido eco en la legislación interna mexicana. Por disposición constitucional (artículo 48) tanto las aguas del mar territorial como las aguas interiores son aguas de la Federación. La gran diferencia que existe entre unas y otras es que en las del mar territorial el ejercicio de la soberanía del Estado mexicano está limitada por el derecho que tienen las embarcaciones extranjeras a ejercer

81 Para mayor detalle, véase los artículos 23-27 de la Ley Federal del Mar.

82 El artículo 36 de la Ley Federal del Mar incluye como aguas marinas interiores a la parte norte del Golfo de California, las de las bahías internas, las de los puertos, las internas de los arrecifes, y las de las desembocaduras o deltas de los ríos, lagunas y estuarios, comunicados permanente o intermitentemente con el mar.

83 Establece el artículo 20 de la Ley Federal del Mar que "Cualquier actividad que implique la explotación, uso y aprovechamiento económico de las zonas marinas mexicanas... se rigen por las disposiciones reglamentarias de los párrafos cuarto, quinto y sexto del artículo 27 de la Constitución Política de los Estados Unidos Mexicanos, así como por la presente Ley, las demás leyes y reglamentos aplicables". 
Esta obra forma parte del acervo de la Biblioteca Jurídica Virtual del Instituto de Investigaciones Jurídicas de la UNAM

el paso inocente $;{ }^{84}$ en las aguas interiores no existe ninguna limitación a dicha soberanía. ${ }^{85}$

Debemos desde ahora preguntarnos si la naturaleza jurídica de las aguas marinas que se encuentren en las zonas conocidas como mar territorial y aguas marinas interiores cambia una vez que son extraídas, como ha sucedido por ejemplo para llevar a cabo procesos de desalación. En este caso, no está del todo claro si las aguas marinas que abandonen las zonas donde se encontraban, pueden ser "apropiadas" por particulares sin que se esté ante una idea de propiedad privada en el sentido tradicional y se requiera concesión para su uso, explotación y aprovechamiento, o si bien, las aguas al ser extraídas pierden su carácter de bienes nacionales y pasan a propiedad (derivada) de los particulares. ${ }^{86}$ En este sentido, la Ley de Aguas Nacionales señala en su artículo 17, párrafo segundo que no se requerirá de concesión para la extracción de las aguas de las zonas marinas interiores y de las del mar territorial para efectos de su explotación, uso o aprovechamiento, salvo las que tengan como fin la desalinización o desalación, las cuales sí requerirán de concesión.

Ahora bien, el artículo 27 constitucional que analizamos en este trabajo, no hace referencia de manera expresa a la zona contigua. Las aguas que se encuentran dentro de esta zona marina (creada por la Ley Federal del Mar) abarcan el doble del ancho que las del mar territorial incluyendo a este último. Es decir, las aguas de la zona contigua incluyen las $12 \mathrm{mi}-$ llas marinas del mar territorial más otras 12 millas adyacentes a éste para alcanzar 24 millas en total (44.448 metros). ${ }^{87}$ En estricto sentido, cualquier discusión sobre el régimen patrimonial de las aguas de esta zona se hará en dos partes: las del mar territorial para lo que se remite a lo que ya se ha dicho sobre el mismo, y las otras 12 millas que no son propiedad de

84 El derecho de paso inocente consiste en el derecho que tienen los buques extranjeros de navegar por o a través del mar territorial de un Estado siempre y cuando no sea perjudicial a la paz, el orden o la seguridad del mismo. Véase Székely, Alberto, Derecho del..., cit., p. 41. Esta figura jurídica se encuentra regulada en los artículos 29 y ss. de la Ley Federal del Mar.

85 Székely, Alberto, “Aguas marinas interiores”, Diccionario jurídico mexicano, 8 a. ed., México, Porrúa-UNAM, Instituto de Investigaciones Jurídicas, t. A-CH, 1995, p. 131.

86 Sobre este punto, véase lo que ya hemos discutido en Nava Escudero, César, Ciencia, ambiente y derecho, México, UNAM, Instituto de Investigaciones Jurídicas, 2012, pp. 143-148.

87 Para mayor detalle, véase los artículos 42 a 45 de la Ley Federal del Mar de 1986. 
Esta obra forma parte del acervo de la Biblioteca Jurídica Virtual del Instituto de Investigaciones Jurídicas de la UNAM

la nación. En efecto, en estas últimas 12 millas, la nación ejerce ciertas competencias específicas en materia aduanera, fiscal, migratoria y sanitaria. ${ }^{88}$ Obviamente, la Ley General de Bienes Nacionales no incluye a esta zona dentro de su texto.

Las otras dos zonas marinas restantes -i. e. la zona económica exclusiva y la plataforma continental y plataformas insulares - son objeto de mención del precepto constitucional multicitado. Es necesario comentar cada una de ellas por separado.

El párrafo noveno del artículo 27 constitucional señala que la nación ejerce derechos de soberanía y jurisdicciones sobre la zona económica exclusiva localizada fuera del mar territorial y adyacente a éste. El mismo precepto constitucional establece que las aguas marinas que abarcan esta zona se extienden a 200 millas marinas (370,400 metros) contadas a partir de la línea de base desde la que se mide el mar territorial. Como es lógico suponer, de estas 200 millas las primeras 12 abarcan las aguas marinas del mar territorial, dejando 188 millas restantes bajo un régimen jurídico diferente a aquél. Las aguas marinas que se encuentran en este segundo espacio de la zona económica exclusiva no son propiedad de la nación. Estas 188 millas marinas no son consideradas parte integrante del territorio mexicano por lo que el Estado mexicano sólo ejerce una jurisdicción y control para ciertos fines específicos entre los que se incluyen la pesca, la protección y preservación del medio marino, y la investigación científica, ente otras ${ }^{89}$ Ahondando en lo anterior, nos explica Gómez-Robledo Verduzco que esta zona constituye una zona de soberanía económica o zona de jurisdicción nacional que se refiere no al espacio marino en sí mismo (ya que éste permanece abierto a libertades tradicionales de navegación y de comunicación) sino a ciertas actividades como lo son la explotación de los recursos naturales (vivos y no vivos) así como a la producción de la energía derivada del agua, de las corrientes $\mathrm{y}$ de los vientos. ${ }^{90}$ Vale la pena añadir que nuestras islas gozan de zona económica exclusiva..$^{91}$

Por lo que respecta a la última de las zonas marinas mencionadas por la Ley Federal del Mar, esto es, la plataforma continental y las platafor-

\footnotetext{
88 Székely, Alberto, Derecho del..., cit., p. 42.

89 Gómez-Robledo Verduzco, Alonso, Derecho del..., cit., p. 35.

90 Ibidem, p. 36.

91 Véase artículo 51 de la Ley Federal del Mar.
} 
Esta obra forma parte del acervo de la Biblioteca Jurídica Virtual del Instituto de Investigaciones Jurídicas de la UNAM

mas insulares, conviene aclarar que no se está frente a la idea de aguas marinas propiamente dicha sino frente a un espacio o zona terrestre. Estas zonas marinas forman parte del territorio nacional según lo establece el párrafo IV del artículo 42 constitucional y se consideran bienes nacionales sujetos a régimen de dominio público de la Federación según se señala en el artículo 3o., fracción I en relación con el artículo 6, fracciones I, III y IV de la Ley General de Bienes Nacionales.

Nos comenta Alberto Székely que desde un punto de vista geológico la plataforma continental o insular "es la prolongación natural del continente o de la isla por debajo del mar, desde el punto en que se sumerge hasta aquel en que la prolongación termina al tocar los fondos oceánicos". ${ }^{92} \mathrm{Si}$ bien la Constitución en su artículo 27, párrafo cuarto hace mención de las plataformas continental e insulares, lo hace en relación con el dominio directo que tiene la nación sobre los recursos naturales que se encuentran en ellas. Lo que interesa mencionar para nuestro trabajo es el hecho de que los derechos de la nación sobre la plataforma continental y las plataformas insulares, no afectan el régimen jurídico aplicable a las aguas suprayacentes..$^{93}$

Concluyendo, el régimen patrimonial de las aguas marinas en un sentido amplio se divide en dos: aquel donde la nación es propietaria (originaria), como lo es sobre las aguas del mar territorial y sobre las aguas que conforman las aguas marinas interiores, y aquel donde la nación, sin ser propietaria, ejerce ciertos derechos de soberanía y otras jurisdicciones como lo son las aguas en la zona contigua y en la zona económica exclusiva (excluyendo para ambos casos las 12 millas marinas que abarcan las aguas del mar territorial). En sentido estricto, el régimen patrimonial de la nación se circunscribe tanto a las aguas del mar territorial como a las aguas marinas interiores; éstas se consideran bienes nacionales, sujetos al régimen de dominio público de la Federación y por lo tanto son inalienables e imprescriptibles al igual que la plataforma continental y las plataformas insulares. ${ }^{94}$ Debe entenderse que el uso, aprovechamiento y

\footnotetext{
92 Székely, Alberto, Derecho del..., cit., p. 45.

93 Véase el artículo 60 de la Ley Federal del Mar.

94 Según la Ley General de Bienes Nacionales, tanto las aguas marinas interiores como el mar territorial son considerados bienes de uso común (artículo 7o., fracciones II y III, respectivamente). Esta Ley dispone en su artículo 6o., fracción II, que estarán sujetos al régimen de dominio público de la Federación, entre otros, los bienes de uso común que señala la propia Ley. También estarán sujetos a este régimen de dominio público los
} 
Esta obra forma parte del acervo de la Biblioteca Jurídica Virtual del Instituto de Investigaciones Jurídicas de la UNAM

explotación de estos bienes por particulares estará sujeto a concesiones, permisos, autorizaciones y demás actos jurídicos permitidos por las leyes respectivas.

\section{Enfoque ambiental}

Como sucede con las aguas continentales, la visión del artículo 27 constitucional en materia de aguas marinas es también fundamentalmente patrimonialista. Sin embargo, las aguas del mar territorial y las de las marinas interiores a la vez que son consideradas por nuestra carta magna como bienes nacionales lo son también como recursos naturales y, por lo tanto, interesan al derecho ambiental. De hecho, todos los recursos (vivos o no) en las zonas marinas mexicanas pueden considerarse recursos naturales; en consecuencia, tienen una connotación de tipo ambiental. A continuación algunas reflexiones desde este enfoque.

En primer lugar, una parte significativa de la regulación de las aguas marinas, tanto a nivel constitucional como legal, es resultado de la influencia que ha tenido en nuestro ordenamiento jurídico el derecho internacional del mar. Nuestro derecho interno, o "derecho del mar mexicano" es, en mucho, el reflejo tanto de negociaciones adoptadas en foros internacionales como de diversos textos consagrados en instrumentos jurídicos internacionales sobre la materia en los que, paradójicamente, México ha tenido una actuación sobresaliente. Nos explica Alberto Székely al respecto lo siguiente:

México ha jugado un papel central en la elaboración de las normas generales del derecho internacional del mar, de tal manera que las normas relativas de su legislación interna son, en casi todas las instancias, resultado de fórmulas generales patrocinadas por México en los foros en los que el derecho internacional del mar se ha desarrollado y codificado... muchas de esas fórmulas generales han sido ideadas y originalmente propuestas por juristas representantes de México en esos foros. ${ }^{95}$

bienes señalados en el artículo 42, fracción IV (que incluye a la plataforma continental y las plataformas insulares) según el artículo 6o., fracciones I y II de la ya citada Ley General de Bienes Nacionales.

95 Székely, Alberto, Derecho del..., cit., p. 10. 
Esta obra forma parte del acervo de la Biblioteca Jurídica Virtual del Instituto de Investigaciones Jurídicas de la UNAM

En segundo lugar, en ese derecho internacional del mar que tanto ha influenciado a nuestro derecho interno, ha prevalecido una discusión de corte patrimonialista que se ha enfocado a tratar temas sobre las jurisdicción nacional e internacional (incluyendo anchura y límites) de los Estados en las zonas marinas. En un principio, el interés por el mar significaba un instrumento de expansión territorial y de imperialismo (idea central de la doctrina mare clausum), que rápido encontró una postura opuesta al rechazar que el mar fuera apropiable por cualquier Estado que tuviera los medios para ello y se le concibió como una zona inmune a la soberanía de los Estados abogando libertad de los mares (idea central de la doctrina mare liberum). Si bien esta última postura se adoptó con el paso del tiempo, su objetivo era el de la protección y seguridad del territorio del Estado costero que rápidamente se amplió al incorporarse la protección económica (por alimentos) y nuevos criterios para establecer zonas de jurisdicción en materia aduanal, fiscal, penal, etcétera. A esto pronto habría de unirse la preocupación por establecer zonas de conservación para la protección de ciertas especies vivas amenazadas por la sobrexplotación y las de aprovechamiento de los recursos naturales. La evolución y el desarrollo del derecho del mar durante la última mitad del siglo XX dieron como resultado el surgimiento de nuevas zonas de jurisdicción nacional como lo fue, en especial, el de la zona económica exclusiva. ${ }^{96}$ Bajo el nuevo derecho del mar, continuaron las discusiones relativas a la propiedad y jurisdicción de las zonas marinas, y con la Convención de las Naciones Unidas sobre el Derecho del Mar de 1982 (en vigor a partir de 1994), se incluyeron nuevas definiciones de conceptos ya existentes (como las de mar territorial y plataforma continental) y se incorporaron nuevas zonas de jurisdicción nacional (como la zona económica exclusiva y las aguas archipiélagas). ${ }^{97}$ Esta influencia patrimonialista a nivel internacional ha sido recogida en mucho por nuestra Constitución y nuestra legislación interna.

En tercer lugar, la discusión de soberanía y jurisdicción relativa a la anchura y límites de las aguas marinas (en especial, la del mar territorial $y$ aguas adyacentes) ha sido originada en ocasiones por motivos de tipo ambiental. Algunos ejemplos de lo anterior lo constituyen la Ley del 24 de diciembre de 1971, emitida por Francia, para extender su mar terri-

\footnotetext{
96 Ibidem, pp. 11 y 12.

97 Gómez-Robledo Verduzco, Alonso, Derecho del..., cit., p. 13.
} 
Esta obra forma parte del acervo de la Biblioteca Jurídica Virtual del Instituto de Investigaciones Jurídicas de la UNAM

torial a 12 millas para ejercer cierta jurisdicción y control sobre el tráfico de tanques petroleros en el Canal de la Mancha, así como el Acta de Prevención de Contaminación de las Aguas del Ártico de 1970, emitida por Canadá, que crea una zona de jurisdicción con una anchura de 100 millas para protegerla de los buques petroleros que transitan por ellas. ${ }^{98}$ No menos importantes fueron las posturas de países como Perú y Ecuador que formaron parte del movimiento a favor de las 200 millas de zona económica exclusiva alegando la necesidad de proteger los biomas y ecosistemas de la Corriente Humboldt que corre a lo largo de sus costas dentro de esta franja. ${ }^{99}$ Por lo que la conservación o protección de las aguas marinas y de ciertas especies o recursos naturales en ellas, han sido temas para la determinación de las posturas de diversos países en torno a la delimitación de estas zonas desde hace ya algunas décadas.

En cuarto lugar, es indispensable acudir a los preceptos que conforman el régimen constitucional ambiental para contar con referentes apropiados para sustentar un análisis que contemple, si se permite la expresión, un enfoque ambiental de las aguas marinas. Por lo que hay que hacer alusión a los postulados que ya hemos mencionado para el caso de las aguas continentales, es decir, los relativos al derecho de toda persona a un medio ambiente sano; a la sustentabilidad en el desarrollo nacional; el cuidado de las aguas marinas y sus recursos naturales considerados como un todo bajo el término ambiente frente a la productividad de los sectores social y privado; la contaminación ambiental marina y las medidas para prevenirla y combatirla; y la protección al ambiente marino y preservación y restauración del equilibrio ecológico marinos. Desafortunadamente, nuestra Constitución no se ha referido explícitamente a un derecho humano de protección a las aguas marinas.

En quinto lugar, si bien la Ley Federal del Mar es reglamentaria de las aguas en las zonas marinas mexicanas que son tratadas con un enfoque patrimonialista por nuestra Constitución, la misma contempla disposiciones que son propias del objeto de regulación ambiental. Esto es, el ejercicio de la soberanía de la nación y de sus respectivas jurisdicciones y competencias en las zonas marinas mexicanas, se realizará conforme

98 Székely, Alberto, "El medio ambiente: derecho internacional", Revista de la Facultad de Derecho de México, México, t. XXVI, núms. 103 y 104, julio-diciembre de 1976, p. 328 .

99 Idem. 
Esta obra forma parte del acervo de la Biblioteca Jurídica Virtual del Instituto de Investigaciones Jurídicas de la UNAM

a lo dispuesto por nuestra carta magna, el derecho internacional y la legislación nacional aplicable respecto al régimen correspondiente de los recursos vivos (y no vivos) atendiendo a su conservación y utilización, así como a la protección y la preservación del medio marino inclusive la prevención de su contaminación. ${ }^{100}$ Aún más, la propia Ley remite a la Ley General del Equilibrio Ecológico y la Protección al Ambiente, la Ley General de Salud, la Ley de Aguas Nacionales y demás disposiciones relativas para aplicar en lo conducente lo relativo a la prevención, la reducción y el control de la contaminación del medio marino.

Por su parte, la Ley General del Equilibrio Ecológico y la Protección al Ambiente señala que se establecerán programas de ordenamiento marinos como parte del ordenamiento ecológico del territorio y de las zonas donde la nación ejerce su soberanía y jurisdicción (artículo, 19 bis). Dichos programas tendrán por objeto establecer lineamientos y previsiones a que deberá sujetarse la preservación, la restauración, la protección y el aprovechamiento sustentable de los recursos naturales existentes en áreas o superficies ubicadas en las zonas marinas mexicanas, lo que hará la Secretaría de Medio Ambiente y Recursos Naturales en coordinación con las demás dependencias competentes (artículo 20, bis 6). Es de singular importancia mencionar que la propia Ley establece la posibilidad de crear áreas naturales protegidas con el propósito de proteger y preservar los ecosistemas marinos, así como regular el aprovechamiento sustentable de la flora y fauna acuática en las zonas marinas (artículo 51). $\mathrm{Al}$ igual que para las aguas continentales, la Ley señala que corresponde al Estado y la sociedad la prevención de la contaminación de las aguas marinas (artículo 117, fracción II).

Por último, vale la pena comentar que debiera precisarse y, en su caso, fortalecerse, la idea de la protección ambiental en el artículo 27 constitucional para las aguas marinas mexicanas. Quizá convendría que se elevara a rango constitucional una disposición que expresara tal situación. Hay que recordar que México posee una riqueza marina envidiable al contar con una superficie de 209,000 kilómetros cuadrados de mar territorial y una vasta área de zona económica exclusiva que abarca 3'149,920 kilómetros cuadrados. Dentro de ellas se cuenta con ecosistemas acuáticos extraordinarios que sirven de residencia permanente o transitoria a diversas poblaciones como la endémica y a punto de extinguirse: vaquita

100 Para mayor detalle véase el artículo 6o. de la Ley Federal del Mar. 
Esta obra forma parte del acervo de la Biblioteca Jurídica Virtual del Instituto de Investigaciones Jurídicas de la UNAM

marina o la fastuosa ballena gris, respectivamente. Lo anterior, sin omitir la riqueza arrecifal ubicada frente a las costas de diversas entidades federativas en el Golfo de México y el Mar Caribe.

El vertimiento de todo tipo de residuos o desechos a nuestros mares y océanos, y el peligro latente por la exploración, extracción y transporte de petróleo y sus derivados son una amenaza de contaminación marina, especialmente ahora con la aprobación de la anti-ambientalista reforma energética durante el sexenio de Enrique Peña Nieto. Si bien el "oro negro" seguirá siendo relevante desde el punto de vista económico, no debemos olvidar que México se encuentra entre los primeros lugares en accidentes por derrame de petróleo desde plataforma: se trata del caso del pozo Ixtoc-I en 1979 que contabilizó 3.5 millones de barriles, sólo superado por el reciente desastre de la Deepwater Horizon en 2010 que alcanzó los 4.9 millones de barriles. ${ }^{101}$ Ambos ocurrieron en el Golfo de México.

101 Para mayor detalle sobre el caso Ixtoc-I, véase Gómez-Robledo Verduzco, Alonso, Temas selectos..., cit., pp. 203-250, y sobre el caso DeepWater Horizon, véase National Geographic, "Tragedia en el Golfo de México. Lo que no sabemos del vertido", Revista National Geographic, España, octubre 2010. 
Esta obra forma parte del acervo de la Biblioteca Jurídica Virtual del Instituto de Investigaciones Jurídicas de la UNAM

\section{LA CLÁUSULA DE INTERPRETACIÓN CONFORME EN EL CASO DEL DERECHO A UN AMBIENTE SANO EN MÉXICO*}

\section{LA CLÁUSULA DE INTERPRETACIÓN CONFORME}

Trajo consigo la reforma constitucional en materia de derechos humanos (publicada en el Diario Oficial de la Federación del 10 de junio de 2011) una figura jurídica - entre otras - de formidable importancia: la cláusula de interpretación conforme. Considerada por algunos como "la gran desconocida" de dicha reforma, ${ }^{1}$ esta cláusula representa ante todo una técnica interpretativa para la armonización de las normas nacionales y las internacionales sobre derechos humanos. Quedó consagrada en el párrafo segundo del artículo 1o. de nuestra carta magna, y su texto guarda estrecha relación con los párrafos primero y tercero de ese mismo artículo. Transcribimos a continuación el contenido de los tres párrafos del precepto aludido:

En los Estados Unidos Mexicanos todas las personas gozarán de los derechos humanos reconocidos en esta Constitución y en los tratados internacionales de los que el Estado mexicano sea parte, así como de las garantías

* Publicado en Derechos del Pueblo Mexicano: México a través de sus constituciones, 9a. ed., México, Miguel Ángel Porrúa-Cámara de Diputados-Suprema Corte de Justicia de la Nación-Senado de la República-Tribunal Electoral del Poder Judicial de la FederaciónInstituto Nacional Electoral-Comisión Nacional de los Derechos Humanos, vol. V, Sección Segunda, Edición Conmemorativa Centenario de la Constitución de 1917, 2016.

1 Así lo llegó a expresar en su momento José Luis Caballero, al enfatizar la enorme importancia de esta cláusula, al tiempo que advertía sobre el hecho de que se "alude muy poco a su potencialidad específica" o que se "intenta disminuir su virtualidad". Para conocer más sobre esto, véase Caballero Ochoa, José Luis, "Comentario sobre el Artículo 1o., segundo párrafo de la Constitución (La cláusula de interpretación conforme al principio pro persona)", en Ferrer Mac-Gregor, Eduardo et al. (coords.), Derechos humanos en la Constitución: comentarios de jurisprudencia constitucional e interamericana, México, Suprema Corte de Justicia de la Nación-Fundación Konrad Adenauer-UNAM, Instituto de Investigaciones Jurídicas, t. I, 2013, p. 51. 
Esta obra forma parte del acervo de la Biblioteca Jurídica Virtual del Instituto de Investigaciones Jurídicas de la UNAM

para su protección, cuyo ejercicio no podrá restringirse ni suspenderse, salvo en los casos y bajo las condiciones que esta Constitución establece.

Las normas relativas a los derechos humanos se interpretarán de conformidad con esta Constitución y con los tratados internacionales de la materia favoreciendo en todo tiempo a las personas la protección más amplia.

Todas las autoridades, en el ámbito de sus competencias, tienen la obligación de promover, respetar, proteger y garantizar los derechos humanos, de conformidad con los principios de universalidad, interdependencia, indivisibilidad y progresividad. En consecuencia, el Estado deberá prevenir, investigar, sancionar y reparar las violaciones a los derechos humanos, en los términos que establezca la ley.

Ayudan a comprender el significado y alcance de la citada cláusula las descripciones conceptuales siguientes: $i$ ) "constituye un método que tiene como finalidad la armonización y complementariedad de las normas inferiores con las normas constitucionales y convencionales"; 2 ii) "lleva a la interpretación armónica entre las normas de derechos humanos, independientemente de su fuente constitucional o internacional, con el resto del texto de la propia Constitución y con los tratados de derechos humanos"; 3 iii) "es la respuesta constitucional o una de las respuestas - a mi juicio, la más pertinente - para acompañar la incorporación de los tratados internacionales sobre derechos humanos al orden interno"; y $i v)$ se sintetiza como

la técnica hermenéutica por medio de la cual los derechos y libertados (sic) constitucionales son armonizados con los valores, principios y normas contenidos en lo tratados internacionales sobre derechos humanos signados por los Estados, así como por la jurisprudencia de los tribunales

2 Salazar Ugarte, Pedro (coord.), La reforma constitucional sobre derechos humanos. Una guía conceptual, México, Senado de la República, Instituto Belisario Domínguez, 2014, p. 21.

3 Carmona Tinoco, Jorge Ulises, "La reforma y las normas de derechos humanos previstas en los tratados internacionales", en Carbonell, Miguel y Salazar, Pedro (coords.), La reforma constitucional de derechos humanos: una nuevo paradigma, México, UNAM, Instituto de Investigaciones Jurídicas, 2011, p. 46.

4 Caballero Ochoa, José Luis, La interpretación conforme. El modelo constitucional ante los tratados internacionales sobre derechos humanos y el control de convencionalidad, México, Porrúa-Instituto Mexicano de Derecho Procesal Constitucional, 2013, p. 14. 
Esta obra forma parte del acervo de la Biblioteca Jurídica Virtual del Instituto de Investigaciones Jurídicas de la UNAM

internacionales (y en ocasiones otras resoluciones y fuentes internacionales), para lograr su mayor eficacia y protección. ${ }^{5}$

Hay tres cuestiones trascendentales que se derivan del párrafo segundo del precepto constitucional mencionado.

Primero, dicho enunciado jurídico no sólo impone la armonización de la norma nacional y la norma internacional, sino que la interpretación misma que se haga de las normas relativas a los derechos humanos deberá favorecer "en todo tiempo a las personas la protección más amplia", según se establece en la última parte del párrafo segundo del citado artículo. Este es el principio pro persona, que representa una "clave de interpretación" dirigida hacia la protección más amplia de los derechos, y que igual se aplica para el caso de que en una norma haya dos o más sentidos posibles o para el caso de una colisión normativa. En ambos supuestos, se estará a la norma que más favorezca a las personas. Así lo explica Carmona Tinoco:

...de entre los sentidos posibles de una norma, habrá que privilegiar aquel más favorable a la persona, o en caso de conflicto normativo, deberá prevalecer la disposición más favorable o la menos restrictiva de los derechos humanos. El principio pro persona, en materia de derechos humanos, deja atrás el viejo principio jerárquico, para dar paso a un nuevo esquema, ya no se trata de la pregunta usual sobre qué norma es jerárquicamente superior, sino de qué norma es la más favorable o la menos restrictiva hacia la persona, la que deberá finalmente ser aplicada al caso concreto. ${ }^{6}$

Segundo, las normas sobre derechos humanos establecidas en cualquier ley del ordenamiento jurídico tienen dos referentes fundamentales: la Constitución y los tratados internacionales. De modo que la aplicación de la cláusula de interpretación conforme implica, como algunos autores señalan, llevar a cabo una remisión interpretativa hacia dichos referen-

5 Ferrer Mac-Gregor, Eduardo, "Interpretación conforme y control difuso de convencionalidad. El nuevo paradigma para el juez mexicano", en Carbonell, Miguel y Salazar, Pedro (coords.), La reforma ..., cit., p. 358.

6 Carmona Tinoco, Jorge Ulises, "La reforma constitucional en derechos humanos de junio de 2011 y su relación con los derechos universitarios", en Carmona Tinoco, Jorge Ulises (coord.), La vinculación entre los derechos humanos y los derechos universitarios. Obra en homenaje al Dr. Jorge Carpizo Mac Gregor, México, UNESCO-UNAM, Defensoría de los Derechos Universitarios, 2013, p. 181. 
Esta obra forma parte del acervo de la Biblioteca Jurídica Virtual del Instituto de Investigaciones Jurídicas de la UNAM

tes, incluyendo desde luego el principio pro persona. ${ }^{7}$ Nos explican FixZamudio y Valencia Carmona lo siguiente:

De ahora en adelante, el intérprete de normas de derechos humanos tendrá la obligación imperativa de aplicar la nueva cláusula constitucional de interpretación conforme. Si encuentra dos o más sentidos posibles en una determinada norma, debe seleccionar aquella cuyo sentido tenga mayor conformidad con la Constitución y los tratados internacionales relativos. Desde luego, para extraer los diferentes sentidos de la norma, se requiere de una interpretación previa, en la cual se utilizan los criterios generalmente admitidos por la teoría de la interpretación. Igualmente, siguen privando las reglas que han caracterizado la interpretación conforme, esto es, la presunción de constitucionalidad de una ley y el deber que el juzgador debe autoimponerse de sólo declarar la inconstitucionalidad en casos verdaderamente necesarios. ${ }^{8}$

Entonces, nos encontramos en un escenario en donde la interpretación conforme es: $i$ ) "de todas las normas relativas a los derechos humanos contenidas en la legislación, hacia los referentes Constitución y los tratados internacionales"; ii) "de las normas sobre derechos humanos contenidas en los tratados internacionales hacia la Constitución y los tratados internacionales; y iii) "de las normas sobre derechos humanos contenidas en la Constitución hacia otras normas de la Constitución y los tratados internacionales". ${ }^{9}$

Tercero, surge una nueva relación entre la Constitución y los tratados internacionales. En efecto, de la lectura del artículo 1o. constitucional se desprende que las normas sobre derechos humanos contenidas en cualquier tratado internacional de los que México sea parte tienen rango constitucional. Es decir, para el caso de derechos humanos en particular ya no priva el supuesto de que los tratados internacionales se encuentran

7 En este sentido, véase lo señalado por Caballero Ochoa, José Luis, "Cláusula de interpretación conforme", en Ferrer Mac-Gregor, Eduardo et al. (coords.), Diccionario de derecho procesal constitucional y convencional, Poder Judicial de la Federación, Consejo de la Judicatura Federal-UNAM, Instituto de Investigaciones Jurídicas, 2014, t. I, p. 166.

8 Fix-Zamudio, Héctor y Valencia Carmona, Salvador, Las reformas en derechos humanos, procesos colectivos y amparo como nuevo paradigma constitucional, 3a. ed., México, Porrúa-UNAM, Instituto de Investigaciones Jurídicas, 2015, pp. 8 y 9.

9 Caballero Ochoa, José Luis, “Cláusula de interpretación...”, cit., pp. 166 y 167. 
Esta obra forma parte del acervo de la Biblioteca Jurídica Virtual del Instituto de Investigaciones Jurídicas de la UNAM

por debajo de la Constitución (segundo nivel o nivel inferior) de conformidad con el sistema jerárquico establecido en el artículo 133 de nuestra carta magna. ${ }^{10}$ De modo que "la tesis que colocaba a los tratados en un rango supra legal, esto es, debajo de la Constitución, pero por encima de la leyes federales y de otras normas ha perdido aplicación en materia de derechos humanos". ${ }^{11}$ Con todo y que estas últimas consideraciones no han sido unánimemente aceptadas, hay autores que enfatizan en la necesidad de abandonar en el ámbito de los derechos humanos el esquema jerárquico, y referirse en todo caso a un sistema hermenéutico o interpretativo. ${ }^{12}$

Es importante aclarar sobre esta nueva relación que la interpretación a realizarse sobre tales referentes actúa de manera simultánea, es decir, la técnica interpretativa debe conducir a una armonización de la norma nacional (Constitución) y la norma internacional (tratados internacionales). Lo explica nítidamente Ferrer Mac-Gregor de la siguiente manera:

No se trata de dos interpretaciones sucesivas (primero la interpretación conforme a la Constitución y luego la interpretación conforme al tratado internacional), sino de una interpretación conforme que armonice ambas. Cuando la fórmula constitucional se refiere a que las normas de derechos humanos se interpretarán "de conformidad con" "esta Constitución y con los tratados internacionales...", la conjunción "y" gramaticalmente constituye una "conjunción copulativa", que sirve para reunir en una sola unidad funcional dos o más elementos homogéneos al indicar su adición. De ahí que esta cláusula cumple con una "función hermenéutica" de armonización. Y entre las posibles interpretaciones conformes de armonización, el intérprete deberá optar por la protección más amplia. ${ }^{13}$

10 Este artículo señala lo siguiente: "Esta Constitución, las leyes del Congreso de la Unión que emanen de ella y todos los tratados que estén de acuerdo con la misma, celebrados y que se celebren por el presidente de la República, con aprobación del Senado serán la ley suprema de toda la Unión. Los jueces de cada entidad federativa se arreglarán a dicha constitución, leyes y tratados, a pesar de las disposiciones en contrario que pueda haber en las constituciones o leyes de las entidades federativas".

11 Fix-Zamudio, Héctor y Valencia Carmona, Salvador, Las reformas..., cit., p. 13.

12 En este sentido, una discusión amplia en Caballero Ochoa, José Luis, La interpretación..., cit., pp. 130 y ss.

13 Ferrer Mac-Gregor, Eduardo, "Interpretación conforme...", cit., p. 365. 
Esta obra forma parte del acervo de la Biblioteca Jurídica Virtual del Instituto de Investigaciones Jurídicas de la UNAM

A partir de esta relación o remisión interpretativa entre las normas constitucionales y las normas convencionales sobre derechos humanos surge lo que se conoce como bloque de derechos o bloque de constitucionalidad. Se asemeja a un catálogo de derechos integrado "por las normas del texto fundamental vigente y las normas derivadas de los tratados internacionales de derechos humanos o que contuviesen disposiciones relativas a ellos, siempre y cuando se hayan debidamente suscrito". ${ }^{14}$

De esta manera, la cláusula de interpretación conforme se complementa con el principio pro persona, el bloque de constitucionalidad y los principios pertenecientes a los derechos humanos — consagrados en el párrafo tercero del artículo 1o. constitucional- que son el de universalidad (los derechos son inherentes a las personas); interdependencia (la satisfacción o afectación incide a su vez en el goce de otros derechos); indivisibilidad (las personas son titulares de todos los derechos reconocidos); y progresividad (avanzar hacia mejores estándares que una vez alcanzados no deben retroceder o estancarse)..$^{15}$

En fin, los intérpretes u operadores jurídicos de la cláusula de interpretación conforme - jueces, legisladores, funcionarios públicos, juristas, cualquier persona - deberán adentrarse en el conocimiento de instrumentos jurídicos tanto nacionales como convencionales. La dimensión nacional comprende la Constitución y cualquier ley del ordenamiento jurídico mexicano (ley sobre derechos humanos propiamente o sobre alguna otra materia pero que contemple uno o más derechos humanos). La dimensión internacional abarca los tratados internacionales en los que México es parte (ya sea que éstos se refieran a derechos humanos propiamente, o bien que se refieran a otra materia pero que incluyan en su texto uno o más derechos humanos).

14 Fix-Zamudio, Héctor y Valencia Carmona, Salvador, Las reformas..., cit., pp. 14 y 15 .

15 Sobre el contenido de estos principios, véase Carmona Tinoco, Jorge Ulises, "La reforma constitucional...", cit., pp. 182 y 183. Otro análisis que recomendamos sobre estos principios es el de Vázquez, Luis Daniel y Serrano, Sandra, "Los principios de universalidad, interdependencia, indivisibilidad y progresividad. Apuntes para su aplicación práctica”, en Carbonell, Miguel y Salazar, Pedro (coords.), La reforma constitucional..., cit., pp. 135 y ss. 
Esta obra forma parte del acervo de la Biblioteca Jurídica Virtual del Instituto de Investigaciones Jurídicas de la UNAM

Para el caso de análisis del derecho a un medio ambiente sano, o derecho a un ambiente sano, ${ }^{16}$ el reto es identificar de qué manera, si es el caso, se ha desarrollado este derecho en la Constitución, en las leyes mexicanas y en los tratados internacionales de los que nuestro país es parte.

\section{LAS NORMAS INTERNAS RELATIVAS AL DERECHO}

A UN AMBIENTE SANO: LA CONSTITUCIÓN Y LAS LEYES

\section{Constitución}

En 1999 se consagró por vez primera en nuestra carta magna el derecho a un ambiente para todas las personas. El texto primigenio quedó plasmado en el párrafo quinto del artículo 4o. constitucional (con reforma publicada el 28 de junio de ese año) de la siguiente manera: "Toda persona tiene derecho a un medio ambiente adecuado para su desarrollo y bienestar". Este enunciado jurídico se movió en 2001 al cuarto párrafo del citado artículo sin que hubiera modificación alguna en su texto. Años después, en octubre de 2011, regresó a su lugar original, el párrafo quinto, y posteriormente, con reforma constitucional de 8 de febrero de 2012 se cambió parte de su contenido y se agregaron elementos nuevos que subsisten hasta nuestros días. El texto vigente señala: "Toda persona tiene derecho a un medio ambiente sano para su desarrollo y bienestar. El Estado garantizará el respeto a este derecho. El daño y deterioro ambiental generará responsabilidad para quien lo provoque en términos de lo dispuesto por la ley". De manera tal, que el intérprete u operador jurídico de la cláusula de interpretación conforme tiene en nuestra carta magna su punto de partida.

Debe entenderse que este derecho pertenece a los llamados derechos de solidaridad o de la tercera generación y que, por lo tanto, se trata de un derecho que establece deberes estatales positivos (de hacer) a la vez que negativos (de no hacer). La titularidad de este derecho es tanto individual como colectiva, y el bien tutelado - el ambiente-corresponde a todos,

16 Aunque el ordenamiento jurídico mexicano hace referencia indistinta a ambas expresiones, ya sea la del derecho a un medio ambiente sano, o la del derecho a un ambiente sano, nosotros preferimos utilizar la segunda por considerar que la expresión "medio ambiente" es reiterativa, tautológica. 
Esta obra forma parte del acervo de la Biblioteca Jurídica Virtual del Instituto de Investigaciones Jurídicas de la UNAM

es decir, es un bien común, un bien colectivo. ${ }^{17}$ Así lo entendía desde hace años Bidart Campos:

Si tomamos al azar un derecho que se suele ahora colocar en la tercera generación, como es el derecho a la preservación del medio ambiente, hay que decir que todos los hombres (sic) que viven en un mismo ámbito (ciudad, región, etc.) tienen subjetivamente ese derecho, pero como el bien a proteger es común, el derecho personal de cada uno y el de todos forma una titularidad que, aun cuando sigue siendo subjetiva de cada sujeto, uno por uno, es a la vez compartida por esa pluralidad en la sumatoria de un interés común. ${ }^{18}$

En la aplicación de la cláusula de interpretación conforme, debe considerarse que el derecho al ambiente sano es un derecho de goce o disfrute, y es plural. ${ }^{19}$ Se trata de un derecho que está estrechamente vinculado con otro derecho humano, el derecho a vivir, y esto significa que dicho derecho corresponde a cada una de las personas, es de cada persona; aquí estamos frente a una titularidad individual. Al mismo tiempo, es un derecho cuyo bien jurídico tutelado es de todos, es uno solo para todos; estamos frente a una titularidad colectiva. ${ }^{20}$ Ésta debe ser la lectura correcta de lo que se establece en el párrafo quinto del artículo 4o. constitucional vigente, aunque no se mencione expresamente la idea de "disfrutar" o "gozar" (incluso la de "vivir"), como sí se hace en algunas leyes mexicanas que analizaremos más adelante.

Es importante enfatizar que el intérprete u operador jurídico debe valorar que el derecho al ambiente, o derecho a un ambiente, se ha adjetivado de sano (cuyo propósito está vinculado a nuestro desarrollo y bienes-

17 Véase lo que hemos señalado al respecto en Nava Escudero, César, "Derecho al medio ambiente", en Ferrer Mac-Gregor, Eduardo et al. (coord.), Diccionario de..., cit., p. 400 .

18 Bidart Campos, Germán J., Teoría general de los derechos humanos, Buenos Aires, Astrea, 1991, pp. 190 y 191.

19 En este sentido, remitimos a las explicaciones formuladas por Jordano Fraga, Jesús, La protección del derecho a un medio ambiente adecuado, Barcelona, José María Bosch, 1995, pp. 500 y ss.

20 Una explicación más amplia en Corzo Sosa, Edgar, "Derecho al medio ambiente adecuado, reconocimiento jurídico y acceso a la justicia (protección). Un esbozo", en Carmona Tinoco, Jorge Ulises y Hori Fojaco, Jorge M., (coords.), Derechos humanos y medio ambiente, México, Secretaría de Medio Ambiente y Recursos Naturales-UNAM, Instituto de Investigaciones Jurídicas, 2010, pp. 163 y ss. 
Esta obra forma parte del acervo de la Biblioteca Jurídica Virtual del Instituto de Investigaciones Jurídicas de la UNAM

tar) y esto representa una cercanía especial con el derecho de protección de la salud humana. ${ }^{21}$ De aquí que se actualice claramente el principio de interdependencia, es decir, este derecho depende para su existencia de la realización del derecho a la protección de la salud consagrado en el párrafo cuarto del artículo 4o. constitucional, y viceversa. Dicha interdependencia incluye, además y entre otros, el derecho a la alimentación y el derecho al agua (párrafos tercero y sexto del artículo 4o., respectivamente), así como el derecho de responsabilidad por daño y deterioro ambiental $^{22}$ establecido en la última parte del párrafo quinto del artículo 4o. multicitado. Como ya hemos señalado, el derecho al ambiente sano "es un derecho que complementa, pero que a su vez se complementa con otros derechos". 23

\section{Leyes secundarias}

Ante el enorme y vertiginoso crecimiento de leyes en nuestro ordenamiento jurídico, representa un verdadero reto para el intérprete u operador jurídico de la cláusula de interpretación conforme identificar las normas relativas al derecho humano a un ambiente sano. Sin embargo, hemos aprendido (a través de la investigación, la docencia y la función pública) que no hay mejor forma de rastrear qué ley o leyes regulan o reglamentan el enunciado constitucional ambiental sobre este derecho, que la de concentrarse principalmente en aquellas leyes que han de ser consideradas ambientales. Por definición, una ley ambiental puede ser reglamentaria o tener apoyo en uno o más preceptos constitucionales ambientales, entre ellos el artículo 4o., párrafo quinto. Las leyes que no sean ambientales difícilmente habrán de referirse de manera expresa a este derecho aunque, como lo veremos a continuación, hay alguna que otra excepción.

21 Sobre esta cercanía, Brañes, Raúl, Manual de derecho ambiental mexicano, 2a. ed., México, Fundación Mexicana para la Educación Ambiental-Fondo de Cultura Económica, 2000, p. 103.

22 Este es considerado un derecho por la Ley Federal de Responsabilidad Ambiental en su artículo 1o. párrafo segundo, y también por la doctrina; por ejemplo en Carmona Lara, María del Carmen, Derechos del medio ambiente, 3a. ed., México, Secretaría de Educación Pública-Instituto Nacional de Estudios Históricos de las Revoluciones de México-UNAM, Instituto de Investigaciones Jurídicas, 2015, p. 8.

23 Nava Escudero, César, "Derecho al...", cit., p. 401. 
Esta obra forma parte del acervo de la Biblioteca Jurídica Virtual del Instituto de Investigaciones Jurídicas de la UNAM

Ahora bien, ¿qué hace que una ley sea ambiental? El criterio que seguimos, propuesto en otras ocasiones, descansa en dos cuestiones. Primero, una ley se considera ambiental si su aplicación e interpretación para efectos administrativos se realiza por la Secretaría de Medio Ambiente y Recursos Naturales (en adelante, Semarnat) a través de sus unidades administrativas, organismos públicos descentralizados u órganos desconcentrados. Segundo, que el contenido de dicha ley sea, desde luego, de tipo ambiental. ${ }^{24}$ En este criterio también entran leyes cuya aplicación e interpretación pudiera corresponder tanto a la Semarnat como a otras secretarías o entes públicos de manera conjunta, lo que se determina la mayoría de las veces por mandato expreso en la propia ley. Es el caso de la Ley de Bioseguridad de Organismos Genéticamente Modificados donde las autoridades competentes además de la Semarnat son, la Secretaría de Agricultura, Ganadería, Desarrollo Rural, Pesca y Alimentación (en adelante, Sagarpa), la Secretaría de Salud, y la Secretaría de Hacienda y Crédito Público.

Hay leyes con cierto contenido ambiental pero que no son de aplicación e interpretación para efectos administrativos por la Semarnat; lo son de alguna otra secretaría o ente público, con todo y que éstos puedan celebrar convenios de coordinación al efecto con aquélla. Este tipo de leyes se clasifican como leyes por materias relacionadas, y son muchas, quizá más de cuarenta (entre las que se incluyen las que conforman la legislación tributaria, así como los códigos civil y penal). Ejemplos son la Ley Federal del Mar, que aplica e interpreta la Secretaría de Marina; la Ley General de Pesca y Acuacultura Sustentables, que aplica e interpreta la Sagarpa, o la Ley de Energía Geotérmica, que aplica e interpreta la Secretaría de Energía.

En la elaboración de una tipología ambiental propia bajo el criterio señalado con antelación, ${ }^{25}$ existe una ley en su conjunto (caracterizada

24 Véase Nava Escudero, César, "Institucionalizar la capacitación jurídico-ambiental en México", en Nava Escudero, César (ed.), Legislación ambiental en América del Norte. Environmental Legislation in North America, Québec-México, Comisión para la Cooperación Ambiental-UNAM, Instituto de Investigaciones Jurídicas, 2011, pp. 798 y ss.

25 Diversos autores, con o sin un método en particular, escogen o seleccionan aquellas leyes que consideran ambientales. Un análisis dogmático de la legislación ambiental en nuestro país para el caso del derecho a un ambiente sano se encuentra en Mariscal Ureta, Karla Elizabeth, Medio ambiente sano. Derecho colectivo global, México, Porrúa, 2015 , pp. 35 y ss. Aunado a lo anterior, existe un caso singular de una ley que en su texto 
Esta obra forma parte del acervo de la Biblioteca Jurídica Virtual del Instituto de Investigaciones Jurídicas de la UNAM

como ley marco o ley integral), y al menos once leyes por sector o sectoriales (véase la tabla siguiente).

\section{TABLA}

Tipología de leyes en materia ambiental

(integral y por sector)

\begin{tabular}{|c|l|}
\hline \multicolumn{1}{|c|}{ Tipo } & \multicolumn{1}{|c|}{ Leyes } \\
\hline Integral & $\begin{array}{l}\text { Ley General del Equilibrio Ecológico y la Protección al ambiente } \\
(1988)\end{array}$ \\
\hline Por sector & $\begin{array}{l}\text { Ley de Aguas Nacionales (1992) } \\
\text { Ley General de Vida Silvestre (2000) } \\
\text { Ley General de Desarrollo Forestal Sustentable (2003) } \\
\text { Ley General para la Prevención y Gestión Integral de los Resi- } \\
\text { duos (2003) } \\
\text { Ley de Bioseguridad de Organismos Genéticamente Modificados } \\
\text { (2005) } \\
\text { Ley de Promoción y Desarrollo de los Bioenergéticos (2008) } \\
\text { Ley General de Cambio Climático (2012) } \\
\text { Ley Federal de Responsabilidad Ambiental (2013) } \\
\text { Ley de Hidrocarburos (2014) } \\
\text { Ley de la Agencia Nacional de Seguridad Industrial y de Protec- } \\
\text { ción al Medio Ambiente del Sector Hidrocarburos (2014) } \\
\text { Ley de Transición Energética (2015) }\end{array}$ \\
\hline
\end{tabular}

Fuente: Clasificación del autor.

Para los propósitos de este trabajo, identificamos cinco leyes de nuestra tipología que se refieren de manera expresa al derecho a un ambiente: una integral y cuatro sectoriales. A éstas se agrega una ley por materias relacionadas, que de manera excepcional se refiere a este derecho. Con una redacción, vocablos, adjetivos y propósitos distintos al texto constitucional — cuestión que deberá ser puntualmente advertida por los intérpretes u operadores jurídicos de la cláusula de interpretación conforme- las leyes son las siguientes (en orden cronológico según fecha de publicación en el Diario Oficial de la Federación).

determina qué leyes serán ambientales: nos referimos a la Ley Federal de Responsabilidad Ambiental, que así lo establece en su artículo 2o., fracción XI. 
Esta obra forma parte del acervo de la Biblioteca Jurídica Virtual del Instituto de Investigaciones Jurídicas de la UNAM

Ley General del Equilibrio Ecológico y la Protección al Ambiente (1988). Es reglamentaria de diversas disposiciones de nuestra carta magna relativas a la preservación y restauración del equilibrio ecológico y la protección al ambiente, y tiene por objeto propiciar el desarrollo sustentable y establecer las bases para "garantizar el derecho de toda persona a vivir en un medio ambiente sano para su desarrollo, salud y bienestar" (artículo 1o. fracción I). El contenido del derecho se reproduce asimismo en la propia ley (aunque no en términos idénticos) como uno de los diversos principios que deberá observar el Ejecutivo federal en la formulación y conducción de la política ambiental. La redacción es la siguiente: "Toda persona tiene derecho a disfrutar de un ambiente adecuado para su desarrollo, salud y bienestar. Las autoridades en los términos de ésta y otras leyes, tomarán las medidas para garantizar este derecho" (artículo 15, fracción XII).

Ley de Desarrollo Rural Sustentable (2001). Esta Ley, que no es una ley ambiental sectorial, está dirigida a promover el desarrollo rural sustentable y "propiciar un medio ambiente adecuado, en los términos del párrafo cuarto del artículo 4o..." (artículo 1o., párrafo segundo). La redacción y fundamento constitucional de la Ley es todavía una reminiscencia del derecho humano al ambiente del texto anterior a la reforma de 2012. En realidad, es reglamentaria de la fracción XX del artículo 27 constitucional relativa al desarrollo rural integral y sustentable.

Ley General para la Prevención y Gestión Integral de los Residuos (2003). También es reglamentaria de diversas disposiciones de la Constitución relativas a la protección al ambiente, específicamente en materia de prevención y gestión integral de los residuos. Sus disposiciones "tienen por objeto garantizar el derecho de toda persona al medio ambiente sano y propiciar el desarrollo sustentable" precisamente a través "de la prevención de la generación, la valorización y la gestión integral de los residuos peligrosos, de los residuos sólidos urbanos y de manejo especial..." (artículo 10., párrafo segundo). El contenido del derecho también se reproduce como principio para la formulación y conducción de la política sobre prevención, valorización y gestión integral de los residuos con la redacción siguiente: "El derecho de toda persona a vivir en un medio ambiente adecuado para su desarrollo y bienestar" (artículo 2o., fracción I). 
Esta obra forma parte del acervo de la Biblioteca Jurídica Virtual del Instituto de Investigaciones Jurídicas de la UNAM

Ley de Bioseguridad de Organismos Genéticamente Modificados (2005). Aunque no señale expresamente que es reglamentaria de alguna disposición en la Constitución, la Ley tiene apoyo en ciertos preceptos constitucionales relativos a la protección al ambiente al señalar que su objeto es el de

regular las actividades de utilización confinada, liberación experimental, liberación en programa piloto, liberación comercial, comercialización, importación y exportación de organismos genéticamente modificados, con el fin de prevenir, evitar o reducir los posibles riesgos que estas actividades pudieran ocasionar a la salud humana o al medio ambiente y a la diversidad biológica o a la sanidad animal, vegetal y acuícola" (artículo 1).

Se hace mención expresa del derecho humano al ambiente como principio en materia de bioseguridad, por lo que para la formulación y conducción de la política de bioseguridad se señala que "El Estado tiene la obligación de garantizar el derecho de toda persona a vivir en un medio ambiente adecuado para su alimentación, salud, desarrollo y bienestar" (artículo 9o., fracción II).

Ley General de Cambio Climático (2012). Se trata de una ley reglamentaria de diversas disposiciones de nuestra carta magna relativas a la protección al ambiente, el desarrollo sustentable y la preservación y restauración del equilibrio ecológico (artículo 1o.). Tiene por objeto, entre otros, "Garantizar el derecho a un medio ambiente sano..." vinculado a la políticas públicas de adaptación al cambio climático y la mitigación de emisiones de gases y compuestos de efecto invernadero (artículo 2o., fracción I). La Ley precisa que entre los objetivos de las políticas públicas para la mitigación se encuentra la de "Promover la protección del medio ambiente, el desarrollo sustentable y el derecho a un medio ambiente sano a través de la mitigación de emisiones" (artículo 33, fracción I).

Ley Federal de Responsabilidad Ambiental (2013). Sus disposiciones son reglamentarias del artículo 4o. constitucional, y tienen por objeto "la protección, la preservación y restauración del ambiente y el equilibrio ecológico" para garantizar el derecho "a un medio ambiente sano para el desarrollo y bienestar de toda persona..." (artículo 1o., párrafo segundo). Es importante mencionar que la Ley regula la responsabilidad ambiental que se origina de daños ocasionados al ambiente así como la reparación y compensación de tales daños cuando sea exigible a través de procesos 
Esta obra forma parte del acervo de la Biblioteca Jurídica Virtual del Instituto de Investigaciones Jurídicas de la UNAM

judiciales federales de conformidad con lo que establece el artículo 17 constitucional, de mecanismos alternativos de solución de controversias, de procedimientos administrativos, y de aquellos que correspondan a la comisión de delitos contra el ambiente y la gestión ambiental (artículo 10., párrafo primero). La ley puntualiza que podrán ser materia de los mecanismos alternativos de solución de controversias, alguna o todas las diferencias que se susciten entre las personas e instituciones previstas en la propia Ley en relación con "la tutela del derecho a un medio ambiente adecuado para el desarrollo y bienestar de las personas" en los términos señalados por dicha Ley (artículo 48).

Por último, vale la pena enfatizar que aunque muchas leyes sectoriales y por materias relacionadas no mencionan de manera expresa el derecho al ambiente, sí se refieren a temas sobre protección ambiental en relación con diversos preceptos constitucionales y con otras leyes federales. Su contenido estaría, eventualmente, vinculado a este derecho humano. Por lo que quedará a juicio del intérprete u operador jurídico de la cláusula de interpretación conforme acudir a estos preceptos y leyes para mejor comprender (y de manera más amplia) el significado del derecho a un ambiente sano. Esto es trascendental, por ejemplo, en materia de hidrocarburos y energía, puesto que las disposiciones más importantes en el contexto de la anti-ambiental reforma energética del sexenio de Enrique Peña Nieto, no hicieron mención expresa alguna a este derecho.

\section{LAS NORMAS EXTERNAS RELATIVAS AL DERECHO \\ A UN AMBIENTE SANO: LOS TRATADOS INTERNACIONALES}

\section{Algunas precisiones sobre el alcance de la expresión tratados internacionales}

Es muy claro el texto del artículo 1o., párrafo segundo, en señalar que la aplicación de la cláusula de interpretación conforme se refiere a normas internacionales contenidas en tratados internacionales. Esto significa dos cosas a la vez. Primero, que la reforma de 2011 omitió, o mejor dicho, no reconoció, otras fuentes de derecho internacional, como la costumbre o los principios generales del derecho. ${ }^{26}$ Segundo, que las

26 Véase lo que se ha advertido en este sentido por Gómez-Robledo, Juan Manuel y Black León, Stephanie Marie, en Pérez Vázquez, Carlos (coord.), El camino para la 
Esta obra forma parte del acervo de la Biblioteca Jurídica Virtual del Instituto de Investigaciones Jurídicas de la UNAM

normas de interpretación se derivan de un tratado internacional y no de cualquier instrumento internacional.

Es en la segunda de ellas donde el intérprete u operador jurídico puede encontrar cierta confusión para llevar a cabo la aplicación de la cláusula de interpretación conforme. En efecto, debe tenerse presente que en el derecho externo se suscriben una enorme cantidad de instrumentos jurídicos que no tienen el estatus de tratado; y de igual manera, en el derecho interno mexicano se suscriben muchos instrumentos internacionales que carecen de tal estatus.

De manera tal, que es fundamental distinguir cuándo un instrumento internacional es tratado y cuando no. Al respecto, debemos recordar que una de las cuestiones que caracteriza a los tratados es precisamente la de crear efectos jurídicos, es decir, la de crear derechos y obligaciones entre las partes que los celebran, sin importar la denominación que reciba. Por lo que debe seguirse en todo momento el concepto de tratado establecido en el artículo 2o. de la Convención de Viena sobre el Derecho de los Tratados de 1969 de la que México es parte: "un acuerdo internacional celebrado por escrito entre Estados y regido por el derecho internacional, ya conste en un instrumento único o en dos o más instrumentos conexos y cualquiera que sea su denominación particular". Los tratados son vinculantes, más allá de que algunas o muchas de sus normas sean meramente declarativas, políticas, programáticas, exhortativas, aspiracionales, etcétera. $^{27}$

Al mismo tiempo, y para mayor claridad sobre cuándo un instrumento internacional es tratado, el intérprete u operador jurídico deberá tener presente que los tratados en nuestro país siguen un procedimiento para su celebración, y que su entrada en vigor a nivel nacional ocurre una vez terminadas ciertas etapas. ${ }^{28}$ Los pasos que se siguen para ello (en particular para los acuerdos multilaterales) son: $a$ ) la adopción; $b$ ) la firma $a d$ referéndum; c) la aprobación por el Senado de la República; $d$ ) la publi-

reforma constitucional de derechos humanos, México, Suprema Corte de Justicia de la Nación-UNAM, Instituto de Investigaciones Jurídicas, 2013, p. 53.

27 Así lo hemos explicado en Nava Escudero, César, "Guía mínima para la enseñanza del derecho internacional ambiental en México", Boletín Mexicano de Derecho Comparado, nueva serie, año XXXVIII, núm. 113, mayo-agosto de 2005, p. 822.

28 Para una buena explicación sobre ello recomendamos acudir a Palacios Treviño, Jorge, Tratados. Legislación y práctica en México, 4a. ed., México, Secretaría de Relaciones Internacionales-Universidad Iberoamericana, 2007, pp. 116 y ss. 
Esta obra forma parte del acervo de la Biblioteca Jurídica Virtual del Instituto de Investigaciones Jurídicas de la UNAM

cación de dicha aprobación en el Diario Oficial de la Federación; e) la ratificación del Ejecutivo federal; $f$ ) el depósito del instrumento de ratificación en el depositario designado; $g$ ) el aviso del depositario de la fecha de entrada en vigor internacional; y $h$ ) la promulgación y publicación del instrumento respectivo en el Diario Oficial de la Federación. ${ }^{29}$

Ahora bien, lo señalado en párrafos anteriores no significa que el intérprete u operador jurídico de la cláusula de interpretación conforme tenga impedimento alguno en acudir a instrumentos internacionales que no sean tratados, especialmente si éstos permiten una protección más amplia del derecho humano en cuestión. ${ }^{30}$ Sin embargo, sería un tanto inexacto e insuficiente que la armonización que se llegue a realizar tenga como único y exclusivo referente una norma internacional derivada de un instrumento no vinculante, o sea, un instrumento que no sea tratado. El mandato constitucional para el que armoniza o interpreta (y que por cierto no es optativo) se refiere a una norma convencional, pero no a normas que no lo son. Y si queremos ser congruentes con el bloque de constitucionalidad (al que nos hemos referido en apartados anteriores), la normas que lo constituyen devienen tanto de tratados internacionales sobre derechos humanos, como de tratados internacionales que no siendo sobre derechos humanos per se (o sea, de otra materia), contienen normas sobre uno o más derechos humanos.

\section{El derecho a un ambiente sano en los tratados internacionales}

Expertos en derecho internacional ambiental advierten sobre la interrelación que existe entre los derechos humanos y la protección ambiental. ${ }^{31}$ Creemos oportuno señalar que el punto de partida para comprender

29 Más detalles en Nava Escudero, César, “Guía mínima...”, cit., pp. 834 y 835.

30 Véase lo que señala en este sentido Ferrer Mac-Gregor, Eduardo, "Interpretación conforme...", cit., pp. 364 y 365 .

31 Beyerlin, Ulrich y Marauhn, Thilo, International Environmental Law, Oxford, Hart-CH Beck-Nomos, 2011, pp. 391-410; Birnie, Patricia et al., International Law and the Environment, 3a. ed., Oxford, Oxford University Press, 2009, pp. 271-302; Bodansky, Daniel, The Art and Craft of International Environmental Law, Cambridge-Londres, Harvard University Press, 2010, pp. 60 y 61; Kiss, Alexandre Ch. y Shelton, Dinah, International Environmental Law, 3a. ed., Nueva York, Transnational Publishers, 2004, pp. 661 y ss; Sands, Philippe, Principles of International Environmental Law, 2a. ed., Cambridge, Cambridge University Press, 2003, pp. 294 y ss. 
Esta obra forma parte del acervo de la Biblioteca Jurídica Virtual del Instituto de Investigaciones Jurídicas de la UNAM

dicha interconexión es doble. ${ }^{32}$ Por un lado, el derecho internacional ambiental incorpora y utiliza derechos humanos que se consideran necesarios para garantizar una efectiva protección al ambiente, y por lo tanto, hace énfasis en los derechos procesales, como el derecho de acceso a la información, el derecho a la participación pública en la toma de decisiones, y el derecho a la justicia (que incluye el derecho a la reparación del daño). Así, el acceso a la información ambiental, la participación pública en el decision-making ambiental, y la justicia ambiental, en ocasiones son considerados "derechos ambientales". 33

Por el otro, el derecho internacional de los derechos humanos inserta la dimensión ambiental —esto es, "enverdece" los derechos humanos sin quitarles su característica antropocéntrica - con el objeto de evitar que las malas condiciones ambientales $(i . e$. el deterioro o degradación ambiental) disminuyan o impidan el goce y disfrute de otros derechos como el derecho a la vida, a la salud, a la familia, a la privacidad, a la cultura, a la alimentación, a satisfacer sus necesidades básicas, etcétera. Dicho de otro modo, los derechos humanos no pueden garantizarse si prevalece un ambiente deteriorado, degradado o contaminado.

Desde estas dos perspectivas, o mejor dicho, a partir de ellas, se logra cierta aproximación al derecho al ambiente, que bien puede ser adjetivado como sano, saludable, seguro o limpio. ${ }^{34}$ Sin embargo, la inclusión de este derecho en los términos señalados con antelación en instrumentos internacionales (vinculantes o no, y en materia de derechos humanos o ambientales) ha sido muy escasa, por no decir notoriamente modesta ${ }^{35} \mathrm{y}$ ambigua. ${ }^{36}$ Además, su existencia se infiere, en la mayoría de los casos,

32 Tomamos como base el análisis realizado por Kiss, Alexandre Ch. y Shelton, Dinah, op. cit., nota anterior, pp. 663 y ss.

33 Birnie, Patricia et al., International Law..., cit., p. 288.

34 La viabilidad de que el derecho al ambiente no sea meramente antropocéntrico, es decir, que no sea sólo para el ser humano sino al menos también para otros seres vivos, ha tenido poco eco en la normatividad internacional. Ciertos avances son palpables a nivel nacional y, particularmente, sólo para las especies animales. Remitimos al lector a lo señalado al respecto en nuestra más reciente obra, Nava Escudero, César, Debates jurídicoambientales sobre los derechos de los animales. El caso de tlacuaches y cacomixtles versus perros y gatos en la Reserva Ecológica del Pedregal de San Ángel de Ciudad Universitaria, México, UNAM, Coordinación de la Investigación Científica-SEREPSAInstituto de Investigaciones Jurídicas, 2015, passim.

35 Birnie, Patricia et al., International Law..., cit., p. 271.

36 Shaw, Malcolm N., International Law, 7a. ed., Cambridge, Cambridge University Press, 2014, p. 615. 
Esta obra forma parte del acervo de la Biblioteca Jurídica Virtual del Instituto de Investigaciones Jurídicas de la UNAM

sólo de manera parcial o tenue a partir de la lectura de ciertos enunciados jurídicos que vinculan (en mayor o menor medida) los derechos humanos con la protección ambiental, y viceversa. Lo que en todo caso prevalece es la interdependencia con otros derechos.

En efecto, a nivel universal o global, no existe en realidad un tratado internacional (acuerdo vinculante) que se refiera expresamente a un derecho al ambiente o al derecho a un ambiente (en inglés, a right to environment) ya sea desde la perspectiva del derecho internacional ambiental o desde la del derecho internacional de los derechos humanos. Es sólo a nivel regional donde encontramos algunos tratados internacionales que contienen normas con una redacción similar a la de este derecho, o al menos muy cercana a él, si bien con algunos vocablos y adjetivos distintos y de contenido vinculado a otros derechos.

En este sentido, la mayoría de los doctrinarios coinciden en que los únicos dos tratados internacionales en referirse a este derecho en el ámbito regional son, ${ }^{37}$ primero, la Carta Africana sobre los Derechos Humanos y de los Pueblos (también conocida como Carta de Banjul) de 1981, que en su artículo 24 establece que "Todos los pueblos tendrán derecho a un entorno general satisfactorio favorable a su desarrollo". Segundo, el Protocolo Adicional a la Convención Americana sobre Derechos Humanos en Materia de Derechos Económicos, Sociales y Culturales (conocido como Protocolo de San Salvador) de 1998, que en su artículo 11 se refiere al derecho a un ambiente sano en los términos siguientes:

Artículo 11. Derecho a un medio ambiente sano.

1. Toda persona tiene derecho a vivir en un medio ambiente sano y a contar con servicios públicos básicos.

2. Los Estados parte promoverán la protección, preservación y mejoramiento del medio ambiente.

Desde luego, nuestro país sólo forma parte del Protocolo de San Salvador.

Hay que señalar que la Convención sobre el Acceso a la Información, la Participación del Público en la Toma de Decisiones y el Acceso a la Justicia en Asuntos Ambientales (llamada Convención de Aarhus) de

37 Beyerlin, Ulrich y Marauhn, Thilo, International Environmental..., cit., p. 392; Kiss, Alexandre Ch. y Shelton, Dinah, International Environmental..., cit., p. 712; Sands, Philippe, Principles of ..., cit., p. 298. 
Esta obra forma parte del acervo de la Biblioteca Jurídica Virtual del Instituto de Investigaciones Jurídicas de la UNAM

1998, sí se refiere al derecho al ambiente, pero su objetivo central es el de los derechos procesales. ${ }^{38}$ En su preámbulo se refiere a "la necesidad de garantizar un medio ambiente sano para el bienestar de las personas" y a que "una protección adecuada del medio ambiente es esencial para el bienestar humano, así como para el goce de los derechos fundamentales, en particular el derecho a la vida". Además, señala que "toda persona tiene el derecho a vivir en un medio ambiente que le permita garantizar su salud y su bienestar". En su artículo 1o. establece lo siguiente:

Artículo 1o. Objetivo. A fin de contribuir a proteger el derecho de cada persona, de las generaciones presentes y futuras, a vivir en un medio ambiente que permita garantizar su salud y su bienestar, cada parte garantizará los derechos de acceso a la información sobre el medio ambiente, la participación del público en la toma de decisiones y el acceso a la justicia en asuntos ambientales de conformidad con las disposiciones de la presente Convención.

Por último, vale la pena precisar que existen ciertos instrumentos internacionales no vinculantes (o sea, no son tratados internacionales de conformidad con lo que hemos señalado en este trabajo) que también hacen alusión al derecho al ambiente aunque de manera indirecta, o si acaso, interdependiente. Destacan, por un lado, la Declaración de la Conferencia de las Naciones Unidas sobre el Medio Humano (Declaración de Estocolmo) de 1972, que en su Principio 1 establece:

El hombre (sic) tiene el derecho fundamental a la libertad, la igualdad y el disfrute de condiciones de vida adecuadas en un medio de calidad tal que le permita llevar una vida digna y gozar de bienestar, y tiene la solemne obligación de proteger y mejorar el medio para las generaciones presentes y futuras...

Pero como se ha señalado, si bien existe una clara relación entre derechos humanos y protección ambiental, no se refiere en realidad al derecho al ambiente. ${ }^{39}$

Por el otro, la Declaración de Río sobre el Medio Ambiente y el Desarrollo (Declaración de Río) de 1992, que se aleja aún más del derecho

38 Birnie, Patricia et al., International Law..., cit., p. 274.

39 Kiss, Alexandre Ch. y Shelton, Dinah, International Environmental..., cit., p. 667. 
Esta obra forma parte del acervo de la Biblioteca Jurídica Virtual del Instituto de Investigaciones Jurídicas de la UNAM

al ambiente ${ }^{40}$ En efecto, esta Declaración cambia el sentido de lo establecido en la Declaración de Estocolmo, que al menos trataba "en forma mucho más próxima [el] derecho del ser humano a un medio ambiente de calidad en el contexto de otros derechos humanos, tales como la libertad, la igualdad y el disfrute de condiciones de vida adecuadas". ${ }^{41}$ En su Principio 1, la Declaración de Río señala textualmente que "Los seres humanos constituyen el centro de las preocupaciones relacionadas con el desarrollo sostenible. Tienen derecho a una vida saludable y productiva en armonía con la naturaleza". Es, por tanto, un enunciado no vinculante $\mathrm{y}$ antropocéntrico, donde la protección del ambiente queda establecida en función de la protección del ser humano. ${ }^{42}$ No obstante la relevancia que tiene este documento a nivel internacional ambiental, no se le dio en el texto adoptado la trascendencia que tiene la cuestión de los derechos humanos. ${ }^{43}$

En suma, el intérprete u operador jurídico de la cláusula de interpretación conforme deberá estar consciente que su labor de armonización relativa al derecho al ambiente tiene hasta el momento un referente exiguo en la norma convencional (global y regional), pero no así en la norma nacional (Constitución y leyes ambientales). La técnica interpretativa deberá incluir: $i$ ) los textos expresos sobre el derecho al ambiente o cercanos a él; ii) los derechos procesales ambientales; iii) las normas de fuente nacional e internacional relativas a la protección ambiental in ge$n e r e ; i v)$ otros derechos: salud, alimentación, agua, atmósfera, etcétera. Lo anterior, sin dejar de acudir a lo que se establezca al respecto en la jurisprudencia y otras resoluciones o decisiones de tribunales e instancias internacionales según corresponda.

40 Ibidem, p. 668. Es en todo caso una versión suavizada del derecho al ambiente, véase Grubb, Michael et al., The Earth Summit Agreements: A Guide and Assessment, Londres, Earthscan, 1993, p. 90.

41 Székely, Alberto y Ponce-Nava, Diana, "La Declaración de Río y el derecho internacional ambiental", en Glender, Alberto y Lichtinger, Víctor (comps.), La diplomacia ambiental, México, Secretaría de Relaciones Exteriores-Fondo de Cultura Económica, 1994, p. 309.

42 En este mismo sentido Brañes, Raúl, Manual de derecho..., cit., p. 21 en la nota 7.

43 Shaw, Malcolm N., Shaw, Malcolm N., International..., cit., p. 616. 
Esta obra forma parte del acervo de la Biblioteca Jurídica Virtual del Instituto de Investigaciones Jurídicas de la UNAM

\section{EVOLUCIÓN CONSTITUCIONAL AMBIENTAL. ANÁLISIS ABREVIADO*}

\section{INTRODUCCIÓN}

En el marco del Centenario de la Constitución Política de los Estados Unidos Mexicanos, el Departamento de Derecho de la Universidad Iberoamericana, Ciudad de México, ha decidido dedicar un número especial de su ejemplar revista a temas constitucionales con el noble propósito de sumarse a las conmemoraciones que al efecto se realizan a lo largo de 2017. Como profesor de derecho ambiental que he sido en dicha Universidad por más de quince años, me uno con entusiasmo a esta excelente iniciativa a través de una serie de reflexiones sobre las tendencias del derecho constitucional ambiental en nuestro país.

Este trabajo tiene por objeto examinar el desarrollo de la normatividad constitucional en materia ambiental. Para ello, se analizan tanto los antecedentes como las tres etapas más importantes de dicha evolución. El precedente inmediato lo constituye la cuestión relativa a la conservación de los recursos naturales; la primera etapa - que marca el comienzo de lo constitucional ambiental - aborda lo referente a la contaminación ambiental y la salud pública; la segunda, alude a una serie de reformas que introducen la idea del ambiente y su protección desde una óptica integral, y la tercera, se centra en el derecho al ambiente y el desarrollo sustentable.

Concluye este trabajo al señalar que la tendencia constitucional ambiental en México para los próximos años será la de seguir con la adición y/o en su caso modificación de preceptos relacionados con los derechos ambientales y con la sustentabilidad.

* Publicado en Jurídica Ibero, revista semestral del Departamento de Derecho de la Universidad Iberoamericana, Nueva Época, núm. 3, julio-diciembre de 2017. 
Esta obra forma parte del acervo de la Biblioteca Jurídica Virtual del Instituto de Investigaciones Jurídicas de la UNAM

\section{ANTECEDENTES: CONSERVACIÓN DE LOS RECURSOS NATURALES}

Una parte importante de la doctrina mexicana tiene una concepción errónea sobre los orígenes de la normatividad ambiental en nuestra carta magna. Se ha sostenido, equivocadamente, que desde la promulgación de la Constitución de 1917 el artículo 27 ha sido la base constitucional que "sentó ciertos postulados en materia ambiental", 1 y que por muchos años dicho precepto fue la "única herramienta constitucional de tutela del ambiente y de derechos ambientales" 2 en el país. Se ha afirmado, incluso, que "ideológicamente, la inclusión que por primera vez se hizo de la materia ambiental [deba ser] atribuible al licenciado Andrés Molina Enríquez y, formalmente, al constituyente Pastor Rouaix". ${ }^{3}$ Sin embargo, creemos que este tipo de aseveraciones son, para decirlo de una manera concisa, inexactas.

En efecto, ninguno de los dos autores mencionados con antelación, como tampoco texto alguno de la Constitución de 1917, pudieron haberse referido a "lo ambiental" por una simple y sencilla razón. El significado de esta expresión - en un sentido moderno o contemporáneo- no corresponde a esa época, es decir, no existía en aquel tiempo. ${ }^{4}$

Es inconcuso que lo que describen los vocablos ambiente o ambiental como hoy los conocemos comienza a concebirse a partir de las décadas de los sesenta y setenta del siglo XX. ${ }^{5}$ De modo que la significación asig-

1 Simental Franco, Víctor Amaury, Derecho ambiental, México, Limusa, 2010, p. 153.

2 Aceves, Carla D., Bases fundamentales de derecho ambiental mexicano, México, Porrúa, 2003, p. 176.

3 Rabasa, Emilio O., "Génesis de la materia ambiental en nuestra Constitución", en Rabasa, Emilio O. (coord.), La Constitución y el medio ambiente, México, UNAM, Instituto de Investigaciones Jurídicas, 2007, p. 10.

4 Véase lo que ya hemos señalado consistentemente en Nava Escudero, César, Estudios ambientales, 2a. ed., México, UNAM, Instituto de Investigaciones Jurídicas, 2011, p. 211; id., Ciencia, ambiente y derecho, México, UNAM, Instituto de Investigaciones Jurídicas, 2012, pp. 80 y ss. Hace algunos años, y en este mismo sentido, Jorge Muñoz enfatizó que era pretencioso afirmar que en 1917 hubiera existido "una clara idea para proteger el ambiente" o que existiera "una concepción global del ambiente". Sobre el particular, Muñoz Barret, Jorge, "Los recursos naturales y su protección jurídica en México", en Varios autores, La industria petrolera ante la regulación jurídico-ecológica en México, México, UNAM, Instituto de Investigaciones Jurídicas, 1992, p. 38.

5 Una buena explicación sobre los orígenes de este concepto durante la década de los sesenta del siglo pasado se encuentra en Calvert, Peter y Susan, The South, the North and the Environment, Londres-Nueva York, Pinter, 1999, pp. 1 y ss. 
Esta obra forma parte del acervo de la Biblioteca Jurídica Virtual del Instituto de Investigaciones Jurídicas de la UNAM

nada desde entonces y hasta nuestros días, si bien no exenta de discusiones conceptuales y con acepciones que han ido evolucionando y transformándose a lo largo de casi medio siglo de vida, es lo que precisamente da contenido al objeto de estudio y regulación del derecho ambiental, y por extensión, del derecho constitucional ambiental. Por lo que ubicar la cuestión ambiental fuera de esta época es totalmente anacrónico. ${ }^{6}$

Lo que originalmente se redactó en la Constitución de 1917 tiene nomenclatura propia y representa, en todo caso, los antecedentes del derecho constitucional ambiental. Se trató del principio de conservación de los recursos naturales (a los que el texto constitucional denominó elementos naturales) consagrado en el párrafo tercero del artículo 27 de nuestra ley fundamental. En aquel entonces se establecía en dicho precepto lo siguiente:

La nación tendrá en todo tiempo el derecho de imponer a la propiedad privada las modalidades que dicte el interés público, así como el de regular el aprovechamiento de los elementos naturales susceptibles de apropiación, para hacer una distribución equitativa de la riqueza pública y para cuidar de su conservación. Con este objeto se dictarán las medidas necesarias... para evitar la destrucción de los elementos naturales... ${ }^{7}$

Amparado en la idea del aprovechamiento de los recursos naturales y en las medidas que habrían de dictarse para evitar su destrucción, este texto era de alguna manera un reflejo bastante aproximado de las discusiones y preocupaciones que existían durante aquella época en otras partes del mundo relativas a la utilización racional de los recursos. ${ }^{8} \mathrm{De}$

6 Indica el Diccionario de la Lengua Española de la Real Academia Española que anacrónico deriva de anacronismo, y éste significa "error consistente en confundir épocas o situar algo fuera de su época".

7 Aunque este enunciado ha sufrido algunas reformas su esencia sigue siendo la misma.

8 Recordemos que hacia finales del siglo XIX y durante las primeras décadas del $\mathrm{XX}$, cuando se discutían temas relativos a la protección de la naturaleza, se desarrolló en ciertos países la idea de la conservación y el aprovechamiento racional de los recursos naturales. Un excelente acercamiento a esto se encuentra en McManus, Phil, "Conservation", en Johnston, R. J. et al. (eds.), The Dictionary of Human Geography, 4a. ed., Malden, Blackwell, 2000, pp. 106-108. De hecho, nuestro país llegó a participar en algunas conferencias sobre conservación. Véase McCormick, John, The Global Environmental Movement, 2a. ed., Chichester, Wiley, 1995, pp. 22 y ss. 
Esta obra forma parte del acervo de la Biblioteca Jurídica Virtual del Instituto de Investigaciones Jurídicas de la UNAM

aquí la tríada aprovechamiento-recursos naturales-conservación. ${ }^{9}$ En voz de quien fuera el fundador del derecho ambiental en México, el chileno Raúl Brañes,

la conclusión más general a extraerse de esta norma se puede resumir diciendo que el Constituyente de 1917 estableció que los recursos naturales debían ser utilizados racionalmente, esto es, de acuerdo con una lógica productiva que considerara su conservación. ${ }^{10}$

Es importante mencionar en este contexto que con todo y el transcurso de los años, y no obstante la enorme cantidad de reformas constitucionales, la idea de conservación de los elementos naturales se ha mantenido vigente en nuestra carta magna. De hecho, en las últimas décadas, se ha reconocido no sólo su importancia asociada a la política económica del Estado (i. e. como objeto de regulación del derecho económico), ${ }^{11}$ sino su relevancia como principio fundamental en el marco constitucional de la protección ambiental. ${ }^{12}$

Ciertamente, este precepto es en nuestros días parte fundamental del análisis del derecho constitucional ambiental mexicano. ${ }^{13}$

\section{EL COMIENZO: CONTAMINACIÓN AMBIENTAL Y SALUBRIDAD}

Por lo dicho con anterioridad no debe haber confusión: el derecho constitucional ambiental en México no comienza en 1917, sino en 1971, al incluirse expresamente por vez primera en nuestra carta magna un

9 Bajo este paraguas constitucional, en 1960 se adicionó el párrafo sexto del artículo 27 en materia de explotación, uso o aprovechamiento de los recursos ahí referidos en el otorgamiento de concesiones para los particulares o sociedades constituidas conforme a las leyes mexicanas.

10 Brañes, Raúl, Manual de derecho ambiental mexicano, 2a. ed., México, Fundación Mexicana para la Educación Ambiental-Fondo de Cultura Económica, 2000, pp. 73 y ss. En esta misma obra se puede conocer sobre el vínculo que este precepto tiene con la propiedad (originaria y derivada) de las tierras y aguas así como con la función social de la propiedad privada.

11 Véase Witker, Jorge, Curso de derecho económico, México, UNAM, Instituto de Investigaciones Jurídicas, 1989, pp. 72 y 73.

12 Véase Carmona Lara, María del Carmen, Derechos del medio ambiente, 3a. ed., México, Secretaría de Educación Pública-Instituto Nacional de Estudios Históricos de las Revoluciones de México-UNAM, Instituto de Investigaciones Jurídicas, 2015, p. 7.

13 Nava Escudero, César, Estudios ambientales, cit., nota 4, pp. 211 y 212. 
Esta obra forma parte del acervo de la Biblioteca Jurídica Virtual del Instituto de Investigaciones Jurídicas de la UNAM

enunciado con el vocablo ambiental. ${ }^{14}$ Se trató de una adición (en julio de ese año) a la base cuarta de la fracción XVI del artículo 73 relativa a la prevención y combate a la contaminación ambiental en el marco de la salubridad general, lo que representó incorporar uno de los muchos significados que traía aparejado el concepto ambiente de esa época. ${ }^{15}$ Esto fue lo que quedó plasmado en esa ocasión:

Artículo 73. El Congreso tiene facultad:

XVI. Para dictar leyes sobre... salubridad general de la República.

4a. Las medidas que el Consejo haya puesto en vigor en la Campaña contra el alcoholismo y la venta de sustancias que envenenan al individuo o degeneran la especie humana, así como las adoptadas para prevenir y combatir la contaminación ambiental, serán después revisadas por el Congreso de la Unión en los casos que le competan. ${ }^{16}$

Cabe señalar que el sentido de esta reforma constitucional iba a tono con los temas que precisamente eran examinados alrededor del mundo y que fueron clave para las discusiones realizadas en la que se considera la primera conferencia ambiental con tintes internacionales: la Conferencia de las Naciones Unidas sobre el Medio Humano, celebrada en 1972, en Estocolmo, Suecia. ${ }^{17}$

Debe enfatizarse que nuestro país estableció en su texto constitucional un precepto que contemplaba el problema de la contaminación ambiental desde la protección a la salud pública. En él, se otorgaron atribuciones al Consejo de Salubridad General (ente público que en aquel entonces como ahora dependía directamente del presidente de la República) para adoptar medidas sobre la materia. Es por esta razón que se dice que el derecho ambiental en México nació como un derecho sanitario y de la salud

14 Se entiende que "lo ambiental" es lo perteneciente o relativo al ambiente.

15 El debate ambiental en aquellos años estaba centrado, entre otros, en el agotamiento de los recursos naturales, la contaminación ambiental y el impacto en la salud humana. Para mayor detalle puede consultarse lo que hemos señalado en Nava Escudero, César, Urban Environmental Governance. Comparing Air Quality Management in London and Mexico City, Aldershot, Ashgate, 2001, pp. 12 y ss.

16 Esto mismo sigue diciendo en nuestros días el precepto aludido.

17 Es importante recordar que esta conferencia tuvo una gran influencia en la creación y modificación de diversos ordenamientos y normas jurídicas en diversos países. 
Esta obra forma parte del acervo de la Biblioteca Jurídica Virtual del Instituto de Investigaciones Jurídicas de la UNAM

pública. ${ }^{18} \mathrm{Y}$ esto último es un acontecimiento que la doctrina ha aceptado sin mayor controversia.

De manera tal, que la prevención y el combate a la contaminación ambiental se incluyó como una de las diversas materias de salubridad establecidas en el precepto constitucional de referencia. Al ser dichas materias consideradas de naturaleza federal, la prevención y el combate a la contaminación ambiental quedó, por consiguiente, federalizada, ${ }^{19}$ situación que cambió en febrero de 1983 cuando se reformó el artículo 4o. de nuestra carta magna en el contexto de la constitucionalización del derecho a la protección de la salud. En ese año se incluyó expresamente lo siguiente:
Artículo 4o...
Toda persona tiene derecho a la protección de la salud. La Ley definirá las bases y modalidades para el acceso a los servicios de salud y establece- rá la concurrencia de la Federación y las entidades federativas en materia de salubridad general, conforme a lo que dispone la fracción XVI del artículo 73 de esta Constitución.

Independientemente de lo anterior, se criticó de la reforma constitucional de 1971 el que se aumentaran ese tipo de facultades — adjetivadas de dictatoriales - a un órgano - calificado de espurio - como el ya mencionado Consejo de Salubridad General, puesto que con ello dicha Dependencia del Ejecutivo Federal tendría facultades tanto legislativas como ejecutivas..$^{20}$ En este sentido, las medidas adoptadas serían aplicables aun sin el conocimiento ni el consentimiento del propio Congreso

18 Para esta afirmación, consúltese Cabrera Acevedo, Lucio, El derecho de protección al ambiente, México, UNAM, Instituto de Investigaciones Jurídicas, 1981, pp. 18 y 19.

19 Sobre las consecuencias jurídicas a la luz de lo que establece el artículo 124 constitucional, véase Brañes, Raúl, Manual de..., cit., pp. 80 y ss.; González Márquez, José Juan y Cancino Aguilar, Miguel Ángel, "La distribución de competencias en materia ambiental", en González Márquez, José Juan (coord.), Derecho ambiental, México, Universidad Autónoma Metropolitana, 1994, p. 38.

20 Vázquez Pando, Fernando, "Notas para el estudio del sistema jurídico mexicano en materia de contaminación del ambiente", Jurídica, Anuario del Departamento de Derecho de la Universidad Iberoamericana, núm. 6, julio de 1974, pp. 702 y 703. 
Esta obra forma parte del acervo de la Biblioteca Jurídica Virtual del Instituto de Investigaciones Jurídicas de la UNAM

de la Unión, al que le correspondería solamente revisar lo ya actuado por dicho Consejo. ${ }^{21}$

Aunque esta discusión prevaleció entre algunos doctrinarios (y de hecho, continúa en nuestros días), reformas constitucionales posteriores provocaron que el foco de atención se centrara ahora en lo ambiental desde una óptica integral. Las expresiones utilizadas bajo esta concepción fueron diversas, por ejemplo, cuidado del medio ambiente, preservación y restauración del equilibrio ecológico, así como la protección ambiental. Algunas de ellas aún existen en nuestra Constitución y se han vuelto a usar en preceptos incorporados recientemente al texto constitucional.

\section{EL AMBIENTE Y SU PROTECCIÓN DESDE UNA ÓPTICA INTEGRAL}

La tendencia constitucional de incluir preceptos ambientales desde una perspectiva mucho más amplia que la salubridad, es decir, con una dimensión ciertamente integral o en su conjunto (como a veces se le describe) durante las décadas de los ochenta y los noventa del siglo pasado, estuvo influenciada - al menos parcialmente - por acontecimientos que tuvieron lugar a nivel internacional. Lo anterior sin descartar, por supuesto, la influencia de ciertos factores internos, como lo fue por ejemplo el de la contaminación atmosférica en la Ciudad de México y su zona conurbada.

En este sentido, uno de los eventos externos de indiscutible relevancia fue la creación en 1983 de la Comisión Mundial sobre el Medio Ambiente y Desarrollo, la cual produjo un documento denominado Informe Brundtland $^{22}$ publicado en 1987. Dicho informe hizo un llamado para que la Organización de las Naciones Unidas convocara a una gran conferencia internacional para discutir sobre diversas cuestiones vinculadas al ambiente y el desarrollo. Esta conferencia, conocida como la Conferencia de las Naciones Unidas sobre el Medio Ambiente y el Desarrollo, se celebró en 1992, en Río de Janeiro, Brasil, y se le bautizó como la Cumbre de la Tierra.

21 Véase Valadés, Diego, Constitución y politica, 2a. ed., México, UNAM, Instituto de Investigaciones Jurídicas, 1994, p. 150.

22 Nos referimos a la obra conocida como Nuestro futuro común. La versión en inglés puede consultarse en World Commission on Environment and Development, Our Common Future, Oxford, WCED, Oxford University Press, 1987. 
Esta obra forma parte del acervo de la Biblioteca Jurídica Virtual del Instituto de Investigaciones Jurídicas de la UNAM

Tanto en el Informe Brundtland como en la conferencia de Río de 1992, se hizo hincapié en considerar seriamente la dimensión global (amplia, no restringida) de lo que constituye el ambiente (y su protección) así como la estrecha relación que guarda con diversos temas. Éstos abarcaban desde el aprovechamiento y la conservación de los recursos naturales, hasta cuestiones vinculadas con la economía, la sociedad y la participación de gobiernos locales, estatales y federales (o centrales), entre muchos otros más.

En este contexto, se generaron cuatro grandes cambios en nuestra Constitución a través de diversas expresiones que incorporaron la idea de ambiente bajo una perspectiva integral. Todas ellas quedaron doctrinalmente enmarcadas dentro de los conceptos genéricos de protección al ambiente, protección ambiental o protección del ambiente. Dichos conceptos no sólo se han utilizado comúnmente para describir la etapa del desarrollo constitucional ambiental que analizamos en este apartado, sino que han sido los de mayor uso entre los iusambientalistas (incluso en nuestros días) para referirse a muchos de los temas que abarca el derecho ambiental en general. Nosotros también haremos uso indistinto de dichos conceptos en este sentido para exponer las modificaciones constitucionales que a continuación se describen.

Primero, se realizó una modificación a un renovado artículo 25 constitucional al incorporarse en febrero de 1983 la idea de protección ambiental en el marco de la parte económica de la Constitución — si bien a través de la noción del cuidado del medio ambiente-.${ }^{23}$ Se trataba, puntualmente, de que las empresas de los sectores social y privado de la economía se sujetaran al interés público y al uso en beneficio general de los recursos productivos, cuidando tanto su conservación como el medio ambiente, según se estableció en el párrafo sexto de dicho artículo. Quedó plasmado en ese año lo siguiente:

23 Véase la opinión al respecto de Brañes, Raúl, Manual de..., cit., p. 83. Para este autor la norma en cuestión se considera "una base importante para la protección del ambiente en su conjunto", lo que está ligado a la idea de una protección ambiental integral como la entendemos nosotros. Sin embargo, y contrario a lo que hemos sostenido aquí, Brañes señala que este principio "identifica por primera vez 'ambiente' o 'medio ambiente' como tal...". Como ya hemos explicado, nuestra postura consiste en identificar por primera vez ambiente y/o ambiental con la reforma constitucional de 1971. Las citas textuales que se transcriben en esta nota de pie de página, se encuentran en la p. 86 del libro de Brañes citado. 
Esta obra forma parte del acervo de la Biblioteca Jurídica Virtual del Instituto de Investigaciones Jurídicas de la UNAM

Bajo criterios de equidad social y productividad se apoyará e impulsará a las empresas de los sectores social y privado de la economía, sujetándolos a las modalidades que dicte el interés público y al uso, en beneficio general, de los recursos productivos, cuidando su conservación y el medio ambiente. ${ }^{24}$

De manera tal, que el cuidado del medio ambiente quedó incluido en lo que se entiende por economía mixta y, en consecuencia, se legitimó como un "valor a proteger por el sistema económico". 25

Segundo, se llevaron a cabo reformas en agosto de 1987 a dos artículos a través de la introducción de las expresiones "preservación y restauración del equilibrio ecológico" y/o "protección al ambiente". Se trató, en un primer caso, de una adición a un previamente modificado párrafo tercero del artículo 27 en el que se agregó el quehacer público de "preservar y restaurar el equilibrio ecológico" como una de las medidas necesarias que se habrían de dictar como consecuencia de lo establecido en la primera parte de dicho párrafo. El planteamiento constitucional quedó plasmado de la siguiente manera:

\section{Artículo 27...}

La nación tendrá en todo tiempo el derecho de imponer a la propiedad privada las modalidades que dicte el interés público, así como el de regular, en beneficio social, el aprovechamiento de los elementos naturales susceptibles de apropiación, con objeto de hacer una distribución equitativa de la riqueza pública, cuidar de su conservación, lograr el desarrollo equilibrado del país y el mejoramiento de las condiciones de vida de la población rural y urbana. En consecuencia, se dictarán las medidas necesarias... para preservar y restaurar el equilibrio ecológico...

Así, desde entonces y hasta la fecha, quedaron ligados los primeros enunciados del párrafo tercero del artículo 27 constitucional a la idea más amplia o integral de protección al ambiente.

El otro caso fue la adición de la fracción XXIX-G al artículo 73 al incluir en el texto constitucional tanto "protección al ambiente" como

24 Este precepto tuvo una adición en diciembre de 2013 (se agregó la voz sustentabilidad) y, posteriormente, en mayo de 2015 se recorrió al párrafo séptimo, que es donde actualmente se encuentra.

25 Witker, Jorge, Curso de..., cit., p. 408. 
Esta obra forma parte del acervo de la Biblioteca Jurídica Virtual del Instituto de Investigaciones Jurídicas de la UNAM

"preservación y restauración del equilibrio ecológico" en el marco de las facultades del Congreso de la Unión "para expedir leyes que establezcan la concurrencia del gobierno federal, de los gobiernos de los estados y de los municipios, en el ámbito de sus respectivas competencias". ${ }^{26}$ Existe en torno a este artículo una discusión doctrinal mucho muy extendida respecto a si se trata de un sistema de distribución de competencias (como facultades concurrentes o coincidentes) o de una simple coordinación o colaboración de acciones administrativas entre los distintos órdenes o niveles de gobierno. ${ }^{27}$

Tercero, se realizaron reformas en el mismo mes de agosto de 1987 al artículo 73 en el marco de la creación de un órgano local llamado en aquel tiempo Asamblea de Representantes del Distrito Federal. Este órgano de representación ciudadana (que no era propiamente legislativo) tuvo, entre otras, facultades en materia de "preservación del medio ambiente" y "protección ecológica" (así redactado en el artículo 73, fracción VI, inciso A). Cabe enfatizar que aunque con una sintaxis diferente, ambas expresiones formaron parte de la idea integral de protección ambiental. A continuación, el texto correspondiente:

Artículo 73. El Congreso tiene facultad:

VI. Para legislar en todo lo relativo al Distrito Federal, sometiéndose a las bases siguientes:

26 Esta fracción fue modificada en enero de 2016, con la reforma política de la Ciudad de México, para sustituir "gobiernos de los estados" por "gobiernos de las entidades federativas" e incluir a las nuevas "demarcaciones territoriales de la Ciudad de México".

27 Para conocer más sobre diversas interpretaciones, recomendamos acudir a Barragán Barragán, José, "Concurrencia de facultades en materia de medio ambiente entre la Federación y los estados", en Carmona Lara, María del Carmen y Hernández Meza, Lourdes (coords.), Temas selectos de derecho ambiental, México, Procuraduría Federal de Protección al Ambiente-UNAM, Instituto de Investigaciones Jurídicas, 2006, pp. 2-4, 87 y 88; Brañes, Raúl, Manual de..., cit., pp. 89 y 90; González Márquez, José Juan y Cancino Aguilar, Miguel Ángel, "La distribución de competencias...", en González Márquez, José Juan (coord.), Derecho ambiental, cit., pp. 32-37; Serna de la Garza, José María, El sistema federal mexicano. Un análisis jurídico, México, UNAM, Instituto de Investigaciones Jurídicas, 2008, pp. 99-101 y 146-149; Vázquez, Aquilino, "El federalismo en materia ambiental", Memorias del Primer Encuentro Internacional de Derecho Ambiental, México, Secretaría de Medio Ambiente y Recursos Naturales, Instituto Nacional de Ecología, 2003, pp. 602 y 603. 
Esta obra forma parte del acervo de la Biblioteca Jurídica Virtual del Instituto de Investigaciones Jurídicas de la UNAM

Son facultades de la Asamblea de Representantes del Distrito Federal las siguientes:

A) Dictar bandos, ordenanzas y reglamentos de policía y buen gobierno que... tengan por objeto atender las necesidades que se manifiesten entre los habitantes del propio Distrito Federal, en materia de... preservación del medio ambiente y protección ecológica...

Sobrevivieron las expresiones arriba mencionadas a dos reformas posteriores. En primer término, a la reforma constitucional de octubre de 1993, en la que tal facultad quedaría establecida ahora en el artículo 122, fracción IV, inciso g. La disposición de referencia quedó redactada como a continuación se transcribe:

Artículo 122...

IV. La Asamblea de Representantes del Distrito Federal tiene facultades para:

g) Legislar en el ámbito local, en lo relativo al Distrito Federal en los términos del Estatuto de Gobierno en materias de... preservación del medio ambiente y protección ecológica...

En segundo término, a la reforma de agosto de 1996, por la que se creó un órgano local un tanto más apegado a un ente legislativo denominado Asamblea Legislativa del Distrito Federal. Éste fue el que precisamente sustituyó a la ya citada asamblea de representantes, según quedó plasmado en el artículo 122, apartado $\mathrm{C}$, base primera, fracción $\mathrm{V}$, inciso $\mathrm{j}$, cuya parte específica transcribimos abajo:

Artículo 122...

C. El Estatuto de Gobierno del Distrito Federal se sujetará a las siguientes bases:

BASE PRIMERA. Respecto a la Asamblea Legislativa:

V. La Asamblea Legislativa, en los términos del Estatuto de Gobierno, tendrá las siguientes facultades:

j) Legislar en materia de... preservación del medio ambiente y protección ecológica... 
Esta obra forma parte del acervo de la Biblioteca Jurídica Virtual del Instituto de Investigaciones Jurídicas de la UNAM

Esta situación prevaleció hasta la reforma política de la Ciudad de México de enero de 2016, por la que tales disposiciones quedaron derogadas.

Cuarto, en la reforma constitucional de octubre de 1993, se incluyó en el propio artículo 122, en la fracción IX, un precepto relativo a la suscripción de convenios para la creación de comisiones metropolitanas utilizando las ya conocidas expresiones de "protección al ambiente" y de "preservación y restauración del equilibrio ecológico". ${ }^{28}$ A continuación, el texto del precepto constitucional aludido.

Artículo $122 \ldots$

IX. Para la eficaz coordinación de las distintas jurisdicciones locales y municipales entre sí, y de éstas con la Federación y el Distrito Federal en la planeación y ejecución de acciones en las zonas conurbadas limítrofes con el Distrito Federal, de acuerdo con el artículo 115 fracción VI de esta Constitución, en materias de... protección al ambiente, preservación y restauración del equilibrio ecológico... sus respectivos gobiernos podrán suscribir convenios para la creación de comisiones metropolitanas en las que concurran y participen con apego a sus leyes.

Dichas expresiones permanecieron inalteradas con las reformas de agosto de 1996 (en el marco de la distribución de competencias entre los Poderes de la Unión y las autoridades locales del Distrito Federal). Si bien los textos respectivos subsistieron tal cual en el mismo artículo 122, ahora se ubicaron en el emergente apartado $\mathrm{G}$, párrafo primero.

Con la reforma constitucional de enero de 2016 mencionada con antelación, las multicitadas expresiones se insertaron en un renovado apartado $\mathrm{C}$, párrafo segundo (en relación con el párrafo primero), del mismo artículo 122, correspondiendo en esta ocasión al Consejo de Desarrollo Metropolitano acordar las acciones de coordinación administrativa en la materia. ${ }^{29}$ Así quedaron las recientes modificaciones a nuestra Constitución:

28 Es de hacerse notar que los legisladores incorporaron, aquí sí, las expresiones acuñadas desde 1987 por nuestra carta magna.

29 Debe entenderse que esta reforma aún corresponde a la visión integral o amplia de protección al ambiente. 
Esta obra forma parte del acervo de la Biblioteca Jurídica Virtual del Instituto de Investigaciones Jurídicas de la UNAM

Artículo $122 \ldots$

C. La Federación, la Ciudad de México, así como sus demarcaciones territoriales, y los estados y municipios conurbados en la zona metropolitana, establecerán mecanismos de coordinación administrativa en materia de planeación del desarrollo y ejecución de acciones regionales para la prestación de servicios públicos, en términos de la ley que emita el Congreso de la Unión.

Para la eficaz coordinación a que se refiere el párrafo anterior, dicha ley establecerá las bases para la organización y funcionamiento del Consejo de Desarrollo Metropolitano, al que corresponderá acordar las acciones en materia de... protección al ambiente; preservación y restauración del equilibrio ecológico...

Por último, vale la pena señalar que los enunciados incluidos en los extensos artículos transitorios de la Constitución relativos a la reforma en materia energética de diciembre de 2013, deben asociarse asimismo a la idea de la protección ambiental bajo una perspectiva integral. ${ }^{30}$ Lo anterior, sin perjuicio de que dicha reforma sea, a todas luces, una reforma anti-ambiental.

\section{EL DERECHO AL AMBIENTE Y EL DESARROLLO SUSTENTABLE}

Hacia finales de la década de los noventa del siglo pasado, específicamente en junio de 1999, se llevaron a cabo reformas a nuestra carta magna por las que se incorporaron dos temas que eran, por lo menos

30 Sabemos que los artículos transitorios pueden extender el contenido del texto de la Constitución, y esto fue ciertamente visible con la reforma energética. Para una reflexión sobre esto véase Nava Negrete, Alfonso, "Enmiendas a la Constitución de 1917", Revista de la Facultad de Derecho de México, México, t. LXIV, núm. 262, julio-diciembre de 2014, pp. 569 y ss. Estos artículos se refieren a las adecuaciones al marco jurídico que debe realizar el Congreso de la Unión por las que el Estado habrá de procurar "la protección y el cuidado del medio ambiente" en todos los procesos relacionados con la materia objeto de reforma (artículo 17), así como a las adecuaciones jurídicas para la creación de la Agencia Nacional de Seguridad Industrial y de Protección al Medio Ambiente del Sector Hidrocarburos y sus atribuciones (artículo 19). Dichas adecuaciones incluyen la regulación de las empresas productivas del Estado para que éstas inserten en su objeto de creación el sentido de responsabilidad ambiental (artículo 20 fracción I). 
Esta obra forma parte del acervo de la Biblioteca Jurídica Virtual del Instituto de Investigaciones Jurídicas de la UNAM

dentro del constitucionalismo ambiental latinoamericano, ${ }^{31}$ parte de una tendencia normativa constitucional bien definida en la región: el derecho al ambiente y el desarrollo sustentable. ${ }^{32}$ Más allá de América Latina, estos dos conceptos formaban parte asimismo de un proceso de consolidación no sólo de tipo constitucional, sino incluso de tipo casuístico a nivel internacional.

En efecto, para 1999, otras Constituciones no latinoamericanas en el mundo ya habían incorporado el derecho al ambiente o estaban por hacerlo, ${ }^{33}$ y el desarrollo sustentable — constitucionalizado en diversas naciones - ya había llegado a ocupar una mención singular a nivel internacional en el conflicto entre Eslovaquia y Hungría (caso Gabcikovo-Nagymaros con sentencia de 1997) ante la Corte Internacional de Justicia, particularmente a través de una opinión separada del entonces vicepresidente de dicho órgano judicial de la Organización de las Naciones Unidas. ${ }^{34}$

Debemos aclarar que si bien los dos temas que examinamos en este apartado nacieron vinculados entre sí, ${ }^{35}$ cada uno ocupó un lugar distinto en el texto constitucional de nuestro país.

31 Expresión acuñada por Raúl Brañes en Programa de las Naciones Unidas para el Medio Ambiente, El desarrollo del derecho ambiental latinoamericano y su aplicación. Informe sobre los cambios jurídicos después de la Conferencia de las Naciones Unidas sobre el Medio Ambiente y el Desarrollo (Río 1992), México, Oficina Regional para América Latina y el Caribe, 2001, p. 47.

32 El proceso de constitucionalización de ambos conceptos en nuestro país no fue de los primeros si lo comparamos con otros países latinoamericanos. Por un lado, la idea de incorporar el derecho al ambiente (cualquiera que hubiera sido su adjetivación: adecuado, saludable, sano, etcétera) ocurrió por vez primera en la Constitución de Perú en 1979, seguida de la de Chile en 1980, de Ecuador en 1983, Nicaragua en 1987, Brasil en 1988, Colombia en 1991, Paraguay en 1992, Argentina en 1994, Costa Rica en 1994, y Venezuela junto con México en 1999. Por el otro, antes de 1999 varias Constituciones habían ya incorporado el concepto o contenido del desarrollo sustentable, como los casos de Guatemala en 1985, Brasil en 1988, Colombia en 1991, Cuba en 1992, Perú en 1993, Bolivia en 1994, Ecuador en 1998, y Venezuela en 1999. Ibidem, pp. 52,53 y 55.

33 Algunos ejemplos en Delhoste, Marie-France, "L'environnement dans les Constitutions du monde", Revue du Droit Public, LGDJ, núm. 2, marzo-abril de 2004, pp. 443 y ss.

34 Más detalles en Campuzano, Raúl F., "El concepto de desarrollo sustentable en la jurisprudencia y en otras fuentes de derecho internacional", Revista de Derecho de la Universidad Católica de Valparaíso, núm. XXIII, Chile, 2002, pp. 407 y ss.

35 Así lo afirmaba Lucio Cabrera en "El derecho a un medio ambiente adecuado", en Rabasa, Emilio O. (coord.), La Constitución y..., cit., p. 13. Esta idea ha sido confirmada por Carmona Lara al señalar que el derecho al ambiente se complementa con el desarrollo 
Esta obra forma parte del acervo de la Biblioteca Jurídica Virtual del Instituto de Investigaciones Jurídicas de la UNAM

\section{El derecho al ambiente}

Por un lado, el derecho al ambiente fue incorporado en el párrafo quinto del artículo 4o. constitucional de la siguiente manera: "Toda persona tiene derecho a un medio ambiente adecuado para su desarrollo y bienestar". Por su obvia brevedad y visible escarceo, el contenido de este precepto estuvo en su momento sujeto a profundas críticas por parte de la doctrina. Algunas de ellas consistieron, por ejemplo, en la señalada ambigüedad de los términos "adecuado", "desarrollo" y "bienestar"; en el hecho de que no se hubieran establecido ni el deber correlativo Estado-sociedad o Estado-individuo de proteger el ambiente ni la responsabilidad por los daños que se ocasionaran; y en la cuestión de que no se hubiesen incluido expresamente los mecanismos o garantías procesales para el debido ejercicio de este derecho. ${ }^{36}$

En agosto de 2001, y derivado de una reforma que derogó el párrafo primero del artículo 4o., el texto íntegro del derecho en cuestión se ubicó en el párrafo cuarto, pero regresó a su lugar original (o sea, al párrafo quinto del mismo artículo) con una reforma en octubre de 2011 por la que se adicionó un párrafo tercero. El contenido del precepto, hasta este momento, no había sufrido cambio alguno.

Sin embargo, en febrero de 2012, el artículo 4o. se vuelve a reformar y en esta ocasión la redacción y el contenido del párrafo quinto cambiaron para quedar de la siguiente manera: "Toda persona tiene derecho a un medio ambiente sano para su desarrollo y bienestar. El Estado garantizará el respeto a este derecho. El daño y deterioro ambiental generará responsabilidad para quien lo provoque en términos de lo dispuesto por la ley". Este es el texto que está vigente y que se complementa con una

sustentable, éste considerado un principio rector de nuestra Constitución, véase Carmona Lara, María del Carmen, Derechos del..., cit., p. 12.

36 Acúdase para conocer sobre la historia de este precepto constitucional y sobre algunas críticas y análisis de su contenido a Corzo Sosa, Edgar, "Derecho al medio ambiente adecuado, reconocimiento jurídico y acceso a la justicia (protección). Un esbozo", en Carmona Tinoco, Jorge Ulises y Hori Fojaco, Jorge M. (coords.), Derechos humanos y medio ambiente, México, Secretaría de Medio Ambiente y Recursos Naturales-UNAM, Instituto de Investigaciones Jurídicas, 2010, pp. 152 y ss.; Mariscal Ureta, Karla Elizabeth, Medio ambiente sano. Derecho colectivo global, México, Porrúa, 2015, pp. 2733; Soto Flores, Armando, "Bases constitucionales del derecho ambiental mexicano y derecho comparado", en Carmona Lara, María del Carmen y Hernández Meza, Lourdes (coords.), Temas selectos..., cit., pp. 334-344. 
Esta obra forma parte del acervo de la Biblioteca Jurídica Virtual del Instituto de Investigaciones Jurídicas de la UNAM

serie de modificaciones constitucionales recientes (específicamente en las materias de derechos humanos y de amparo) que permiten afirmar que ahora se cuentan con más y mejores herramientas para garantizar este derecho y hacerlo valer ante diversas instancias jurisdiccionales $\mathrm{u}$ operadores jurídicos. ${ }^{37}$

Es importante advertir que con el paso de los años, se han incorporado otros derechos que se encuentran estrechamente vinculados con el derecho a un ambiente sano, lo que hace que éste complemente y a su vez se complemente de tales preceptos emergentes. ${ }^{38}$ En cierto modo, estos derechos se consideran ambientales y forman parte de las ideas ya sea de la protección del ambiente desde una perspectiva integral o bien de la conservación de los recursos naturales a las que nos hemos referido en apartados anteriores. Sobresalen, por ejemplo, el derecho de los pueblos y las comunidades indígenas a la conservación y mejoramiento del hábitat conforme a lo establecido en el artículo 2o. constitucional, apartado A, fracción V (agosto de 2001), ${ }^{39}$ y los derechos a la alimentación (octu-

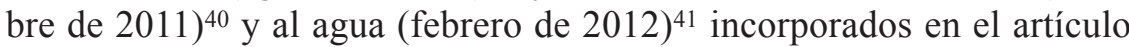
4o. constitucional en los párrafos tercero y sexto respectivamente.

37 Para conocer sobre la esencia jurídica de este derecho y los alcances de la nueva redacción del artículo constitucional de referencia, así como el significado de la reforma en derechos humanos y amparo, recomendamos Carmona Lara, María del Carmen, Derechos del..., cit., pp. 9-17; Fix-Zamudio, Héctor y Valencia Carmona, Salvador, Las reformas en derechos humanos, procesos colectivos y amparo como nuevo paradigma constitucional, 3a. ed., México, Porrúa-UNAM, Instituto de Investigaciones Jurídicas, 2015, passim; Mariscal Ureta, Karla Elizabeth, ibidem, pp. 1-45; Nava Escudero, César, "Derecho al medio ambiente", en Ferrer Mac-Gregor, Eduardo et al. (coords.), Diccionario de Derecho Procesal Constitucional y Convencional, México, Poder Judicial de la Federación-UNAM, Instituto de Investigaciones Jurídicas, 2014, t. I, pp. 399-401.

38 Nava Escudero, César, ibidem, p. 401.

39 Establece el precepto en cuestión lo siguiente: "Artículo 2o. ...A. Esta Constitución reconoce y garantiza el derecho de los pueblos y las comunidades indígenas a la libre determinación y, en consecuencia, a la autonomía para:... V. Conservar y mejorar el hábitat y preservar la integridad de sus tierras en los términos establecidos en esta Constitución".

40 El texto relativo señala lo siguiente: "Artículo 4o. ... Toda persona tiene derecho a la alimentación nutritiva, suficiente y de calidad. El Estado lo garantizará".

41 El enunciado al que aludimos - muy extenso - quedó redactado de la siguiente manera: "Artículo 4o. ... Toda persona tiene derecho al acceso, disposición y saneamiento de agua para consumo personal y doméstico en forma suficiente, salubre, aceptable y asequible. El Estado garantizará este derecho y la ley definirá las bases, apoyos y modalidades para el acceso y uso equitativo y sustentable de los recursos hídricos, estableciendo 
Esta obra forma parte del acervo de la Biblioteca Jurídica Virtual del Instituto de Investigaciones Jurídicas de la UNAM

\section{El desarrollo sustentable}

Por el otro, el concepto de desarrollo sustentable fue insertado por vez primera en nuestra Constitución a través de una adición al párrafo primero del artículo 25. Quedó así ligado al capítulo económico e implicó, entre otras cosas, que la rectoría del desarrollo nacional (que corresponde al Estado) fuera no sólo integral sino también sustentable, idea que aún persiste en el texto constitucional vigente. El texto completo en aquel entonces se cita a continuación:

Artículo 25. Corresponde al Estado la rectoría del desarrollo nacional para garantizar que éste sea integral y sustentable, que fortalezca la Soberanía de la Nación y su régimen democrático y que, mediante el fomento del crecimiento económico y el empleo y una más justa distribución del ingreso y la riqueza, permita el pleno ejercicio de la libertad y la dignidad de los individuos, grupos y clases sociales, cuya seguridad protege esta Constitución. ${ }^{42}$

Es indispensable precisar que semejante incorporación al texto constitucional no significó en momento alguno la creación de un nuevo derecho humano, sino su consagración como principio.

A partir de ese año, la idea misma de la sustentabilidad se fue incorporando paulatinamente en preceptos de muy diversa índole y con alcances distintos. En nuestros días este concepto tiene muchas caras y adjetiva temas por igual. Es, al mismo tiempo, principio que tarea pública, y también proceso y fin según corresponda.

la participación de la Federación, las entidades federativas y los municipios, así como la participación de la ciudadanía para la consecución de dichos fines".

42 Conviene agregar que el "desarrollo nacional sustentable" también quedó relacionado con el sistema nacional de planeación democrática (contemplado en el primer párrafo del apartado A del artículo 26 constitucional), lo que significa que la planeación nacional (Plan Nacional de Desarrollo y programas gubernamentales) están ligados constitucionalmente desde entonces a lo sustentable. Véase Nava Escudero, César, "El turismo sustentable en la Constitución", Revista de la Facultad de Derecho de México, México, t. LXIII, núm. 260, julio-diciembre de 2013, pp. 350 y 351. La reforma que se hiciera en junio de 2013 al primer párrafo de este artículo dejó intacto lo que hemos señalado con antelación. 
Esta obra forma parte del acervo de la Biblioteca Jurídica Virtual del Instituto de Investigaciones Jurídicas de la UNAM

Traemos a colación cuatro ejemplos muy puntuales. ${ }^{43}$ Primero, en agosto de 2001, el desarrollo sustentable se convierte (según lo establecido en el artículo 2o, apartado B, párrafo segundo, fracción VII) en una de las muchas "obligaciones" o "tareas" que las autoridades federales, estatales y municipales deben realizar y apoyar para "abatir las carencias y rezagos que afectan a los pueblos y comunidades indígenas" como parte integral de la reforma en materia de derechos y cultura indígenas. ${ }^{44}$ Segundo, en agosto de 2007, se le incluye en relación con las facultades del Congreso de la Unión para expedir leyes sobre las sociedades cooperativas (por adición de la fracción XXIX-N al artículo 73)..$^{45}$ Tercero, en octubre de 2011 (a partir de la incorporación de un segundo párrafo a la fracción XX del artículo 27) se establece que el desarrollo rural integral será sustentable. ${ }^{46} \mathrm{Y}$ por último, las reformas en materia energética de diciembre de 2013 adjetivaron a la energía de sustentable (como se desprende de la lectura del artículo décimo cuarto transitorio). ${ }^{47}$

43 Para mayor abundamiento véase lo que hemos escrito sobre los tres primeros ejemplos en ibidem, pp. 350-355.

44 El texto de referencia en aquel año establecía: "Artículo 2o. ...B. La Federación, los estados y los municipios... Para abatir las carencias y rezagos que afectan a los pueblos y comunidades indígenas, dichas autoridades tienen la obligación de: ...VII. Apoyar las actividades productivas y el desarrollo sustentable de las comunidades indígenas mediante acciones que permitan alcanzar la suficiencia de sus ingresos económicos...". En enero de 2016, una reforma constitucional sustituyó del texto aludido "los estados" por "las entidades federativas".

45 La reforma constitucional incorporó en aquel entonces la siguiente redacción: “Artículo 73. El Congreso tiene facultad: ...XXIX-N Para expedir leyes en materia de constitución, organización, funcionamiento y extinción de las sociedades cooperativas. Estas leyes establecerán las bases para la concurrencia en materia de fomento y desarrollo sustentable de la actividad cooperativa de la Federación, estados y municipios, así como del Distrito Federal, en el ámbito de sus respectivas competencias". El precepto vigente tiene una redacción un poco distinta pero conserva lo relativo al desarrollo sustentable.

46 Quedó plasmado el siguiente enunciado: "Artículo 27 ...XX. El Estado promoverá... El desarrollo rural integral y sustentable a que se refiere el párrafo anterior, también tendrá entre sus fines que el Estado garantice el abasto suficiente y oportuno de los alimentos básicos que la ley establezca". Y éste es el texto vigente.

47 Se redactó lo siguiente en este artículo: "Décimo cuarto... El Fondo Mexicano del Petróleo para la Estabilización y el Desarrollo... Los ingresos se administrarán y distribuirán conforme a la siguiente prelación y conforme se establezca en la ley para... 3. Realizar las transferencias al Fondo de Extracción de Hidrocarburos; a los fondos de investigación en materia de hidrocarburos y sustentabilidad energética, y en materia de fiscalización petrolera... 
Esta obra forma parte del acervo de la Biblioteca Jurídica Virtual del Instituto de Investigaciones Jurídicas de la UNAM

\section{CONCLUSIÓN: ¿MÁS DERECHOS, MÁS SUSTENTABILIDAD?}

Al conmemorarse los cien años de vida de nuestra carta magna - febrero de 2017- no es nada aventurado afirmar que el derecho constitucional ambiental en México ha transitado pausada pero decididamente hacia una era en la que así como se ha consolidado el derecho al ambiente, también se han adicionado otro tipo de derechos que se consideran ambientales. Al mismo tiempo, en este transitar constitucional, el principio de sustentabilidad ha tenido una franca expansión, por cierto muy diversa, hacia otros artículos de nuestra ley fundamental.

Hablemos primero de los derechos. La nueva redacción del derecho al ambiente, que vigorizó el alcance del ya existente derecho a la protección de la salud, representa un avance singular en su reconocimiento y protección. Esta situación se ha visto reforzada no sólo por la tendencia constitucional de agregar más derechos ambientales (como los ya referidos derechos a la alimentación y al agua) sino porque su salvaguarda (y la de todos ellos) se ha ampliado considerablemente al estar vinculados con lo establecido en el artículo 1o. de nuestra carta magna en relación con lo que se conoce como la cláusula de interpretación conforme, el bloque de constitucionalidad, el control de convencionalidad, el principio pro 
Esta obra forma parte del acervo de la Biblioteca Jurídica Virtual del Instituto de Investigaciones Jurídicas de la UNAM

persona, y los principios interpretativos de los derechos humanos in genere (universalidad, interdependencia, indivisibilidad, progresividad). ${ }^{48}$

Podría pensarse que hemos llegado a un escenario óptimo de protección de los derechos ambientales, incluso porque al aplicar el bloque de constitucionalidad se crea un catálogo amplio conformado por normas constitucionales en sede nacional ( $i$. e . de nuestra Constitución) y por normas constitucionales en sede internacional (i. e. derivadas de tratados internacionales de derechos humanos o que tuvieran normas relativas a ellos). ${ }^{49}$ Sin embargo, esto no ha sido así porque no siempre, en uno $u$ otro caso, se contemplan derechos ambientales que demandan su urgente reconocimiento y protección. Ejemplos tan obvios para nuestro país (ignorados por legisladores) incluyen el derecho (a respirar) un aire limpio, el derecho al agua de mar o el derecho al litoral..$^{50}$

Aunado a lo anterior, es creciente la exigencia de que se inserten preceptos relacionados con la constitucionalización de ciertos derechos ambientales que no son propiamente humanos, sino de o para otros entes, como los derechos de la Tierra, de la naturaleza, o de los animales. ${ }^{51}$ Pero esto es aún poco probable que suceda porque muchos juristas temen (por cortedad de pensamiento o por raigambres egoístas y ortodoxas) que la

48 Para un primer acercamiento véase Fix-Zamudio, Héctor y Valencia Carmona, Salvador, Las reformas..., cit.

49 Ibidem, pp. 14 y 15.

50 Estos derechos pueden y de hecho han recibido diversas denominaciones, pero lo importante aquí es destacar su relevancia para un país como el nuestro que por un lado sufre de altos niveles de contaminación atmosférica en la megalópolis del centro del país y en otros centros urbanos, y que por el otro cuenta con una extensión marina y litoral verdaderamente envidiables. La doctrina extranjera ya se ha ocupado de este tipo de derechos, como ha sucedido por ejemplo en Francia. Véase Prieur, Michel, Droit de l'environnement, 4a. ed., París, Dalloz, 2001, p. 62.

51 A nivel regional (en ciertos países latinoamericanos) se tienen algunas experiencias al respecto. Incluso, a nivel local, en la Ciudad de México la legislación ha avanzado en esta dirección, si bien con ciertos matices jurídicos importantes, al establecer no sólo el reconocimiento de "las obligaciones y deberes tanto del gobierno como de la sociedad, para garantizar el respeto a la Tierra" (según la fracción IX del artículo 1o. de la Ley Ambiental de Protección a la Tierra en el Distrito Federal) sino el respeto y defensa de los recursos naturales de la Tierra como una obligación de las personas que se encuentran en el Distrito Federal (fracción I del artículo 23 de la misma ley). Algo semejante, pero con mayor precisión, ha sucedido con la legislación relativa a la protección de los animales, ya que se han establecido si bien como principios, una serie de derechos para ellos (artículo 5o. de la Ley de Protección a los Animales del Distrito Federal). 
Esta obra forma parte del acervo de la Biblioteca Jurídica Virtual del Instituto de Investigaciones Jurídicas de la UNAM

esencia y estructura de los derechos quede desvirtuada en caso de extenderlos a entes que supuestamente no tienen — ni tendrían - la condición respectiva para ser titulares de un derecho.

Hablemos ahora de la sustentabilidad. Comencemos por enfatizar que los tres pilares en los que se edifica este concepto son el económico-financiero, el sociocultural y el ecológico-ambiental y, por lo tanto, los tres son consustanciales a él. De manera tal que así como el principio del desarrollo sustentable no puede ni debe entenderse única y exclusivamente desde una perspectiva ambiental, tampoco desde una que lo sea tan sólo económica o social.

No obstante, la constitucionalización de la sustentabilidad ha estado orientada a privilegiar fundamentalmente sólo la dimensión económica, lo que supone cierta desviación o distorsión conceptual como podría argumentarse para los preceptos ya mencionados del artículo 2o., apartado B, fracción VII en materia indígena (con la reforma de agosto de 2001) y del artículo 25 del ahora párrafo séptimo dentro de la parte económica de la Constitución (con una adición en diciembre de 2013). ${ }^{52}$ Pocos son los casos donde la sustentabilidad es algo más que una noción económica. Esto sucedió cuando se relativizó su significado al quedar vinculado con un derecho ambiental en particular al que ya hemos hecho alusión en repetidas ocasiones: el derecho al agua.

En conclusión, si bien cualquier otra reforma en la materia estará bajo la égida de la protección del ambiente desde una óptica integral, habrán de prevalecer adiciones o modificaciones relacionadas con los derechos ambientales y/o con el desarrollo sustentable. De aquí en adelante, y si la absurda propuesta de establecer una moratoria de reformas a nuestra carta magna no se actualiza, estos dos temas — derechos y sustentabilidadserán los trending topics del constitucionalismo ambiental mexicano. Esto es así porque, como se demuestra en este trabajo, la tendencia hacia el futuro será la de propagar ambos tópicos en el texto constitucional.

52 Se agregó tal concepto al principio de este párrafo para quedar como sigue: "Bajo criterios de equidad social, productividad y sustentabilidad se apoyará e impulsará a las empresas de los sectores social y privado de la economía...". Esta adición se llevó a cabo en el marco de las reformas constitucionales en materia energética. 
Esta obra forma parte del acervo de la Biblioteca Jurídica Virtual del Instituto de Investigaciones Jurídicas de la UNAM

\section{EL PRINCIPIO DE PRECAUCIÓN EN EL DERECHO INTERNACIONAL AMBIENTAL*}

\section{INTRODUCCIÓN}

Concebida por vez primera en la década de los ochenta y popularizada años más tarde a propósito de la conferencia de Río de 1992, la idea de precaución es actualmente parte fundamental del derecho internacional ambiental. Diversos instrumentos jurídicos (de lege ferenda y de lege lata) plasman indistintamente en sus principios, preámbulos y artículos su significado; incuestionable es ya su intromisión en la órbita de lo internacional ambiental.

Como es natural, prevalecen las discrepancias sobre su correcto nombre y apellido, sus alcances y significado, según el instrumento vinculante o no del que se trate; sin embargo, uno de los documentos de mayor trascendencia para el entendimiento y diseminación del concepto de precaución es la Declaración de Río sobre el Medio Ambiente y el Desarrollo de 1992, que recoge en su principio 15 la idea de que cuando exista peligro de daño grave e irreversible, la falta de certeza científica absoluta no podrá invocarse por los Estados para no adoptar medidas de protección ambiental. La paulatina aceptación que este concepto tiene a nivel mundial permite deliberar acerca de su creciente predominio, incluso sobre acuerdos internacionales ajenos a lo propiamente ambiental, como los relativos al comercio.

Las implicaciones económicas, sociales y ambientales que pueden derivarse de la aplicación de la acción precautoria son aún inimaginables; su adopción entraña la necesidad de replantear por completo el actuar ambiental preventivo de los Estados que hasta hace pocos años se daba sólo si existía base científica para ello. De cualquier modo, en su expansión global, la idea de precaución se propaga de tal manera que los Esta-

* Publicado en Derecho Ambiental y Ecología, México, año 1, núm. 2, agosto-septiembre de 2004. 
Esta obra forma parte del acervo de la Biblioteca Jurídica Virtual del Instituto de Investigaciones Jurídicas de la UNAM

dos se ven cada vez más comprometidos a incorporarla en sus legislaciones domésticas. El objetivo de este artículo es, precisamente, contribuir al entendimiento y comprensión respecto de su denominación, significado y trascendencia.

\section{ORÍGENES Y TERMINOLOGÍA}

Al parecer, lo que se conoce como precaución o precautorio en el derecho internacional ambiental surge en un instrumento no vinculante. Da cuenta de ello José Juste Ruiz, ${ }^{1}$ quien afirma que como idea fue implícitamente enunciada por vez primera en la Carta Mundial de la Naturaleza (resolución de la Asamblea General de las Naciones Unidas de 1982). A partir de esta fecha, un sinnúmero de instrumentos - vinculantes y nose han referido en sus textos a la acción de precaución, aunque de manera muy diversa. Así, en ocasiones se ha hecho simple mención a ella sin definirla, en otras, si bien se le ha dado un significado no se le menciona expresamente, y en algunas más se le define e incluye explícitamente. Por si fuera poco, también se le ha asociado incorrectamente con otros conceptos o principios y ha tenido nombres diferentes. Así lo demuestran los ejemplos siguientes:

- Como simple mención a medidas de precaución en el Convenio de Viena para la Protección de la Capa de Ozono de 1985: "Teniendo presentes también las medidas de precaución que ya se han adoptado, en los ámbitos nacional e internacional, para la protección de la capa de ozono" (preámbulo, párrafo quinto). ${ }^{2}$

- Por asociación a medidas preventivas en el Protocolo de Montreal Relativo a las Sustancias que Agotan la Capa de Ozono de 1987: "Tomando nota de las medidas preventivas para controlar las emisiones de ciertos clorofluorocarbonos que ya se han tomado en los planos nacional y regional" (preámbulo, párrafo octavo). ${ }^{3}$

1 Para mayor detalle, véase Juste Ruiz, José, Derecho internacional del medio ambiente, Madrid, McGraw-Hill, 1999, p. 79.

2 El texto completo puede consultarse en el sitio de Internet de la Secretaría de Relaciones Exteriores utilizando las ligas correspondientes: http://www.sre.gob.mx.

3 La cita textual corresponde a Programa de las Naciones Unidas para el Medio Ambiente, Protocolo de Montreal relativo a las sustancias que agotan la capa de ozono en 
Esta obra forma parte del acervo de la Biblioteca Jurídica Virtual del Instituto de Investigaciones Jurídicas de la UNAM

- Como criterio de precaución en la Declaración de Río sobre Medio Ambiente y Desarrollo de 1992:

Con el fin de proteger el medio ambiente, los Estados deberán aplicar ampliamente el criterio de precaución conforme a sus capacidades. Cuando haya peligro de daño grave o irreversible, la falta de certeza científica absoluta no deberá utilizarse como razón para postergar la adopción de medidas eficaces en función de los costos para impedir la degradación del medio ambiente (principio 15). ${ }^{4}$

- Por mencionar sólo su significado en el Convenio sobre la Diversidad Biológica de 1992: "Observando también que cuando exista una amenaza de reducción o pérdida sustancial de la diversidad biológica no debe alegarse la falta de pruebas científicas inequívocas como razón para aplazar las medidas encaminadas a evitar o reducir al mínimo esa amenaza" (preámbulo, párrafo noveno). ${ }^{5}$

- Como medidas de precaución y con significado en la Convención Marco de las Naciones Unidas sobre el Cambio Climático de 1992: "Las Partes deberían tomar medidas de precaución para prever, prevenir o reducir al mínimo las causas del cambio climático y mitigar sus efectos adversos. Cuando haya amenaza de daño grave o irreversible, no debería utilizarse la falta de total certidumbre científica como razón para posponer tales medidas..." (artículo 3o.). ${ }^{6}$

- Por sinonimia con otros principios como el de "cautela" en el Tratado Constitutivo de la Comunidad Europea de texto consolidado con las modificaciones insertadas hasta el Tratado de Amsterdam de 1997: "La política de la Comunidad en el ámbito del medio ambiente tendrá como objetivo alcanzar un nivel de protección elevado, teniendo presente la diversidad de situaciones existentes en las

su forma ajustada y/o enmendada en Londres, 1990; Copenhague, 1992; Viena, 1995; Montreal, 1997; Beijing 1999, Programa de las Naciones Unidas para el Medio Ambiente-Secretaría del Ozono, 2000, http://www.unep.org/ozone.

4 El texto puede consultarse en http://www.rolac.unep.mx/docamb/esp/dr1992.htm.

5 El texto íntegro (copia fiel y completa en español) del Convenio sobre la Diversidad Biológica puede consultarse en el Diario Oficial de la Federación del 7 de mayo de 1993.

6 Al igual que el convenio sobre biodiversidad, el texto íntegro (copia fiel y completa en español) de la Convención Marco de las Naciones Unidas sobre el Cambio Climático puede consultarse en el Diario Oficial de la Federación del 7 de mayo de 1993. 
Esta obra forma parte del acervo de la Biblioteca Jurídica Virtual del Instituto de Investigaciones Jurídicas de la UNAM

distintas regiones de la Comunidad. Se basará en los principios de cautela y de acción preventiva..." (artículo 174, antes $130 \mathrm{R}$ ). ${ }^{7}$

- Como enfoque de precaución en el Protocolo de Cartagena sobre Seguridad de la Biotecnología de 2000: "Reafirmando el enfoque de precaución que figura en el Principio 15 de la Declaración de Río sobre el Medio Ambiente y el Desarrollo" y también "De conformidad con el enfoque de precaución que figura en el Principio 15 de la Declaración de Río... el objetivo del presente Protocolo..." (preámbulo, párrafo cuarto y artículo 1o., respectivamente). ${ }^{8}$

- Como idea de precaución y a la vez principio de precaución en el Convenio de Estocolmo sobre Contaminantes Orgánicos Persistentes de 2001: "Reconociendo que la idea de precaución es el fundamento de las preocupaciones de todas las Partes y se halla incorporada de manera sustancial en el presente Convenio" así como también "teniendo presente el principio de precaución consagrado en el principio 15 de la Declaración de Río sobre el Medio Ambiente y el Desarrollo, el objetivo del presente Convenio es proteger la salud humana y el medio ambiente frente a los contaminantes orgánicos persistentes" (preámbulo, párrafo octavo y artículo 1o., respectivamente) ${ }^{9}$

Es así que en las últimas dos décadas, diversos instrumentos internacionales ambientales han hecho referencia a una misma idea pero con nombres y apellidos distintos. Al paso de los años, el término que más se ha popularizado en el concierto internacional de las naciones es el que corresponde al de principio de precaución; sin embargo, la presencia de

7 Texto obtenido de una edición preparada por Mangas Martín, Araceli, Tratado de la Unión Europea, Tratados constitutivos de las Comunidades Europeas, 6a. ed., Madrid, Tecnos, 1998. En este sentido, L. Krämer explica que existe una tendencia de varios autores a identificar el significado del principio de cautela con el significado del principio 15 de la declaración de Río, véase Krämer, Ludwig, Derecho ambiental y Tratado de la Comunidad Europea, 3a. ed., trad. de Luciano Parejo Alfonso y Ángel Manuel Moreno Molina, Madrid, Marcial Pons, 1999, p. 93.

8 El texto íntegro (copia fiel y completa en español) del Protocolo de Cartagena sobre Seguridad de la Biotecnología del Convenio sobre la Diversidad Biológica puede consultarse en el Diario Oficial de la Federación del 28 de octubre de 2003.

9 El texto íntegro (copia fiel y completa en español) del Convenio de Estocolmo sobre Contaminantes Orgánicos Persistentes puede consultarse en el Diario Oficial de la Federación del 17 de mayo de 2004. 
Esta obra forma parte del acervo de la Biblioteca Jurídica Virtual del Instituto de Investigaciones Jurídicas de la UNAM

tantas expresiones ha derivado en suponer que cada una de ellas tiene características e implicaciones diversas. Sin duda, los términos que más polémica han causado en este sentido son el de "criterio" vis à vis el de "principio" en el marco de referencia de la declaración de Río.

Al referirse a estos dos vocablos, Birnie y Boyle ${ }^{10}$ explican que en realidad son sólo algunos los autores que consideran como significativa esta diferencia terminológica. En este sentido, señalan que uno de los principales argumentos que existen para diferenciarlos radica en que mientras la voz principio hace referencia a situaciones de gran incertidumbre con riesgo de daño irreversible a costos elevados, la de criterio se refiere a situaciones donde el grado de incertidumbre y los costos son meramente significativos y el daño es poco probable que sea irreversible. Se aduce incluso - añaden estos autores - que el término criterio es más flexible o menos restrictivo que el de principio. Destaca de igual manera la opinión que vierte Juste Ruiz sobre ambas expresiones a propósito del enunciado en el principio 15 de la declaración de Río. Este autor señala que el alcance del principio de precaución ha sido minimizado, esto es, la propia declaración "ha devaluado el rango del principio al conferirle la denominación de mero criterio". ${ }^{11} \mathrm{Al}$ mismo tiempo, el autor reconoce que aún como criterio debe ser ampliamente aplicado con la consecuencia de que se adopten medidas para evitar peligros de un daño grave e irreversible, incluso a falta de certeza científica.

Por si fuera poco, el anhelo de establecer un parámetro con el que se pueda determinar si las expresiones criterio y principio son lo mismo o diferentes y en qué forma, se topa con el contundente hecho de que algunos tratados internacionales se refieren indistintamente a ambas expresiones —incluso a la de "enfoque" - para aludir a un mismo concepto y significado. Es el caso del protocolo de Cartagena y del convenio de Estocolmo que por igual aluden en sus textos al principio 15 de la declaración de Río, pero que de manera diversa el de Cartagena se refiere a enfoque y el de Estocolmo a principio, tal y como se observa en los textos arriba citados.

De todo lo anterior se desprende que si bien el vocablo principio pareciera tener un mayor grado de presencia o influencia normativa $-\mathrm{y}$ por

10 Véase Birnie, Patricia y Boyle, Alan, International Law and the Environment, 2a. ed., Oxford, Oxford University Press, 2002, p. 116.

11 Véase Juste Ruiz, José, op. cit., nota 1, p. 84. 
Esta obra forma parte del acervo de la Biblioteca Jurídica Virtual del Instituto de Investigaciones Jurídicas de la UNAM

tanto de compromiso- que un simple criterio o enfoque, ${ }^{12}$ lo cierto es que no hay consenso entre los diversos autores sobre si existe o no alguna diferencia entre ellos. Si la práctica internacional no da pauta para esclarecer esta situación terminológica (como se describió en el ejemplo del párrafo anterior entre el protocolo de Cartagena y el convenio de Estocolmo), entonces parece más sensato atender al significado e implicaciones que entraña el concepto mismo de precaución. Consecuentemente, cobra mayor interés la definición y el contexto del instrumento internacional en el que se haya plasmado, que el nombre con el que se haya bautizado (ya sea principio, enfoque, criterio o medida). Así, en el marco de la declaración de Río, aunque el concepto de precaución esté impreso en un instrumento declarativo no vinculante, éste forma parte de uno de los muchos principios que dan sustancia a una declaración con alto contenido político-jurídico en la que se expresan compromisos ambientales voluntariamente adquiridos por los Estados.

\section{SIGNIFICADO}

Precaución no es lo mismo que prevención. Desde luego, en ambos casos existe la característica común de la adopción de medidas preventivas para la protección del ambiente; sin embargo, y a partir de que la idea de precaución se consagra en el principio 15 de la declaración de Río, el elemento fundamental que lo distingue de éste y otros principios es la evidencia científica. Esto es, si tradicionalmente las medidas ambientales preventivas se originaban sólo a partir de información científica existente, la idea de precaución estableció precisamente que "la falta de certeza científica absoluta no será razón para posponer medidas de protección ambiental". ${ }^{13}$

El componente esencial que da significado al concepto de precaución - i. e. la falta de evidencia científica - forma parte de un enunciado

12 Conviene acudir a Birnie, Patricia y Boyle, Alan, op. cit., nota 10, para conocer sobre el "valor" de los principios generales de derecho internacional y la aceptación como tales de ciertos enunciados ambientales.

13 Székely, Alberto y Ponce-Nava, Diana, "La declaración de Río y el derecho internacional ambiental", en Glender, Alberto y Lichtinger, Víctor (comps.), La diplomacia ambiental, México, Secretaría de Relaciones Exteriores-Fondo de Cultura Económica, 1994, p. 320. 
Esta obra forma parte del acervo de la Biblioteca Jurídica Virtual del Instituto de Investigaciones Jurídicas de la UNAM

mayor que, según la definición en el instrumento internacional del que se trate, permite hacer un desglose del mismo para entender sus implicaciones. Partiendo del principio 15 de la declaración de Río se puede afirmar que el criterio o principio de precaución presupone la identificación de una situación de peligro (derivada de una actividad) de daño grave e irreversible al ambiente, pero sin tener la certidumbre científica absoluta sobre esto; por lo que los Estados deberán tomar medidas para evitar dicho peligro de daño o reducir, en su caso, ese daño potencial. Así también lo entiende José Juan González Márquez al señalar que "el principio de precaución exige que cuando surja una duda razonable en relación con la peligrosidad de cualquier actividad con repercusiones ambientales, se evite la misma, o se tomen las medidas pertinentes para que ese eventual daño, todavía no comprobado científicamente, no llegue a producirse". ${ }^{14}$

Como consecuencia de lo anterior, es posible establecer algunos caracteres propios del principio de precaución (así como sus implicaciones) sin pretender que sean absolutos o concluyentes en toda aplicación de la normativa ambiental:

1) Es indispensable que se prevea la existencia de una situación de peligro de daño derivada de una actividad cualquiera. Es lógico suponer que a ningún Estado se le podrá exigir que lleve a cabo medidas para evitar un daño ambiental sin que se haya hecho previsible o probable el peligro de daño, o que al menos el Estado no hubiera estado consciente o razonablemente consciente de él.

2) Desde luego, es necesaria cierta base científica para que el peligro de daño sea evaluable. Por ejemplo, si ningún Estado hubiera previsto el peligro potencial de los clorofluorocarbonos en el agotamiento de la capa de ozono (independientemente de su eventual impacto) no se hubieran elaborado instrumentos jurídicos de protección. ${ }^{15}$ Esto no quiere decir que se tenga certeza científica - y mucho menos absoluta - sobre el peligro de daño o los daños causados al ambiente; de tener certidumbre científica sobre el peligro de daño entonces no

14 González Márquez, José Juan, La responsabilidad por el daño ambiental en México, México, Universidad Autónoma Metropolitana, 2002, p. 39. Para mayor detalle también se pueden consultar Birnie, Patricia y Boyle, Alan, op. cit., nota 10, y Thornton, Justine y Beckwith, Silas, Environmental Law, Londres, Sweet \& Maxwell, 1997.

15 Birnie, Patricia y Boyle, Alan, op. cit., nota 10, pp. 115-117. 
Esta obra forma parte del acervo de la Biblioteca Jurídica Virtual del Instituto de Investigaciones Jurídicas de la UNAM

sería necesario invocar el principio de precaución, sino, en su caso, el de prevención.

3) El elemento esencial de la idea de precaución - la incertidumbre científica - se traduce en que "no se debería permitir a los Estados ocultarse bajo el pretexto de la falta de evidencia científica como medio de evitar las acciones necesarias para protegerlo". ${ }^{16}$ No hay un criterio único para determinar si la falta de evidencia científica de la que habla el principio 15 de la declaración de Río se refiera a las actividades que generan el peligro de daño potencial, al propio peligro de daño potencial, o bien a los posibles daños que ocurran. En cualquiera de los tres casos pudiera existir la incertidumbre científica aunque en principio parece estar orientada a los efectos adversos; de cualquier manera la idea de su aplicación descansa en que más vale equivocarse del lado de la seguridad. ${ }^{17}$ Lo que sí es claro es que la falta de certidumbre científica (absoluta o no) no debe invocarse por parte de los Estados para no tomar las acciones conducentes.

4) El peligro de daño potencial está sujeto a que deba ser grave o irreversible. La ambigüedad que conllevan estos dos últimos términos a la vez que admite diversas interpretaciones, da mayor flexibilidad para su aplicación. Es de esperarse que en la práctica internacional la aplicación del principio o criterio precautorio, como lo señala Juste Ruiz, sea restringida por encontrarse condicionada a la gravedad e irreversibilidad de los efectos o daños potenciales. ${ }^{18}$

5) Se inserta en su contenido la dimensión económica al establecer que la adopción de medidas eficaces —el término eficaz es, asimismo, ambiguo - estará en función de los costos que esto pueda representar. Si bien la acción precautoria es ampliamente aceptada dentro de los foros ambientales, no todos los Estados tienen los mismos incentivos económicos para ponerla en práctica ni tampoco la base financiera suficiente para sustentarla. Para la aplicación de esta parte del enunciado, la creación, por ejemplo, de impuestos ambientales es sugerida como alternativa a rígidas disposiciones

16 Adede, Andrónico O., Digesto de derecho internacional ambiental, trad. de Diana Lucero Ponce-Nava, México, Secretaría de Relaciones Exteriores, 1995, p. 182.

17 Juste Ruiz, José, op. cit., nota 1, p. 81.

18 Ibidem, p. 80. 
Esta obra forma parte del acervo de la Biblioteca Jurídica Virtual del Instituto de Investigaciones Jurídicas de la UNAM

administrativas. ${ }^{19}$ Es fácil advertir, sin embargo, la problemática de asignar valores económicos a daños potenciales (graves e irreversibles) sobre una base donde priva la incertidumbre científica. El difícil cálculo del importe del costo ambiental debe establecer, en todo caso, un máximo que ayude a determinar un punto medio entre la aplicación de la acción precautoria (con los respectivos costos económico-ambientales de acción y abstención) y el tipo y grado de desarrollo que los Estados y las sociedades estén dispuestos a generar según sus actividades productivas, industriales, comerciales, de servicios, etcétera.

6) Finalmente, conduce la acción precautoria a un replanteamiento sobre la llamada reversión completa de la carga de la prueba. Lo anterior en el sentido de que quien realiza una actividad es el que ahora tiene que probar que no causará daño, y no que sea el Estado el que tenga que probar si la actividad en cuestión causará ese daño. Aunque no es claro aún si el efecto principal del principio 15 de la declaración de Río sea precisamente el de revertir por completo dicha carga, diversas opiniones parecen inclinarse en este sentido. ${ }^{20}$ Un ejemplo lo constituye la actividad consistente en el movimiento transfronterizo intencional de organismos vivos modificados (OVMs) plasmada en el protocolo de Cartagena de 2000. El hecho de que no se tenga certeza científica sobre los posibles efectos adversos de un organismo vivo modificado no impide a la parte importadora el adoptar la decisión de prohibir dicha importación. A la luz de lo que parece una opinión generalizada, la carga de la prueba ante la incertidumbre científica del daño potencial de un OVM sobre la conservación y utilización sostenible de la diversidad biológica, en este caso concreto, no correspondería a la parte importadora. ${ }^{21}$

19 Herrera Molina, Pedro M., Derecho tributario ambiental, Madrid y Barcelona, Ministerio de Medio Ambiente, Marcial Pons, 2000, p. 37.

20 Véase por ejemplo en relación con esto, González Márquez, José Juan, op. cit., nota 14, p. 39 particularmente lo que se señala en la nota 94 al citar a Pérez Miranda, Rafael; Székely, Alberto y Ponce-Nava, Diana, op. cit., nota 13, p. 321, y Thornton, Justine y Beckwith, Silas, op. cit., nota 14, p. 38.

21 Para mayor detalle véase el artículo 1o. en relación con el artículo 10 del citado protocolo de Cartagena. 
Esta obra forma parte del acervo de la Biblioteca Jurídica Virtual del Instituto de Investigaciones Jurídicas de la UNAM

\section{CONCLUSIONES}

Para efectos prácticos, es indispensable preguntarse si los Estados están obligados o no y en qué grado a cumplir con la idea de precaución tal y como se encuentra plasmada en el principio 15 de la declaración de Río, así como en otros instrumentos internacionales. La respuesta a ello tiene muchos matices y dista de ser concluyente; uno de los más importantes radica en el hecho de que la idea de precaución, incorporada lo mismo en instrumentos soft law (derecho suave o no vinculante como la declaración de Río) que hard law (derecho duro o vinculante como el protocolo de Cartagena o el convenio de Estocolmo) se ha concebido ante todo como una guía de acción para los Estados. Desde luego, es difícil afirmar con toda seguridad que la acción de precaución entraña para los Estados - como partes contratantes - una conducta obligatoria con todo el rigor de una norma jurídica vinculante.

Si bien es cierto que por lo menos es contundente la obligación de los Estados de invocar la idea de precaución, la incertidumbre y ambigüedades que giran en torno a su contenido, implicaciones y alcances hace aún más difícil determinar el grado de cumplimiento. Quedan pendientes de contestar preguntas tales como ¿qué se debe entender por incertidumbre científica absoluta?, ¿cuál es el alcance y qué significado tiene el daño grave e irreversible?, ¿cuáles son los indicadores para determinar las capacidades conforme a las que los Estados deberán aplicar ampliamente el principio o criterio de precaución?, etcétera.

Con todo, los disensos que existen alrededor de su significado y alcances no excusan a los Estados a no orientar sus acciones para comprometerse y comportarse dentro de los parámetros jurídicos que se desprenden de la idea de precaución. Independientemente del término que se quiera usar (principio, enfoque, criterio, medida) parte de ese comportamiento debe reflejarse en las legislaciones internas de los Estados en el entendimiento de que su aplicación tendrá implicaciones a nivel económico, sociocultural y ambiental; estas áreas constituyen los pilares del desarrollo sustentable. 
Esta obra forma parte del acervo de la Biblioteca Jurídica Virtual del Instituto de Investigaciones Jurídicas de la UNAM

\section{LA SEGURIDAD DE LA BIOTECNOLOGÍA: LA NORMATIVIDAD INTERNACIONAL $V I S$ - $A$-VIS LA REGULACIÓN NACIONAL MEXICANA*}

\section{INTRODUCCIÓN}

Existe ya una mayor aceptación dentro de la comunidad jurídico-ambiental de que el denominado derecho internacional ambiental tiene una doble influencia en el desarrollo del derecho interno de las naciones. Primero, porque se ha convertido en uno de los principales propulsores de la normatividad doméstica de un país, o como lo señala un informe sobre el desarrollo del derecho ambiental latinoamericano publicado por la Oficina Regional para América Latina y el Caribe, el derecho internacional ha pasado a ser "en muchos sentidos... la locomotora que conduce el tren del derecho ambiental", ${ }^{1}$ y segundo, porque tal y como lo señalan Patricia Birnie y Alan Boyle en su excelente obra International Law and the Environment, muchos instrumentos en materia internacional ambiental buscan, o al menos tienen, el efecto de armonizar los derechos nacionales de los países que intervienen como partes contratantes en dichos instrumentos. ${ }^{2}$

Sin embargo, el hecho de que en el concierto internacional de las naciones los Estados expresen su deseo y hagan constar su consentimiento en

* Publicado en Memorias del Segundo Encuentro Internacional de Derecho Ambiental, México, Instituto Nacional de Ecología-Secretaría de Medio Ambiente y Recursos Naturales-Programa de las Naciones Unidas para el Medio Ambiente, diciembre de 2004.

1 Programa de las Naciones Unidas para el Medio Ambiente, El desarrollo del derecho ambiental latinoamericano y su aplicación. Informe sobre los cambios jurídicos después de la Conferencia de las Naciones Unidas sobre el Medio Ambiente y el Desarrollo (Río 1992), México, Oficina Regional para América Latina y el Caribe, 2001, p. 20.

2 Birnie, Patricia W. y Boyle, Alan E., International Law and the Environment, 2a. ed., Oxford, Oxford University Press, 2002, p. 8. 
Esta obra forma parte del acervo de la Biblioteca Jurídica Virtual del Instituto de Investigaciones Jurídicas de la UNAM

obligarse por instrumentos internacionales ambientales, no significa que en lo interno incorporen dichas obligaciones a sus propios sistemas jurídicos. La materialización de esta doble influencia de la normatividad internacional ambiental en la creación y armonización de los derechos nacionales, dependerá no sólo de la capacidad institucional doméstica para incorporar compromisos adquiridos internacionalmente respecto de una misma problemática ambiental, sino de los intereses políticos, económicos y sociales, de las prioridades legislativas y hasta de los tiempos electorales, que tengan en lo interno los países. Estas y muchas otras razones contribuyen a que ciertos temas - como el de la seguridad de la biotecnología y la liberación de los organismos genéticamente modificados- estén prácticamente ausentes o medianamente regulados a nivel nacional no obstante su amplia discusión y debida adopción normativa a nivel internacional.

México es un país que al exterior se ha mostrado como una nación con el suficiente interés y capacidad para adquirir compromisos en los temas arriba señalados, pero que en lo interno ha hecho poco para ampliar y armonizar su legislación existente. Aunque la normatividad mexicana actualmente aborda algunas cuestiones sobre diversos aspectos de la seguridad de la biotecnología y la liberación de los organismos genéticamente modificados en sus dimensiones ambiental, agrícola, vegetal, animal o de salud pública, es todavía en su conjunto insuficiente, dispersa y poco armónica.

Este artículo tiene por objeto identificar la respuesta que el Estado mexicano ha dado a través de su legislación nacional al desarrollo y evolución de la normatividad internacional en materia de bioseguridad y organismos genéticamente modificados. El punto de referencia internacional lo constituyen los tres instrumentos jurídicos más significativos que al respecto se hayan discutido y adoptado en diversos foros ambientales: el programa o Agenda 21, el Convenio sobre la Diversidad Biológica, y el protocolo de Cartagena. Por tal motivo, este trabajo pretende describir y establecer parámetros informativos y explicativos del estado actual que guarda la legislación mexicana (disposiciones jurídicas de mayor relevancia de los sectores ambiental, agropecuario y salud) con diversos aspectos de la seguridad de la biotecnología. 
Esta obra forma parte del acervo de la Biblioteca Jurídica Virtual del Instituto de Investigaciones Jurídicas de la UNAM

\section{ANTES Y DURANTE RÍO DE JANEIRO}

Hacer biotecnología no es algo nuevo para los seres humanos. Tal actividad se realizaba desde tiempos prehistóricos a través de la selección de plantas y animales y del uso de técnicas ancestrales (manipulación de organismos o microorganismos) para la producción de ciertos productos como el pan, el vino, el queso o la cerveza. ${ }^{3} \mathrm{El}$ avance científico en el uso renovado de procesos, técnicas y métodos de esta actividad, ha derivado en distinguir la biotecnología tradicional o convencional practicada hace cientos de años de una biotecnología moderna de hace sólo unas dos o tres décadas. Así, la biotecnología moderna se refiere primordialmente a aquéllas técnicas o procesos no convencionales capaces de modificar el patrimonio genético de un organismo vivo, esto es, transferencia de genes de un organismo a otro (incluso de diferente especie), fusión de células que superen barreras naturales de reproducción o recombinación, etcétera. A los organismos que resultan de la aplicación de estas técnicas o procesos se les conoce con la expresión moderna de organismos genéticamente modificados (OGMs). ${ }^{4}$

La manipulación genética a través de estas innovadoras técnicas, puso en relieve dos aspectos de interés fundamental para la comunidad internacional desde que inició su utilización. Primero, que la biotecnología moderna conoce de procesos específicos con aplicaciones en diversos sectores y para fines distintos, como lo son, por ejemplo, para la agricultura, la acuacultura, el tratamiento de aguas residuales, los productos farmacéuticos e industriales, la conservación y producción de alimentos, la llamada biorremediación, e incluso la creación de fuentes alternativas

3 Pérez Salom, José Roberto, Recursos genéticos, biotecnología y derecho internacional, Navarra, Aranzadi, 2002, p. 41, y Villalobos, V. M., "Transgénicos: la ciencia superó a la ficción”, Desarrollo Sustentable, México, año 1, vol. 1, núm. 5, 1999, p. 10.

4 A lo largo de este trabajo se usarán de manera indistinta las expresiones organismos genéticamente modificados (OGMs) y organismos vivos modificados (OVMs), en virtud de que el propio protocolo de Cartagena equipara el significado de ambos términos al establecer en su artículo 3o., inciso g, que por organismo vivo modificado se entiende "cualquier organismo vivo que posea una combinación nueva de material genético que se haya obtenido mediante la aplicación de la biotecnología moderna”. En estricto sentido, sin embargo, el significado del término organismo vivo modificado es más amplio y abarca tanto a un organismo resultante de la biotecnología tradicional como a un organismo resultante de la biotecnología moderna. Véase, por ejemplo, Ascencio, Alfonso, "The Transbounday Movement of Living Modified Organisms: Issues Relating to Liability and Compensation", Reciel, Oxford, núm. 3, vol. 6, 1997, p. 293. 
Esta obra forma parte del acervo de la Biblioteca Jurídica Virtual del Instituto de Investigaciones Jurídicas de la UNAM

de energía. ${ }^{5}$ Segundo, que así como el uso de la biotecnología moderna - principalmente a través de la ingeniería genética- produce ciertos beneficios sociales (medicinas), ambientales (diversidad biológica), agrícolas (alimentación) o económicos (ganancias considerables), a la vez puede crear riesgos a la salud humana y producir efectos adversos a la diversidad biológica o al ambiente en general. ${ }^{6}$ Estos dos aspectos derivaron en una creciente preocupación pública de la comunidad internacional por discutir y reconocer la necesidad de desarrollar y utilizar medidas de seguridad adecuadas de las biotecnologías para el ambiente y la salud humana: ${ }^{7}$ de aquí el uso común que empezó a hacerse del término bioseguridad. ${ }^{8}$

Ya desde 1987 la Comisión Mundial sobre el Medio Ambiente y el Desarrollo $^{9}$ había hecho público un informe en el que se reconocían las implicaciones (positivas y negativas) que la biotecnología podría acarrear a la diversidad genética, la salud humana y al medio ambiente. ${ }^{10}$ Este documento — también conocido como Informe Brundtland- ${ }^{11} \mathrm{se}$

5 Ascencio, Alfonso, op. cit., nota anterior, y Mannion, Antoinette M., "Biotechnology and Genetic Engineering: New Environmental Issues", en Mannion, Antoinette M., y Bowlby, Sophia R. (comps.), Environmental Issues in the 1990s, Chichester, Wiley, 1992 , pp. 147 y 148.

6 Paoletti, Maurizio, G. y Pimentel, David, "Genetic Engineering and Agricultural: Limits and Options for Maintaining Biodiversity and Sustainability", en Nath, Bhaskar et al. (comps.), Sustainable Development, Bruselas, Vubpress, 1996, p. 235.

7 Así se reconoce en el preámbulo del Protocolo de Cartagena sobre Seguridad de la Biotecnología.

8 La expresión bioseguridad o seguridad de la biotecnología que aquí se utiliza corresponde en general a los diversos aspectos o medidas de seguridad, vinculados a la aplicación de las biotecnologías y la liberación de organismos genéticamente modificados con posibles efectos adversos al ambiente y la diversidad biológica y los riesgos para la salud humana.

9 La Comisión Mundial sobre el Medio Ambiente y el Desarrollo se crea como un organismo internacional independiente a partir de un llamado urgente que hace la Asamblea General de las Naciones Unidas en 1983 con el objeto de revisar, como su nombre lo indica, diversos aspectos sobre ambiente y desarrollo y sus interrelaciones. La comisión fue presidida por la primer ministro noruega Gro Harlem Brundtland y tuvo su primera reunión en ese mismo año. Cinco años después, en 1987, la comisión prepara y hace público un informe al que le denominan Nuestro Futuro Común.

10 World Commission on Environment and Development, Our Common Future, Oxford, Oxford University Press, 1987, pp. 217-219.

11 Se conoce así popularmente por el apellido de quien encabezara la propia comisión mundial. 
Esta obra forma parte del acervo de la Biblioteca Jurídica Virtual del Instituto de Investigaciones Jurídicas de la UNAM

convirtió en un antecedente fundamental para que la Asamblea General de las Naciones Unidas convocara en 1989 a una conferencia sobre medio ambiente y desarrollo. Como resultado de esta convocatoria, se llevó a cabo la Conferencia de las Naciones Unidas sobre el Medio Ambiente y el Desarrollo — celebrada en Río de Janeiro, Brasil, en junio de 1992 - que habría de constituirse en el punto de partida de la regulación internacional (y no sólo regional) de la seguridad de la biotecnología desde un enfoque global. Precisamente, uno de los grandes méritos de esta conferencia fue el haber logrado vincular diversos aspectos derivados de la bioseguridad a cuestiones ambientales relacionadas directamente con la conservación y utilización sustentable de la diversidad biológica en un contexto más amplio y específico que en reglamentaciones anteriores que se dieron dentro y fuera de la Organización de las Naciones Unidas. Y es que antes de esta conferencia, las primeras normas de carácter internacional fueron en mucho el reflejo de la propia variedad de sectores en los que se podía aplicar la entonces incipiente biotecnología moderna. En efecto, al referirse a las primeras iniciativas de regulación en la materia, el profesor José Roberto Pérez Salom de la Universidad de Valencia, afirma que debido a que fueron diversas las organizaciones internacionales que adoptaron disposiciones sobre la bioseguridad, es que se explica "el carácter fundamentalmente fragmentario e incompleto de la regulación internacional... ya que cada organización ha tratado de reglamentar los aspectos de la bioseguridad directamente relacionados con sus propios fines y ámbitos de acción". ${ }^{12}$

Así, durante los años previos a la celebración de la llamada "cumbre de la Tierra" en Río de Janeiro, se emitieron instrumentos internacionales que abordaron de manera directa (pero inconclusa) e indirecta diversas cuestiones relacionadas con la seguridad de la biotecnología: desde regulaciones y estándares en materia alimenticia, hasta disposiciones relativas al transporte de sustancias infecciosas o peligrosas para los animales, el ambiente y los seres humanos. ${ }^{13} \mathrm{La}$ excepción a lo anterior fueron los trabajos y reglamentaciones realizados por la Comunidad Europea, la que a través de su comisión estableció desde 1986 y de manera más extensa y pormenorizada, un marco comunitario - comúnmente referen-

12 Pérez Salom, José Roberto, op. cit., nota 3, p. 288.

13 Algunos ejemplos sobre reglamentaciones internacionales anteriores a la conferencia de Río pueden ser consultados en ibidem, pp. 288 y ss. 
Esta obra forma parte del acervo de la Biblioteca Jurídica Virtual del Instituto de Investigaciones Jurídicas de la UNAM

ciado como COM[86]573 - para la regulación de los organismos genéticamente modificados. Dos años después, la propia comisión presentó una propuesta de directivas de implementación del marco comunitario, y para 1990, la Comunidad Europea había ya adoptado dos directivas relacionadas con la utilización confinada y la liberación intencional de OGMs para proteger la salud humana y el medio ambiente: las directivas 90/219/CE y la 90/220/CE respectivamente, ambas del 23 de abril de $1990 .{ }^{14}$

Con motivo de la realización de la conferencia de Río, surgieron dos documentos de derecho internacional ambiental fundamentales para la regulación de la bioseguridad y los OGMs. Primero, la Agenda 21, instrumento no vinculante (soft law) que se erige como el programa o plan de acción de implementación del desarrollo sustentable rumbo al siglo XXI. Este instrumento, de lege ferenda, dedica el capítulo 16 a lo que el propio documento denomina como gestión ecológicamente racional de la biotecnología. En este segmento se establecen diversas áreas de programas que buscan reafirmar los principios internacionalmente acordados que se aplicarán para asegurar dicha gestión. Estas áreas se enfocan al aumento de la disponibilidad de alimentos, piensos y materias primas renovables, mejoramiento de la salud humana, aumento de la protección del medio ambiente, aumento de la seguridad y establecimiento de mecanismos internacionales de cooperación que faciliten el desarrollo y la aplicación ecológicamente racional de la biotecnología. Los objetivos específicos que destacan en estas áreas incluyen el de velar por la seguridad en el desarrollo, aplicación, intercambio y transferencia de biotecnologías relativas al ambiente y la salud a través de un acuerdo internacional sobre los principios de aplicación en materia de evaluación y gestión de los riesgos, así como el de prevenir, detener e invertir la degradación ambiental mediante la utilización adecuada de la biotecnología. ${ }^{15}$ La Agenda 21, documento que en su versión original consta de más de 900 páginas, sugiere a los gobiernos el uso sustentable en las aplicaciones de la

14 Grossman, M. R. y Endres, A. B., "Regulation of Genetically Modified Organisms in the European Union", American Behavioral Scientist, Estados Unidos de América, vol. 44, núm. 3, noviembre de 2000, pp. 392-393.

15 La información que aquí se presenta, puede ser consultada con más detalle en Organización de las Naciones Unidas (ONU), “16. Gestión Ecológicamente Racional de la Biotecnología", Programa 21, capítulo 16, División de Desarrollo Sostenible, 24 de marzo de 2003, http://www.un.org/esa/sustdev/documents/agenda21/spanish/agenda21spchapter16.htm. 
Esta obra forma parte del acervo de la Biblioteca Jurídica Virtual del Instituto de Investigaciones Jurídicas de la UNAM

biotecnología y reconoce la importancia de la cooperación internacional entre los estados industrializados, ricos en conocimiento tecnológico, y los países subdesarrollados, ricos en recursos biológicos pero carentes de recursos económicos y tecnología. ${ }^{16}$

El énfasis que hace la Agenda 21 en el reconocimiento sobre la cooperación internacional entre países ricos y pobres, está vinculado al hecho de que ya desde inicios de la década de los noventa en el siglo pasado era evidente que el uso de las innovaciones biotecnológicas generaba grandes beneficios económicos a unos cuantos. En efecto, dadas las condiciones desiguales de desarrollo de los países, la utilización avanzada de la biotecnología otorgaba (y de hecho sigue otorgando) jugosas ganancias sólo a quienes la conocían e implementaban. Por lo que la continua expansión de productos derivados de la ingeniería genética a gran escala (monopolizados a través de un incipiente pero creciente sistema de patentes), pronto despertó la suspicacia y desconfianza de los pueblos y países más pobres y en vías de desarrollo, respecto a los intereses de los países más desarrollados, los de sus investigadores y empresas, y por supuesto los de las grandes empresas trasnacionales. ${ }^{17}$ Bastan algunos ejemplos con datos recientes para ilustrar lo anterior. Actualmente, el llamado Grupo de los Siete (G-7) mantiene un monopolio de la industria agroalimentaria al contar con 416 de las 500 compañías más grandes en el sector: 197 son estadounidenses, 88 japonesas, 37 francesas, 35 inglesas, 35 alemanas, 16 canadienses y 8 italianas. En términos económicos, la cifra de ventas anuales en el sector alimenticio es superior a los 154000 millones de dólares para sólo cinco empresas trasnacionales entre las que se encuentran Nestlé y Unilever. Mientras que las estadounidenses Archer Daniels, Midland Farmland Industries y Tyson Foods junto con la italiana Edison representan 56705 millones de dólares, la popular McDonald's, la Compass Group y Sodexho Alliance suman 38000 millones de dólares adicionales. ${ }^{18}$ Esta

16 Hens, Luc, “The Rio Conference and Thereafter", en Nath, Bhaskar et al. (comps.), op. cit., nota 6, pp. 91-94, y Keating, Michael, Agenda for Change, Ginebra, Centre for Our Common Future, 1993, p. 28.

17 Martínez Alier, Joan y Roca Jusmet, Jordi, Economía ecológica y política ambiental, México, Programa de las Naciones Unidas para el Medio Ambiente-Fondo de Cultura Económica, 2000, pp. 466-470.

18 Alponte, Juan María, Alimentación mundial y desigualdad productiva. Nuevos conceptos de salud en el mundo. Transformación de la producción de alimentos. Revolución 
Esta obra forma parte del acervo de la Biblioteca Jurídica Virtual del Instituto de Investigaciones Jurídicas de la UNAM

cruda realidad corrobora lo que en su momento trató de advertir y reconocer la Agenda 21.

El segundo documento de importancia lo constituye el Convenio sobre la Diversidad Biológica (CDB), ${ }^{19}$ instrumento vinculante (hard law) que reconoce en su preámbulo - entre otras cosas - la importancia que tiene para las partes contratantes la conservación de la diversidad biológica y la utilización sustentable de sus componentes. Este instrumento, de lege lata, señala en su artículo 8o., apartado g, un principio básico de la regulación sobre la bioseguridad y los OGMs al establecer la obligación para cada parte contratante en la medida de lo posible y según proceda de:

... regular, administrar o controlar los riesgos derivados de la utilización y la liberación de organismos vivos modificados como resultado de la biotecnología que es probable tengan repercusiones ambientales adversas que puedan afectar a la conservación y a la utilización sostenible de la diversidad biológica, teniendo también en cuenta los riesgos para la salud humana.

Los alcances e implicaciones de este artículo y su inciso son de gran trascendencia para el derecho interno de las naciones. En efecto, lo que está detrás de esta disposición jurídica es la obligación que tiene cada parte contratante para llevar a cabo medidas legislativas y reglamentarias o administrativas por los riesgos que se deriven de la utilización y liberación de los OGMs. En estricto sentido, cada parte contratante decidirá si existe o no la probabilidad de que se dieran "repercusiones ambientales adversas" por el uso y liberación de los OGMs que a su vez pudieran afectar la diversidad biológica o la salud humana.

Lo criticable del artículo 8o. es que incluye una frase en su encabezado (tal y como sucede con otros artículos a lo largo del convenio) demasiado flexible - i. e. en la medida de lo posible y según proceda- que hace exageradamente difuso el debido cumplimiento de las obligaciones de las

de los transgénicos, México, séptima conferencia del profesor Juan María Alponte, Secretaría de Medio Ambiente y Recursos Naturales, agosto de 2003.

19 El texto completo e íntegro (copia fiel y completa en español) del Convenio sobre la Diversidad Biológica adoptado en Río de Janeiro, Brasil en junio de 1992, puede consultarse en el Diario Oficial de la Federación del 7 de mayo de 1993 (día, mes y año en el que fue publicado). El convenio entró en vigor internacionalmente el 29 de diciembre de 1993 una vez transcurridos noventa días después de la fecha en que se depositó el trigésimo instrumento de ratificación, aceptación, aprobación o adhesión. 
Esta obra forma parte del acervo de la Biblioteca Jurídica Virtual del Instituto de Investigaciones Jurídicas de la UNAM

partes. ${ }^{20}$ Esta expresión supone la relativización de sus obligaciones en el sentido de que cada parte cumplirá con ella según sus capacidades financieras, técnicas o humanas (i. e. en la medida de lo posible) y según la estrategia o política ambiental que desplieguen (i.e. según proceda). ${ }^{21}$

Ciertamente, existen otras disposiciones jurídicas importantes en el convenio que deben mencionarse. Por ejemplo, se encuentra regulada la obligación de los Estados de adoptar medidas legislativas, administrativas o de política para asegurar la participación en actividades de investigación sobre biotecnología (artículo 19, párrafo 1). O bien, la obligación de cada parte contratante de proporcionar directamente a la otra toda la información disponible sobre el organismo genéticamente modificado (reglamentaciones de uso y seguridad requeridas así como posibles efectos adversos) que será introducido a ésta última (artículo 19, párrafo 4). Sin duda, la disposición que sobresale es la consagrada en el párrafo 3 del mismo artículo 19 en el sentido de que establece la obligación para los Estados de estudiar la necesidad y modalidades de un protocolo sobre bioseguridad atendiendo a tres aspectos fundamentales:

1) Las actividades de regulación lo serán en la esfera de la transferencia, manipulación y utilización de organismos vivos modificados (OVMs) resultado de la biotecnología.

2) Los OVMs que se comprendan serán aquéllos que puedan tener efectos adversos para la conservación y la utilización sostenible de la diversidad biológica.

3) Deberá incluirse el consentimiento fundamentado previo.

Esta última disposición hizo del CDB un instrumento internacional de obvia referencia en materia de bioseguridad y liberación de OGMs, al dejar la puerta abierta para que los Estados analizaran a futuro la posibilidad de una reglamentación adicional y vinculante. Como puede suponerse, el CDB fue más allá que la Agenda 21 ya que mientras ésta exhortaría a los gobiernos a considerar la necesidad de emitir documen-

20 Birnie, Patricia W. y Boyle, Alan E., op. cit., nota 2, p. 572, y Munson, Abby, "The United Nations Convention on Biological Diversity", en Grubb, Michael et al., The Earth Summit Agreements: a Guide and Assessment, Londres, The Royal Institute of International Affairs-Earthscan, 1993, p. 83.

21 Pérez Salom, José Roberto, op. cit., nota 3, p. 300. 
Esta obra forma parte del acervo de la Biblioteca Jurídica Virtual del Instituto de Investigaciones Jurídicas de la UNAM

tos de derecho suave como lineamientos o directrices, aquélla establecería el mandato de considerar la necesidad y posibles modalidades de un instrumento de derecho duro. ${ }^{22}$

\section{DE RÍO DE JANEIRO A CARTAGENA DE INDIAS Y KUALA LUMPUR}

Las discusiones de un posible protocolo sobre bioseguridad basado en el mandato del artículo 19, párrafo 3, del CDB se iniciaron con la primera reunión de la Conferencia de las Partes (Cop) celebrada en 1994 en Nassau, Bahamas. A partir de esta fecha, suceden una serie de decisiones en diversas reuniones de la Cop que concluyeron con la adopción del Protocolo de Cartagena sobre Seguridad de la Biotecnología ${ }^{23}$ en Montreal, Canadá, el 29 de enero de 2000. Durante este periodo destacan las decisiones siguientes: ${ }^{24}$

- Decisión I/9 (adoptada en la primera reunión de la Cop en Nassau, Bahamas, del 28 de noviembre al 9 de diciembre de 1994) en la que se crea un grupo especial de expertos para examinar la necesidad y modalidades de un protocolo.

- Decisión II/5 (adoptada en la segunda reunión de la Cop en Yakarta, Indonesia, en noviembre de 1995) en la que se determina la elaboración de un protocolo sobre bioseguridad, pero restringido a dos aspectos: primero, sólo lo relativo a movimientos transfronterizos de OVMs, y segundo, que éstos serán sólo los resultantes de la biotecnología moderna. Se crea asimismo un grupo de trabajo ad hoc de composición abierta para la elaboración del protocolo que de-

22 Munson, Abby, op. cit., nota 20, p. 80.

23 De la misma manera, el texto completo e íntegro (copia fiel y completa en español) del Protocolo de Cartagena sobre Seguridad de la Biotecnología del Convenio sobre la Diversidad Biológica, adoptado en Montreal, Canadá el 29 de enero de 2000, puede consultarse en el Diario Oficial de la Federación del 28 de octubre de 2003. El protocolo entró en vigor internacionalmente el 11 de septiembre de 2003 una vez transcurridos noventa días después de la fecha en que se depositó el quincuagésimo instrumento de ratificación, aceptación, aprobación o adhesión.

24 La información que aquí se presenta puede ser consultada con más detalle en el sitio de Internet de la Secretaría del Convenio sobre la Diversidad Biológica utilizando las ligas correspondientes: http://www.biodiv.org/biosafety/default.aspx. 
Esta obra forma parte del acervo de la Biblioteca Jurídica Virtual del Instituto de Investigaciones Jurídicas de la UNAM

berá tomar en cuenta el enfoque precautorio (principio 15) de la declaración de Río.

- Decisión III/20 (adoptada en la tercera reunión de la Cop en Buenos Aires, Argentina, en noviembre de 1996) en la que se abordan diversos temas relacionados con la seguridad de la biotecnología y en particular se acogen las Directrices Técnicas Internacionales del Programa de las Naciones Unidas para el Medio Ambiente (PNUMA) sobre la seguridad de la biotecnología ${ }^{25}$ aprobadas en la Consulta Mundial de Expertos celebrada en El Cairo, Egipto, del 11 al 14 de diciembre de 1995.

- Decisión IV/3 (adoptada en la cuarta reunión de la Cop en Bratislava, Slovakia en mayo de 1998) en la que se establece que la última reunión del grupo de trabajo ad hoc de composición abierta y en particular una reunión extraordinaria se llevarán a cabo en 1999. El programa de esta reunión extraordinaria incluirá todos los aspectos relativos a la aprobación del protocolo sobre seguridad de la biotecnología.

- Decisión EM-I/1 (adoptada en la reunión extraordinaria en Cartagena de Indias, Colombia, en febrero de 1999) en la que la Cop decide suspender su reunión extraordinaria por no haber concluido con los trabajos en el tiempo establecido debido a la falta de consenso entre los Estados participantes, se convoca a retomar esta reunión lo antes posible.

- Decisión EM-I/3 (adoptada en la continuación de la reunión extraordinaria en Montreal, Canadá, en enero de 2000) por la que después del intento fallido en Cartagena, adopta el Protocolo de Cartagena

25 Ya desde la Decisión II/5, la Conferencia de las Partes reconocía la importancia que tendrían las directrices técnicas del PNUMA para contribuir a la elaboración y aplicación de un protocolo sobre seguridad de la biotecnología una vez que éstas estuvieran concluidas. En esa ocasión, la conferencia hizo notar que las directrices podrían tomarse como un mecanismo provisional durante la elaboración del protocolo y complementarlo una vez finalizado a efecto de facilitar el desarrollo de la capacidad nacional en materia de evaluación y gestión de riesgos, establecer sistemas adecuados de información, así como desarrollar recursos humanos especializados en biotecnología. Aunque no son un instrumento vinculante, estas directrices han sido consideradas como una de las iniciativas más importantes en bioseguridad, por lo menos hasta antes que entrara en vigor el protocolo de Cartagena. Pérez Salom, José Roberto, op. cit., nota 3, p. 293. 
Esta obra forma parte del acervo de la Biblioteca Jurídica Virtual del Instituto de Investigaciones Jurídicas de la UNAM

sobre Seguridad de la Biotecnología del Convenio sobre la Diversidad Biológica.

En la Decisión EM-I/3, la Conferencia de las Partes creó un comité intergubernamental ad hoc de composición abierta para llevar a cabo los preparativos de la primera reunión de las partes al protocolo. En ese mismo año, pero en mayo, la quinta reunión de la Cop adoptó la Decisión V/1 en Nairobi, Kenia, en la que se establece el plan de trabajo de dicho comité intergubernamental. El comité se reunió en tres ocasiones antes de la entrada en vigor internacional del protocolo: Montpellier, Francia (diciembre de 2000); Nairobi, Kenia (octubre de 2001), y La Haya, Países Bajos (abril de 2002). Días antes a esta última reunión, la COP-VI celebrada del 7 al 19 de abril de 2000 en los Países Bajos, decidió respaldar en su Decisión VI/1 la tercera reunión del comité intergubernamental estableciendo que de entrar en vigencia el protocolo en el lapso de un año a partir de la fecha de celebración de la COP-VI, convocaría a una reunión extraordinaria; de no entrar en vigor en este periodo, entonces se harían los arreglos necesarios para celebrar la primera reunión de las partes al protocolo - conocida como COP-MOP 1- conjuntamente con la celebración de la séptima reunión de la Cop. ${ }^{26}$

Finalmente, el 13 de junio de 2003, la República de Paláu (en asociación libre con Estados Unidos de América), ${ }^{27}$ deposita el quincuagésimo instrumento de ratificación lo que permite al protocolo de Cartagena entrar en vigor al nonagésimo día contado a partir de la fecha de dicho depósito, según lo establecido en el párrafo 1 del artículo 37 del mismo protocolo. Días antes de que diera inicio a principios de octubre de 2003 el Segundo Encuentro Internacional de Derecho Ambiental celebrado en

26 La información que aquí se presenta puede ser consultada con más detalle en la dirección electrónica de la Secretaría del Convenio sobre la Diversidad Biológica, http:// www.biodiv.org/biosafety/background.asp\#.

27 Palau, país formado por varios grupos de islas situadas en el Pacífico nor-occidental, cerca de las Islas Filipinas, se convirtió en 1994 en el miembro número 185 de las Naciones Unidas. Desde 1982, entró a formar parte del Convenio de Libre Asociación con Estados Unidos; sin embargo, no fue sino hasta 1993 que sus votantes aprobaron dicho convenio lo que le valió una ayuda de 500 millones de dólares americanos durante 15 años a cambio de que Estados Unidos tuviera derecho a conservar en ese territorio sus bases militares. Cheers, Gordon (ed.), Geographica. El gran atlas mundial ilustrado, trad. de Gemma Deza Guil, Vicky Santolaría Malo, Cruz Rodríguez Juiz y Rita da Costa García, Colonia, Könemann, 2000, pp. 117 y 118. 
Esta obra forma parte del acervo de la Biblioteca Jurídica Virtual del Instituto de Investigaciones Jurídicas de la UNAM

la Ciudad de México, el Protocolo de Cartagena sobre Seguridad de la Biotecnología del Convenio sobre la Diversidad Biológica había entrado en vigor internacionalmente el 11 de septiembre.

Como era de esperarse, el protocolo ha estado sujeto (incluso antes de que entrara en vigor internacionalmente) a una serie de comentarios y análisis favorables y alentadores. Lógico es suponer que, por ejemplo, la Secretaría del Convenio sobre la Diversidad Biológica hiciera mención de las bondades del protocolo al ser éste:

... un importante paso decisivo al proporcionar un marco normativo internacional para reconciliar las necesidades respectivas de protección del comercio y del medio ambiente en una industria mundial en rápido crecimiento, la industria de la biotecnología. El Protocolo ha creado así un entorno habilitante para la aplicación de la biotecnología en una forma que sea favorable para el medio ambiente, haciendo posible que se obtengan los máximos beneficios del vasto potencial latente en la biotecnología y que se reduzcan a la vez a un mínimo los riesgos para el medio ambiente y para la salud humana. ${ }^{28}$

El propio secretario general de la Organización de las Naciones Unidas Kofi Annan, comentó el 10 de septiembre de 2003 que la inminente entrada en vigor del protocolo sería un acontecimiento decisivo para el desarrollo sustentable y un hito en los esfuerzos globales para reconciliar la conservación del ambiente con el desarrollo. La vigencia del protocolo habría de ser, según el secretario general, un paso en la dirección correcta. ${ }^{29}$

Sin embargo, también han surgido comentarios desfavorables y análisis que advierten sobre los posibles conflictos que habrán de suscitarse con otras disposiciones internacionales ya existentes por la aplicación del protocolo; conflictos que por cierto habían sido detectados en las negociaciones previas a la adopción de dicho instrumento. Un ejemplo clásico sobre esto es el conflicto de implementación del régimen jurídico establecido por el protocolo vis-à-vis los mandatos emanados de la Organización Mundial del Comercio (OMC) en materia de importación

28 Secretaría del Convenio sobre la Diversidad Biológica, op. cit., nota 24, p. 1.

29 Mensaje obtenido de: M2 Presswire, UN: Entry into Force of Cartagena Protocol on Biosafety "Landmark for Sustainable Development", Says Secretary-General, versión electrónica, 10 de septiembre de 2003, p. 1, proquest database, consultado en febrero de 2004 . 
Esta obra forma parte del acervo de la Biblioteca Jurídica Virtual del Instituto de Investigaciones Jurídicas de la UNAM

de productos. Lo anterior, en el sentido de que a la luz del protocolo, la parte contratante a través del acuerdo fundamentado previo podrá decidir si permite o no, y bajo qué condiciones, la importación de un OVM aun cuando no se tenga certidumbre científica sobre los efectos adversos que dicho OVM pudiera tener para la conservación y la utilización sostentible de la diversidad biológica, así como los riesgos para la salud humana. Contrario sensu bajo la óptica del régimen comercial, dichas prohibiciones en principio deberán estar fundamentadas científicamente. De aquí que el punto de conflicto sobre la aplicación de un régimen u otro sea el de decidir si la prohibición a la importación de un OGM deberá o no estar basado en evidencia científica. ${ }^{30}$

En este conflicto ambiente-comercio, desde la perspectiva ambiental y porque así lo establece expresamente el propio protocolo en su preámbulo y artículo 1o., es contundente la obligación para las partes contratantes de invocar el enfoque precautorio que figura en el principio $15 \mathrm{de}$ la Declaración de Río sobre el Medio Ambiente y el Desarrollo que al efecto señala:

Con el fin de proteger el medio ambiente, los Estados deberán aplicar ampliamente el criterio de precaución conforme a sus capacidades. Cuando haya peligro de daño grave e irreversible, la falta de certeza científica absoluta no deberá utilizarse como razón para postergar la adopción de medidas eficaces en función de los costos para impedir la degradación del medio ambiente. $^{31}$

30 Para conocer más al detalle el conflicto ambiente-comercio, así como otros conflictos emergentes, se recomienda acudir a las secciones III y IV relativas a The Cartagena Protocol on Biosafety y Biosafety versus Biodiversity respectivamente, en Adler, J. H., "The Cartagena Protocol and Biological Diversity: Biosafe or Biosorry?", Georgetown International Environmental Law Review, versión electrónica, Washington D.C., vol. 12, núm. 3, primavera de 2000, proquest database, consultado en febrero de 2004; Birnie, Patricia W. y Boyle, Alan E., op. cit. nota 2, pp. 580 y 581 y su capítulo 14, así como a la sección I relativa a Key provisions and potential sources of tension between the regimes, en Safrin, S., "Treaties in Collision? The Biosafety Protocol and the World Trade Organisation Agreements", The American Journal of International Law, versión electrónica, Washington D.C., vol. 96, núm. 3, julio de 2002, proquest database, consultado en febrero de 2004.

31 El contenido de la Declaración de Río sobre el Medio Ambiente y el Desarrollo de 1992 puede obtenerse acudiendo a la dirección electrónica del Programa de las Naciones Unidas para el Medio Ambiente, http://www.rolac.unep.mx/docamb/esp/dr1992.htm. 
Esta obra forma parte del acervo de la Biblioteca Jurídica Virtual del Instituto de Investigaciones Jurídicas de la UNAM

Aunque es evidente la necesidad de respetar el enfoque de precaución derivado de normatividad de lege lata (protocolo de Cartagena) apoyado en un instrumento de lege ferenda (declaración de Río), para los fieles y devotos correligionarios del libre comercio la observancia de dicho enfoque precautorio en el ejemplo anterior representa la inaceptable construcción de barreras no arancelarias en aras de proteger la salud humana y el ambiente. Independientemente de la postura que se quiera apoyar, lo cierto es que el protocolo se adoptó bajo las presiones de los principales Estados importadores y exportadores de productos (semillas) modificados genéticamente (i.e. el llamado Grupo de Miami integrado por Estados Unidos, Canadá, Argentina, Uruguay, Chile y Australia). La ambigüedad en la redacción de disposiciones relacionadas con este asunto en particular trajo como consecuencia "la indeterminación sobre la prevalencia o no de los convenios internacionales de comercio sobre el Protocolo" para su aplicación y en caso de litigio. ${ }^{32}$ Se lee en el antepenúltimo y penúltimo párrafos del preámbulo que las partes contratantes reconocen que "los acuerdos relativos al comercio y al medio ambiente deben apoyarse mutuamente con miras a lograr el desarrollo sostenible" y destacan que dicho protocolo "no podrá interpretarse en el sentido de que modifica los derechos y las obligaciones de una parte con arreglo a otros acuerdos internacionales ya en vigor". Concluye el último párrafo del preámbulo diciendo que las partes están en el entendido de que dichos párrafos "no tienen por objeto subordinar [el protocolo]... a otros acuerdos internacionales". Por lo que no es difícil imaginar lo complicado que ha sido para las partes contratantes del protocolo que a su vez son miembros de la $\mathrm{OMC}$, crear leyes nacionales que aborden y busquen encontrar respuestas a esta problemática al interior de sus sistemas jurídicos.

Con todo, y no obstante lo restringido de sus objetivos, ${ }^{33}$ el protocolo de Cartagena contiene muchas disposiciones jurídicas que dan cabida a ciertas preocupaciones alrededor de los diversos aspectos de la bioseguridad y los organismos genéticamente modificados en el marco de la conservación

32 Pérez Salom, José Roberto, op. cit., nota 3, p. 316.

33 Hay que tomar en cuenta que el objeto del protocolo incluye en su artículo 1o., sólo las actividades de transferencia, manipulación y utilización de OGMs vinculadas a movimientos transfronterizos y resultado de la biotecnología moderna cuando puedan tener efectos adversos para la conservación y utilización de la diversidad biológica o presentar riesgos para la salud humana. Las demás restricciones de aplicación material del protocolo se encuentran en los artículos 5o. y 6 o. 
Esta obra forma parte del acervo de la Biblioteca Jurídica Virtual del Instituto de Investigaciones Jurídicas de la UNAM

y utilización sostenible de la diversidad biológica. Dichas disposiciones, cuya exégesis merece un estudio aparte, incluyen temas como el enfoque de precaución, la aplicación de la biotecnología moderna, las actividades que se regulan (i.e. transferencia, manipulación y utilización relacionados con movimientos transfronterizos), el procedimiento del consentimiento o acuerdo fundamentado previo (i. e. notificación del exportador, acuse de recibo de la notificación del importador, adopción de decisiones y sus respectivas revisiones y modificaciones, exenciones de OGMs al acuerdo, etcétera), etiquetado, autoridades nacionales competentes y centros focales nacionales, intercambio de información, evaluación y gestión del riesgo, información confidencial, responsabilidad y compensación, mecanismo y recursos financieros, entre otros.

Es en la última semana de febrero de 2004 - del 23 al 27-que se lleva a cabo en Kuala Lumpur, Malasia, la primera reunión de las partes al protocolo de Cartagena COP-MOP 1, sólo algunos días después de haberse celebrado en ese mismo lugar y mes (del 9 al 20) la séptima Cop al Convenio sobre la Diversidad Biológica. En esta primera reunión de las partes al protocolo habrían de analizarse temas como el intercambio de información (incluyendo el Biosafety Clearing-House), lo relativo a responsabilidad y compensación y el programa de trabajo de la COP-MOP para las siguientes reuniones, entre otros más. ${ }^{34}$

Se llegó a esta primera reunión con casi 90 instrumentos de ratificación depositados (al 13 de febrero sumaban 87), con el avance de pocos pero loables esfuerzos de cuerpos legislativos a nivel nacional (en América Latina destacan: la Ley de Bioseguridad conocida como Ley núm 8.974 de Brasil de 1995, el Decreto Supremo 24,676 que aprueba un reglamento de bioseguridad en Bolivia de 1997, la Ley de Biodiversidad de Costa Rica de 1998, el Decreto-Ley No. 190 sobre Seguridad Biológica de Cuba de 1999, la Ley No. 27104 o Ley de Prevención de Riesgos derivados del Uso de la Biotecnología de Perú de 1999, y bajo la nueva República Bolivariana la Ley de Diversidad Biológica de Venezuela de 2000), ${ }^{35}$ y con la adopción a nivel regional de la Directiva 2001/18/CE

34 Los resultados de esta reunión podrán ser consultados (cuando estén disponibles) en la página web del Secretariado del Convenio sobre la Diversidad Biológica: http:// www.biodiv.org/.

35 Para mayor detalle, véase Programa de las Naciones Unidas para el Medio Ambiente, op. cit., nota 1. 
Esta obra forma parte del acervo de la Biblioteca Jurídica Virtual del Instituto de Investigaciones Jurídicas de la UNAM

del Parlamento Europeo y del Consejo que entró en vigor en octubre de 2003, entre muchos otros instrumentos más. Lamentablemente, México acudió a esta primera reunión con un derecho interno conformado sólo por párrafos aislados y dispersos en sus leyes, algunas disposiciones normativas de jerarquía menor a éstas y sin contenido ambiental (como la NOM-056-FITO-1995), y varios anteproyectos de iniciativa de ley sobre la materia debidamente "guardados" y "olvidados" por el Congreso de la Unión de este país.

\section{EL CASO MEXICANO: DISPERSIÓN Y PARSIMONIA REGULADORA}

En la evolución de la normatividad mexicana sobre bioseguridad y organismos genéticamente modificados, aún no se cuenta con un punto de referencia crucial que permita identificar un antes, un durante, o un después para efectos de análisis y estudio jurídico. Lo anterior puede explicarse de la siguiente manera. En los hechos, el avance de la reglamentación internacional con un enfoque más integral —particularmente a raíz de la adopción del protocolo de Cartagena - no ha tenido el eco suficiente para consolidar el nacimiento de una regulación amplia de la seguridad de la biotecnología y la liberación de los OGMs en México. Lo que existe en el país es un marco jurídico impreso en diferentes cuerpos legales cuyas disposiciones abordan respectivamente la biotecnología ambiental, la agrícola y la biotecnología de la salud de manera aislada y fragmentada. Por lo que puede afirmarse que en el desarrollo de su derecho interno, México ha experimentado en los últimos años algo semejante a lo ocurrido a nivel internacional antes de la conferencia de Río: una normatividad que ha sido el reflejo de la variedad de sectores en los que se puede aplicar la biotecnología. A esto hay que agregar la ausencia de medidas apropiadas para la aplicación e implementación de las pocas, pero existentes, normas jurídicas nacionales al respecto. Así, la falta de una ley integral que incluya en su conjunto a los diversos sectores (ambiente, agropecuario, salud) impide que se haga referencia a un momento "histórico" en la evolución de la regulación jurídica sobre los diversos aspectos de la bioseguridad y los OGMs en México.

Uno de los antecedentes más importantes en el proceso de regulación en México, lo constituye la creación hacia finales de la década de los ochenta del Comité Nacional de Bioseguridad Agrícola como órga- 
Esta obra forma parte del acervo de la Biblioteca Jurídica Virtual del Instituto de Investigaciones Jurídicas de la UNAM

no auxiliar de consulta de las autoridades fitosanitarias de la entonces Secretaría de Agricultura y Recursos Hidráulicos, ahora Secretaría de Agricultura, Ganadería, Desarrollo Rural, Pesca y Alimentación (Sagarpa). En el seno de este comité nacional se iniciaron las discusiones sobre los requisitos fitosanitarios para la movilización nacional, importación y establecimiento de pruebas de campo (con fines experimentales) de productos manipulados derivados de la ingeniería genética, y que concluyeron años más tarde — en 1996- con la emisión de uno de los textos normativos más importantes de regulación de los OGMs: la norma oficial mexicana NOM-056-FITO-1995. ${ }^{36}$ Por lo que no es sino hasta la primera mitad de la década de los noventa del pasado siglo, que se dieron los primeros pasos de regulación enfocados principalmente al sector agropecuario. Aunque actualmente el mayor número de disposiciones relacionadas a la biotecnología se encuentran dentro de éste último, los sectores salud y ambiente han incorporado algunas disposiciones al respecto. Las principales leyes que contienen preceptos relacionados con la seguridad de la biotecnología y los OGMs son las siguientes: ${ }^{37}$

- La Ley General de Salud (publicada en el Diario Oficial de la Federación el 7 de febrero de 1984) que tiene por objeto reglamentar "el derecho a la protección de la salud que tiene toda persona en los términos del artículo 4o. de la Constitución Política de los Estados Unidos Mexicanos" y establecer "las bases y modalidades para el acceso a los servicios de salud y... salubridad general" (artículo 1o.). Sus disposiciones contemplan la creación de un ente - Comisión de Bioseguridad - en las instituciones de salud para regular el uso de radiaciones ionizantes o de técnicas derivadas de la ingeniería genética (artículo 98). Aunado a lo anterior, la ley otorga a la Comisión Federal para la Protección contra Riesgos Sanitarios - órgano desconcentrado de la Secretaría de Salud (SS) - la facultad para proponer al titular de esta secretaría todo lo relativo a la instrumentación de los productos biotecnológicos (artículo 17 bis,

36 Lugo Rodríguez, José, "La biotecnología y la propiedad intelectual", Memorias del Primer Encuentro Internacional de Derecho Ambiental, México, Secretaría de Medio Ambiente y Recursos Naturales, Instituto Nacional de Ecología, 2003, p. 354.

37 Las leyes que aquí se mencionan fueron consultadas en la página electrónica del Instituto de Investigaciones Jurídicas de la UNAM con información vigente al 16 de febrero de 2004, http://www.juridicas.unam.mx/inst/. 
Esta obra forma parte del acervo de la Biblioteca Jurídica Virtual del Instituto de Investigaciones Jurídicas de la UNAM

fracción II), a los que define como "aquellos alimentos, ingredientes, aditivos, materias primas, insumos para la salud, plaguicidas, sustancias tóxicas o peligrosas, y sus desechos, en cuyo proceso intervengan organismos vivos o parte de ellos, modificados por técnica tradicional o ingeniería genética" (artículo 282 bis). Como podrá fácilmente advertirse, esta disposición va más allá de lo que el propio protocolo de Cartagena regula en materia de OGMs ya que éste abarca sólo aquéllos que se deriven de la biotecnología moderna. El texto de la ley incluye asimismo la obligación de notificar a la propia secretaría de estos productos o sus derivados destinados al uso o consumo humano (artículo 282 bis 1). Finalmente, se hace mención que las disposiciones y especificaciones relacionadas con el proceso, características y etiquetas de dichos productos se establecerán en normas oficiales mexicanas (artículo 282 bis 2). La aplicación de la ley y su interpretación para efectos administrativos corresponde a la SS.

- La Ley General del Equilibrio Ecológico y la Protección al Ambiente (publicada en el Diario Oficial de la Federación el 28 de enero de 1988) que es reglamentaria de las disposiciones constitucionales que se refieren a "la preservación y restauración del equilibrio ecológico, así como a la protección al ambiente" y que señala que sus disposiciones "... tienen por objeto propiciar el desarrollo sustentable..." (artículo 1o.). La ley contiene varias definiciones relevantes al tema que aquí se trata, por ejemplo, conceptualiza a la biotecnología como "toda aplicación tecnológica que utilice recursos biológicos, organismos vivos o sus derivados para la creación o modificación de productos o procesos para usos específicos". Define además a los recursos biológicos como "los recursos genéticos, los organismos o partes de ellos, las poblaciones, o cualquier otro componente biótico de los ecosistemas con valor o utilidad real o potencial para el ser humano" y a los recursos genéticos como "el material genético [material de origen vegetal, animal, microbiano o de otro tipo con unidades funcionales de herencia] de valor real o potencial" (artículo 3o., fracciones V, XXI, XXVII y XXVIII). La ley se estructura en seis títulos y dedica el segundo al tema de la biodiversidad. Entre otros asuntos, este segmento normativo hace referencia a cuestiones relacionadas con la preservación, aprovechamiento y 
Esta obra forma parte del acervo de la Biblioteca Jurídica Virtual del Instituto de Investigaciones Jurídicas de la UNAM

protección (incluyendo medidas de exportación o importación) de la flora y la fauna silvestres así como a ciertas actividades vinculadas al material genético (artículos 79 a 86); sin embargo, sólo los artículos 87 y 87 bis (con reformas y adiciones publicadas en el Diario Oficial de la Federación el 13 de diciembre de 1996) hacen mención expresa sobre algunos aspectos relacionados con la biotecnología. Así, la ley señala que "el aprovechamiento de especies de flora y fauna silvestre, así como de otros recursos biológicos con fines de utilización de la biotecnología requiere de autorización" de la Secretaría de Medio Ambiente y Recursos Naturales (Semarnat) (artículo 87 bis, párrafo primero). Dicha autorización se otorgará si se cuenta con el consentimiento previo - expreso e informado - del propietario o legítimo poseedor del predio donde se localiza el recurso biológico. No obstante, la ley no menciona que se necesite de autorización emitida por la Semarnat cuando se haga colecta de especies de flora y fauna silvestre, así como otros recursos biológicos con fines de investigación científica cuando se trate de aprovechamiento para fines de utilización en biotecnología. Esta disposición (artículo 87, párrafo cuarto) está íntimamente vinculada a disposiciones similares que se encuentran en la Ley General de Vida Silvestre y que también se relacionan con una reciente reforma al Código Penal Federal, cuerpos legales que más adelante se comentarán. La aplicación de la ley y su interpretación para efectos administrativos corresponde a la Semarnat.

- La Ley sobre Producción, Certificación y Comercio de Semillas (publicada en el Diario Oficial de la Federación el 15 de julio de 1991) tiene por objeto regular "trabajos de investigación oficial para el mejoramiento de las variedades de plantas existentes, o para la formación de nuevas y mejores variedades..." así como "la producción y el beneficio de las semillas certificadas y verificadas" y "la certificación de semillas y las actividades de distribución y venta de las mismas" (artículo 2o. fracciones I-III). Esta ley hace mención explícita de los materiales transgénicos que sean de alto riesgo a los que define como "aquellos con capacidad para transferir a otro organismo una molécula o gen recombinatorio con un potencial de alto riesgo por efectos inesperados, debido a sus características de supervivencia, multiplicación y dispersión" (artículo 3o., fracción VII). El texto de la ley 
Esta obra forma parte del acervo de la Biblioteca Jurídica Virtual del Instituto de Investigaciones Jurídicas de la UNAM

regula estos materiales cuando se desee hacer investigación, para lo cual se requerirá de un permiso otorgado por la Sagarpa que es la encargada de determinar cuáles son productos o materiales transgénicos de alto riesgo a través de un dictamen técnico fundado en consideraciones científicas y análisis de laboratorio (artículo 5o.). Existe una sanción administrativa (multa) a quienes hagan investigación con estos materiales y no cuenten con la autorización respectiva (artículo 16, fracción IV). Aunque esta ley, como la correspondiente en materia de sanidad vegetal, no hagan mención expresa de los OGMs en sus textos, son cuerpos jurídicos relevantes porque todos los organismos (materiales o productos) transgénicos son en realidad OGMs; desde luego, no todos los OGMs son transgénicos. La aplicación de la ley y su interpretación para efectos administrativos corresponde a la Sagarpa.

- La Ley Federal de Sanidad Animal (publicada en el Diario Oficial de la Federación el 18 de junio de 1993) tiene el objeto de "fijar las bases para el diagnóstico, la prevención, control y erradicación de las enfermedades y plagas de los animales, con excepción de los que tengan como hábitat el medio acuático" (artículo 1o.). Aunque el texto de la ley no hace mención explícita sobre los OGMs establece preceptos relativos a la evaluación de la entrada, radicación y propagación de enfermedades y plagas en los animales y sus posibles consecuencias biológicas, económicas y ambientales (artículo 2o.). La aplicación de la ley y su interpretación para efectos administrativos corresponde a la Sagarpa.

- La Ley Federal de Sanidad Vegetal (publicada en el Diario Oficial de la Federación el 5 de enero de 1994) que tiene por objeto

promover y vigilar la observancia de las disposiciones fitosanitarias, diagnosticar y prevenir la diseminación e introducción de plagas de los vegetales, sus productos y subproductos, establecer medidas fitosanitarias, y regular la efectividad biológica, aplicación, uso y manejo de insumos, así como el desarrollo y prestación de actividades y servicios,

en donde las medidas fitosanitarias buscan "asegurar el nivel adecuado de protección y calidad fitosanitarias... tomando en cuenta "el análisis de riesgo así como las características de la zona donde se origine el problema y las de la zona a la que se destinen los 
Esta obra forma parte del acervo de la Biblioteca Jurídica Virtual del Instituto de Investigaciones Jurídicas de la UNAM

vegetales" (artículos 10.-3o.). La ley regula el llamado "material transgénico" al que considera como insumo fitosanitario, y lo define como genotipos modificados artificialmente con la capacidad para transferir a otro organismo genes recombinantes con potencial de presentar efectos previsibles o inesperados (artículo 5o.). Para la aplicación, uso y manejo de este material en programas experimentales o en el combate de plagas se requerirá de un certificado fitosanitario que expedirá la secretaría (artículo 43). La aplicación de la ley y su interpretación para efectos administrativos corresponde a la Sagarpa.

- La Ley Federal de Variedades Vegetales (publicada en el Diario Oficial de la Federación el 25 de octubre de 1996) con el objeto de "fijar las bases y procedimientos para la protección de los derechos de los obtentores de variedades vegetales" (artículo 1o.). Esta ley tampoco hace mención expresa de los OGMs; sin embargo, se orienta a regular someramente cuestiones relacionadas con el reconocimiento de los derechos de los denominados obtentores. Estos son definidos por la propia ley como las personas físicas o morales que a través de "un proceso de mejoramiento haya obtenido y desarrollado, una variedad vegetal de cualquier género y especie" (artículo 2o. fracción IV). La aplicación de la ley y su interpretación para efectos administrativos corresponde a la Sagarpa.

- La Ley General de Vida Silvestre (publicada en el Diario Oficial de la Federación el 3 de julio de 2000) con el objeto de regular la conservación y aprovechamiento sustentable de la vida silvestre y su hábitat (artículo 1o.). Esta ley establece algunas disposiciones relativas a la biotecnología. En primer lugar, el texto señala que en materia de traslado de ejemplares vivos y de exportación o importación de ejemplares, partes y derivados de especies silvestres se necesitará autorización de la Semarnat; no se requerirá de dicha autorización cuando se trate de material biológico de vida silvestre de colecciones científicas y museográficas debidamente registradas, con destino a otras colecciones científicas en calidad de préstamo o donativo. La excepción que hace la ley en el sentido de no sujetar a una autorización de la secretaría el traslado de dicho material biológico, no aplica cuando éste tenga fines de utilización en biotecnología (artículos 52, 53 y 54). En segundo lugar, el texto nor- 
Esta obra forma parte del acervo de la Biblioteca Jurídica Virtual del Instituto de Investigaciones Jurídicas de la UNAM

mativo excluye también de la obligación de solicitar autorización a quienes realicen actividades de colecta científica con el objeto de llevar a cabo investigación o enseñanza cuando el aprovechamiento tenga fines biotecnológicos. El artículo correspondiente señala lo siguiente:

La colecta de ejemplares, partes y derivados de vida silvestre con fines de investigación científica y con propósitos de enseñanza requiere de autorización de la Secretaría y se llevará a cabo con el consentimiento previo, expreso e informado del propietario o poseedor legítimo del predio en donde esta se realice. Esta autorización no amparará el aprovechamiento para fines comerciales ni de utilización de la biotecnología, que se regirá por las disposiciones especiales que resulten aplicables (artículo 97).

Desde luego que si dichas disposiciones especiales no existen, el aprovechamiento para fines biotecnológicos cuando se trate de colecta para investigación científica y de enseñanza no estará sujeto a autorización alguna. En tercer lugar, la ley contiene diversos preceptos en materia de infracciones y sanciones administrativas, que podrán aplicarse a quienes realicen actividades con fines biotecnológicos en contravención con lo dispuesto en la propia ley; sin embargo, aunque la ley establezca en su artículo 122, fracción XIX, como infracción "utilizar material biológico proveniente de la vida silvestre... para objetivos de biotecnología, sin cumplir con las disposiciones aplicables..." sujeta a la actualización de la misma (este artículo remite al artículo 4o., párrafo tercero de la propia ley) a lo establecido en los tratados internacionales y a las demás regulaciones aplicables en la materia (que son por demás insuficientes). La aplicación de la ley y su interpretación para efectos administrativos corresponde a la Semarnat.

- La Ley de Desarrollo Rural Sustentable (publicada en el Diario Oficial de la Federación el 7 de diciembre de 2001) con el objeto de "promover el desarrollo rural sustentable del país, propiciar un medio ambiente adecuado... y garantizar la rectoría del Estado y su papel en la promoción de la equidad..." (artículo 1o., párrafo segundo). Esta ley establece la creación de diversos sistemas nacionales entre los que destaca para los propósitos de este trabajo, el Sistema Nacional de Investigación y Transferencia Tecnológica para el De- 
Esta obra forma parte del acervo de la Biblioteca Jurídica Virtual del Instituto de Investigaciones Jurídicas de la UNAM

sarrollo Rural Sustentable (artículo 22, párrafo segundo, fracción I). Este sistema tiene por objeto coordinar y concertar acciones de entes públicos, sociales y privados que promuevan y realicen actividades de investigación científica, desarrollo tecnológico, y validación y transferencia de conocimientos en materia agropecuaria. En particular, busca aprovechar la investigación científica existente para desarrollar trabajos de alta prioridad en los que se incluyen la biotecnología, la ingeniería genética y la bioseguridad e inocuidad (artículos 32, párrafo tercero, y 37, fracción XIV). El texto de la ley hace referencia explícita a los OGMs y los define como organismos que posean una combinación de material genético derivado de la aplicación de la biotecnología moderna (artículo 3o., fracción XXI). Sin duda, una de las aportaciones más importantes de esta ley, es la de incluir en su texto el enfoque de precaución (al que la ley denomina principio de precaución) para los casos de presunción de riesgo fitozoosanitario o de efectos indeseados por la utilización de los OGMs ante la falta de evidencia científica adecuada. No obstante lo anterior, sujeta la regulación de esta materia a las leyes, reglamentos y normas que apruebe el Congreso de las Unión y el Ejecutivo Federal (artículo 97, párrafos segundo y tercero). Además de esto, la ley contiene otras disposiciones sobre OGMs que están orientadas fundamentalmente a reducir los riesgos para la producción agropecuaria y la salud pública (incluidos, desde luego, la sanidad vegetal y la salud animal), instrumentar medidas de inspección y certificación para garantizar la inocuidad de semillas, promover y regular la investigación, facilitar la comercialización nacional e internacional de dichos organismos, y en términos generales, la posibilidad para que se promueva la adopción de instrumentos internacionales en materia de sanidad agropecuaria y OGMs, así como aquellos tendientes a la armonización y equivalencia internacional de normas fitozoosanitarias (artículos 40, 91, 95, 97 y 102 fracción V). Este cuerpo legal, hace hincapié en que el gobierno federal establecerá diversos mecanismos e instrumentos relativos a la seguridad de la biotecnología y a la "producción, importación, movilización, propagación, liberación, consumo y, en general uso y aprovechamiento de dichos organismos, sus productos y subproductos con la información suficiente y oportuna a los consumidores" (artículo 97, primer párrafo). 
Esta obra forma parte del acervo de la Biblioteca Jurídica Virtual del Instituto de Investigaciones Jurídicas de la UNAM

Por último, será el Sistema Nacional de Capacitación y Asistencia Técnica Rural Integral el encargado de "habilitar a los productores para el aprovechamiento de las oportunidades y el conocimiento y cumplimiento de la normatividad en materia ambiental y de bioseguridad" (artículo 42, fracción VI). La aplicación de la ley y su interpretación para efectos administrativos corresponde a la Sagarpa.

- La Ley General de Desarrollo Forestal Sustentable (publicada en el Diario Oficial de la Federación el 25 de febrero de 2003) cuyo objeto es "regular y fomentar la conservación, protección, restauración, producción, ordenación, el cultivo, manejo y aprovechamiento de los ecosistemas forestales del país y sus recursos... con el fin de propiciar el desarrollo forestal sustentable" (artículo 1o.). Esta ley incluye algunas disposiciones aisladas en materia de biotecnología y OGMs. Así, señala que se requiere de autorización por parte de la Semarnat para los casos de colecta y uso de recursos biológicos forestales que tengan fines de investigación y/o biotecnológicos; dicha autorización deberá contar con el consentimiento previo y por escrito (expreso e informado) del propietario o legítimo poseedor del predio en el que el recurso biológico forestal se localice (artículo 101). Como podrá fácilmente observarse, a diferencia de la Ley General de Vida Silvestre, esta ley señala que las actividades de colecta de recursos forestales con fines de utilización de la biotecnología sí se encuentran sujetas a una autorización administrativa. En este sentido, la ley incluye como recurso biológico forestal a todas aquellas especies y variedades de plantas, animales y microorganismos de los ecosistemas forestales que sean de interés biotecnológico aunado al interés científico y comercial (artículo 7o., fracción XXIV). Por otro lado, la ley hace mención expresa de los OGMs, aunque de manera tautológica al denominarlos organismos vivos genéticamente modificados. El texto señala que se requiere de autorización para los casos de manipulación o modificación genética para la obtención de organismos modificados genéticamente con fines comerciales. Para esto, se deberá contar previamente con un dictamen favorable de la secretaría y se observará lo que al respecto establezcan en su caso la Ley General del Equilibrio Ecológico y la Protección al Ambiente y otras disposiciones aplicables (artículo 
Esta obra forma parte del acervo de la Biblioteca Jurídica Virtual del Instituto de Investigaciones Jurídicas de la UNAM

103, párrafo tercero). La aplicación de la ley y su interpretación para efectos administrativos corresponde a la Semarnat.

- El Código Penal Federal (publicado en el Diario Oficial de la Federación el 14 de agosto de 1931, tomando esta denominación y modificando ciertos preceptos mediante decreto publicado en el Diario Oficial de la Federación el 18 de mayo de 1999) al cual se adiciona el artículo 420 Ter, mediante reformas publicadas en el Diario Oficial de la Federación el 6 de febrero de 2002 relativas a la comisión de un delito ambiental en materia de OGMs. Este artículo señala la pena que se impondrá (de uno a nueve años de prisión y de trescientos a tres mil días multa) a quien contraviniendo lo establecido en la normatividad aplicable "introduzca al país o extraiga del mismo, comercie, transporte, almacene o libere al ambiente, algún organismo genéticamente modificado que altere o pueda alterar negativamente los componentes, la estructura o el funcionamiento de los ecosistemas naturales" (artículo 420 ter, primer párrafo). El propio código define al organismo genéticamente modificado como "cualquier organismo que posea una combinación nueva de material genético que se haya obtenido mediante la aplicación de la biotecnología, incluyendo los derivados de técnicas de ingeniería genética" (artículo 420 Ter, segundo párrafo). De la lectura y concordancias de las leyes de vida silvestre y de equilibrio ecológico y protección al ambiente con el código, es lógico suponer la preocupación que esta disposición ha generado en los sectores científico y académico por la incertidumbre jurídica que dicha reforma significa para quienes llevan a cabo actividades de biotecnología en el país; ante todo, por el temor de que un artículo así redactado pueda impedir el desarrollo biotecnológico como política nacional. Esta disposición penal relativiza y sujeta su propio contenido a una normatividad aplicable todavía no desarrollada en México.

- La NOM-056-FITO-1995 (publicada en el Diario Oficial de la Federación el 11 de julio de 1996), norma oficial mexicana por la que se establecen requisitos fitosanitarios para la movilización nacional, importación y establecimiento de pruebas de campo de organismos manipulados mediante la aplicación de ingeniería genética. Esta norma tiene por objeto "establecer el control de la movilización dentro del territorio nacional, importación, liberación y evaluación 
Esta obra forma parte del acervo de la Biblioteca Jurídica Virtual del Instituto de Investigaciones Jurídicas de la UNAM

en el medio ambiente o pruebas experimentales de organismos manipulados por ingeniería genética para usos agrícolas". La norma equipara un producto manipulado a uno transgénico y los define como "material de origen vegetal o microbiano sujeto a recombinaciones in vitro o en condiciones especiales de laboratorio, mediante la aplicación de la ingeniería genética". Las actividades que aquí se mencionan están sujetas a la emisión de certificados fitosanitarios por parte de diversas autoridades de la Sagarpa. Desde luego, es ésta la secretaría encargada de vigilar y hacer cumplir las disposiciones contenidas en la norma.

- El Reglamento Interior de la Secretaría de Medio Ambiente y Recursos Naturales (publicado en el Diario Oficial de la Federación el 21 de enero de 2003) que establece la organización y estructura de la secretaría y determina las facultades indelegables de su titular así como las delegables a servidores públicos subalternos. Dentro de su estructura se señala a la Subsecretaría de Gestión para la Protección Ambiental, que a través de su Dirección General de Vida Silvestre, será la encargada de emitir ciertos actos de autoridad (i. e. expedir, suspender, modificar, anular, nulificar o revocar, total o parcialmente, los permisos, autorizaciones, licencias, dictámenes, opiniones técnicas, registros, certificados y demás documentación) relacionados con la colecta de

vida silvestre con fines científicos, de investigación o aprovechamiento, relativos a su utilización en la biotecnología y el manejo, tránsito y liberación al ambiente de organismos genéticamente modificados y de organismos vivos modificados, así como realizar los demás actos y actividades tendientes a garantizar un nivel adecuado de protección en materia de seguridad de la biotecnología, en los términos de la legislación aplicable... (artículo 31 fracción XXVI).

Aunque este precepto establece la posibilidad de que una autoridad ambiental emita actos relacionados con la bioseguridad y la liberación de los OGMs conforme al principio de legalidad, su aplicación está relativizada a la legislación actual que es francamente escasa y que impide, como en el caso de la colecta para fines científicos y de investigación con propósitos biotecnológicos en vida silvestre, que disposiciones como ésta se actualicen. 
Esta obra forma parte del acervo de la Biblioteca Jurídica Virtual del Instituto de Investigaciones Jurídicas de la UNAM

Desde luego, existen otros cuerpos normativos de menor jerarquía (en específico los reglamentos y las normas oficiales mexicanas) que regulan algunas de las disposiciones contenidas en las leyes aquí mencionadas. Actualmente se encuentran pendientes de discusión, modificación y/o aprobación algunos proyectos legales que pretenden regular de manera más extensa el tema de la bioseguridad y los organismos genéticamente modificados. Por ejemplo, por lo que hace a normas oficiales mexicanas, la NOM-056-FITO-1995 arriba citada ha estado sujeta en los últimos años al análisis y comentarios de los diferentes actores interesados para su posible modificación. Entre muchas otras cosas más, se ha venido discutiendo la conveniencia de que pueda insertarse la dimensión ambiental (i.e. procedimiento de regulación e intervención de la Semarnat) en la emisión, en su caso, de los permisos correspondientes y convertir así a ésta en una norma oficial mexicana en la que participen tanto la Sagarpa como la Semarnat. De igual manera, se han elaborado varias versiones de un anteproyecto de norma a la que se le conoce como NOM-FITO-ECOL-2002 o NOM-FITO-SEMARNAT-2002 sobre "Importación, movilización y liberación al ambiente en programas piloto y con fines comerciales de organismos genéticamente modificados destinados al uso agrícola" y que pretende complementar las disposiciones contenidas en la norma anteriormente descrita. De por sí lento el proceso para su elaboración, el anteproyecto de la NOM-FITO-ECOL-2002 ha tenido que someterse al dilatado y tortuoso procedimiento de impacto regulatorio ante la Comisión Federal de Mejora Regulatoria de la Secretaría de Economía para obtener el dictamen favorable (o en su caso exención) y cumplir con lo que establece el artículo 69-H y siguientes de la Ley Federal de Procedimiento Administrativo que obliga injustamente a casi todas las dependencias a acudir a una unidad administrativa "domiciliada" en otra dependencia del Ejecutivo Federal.

El avance de la dispersión normativa que se observa en México, ha estado acompañado en los últimos años de lo que se puede denominar con justa razón la parsimonia reguladora de los legisladores federales en el Congreso de la Unión. En efecto, desde finales del siglo pasado se han presentado seis iniciativas de ley sobre bioseguridad (o aspectos relacionados) y/o OGMs, ninguna de ellas ha sido debidamente aprobada por las cámaras respectivas y remitidas consecuentemente al Ejecutivo Federal para que, en su caso, publique alguna. Cierto es que las seis iniciativas 
Esta obra forma parte del acervo de la Biblioteca Jurídica Virtual del Instituto de Investigaciones Jurídicas de la UNAM

de ley han tenido objetos diferentes, pero todas dentro de un marco de regulación de temas vinculados a los OGMs. En su conjunto, diversos partidos políticos se han encargado de presentar ante el congreso estos seis anteproyectos de ley creando un distintivo collage multipartidos. Estas son las iniciativas: ${ }^{38}$

1) Ley de Bioseguridad de Organismos Vivos y Material Genético - Partido Verde Ecologista de México

2) Ley de Bioseguridad - Partido Acción Nacional

3) Ley sobre la Producción, Distribución, Comercialización, Control y Fomento de los Productos Transgénicos

- Partido de la Revolución Democrática

4) Ley de Investigación y Desarrollo Biotecnológico

- Partido Revolucionario Institucional

5) Ley de Bioseguridad

- Partido Acción Nacional y Partido Verde Ecologista de México

6) Ley de Bioseguridad de los Organismos Genéticamente Modificados

— Partido de la Revolución Democrática

De todas estas iniciativas, la última parece contar con el consenso de la mayoría de los actores alrededor del campo de la bioseguridad, en especial de académicos y científicos a través de la Academia Mexicana de Ciencias. Esta iniciativa de ley se presentó al pleno de la Cámara de Senadores en noviembre de 2002 y el dictamen correspondiente fue aprobado el 24 de abril de 2003 durante el segundo periodo ordinario de sesiones del tercer año de ejercicio de la LVIII Legislatura, pasando a la Cámara de Diputados el 28 de ese mismo mes y año quedando pendiente de dictamen la minuta con proyecto de decreto turnada a las comisiones de Medio Ambiente y Recursos Naturales y Agricultura y Ganadería de dicha cámara baja. Durante el primer periodo ordinario de sesiones de la siguiente legislatura (abierto el 1o. de septiembre de 2003) dicho proyecto no fue de in-

38 La información sobre estas iniciativas de ley puede consultarse en el sitio de Internet de la Comisión Intersecretarial de Bioseguridad y Organismos Genéticamente Modificados (Cibiogem) en la dirección electrónica siguiente: http://www.cibiogem.gob.mx/. 
Esta obra forma parte del acervo de la Biblioteca Jurídica Virtual del Instituto de Investigaciones Jurídicas de la UNAM

terés de los legisladores cuyo quehacer regulador estuvo enfocado principalmente a las ya típicas discusiones de fin de año: las presupuestarias.

Mientras que existe la expectativa de que la Cámara de Diputados de la LIX Legislatura en su segundo periodo ordinario de sesiones incluya en su agenda la discusión sobre la regulación integral de la seguridad de la biotecnología a la luz del dictamen de la llamada Ley de Bioseguridad de los Organismos Genéticamente Modificados, ${ }^{39}$ el Ejecutivo Federal, a través de la Comisión Intersecretarial de Bioseguridad y Organismos Genéticamente Modificados (Cibiogem) intenta cumplir con el objeto para el que fue creado, esto es, coordinar las políticas de la administración pública federal respecto a la bioseguridad y a diversas actividades (producción, importación, exportación, movilización, etcétera) para el uso y aprovechamiento de OGMs. La comisión — creada por acuerdo presidencial del 28 de octubre de 1999 y quizá la medida administrativa más importante desde la entrada en vigor del CDB - lleva a cabo reuniones a través de sus subcomités especializados para proponer, entre otras cosas, la actualización y mejoramiento del marco jurídico respectivo. Esta comisión está integrada por los titulares de las dependencias siguientes: Secretaría de Hacienda y Crédito Público; Secretaría de Medio Ambiente y Recursos Naturales; Secretaría de Economía; Secretaría de Agricultura, Ganadería, Desarrollo Rural, Pesca y Alimentación; Secretaría de Educación Pública; Secretaría de Salud, y desde luego el Consejo Nacional de Ciencia y Tecnología, a las que se unen representantes de los sectores académico, empresarial y social. ${ }^{40}$ Con todo, el papel que ha jugado la Cibiogem y que podría facilitar el entendimiento y consenso para el desarrollo de la legislación nacional, no ha sido lo suficientemente relevante

39 Lo más destacado que el Poder Legislativo ha realizado desde abril de 2003 (fecha en la que el Senado de la República turnó la minuta correspondiente a la Cámara de Diputados) al momento de escribir estas líneas (marzo de 2004), ha sido la constitución de un foro nacional para discutir dichos temas sólo algunos días antes de que diera inicio el segundo periodo ordinario de sesiones de la LIX Legislatura el 15 de marzo del presente año. La celebración de dicho foro nacional (precedido de foros regionales) fue impulsada por la fracción legislativa del Partido de la Revolución Democrática a través de su Área de Desarrollo Rural y Medio Ambiente. La información relativa a estos foros puede ser consultada en: http://prdleg.camara.gob.mx/otros/bioseguridad.htm.

40 El espacio que la Secretaría de Medio Ambiente y Recursos Naturales dedica a los temas de bioseguridad y OGMs en su Programa Nacional de Medio Ambiente y Recursos Naturales 2001-2006 es lamentablemente reducido, la información ahí contenida es, además, meramente descriptiva. 
Esta obra forma parte del acervo de la Biblioteca Jurídica Virtual del Instituto de Investigaciones Jurídicas de la UNAM

para empujar y llevar a feliz término la regulación - dispersa o no- que se requiere en materia de bioseguridad y organismos genéticamente modificados.

\section{CONCLUSIONES}

En un periodo de casi doce años, desde la conferencia de Río en 1992 hasta nuestros días, la normatividad internacional ha dado pasos agigantados - aunque inacabados - para regular el campo de la seguridad de la biotecnología. A lo largo de estos años, México ha sido parte activa de este proceso evolutivo concluyendo uno a uno, y sin inquietante demora, los trámites respectivos de adopción, aprobación, ratificación y depósito de los instrumentos internacionales más importantes en la materia.

La distancia temporal es clara para México: suscribe la Agenda 21 en junio de 1992; firma ad referéndum el Convenio sobre la Diversidad Biológica en junio de 1992, lo aprueba el Senado de la República en diciembre de ese mismo año, y en 1993 el propio Ejecutivo Federal lo ratifica (febrero), deposita el instrumento de ratificación (marzo), y lo promulga y publica (mayo) para su debida observancia en todo el territorio nacional; de igual manera, firma ad referéndum el protocolo de Cartagena en mayo de 2000, lo aprueba el Senado de la República en abril de 2002, y el Ejecutivo Federal lo ratifica (julio) y hace el depósito (agosto) en ese mismo año, para luego promulgarlo en septiembre y publicarlo en el Diario Oficial de la Federación del 28 octubre de 2003 también para su debida observancia en todo el territorio nacional.

Surge entonces la interrogante ¿por qué el Estado mexicano en lo interno no cuenta con una legislación ad hoc de regulación de la bioseguridad y los organismos genéticamente modificados desde su inclusión en el CDB y el protocolo de Cartagena si ya se ha comprometido internacionalmente a cumplir los mandatos de estos dos instrumentos vinculantes? Bien hacía Flores D’Arcais — citado por el escritor catalán Manuel Vázquez Montalbán - en siempre pronunciarse por una ética sin fe para así escapar de la perniciosa búsqueda de la verdad única. ${ }^{41}$ Pronunciarse de esta manera ante semejante interrogante parece lo más sensato, pues dar una respuesta única y verdadera impediría la búsqueda de posibles

41 Vázquez Montalbán, Manuel, Marcos: el señor de los espejos, México, Aguilar, 1999, p. 13. 
Esta obra forma parte del acervo de la Biblioteca Jurídica Virtual del Instituto de Investigaciones Jurídicas de la UNAM

alternativas de explicación al estado que guarda actualmente la legislación mexicana al respecto. Por el momento, es adecuado señalar - como verdades posibles - que si el derecho nacional en México no avanza se debe a la combinación de una serie de factores que incluyen la pasividad del Ejecutivo Federal para impulsar la armonización de la regulación, la falta de consensos entre los actores (y desde luego una cabeza para lograr dicho consenso), el temor de algunos sectores de que se apruebe una legislación inhibitoria del desarrollo en la investigación biotecnológica y lo que de esto pueda derivarse en ganancias o pérdidas económicas y la falta de conocimiento e interés de los legisladores federales para crear una ley, o en su caso, aprobar una de las muchas iniciativas de ley que ya existen en el Congreso de la Unión.

Por lo tanto, la doble influencia del derecho internacional en su dimensión creadora y armonizadora de las regulaciones domésticas no ha logrado insertarse del todo en la nación mexicana en lo que corresponde al tema de la bioseguridad y los organismos genéticamente modificados. No obstante lo anterior, cabe mencionar que tanto el Convenio sobre la Diversidad Biológica como el protocolo de Cartagena forman parte del ordenamiento jurídico nacional (inclusive por encima de la leyes emanadas del Congreso de la Unión) y por tanto sus mandatos son de observancia obligada para el Estado mexicano. ${ }^{42}$ Además, en 1999, la Suprema Corte de Justicia de la Nación determinó a través de una tesis jurisprudencial que los tratados internacionales "se encuentran en un segundo plano inmediatamente debajo de la ley fundamental [sólo la Constitución es la Ley Suprema] y por encima del derecho federal y el local [por lo que los] compromisos internacionales son asumidos por el Estado mexicano en su conjunto y comprometen a todas sus autoridades frente a la comunidad internacional". ${ }^{43}$ Esto significa que ninguna ley que emane del Congreso de la Unión para regular el campo de la seguridad de la biotecnología podrá contravenir lo que disponga en esta materia el protocolo de Cartagena. Si el legislador pretende incluir en una ley nacional temas,

42 Conviene aquí remitir a la lectura del artículo 133 de la Constitución Política de los Estados Unidos Mexicanos que en sus primeras líneas establece lo siguiente: "Esta Constitución, las leyes del Congreso de la Unión que emanen de ella y todos los Tratados que estén de acuerdo con la misma, celebrados y que se celebren por el presidente de la República, con aprobación del Senado, serán la Ley Suprema de toda la Unión".

43 Véase tesis P. LXXVII/99, Semanario Judicial de la Federación y su Gaceta, Novena Época, t. X, noviembre de 1999, p. 46. 
Esta obra forma parte del acervo de la Biblioteca Jurídica Virtual del Instituto de Investigaciones Jurídicas de la UNAM

conceptos, procedimientos o requisitos no contemplados en el protocolo mencionado, podrá hacerlo siempre y cuando sólo lo tome en cuenta y como un antecedente jurídico; por el contrario, si pretende elaborar una ley de conformidad con el protocolo deberá abstenerse de incluir temas no previstos en el mismo. Por otra parte, a la luz de lo que dispone el artículo 89 fracción primera de la Constitución Política de los Estados Unidos Mexicanos, el Ejecutivo Federal podrá expedir reglamentos, decretos, acuerdos u otras disposiciones administrativas de menor jerarquía para regular diversos aspectos de la bioseguridad, sólo si existe previamente una ley que al efecto haya expedido el Congreso de la Unión. Así, aunque el protocolo de Cartagena sea derecho interno y forme parte del ordenamiento jurídico mexicano, es claro que no se trata stricto sensu de una ley expedida por el Congreso de la Unión pues no estuvo propiamente sujeta al procedimiento legislativo de ambas cámaras, y por lo tanto, sería impropio que el Ejecutivo Federal ejerciera su facultad reglamentaria basándose en instrumentos jurídicos (tratados o protocolos) que no tienen la naturaleza jurídica de verdaderas leyes emanadas del Congreso de la Unión. Si el protocolo de Cartagena o cualquier otro tratado se consideraran como leyes del Congreso de la Unión y por lo tanto pudieran colocarse en el supuesto jurídico del artículo 89 en su fracción primera, entonces la Suprema Corte de Justicia de la Nación no hubiera tenido que molestarse en hacer una distinción entre tratados internacionales (incluyendo protocolos) y leyes federales.

No es de soslayar lo difícil que resulta para las partes contratantes del protocolo de Cartagena llevar a cabo una regulación doméstica que no sólo no contravenga al mismo protocolo, sino que cumpla con los requisitos jurídicos necesarios para su implementación, satisfaga las necesidades propias de cada país e intente resolver conflictos como el de la aplicación de normas comerciales versus ambientales o incluso agropecuarias versus ambientales; sin embargo, pueden existir otros factores muchísimo más decisivos que impidan la elaboración de una legislación adecuada. El reto que enfrenta México en este sentido se torna complicado por razones que no sólo tienen que ver con la regulación de la bioseguridad y los organismos genéticamente modificados per se. El temprano - $\mathrm{y}$ por lo tanto desafortunado - inicio de la carrera presidencial hacia 2006, la acrecentada descomposición política por luchas internas o escándalos de corrupción que viven los principales partidos políticos y la insistencia 
Esta obra forma parte del acervo de la Biblioteca Jurídica Virtual del Instituto de Investigaciones Jurídicas de la UNAM

del Ejecutivo Federal en priorizar la discusión legislativa sobre las llamadas reformas estructurales del Estado (i. e. hacendaria y energética), prometen distraer la atención de los legisladores para debatir seriamente y a fondo las cuestiones relacionadas con los diversos aspectos de la seguridad de la biotecnología en sus dimensiones ambiental, agropecuaria y de salud.

En el campo de lo estrictamente ambiental, está latente el riesgo de que se apruebe una ley al interior del Congreso de la Unión cuyo texto no incluya cabalmente los diversos compromisos internacionales adquiridos en foros ambientales. Los accidentados cambios que se dieron al interior de la Semarnat poco antes de que entrara en vigor internacionalmente el protocolo de Cartagena, y la habilidad política con la que otras dependencias del Ejecutivo Federal han actuado en los últimos años para lograr sus propios objetivos de regulación (sector agropecuario y comercial) en esta materia, comprometen seriamente el ideal de contar con una ley para todos. 
Esta obra forma parte del acervo de la Biblioteca Jurídica Virtual del Instituto de Investigaciones Jurídicas de la UNAM

\section{GUÍA MÍNIMA PARA LA ENSEÑANZA DEL DERECHO INTERNACIONAL AMBIENTAL EN MÉXICO*}

\section{INTRODUCCIÓN}

Quienes impartimos clases de la materia de derecho ambiental (o denominaciones similares) a nivel licenciatura en las diferentes universidades, institutos o centros de enseñanza del país, nos preguntamos con admisible inquietud qué temas deben abordarse cuando se llega a tratar la parte, capítulo o módulo internacional en este curso. Y decimos admisible inquietud porque en México, no obstante su relevancia jurídica, son escasísimos los estudios que se tienen sobre lo que se conoce como derecho internacional ambiental o derecho ambiental internacional. Esta inquietud compartida con algunos otros colegas no radica en si deberiamos o no incluir la parte internacional del derecho ambiental (de por sí vagamente incorporada en algunos programas de estudio o curricula), sino en especificar su contenido, esto es, en determinar los temas que creemos indispensables conozca el alumno. Si bien muchas carreras de derecho (o afines a ésta) cuentan en su mayoría con sendos cursos de derecho internacional (público y/o privado), las cuestiones ambientales requieren cada vez más de un estudio detallado (aunque multidimensional y multidisciplinario) para su mejor comprensión.

Es por esto que este trabajo busca elaborar una guía mínima sobre el contenido y temas que creemos indispensables para la enseñanza de esta disciplina o subespecialización jurídica. Hacemos hincapié en que se trata de una guía mínima por lo que advertimos al lector que hay temas que no pudieron ser debidamente incluidos, pero que forman indiscutiblemente parte del estudio del derecho internacional ambiental, como lo es la parte adjetiva o contenciosa. Aunado a esto, es también probable que el lector experimente cierta frustración ante el desarrollo tan breve que se hace de

* Publicado en Boletín Mexicano de Derecho Comparado, México, nueva serie, año XXXVIII, núm. 113, mayo-agosto de 2005. 
Esta obra forma parte del acervo de la Biblioteca Jurídica Virtual del Instituto de Investigaciones Jurídicas de la UNAM

algunos temas sustantivos. En este sentido, confesamos que tiempo y espacio - como es común en los artículos - no permiten que nuestra guía mínima se vuelva al menos una guía semi-completa. Pero hay otra razón para su obligada brevedad: este trabajo está orientado a cubrir las pocas horas que se pueden destinar a la parte internacional de los ya de por sí cortísimos cursos de derecho ambiental (o materias afines) en nuestras universidades.

Con todo, esperamos lograr el objetivo de presentar aquí (aunque breve) una guía - sólo eso: una guía - que sea útil para catedráticos vinculados al derecho ambiental y que desde luego asista al alumno en la comprensión de lo internacional ambiental en el mundo jurídico. Ojalá que al mismo tiempo estas líneas sirvan para que en lo futuro se realicen estudios serios, amplios y sistematizados de esta disciplina jurídica. Dividimos a este artículo en cinco partes: Orígenes: ¿qué es y cuándo nace?; Instrumentos internacionales soft y hard law; Principios fundamentales del derecho internacional ambiental; El caso mexicano. Tratados ambientales y acuerdos interinstitucionales ambientales, y Conclusiones.

\section{ORÍGENES: ¿QUÉ ES Y CUÁNDO NACE?}

Al acercarnos a la enseñanza del derecho internacional ambiental se producen una serie de interrogantes que obligan a un planteamiento concreto. La primera de ellas es sin duda respecto a su constitución conceptual: ¿es correcto referirse a un derecho internacional ambiental en lugar de a un derecho ambiental internacional? La respuesta a esto tiene que ver con el enfoque que se le quiera dar al objeto de estudio de estas disciplinas o subespecializaciones jurídicas. Es decir, si lo que se busca es analizar los instrumentos internacionales desde la óptica de aquello que constituye el derecho ambiental, entonces conviene utilizar la segunda expresión, y viceversa, si lo que interesa es insertar e integrar la dimensión ambiental a lo que conforma el derecho internacional, conviene entonces hacer uso de la primera. De esta manera, es preferible que los abogados internacionalistas usen la expresión derecho internacional ambiental y que los abogados ambientalistas usen la expresión derecho ambiental internacional. Desde luego, ambos enfoques son válidos y legítimos, por lo que ambientalistas o internacionalistas pueden utilizar indistintamente uno o el otro. Al menos en nuestro idioma, ha tenido mayor incidencia el uso de la primera 
Esta obra forma parte del acervo de la Biblioteca Jurídica Virtual del Instituto de Investigaciones Jurídicas de la UNAM

expresión; esto es, lo ambiental aparece como el elemento que se integra a la rama jurídico-internacional y se habla entonces de un derecho internacional ambiental. Esta tendencia de insertar en una disciplina jurídica la dimensión ambiental ha sido ya práctica para otros casos como, por ejemplo, en el administrativo, en el atmosférico o en el tributario, para crear respectivamente el llamado derecho administrativo ambiental, ${ }^{1}$ el derecho atmosférico ambiental ${ }^{2} \mathrm{o}$ el derecho tributario ambiental. ${ }^{3}$

Si bien preferimos utilizar la expresión derecho internacional ambiental, surge una segunda interrogante que tiene que ver con su objeto de estudio, es decir, ¿a qué se refiere lo ambiental? Desde que apareció el derecho ambiental en su acepción moderna, hacia finales de la década de los sesenta y principios de los setenta del siglo pasado, se han hecho esfuerzos importantes para delimitar el alcance de la voz ambiente y así uniformar su contenido. Paradójicamente, si algún consenso se ha alcanzado en este sentido, es que se trata ante todo de una idea (o concepto) que bien puede abarcar cualquier cosa y que en todo caso sugiere significados diferentes para áreas de conocimiento o saberes científicos diferentes. Así, de manera muy simplista, mientras que para el climatólogo podrá significar atmósfera y para el ecologista hábitat, ${ }^{4}$ para el sociólogo significará nexo entre sociedad y naturaleza, ${ }^{5}$ y para el jurista podrá ser bien o valor jurídico a proteger por las normas de carácter ambiental. ${ }^{6}$ Por esto, quienes pretendan identificar qué temas contiene el derecho internacional ambiental requieren de una visión amplia y flexible sin olvidar que muchos de ellos pueden abordarse desde otras disciplinas jurídicas o bien pueden pertenecer en la práctica internacional a foros no ambientales per se. De

1 Botassi, Carlos Alfredo, Derecho administrativo ambiental, La Plata, Librería Editora Platense, 1997.

2 Nava Escudero, César, "Hacia un derecho atmosférico ambiental", Derecho Ambiental y Ecología, México, año 1, núm. 4, diciembre de 2004-enero de 2005.

3 Herrera Molina, Pedro M., Derecho tributario ambiental, Madrid, Ministerio de Medio Ambiente-Marcial Pons, 2000.

4 Véase The Environment Encyclopedia and Directory: a World Survey, Londres, Europa Publications, 1994.

5 López Ramírez, Alfonso, "Medio ambiente, desarrollo sustentable y pobreza rural en América Latina. Modelo teórico-metodológico", en López Ramírez, Alfonso y Hernández, Pedro F. (coords.), Sociedad y medio ambiente: contribuciones a la sociología ambiental en América Latina, México, Asociación Latinoamericana de Sociología-Benemérita Universidad Autónoma de Puebla-La Jornada Ediciones, 1996, p. 40.

6 Jaquenod de Zsögön, Silvia, Derecho ambiental, Madrid, Dykinson, 2002, p. 21. 
Esta obra forma parte del acervo de la Biblioteca Jurídica Virtual del Instituto de Investigaciones Jurídicas de la UNAM

cualquier manera, debe tenerse presente que a lo que comúnmente se refiere, y de manera muy simplificada, la expresión ambiente al ser introducida como objeto de estudio de una disciplina jurídica es a la protección ambiental y al control o prevención de la contaminación ambiental.

Independientemente de lo anterior, creemos de gran utilidad auxiliarse de los siguientes criterios para acotar en lo posible lo que pertenece a lo jurídico-internacional-ambiental: $a$ ) serán temas de estudio de esta disciplina los que se discutan en los llamados foros ambientales (como el del cambio climático o el de la biodiversidad); $b$ ) también lo serán aquellos que sin ser el centro de la discusión en estos foros $-\mathrm{y}$ por lo tanto no puedan considerarse propiamente ambientales - tengan de cualquier manera repercusiones ambientales evidentes (como diversos aspectos en torno a temas comerciales o urbanos), y c) lo serán del mismo modo aquéllos temas que han pertenecido tradicionalmente a otros foros de discusión internacional $-\mathrm{y}$ que de hecho han propiciado el surgimiento de verdaderas disciplinas jurídicas - pero que con el paso del tiempo se han incorporado como parte de un todo ambiental como es el caso del derecho del mar, rama jurídica en continua transformación y ejemplo auténtico de creación de normas internacionales por métodos novedosos y diferentes a los ordinarios. ${ }^{7}$

Aceptamos entonces que existe un cuerpo jurídico internacional ambiental, esto es, un listado de instrumentos internacionales ambientales. Pero, ¿podemos estudiar esta materia desde un enfoque normativo y además científico como se hace tradicionalmente para la mejor comprensión y entendimiento de cualquier disciplina jurídica? La respuesta a esta tercera interrogante es muy sencilla: en la actualidad ya es posible estudiar al derecho internacional ambiental como norma y como ciencia. En efecto, por una parte es indudable el extenso inventario de instrumentos ambientales que en forma de tratados, protocolos, convenciones, acuerdos, declaraciones, programas, etcétera, existen a nivel internacional. Cuantitativamente hablando es difícil contar con un dato exacto. Sands ${ }^{8}$ nos dice, por ejemplo, que a principios de la década de los noventa existían algunos miles de acuerdos ambientales bilaterales, varias docenas de

7 Sepúlveda, César, Derecho internacional, 20a. ed., México, Porrúa, 2000, p. 463.

8 Sands, Philippe, "International Environmental Law: an Introductory Overview", en Sands, Philippe (comp.), Greening International Law, Nueva York, The New Press, 1994, p. XXII. 
Esta obra forma parte del acervo de la Biblioteca Jurídica Virtual del Instituto de Investigaciones Jurídicas de la UNAM

acuerdos regionales y unas cuantos más —alrededor de 30 - de acuerdos multilaterales. Desde luego, esta cifra se ha incrementado en los últimos años. Por otra parte, existe paralelamente a la cuestión normativa un conjunto de reglas, principios, teorías y conceptos fundamentales que ordenadamente y relacionados entre sí tratan de explicar y analizar lo internacional ambiental desde la óptica científico-jurídica. Encontramos trabajos enteros que se han dedicado a esto y que son ya referentes obligados para el estudio de esta disciplina como son los de Adede, ${ }^{9}$ Birnie y Boyle, ${ }^{10}$ Juste Ruiz, ${ }^{11}$ o Kiss y Shelton. ${ }^{12}$ Acompañan a éstos, diversos artículos y capítulos en libros de derecho ambiental que incluyen diferentes cuestiones internacionales. Vale la pena señalar que quizá el antecedente más remoto que tenemos en México en este sentido sea un artículo publicado en 1976 por Alberto Székely en la Revista de la Facultad de Derecho de la Universidad Nacional Autónoma de México y que lleva por título "El medio ambiente: derecho internacional". ${ }^{13}$ Sin embargo, este país carece de una obra amplia y detallada que haya abordado sistemáticamente esta materia.

Finalmente, el estudio del derecho internacional ambiental no podría estar completo sin un referente histórico. Por lo que necesitamos preguntarnos ¿cuándo nace esta materia? En realidad, no hay consenso entre los especialistas en cuanto a la fecha exacta de su aparición. Nos comenta Sands ${ }^{14}$ que lo que él llama proceso de enverdecimiento del derecho internacional se inició en el siglo XIX con la celebración de acuerdos bilaterales para prohibir la sobreexplotación en la pesca de ciertas especies (focas) en el Océano Pacífico. Este autor identifica como etapas posteriores en este proceso: la creación de la Organización de las Naciones

9 Adede, A. O., Digesto de derecho internacional ambiental, México, Secretaría de Relaciones Exteriores, 1995.

10 Birnie, Patricia W. y Boyle, Alan E., International Law and the Environment, 2a. ed., Oxford, Oxford University Press, 2002.

11 Juste Ruiz, José, Derecho internacional del medio ambiente, Madrid, McGrawHill, 1999.

12 Kiss, Alexandre Ch. y Shelton, Dinah, International Enviornmental Law, Nueva York, Trasnational Publishers, 1991.

13 Székely, Alberto, "El medio ambiente: derecho internacional", Revista de la Facultad de Derecho de la Universidad Nacional Autónoma de México, México, t. XXVI, núms. 103-104, julio-diciembre de 1976, pp. 325-339.

14 Sands, Philippe, op. cit., nota 8, pp. XXIII-XXIX. 
Esta obra forma parte del acervo de la Biblioteca Jurídica Virtual del Instituto de Investigaciones Jurídicas de la UNAM

Unidas en 1945, la celebración de la Conferencia de las Naciones Unidas sobre el Medio Humano en Estocolmo, Suecia, en 1972 y la realización de la llamada "cumbre de la Tierra" o Conferencia de las Naciones Unidas sobre el Medio Ambiente y el Desarrollo celebrada en Río de Janeiro, Brasil, en 1992. Sin embargo, hay autores que si bien reconocen que el derecho internacional ambiental tiene su antecedente a lo largo de las primeras tres cuartas partes del siglo $\mathrm{XX}$, sostienen que su verdadero inicio surge hacia finales de la década de los sesenta y principios de los setenta de ese mismo siglo. ${ }^{15} \mathrm{Al}$ parecer, es en 1968 - al mismo tiempo que diversas ciudades en el mundo (Pekín, Londres, París, Praga, Ciudad de México) se cimbraban ante multitudinarias movilizaciones estudiantiles - que lo ambiental toma forma definitiva e irrumpe decididamente en el campo del derecho internacional.

De cualquier manera, el derecho internacional ambiental como ahora lo entendemos y explicamos pertenece a una época - moderna- que se consolida y que encuentra eco a partir de la internacionalización de los temas ambientales, con la celebración de la conferencia de Estocolmo de 1972 arriba mencionada. A partir de esta fecha, la normativa internacional ambiental se expande a pasos agigantados como resultado de un nuevo fenómeno de concienciación ambiental global. Son muchas las reuniones y foros ambientales realizados con posterioridad a la de Estocolmo, pero entre ellas destaca indudablemente la ya citada conferencia de Río de 1992 que ha orientado en mucho la discusión internacional ambiental de los últimos quince años.

El nuevo pilar de la normativa ambiental ha descansado en la idea del desarrollo sustentable que ha intentando acercar visiones polarizadas o desencuentros discursivos entre países del sur y del norte, pero sin tener mucho éxito. Aunque se ha logrado consenso para ciertos temas, las preocupaciones y prioridades ambientales de cada bloque continúan siendo diferentes en muchos sentidos. ${ }^{16}$ De una u otra forma, el derecho internacional ambiental actual sigue siendo en mucho el derecho del desarrollo sustentable de principios de la década de los noventa del siglo pasado.

\footnotetext{
15 Véase Kiss, Alexandre Ch. y Shelton, Dinah, op. cit., nota 12, pp. 36 y 37.

16 Nava Escudero, César, Urban Environmental Governance: Comparing air Quality Management in London and Mexico City, Aldershot, Ashgate, 2001, pp. 14 y 15.
} 
Esta obra forma parte del acervo de la Biblioteca Jurídica Virtual del Instituto de Investigaciones Jurídicas de la UNAM

\section{INSTRUMENTOS INTERNACIONALES SOFT Y HARD LAW}

El cuerpo normativo del derecho internacional ambiental está compuesto por lo que los especialistas denominan instrumentos internacionales soft law (de derecho blando o suave) y hard law (de derecho duro). Por un lado, el carácter soft o de lege ferenda se manifiesta de tres maneras en el mundo jurídico internacional. Primero, a través de instrumentos internacionales que se distinguen por no tener per se fuerza jurídica vinculante, esto es, se trata de instrumentos normativos que carecen de obligatoriedad. En la práctica internacional se les conoce generalmente como lineamientos, resoluciones, declaraciones, principios, programas, estrategias, cartas, códigos de conducta, actas (finales), informes de grupos de expertos o de grupos de trabajo, minutas, reuniones, memoranda de entendimiento o de intención, modus vivendi, por mencionar algunos. Segundo, a través de normas o disposiciones que se establecen en instrumentos no considerados soft law, es decir, independientemente de la naturaleza jurídica del instrumento (obligatorio o no) existen normas que tienen este carácter blando por su contenido político, programático, declarativo o de buena voluntad, más que jurídico-vinculante. ${ }^{17} \mathrm{Y}$ tercero, a través de normas que apenas están en proceso de gestación, aún sin consolidarse, sin que hayan entrado en vigor o que no revistan un carácter consuetudinario. ${ }^{18}$ Este tipo de instrumentos suaves pueden ser multilaterales, ${ }^{19}$ regionales ${ }^{20} \mathrm{o}$ bilaterales. ${ }^{21}$ Quizá las tres consecuencias más importantes del carácter soft de los instrumentos internacionales ambientales sean, primero, que permiten identificar principios básicos ambientales que los Estados han aceptado observar; ${ }^{22}$ segundo, que estos principios normativos o instrumentos enteros sirven de guía para el comportamiento y

17 Birnie, Patricia W. y Boyle, Alan E., op. cit., nota 10, p. 25.

18 Juste Ruiz, José, op. cit., nota 11, p. 44.

19 Por ejemplo, la Declaración de Río sobre el Medio Ambiente y el Desarrollo de 1992.

20 Como es el caso de la Declaración de Bergen sobre Desarrollo Sustentable adoptada por la Comisión Económica para Europa y la Comunidad Europea de 1990.

21 Podemos mencionar como ejemplo el Acta Constitutiva del Grupo de Trabajo para la Cooperación Bilateral en Materia Forestal, Vida Silvestre y Áreas Naturales Protegidas entre México y Guatemala adoptada en Tapachula, Chiapas, en 2001.

22 Birnie, Patricia W. y Boyle, Alan E. op. cit., nota 10, p. 26. 
Esta obra forma parte del acervo de la Biblioteca Jurídica Virtual del Instituto de Investigaciones Jurídicas de la UNAM

conducta de los Estados, ${ }^{23}$ y tercero, que se constituyen - aunque no en todos los casos - como un antecedente del derecho duro que habrá de emerger en el futuro.

Por otro lado, el carácter hard o de lege lata se manifiesta en instrumentos internacionales con el rigor jurídico propio de una norma obligatoria, constituyéndose en realidad como un auténtico ius cogens. ${ }^{24}$ Generalmente, se les identifica por el nombre que lleva el instrumento que en la práctica internacional incluye - entre otros - tratados, convenciones, convenios, protocolos, acuerdos y más recientemente Constituciones. ${ }^{25}$ Este tipo de instrumentos duros pueden ser multilaterales, ${ }^{26}$ regionales $^{27}$ o bilaterales ${ }^{28}$ (aunque algunos autores añaden la categoría de instrumentos específicos). ${ }^{29} \mathrm{Si}$ bien se trata de instrumentos a los que la comunidad internacional les reconoce fuerza vinculante por sí mismos, surge invariablemente la duda sobre el cabal cumplimiento por parte de los Estados. Al igual que en otras áreas del derecho internacional público, se requiere del establecimiento de mecanismos que permitan la aplicación, control, seguimiento, resolución de controversias, y en su caso, sanción por inobservancia de la normativa ambiental.

Pero las limitaciones para la debida observancia e implementación de estos instrumentos son muchas. Primero, porque no se puede "obligar" a Estado alguno a que los suscriba ${ }^{30}$ incluso ante la presión internacional,

23 Véase, por ejemplo, Nava Escudero, César, "El principio de precaución en el derecho internacional ambiental”, Derecho Ambiental y Ecología, México, año 1, núm. 2, agosto-septiembre de 2004, p. 53.

24 Juste Ruiz, José, op. cit., nota 11, p. 48.

25 Al momento de escribir, diversos parlamentos de la Unión Europea se encuentran votando (ad referéndum) la llamada Constitución europea, instrumento internacional regional que habrá de ser obligatorio para los 25 miembros que constituyen la unión una vez que se hayan cumplido los requisitos de procedimiento para su entrada en vigor.

26 Es el caso del Convenio sobre la Diversidad Biológica de 1992.

27 Por ejemplo, el Acuerdo de Cooperación Ambiental de América del Norte de 1994, celebrado entre Canadá, Estados Unidos de América y México.

28 Como ejemplo, el Tratado entre los Estados Unidos Mexicanos y los Estados Unidos de América relativo a la Utilización de las Aguas de los Ríos Colorado y Tijuana y del Río Bravo (Grande) desde Fort Quitman, Texas, hasta el Golfo de México de 1944.

29 Un ejemplo lo constituye el Acuerdo Internacional sobre la Conservación de Osos Polares y su Hábitat de 1973 (acuerdo de Oslo) celebrado entre Canadá, Dinamarca, Estados Unidos de América, Noruega y la entonces Unión Soviética.

30 Ferrey, S., Environmental Law, 3a. ed., Nueva York, Aspen, 2004, p. 576. 
Esta obra forma parte del acervo de la Biblioteca Jurídica Virtual del Instituto de Investigaciones Jurídicas de la UNAM

como ha sido el lamentable caso de la negativa de Estados Unidos de América y de Australia de adherirse al protocolo de Kyoto en materia de cambio climático, cuando la gran mayoría de los países que emiten los gases de efecto invernadero causantes de este fenómeno ya lo han hecho (e. g. la Comunidad Europea y Rusia); segundo, porque muchos instrumentos de este tipo acaban por redactarse con amplios márgenes de acción para los Estados, puesto que de lo contrario no manifestarían su voluntad en comprometerse con temas ambientales: esto aún con la existencia del principio de soberanía que poseen sobre sus recursos naturales; tercero, porque los costos económicos de observancia de las normas ambientales pueden ser muy altos, en especial para casos donde no existe cooperación financiera adecuada; cuarto, porque para verificar el cumplimiento de una norma hard, la mayoría de las veces los Estados no han optado por la aplicación coactiva sino por otros mecanismos como, por ejemplo, los de edificación de confianza que son sistemas de advertencia oportuna o de rendición de cuentas; ${ }^{31}$ quinto, y aunado a lo anterior, porque en su caso se requiere de organismos judiciales adecuados que son difíciles de aceptar por la comunidad internacional para la resolución de controversias (nos preguntamos si sería deseable y práctico contar con un tribunal internacional ambiental); sexto, porque aún existiendo estas instancias u organismos internacionales (como la Sala Especial Permanente para Temas Ambientales de 1993 de la Corte Internacional de Justicia), su papel judicial es aún incipiente: los propios Estados deciden que la resolución de controversias sea a través de otros mecanismos jurisdiccionales más flexibles o amistosos como el arbitraje internacional y no a través de decisiones judiciales, y séptimo, porque aún con sentencias emanadas de instancias judiciales internacionales, es difícil imponer sanciones en caso de incumplimiento de dichas sentencias. Pensemos para este último punto el caso de países que tengan sentencias en su contra y no las quieran acatar, pero que pertenecen al Consejo de Seguridad de la Organización de las Naciones Unidas - órgano encargado de mantener la paz y la seguridad internacionales así como de "imponer embargos o

31 Székely, Alberto y Ponce-Nava, Diana, "La declaración de Río y el derecho internacional ambiental", en Lichtinger, Víctor y Glender, Alberto (comps.), La diplomacia ambiental, México, Secretaría de Relaciones Exteriores-Fondo de Cultura Económica, 1994, p. 332. 
Esta obra forma parte del acervo de la Biblioteca Jurídica Virtual del Instituto de Investigaciones Jurídicas de la UNAM

sanciones económicas o autorizar el uso de la fuerza para hacer cumplir los mandatos"-. ${ }^{32}$

Más difícil se convierte este asunto si pensamos que se trata de países que poco respetan el orden internacional y que resuelven sus diferencias a través de la amenaza, la imposición de voluntad o de plano el ejercicio de la acción militar: ¿es acaso factible que el Consejo de Seguridad le diera efectividad a un hipotético fallo judicial de embargo comercial contra los Estados Unidos de América por incumplimiento de alguna norma internacional ambiental?

Aunque el panorama que aquí se presenta parece a todas luces decepcionante o frustrante, existen algunas razones para creer que no todo es así. En primer lugar, si bien el derecho duro de lo internacional ambiental padece de severas limitaciones, su consolidación y desarrollo ha producido un fenómeno más que alentador: ha propiciado en su corta existencia la creación y desarrollo del derecho interno ambiental de las naciones. En efecto, aunque para algunos países y para ciertos temas de regulación, el derecho internacional ambiental se ha derivado de las preocupaciones o la legislación doméstica, ${ }^{33}$ para otros, y según el tema ambiental del que se trate la influencia de lo internacional ambiental, ha enriquecido y de hecho propiciado la creación de legislación nacional ambiental. Así ha sucedido, por ejemplo, para muchos países latinoamericanos ${ }^{34} \mathrm{o}$ para el caso de ciertos temas como el de la seguridad de la biotecnología. ${ }^{35}$

En segundo lugar, existen algunos casos - aunque aislados - con resultados positivos derivados del funcionamiento de ciertos mecanismos institucionales creados a partir de normativa ambiental hard, como es

32 Véase Organización de las Naciones Unidas, ¿Que es el Consejo de Seguridad?, Organización de las Naciones Unidas, s.f., http://www.unorg/spanish/docs/sc/unsc_info Basica.html.

33 Véase, por ejemplo, Ferrey, S., op. cit., nota 30, p. 575.

34 Programa de las Naciones Unidas para el Medio Ambiente, El desarrollo del derecho ambiental latinoamericano y su aplicación. Informe sobre los cambios jurídicos después de la Conferencia de las Naciones Unidas sobre el Medio Ambiente y el Desarrollo (Río 1992), México, Programa de las Naciones Unidas para el Medio Ambiente-Oficina Regional para América Latina y el Caribe, 2001, p. 20.

35 Nava Escudero, César, "La seguridad de la biotecnología: la normatividad internacional vis à vis la regulación nacional mexicana", Memorias del Segundo Encuentro Internacional de Derecho Ambiental, México, Secretaría de Medio Ambiente y Recursos Naturales-Instituto Nacional de Ecología-Programa de las Naciones Unidas para el Medio Ambiente, septiembre de 2004, p. 433. 
Esta obra forma parte del acervo de la Biblioteca Jurídica Virtual del Instituto de Investigaciones Jurídicas de la UNAM

el caso del Secretariado de la Comisión para la Cooperación Ambiental conformada por representantes de los tres países miembros del Acuerdo de Cooperación Ambiental de América del Norte (del tratado de libre comercio de 1994). En este acuerdo - conocido comúnmente como "acuerdo paralelo ambiental"- se contemplan tres mecanismos para la presentación, discusión y resolución de los problemas ambientales. Uno de estos, consistente en la elaboración de informes por el secretariado para tratar los problemas que se presenten, según lo dispuesto en el artículo 13 del citado acuerdo, ha producido dos casos exitosos: el de la Presa de Silva (en la que se dio apoyo financiero y técnico para México, se procedió a la limpieza de la presa y a la declaración del lugar como zona protegida) y el del río San Pedro (en el que se propuso mayor apertura y participación de las comunidades de la región para la protección de la cuenca). ${ }^{36} \mathrm{Si}$ bien estos casos no se derivan de la aplicación de la parte contenciosa del mismo acuerdo, ambos nos enseñan la importancia que tienen la cooperación y voluntad de las partes en un marco de derecho internacional ambiental en el que existe un organismo formalmente creado — la Comisión para la Cooperación Ambiental— que responde a ciertas situaciones críticas.

\section{PRINCIPIOS FUNDAMENTALES}

DEL DERECHO INTERNACIONAL AMBIENTAL

Los llamados principios fundamentales del derecho internacional ambiental se erigen como verdaderas guías o parámetros jurídicos para la acción y comportamiento de las naciones. Es común encontrarlos en instrumentos internacionales soft law y de hecho la mayoría se agrupan en las llamadas declaraciones de principios; para nosotros las dos más importantes son la declaración de Estocolmo de 1972 y la declaración de Río de 1992. La importancia de contar con declaraciones de este tipo es que se generan, a decir de Kiss ${ }^{37}$ nuevos valores sociales que requieren

36 Vega Cánovas, Gustavo et al., México, Estados Unidos y el Canadá: resolución de controversias en la era post-TLCAN, México, UNAM, Instituto de Investigaciones Jurídicas-Programa Interinstitucional de Estudios sobre la Región de América del Norte, 2004, pp. 219-222.

37 Kiss, Alexandre Ch., Survey of Current Developments in International Environmental Law, Morges, IUCN Environmental Policy and Law Paper, núm. 10, 1976, pp. 26 y 27. 
Esta obra forma parte del acervo de la Biblioteca Jurídica Virtual del Instituto de Investigaciones Jurídicas de la UNAM

de reglas jurídicas para protegerlos. En el contexto de lo internacional ambiental esto puede traducirse en normas jurídicas internacionales de protección ambiental. De hecho, debido al rápido y creciente desarrollo que ha tenido esta rama del derecho es posible encontrarlos de manera precisa en instrumentos hard law.

Coincidimos con Juste Ruiz ${ }^{38}$ en que la problemática relacionada con la definición y naturaleza jurídica de estos principios no se ha resuelto; tampoco es intención hacerlo en este trabajo. Basta con mencionar (aunque sea bajo un criterio propio y por lo tanto subjetivo) los principios que creemos de mayor importancia para la enseñanza del derecho internacional ambiental en México: ${ }^{39}$

1) Principio de soberanía sobre los recursos naturales. Este principio conlleva la idea de que así como los Estados tienen el derecho soberano de aprovechar sus recursos, el ejercicio de este derecho no deberá dañar el ambiente (ni de otros Estados ni de zonas fuera de su jurisdicción nacional). Este principio ha sido considerado como la base del derecho internacional ambiental.

2) Principio de cooperación internacional para la protección ambiental. Se traduce en dos deberes. Primero, el deber general de concluir (aunque la obligatio negotiandi no supone una paralela obligatio concluendi) o implementar los objetivos de los tratados $\mathrm{u}$ otros instrumentos internacionales. Segundo, el deber específico de intercambiar información, notificación, consulta y participación en la toma de ciertas decisiones, de otorgar asistencia en casos de emergencia, promover investigación científica y tecnológica, elaborar programas de evaluación de impacto ambiental, etcétera.

3) Principio de prevención. Tiene también dos vertientes. La primera, que se traduce en la prevención del daño ambiental in genere, y la

38 Juste Ruiz, José, op. cit., nota 11, p. 69.

39 Para mayor detalle sobre cada uno de estos y otros principios internacionales ambientales se recomienda acudir a Hens, Luc, "The Rio Conference and Thereafter", en Nath, Bhaskar et al. (comps.), Sustainable Development, Bruselas, European Centre for Pollution Research-The Free University of Brussels-United Nations Educational, Scientific and Cultural Organisation-Vubpress, 1996, pp. 85 y 87; Juste Ruiz, José, op. cit., nota 11, pp. 69-89; Kiss, Alexandre Ch., op. cit., nota 37, pp. 30-39; Nava Escudero, César, op. cit., nota 23; Sands, Philippe, op. cit., nota 8, pp. XXX-XXXV, y Székely, Alberto y Ponce-Nava, Diana, op. cit., nota 31, pp. 306-333. 
Esta obra forma parte del acervo de la Biblioteca Jurídica Virtual del Instituto de Investigaciones Jurídicas de la UNAM

segunda, que se refiere a la prevención del daño ambiental transfronterizo. Este principio se basa en la idea de la diligencia debida, el uso equitativo de los recursos naturales, la buena fe y en general la buena vecindad. Lo que se busca es que se lleven acciones para evitar que ocurra un daño ambiental.

4) Principio de precaución. Aquí se hace referencia a la siguiente idea: cuando exista peligro de daño grave e irreversible, la falta de certeza científica absoluta no podrá invocarse por los Estados para no adoptar medidas de protección ambiental. Precaución no es lo mismo que prevención; aquélla implica medidas ambientales (preventivas) aun ante la incertidumbre científica, ésta implica medidas ambientales a partir de información científica existente.

5) Principio de responsabilidad y reparación de daño ambiental. Subyace en este principio la idea de que los Estados podrán ser responsables (por actos ilícitos) ante el incumplimiento o violación de la normativa internacional ambiental. Asimismo, podrán estar sujetos a la reparación (indemnización) de los daños causados o la contaminación producida. No obstante lo difícil que resulta aplicar esto en la práctica (y aún más si se tratara de responsabilidad y reparación de daños ambientales por actos lícitos), la comunidad internacional acordó incluirlo como principio ambiental.

6) Principio quien contamina paga. Vinculado a la ciencia económica, este principio significa que el causante de la contaminación habrá de internalizar (o asumir) los costos ambientales de los mecanismos de prevención y control de la misma contaminación que genera. Mucho se ha advertido que el efecto perverso de esta idea es que si el contaminador paga, entonces se produce a su favor un "derecho" a contaminar. La actualización de este principio deberá tomar en cuenta el interés público sin distorsionar el comercio ni las inversiones internacionales.

7) Principio de equidad intergeneracional. Consiste en el derecho al desarrollo que permita de manera equitativa satisfacer las necesidades de las generaciones presentes, sin comprometer la capacidad de las generaciones futuras para satisfacer sus propias necesidades. Este principio reproduce la definición elaborada por la Comisión Mundial sobre Medio Ambiente y Desarrollo de 1987 sobre el concepto de desarrollo sustentable. 
Esta obra forma parte del acervo de la Biblioteca Jurídica Virtual del Instituto de Investigaciones Jurídicas de la UNAM

8) Principio de equidad intrageneracional. Se trata aquí del derecho que tienen las generaciones presentes a beneficiarse de manera equitativa (todos) del aprovechamiento de los recursos naturales y a gozar (como derecho) de un medio ambiente limpio y saludable.

9) Principio de subsidiariedad. Consiste en que las decisiones ambientales habrán de provenir de las comunidades más afectadas, o bien, de las autoridades más cercanas a ellas. La idea es fortalecer la participación de comunidades o grupos locales, por lo que se prefieren las decisiones locales a las nacionales, así como las nacionales a las internacionales.

10) Principio de responsabilidades comunes pero diferenciadas. Contiene dos elementos fundamentales. Primero, se acepta la idea de la responsabilidad común que tienen todos los Estados para la protección ambiental. Segundo, se reconoce que los Estados por un lado han contribuido de manera diferenciada a los problemas ambientales y por el otro que tienen capacidades distintas para responder, prevenir, reducir o controlar la contaminación ambiental.

11) Principio de resolución pacifica de las controversias. Este principio busca establecer que los Estados deberán resolver todas sus controversias ambientales de manera pacífica y con los mecanismos apropiados para esto. Estas ideas descansan, desde luego, en lo que al respecto se establece en la Carta de las Naciones Unidas.

12) Principio de evaluación de impacto ambiental. Rescata la idea sobre la elaboración técnica de documentos de prevención por actividades realizadas que probablemente pudieran producir un impacto negativo considerable en el ambiente. Aunque este postulado se deriva de técnicas de derecho interno, la comunidad internacional reafirma su importancia e incita a su existencia en calidad de instrumento nacional.

\section{El CASO MEXicAno. TRATAdos ambientales Y ACUERDOS INTERINSTITUCIONALES AMBIENTALES}

El derecho interno en México denomina a los instrumentos internacionales de dos maneras: tratados y acuerdos interinstitucionales. Bajo estas dos categorías conceptuales se pueden enmarcar todos los instru- 
Esta obra forma parte del acervo de la Biblioteca Jurídica Virtual del Instituto de Investigaciones Jurídicas de la UNAM

mentos internacionales (tratados, protocolos, convenios, declaraciones, acuerdos, etcétera) en los que nuestro país ha intervenido en materia ambiental. Existen similitudes y diferencias entre ambas categorías, aquí presentamos las más relevantes: ${ }^{40}$

a) Ambos conceptos se rigen por el derecho internacional público, lo que se traduce en que los dos tienen el mismo valor jurídico frente a éste y por lo tanto al momento de celebrarlos se asumen compromisos para los Estados Unidos Mexicanos.

b) Las partes que intervienen en su celebración son diferentes. En los tratados, quien interviene es el gobierno de los Estados Unidos Mexicanos y lo hace en su calidad de sujeto de derecho internacional público (poseedor del jus tractati), y en los acuerdos interinstitucionales, quien interviene es cualquier dependencia u organismo descentralizado de la administración pública federal, estatal o municipal, y lo hacen en su calidad de instituciones (y no de sujetos de derecho internacional público) con la competencia para pactar en nombre de los Estados Unidos Mexicanos.

c) Tratados y acuerdos interinstitucionales deben celebrarse por escrito y pueden recibir cualquier denominación. En principio, éstos pueden tener naturaleza soft o hard, aunque aquéllos generalmente son de naturaleza hard.

d) Aunque nuestro derecho interno regula la existencia de ambos, los tratados tienen fundamento constitucional y los acuerdos interinstitucionales no. Estos últimos son creados por ley del Congreso de la Unión: la Ley sobre la Celebración de Tratados.

e) Por lo anterior, los tratados siguen un procedimiento constitucional para su celebración, mientras que los acuerdos interinstitucionales no.

f) En este procedimiento, los tratados requieren forzosamente de la aprobación del Senado, los acuerdos interinstitucionales no.

40 Esta clasificación sigue en mucho la comparación que hace Palacios Treviño, Jorge, Tratados. Legislación y práctica en México, 3a. ed., México, Secretaría de Relaciones Exteriores, 2001, entre ambos instrumentos. Este autor tiene como guía lo establecido en la Ley sobre la Celebración de Tratados de 1992, remitimos a su obra para mayor abundamiento. 
Esta obra forma parte del acervo de la Biblioteca Jurídica Virtual del Instituto de Investigaciones Jurídicas de la UNAM

g) Los tratados son considerados por la Constitución como ley suprema de toda la unión (artículo 133), pero los acuerdos interinstitucionales no.

h) Los tratados deben estar de acuerdo con la Constitución, es decir, no deben ir ni en contra ni más allá de nuestra carta magna. Aunque ni la Constitución ni la citada Ley sobre la Celebración de Tratados señale expresamente que los acuerdos interinstitucionales tengan esta misma suerte, éstos también deberán estar acorde con ella.

i) La entrada en vigor de un tratado se somete a todo un procedimiento donde es posible distinguir una entrada en vigor internacional y otra nacional. Para el caso de los acuerdos interinstitucionales, éstos entrarán en vigor en el momento mismo de su firma.

j) Para que los tratados sean obligatorios en el territorio nacional deberán haberse publicado previamente en el Diario Oficial de la Federación. No existe disposición alguna que señale que para la entrada en vigor o para que sean obligatorios los acuerdos interinstitucionales deban publicarse en el Diario Oficial de la Federación.

k) La Secretaría de Relaciones Exteriores interviene para determinar en ambos casos la procedencia de su suscripción: para los tratados formulará una opinión y para los acuerdos interinstitucionales un dictamen. Una vez suscritos, tanto tratados como acuerdos interinstitucionales serán inscritos en el registro correspondiente a cargo de la propia secretaría.

\section{Tratados ambientales}

El origen de los tratados ambientales en México sigue en mucho el procedimiento requerido para la celebración de cualquier otro tratado en este país. La normativa interna aplicable se encuentra en la Constitución Política de los Estados Unidos Mexicanos, ${ }^{41}$ en tres artículos de donde también se desprende la base para su celebración. En primer término, el artículo 89 , fracción $\mathrm{X}$, que señala:

Artículo 89. Las facultades y obligaciones del presidente son las siguientes: $\mathrm{X}$. Dirigir la política exterior y celebrar tratados internacionales, some-

41 Constitución Politica de los Estados Unidos Mexicanos, 145a. ed., rev. y act. por Miguel Carbonell, México, Porrúa, 2003. 
Esta obra forma parte del acervo de la Biblioteca Jurídica Virtual del Instituto de Investigaciones Jurídicas de la UNAM

tiéndolos a la aprobación del Senado. En la conducción de tal política, el titular del Poder Ejecutivo observará los siguientes principios normativos: la autodeterminación de los pueblos; la no intervención; la solución pacífica de controversias; la proscripción de la amenaza o el uso de la fuerza en las relaciones internacionales; la igualdad jurídica de los Estados; la cooperación internacional para el desarrollo; y la lucha por la paz y la seguridad internacionales.

Si bien no hay mención expresa a lo ambiental, es fácil detectar el eco que algunos de estos principios normativos con rango constitucional encuentran en la normativa soft y hard de lo internacional ambiental, según lo hemos descrito anteriormente.

En segundo término, complementa a esta disposición constitucional el artículo 76, fracción I, que establece lo siguiente:

Artículo 76. Son facultades exclusivas del Senado:

I. Analizar la política exterior desarrollada por el Ejecutivo Federal... además, aprobar los tratados internacionales y convenciones diplomáticas que celebre el Ejecutivo de la Unión.

Esta disposición constitucional reafirma la intervención del Senado a través de la aprobación de los tratados internacionales - hacemos hincapié en lo siguiente: el Senado aprueba pero no ratifica, como todavía suele confundirse - . La otra expresión — convenciones diplomáticasno sólo es imprecisa sino poco afortunada, pues no es común observarla al menos en el marco de lo internacional ambiental de nuestro país. Nos comenta don César Sepúlveda, ${ }^{42}$ al respecto, que en realidad existe una pequeña falla de redacción en esta fracción, puesto que tanto los tratados como las convenciones son internacionales y al hablar de "diplomáticas" el texto constitucional introduce un elemento de confusión.

Por último, se señala el artículo 133 que establece lo siguiente:

Artículo 133. Esta Constitución, las leyes del Congreso de la Unión que emanen de ella y todos los tratados que estén de acuerdo con la misma, celebrados y que se celebren por el presidente de la República, con aprobación del Senado, serán la ley suprema de toda la unión. Los jueces de cada Estado se arreglarán a dicha Constitución, leyes y tratados, a pesar

42 Sepúlveda, César, op. cit., nota 7, p. 135. 
Esta obra forma parte del acervo de la Biblioteca Jurídica Virtual del Instituto de Investigaciones Jurídicas de la UNAM

de las disposiciones en contrario que pueda haber en las Constituciones o leyes de los Estados.

Los tratados ambientales celebrados forman parte del ordenamiento jurídico nacional y son de observancia obligada para el Estado mexicano, si bien están por debajo de la Constitución, jerárquicamente hablando. En este contexto, es imprescindible tener presente una tesis jurisprudencial de la Suprema Corte de Justicia de la Nación de 1999 que determinó que los tratados "se encuentran en un segundo plano inmediatamente debajo de la ley fundamental [sólo la Constitución es la Ley Suprema] y por encima del derecho federal y el local [por lo que los] compromisos internacionales son asumidos por el Estado mexicano en su conjunto y comprometen a todas sus autoridades frente a la comunidad internacional". ${ }^{43}$

En nuestro derecho interno no existe un instrumento jurídico que de manera coherente y sistemática permita conocer los criterios o las etapas del procedimiento para la celebración de un tratado ambiental. Sin embargo, existen algunas disposiciones legales que ayudan a delimitar la participación que se da al interior del Ejecutivo Federal, como lo son las contenidas en la Ley sobre la Celebración de Tratados de 1992, en la Ley Orgánica de la Administración Pública Federal de 1976 o en los reglamentos interiores vigentes de la Secretaría de Relaciones Exteriores y de la Secretaría de Medio Ambiente y Recursos Naturales. Desde luego, conviene también acudir a la Convención de Viena sobre el Derecho de los Tratados (de la que México es parte) para conocer sobre este tema en particular.

En materia ambiental, se parte de la idea de que corresponde a la Secretaría de Medio Ambiente y Recursos Naturales intervenir en foros internacionales ambientales, con la participación que corresponda a la Secretaría de Relaciones Exteriores, y proponer a ésta la celebración de tratados y acuerdos internacionales en la materia, según se establece en el artículo 32 bis, fracción IX, de la Ley Orgánica de la Administración Pública Federal. Asimismo, corresponde a la cancillería mexicana intervenir en toda clase de tratados, acuerdos y convenciones en los que el país sea parte, como lo señala el artículo 28, fracción I, de la Ley Orgánica de la Administración Pública Federal. Respetando el ejercicio de

43 Tesis P. LXXVII-99, Semanario Judicial de la Federación y su Gaceta, Nóvena Época, t. X, noviembre de 1999, p. 46. 
Esta obra forma parte del acervo de la Biblioteca Jurídica Virtual del Instituto de Investigaciones Jurídicas de la UNAM

las atribuciones de cada dependencia (incluyendo a la de medio ambiente y recursos naturales), la propia Secretaría de Relaciones Exteriores ha intentado emitir guías o lineamientos para la celebración de tratados in genere, pero no han sido definitivos. Recordamos, por ejemplo, la Guía para la conclusión de tratados y acuerdos interinstitucionales en el ámbito internacional según la Ley sobre la Celebración de Tratados elaborada en 1999 por tal dependencia a cargo de la entonces canciller Rosario Green. ${ }^{44}$ Dicho documento se publicó con el propósito de proporcionar a dependencias y organismos descentralizados de la administración pública federal, estatal o municipal, criterios adicionales para determinar si un asunto debe ser materia de un tratado o de un acuerdo interinstitucional. Otro ejemplo más reciente lo constituye un oficio enviado por la cancillería a la propia Secretaría de Medio Ambiente y Recursos Naturales en la que se determinan algunos aspectos relacionados con el procedimiento para la celebración de tratados. En efecto, el 27 de agosto de 2002, el consultor jurídico de la Secretaría de Relaciones Exteriores, mediante oficio CJA-3779, dio a conocer criterios importantes para iniciar y llevar a cabo los trámites correspondientes para la celebración de tratados. ${ }^{45}$

Sin que sea un rígido procedimiento a seguir, el Ejecutivo Federal lleva a cabo ciertas etapas después de concluidas las negociaciones respectivas para la celebración de un tratado y su entrada en vigor.

Aquí seguimos el ejemplo para un tratado multilateral: $a$ ) adopción del texto (y forma) del tratado; $b$ ) firma ad referéndum (que en realidad hace alusión a la firma a reserva de ratificación $)^{46}$ por la que los Estados Unidos Mexicanos hacen constar que su consentimiento en obligarse por un

44 Secretaría de Relaciones Exteriores, Guía para la conclusión de tratados y acuerdos interinstitucionales en el ámbito internacional según la Ley sobre la Celebración de Tratados, México, Secretaría de Relaciones Exteriores, 1999.

45 Deben existir en los archivos de la Unidad Coordinadora de Asuntos Internacionales y en los de la Coordinación General Jurídica, unidades administrativas de la Secretaría de Medio Ambiente y Recursos Naturales, original y copias del oficio que aquí se menciona.

46 En este sentido, nos aclara Jorge Palacios Treviño: "De conformidad con lo que disponen el artículo 12, 2, b) y el artículo 14, 1, d) de la Convención de 1969 son dos cosas diferentes pues la firma ad referéndum equivale a la firma definitiva si el Estado la confirma, es decir, tiene efectos retroactivos, lo cual es distinto de la firma a reserva de ratificación, que es como en México se debiera llamar a la firma llamada ad referéndum, ya que cuando México firma un tratado lo hace a reserva de ratificarlo después de que se han cumplido los trámites que señala la Constitución. La firma ad referéndum y la 
Esta obra forma parte del acervo de la Biblioteca Jurídica Virtual del Instituto de Investigaciones Jurídicas de la UNAM

tratado requiere, para ser definitivo, de su posterior ratificación; c) aprobación por el Senado de la República; $d$ ) publicación de dicha aprobación en el Diario Oficial de la Federación (no se publica el texto completo del tratado); e) elaboración del instrumento de ratificación o de adhesión por el Ejecutivo Federal; la ratificación o adhesión se considera el acto por el cual los Estados Unidos Mexicanos hacen constar en el ámbito internacional su consentimiento en obligarse por un tratado; $f$ ) depósito del instrumento de ratificación o adhesión en el organismo o gobierno designado como depositario del tratado; $g$ ) aviso que da el depositario de la fecha de entrada en vigor internacional, y $h$ ) promulgación y publicación en el Diario Oficial de la Federación (texto completo del tratado), para su entrada en vigor nacional.

Es importante señalar que tanto para tratados bilaterales, regionales o multilaterales existe una entrada en vigor internacional y otra nacional. En efecto, un tratado comienza a obligar internacionalmente desde el momento en que éste se ratifica, siempre y cuando el propio tratado no señale una fecha posterior a la ratificación para su entrada en vigor. ${ }^{47} \mathrm{La}$ gran mayoría de los tratados ambientales de los últimos años han señalado cuándo habrán de entrar en vigor internacionalmente, que es generalmente cuando hayan pasado cierto número de días contados desde la fecha en que se haya depositado un número determinado de instrumentos de ratificación, aceptación, aprobación o adhesión; ${ }^{48}$ sin embargo, en lo interno, ese mismo tratado sólo puede ser obligatorio cuando se promulga y publica (su texto completo) en el Diario Oficial de la Federación, como lo dispone el párrafo segundo del artículo 4o. de la Ley sobre la Celebración de Tratados. Es lógico suponer, por lo tanto, que el Ejecutivo Federal deberá estar atento para promulgar y publicar en el Diario Oficial de la Federación el texto completo de un tratado en la misma fecha de su

ratificación son dos maneras distintas de manifestar el consentimiento de un Estado en obligarse por un tratado" (op. cit., nota 40, p. 116).

47 Ibidem, p. 101.

48 Algunos ejemplos incluyen a la Convención Marco de las Naciones Unidas sobre el Cambio Climático (Diario Oficial de la Federación del 7 de mayo de 1993), el Convenio sobre la Diversidad Biológica (Diario Oficial de la Federación del 7 de mayo de 1993), el Protocolo de Cartagena sobre Seguridad de la Biotecnología del Convenio sobre la Diversidad Biológica (Diario Oficial de la Federación del 28 de octubre de 2003), el Convenio de Estocolmo sobre Contaminantes Orgánicos Persistentes (Diario Oficial de la Federación de 17 de mayo de 2004). 
Esta obra forma parte del acervo de la Biblioteca Jurídica Virtual del Instituto de Investigaciones Jurídicas de la UNAM

entrada en vigor en el ámbito internacional. Lo anterior, con el objeto de evitar que se exija a nivel internacional el cumplimiento de un tratado en vigor internacionalmente y no poder cumplir por no haberse publicado y por tanto no ser obligatorio en el ámbito interno, y viceversa, que a nivel interno surja la exigencia del cumplimiento de un tratado porque ya fue promulgado y publicado en el Diario Oficial de la Federación, y por tanto es obligatorio, pero que no puede exigirse su cumplimiento a alguna de las partes contratantes por no haber entrado en vigor internacionalmente.

En materia ambiental existen dos casos muy curiosos en los que el Ejecutivo Federal no siguió ninguno de los criterios arriba señalados. El primero de éstos es el Protocolo de Kyoto de la Convención Marco de las Naciones Unidas sobre el Cambio Climático. El decreto promulgatorio (texto completo) fue publicado en el Diario Oficial de la Federación el 24 de noviembre de 2000 (últimos días del sexenio del ex presidente Ernesto Zedillo Ponce de León) sin que el protocolo mencionado hubiera entrado en vigor internacionalmente. Como es sabido, el protocolo de Kyoto entró en vigor internacionalmente el 16 de febrero de 2005. El segundo caso lo constituye el Protocolo de Cartagena sobre Seguridad de la Biotecnología del Convenio sobre la Diversidad Biológica. Aquí, lo que sucedió fue exactamente al revés: el protocolo entró en vigor internacionalmente el 11 de septiembre de 2003, pero el Ejecutivo Federal (ya como su titular el presidente constitucional Vicente Fox Quesada) no lo promulgó y publicó sino hasta el 28 de octubre de ese mismo año.

\section{Acuerdos interinstitucionales ambientales}

Como hemos visto, es la Secretaría de Medio Ambiente y Recursos Naturales la que interviene para su celebración. Corresponde al titular del ramo suscribir estos instrumentos internacionales como una de sus muchas facultades indelegables, en el ámbito de su competencia y en coordinación con la Secretaría de Relaciones Exteriores. Desde luego, el secretario de Estado en turno podrá designar a un funcionario subalterno para que en su nombre y en representación de la secretaría suscriba dichos instrumentos. Para esto, deberá elaborar un "oficio designatorio" (al que erróneamente también se le conoce como "oficio delegatorio") donde se le autorice la realización de dicho acto. En todo momento, la Secretaría de Medio Ambiente y Recursos Naturales deberá mantener 
Esta obra forma parte del acervo de la Biblioteca Jurídica Virtual del Instituto de Investigaciones Jurídicas de la UNAM

informada a su similar de relaciones exteriores acerca de cualquier acuerdo interinstitucional que pretenda celebrar, quien a su vez formulará el dictamen correspondiente sobre la procedencia de suscribirlo y cumplir así con lo establecido en el artículo 7o. de la Ley sobre la Celebración de Tratados.

Desafortunadamente, el hecho de que estos instrumentos no se publiquen en el Diario Oficial de la Federación provoca el desconocimiento e incertidumbre de la población respecto a los compromisos internacionales que adquieren los Estados Unidos Mexicanos a través de la Secretaría de Medio Ambiente y Recursos Naturales. Es un grave error pensar que sólo los tratados ambientales representan compromisos internacionales relevantes para el país. En efecto, estos acuerdos interinstitucionales tienen diversos objetos como la cooperación científica, técnica o educativa, o bien la adquisición de compromisos de tipo financiero de la mayor importancia. Es el caso de los llamados convenios de donación (donativos provenientes de los comúnmente denominados Fondos GEF Global Environment Fund) que se celebran entre la Secretaría de Medio Ambiente y Recursos Naturales y el Banco Mundial para financiar diversos proyectos, y que en ocasiones participan de manera conjunta otros gobiernos u organismos internacionales. Un ejemplo de lo anterior lo constituye el convenio TF-027739 celebrado entre el gobierno de los Estados Unidos Mexicanos (por conducto de la Secretaría de Medio Ambiente y Recursos Naturales), la Comisión Centroamericana de Ambiente y Desarrollo, la República de Guatemala, Belice, la República de Honduras y el Banco Mundial, por la que habrían de destinarse donativos a favor de dicha comisión centroamericana para ejecutar un proyecto para la conservación y uso sustentable del Sistema Arrecifal Mesoamericano. ${ }^{49}$

\section{CONCLUSIONES}

Uno de los principales retos que tenemos los catedráticos de derecho ambiental en México es el de convencer a autoridades universitarias e interesar a huestes estudiantiles sobre la trascendencia del derecho internacional ambiental para las relaciones de las naciones en la protección del ambiente y control y prevención de la contaminación ambiental. Si

49 Debe obrar en los archivos de la Coordinación General Jurídica de la Secretaría de Medio Ambiente y Recursos Naturales copia de este convenio. 
Esta obra forma parte del acervo de la Biblioteca Jurídica Virtual del Instituto de Investigaciones Jurídicas de la UNAM

enfrentáramos con éxito este reto lograríamos probablemente más espacios para su enseñanza y seguramente más adeptos para su estudio.

Esta tarea no es fácil por varias razones. Primero, porque la consolidación de los cursos sobre derecho ambiental (o afines a él) donde podrían abordarse los aspectos internacionales, no es todavía una realidad en el país. La materia de derecho ambiental apenas y sobrevive a nivel licenciatura (abarcando un semestre) y casi es nula a nivel posgrado, aunque con sus muy honrosas excepciones. Tenemos que conformarnos (y suplicar) por que los catedráticos de la materia de derecho internacional incluyan en sus cursos los temas ambientales. Segundo, porque tanto en lo interno como en lo externo se da mayor importancia a temas no ambientales. En lo interno, son muchas las hojas de papel utilizadas en periódicos y muchas las horas habladas por la radio y proyectadas por la televisión que dedican los medios de comunicación a temas no ambientales. En lo externo, los reprobables sucesos bélicos al comenzar el segundo milenio han acaparado la atención de gobiernos, universidades, pueblos y medios de comunicación. Las injustas y cobardes invasiones orquestadas por Estados Unidos de América (y apoyadas por algunos de sus más cercanos aliados) en octubre de 2001 a Afganistán y en marzo de 2003 a Irak, han distraído la atención mundial de temas ambientales, como sucedió con la opacada Cumbre Mundial sobre el Desarrollo Sostenible celebrada en Johannesburgo, Sudáfrica, en 2002. Tercero, porque los docentes mexicanos tenemos que lidiar con un asunto elemental: la delirante escasez de trabajos jurídicos sobre temas internacionales ambientales que sirvan de base para una enseñanza acorde a las exigencias de una excelencia académica de primer nivel. Es por esta última razón que hemos intentado elaborar una guía mínima que permita acercarnos a algunos de los aspectos más importantes que deben incluirse en la enseñanza de la parte internacional del derecho ambiental.

Utilizamos aquí la expresión derecho internacional ambiental en vez de derecho ambiental internacional porque permite tener como punto de arranque una disciplina jurídica —el derecho internacional- bastante consolidada para analizar un tema en particular: todo lo relativo al ambiente. De aquí que podamos definir al derecho internacional ambiental como un conjunto de normas que regulan las relaciones internacionales (entre Estados y organizaciones internacionales) que tienen como objeto la protección ambiental y el control o prevención de la contaminación 
Esta obra forma parte del acervo de la Biblioteca Jurídica Virtual del Instituto de Investigaciones Jurídicas de la UNAM

ambiental. Esto no obstruye de manera alguna que podamos referirnos ahora o en el futuro a la existencia de un derecho ambiental internacional, al que habremos de definir como una rama del derecho ambiental que regula la protección ambiental y el control o prevención de la contaminación ambiental entre Estados y organizaciones internacionales en el marco de un conjunto de normas internacionales (tratados, protocolos, convenciones, declaraciones, etcétera).

Si bien el derecho internacional ambiental se consolida recientemente, su enseñanza permite ya una referencia tanto de tipo normativo como científico. La normatividad ambiental reviste las características propias de cualquier instrumento internacional por ser vinculante (hard law) y/o no vinculante (soft law). Aunque existen formas para verificar el cumplimiento de las normas ambientales y de solucionar las controversias a través de medios políticos (por ejemplo, negociación, mediación, conciliación) o medios jurisdiccionales (por ejemplo, arbitraje, arreglos judiciales), el éxito de la normativa ambiental descansa en la voluntad de los Estados. Los llamados principios fundamentales del derecho internacional ambiental siguen siendo la verdadera guía del actuar de las naciones.

Los Estados Unidos Mexicanos han celebrado un sinnúmero de instrumentos internacionales ambientales que, para fines de su derecho interno, los clasifica en tratados y acuerdos interinstitucionales (ambientales). Son pocas las obras que han tratado de elaborar una lista de los tratados ambientales en los que México es parte sin que exista en realidad un criterio para determinarlos. Hace algunos años fue publicada una obra intitulada Grado de cumplimiento de los tratados ambientales internacionales por parte de la República de México a 1999 en la que identifica al menos 63 tratados..$^{50}$ Más recientemente, la Secretaría de Gobernación publicó la Guía de tratados promulgados y otros instrumentos internacionales vigentes suscritos por México, en la que se identifican al menos 100 tratados bajo una clasificación gubernamental de temas ambientales (incluidos los relacionados con derecho del mar y derecho marítimo) de 1970 a $2000 .{ }^{51}$ Cualquiera que sea la clasificación o el número, lo cierto

50 Centro Mexicano de Derecho Ambiental, Grado de cumplimiento de los tratados ambientales internacionales por parte de la República de México a 1999, México, IDEADS, 2000.

51 Secretaría de Gobernación, Guía de tratados promulgados y otros instrumentos internacionales vigentes suscritos por México, México, Secretaría de Gobernación, 2003. 
Esta obra forma parte del acervo de la Biblioteca Jurídica Virtual del Instituto de Investigaciones Jurídicas de la UNAM

es que México participa activamente en la celebración de tratados ambientales. Si es difícil tener un listado sobre éstos, más lo es la de los acuerdos interinstitucionales ambientales que no se publican en el Diario Oficial de la Federación.

Esperamos fervientemente que estas líneas sobre el contenido en la enseñanza del derecho internacional ambiental sean de utilidad. La docencia no es sólo impartir clases con vocación, conlleva una buena dosis de experiencia práctica y asidua investigación, la determinación de un bloque de conocimientos basados en teoría y práctica y la férrea convicción de que en las universidades se siembran semillas en el alumnado que tarde o temprano habrán de germinar. 
Esta obra forma parte del acervo de la Biblioteca Jurídica Virtual del Instituto de Investigaciones Jurídicas de la UNAM

\section{LOS ACUERDOS INTERINSTITUCIONALES AMBIENTALES*}

\section{INTRODUCCIÓN}

Existen dos tipos de instrumentos internacionales que puede celebrar nuestro país en materia ambiental: los tratados internacionales y los acuerdos interinstitucionales. En aquéllos interviene el gobierno de los Estados Unidos Mexicanos y en éstos cualquier dependencia u organismo descentralizado de la administración pública federal, estatal o municipal ambiental; sin embargo, y aun cuando ambos tienen el mismo valor jurídico frente al derecho internacional público (y por lo tanto al momento de su celebración se asumen compromisos para México) sólo los tratados tienen fundamento en nuestra Constitución. Aunque subsiste la discusión sobre la inconstitucionalidad de los acuerdos interinstitucionales por este solo hecho, dichos acuerdos se han convertido para las autoridades ambientales en verdaderos mecanismos que facilitan y permiten actualizar muchas de las atribuciones que les han sido otorgadas por diversos ordenamientos ambientales. Su presencia y uso jurídicos son ya innegables.

Este breve ensayo tiene por objeto examinar algunos de los puntos más debatibles respecto al fundamento jurídico, naturaleza jurídica, características propias y aspectos de constitucionalidad de los acuerdos interinstitucionales en un marco de análisis ambiental federal. Nos enfocamos al estudio de aquellos instrumentos internacionales que celebra la Secretaría de Medio Ambiente y Recursos Naturales (Semarnat) como autoridad federal competente en materia ambiental.

* Publicado en Derecho Ambiental y Ecología, año 2, número 12, abril-mayo de 2006. 
Esta obra forma parte del acervo de la Biblioteca Jurídica Virtual del Instituto de Investigaciones Jurídicas de la UNAM

\section{REFLEXIÓN PRIMERA: FUNDAMENTO JURÍDICO}

Partimos de la idea de que corresponde a la Semarnat intervenir en la celebración de los acuerdos interinstitucionales en materia ambiental. El fundamento jurídico para ello se desprende de una lectura adminiculada de diversas disposiciones de nuestra legislación debido a que no existe disposición constitucional alguna que así lo señale de manera expresa.

La primera de estas disposiciones se encuentra en la Ley sobre la Celebración de Tratados que señala en su artículo 1o. que los acuerdos interinstitucionales sólo podrán celebrarse entre una dependencia de la administración pública federal (entre otras) y uno o varios órganos gubernamentales extranjeros $\mathrm{u}$ organizaciones internacionales. La propia ley acude al ámbito material de los acuerdos para delimitar claramente cuándo podrá intervenir cada una de las dependencias (o en su caso entidades) gubernamentales. La última parte de la fracción II del artículo 20. de esta ley establece: "El ámbito material de los acuerdos interinstitucionales deberá circunscribirse exclusivamente a las atribuciones propias de las dependencias y organismos descentralizados de los niveles de gobierno mencionados que los suscriben".

Entonces, la Semarnat (o sus organismos públicos descentralizados) podrá celebrar aquellos acuerdos interinstitucionales que exclusivamente se refieran a las atribuciones que le hayan sido asignadas. En el caso de la secretaría mencionada, estas atribuciones - o lo que hace ambiental a un acuerdo de este tipo - se encuentran señaladas en la Ley Orgánica de la Administración Pública Federal en su artículo 32-bis, así como en otras leyes del Congreso de la Unión que otorguen funciones a la misma. ${ }^{1}$

En segundo lugar, se acude a la fracción IX del artículo 32-bis de la ya citada Ley Orgánica de la Administración Pública Federal en la que se señala que corresponde a la Semanat intervenir en foros internacionales de su competencia (es decir los ambientales), con la participación que desde luego corresponda a la Secretaría de Relaciones Exteriores (SRE) y proponer a ésta la celebración de acuerdos internacionales. Esta disposición debe leerse en conjunto con lo que dispone el artículo 7o. de la Ley sobre la Celebración de Tratados en tanto que dicho artículo establece que las dependencias de la administración pública federal deberán man-

1 Para los organismos públicos descentralizados será lo que al respecto señalen sus leyes orgánicas o sus decretos presidenciales de creación según sea el caso. 
Esta obra forma parte del acervo de la Biblioteca Jurídica Virtual del Instituto de Investigaciones Jurídicas de la UNAM

tener informada a la SRE sobre cualquier acuerdo interinstitucional que pretenda celebrarse. Es la propia SRE quien determina sobre la procedencia de su suscripción por lo que para tal efecto elaborará el dictamen correspondiente.

En tercer lugar, señalamos el Reglamento Interior de la Semarnat. En este ordenamiento jurídico se determina que corresponde al titular de la secretaría suscribir este tipo de acuerdos en el ámbito de su competencia y en coordinación con la SRE. Señala la fracción VIII del artículo 5o. del reglamento lo siguiente:

Artículo 5. El secretario tendrá las facultades indelegables siguientes:

VIII. Suscribir, en el ámbito de su competencia y en coordinación con la Secretaría de Relaciones Exteriores, de conformidad con la legislación aplicable, los instrumentos internacionales a formalizarse con gobiernos extranjeros u organismos internacionales

Aunque dicha intervención se trate de una de las muchas facultades indelegables del secretario en turno, éste podrá designar a un funcionario subalterno para que en su nombre y en representación de la secretaría, los suscriba. Para ello, se deberá elaborar un "oficio designatorio" (al que en ocasiones se le conoce erróneamente como "oficio delegatorio") donde se autorice la realización de tal acto a alguno de sus subsecretarios (subsecretarios de planeación y política ambiental, de fomento y normatividad ambiental o de gestión para la protección ambiental), o a alguno de los titulares de sus órganos desconcentrados (como podrían ser el director general de la Comisión Nacional del Agua, el presidente de la Comisión Nacional de Áreas Naturales Protegidas, el procurador federal de protección al ambiente o el presidente del Instituto Nacional de Ecología, entre otros).

Por último, es importante señalar que al no existir disposición constitucional expresa sobre los acuerdos interinstitucionales (ambientales), su fundamento jurídico es exclusivamente legal, tal y como sucede con el de muchas otras figuras de carácter federal en nuestro derecho interno (i. e. misceláneas fiscales, circulares, normas oficiales mexicanas, etcétera). 
Esta obra forma parte del acervo de la Biblioteca Jurídica Virtual del Instituto de Investigaciones Jurídicas de la UNAM

\section{REFLEXIÓN SEGUNDA: CARACTERÍSTICAS}

Los acuerdos interinstitucionales ambientales tienen características que les son propias y que los diferencian (y a la vez asemejan) de los otros instrumentos internacionales que existen en nuestro derecho interno, i. e. los tratados ambientales. Las características más importantes de estos acuerdos son las siguientes: ${ }^{2}$

1) Interviene como parte mexicana para su suscripción la Semarnat como dependencia de la administración pública federal (y desde luego cualquiera de sus dos organismos públicos descentralizados: el Instituto Mexicano de Tecnología del Agua o la Comisión Nacional Forestal). Como señala Palacios Treviño, ${ }^{3}$ esta participación la realiza no en calidad de sujeto de derecho internacional público (pues no posee el jus tractati) sino con la competencia para pactar en nombre de los Estados Unidos Mexicanos. Las contrapartes mexicanas pueden ser uno o varios órganos gubernamentales extranjeros u organizaciones internacionales. Han sido los casos, por ejemplo, del Banco Mundial para la celebración de convenios de donación (donativos provenientes de los llamados Fondos GEF Global Environment Fund); del Programa de las Naciones Unidas para el Medio Ambiente para un sinnúmero de fines ambientales, o de la Oficina Regional para Mesoamérica de la Unión Internacional para la Conservación de la Naturaleza para la realización de proyectos conjuntos ambientales. Desde luego, pueden intervenir partes que quizá no tengan presencia a nivel internacional pero que sí la tengan a nivel regional, nacional o local y cuya participación y objeto de acuerdo no sean por ello menos importantes. Estas han sido, por ejemplo, la Oficina de Áreas Protegidas del Ministerio de Recursos Naturales, Ambientales e Industria de Belice; el Departamento de Parques y Vida Silvestre del estado de Texas en los Estados Unidos

2 Nos basamos en algunas de las reflexiones vertidas en un artículo arbitrado y publicado con anterioridad. Véase Nava Escudero, César, "Guía mínima para la enseñanza del derecho internacional ambiental en México", Boletín Mexicano de Derecho Comparado, México, nueva serie, año XXXVIII, núm. 113, mayo-agosto de 2005, pp. 815-844.

3 Véase Palacios Treviño, Jorge, Tratados. Legislación y práctica en México, 3a. ed., México, Secretaría de Relaciones Exteriores, 2001, p. 68. 
Esta obra forma parte del acervo de la Biblioteca Jurídica Virtual del Instituto de Investigaciones Jurídicas de la UNAM

de América o el Ministerio de Ciencia, Tecnología y Medio Ambiente de la República de Cuba.

2) Son instrumentos jurídicos que se rigen por el derecho internacional público y por lo tanto son válidos frente a éste. Al momento que la Semarnat los celebra, se asumen compromisos (incluso para casos de incumplimiento y por tanto de responsabilidad) para los Estados Unidos Mexicanos. Dichos compromisos pueden o no ser jurídicamente vinculantes según se establezcan en acuerdos interinstitucionales de naturaleza hard o derecho duro, o de naturaleza soft o derecho suave, respectivamente.

3) Mucho se ha insistido en que los acuerdos interinstitucionales -incluyendo desde luego a los ambientales - deben versar sobre temas poco trascendentes porque de lo contrario deberá celebrarse un tratado. De hecho, se ha interpretado que precisamente al carecer de aprobación senatorial y por lo tanto de categoría de ley suprema de toda la unión estos acuerdos no podrán referirse a materias de importancia. ${ }^{4}$ La propia exposición de motivos de la Ley sobre la Celebración de Tratados presentada ante el Senado en 1991, no sólo reafirma la idea de que los acuerdos no requieren ser sometidos a la aprobación del Senado (pues no son ley suprema de la nación) sino que se refiere a ellos sólo como fenómenos jurídicos que buscan mayor cooperación entre órganos gubernamentales con responsabilidades similares en sus respectivos gobiernos. ${ }^{5}$ Sin embargo, y como bien se ha advertido, la falta de claridad sobre cuándo un asunto debe considerarse materia de un acuerdo y cuándo un tratado ha llevado a la situación de que se celebren acuerdos interinstitucionales de la mayor trascendencia. ${ }^{6}$ Aunque la propia SRE habría expedido una guía para aclarar esta situación a través del establecimiento de criterios administrativos, ${ }^{7}$ lo cierto es que en materia ambiental existen acuerdos interinstitucionales de primerí-

4 Ibidem, p. 64.

5 Véase la exposición de motivos de la Ley sobre la Celebración de Tratados publicada en el Diario de los Debates de la Cámara de Senadores del Congreso de los Estados Unidos Mexicanos, número 20, de 6 de diciembre de 1991.

6 Palacios Treviño, Jorge, op. cit., nota 3, p. 64.

7 Secretaría de Relaciones Exteriores, Guía para la conclusión de tratados y acuerdos interinstitucionales en el ámbito internacional según la Ley sobre la Celebración de Tratados, México, Secretaría de Relaciones Exteriores, 1999. 
Esta obra forma parte del acervo de la Biblioteca Jurídica Virtual del Instituto de Investigaciones Jurídicas de la UNAM

simo orden que afectan no sólo al territorio nacional involucrando a toda la nación, sino que podrían afectar la esfera jurídica de los individuos. Veamos un ejemplo: ¿acaso se negaría la trascendencia $\mathrm{y}$ efectos que tienen los diversos compromisos que se adquieren con otras instituciones extranjeras en materia de cambio climático para el desarrollo e instrumentación de proyectos de reducción y captura de emisiones de gases de efecto invernadero en los Estados Unidos Mexicanos, siendo que nuestro país está entre los primeros en América Latina en la emisión de estos gases (tanto en volumen como per cápita) y cuya viabilidad podrá tener un efecto en toda la nación y más allá de sus fronteras? México seguramente seguirá suscribiendo instrumentos sobre una misma materia a veces a través de tratados internacionales (como en el caso del Acuerdo entre el gobierno de los Estados Unidos Mexicanos y el gobierno de la República Francesa sobre el Mecanismo de Desarrollo Limpio, en el marco del artículo 12 del Protocolo de Kyoto de la Convención Marco de las Naciones Unidas sobre el Cambio Climático publicado en el Diario Oficial de la Federación el 30 de junio de 2005) y a veces a través de acuerdos interinstitucionales (como en el caso del memorandum de entendimiento entre la Secretaría de Medio Ambiente y Recursos Naturales de nuestro país y el Ministerio de Medio Ambiente del Reino de España para la cooperación en el marco del mecanismo de desarrollo limpio dentro del ya mencionado artículo 12 del protocolo de Kyoto).

4) Cualquiera puede ser su denominación. Así, han trascendido las negociaciones internacionales ambientales para la celebración de acuerdos denominados memorandum de entendimiento (i.e. para la cooperación en materia de hermanamiento de áreas naturales protegidas), programas (i. e. para el hermanamiento de cuencas o actividades de fomento a la cooperación y el desarrollo entre ciudades diferentes en la materia) o los típicos acuerdos bilaterales de cooperación (i.e. para el establecimiento de los ya mencionados y cada vez más famosos mecanismos de desarrollo limpio consagrados en el protocolo de Kyoto). Si bien su denominación varía, los acuerdos interinstitucionales son lo que tradicionalmente la doctrina mexicana ha conocido como "tratados de forma simplificada" o "acuerdos administrativos". En cualquier caso, la Semarnat (a través de la 
Esta obra forma parte del acervo de la Biblioteca Jurídica Virtual del Instituto de Investigaciones Jurídicas de la UNAM

Unidad Coordinadora de Asuntos Internacionales que se constituye en la depositaria y custodia de los acuerdos en los que la secretaría sea parte) debe informar a la SRE acerca de la celebración de un acuerdo interinstitucional ambiental. Como ya hemos dicho, ésta última interviene para determinar su procedencia y para ello elabora un dictamen.

5) Por último, sin tener un procedimiento constitucional para su celebración, basta con que se firmen para que entren en vigor. Desafortunadamente, estos acuerdos no se publican en el Diario Oficial de la Federación. Por lo que para saber de su existencia debemos acudir a la página de Internet de la propia Semarnat ( $w w w$. semarnat.gob.mx.) o formular una solicitud para tener acceso a esa información. De cualquiera manera, el material que se obtiene ya sea de la consulta por Internet o de la solicitud de información, es - por experiencia propia - francamente incompleto y poco preciso.

\section{REFLEXIÓN TERCERA: NATURALEZA JURÍDICA}

Desde su creación a través de una ley del Congreso de la Unión - la Ley sobre la Celebración de Tratados de 1992- los acuerdos interinstitucionales han estado sujetos a un debate nada estéril sobre su naturaleza jurídica. Es indiscutible que estos instrumentos forman parte del sistema jurídico mexicano, pero si no son tratados, entonces ¿qué son?

Para mejor comprender la naturaleza jurídica de los acuerdos interinstitucionales ambientales se requiere acudir a su doble carácter tanto de instrumento externo como interno. En el primer caso, el hecho de que la Semarnat suscriba estos documentos con otras instituciones internacionales, no les resta el rango de acuerdos regidos por el derecho internacional público. Si bien los acuerdos interinstitucionales ambientales no tienen la misma naturaleza jurídica que los tratados internacionales ambientales (pues entre otras cosas las partes que intervienen son diferentes), a través de ellos se asumen compromisos que en muchas ocasiones constituyen verdaderas obligaciones de dar y/o hacer. El suscriptor que participa en los acuerdos es un representante del Poder Ejecutivo Federal debidamente legitimado pero no lo hace, como ya vimos, en calidad de sujeto de derecho internacional público. Es decir, se trata de un representante (legítimo) de la administración pública federal centralizada que 
Esta obra forma parte del acervo de la Biblioteca Jurídica Virtual del Instituto de Investigaciones Jurídicas de la UNAM

actúa en nombre y en representación del Poder Ejecutivo (de la unión) de los Estados Unidos Mexicanos que adquiere compromisos y que en caso de tratarse de acuerdos de derecho duro su cumplimiento es obligatorio y jurídicamente vinculante (vis à vis los de derecho suave).

Así, independientemente de su denominación o naturaleza jurídica interna este tipo de acuerdos ambientales en el ámbito de lo externo se asemejan a los tratados ambientales, en tanto que ambos tienen la misma validez frente al derecho internacional público (ambiental) además de que pueden generan compromisos hard o soft. En estricto sentido, poco le importa a la contraparte mexicana (i. e. la institución extranjera) cómo regula y nombra el derecho mexicano a los acuerdos internacionales que habrá de suscribir con la Semarnat. Lo que verdaderamente importa es que tienen validez internacional y que en caso de incumplimiento podrá haber responsabilidad internacional para los Estados Unidos Mexicanos. De aquí que se haya afirmado - aunque aún sea debatible — que las disposiciones legales y reglamentarias de derecho interno de México no podrían afectar la validez externa de un instrumento internacional suscrito por entes públicos competentes (como lo es la propia Semarnat). ${ }^{8}$

En el segundo caso, es decir en la parte interna, es claro que nuestra legislación no considera a los acuerdos interinstitucionales ambientales con el mismo rango de los tratados ambientales. Su naturaleza propia es distinta puesto que pueden ser celebrados por una dependencia de la administración pública federal (centralizada) sin aprobación del Senado. ${ }^{9}$ Si no son tratados y por lo tanto no son ley suprema de la unión, ¿son para nuestro derecho sólo disposiciones de tipo administrativo?

Algunos autores han señalado que el "fundamento constitucional" de los acuerdos interinstitucionales se encuentra en el artículo 89, fracción I, relativo a la facultad reglamentaria del presidente de la República para proveer en la esfera administrativa a la exacta observancia de las leyes

8 López Mata, Rosendo, "Notas para el análisis sobre la constitucionalidad de algunas disposiciones contenidas en la Ley sobre la Celebración de Tratados", Jurídica, Anuario del Departamento de Derecho de la Universidad Iberoamericana, México, núm. 24, 1995-I, p. 238.

9 En este sentido, véase a Sepúlveda Iguiniz, Ricardo J., “Análisis constitucional de la Ley sobre la Celebración de Tratados”, Revista de Investigaciones Jurídicas, México, núm. 18, año 18, 1994, pp. 249-251. 
Esta obra forma parte del acervo de la Biblioteca Jurídica Virtual del Instituto de Investigaciones Jurídicas de la UNAM

que expide el Congreso de la Unión. ${ }^{10}$ Sin embargo, pensamos que los acuerdos interinstitucionales ambientales son sólo disposiciones administrativas (como las misceláneas fiscales o las circulares a las que ya hemos aludido) que no se refieren a la facultad reglamentaria del artículo 89, fracción I. En efecto, esta fracción se refiere - entre otros - a dos aspectos fundamentales: $i$ ) la facultad ahí señalada es exclusiva del presidente, y ii) esa facultad hace alusión a la expedición de reglamentos. ${ }^{11} \mathrm{Si}$ el acuerdo interinstitucional ambiental puede suscribirse por el titular de la Semarnat es obvio que no se trata de un acto "exclusivo" del presidente y por lo tanto no puede referirse al artículo constitucional ya citado. La facultad reglamentaria del presidente de la República es indelegable. ${ }^{12}$ Recordamos lo que en este sentido señala Tena Ramírez: ${ }^{13}$

Por ser materialmente legislativa, la facultad reglamentaria constituye una excepción al principio de separación de poderes. Subordinado y todo a la voluntad del legislador contenida en la ley, el reglamento no obstante es prolongación de la misma ley y participa de la naturaleza de ésta. La excepción de que hablamos se estableció por la Constitución a favor exclusivamente del presidente de la República, nunca de los secretarios de Estado... ni de ningún otro órgano dependiente del Ejecutivo. ${ }^{14}$

En tanto acuerdos o disposiciones administrativas, los acuerdos interinstitucionales ambientales son desde el punto de vista formal actos administrativos ya que emanan del Poder Ejecutivo Federal, y son desde el punto de vista material actos legislativos que reúnen las características de ser normas generales, abstractas, obligatorias y en su caso coercitivas. Se trata entonces de acuerdos administrativos para nuestro derecho interno

10 Se agrega a este fundamento el de la fracción X del mismo artículo 89 respecto a las facultades que tiene el Poder Ejecutivo para dirigir la política exterior. Remitimos para una mayor discusión a Palacios Treviño, Jorge, op. cit., nota 3, pp. 73 y ss.

11 Es interesante observar que los estudios que hacen Fraga y Tena Ramírez respecto a la facultad reglamentaria del artículo 89 fracción I, se refieren a reglamentos y no a acuerdos, decretos, etcétera. Véase Fraga, Gabino, Derecho administrativo, 22a. ed., México, Porrúa, 1982, pp. 108-112 y Tena Ramírez, Felipe, Derecho constitucional mexicano, 33a. ed., México, Porrúa, 2000, pp. 465 y 466.

12 Véase Nava Negrete, Alfonso, Derecho administrativo mexicano, 2a. ed., México, Fondo de Cultura Económica, 2001, p. 96.

13 Tena Ramírez, op. cit., nota 11, p. 468.

14 Énfasis del autor. 
Esta obra forma parte del acervo de la Biblioteca Jurídica Virtual del Instituto de Investigaciones Jurídicas de la UNAM

que pueden ser reglamentarios, pero no de exclusividad del presidente de la República.

En este tenor, y como sucede para las demás disposiciones administrativas, para que un acuerdo como estos obligue y surta sus efectos deberá publicarse en el Diario Oficial de la Federación en los términos que señala el vigente Código Civil Federal en sus artículos 3o. y 4o. Sin embargo, sabemos que en la práctica administrativa-ambiental estos acuerdos no se publican en el periódico oficial pero de cualquier manera entran en vigor, al menos internacionalmente, desde el momento de su celebración. En estricto sentido, los acuerdos interinstitucionales ambientales no son por lo tanto obligatorios para el derecho nacional pero sí para el derecho internacional.

\section{REFLEXIÓN CUARTA: ASPECTOS SOBRE SU CONSTITUCIONALIDAD}

Son cinco los aspectos que queremos revisar sobre la constitucionalidad de los acuerdos interinstitucionales ambientales. Partimos aquí de la idea de que una ley es constitucional —en este caso la Ley sobre la Celebración de Tratados - si ésta ha sido expedida por el Congreso de la Unión de acuerdo con el texto de la Constitución y que además no va en contra de los mandatos constitucionales: ${ }^{15}$

1) Los acuerdos interinstitucionales ambientales no forman parte de la ley suprema de la unión. Por tanto, no deben ir más allá ni contrariar la Constitución, las leyes del Congreso de la Unión o los tratados internacionales (se hayan derivado de ellos o no). Estos acuerdos serán inconstitucionales si exceden el alcance de cualquiera de las tres categorías normativas arriba señaladas y serán anticonstitucionales si van en contra de cualquiera de ellas.

2) El hecho de que nuestra Constitución no se refiera a ellos de manera expresa, no los hace inconstitucionales. En efecto, no todas las figuras jurídicas requieren de fundamento constitucional expreso para que no sean inconstitucionales. Mencionamos los ejemplos de las misceláneas fiscales o las normas oficiales mexicanas que son disposiciones administrativas y que como los acuerdos interinstitucionales no se establecen expresamente por la Constitución, ¿acaso

15 Nava Negrete, Alfonso, op. cit., nota 12, pp. 74 y 75. 
Esta obra forma parte del acervo de la Biblioteca Jurídica Virtual del Instituto de Investigaciones Jurídicas de la UNAM

esta circunstancia hace a estas disposiciones administrativas inconstitucionales? Pensamos que no. La Constitución no es ni debe ser catálogo de cuanta figura jurídica exista en nuestro derecho interno. Además, hay que recordar que la intención de los legisladores no fue la de equiparar los acuerdos a los tratados, sino la de facilitar el cumplimiento de las exigencias cada vez más crecientes de mayor cooperación entre órganos gubernamentales con responsabilidades similares en sus respectivos gobiernos. ${ }^{16}$

3) Los acuerdos interinstitucionales ambientales no sufren de inconstitucionalidad si estos se circunscriben a las atribuciones que las leyes y reglamentos señalan en la materia al titular de la Semarnat. Cualquiera que sea el acto jurídico que una autoridad federal realice, deberá estar prevista por una disposición general anterior para ello. ${ }^{17}$ Este es el principio de legalidad que toda autoridad — en este caso la ambiental - debe observar para realizar sus funciones; esto es, la autoridad ambiental sólo podrá hacer lo que la ley (o todo ordenamiento general capaz de prever la competencia de dicha autoridad, como el caso de un reglamento) le autorice. ${ }^{18}$

4) El hecho de que la SRE sea la encargada de formular un dictamen acerca de la procedencia para su suscripción, no los hace inconstitucionales. Situación distinta cuando se trata de una entidad federativa pues se ha argumentado que si una dependencia del Poder Ejecutivo Federal tiene el poder para aprobar o desaprobar tal celebración significa transgredir el principio de división de poderes. ${ }^{19}$

5) Por último, se discute sobre la inconstitucionalidad de la propia Ley sobre la Celebración de Tratados puesto que se argumenta que el Congreso de la Unión carece de facultades expresas para legislar en materia de celebración de tratados y también de acuerdos interinstitucionales que ni siquiera aparecen en el texto de nuestra carta magna. ${ }^{20}$ Por lo que toca a los tratados, es cierto que el artículo 73 de

16 Véase la exposición de motivos de la Ley sobre la Celebración de Tratados, op. cit., nota 5 .

17 En este sentido Fraga, Gabino, op. cit., nota 11, pp. 99 y ss.

18 Nava Negrete, Alfonso, op. cit., nota 12, pp. 109 y 110.

19 López Mata, Rosendo, op. cit., nota 8, pp. 257 y 258.

20 En este sentido, recomendamos acudir a Laura Trigueros quien sostiene que efectivamente no existen facultades expresas del Poder Legislativo para legislar en esta ma- 
Esta obra forma parte del acervo de la Biblioteca Jurídica Virtual del Instituto de Investigaciones Jurídicas de la UNAM

nuestra Constitución — que establece las atribuciones del congreso para legislar en diversas materias - no señala la facultad expresa para legislar sobre el procedimiento o celebración de los mismos; sin embargo, sabemos que el Congreso de la Unión puede legislar en materias que no sólo se encuentran expresamente en el artículo 73. Por ejemplo, cuando la Constitución se refiere a la palabra ley o leyes hace alusión a una ley del Congreso de la Unión y entonces podrá legislar tal y como sucede con la fracción IV del artículo 31 en materia de contribuciones, en la que se establecen como obligaciones de los mexicanos el contribuir para los gastos públicos de la manera proporcional y equitativa que dispongan las leyes. Inclusive, el Congreso ha legislado sobre materias que no se mencionan en nuestra carta magna, como es el caso de la Ley Federal sobre Metrología y Normalización que regula las normas oficiales mexicanas que no se establecen como materia en la que el Congreso de la Unión tiene la facultad expresa para legislar, ni tampoco como una figura jurídica creada por la Constitución. Aunado a lo anterior, el Congreso de la Unión también interviene cuando reglamenta una o varias partes de la Constitución aunque no se prevenga esto expresamente en el artículo 73. Este es precisamente el caso de la Ley sobre la Celebración de Tratados que, para nosotros, es una ley reglamentaria de la Constitución: fundamentalmente del artículo 89, fracción $\mathrm{X}$, relativo a las facultades y obligaciones del presidente para celebrar tratados y someterlos a la aprobación del Senado. Este ordenamiento es una ley reglamentaria de tipo procedimental ya que no se ocupa de fijar contenidos sustantivos sino de la forma y procedimientos para la suscripción de tratados. Entonces, no podemos hablar de que la ley que comentamos sea inconstitucional porque no se encuentre la materia de celebración de tratados expresamente otorgada al Congreso de la Unión en el artículo 73. Por lo que toca a los acuerdos interinstitucionales, como ya hemos dicho, su fundamento es legal y no constitucional, por lo que no debería siquiera pensarse en plantear su inconstitucionalidad.

teria, pero tampoco facultades implícitas. Además, señala que en todo caso para esta cuestión se mantiene como principio el de la discrecionalidad absoluta del presidente donde el control sobre su ejercicio se confía a la Cámara de Senadores. Véase Trigueros Gaisman, Laura, "Comentarios en torno a la Ley sobre la Celebración de Tratados", Alegatos, núm. 21, mayo-agosto de 1992. 
Esta obra forma parte del acervo de la Biblioteca Jurídica Virtual del Instituto de Investigaciones Jurídicas de la UNAM

\section{CONCLUSIÓN}

Los acuerdos interinstitucionales en tanto instrumentos jurídicos son útiles desde el punto de vista administrativo, convenientes desde el punto de vista internacional e indispensables desde el punto de vista ambiental. Útiles en lo administrativo porque permiten cierta operatividad en nuestro derecho interno para el mejor ejercicio de las funciones que han sido asignadas a las dependencias del Ejecutivo Federal; convenientes en lo internacional porque son favorables para la ágil consecución de acuerdos con otras instituciones internacionales sin que medien los procedimientos de los tratados internacionales, e indispensables en lo ambiental porque la Secretaría de Medio Ambiente y Recursos Naturales requiere de instrumentos capaces que le permitan reflejar e incluir temas del más alto nivel de su agenda política, en un marco de cooperación internacional con sus homólogas o con otras instituciones interesadas para la realización conjunta de proyectos ambientales; sin embargo, es necesario darles mayor cuerpo jurídico. Es decir, es indispensable que se aclaren diversos aspectos sobre su naturaleza jurídica y su constitucionalidad, así como señalar expresamente por ley — como sí se hace para el caso de los tratados- que deben publicarse en el Diario Oficial de la Federación para que no quede duda sobre su entrada en vigor nacional y para que los ciudadanos mexicanos conozcan sobre su contenido y alcances. 
Esta obra forma parte del acervo de la Biblioteca Jurídica Virtual del Instituto de Investigaciones Jurídicas de la UNAM

\title{
TURISMO INTERNACIONAL DE PLAYA Y CAMBIO CLIMÁTICO EN MÉXICO*
}

\begin{abstract}
El Comité Nobel Noruego ha decidido que el Premio Nobel de la Paz de 2007 ha de ser compartido, en dos partes iguales, entre el Grupo Intergubernamental de Expertos sobre el Cambio Climático (IPCC) y Albert Arnold (Al) Gore Jr. por sus esfuerzos para crear y difundir un mayor conocimiento sobre el hombre, el cambio climático, y para sentar las bases de las medidas que se necesitan para contrarrestar ese cambio. ${ }^{1}$
\end{abstract}

\section{INTRODUCCIÓN}

Según cifras y estadísticas de la Organización Mundial del Turismo — organismo especializado de la Organización de las Naciones Unidas en el ámbito del turismo - México ocupa un lugar privilegiado dentro del sector turístico mundial. Sólo por número de llegadas internacionales y por ingresos de turismo internacional nuestro país se encuentra en el lugar octavo y decimocuarto, respectivamente, de un total de 157 naciones que integran dicha organización. A nivel nacional, datos recientes del gobierno federal señalan que el grupo más importante de esos visitantes internacionales hacia México —i.e. los de internación_ — ha crecido en los últimos años tanto en el número

* Publicado en Revista de la Facultad de Derecho de México, México, t. LVIII, núm. 250, julio-diciembre de 2008.

1 Palabras pronunciadas el 12 de octubre de 2007 por el profesor Ole Danbolt Mjøs, presidente del Comité Nobel de Noruega, a propósito del anuncio para el otorgamiento del Premio Nobel de la Paz 2007. 
Esta obra forma parte del acervo de la Biblioteca Jurídica Virtual del Instituto de Investigaciones Jurídicas de la UNAM

de turistas (pasando de más de 10000 en 2001 a más de 12600 en 2006) como en el gasto efectuado (pasando de más de 5900 millones de dólares en 2001 a casi 9000 millones para 2006). Los destinos preferidos para esta categoría de turistas internacionales son los de playa, particularmente los centros integralmente planeados conformados por dos regiones: Cancún y Cozumel, y Los Cabos.

Ciertamente, el panorama en cifras que brinda el turismo internacional de playa en México es alentador y optimista; sin embargo, el potencial turístico (y ambiental) que ofrecen nuestras zonas costeras se ve amenazado por un fenómeno que implica un riesgo para su viabilidad y desarrollo: el cambio climático.

Este artículo tiene por objeto vincular la importancia del turismo internacional de playa en México con el dilema del cambio climático. Para ello, se realiza una descripción sucinta tanto del turismo internacional en nuestro país (específicamente el del turismo de internación por número de llegadas de turistas y por ingresos captados), como del cambio climático (sus causas y consecuencias). En este contexto se presenta información relativa a la vulnerabilidad en la que se encuentran los principales destinos de playa en México para enfrentar dos de las muchas consecuencias del calentamiento global: los huracanes y la elevación del nivel del mar. Concluye este trabajo con algunas reflexiones finales sobre el significado del cambio climático en el turismo internacional de playa en México.

\section{TURISMO INTERNACIONAL Y DESTINOS DE PLAYA}

Tres veces al año —en enero, junio y octubre — la Organización Mundial del Turismo (OMT) publica un documento conocido como Barómetro OMT del Turismo Mundial. En cada número, este organismo especializado de la Organización de las Naciones Unidas reúne información en torno a tres aspectos centrales del turismo: $i$ ) la visión general de las tendencias estadísticas de países receptores y emisores y del transporte aéreo; ii) los resultados de las encuestas que se realizan al Grupo de Expertos en Turismo de la propia organización mundial y que versan sobre la prospectiva del turismo a corto plazo, y iii) datos de tipo económico según su importancia para el sector turístico. ${ }^{2}$

2 Véase Organización Mundial del Turismo, Barómetro OMT del Turismo Mundial, vol. 5, núm. 2, junio de 2007, p. 2, www.unwto.org/facts/menu/.html. 
Esta obra forma parte del acervo de la Biblioteca Jurídica Virtual del Instituto de Investigaciones Jurídicas de la UNAM

Una de las grandes aportaciones del Barómetro OMT del Turismo Mundial es sin duda la que corresponde a las estadísticas comparadas del número de llegadas de turistas internacionales (por destino) y de ingresos por turismo internacional en general (tanto a nivel mundial como por regiones, sub-regiones y países). Esta valiosa información permite ubicar a nuestro país dentro del contexto internacional turístico para establecer un análisis de las tendencias observadas así como una evaluación a futuro sobre su posible desarrollo. El lugar que México ha ocupado a nivel mundial en los últimos años, indica claramente un posicionamiento dentro de los diez primeros países por llegadas de turistas internacionales y dentro de los primeros quince por ingresos de turismo internacional. El pronóstico de crecimiento (aunque no significativo en número de turistas pero sí en ingresos) para los siguientes años es alentador.

\section{Llegadas de turistas e ingresos por turismo internacional}

\section{A. Llegadas de turistas internacionales}

En su último barómetro publicado, ${ }^{3}$ la OMT reportó que para 2006 a nivel mundial hubo un crecimiento en el número de llegadas en poco menos del 5\% respecto al índice reportado para 2005; esto es, el incremento de turistas pasó respectivamente de 802 a 842 millones de turistas internacionales. Dentro de estas cifras, cada una de las cinco regiones en las que la OMT divide al mundo (Europa, Asia y el Pacífico, Américas, África, y Oriente Medio) se detectaron incrementos —en algunas más que en otras - en el volumen de las llegadas. Aunque desde hace ya algunos años la región de Asia y el Pacífico ha pasado en número de turistas internacionales a la región de América, ${ }^{4}$ ésta continúa ubicándose como la tercera región más visitada muy por encima de las regiones de África y de Oriente Medio. Europa, desde luego, continúa siendo la región más importante en este rubro (véase tabla 1).

3 Al momento de escribir se encontraba disponible el barómetro número 2, correspondiente a junio de 2007.

4 Hacemos notar que la OMT utiliza el término "Américas" para referirse a todo el continente americano, idea que no compartimos. Para nosotros existe un solo continente americano al que llamamos simple y sencillamente América. 
Esta obra forma parte del acervo de la Biblioteca Jurídica Virtual del Instituto de Investigaciones Jurídicas de la UNAM

TABLA 1

Llegadas de turistas internacionales por regiones

\begin{tabular}{|c|c|c|}
\cline { 2 - 3 } \multicolumn{1}{c|}{} & \multicolumn{2}{c|}{$\begin{array}{c}\text { Llegadas } \\
\text { (millones de turistas) }\end{array}$} \\
\hline & 2005 & 2006 \\
\hline Mundo & 802.0 & 842.0 \\
\hline Europa & 438.3 & 456.9 \\
\hline Asia y el Pacifico & 155.4 & 167.4 \\
\hline América & 133.2 & 136.0 \\
\hline África & 37.3 & 40.9 \\
\hline Medio Oriente & 38.3 & 40.7 \\
\hline
\end{tabular}

Fuente: Adaptado de la Organización Mundial del Turismo, 2007.

TABLA 2

Llegadas de turistas internacionales por sub-regiones

\begin{tabular}{|c|c|c|}
\cline { 2 - 3 } \multicolumn{1}{c|}{} & \multicolumn{2}{c|}{$\begin{array}{c}\text { Llegadas } \\
\text { (millones de turistas) }\end{array}$} \\
\hline & 2005 & 2006 \\
\hline América & 133.2 & 136.0 \\
\hline América del Norte & 89.9 & 90.7 \\
\hline El Caribe & 18.8 & 19.4 \\
\hline América del Sur & 18.2 & 18.9 \\
\hline América Central & 6.3 & 7.0 \\
\hline
\end{tabular}

Fuente: Adaptado de la Organización Mundial del Turismo, 2007.

La región de América se subdivide (tanto para contabilizar el número de llegadas de turistas internacionales como para determinar los ingresos por turismo internacional) en cuatro sub-regiones: América del Norte, El Caribe, América del Sur, y América Central. Nuestro país se ubica en la sub-región denominada América del Norte. Es importante señalar que a nivel regional, la sub-región en la que se encuentra México (i.e. América del Norte) es la que mayor número de llegadas acumula respecto de las 
Esta obra forma parte del acervo de la Biblioteca Jurídica Virtual del Instituto de Investigaciones Jurídicas de la UNAM

otras tres sub-regiones en el continente americano (i. e. El Caribe, América del Sur, y América Central) con más de 90 millones de turistas de un total de 136 millones para 2006 (véase tabla 2).

La sub-región América del Norte se compone de tres países: México, Canadá y Estados Unidos de América. Aunque nuestro país esté muy por debajo del volumen registrado por nuestro vecino del norte, ocupamos el segundo lugar en importancia para la región por llegadas de turistas internacionales. Más importante aún es que mientras Estados Unidos y Canadá han observado variaciones un tanto significativas para ciertos periodos (de incremento o de disminución), México ha mantenido desde hace más de diez años un crecimiento pequeño pero constante y que sobre todo no ha estado sujeto a variaciones tan marcadas (incluso la de disminución) como la de sus homólogos vecinos (véase tabla 3).

TABLA 3

Llegadas de turistas internacionales para América del Norte

\begin{tabular}{|c|c|c|c|c|c|}
\cline { 2 - 6 } \multicolumn{1}{c|}{} & \multicolumn{5}{c|}{$\begin{array}{c}\text { Llegadas } \\
\text { (millones de turistas) }\end{array}$} \\
\hline & 1995 & 2000 & 2004 & 2005 & 2006 \\
\hline Estados Unidos & 43.5 & 51.2 & 46.1 & 49.2 & 51.1 \\
\hline México & 20.2 & 20.6 & 20.6 & 21.9 & 21.4 \\
\hline Canadá & 16.9 & 19.6 & 19.1 & 18.8 & 18.2 \\
\hline
\end{tabular}

Fuente: Adaptado de la Organización Mundial del Turismo, 2007.

De manera tal que la información estadística de la OMT muestra que en materia turística México se distingue como uno de los principales destinos para el turismo internacional. Así, por volumen de llegadas nuestro país ocupa a nivel mundial el lugar octavo, a nivel regional (todo el continente americano) el segundo lugar, y a nivel sub-regional (América del Norte) también el lugar número dos.

\section{B. Ingresos por turismo internacional}

En materia de ingresos por turismo internacional, las estadísticas del último número del barómetro de la OMT también reportaron para 2006 
Esta obra forma parte del acervo de la Biblioteca Jurídica Virtual del Instituto de Investigaciones Jurídicas de la UNAM

un crecimiento a nivel mundial respecto a lo indicado para 2005. Este aumento (que fue de 57000 millones de dólares en términos absolutos) representa alrededor de un $4.5 \%$ en el que los ingresos pasaron respectivamente de 678000 a 735000 millones de dólares en un solo año. Vale la pena señalar que por regiones, mientras que Europa ocupa el primer lugar con 377.6 millones de dólares tanto la región de Asia y el Pacífico como la de América comparten el mismo sitio con 153.4 millones, cifras que corresponden todas a 2006 (véase tabla 4).

TABLA 4

Ingresos de turismo internacional por regiones

\begin{tabular}{|c|c|c|}
\cline { 2 - 3 } \multicolumn{1}{c|}{} & \multicolumn{2}{c|}{\begin{tabular}{c} 
Ingresos \\
\multicolumn{1}{c|}{}
\end{tabular}} \\
\hline & 2005 & 2006 \\
\hline Mundo & 678,0 & 35,0 \\
\hline Europa & 350,5 & 377,6 \\
\hline Asia y el Pacifico & 134,5 & 153,4 \\
\hline América & 144,7 & 153,4 \\
\hline Medio Oriente & 262 & 26,8 \\
\hline Africa & 21,6 & 24,2 \\
\hline
\end{tabular}

Fuente: Adaptado de la Organización Mundial del Turismo, 2007.

Como se puede observar claramente en las cifras de la tabla 5, la subregión de América del Norte excede - y por mucho- los ingresos por turistas internacionales de las otras tres regiones. Ni sumando el total de los ingresos de El Caribe, América del Sur y América Central se llega siquiera a la mitad de lo que ingresa a la región a la que pertenece México. 
Esta obra forma parte del acervo de la Biblioteca Jurídica Virtual del Instituto de Investigaciones Jurídicas de la UNAM

TABLA 5

Ingresos de turismo internacional por sub-regiones

\begin{tabular}{|c|c|c|}
\cline { 2 - 3 } \multicolumn{1}{c|}{} & \multicolumn{2}{c|}{\begin{tabular}{c} 
Ingresos \\
\multicolumn{1}{c|}{}
\end{tabular}} \\
\hline & 2005 & 2006 \\
\hline América & 144,7 & 153,4 \\
\hline América del Norte & 107,2 & 112,4 \\
\hline El Caribe & 20,5 & 21,7 \\
\hline América del Sur & 12,4 & 14,0 \\
\hline América Central & 4,6 & 5,3 \\
\hline
\end{tabular}

Fuente: Adaptado de la Organización Mundial del Turismo, 2007.

Sin embargo, a nivel de la sub-región de América del Norte, mientras que nuestro país ocupa el tercer lugar, los Estados Unidos de América se encuentran en un muy distante primer sitio seguido de un más cercano, para nosotros, segundo lugar canadiense (véase tabla 6).

TABLA 6

Ingresos de turismo internacional para América del Norte

\begin{tabular}{|c|c|c|c|c|c|}
\cline { 2 - 6 } \multicolumn{1}{c|}{} & \multicolumn{5}{c|}{$\begin{array}{c}\text { Ingresos } \\
\text { (\$EEUU miles de millones) }\end{array}$} \\
\hline & 1995 & 2000 & 2004 & 2005 & 2006 \\
\hline Estados Unidos & 63,4 & 82,4 & 74,5 & 81,8 & 85,7 \\
\hline Canadá & 7,9 & 10,8 & 12,9 & 13,6 & 14,5 \\
\hline México & 6,2 & 8,3 & 10,8 & 11,8 & 12,2 \\
\hline
\end{tabular}

Fuente: Adaptado de la Organización Mundial del Turismo, 2007.

Es así que las estadísticas proporcionadas por la OMT demuestran que México es uno de los países que más destaca en materia de ingresos por turistas internacionales. A nivel mundial nuestro país ocupa el catorceavo lugar, a nivel regional (todo el continente americano) el tercer lugar, y a nivel sub-regional (América del Norte) también el lugar número tres. 
Esta obra forma parte del acervo de la Biblioteca Jurídica Virtual del Instituto de Investigaciones Jurídicas de la UNAM

\section{Comparativo de llegadas e ingresos}

Según el último barómetro de la OMT, mientras que las llegadas de turistas internacionales aumentaron casi en un 5\% para 2006 a nivel mundial, el crecimiento de los ingresos por turismo internacional fue ligeramente inferior a aquél: 4.5\% para el mismo año (véase tabla 7).

TABLA 7

Llegadas e ingresos de turismo internacional por regiones

\begin{tabular}{|c|c|c|c|c|}
\hline & \multicolumn{2}{|c|}{$\begin{array}{c}\text { Llegadas } \\
\text { (millones de turistas }\end{array}$} & \multicolumn{2}{c|}{$\begin{array}{c}\text { Ingresos } \\
\text { (\$EEUU miles de millones) }\end{array}$} \\
\hline & 2005 & 2006 & 2005 & 2006 \\
\hline Mundo & 802 & 842 & 678 & 735 \\
\hline Europa & 438.3 & 456.9 & 350,5 & 377,6 \\
\hline Asia y el Pacifico & 155.4 & 167.4 & 134,5 & 153,4 \\
\hline América & 133.2 & 136.0 & 144,7 & 153,4 \\
\hline Africa & 37.3 & 40.9 & 21,6 & 24,2 \\
\hline Medio Oriente & 38.3 & 40.7 & 26,2 & 26,8 \\
\hline
\end{tabular}

Fuente: Adaptado de Organización Mundial del Turismo, 2007.

Aunque debemos ser cautelosos con esta información estadística, es posible afirmar que los datos sobre las llegadas tienen cierta correlación con los de los ingresos para 2006, salvo para el caso de la región de Medio Oriente. Así lo explica la Organización Mundial del Turismo:

En todas las regiones, a excepción de Oriente Medio, el crecimiento de los ingresos estuvo estrechamente ligado al de las llegadas en 2006. En Oriente Medio, tanto en 2005 como en 2006, el incremento de las llegadas no supuso crecimiento de los ingresos, aunque ha de tenerse en cuenta que los datos comunicados hasta la fecha por los países son todavía incompletos y en ciertos casos parecen incoherentes. ${ }^{5}$

En el caso de las sub-regiones, y para América del Norte en particular, también es posible encontrar cierta correlación entre llegadas e ingresos, aunque son un poco más notorias las variaciones (véase tabla 8).

5 Organización Mundial del Turismo, op. cit., nota 2, p. 6. 
Esta obra forma parte del acervo de la Biblioteca Jurídica Virtual del Instituto de Investigaciones Jurídicas de la UNAM

TABLA 8

Llegadas e ingresos de turismo internacional por sub-regiones

\begin{tabular}{|c|c|c|c|c|}
\cline { 2 - 5 } \multicolumn{1}{c|}{} & \multicolumn{3}{c|}{ Llegadas } & \multicolumn{2}{c|}{ Ingresos } \\
& 2005 & 2006 & 2005 & 2006 \\
\hline & 133.2 & 136.0 & 144,7 & 153,4 \\
\hline Amillones de turistas) & (\$EEUU miles de millones) \\
\hline América del Norte & 89.9 & 90.7 & 107,2 & 112,4 \\
\hline El Caribe & 18.8 & 19.4 & 20,5 & 21,7 \\
\hline América del Sur & 18.2 & 18.9 & 12,4 & 14,0 \\
\hline América Central & 6.3 & 7.0 & 4,6 & 5,3 \\
\hline
\end{tabular}

Fuente: Adaptado de la Organización Mundial del Turismo, 2007.

Evidentemente, es posible detectar mayor número de discrepancias o variaciones entre llegadas e ingresos por países que por sub-regiones. Como se observa en la siguiente tabla, si bien algunas naciones se mantienen dentro de los cinco primeros lugares tanto por llegadas como por ingresos, casi todas las naciones saltan de posiciones, algunas incluso de manera espectacular (véase tabla 9).

Así por ejemplo, el país que mayor volumen de llegadas registró en 2006 fue Francia, que ocupó el primer lugar y que sin embargo en el rubro de ingresos cayó al tercero. Algo semejante ocurrió para Estados Unidos de América, por número de turistas internacionales ocupó el tercer lugar pero en ingresos subió al primero. Otros casos son muy curiosos: España, Reino Unido y Alemania ocuparon para 2006 el segundo, sexto y séptimo sitios respectivamente tanto en llegadas como en ingresos. 
Esta obra forma parte del acervo de la Biblioteca Jurídica Virtual del Instituto de Investigaciones Jurídicas de la UNAM

TABLA 9

Llegadas e ingresos de turismo internacional por países

\begin{tabular}{|l|c|l|c|}
\hline \multicolumn{2}{|c|}{$\begin{array}{c}\text { Llegadas } \\
\text { (millones de turistas) }\end{array}$} & \multicolumn{2}{c|}{$\begin{array}{c}\text { Ingresos } \\
\text { (\$EEUU miles de millones) }\end{array}$} \\
\hline & 2006 & & 2006 \\
\hline 1. Francia & 79.1 & 1. Estados Unidos & 85,7 \\
\hline 2. España & 58.5 & 2. España & 51,1 \\
\hline 3. Estados Unidos & 51.1 & 3. Francia & 46,3 \\
\hline 4. China & 49.6 & 4. Italia & 38,1 \\
\hline 5. Italia & 41.1 & 5. China & 33,9 \\
\hline 6. Reino Unido & 30.1 & 6. Reino Unido & 33,5 \\
\hline 7. Alemania & 23.6 & 7. Alemania & 32,8 \\
\hline 8. México & 21.4 & 8. Australia & 17,8 \\
\hline 9. Austria & 20.3 & 9. Turquía & 16,9 \\
\hline 10. Rusia & 20.2 & 10. Austria & 16,7 \\
\hline 11. Turquía & 18.9 & 11. Canadá & 14,5 \\
\hline 12. Canadá & 18.2 & 12. Grecia & 14,3 \\
\hline 13. Ucrania & $\ldots$ & 13. Tailandia & 12,4 \\
\hline 14. Malasia & 17.5 & 14. México & 12,2 \\
\hline 15. Hong Kong (China) & 15.8 & 15. Suiza & 11,8 \\
\hline
\end{tabular}

Fuente: Adaptado de la Organización Mundial del Turismo, 2007.

Ciertas naciones reciben muchos turistas internacionales pero los ingresos son pocos, como es el caso de la Federación de Rusia que por llegadas ocupó el décimo lugar pero por ingresos cayó hasta el trigésimo sitio. Australia experimentó exactamente lo mismo pero al revés: por llegadas se ubicó en el lugar trigésimo octavo y por ingresos subió al lugar octavo. Aunque México cambió también de posición, su variación no fue estrepitosa: del lugar octavo por llegadas pasó al lugar décimo cuarto por ingresos. 
Esta obra forma parte del acervo de la Biblioteca Jurídica Virtual del Instituto de Investigaciones Jurídicas de la UNAM

\section{Turismo de internación y destinos de playa en México}

La Secretaría de Turismo clasifica a los turistas o visitantes internacionales hacia México en cuatro grandes grupos: turistas de internación, turistas fronterizos, pasajeros en cruceros y excursionistas fronterizos. De todos ellos, los primeros son los de mayor importancia para el sector turístico mexicano por razón del periodo de su estancia en el país, uso de los servicios turísticos y derrama económica o gasto. ${ }^{6} \mathrm{Ni}$ la Ley Federal de Turismo (publicada en el Diario Oficial de la Federación el 31 de diciembre de 1992) ni su reglamento (publicado en el Diario Oficial de la Federación el 2 de mayo de 1994) se refieren a ellos de forma expresa: es a través de documentos oficiales que conocemos sobre su existencia e importancia. De modo que es la propia Secretaria de Turismo la que los define y lo hace de la siguiente manera: “... [son] aquellos que rebasan la franja fronteriza o que directamente llegaron al país a cualquiera de las ciudades o destinos turísticos del interior...".

Según los datos estadísticos presentados por esa dependencia del Ejecutivo Federal, el turismo de internación en México correspondió en 2005 sólo al $12.15 \%$ del total de turistas internacionales; sin embargo, el gasto de este grupo de turistas representó para ese mismo año el $72.03 \%$ del total del gasto efectuado por todos los visitantes internacionales a nuestro país. ${ }^{8}$ Como se observa en la tabla 10, desde 2002 tanto el número de turistas (en millones) como el gasto realizado (en miles de millones de dólares) han ido en paulatino crecimiento.

La mayor parte de los turistas de internación provienen de Estados Unidos de América y de Canadá. Aunque las cifras en este rubro parecen variar según el criterio utilizado para su conteo, los datos presentados por la Secretaría de Turismo antes de 2006 señalaban que mientras los visitantes de estos dos países representaban más del $73 \%$ del total de los turistas de internación, los visitantes de toda Europa y de los demás países de América Latina y el Caribe sumaban todos juntos apenas alrededor de un $12 \%$ de ese total, otro $14 \%$ correspondía a otras nacionalidades del resto

6 Para mayor detalle véase Secretaría de Turismo, Visitantes internacionales hacia México, el turismo de internación 2000-2005, México, Secretaría de Turismo, noviembre de 2006.

7 Ibidem, p. 3.

8 Idem. 
Esta obra forma parte del acervo de la Biblioteca Jurídica Virtual del Instituto de Investigaciones Jurídicas de la UNAM

del mundo. Los motivos de sus visitas han sido distintos, pero sobresalieron los de placer y los familiares. ${ }^{9}$

TABLA 10

Turismo de internación 2001-2006

\begin{tabular}{|c|c|c|c|c|c|c|}
\hline & 2001 & 2002 & 2003 & 2004 & 2005 & 2006 \\
\hline $\begin{array}{c}\text { Turistas } \\
\text { (millones) }\end{array}$ & 10.1 & 9.8 & 10.3 & 11.5 & 12.5 & 12.6 \\
\hline $\begin{array}{c}\text { Gasto } \\
\text { (millones } \\
\text { de } \\
\text { dólares) }\end{array}$ & 5041.4 & 6083.7 & 6680.1 & 7783.5 & 8502.4 & 8955.0 \\
\hline
\end{tabular}

Fuente: Adaptado de la Secretaría de Turismo, 2006 y 2007.

Toda esta información adquiere singular relevancia si tomamos en cuenta que el destino preferido de los turistas de internación es el de playa, situación nada sorprendente ante el enorme potencial turístico que ofrece el país en ese rubro. En México son 17 las entidades federativas que cuentan con zona costera y en total el país tiene una extensión (longitud) de la línea de costa de 11122 kilómetros de los cuales 7828 corresponden a estados de cara al Océano Pacífico y al Golfo de California y 3294 kilómetros a estados del Golfo de México y del Mar Caribe. Si sumamos a estas cifras el perímetro de islas, lagunas costeras y esteros, el total de nuestra línea de costa abarca los 11592.76 kilómetros. Se calcula que la zona costera es habitada aproximadamente por el $15 \%$ de la población del país y que en ella se realiza el $45 \%$ de toda la actividad turística en México. ${ }^{10}$

9 Es importante señalar que en estos porcentajes que manejamos, la propia Secretaría de Turismo ha reconocido que los turistas de internación que provienen de la región de América del Norte, particularmente los de Estados Unidos de América, comprenden a mexicanos residentes en ese país. Ibidem, p. 5.

10 Las cifras sobre el número de habitantes, el número de municipios costeros y el número de otros indicadores, depende de la definición que se utilice para determinar lo que es playa o zona costera. Los números que en este párrafo presentamos corresponden a un documento oficial publicado por el gobierno federal a mediados del año pasado por la Secretaría de Medio Ambiente y Recursos Naturales la cual define a la zona costera como "el espacio geográfico de interacción mutua entre el medio marino, el medio terrestre y 
Esta obra forma parte del acervo de la Biblioteca Jurídica Virtual del Instituto de Investigaciones Jurídicas de la UNAM

En efecto, es muy importante señalar que cinco de los diez principales lugares que visitan esta categoría de turistas internacionales son de playa. Según su estructura porcentual (con datos de 2005) estos diez destinos son los siguientes: Cancún y Cozumel 21.4\%, Guadalajara 7.2\%, Los Cabos 6.7\%, Puerto Vallarta 6.3\%, México D. F. 5.2\%, Acapulco 4.2\%, Monterrey $3 \%$, Mazatlán 2\%, Oaxaca $1.1 \%$ y Puebla $1 \% .{ }^{11}$ La propia Secretaría de Turismo clasifica a su vez a los destinos de playa en tres grandes categorías: $i$ ) los centros integralmente planeados, a los que corresponden las dos zonas o regiones costeras más importantes: Cancún y Cozumel, y Los Cabos; ii) los tradicionales de playa, a los que corresponden los otros tres destinos de importancia significativa: Puerto Vallarta, Acapulco y Mazatlán, y iii) los otros de playa, al que corresponde sólo Isla Mujeres. Todas las demás zonas de playa se agrupan en otros destinos. ${ }^{12}$

Lo anterior es un indicador que en cierto modo explica el crecimiento de la inversión privada en los destinos de playa mexicanos. De modo que las diez entidades federativas que más dinero reciben de ella para desarrollo turístico abarcan a los cinco destinos de playa arriba mencionados que se encuentran dos en Quintana Roo, uno en Jalisco, otro en Guerrero y otro más en Sinaloa, respectivamente (véase tabla 11). En 2005 la

la atmósfera, comprendido por $a$ ) una porción continental definida por 263 municipios costeros; 150 con frente de playa y 113 municipios interiores adyacentes a esto con influencia costera alta y media; $b$ ) una porción marina definida a partir de la plataforma continental delimitada por la isobata de $\operatorname{los}-200 \mathrm{~m}, \mathrm{y} c$ ) una porción insular representada por las islas nacionales". Véase Secretaría de Medio Ambiente y Recursos Naturales, Política ambiental nacional para el desarrollo sustentable de océanos y costas de México, México, Secretaría de Medio Ambiente y Recursos Naturales, junio de 2006, p. 17. Esta definición, desde luego, no corresponde en lo absoluto a lo que establece la legislación mexicana al respecto, la cual distingue para la parte territorial entre playa marítima, zona federal marítimo terrestre, terrenos ganados al mar, acantilados y formaciones rocosas y ambientes costeros (como pueden ser humedales, marismas, etcétera) y para la parte marina, entre mar territorial, zona económica exclusiva y demás zonas marinas. Para conocer más sobre esto acúdase a Nava Escudero, César, "La privatización de las zonas costeras en México", en López Olvera, Miguel Alejandro (coord.), Estudios en homenaje a don Alfonso Nava Negrete. En sus 45 años de docencia, México, UNAM, Instituto de Investigaciones Jurídicas, 2006.

11 Secretaría de Turismo, op. cit., nota 6, p. 13.

12 Véase Secretaría de Turismo, Boletín cuatrimestral de Turismo, México, Secretaría de Turismo, núm. 19, enero-abril, 2007, p. 24, http://datatur.sectur.gob.mx/pubyrep/ bol/2007/m01/boll2007.pdf. 
Esta obra forma parte del acervo de la Biblioteca Jurídica Virtual del Instituto de Investigaciones Jurídicas de la UNAM

inversión en el sector turístico alcanzó poco más de 2700 millones de dólares de los cuales alrededor de 1800 millones correspondieron a los destinos de playa. ${ }^{13}$

\section{TABLA 11}

Principales destinos e inversión privada

\begin{tabular}{|c|c|c|c|}
\hline \multicolumn{2}{|c|}{$\begin{array}{c}\text { Principales destinos } \\
\text { (porcentaje de turistas de } \\
\text { internación) }\end{array}$} & \multicolumn{2}{|c|}{$\begin{array}{c}\text { Inversión privada* } \\
\text { (porcentaje acumulado) }\end{array}$} \\
\hline Ciudades & 2005 & Entidades federativas & 2001-06 \\
\hline 1. Cancún y Cozumel (Q. Roo) & 21.4 & 1. Sinaloa & 81.6 \\
\hline 2. Guadalajara (Jalisco) & 7.2 & 2. Nuevo León & 80.2 \\
\hline 3. Los Cabos (Baja California Sur) & 6.7 & 3. Jalisco & 78.2 \\
\hline 4. Puerto Vallarta (Jalisco) & 6.3 & 4. Baja California Sur & 76.2 \\
\hline 5. Cd. de México (D.F.) & 5.2 & 5. Cd. de México (D.F.) & 71.2 \\
\hline 6. Acapulco (Guerrero) & 4.2 & 6. Sonora & 66.1 \\
\hline 7. Monterrey (Nuevo León) & 3.0 & 7. Baja California & 59.3 \\
\hline 8. Mazatlán (Sinaloa) & 2.0 & 8. Nayarit & 51.9 \\
\hline 9. Oaxaca (Oaxaca) & 1.1 & 9. Quintana Roo & 43.9 \\
\hline 10. Puebla (Puebla) & 1.0 & 10. Guerrero & 22.6 \\
\hline
\end{tabular}

* Se refiere a la inversión identificada por año de 2001 a mayo de 2006

Fuente: Adaptado de la Secretaría de Turismo 2006 y 2006 a.

Por último, es importante comentar que la propia Secretaría de Turismo $^{14}$ ha señalado que desde el tercer cuatrimestre de 2005 y los dos primeros de 2006 el flujo de todos los visitantes internacionales presentó tasas de crecimiento negativas, situación que es diferente si tomamos en cuenta sólo las cifras que aplican para los de internación que han mostrado un crecimiento constante en términos reales desde 2001. Esta contrac-

13 Véase Secretaría de Turismo, La inversión privada en el sector turístico, México, Secretaría de Turismo, 2006a, http://datatur.sectur.gob.mx/pubyrep/cargas_manuales/ docext/Invturmay.pdf.

14 Véase Secretaría de Turismo, op. cit., nota 12, pp. 6 y ss. 
Esta obra forma parte del acervo de la Biblioteca Jurídica Virtual del Instituto de Investigaciones Jurídicas de la UNAM

ción en el sector de turistas internacionales coincide con ciertas medidas establecidas en los Estados Unidos de América para ciudadanos residentes en ese país que ingresen por vía aérea (i.e. solicitar pasaportes bajo el esquema de la Iniciativa de Viajes para el Hemisferio Occidental), pero sobre todo con la entrada del huracán Wilma por las costas de Quintana Roo en 2005. Ambos eventos significaron para el turismo de internación sólo una ligera desaceleración en su crecimiento. Pasado el impacto y secuelas de este fenómeno meteorológico, a partir del último cuatrimestre de 2006 y del primero de 2007, el ingreso de divisas aumentó considerablemente gracias a la derrama del turismo de internación.

\section{CAMBIO CLIMÁTICO: ¿ALGUIEN DUDA TODAVÍA DE SU EXISTENCIA?}

Cambios climáticos en nuestro planeta han ocurrido desde hace cientos de miles de años y lo más seguro es que sigan ocurriendo en el futuro. Esto ha sido, es y será parte de los procesos naturales de la Tierra. En la actualidad, la ciencia reconoce que existen diversos tipos de fluctuaciones climáticas como lo son las de muy corto tiempo que se observan entre estaciones o se refieren al ciclo regular anual del clima, las que no son muy cortas que podrían abarcar desde algunas décadas hasta unos cuantos cientos de años (como ocurrió con el Pequeño Medioevo Cálido con duración de alrededor de 400 años, del 800 al 1200 de nuestra era), y otras más que se refieren a las de largo y/o muy largo plazo y que se tratan de cambios milenarios (relacionados algunos de ellos a las diferentes fases glaciales e interglaciales) o de origen orbital. ${ }^{15} \mathrm{Si}$ tomamos como válida esta explicación científica sobre la variabilidad del clima, ¿a qué se debe que la comunidad internacional se preocupe por la fluctuación climática actual, que no es, sino una de las muchas variaciones climáticas que inevitablemente habrán de seguir ocurriendo?

Las preocupaciones y reflexiones sobre el cambio climático de nuestros días se centran en tres ideas fundamentales:

i) Se ha detectado una variación climática significativa o anómala que corresponde a un lapso de corta duración la cual comprende a partir

15 Para mayores detalles, recomendamos acudir a Martínez, Julia y Fernández, Adrián (comps.), Cambio climático: una visión desde México, México, Instituto Nacional de Ecología, 2004. 
Esta obra forma parte del acervo de la Biblioteca Jurídica Virtual del Instituto de Investigaciones Jurídicas de la UNAM

de los últimos 150 a 100 años y que se prevé continúe a futuro en los próximos 50 a 100 años o más; en otras palabras, no se trata de ese tipo de cambios climáticos que se refieren a periodos muy cortos estacionales o interanuales, ni tampoco a esos cambios climáticos de periodos largos de cientos de miles de años como llegaron a ocurrir en diversas épocas geológicas. ${ }^{16}$

ii) Existe evidencia científica de que esta fluctuación climática es resultado de un incremento (desde 1750) en las concentraciones atmosféricas globales de ciertos gases conocidos como gases de efecto invernadero - particularmente el bióxido de carbono $\left(\mathrm{CO}_{2}\right)$, el metano $\left(\mathrm{CH}_{4}\right)$ y el óxido nitroso $\left(\mathrm{N}_{2} \mathrm{O}\right)$ - provenientes de diversas actividades de los seres humanos vinculadas principalmente a la quema de combustibles fósiles, a los cambios de uso de suelo (como lo es la deforestación) y a la agricultura.

iii) La vulnerabilidad o probabilidad de que los seres humanos, el mundo construido y otros procesos naturales, puedan sufrir daños de diversas magnitudes ante los impactos del cambio climático detectado (el cual se percibe como una amenaza), y de ahí la necesidad de establecer medidas de adaptación a dichos impactos y de mitigación para la reducción de los gases de efecto invernadero.

Aunque todavía existen voces que dudan sobre su existencia, el cambio climático que ocurre hoy en día ha sido reconocido como uno de los dilemas ambientales más grandes que enfrenta la humanidad en este siglo XXI. El órgano intergubernamental más importante que a nivel internacional aborda este tema - el Grupo Intergubernamental de Expertos sobre el Cambio Climático- $-{ }^{17}$ ha señalado en su último informe de eva-

16 Véase, por ejemplo, Gallegos García, Artemio, "Clima oceánico: los mares mexicanos ante el cambio climático global”, y Magaña Rueda, Víctor O., "El cambio climático global: comprender el problema", ambos en ibidem, pp. 18 y 44.

17 Este grupo de expertos (también conocido como el Panel Intergubernamental de Cambio Climático, PICC por sus siglas en español e IPCC por sus siglas en inglés) fue creado a instancias de la Organización Meteorológica Mundial y del Programa de las Naciones Unidas para el Medio Ambiente en 1988. Véase Organización Meteorológica Mundial y Programa de las Naciones Unidas para el Medio Ambiente, Introducción, Grupo Intergubernamental sobre el Cambio Climático, Organización Meteorológica Mundial-Programa de las Naciones Unidas para el Medio Ambiente, http://www.ipcc.ch/ about/faq/IPCC\%20Introduction\%20S.pdf. 
Esta obra forma parte del acervo de la Biblioteca Jurídica Virtual del Instituto de Investigaciones Jurídicas de la UNAM

luación ${ }^{18}$ publicado en 2007 , que el calentamiento del sistema climático en nuestro planeta es inequívoco como es evidente por las observaciones siguientes: 1) el incremento de las temperaturas medias globales del aire y del océano; 2) la expansión del derretimiento de la nieve y el hielo, y 3) el incremento promedio global del nivel del mar. ${ }^{19}$

\section{La temperatura media global del aire y del océano}

Según el Cuarto Informe de Evaluación presentado por el Grupo de Trabajo I del Panel Intergubernamental sobre Cambio Climático y publicado en febrero de 2007, lo datos más relevantes sobre la temperatura media global del aire y del océano son los siguientes: ${ }^{20}$

- El aumento en la temperatura para el periodo 1906 a 2005 fue de $0.74^{\circ} \mathrm{C}$. Esta cifra es mayor a la previamente indicada por el Tercer Informe de Evaluación de 2001 publicado por el mismo panel intergubernamental en el cual se señalaba que el aumento de 1901 a 2000 habría sido de $0.6^{\circ} \mathrm{C}$. Se ha concluido que el incremento total de la temperatura de $1850-1899$ a $2001-2005$ ha sido de $0.76^{\circ} \mathrm{C}$.

- Desde 1850 a la fecha, los once años más cálidos que se han registrado en el planeta corresponden a los últimos doce años del periodo 1995-2006.

- Desde el Primer Informe de Evaluación en 1990, el panel intergubernamental pronosticó un aumento de la temperatura promedio global de entre 0.15 a $0.3^{\circ} \mathrm{C}$ por década para el periodo $1990-2005$. Esta proyección ahora puede compararse con los datos del cuarto

18 A partir de su creación, el PICC ha publicado cuatro informes de evaluación: en 1990 el primero, en 1995 el segundo, en 2001 el tercero y en 2007 el cuarto. La información que en este artículo se proporciona proviene de este último informe que, al igual que su antecesor, está conformado por tres documentos emanados cada uno de un grupo de trabajo abarcando los siguientes temas: Grupo-I alude a las bases científicas, Grupo-II se refiere a los impactos, vulnerabilidad y adaptación, y finalmente, Grupo-III que hace alusión a la mitigación de las emisiones de los gases de efecto invernadero.

19 Intergovernmental Panel on Climate Change, "Summary for Policymakers", en Solomon, S. et al. (eds.), Climate Change 2007: The Physical Science Basis. Contribution of Working Group I to the Fourth Assessment Report of the Intergovernmental Panel on Climate Change, Cambridge-Nueva York, Cambridge University Press, 2007.

20 Idem. 
Esta obra forma parte del acervo de la Biblioteca Jurídica Virtual del Instituto de Investigaciones Jurídicas de la UNAM

informe en el sentido de que en las próximas dos décadas habrá de incrementarse la temperatura promedio global cerca de $0.2^{\circ} \mathrm{C}$ por década.

- Existen seis escenarios a futuro (para finales del siglo XXI) sobre el aumento de la temperatura promedio global: el más optimista estima un incremento de $1.8^{\circ} \mathrm{C}$ (con un rango de variación entre 1.1 a $2.9^{\circ} \mathrm{C}$ ) y el más alarmante un aumento de $4^{\circ} \mathrm{C}$ (con un rango de variación entre 2.4 a $6.4^{\circ} \mathrm{C}$ ).

- Las temperaturas promedio en las zonas polares hace 125000 años ${ }^{21}$ (i. e. en el último periodo interglacial) eran de 3 a $5^{\circ} \mathrm{C}$ por encima de las temperaturas actuales.

- Las temperaturas promedio en el Ártico aumentaron casi el doble del promedio global durante los últimos cien años (las temperaturas en esta zona tienen una variabilidad por década muy alta: se detectó un periodo cálido de 1925 a 1945). Las temperaturas por encima de la capa del llamado permafrost se han incrementado en toda esta zona hasta casi $3^{\circ} \mathrm{C}$ desde la década de los ochenta.

- En los últimos cincuenta años se ha observado una expansión de cambios en las temperaturas extremas: mientras que los días y las noches frías así como las heladas han sido menos frecuentes, los días, las noches y las ondas cálidas han sido todo lo contrario (i.e. más frecuentes).

- El contenido promedio de vapor que se encuentra en la atmósfera ha tenido un incremento sobre el suelo, el mar y la troposfera por lo menos desde la década de los ochenta.

- Desde 1961 se ha observado que la temperatura promedio global del océano ha aumentado hasta profundidades que alcanzan los 3000 metros y que ésta ha estado absorbiendo más del $80 \%$ del calor adicional al sistema climático.

Cabe mencionar que el propio grupo de expertos en este cuarto informe ha señalado asimismo algunos casos en los que no se observa un cambio en ciertos aspectos del clima, como por ejemplo el de la ausencia

21 Recordemos que la especie a la cual pertenecemos nosotros, el último grupo de los homínidos, es decir el homo sapiens, habría aparecido en la Tierra hace unos $120000 \mathrm{a}$ 150000 años. 
Esta obra forma parte del acervo de la Biblioteca Jurídica Virtual del Instituto de Investigaciones Jurídicas de la UNAM

de calentamiento en las temperaturas promedio a lo largo de la región de la Antártica.

\section{La expansión del derretimiento de la nieve y el hielo}

En el mismo informe del Grupo de Trabajo I del PICC se indica con relación al derretimiento de nieve y hielos lo siguiente: ${ }^{22}$

- Los glaciares y las cubiertas de nieve han disminuido en promedio en ambos hemisferios del planeta (norte y sur).

- Información satelital desde 1978 demuestra que en promedio cada año el hielo marino del Ártico se ha reducido en un $2.7 \%$ por década, con disminuciones más grandes hasta de un $7.4 \%$ por década durante las épocas de verano.

- En los seis escenarios que se manejan sobre el aumento de la temperatura promedio global para finales del siglo XXI, tanto el hielo marino del Ártico como el de la Antártica habrán disminuido. De hecho, se pronostica que para la segunda mitad del siglo XXI, el hielo marino del Ártico durante la última parte del verano habrá de desaparecer casi por completo.

- Se pronostica que la capa de hielo de Groenlandia continuará su reducción durante el presente siglo con una posible tendencia a desaparecer por completo de prolongarse el aumento en la temperatura promedio global durante los próximos siglos.

\section{Elevación del nivel del mar}

Por último, estas son las cifras y consideraciones que el Grupo-I de expertos publicó para el tema del incremento del nivel del mar: ${ }^{23}$

- Es probable hasta en un 66\% que el promedio global del nivel del mar en el último periodo interglacial (i. e. hace unos 125,000 años) haya sido de 4 a 6 metros más alto del que prevaleció durante el siglo XX debido a la retirada del hielo polar (la temperatura promedio polar

22 Intergovernmental Panel on Climate Change, op. cit., nota 19.

23 Idem. 
Esta obra forma parte del acervo de la Biblioteca Jurídica Virtual del Instituto de Investigaciones Jurídicas de la UNAM

en aquel tiempo era de $3^{\circ} \mathrm{C}$ a $5^{\circ} \mathrm{C}$ mayor que la actual debido a la inclinación orbital de la Tierra). Es también probable en un $66 \%$ que la capa de hielo de Groenlandia así como otros yacimientos de hielo árticos contribuyeron con un poco menos de 4 metros en la elevación del nivel del mar. En este escenario es posible también cierta contribución de la Antártica.

- Para el periodo 1961-2003, el promedio global del nivel del mar se incrementó a razón de 1.8 (con un rango de variación entre 1.3 y 2.3) milímetros por año. Esta tasa de elevación fue más rápida para el periodo 1993-2003 que consistió en 3.1 (con un rango de variación entre 2.4 y 3.8) milímetros por año. Aunque no está del todo claro que el rápido incremento en la elevación del mar para ese periodo esté asociado a una simple fluctuación climática decadal o a una tendencia de largo plazo, existe gran certeza de que el nivel del mar en efecto aumentó del siglo XIX al siglo XX.

- En la actualidad, mientras que el derretimiento de los glaciares y las cubiertas de nieve han contribuido en definitiva a la elevación del nivel del mar, existe hasta un $90 \%$ de probabilidades de que la pérdida de las capas de hielo en Groenlandia y la Antártica hayan contribuido para ello en el periodo 1993-2003.

- La desaparición de la capa de hielo de Groenlandia (con temperaturas similares a las de hace 125000 años) podría contribuir a un incremento de 7 metros de nivel del mar, situación que no se prevé ocurra en los próximos 100 años.

- Se estima que el incremento total del nivel del mar durante todo el siglo XX fue de 0.17 (con un rango de variación entre 0.12 y 0.22 ) metros, es decir, 17 centímetros.

- Para el periodo 2090-2099 se espera un incremento del nivel del mar de 0.18 a 0.38 metros (de 18 a 38 centímetros) si la temperatura cambia en $1.8^{\circ} \mathrm{C}$ teniendo un $66 \%$ de probabilidades que el rango fluctúe entre los 1.1 a $2.9^{\circ} \mathrm{C}$; sin embargo, ese incremento será de 0.26 a 0.59 metros (de 26 a 59 centímetros) si la temperatura alcanza $4^{\circ} \mathrm{C}$ con un similar $66 \%$ de probabilidad que el rango sea entre 2.4 y $6.4^{\circ} \mathrm{C}$. 
Esta obra forma parte del acervo de la Biblioteca Jurídica Virtual del Instituto de Investigaciones Jurídicas de la UNAM

\section{UN MARIDAJE DE TRES: \\ TURISMO, PLAYAS Y CAMBIO CLIMÁTICO}

Como hemos observado, la actividad turística en las playas de nuestro país representa, entre muchas otras cosas más, una derrama económica substancial que no puede subestimarse en lo absoluto. El cúmulo de oportunidades para el turismo que ofrecen nuestras zonas costeras se encuentran, sin embargo, amenazadas por la ocurrencia de un fenómeno insoslayable: el cambio climático. Mientras que el extraño maridaje que existe entre el turismo, las playas y el cambio climático ha sido reconocido por la comunidad internacional en los foros más importantes para discutir esos temas, los efectos del cambio climático en el turismo de playa en México empiezan a manifestarse en dos rubros específicos: $i$ ) la intensidad (aunque no necesariamente el número) de los huracanes, y ii) el paulatino (aunque casi inadvertido) aumento del nivel del mar.

\section{Nivel internacional: dos organismos con una misma preocupación}

\section{A. Organización Mundial del Turismo}

La principal organización a nivel internacional en el ámbito del turismo - la OMT - se ha constituido como un foro mundial para discutir diversas cuestiones de política turística y una fuente de conocimientos prácticos y útiles sobre el turismo en general. Integrada en la actualidad por 157 países y territorios y más de 300 miembros afiliados (como gobiernos locales, asociaciones turísticas, compañías aéreas, grupos hoteleros, etcétera) la OMT ha participado en diversos foros ambientales internacionales de suma importancia, como lo han sido, por ejemplo, la llamada cumbre de la Tierra (i. e. la Conferencia de las Naciones Unidas sobre el Medio Ambiente y el Desarrollo celebrada en Río de Janeiro, Brasil, en 1992) y la cumbre de Johannesburgo (i. e. Cumbre Mundial sobre el Desarrollo Sostenible celebrada en Johannesburgo, Sudáfrica, en 2002). ${ }^{24}$ Sin embargo, el maridaje entre el turismo, las zonas costeras y el cambio climático no se da de manera puntual dentro de esta organización

24 Para mayor información en este sentido, véase World Tourism Organisation, About UNWTO, World Tourism Organisation, 2006, http://www.unwto.org/aboutwto/index. php. 
Esta obra forma parte del acervo de la Biblioteca Jurídica Virtual del Instituto de Investigaciones Jurídicas de la UNAM

sino hasta principios del siglo XXI, cuando la propia OMT reconoce la importancia del impacto de este fenómeno en diversas actividades y destinos turísticos en el mundo (incluyendo los litorales costeros) así como la contribución que tiene el sector en la lucha contra el calentamiento global.

Para discutir la complejidad que une a estos tres temas, la OMT ha convocado en menos de cinco años a dos cumbres sobre turismo y cambio climático. La primera de ellas, denominada Primera Conferencia Internacional sobre Cambio Climático y Turismo, se celebró en Djerba, Túnez, del 9 al 11 de abril de 2003. De ella emanó un instrumento jurídico no vinculante: la Declaración de Djerba sobre Cambio Climático y Turismo. ${ }^{25}$ Entre las cosas más importantes que se acordaron en ese documento fueron las de exhortar a todos los gobiernos a suscribir cuanto acuerdo internacional de relevancia estuviera vinculado al cambio climático, además incitar al sector turístico a la utilización de energías eficientes y tecnologías limpias para minimizar lo más posible su contribución al cambio climático, y sobre todo, invitar al Panel Intergubernamental sobre el Cambio Climático a que pusiera mayor atención a los temas turísticos y que los incluyera de manera específica en su Cuarto Informe de Evaluación. Aunado a lo anterior, y de suma relevancia para nuestro artículo, se reconoció la existencia y potencial impacto dañino del cambio climático en el desarrollo del turismo en ciertos ecosistemas como lo son los costeros.

La segunda de las cumbres, conocida como la Segunda Conferencia Internacional sobre Cambio Climático y Turismo, se celebró en Davos, Suiza, del 1o. al 3 de octubre de 2007. De aquí también emanó un instrumento jurídico no vinculante: la Declaración de Davos, que establece - entre otras cosas - que el clima es clave para el turismo y por lo tanto el sector deberá responder de manera rápida al avance del cambio climático a través de la mitigación de la emisión de gases de efecto invernadero resultantes del transporte y el alojamiento. Asimismo, este documento enfatizó que el turismo deberá adaptarse a los cambios en el clima por lo que invita a los gobiernos a incluir este tema en el cumplimiento de sus compromisos relacionados con el cambio climático. A todo lo anterior, y de

25 Documento oficial disponible en World Tourism Organisation, Djerba Declaration on Tourism and Climate Change, World Tourism Organisation, abril de 2003, http:// www.world-tourism.org/sustainable/climate/decdjerba-eng.pdf. 
Esta obra forma parte del acervo de la Biblioteca Jurídica Virtual del Instituto de Investigaciones Jurídicas de la UNAM

mucha relevancia para nosotros, se suma el hecho de que en el documento se exhorta a la industria del turismo y a los centros con destino de playa a proteger el litoral costero (tanto humedales como arrecifes coralinos). ${ }^{26}$

\section{B. Panel Intergubernamental sobre el Cambio Climático (PICC)}

De la misma manera en que no queda duda de la importancia que la OMT otorga al cambio climático en las zonas costeras desde el ámbito del turismo, así tampoco vacila el panel intergubernamental en reconocer el impacto que ese fenómeno habrá de tener en el turismo y en las zonas costeras desde la discusión de las variaciones climáticas en el planeta.

De los tres documentos que el multicitado panel intergubernamental elaboró para conformar su Cuarto Informe de Evaluación, es en el segundo - relativo al impacto, vulnerabilidad y adaptación - que encontramos referencias expresas al sector turístico y a las costas..$^{27}$ De esta manera, en un principio preocupa al Grupo de Expertos del PICC en materia turística la reducción de lo que llama turismo de invierno (inclusive el costero) por el retiro de glaciares y disminución de la cubierta de nieve, por ejemplo en áreas montañosas, así como la reducción del turismo de verano, específicamente en el sur de Europa ante las condiciones climáticas. En materia de costas, aunque el PICC reconoce que no existe una tendencia clara en cuanto a los impactos, señala que el crecimiento del nivel del mar (y el desarrollo humano) están contribuyendo a la pérdida de humedales costeros y manglares. Además, pronostica una expansión en la mortandad de los corales y daño costero en general por inundaciones y tormentas tropicales; hace hincapié en los probables derretimientos de las capas de hielo

26 La Declaración de Davos será la base de la próxima reunión ministerial en Londres, Inglaterra, a mediados de noviembre de 2007. El documento y resultados de la conferencia también habrán de ser presentados en la siguiente conferencia de la Organización de las Naciones Unidas sobre cambio climático a celebrarse en Bali, Indonesia en diciembre de este mismo año. El documento oficial está disponible en: World Tourism Organisation et al, Davos Declaration, WTO/UNEP/WEF/WM0/Confederación Suiza, octubre de 2007, http://www.unwto.org/pdf/pr071046.pdf.

27 Intergovernmental Panel on Climate Change, "Summary for Policymakers", en Parry, M. L. et al. (eds.), Climate Change 2007: Impacts, Adaptation and Vulnerability. Contribution of Working Group II to the Fourth Assessment Report of the Intergovernmental Panel on Climate Change, Cambridge, Reino Unido-Nueva York, Estados Unidos, Cambridge University Press, 2007. 
Esta obra forma parte del acervo de la Biblioteca Jurídica Virtual del Instituto de Investigaciones Jurídicas de la UNAM

de Groenlandia y de la parte oeste de la Antártica, que habrán de producir cambios en las líneas costeras y sus ecosistemas. En suma, para el grupo de expertos las costas son altamente vulnerables tanto para el hábitat como para los pobladores y la infraestructura que se encuentra en ellas.

Por lo que hace al turismo en las zonas costeras, el PICC señala que con las afectaciones a las áreas bajas o al nivel del mar en zonas altamente pobladas, así como con la degradación de manglares y arrecifes coralinos habrá consecuencias de adaptación costosas para el propio sector turístico. Todavía más importante, indica que para las islas pequeñas en lo particular el valor de los destinos de turismo en costa disminuirá debido a la degradación de las condiciones costeras por la erosión de playa y el daño a los corales.

\section{Nivel nacional: dos amenazas al turismo de playa}

Con todo lo dicho hasta aquí es posible detectar, entre otros, dos aspectos derivados del cambio climático que amenazan al turismo (internacional) de playa en nuestro país: los huracanes y el aumento del nivel del mar.

\section{A. Huracanes}

Uno de los temas al que mayor atención ha puesto el Cuarto Informe de Evaluación del PICC es al de la actividad ciclónica tropical. ${ }^{28}$ Según este informe, existe hasta $66 \%$ de probabilidad de que a partir de 1970 haya ocurrido un incremento en la intensidad de los ciclones tropicales en ciertas regiones, como en el caso del Atlántico del Norte. Aunque sólo existe el $50 \%$ de probabilidades que este incremento en la intensidad esté relacionado directamente con la actividad humana, existe la misma probabilidad de un $66 \%$ de que dicha intensidad continúe incrementándose durante el siglo XXI. Es de hacerse notar que el grupo de expertos del panel intergubernamental ha señalado que no existe una tendencia clara que indique el número de huracanes y/o tifones por año, pero tampoco se espera que su número decrezca globalmente. De cualquier manera, los impactos que se pronostican a futuro están relacionados de manera

28 El PICC engloba bajo la expresión ciclón tropical tanto a huracanes como a tifones. Véase Intergovernmental Panel on Climate Change, op. cit., nota 19, p. 7. 
Esta obra forma parte del acervo de la Biblioteca Jurídica Virtual del Instituto de Investigaciones Jurídicas de la UNAM

directa o indirecta a la actividad turística, como por ejemplo, el daño producido a los arrecifes de coral, daños a instalaciones hidráulicas, pérdida de propiedades, retiro de las coberturas por riesgo por parte de las aseguradoras en zonas vulnerables, etcétera. ${ }^{29}$

Los efectos del cambio climático en México son ya palpables y se han manifestado de diversas maneras, como lo ha sido, por ejemplo, en el incremento de la precipitación media anual en el noroeste de la República y en el aumento del número de depresiones tropicales registradas en el Golfo de México y la zona del Caribe. Más relevante es que, por su posición geográfica, nuestro país tiene un alto grado de vulnerabilidad frente a los huracanes a lo largo de todo su litoral costero: tanto por el lado del Océano Pacífico como por el del Atlántico. El propio gobierno mexicano ha reconocido cierta intensificación en la fuerza de los huracanes al señalar que 2004 fue la tercera temporada más activa registrada desde 1950 y 2005 representó la más activa que jamás se haya registrado. ${ }^{30}$

En párrafos anteriores, hemos señalado que los dos destinos de playa más importantes por número de turistas internacionales (turistas de internación) son los de Cancún y Cozumel, en Quintana Roo, y el de Los Cabos, en Baja California Sur. Como se observa en las tablas 12 y 13, aunque ambos destinos han sido afectados por el impacto de huracanes, cada uno de ellos observa características distintas en cuanto a su número e intensidad. ${ }^{31}$ Así, en las últimas tres décadas (1980-2007) mientras que en el estado de Quintana Roo (Cancún y Cozumel o zonas cercanas) han impactado seis huracanes, en el estado de Baja California Sur (Los Cabos o zonas cercanas) el impacto ha sido del doble: doce. Sin embargo, por lo que se refiere a intensidad ha sido aquélla entidad federativa y no ésta la que ha sufrido las categorías más altas, ya que mientras Quintana Roo ha registrado en dos ocasiones huracanes de categoría 5 y en otras dos de

29 Para mayor detalle en este último punto, véase Intergovernmental Panel on Climate Change, op. cit., nota 27, p. 18.

30 Se calcula que alrededor de 20 millones de personas se ubican en áreas susceptibles al impacto de los huracanes. Para más detalles, Comisión Intersecretarial de Cambio Climático, Estrategia nacional del cambio climático, México, Comisión Intersecretarial de Cambio Climático, Secretaría de Medio Ambiente y Recursos Naturales, 2007.

31 Para mayor información, véase idem, y Comisión Nacional del Agua, Resumen de la temporada de ciclones tropicales 2006, México, CNA, s.f., http://smn.cna.gob.mx/ ciclones/tempo2006/crt2006.pdf. 
Esta obra forma parte del acervo de la Biblioteca Jurídica Virtual del Instituto de Investigaciones Jurídicas de la UNAM

categoría 4, Baja California Sur no ha registrado huracanes de categoría 5 o 4, sólo uno de categoría 3, en veintisiete años.

TABLA 12

Huracanes que han impactado en Quintana Roo (1980-2007)

\begin{tabular}{|c|c|c|c|}
\hline Año & Nombre del huracán & Lugar de entrada & Categoría \\
\hline 2007 & Dean & Mahahual & 5 \\
\hline 2005 & Wilma & Isla Cozumel / Puerto Morelos & 4 \\
\hline 2005 & Stan & Felipe Carrillo Puerto & TT \\
\hline 2005 & Emily & Norte de Tulum & 4 \\
\hline 2000 & Keith & Chetumal & 1 \\
\hline 1996 & Dolly & Felipe Carrillo Puerto & TT \\
\hline 1995 & Roxanne & Tulum & 3 \\
\hline 1993 & Gert & Chetumal & TT \\
\hline 1990 & Diana & Chetumal & TT \\
\hline 1988 & Gilberto & Puerto Morelos & 5 \\
\hline
\end{tabular}

Nota: Las siglas TT corresponden a tormenta tropical que derivó en huracán después de su paso por la entidad federativa.

Fuente: Comisión Nacional del Agua, s.f., y Comisión Intersecretarial de Cambio Climático, 2007.

Ahora bien, se observa una muy ligera tendencia - aunque no del todo clara- en el incremento del número de huracanes en ambos destinos de playa, lo mismo sucede en cuanto a su intensidad. En efecto, si contamos tres décadas a partir de 1980 nos daremos cuenta de que para el caso de Quintana Roo mientras que de 1980 a 1989 impactó sólo un huracán (de categoría 5) sin registros de tormentas tropicales y para la siguiente década de 1990 a 1999 impactó nuevamente sólo uno (ahora de categoría 3) pero con registros de tres tormentas tropicales, para el periodo de 2000 a $2007 \mathrm{se}$ duplicó el número de huracanes de las dos décadas anteriores y se registraron en total cuatro (uno de categoría 5 , dos de 4 y uno de 1 ) más una tormenta tropical. En otras palabras, de la década de los noventa del siglo pasado a la década actual, el número de ciclones tropicales se ha incrementado 
Esta obra forma parte del acervo de la Biblioteca Jurídica Virtual del Instituto de Investigaciones Jurídicas de la UNAM

ligeramente y han pasado de tormentas tropicales a huracanes de mayor intensidad. ${ }^{32}$

TABLA 13

Huracanes que han impactado en Baja California Sur (1980-2007)

\begin{tabular}{|c|c|c|c|}
\hline Año & Nombre del huracán & Lugar de entrada & Categoría \\
\hline 2007 & Henriette & San José del Cabo & 1 \\
\hline 2006 & John & El Saucito & 2 \\
\hline 2003 & Ignacio & Cd. Constitución & 2 \\
\hline 2003 & Marty & San José del Cabo & 2 \\
\hline 2001 & Juliette & La Paz, Constitución & 1 \\
\hline 1999 & Greg & San José del Cabo & 1 \\
\hline 1998 & Isis & Los Cabos & TT \\
\hline 1997 & Nora & Bahía Tortugas, Punta Canoas & 1 \\
\hline 1996 & Fausto & Todos Santos & 1 \\
\hline 1995 & Henriette & Cabo San Lucas & 2 \\
\hline 1993 & Calvin & Las Lagunas & TT \\
\hline 1992 & Lester & Punta Abreojos & 1 \\
\hline 1989 & Kilo & Bahía los Muertos & 3 \\
\hline 1982 & Paul & Las Lagunas & 2 \\
\hline
\end{tabular}

Nota: Las siglas TT corresponden a tormenta tropical que solo en el caso de Isis derivó en huracán después de su paso por la entidad federativa

Fuente: Comisión Nacional del Agua, s.f. y Comisión Intersecretarial de Cambio Climático, 2007.

Para el caso de Baja California Sur sucede algo similar. Si bien se observa que durante el periodo 1980 a 2007 se presenta un aumento en el número de huracanes, en las últimas dos décadas se ha mantenido el mismo número. Es decir, de la primera década con dos huracanes (19801989) se pasa a la segunda con cinco (1990-1999) y de la segunda a la tercera (2000-2007) se presentan igual número de huracanes (claro que en este caso falta esperar a que concluya la última década). Al mismo

32 Por cierto, al momento de escribir (octubre de 2007) aún no termina la temporada de huracanes de este mismo año y faltan aún dos más para completar la década 20002009. 
Esta obra forma parte del acervo de la Biblioteca Jurídica Virtual del Instituto de Investigaciones Jurídicas de la UNAM

tiempo, se detecta un pequeño, casi inadvertido (y podría ser hasta confuso) incremento en la intensidad de los huracanes por década. Así, mientras que en la primera década se registraron sólo dos huracanes (uno de categoría 2 y otro de categoría 3 que es la más alta de los huracanes que haya registrado esa entidad federativa) y ninguna tormenta tropical, para la siguiente década (de 1990 a 1999) aunque haya aumentado el número de huracanes a más del doble con cinco en total (uno de categoría 2 y cuatro de categoría 1) y se hayan registrado dos tormentas tropicales, no alcanzaron ninguno de ellos la categoría 3. Para la siguiente década, de 2000 a 2007, se han registrado el mismo número de huracanes, cinco en total, pero ahora sí han sumado más huracanes de categoría 2 respecto a la década inmediata anterior $(i$. e. hasta el momento han ocurrido tres de categoría 2 y dos de categoría 1) y sin registro de tormentas tropicales. Aunque desde 1989 no se hayan registrado huracanes de categoría 3, de cualquier modo es claro el incremento en número de los de categoría 2.

En suma, aunque existen ciertas dudas sobre las tendencias en número e intensidad de los huracanes para las próximas décadas, es claro que los dos destinos de playa más importantes en México para el turismo internacional seguirán estando amenazados en el futuro inmediato por la ocurrencia de estos fenómenos a consecuencia del cambio climático.

\section{B. Nivel del mar}

Otra de las preocupaciones que ha estado presente en el Cuarto Informe de Evaluación del PICC es el paulatino, pero ya comprobado, aumento en el nivel del mar. Como hemos señalado anteriormente, se calcula que durante el siglo XX el incremento del nivel del mar fue de 17 centímetros (con un rango de variación entre 0.12 y 0.22 ) y que en los últimos años — particularmente de 1993 a 2003 — la tasa de aumento fue de 3.1 milímetros (con un rango de variación entre 2.4 y 3.8) anuales. Para el 2090-2099 con pronóstico reservado se espera un incremento del nivel del mar de 18 a 38 centímetros si la temperatura cambia en $1.8^{\circ} \mathrm{C}$; pero en un escenario no tan optimista, el incremento será de 26 a 59 centímetros si la temperatura alcanza $4^{\circ} \mathrm{C}$. Estas cifras, desde luego, podrían ser aún mayores dependiendo de la velocidad con que ocurran ciertos fenómenos, como la retirada de los glaciares en Groenlandia. 
Esta obra forma parte del acervo de la Biblioteca Jurídica Virtual del Instituto de Investigaciones Jurídicas de la UNAM

Debido a que la elevación del mar no es del todo homogénea por el cambio climático, ${ }^{33}$ sólo es posible hacer ciertas predicciones sobre sus impactos en las zonas costeras. De esta manera, en la Estrategia $\mathrm{Na}$ cional de Cambio Climático se han difundido las posibles afectaciones por incremento del nivel medio del mar en regiones críticas de la zona costera, entre las cuales se encuentra una de las dos zonas turísticas más importantes para nuestro país. Se trata de la región Bahías de Sian Ka'an Chetumal, Quintana Roo, muy cercana a Cancún y Cozumel donde se establece que un aumento del nivel medio del mar entre 0 y 1 metros (cifra que puede compararse con el más o el menos optimista de los escenarios planteados por el PICC) afectaría a un área de 585 kilómetros cuadrados con hasta 500 metros tierra adentro y hasta 32 kilómetros tierra adentro en los esteros. ${ }^{34}$

Aunque pareciera muy distante cualquier afectación a la zona costera y la actividad turística por razones de un aumento de sólo unos 3.1 milímetros al año, el incremento paulatino ha sido considerado por el gobierno mexicano como una verdadera amenaza. En principio, la elevación del mar amenazaría, tal y como expresamente lo señala la estrategia nacional, "la localización actual de determinados asentamientos turísticos y de sus infraestructuras"; si este problema se relaciona con otros eventos derivados del calentamiento global no cabe duda que se provocarán daños significativos en las playas afectando "drásticamente las actividades turísticas del país". ${ }^{35}$ Por consiguiente, no es aventurado suponer que el turismo de internación a destinos como el de Cancún y Cozumel podría cambiar la dirección de sus visitas a otros países y con ello afectar los ingresos que por este concepto recibe México.

\section{REFLEXIONES FINALES}

De nuestro análisis descriptivo sobre el turismo internacional de playa y el cambio climático en México, hemos llegado a las conclusiones siguientes:

33 Para mayores detalles véase Ortiz Pérez, Mario Arturo y Méndez Linares, Ana Patricia, Repercusiones por ascenso del nivel del mar en el litoral del Golfo de México, México, UNAM, s.f., http://www.atmosfera.unam.mx/editorial/libros/cambio_climatico/ costas.pdf.

34 Comisión Intersecretarial de Cambio Climático, op. cit., nota 30, p. 130.

35 Ibidem, pp. 129 y ss. 
Esta obra forma parte del acervo de la Biblioteca Jurídica Virtual del Instituto de Investigaciones Jurídicas de la UNAM

- Es previsible que México permanezca dentro del rango de los primeros quince países más importantes del planeta en el sector turístico, tanto por llegadas de turistas internacionales como por derrama económica (en ninguno de estos dos rubros se pronostica un cambio abrupto de posición con respecto a otras naciones). Sin duda alguna, el turismo de playa en nuestro país continuará jugando un papel fundamental en este sentido.

- El llamado "turismo de internación" representa el grupo más importante de los visitantes internacionales a nuestro país. En los últimos cinco años (2002-2006) este grupo ha mostrado un desarrollo constante con tasas positivas de crecimiento tanto en número de llegadas como en gasto efectuado. Sin embargo, de 2005 a 2006 se observó una ligera desaceleración - que no llegó a ser negativa - causada principalmente por la entrada del huracán Wilma en las costas de Quintana Roo. Existe la posibilidad de que esta desaceleración, sin que necesariamente sea negativa, vuelva a repetirse por la entrada del huracán Dean en 2007, habrá que esperar las estadísticas oficiales del próximo año.

- Los turistas de internación tienen entre sus preferencias los destinos de playa: en efecto, cinco de los ocho más importantes en todo el país son costeros (Acapulco, Cancún y Cozumel, Los Cabos, Mazatlán, y Puerto Vallarta); los otros tres son urbanos no costeros (Ciudad de México, Guadalajara y Monterrey). Por rango de importancia de todos esos destinos aparecen en primer lugar Cancún y Cozumel en el estado de Quintana Roo, y en segundo, Los Cabos en el estado de Baja California Sur.

- El calentamiento del sistema climático en nuestro planeta (i.e. cambio climático o también llamado calentamiento global) es inequívo$c o$. Dos consecuencias que entre otras acarrea este fenómeno son: $i$ ) el incremento en la intensidad (y quizá el número) de los huracanes, y ii) el aumento paulatino pero constante en el nivel del mar. No hay indicios científicos por el momento que indiquen que la intensidad (y número) de huracanes o el nivel del mar decrezcan en las próximas décadas.

- La Organización de las Naciones Unidas a través de la Organización Mundial del Turismo y el Panel Intergubernamental del Cam- 
Esta obra forma parte del acervo de la Biblioteca Jurídica Virtual del Instituto de Investigaciones Jurídicas de la UNAM

bio Climático ha reconocido que los efectos del cambio climático impactan al turismo de playa en el mundo.

- En México, información estadística de los últimos años demuestra que, en efecto, nuestros destinos turísticos de playa — particularmente los más importantes para el turismo de internación: Cancún y Cozumel y Los Cabos - se encuentran cada vez más amenazados por los efectos del cambio climático. Por lo que corresponde a los huracanes, existe un ligero pero perceptible incremento (y sin que ello denote una clara tendencia) en su intensidad y número para ambos destinos de playa. Por lo que corresponde al aumento en la elevación del nivel del mar, es más claro el grado de vulnerabilidad en el que se encuentra la región de Cancún y Cozumel que la de Los Cabos.

- De la lectura de los documentos oficiales que el gobierno mexicano ha elaborado y que hemos consultado para este artículo, no se desprende que existan medidas jurídicas claras como líneas de acción para la adaptación climática desde el sector turístico costero. Si bien hemos adquirido como país compromisos internacionales que suponen ciertas restricciones al desarrollo de un marco jurídico apropiado, debemos recordar que los preceptos constitucionales ambientales (y por tanto climáticos) entrañan mandatos que deberán prevalecer en todo momento sobre disposiciones contenidas en tratados internacionales $\mathrm{y} / \mathrm{o}$ acuerdos interinstitucionales que son jerárquicamente inferiores a nuestra carta magna. 
Esta obra forma parte del acervo de la Biblioteca Jurídica Virtual del Instituto de Investigaciones Jurídicas de la UNAM

\section{MÉXICO ANTE LA COP-16. ENTRE LA SIMULACIÓN CLIMÁTICA Y LA INCERTIDUMBRE JURÍDICA*}

\section{PRELIMINAR: EL CALENTAMIENTO DEL SISTEMA CLIMÁTICO EN NUESTRO PLANETA ES INEQUÍVOCO}

Es creciente, y cada vez más convincente, la evidencia científica sobre la existencia de un cambio climático inducido por los seres humanos como resultado de la acumulación en la atmósfera de emisiones de gases de efecto invernadero. Uno de los estudios académicos más consultados y citados de los últimos años, el Informe Stern, ${ }^{1}$ anunció en 2006 lo siguiente:

Los indicios científicos de la gravedad y la urgencia del problema del cambio climático son actualmente convincentes, hasta el punto de justificar la aplicación de medidas contundentes de reducción de las emisiones de gases invernadero en todo el mundo para reducir el riesgo de consecuencias muy dañinas y potencialmente irreversibles en los ecosistemas, las sociedades y las economías. ${ }^{2}$

En este mismo sentido, la postura de organismos internacionales expresada a través de diversos documentos sobre la certidumbre de la ocurrencia del calentamiento global ha sido mucho más firme en los últimos años. Es el caso del organismo más importante en materia internacional ambiental - el Programa de las Naciones Unidas para el Medio Ambiente (PNUMA) - al aseverar en su cuarto informe mundial de 2007 que

* Publicado en Revista del Posgrado en Derecho de la UNAM, México, núm. 13, julio-diciembre de 2011.

1 Este informe fue encargado por el gobierno británico al académico Sir Nicholas Stern y se hizo público en octubre de 2006.

2 Stern, Nicholas, El Informe Stern. La verdad del cambio climático, trad. de Albino Santos (1a. parte) y Joan Vilaltella (2a. parte), Barcelona, Paidós, 2007, p. 17. 
Esta obra forma parte del acervo de la Biblioteca Jurídica Virtual del Instituto de Investigaciones Jurídicas de la UNAM

"la tendencia del calentamiento global es realmente cierta". ${ }^{3}$ Con base en diferentes fuentes científicas enuncia lo que incluye la evidencia del cambio climático:

...la reducción de los glaciares de montaña...el deshielo del permafrost... el deshielo prematuro de lagos y ríos, la prolongación de las temporadas de crecimiento en latitudes promedios y altas, los cambios en las variedades de plantas, insectos y animales, el adelanto en el florecimiento de los árboles, en la aparición de insectos y en la puesta de huevos de pájaros... los cambios en las pautas de precipitaciones en las corrientes oceánicas... $\mathrm{y}$, posiblemente, el incremento en la intensidad y en la persistencia de las tormentas tropicales en algunas regiones... ${ }^{4}$

Aunado al caso anterior, sobresale el organismo por excelencia que emite opiniones científicas sobre el calentamiento global, el Grupo Intergubernamental de Expertos sobre el Cambio Climático - también conocido como Panel Intergubernamental de Cambio Climático (PICC) - ${ }^{5}$ el cual señaló en su cuarto y último Informe de Evaluación (publicado en 2007) que el calentamiento del sistema climático en este planeta es inequívoco, como es evidente por las observaciones realizadas fundamentalmente en relación con:

- El incremento de las temperaturas medias globales del aire y del océano

- La expansión del derretimiento de la nieve y el hielo

- El incremento promedio global del nivel del mar

3 Programa de las Naciones Unidas para el Medio Ambiente, Perspectivas del Medio Ambiente Mundial Geo4, Madrid, Grupo Mundi-Prensa, 2007, p. 59.

4 Idem.

5 El PICC fue creado en 1988 a instancias de la Organización Meteorológica Mundial y del Programa de las Naciones Unidas para el Medio Ambiente y está conformado por todos los Estados miembros de la Organización de las Naciones Unidas. Desde su creación, ha publicado cuatro informes de evaluación: en 1990, 1995, 2001 y 2007. El Cuarto Informe de Evaluación comprende tres documentos emanados cada uno de un grupo de trabajo para temas diversos, esto es, Grupo-I: bases científicas; Grupo-II: impactos, vulnerabilidad y adaptación; y Grupo-III: mitigación de las emisiones de los gases de efecto invernadero. Para más detalles sobre los orígenes y estructura organizacional del PICC, recomendamos Ávalos Gómez, Montserrat, "Panel Intergubernamental sobre el Cambio Climático, PICC”, en Martínez, Julia y Fernández, Adrián (comps.), Cambio climático: una visión desde México, México, Instituto Nacional de Ecología, 2004. 
Esta obra forma parte del acervo de la Biblioteca Jurídica Virtual del Instituto de Investigaciones Jurídicas de la UNAM

Aunque este informe no ha estado exento de críticas por algunos errores en su contenido, ${ }^{6}$ su aportación científica para el debate académico, la discusión jurídica, y el diseño de políticas públicas en los contextos internacional y nacional de los Estados ha sido trascendentalísima. Por ello, es indispensable mencionar, aunque sea de manera sintetizada, algunos de los datos más relevantes que se han presentado para cada uno de los tres temas mencionados en las viñetas anteriores: ${ }^{7}$

i) Temperatura media global del aire y del océano. El incremento total de la temperatura de $1850-1899$ a $2001-2005$ ha sido de $0.76^{\circ} \mathrm{C}$, y para las próximas dos décadas la temperatura promedio global habrá de incrementarse cerca de $0.2^{\circ} \mathrm{C}$ por década. Existen seis escenarios para finales del siglo XXI sobre el aumento de la temperatura promedio global: el más optimista estima un incremento de $1.8^{\circ} \mathrm{C}$ (con un rango de variación entre $1.1^{\circ} \mathrm{C}$ a $2.9^{\circ} \mathrm{C}$ ) y el más alarmante un aumento de $4^{\circ} \mathrm{C}$ (con un rango de variación entre $2.4^{\circ} \mathrm{C} \mathrm{a} 6.4^{\circ} \mathrm{C}$ ). Desde 1850 a la fecha, los once años más cálidos que se han registrado en el planeta corresponden a los últimos doce años del periodo 1995-2006, y en los últimos cincuenta años se ha observado una expansión de cambios en las temperaturas extremas: mientras que los días y noches frías así como las heladas han sido menos frecuentes, los días, noches y ondas cálidas han sido más frecuentes. Por otro lado, las temperaturas promedio en las zonas polares hace 125,000 años (en el último periodo interglacial) eran de $3^{\circ} \mathrm{C}$ a $5^{\circ} \mathrm{C}$ por encima de las temperaturas actuales. Las temperaturas promedio en el Ártico aumentaron casi el doble del promedio global durante los últimos cien años (las temperaturas en esta zona tienen una variabilidad por década muy alta: se detectó un periodo cálido de 1925 a 1945); las temperaturas por encima de la capa del llamado perma-

6 Uno de los más llamativos es el supuesto derretimiento de los glaciares del Himalaya (del nepalés $h i m=$ nieves, y alya $=$ lugar de) hacia 2035.

7 Intergovernmental Panel on Climate Change, "Summary for policymakers", en Solomon, S. et al. (eds.), Climate Change 2007: The Physical Science Basis. Contribution of Working Group I to the Fourth Assessment Report of the Intergovernmental Panel on Climate Change, Cambridge-Nueva York, Cambridge University Press, 2007. Algunos enunciados de esta síntesis los publicamos en Revista de la Facultad de Derecho de México, t. LVIII, núm. 250, julio-diciembre de 2008. En esta revista el lector encontrará cierta información adicional. 
Esta obra forma parte del acervo de la Biblioteca Jurídica Virtual del Instituto de Investigaciones Jurídicas de la UNAM

frost se han incrementado en toda esta zona hasta casi $3^{\circ} \mathrm{C}$ desde la década de los ochenta. Finalmente, el contenido promedio de vapor que se encuentra en la atmósfera ha tenido un incremento sobre el suelo, el mar y la troposfera por lo menos desde la década de los ochenta; desde 1961, se ha observado que la temperatura promedio global del océano ha aumentado hasta profundidades que alcanzan los 3,000 metros y que ésta ha estado absorbiendo más del $80 \%$ del calor adicional al sistema climático.

ii) Derretimiento de la nieve y el hielo. Los glaciares y las cubiertas de nieve han disminuido en promedio en ambos hemisferios del planeta (norte y sur). Información satelital desde 1978 demuestra que en promedio cada año el hielo marino del Ártico se ha reducido en un $2.7 \%$ por década, con disminuciones más grandes hasta de un $7.4 \%$ por década durante las épocas de verano. En los seis escenarios que se manejan sobre el aumento de la temperatura promedio global para finales del siglo XXI, tanto el hielo marino del Ártico como el de la Antártica habrán disminuido. De hecho, se pronostica que para la segunda mitad del siglo XXI, el hielo marino del Ártico durante la última parte del verano habrá de desaparecer casi por completo. Se pronostica que la capa de hielo de Groenlandia continuará su reducción durante el presente siglo con una posible tendencia a desaparecer por completo de prolongarse el aumento en la temperatura promedio global durante los próximos siglos.

iii) Elevación del nivel del mar. Para el periodo de 1961 a 2003, el promedio global del nivel del mar se incrementó a razón de 1.8 milímetros por año (con un rango de variación entre 1.3 a 2.3). Esta tasa de elevación fue más rápida para el periodo 1993 a 2003 que consistió en 3.1 milímetros por año (con un rango de variación entre 2.4 a 3.8). Aunque no está del todo claro que el rápido incremento en la elevación del mar para ese periodo esté asociado a una simple fluctuación climática decadal o a una tendencia de largo plazo, existe gran certeza de que el nivel del mar en efecto aumentó del siglo XIX al siglo XX. De manera que se estima que el incremento total del nivel del mar durante todo el siglo $\mathrm{XX}$ fue de 0.17 metros (con un rango de variación entre 0.12 a 0.22 ), es decir, de 17 centímetros. Para 2090-2099 se espera un incremento del nivel del mar de 0.18 a 0.38 metros (es decir, de 18 a 38 centímetros) si la temperatura 
Esta obra forma parte del acervo de la Biblioteca Jurídica Virtual del Instituto de Investigaciones Jurídicas de la UNAM

cambia en $1.8^{\circ} \mathrm{C}$ teniendo un $66 \%$ de probabilidades que el rango fluctúe entre los $1.1^{\circ} \mathrm{C}$ a $2.9^{\circ} \mathrm{C}$. Sin embargo, ese incremento será de 0.26 a 0.59 metros (es decir, de 26 a 59 centímetros) si la temperatura alcanza $4^{\circ} \mathrm{C}$ con un similar $66 \%$ de probabilidad que el rango sea entre $2.4^{\circ} \mathrm{C}$ a $6.4^{\circ} \mathrm{C}$. En la actualidad, mientras que el derretimiento de los glaciares y las cubiertas de nieve han contribuido en definitiva a la elevación del nivel del mar, existe hasta un $90 \%$ de probabilidades de que la pérdida de las capas de hielo en Groenlandia y la Antártica hayan contribuido para ello en el período de 1993 a 2003. La desaparición de la capa de hielo de Groenlandia (con temperaturas similares a las de hace 125,000 años) podría contribuir a un incremento de 7 metros del nivel del mar, situación que no se prevé ocurra en los próximos 100 años.

Como resultado del testimonio ofrecido en los documentos aquí mencionados (que se suman a otros más, ciertamente anteriores y coetáneos a ellos) podría pensarse que toda la comunidad internacional está verdaderamente convencida de seguir uniendo esfuerzos para enfrentar el cambio climático. Aún más, podría asegurarse que tales datos y aseveraciones reafirman en las naciones el interés por alcanzar para los próximos años compromisos vinculantes renovados, tal y como lo habrían hecho en el pasado con la adopción de la Convención Marco de las Naciones Unidas sobre el Cambio Climático (CMNUCC, que entró en vigor a nivel internacional en marzo de 1994), del protocolo de Kyoto a dicha convención (que lo hizo en febrero de 2005), y de otros acuerdos alcanzados en diversas conferencias de las partes. Sin embargo, aún con la evidencia de reportes científicos y después de más de 15 años de contar con un régimen jurídico climático a nivel internacional, no está del todo claro si en verdad nos encontramos en un escenario que podríamos adjetivar de optimista. Me parece que estamos lejos de creer que la primigenia preocupación e intención de respuesta de las naciones a este fenómeno inducido, haya logrado actualizarse en las diversas acciones tomadas por la comunidad internacional.

En realidad, el panorama se antoja un tanto decepcionante. Por un lado, las metas y mecanismos desarrollados en el propio régimen jurídico climático han sido criticados - entre otras razones - por su laxitud; y todavía más, ha trascendido que no todos los Estados habrán de cumplir con las obligaciones adquiridas (sean vinculantes o no) en los instrumen- 
Esta obra forma parte del acervo de la Biblioteca Jurídica Virtual del Instituto de Investigaciones Jurídicas de la UNAM

tos internacionales respectivos para el primer periodo acordado 20082012. Por el otro, la no ratificación del protocolo de Kyoto por Estados Unidos no permite afirmar que la comunidad internacional toda esté enfrentando conjuntamente el calentamiento global; además, las expectativas de alcanzar un acuerdo hard de régimen post-Kyoto para adoptar compromisos de carácter vinculante para los próximos años no se cristalizaron ni en la reunión climática de Copenhague en 2009, ni lo harán previsiblemente en la de Cancún a finales de 2010.

\section{KYOTO, COPENHAGUE Y CANCÚN: ¿COMÚN DENOMINADOR DE LA DECEPCIÓN?}

Son tres los nombres de las ciudades que simbolizan - sin pretender con ello negar avances- lo que hemos de llamar el común denominador de la decepción en materia de cambio climático: $i$ ) Kyoto, por haberse adoptado en esa ciudad (en 1997), en la COP-3, un protocolo a la CMNUCC un tanto alejado de lo esperado; ii) Copenhague, sede de la COP-15 y en donde se tenía la enorme expectativa de que se alcanzara un consenso para adoptar compromisos vinculantes pos-2012; y iii) Cancún, lugar donde se llevará a cabo la COP-16 pero en el que seguramente tampoco se habrá de actualizar la expectativa creada en Copenhague de adoptar compromisos vinculantes para un periodo posterior a 2012. Si bien es loable reconocer avances en el régimen jurídico climático, existen razones suficientes para no estar satisfechos del todo con los resultados hasta ahora alcanzados.

En primer lugar, el Protocolo de Kyoto (PK) resultó ser un tratado internacional que desde sus orígenes fue criticado por haber establecido un objetivo de reducción de emisiones muy bajo comparado con los escenarios del calentamiento global. Es decir, aun cuando el protocolo llegara a implementarse de manera absoluta, sus resultados serían marginales alcanzando apenas una reducción de la temperatura en $0.15 \%{ }^{\circ} \mathrm{C}$ (o menos de una sexta parte de un grado) si se comparara con un escenario en donde no existiera reducción de bióxido de carbono (business as usual). ${ }^{8}$

Aunado a lo anterior, desde comienzos de este siglo se ha sostenido que la obligación vinculante de los países anexo I (i. e. países desarro-

8 Más detalles en Guruswamy, Lakshman D., International Environmental Law, 2 a. ed., St. Paul, Minnesota, Thomson / West, 2003, p. 218 y ss. 
Esta obra forma parte del acervo de la Biblioteca Jurídica Virtual del Instituto de Investigaciones Jurídicas de la UNAM

llados y con economías en transición) respecto a sus compromisos cuantificados de limitación o reducción de emisiones conjunta en $5.2 \%$ por debajo de los niveles de 1990 para el primer periodo acordado de 20082012, no habrá de ser cumplida (como podría ser el caso de España). ${ }^{9}$ A esta situación debemos agregar que con la información que ha ofrecido recientemente el Informe Stern y el Cuarto Informe de Evaluación del PICC sobre las acciones que deberán llevarse a cabo para enfrentar el cambio climático, el actual régimen de reducción de emisiones parece francamente inadecuado. ${ }^{10}$ Adicionalmente, no es nada alentador saber que, independientemente de la negativa de Estados Unidos de ratificar y cumplir con las disposiciones del PK, ciertos países no-anexo I que no tienen compromisos cuantificados de limitación o reducción de emisiones (conforme al anexo B del protocolo) como China, Brasil, India, México o Sudáfrica, siguen siendo grandes emisores de gases de efecto invernadero.

En segundo lugar, las expectativas de alcanzar un acuerdo hard de régimen post-2012 se desvanecieron en la Conferencia de las Partes COP15 celebrada hacia finales de 2009 en Copenhague, Dinamarca. En efecto, lo sucedido en esta reunión de las partes, dejó en claro que aunque los países argumentaran en el texto del instrumento denominado Acuerdo de Copenhague que existe una firme voluntad política para enfrentar el calentamiento global con urgencia, ${ }^{11}$ la comunidad internacional no logró cumplir con la gran expectativa de que se adoptaran los compromisos vinculantes elaborados respecto al régimen pos-Kyoto.

El citado Acuerdo de Copenhague contiene normas soft importantes como lo son, entre otras, la de mantener el aumento de la temperatura por debajo de $\operatorname{los} 2^{\circ} \mathrm{C}$; la de que las naciones anexo I se comprometan a aplicar de manera individual o colectiva las metas cuantificadas de reducción

9 Según las proyecciones de la Organización para la Cooperación y el Desarrollo Económico (OCDE), los países anexo I habrán de exceder sus compromisos de reducción de emisiones hasta en un 30\% hacia 2010. Véase, ibidem, pp. 200 y 201.

${ }^{10}$ Birnie, Patricia W., Boyle, Alan E. y Redgwell, Catherine, International Law and the Environment, 3a. ed., Oxford, Oxford University Press, 2009, pp. 371 y ss.

${ }^{11}$ En el numeral 1 del acuerdo se señala al principio lo siguiente: "1. Subrayamos que el cambio climático es uno de los mayores desafíos de nuestros tiempos. Destacamos nuestra firme voluntad política de combatirlo con urgencia...". Véase United Nations Framework Convention on Climate Change, Decisión 2/CP.15 Acuerdo de Copenhague, Informe de la Conferencia de las Partes sobre su $15^{\circ}$ periodo de sesiones, celebrado en Copenhague del 7 al 19 de diciembre de 2009, marzo de 2010. 
Esta obra forma parte del acervo de la Biblioteca Jurídica Virtual del Instituto de Investigaciones Jurídicas de la UNAM

de emisiones relativas al conjunto de la economía para 2020; la de reducir a través de un mecanismo las emisiones debidas a la deforestación y la degradación forestal (actividades REDD-plus); o la de establecer el Fondo Verde de Copenhague para apoyar programas, políticas y actividades (incluidas las REDD-plus) vinculadas a la mitigación, adaptación, fomento de la capacidad y el desarrollo, y la transferencia de tecnología.

Con disposiciones nada espectaculares, las buenas intenciones de la comunidad internacional quedaron plasmadas con la suficiente ambigüedad posible como lo demuestra la redacción del siguiente párrafo del Acuerdo de Copenhague:

2. Convenimos en que se requieren fuertes reducciones de las emisiones mundiales, a la luz de la ciencia y de la información recogida en el Cuarto Informe de Evaluación del IPCC, con miras a lograr una disminución de dichas emisiones que permita mantener el aumento de la temperatura mundial por debajo de $\operatorname{los} 2^{\circ} \mathrm{C}$, y nos proponemos tomar medidas para cumplir este objetivo de conformidad con la ciencia y sobre la base de la equidad. Deberíamos cooperar para lograr que las emisiones mundiales y nacionales alcancen su punto máximo lo antes posible, reconociendo que el plazo para ello será más largo en el caso de los países en desarrollo, y teniendo presente que el desarrollo económico y social y la erradicación de la pobreza son las prioridades primeras y esenciales de esos países y que para lograr el desarrollo sostenible es indispensable una estrategia de desarrollo con bajas emisiones. ${ }^{12}$

En tercer y último lugar, lo que habrá de suceder en Cancún, en la COP-16, será una especie de "evento clonado" igual de decepcionante que el de Copenhague. A un par de meses de que comience tal reunión, no existen noticias alentadoras ni optimistas respecto a la adopción de compromisos vinculantes para el régimen post-2012. En todo caso, la COP-16 en Cancún habrá de ser vista en lo futuro como una reunión en donde lo más destacado habrá sido no sólo la acusada continuación del proceso de negociación hacia la construcción de consensos de un renovado régimen jurídico climático sino la muy probable pero insuficiente en términos globales elaboración de normativa soft.

En suma, contamos con una comunidad internacional que por un lado reconoce la importancia de responder conjuntamente a un problema glo-

12 Idem. 
Esta obra forma parte del acervo de la Biblioteca Jurídica Virtual del Instituto de Investigaciones Jurídicas de la UNAM

bal, pero que por el otro lo hace de manera inquietantemente lenta o de manera un tanto reservada. Bajo este panorama, es fundamental reflexionar sobre la posición que México habrá de adoptar frente a la próxima COP-16. En este sentido, pensamos que si bien el gobierno mexicano ha realizado acciones consecuentes para construir una imagen hacia el exterior que pueda ser considerada como firme y responsable, algunas de esas acciones junto con otros sucesos ocurridos internamente, conducen a creer que estamos frente a una simulación climática.

\section{LA SIMULACIÓN CLIMÁTICA: “CANDIL DE LA CALLE Y OSCURIDAD DE SU CASA"}

Ya sea en el contexto internacional o en el nacional, la posición que México habrá de asumir frente al calentamiento global supone un gran dilema. Por un lado, nuestro país se muestra hacia el exterior como una nación activa y constructiva bajo los márgenes de los compromisos del actual régimen climático; ${ }^{13}$ como veremos más adelante, ciertas acciones sustentan acertadamente esta imagen del país. Por el otro, su actuar doméstico evidencia una actitud contraria respecto a lo que proyecta en el plano internacional; un buen número de datos, estadísticas y hechos contundentes no solo contrarían esa imagen proyectada hacia fuera, sino

${ }^{13}$ Hay que recordar que una de las condiciones que se negociaron para que México se integrara a la Organización para la Cooperación y el Desarrollo Económicos en 1994, fue que dicha organización aceptara que nuestro país no fuera incluido en el anexo I de la CMNUCC, lo que al mismo tiempo provocó su salida del Grupo de los 77 + China. Fernando Tudela explica las consecuencias que derivaron de ello: "Estas circunstancias determinaron el relativo aislamiento inicial de nuestro país en algunas negociaciones multilaterales, como la relativa al cambio climático global. En el marco de los acuerdos ambientales multilaterales, no se incorporaba al listado de los países desarrollados, al tiempo que se desvinculaba de la agrupación negociadora por medio de la cual había defendido tradicionalmente sus intereses como país en desarrollo". Al iniciarse las negociaciones el PK, México se vio sometido - como explica del propio Tudela - a presiones para incorporarse al anexo I, y posteriormente a la adopción del PK, a que asumiera compromisos voluntarios cuantitativos de emisiones de gases de efecto invernadero. La estrategia gubernamental construida para enfrentar esta situación permitió que México fuera ahora considerado como un "socio responsable" y "constructivo" a la vez que cesaron las presiones internacionales para que asumiéramos compromisos ajenos a los que se establecieron en la CMNUCC. Véase, Tudela, Fernando, "México y la participación de países en desarrollo en el régimen climático", en Martínez, Julia y Fernández, Adrián (comps.), Cambio climático: una visión desde México, cit., nota 5, pp. 155 y ss. 
Esta obra forma parte del acervo de la Biblioteca Jurídica Virtual del Instituto de Investigaciones Jurídicas de la UNAM

que han sido en ocasiones engañosamente utilizados para consolidar su posicionamiento en las negociaciones multilaterales, para demostrar un supuesto interés en el tema, o para congratularse por los premios internacionales recibidos. El aparente liderazgo ambiental que se pretende invocar en materia climática tiene en realidad fisuras de gran trascendencia.

\section{Candil de la calle}

Nadie puede negar la activa participación que México ha tenido en el plano internacional climático. Por ejemplo, a través de la continua suscripción de documentos internacionales, de propuestas de tipo financiero, o de la integración con otros países para fijar posturas comunes (como lo fue el grupo de negociación conocido como Environmental Integrity Group, el cual comenzó a operar en 2000). A futuro destaca sin duda alguna la asunción de la presidencia para la próxima $16^{\mathrm{a}}$ Conferencia de las Partes de la CMNUCC y la Conferencia de las Partes en calidad de reunión de las Partes del PK (COP-16/CMP-6). Parte de ese accionar climático ha supuesto una base de tipo jurídica y programática al interior del país que tiene un referente claro a través de diversos documentos publicados en los últimos años.

Algunas de las actividades más importantes en este sentido comprenden tanto aquellas que han sido consecuentes con una respuesta honesta y responsable al cambio climático como aquéllas que han sido ficticiamente presentadas como compromisos singulares.

\section{A. Suscripción de instrumentos internacionales}

Se ha llevado a cabo la suscripción de un buen número de instrumentos internacionales ( $h a r d$ y soft) donde sin duda alguna destacan la adopción (con su respectiva ratificación) de los dos documentos jurídicos principales de carácter vinculante: la CMNUCC y el PK. Para este último caso, es de llamar la atención que México haya estado dentro de los primeros 30 países en depositar el instrumento de ratificación (adhesión o aceptación) de las 184 naciones que ya lo han hecho.

Aunado a lo anterior, se han suscrito distintos instrumentos internacionales (acuerdos, memoranda de entendimiento, cartas de intención) en el marco de la cooperación en materia de mecanismos de desarrollo 
Esta obra forma parte del acervo de la Biblioteca Jurídica Virtual del Instituto de Investigaciones Jurídicas de la UNAM

limpio (MDL). Así, se han celebrado acuerdos interinstitucionales entre la Secretaría de Medio Ambiente y Recursos Naturales de este país y diversos ministerios (primordialmente ambientales) de otros gobiernos de diversos países. Por ejemplo, en 2004 se firmaron acuerdos interinstitucionales con los Países Bajos, Italia, Canadá y España, en 2005 con Alemania y Dinamarca, y en 2006 con Portugal. Existe también un acuerdo interinstitucional celebrado en 2004 entre el Comité Mexicano para Proyectos de Reducción de Emisiones y de Captura de Gases de Efecto Invernadero y el Banco Japonés de Cooperación Internacional.

Asimismo, destaca la celebración de un tratado internacional (aprobado por el Senado el 17 de marzo de 2005 y publicado en el Diario Oficial de la Federación el 30 de junio de ese mismo año) entre nuestro gobierno y el gobierno de la República Francesa también en el marco de los MDL.

\section{B. Actualización de inventarios y entrega de comunicaciones nacionales}

Como parte no anexo I, nuestro país ha cumplido con los compromisos adoptados en la CMNUCC relativos a las actualizaciones correspondientes de sus inventarios de emisiones de gases de efecto invernadero, así como con la entrega periódica de diversas comunicaciones nacionales (que contienen además las medidas adoptadas para enfrentar el calentamiento global) según el principio de responsabilidades comunes pero diferenciadas. México se jacta, por ejemplo, de haber sido el segundo país en desarrollo (Uruguay fue el primero) en presentar la primera comunicación ante la conferencia de las partes, y el primero en haber presentado la segunda y cuarta comunicaciones nacionales. ${ }^{14}$

${ }^{14}$ Las cuatro comunicaciones nacionales fueron entregadas respectivamente en 1997, 2001, 2006, y 2009. En la última comunicación, la cuarta, México presentó, entre otras cosas, la actualización del inventario de emisiones de gases de efecto invernadero (INEGEI) 1990-2006, un estudio del impacto del cambio climático en la economía del país, y algunos extractos del PECC 2008-2012. Más información se puede encontrar en Secretaría de Medio Ambiente y Recursos Naturales, "Cuarta Comunicación Nacional", Biosfera. Sala de prensa. Noticias del medio ambiente, México, 2009, http://www.semarnat.gob.mx. 
Esta obra forma parte del acervo de la Biblioteca Jurídica Virtual del Instituto de Investigaciones Jurídicas de la UNAM

\section{Plantación de millones y millones de árboles al año}

Ante el llamado del PNUMA en 2007 para plantar mil millones de árboles cada año (Campaña de los Mil Millones de Árboles), nuestro país se comprometió con una cuarta parte de esa cantidad de árboles. En efecto, México informó a ese organismo de las Naciones Unidas haber plantado 250 millones de árboles en 2007, es decir, el 25\% de la meta fijada para todo el mundo. Parte de dichas acciones se llevaron a cabo a través del Programa ProÁrbol con una inversión aproximada de 2 mil $700 \mathrm{mi}-$ llones de pesos. En 2008 (a propósito de la celebración del 5 de junio por el Día Mundial del Medio Ambiente) el PNUMA entregó al titular del Ejecutivo Federal y al pueblo de México el Reconocimiento al $\mathrm{Li}$ derazgo Global. Algunos de los razonamientos que esgrimió el organismo internacional estuvieron basados en las cifras de millones de árboles sembrados que proporcionó el gobierno federal. Las palabras de Magdy Martínez-Solimán, quien entregara el premio, fueron las siguientes:

Como coordinador residente de las Naciones Unidas en su país, es para mí un honor entregarle hoy a usted, señor presidente, y al pueblo de México el Reconocimiento al Liderazgo Global en nombre del Programa de las Naciones Unidas para el Medio Ambiente, PNUMA, la más alta autoridad mundial en la materia, por su destacada contribución al cumplimiento de la convocatoria: Plantemos para el Planeta: Campaña de los Mil Millones de Árboles... México contribuyó... con una cuarta parte de los mil millones de árboles a plantar en el mundo durante 2007. Este resultado asombroso para algunos, no es producto del azar, sino fruto de un esfuerzo fiscal que usted ha impulsado poniendo la reforestación a la par de otras múltiples prioridades del gasto público y de un ejercicio de cuidada planificación por parte de su secretario de Medio Ambiente, señor Elvira, y de su equipo. ${ }^{15}$

Como veremos más adelante, la información proporcionada por el gobierno federal no resultó exacta y estuvo plagada de irregularidades.

${ }^{15}$ El discurso completo puede consultarse en Presidencia, Discursos. Diversas intervenciones en la celebración del Día Mundial del Medio Ambiente, México, 5 de junio de 2008, http://calderon.presidencia.gob.mx. 
Esta obra forma parte del acervo de la Biblioteca Jurídica Virtual del Instituto de Investigaciones Jurídicas de la UNAM

\section{Fondo Verde}

El gobierno federal mexicano ha propuesto a la comunidad internacional la creación de un Fondo Mundial contra el Cambio Climático conocido comúnmente como Fondo Verde- como mecanismo financiero (no sustitutivo sino complementario de los instrumentos establecidos en el PK) con el objeto de ampliar la participación de todos los países para sustentar financiera y tecnológicamente las acciones de mitigación y adaptación.

En 2009, en el marco de la reunión en Copenhague, el Ejecutivo Federal (pero no el pueblo de México) recibió un premio, el premio GLOBE (Global Legislators Organization) de manos del saliente primer ministro del Reino Unido, Gordon Brown, quien habría expresado que ninguna propuesta había tenido tanta influencia sobre el financiamiento para enfrentar el cambio climático como la del Fondo Verde del actual presidente mexicano Felipe Calderón Hinojosa.

\section{E. La normatividad doméstica}

En el ámbito jurídico interno, y para la aplicación de la normativa internacional, el Ejecutivo Federal ha expedido diversos instrumentos jurídicos administrativos. Por ejemplo, dos acuerdos presidenciales (el primero, publicado en el Diario Oficial de la Federación el 23 de enero de 2004, que creó con carácter permanente la Comisión Intersecretarial denominada Comité Mexicano para Proyectos de Reducción de Emisiones y de Captura de Gases de Efecto Invernadero, y el segundo, publicado en el Diario Oficial de la Federación el 25 de abril de 2005, que creó con carácter permanente la actual Comisión Intersecretarial de Cambio Climático, y que a su vez abrogó el acuerdo anterior), y un acuerdo secretarial (publicado en el Diario Oficial de la Federación el 27 de octubre de 2005, por el cual se expidieron los procedimientos para la emisión de cartas de aprobación de proyectos de reducción o captura de emisiones de gases de efecto invernadero).

\section{F. Programas}

A nivel programático, además de las referencias generales al cambio climático en los programas sectoriales ambientales, sobresalen particu- 
Esta obra forma parte del acervo de la Biblioteca Jurídica Virtual del Instituto de Investigaciones Jurídicas de la UNAM

larmente dos documentos. Primero, la Estrategia Nacional de Cambio Climático 2007, que contiene un resumen de la respuesta de México y la comunidad internacional al problema del calentamiento global; un diagnóstico sobre las emisiones de gases de efecto invernadero y las oportunidades de mitigación (relativas a la generación y uso de energía así como a la vegetación y el uso del suelo); una descripción sobre la condiciones de vulnerabilidad y las necesidades de adaptación; y finalmente la posición que asume nuestro país ante el régimen internacional climático. ${ }^{16}$

Segundo, el Programa Especial de Cambio Climático 2008-2012, que con 106 objetivos y 303 metas, está dividido en cuatro componentes: visión a largo plazo (donde se asume, entre otras cosas, el objetivo indicativo o meta aspiracional de reducir un 50\% sus emisiones al 2050 con respecto a lo emitido en 2000); mitigación (que con 41 objetivos y 95 metas está orientado a la reducción de emisiones de gases de efecto invernadero y alcanzar lo que llama "la descarbonización de la economía mexicana"); adaptación (donde se plantean 37 objetivos y 143 metas centrándose en la reducción de la vulnerabilidad y la necesidad de desarrollar una gestión integral de riesgos), y por último, elementos de política transversal (que abarca 28 objetivos y 65 metas, en el que se diseñan y agrupan elementos de las políticas y acciones, y que aborda los temas de política exterior; fortalecimiento institucional; economía del cambio climático; educación, capacitación, información y comunicación; e investigación y desarrollo tecnológico). ${ }^{17}$

Como más adelante veremos, existen ciertas incongruencias entre los programas gubernamentales.

\section{Oscuridad de su casa}

La imagen de compromiso que el gobierno de México ha construido hacia el exterior para enfrentar el cambio climático, contrasta con una serie de situaciones que en lo interno no sólo desmienten ese supuesto liderazgo ambiental, sino que dan cuenta de una realidad distinta, cruda y

16 Para mayor detalle, Comisión Intersecretarial de Cambio Climático (CICC), Estrategia Nacional del Cambio Climático, México, CICC, Secretaría de Medio Ambiente y Recursos Naturales, 2007.

17 Más detalle en Poder Ejecutivo Federal, Programa Especial de Cambio Climático 2008-2012, México, versión consulta pública del 24 de marzo de 2009. 
Esta obra forma parte del acervo de la Biblioteca Jurídica Virtual del Instituto de Investigaciones Jurídicas de la UNAM

lamentable de la que el propio gobierno poco o nada dice en las reuniones y foros internacionales. Si bien algunas de las acciones climáticas mencionadas en el apartado anterior son plausibles y han sido bien recibidas por una parte importante de la comunidad científico-ambientalista de este país, es menester señalar puntualmente los aspectos negativos de esta otra lastimosa realidad.

\section{A. Constante deforestación y degradación forestal}

Continúan, por un lado, la pérdida total (o casi totalmente) de la cubierta forestal en diversas áreas boscosas de nuestro país, y por el otro, la degradación o deterioro (no es propiamente una deforestación) de nuestros bosques. Es difícil establecer cuáles son las cifras en este sentido, pero se calcula que al menos para el concepto de deforestación se tiene un dato que oscila entre unas 300 a 600 mil hectáreas por año. Información reciente del gobierno federal, que comprende datos que son los que habrían de "alimentar" el documento denominado Evaluación de los Recursos Forestales Mundiales 2005 (FRA 2005) de la Organización de las Naciones Unidas para la Agricultura y la Alimentación (FAO), señala lo siguiente:

Para el FRA 2005 la FAO solicitó dos piezas básicas de información: a) una estimación de las existencias forestales en 1990 y 2000 y b) una proyección de las existencias para el 2005. La primera estimación se hizo identificando en las dos series de datos elegidas las categorías que corresponden a las definiciones de Bosques y Otras tierras boscosas de la FAO y calculando las existencias de estas coberturas en ambas fechas. Este cálculo arrojó una existencia de 68.720 millones de hectáreas de Bosques en 1993 y de 65.557 millones de hectáreas en el 2002, lo que representa una pérdida total de 3.164 millones de hectáreas en el periodo o una tasa simple de deforestación de 351445 hectáreas/año. Si se considera también la pérdida de Otras tierras boscosas, la tasa total de deforestación es de 401 mil hectáreas/año. ${ }^{18}$

18 Secretaría de Medio Ambiente y Recursos Naturales, Inventarios forestales y tasas de deforestación, México, s.f., http://app1.semarnat.gob.mx/dgeia/informe_04/02_vegetacion/recuadros/c_rec3_02.htm. 
Esta obra forma parte del acervo de la Biblioteca Jurídica Virtual del Instituto de Investigaciones Jurídicas de la UNAM

Si bien se señala en el FRA 2005 de la FAO que México no se encuentra entre los países con mayor pérdida neta anual de área de bosque para el periodo 2000-2005, tampoco se encuentra entre los diez países con mayor ganancia neta anual para el mismo periodo. Existe, para la FAO, una "constante aunque decreciente pérdida neta de bosques en México". ${ }^{19}$

\section{B. Cárcel y asesinato de campesinos ecologistas mexicanos}

Continúan las agresiones en contra de campesinos mexicanos en su lucha por defender los bosques y otros recursos naturales. Un caso emblemático es el de los campesinos guerrerenses Rodolfo Montiel y Teodoro Cabrera, cuyo ejemplo representa tan sólo la punta del iceberg de lo que le ocurre a ciertos activistas que luchan en favor de la protección y conservación del ambiente. Algunos casos de tortura, amenazas, cárcel y asesinato son los siguientes: ${ }^{20}$

- Rodolfo Montiel y Teodoro Cabrera. Son conocidos por haberse opuesto a la tala de árboles por empresas como la trasnacional canadiense Boise Cascade. Integrantes de la Organización de Campesinos Ecologistas de la Sierra de Petatlán y Coyuca de Catalán (OCESP), fueron detenidos en 1999 por el Ejército Mexicano en Guerrero. Torturados y encarcelados, fueron sentenciados a seis y diez años de prisión, respectivamente. Recibieron, entre otros, el Premio Chico Mendes y a Rodolfo Montiel se le otorgó el Premio Goldman en 2000 (dotado en aquel entonces de \$125,000 dólares). Aunque fueron liberados en los primeros meses de 2001, su situación jurídica en México aún no termina y su caso además se ventila actualmente en la Corte Interamericana de Derechos Humanos. Fueron declarados presos de conciencia por Amnistía Internacional.

19 Organización de las Naciones Unidas para la Agricultura y la Alimentación, Evaluación de los Recursos Forestales Mundiales 2005. Hacia la ordenación forestal sustentable, Roma, Estudio FAO: Montes, 147, FAO, 2006, p. 19 y ss.

${ }^{20}$ La información que aquí se presenta ha sido obtenida principalmente de los sitios web de la Comisión Interamericana de Derechos Humanos, en www.cidh.org; del Centro de Derechos Humanos Miguel Agustín Pro Juárez A.C., en www.centroprodh.org.mx; de Amnistía Internacional, en www.amnesty.org; del Premio Goldman, en www.goldmanpri ze.org; y del periódico La Jornada, en www.jornada.unam.mx. 
Esta obra forma parte del acervo de la Biblioteca Jurídica Virtual del Instituto de Investigaciones Jurídicas de la UNAM

Rodolfo Montiel reside en Estados Unidos como asilado político desde 2006.

- Felipe Arreaga. Fundador de la OCESP, también enfrentó a la Boise Cascade y fue detenido y encarcelado en 2004 por el presunto asesinato del hijo de un cacique de Guerrero quien se dedicaba a la explotación irracional de recursos forestales. Fue liberado en 2005 y recibió el Premio Chico Mendes. Declarado preso de conciencia por Amnistía Internacional y por la Oficina en Washington para Asuntos Latinoamericanos, extrañamente murió en 2009 cuando viajaba en su cuatrimoto sobre la carretera federal Acapulco-Zihuatanejo al ser atropellado por un vehículo público.

- Miguel Ángel Pérez Cazales. Comunero de Tepoztlán, Estado de Morelos, y dirigente del Consejo de Pueblos de Morelos, luchó por preservar el agua y los bosques en esa entidad federativa. Entre otras actividades realizadas, se opuso a la construcción de viviendas cerca de manantiales de su estado, y es conocido por haber formado parte de la defensa del manantial del Chihuahuita, fuente primordial de agua para la comunidad indígena de Xoxocotla. Defensor de la zona ecológica de Texcal, fue asesinado en octubre de 2009.

- Mariano Abarca. Luchó contra ingenios mineros extranjeros en Chiapas, particularmente contra la trasnacional minera canadiense Blackfire Exploration. Detenido en agosto de 2009 se le acusó, entre otros, de atentados contra la paz y de daños y perjuicios contra esa empresa minera. Estuvo encarcelado unos cuantos días y fue liberado en el mismo mes y año de su aprehensión. Recibió diversas amenazas de muerte hasta que finalmente fue asesinado en noviembre de 2009.

- Isidro Baldenegro y Hermenegildo Rivas. En marzo de 2003 detuvieron sin orden judicial a Isidro Baldenegro (dirigente indígena tarahumara o rarámuri) y a Hermenegildo Rivas (de la comunidad de Coloradas de la Virgen), ambos del Estado de Chihuahua, acusándoseles de posesión ilegal de armas de uso exclusivo del ejército. Conocidos por luchar contra la tala inmoderada de árboles en zonas forestales de ésa entidad federativa, estuvieron en la cárcel poco más de 2 años. Amnistía Internacional los consideró presos de conciencia y en 2005 Isidro Baldenergro fue galardonado con el Premio Goldman. 
Esta obra forma parte del acervo de la Biblioteca Jurídica Virtual del Instituto de Investigaciones Jurídicas de la UNAM

- Aldo Zamora. Campesino tlahuica, activista de Greenpeace, comunero del Municipio de Ocuilan, y opositor a la tala ilegal de bosques en el Estado de México, es hijo de Ildefonso Zamora, uno de los principales defensores de bosques de San Juan Atzingo en el Parque Nacional Lagunas de Zempoala en esa entidad. Se ha señalado que en mayo de 2007, Aldo y su hermano Misael fueron atacados por bandas taladoras de montes que operan en ese parque nacional como represalia al activismo de su padre Ildefonso. En ese ataque muere Aldo y al mes siguiente, en junio de ese mismo año, el gobierno federal a través de la Secretaría de Medio Ambiente y Recursos Naturales le otorga a Ildefonso Zamora el Premio al Mérito Ecológico.

\section{Irregularidades en los programas forestales. El caso ProÁrbol 2007}

El ilusionismo creado por las autoridades ambientales mexicanas respecto al éxito de los programas de reforestación en 2007, desapareció con el Informe sobre la Cuenta Pública de ese mismo año presentado a principios de 2009 por la Auditoría Superior de la Federación (ASF) de la Cámara de Diputados. ${ }^{21}$ La ASF encontró manipulación de cifras, alteración de resultados, y discrecionalidad en los programas de reforestación (particularmente ProÁrbol 2007) para justificar las metas incumplidas.

En los informes de la ASF se señala el hecho de que el gobierno federal no logró la meta que se había fijado (tal y como lo había señalado) de reforestar 400 mil hectáreas, y plantó tan sólo 341.4 mil. Pero todavía más grave, el propio gobierno habría de incrementar su objetivo de reforestación en 160 mil hectáreas para justificar su compromiso con el PNUMA. De manera que las autoridades ambientales presentaron una cifra final de reforestación que fue mayor a la meta de sembrar árboles pero que se refiere a la siembra de plantas. Aunque existe una guerra de cifras entre diversas organizaciones no gubernamentales y las propias autoridades ambientales, se calcula que sólo habría sobrevivido un $40 \%$ o menos de lo plantado durante 2007.

21 Son consultables por Internet un resumen ejecutivo y todo el informe en http:// www.asf.gob.mx. 
Esta obra forma parte del acervo de la Biblioteca Jurídica Virtual del Instituto de Investigaciones Jurídicas de la UNAM

Aunado a lo anterior, el informe de la ASF señaló la falta de conclusión de instrumentos de política forestal gubernamental y la falta de documentación probatoria sobre el depósito a beneficiarios de ProÁrbol.

Algunos de los resultados presentados por la ASF son los siguientes:

La Semarnat y la Conafor no concluyeron los 6 instrumentos de política forestal federal: Sistema Nacional de Información Forestal, Inventario Nacional Forestal y de Suelos, Zonificación Forestal, Registro Forestal Nacional, Sistema Nacional de Gestión Forestal, y Estudio Satelital Anual del Índice de Cobertura Forestal...

La Conafor promovió la producción de 139,893 miles de plántulas, $65.1 \%$ de la meta establecida; la producción disminuyó en $21.0 \%$ en promedio anual, al pasar de 53,636 miles en 2005 a 33,489 miles en 2007; y el índice de sobrevivencia de las 322,320 miles de plántulas fue de $54.3 \%$. En 2007 se lograron reforestar 341.4 miles de hectáreas, $62.3 \%$ de la superficie deforestada, lo que significó que por cada hectárea que se perdió se reforestaron 0.6 has. como medida compensatoria...

La Conafor no proporcionó documentación comprobatoria del depósito a beneficiarios de Pro-Árbol por 1,826.5 miles de pesos y no se reintegraron 530.9 miles de pesos a la TESOFE por concepto de recursos no ejercidos. $^{22}$

\section{Destrucción costera por desarrollo urbano y turístico}

Alarmante es el desarrollo urbano y turístico que ocurre en nuestras zonas costeras con la obvia consecuencia de alteraciones ambientales gravísimas. Algunos de los centros costeros o destinos de playa más importantes del país por concepto de turistas internacionales y por captación de divisas experimentan un crecimiento urbano y turístico en detrimento de los recursos naturales de la zona, y se colocan como lugares ascendentemente vulnerables al cambio climático por huracanes y elevación del mar. ${ }^{23}$ El corredor Cancún-Playa del Carmen-Tulum en el estado de Quintana Roo es un excelente ejemplo de esto. La situación

22 Consultable en Auditoría Superior de la Federación, "X. Sector Medio Ambiente y Recursos Naturales", Informe de la Cuenta Pública, México, 2009, http://www.asf.gob. $m x /$ Trans/Obliga/Resumenejec07.pdf.

23 Véase para mayor detalle, Nava Escudero, César, Estudios ambientales, México, UNAM, Instituto de Investigaciones Jurídicas, 2009, pp. 337-367. 
Esta obra forma parte del acervo de la Biblioteca Jurídica Virtual del Instituto de Investigaciones Jurídicas de la UNAM

que prevalece en esa zona del país ha sido detectada incluso por el propio PNUMA.

El turismo, especialmente cuando se asienta en las costas y en el mar, es la industria con mayor crecimiento de la región. El estado de Quintana Roo en México está experimentando un crecimiento importante en cuanto a la infraestructura turística por toda la costa del Caribe hasta Belice. La conversión de los bosques de manglares en centros turísticos a pie de playa a lo largo de la Riviera Maya, al sur de Cancún, ha dejado a las costas sin protección. Playa del Carmen, con un $14 \%$ está experimentando el mayor crecimiento en infraestructura turística de México. ${ }^{24}$

Otras zonas costeras han estado experimentando igualmente desarrollos hoteleros, de régimen de condominio, o urbanos en general, de gran envergadura. Las áreas conocidas como Punta Diamante y Playa Revolcadero en Acapulco, en el estado de Guerrero, evidencian esta incontrolable situación.

\section{E. Incertidumbre jurídica}

Ante la indefinición programática del gobierno mexicano hacia el interior del país para enfrentar el cambio climático, continúa cierta incertidumbre sobre el tipo de ordenamiento jurídico que habremos de tener. Mientras el Ejecutivo Federal organiza la próxima reunión en Cancún (la COP-16), el Poder Legislativo se alista para discutir y aprobar al vapor una ley en la materia.

Sin los mínimos cuidados de técnica legislativa y sin que haya incorporado ciertos aspectos desarrollados en los programas gubernamentales climáticos (de por sí con ciertas contradicciones entre ellos mismos), se presentó en el Senado de la República (a principios de 2010) un proyecto de decreto de ley sobre la materia. Durante los meses siguientes, y a pocas semanas de que se lleve a cabo la conferencia de las partes en Cancún, dicho proyecto de ley se ha modificado profundamente y aunque ha mejorado notablemente, prevalecen irregularidades jurídicas que ameritan una discusión técnica profunda.

24 Programa de las Naciones Unidas para el Medio Ambiente, Perspectivas del Medio Ambiente Mundial Geo4, cit., nota 3, p. 137. 
Esta obra forma parte del acervo de la Biblioteca Jurídica Virtual del Instituto de Investigaciones Jurídicas de la UNAM

Lamentablemente, y sin el cuidado jurisprudencial que merece la regulación en materia climática, se pretende que dicho proyecto de ley (con cualesquiera que sean las propuestas de modificación sugeridas) ya esté publicado en el Diario Oficial de la Federación antes de dicha reunión.

\section{LA INCERTIDUMBRE JURÍDICA: ¿QUÉ LEY TENDREMOS?}

De confirmarse la tendencia de contar con una ley en materia de cambio climático antes de la reunión de las partes en Cancún, es probable que dicho ordenamiento jurídico contemple en su texto una serie de incongruencias programáticas e irregularidades jurídicas. Los comentarios que a continuación habremos de desarrollar respecto a algunas de estas incongruencias e irregularidades bien podrían servir como propuestas de modificación a la iniciativa de ley.

Primero, se deberá corregir la posición que desde la concepción programática México adopta frente al derecho internacional normativo. Esta incongruencia parte de la confusión creada en uno de los documentos de política pública gubernamentales más importantes de este sexenio: la ya citada ENACC 2007.

En efecto, el texto de este documento establece erróneamente que: “... México plantea que lo que cuenta en definitiva es la realización de acciones efectivas de mitigación, se base o no en la asunción de compromisos jurídicamente vinculantes". ${ }^{25}$ Esta aseveración implica lo siguiente; debido a que con ella se pretende remarcar la importancia que nuestro país da al cambio climático para llevar a cabo acciones de mitigación independientemente si existe o no un arreglo jurídicamente vinculante en el concierto internacional de las naciones, debemos entender que México i) habrá de responder al reto climático sin supeditar sus decisiones programáticas y jurídicas a lo que se discuta o acuerde internacionalmente; y ii) en la construcción de su ordenamiento jurídico para sustentar su actuar climático estará aplicando el principio de que la ley posterior habrá de modificar un instrumento internacional anterior.

25 Comisión Intersecretarial de Cambio Climático (CICC), Estrategia Nacional del Cambio Climático, cit., nota 16, p. 143. 
Esta obra forma parte del acervo de la Biblioteca Jurídica Virtual del Instituto de Investigaciones Jurídicas de la UNAM

Tales implicaciones podrían contrariar el reconocimiento y respeto al derecho internacional. Por lo tanto, es indispensable que se haga la salvedad o remisión a los tratados de manera conducente.

En México, casi todas las leyes cuya materia es susceptible de ser objeto de un tratado internacional, contienen disposiciones en las que se establece que los tratados que existan sobre la misma materia, y que estén vigentes en el país, constituyen excepciones a lo que las propias leyes disponen, lo cual indica que los legisladores están conscientes del imperativo de respetar los tratados que México ha celebrado. ${ }^{26}$

Es de llamar la atención que el proyecto de ley original sometido a la consideración de la Cámara de Senadores no haya contemplado en su texto tal remisión a los tratados internacionales.

Segundo, si bien ha trascendido que en un documento de trabajo que contiene una serie de modificaciones al proyecto de ley original ya se incluyó la salvedad a los tratados, ${ }^{27}$ ésta lo hace sólo en relación con los acuerdos comerciales. No se comprende ni se justifica la especificación hecha en este sentido, salvo que se tuviera la errónea pretensión de hacer a la ley de cambio climático una ley comercial y/o economicista en virtud de intentar un reconocimiento de superioridad jerárquica sólo en los acuerdos de ese tipo y no en los de tipo ambiental. Con todo, nos parece equívoca la remisión: los foros en los que se discuten los temas del cambio climático son, por definición, esencialmente ambientales. Aún más, recordemos que la Comisión Intersecretarial de Cambio Climático está encabezada —y seguramente así lo estará en el futuro- por la Secretaría de Medio Ambiente y Recursos Naturales (la dependencia de la administración pública federal que se ocupa de los temas ambientales) y no por la Secretaría de Economía (la similar que se ocupa de los comerciales).

Tercero, la ley que habrá de aprobarse deberá establecer con toda claridad si el cambio climático es o no un asunto de seguridad nacional; lo que de suyo trae consigo ciertas consecuencias de derecho. La sugerencia

26 Palacios Treviño, Jorge, Tratados. Legislación y práctica en México, 4a. ed., México, Secretaría de Relaciones Exteriores-Universidad Iberoamericana, 2007, pp. 107 y 108.

27 El proyecto de ley con modificaciones fue dado a conocer durante la celebración del ya mencionado $9^{\circ}$ Encuentro Internacional de Derecho Ambiental a principios de octubre de 2010. 
Esta obra forma parte del acervo de la Biblioteca Jurídica Virtual del Instituto de Investigaciones Jurídicas de la UNAM

que formulamos en este sentido se deriva de la gran confusión que crean sobre este punto en particular tres programas gubernamentales sobre la materia. En primer término, el Programa Sectorial de Medio Ambiente y Recursos Naturales 2007-2012 (publicado en el Diario Oficial de la Federación el 21 de enero de 2008) que considera al cambio climático simplemente como un problema de seguridad. En el Objetivo 4 relativo a la coordinación de la instrumentación de la ENACC para avanzar en las medidas de adaptación y mitigación se establece lo siguiente:

Justificación: El problema global de mayor trascendencia es el cambio climático. En México no existe un solo sector de la economía o alguna región que quede liberada de sus impactos. Se trata de un problema de seguridad del país, por lo que es urgente incrementar los esfuerzos de mitigación de emisiones de gases de efecto invernadero y de adaptación ante los impactos perversos previsibles. ${ }^{28}$

En segundo término, la ENACC, que contrariamente a lo establecido en el programa sectorial, considera al cambio climático como un asunto de seguridad estratégica nacional:

El cambio climático inducido por el incremento en la atmósfera de las concentraciones de gases de efecto invernadero (GEI) constituye, junto con la degradación de ecosistemas y la pérdida de biodiversidad, el problema ambiental más trascendente en el siglo XXI y uno de los mayores desafíos globales que enfrenta la humanidad. Por consiguiente, el cambio climático es un problema de seguridad estratégica nacional y mundial, cuya solución exige movilizar esfuerzos sin precedentes de mitigación (reducción de emisiones de GEI) así como desarrollar capacidades de adaptación ante sus impactos adversos previsibles, algunos de los cuales empiezan ya a detectarse. ${ }^{29}$

28 Secretaría de Medio Ambiente y Recursos Naturales, Programa Sectorial de Medio Ambiente y Recursos Naturales, México, publicado en el Diario Oficial de la Federación el 21 de enero de 2008.

29 Comisión Intersecretarial de Cambio Climático, Estrategia Nacional del Cambio Climático, cit., nota 16, p. 141. 
Esta obra forma parte del acervo de la Biblioteca Jurídica Virtual del Instituto de Investigaciones Jurídicas de la UNAM

Y en último lugar, el PECC 2008-2012, el cual no considera al cambio climático ni asunto de seguridad, ni asunto de seguridad estratégica nacional, sino una amenaza, reto o desafío. ${ }^{30}$

De manera que no está claro si el cambio climático habrá o no de adquirir el estatus de asunto de seguridad nacional como ha sucedido con otros temas o recursos naturales, tal y como sucedió en 2004 con el agua a través de una serie de reformas y adiciones realizadas en ese año a la Ley de Aguas Nacionales de 1992. Y es que declarar al cambio climático de esa manera, supondría aceptar que existe un riesgo o amenaza que el Estado mexicano debe atender prioritariamente sobre otros temas a través del establecimiento de medidas excepcionales tanto a nivel político, programático, presupuestario, jurídico, etcétera. ${ }^{31}$

Ahora bien, deberán pensar bien los legisladores si es conveniente o no insertar en el texto de la ley que estamos analizando el que se considere al cambio climático como un asunto de seguridad nacional dadas las malas experiencias que resultaron para el caso de las aguas nacionales. Debemos recordar que aunque tanto el Poder Legislativo como el Poder Ejecutivo estuvieron de acuerdo en reconocerle ese rango al agua, éste último nunca estuvo de acuerdo con la iniciativa de ley en la materia aprobada en el Congreso de la Unión, lo que ha derivado en que muchas de las disposiciones jurídicas que se apoyan en la idea de la seguridad nacional no se hayan actualizado por la falta de reglamentos que no ha querido expedir (desde 2004 a la fecha) el Ejecutivo Federal.

El proyecto de ley original no recoge ni la idea plasmada en el programa sectorial (sobre seguridad) ni en la ENACC (sobre seguridad nacional). El documento de modificaciones tampoco se refiere a este asunto.

Cuarto, aunque el proyecto de ley original omitió referirse al fundamento constitucional y tan sólo hacer mención de las "facultades concurrentes" establecidas en nuestra carta magna, el documento con modificaciones al mismo señala expresamente que el fundamento de la ley serán los artículos 27 párrafo tercero y 73 fracción XXIX-G. De quedar esta última disposición, se estaría repitiendo lo que ha sucedido con otras leyes ambientales, como son los casos de la Ley General de Vida Silvestre

${ }^{30}$ Poder Ejecutivo Federal, Programa Especial de Cambio Climático 2008-2012, cit, nota 17 , passim.

31 Véase lo que al respecto ya hemos señalado en Nava Escudero, César, Estudios ambientales, cit., nota 23, pp. 291 y ss. 
Esta obra forma parte del acervo de la Biblioteca Jurídica Virtual del Instituto de Investigaciones Jurídicas de la UNAM

(de 2000), y el de la Ley General de Desarrollo Forestal Sustentable (de 2003), cuyo fundamento atiende de la misma manera a esos dos artículos constitucionales. Deberá advertirse que la insistencia del gobierno federal y de las últimas legislaturas por apostar a una concurrencia, o mejor dicho, a una distribución de competencias en ciertas áreas, implica canalización de recursos y facultades suficientes para que tenga sentido la participación de entidades federativas, municipios y el Distrito Federal por esta vía jurídica. No me parecería congruente que la ley introdujera en su texto la idea de que el cambio climático es un asunto de seguridad nacional a la vez que permitiera que estados y Distrito Federal legislaran y tuvieran su propia ley en la materia.

En cambio, bien podría ser novedosa esta ley y apoyarse en dos artículos constitucionales de la mayor trascendencia. Se trata del artículo 4o. párrafo cuarto respecto al derecho que tiene toda persona a un medio ambiente adecuado para su desarrollo y bienestar, y del artículo 17 párrafo 3o. relativo a las acciones colectivas que se encuentra vinculado al artículo anterior.

Quinto, nos parece inadecuado que tanto en el proyecto de ley original como en el documento de modificaciones al mismo se supedite el objetivo indicativo o meta aspiracional de reducción de emisiones de GEI al desarrollo de un régimen internacional en el que se establezcan mecanismos de apoyo financiero y tecnológico por parte de países desarrollados. Así se establece en el artículo segundo transitorio del proyecto de ley original:

Artículo segundo. El país asume el objetivo indicativo o meta aspiracional de reducir 51 millones de toneladas de dióxido de carbono equivalente al 2012 con respecto al escenario tendencial, así como un 50\% de reducción de emisiones de gases efecto invernadero al 2050, en relación con las emitidas en el año 2000. La meta mencionada sólo se podrá alcanzarse (sic) si se establece un régimen multilateral que disponga de mecanismos de apoyo financiero y tecnológico por parte de países desarrollados a una escala sin precedentes.

El documento de modificaciones a la ley original establece algo semejante pero en los siguientes términos:

Artículo segundo. El país asume el objetivo indicativo o meta aspiracional de reducir al año 2020 un treinta por ciento de Emisiones con respecto a 
Esta obra forma parte del acervo de la Biblioteca Jurídica Virtual del Instituto de Investigaciones Jurídicas de la UNAM

la tendencia; así como un cincuenta por ciento de reducción de Emisiones al 2050 en relación con las emitidas en el año 2000. Las metas mencionadas podrán alcanzarse si se establece un régimen internacional que disponga de mecanismos de apoyo financiero y tecnológico por parte de países desarrollados hacia países en desarrollo entre los que se incluye los Estados Unidos Mexicanos. Estas metas se revisarán cuando se publique la siguiente Estrategia Nacional.

Nos preguntamos, ¿qué pasa si no se establece tal régimen internacional financiero? ¿Debemos entender entonces que México tendrá una justificación para no comprometerse a la reducción de emisiones que señala el texto que hemos transcrito? El contenido en estos artículos transitorios parece un despropósito climático que contrasta diametralmente con la idea de erigirnos como una nación con liderazgo ambiental en el tema asumiendo la idea de que nuestro país (al igual que otros países no anexo I) ha estado enarbolando la ampliación de compromisos voluntarios para el régimen pos-2012. Aún más, contradice lo que ya hemos señalado en párrafos anteriores respecto a la pretensión que tiene México de llevar a cabo acciones de mitigación independientemente de que se asuman o no compromisos jurídicos vinculantes en el contexto internacional.

Sexto, es importante revisar todo el cuerpo legal para evitar que ciertas disposiciones nazcan muertas por la imposibilidad fáctica y jurídica de llevarse a cabo, o que al ponerlas en práctica se obtengan resultados deficientes y con poca seriedad técnica. Un ejemplo de esto es lo que el proyecto de ley original llama "diagnóstico de la legislación". En efecto, el artículo quinto transitorio establece algo que se antoja ridículo de cumplir en los tiempos y con la amplitud analítica que marca la propia disposición:

Artículo quinto. El Ejecutivo Federal a través de la Comisión deberá entregar al Congreso de la Unión dentro de los ciento ochenta días siguientes a su instalación, un diagnóstico de la legislación en materia, por lo menos, de energía, agua, medio ambiente, protección civil, turismo, recursos forestales, biodiversidad, agroalimentaria, manejo de residuos, transporte, industria, uso de suelo, desarrollo urbano, para su actualización de acuerdo a los retos del cambio climático.

De la lectura de este transitorio, resulta que la Comisión Intersecretarial contará con tan sólo unos cuantos meses para presentar al Congreso 
Esta obra forma parte del acervo de la Biblioteca Jurídica Virtual del Instituto de Investigaciones Jurídicas de la UNAM

de la Unión un documento que suponga el ejercicio siguiente $i$ ) realizar un análisis del universo legal que abarca cada tema o sector mencionado, lo que se traduce en examinar preceptos constitucionales, instrumentos internacionales hard y soft law, leyes, decretos, acuerdos, reglamentos, normas oficiales mexicanas, y otras disposiciones administrativas; ii) incorporar a ese análisis los ordenamientos jurídicos estatal, municipal y del Distrito Federal correspondientes sobre cada tema o sector cuando así proceda; iii) llevar a cabo la sistematización transversal y su consiguiente vinculación a los retos del cambio climático (los cuales se tendrán que definir claramente) según los resultados del análisis arriba mencionado; y iv) crear los indicadores o parámetros que den sustento y permitan evaluar los procesos de eficiencia y eficacia del universo legal citado para darle sentido a la palabra "diagnóstico".

Tomando en cuenta la existencia del enorme arsenal de leyes ambientales y de leyes que tienen alguna relación de aplicación con lo ambiental según los temas o sectores mencionados (podríamos contar al menos unas treinta con sus respectivos reglamentos y otras disposiciones), no podemos imaginarnos la constitución en número de especialistas (juristas y de otras ramas científicas) que se necesitarían para realizar ese ejercicio en tan solo unos seis meses. Por conveniente que pudiera presentarse el contenido de esta disposición, el término de ciento ochenta días señalado hace patente el profundo desconocimiento que tienen los que redactaron el texto de la ley respecto al vasto ordenamiento jurídico ambiental y sectorial existente.

Esta situación no mejora con el documento de modificaciones al mismo. Se establece en el artículo sexto transitorio lo siguiente:

Artículo sexto. El Ejecutivo Federal a través de la Comisión, deberá entregar al Congreso de la Unión dentro de los ciento ochenta días hábiles a su instalación, una propuesta de modificaciones a la legislación relacionadas con la Mitigación y Adaptación al Cambio Climático en materia de: generación y uso de energía, transporte, agua, medio ambiente, protección civil, salud, educación, turismo, recursos forestales, biodiversidad, seguridad agroalimentaria, manejo de residuos, industria, vivienda, desarrollo urbano de los centros de población, ordenamiento territorial de los asentamientos humanos y las demás que considere necesarias para el cumplimiento de esta ley. 
Esta obra forma parte del acervo de la Biblioteca Jurídica Virtual del Instituto de Investigaciones Jurídicas de la UNAM

De manera que lo que habrá de entregar la Comisión Intersecretarial después de su instalación (ahora especifica que los ciento ochenta días serán hábiles) será un documento con propuestas de modificación a la legislación no sólo en los sectores que ya menciona el proyecto de ley original, sino que aumenta e incluye a los de salud, educación, vivienda, desarrollo urbano de centros de población, y el ordenamiento territorial de los asentamientos humanos. Inexplicablemente, restringe la propuesta de modificaciones legislativa a los temas de mitigación y adaptación; y aunque la lista de los sectores no es limitativa sino solo enunciativa, es lamentable que no se haya incluido expresamente - como tampoco lo hizo el proyecto de ley original - el rubro de ciencia y tecnología.

\section{EPÍlogo}

Ante la COP-16, el gobierno de México podría manifestarse de tres maneras distintas ante el ya casi evidente resultado en Cancún de no adopción de compromisos vinculantes para el régimen post-2012. En primer lugar, podría sumarse a las expresiones de preocupación - y en su caso de desilusión o decepción-que seguramente habrán de formular algunos gobiernos, organizaciones no gubernamentales, medios de comunicación, científicos, y ambientalistas, por la falta de un acuerdo jurídicamente vinculante. En segundo lugar, y como resultado de lo anterior, podría estar confiado y tranquilo de que habrá de prolongarse o postergarse en el tiempo la idea de que los compromisos de países en desarrollo como México habrán de evolucionar en el sentido de una progresiva ampliación voluntaria participativa (lo anterior, sin perjuicio de que de cualquier manera se ha argumentado que las metas cuantitativas vinculantes habrán de ser escalonadas, paso a paso, y sin aceptar ningún tipo de penalización por incumplimientos). Por último, y ante la falta de acuerdos vinculantes, podría sentirse un tanto enfadado e insatisfecho por la razón de no ver materializado su liderazgo ambiental al no haber obtenido éxito en la mediación o acercamiento de posturas entre los países y lograr con ello consensos en este sentido. Tampoco estará muy complacido en no ver reflejado como compromiso vinculante la propuesta de creación de un mecanismo financiero: nos referimos al Fondo Verde.

Independientemente de cómo habrá de comportarse el gobierno mexicano en el contexto de lo que hemos explicado en el párrafo anterior, lo 
Esta obra forma parte del acervo de la Biblioteca Jurídica Virtual del Instituto de Investigaciones Jurídicas de la UNAM

cierto es que difícilmente habrá de aceptar que hacia el interior del país existen aspectos negativos que necesita corregir urgentemente. No veo a funcionario público alguno manifestando ante los representantes de otros países su preocupación sobre la situación de los campesinos ecologistas mexicanos defensores de los bosques. Tampoco creo que alguien del gobierno federal reconozca los fracasos de los programas forestales e invoque los resultados de la cuenta pública de 2007 de la Auditoria Superior de la Federación. Menos aún se referirá a las incongruencias programáticas o a la condición de los manglares y los humedales por el desarrollo urbano y turístico que sufre precisamente la zona donde se estará llevando a cabo la cumbre climática.

Más preocupante aún, es posible que el gobierno mexicano anuncie con algarabía que ya cuenta con una ley sobre cambio climático. Al hacerlo, no aceptará ni que se trató de una ley hecha al vapor ni que el proceso legislativo de aprobación fue más político que técnico-jurídico. Escucharemos de algún político o legislador lo de siempre: que no se trata de una ley que resolverá de inmediato todos los pendientes en la materia pero que es sin duda un paso en el camino correcto, y que en todo caso, ésa como cualquier otra ley no es perfecta, sino perfectible. 
Esta obra forma parte del acervo de la Biblioteca Jurídica Virtual del Instituto de Investigaciones Jurídicas de la UNAM

\section{EL ACUERDO DE PARÍS. PREDOMINIO DEL SOFT LAW EN EL RÉGIMEN CLIMÁTICO*}

\section{INTRODUCCIÓN}

Entre aplausos, ovaciones y algunos llantos de alegría, líderes y políticos del mundo y representantes de 195 países festejaron el 12 diciembre de 2015 la aprobación del tan esperado acuerdo jurídico sobre el clima: ${ }^{1}$ el Acuerdo de París (en adelante, AP). El escenario fue la 21a. Conferencia de las Partes (COP-21) de la Convención Marco de las Naciones Unidas sobre Cambio Climático (CMNUCC) que fungió también como la 11a. Reunión de las Partes (CMP-11) en el Protocolo de Kioto (en adelante, PK), a la CMNUCC celebrada en París, Francia. La difusión en medios masivos de comunicación del éxito alcanzado no logró opacar, sin embargo, las voces disidentes de científicos, académicos, o activistas que no otorgaron su beneplácito. Frente a las frases de "el mundo ha escrito una nueva página de su historia" (François Hollande), "es el marco sostenible que el mundo necesita para resolver la crisis climática" (Barack Obama), o "es un triunfo monumental para los pueblos y para nuestro planeta" (Ban Ki-Moon), surgieron las de "estamos ante un fraude y una farsa... no hay acciones sólo promesas" (James Hansen), la cumbre fracasó "antes de empezar" (Naomi Klein), o "nada va a ocurrir sustancialmente hasta 2020" (Ilan Kelman). ${ }^{2}$

* Publicado en Boletín Mexicano de Derecho Comparado, México, nueva serie, año XLIX, núm. 147, septiembre-diciembre de 2016.

1 Enfatizamos el "tan esperado" porque desde 2009 (COP-15 en Copenhague) y luego el 2010 (COP-16 en Cancún) se tuvo tal expectativa. Los documentos aprobados en ellas no alcanzaron el estatus vinculante.

2 Las frases atribuidas a F. Hollande (presidente de Francia), B. Obama (presidente de los Estados Unidos), Ban Ki-Moon (secretario general de la ONU), J. Hansen (profesor de la Universidad de Columbia), N. Klein (activista canadiense), e I. Kelman (investigador en University College London) disponibles en www.elmundo.es y www.excelsior. com.mx (consultadas el 13 de diciembre de 2015) y www.bb.com (consultada el 14 de diciembre de 2015). 
Esta obra forma parte del acervo de la Biblioteca Jurídica Virtual del Instituto de Investigaciones Jurídicas de la UNAM

Desde la perspectiva estrictamente jurídica, tanta algarabía tiene mucho de su fundamento en el hecho de que se haya aprobado un instrumento internacional de naturaleza vinculante con el objeto de mejorar la aplicación de la CMNUCC, y de reforzar con ello la respuesta global al cambio climático. A priori, esto significa que las partes contratantes habrían manifestado su voluntad para crear preceptos de carácter obligatorio - normas hard law - en el texto de un instrumento considerado tratado en todos los sentidos. Sin embargo, tanto optimismo oculta, o ignora, que es práctica común entre los Estados en el régimen internacional de protección al ambiente (al cual pertenece el régimen climático) el adoptar acuerdos vinculantes con un alto contenido de normas que en realidad carecen de obligatoriedad — normas soft law-.

Este artículo tiene por objeto explicar, con base en un examen sobre la naturaleza jurídica de las normas en los tratados, la existencia y predominio del soft law en el derecho internacional ambiental y en lo particular en el régimen climático. A través de un breve análisis del contenido soft en los dos antecedentes convencionales más importantes en la materia (i. e. la CMNUCC de 1992 y el PK de 1997), se estudian algunos de los preceptos más relevantes del AP de 2015 para corroborar la reincidencia de los Estados en el uso de normas no vinculantes para este tipo de tratados. Esto evidencia que dicho acuerdo no es, jurídicamente hablando, un instrumento excepcional o histórico, sino tan sólo la manifestación reiterada de la comunidad internacional para enfrentar de esta manera el cambio climático. Por lo tanto, en el contexto jurídico, las expresiones de triunfalismo se antojan exageradas y engañosas.

\section{SOBRE LOS TRATADOS Y LA NATURALEZA DE SUS NORMAS}

Es aceptado entre los especialistas de derecho internacional que una de las características o elementos esenciales de los tratados es la de producir efectos jurídicos, es decir, la de crear obligaciones entre los Estados que los celebran.

El tratado internacional otorga derechos e impone obligaciones a las partes contratantes, preferentemente. Es una regla de conducta obligatoria para los Estados que los suscriben y ratifican. La teoría de la fuerza obligatoria de los pactos internacionales ha sido muy amplia y se ha orientado hacia los más variados criterios...pero la esencia de ellas es la afirmación del 
Esta obra forma parte del acervo de la Biblioteca Jurídica Virtual del Instituto de Investigaciones Jurídicas de la UNAM

carácter obligatorio de los tratados, cualquiera que sea el fundamento que las informa. ${ }^{3}$

Descansan los tratados en tres principios: $i)$ todo tratado al entrar en vigor obliga a las partes y debe cumplirse de buena fe (pacta sunt servanda); $i$ ) un tratado produce efectos únicamente entre las partes que lo celebran (res inter alios acta): en principio, no crean obligaciones para un tercer Estado sin su consentimiento; y iii) el consentimiento es la base de las obligaciones convencionales: del consentimiento deviene la obligación (ex consensu advenit vinculum). ${ }^{4}$ Se entiende, por tanto, que los tratados son instrumentos internacionales, o como los llama la Convención de Viena sobre el Derecho de los Tratados de 1969 (CV de 1969), acuerdos internacionales ${ }^{5}$ que son obligatorios, i. e. vinculantes. Son usualmente denominados por la doctrina como instrumentos de derecho duro o fuerte, en inglés, hard law.

Con el objetivo de brindar una visión general de términos clave que se emplean en su Colección de Tratados, la Organización de las Naciones Unidas ha señalado que el vocablo tratado se utiliza ya sea de forma particular para designar un instrumento con características definidas, o bien de forma genérica para referirse a cualquier instrumento vinculante en el derecho internacional que haya sido concluido entre entidades internacionales. ${ }^{6}$ En este último supuesto, para que se considere tratado, un instrumento internacional debe cumplir, entre otros, con el criterio de

3 Sepúlveda, César, Derecho internacional, 20a. ed., México, Porrúa, 2000, p. 139. En esta obra, al principio, se hace alusión a las doctrinas que abordan la teoría de la fuerza obligatoria de los tratados.

4 Véase Méndez Silva, Ricardo, "Tratados internacionales", Diccionario jurídico mexicano, 8a. ed., México, Porrúa-UNAM, Instituto de Investigaciones Jurídicas, 1995, pp. 3150 y 3151. En este mismo sentido, Seara Vázquez, Modesto, Derecho internacional público, 24a. ed., México, Porrúa, 2012, pp. 71 y 72.

5 La CV de 1969 (en vigor desde el 27 de enero de 1980) establece en su artículo 20. que tratado es "un acuerdo internacional celebrado por escrito entre Estados y regido por el derecho internacional, ya conste en un instrumento único o en dos o más instrumentos conexos y cualquiera que sea su denominación particular".

6 Sigue consecuentemente lo establecido al respecto tanto por la CV de 1969 como por su similar de 1986, es decir, la Convención de Viena sobre el Derecho de los Tratados entre Estados y Organizaciones Internacionales o entre Organizaciones Internacionales de 1986 que aún no entra en vigor. 
Esta obra forma parte del acervo de la Biblioteca Jurídica Virtual del Instituto de Investigaciones Jurídicas de la UNAM

que sea vinculante, lo que ocurre cuando las partes contratantes se han comprometido a crear derechos y obligaciones jurídicas. ${ }^{7}$

En realidad, no es relevante para el derecho internacional el nombre con el que se bautice a un tratado. ${ }^{8}$ En efecto, ya desde los trabajos realizados por la Comisión de Derecho Internacional hace algunas décadas, y ahora por norma convencional, un tratado puede adoptar cualquier denominación: acuerdo, convenio, convención, protocolo, pacto, carta, declaración, memorandum de entendimiento, modus vivendi, canje de notas, estatuto, acta, o incluso tratado, entre otras. ${ }^{9}$ Lo que es relevante, como ya se dijo, es que para que un instrumento internacional se considere tratado deberá tener per se fuerza jurídica vinculante. Esa es la esencia del tratado. De aquí que la expresión tratado vinculante o tratado de derecho duro sea tautológica: es una acumulación reiterativa de términos.

Siguiendo lo anterior, dos instrumentos pueden tener un mismo sustantivo, pero uno ser tratado y otro no. Por ejemplo, la Carta de la Organización de las Naciones Unidas es (y se considera) un tratado, ${ }^{10}$ pero no así la Carta Mundial de la Naturaleza. ${ }^{11}$ Ambos instrumentos internacionales se llaman carta, pero uno es obligatorio y el otro no. Para estos casos, como en otros, lo que es determinante para el estatus del documento no es el título que adquiera sino la intención de las partes para crear relaciones jurídicamente vinculantes. ${ }^{12}$ Dicho de otra manera, el nombre del instrumento no necesariamente determina su naturaleza jurídica.

7 Los otros criterios son que el instrumento debe celebrarse por Estados u organizaciones internacionales con poder de establecer tratados, debe regirse por el derecho internacional y debe estar por escrito. Véase United Nations Organization, "Definitions of key terms used in the UN Treaty Collection, United Nations, Treaty Collection, disponible en https://treaties.un.org/Pages/overview.aspx?path=overview/definition/page1_en.xml.

8 A veces, el término "tratado" designa instrumentos sobre materias de la mayor importancia, pero se reconoce que "si bien existen ciertos usos, no puede hablarse de una práctica uniforme respecto a la manera de designar los tratados...". Palacios Treviño, Jorge, Tratados. Legislación y práctica en México, 4a. ed., México, Secretaría de Relaciones Internacionales-Universidad Iberoamericana, 2007, pp. 36-43.

9 Estos trabajos sirvieron de base para la elaboración de la CV de 1969. Para mayor referencia, Brownlie, Ian, Principles of Public International Law, 7a. ed., Oxford, Oxford University Press, 2008, pp. 607 y 608.

10 Se aprobó el 26 de junio de 1945 y entró en vigor el 24 de octubre del mismo año.

11 Aprobada el 28 de octubre de 1982 por Resolución 37/7 de la Asamblea General de la ONU.

12 Shaw, Malcolm N., International Law, 7a. ed., Cambridge, Cambridge University Press, 2014, p. 84. 
Esta obra forma parte del acervo de la Biblioteca Jurídica Virtual del Instituto de Investigaciones Jurídicas de la UNAM

Entonces, es claro que el carácter obligatorio o hard de los tratados se manifiesta a través de preceptos de naturaleza vinculante, que son los que dotan de contenido al instrumento y que resultan del consentimiento de los Estados. La práctica internacional y la doctrina suelen referirse a ellos como normas, aunque también como compromisos, mandatos o reglas, entre otros. Este tipo de disposiciones se adjetivan de jurídicas, vinculantes, legales, obligatorias o, incluso, jurídicamente vinculantes, para diferenciarlas de aquellas que no lo son. Así, se dice que las normas contenidas en un tratado son, en principio, normas jurídicas, normas de derecho duro o fuerte, en inglés, normas hard law.

Es fundamental precisar que las obligaciones jurídicas en el derecho internacional no tienen el mismo significado y alcances que en el derecho interno, particularmente por lo que se refiere a las sanciones, a los mecanismos coactivos para el cumplimiento de las normas y, desde luego, a la naturaleza misma de las obligaciones. ${ }^{13}$ Pero no por ello la normatividad internacional carece de obligatoriedad.

En efecto, hay quienes sostienen que el fundamento de la obligatoriedad de una norma internacional es la coercibilidad, ${ }^{14}$ típica en cualquier norma de derecho: "la norma jurídica es coercible, es decir, ante su incumplimiento se actualiza la consecuencia jurídica que es la sanción. El Estado está obligado a cumplir con la norma jurídica internacional, sabedor de que si la destaca (sic) se hace acreedor a una sanción internacional". ${ }^{15}$ De forma similar, se ha señalado que el carácter jurídico del derecho internacional es determinado por la sanción, particularmente "la responsabilidad internacional que la violación del D.I. origina", y de aquí que se pueda hablar de la existencia de coacción ${ }^{16}$ en el derecho

13 Un buen análisis sobre esta cuestión se encuentra en Vallarta Marrón, José Luis, Derecho internacional público, 2a. ed., México, Porrúa, 2014, pp. 1-10; López-Bassols, Hermilo, Los nuevos desarrollos del derecho internacional público, 3a. ed., México, Porrúa, 2008, pp. 31 y 32.

14 Coerción es "el empleo necesario de la fuerza", coercibilidad el "uso forzoso de la fuerza". Villoro Toranzo, Miguel, Introducción al estudio del derecho, 21a. ed., México, Porrúa, 2012, p. 452.

15 Véase Arellano García, Carlos, Primer curso de derecho internacional público, 7a. ed., México, Porrúa, 2013, p. 131.

16 Tradicionalmente se ha dicho que todo ordenamiento jurídico, o derecho, debe ser coactivo. Una sinonimia de coacción es la de empleo de la fuerza, y se considera como "un medio de que dispone un órgano de autoridad para hacer cumplir una norma sancionada". Villoro Toranzo, Miguel, Introducción al..., cit., p. 452. 
Esta obra forma parte del acervo de la Biblioteca Jurídica Virtual del Instituto de Investigaciones Jurídicas de la UNAM

internacional. ${ }^{17} \mathrm{Y}$ es que no podría hablarse de responsabilidad de los Estados si no se aceptara la existencia misma de una posible violación del derecho internacional, la cual se entiende "por referencia a las obligaciones positivas y negativas del derecho internacional", es decir, por la existencia de una acción o una omisión. ${ }^{18}$

Todavía más allá, hay juristas que proponen la tesis de que el carácter jurídico-obligatorio del derecho internacional se entiende aún suprimiendo la sanción como es concebida tradicionalmente en el derecho interno. Aquí, en todo caso, lo que importa es determinar si existen derechos y obligaciones entre los Estados y de que éstos acepten tal situación. ${ }^{19}$ Aunque en principio la idea de que un tratado produzca efectos jurídicos supone que sus normas serán "exigibles en derecho con todas la consecuencias que ello implica en caso de incumplimiento", ${ }^{20}$ no necesariamente deben existir sanciones para que se le considere hard law. En esta línea de pensamiento se argumentaría que las sanciones no son un elemento constitutivo del derecho, ciertamente no lo serían como criterio para distinguir una norma vinculante de una norma que no lo es. ${ }^{21} \mathrm{El}$ sentirse obligado por una norma cuyo cumplimiento no es opcional sino algo esperado, o mejor aún, requerido, juega un papel importantísimo para determinar la naturaleza hard de una norma. ${ }^{22}$

Ahora bien, aunque el contenido normativo de los tratados sea en principio de naturaleza vinculante, estos instrumentos pueden contener disposiciones que no tengan tal naturaleza, es decir, enunciados que carezcan de obligatoriedad de conformidad con lo señalado en párrafos anteriores. La existencia, terminología y significado de estos preceptos en

17 Diez de Velasco, Manuel, Instituciones de derecho internacional público, 16a. ed., Madrid, Tecnos, 2007, p. 74. Este autor observa que el carácter jurídico del derecho internacional está asociado a la aplicación del mismo, las consecuencias de su violación y los mecanismos para garantizar su aplicación.

18 Véase Seara Vázquez, Modesto, Derecho internacional..., cit., pp. 373 y ss.

19 Vallarta Marrón, José Luis, Derecho internacional..., cit., pp. 2-4.

20 Palacios Treviño, Jorge, Tratados. Legislación..., cit., p. 34.

21 Peters, Anne y Pagotto, Isabella, "Soft Law as a New Mode of Governance: A Legal Perspective", NEWGOV: New Modes of Governance, 28 de febrero de 2006, p. 11, disponible en http://dx.doi.org/10.2139/ssm.1668531.

22 Para ciertos autores esto podría ser, en última instancia, lo que en realidad hace hard a una norma. Véase Bodansky, Daniel, The Art and Craft of International Environmental Law, Cambridge-Londres, Harvard University Press, 2010, p. 101. 
Esta obra forma parte del acervo de la Biblioteca Jurídica Virtual del Instituto de Investigaciones Jurídicas de la UNAM

tratados ha sido discutida desde hace algunas décadas. ${ }^{23} \mathrm{Su}$ importancia actual es inobjetable, y se les conoce comúnmente como normas de derecho suave, blando o flexible, en inglés, soft law. En ocasiones también se hace referencia a ellas como compromisos u "obligaciones".

Sin embargo, y aunque la doctrina admita su existencia, no hay consenso entre los especialistas sobre cómo adjetivar a este tipo de normas, ni sobre cómo determinar si tienen o no cierto grado o nivel de obligatoriedad. Hay quienes optarían por llamarles normas, compromisos u obligaciones no jurídicas, no legales, no vinculantes o no jurídicamente vinculantes, y quienes preferirían referirse a ellas (conjunta o separadamente) como declarativas, políticas, programáticas, exhortativas, aspiracionales, no autoejecutables, vagas e imprecisas, menos vinculantes, o normas que generan obligaciones mínimas, obligaciones de comportamiento, obligaciones generales (i. e. normas de carácter general). Ante este desacuerdo doctrinal, se han creado expresiones genéricas como las de legal soft law o soft law material. De aquí la existencia de un derecho suave legal o de normas jurídicas de derecho suave en los tratados.

Hay que precisar que la existencia de normas de soft law en acuerdos internacionales de hard law forma parte de un proceso mucho más amplio de creación normativa no vinculante en el derecho internacional, que estaría abarcando, por ejemplo, resoluciones no obligatorias de las organizaciones internacionales, acuerdos interestatales no normativos o no vinculantes, el derecho suave de actores no estatales, y el ya aludido soft law material. ${ }^{24}$

Es probable que la emergencia del soft law en general haya comenzado a percibirse y discutirse por la doctrina (de hecho su aparición es de tipo doctrinal y no convencional) hacia comienzos de la década de los setenta del siglo pasado, ${ }^{25}$ pero con el transcurso del tiempo se ha convertido en

23 Destacan como primeros escritos sobre el particular, el de Baxter, R. R., "International Law in «Her Infinite Variety»", The International and Comparative Law Quarterly, vol. 29, núm. 4, octubre de 1980, pp. 552 y ss.; Chinkin, C. M., "The Challenge of Soft Law: Development and Change in International Law", The International and Comparative Law Quarterly, vol. 38, núm. 4, octubre de 1989, pp. 851 y ss.

24 Estos cuatro rubros se proponen en Toro Huerta, Mauricio Iván del, "El fenómeno del soft law y las nuevas perspectivas del derecho internacional", Anuario Mexicano de Derecho Internacional, vol. VI, 2006, pp. 536.

25 Así lo han señalado Dupuy, Pierre-Marie, "Soft Law and the International Law of the Environment", Michigan Journal of International Law, vol. 12, núm. 420, invierno 
Esta obra forma parte del acervo de la Biblioteca Jurídica Virtual del Instituto de Investigaciones Jurídicas de la UNAM

un tema de referencia indispensable entre los expertos del derecho internacional. ${ }^{26}$ Hoy es fácil encontrarlo mencionado en una gran cantidad de textos sobre la materia. ${ }^{27}$

Tema central en la discusión sobre el derecho suave (que comprende el de normas soft en tratados) es la terminología y el tipo de preceptos que designa. La cuestión a resolver es, por un lado, si con esta expresión estamos frente a normas que no son de derecho, i. e. normas que no son jurídicas y, por lo tanto, el uso de la palabra "derecho" o "law" sería incorrecto, confuso, paradójico o contradictorio porque en la concepción tradicional la norma de derecho es vinculante: si no es vinculante, entonces no es jurídica. O si, por el contrario, el derecho debe entenderse como un conjunto de diversos tipos de normas jurídicas las cuales se encuentran en "niveles" o "grados" distintos, donde algunas son más duras que otras, o a la inversa, algunas menos vinculantes que otras.

Para esta discusión la doctrina se ha basado fundamentalmente en dos planteamientos. El primero de ellos, conocido como visión o modelo dicotómico (en inglés, binary view), se deriva de la teoría tradicional de las fuentes del derecho internacional ${ }^{28}$ y consiste, grosso modo, en que la esencia del derecho es su normatividad vinculante, no está sujeta a grada-

de 1991, p. 420; Klabbers, Jan, "Reflections on Soft International Law in a Privatized World", Lakimies, vol. 104, 2006.

26 Algunas referencias se citan en Shelton, Dinah, "Comments on the Normative Challenge of Environmental «Soft Law»", en Kerbrat, Yann y Maljean-Dubois, Sandrine (eds.), The Transformation of International Environmental Law, Oxford-París, A. Pedone \& Hart, 2011, p. 61; Toro Huerta, Mauricio Iván del, "El fenómeno...", cit., pp. 516 y ss.

27 Casese, Antonio, International Law, 2a. ed., Oxford, Oxford University Press, 2005, pp. 196 y 197; Dixon, Martin et al., Cases \& Materials on International Law, 5a. ed., Oxford, Oxford University Press, 2011, pp. 48-52; Herdegen, Matthias, Derecho internacional público, trad. de Marcela Anzola, México, Fundación Konrad AdenauerUNAM, Instituto de Investigaciones Jurídicas, 2005, pp. 163 y 164; López-Bassols, Hermilo, Los nuevos..., cit., pp. 58 y 59; Shaw, Malcolm N., International Law..., cit., pp. 83 y 84 .

28 En efecto, se ha sostenido que tal "modelo de aproximación al fenómeno desde la contraposición formal soft law/hard law busca identificar como derecho (hard) solamente aquellas normas que hayan sido producidas mediante las denominadas "fuentes" tradicionales del derecho internacional, en particular, mediante los tratados y la costumbre, dejando fuera del ámbito de lo jurídico otras manifestaciones de voluntad de los sujetos de derecho internacional”. Toro Huerta, Mauricio Iván del, "El fenómeno...”, cit., p. 524, para la cita textual, p. 528 . 
Esta obra forma parte del acervo de la Biblioteca Jurídica Virtual del Instituto de Investigaciones Jurídicas de la UNAM

ción y, en consecuencia, una norma de derecho o es jurídica o no lo es. La expresión soft law debiera, en este sentido, evitarse, puesto que conduce a una contradicción lógica. El segundo de los planteamientos, denominado visión o modelo de gradación normativa, normatividad graduada y variable, o simplemente continua (en inglés, graduated and diverse normativity o continuum view) radica, en términos generales, en que el derecho puede tener una variedad de impactos y efectos legales, directos e indirectos, algunos de ellos más rigurosos que otros. Aquí se reconoce que el derecho (una norma jurídica) puede ser más fuerte o más suave. Existe un continuo entre lo soft y lo hard que está en constante evolución: no hay polarización. Representa la realidad y la práctica internacionales en su diversidad, y así evita que la normatividad sea encapsulada en categorías tan simplistas como lo jurídico y lo no jurídico, lo legal y lo no legal. El binomio hard/soft sería inadecuado e insuficiente para describir y evaluar la norma internacional. ${ }^{29}$

Estos planteamientos han generado tipologías diversas que intentan explicar su naturaleza y terminología. En un primer ejemplo ${ }^{30}$ se distingue entre normas de soft law y de hard law, por un lado, y entre normas de soft law y normas no legales (políticas, morales, éticas, etcétera), ${ }^{31}$ por el otro. Mientras que en este último supuesto el soft law debe y puede distinguirse de los preceptos meramente políticos (según la cercanía de lo soft con lo que se llegue a definir como derecho), en aquél no existe entre el soft law y el hard law una línea clara de diferenciación: los tex-

29 Para un resumen puntual Peters, Anne y Pagotto, Isabella, "Soft Law..., cit., pp. 6-9, de donde obtuvimos parte de esta discusión. También sugerimos Dixon, Martin et al., Cases \&..., cit., pp. 48-52, quienes recopilan argumentos de diversos autores sobre el tema. Dos artículos más que enriquecen la discusión Toro Huerta, Mauricio Iván del, "El fenómeno...", cit., pp. 518 y ss.; Cárdenas Castañeda, Fabián Augusto, "A Call for Rethinking the Sources of International Law: Soft Law and the Other Side of the Coin", Anuario Mexicano de Derecho Internacional, vol. XIII, 2013, pp. 376 y ss. Finalmente, para una distinción entre las normas y las no-normas, lo no legal y lo legal, o lo pre-legal y lo legal, véase Weil, Prosper, "Towards Relative Normativity in International Law?", The American Journal of International Law, vol. 77, núm. 3, julio de 1983, pp. 415 y ss.

30 Peters, Anne y Pagotto, Isabella, "Soft Law...", cit., pp. 9-12.

31 La expresión "normas no legales" se ha utilizado en el régimen de control de armamento. Más detalles en Williamson, Richard L. Jr., "Hard Law, Soft Law, and NonLaw in Multilateral Arms Control: Some Compliance Hypotheses", Chicago Journal of International Law, vol. 4, núm. 1, Article 7, 2003, pp. 62 y 63. 
Esta obra forma parte del acervo de la Biblioteca Jurídica Virtual del Instituto de Investigaciones Jurídicas de la UNAM

tos legales pueden ser más fuertes o más suaves. De cualquier modo, en ninguno de estos dos supuestos se podrían hacer delimitaciones precisas.

En otro ejemplo ${ }^{32}$ se distingue entre el legal soft law y el non-legal soft law. La primera se refiere a preceptos (reglas de conducta) en tratados suscritos bajo las reglas de la CV de 1969 sin que se formule una obligación directa: se trata de normas vagas, ambiguas, que no tienen aplicabilidad directa de hacer, dejar hacer, o no hacer. Éstas se constituyen en preceptos de aspiración (metas aspiracionales), escritas de manera abstracta en su máxima expresión. Crean propósitos amplios y generales, no específicos. ${ }^{33} \mathrm{Si}$ la norma aparece aislada o desconectada de otras normas del instrumento, no tendrá implicación jurídica y se estará ante el non-legal soft law. Si el precepto se localiza en alguna parte específica del tratado para dar sentido a todo o a una parte del cuerpo normativo y se redacta como paradigma o lineamiento para interpretar otras normas del mismo, podrá ser considerado legal soft law. Los instrumentos no vinculantes, como declaraciones políticas, lineamientos, reportes de organizaciones internacionales u organismos no internacionales, son nonlegal soft law. ${ }^{34}$

Se advierte, entonces, que la terminología y tipo de normas que designa la expresión soft law serán tan diversos como sean las visiones o planteamientos de los autores que aborden el tema. Por ello, para los fines de este trabajo podemos elaborar algunas reflexiones según lo examinado en párrafos anteriores sin pretender hacer una generalización conceptual ni sugerir una tendencia doctrinal.

Primero, los tratados son acuerdos internacionales cuyo contenido normativo es, en principio, de naturaleza jurídico-vinculante o hard law. Priva la idea de la coacción o exigibilidad en el cumplimiento de las normas independientemente de que exista o no o de que esté claramente identificada o no, una sanción, la naturaleza de la obligación misma, o el mecanismo para hacer efectivo el cumplimiento de una norma o una sentencia. Es relevante que los Estados acepten (perciban y sientan) que una norma representa una obligación, por lo que su cumplimiento es requeri-

32 Cárdenas Castañeda, Fabián Augusto, “A Call for...”, cit., pp. 382 y ss.

33 En sentido estricto, estas normas podrían ser vinculantes por sí mismas, no obstante el hecho de que no tengan implicaciones directas. Para comprender el significado de esto, ibidem, p. 383.

34 Para un significado parecido de estas dos expresiones acúdase a Chinkin, C. M., “The Challenge...", cit., pp. 851 y ss. 
Esta obra forma parte del acervo de la Biblioteca Jurídica Virtual del Instituto de Investigaciones Jurídicas de la UNAM

do y no es meramente opcional. Coincidimos en que algunas normas de hard law pueden ser más o menos rigurosas que otras, pero en definitiva la obligatoriedad las caracteriza: todas producen efectos jurídicos.

Segundo, aceptamos que los tratados pueden contener preceptos de naturaleza distinta a las normas de hard law, y que la mejor forma de describirlos es como normas de derecho suave, blando o flexible, esto es, normas de soft law. Independientemente de que estos preceptos se consideren jurídicos o no (ergo tengan naturaleza vinculante o no desde la visión dicotómica) o que sean graduados o relativos (ergo tengan naturaleza más o menos vinculante desde la visión continua), son normas que carecen de obligatoriedad. Esto no quiere decir que no tengan relevancia jurídica: sí la tienen, pero en definitiva no son vinculantes. Esta característica es lo que precisamente las diferencia de las normas de hard law, por lo que las normas de soft law no pueden ser menos vinculantes o casi vinculantes. Es verdad que en muchas ocasiones el soft law es el antecedente inmediato del hard law, pero mientras no adquiera tal estatus, simplemente no es hard law. En consecuencia, unas normas podrán ser más soft que otras o incluso menos soft, pero al fin y al cabo soft law, o sea, no vinculantes. De otro modo ¿para qué la diferenciación doctrinal entre lo hard y lo soft?

Tercero, y no obstante lo anterior, admitimos como lo hacen otros doctrinarios que no es fácil distinguir cuándo una norma en un tratado es de hard law y cuándo de soft law (o cuándo es más rigurosa o cuándo es menos suave). Desde luego, hay que atender al origen y características del precepto mismo (i.e. intencionalidad, negociación, redacción, lenguaje, precisión, generalidad, etcétera), $\mathrm{y}$ al hecho de sentirse obligado por una norma, pero no siempre existe la nitidez normativa que se quisiera para lograr tal diferenciación.

Finalmente, y como lo veremos en los próximos apartados, nos sumamos al pronunciamiento doctrinal de que el soft law se ha manifestado de manera clara en el derecho internacional ambiental y, por ende, en el régimen climático. Es común la existencia de normas de soft law en instrumentos internacionales de hard law. 
Esta obra forma parte del acervo de la Biblioteca Jurídica Virtual del Instituto de Investigaciones Jurídicas de la UNAM

\section{EL SOFT LAW EN EL DERECHO INTERNACIONAL AMBIENTAL}

Cuna principal del soft law es el derecho internacional relativo al régimen de protección del ambiente, es decir, el derecho internacional ambiental. ${ }^{35}$ Es aquí donde el soft law se ha constituido en un "fenómeno dominante" 36 y donde esa "infinita variedad de formas" 37 que lo caracteriza, se ha expresado de manera constante y diversa. Las razones de su presencia y desarrollo en la rama jurídica aludida se han abordado de manera profusa en la literatura existente, lo que permite comprender los motivos por los que los Estados lo han adoptado en la práctica para regular diversos temas ambientales, el climático incluido. Por lo que es importante distinguir cuándo se estará frente a una norma soft y cuáles son las explicaciones más relevantes que han esbozado los especialistas sobre su recurrencia. El enfoque que adoptamos en los párrafos siguientes es, desde luego, en relación con aquellas normas que se insertan en los tratados, lo que corresponde en última instancia a la parte esencial de análisis en este artículo.

Comencemos por señalar que es común que los tratados relativos al derecho internacional ambiental incorporen normas, preceptos, disposiciones, o inclusive textos completos de soft law. ${ }^{38}$ Lo anterior, sin dejar de reconocer al mismo tiempo, la obvia manifestación de este fenómeno

35 Ejemplos histórico-doctrinales que sustentan esta afirmación son Dupuy, PierreMarie, "Soft Law...", cit., p. 421; Kiss, Alexandre Ch., Survey of Current Developments in International Environmental Law, Morges, IUCN Environmental Policy and Law Paper, núm. 10, 1976, p. 17.

36 Juste Ruiz, José, Derecho internacional del medio ambiente, Madrid, McGrawHill, 1999, p. 47.

37 La expresión entrecomillada se ha vuelto un tanto famosa a partir del artículo de Baxter, R. R., "International Law...", cit.

38 Esto se observa de manera clara en Bodansky, Daniel, The Art and ..., cit., p. 104; Dupuy, Pierre-Marie, "Soft Law...", cit., p. 430; Guruswamy, Lakshman, International Environmental Law, 2a. ed., Thomson-West, 2003, p. 27; Juste Ruiz, José, Derecho internacional..., cit., p. 47; Kiss, Alexandre Ch. y Shelton, Dinah, International Environmental Law, 3a. ed., Ardsley, Nueva York, Trasnational Publishers, 2004, p. 73; Maljean-Dubois, Sandrine, "The Making of International Law Challenging Environmental Protection", en Kerbrat, Yann y Maljean-Dubois, Sandrine (eds.), The Transformation..., cit., p. 46; Rey Caro, Ernesto J., Temas de derecho internacional ambiental, Córdoba, Argentina, Marcos Lerner Editora Córdoba, 1998, p. 18. Cada autor realiza las especificaciones pertinentes sobre lo que para ellos significa el soft law. 
Esta obra forma parte del acervo de la Biblioteca Jurídica Virtual del Instituto de Investigaciones Jurídicas de la UNAM

a través de instrumentos que carecen de obligatoriedad o a través de normas que aún no se han consolidado formalmente como tales. ${ }^{39}$

Ahora bien, distinguir cuándo una norma convencional es de naturaleza soft, vis à vis una de naturaleza hard, no es tarea fácil de realizar. ${ }^{40}$ Por ello, se ha sugerido que ante todo se examine para su identificación el contenido mismo del precepto en cuestión, que sea caso por caso, y que se atienda a diversos factores o variables que están relacionados, por ejemplo, con el origen mismo del texto convencional y con las condiciones formales y políticas de su adopción. ${ }^{41}$ En este sentido, hay que tomar en cuenta para cada norma analizada, en su caso, el tipo de conducta o comportamiento que se espera o se requiere de los Estados parte en un tratado. Esto conducirá, eventualmente, a reconocer una norma de soft law.

¿Cuántos y cuáles podrían ser los criterios para la identificación de la normativa soft? Bueno, como es de suponer no hay un número exacto ni tampoco una tipología uniforme. Sin embargo, podemos señalar que uno de estos criterios es la dimensión del lenguaje que se emplea en una determinada disposición convencional. En efecto, el lenguaje (o incluso la redacción) pueden revelar la existencia de una norma de soft law, como sucede por ejemplo con enunciados que son exhortativos o meramente "aspiracionales", ${ }^{42}$ sin ser vinculantes en lo absoluto. ${ }^{43}$ En este caso, se

39 Para efectos didácticos, el soft law se manifiesta in genere a través de: $i$ ) instrumentos que no tienen per se fuerza jurídica vinculante; $i i)$ normas que se establecen en instrumentos hard; y iii) normas en proceso de gestación, es decir, normas que no han entrado en vigor o aún no se cristalizan como tales. Véase Nava Escudero, César, "Guía mínima para la enseñanza del derecho internacional ambiental en México", Boletín Mexicano de Derecho Comparado, nueva serie, año XXXVIII, núm. 113, mayo-agosto de 2005 , p. 822 .

40 El problema de la distinción entre derecho suave y derecho duro en instrumentos internacionales, de donde se infiere la problemática para las normas en tratados, ocupa un lugar de discusión desde hace algún tiempo en la literatura relativa a lo internacional ambiental. Véase Cabrera Acevedo, Lucio, El derecho de protección al ambiente, México, UNAM, Instituto de Investigaciones Jurídicas, 1981, pp. 97 y 98.

41 Dupuy, Pierre-Marie, "Soft Law...", cit., pp. 430 y 431.

42 La voz "aspiracional” no está registrada en el Diccionario de la Lengua Española, pero con ella nos referimos a la declaración o aspiración de alcanzar o lograr algo, es desear o querer conseguir algo.

43 Para una afirmación de este tipo véase Guruswamy, Lakshman, International Environmental..., cit., p. 27. 
Esta obra forma parte del acervo de la Biblioteca Jurídica Virtual del Instituto de Investigaciones Jurídicas de la UNAM

diría en idioma inglés que estamos frente a normas internacionales de comportamiento hortatory o aspirational. ${ }^{44}$

El lenguaje soft puede manifestarse de formas distintas, pero una de las más recurrentes es a través de ciertos verbos ${ }^{45}$ como "deberían", "podrán" o "recomendarán", en contraposición a aquellos utilizados en normas hard como "deberán" o "requerirán". ${ }^{46}$ Otros verbos del soft law pueden ser "pedir", "solicitar", “invitar", "alentar" o "exhortar", y en contraposición "ordenar" o "prohibir". ${ }^{47}$ Aunado a lo anterior, también es recurrente que el lenguaje incluya ciertas frases que hacen que la norma sea imprecisa o vaga. Son frases o expresiones casi sacramentales que relativizan el contenido mismo del precepto y otorgan un amplio margen de acción a los Estados. Los ejemplos más comunes son: "según corresponda", "cuando proceda", "cuando corresponda", "cuando sea el caso", "según el caso", "según proceda", "en lo posible", "lo antes posible", "en la medida de lo posible", "en la medida de sus posibilidades", "a la luz de sus circunstancias nacionales", "de interés nacional", entre otros. ${ }^{48}$ En ocasiones los preceptos imprecisos o vagos se utilizan para crear estándares más que reglas propiamente; mientras aquéllas dejan que el actuar de los Estados sea discrecional o que quede a su arbitrio, éstas establecen qué conductas son permisibles y cuáles no. En principio, los estándares pueden ser más flexibles o laxos y las reglas más rigurosas, pero se advierte que esto no es necesariamente una constante. ${ }^{49}$

44 Williamson, Richard L. Jr., "Hard Law...", cit., p. 63.

45 Véase Bodansky, Daniel, The Art and..., cit., pp. 103 y 104. En nuestro idioma puede consultarse Juste Ruiz, José, Derecho internacional..., cit., p. 55, en la nota de pie de página 61.

46 Respectivamente, en inglés son should, may y recommend, y las que se contraponen son shall y require.

47 Respectivamente, en inglés serán request, ask, invite, call, y en contraposición order o forbid.

48 En inglés las frases favoritas son as appropriate, as far as possible, e incluso, as soon as posible según el contexto de la disposición. En este sentido, se ha señalado que tales expresiones tienen el efecto drástico de mitigar, cuando no de mutilar, cualquier posibilidad de medir la obligación respectiva. Véase Van Lierop, Robert F. y Székely, Alberto, "Compliance with Environmental Treaties: The Empirical Evidence A Commentary on the Softening of International Environmental Law", Proceedings of the Annual Meeting (American Society of International Law), American Society of International Law, vol. 91, 9-12 de abril de 1997, p. 238.

49 Detalles en Bodansky, Daniel, The Art and..., cit., pp. 104-106. Sobre los estándares, véase Maljean-Dubois, Sandrine, "The Making of...”, cit., p. 47. 
Esta obra forma parte del acervo de la Biblioteca Jurídica Virtual del Instituto de Investigaciones Jurídicas de la UNAM

Estos verbos y expresiones se localizan comúnmente en el articulado de los tratados internacionales ambientales - aunque también en sus preámbulos - manifestándose de forma aleatoria. Por ejemplo, en la Convención Relativa a los Humedales de Importancia Internacional Especialmente como Hábitat de Aves Acuáticas (adoptada en Ramsar, Irán, el 2 de febrero de 1971) se distingue un precepto con expresiones de soft law como lo hemos especificado con antelación. Se establece en el numeral 2 del artículo 4o. lo siguiente:

Cuando una parte contratante por motivos urgentes de interés nacional retire de la lista o reduzca los límites de un humedal incluido en ella, deberá compensar en la medida de lo posible la pérdida de recursos de humedales y en particular crear nuevas reservas naturales para las aves acuáticas y para la protección de una porción adecuada de su hábitat original, en la misma región o en otro lugar. ${ }^{50}$

En este mismo sentido también son ejemplo los encabezados de los artículos para dar a los Estados enorme flexibilidad en el cumplimiento de una norma. Un tratado puede, incluso, reiterar este tipo de expresiones a lo largo de su texto, como es el caso del Convenio sobre la Diversidad Biológica (adoptado en Río de Janeiro, Brasil, el 5 de junio de 1992), donde la frase habitual para varios encabezados en sus primeros artículos es la de "en la medida de lo posible y según proceda". ${ }^{51}$ A continuación algunos ejemplos (las cursivas son nuestras):

Artículo 5o. Cada parte contratante, en la medida de lo posible y según proceda, cooperará con otras partes contratantes, directamente o, cuando proceda, a través de las organizaciones internacionales competentes, en lo que respecta a las zonas no sujetas a jurisdicción nacional, y en otras cuestiones de interés común para la conservación y la utilización sostenible de la diversidad biológica.

50 Las cursivas son nuestras para enfatizar expresiones amplias e imprecisas. Habrá laxitud en las interpretaciones y explicaciones que cada Estado haga sobre lo que signifique "urgente" e "interés nacional".

51 Los encabezados incluyen los temas de: cooperación (artículo 5o.); identificación y seguimiento (artículo 7o.); conservación in situ (artículo 8o.); conservación ex situ (artículo 9o.); utilización sostenible de los componentes de la diversidad biológica (artículo 10); incentivos (artículo 11). Lo anterior, sin perjuicio de que en otras partes del texto (en numeral e inciso) aparezca tal frase. 
Esta obra forma parte del acervo de la Biblioteca Jurídica Virtual del Instituto de Investigaciones Jurídicas de la UNAM

Artículo 7o. Identificación y seguimiento. Cada parte contratante, en la medida de lo posible y según proceda, en especial para los fines de los artículos 8o. a 10...

Artículo 8o. Conservación in situ. Cada parte contratante, en la medida de lo posible y según proceda...

Artículo 9o. Conservación ex situ. Cada parte contratante, en la medida de lo posible y según proceda, y principalmente a fin de complementar las medidas in situ...

Otro criterio para identificar normas de soft law es el de ubicar la existencia de principios ambientales $(i$. e conocidos como principios fundamentales de derecho internacional ambiental), ${ }^{52}$ que se incorporan en los preámbulos o en el articulado de los tratados. Es común que estos principios, originariamente plasmados en instrumentos de derecho suave, sigan siendo soft al insertarse en un tratado, particularmente cuando el propio principio en texto convencional se liga a verbos o expresiones como los arriba descritos. Esto sucedió en su momento con el principio de precaución en la CMNUCC (adoptada el 9 de mayo de 1992), la cual incluyó en diversas ocasiones el verbo "deberían" y dejó como potestativa la cooperación entre aquellas partes que estuvieran interesadas para hacer frente al cambio climático. Así lo establece el artículo 3.3 de dicho tratado:

\section{Artículo 3. Principios.}

3. Las partes deberían tomar medidas de precaución para prever, prevenir o reducir al mínimo las causas del cambio climático y mitigar sus efectos adversos. Cuando haya amenaza de daño grave o irreversible, no debería utilizarse la falta de total certidumbre científica como razón para posponer tales medidas, tomando en cuenta que las políticas y medidas para hacer frente al cambio climático deberían ser eficaces en función de los costos a fin de asegurar beneficios mundiales al menor costo posible. A tal fin, esas políticas y medidas deberían tener en cuenta los distintos contextos socioeconómicos, ser integrales, incluir todas las fuentes, sumideros

52 Estos principios se distinguen de los principios generales de derecho internacional, Sands, Philippe, Principles of International Environmental Law, 2a. ed., Cambridge, Cambridge University Press, 2003, p. 232. Hace tiempo que la doctrina se refiere a ellos como principios fundamentales de derecho internacional ambiental. Juste Ruiz, José, Derecho internacional..., cit., p. 47; Kiss, Alexandre Ch., Survey of..., cit., p. 29; Nava Escudero, César, "Guía mínima...", cit., pp. 826 y ss. 
Esta obra forma parte del acervo de la Biblioteca Jurídica Virtual del Instituto de Investigaciones Jurídicas de la UNAM

y depósitos pertinentes de gases de efecto invernadero y abarcar todos los sectores económicos. Los esfuerzos para hacer frente al cambio climático pueden llevarse a cabo en cooperación entre las partes interesadas. ${ }^{53}$

Algo similar podría ocurrir cuando se incorporan principios generales de derecho al tratado. Es el caso del tema de la responsabilidad y reparación de daño, donde ha llegado a utilizarse un lenguaje en "tono esencialmente exhortatorio, cercano a un pronunciamiento de mera lege ferenda. ${ }^{54}$

No obstante lo anterior, dentro del régimen internacional de protección al ambiente también sucede que algunos principios ambientales son dotados de un significado concreto en los tratados, ${ }^{55}$ lo que eventualmente se traduce en un acercamiento a la dimensión hard. Esto explica en parte el porqué algunos doctrinarios sostienen que un principio de este tipo pueda llegar a ser vinculante por derecho convencional o por derecho consuetudinario. ${ }^{56}$ Por ejemplo, el principio de precaución (uno de los principios fundamentales del derecho internacional ambiental por excelencia) aparenta o quiere adquirir, al menos en el plano estrictamente regional europeo, el estatus de un principio de derecho consuetudinario, ${ }^{57}$ lo que sin embargo no está del todo claro todavía.

Dos cuestiones más. Primera, que la frecuente referencia e incorporación de este tipo de principios en tratados deriva, a su vez, en la formulación y desarrollo de la costumbre. Esto parece haber ocurrido con el principio relativo al derecho soberano que tienen los Estados para explotar sus recursos naturales y el deber de no causar daño al ambiente de otros Estados ni de zonas fuera de su jurisdicción nacional. ${ }^{58} \mathrm{El}$ principio

53 Las cursivas son nuestras para hacer patente el lenguaje soft.

54 Para más sobre esto, Juste Ruiz, José, Derecho internacional..., cit., p. 75.

55 Kiss, Alexandre Ch. y Shelton, Dinah, International Environmental..., cit., p. 93.

56 En este sentido, Kiss, Alexandre Ch., op. cit., Survey of..., p. 27; Sands, Philippe, Principles of..., cit., p. 232; Székely, Alberto, "El medio ambiente: derecho internacional", Revista de la Facultad de Derecho de la Universidad Nacional Autónoma de México, México, t. XXVI, núms. 103 y 104, julio-diciembre de 1976, p. 332.

57 Véase Sadeleer, Nicolas de, “The Precautionary Principle in International Law", en Kerbrat, Yann y Maljean-Dubois, Sandrine (eds.), The Transformation..., cit., p. 88.

58 Este principio (que recoge el principio de soberanía de los Estados sobre sus recursos naturales y el principio de prevención del daño ambiental) se consagró en la Declaración de Estocolmo de 1972, que a la letra dice: "Principio 21. De conformidad con la Carta de las Naciones Unidas y con los compromisos del derecho internacional, los 
Esta obra forma parte del acervo de la Biblioteca Jurídica Virtual del Instituto de Investigaciones Jurídicas de la UNAM

es considerado derecho consuetudinario por la doctrina y como tal confirmado por la propia Corte Internacional de Justicia (en adelante, CIJ) a partir de 1996. ${ }^{59}$ Segundo, que un principio ambiental consagrado en un tratado como norma puede convertirse en un principio general del derecho, como a los que se refiere el artículo 38 del Estatuto de la CIJ, y de aquí seguir la suerte jurídica que tienen estos principios frente y respecto a otras fuentes del derecho internacional. Es el caso del principio relativo a que los Estados tienen la obligación general de proteger y preservar el medio marino según el artículo 192 de la Convención de las Naciones Unidas sobre el Derecho del Mar (adoptada en Montego Bay, Jamaica en 1982). ${ }^{60}$

Independientemente de la existencia de otros criterios que pudieran ser útiles en la identificación de normas soft law en los tratados (como detectar la falta de mecanismos normativos o institucionales para el cumplimiento de un precepto convencional determinado), es relevante referirnos a dos de las razones más importantes por las que los Estados optan por este tipo de normas. En primer lugar, la propia flexibilidad o elasticidad que la norma soft law permite a los Estados alcanzar cierto consenso respecto a un asunto ambiental, que no se lograría si la naturaleza misma del precepto fuera muy rigurosa. Esto se explica en parte porque los Estados pueden tener intereses políticos y socioeconómicos muy divergen-

Estados tienen el derecho soberano de explotar sus propios recursos en aplicación de su propia política ambiental y la obligación de asegurar que las actividades que se lleven a cabo dentro de su jurisdicción o bajo su control no perjudiquen al medio de otros Estados o de zonas situadas fuera de toda jurisdicción nacional". El texto fue incorporado casi íntegro como Principio 2 en la Declaración de Río de 1992. Los antecedentes de dicho principio son la sentencia arbitral en el asunto de la Fundición de Trail de 1941, la sentencia del Tribunal Internacional de Justicia en el asunto del Estrecho de Corfú de 1949, y la sentencia arbitral en el asunto del Lago Lanós de 1957. Para mayor detalle véase Juste Ruiz, José, Derecho internacional..., cit., pp. 72 y ss.; Sands, Philippe, Principles of..., cit., pp. 236 y ss.; Székely, Alberto y Ponce-Nava, Diana, "La Declaración de Río y el Derecho Internacional Ambiental", en Glender, Alberto y Lichtinger, Víctor, La diplomacia ambiental. México y la Conferencia de las Naciones Unidas sobre Medio Ambiente y Desarrollo, México, Secretaría de Relaciones Exteriores-Fondo de Cultura Económica, 1994, pp. 310 y 311.

59 Sands, Philippe, Principles of ..., cit., p. 236.

60 Esta es la opinión de Vallarta Marrón, José Luis, Derecho internacional..., cit., p. 61. Entendemos que este precepto, como obligación general, es una obligación de comportamiento más que de resultado y por lo tanto está ligado a una concepción de soft law, como lo hemos explicado en este trabajo. 
Esta obra forma parte del acervo de la Biblioteca Jurídica Virtual del Instituto de Investigaciones Jurídicas de la UNAM

tes sobre un tema que les impidan llegar a un acuerdo en relación con la adopción de una obligación ambiental común. ${ }^{61}$ Entre más vaga, imprecisa, genérica o relativizada se encuentre la norma, el Estado podrá adecuarse con mayor facilidad a ella sin la presión del cumplimiento forzoso de la misma o de la posibilidad de ser sancionado por incumplimiento.

En segundo lugar, la norma de soft law es una herramienta utilísima que supone (aunque no infaliblemente) un escenario donde todos los Estados y el objetivo del tratado en cuestión puedan beneficiarse (win-win scenario), al menos en términos temporales y con la expectativa de que así será. En efecto, el derecho suave convencional destraba no sólo aspectos de difícil consenso entre las partes sino también cuestiones relativas a conductas o resultados que supondrían una respuesta rápida o sujeta a plazos muy específicos pero que no siempre es bienvenida. En ocasiones, los Estados prefieren actuar con cierta cautela, a mediano o largo plazos, esperando la cooperación y el financiamiento de otras naciones $\mathrm{u}$ organizaciones internacionales; a veces esta conducta es resultado de la naturaleza del problema ambiental a enfrentar. ${ }^{62} \mathrm{~A}$ su vez, se abre la posibilidad de consolidar procesos que formen hacia el futuro obligaciones hard law. Recordemos que ante la negativa de ciertos Estados para adoptar compromisos vinculantes en tal o cual sentido en un tratado, un precepto de soft law podría dar la pauta para que su contenido se incluya posteriormente en otros instrumentos. ${ }^{63}$ Así como el soft law puede crear más soft law, también puede crear hard law. Esto contribuye, como ya lo señalamos, a la formación eventual y hacia el futuro del derecho internacional convencional o consuetudinario.

Lo criticable de estas razones es que no representan en lo absoluto la mejor respuesta que plantea un problema ambiental de características globales para un accionar concreto, rápido y específico de los Estados. Si bien las normas soft law en los tratados sirven para consolidar principios básicos ambientales, guiar o dirigir el comportamiento y conducta de las partes contratantes, y constituirse como un antecedente del derecho duro, también son utilizadas para enmascarar desacuerdos interestatales

61 Guruswamy, Lakshman, International Environmental..., cit., p. 28.

62 En efecto, hay ocasiones que la naturaleza misma del problema ambiental hace casi imposible definir el contenido exacto de una obligación, como cuando ocurre con asuntos relacionados con la contaminación de largo alcance o a largo plazo. Véase Kiss, Alexandre Ch. y Shelton, Dinah, International Environmental..., cit., p. 95.

63 Véase lo señalado en Shelton, Dinah, "Comments on...", cit., pp. 63 y 64. 
Esta obra forma parte del acervo de la Biblioteca Jurídica Virtual del Instituto de Investigaciones Jurídicas de la UNAM

y la falta de compromisos verdaderos de algunos Estados para enfrentar conjuntamente dilemas de la mayor trascendencia. Conducirse de manera laxa, posponer decisiones, comportarse de tal o cual manera en la medida en la que otros se comporten sin sentirse obligados a ello, es característico de la norma convencional en el derecho internacional ambiental.

No debe sorprender que en cualquiera de los regímenes internacionales de protección al ambiente los tratados desarrollen tales contenidos. E1 derecho suave es simple y sencillamente un proceso de creación de normas bastante común dentro de lo jurídico internacional ambiental. Los Estados acuden reiteradamente a él al momento de negociar y redactar los textos respectivos. En consecuencia, y aún sin considerarlo trivial o superfluo, este proceso no siempre ofrece el mejor de los escenarios para responder a los grandes retos ambientales.

\section{EL ACUERDO DE PARÍS: REINCIDENCIA DEL SOFT LAW EN EL RÉGIMEN CLIMÁTICO}

Empecemos por aclarar que el régimen climático pertenece a foros propiamente ambientales, $i$. e., es uno de los diversos regímenes internacionales de protección al ambiente. ${ }^{64}$ En efecto, ya desde hace algunos años que la doctrina lo ha incluido como un sector o capítulo del derecho internacional ambiental. ${ }^{65} \mathrm{Y}$ desde el punto de vista normativo, este régimen se ha caracterizado por tener un desarrollo normativo ambiental altamente orientado al soft law. Esto se refleja en mayor o menor medida en los tres tratados más importantes en la materia: la CMNUCC de 1992, el PK de 1997 y el AP de 2015.

\section{La Convención Marco de las Naciones Unidas sobre el Cambio Climático}

Como ha sucedido con otros regímenes internacionales ambientales, el del cambio climático tuvo su inicio y preliminar desarrollo con reuniones

64 Por ejemplo, Borrás Pentinat, Susana, Los regímenes internacionales de protección del medio ambiente, Valencia, Tirant lo Blanch, 2011.

65 Prácticamente todos los libros sobre derecho internacional ambiental consultados dedican espacio considerable al tema. También es común como capítulo o apartado en libros de derecho ambiental. 
Esta obra forma parte del acervo de la Biblioteca Jurídica Virtual del Instituto de Investigaciones Jurídicas de la UNAM

y conferencias ${ }^{66}$ que derivaron en una serie de declaraciones y otros instrumentos de naturaleza soft law. Al adquirir decidida relevancia internacional a finales de la década de los ochenta del siglo pasado, el fenómeno del cambio climático fue objeto de una serie de evaluaciones científicas y técnicas del órgano intergubernamental más importante creado ex profeso para este tema: el Grupo Intergubernamental de Expertos sobre el Cambio Climático, también conocido como Panel Intergubernamental de Cambio Climático (en adelante, PICC). Establecido en 1988 por la Organización Meteorológica Mundial y el Programa de las Naciones Unidas para el Medio Ambiente, el PICC publicó en 1990 un primer informe de evaluación que fue, entre otros, fundamental para el inicio de las negociaciones en la elaboración de un tratado bajo el auspicio de las Naciones Unidas, lo que ocurriría en 1990 con base en la Resolución 45/212 de la Asamblea General. ${ }^{67}$ El resultado de los trabajos fue la creación de la CMNUCC, en vigor desde el 21 de marzo de 1994.

Aunque la CMNUCC representa el primer acuerdo internacional ambiental vinculante sobre el clima, su contenido normativo es predominantemente de derecho suave. ${ }^{68} \mathrm{Si}$ bien se establecen algunas obligaciones concretas para las partes contratantes, el texto es un ir y venir de disposiciones con lenguaje genérico, impreciso, vago o relativizado. Un ejemplo de esto es el que se refiere a las concentraciones de gases de efecto invernadero (en adelante, GEI) en la atmósfera que es lo que está produciendo el cambio climático. El objetivo último de la CMNUCC es lograr la estabilización de tales concentraciones "a un nivel que impida interferencias antropógenas peligrosas", pero no se precisa cuál debe ser tal nivel ni en qué tiempo hacerlo, ${ }^{69}$ amén de utilizar el vocablo "debería" en el texto de referencia, lo que es característico en un enunciado de soft law. ${ }^{70}$

66 Destacan durante este periodo la I Conferencia mundial sobre el clima en Ginebra, Suiza, 1979, y las reuniones en Villach, Austria, 1985, Bruselas, Bélgica, 1986, Toronto, Canadá, 1988, Ottawa, Canadá, 1989, La Haya, Países Bajos, 1989, y la II Conferencia mundial sobre el clima otra vez en Ginebra, Suiza, 1990.

67 Más detalles sobre esto en Birnie, Patricia et al., International Law and the Environment, 3a. ed., Oxford, Oxford University Press, 2009, p. 356; Sands, Philippe, Principles of..., cit., pp. 358 y 359.

68 Esto puede constatarse en Juste Ruiz, José, Derecho internacional..., cit., p. 290.

69 Véase lo que también se señala en Birnie, Patricia et al., International Law..., cit. p. 358 .

70 El artículo 2o. respectivo señala: "El objetivo último de la presente Convención... es lograr... la estabilización de las concentraciones de gases de efecto invernadero en 
Esta obra forma parte del acervo de la Biblioteca Jurídica Virtual del Instituto de Investigaciones Jurídicas de la UNAM

Otro ejemplo son los enunciados relativos a la incorporación de diversos principios fundamentales de derecho internacional ambiental como los de equidad intergeneracional, responsabilidades comunes pero diferenciadas, o de precaución. Independientemente de que en todos ellos se hace un uso extenso de la palabra "deberían", el encabezado del precepto donde se incluyeron (artículo 3), se refiere a ellos como meras guías y no como reglas vinculantes. ${ }^{71}$

Aunado a lo anterior, el importante artículo relativo a los compromisos para todas las partes contratantes, el artículo 4, tiene un encabezado que sujeta tales compromisos a las prioridades nacionales y regionales de desarrollo y a los objetivos y circunstancias de cada una de ellas. El contenido mismo de cada compromiso está redactado, igualmente, de manera que difícilmente pudiera pensarse en disposiciones rigurosas, con todo y que en el propio artículo 4.2 incisos a) y b) se establezca que las partes que son países desarrollados y las incluidas en el anexo I se comprometen específicamente a regresar sus emisiones a los niveles de 1990 antes del año $2000 .^{72}$ De aquí que a estos preceptos se les haya correctamente caracterizado de obligaciones mínimas, lo que ha conducido a decir que este tratado "establece un régimen particularmente confuso de compromisos a cargo de las partes, en el que la ambigüedad es la característica dominante...". ${ }^{73}$

Advertimos que el contenido de soft law en la CMNUCC se explica en gran medida porque fue un instrumento adoptado como convención mar-

la atmósfera a un nivel que impida interferencias antropógenas peligrosas en el sistema climático. Ese nivel debería lograrse en un plazo suficiente para permitir que los ecosistemas se adapten naturalmente al cambio climático". Las cursivas son nuestras.

71 De esta opinión es Birnie, Patricia et al., International Law..., cit., p. 359. E1 encabezado en cuestión señala: "Las partes, en las medidas que adopten para lograr el objetivo de la Convención y aplicar sus disposiciones, se guiarán, entre otras cosas, por lo siguiente...", y luego enumera los principios.

72 Más detalles en Birnie, Patricia et al., ibidem, pp. 359 y 360. Las partes incluidas en el anexo I (i.e. países miembros de la OCDE, la Comunidad Europea y países en proceso de transición a una economía de mercado) tienen ciertos compromisos específicos, pero aún así, son imprecisos, como el que no exista cuantificación sobre la limitación de las emisiones de GEI.

$73 \mathrm{Y}$ es que en el artículo se establecen distinciones, categorías entre las partes, y se desarrolla un régimen asimétrico de obligaciones. En suma, diversifica, condiciona y matiza los compromisos establecidos. Véase Juste Ruiz, José, Derecho internacional..., cit., pp. 291 y 292; para la cita textual, p. 296. 
Esta obra forma parte del acervo de la Biblioteca Jurídica Virtual del Instituto de Investigaciones Jurídicas de la UNAM

co. Este tipo de tratados, propios para la regulación de temas ambientales regionales o globales, establecen obligaciones generales, crean arreglos institucionales básicos y determinan procedimientos para la adopción futura de obligaciones más precisas en protocolos subsecuentes. ${ }^{74}$ Por ende, no sorprende que este tratado tenga un alto contenido de normativa suave. Más allá de que esto mismo haya servido para cuestionar moralmente si tal formato jurídico fue el adecuado para enfrentar el cambio climático, ${ }^{75}$ lo cierto es que los Estados así lo decidieron.

\section{El Protocolo de Kyoto y la CMNUCC}

Dentro de los arreglos institucionales de la CMNUCC se creó, entre otros, la Conferencia de las Partes (en adelante, COP) en calidad de órgano supremo de la propia convención. A ésta corresponde, según el artículo 7, examinar la aplicación del tratado y de todo instrumento jurídico conexo que adopte, así como tomar, conforme a su mandato, las decisiones necesarias para promover la aplicación eficaz del mismo. Entre sus diversas competencias se determinó que la COP podía aprobar protocolos, según el artículo 17, lo que habría de suceder durante su tercer periodo de sesiones en el que se adoptó en Kyoto, Japón, el PK. ${ }^{76}$

En el nuevo instrumento se incluyeron, ahora sí de manera más palpable, normas de hard law, lo que no significó que se dejaran de insertar enunciados soft law. Por un lado, el derecho duro se manifestó, entre otros, a través de obligaciones vinculantes para los países anexo I de la CMNUCC, relativas a compromisos cuantificados de limitación y reduc-

74 Kiss, Alexandre Ch. y Shelton, Dinah, International Environmental..., cit., p. 78; Sands, Philippe, Principles of ..., cit., p. 128.

75 Para una excelente discusión sobre la idoneidad moral de la CMNUCC acúdase a Garvey, James, The Ethics of Climate Change. Right and Wrong in a Warming World, Londres, Continuum, 2008, pp. 114-120.

76 Las negociaciones del PK tuvieron como base el Mandato de Berlín de 1995 adoptado en la primera COP de ese año, y se estableció que los compromisos del artículo 4.2, incisos a) y b), no eran adecuados y por tanto era necesario fortalecerlos, entre otras, a través de una limitación cuantificada de sus emisiones en periodos específicamente establecidos. En la siguiente conferencia, en la COP-2, celebrada en Ginebra, Suiza, en 1996, se adoptó una declaración ministerial, que también sirvió de base al PK, puesto que en ella se instó a los participantes respectivos a acelerar las negociaciones para la adopción de un instrumento que incorporara los preceptos antes mencionados. Los detalles en Sands, Philippe, Principles of..., cit., pp. 369 y 370. 
Esta obra forma parte del acervo de la Biblioteca Jurídica Virtual del Instituto de Investigaciones Jurídicas de la UNAM

ción de emisiones para un primer periodo específico: de 2008 a 2012. Las partes contratantes obligadas, según el artículo 3.1 , habrían de reducir ya sea de manera individual o conjuntamente, el total de sus emisiones de un número determinado de gases (enumerados en el anexo A del PK) a un nivel inferior en no menos de 5\% tomando como referencia los niveles de emisión de 1990.

Por otro lado, el derecho suave se plasmó al establecer, una vez más, obligaciones generales o flexibles para las partes contratantes. Esto se observa con claridad en relación con las políticas y medidas que habrían de aplicar o seguir elaborando las partes (anexo I) según el artículo 2.1 que señala que con el fin de promover el desarrollo sustentable, cada una de ellas, al cumplir con sus compromisos cuantificados contraídos, "aplicará y/o seguirá elaborando políticas y medidas de conformidad con sus circunstancias nacionales". ${ }^{77}$

Otro ejemplo lo constituye el hecho de que no se hubieran establecido compromisos cuantificados de reducción para los países no desarrollados: ninguno de ellos se incluyó en el anexo B del Protocolo. ${ }^{78}$ Esto significa, en realidad, que a estos países no se les requiere de otra cosa que no sea la de cumplir con sus obligaciones ya existentes bajo el artículo 4.1 de la CMNUCC. 79

Aunado a lo anterior, se incluyeron enunciados que dejan para futuras negociaciones ciertas reglas específicas, guías y metodologías necesarias para la implementación del Protocolo, lo que habría de cristalizarse años más tarde en instrumentos como los Acuerdos de Bonn y los Acuerdos de Marrakech, ambos de 2001, para tales efectos. ${ }^{80}$ Esto sucedió en lo particular con los procedimientos en caso de incumplimiento según lo establecido en el artículo 18 del PK:

En su primer periodo de sesiones, la Conferencia de las Partes en calidad de reunión de las partes en el presente Protocolo aprobará unos procedi-

77 La redacción de tal enunciado se debió a la resistencia de Estados Unidos, Canadá, Australia y otras partes (anexo I) que prefirieron un enfoque flexible en esta cuestión en particular, como nos lo recuerda Sands, Philippe, Principles of..., cit., p. 372. Las cursivas en la cita textual del artículo son nuestras.

78 En este anexo figuran las partes cuyos compromisos cuantificados son de limitación o reducción de emisiones.

79 Birnie, Patricia et al., International Law..., cit., p. 361.

80 Véase Sands, Philippe, Principles of..., cit., p. 370. 
Esta obra forma parte del acervo de la Biblioteca Jurídica Virtual del Instituto de Investigaciones Jurídicas de la UNAM

mientos y mecanismos apropiados y eficaces para determinar y abordar los casos de incumplimiento de las disposiciones del presente Protocolo, incluso mediante la preparación de una lista indicativa de consecuencias, teniendo en cuenta la causa, el tipo, el grado y la frecuencia del incumplimiento. Todo procedimiento o mecanismo que se cree en virtud del presente artículo y prevea consecuencias de carácter vinculante será aprobado por medio de una enmienda al presente Protocolo.

Fue la COP la que adoptó posteriormente un texto para definir los procedimientos y mecanismos en cuestión y propuso que esto mismo se hiciera en la primera Reunión de las Partes COP11/CMP1 (celebrada en 2005 en Montreal, Canadá), cuestión que derivó sin embargo en la adopción mutatis mutandis del texto antes presentado. Sin revisión del Protocolo, los preceptos relacionados con el procedimiento descansaron, entonces, en una mera decisión de la reunión de las partes por lo que no habría tenido, en principio, consecuencias vinculantes. ${ }^{81}$

Todo el aparato de hard law/soft law logrado en la CMNUCC, el PK y sus reuniones y conferencias posteriores, no fueron suficientes para evitar la crítica sobre sus alcances reales en el combate al cambio climático. Si bien algunos sectores importantes de la comunidad internacional y no pocos científicos aplaudieron los esfuerzos logrados, otros más consideraron al marco jurídico climático como "un avance simplemente simbólico", 82 y en particular al PK como un instrumento más dañino que benéfico. ${ }^{83} \mathrm{Y}$ es que el objetivo de reducción de emisiones resultó ser muy bajo para lo que se esperaba en ciertos escenarios del calentamiento global, ${ }^{84}$ lo que aunado a la falta de reducciones cuantificadas vinculantes

81 Para esta explicación y sobre los alcances vinculantes o no de este texto por las "sanciones" impuestas a Grecia ante los problemas metodológicos en su inventario de GEI, Maljean-Dubois, Sandrine, "The Making of International Law...”, cit., p. 49.

82 Al respecto, Antal, Edit, Cambio climático: desacuerdo entre Estados Unidos y Europa, México, Plaza y Valdés-UNAM, Centro de Investigaciones sobre América del Norte (CISAN), 2004, pp. 78 y ss.

83 Véase Beyerlin, Ulrich y Marauhn, Thilo, International Environmental Law, Oxford, Hart-CH Beck-Nomos, 2011, p. 163.

84 Por ejemplo, la reducción para el periodo $2008-2012$ de un promedio de $5.2 \%$ entre los países desarrollados contrasta con la necesidad de reducción de entre 50 y $80 \%$ para enfrentar los efectos más catastróficos identificados. Borrás Pentinat, Susana, Los regímenes..., cit., pp. 136 y 137. En otro ejemplo, los resultados de la implementación absoluta del PK habrán sido marginales, con una reducción de la temperatura en $0.15 \%$ al compararse con un escenario donde no existiera reducción de bióxido de carbono 
Esta obra forma parte del acervo de la Biblioteca Jurídica Virtual del Instituto de Investigaciones Jurídicas de la UNAM

de países no desarrollados -i. e. discriminación positiva o benigna en su favor-,${ }^{85} \mathrm{y}$ a la información científica publicada posteriormente a la adopción el PK, se concluyó que el régimen acordado era francamente inadecuado. 86

En años recientes, la crítica se ha centrado en que los supuestos "estancamientos" o "reducciones" de emisiones de países desarrollados se deben al comercio internacional de traslado de producción sucia a países no desarrollados, ${ }^{87} \mathrm{y}$ al proceso de compensación que aquéllos tienen para alcanzar la reducción requerida a través de mecanismos flexibles en el PK (i.e. aplicación conjunta, desarrollo limpio y comercio de derechos de emisión) ${ }^{88}$ mismos que por su naturaleza se asemejan más a enunciados de soft law que de hard law.

Después de todo, en el último informe del PICC —el Quinto Informe de Evaluación- se mencionó que, de acuerdo con los inventarios nacionales de GEI de 2012 presentados a la CMNUCC en octubre de 2013, "las Partes incluidas en el anexo B que habían adoptado compromisos de limitación (y reducción de las emisiones) cuantificadas podían haber mejorado su meta conjunta de reducción de las emisiones durante el primer periodo de compromiso..." ${ }^{89}$ En este mismo informe se dio a conocer que la conclusión final sobre el cumplimiento de las partes anexo B estaba, en octubre de 2014, todavía en proceso de examen en el marco del PK.

(business as usual). Guruswamy, Lakshman, International Environmental..., cit., pp. 218 y ss.

85 Beyerlin, Ulrich y Marauhn, Thilo, International Environmental..., cit., p. 161.

86 Birnie, Patricia et al., International Law..., cit., p. 371.

87 Véase Klein, Naomi, Esto lo cambio todo. El capitalismo contra el clima, trad. de Albino Santos Mosquera, Barcelona, Paidós, 2015, p. 108.

88 Beyerlin, Ulrich y Marauhn, Thilo, International Environmental..., cit., pp. 162 y ss. En lo particular, se ha cuestionado la efectividad de los Mecanismos de Desarrollo Limpio por lo que toca a los primeros años de aplicación. Más detalles en IPCC, Cambio climático 2014: Informe de sintesis. Contribución de los Grupos de trabajo I, II y III al Quinto Informe de Evaluación del Grupo Intergubernamental de Expertos sobre el Cambio Climático, Ginebra, [Equipo principal de redacción, R. K. Pachauri y L. A. Meyer (eds.)], IPCC, 2015, p. 115

89 Ibidem, pp. 114 y 115. 
Esta obra forma parte del acervo de la Biblioteca Jurídica Virtual del Instituto de Investigaciones Jurídicas de la UNAM

\section{El Acuerdo de París}

Con elogios y críticas, lo plasmado en el PK y lo establecido en las decisiones tomadas por subsecuentes conferencias y reuniones de las partes, fue resultado de arduas negociaciones y de consensos y disensos entre los Estados. Conscientes de que el primer periodo de compromisos expiraría en 2012, la comunidad internacional comenzó, poco después de que el PK entrara en vigor (en febrero de 2005), las discusiones para llegar a un acuerdo que modificara o, en su caso, sustituyera al PK para fortalecer el régimen climático. ${ }^{90}$ Las primeras expectativas de que esto ocurriera se centraron tanto en la COP-15 en Copenhague en 2009 como en la COP16 en Cancún en 2010, ${ }^{91}$ pero en ninguna de ellas se alcanzó un instrumento vinculante para un periodo posterior a 2012.92

Al poco tiempo, y ante la falta de consenso para lograr un acuerdo vinculante, se adoptó en Doha, Qatar, en diciembre de 2012, en la COP18/CMP8, la Enmienda de Doha al PK, que entre otras cosas estableció: un segundo periodo de compromisos por ocho años: 2013-2020; la continuidad de los mecanismos flexibles del PK; nuevos compromisos cuantificados de limitación o reducción de emisiones para el segundo periodo (en anexo B); el compromiso de las partes (anexo I) para reducir el total de sus emisiones "a un nivel inferior en no menos del 18\% al de 1990 en el periodo de compromiso comprendido entre los años 2013 y 2020" (artículo 3.1 bis); etcétera. Muy importante, en dicha conferencia/reunión se fijó un calendario internacional para alcanzar un acuerdo mundial en 2015, lo que sucedió hacia finales de ese año en París, Francia.

En cierta medida, y con algunas diferencias, el AP confirma y repite lo que ha ocurrido en el régimen climático cuando la adopción de la CMNUCC y el PK: se trata de un instrumento hard law con un alto

90 Beyerlin, Ulrich y Marauhn, Thilo, International Environmental..., cit., p. 148. Detalles sobre lo que habría de ocurrir de 2007 en la COP-13/CMP-3 en Bali, Indonesia, hasta 2014 en la COP-20/CMP-10 en Lima, Perú, se encuentran en Flores Liera, Socorro, "El cambio climático, ¿un reto que rebasa a la comunidad internacional?”, en González G., Guadalupe et al., (eds.), México y el multilateralismo del siglo XXI. Reflexiones a los 70 años de la ONU, México, siglo XXI-ITAM-Senado de la República, 2015, pp. 372 y ss.

91 Véase Borrás Pentinat, Susana, Los regímenes..., cit., p. 144.

92 Nava Escudero, César, "México ante la COP-16. Entre la simulación climática y la incertidumbre jurídica", Revista del Posgrado en Derecho de la UNAM, México, núm. 13, julio-diciembre de 2011, pp. 212 y ss. 
Esta obra forma parte del acervo de la Biblioteca Jurídica Virtual del Instituto de Investigaciones Jurídicas de la UNAM

contenido de normas soft law. Esta reincidencia jurídico-ambiental-climática se ha expresado de maneras diversas en el texto aprobado, algunas de obvia inserción y otras como resultado de una negociación para que los Estados participantes lograran un acuerdo vinculante y pudieran responder así a las demandas formuladas por diversos actores de la propia comunidad internacional y de la sociedad en general. Muchas de las críticas han estado dirigidas, precisamente, a la parte del soft law de este tratado.

Comencemos, como es lógico, por el preámbulo, que contiene un caudal de declaraciones políticas y de buena voluntad que en el marco de la respuesta al cambio climático se encuentran asociadas a la erradicación de la pobreza, la seguridad alimentaria, los empleos dignos y los derechos humanos, entre otros. En este sentido, se incluye la importancia de conceptos como los de la Madre Tierra, la justicia climática, o los estilos de vida y pautas de consumo y producción sustentables. Vinculadas a ellas, se da cuenta de que el cambio climático "es un problema de toda la humanidad". Stricto sensu, sin embargo, las críticas al texto del AP no están enfocadas a su preámbulo, sino a su articulado.

Una de las críticas que más ha llamado la atención es aquella que señala que en lugar de que se establecieran contribuciones obligatorias de reducción de emisiones (i. e. metas cuantificadas) se plasmaran enunciados basados en promesas voluntarias a través de las llamadas contribuciones determinadas a nivel nacional (antes en inglés, INDC y ahora NDC). ${ }^{93}$ Independientemente de lo poco idóneo de éstas para mantener el aumento de la temperatura mundial muy por debajo de $\operatorname{los} 2^{\circ} \mathrm{C}$ respecto a los niveles preindustriales según lo establece el artículo 2.1 a) del AP, el lenguaje utilizado y la esencia de tales contribuciones es flexible e impreciso, lo que permite suponer que se trata de enunciados de derecho suave. De hecho, todo el sistema en torno a ellas descansa en lo que se ha dado

93 Los países presentarán tales contribuciones en el marco del AP. Antes de la COP21, el 30 de octubre de 2015, la Secretaría de la CMNUCC publicó un informe de síntesis sobre el efecto agregado de 119 contribuciones entregadas de 147 partes (hasta el 1o. de octubre de 2015) como respuesta a la invitación formulada por la COP para tal efecto. Este informe puede consultarse en United Nations Framework Convention on Climate Change, Synthesis Report on the Aggregate Effect of INDCs, UNFCC, 2015, disponible en unfccc.int/focus/indc_portal/items/9240.php. Una crítica puntual de antes de la COP21 en Solón, Pablo, "COP21: A New Disguise for an Old Agreement", noviembre de 2015, disponible en https://pablosolon.wordpress.com 
Esta obra forma parte del acervo de la Biblioteca Jurídica Virtual del Instituto de Investigaciones Jurídicas de la UNAM

por llamar una "estructura soft". ${ }^{94} \mathrm{Si}$ bien las partes deberán de entregar sus contribuciones cada cinco años (lo que aparenta ser de hard law), el texto del tratado las sujeta a una vaga disposición de "progresión a lo largo del tiempo" (artículo 3 del AP). ${ }^{95}$ La idea de cumplir con el objetivo del "largo plazo" al que se refiere el artículo antes citado, se encuentra vinculado al ambiguo, impreciso e indeterminable precepto de que las partes se proponen lograr que las emisiones mundiales de GEI "alcancen su punto máximo lo antes posible" (artículo 4.1). Así, la entrega es de hard law (aunque no es muy rigurosa), y lo que se entrega en contenido (cada país fija sus contribuciones, su nivel de ambición) es de soft law.

Alrededor de las NDC se encuentran, además, disposiciones relativizadas. Esto sucede, por ejemplo, con el artículo 6.1 para lograr una mayor ambición en las medidas de mitigación y adaptación. El texto contiene expresiones y palabras soft law que son potestativas y genéricas (las cursivas son nuestras):

La partes reconocen que algunas partes podrán optar por cooperar voluntariamente en la aplicación de sus contribuciones determinadas a nivel nacional para lograr una mayor ambición en sus medidas de mitigación y adaptación y promover el desarrollo sostenible y la integridad ambiental.

Otro aspecto es el relativo a los preceptos sobre la deforestación (y, por extensión, los bosques en su función de sumideros) como un asunto

94 Así lo describe (soft structure) el profesor Jorge E. Viñuales, director del Cambridge Centre for Environment, Energy and Natural Resource Governance de la Universidad de Cambridge, Inglaterra. Más detalles sobre las NDC desde su perspectiva en Viñuales, Jorge, "The Paris Climate Agreement: An Initial Examination (Part II of III)", EJIL: Talk!, Blog of the European Journal of International Law, 8 de febrero de 2016, disponible en www.ejiltalk,org/the-pari-climate-agreement-an-initial-examination-part-ii-of-iii/.

95 Las NDC “[son] promesas (pledges) que cada Estado deberá entregar formalmente. El objetivo es que acumuladamente, las medidas nacionales contribuyan a lograr las metas comunes del Acuerdo de París a largo plazo y de manera voluntaria... Es cierto que las contribuciones nacionales deben actualizarse cada cinco años y están sujetas al principio de progresión; es decir, cada promesa renovada será más ambiciosa a lo prometido previamente. Sin embargo, mientras la entrega, comunicación y actualización de las contribuciones nacionales están claramente plasmadas en lenguaje directivo («deberá»), el principio de progresión no lo está (la contribución sucesiva «representará una progresión»”). Rodiles, Alejandro, "El Acuerdo de París: un empujoncito hacia la justicia climática”, Nexos, 25 de febrero de 2016. 
Esta obra forma parte del acervo de la Biblioteca Jurídica Virtual del Instituto de Investigaciones Jurídicas de la UNAM

primordial para combatir el cambio climático. ${ }^{96} \mathrm{~A}$ lo largo de la COP-21 se alertó sobre la no inclusión o, en su caso, minimización del tema, particularmente por lo que respecta a no insertar en el AP medidas rigurosas para evitar la deforestación..$^{97}$ Lo que quedó plasmado en el artículo 5.1 y 2 del AP es un claro ejemplo del derecho suave convencional, donde los enunciados son exhortativos, vagos y con tintes propios de normas no coercibles que reflejan meras expectativas de comportamiento internacional. ${ }^{98}$ Aquí los dos párrafos (las cursivas son nuestras):

Artículo 5o.

1. Las partes deberían adoptar medidas para conservar y aumentar, según corresponda, los sumideros y reservorios de gases de efecto invernadero a que se hace referencia en el artículo 4, párrafo 1 d) de la Convención, incluidos los bosques.

2. Se alienta a las partes a que adopten medidas para aplicar y apoyar, también mediante los pagos basados en los resultados, el marco establecido en las orientaciones y decisiones pertinentes ya adoptadas en el ámbito de la Convención respecto de los enfoques de política y los incentivos positivos para reducir las emisiones debidas a la deforestación y la degradación de los bosques, y de la función de la conservación, la gestión sostenible de los bosques, y el aumento de las reservas forestales de carbono en los países en desarrollo, así como de los enfoques de política alternativos, como los que combinan la mitigación y la adaptación para la gestión integral y sostenible de los bosques, reafirmando al mismo tiempo la importancia de incentivar, cuando proceda, los beneficios no relacionados con el carbono que se derivan esos enfoques.

Dos cuestiones más de derecho suave apuntan a la normatividad de no cumplimiento y al arreglo de controversias. Como es común que suceda en el derecho internacional ambiental y por ende en el régimen climático, el AP establece un mecanismo no contencioso para los casos de

96 Véase Sarasíbar Iriarte, Miren, El derecho forestal ante el cambio climático: las funciones ambientales de los bosques, Navarra, Thomson-Aranzadi, 2007, pp. 169 y ss.

97 Pablo Solón, activista, propuso "un alto en seco a la deforestación" para reducir las emisiones. Más de esto en una nota de Acedo, Alfredo, "Con el Acuerdo de París arderá el planeta", Agencia Latinoamericana de Información (ALAI), 10 de diciembre de 2015, disponible en www.alainet.org/es/articulo/174215

98 Esto último constituye una de las formas clásicas de definir el soft law. Véase la clasificación propuesta por Cárdenas Castañeda, Fabián Augusto, “A Call for...”, cit., pp. 376 y ss. 
Esta obra forma parte del acervo de la Biblioteca Jurídica Virtual del Instituto de Investigaciones Jurídicas de la UNAM

incumplimiento ahora a través de un comité compuesto por expertos y de carácter facilitador para la aplicación y promoción en el acatamiento de las disposiciones del tratado (artículo 15.1, 2 y 3). Sobre la cuestión del arreglo de controversias, se aplica mutatis mutandis lo establecido en la CMNUCC, que en su artículo 14 abre la posibilidad para que los Estados acepten, en caso de controversia, la jurisdicción de la CIJ o el arbitraje, pero esto no se ha utilizado hasta el momento. ${ }^{99}$

Finalmente, la preocupación del aumento de la temperatura y su consecuente limitación en menos de $2{ }^{\circ} \mathrm{C}$ se plasmó en una norma meramente aspiracional y, por tanto, de soft law. El artículo 2.1 a) del AP señala:

Artículo 2o.

1. El presente Acuerdo, al mejorar la aplicación de la Convención [se refiere a la CNMUCC], incluido el logro de su objetivo, tiene por objeto reforzar la respuesta mundial a la amenaza del cambio climático, en el contexto del desarrollo sostenible y de los esfuerzos por erradicar la pobreza, y para ello:

a) Mantener el aumento de la temperatura media mundial muy por debajo de $2{ }^{\circ} \mathrm{C}$ con respecto a los niveles preindustriales, y proseguir los esfuerzos para limitar ese aumento de la temperatura a $1.5^{\circ} \mathrm{C}$ con respecto a los niveles preindustriales, reconociendo que ello reduciría considerablemente los riesgos y los efectos del cambio climático

Poco abona a estos preceptos de soft law el hecho de que en el informe de síntesis de la Secretaría de la CMNUCC (antes referido) sobre el efecto agregado de las contribuciones determinadas a nivel nacional entregadas hasta el 1o. de octubre de 2015 , se haya señalado que tales contribuciones sobrepasan el límite de $\operatorname{los} 2{ }^{\circ} \mathrm{C}$ de temperatura media mundial, dato un tanto alejado del objetivo originario. De hecho, en el documento de decisión de la COP-21 (a la cual se anexa el AP) se reconoce esto en los términos siguientes: "17. Observa con preocupación que los niveles estimados de las emisiones agregadas de gases de efecto invernadero en 2025 y 2030 resultantes de las contribuciones previstas determinadas a nivel nacional no son compatibles con los escenarios de $2{ }^{\circ} \mathrm{C}$ de menor

99 Véase para mayor información Viñuales, Jorge, "The Paris Climate Agreement: An Initial Examination (Part III of III)", EJIL: Talk!, Blog of the European Journal of International Law, 8 de febrero de 2016, disponible en www.ejiltalk,org/the-pari-climateagreement-an-initial-examination-part-iii-of-iii/. 
Esta obra forma parte del acervo de la Biblioteca Jurídica Virtual del Instituto de Investigaciones Jurídicas de la UNAM

costo...". Y agrega que para mantener el aumento de la temperatura media mundial por debajo de $2^{\circ} \mathrm{C}$ o incluso por debajo de $1.5^{\circ} \mathrm{C}$ con respecto a niveles preindustriales "se requerirá un esfuerzo de reducción de las emisiones mucho mayor que el que suponen las contribuciones previstas determinadas a nivel nacional". ${ }^{100}$

\section{REFLEXIÓN FINAL}

En el recorrido de análisis sobre la existencia de normas de soft law en los tratados, se ha corroborado la tendencia por parte de los Estados de adoptar dentro del derecho internacional ambiental instrumentos de hard law con alto contenido de preceptos no vinculantes. Al pertenecer al régimen internacional de protección al ambiente, el régimen jurídico sobre el clima es una muestra del uso de normas convencionales de derecho suave en instrumentos de derecho duro. El Acuerdo de París adoptado en diciembre de 2015, permite identificar el predominio de normatividad soft en este tipo de tratados, tal y como sucedió, si bien con rasgos y matices diferentes, con sus antecesores la CMNUCC y el PK.

Desde el punto de vista jurídico, no debe adjetivarse como bueno o malo, ni como correcto o incorrecto, el uso del derecho suave en el formato convencional del régimen climático. Simplemente ha sido una herramienta a la cual han acudido reiteradamente los Estados desde hace tiempo para enfrentar uno de los fenómenos más graves que afecta a la humanidad y, si se permite la expresión, al planeta entero.

100 Algunas voces críticas sobre tales metas aspiracionales y el contenido del AP señalan, entre otras cosas, lo siguiente: $i$ ) “...el acuerdo es una excusa que tienen los políticos para poder decir: tenemos una meta de dos grados e intentaremos hacerlo mejor cada cinco años..." (James Hansen, profesor de la Universidad de Columbia); ii) “.... la meta ambiciosa de la temperatura le faltan los medios ambiciosos para la mitigación... Para llegar al objetivo de $1.5^{\circ} \mathrm{C}$ hay que rebajar las emisiones del 70 al $95 \%$ a mediados de siglo..." (Steffen Kallbekken Director del Centre for International Climate and Energy Policy del Research Council of Norway); iii) "el calentamiento causado por las actividades humanas se está acercando ya a un grado y es muy posible que llegue a $1.2^{\circ} \mathrm{C}$ en 2030 con la tendencia actual... Quedarnos en $1.5^{\circ} \mathrm{C}$ en 2050 va a ser realmente un reto" (Myles Allen profesor de la Universidad de Oxford). Más sobre esto en un reportaje de Fresneda, Carlos, "El Acuerdo de París: ¿éxito o fraude?", El Mundo, 13 de diciembre de 2015, disponible en www.elmundo.es/ciencia/2015/12/13/566dc1dfee2704ece3d 8b4614.html. 
Esta obra forma parte del acervo de la Biblioteca Jurídica Virtual del Instituto de Investigaciones Jurídicas de la UNAM

Si bien los textos jurídicos climáticos existentes, y en lo particular el $\mathrm{AP}$, no han sido ni serán suficientes para alcanzar los objetivos trazados de mantener muy por debajo de $\operatorname{los} 2{ }^{\circ} \mathrm{C}$ la temperatura media global y de limitar ese aumento a $1.5^{\circ} \mathrm{C}$, ambos respecto a niveles preindustriales, no se debe per se al soft law. Es la voluntad de los Estados y de la comunidad internacional lo que al fin y al cabo puede hacer la diferencia, porque sea soft law o hard law, el diseño y cumplimiento de la norma (la redacción, el lenguaje, lo suave o riguroso, o los mecanismos para hacerla cumplir, haya o no sanción) dependerá en mucho de todos ellos.

Por lo expuesto con antelación, nos parece exagerado el triunfalismo con el que se ha querido caracterizar al AP, al menos desde la perspectiva jurídica. No hay nada de novedoso o espectacular en el hecho de haber adoptado un instrumento hard con mucha normativa soft. Esto se hace con una infinidad de tratados ambientales, y nada parece indicar en nuestros días que este esquema jurídico vaya a cambiar sustancialmente. Era muy ingenuo creer que el AP, con todo y su naturaleza vinculante, hubiera sido normativamente muy riguroso. 
Esta obra forma parte del acervo de la Biblioteca Jurídica Virtual del Instituto de Investigaciones Jurídicas de la UNAM

\section{DEBATE AMBIENTAL Y CONTAMINACIÓN ATMOSFÉRICA URBANA: LOS CASOS DE LONDRES Y LA CIUDAD DE MÉXICO*}

Me dijeron que antes había árboles, mariposas, aire puro, ríos cristalinos; me dijeron que antes la gente era sencilla y conocía el lenguaje de las flores, que también cantaban al amanecer y despedían el día danzando... y cuando abrí los ojos todo había desaparecido, quedando sólo en mí, la sensación, la certeza de haber tenido antepasados que hablaban un lenguaje común, ese idioma que en el día hablan los árboles y en la noche las estrellas. ${ }^{1}$

\section{INTRODUCCIÓN}

En los últimos años, los temas ambientales han adquirido en todo el mundo una gran importancia a nivel internacional, nacional y local. ${ }^{2}$ La percepción de que en la actualidad existe algo a lo que llamamos crisis ambiental, proviene de las preocupaciones que se originaron durante las décadas de los

* Título original: "The Environmental Debate and the Problem of Urban Air Pollution". Publicado por vez primera como segundo capítulo en Urban Environmental Governance: Comparing Air Quality Management in London and Mexico City, Aldershot, Ashgate, 2001. Agradezco a la editorial británica Ashgate el permiso otorgado para realizar la traducción y proceder a su publicación en español.

1 Palabras de Chamalú, indio quechua, chamán andino. Véase Espinoza, Luis (Chamalú), Ecología chamánica, 3a. ed., Barcelona, Ediciones Obelisco, 1994, p. 25.

2 Mannion, Antoinette M. y Bowlby, Sophia R., "Introduction”, en Mannion, Antoinette M. y Bowlby, Sophia R. (comps.), Environmental Issues in the 1990s, Chichester, Wiley, 1992, p. 17, y Thomas, C., The Environment in International Relations, Londres, The Royal Institute of International Affairs-Earthscan, 1992, p. 61. 
Esta obra forma parte del acervo de la Biblioteca Jurídica Virtual del Instituto de Investigaciones Jurídicas de la UNAM

sesenta y setenta (principalmente en los países del norte) sobre el agotamiento de los recursos naturales, la contaminación ambiental y su impacto en la salud humana. ${ }^{3}$ Aunque a lo largo de esos años predominó una visión enfocada a problemas locales o regionales, en la década de los ochenta las preocupaciones ambientales se orientaron hacia un debate global, bajo la idea compartida de la sustentabilidad. Iniciada la década siguiente, el debate ambiental comenzó a centrarse en temas urbanos relacionados particularmente con lo que se conoce como sustentabilidad de las ciudades o desarrollo urbano sustentable. A partir de este momento, surgió la necesidad de discutir cuáles habrían de ser las formas de acción local más adecuadas para mejorar las condiciones ambientales en los centros urbanos, lo que derivó en reconocer la importancia que los gobiernos locales tienen para combatir la contaminación a lo largo y ancho de una ciudad. De manera que se identificaron como factores clave dentro del debate de la sustentabilidad urbana, tanto el fortalecimiento de la participación de las autoridades locales, como la creación de estructuras gubernamentales locales más eficientes y efectivas a través de mayores niveles de coordinación y representación ciudadana. ${ }^{4}$

Este trabajo tiene por objeto realizar una síntesis de los principales acontecimientos y puntos de vista del debate ambiental de los últimos años ocurridos en los países del norte y del sur. Con ello, se tiene el doble propósito de identificar, por un lado, el papel que juegan los centros urbanos y las autoridades locales para enfrentar los diversos problemas urbano-ambientales que aquejan a las grandes ciudades del mundo y, por el otro, la magnitud de uno de esos problemas urbano-ambientales que constituye el tema principal que aquí tratamos: la contaminación atmosférica urbana. Una vez realizado este análisis, se aborda la situación de la calidad del aire en dos casos de estudio que corresponden respectivamente a un país desarrollado y a uno en vías de desarrollo: Londres y la Ciudad de México.

3 Lovell, L. y Johnson, D. L., "The Environmental Crisis and Direct Social Work Practice", en Hoff, M. D. y McNutt, J. G., (comps.), The Global Environmental Crisis, Aldershot, Avebury, 1994, p. 199; Rees, A., The Pocket Green Book: the Environmental Crisis in a Nutshell, Londres y Nueva Jersey, Zed Books, 1991, p. 1; White, R. R., North, South and the Environmental Crisis, Toronto, University of Toronto, 1993, pp. xi y xii, y Wilson, D., "The environmental crisis", en Wilson, D. (comp.), The Environmental Crisis. A Handbook for All Friends of the Earth, Londres y Exeter, Heinemann, 1984, p. 3.

4 Gilbert, Richard et al., Making Cities Work, Londres, Earthscan, 1996, pp. 23-42; Hardoy, J. E. et al., Environmental Problems in Third World Cities, Londres, Earthscan, 1992, pp. 162-164, y Haughton, Graham y Hunter, Colin, Sustainable Cities, Londres, Kingsley-Regional Studies Association, 1994, pp. 300-303. 
Esta obra forma parte del acervo de la Biblioteca Jurídica Virtual del Instituto de Investigaciones Jurídicas de la UNAM

\section{EL DEBATE AMBIENTAL: LA DISTINCIÓN NORTE-SUR}

Los vocablos norte y sur se refieren comúnmente a países desarrollados y a países en vías de desarrollo, respectivamente. Dentro de esta terminología, se acepta generalmente que el norte está conformado por una parte de América del Norte (i. e. Estados Unidos de América y Canadá), Europa (países occidentales), la antigua Unión Soviética, Japón, Australia y Nueva Zelanda; el sur se compone de todos los demás países. ${ }^{5}$ Esta distinción entre países desarrollados y en vías de desarrollo, basada según su ingreso económico, ${ }^{6}$ nos permite entender las diversas posturas que se han adoptado dentro de un discurso ambiental que en las últimas décadas se ha expandido velozmente alrededor del mundo.

El debate ambiental de finales de la década de los sesenta y de principios de los setenta en los países del norte se originó de tres preocupaciones fundamentales: $i$ ) la preservación de los paisajes naturales; $i$ ) el impacto de los químicos tóxicos, y sobre todo iii) el agotamiento de los recursos naturales. ${ }^{7}$ Este último tema, el de la escasez de recursos — asunto de gran preocupación durante la primera crisis del petróleo de la Organización de Países Exportadores de Petróleo- 8 llevó a la discusión de la famosa tesis los límites del crecimiento cuya aportación fue la de vincular proyecciones de crecimiento económico, poblacional y de recursos. ${ }^{9}$ Esta tesis, formulada por el Club de Roma, se basó en el argumento maltusiano de que el crecimiento poblacional y la explotación de recursos descontrolados serían la causa de un inminente agotamiento de la reserva humana de recursos naturales. Por lo que el debate ambiental se centró en la incompatibilidad entre el crecimiento económico continuo y la protección ambiental. ${ }^{10}$

5 Pearson, Ch. S. y Pryor, A., Environment: North and South, Nueva York, Wiley, 1978, pp. 3-6 y White, R. R., op. cit., nota 3, p. 3.

6 Keating, Michael, Agenda for Change, Ginebra, Centre for Our Common Future, 1993, p. ix.

7 White, R. R., op. cit., nota 3, p. 12.

8 Sandbrook, R., "Opening the Environmental Debate", en Wilson, D. (comp.), op. cit., nota 3, p. 12.

9 Véase, Meadows, D. H. et al., (comps.), The Limits to Growth, Nueva York, Potomac Associates Books, 1972, y White, R. R., op. cit., nota 3, p. 14.

10 Véase Ehrlich, P. R., The Population Bomb, Nueva York, Ballantine Books, 1969; Ehrlich, P. R., y Ehrlich, A. H., Population, Resources, Environment: Issues in Human Ecology, San Francisco, Freeman, 1970; Gandy, M., Recycling and Waste: an Exploration of Contemporary Environmental Policy, Aldershot, Avebury, 1993, p. 10; McCor- 
Esta obra forma parte del acervo de la Biblioteca Jurídica Virtual del Instituto de Investigaciones Jurídicas de la UNAM

Al darse cuenta de que los temas eran realmente globales y de que las preocupaciones por la calidad ambiental no eran exclusivamente de los países ricos, ${ }^{11}$ el norte reconoció que era necesario incluir al sur. A partir de esto, se hicieron rápidamente visibles las diferencias que existían entre ambos bloques.

Después de la Conferencia de las Naciones Unidas sobre el Medio Humano (CNUMH) celebrada en 1972 en Estocolmo, Suecia, y de la Declaración de Cocoyoc de $1974,{ }^{12}$ se advirtió que las cuestiones ambientales en el sur no eran principalmente sobre la conservación del campo, el uso de químicos tóxicos o el agotamiento de recursos. En realidad, estaban relacionadas con los problemas del desarrollo, esto es, el énfasis que se hacía era sobre las relaciones entre ambiente y desarrollo. Por lo tanto, los temas de discusión dentro del debate ambiental para los países del sur se centraban fundamentalmente en dos argumentos: $i$ ) necesidades básicas, y ii) estrategias de supervivencia. Además de diversos temas ambientales, también se incluían aspectos socio-culturales que en su conjunto abarcaban aspectos tales como los de igualdad, diversidad cultural, autosuficiencia de comunidades, democracia, autogestión de recursos, etcétera. ${ }^{13}$ Tal cuestión llevó a varios países de ese bloque a meditar sobre la importancia de contar con una estrategia en la que se insertara la dimensión ambiental en los procesos de desarrollo. Dicha estrategia,

mick, John, The Global Environmental Movement, 2a. ed., Chichester, Wiley, 1995, pp. 80 y 81, y Meadows, D. H. et al., (comps.), op. cit., nota anterior.

11 Pearson, Ch. S. y Prior, A., op. cit., nota 5, p. 1.

12 Esta declaración se adoptó en un simposium — también conocido como Founex II - celebrado en Cocoyoc, México, en octubre de 1974, y tuvo por objeto, entre otras cosas, discutir la relación entre ambiente y desarrollo y analizar el impacto que las cuestiones ambientales estaban teniendo en las estrategias de desarrollo y en las relaciones económicas internacionales. Véase McCormick, John, op. cit. nota 10, pp. 183-184.

13 Atkinson, A., "Environment and Development: Concepts and Practices in Transition", Public Administration and Development, vol. 11, 1991, pp. 401 y ss.; Leff, Enrique, "Análisis sociológico del movimiento ambientalista en América Latina", en García Guadilla, M. P. (comp.), Ambiente, Estado y sociedad, Caracas, Universidad Simón Bolívar-Centro de Estudios del Desarrollo, 1991, pp. 134 y 135, y del mismo autor, Green Production: Toward an Environmental Rationality, Nueva York, Guildford, 1995, p. 120; Pearson Ch. S. y Prior, A., op. cit., nota 5, pp. 2-3; Redclift, M., Development and the Environmental Crisis, Londres, Methuen, 1984, pp. 46 y 47, y Redclift, M. y Goodman, D., "Introduction", en Goodman D. y Redclift, M. (comps.), Environment and Development in Latin America: the Politics of Sustainability, Manchester, University of Manchester, 1991, p. 4. 
Esta obra forma parte del acervo de la Biblioteca Jurídica Virtual del Instituto de Investigaciones Jurídicas de la UNAM

que surgió durante la década de los setenta y que se consolidó a raíz de la ya mencionada conferencia sobre el medio humano (CNUMH) y del Programa de las Naciones Unidas para el Medio Ambiente (PNUMA), llegó a conocerse mundialmente como ecodesarrollo. ${ }^{14}$ Aunque la idea del ecodesarrollo estuvo presente en el debate ambiental de las décadas de los ochenta y noventa en los países del sur, quedó al poco tiempo circunscrita bajo el nuevo slogan de principios de los ochenta: el desarrollo sustentable. ${ }^{15}$

Mientras tanto, la tesis pesimista neo-maltusiana del norte pronto se convirtió en objeto de duras críticas, lo que derivó en que el debate ambiental durante la década de los ochenta en los países del norte cambiara de las preocupaciones por la escasez de recursos, a las consecuencias ambientales por la utilización de dichos recursos. Ya para la década de los noventa, la discusión en los países más desarrollados quedó también ceñida a los temas de sustentabilidad y desarrollo. ${ }^{16}$

Basada en el informe Nuestro Futuro Común de 1987 (documento elaborado por la Comisión Brundtland), ${ }^{17}$ la Organización de las Naciones Unidas convocó en 1989 a una conferencia mundial a celebrarse en Río de Janeiro, Brasil, en junio de 1992: la Conferencia de las Naciones Unidas sobre el Medio Ambiente y el Desarrollo (CNUMAD). Considerada como un hito en la historia ambiental, esta conferencia (también conocida como "la cumbre de la Tierra") generó conciencia sobre temas globales como la pérdida de los bosques tropicales, la diversidad biológica mundial, las condiciones climáticas cambiantes y, sobre todo, el desarrollo sustentable. ${ }^{18}$ No obstante que los intereses y posiciones de

14 Véase Brañes, Raúl, Manual de derecho ambiental mexicano, México, Fundación Mexicana para la Educación Ambiental-Fondo de Cultura Económica, 1994; García Guadilla, M. P. (comp.), op. cit., nota anterior, y Székely, Francisco (comp.), El medio ambiente en México y América Latina, México, Nueva Imagen, 1978.

15 Leff, Enrique, Green Production..., cit., nota 13, p. 59, y MacManus, Phil, “Contested Terrains: Politics, Stories and Discourses of Sustainability", Environmental Politics, Londres, vol. 5, núm. 1, primavera de 1996, p. 50.

16 Gandy, M. op. cit., nota 10, p. 13; O'Riordan, Timothy, Environmentalism, 2a. ed., Londres, Pion, 1981, pp. 60-65, y Soussan, John G., "Sustainable Development", en Mannion, Antoinette M. y Bowlby, Sophia R. (comps.), op. cit., nota 2, pp. 22-23;

17 Véase World Commission on Environment and Development, Our Common Future, Oxford, World Commission on Environment and Development-Oxford University, 1987.

18 Véase Birnie, Patricia W. y Boyle, Alan E., International Law and the Environment, 2a. ed., Oxford, Oxford University Press, 2002, pp. 4 y 5; Grubb, Michael et al., The Earth 
Esta obra forma parte del acervo de la Biblioteca Jurídica Virtual del Instituto de Investigaciones Jurídicas de la UNAM

los países del norte y del sur fueron más conciliatorios durante la década de los ochenta, sus inquietudes ambientales y prioridades permanecieron distanciadas incluso bajo el paraguas del desarrollo sustentable. ${ }^{19}$ Así, hacia finales de esa década y principios de la siguiente, las preocupaciones ambientales para el norte comprendían las emisiones de bióxido de carbono, el agotamiento de la capa de ozono, la pérdida de especies exóticas y la disposición de desperdicios tóxicos. Para el sur, seguía siendo el argumento sobre necesidades básicas, el cual se refería al insuficiente abastecimiento de agua, las malas condiciones de higiene, la erosión de suelos, la reducción del suministro de madera y la salud ambiental. Al mismo tiempo, el sur enfatizó la importancia de reducir la deuda de bancos y gobiernos del norte para enfrentar de manera más adecuada los problemas ambientales. A todo esto, empezaba a quedar más clara la idea de que el norte tenía una gran responsabilidad — quizá una responsabilidad preponderante - en temas como el calentamiento global. ${ }^{20}$

A principios la década de los noventa, el debate ambiental comenzó a enfocarse en temas urbano-ambientales y se orientó hacia la noción del desarrollo urbano sustentable; sin embargo, la creciente discusión generada bajo este concepto en el marco de la distinción norte-sur, condujo a diferenciar una agenda verde de una agenda café. Por un lado, la agenda verde - generalmente identificada como un reto para los países del norte - incluía lo relativo a la preservación y gestión de los recursos naturales y se orientaba a temas como el agotamiento de recursos, la deforestación, la biodiversidad y el calentamiento global. Por el otro, la agenda café - comúnmente identificada como un reto para los países del sur- abarcaba aspectos urbano-ambientales y se concentraba en temas como el impacto

Summit Agreements: a Guide and Assessment, Londres, The Royal Institute of International Affairs-Earthscan, 1993, pp. 6 y 7, y Keating, Michael, op. cit., nota 6, p. 6.

19 Algunos de los esfuerzos que se realizaron dentro del pensamiento ambientalista durante las décadas de los ochenta y noventa para identificar la gran variedad de enfoques y posiciones existentes relacionadas al concepto de desarrollo sustentable, incluyen Daly, H. E., "The Perils of Free Trade", Scientific American, noviembre de 1993; MacManus, Phil, op. cit., nota 15, y Turner, R. K. "Sustainability: Principles and Practice", en Turner, R. K. (comp.), Sustainable Environmental Economics and Management: Principles and Practice, Londres, Belhaven, 1993.

${ }^{20}$ Véase Redclift, M. y Sage, C., "Introduction”, en Redclift, M. y Sage, C. (comps), Strategies for Sustainable Development: Local Agendas for the Southern Hemisphere, Chichester, Wiley, 1994, pp. 4-8. 
Esta obra forma parte del acervo de la Biblioteca Jurídica Virtual del Instituto de Investigaciones Jurídicas de la UNAM

en la salud a consecuencia de servicios inadecuados de agua, sanidad, drenaje, residuos sólidos, basura y gestión de la calidad del aire. ${ }^{21}$

Debemos aclarar que esta diferenciación no ha sido del todo afortunada puesto que es posible detectar ciertos eventos o casos dentro de la agenda café que se presentan también en los países desarrollados y viceversa. Es decir, las ciudades del norte también pueden sufrir de problemas urbano-ambientales - como son los casos de la contaminación del aire o de la disposición de residuos - con todo y que cuentan con los recursos para reducir la contaminación que localmente producen..$^{22}$ De igual manera, no todos los centros urbanos del sur, como la creciente ciudad de Curitiba en Brasil, sufren de problemas ambientales serios. ${ }^{23}$ Bajo este contexto, es importante subrayar que el tema principal de este trabajo - i. e. la contaminación atmosférica- puede convertirse en un asunto de mucha preocupación para una ciudad ya sea del norte o del sur. Es por esto que la buena calidad del aire es un indicador local de sustentabilidad para cualquier centro urbano. ${ }^{24}$

Ahora bien, para lograr la sustentabilidad urbana en una ciudad se deben tomar en cuenta no sólo los aspectos ambientales sino también los socio-económicos, culturales, políticos e institucionales. ${ }^{25}$ En otras pala-

21 Véase, Bartone, C. et al., Toward environmental strategies for cities: policy considerations for urban environmental management in developing countries, Washington D.C., Urban Management Programme-United Nations Development Programme-United Nations Conference on Human Settlements-World Bank, 18, 1994, p. 1; Serageldin, I. y Cohen, M. A. (comps.), The Human Face of the Urban Environment: a Report to the Development Community, Washington D.C., Second Annual World Bank Conference on Environmentally Sustainable Development, Environmentally Sustainable Development Proceedings Series núm. 5, 10-21 de septiembre de 1994, 1995, p. 1, y World Bank, Making Development Sustainable, Washington D.C., Environment Department of the World Bank, 1994, p. 32.

22 Gilbert, Richard et al., op. cit., nota 4, p. 13.

23 Hardoy, J. E. et al., op. cit., nota 4, p. 17.

24 Elsom, Derek, Smog Alert: Managing Urban Air Quality, Londres, Earthscan, 1996, pp. 1 y 214-220; Hatcher, R. Lee, "Local Indicators of Sustainability: Measuring the Human Ecosystem", en Nath, Bhaskar et al. (comps.), Sustainable Development, Bruselas, Vubpress, 1996, pp. 192-197, y United Nations Centre for Human Settlements, An Urbanising World: Global Report on Human Settlements, Oxford, Oxford University, United Nations Centre for Human Settlements-HABITAT, 1996, p. 143.

25 Breheny, Michael J., "Sustainable Development and Urban Form: an Introduction", en Breheny, Michael J., (comp.), Sustainable Development and Urban Form, Londres, Pion, 1992, p. 2 y del mismo autor "Towards Sustainable Urban Development", en Man- 
Esta obra forma parte del acervo de la Biblioteca Jurídica Virtual del Instituto de Investigaciones Jurídicas de la UNAM

bras, garantizar la sustentabilidad a nivel urbano implica la adopción de un enfoque integrado o de conjunto para enfrentar los problemas ambientales que se presenten. Por lo tanto, una estrategia de este tipo debe contar con la voluntad política de los gobernantes, con las políticas públicas adecuadas que permitan la participación de todas las autoridades en todos los niveles de gobierno, con medidas que faciliten la intervención del sector privado, con los mecanismos para fomentar la participación social, etcétera. ${ }^{26}$

Sin embargo, las razones para alcanzar el desarrollo urbano sustentable a través de un enfoque integrado, no son necesariamente las mismas para los países desarrollados que para los que están en vías de serlo. Por ejemplo, para aquellas ciudades con altos niveles en el uso de energías no renovables — generalmente las ciudades más ricas —, la prioridad es la de reducir los niveles de consumo de combustibles fósiles así como la generación de residuos manteniendo una economía productiva y preservando los medios natural y construido. Por el contrario, para aquellas ciudades con bajos niveles en el uso de energías no renovables - usualmente las ciudades más pobres - , la prioridad es alcanzar metas de tipo socio-económico y político sin aumentar el uso de esos recursos y preservando los medios natural y construido.

Además de que cada centro urbano tiene sus razones y prioridades para lograr la sustentabilidad urbana, ésta se concibe de maneras distintas. Si bien es cierto que ciudades del norte o del sur coinciden en enfren-

nion, Antoinnette M. y Bowlby, Sophia R. (comps.), op. cit., nota 2, p. 277; Greig, A. D., "Urban Sustainability: an Annotated Bibliography", Research Papers, Londres, Department of Geography, London School of Economics, 1993, p. 1; Hardoy, J. E. et al., op. cit., nota 4, p. 171; Haughton, Graham y Hunter, Colin, op. cit., nota 4, p. 10, y Stren, Richard, "A Comparative Approach to Cities and the Environment", en Stren, Richard et al. (comps.), Sustainable Cities: Urbanisation and the Environment in International Perspective, Oxford, Westview, 1992, p. 1.

26 Así se establece en Breheny, Michael J. y Rookwood, R., "Planning the Sustainable City Region", en Blowers, A. (comp.), Planning for a Sustainable Environment, Londres, Town and Country Planning Association-Earthscan, 1993, p. 150; Elkin, T. et al., Reviving the City: Towards Sustainable Urban Development, Londres, Friends of the Earth, 1991, p. 9; Hardoy, J. E. et al., op. cit., nota 4, pp. 188-197; Keating, Michael, op. cit., nota 6, p. ix.; Organisation for Economic Cooperation and Development, Environmental Policies for Cities in the 1990s, París, Organisation for Economic Cooperation and Development, 1990, pp. 39-43, y de la misma organización Innovative Policies for Sustainable Urban Development: the Ecological City, París, Organisation for Economic Cooperation and Development, 1996, p. 168, y World Commission on Environment and Development, op. cit., nota 17, pp. 243-247. 
Esta obra forma parte del acervo de la Biblioteca Jurídica Virtual del Instituto de Investigaciones Jurídicas de la UNAM

tar el reto de reducir la contaminación local a través de ella, las primeras la consideran también pieza clave en la solución de problemas globales, y las segundas la perciben como algo indispensable para resolver problemas locales. ${ }^{27}$

De cualquier modo, es precisamente bajo el debate del desarrollo urbano sustentable y en el contexto de la CNUMAD (en particular a través del capítulo 7 de la Agenda 21) que se le dio importancia tanto a la necesidad de actuar a nivel local como al papel fundamental que tienen las autoridades locales para abordar diversos asuntos urbano-ambientales. Lo anterior adquirió aún mayor reconocimiento con la celebración de la segunda Conferencia de las Naciones Unidas sobre los Asentamientos Humanos, Habitat II, realizada en Estambul, Turquía, en 1996 y también conocida como "la cumbre de las ciudades". ${ }^{28}$ En esta conferencia se llegó al consenso sobre el hecho de que el futuro de la Tierra dependerá en gran medida de la calidad de vida que se tenga en los centros urbanos. En este sentido, se aceptó que tanto la dimensión y alcance de los temas así como los actores involucrados en relación con los asentamientos humanos se habían modificado y de hecho se siguieron expandiendo desde la primera Conferencia de las Naciones Unidas sobre los Asentamientos Humanos, Habitat I, celebrada en Vancouver, Canadá, en 1976. Habitat II planteó diversos aspectos y problemas de los asentamientos humanos (urbanos y rurales) para el siglo entrante incorporando nuevos tópicos tales como la democracia, los derechos humanos, la participación social, la sustentabilidad, la descentralización gubernamental, la llegada de las mujeres al poder y la creación de entes público-privados. Cabe mencionar que en la citada conferencia participaron regentes y representantes de gobiernos locales, así como organizaciones no gubernamentales que tuvieron una intervención muy activa a través de eventos, manifestaciones y otras actividades. ${ }^{29}$

27 Véase Gilbert, Richard et al., op. cit., nota 4, p. 14; Hardoy, J. E. et al., op. cit., nota 4, pp. 188 y 189.

28 Satterthwaite, David, "Sustainable Cities or Cities that contribute to Sustainable Development?", Urban Studies, vol. 32, núm. 10, 1997, p. 1686, y Serageldin, I. y Cohen, M. A. (comps.), op. cit., nota 21, p. 1.

29 Véase Carlson, E., "The Legacy of Habitat II", y Cohen, M., "Habitat II: a Critical Assessment", ambos en The Urban Age, Washington D.C., vol. 4, núm. 2, Banco Mundial, agosto de 1996, pp. 4, 5 y 8; Hundsalz, M., "The Habitat Debate: Goals, Commitments and Action Plans", y United Nations Conference for Human Settlements, "Habitat II Spells out Road Map to the Future", ambos en Habitat Debate, Nairobi, vol. 2, núm. 3/4, 
Esta obra forma parte del acervo de la Biblioteca Jurídica Virtual del Instituto de Investigaciones Jurídicas de la UNAM

El naciente interés que comenzó a demostrarse respecto a la participación de las autoridades locales en los centros urbanos, ha llevado a considerar que la mayoría de los gobiernos locales (particularmente en el sur) carecen de personal capacitado, recursos financieros y estructuras institucionales para asegurar una respuesta gubernamental a los problemas ambientales que sea efectiva, coordinada y representativa. Curiosamente, tanto en países del norte como del sur se han llevado a cabo ciertas acciones que son semejantes, como es el caso del fortalecimiento de las autoridades locales para participar en materia de gestión ambiental. ${ }^{30}$ Por ejemplo, en los dos casos de estudio que se analizan en este trabajo, se han otorgado mayores atribuciones a los gobiernos locales en asuntos relacionados con la gestión de la calidad del aire, concretamente respecto a los sistemas de monitoreo atmosférico.

No obstante las divergencias que pudieran existir en el contexto de la distinción norte-sur, las recomendaciones elaboradas para reorganizar las estructuras de los gobiernos locales son bastante similares en muchos sentidos:

- Primero, las autoridades locales deben tener liderazgo para acercar y reconciliar las diferentes posturas e intereses dentro de una comunidad determinada y así adoptar un enfoque más efectivo para combatir la contaminación en la ciudad.

- Segundo, así como esas mismas autoridades locales deben convertirse en las coordinadoras y reguladoras de la prestación de servicios y en las facilitadoras de la participación social dentro de un centro urbano, también deben ser vistas como actores legítimos (i. e. autoridades electas) dentro del sistema de gobernabilidad.

- Tercero, en la búsqueda por una respuesta efectiva y coordinada a los problemas urbano-ambientales, las autoridades locales necesitan fortalecer su capacidad de trabajo de conjunto con otros sectores públicos y privados de la comunidad en cuestión.

- Cuarto, al establecer un sistema de asociaciones público-privadas deben construir una red de trabajo que les permita adquirir apoyo

United Nations Conference for Human Settlements-HABITAT, septiembre-diciembre de 1996, pp. 1 у 6.

30 Véase Gilbert, Richard et al., op. cit., nota 4, p. 24, y Hardoy, J. E. et al., op. cit., nota 4 , p. 220. 
Esta obra forma parte del acervo de la Biblioteca Jurídica Virtual del Instituto de Investigaciones Jurídicas de la UNAM

financiero y técnico de otras autoridades locales, de los gobiernos centrales, de actores locales diversos, de organizaciones no gubernamentales y del sector privado. ${ }^{31}$

Algunos de los puntos antes descritos son centrales en la discusión sobre la reorganización de las estructuras de los gobiernos locales en Londres y la Ciudad de México. Para el primer caso, el asunto de mayor importancia se refiere a la necesidad de contar con una respuesta gubernamental al problema de la contaminación del aire que a nivel local sea más eficiente, legítima y coordinada. Para el segundo caso, si bien existe cierta discusión sobre la importancia de mejorar las estructuras del gobierno local, una respuesta más efectiva al problema de la contaminación atmosférica parece estar vinculada al fortalecimiento de la democracia de las unidades gubernamentales locales.

\section{CEnTROS URBANOS Y CONTAMINACIÓN DEL AIRE: \\ LA MAGNITUD DEL PROBLEMA}

La importancia que han adquirido los centros urbanos dentro del debate ambiental es cada vez mayor debido a los efectos (positivos y negativos) que producen en el medio natural. ${ }^{32}$ Por un lado, las ciudades son elementos clave en el desarrollo de las economías local, nacional e internacional: son centros de producción, intercambio y consumo donde se realizan todo tipo de actividades culturales, artísticas y sociales. Por el otro, las ciudades son centros obsoletos que subsisten en una era de adelantos tecnológicos e información avanzada en donde se produce un alto grado de contaminación ambiental. ${ }^{33}$

31 Véase, por ejemplo, Gilbert, Richard et al., op. cit., nota 4; Hardoy, J. E. et al., op. cit., nota 4, y Haughton, Graham y Hunter, Colin, op. cit., nota 4.

32 Véase Breheny, Michael J., "Towards Sustainable Urban Development", op. cit., nota 25, p. 277; Haughton, Graham y Hunter, Colin, op. cit., nota 4, p. 1, y Stren, Richard, op. cit., nota 25 , p. 1 .

33 Commission of the European Communities, Green Paper on the Urban Environment, Luxemburgo, Commission of the European Communities, 1990, pp. 20 y 21; Elkin, T. et al., op. cit., nota 26, p. 4; Organisation for Economic Cooperation and Development, Enviromental Policies..., cit., nota 26, p. 9, y Sherlock, H., Cities are Good for Us, Londres, Paladin, 1991, p. 13. 
Esta obra forma parte del acervo de la Biblioteca Jurídica Virtual del Instituto de Investigaciones Jurídicas de la UNAM

Desde el punto de vista ambiental, los centros urbanos juegan un papel esencial que es complicado pero a la vez ambivalente. ${ }^{34}$ Así como se erigen en grandes consumidores de recursos y descomunales generadores de contaminación y residuos, también pueden contribuir de manera fundamental a la solución de los problemas ambientales locales, regionales y globales. ${ }^{35}$ Como hemos mencionado anteriormente, el reto ambiental de los centros urbanos es el de la utilización de recursos naturales y la reducción de la contaminación al tiempo de garantizar patrones de vida sustentables. Si bien las ciudades continúan creciendo - se calculaba que para 2000 la mitad de la población mundial estaría viviendo en ellas - ${ }^{36}$ es el impacto ambiental que generan y no su tamaño o riqueza lo que es central para alcanzar la sustentabilidad global y urbana. ${ }^{37}$

En efecto, aunque el grado de deterioro ambiental varía según la ciudad de la que se trate, los habitantes citadinos están expuestos a una mezcla de problemas ambientales cuyos efectos dañinos no se restringen al tamaño, edad o tipo de ciudad. ${ }^{38}$ Como se observa en la tabla 1 , las amenazas típicas a todo centro urbano y que pueden dañar la salud humana, la flora, fauna y el medio natural son la contaminación del aire, del ruido y del agua, la disposición de la basura y la erosión del suelo.

34 Stren, Richard, op. cit., nota 25, p. 1.

35 Breheny, Michael J., "Sustainable Development and Urban Form: an Introduction", cit., nota 25, p. 2; Gilbert, Richard et al., op. cit., nota 4, p. 15, y Gossop, Ch. y Webb, A. "Getting Around: Public and Private Transport" en Blowers, A. (comp.), op. cit., nota 26, p. 129.

36 Desde 1950 la población en los países desarrollados se ha duplicado (pasando de 447 a 838 millones) y en los países en vías de desarrollo cuadruplicado (pasando de 286 a 1140 millones). Mientras que uno de cada cien vivían en una ciudad de 1 millón o más habitantes en 1940, uno de cada diez vivían en una ciudad del mismo número de habitantes en 1980. World Commission on Environment and Development, op. cit., nota 17, pp. 16,236 у 237.

37 Véase Gilbert, Richard et al., op. cit., nota 4, pp. 14 y 15, y Haughton, Graham y Hunter, Colin, op. cit., nota 4, p. 10.

38 Organisation for Economic Cooperation and Development, Enviromental Policies..., cit., nota 26, pp. 21 y 22. 
Esta obra forma parte del acervo de la Biblioteca Jurídica Virtual del Instituto de Investigaciones Jurídicas de la UNAM

DEBATE AMBIENTAL Y CONTAMINACIÓN ATMOSFÉRICA...

\section{TABLA 1}

Problemas ambientales de contaminación en centros urbanos

\begin{tabular}{|c|c|c|}
\hline & Fuente & Consecuencia \\
\hline Aire & $\begin{array}{l}\text { Vehículos, industria e } \\
\text { incineración de basura }\end{array}$ & $\begin{array}{l}\text { Afectación a la salud humana } \\
\text { (enfermedades respiratorias; puede } \\
\text { contribuir a muertes prematuras). } \\
\text { Reduce el potencial productivo } \\
\text { humano y la productividad industrial. } \\
\text { Afecta el ambiente atmosférico }\end{array}$ \\
\hline Agua & $\begin{array}{c}\text { Sector doméstico e } \\
\text { industrial (industria pesada y } \\
\text { vertimiento de residuos) }\end{array}$ & $\begin{array}{l}\text { Riesgos considerables a la salud } \\
\text { humana (mala calidad para consumo } \\
\text { humano, } i \text {.e } \text {. agua para beber). } \\
\text { Daños al ambiente acuático y a los } \\
\text { requerimientos industriales }\end{array}$ \\
\hline Ruido & $\begin{array}{l}\text { Tránsito vehicular, vecindad } \\
\text { y aviones }\end{array}$ & $\begin{array}{l}\text { Afectación a la salud humana: } \\
\text { interrumpe el sueño y causa estrés }\end{array}$ \\
\hline Residuos & $\begin{array}{l}\text { Sector doméstico y por } \\
\text { residuos radioactivos, } \\
\text { clínicos y otros (hospitales, } \\
\text { fábricas, industria) }\end{array}$ & $\begin{array}{l}\text { Peligroso para la salud humana. } \\
\text { Puede contaminar aire, agua y suelo }\end{array}$ \\
\hline Suelo & $\begin{array}{l}\text { Expansión urbana (cambio } \\
\text { de uso de suelo), sector } \\
\text { industrial (extracción de } \\
\text { metales y procesamiento de } \\
\text { minerales) residuos industrial } \\
\text { y doméstico }\end{array}$ & $\begin{array}{c}\text { Afectación a la salud humana } \\
\text { (partículas con químicos irritantes } \\
\text { o venenosos) y a usos para la } \\
\text { agricultura }\end{array}$ \\
\hline
\end{tabular}

Fuente: Adaptado de Murley, Loveday (comp.), 1994; Organisation for Economic Cooperation and Development, 1990; United Nations Environment Programme, 1993 y World Resources Institute, 1992.

En particular, los efectos adversos que ocasiona la contaminación urbana atmosférica en la salud y bienestar de los seres humanos y en el medio ambiente varía según el tipo de contaminantes atmosféricos que existan en una determinada ciudad, dichos efectos no sólo son locales, sino regionales (como la lluvia ácida) y globales (como el agotamiento de la capa de ozono y el calentamiento global). ${ }^{39}$ Las fuentes más comunes de los contaminantes atmosféricos urbanos son la industria, la producción y consumo de energía, pero sobre todo, los vehículos automotores (véase tabla 2).

39 Haughton, Graham y Hunter, Colin, op. cit., nota 4, p. 157. 
Esta obra forma parte del acervo de la Biblioteca Jurídica Virtual del Instituto de Investigaciones Jurídicas de la UNAM

TABLA 2

Contaminantes atmosféricos urbanos y salud humana

\begin{tabular}{|c|c|c|}
\hline Contaminante & Causa & Efecto \\
\hline Asbesto & $\begin{array}{c}\text { Calefacción y materiales para } \\
\text { aislamiento térmico, embrague } \\
\text { de vehículos y frenos }\end{array}$ & $\begin{array}{l}\text { Fibrosis pulmonar, asbestosis. } \\
\text { Placa pleural, cáncer de pulmón }\end{array}$ \\
\hline $\begin{array}{l}\text { Monóxido de } \\
\text { carbono }\end{array}$ & $\begin{array}{l}\text { Combustión incompleta; escapes } \\
\text { de vehículos a gasolina, hornos } \\
\text { industriales, plantas de energía, } \\
\text { fallas en electrodomésticos }\end{array}$ & $\begin{array}{c}\text { Asfixia, afectación al sistema } \\
\text { nervioso central, dolores de } \\
\text { cabeza, vómito, colapso-coma- } \\
\text { muerte }\end{array}$ \\
\hline Plomo & $\begin{array}{c}\text { Escapes de vehículos en un } 75 \% \\
\text { (existe en forma de polvos o } \\
\text { humos) }\end{array}$ & $\begin{array}{l}\text { Afectación al sistema nervioso } \\
\text { central (en jóvenes y fetos), } \\
\text { problemas de aprendizaje } \\
\text { (especialmente en niños incluso } \\
\text { a niveles bajos de exposición) }\end{array}$ \\
\hline $\begin{array}{l}\text { Óxidos de } \\
\text { nitrógeno }\end{array}$ & $\begin{array}{c}\text { Plantas generadoras de energía } \\
\text { (incluso calefacción), escapes de } \\
\text { vehículos. Los más importantes: } \\
\text { óxido nítrico y bióxido de } \\
\text { nitrógeno }\end{array}$ & $\begin{array}{l}\text { Óxido de nitrógeno: irritación de } \\
\text { garganta y ojos, enfermedades } \\
\text { respiratorias (especialmente en } \\
\text { niños). Óxido nítrico: inhibe o } \\
\text { reduce el paso de oxígeno }\end{array}$ \\
\hline $\begin{array}{l}\text { Oxidantes } \\
\text { fotoquímicos }\end{array}$ & $\begin{array}{l}\text { En presencia de rayos solares los } \\
\text { óxidos de nitrógeno reaccionan } \\
\text { con hidrocarburos (de vehículos, } \\
\text { industria, etc.) formándose el } \\
\text { ozono (contaminante secundario) }\end{array}$ & $\begin{array}{l}\text { Irritación de ojos, nariz y } \\
\text { garganta, tos, dolores de cabeza } \\
\text { y pecho. Peligrosos para quien } \\
\text { sufre de bronquitis o asma: } \\
\text { reduce la resistencia de los } \\
\text { pulmones a enfermedades }\end{array}$ \\
\hline $\begin{array}{l}\text { Bióxido de } \\
\text { azufre }\end{array}$ & $\begin{array}{l}\text { Combustión de carbón y otros } \\
\text { combustibles fósiles con azufre } \\
\text { (gasolinas, combustóleo) }\end{array}$ & $\begin{array}{l}\text { Irritante a ojos y membranas } \\
\text { mucosas, tos. Bronco- } \\
\text { constricción en asmáticos. } \\
\text { Peligroso en pacientes con } \\
\text { problemas cardiorrespiratorios }\end{array}$ \\
\hline $\begin{array}{l}\text { Material } \\
\text { particulado } \\
\text { suspendido }\end{array}$ & $\begin{array}{l}\text { Procesos de combustión, } \\
\text { actividades industriales, fuentes } \\
\text { naturales (i.e. polvos) }\end{array}$ & $\begin{array}{c}\text { Afecta los pulmones, los } \\
\text { bronquiolos respiratorios y los } \\
\text { alvéolos }\end{array}$ \\
\hline $\begin{array}{l}\text { Compuestos } \\
\text { orgánicos } \\
\text { volátiles }\end{array}$ & $\begin{array}{l}\text { Gases de escape de vehículos, } \\
\text { humo de cigarros, materiales } \\
\text { sintéticos y químicos domésticos }\end{array}$ & $\begin{array}{c}\text { Cancerígenos. Anemia, irritación } \\
\text { de ojos, piel y garganta, nauseas, } \\
\text { alergias, enfermedades de } \\
\text { pulmón }\end{array}$ \\
\hline
\end{tabular}

Fuente: Murley, Loveday (comp.), 1994. 
Esta obra forma parte del acervo de la Biblioteca Jurídica Virtual del Instituto de Investigaciones Jurídicas de la UNAM

Alcanzar y preservar niveles atmosféricos saludables en las ciudades requiere de la adopción de un adecuado y eficiente régimen de gestión de calidad del aire urbana. Idealmente, como un sistema funcional integrado, deberá incluir componentes como redes de monitoreo atmosférico, inventarios de emisiones, modelos de predicción numérica, índices de calidad del aire, información al público disponible, una muy variada gama de políticas costo-efectivas para el control de la contaminación (i. e. transporte público y medidas de tránsito vehicular), recursos financieros y un sistema de distribución de competencias adecuado. ${ }^{40}$

En el establecimiento y operación de un sistema efectivo para la gestión de la calidad del aire, la cuestión sobre lo que constituye el término contaminación atmosférica o contaminación del aire, se vuelve fundamental, con todo y que sus definiciones hayan variado a lo largo de los años. En este sentido, es conveniente referirnos antes que nada al concepto mismo de contaminación. Así, se ha dicho tradicionalmente que existe contaminación ante la presencia en el ambiente de una sustancia o forma de energía emitida o producida por los seres humanos que resulta en algún efecto dañino en el propio ambiente. ${ }^{41}$ La contaminación y daño ambientales ocurren cuando los contaminantes y sumideros no se encuentran en equilibrio, es decir, cuando las sustancias emitidas, ya sea por su naturaleza o cantidad, no pueden ser absorbidas con rapidez por el ecosistema. ${ }^{42}$ Aunque esta explicación es comúnmente aceptada, no existe consenso para determinar qué cantidad de sustancias es necesaria para producir dicha contaminación y daño. Por

40 Elsom, Derek, op. cit., nota 24, pp. 67 y 68, y Richardson, N. G., "Canada", en Stren, Richard et al. (comps.), op. cit., nota 25, pp. 148 y 149.

41 Véase, por ejemplo, Blowers, A., "Pollution and Waste - A Sustainable Burden?", en Blowers, A. (comp.), op. cit., nota 26, p. 72; National Society for Clean Air, Pollution Handbook, 1991, Brighton, National Society for Clean Air and Environmental Protection, 1991, p. 133, y Royal Commission on Environmental Pollution, First Report, Londres, Cmnd 4585, Her Majesty's Stationery Office, 1971, p. 4.

42 Button, J., A Dictionary of Green Ideas: Vocabulary for a Sane and Sustainable Future, Londres, Routledge, 1988; Haughton, Graham y Hunter, Colin, op. cit., nota 4, p. 125; Levinson, A. y Shetty, S., "Efficient Environmental Regulation: Case Studies of Urban Air Pollution”, Working Papers, Washington D.C., Banco Mundial, agosto de 1992, p. 16, y Strauss, J. y Mainwaring, S. J., Air Pollution, Baltimore, Edward Arnold, 1984, p. 3. 
Esta obra forma parte del acervo de la Biblioteca Jurídica Virtual del Instituto de Investigaciones Jurídicas de la UNAM

lo que al no existir una regla o parámetro absoluto que establezca semejante equivalencia, la contaminación se vuelve un concepto relativo. ${ }^{43}$

Al vincular las reflexiones anteriores a las cuestiones atmosféricas, podemos señalar que la contaminación del aire existe cuando la emisión o descarga de substancias en el ambiente esté asociada con un daño o amenaza a la salud humana, a otras especies vivas y sus interrelaciones y a los medios natural y construido. ${ }^{44}$ Sin la existencia de un parámetro que sea único para identificar su presencia, se acude en su lugar a lo que se conoce como niveles permisibles de contaminación.

Establecer o fijar los niveles permisibles de contaminación es resultado de dos circunstancias. Primero, de construcciones sociales y políticas, es decir, la decisión final sobre lo que equivalen los valores máximos de contaminación en un lugar determinado (ciudad, pueblo, comunidad) o para una nación o región enteras, es social y particularmente político, por lo que debe ponerse especial atención a las muy diversas formas en las que las sociedades y los gobiernos conciben la contaminación. Dentro de este contexto, conviene en ocasiones tomar en cuenta los índices y lineamientos establecidos por organismos internacionales — como es el caso de las Organización Mundial de la Salud (OMS) - que contribuyen enormemente a definir los límites permisibles de contaminación local. Segun do, del intercambio o balance que existe entre la contaminación misma y diversos factores sociales, objetivos políticos, el modelo de desarrollo económico, costos económicos, índices de calidad ambiental, acuerdos internacionales vinculantes, etcétera.

43 Para una explicación en este sentido, véase Ball, Simon y Bell, Stuart, Environmental Law, 2a. ed., Londres, Blackstone, 1994, p. 90.

44 Véase, por ejemplo, Brañes, Raúl, op. cit., nota 14, p. 435; Elsom, Derek, Atmospheric Pollution: a Global Problem, 2a. ed., Oxford, Blackwell, 1992, p. 3; Strauss, J. y Mainwaring, S. J., op. cit., nota 42, p. 6, y lo que al respecto establece la ley de protección ambiental, Environmental Protection Act 1990, Londres, Chapter 43, Her Majesty's Stationary Office, 1990. 
Esta obra forma parte del acervo de la Biblioteca Jurídica Virtual del Instituto de Investigaciones Jurídicas de la UNAM

\section{LONDRES ${ }^{45}$}

Si bien el incidente más antiguo del que se tenga conocimiento sobre contaminación atmosférica en Inglaterra ocurrió en la ciudad de Nottingham, la contaminación del aire en Londres fue detectada y combatida por vez primera en $1273 .{ }^{46}$ En aquél entonces, la principal fuente de contaminación para la ciudad londinense era el carbón que habría comenzado a sustituir a la madera como combustible para la industria.

Aunque la contaminación proveniente de la quema de carbón fue considerada en tiempos medievales como un problema para Londres ${ }^{47}$ la contaminación del aire en la capital inglesa empeoró severamente con el comienzo de la Revolución industrial. El rápido avance tecnológico, la demanda en el consumo de combustibles y el uso del carbón para fines industriales y domésticos junto con la expansión urbana ocurrida durante los siglos XVII y XVIII en una creciente nación industrial, empezó a

45 En este trabajo nos referimos con el término Londres (London) a la capital de la Gran Bretaña, que se identifica también con la expresión Gran Londres (Greater London). Londres o el Gran Londres abarca un espacio físico de $1578 \mathrm{kms}^{2}$ con una población cercana a los 7 millones de habitantes. Durante el periodo de investigación y desarrollo de este apartado (i.e. 1994-1998) las autoridades locales de Londres se aglutinaban en un solo nivel de gobierno y estaban organizadas administrativamente en 32 unidades gubernamentales llamadas boroughs más la City of London. Esta situación cambió a partir de 1999 con la denominada Ley de la Autoridad del Gran Londres (Greater London Authority Act 1999) que creó una autoridad local por encima de las ya existentes 32 autoridades locales y la City of London. Al momento de realizar esta traducción (i. e. 2008), el gobierno de Londres está conformado por dos niveles de gobierno: en un primer nivel por la Autoridad del Gran Londres - Greater London Authority (GLA) formalmente establecida en 2000 - que se integra por un jefe de gobierno o alcalde (Mayor of London) y una asamblea constituida por 25 miembros (London Assembly) ambos electos por vez primera en 2000 (con subsiguientes elecciones en 2004 y 2008), y en un segundo nivel, por los mismos 32 boroughs más la City of London.

46 Véase Ashby, E. y Anderson, M., The Politics of Clean Air, Oxford, Clarendon, 1981; Ball, Simon y Bell, Stuart, op. cit., nota 43; Brimblecombe, P., The Big Smoke, Londres, Routledge, 1987; Elsom, Derek, op. cit., nota 44; Murley, Loveday (comp.), Pollution Handbook 1994, Brighton, National Society for Clean Air and Environmental Protection, 1994, p. 47, así como diversos Royal Commission on Environmental Pollution, First Report, nota 41; Fourth Report, Londres, Cmnd 5780, Her Majesty's Stationery Office, 1974; Fifth Report, Londres, Cmnd 6371, Her Majesty's Stationery Office, 1976 y Tenth Report, Londres, Cmnd 9149, Her Majesty's Stationery Office, 1984.

47 Brimblecombe, P., op. cit., nota anterior, pp. 10 y 11. 
Esta obra forma parte del acervo de la Biblioteca Jurídica Virtual del Instituto de Investigaciones Jurídicas de la UNAM

tener un impacto importante en la atmósfera de esa ciudad y por consiguiente en los seres humanos, la flora, la fauna y el medio construido. ${ }^{48}$

Al tiempo que se expidió la primera ley atmosférica en 1863, la Ley Álcali (Alkali Act), Londres experimentaba episodios con altos niveles de aire contaminado denominados pea-soupers (sopa de guisantes) o mejor conocidos como London smogs. ${ }^{49}$ Conforme pasaron los años, y particularmente hacia finales de la época victoriana, dichos incidentes se volvieron cada vez más frecuentes y severos derivando en trágicos acontecimientos. De manera tal que durante ese periodo y hasta mediados del siglo XX se registraron en Londres varios decesos como consecuencia de episodios críticos $^{50}$ de contaminación (véase la tabla 3). El peor de estos eventos ocurrió del 5 al 8 de diciembre de 1952 cuando una enorme concentración de smog permaneció sobre la ciudad bajo condiciones atmosféricas estables (i.e. aire calmado) y temperaturas bajo cero. Este suceso provocó un incremento en el número de muertes — cerca de 4,000 - particularmente entre los ancianos por bronquitis,

48 Ibidem, pp. 9-36 y 65-68, y Ball, Simon y Bell, Stuart, op. cit., nota 43, pp. 286-303.

49 Los llamados London smogs - el término smog es el resultado de la contracción de los términos smoke (humo) y fog (niebla o neblina) - se refieren a una combinación o síntesis de niebla o neblina, altos niveles de humo y bióxido de azufre con determinadas condiciones meteorológicas como los son las temperaturas bajo cero. Véase Elsom, Derek, op. cit. nota 44, pp. 22, 23 y 242-244.

50 Según el último reporte del Advisory Group —órgano consultivo establecido por el Department of Health (Departamento de Salud) de la Gran Bretaña para brindar asesoría al Chief Medical Officer (autoridad competente en la materia) sobre las medidas de protección personal durante episodios de contaminación del aire - es hasta cierto punto arbitrario determinar cuándo se esta en presencia de altos niveles de contaminación atmosférica; lo que se llega a complicar aún más por el hecho de que los criterios utilizados para ello se han estado modificando con el paso de los años. Sin embargo, este órgano ha identificado tres tipos de episodios de contaminación del aire para Gran Bretaña. Primero, el summer smog (smog de verano) que consiste en una mezcla de contaminación en la que el principal contaminante o contaminante criterio es el ozono. Segundo, el vehicle smog (smog vehicular) donde el contaminante criterio son los óxidos de nitrógeno. Tercero, el winter smog (smog de invierno) cuyo contaminante criterio es el bióxido de azufre con cierta contribución de óxidos de nitrógeno. Para mayor detalle sobre esta clasificación en la que se incluyen estudios de caso por episodios de contaminación, véanse Department of Health, Health Effects of Exposures to Mixtures of Air Pollutants, Londres, Fourth Report, Advisory Group on the Medical Aspects of Air Polllution Episodes, Department of Health, Her Majesty's Stationery Office, 1995 y del mismo ente público Handbook on Air Pollution and Health, Londres, Committee on the Medical Effects of Air Pollutants, Department of Health, The Stationery Office, 1997. 
Esta obra forma parte del acervo de la Biblioteca Jurídica Virtual del Instituto de Investigaciones Jurídicas de la UNAM

gripe, neumonía, tuberculosis y otras enfermedades respiratorias. ${ }^{51}$ Los estudios que en la actualidad existen en salud sobre mortandad y morbilidad — principalmente investigaciones epidemiológicas — por estos infames pea-soupers de Londres, ${ }^{52}$ son muy variados y están bien documentados.

Durante la década de los cincuenta y años siguientes, los niveles de humo, polvo y bióxido de azufre en Londres comenzaron a disminuir debido a un número de factores que actuaron de manera independiente pero de forma paralela. Nos referimos, por un lado, a las iniciativas de las autoridades locales para establecer sus propias medidas de control de humos y, por el otro, a los esfuerzos realizados por los inspectores álcali. A ello debe añadirse la implementación de medidas tecnológicas como el cambio al uso de gas y electricidad y la expansión de los sistemas de calefacción central. La migración de la ciudad hacia los suburbios durante esos años también jugó un papel importante a favor de la calidad del aire en Londres. ${ }^{53}$

51 Ball, Simon y Bell, Stuart, op. cit., nota 43, p. 288, y Elsom, Derek, op. cit., nota 44 , pp. 242 у 243.

52 Véase, por ejemplo, Brimblecombe, P., op. cit., nota 46; Medina S. y Quenel, P. (comps.), Technical Report: Air Pollution and Health in Large Metropolises, París, Observatoire regional de sante d'Ile-de-France, junio de 1993 y Schwartz, J. y Marcus, A., "Mortality and Air Pollution in London: a Time Series Analysis", American Journal of Epidemiology, vol. 131, núm. 1, The Johns Hopskins University School of Hygiene and Public Health, 1990. Asimismo, diversas publicaciones del Department of Health, Ozone, Londres, First Report, Advisory Group on the Medical Aspects of Air Pollution Episodes, Department of Health, Her Majesty's Stationery Office, 1991; Sulphur Dioxide, Londres, Second Report, Advisory Group on the Medical Aspects of Air Pollution Episodes, Department of Health, Her Majesty's Stationery Office, 1992; Oxides of Nitrogen, Londres, Third Report, Advisory Group on the Medical Aspects of Air Pollution Episodes, Department of Health, Her Majesty's Stationery Office, 1993; Department of Health, Health Effects of Exposures to Mixtures of Air Pollutants, cit., nota 50, y Department of Health, Handbook on Air Pollution and Health, cit., nota 50.

53 Véase Ashby, E. y Anderson, M., op. cit., nota 46, pp. 116-119. 
Esta obra forma parte del acervo de la Biblioteca Jurídica Virtual del Instituto de Investigaciones Jurídicas de la UNAM

TABLA 3

Episodios críticos de contaminación del aire

y muertes prematuras en Londres (1873-1994)

\begin{tabular}{|c|c|c|c|}
\hline Año & Mes & Duración (en dias) & Muertes prematuras \\
\hline 1873 & diciembre & 3 & $270-700$ \\
\hline 1880 & enero & 4 & $700-1100$ \\
\hline 1882 & febrero & - & - \\
\hline 1891 & diciembre & - & $\sim 1000$ \\
\hline 1892 & diciembre & 3 & $\sim 300$ \\
\hline 1948 & noviembre & 6 & 4000 \\
\hline 1952 & diciembre & 5 & $480-1000$ \\
\hline 1956 & enero & - & $700-800$ \\
\hline 1957 & diciembre & - & $200-250$ \\
\hline 1959 & - & - & $340-700$ \\
\hline 1962 & diciembre & 4 & - \\
\hline 1975 & diciembre & 3 & - \\
\hline 1976 & junio & - & - \\
\hline 1982 & noviembre & - & $100-180$ \\
\hline 1989 & junio & 2 & - \\
\hline 1991 & diciembre & 4 & - \\
\hline 1993 & noviembre & 2 & 1 \\
\hline 1994 & diciembre & & - \\
\hline
\end{tabular}

Fuente: Brimblecombe, P., 1987 y Department of Health, 1995 y 1997.

De tal manera que el tipo de contaminación atmosférica que se ha presentado en Londres en las últimas tres décadas es substancialmente diferente al de épocas pasadas. Actualmente, la preocupación por el aire contaminado en la ciudad de Londres no está relacionada con los temidos London smogs del siglo XIX y mediados del XX, sino más bien con los crecientes niveles de los llamados contaminantes modernos o contemporáneos ${ }^{54}$ asociados primordialmente a las emisiones de vehículos

54 No existe una clasificación estandarizada o universal para distinguir los contaminantes tradicionales de los contemporáneos. Por ejemplo, mientras que en la Gran Bretaña se consideran como contaminantes modernos el monóxido de carbono, los óxidos de nitrógeno y el ozono, para la Organización para la Cooperación y el Desarrollo Económico todos ellos se consideran contaminantes tradicionales. Véase, respectivamente, 
Esta obra forma parte del acervo de la Biblioteca Jurídica Virtual del Instituto de Investigaciones Jurídicas de la UNAM

automotores. ${ }^{55}$ En la Gran Bretaña se han identificado como tradicionales a tres contaminantes: el bióxido de azufre $\left(\mathrm{SO}_{2}\right)$, el humo y las partículas cuyo origen es el uso de carbón u otros combustibles para la generación de energía. Los nuevos contaminantes provienen generalmente de las emisiones de vehículos automotores, aunque algunos también se derivan de fuentes para la generación de energía, como por ejemplo, el bióxido de nitrógeno $\left(\mathrm{NO}_{2}\right) .{ }^{56}$ En otros centros urbanos, los contaminantes contemporáneos más comunes son, además del bióxido de nitrógeno, el monóxido de carbono (CO), los hidrocarburos (HC), generalmente los compuestos orgánicos volátiles (COVs) como el benceno y el 1,3-butadieno, los óxidos de nitrógeno $\left(\mathrm{NO}_{\mathrm{x}}\right)$ y el ozono $\left(\mathrm{O}_{3}\right)$. A estos se han incorporado el material particulado suspendido (especialmente el humo negro o black smoke y las partículas menores a $\left.10 \mu \mathrm{m}: \mathrm{PM}_{10}\right)$ y el bióxido de carbono $\left(\mathrm{CO}_{2}\right){ }^{57}$

Además de los vehículos automotores, otras fuentes de contaminación en Londres incluyen todos aquellos procesos que abarcan la quema de combustibles fósiles, por ejemplo los sistemas de calefacción de uso doméstico y comercial, las plantas generadoras de energía eléctrica para la industria, y dos estaciones de energía que generan electricidad para el organismo de transporte en la capital London Transport. ${ }^{58}$ Las condiciones

Department of Health, Oxides of..., cit., nota 52, p. 3, y Organisation for Economic Cooperation and Development, Control of Hazardous Air Pollutants in OECD Countries, París, Organisation for Economic Cooperation and Development, 1995, pp. 13 y 14.

55 Bell, Sandra, Capital Killer II: Still Fuming over London's Traffic Pollution, Londres, London Boroughs Association, 1993, pp. 12 y 13; Elsom, Derek, op. cit., nota 24, p. 185; Friends of the Earth, Transport-Related Atmospheric Pollution in London: Summary of Evidence from Friends of the Earth, Londres, Friends of the Earth, 1994; Quality of Urban Air Review Group, Urban Quality in the United Kingdom, Londres, First Report of the Quality of Urban Air Review Group, Quality of Urban Air Review Group, enero de 1993, p. 1; South East Institute of Public Health, Air Quality in London: the First Report of the London Air Quality Network, Londres, South East Institute of Public Health, 1994, pp. I/2-I/3, y Weir, F., A Critique of UK Air Quality Strategy, Londres, Friends of the Earth Paper to the IEHO Congress, The Institution of Environmental Health Officers, 13-16 de septiembre de 1993, pp. 1-3.

56 Department of Health, Oxides of..., cit., nota 52, p.3.

57 Véase, por ejemplo, World Health Organisation y United Nations Environment Programme, Urban Air Pollultion in Megacities of the World, Oxford, Blackwell, 1992, pp. 7-10.

58 London Research Centre, London Energy Study, Londres, documento elaborado en el marco del programa "Commission of the European Communities Urban and Regional Energy Management Programme", Londres, London Research Centre, septiembre de 1993, p. 119. 
Esta obra forma parte del acervo de la Biblioteca Jurídica Virtual del Instituto de Investigaciones Jurídicas de la UNAM

geográficas y meteorológicas de la ciudad también han jugado un papel importante en la formación de ciertos contaminantes como los óxidos de nitrógeno o el ozono. Cuando llega a ocurrir un episodio de contaminación, estos dos contaminantes pueden llegar a ser predominantes según las temperaturas o la estación del año. ${ }^{59}$

Investigaciones recientes sobre los contaminantes contemporáneos y sus efectos en el ambiente realizadas por órganos creados por el gobierno y por organizaciones independientes como el Advisory Group (órgano consultivo creado por el departamento o ministerio de salud), el Quality of Urban Air Review Group (grupo de análisis de la calidad del aire urbano), el London Research Centre (centro de investigaciones de Londres) o el London Air Quality Network (red de calidad del aire en Londres), confirman el impacto que tienen las emisiones de vehículos en la atmósfera de la ciudad capital (véase tabla 4). Estos datos se encuentran estrechamente vinculados al hecho de que el número de automóviles aumentó considerablemente en los últimos años debido a que muchas familias adquirieron un segundo o tercer vehículo (véase tabla 5). Según las cifras presentadas por el Department of Transport (Departamento del Transporte) el crecimiento de automóviles disponibles en las familias londinenses se estima en un 32\% (esto entre 1991 y 2011).

\section{TABLA 4}

Emisiones totales en Londres por sector en 1991 (porcentajes)

\begin{tabular}{|c|r|r|c|c|c|c|}
\hline Sector & $\mathrm{CO}_{2}$ & $\mathrm{SO}_{2}$ & $\begin{array}{c}\text { Black } \\
\text { smoke }\end{array}$ & $\mathrm{CO}$ & $\mathrm{NO}_{x}$ & COVs \\
\hline Transporte & 36.0 & 23.0 & 97.0 & 100.00 & 80.0 & 98.0 \\
\hline Industria (electricidad) & 2.0 & 0.0 & 0.0 & 0.0 & 1.0 & 0.0 \\
\hline Industria (otros) & 13.0 & 43.0 & 1.0 & 0.0 & 5.0 & 1.0 \\
\hline Doméstico & 30.0 & 1.0 & 0.0 & 0.0 & 6.0 & 1.0 \\
\hline Otros & 19.0 & 32.0 & 2.0 & 0.0 & 8.0 & 0.0 \\
\hline
\end{tabular}

Fuente: London Research Centre, 1993.

59 Department of Health, Sulphur Dioxide, cit., nota 52, pp. 3-6; Oxides of Nitrogen..., cit., nota 52, pp. 3 y 4, y Quality of Urban Air Review Group, op. cit., nota 55, pp. 29-30 y $111-112$. 
Esta obra forma parte del acervo de la Biblioteca Jurídica Virtual del Instituto de Investigaciones Jurídicas de la UNAM

\section{TABLA 5}

Crecimiento del parque vehicular en Londres (1971-1991)

\begin{tabular}{|c|r|r|r|c|}
\hline Area & 1971 & \multicolumn{1}{|c|}{1981} & \multicolumn{1}{c|}{1991} & $\begin{array}{c}\text { 1971-1991 } \\
\text { (cambio porcentual) }\end{array}$ \\
\hline Inner $^{*}$ & 472000 & 502000 & 580000 & 23.0 \\
\hline Outer** $^{*}$ & 1382000 & 1682000 & 1969000 & 41.0 \\
\hline Londres & 1893000 & 2213000 & 2581000 & 36.0 \\
\hline
\end{tabular}

* La expresión Inner London corresponde a 12 boroughs (unidades locales de gobierno) más la City of London (unidad local de gobierno con estatus de borough sin ser uno de ellos) que conforman la parte interior de Londres. Los boroughs que la conforman en orden alfabético además de la City of London son: Camden, Greenwich, Hackney, Hammersmith and Fulham, Islington, Kensington and Chelsea, Lambeth, Lewisham, Southwark, Tower Hamlets, Wandsworth y la City of Westminster.

** La expresión Outer London corresponde a los restantes 20 boroughs que conforman la parte exterior de Londres. En orden alfabético son: Barking and Dagenham, Barnet, Bexley, Brent, Bromely, Croydon, Ealing, Enfield, Haringey, Harrow, Havering, Hillingdon, Hounslow, Kingston Upon Thames, Merton, Newham, Redbridge, Richmond upon Thames, Sutton y Waltham Forest.

Fuente: Department of Transport, 1996.

No obstante toda esta información, el propio Departamento de Transporte ha enfatizado que los pronósticos sobre el incremento en la propiedad de los automóviles no son tan importantes para cuestiones de calidad del aire como lo son los relativos al uso que de éstos se haga al adquirirlos. ${ }^{60}$

El impacto de las emisiones vehiculares no sólo está afectando la atmósfera sino también la salud de los habitantes de Londres. En efecto, en 1994, en su decimoctavo informe relativo a temas sobre contaminación ambiental, la comisión real establecida para ello -i. e. Royal Commission on Environmental Pollution- manifestó su preocupación ante el hecho de que la contaminación proveniente de los automóviles pudiera estar causando efectos adversos en la salud humana.

60 Department of Transport, A Transport Strategy for London, Londres, Department of Transport and Government Office for London, Her Majesty's Stationery Office, 1996, pp. 72 y 73 . 
Esta obra forma parte del acervo de la Biblioteca Jurídica Virtual del Instituto de Investigaciones Jurídicas de la UNAM

Aunque los estudios epidemiológicos sobre los efectos en los humanos por emisiones vehiculares no se hayan desarrollado del todo, ${ }^{61}$ existe cierta información relativa a los efectos respiratorios por la exposición a $\mathrm{NO}_{2}, \mathrm{O}_{3}$ y partículas, así como al riesgo de adquirir cáncer por la exposición al benceno y otros COVs. ${ }^{62}$ Gracias a estos estudios se tiene conocimiento de que Londres puede experimentar todavía episodios de contaminación del aire y que existe una creciente evidencia de los peligros que los altos niveles de contaminación pueden generar en la salud humana. ${ }^{63}$

Claro está que el estado que guarda la calidad del aire en Londres puede o no considerarse como un problema serio según se compare con otras ciudades a nivel mundial, europeo o nacional. Así, desde la perspectiva de cada uno de estos niveles encontramos lo siguiente:

a) En el plano internacional, los niveles de contaminación atmosférica en Londres son muchísimo menos alarmantes que en otros centros urbanos. En un reporte sobre contaminación atmosférica publicado a principios de la década de los noventa por la OMS y el PNUMA, ${ }^{64}$ se señala que la concentración de los contaminantes atmosféricos de Londres no exceden regularmente los valores máximos establecidos por la propia organización de salud. Por ejemplo, mientras que los niveles de $\mathrm{O}_{3}$ en Londres no rebasan dichos parámetros, sí lo hacen normalmente en ciudades como Los Ángeles, la Ciudad de México, Sao Paulo y Tokio. Lo mismo sucede con los niveles del material particulado suspendido que generalmente son bajos en Londres pero que en otras ciudades representan un grave problema como en Bangkok, Beijing, Bombay, El Cairo, Calcuta, Nueva Delhi, Yakarta, Karachi, Manila, la Ciudad de México, Seúl y Shangai.

b) En el contexto europeo, Londres no es la ciudad con mayores niveles de contaminación pero tampoco la menos contaminada. Si com-

61 Véase lo que al respecto señalan Department of Health, Health Effects of..., cit., nota 50, p. 84, y South East Institute of Public Health, op. cit., nota 55, 3/13/7.

62 Véase Royal Commission on Environmental Pollution, Eighteenth Report, Londres, Cm 2674, Her Majesty's Stationery Office, 1994, pp. 28-31.

63 Bell, Sandra, op. cit., nota 55, pp. 18-25, y South East Institute of Public Health, op. cit., nota 55, pp. 3/1-3/7. Véase también Department of Health, Ozone, cit., nota 52, pp. $67-$ 87; Sulphur Dioxide, cit., nota 52, pp. 101-127; Oxides of Nitrogen, cit., nota 52, pp. 89-116, y del mismo ente público, Health Effects of..., cit., nota 50, pp. 83-118.

64 World Health Organisation y United Nations Environment Programme, op. cit., nota 57. 
Esta obra forma parte del acervo de la Biblioteca Jurídica Virtual del Instituto de Investigaciones Jurídicas de la UNAM

paramos lo que sucede entre diversas ciudades europeas con ciertos contaminantes como el $\mathrm{O}_{3}, \mathrm{SO}_{2}$ y $\mathrm{NO}_{2}$ encontramos que para 1991 los niveles de exposición para el caso de ozono $\left(\mu \mathrm{g} / \mathrm{m}^{3} / \mathrm{día} / \mathrm{año}\right)$ eran menores en Londres que en Atenas, Barcelona, Berlín, Lisboa y Turín; sin embargo, en el mismo año los niveles de exposición en Londres para el caso del bióxido de azufre si bien eran menores que en Atenas, Barcelona, Berlín y Turín, eran mayores que en Lisboa, París y Varsovia; para el tercer caso, i. e. el bióxido de nitrógeno, los niveles de exposición en la ciudad londinense eran mayores que en ciudades como Atenas, Madrid o Turín, pero menores que en Lisboa y París. ${ }^{65}$

c) Aunque Londres no sea de los centros urbanos más contaminados en los planos internacional y europeo, sí lo es a nivel nacional entre diversas ciudades del Reino Unido. Así, por ejemplo, las concentraciones de $\mathrm{NO}_{2}$ en grandes áreas de Londres han sido mayores que en el resto de otras áreas del país y han excedido los valores permisibles establecidos por la Comunidad Europea. ${ }^{66} \mathrm{Si}$ bien en años recientes ciudades como Glasgow y Manchester también han experimentado altas concentraciones de bióxido de nitrógeno, estas no han excedido los límites determinados por la Comunidad Europea y sólo han violado en algunas ocasiones los niveles máximos permisibles para la salud según los parámetros de la OMS. ${ }^{67}$ Es de tomarse en cuenta que el porcentaje de emisiones totales provenientes de fuentes móviles — como el CO, $\mathrm{HC}$, black smoke, $\mathrm{NO}_{\mathrm{x}} \mathrm{y} \mathrm{SO}_{2}$ - es mayor en Londres que en todo el Reino Unido. ${ }^{68}$

El hecho de que hacia finales del siglo XX Londres experimentó crecientes niveles de contaminación del aire a causa de contaminantes contemporáneos, tiene que ver con el antecedente de que el mejoramiento de la calidad del aire en la Gran Bretaña durante las décadas de los setenta y ochenta no parece haber sido una prioridad para el gobierno. ${ }^{69}$ Lo anterior se explica con tres aspectos muy puntuales: la falta de interés del gobierno central, una legislación enfocada a combatir contaminantes tra-

\footnotetext{
65 Medina, S. y Quenel, P., op. cit., nota 52.

66 Bell, Sandra, op. cit., nota 55, p. 15.

67 Quality of Urban Air Review Group, op. cit., nota 55, p. 48.

68 South East Institute of Public Health, op. cit., nota 55, pp. 4/2-4/3.

69 Elsom, Derek, op. cit., nota 44, p. 276.
} 
Esta obra forma parte del acervo de la Biblioteca Jurídica Virtual del Instituto de Investigaciones Jurídicas de la UNAM

dicionales y la ausencia de evidencia de que las emisiones de vehículos dañaran la salud humana. Analicemos cada una de ellas.

En primer lugar, el poco interés demostrado por el gobierno para enfrentar el creciente problema de contaminación atmosférica durante dos décadas seguidas está íntimamente ligado al hecho de que los temas ambientales contemporáneos no estuvieran presentes en su agenda política sino hasta finales de la década de los ochenta; esta situación provocó que la respuesta del gobierno fuera lenta y dispersa durante ese periodo. ${ }^{70}$ Un ejemplo de semejante parsimonia lo constituye el tardío reconocimiento (apenas hacia mediados de la década de los ochenta) del impacto de la lluvia ácida en ecosistemas acuáticos y forestales en el Reino Unido. ${ }^{71} \mathrm{Si}$ el gobierno hubiera atendido desde un principio los llamados de diversas organizaciones ambientales y grupos de investigación sobre los efectos de las deposiciones ácidas, se hubieran podido combatir contaminantes urbanos modernos como los $\mathrm{NO}_{\mathrm{x}}$ (y oxidantes fotoquímicos) precursores de la lluvia ácida.

En segundo lugar, las leyes y demás disposiciones jurídicas relativas al control de la contaminación atmosférica se enfocaron principalmente a regular contaminantes tradicionales por emisiones provenientes de fuentes industriales y domésticas (como el humo y el bióxido de azufre) e ignoraron prácticamente a los contaminantes modernos, si bien con la única excepción del plomo. ${ }^{72}$ En estricto sentido, lo que verdaderamente originó que se desarrollara la legislación para combatir los crecientes niveles de contaminación originados por fuentes móviles (como el $\mathrm{CO}$ y los $\mathrm{NO}_{\mathrm{x}}$ ) durante la década de los ochenta, ${ }^{73}$ fue el requerimiento específico de diversas directivas de la Comunidad Europea para que se establecieran estándares de calidad del aire.

En efecto, gracias a estas directivas se determinaron los límites máximos permisibles a través de normas jurídicas conocidas como Air Qua-

70 McCormick, John, British Politics and the Environment, Londres, Earthscan, 1991.

71 Elsom, Derek, op. cit., nota 44, p. 257.

72 La razón por la cual se establecieron disposiciones jurídicas para eliminar el plomo de las gasolinas radica fundamentalmente en la presión ejercida por el grupo ambientalista Campaign for Lead-Free Air (CLEAR) cuyo cabildeo logró que el tema se convirtiera en un asunto nacional en 1982. Aunque el gobierno británico habría empezado a tomar ciertas medidas antes de ese año, este tipo de campañas y las futuras directivas europeas en la materia fueron las que realmente lograron la eliminación de este contaminante de las gasolinas. Véase ibidem, pp. 244-250 y 263.

73 Quality of Urban Air Review Group, op. cit., nota 55, pp. 32, 82 y 83. 
Esta obra forma parte del acervo de la Biblioteca Jurídica Virtual del Instituto de Investigaciones Jurídicas de la UNAM

lity Standards Regulations en las que se incluyeron, por ejemplo, el tradicional $\mathrm{SO}_{2}$, contaminantes como las partículas suspendidas, el plomo y el $\mathrm{NO}_{2} .{ }^{74}$ Con el paso del tiempo, las directivas, regulaciones y otras medidas europeas han tenido tal influencia que en la actualidad una gran parte de las políticas públicas y de la legislación ambiental sobre calidad del aire del gobierno británico provienen de la Comunidad Europea. ${ }^{75}$ No debemos pasar por alto, sin embargo, que desde su incorporación en 1973 a la Comunidad Europea, el Reino Unido siempre ha mostrado resistencia y actuado con lentitud en la implementación de las directivas ambientales europeas. Un ejemplo de lo anterior lo constituye el caso de las concentraciones máximas en centros urbanos de humo y $\mathrm{SO}_{2}$ establecidas por una directiva europea (i. e. 80/779/EEC) en 1980 cuya implementación por el gobierno británico tardó al menos cuatro años. La razón de esto fue que la estrategia europea sobre estándares de calidad del aire era diferente a la entonces estrategia adoptada por el Reino Unido - conocida como best practicable means - de aplicar instrumentos flexibles para controlar la contaminación atmosférica. Lejos de que estableciera estándares claramente definidos y obligatorios, esta estrategia descansaba en la idea del cumplimiento voluntario por parte de los contaminadores (e. g. sector industrial) bajo lineamientos ambiguos y no obligatorios. ${ }^{76}$ Esta situación no se modificó mucho con la entrada en vigor en 1990 de una nueva ley ambiental, la Environmental Protection Act, que en su primera parte adoptó una estrategia con membrete nuevo pero con un sistema de cumplimiento similar al anterior; esto es, a partir de ese año el control de la contaminación atmosférica se basó en implementar medidas flexibles según las técnicas disponibles del momento pero sin que fueran obligatorias. La estrategia diseñada en dicha disposición jurídica supone demora nuevamente para el cumplimiento por parte del gobierno británico de las directivas de la Comunidad Europea. ${ }^{77}$

En tercer y último lugar, aunque desde la década de los setenta surgió la preocupación sobre las emisiones originadas por vehículos automotores, no se contaba con suficiente evidencia de que dichas emisiones pudieran dañar

\footnotetext{
74 Ibidem, p. 174, y Department of Health, Oxides of Nitrogen, cit., nota 52, p. 10.

75 Véase Ball, Simon y Bell, Stuart, op. cit., nota 43, p. 70 y McCormick, John, op. cit., nota 70, p. 20.

76 Elsom, Derek, op. cit., nota 44, pp. 260 y 274.

77 Ibidem, pp. 240 y 241, y Ball, Simon y Bell, Stuart, op. cit., nota 43, pp. 21-22.
} 
Esta obra forma parte del acervo de la Biblioteca Jurídica Virtual del Instituto de Investigaciones Jurídicas de la UNAM

seriamente la salud humana. ${ }^{78}$ De tal manera que si bien existieron ciertos estudios sobre temas específicos de salud como lo fue el asma, las políticas públicas se centraron en aspectos relacionados con las fuentes fijas. No fue sino hasta la década de los noventa que el vínculo entre contaminación atmosférica y transporte se hizo patente a partir de la publicación del ya mencionado décimo octavo informe sobre contaminación ambiental de la Royal Commission on Environmental Pollution. ${ }^{79}$ Con ello y debido a la presión ejercida por los medios de comunicación y la opinión pública, el gobierno británico finalmente reconoció el tema de la calidad del aire urbana como un asunto prioritario en el marco de su estrategia para el desarrollo sustentable de $1994 .{ }^{80}$

A partir de que el gobierno británico admite la imperiosa necesidad de mejorar la calidad del aire, se empiezan a implementar medidas de aplicación específica para Londres: por un lado, se desarrollan diversas políticas de tránsito vehicular y de transporte público, y por el otro, se diseña una nueva estrategia de gestión de la calidad del aire. Los ejemplos más relevantes sobre cada una de ellas son los siguientes: respecto a la primera medida, se introdujeron en 1995 diversos límites de velocidad en la autopista que conforma el anillo vehicular que rodea la ciudad de Londres (conocido como Motorway 25 o M25). Lo anterior, con el objeto de agilizar el flujo vehicular y reducir el congestionamiento vial buscando disminuir el número de ocasiones de arranque-frenado cuando los vehículos transitan a baja velocidad o cuando están inmóviles con el motor encendido, situaciones ambas que en sí mismas generan emisiones más altas. Otro ejemplo es la creación del sistema de carriles de preferencia en color rojo Priority Red Routes en toda la ciudad sobre los que se prohíbe estacionarse durante horas hábiles (i. e. horas laborables o de trabajo). Iniciado en 1991 con un programa piloto en el norte y este de Londres, este sistema busca acortar el tiempo que realizan de un lugar a otro los automóviles y autobuses (buses) para así desahogar el congestionamiento vehicular. ${ }^{81}$

78 Ashby, E. y Anderson, M., op. cit., nota 46, p. 143.

79 Royal Commission on Environmental Pollution, op. cit., nota 62.

80 Ball, Simon y Bell, Stuart, Environmental Law, 3a. ed., Londres, Blackstone, 1995, p. 327; Bell, Sandra, op. cit., nota 55, p. 7; Department of the Environment, Sustainable Development: the UK Strategy, Londres, Department of the Environment, Her Majesty's Stationery Office, 1994, p. 49-57, y Elsom, Derek, op. cit., nota 24, p. 185.

81 Para mayor detalle, véase Department of the Environment, Transport and the Regions, Keeping Buses Moving, Londres, Local Transport Note 1/97, Department of the 
Esta obra forma parte del acervo de la Biblioteca Jurídica Virtual del Instituto de Investigaciones Jurídicas de la UNAM

Por lo que toca a la segunda medida, sobresale el hecho de que en 1995 el gobierno británico sometió a consulta pública su nueva estrategia de calidad del aire a la que le llamó Air Quality: Meeting the Challenge. ${ }^{82}$ En ese mismo año, entra en vigor una nueva ley ambiental, la Environment Act, que establece los principios para una estrategia coherente a nivel nacional de gestión de la calidad del aire e introduce la que habrá de conocerse como la National Air Quality Strategy, adoptada a principios de 1997. Tanto la ley ambiental de 1995 como la estrategia nacional de 1997 crearon las bases para el desarrollo de la gestión y evaluación de la calidad del aire local así como las nuevas atribuciones de las autoridades londinenses para combatir los problemas atmosféricos episódicos y a largo plazo. No obstante, el cumplimiento de las metas establecidas para alcanzar los estándares específicos de calidad del aire se pospusieron hasta 2005 para permitir que las directivas europeas entraran en vigor y para implementar otro tipo de medidas como lo era la introducción de gasolinas mejoradas en vehículos nuevos. El gobierno británico explicó que el aplazamiento en el cumplimiento de dichas metas era razonable y justificado en razón de los costos y beneficios derivados de los objetivos trazados en la estrategia de 1997. ${ }^{83}$

Debemos enfatizar que sin lugar a dudas los tres aspectos que en los últimos treinta años han sido determinantes en la calidad del aire en Londres son $i$ ) la poca inversión en transporte público; ii) el compromiso del gobierno del Reino Unido en la construcción de más vialidades (caminos y carreteras), y iii) el incremento en el número (propiedad) y uso de los vehículos automotores. Como ejemplo de esto podemos mencionar que si bien ha existido en los últimos años un incremento en el gasto para el sistema del metro londinense (London Underground), los programas de construcción de más vías - que contienen propuestas para ampliar la autopista que rodea Londres, i. e. la M25 - continúan siendo una prioridad

Environment, Transport and the Regions, The Stationery Office, 1997, p. 7, y Elsom, Derek, op. cit., nota 24, pp. 188 y 189.

82 Department of the Environment, Air Quality: Meeting the Challenge, Londres, Departament of the Environment, enero de 1995.

83 Véase Department of the Environment, The United Kingdom National Air Quality Strategy - Consultation Draft, Londres, Department of the Environment, agosto de 1996, y The United Kingdom National Air Quality Strategy, Londres, Cm 3587, Department of the Environment, The Stationery Office, marzo de 1997. 
Esta obra forma parte del acervo de la Biblioteca Jurídica Virtual del Instituto de Investigaciones Jurídicas de la UNAM www.juridicas.unam.mx

para el gobierno ${ }^{84}$ En efecto, el sector de transporte de superficie no sólo ha significado un considerable incremento en el gasto público - más del 50\% para el periodo 1994-1995 en términos reales si lo comparamos con toda la década de los ochenta - sino que es el único sector donde existe un programa de inversión a largo plazo como parte de la política gubernamental. ${ }^{85}$ Ante esta situación y como es lógico suponer, no han sido pocas las solicitudes al gobierno central para que aumente la inversión en los sistemas de transporte público en Londres. ${ }^{86}$

\section{CIUDAD DE MÉXICO ${ }^{87}$}

El lugar donde actualmente se ubica la Ciudad de México (i.e. el valle de México, o mejor aún, la cuenca de México), ha sido testigo de un

84 Desde mediados de la década de los ochenta, la inversión en el sistema del metro londinense aumentó de aproximadamente $£ 250$ a $£ 500$ millones de libras esterlinas por año en los últimos tres años. Aunque el London Underground representa la inversión más cuantiosa de todo el transporte en Londres, durante la década de los noventa su presupuesto sufrió varios recortes; mientras, el gasto destinado a la construcción de vialidades no ha sido modificado de manera alguna. Para 1992, la inversión para London Transport se redujo en un tercio y el programa para vialidades permaneció intacto. Además, en 1993 el gobierno del Reino Unido anunció que la M25 habría de ampliarse a 14 carriles en total en las zonas más transitadas, por lo que al año siguiente, en 1994, el sistema del metro sufrió otro recorte en su presupuesto asignado. Antes de las elecciones generales de mayo de 1997, el departamento de transporte (DoT) anunciaba que otras partes de la M25 habrían de ampliarse bajo un esquema a largo plazo. Véase Bell, Sandra, op. cit., nota 55, p. 38; Department of Transport, op. cit., nota 60, pp. 63, 64, 90 y 212, y Elsom, Derek, op. cit., nota 24, p. 188.

85 Elsom, Derek, op. cit., nota 24, pp. 14 y 191, y Royal Commission on Environmental Pollution, op. cit., nota 62, p. 82.

86 Para esto, véase por ejemplo, Bell, Sandra, op. cit., nota 55, p. 38; Dobson, Frank, Creating a Bad Atmosphere: the Tory Threat to Britain's Air Quality, Londres, informe de Frank Dobson MP (miembro del parlamento), Shadow Environment Secretary, Labour, s.f., p. 11; London Research Centre, op. cit., nota 58, pp. 114-155, y Royal Commission on Environmental Pollution, op. cit., nota 62, pp. 15, 16 y 244.

87 La Ciudad de México es el Distrito Federal (DF), sede de los Poderes de la Unión y capital de los Estados Unidos Mexicanos tal y como lo señala desde 1993 el artículo 44 de la Constitución Política de los Estados Unidos Mexicanos. Por lo que desde un punto de vista estrictamente constitucional, el espacio territorial de la Ciudad de México es el mismo espacio que abarca el DF y corresponde a $1486 \mathrm{kms}^{2}$ con una población de poco más de 8 millones de habitantes. Sin embargo, por tradición a la Ciudad de México se le ha identificado con el espacio geográfico del área urbana contigua independientemente de los límites territoriales del DF o de la vecina entidad federativa conocida como Estado de México (Edomex). Antes de 1950, el área urbana se encontraba dentro de los 
Esta obra forma parte del acervo de la Biblioteca Jurídica Virtual del Instituto de Investigaciones Jurídicas de la UNAM

sinnúmero de alteraciones ambientales que empezaron hace quizá unos 600 años. Según algunas fuentes académicas y gubernamentales, ${ }^{88}$ antes de la invasión de los españoles a este continente, la antigua y espléndida ciudad capital de Anáhuac, México Tenochtitlan — fundada en 1321 o 1324 por el pueblo mexica (antes pueblo azteca) - , no podía mantenerse así misma con los recursos naturales existentes dentro de los límites de la cuenca debido principalmente al crecimiento poblacional en la ciudad que llegó a contabilizar alrededor de 300000 habitantes en el año 1500. De manera tal que tuvo que importar de otras regiones ciertos productos como frutas tropicales, sal, madera y probablemente maíz y frijol.

límites del DF, pero a partir de ese año empezó a extenderse más allá de dichos límites $(i$. e. fenómeno de conurbación). Con el paso del tiempo, el término Ciudad de México se utilizó para identificar tanto al espacio geográfico urbano y rural del DF como al espacio de algunas zonas territoriales conurbadas del Edomex adoptándose así el término de zona metropolitana. En la actualidad, es frecuente que a todo este espacio geográfico se le llame Zona Metropolitana de la Ciudad de México (ZMCM) o Zona Metropolitana del Valle de México (ZMVM), aunque en ocasiones también se le denomine Área Metropolitana de la Ciudad de México (AMCM). Todas estas expresiones pueden abarcar espacios geográficos distintos por lo que no existe una definición única sobre lo que realmente constituye la actual zona o área metropolitana de la Ciudad de México. Cabe aclarar que, durante el tiempo de investigación y desarrollo de este apartado (i.e. 1994-1998), los términos más utilizados por documentos oficiales y trabajos académicos para efectos de tipo estadístico y de evaluación y análisis de la contaminación atmosférica y de la calidad del aire en la Ciudad de México fueron los de ZMCM y ZMVM. Por ZMCM se aludía en aquél entonces a un espacio cubierto por las 16 delegaciones del DF y por 17 municipios conurbados del circundante Edomex abarcando en su conjunto $3399 \mathrm{kms}^{2}$ con una población de más de 14 millones de habitantes. En este trabajo se utilizan de manera indistinta los términos ciudad de México o ZMCM para referirse a este último espacio geográfico. En nuestros días (i.e. 2008), la ZMCM está conformada por las mismas 16 delegaciones y por 18 municipios conurbados, con una superficie de $3540 \mathrm{kms}^{2}$ y con una población de más de 18 millones de habitantes. De 1997 a la fecha, las autoridades locales que intervienen en la ZMCM son, por un lado, el gobierno del Distrito Federal cuyo jefe fue electo por vez primera en 1997 y las 16 delegaciones cuyo jefes fueron electos por primera ocasión en 2000, y por el otro, el gobierno del Estado de México (cuyo gobernador se elige cada seis años) y los 18 municipios conurbados cuyos presidentes municipales son electos cada tres años.

88 Comisión Metropolitana para la Prevención y Control de la Contaminación Ambiental en el Valle de México, La contaminación atmosférica en el Valle de México, México, Comisión Metropolitana para la Prevención y Control de la Contaminación Ambiental en el Valle de México, 1994, p. 9, y Gamboa de Buen, Jorge, Ciudad de México, una visión, México, Fondo de Cultura Económica, 1994, pp. 19-22. 
Esta obra forma parte del acervo de la Biblioteca Jurídica Virtual del Instituto de Investigaciones Jurídicas de la UNAM

Sin embargo, la verdadera degradación ambiental en la cuenca de México comenzó a partir del periodo colonial (iniciado en 1521) prolongándose hacia los periodos independiente (surgido en 1810), revolucionario (empezado en 1910) y hasta nuestros días. Desde aquél entonces y de manera progresiva los problemas ambientales de la cuenca de México se han manifestado de diversas maneras: inundaciones frecuentes por la planeación colonial de la ciudad, desecación de los lagos circundantes, erosión del suelo, devastación forestal, falta de suministro y calidad de agua y más recientemente altos niveles de contaminación atmosférica. ${ }^{89}$

Fue durante las décadas de los cincuenta y sesenta del siglo XX que la presencia de aire contaminado en la Ciudad de México fue detectada por vez primera. Las dos razones que explican los orígenes de la contaminación atmosférica en la capital mexicana son tanto el rápido crecimiento industrial como la expansión urbana y poblacional que en su conjunto han exigido un constante e intenso consumo de energía para mantener la propia productividad industrial, generar electricidad, prestar servicios públicos, cubrir las necesidades domésticas, desarrollar el transporte, etcétera..$^{90}$ Este fenómeno se ha desarrollado bajo dos circunstancias que han jugado un papel importante en la calidad del aire y que incluso han contribuido a la formación de ciertos contaminantes como es el caso del

89 Véase, por ejemplo, Ezcurra, Ezequiel, "Reunión sobre el manejo de la cuenca atmosférica de la Ciudad de México: el marco histórico-urbano", ponencia presentada en el Seminario Internacional sobre Sustentabilidad Urbana y el Manejo de la Cuenca Atmosférica de la Zona Metropolitana del Distrito Federal y del Estado de México, México, 22-25 de mayo de 1995; Fried, R. C., "Mexico City", en Robson W. A. y Regan D. E. (comps.), Great Cities of the World, Londres, Allen and Unwin, 1972, vol. II, pp. 647-654 y Schteingart, Martha, "The Environmental Problems Associated with Urban Development in Mexico City", Environment and Urbanization, vol. 1, núm. 1, abril de 1989, p. 44.

90 Bravo Álvarez, Humberto, La contaminación del aire en México, México, Universo Veintiuno, 1987, p. 127; Comisión Metropolitana para la Prevención y Control de la Contaminación Ambiental en el Valle de México, Air Pollution in Mexico City. Present Situation, México, Comisión Metropolitana para la Prevención y Control de la Contaminación Ambiental en el Valle de México, 1994, p. 4; Collins, Charles O. y Scott, Steven L., "Air Pollution in the Valley of Mexico", Geographical Review, vol. 38, núm. 2, abril de 1993, p. 120; Díaz Díaz, D. y Perló Cohen, M., Retos y propuestas: Ciudad de México, México, Fundación Mexicana Cambio XXI Luis Donaldo Colosio, 1994, p. 44, y Pezzoli, K., "Environmental Conflicts in the Urban Milieu: the Case of Mexico City", en Goodman D. y Redclift M. (comps.), op. cit., nota 13, pp. 205-207. 
Esta obra forma parte del acervo de la Biblioteca Jurídica Virtual del Instituto de Investigaciones Jurídicas de la UNAM

\section{ozono: la ubicación geográfica y las condiciones meteorológicas propias} de la cuenca de México. ${ }^{91}$

En México, las fuentes emisoras de contaminantes a la atmósfera se han agrupado generalmente en tres tipos: fijas, móviles y naturales. Aunque la legislación mexicana las clasifica y define de maneras distintas

91 La ubicación geográfica y las condiciones climatológicas de la cuenca de México han contribuido enormemente no sólo a la formación de ciertos contaminantes sino que han obstaculizado su dispersión debido a que el área en cuestión se encuentra rodeada por sierras y montañas (excepto por el norte) que dificultan la ventilación o circulación del viento. La dirección predominante de los vientos (de norte a sur) acarrea los contaminantes emitidos en los lugares donde se localizan la mayor actividad industrial, urbana y de transporte (que son el norte y centro de la ciudad) hacia el resto del conglomerado urbano. A esta situación hay que aumentar la ocurrencia de fenómenos naturales conocidos como inversiones térmicas las cuales se producen como resultado de la presencia de una masa de aire frío durante las primeras horas del día (temprano en las mañanas) que queda atrapada por una masa de aire caliente a mayor altura. De esta manera, la inversión térmica provoca la acumulación y estancamiento de contaminantes en la atmósfera que quedan atrapados por capas superiores, situación que durará hasta que la temperatura aumente y se inicie un proceso de rompimiento de dicha inversión (generalmente hacia el mediodía). Aunque este fenómeno puede registrarse durante la época de lluvias (entre mayo y octubre) y la de secas (entre noviembre y abril) es en esta última (que por cierto coincide con casi todo el periodo invernal) en la que son más frecuentes y duraderas. Otros dos factores que están vinculados a la calidad del aire en la ciudad son, en primer lugar, la intensa radiación solar que se registra en la cuenca y que intensifica las reacciones fotoquímicas entre $\mathrm{NO}_{x}$ y $\mathrm{HC}$ que favorecen la formación del $\mathrm{O}_{3}$, y en segundo lugar, la altitud a la que se encuentra la cuenca, esto es a 2244 metros sobre el nivel del mar, puesto que el contenido de oxígeno a este nivel es $23 \%$ menor que a nivel del mar lo que provoca que todos los procesos de combustión sean menos eficientes o lo que es lo mismo más contaminantes. Para mayor detalle sobre esta información, véanse, Bravo Álvarez, Humberto, op. cit., nota anterior, pp. 127-136; Bravo Álvarez, Humberto y Torres Jardón, Ricardo, "Prioridades en contaminación atmosférica en la Ciudad de México: ozono y partículas respirables", Foro de Consulta Popular Medio Ambiente y Desarrollo Sustentable en el Valle de México, México, s.e., 1995, pp. 2 y 3; Collins, Charles O. y Scott, Steven L., op. cit., nota anterior, pp. 120-122; Fried, R. C., op. cit., nota 89, p. 647; Schteingart, Marta, op. cit., nota 89, p. 44, y Secretariado Técnico Intergubernamental, Programa Integral Contra la Contaminación Atmosférica de la Zona Metropolitana de la Ciudad de México, México, Secretariado Técnico Intergubernamental, 1990, p. 131. Asimismo, diversas referencias de la Comisión Metropolitana para la Prevención y Control de la Contaminación Ambiental en el Valle de México que incluyen ¿Qué estamos haciendo para combatir la contaminación del aire en el Valle de México?, México, Comisión Metropolitana para la Prevención y Control de la Contaminación Ambiental en el Valle de México, 1992, pp. 7-13; Avances a junio de 1994 del Programa Integral Contra la Contaminación Atmosférica, 1994, p. I/5; Air Pollution..., cit., nota anterior, p. 5, у op. cit., nota 88, pp. 16-19. 
Esta obra forma parte del acervo de la Biblioteca Jurídica Virtual del Instituto de Investigaciones Jurídicas de la UNAM

- tal y como se observa en la ya abrogada Ley Federal de Protección Ambiental de 1982 y en la vigente Ley General del Equilibrio Ecológico y la Protección al Ambiente de 1988-, para datos estadísticos y de elaboración de los dos últimos inventarios de emisiones (de 1989 y 1994), las fijas se refieren a la industria y a los procesos de combustión que generan contaminación, las móviles a todo tipo de vehículos automotores y las naturales a la degradación ecológica o también vegetación y suelos que se componen de partículas suspendidas (asociadas a las tormentas de polvo o tolvaneras por erosión de suelo, incendios, etcétera). ${ }^{92}$

Ahora bien, las fuentes de emisiones han sido tradicionalmente clasificadas por sector, tal y como se realizó en el caso del inventario de emisiones de contaminantes atmosféricos de 1989 que las divide en cuatro grandes rubros: energía, industria y servicios, transporte y degradación ecológica. En este inventario, y como se observa en las tablas 6 y 7 , el sector transporte (i.e. fuentes móviles) aparece hacia finales de la década de los ochenta como la principal fuente de contaminación en la zona metropolitana de la Ciudad de México (ZMCM) tanto en peso con $76.7 \%$ del total, como por toxicidad con $42.4 \%$ del total. Lo anterior frente al sector degradación ecológica (i.e. fuentes naturales) con $15.0 \%$ en peso y $29.9 \%$ por toxicidad, y a los sectores energía e industria y servicios (i. e. fuentes fijas) con $8.4 \%$ en peso y $27.7 \%$ por toxicidad del total.

La información obtenida hacia finales de la década de los ochenta señalaba que los niveles de contaminación de los contaminantes urbanos tradicionales como $\mathrm{SO}_{2}$, material particulado suspendido, $\mathrm{Pb}$ y $\mathrm{NO}_{x}$ se encontraban, con la excepción del CO, muy por encima de los límites permisibles establecidos por la OMS. ${ }^{93}$ Por lo que los altos niveles de aire contaminado durante este periodo y principios de la década de los noventa - entre otros muchos problemas ambientales - le dieron a la

92 Bravo Álvarez, Humberto, op. cit., nota 90, pp. 136-164; Comisión Metropolitana para la Prevención y Control de la Contaminación Ambiental en el Valle de México, Avances a junio de 1994, cit., nota anterior, p. I/4, y Gamboa de Buen, Jorge, op. cit., nota 88, p. 139.

93 Calderón-Garcidueñas, Lilian et al., "Histopathologic Changes of the Nasal Mucosa in Southwest Metropolitan Mexico City Inhabitants", American Journal of Pahtology, vol. 140, núm. 1, enero de 1992, p. 225; Kandell, J., La Capital: the Biography of Mexico City, New York, Random House, 1988, p. 528; Schteingart, Marta, op. cit., nota 89, p. 44, y World Health Organisation y United Nations Environment Programme, op. cit., nota 57, pp. 155-163. 
Esta obra forma parte del acervo de la Biblioteca Jurídica Virtual del Instituto de Investigaciones Jurídicas de la UNAM

Ciudad de México el estatus de una de las ciudades más contaminadas en el mundo: "Considerada recientemente como la antesala a un Hiroshima ecológico, la Ciudad de México se ha convertido en una de las ciudades más contaminadas e insalubres del mundo... algunos autores la han declarado como un ecosistema urbano negativo o anti-ecosistema". ${ }^{94}$

TABLA 6

Inventario de emisiones (1989) por sector (\% en peso)

\begin{tabular}{|c|r|r|r|r|r|r|}
\hline Sector & $\mathrm{SO}_{2}$ & $\mathrm{NO}_{x}$ & $\mathrm{HC}$ & $\mathrm{CO}$ & $\mathrm{PST}$ & Total \\
\hline Energía & 35.5 & 5.6 & 5.6 & 1.8 & 1.0 & 4.0 \\
\hline Industria y servicios & 42.7 & 18.5 & 7.0 & 0.6 & 2.8 & 4.4 \\
\hline Transporte & 21.8 & 75.4 & 52.5 & 96.7 & 2.1 & 76.7 \\
\hline Degradación ecológica & 0.1 & 0.5 & 34.9 & 0.9 & 94.0 & 15.0 \\
\hline Total & 100.0 & 100.0 & 100.0 & 100.0 & 100.0 & 100.0 \\
\hline
\end{tabular}

Fuente: Secretariado Técnico Intergubernamental, 1990.

TABLA 7

Inventario de emisiones (1989) por sector (\% por toxicidad)

\begin{tabular}{|c|c|c|c|c|c|c|}
\hline Sector & $\mathrm{SO}_{2}$ & $\mathrm{NO}_{x}$ & $\mathrm{HC}$ & $\mathrm{CO}$ & PST & Total \\
\hline Energía & 7.2 & 1.1 & 1.3 & 0.2 & 1.0 & 10.8 \\
\hline Industria y servicios & 8.6 & 3.7 & 1.7 & 0.0 & 2.8 & 16.9 \\
\hline Transporte & 4.4 & 14.9 & 12.6 & 8.4 & 2.1 & 42.4 \\
\hline Degradación ecológica & 0.0 & 0.1 & 8.4 & 0.1 & 21.3 & 29.9 \\
\hline Total & 20.2 & 19.8 & 23.9 & 8.7 & 27.3 & 100.0 \\
\hline
\end{tabular}

Fuente: Secretariado Técnico Intergubernamental, 1990.

94 Pezzoli, K., op. cit., nota 90, p. 205. En inglés, el párrafo se lee: Mexico City, recently referred to as the "anteroom to an ecological Hiroshima", has become one of the most contaminated, unhealthy cities in the world... some authors have declared it a 'negative urban ecosystem or antiecosystem'. 
Esta obra forma parte del acervo de la Biblioteca Jurídica Virtual del Instituto de Investigaciones Jurídicas de la UNAM

Si comparamos la calidad del aire de la Ciudad de México con otras ciudades de América Latina, no cabe duda de que es de las más contaminadas por diversos contaminantes. Por ejemplo, en el reporte sobre contaminación atmosférica preparado por la OMS y el PNUMA al cual ya hemos hecho referencia anteriormente, se señala que los niveles de ciertos contaminantes como el $\mathrm{SO}_{2}$, material particulado suspendido y $\mathrm{CO}$ son mayores que en ciudades como Buenos Aires en Argentina o Río de Janeiro y Sao Paulo en Brasil. Otro ejemplo en este mismo sentido es el caso de la concentración de partículas, que sólo se compara con ciudades como la de Santiago, capital de Chile, donde también los niveles son de lo más alto incluso que en cualquier otra parte del mundo; ${ }^{95} \sin$ embargo, el mejor ejemplo de todos estos es el del $\mathrm{O}_{3}$ que si bien representa un serio problema para ciudades como Sao Paulo, las concentraciones observadas para la Ciudad de México son de las más altas si las comparamos con cualquier otro centro urbano latinoamericano. ${ }^{96}$

En efecto, según información del gobierno mexicano sobre niveles de ozono, la norma de calidad del aire para este contaminante ha sido rebasada 750 horas en 1987 y 959 horas en 1988, y desde 1989 a los primeros seis meses de 1990 lo ha sido 1000 horas en promedio al año. Estos datos tan alarmantes serían todavía más graves si la norma de calidad mexicana tuviera los mismos valores que a nivel internacional. Mientras que la norma mexicana para ozono equivale a una concentración de $0.11 \mathrm{ppm}$ o $216 \mu \mathrm{g} / \mathrm{m}^{3}$ en una hora, los estándares de la OMS son de $150-200 \mu \mathrm{g} / \mathrm{m}^{3}$ en una hora (en promedio), es decir, éstos se encuentran por debajo de aquéllos, la tabla 8 permite comparar los valores que a nivel internacional se utilizan para este contaminante.

TABLA 8

Valores criterio para $\mathrm{O}_{3}$ (ppm en 1 hora)

\begin{tabular}{|c|c|c|c|c|}
\hline & OMS & $\begin{array}{c}\text { Unión } \\
\text { Europea }\end{array}$ & $\begin{array}{c}\text { Estados } \\
\text { Unidos }\end{array}$ & México \\
\hline Valores & $0.05-0.10$ & $0.076-0.10$ & 0.12 & 0.11 \\
\hline
\end{tabular}

Fuente: Instituto Nacional de Estadística, Geografía e Informática, 1994.

95 Ostro, B. et al, "Air Pollution and Mortality: Results from Santiago, Chile", Working Papers, Washington D.C., Banco Mundial, mayo de 1995, p. 6.

96 Medina, S. y Quenel, P., op. cit., nota 52, y World Health Organisation y United Nations Environment Programme, op. cit., nota 57. 
Esta obra forma parte del acervo de la Biblioteca Jurídica Virtual del Instituto de Investigaciones Jurídicas de la UNAM

Aunque en primera instancia no parece haber una gran diferencia entre cada uno de ellos, cabe destacar que los límites permisibles del índice de valores para contaminantes denominado Índice Metropolitano de la Calidad del Aire (Imeca) ${ }^{97}$ maneja parámetros muy altos. En otras palabras, si bien la norma para ozono equivale a una concentración de 0.11 ppm o lo que es lo mismo a 100 puntos Imeca, el plan de contingencias ambientales para la Ciudad de México empieza a implementarse a partir de que los niveles de ozono alcanzan una muy alta concentración -más del doble — de 0.29 ppm en una hora, es decir, cuando alcanzan los 250 puntos Imeca. ${ }^{98}$

97 El Índice Metropolitano de la Calidad del Aire es el índice de valores para medir la calidad del aire en la ZMCM. El cálculo del Imeca hace que el valor criterio (ya sea en ppm o $\mu \mathrm{g} / \mathrm{m}^{3}$ ) para cada contaminante como nivel máximo permisible por la norma equivalga a 100 puntos. Algunos ejemplos: para el $\mathrm{O}_{3}$ los 100 puntos Imeca significan $0.11 \mathrm{ppm}$ en 1 hora; para el $\mathrm{SO}_{2}$ significan 0.13 ppm en 24 horas; para el CO significan 13 ppm en 8 horas; para el $\mathrm{NO}_{2}$ significa $0.21 \mathrm{ppm}$ en 1 hora y para las partículas suspendidas totales (PST) significan $275 \mu \mathrm{g} / \mathrm{m}^{3}$ en 24 horas. Para una mayor explicación sobre el índice de valores Imeca y los valores criterio de la mayoría de los contaminantes para la ZMCM, véanse Secretaría de Desarrollo Social, Informe de la situación general en materia de equilibrio ecológico y protección al ambiente 1991-1992, México, Secretaría de Desarrollo Social-Instituto Nacional de Ecología, 1993, p. 155 y del mismo ente público Informe de la Situación General en Materia de Equilibrio Ecológico y Protección al Ambiente 1993-1994, México, Secretaría de Desarrollo Social-Instituto Nacional de Ecología, 1994, p. 217; Secretariado Técnico Intergubernamental, op. cit., nota 91, p. 29, y World Health Organisation y United Nations Environment Programme, op. cit., nota 97, pp. 157 y 158.

98 Bravo Álvarez, Humberto y Torres Jardón, Ricardo, op. cit., nota 91, p. 10; Calderón-Garcidueñas, Lilian et al., op. cit., nota 93, p. 225; Calvillo, Alejandro, "Seminario el Transporte y la Contaminación en la Ciudad de México", El transporte y la contaminación, México, Greenpeace México, 1993, p. 5; Campos Ruiz, H. et al, "Políticas para la prevención y control de la contaminación: el caso de la Ciudad de México", Diagnóstico de los países centroamericanos en torno a la implementación de los problemas de la política ambiental, Berlín, ZöV Zentralstelle für öffentliche Verwaltung, 1993, p. 71; Collins, Charles O. y Scott, Steven L., op. cit., nota 90, pp. 123 y 124; Comisión Metropolitana para la Prevención y Control de la Contaminación Ambiental en el Valle de México, Informe Mensual de la Calidad del Aire, México, Comisión Metropolitana para la Prevención y Control de la Contaminación Ambiental en el Valle de México, mayo de 1995, p. VII/19; Quadri, Gabriel, "Economía, sustentabilidad y política ambiental", en Yúnez-Naude, A. (comp.), Medio ambiente: problemas y soluciones, México, El Colegio de México, 1994, p. 24; Secretaría de Desarrollo Social, nota 97, 1993, pp. 166 y 167, y World Health Organisation y United Nations Environment Programme, op. cit., nota 587 p. 226. 
Esta obra forma parte del acervo de la Biblioteca Jurídica Virtual del Instituto de Investigaciones Jurídicas de la UNAM

Con todo y que la calidad del aire en la Ciudad de México es mala, existen a la fecha pocos estudios que hayan examinado la relación entre la contaminación atmosférica y el incremento en los índices de mortandad. Mencionamos los tres de mayor relevancia. En primer lugar, un estudio con análisis realizado para la ZMCM para el periodo 1987-1989, el cual demostró la existencia de una correlación positiva y significativa entre el material particulado suspendido y el $\mathrm{SO}_{2}$ con la mortandad. ${ }^{99}$ En segundo lugar, un estudio de análisis elaborado por la Organización Panamericana para la Salud y la Secretaría de Salud, en el que se estimó que las concentraciones de contaminantes en la Ciudad de México podrían estar produciendo un índice de mortandad anual del 5\% para todos los contaminantes. Lo cual pudo haber significado que a principios de la década de los noventa, la contaminación atmosférica habría provocado al año un incremento de 800 muertes prematuras en el área noroeste (Xalostoc) y de otras 600 muertes prematuras más en la región del suroeste (Pedregal). ${ }^{100}$ En tercer lugar, un estudio llevado a cabo para el Banco Mundial en 1992, en el cual se determinó que según cálculos conservadores existía una relación significativa entre partículas suspendidas totales e índices de mortandad. Con base en los niveles de este contaminante en la Ciudad de México, se estimó que durante 1990 alrededor de unas 6400 personas pudieron haberse salvado si no se hubieran presentado dichos niveles: lo que equivale a 3.8 vidas por cada 10000 habitantes. ${ }^{101}$

Aunque son pocos los estudios en mortandad, no así los de morbilidad. ${ }^{102}$ En efecto, en los últimos años se han realizado estudios epide-

99 Véase Santos-Burgoa, Carlos y Rojas Bracho, Leonora, "Los efectos de la contaminación atmosférica en la salud", en Restrepo, Iván (comp.), La contaminación atmosférica en México, sus causas y efectos en la salud, México, Comisión Nacional de los Derechos Humanos, 1992, p. 229.

100 Calvillo, Alejandro, op. cit., nota 98, p. 27.

101 Margulis, Sergio, "Back-of-the-Envelope Estimates of Environmental Damage Cost in Mexico", Working Papers, Washington D.C., Banco Mundial, enero de 1992, p. 13.

102 Algunas de las organizaciones no gubernamentales más importantes que han llevado a cabo estudios sobre los efectos de contaminación atmosférica en la salud humana son la Organización Panamericana para la Salud, el Hospital ABC y el Centro de Investigaciones de Salud Pública, véase Hernández Ávila, M., Producción bibliográfica en el área de salud ambiental, Cuernavaca, Centro de Investigaciones de Salud Pública, s.f. Por su lado, el gobierno federal a través de la Secretaría de Salud ha participado y coordinado algunos trabajos sobre los efectos de los contaminantes atmosféricos en la Ciudad de México en el marco del Sistema Nacional de Salud, véase, por ejemplo, Secretaría de Salud, Acciones 
Esta obra forma parte del acervo de la Biblioteca Jurídica Virtual del Instituto de Investigaciones Jurídicas de la UNAM

miológicos sobre enfermedades respiratorias y otros efectos a la salud humana durante la ocurrencia de episodios de contaminación atmosférica o contingencias ambientales en la Ciudad de México. Vale la pena señalar, sin embargo, que la gran mayoría de estos estudios se han centrado principalmente en el análisis de los efectos de contaminantes como el plomo, el ozono y, más recientemente, las partículas. ${ }^{103}$ Tomando como ejemplo el ozono, los estudios realizados sobre este contaminante han documentado casos de abstencionismo de los niños en las escuelas así como la aparición de asma en la niñez mexicana. Los resultados de estas investigaciones sugieren que la exposición de los niños a tal contaminante no sólo podría tener efectos adversos en su sistema respiratorio sino que de hecho estaría asociado con el número de visitas de emergencia que realizan a clínicas y hospitales por asma. ${ }^{104}$

No obstante que los altos niveles de contaminación atmosférica se convirtieron en una de las principales preocupaciones de todos los sectores de la sociedad mexicana, ${ }^{105}$ y que el total de emisiones a la atmósfera durante las décadas de los setenta y ochenta se incrementó alrededor de un 45\% (véase

desarrolladas para evaluar el efecto en la salud, por la contaminación atmosférica en el Valle de México, México, Sistema Nacional de Salud, 1993.

103 Véase, por ejemplo, Calderón-Garcidueñas, Lilian et al., op. cit., nota 93; Calvillo, Alejandro, op. cit., nota 98; Departamento del Distrito Federal et al., Programa para Mejorar la Calidad del Aire en el Valle de México 1995-2000, México, Departamento del Distrito Federal-Gobierno del Estado de México-Secretaría de Medio Ambiente, Recursos Naturales y Pesca-Secretaría de Salud, marzo de 1996; Hernández Ávila, M., op. cit., nota anterior; Margulis, Sergio, op. cit., nota 101; Medina, S. y Quenel, P., op. cit., nota 52; Restrepo, Iván (comp.), op. cit., nota 99, y Secretaría de Salud, op. cit., nota anterior.

104 Véase, Romieu, Isabel et al., "Air Pollution and School Absenteeism Among Children in Mexico", en Medina S. y Quenel, P. (comps.), op.cit., nota 52, y Romieu, Isabel et al., "Effect of Urban Air Pollutants on Emergency Visits for Childhood Asthma in Mexico City", en Hernández Ávila, M., op. cit., nota 102.

105 Véase, en este sentido, Cancino Aguilar, Miguel Ángel, "El marco jurídico para la prevención y control de la contaminación atmosférica", en González Márquez, José Juan (coord.), Derecho ambiental, México, Universidad Autónoma Metropolitana, 1994, p. 105; Comisión Metropolitana para la Prevención y Control de la Contaminación Ambiental en el Valle de México, op. cit., nota 91, 1992, p. 7; Díaz Díaz, D. y Perló Cohen, M., op. cit., nota 90, pp. 43 y 44; Ezcurra, Ezequiel, "The Basin of Mexico City", en Turner II, B. L. (coord.), The Earth as Transformed by Human Action, Cambridge, University of Cambridge, 1990, p. 583 y del mismo autor op. cit., nota 89, y Secretaría de Desarrollo Social, Informe de la situación general en materia de equilibrio ecológico y protección al ambiente 1991-1992, cit., nota 97, p. 153. 
Esta obra forma parte del acervo de la Biblioteca Jurídica Virtual del Instituto de Investigaciones Jurídicas de la UNAM

tabla 9), no fue sino hasta 1986 que este problema se volvió una prioridad para el gobierno mexicano. Por lo que antes de que esto último sucediera, los esfuerzos gubernamentales para controlar la contaminación atmosférica - expedición de la Ley para Prevenir y Controlar la Contaminación Ambiental de 1971, creación de la Subsecretaría de Mejoramiento al Ambiente en 1972 y elaboración del Programa Coordinado para Mejorar la Calidad del Aire en el Valle de México de 1979- habían sido insuficientes.

\section{TABLA 9}

Emisiones atmosféricas totales en la ZMCM (millones de toneladas/año)

\begin{tabular}{|c|c|c|c|c|c|}
\hline Año & Toneladas & Año & Toneladas & Año & Toneladas \\
\hline 1972 & 2.653 & 1979 & 3.521 & 1989 & 4.365 \\
\hline 1973 & 2.868 & 1980 & 3.600 & 1990 & n.d. \\
\hline 1974 & 3.244 & 1981 & 3.672 & 1991 & 4.300 \\
\hline 1975 & 3.394 & 1982 & 3.757 & $1992-1993$ & n.d. \\
\hline 1976 & 3.431 & 1983 & 3.851 & 1994 & 4.009 \\
\hline 1977 & 3.438 & $1984-1987$ & n.d. & 1995 & n.d. \\
\hline 1978 & 3.449 & 1988 & 4.900 & $1996-1997$ & n.d. \\
\hline
\end{tabular}

n.d. $=$ no disponible

Fuente: Comisión Metropolitana para la Prevención y Control de la Contaminación Ambiental en el Valle de México, 1992; Departamento del Distrito Federal et al., 1996; Schteingart, Marta, 1989, y Secretariado Técnico Intergubernamental, 1990.

Lo anterior se explica en parte porque durante todo ese periodo - incluso en los primeros años del sexenio del entonces presidente Miguel de la Madrid Hurtado (1982-1988) — el gobierno mexicano no reconocía ni daba la importancia debida a los temas ambientales. De aquí que la respuesta del gobierno durante esos años a la problemática ambiental se haya caracterizado por ser excesivamente centralizada, fragmentada y, además, no democrática. ${ }^{106}$

106 Véase Brañes, Raúl, op. cit., nota 14, p. 157 y Nuccio, R. A. et al., "Mexico's Environment: Securing the Future", en Bagley, B. M. y Aguayo Quezada, Sergio (coords.), Mexico: in Search of Security, Miami, North-South Centre, University of Miami, 1993, p. 270. 
Esta obra forma parte del acervo de la Biblioteca Jurídica Virtual del Instituto de Investigaciones Jurídicas de la UNAM

Es así que a partir de 1986, la administración de Miguel de la Madrid llevó a cabo ciertas acciones para combatir los crecientes niveles de contaminación atmosférica, como lo fueron, por ejemplo, la reubicación de la industria, un sistema de control de emisiones vehiculares, la instalación de una red automática de monitoreo atmosférico, la introducción de gasolinas sin plomo y la sustitución de combustóleo con azufre por gas natural en las termoeléctricas. ${ }^{107}$

Sin embargo, no fue sino hasta la llegada de Carlos Salinas de Gortari a la Presidencia (1988-1994) que se elaboró el primer programa sistemático en la materia para la Ciudad de México: el Programa Integral Contra la Contaminación Atmosférica de la Zona Metropolitana de la Ciudad de México (PICCA) de 1990. Este programa, mucho más estricto que las acciones anteriores y con 41 medidas o compromisos claramente identificados, ${ }^{108}$ se basó en cinco líneas de acción: $i$ ) el mejoramiento de los combustibles; ii) la expansión del transporte público y el establecimiento de un estricto control de emisiones vehiculares; iii) el mejoramiento (modernización) de los procesos de combustión y control de emisiones de industrias y servicios; iv) la restauración ecológica, y v) la educación e investigación ambientales y la participación social. De aquí se derivaron una serie de medidas legales y económicas y la creación de un ente intergubernamental denominado Comisión Metropolitana para la Prevención y Control de la Contaminación Ambiental en el Valle de México (CMPCCAVM). Esta nueva comisión — que habría de cambiar su nombre en 1996 al de la actual Comisión Ambiental Metropolitana - desde entonces ha estado encargada de coordinar todas las actividades para el control y prevención de la contaminación atmosférica en la ZMCM. ${ }^{109}$

Con este nuevo programa parecía claro que Salinas de Gortari reafirmaba su intención política de enfrentar el problema de la contaminación

107 Bravo Álvarez, Humberto, op. cit., nota 90, pp. 237-255; Díaz Díaz, D. y Perló Cohen, M., op. cit., nota 90, p. 46, y Gamboa de Buen, Jorge, op. cit., nota 88, p. 138.

108 Para conocer a detalle estas 41 medidas, véase Secretariado Técnico Intergubernamental, op. cit., nota 91, pp. 34-41.

109 Comisión Metropolitana para la Prevención y Control de la Contaminación Ambiental en el Valle de México, La contaminación atmosférica..., cit., nota 88, e id., Avances a junio de 1994, cit., nota 91; Departamento del Distrito Federal et al., op. cit., nota 103; Secretaría de Desarrollo Social, op. cit., nota 97, 1993 y 1994; Secretariado Técnico Intergubernamental, op. cit., nota 91 . 
Esta obra forma parte del acervo de la Biblioteca Jurídica Virtual del Instituto de Investigaciones Jurídicas de la UNAM

atmosférica tal y como lo había enfatizado en su discurso de toma de posesión como presidente en diciembre de 1988: “... doy instrucciones precisas, urgentes y enérgicas al jefe del Departamento del Distrito Federal para que actúe de inmediato con acciones eficaces alentando la participación de la comunidad para abatir la contaminación". ${ }^{110}$

A pesar de ello, las palabras pronunciadas por Salinas de Gortari no fueron del todo congruentes con los alcances obtenidos al término de su sexenio. Lo que en realidad buscaba el entonces presidente de México eran resultados inmediatos y a corto plazo por razones de tipo socio-político. ${ }^{111} \mathrm{Si}$ bien el gobierno salinista impulsó la elaboración del PICCA de 1990 que contaba con el primer inventario de emisiones de contaminantes criterio, ${ }^{112}$ su política para el control de la contaminación del aire empezó a ser cuestionada desde sus orígenes. ${ }^{113}$ Algunas de las críticas más importantes en este sentido se refieren a lo siguiente:

a) Se ignoraron recomendaciones científicas y experiencias internacionales previas en el combate de ciertos contaminantes - como el $\mathrm{Pb}$ y el $\mathrm{SO}_{2}$ - cuyo control ha tenido en esta ciudad efectos secundarios o colaterales no deseados. Ciertamente, la decisión tomada de continuar la estrategia para reducir los niveles de estos dos contaminantes a través de cambios en el contenido de las gasolinas para vehículos automotores y a través de la sustitución de combustóleo por gas natural en plantas termoeléctricas e industrias, respectivamente, provocó el incremento de las emisiones de contaminantes como los $\mathrm{HC}$ y los $\mathrm{NO}_{2}$ que a su vez han contribuido a la formación de niveles elevados de ozono. ${ }^{114}$

110 Secretariado Técnico Intergubernamental, op. cit., nota 91, p. 2.

111 En este sentido, debemos recordar que las elecciones presidenciales de 1988 en las que contendió Salinas de Gortari han sido a la fecha las más peleadas en la historia del México post-revolucionario del siglo XX y fueron consideradas como fraudulentas: la popularidad de Salinas y su legitimidad política estuvieron al principio de su mandato por debajo de cualquiera otro de sus predecesores. Véase Ward, Peter, Mexico City, Londres, Belhaven, 1990, pp. 66 y 67.

112 Secretariado Técnico Intergubernamental, op. cit., nota 91, p. 2.

113 Véase, por ejemplo, Díaz Díaz, D. y Perló Cohen, M., op. cit., nota 90, p. 46 y Gamboa de Buen, Jorge, op. cit., nota 88, pp. 138 y 139.

114 Bravo Álvarez, Humberto y Torres Jardón, Ricardo, op. cit., nota 91, pp. 3 y 4, y Ezcurra Ezequiel, op. cit., nota 105, p. 583. 
Esta obra forma parte del acervo de la Biblioteca Jurídica Virtual del Instituto de Investigaciones Jurídicas de la UNAM

b) Aunque los niveles de $\mathrm{Pb}$ se encuentran actualmente por debajo de los estándares internacionales recomendados (i. e. 1.5 microgramos por metro cúbico) y ciertos contaminantes como el $\mathrm{NO}_{2}$, el $\mathrm{SO}_{2}$ y el $\mathrm{CO}$ ocasionalmente exceden la norma mexicana de calidad del aire, la Ciudad de México continúa sufriendo de altos niveles de contaminación atmosférica, tal y como lo han reconocido los gobiernos federal y local. ${ }^{115}$ Por ejemplo, dos de los principales contaminantes que ahora se encuentran presentes en la atmósfera de la ZMCM y que no representaban un problema serio antes de la implementación de las acciones gubernamentales de 1986 y regulaciones subsiguientes, son las partículas suspendidas (como las $\mathrm{PM}_{10}$ ) y el $\mathrm{O}_{3}$ (resultado de la combinación de $\mathrm{HC}+\mathrm{NO}_{\mathrm{x}}+$ luz solar). ${ }^{116}$

c) Los datos y estadísticas de los inventarios de emisiones (en particular el de 1989 y de publicaciones oficiales posteriores) no han sido congruentes, por lo que la información sobre la situación de ciertos contaminantes no es del todo confiable. En consecuencia, suponemos que la adopción e instrumentación de políticas públicas tienen bases un tanto endebles. Por ejemplo, aunque diversos estudios científicos han señalado que las fuentes primarias de emisión de partículas son los procesos de combustión y aerosoles condensados de la combustión en vehículos y fuentes estacionarias y no así las tormentas de polvo o tolvaneras, ${ }^{117}$ el gobierno mexicano señaló en el inventario de emisiones de 1989 que casi el 95\% de las partículas suspendidas provenían de fuentes naturales de la cuenca de la Ciudad de México, es decir, de la degradación ecológica y zonas deforestadas. Siguiendo su propia información y con el objeto de combatir este contaminante, el gobierno elaboró un programa de reforestación en 1990 que significó la plantación de 41.6 millones de árboles en las áreas urbana y rural de la cuenca $(40 \%$ de los cuales

115 Véase Departamento del Distrito Federal et al., op. cit., nota 103, y Secretaría de Desarrollo Social, op. cit., nota 97, 1994, pp. 223-232.

116 Bravo Álvarez, Humberto y Torres Jardón, Ricardo, op. cit., nota 91, p. 3; Campos Ruiz, H. et al., op. cit., nota 98, p. 73; Comisión Metropolitana para la Prevención y Control de la Contaminación Ambiental en el Valle de México, op. cit., nota 88, pp. 40-64; Collins, Charles O. y Scott, Steven L., op. cit., nota 90, pp. 123 y 124, y Hardie, R. Wayne et al., "Development of a methodology for evaluating air pollution options for improving the air quality in Mexico City", The Science of the Total Environment, vol. 1, pp. 1-7.

117 Bravo Álvarez, Humberto y Torres Jardón, Ricardo, op. cit., nota 91, p. 7. 
Esta obra forma parte del acervo de la Biblioteca Jurídica Virtual del Instituto de Investigaciones Jurídicas de la UNAM

desaparecieron al poco tiempo). ${ }^{118}$ Años más tarde, el inventario de emisiones de 1994 arrojó información en el que se señalaba que el porcentaje de partículas suspendidas proveniente de fuentes naturales (ahora bajo el sector de vegetación y suelos) era el mismo que el reportado en 1989 (confróntense tablas 6 y 10).

TABLA 10

Inventario de emisiones (1994) por sector (\% en peso)

\begin{tabular}{|c|r|r|r|r|r|r|}
\hline Sector & \multicolumn{1}{|c|}{$\mathrm{SO}_{2}$} & $\mathrm{NO}_{x}$ & $\mathrm{HC}$ & $\mathrm{CO}$ & PST & Total \\
\hline Industria & 57.3 & 24.5 & 3.2 & 0.4 & 1.4 & 3.0 \\
\hline Servicios & 15.9 & 4.2 & 38.9 & 0.1 & 0.2 & 10.0 \\
\hline Transporte & 26.8 & 71.3 & 54.1 & 99.5 & 4.2 & 75.0 \\
\hline Vegetación y suelos & 0.0 & 0.0 & 3.8 & 0.0 & 94.2 & 12.0 \\
\hline Total & 100.0 & 100.0 & 100.0 & 100.0 & 100.0 & 100.0 \\
\hline
\end{tabular}

Fuente: Departamento del Distrito Federal et al., 1996.

Si el gobierno estaba en lo cierto de que la fuente principal de partículas eran las tolvaneras, entonces la estrategia para disminuir las concentraciones de este contaminante a través de la plantación de árboles fue un rotundo fracaso. ${ }^{119}$ Es posible entonces que la explicación de que no disminuyeran los niveles de partículas se deba más bien a que muchas de ellas provenían de fuentes emisoras distintas a las determinadas por el gobierno. De cualquier manera, lo cierto es que los niveles de partículas suspendidas en la ZMCM aún continúan por encima de la norma mexicana

118 Comisión Metropolitana para la Prevención y Control de la Contaminación Ambiental en el Valle de México, op. cit., nota 88, pp. 60 y 86, у op. cit., nota 91, 1994, pp. II/39.

119 Según trascendió de nuestra investigación, mucha de la información contenida en el inventario de emisiones de 1994 y que está relacionada con partículas, fue tomada de publicaciones realizadas en 1990. Si este es el caso, la falla no está propiamente en la fuente y/o sus porcentajes sino en el lamentable hecho de que el gobierno mexicano no hubiera actualizado el inventario de 1994 o en su caso homologado la información, lo que hace extremadamente difícil darle seguimiento al PICCA y mucho menos hacer un ejercicio de comparación confiable. Por otro lado, también existen datos y estadísticas ahora en relación con los $\mathrm{HC}$ que crean confusión y/o que son difíciles de creer: mientras que el sector degradación ecológica contribuyó en 1989 con 34.9\% de emisiones para este contaminante, en menos de 6 años (para 1994) decreció a 3.8\%. Para mayor información, véase Departamento del Distrito Federal et al., op. cit., nota 103. 
Esta obra forma parte del acervo de la Biblioteca Jurídica Virtual del Instituto de Investigaciones Jurídicas de la UNAM

de calidad del aire y se han convertido, después del ozono, en el segundo problema atmosférico en importancia para la Ciudad de México. ${ }^{120}$

Aunado a todo lo anterior, debemos señalar que las causas que han dado origen a la contaminación atmosférica y que han jugado un papel importante en la calidad del aire permanecen como factores determinantes que inciden en el proceso de formulación e instrumentación de las políticas públicas respectivas. Un ejemplo de esto es el hecho de que no obstante los esfuerzos realizados por el gobierno para contener la descontrolada expansión de la ciudad a través de regulaciones sobre uso del suelo y la creación de un cinturón verde, el crecimiento poblacional y urbano continúan en toda la ZMCM avanzando sobre zonas de conservación. ${ }^{121}$ Otro ejemplo más lo constituye el sector industrial: aunque ciertas industrias en la Ciudad de México han sido cerradas - como la refinería 18 de marzo - o han decidido mudarse a otra parte - como la General Motors - los programas de reubicación industrial no han tenido éxito y la instalación de equipo para controlar las emisiones no se ha conseguido del todo por los altos costos que ello representa. ${ }^{122} \mathrm{El}$ fracaso de reubicar a la industria hacia finales de la administración salinista se debió en mucho a la crisis económica de 1994; sólo algunas compañías, las más grandes, han estado en posibilidad de salirse de la Ciudad de México tras el retorno de la estabilidad económica al país.

A la llegada de Ernesto Zedillo Ponce de León al poder a mediados de la década de los noventa (para el periodo 1994-2000), la situación de la calidad del aire en la Ciudad de México continuaba siendo considerablemente mala. Si bien al final del sexenio de Salinas de Gortari las medidas de control de la contaminación produjeron algunos resultados positivos (pero no los prometidos y/o esperados), los altos niveles de concentración de contaminantes como el ozono, las partículas y los compuestos or-

120 Bravo Álvarez, Humberto y Torres Jardón, Ricardo, op. cit., nota 91, p. 7; Calderón-Garcidueñas, Lilian et al., op. cit., nota 93, p. 225; Departamento del Distrito Federal et al., op. cit., nota 103, p. 60, y Hardie, R. Wayne, et al., op. cit., nota 116.

121 Comisión Metropolitana para la Prevención y Control de la Contaminación Ambiental en el Valle de México, op. cit., nota 88, pp. 85 y 86; Gamboa de Buen, Jorge, op. cit., nota 88, pp. 123-138; Nava Escudero, César, El derecho de las concesiones y permisos en los servicios y obras públicas en México. Estudio constitucional y administrativo, México, tesis presentada para optar por el grado de licenciatura en derecho, Facultad de Derecho-UNAM, 1992, pp. 114-116, y Pezzoli, K., op. cit., nota 90, p. 207.

122 Collins, Charles O. y Scott, Steven L., op. cit., nota 90, p. 126. 
Esta obra forma parte del acervo de la Biblioteca Jurídica Virtual del Instituto de Investigaciones Jurídicas de la UNAM

gánicos volátiles quedaron y siguen siendo un asunto aún por resolverse. Para el caso del ozono, por ejemplo, aunque los niveles de contaminación durante la primera parte de la década de los noventa no hayan rebasado ya los 300 puntos Imeca (a excepción de 1992 en los que se registraron 11 días por encima de ese nivel) y aunque el número de ocasiones de implementación del plan de contingencias haya disminuido de 7 en 1996 a 3 en 1997, la norma mexicana de calidad del aire - 100 puntos Imeca - ha sido rebasada a la fecha en más del $90 \%$ del total del número de días por año. Para el caso de diversos compuestos orgánicos, como lo es el de los aldehídos que contribuyen a la formación de la contaminación fotoquímica, se han observado incrementos en los niveles de concentración tal y como sucedió para el periodo 1993-1996.123

Ante tal escenario, el gobierno zedillista lanzó un renovado programa de calidad del aire más integrado y mucho más estricto que su predecesor en 1996: el Programa para Mejorar la Calidad del Aire en el Valle de México 1995-2000, conocido popularmente con el nombre de Proaire. Este programa (que de hecho actualizó y amplió en muchos sentidos lo establecido en el PICCA de 1990) se propuso llevar a cabo 9 estrategias, todas ellas a través de cuatro grandes metas: industria limpia (reducción de emisiones en industria y servicios); vehículos limpios (disminución de emisiones por kilómetro); nuevo orden urbano y transporte público (regulación del total de kilómetros recorridos por vehículos automotores), y recuperación ecológica (abatimiento de la erosión). Entre sus objetivos se encuentra el de disminuir el número y niveles de concentración de contaminantes por día así como el de reducir el número de contingencias o situaciones de emergencia por año. ${ }^{124}$

Finalmente y sin lugar a dudas, debemos enfatizar que los tres aspectos que en los últimos años han sido determinantes en la calidad del aire en la Ciudad de México son $i$ ) el incremento en el número (propiedad) y uso de los vehículos; ii) el compromiso del gobierno de México en la construcción de más vialidades (avenidas, calles y carreteras), y iii) la falta de un sistema integrado y mejorado de transporte público para toda la ZMCM.

123 Véase Departamento del Distrito Federal et al., op. cit., nota 103, y García, R. et al., "Aldehídos: contaminantes atmosféricos", Teorema, México, año 4, núm. 16, marzomayo de 1998, p. 31.

124 Véase Departamento del Distrito Federal et al., op. cit., nota 103. 
Esta obra forma parte del acervo de la Biblioteca Jurídica Virtual del Instituto de Investigaciones Jurídicas de la UNAM

Mientras tanto, el consumo de energía continúa incrementándose a través del uso elevado de gasolina, combustóleo, diesel y gas natural. ${ }^{125}$ Así, en los primeros cuatro años de la década de los noventa el consumo diario de gasolina en la ZMCM se incrementó en un $13.66 \%$ pasando de 16.1 millones de litros al día en 1990 a 18.3 millones en 1994. ${ }^{126}$ Este aumento en el consumo de gasolina en parte se debió al rápido incremento en el número de vehículos: las ventas anuales en toda la ZMCM creció de aproximadamente 100000 unidades en 1983 a casi 250000 en 1992 (véase tabla 11). Aunque estas cantidades empezaron a declinar para el periodo 1993-1995 (las ventas cayeron dramáticamente debido a la crisis económica de 1994) se espera que el número y uso de vehículos aumente con la recuperación financiera del país. ${ }^{127}$

\section{TABLA 11}

Crecimiento vehicular y habitantes/vehículo en el Distrito Federal (1940-1990)

\begin{tabular}{|c|c|c|c|c|c|c|}
\hline & 1940 & 1950 & 1960 & 1970 & 1980 & 1990 \\
\hline $\begin{array}{c}\text { Número de } \\
\text { vehiculos }\end{array}$ & 46361 & 72189 & 234638 & 676005 & 1803559 & 2200000 \\
\hline $\begin{array}{c}\text { Habitantes/ } \\
\text { vehículo } \\
(\%)\end{array}$ & 37.1 & 42.6 & 20.7 & 19.1 & 4.9 & 4.0 \\
\hline
\end{tabular}

Fuente: Díaz Díaz, D. y Perló Cohen, M., Retos y propuestas: Ciudad de México, México, Fundación Mexicana Cambio XXI Luis Donaldo Colosio, 1994, y periódico Excélsior del 1 de junio de 1995.

125 Bauer, M. y Quintanilla, J., "Emissions of the Energy Chaings in the Mexican Energy System", ponencia presentada en Seminario Internacional sobre Sustentabilidad Urbana y el Manejo de la Cuenca Atmosférica en la Zona Metropolitana del Distrito Federal y del Estado de México, México, 22-25 de mayo de 1995.

126 Comisión Metropolitana para la Prevención y Control de la Contaminación Ambiental en el Valle de México, Medidas de invierno 1994-1995: informe final, México, Comisión Metropolitana para la Prevención y Control de la Contaminación Ambiental en el Valle de México, abril de 1995.

127 Comisión Metropolitana para la Prevención y Control de la Contaminación Ambiental en el Valle de México, op. cit., nota 88, p. 27, y Departamento del Distrito Federal et al., op. cit., nota 103, p. 86. 
Esta obra forma parte del acervo de la Biblioteca Jurídica Virtual del Instituto de Investigaciones Jurídicas de la UNAM

Lamentablemente, mientras que en los últimos años se ha dado preferencia al uso de vehículos privados a través de programas para la construcción de caminos, avenidas y calles, ${ }^{128}$ el sistema de transporte público en la Ciudad de México ha sido insuficiente, corrupto y en ocasiones sujeto a restricciones financieras significativas. Así se ha observado con la supuesta expansión y mejoramiento del sistema del metro denominado Sistema de Transporte Colectivo-Metro, la cual se detuvo durante los periodos 1972-1976 y 1989-1990. Aunque esta situación cambió a partir de principios de la década de los noventa en la que se comenzó su ampliación de manera sistemática, no se ha logrado con ello a la fecha incentivar a los conductores a que dejen de usar sus vehículos. ${ }^{129}$ De hecho, el nuevo programa de transporte para la Ciudad de México de 1995, continuará favoreciendo a los vehículos particulares no obstante que contemple la expansión y mejoramiento de todo el sistema de transporte público (e. g. el metro, autobuses eléctricos, el tren ligero y los camiones). Este ambicioso programa propone la creación de nuevas vialidades dentro y alrededor de la Ciudad de México: la construcción de anillos metropolitanos están ya en marcha. ${ }^{130}$

\section{CONCLUSIÓN}

En la actualidad, la contaminación atmosférica representa en el debate ambiental sobre ciudades una de las principales preocupaciones para países tanto del norte como del sur. Es por ello que abordar el tema de la gestión de la calidad del aire en un contexto norte-sur (en el que se exploren sus diferencias y similitudes) justifica realizar un estudio comparado entre Londres y la Ciudad de México.

Como resultado de nuestro análisis ha quedado demostrado que las dos ciudades objeto de estudio en este trabajo sufren de mala calidad del aire aun cuando la magnitud del problema para cada una de ellas es ciertamente diferente. Así, mientras que los niveles de contaminación atmos-

128 Véase Ward, Peter, Mexico City, 2a. ed., Chichester, Wiley, 1998, p. 145.

129 Navarro, B., El metro y sus usuarios, México, Universidad Autónoma Metropolitana, 1993, pp. 41-55.

130 Calvillo, Alejandro, op. cit., nota 98, y Departamento del Distrito Federal, Programa Integral de Transporte y Vialidad 1995-2000 (Pitvi 1995-2000), México, Departamento del Distrito Federal, 1995. 
Esta obra forma parte del acervo de la Biblioteca Jurídica Virtual del Instituto de Investigaciones Jurídicas de la UNAM

férica son mucho más elevados y alarmantes para la Ciudad de México que para Londres, el camino que deben seguir ambas ciudades apunta en una misma dirección: enfrentar la problemática del crecimiento y uso de vehículos automotores. Por lo que el dilema en el que se encuentran centros urbanos como los aquí estudiados es el de mejorar la calidad del aire sin comprometer la movilidad urbana de sus habitantes. De modo que la implementación de medidas tales como la agilización del tránsito, el control de emisiones vehiculares, la prohibición de usar vehículos un día o más a la semana, el mejoramiento de las gasolinas, etcétera, pueden contribuir a combatir la contaminación atmosférica; sin embargo, en tanto la compra y uso de vehículos continúen incrementándose, por más acciones y medidas de tránsito que se establezcan y por más que se amplíe y mejore el sistema de transporte público, los altos niveles de emisiones de los vehículos automotores seguirán prolongándose. Por consiguiente, así como las políticas a corto plazo pudieran ser en principio deseables para prevenir la exposición de las generaciones presentes a niveles elevados de contaminación, las políticas a mediano y largo plazos son indispensables para que las generaciones futuras satisfagan sus propias necesidades de contar con una buena calidad del aire.

Alcanzar y mantener una atmósfera saludable en centros urbanos requiere de una respuesta integrada y adecuada en la que participen todos los sectores de la sociedad, particularmente a nivel local. Son precisamente los gobiernos y las autoridades locales las que se erigen como las vías institucionales para asegurar una respuesta eficiente, coordinada y legítima a cualquier asunto urbano ambiental como lo es el de la gestión de la calidad del aire. 
Esta obra forma parte del acervo de la Biblioteca Jurídica Virtual del Instituto de Investigaciones Jurídicas de la UNAM

\section{HACIA UN DERECHO ATMOSFÉRICO AMBIENTAL*}

\section{INTRODUCCIÓN}

Son pocas las ocasiones en que abogados y juristas se han sentado a reflexionar sobre cuestiones atmosféricas desde un punto de vista jurídico. Si sólo pusieran mayor atención al hecho de que a menos de 40 kilómetros sobre la superficie de la tierra ocurren los más variados y fascinantes fenómenos atmosféricos que permiten al ser humano respirar, a la fauna silvestre sobrevivir y a la flora continuar con su función fotosintética, ya contaríamos con muchas páginas escritas al respecto. Si sólo le dieran la importancia que merece, esas páginas estarían redactadas bajo los mejores enfoques de la disciplina jurídica. Así, en relación con las afectaciones atmosféricas y sus consecuencias, seguramente el abogado ambientalista nos convencería de prevenir y preservar más que de corregir y sancionar; el abogado civilista nos hablaría del daño, la reparación y, en su caso, el monto de la indemnización; el abogado penalista nos ayudaría a encontrar al presunto responsable; el abogado administrativista nos enseñaría cómo y cuándo aplicar el principio de legalidad, la multa, y/o la infracción; el abogado internacionalista nos platicaría del por qué de su dimensión regional o global; el abogado urbanista nos alertaría sobre la inconveniente ubicación industrial y el inconmensurable crecimiento vehicular, y el abogado mercantilista o corporativista nos explicaría la póliza y nos invitaría a firmar contratos de seguros.

Pero esto no ha sido así, por lo menos no en México. Aunque existen algunos estudios interesantes, estos apenas empiezan a tomar forma y presencia científica en el mundo jurídico. De aquí que sea fundamental captar la atención de abogados y juristas (cualquiera que sea su especialidad) para invitarlos a la reflexión y estudio de un tema de mucha

* Publicado en Derecho Ambiental y Ecología, México, año 1, núm. 4, diciembre de 2004-enero de 2005. 
Esta obra forma parte del acervo de la Biblioteca Jurídica Virtual del Instituto de Investigaciones Jurídicas de la UNAM

actualidad, ya que así como permite la vida misma en este planeta, también afecta la salud y la existencia de millones de seres humanos y sus medios natural y construido. Por tanto, el objeto de este artículo es sentar las bases para la construcción de una incipiente rama del derecho a la que habremos de denominar derecho atmosférico y buscar con ello un mejor entendimiento y acercamiento jurídicos a la cuestión atmosférica. En última instancia, se intenta dar las primeras pinceladas para reflexionar sobre la necesidad de perfeccionar las herramientas jurídicas (teóricas o prácticas) que se requieran para combatir, controlar o prevenir las acciones que originan un desequilibrio atmosférico (que llamamos contaminación atmosférica) en detrimento no sólo de los ambientes natural y artificial, sino de quienes son los principales causantes de ello: los seres humanos.

Lejos de enfocarnos en una discusión sobre su autonomía respecto de otras disciplinas jurídicas - lo que podría resultar bizantino-, buscamos comprenderla y construirla atendiendo a su parte normativa y a su parte científica. Al hacerlo, queremos compartir con el lector la idea de que el derecho atmosférico puede explicarse por sí mismo pero que necesita también de otras disciplinas jurídicas. Dentro de este vínculo con otras ramas de la ciencia jurídica, encuentra un profundo hermanamiento con el derecho ambiental y de aquí que se sugiera en la conclusión de este artículo la conveniencia de hablar de un derecho atmosférico ambiental.

\section{DERECHO ATMOSFÉRICO}

No debe sorprender ni preocupar a los estudiosos del derecho el uso de nuevas expresiones como la que aquí se pretende. Si algo nos enseñan los conocedores de la historia del derecho, es que diversos fenómenos económicos, políticos, sociales, artístico-culturales y tecnológicos contribuyen decididamente al crecimiento de un sistema jurídico que enriquece y renueva su lenguaje en una espiral constante a través de nuevos campos de regulación. Existen áreas o temas jurídicos que han surgido a propósito de fenómenos o preocupaciones recientes y que se han ido consolidando como disciplinas jurídicas, a tal grado que en la actualidad ya nadie discute sobre su trascendencia como lo son el derecho ambiental, urbano o urbanístico, forestal, pesquero, marítimo, del mar, minero, aéreo, etcétera. Algo semejante ha sucedido con la cuestión atmosférica en tanto que ha experimentado en las últimas décadas un crecimiento en su 
Esta obra forma parte del acervo de la Biblioteca Jurídica Virtual del Instituto de Investigaciones Jurídicas de la UNAM

regulación así como un fortalecimiento - aunque todavía muy rudimentario- en el campo de la ciencia jurídica. Esto nos permite suponer que no es aventurado hablar de la conveniencia de construir una disciplina a la que se le denomine derecho atmosférico. Pero no es sólo el creciente cuerpo normativo y la cada vez más reconocida presencia científicojurídica de las instituciones atmosféricas lo que nos anima a ello, sino la trascendencia que tiene para la supervivencia misma del ser humano y de toda forma de vida en el planeta.

Como todo buen inicio, debemos comenzar por definir al derecho atmosférico. Se trata pues de una rama del derecho que tiene por objeto la regulación y el estudio de las conductas humanas que afectan de manera negativa o positiva el conjunto de gases, líquidos y sólidos que componen la atmósfera y cuya afectación derive en causar un daño a la salud humana, el medio natural y el medio construido, o bien, en propiciar su equilibrio o capacidad auto-depurativa necesarios para la vida en la Tierra. El término atmósfera proviene del griego (vapor, aire y esfera) y significa según el Diccionario de la lengua española "capa de aire que rodea a la Tierra". 1

La atmósfera se eleva a unos 100 kilómetros aproximadamente por encima de la superficie terrestre y se divide en varias capas, la forma más común para diferenciar unas de otras está basada en la temperatura. Sin que exista un criterio único para denominarlas y definirlas, una de las versiones más aceptadas es aquélla que divide a la atmósfera en cuatro capas principales: la troposfera, la estratosfera, la mesosfera y la termosfera. ${ }^{2}$ A este bloque de capas que constituyen la atmósfera también se le conoce como "atmósfera terrestre" o "espacio atmosférico" y ha servido para diferenciarlo de lo que es el "espacio ultraterrestre", "espacio sideral" o simplemente "espacio". ${ }^{3}$ Sin mayor detalle, las dos primeras capas

1 Real Academia de la Lengua Española, Diccionario de la lengua española, 21a. ed., Madrid, 1992.

2 Cheers, Gordon (ed.), Geographica. El gran atlas mundial ilustrado, trad. de Gemma Deza Guil, Vicky Santolaría Malo, Cruz Rodríguez Juiz y Rita da Costa García, Colonia, Könemann, 2000, p. 21, y Kemp, David D., The Environment Dictionary, Londres, Routledge, 1998, pp. 33 y 34.

3 Sobre el estatus jurídico del término atmósfera a nivel internacional se recomienda Birnie, Patricia W. y Boyle, Alan E., International Law and the Environment, 2a. ed., Oxford, Oxford University Press, 2002. 
Esta obra forma parte del acervo de la Biblioteca Jurídica Virtual del Instituto de Investigaciones Jurídicas de la UNAM

atmosféricas — la troposfera y la estratosfera — ${ }^{4}$ son las que más importan a climatólogos, ambientalistas, políticos, internacionalistas, legisladores, y desde luego, abogados y juristas, pues es ahí donde se realizan la mayor parte de las afectaciones atmosféricas esenciales para la vida en el planeta, y por lo tanto de donde se derivan las principales instituciones atmosféricas de regulación y estudio jurídicos.

Ahora bien, el derecho atmosférico no se ocupa de todo lo que sucede en la atmósfera. En principio, regula y estudia aquellas instituciones atmosféricas comprendidas en cuatro grandes áreas o temas.

Primero, la llamada contaminación atmosférica urbana, propia de los grandes centros urbanos y a la que se le llegó a conocer en sus orígenes simplemente como smog (término acuñado en Londres, Inglaterra).

Segundo, la denominada lluvia ácida, problemática que a nivel internacional fue llevada a tribunales por vez primera durante la primera mitad del siglo XX y a la que se le ha encasillado como una cuestión fundamentalmente transfronteriza. Fueron precisamente los problemas de acidificación de los sistemas acuáticos en los países escandinavos ocasionados presumiblemente por las emisiones industriales provenientes de Inglaterra y otros países de Europa Central, los que provocaron en gran medida que se convocara en 1972 a la Conferencia de las Naciones Unidas sobre el Medio Humano en Estocolmo, Suecia, y se diera con ello la internacionalización de los temas ambientales. ${ }^{5}$

Tercero, el denominado adelgazamiento o destrucción de la capa de ozono, fenómeno reconocido por la comunidad internacional hasta hace apenas unos cuantos años y cuyo planteamiento en la década de los setenta le valió el Premio Nobel de Química en 1995 al mexicano-estadounidense Mario Molina, egresado de la Facultad de Química de la Universidad Nacional Autónoma de México (UNAM) y actualmente investigador

4 La troposfera (incluyendo la tropopausa como zona de transición entre ésta y la siguiente capa) se eleva a unos 16 o 17 kilómetros aproximadamente de la superficie terrestre (desde la zona del Ecuador); la estratosfera (incluyendo la estratopausa como zona de transición entre ésta y la capa siguiente) alcanza una altitud aproximada de 50 kilómetros por encima de la superficie terrestre (desde la zona del Ecuador).

5 Grubb, Michael et al., The Earth Summit Agreements: a Guide and Assessment, Londres, The Royal Institute of International Affairs-Earthscan, 1993, p. 4, y McCormick, John, The Global Environmental Movement, 2a. ed., Chichester, Wiley, 1995, pp. 239 y 240 . 
Esta obra forma parte del acervo de la Biblioteca Jurídica Virtual del Instituto de Investigaciones Jurídicas de la UNAM

en el Massachussets Institute of Technology (MIT) en Estados Unidos de América. ${ }^{6}$

Y por último, el popularmente llamado sobrecalentamiento de la tierra o efecto invernadero, al que se le conoce científicamente con el nombre de cambio climático. Este tema ha permitido a las naciones reflexionar sobre el hecho de que se trata de un problema atmosférico que no tiene fronteras en cuanto a sus consecuencias, aunque sí responsabilidades comunes pero diferenciadas en cuanto a sus orígenes y tratamiento (i.e. los países desarrollados son los que más han contribuido en la emisión de gases de efecto invernadero ocasionando dicho problema, además de ser los que cuentan con más recursos financieros y tecnológicos para combatirlo).

Aparte de estos cuatro grandes rubros, existen otros temas que en ocasiones se han incluido dentro del campo de regulación y estudio atmosféricos. Por ejemplo, lo relativo a las actividades realizadas en el espacio ultraterrestre en cuanto a su posible afectación al espacio atmosférico. Otros ejemplos abarcan la presencia de diversas formas de energía en la atmósfera que pudieran ser potencialmente perjudiciales como la nuclear, la lumínica, la térmica o la que proviene de radiaciones electromagnéticas. Se han agregado incluso los casos de las vibraciones, el ruido y los olores, que también ocurren en la atmósfera. La importancia que empiezan a adquirir estos temas conlleva a considerar seriamente si deberían o no incluirse como parte del derecho atmosférico, situación que merece un análisis amplio e informado en un estudio posterior.

Por lo pronto, es necesario hacer hincapié en que el derecho atmosférico regula y estudia actividades desarrolladas por los seres humanos, ya que existen eventos naturales (como la erupción de un volcán) que pueden producir afectaciones atmosféricas bajo la óptica de cualquiera de las áreas arriba señaladas pero que escapan a su objeto de estudio. Estas conductas deben afectar la composición atmosférica puesto que muchas actividades humanas relacionadas con la utilización de la atmósfera (como espacio) no producen desequilibrios o alteraciones significativas, por ejemplo, volar un papalote, practicar el paracaidismo o hacer surfing en el aire cuando las condiciones de viento así lo permitan. Desde luego, los desequilibrios atmosféricos deben producir efectos dañinos o, en su caso, benéficos, y es que hay que recordar que la propia atmósfera contiene

6 El doctor Mario Molina compartió dicho premio con sus colegas F. S. Rowland y P. Curtzen. 
Esta obra forma parte del acervo de la Biblioteca Jurídica Virtual del Instituto de Investigaciones Jurídicas de la UNAM

una capacidad de carga o de auto-regeneración que permite un balance de sus componentes y que a la vez impide se produzcan dichos efectos. En otras palabras, es indispensable que exista un nexo de causalidad entre la actividad desarrollada y la afectación atmosférica que habrá de producir un daño o beneficio a la salud humana y los medios natural y construido. Esta relación causal es característica fundamental en la definición propuesta, ya que los seres humanos desarrollan una infinidad de actividades que, como ya dijimos, no producen afectaciones atmosféricas y que incluso produciéndolas no generan efectos perjudiciales (o, en su caso, benignos).

En la construcción y entendimiento de una nueva disciplina jurídica es lógico preguntarse si ésta cuenta o no con autonomía propia. Para decidir tal cuestión, es necesario precisar si el estudio del derecho atmosférico contiene teorías, principios, métodos, fines, conceptos generales, figuras jurídicas o instituciones propias que no pudieran explicarse por otras ramas del derecho o que simplemente su contenido fuera distinto a estas. De ser el caso, podría afirmarse que el tema jurídico-atmosférico no es ya un capítulo más de otra disciplina jurídica sino una auténtica rama del derecho de creación reciente. De no ser así, se podrían esbozar argumentos suficientes para considerarla simple y sencillamente una rama sin autonomía propia derivada del derecho ambiental, disciplina jurídica que a su vez estaría catalogada como una de las muchas ramificaciones que ha tenido el derecho administrativo. Pero cualquier reflexión que se hiciere en este sentido desde la perspectiva ontológica, metodológica, teleológica y axiológica, requiere de un análisis ciertamente más detallado que escapa a los fines de este trabajo.

No obstante lo anterior, es necesario hacer dos breves comentarios al respecto. El primero radica en que ya sea que se le otorgue autonomía científica y se le ubique dentro del derecho público, que se le clasifique como una especialidad dentro de un todo único que es la ciencia del derecho, o que se le considere una rama más de alguna otra disciplina jurídica, el derecho atmosférico requiere apoyarse de criterios jurídicos consolidados en otras ramas del derecho. Actualmente, el mayor vínculo lo tiene con el derecho ambiental que a su vez guarda una estrechísima relación con el derecho administrativo $;{ }^{7}$ acompañan a estas dos ciencias

7 Véase, por ejemplo, López Ramón, Fernando, "Régimen jurídico de la protección del aire", Revista Española de Derecho Administrativo, núm. 84, octubre-diciembre de 1994, p. 533. 
Esta obra forma parte del acervo de la Biblioteca Jurídica Virtual del Instituto de Investigaciones Jurídicas de la UNAM

el derecho constitucional, el derecho urbano, el derecho internacional y el derecho espacial (como espacio sideral).

Un segundo comentario se refiere al hecho de que así como es indispensable el apoyo en otras ramas jurídicas, también es fundamental y además conveniente analizar las instituciones atmosféricas de manera separada de los estudios que proveen el derecho ambiental o el derecho administrativo. Esto puede y debe hacerse bajo la lupa de la doble naturaleza con la que se explica cualquier otra disciplina jurídica: como norma y como ciencia. Así lo han hecho algunos autores precisamente con las ramas jurídicas que tienen mayor vinculación con el derecho atmosférico como lo son, por ejemplo, Raúl Brañes Ballesteros ${ }^{8}$ para el derecho ambiental y Alfonso Nava Negrete ${ }^{9}$ para el derecho administrativo. Como norma el derecho atmosférico es el conjunto de leyes o disposiciones jurídicas que regulan las conductas humanas y su vínculo con las instituciones atmosféricas; como ciencia el derecho atmosférico es conjunto de principios, teorías o conceptos que explican no sólo las instituciones atmosféricas per se sino la relación entre esas conductas humanas y las propias instituciones atmosféricas.

De atender y dar seguimiento a estos dos comentarios, se permitiría - aunque no de manera concluyente- sentar las bases para explicar de un modo integral y sistemático instituciones atmosféricas. Esto tiene sus bondades, por ejemplo, el derecho atmosférico insertaría la dimensión jurídica al desarrollo del entendimiento de las cuestiones atmosféricas por otras ciencias no jurídicas. Las relaciones de interdisciplinariedad tan necesarias para abordar un tema como estos se verían fortalecidas con la aportación de la ciencia jurídica y permitiría a químicos, biólogos, economistas, sociólogos, filósofos, psicólogos y demás científicos mirar estas cuestiones bajo una perspectiva diferente pero complementaria. La conjunción de todas las instituciones atmosféricas en un estudio sistemático podría coadyuvar incluso a la creación de un cuerpo normativo coherente evitando la dispersión y con ello la incertidumbre jurídica y los conflictos de interpretación y aplicación de la ley.

8 Brañes, Raúl, Manual de derecho ambiental mexicano, 2a. ed., México, Fundación Mexicana para la Educación Ambiental-Fondo de Cultura Económica, 2000, pp. 46-56.

9 Nava Negrete, Alfonso, Derecho administrativo mexicano, 2a. ed., México, Fondo de Cultura Económica, 2001, pp. 13-15. 
Esta obra forma parte del acervo de la Biblioteca Jurídica Virtual del Instituto de Investigaciones Jurídicas de la UNAM

\section{DERECHO ATMOSFÉRICO COMO NORMA}

Una de las muchas formas que existen para conocer los orígenes y desarrollo de lo que ahora se pretende denominar derecho atmosférico desde el punto de vista normativo, es a través de divisiones por regiones geográficas, físicas o políticas (aldeas, comunidades, ciudades, áreas metropolitanas, países, continentes), por periodos o series temporales (años, decenios, siglos, milenios), o por temas o rubros (atmósfera urbana, lluvia ácida, capa de ozono, cambio climático). Todas éstas, desde luego, no son excluyentes entre sí. La razón para ello es muy sencilla: las regulaciones jurídicas que se han elaborado al respecto son mayoritariamente el resultado de un fenómeno que se ha presentado en espacios y tiempos diferentes, y que en un principio se manifestó como un hecho local y después adquirió dimensiones regionales y globales. En otras palabras, la normativa atmosférica no ha sido lineal ni debe explicarse así en cuanto que ésta ha surgido en diferentes etapas del desarrollo humano, se ha presentado indistintamente en países del norte y del sur, y ha estado confinada a resolver problemas locales, y con el tiempo, metropolitanos, regionales (transfronterizos) y/o globales. Por ejemplo, mientras que la regulación jurídica de la contaminación atmosférica urbana ha existido desde el siglo XIX para la mayoría de los países más desarrollados, ésta empezó a desarrollarse hace apenas unas cuantas décadas para los menos desarrollados. Si lo analizamos por tema, veremos que la consolidación de la normativa vinculante reflejada en instrumentos internacionales sobre el adelgazamiento de la capa de ozono y el cambio climático - ambos de corte global - se iniciaron, el primero en la década de los ochenta y el segundo en la década de los noventa. Las disposiciones contenidas en cada uno de estos instrumentos jurídicos formarán parte de los ordenamientos domésticos según las naciones los suscriban o ratifiquen.

La reflexión anterior conlleva a señalar que si optamos por dividir a lo atmosférico por periodos, regiones geográficas y grupos humanos, lograríamos hablar de un derecho atmosférico universal o general. Dentro de este marco universal se identifican dos momentos clave para la regulación jurídica de la atmósfera: la Revolución industrial de finales del siglo XVIII y la crisis ambiental moderna iniciada en la década de los sesenta del siglo XX. Como antecedentes normativos a estos dos fenómenos se sabe que las primeras regulaciones (o decisiones judiciales) provienen de la Edad Media en la que se incluyen casos aislados de molestias por 
Esta obra forma parte del acervo de la Biblioteca Jurídica Virtual del Instituto de Investigaciones Jurídicas de la UNAM

olores y humos en algunos países de lo que ahora es Europa, como la famosa sentencia emitida por un juez de Córdoba (España) en el siglo IX de nuestra era para que a través de la colocación de un tubo en la parte superior de un horno se evitara que los humos de éste perjudicaran a los vecinos; ${ }^{10}$ o los también famosos Bandos u Ordenanzas Reales (Royal Proclamations) en la Inglaterra del Medievo expedidos el primero por Eduardo I en 1273 en el que se prohibía la quema del carbón para proteger la salud de sus súbditos, y el segundo por Elizabeth I en 1306 para prohibir también el uso del carbón y que derivó en la ejecución de uno de sus infractores. ${ }^{11}$

El desarrollo de la normatividad para el caso de la contaminación atmosférica urbana se produjo a partir de una combinación de factores que incluyen la expansión de la actividad industrial, la intensificación de ciertas actividades productivas y no productivas (como la explotación de recursos renovables y no renovables o las actividades domésticas y de servicios, respectivamente), el crecimiento poblacional, la urbanización y la llegada y masificación durante el siglo XX de los vehículos automotores y su uso indiscriminado. Algo que ha caracterizado a este periodo de más de dos siglos es que la regulación atmosférica ha estado vinculada en mucho a cuestiones sanitarias o de salud pública. ${ }^{12}$ Los cuerpos jurídicos relacionados con el fenómeno atmosférico han empezado ahora a formar parte también de la nueva normatividad ambiental. En efecto, la llamada dimensión ambiental que se derivó del surgimiento del movimiento ambientalista de las décadas de los sesenta y setenta del siglo XX se insertó de inmediato en la forma y estructuración de las normas jurídicas sobre contaminación atmosférica urbana.

Pero los nuevos planteamientos ambientales no sólo han sido en estas últimas décadas fundamentales para la regulación jurídica de la atmósfera urbana, sino que han sido la base en la elaboración de sendos cuerpos normativos de derecho duro o vinculante a nivel internacional sobre cuestiones atmosféricas de reciente aparición. La influencia de la

10 Martín Mateo, Ramón, Derecho ambiental, Madrid, Instituto de Estudios de Administración Local, 1977, p. 488.

11 Thornton, Justine y Beckwith, Silas, Environmental Law, Londres, Sweet \& Maxwell, 1997, p. 5.

12 Véase, por ejemplo, Loperena Rota, Demetrio, "Tratamiento jurídico de la protección de la atmósfera", Revista Española de Derecho Administrativo, núm. 81, eneromarzo de 1994, p. 84. 
Esta obra forma parte del acervo de la Biblioteca Jurídica Virtual del Instituto de Investigaciones Jurídicas de la UNAM

normatividad internacional ambiental en el desarrollo de la regulación atmosférica interna de los países es ya innegable. Son ejemplos de la creciente normatividad internacional atmosférica la lluvia ácida transfronteriza (con el Convenio de Ginebra sobre la Contaminación Atmosférica Transfronteriza a Larga Distancia de 1979 y sus protocolos adicionales), la capa de ozono (con el Convenio de Viena sobre la Protección de la Capa de Ozono de 1985 y el Protocolo de Montreal relativo a las Sustancias que Agotan la Capa de Ozono de 1987 y sus ajustes y enmiendas) y el cambio climático (a través de la Convención Marco de las Naciones Unidas sobre el Cambio Climático de 1992 y su protocolo de 1997).

El derecho atmosférico mexicano como norma es en realidad bastante nuevo. Y es que los fenómenos atmosféricos que pudieron haber provocado la elaboración de una normatividad al respecto, fueron detectados por vez primera en la década de los cincuenta vinculados a la contaminación atmosférica urbana. El antecedente más remoto que documentan la mayoría de los especialistas en cuestiones atmosféricas es el ocurrido en 1950 en la ciudad de Poza Rica, Veracruz, ante una falla sucedida (fuga de ácido sulfhídrico) en el proceso industrial de una planta de Petróleos Mexicanos que ocasionó al menos 22 muertes y 320 enfermos respiratorios. ${ }^{13}$ El principal foco de atención se centraba, sin embargo, en la Ciudad de México, donde la existencia de contaminación del aire había sido detectada desde la década de los cincuenta y sesenta del siglo pasado pero que sólo hasta 1986 se convirtió en una prioridad para las autoridades mexicanas. ${ }^{14}$ Las primeras acciones gubernamentales comenzaron por medir de manera oficial los niveles de contaminación atmosférica en $1967^{15}$ y se elaboraron algunas estrategias o programas para combatirla entre los que destacan el Programa Coordinado para Mejorar la Calidad del Aire en el Valle de México de 1979 a nivel local, las 21 Medidas Concretas para el Control de la Contaminación del Aire de 1986 y el Programa de Cien Acciones Necesarias 1987-1988 de 1987 ambos a nivel federal. No fue sino hasta 1990 que se elaboraron programas más estrictos

13 Rivero Serrano, Octavio et al., Contaminación atmosférica y enfermedad respiratoria, México, Biblioteca de la Salud-Secretaría de Salud-Fondo de Cultura EconómicaUNAM, 1993, p. 56.

14 Nava Escudero, César, Urban Environmental Governance: Comparing air Quality Management in London and Mexico City, Aldershot, Ashgate, 2001, pp. 32-37.

15 Lezama de la Torre, José Luis, Aire dividido. Crítica a la politica del aire en el Valle de México, 1979-1996, México, El Colegio de México, 2000, p. 72. 
Esta obra forma parte del acervo de la Biblioteca Jurídica Virtual del Instituto de Investigaciones Jurídicas de la UNAM

para combatir la contaminación atmosférica en la Ciudad de México y su zona metropolitana. En efecto, fueron tres los inventarios de emisiones que a partir de la década de los ochenta —en 1989, 1994 y 1998 — han servido respectivamente para la construcción de tres programas consecutivos: el Programa Integral Contra la Contaminación Atmosférica de la Zona Metropolitana de la Ciudad de México (PICCA) de 1990, el Programa para Mejorar la Calidad del Aire en el Valle de México (Proaire 1995-2000) de 1996 y el Programa para Mejorar la Calidad del Aire de la Zona Metropolitana del Valle de México (Proaire 2002-2010) de 2002. ${ }^{16}$

Nos explica Brañes Ballesteros que los orígenes normativos (por cierto aislados) que antecedieron a la regulación atmosférica con la que actualmente cuenta este país están basados en las relaciones de vecindad, de naturaleza sanitaria o de tránsito. ${ }^{17}$ Como señala este autor, el entonces Código Civil para el Distrito Federal en materia común y para toda la República en materia federal de 1928 (en vigor a partir de 1932) en su artículo 845 señalaba disposiciones relativas a que nadie podía construir chimeneas cerca de una pared ajena o copropiedad sin guardar las distancias que establecieran los reglamentos respectivos. El vigente Código Civil Federal (a partir de 2000) conserva dicha disposición en su artículo 845. Como ha sucedido en otros países, existían en México además ordenamientos que regulaban la atmósfera desde la salud pública como el Reglamento para los Establecimientos Molestos, Insalubres o Peligrosos de 1940 o desde la perspectiva, años más tarde, de la regulación sobre cuestiones vehiculares.

Desde el punto de vista constitucional, la normatividad que sirve de base para la regulación atmosférica está contenida en los artículos 27 , párrafo cuarto, que establece que a la nación le corresponde el dominio directo del espacio situado sobre el territorio nacional, en la extensión y términos que fije el derecho internacional; 42, fracción sexta, que establece que el territorio nacional comprende, entre otras, el espacio situado sobre éste, con la extensión y modalidades que establezca el propio derecho internacional, y finalmente, 48 , que establece que el espacio situado

16 Para mayor detalle, véase Nava Escudero, César, "From homo sapiens to homo automobilis: revisiting air quality management in Mexico City", ponencia presentada en el seminario Urban Governance in Global Perspective International Workshop, University of Southern California, Los Ángeles, 17 y 18 de septiembre de 2004.

17 Brañes, Raúl, op. cit., nota 8, pp. 513 y 514. 
Esta obra forma parte del acervo de la Biblioteca Jurídica Virtual del Instituto de Investigaciones Jurídicas de la UNAM

sobre el territorio nacional dependerá directamente del gobierno de la Federación. Aunque nuestra carta magna no utilice el término atmósfera es obvio que se refiere a ella y además lo hace desde un punto de vista patrimonial. Con ello, la normativa constitucional obliga a debatir sobre las implicaciones jurídicas que giran en torno a los derechos de propiedad respecto a la utilización (para nuestro caso sobre el uso y aprovechamiento sustentables) de la atmósfera. Desde luego, existen otras disposiciones constitucionales que complementan dicha base y que están vinculadas a cuestiones ambientales. Lo son, por ejemplo, el artículo 73, fracción XXIX-G, en materia de equilibrio ecológico y la protección al ambiente del que se deriva el fundamento para la distribución de competencias, establecidas por ley del Congreso de la Unión en materia de prevención y control de la contaminación atmosférica, o el artículo 4o. relacionado con el derecho que todo mexicano tiene a un medio ambiente adecuado para su desarrollo y bienestar que deriva en el derecho a tener una adecuada calidad del aire.

A nivel legal, la legislación que emerge para combatir la contaminación atmosférica urbana fue incluida principalmente en leyes ambientales. Así se hizo con la Ley Federal para Prevenir y Controlar la Contaminación Ambiental de 1971, la Ley Federal de Protección al Ambiente de 1982 y la actual Ley General del Equilibrio Ecológico y la Protección al Ambiente de 1988 que han registrado capítulos con disposiciones jurídico-atmosféricas. Las han reglamentado diversos ordenamientos como el ya abrogado Reglamento para la Prevención y Control de la Contaminación Atmosférica Originada por la Emisión de Humos y Polvos de 1971 o los vigentes Reglamento de la Ley General del Equilibrio Ecológico y la Protección al Ambiente en materia de Prevención y Control de la Contaminación de la Atmósfera de 1988, y Reglamento de la Ley General del Equilibrio Ecológico y la Protección al Ambiente para la Prevención y Control de la Contaminación generada por los Vehículos Automotores que circulan por el Distrito Federal y los Municipios de su Zona Conurbada de 1988.

Acompañan a leyes y reglamentos otras disposiciones administrativas, de salud y/o ambientales como decretos, acuerdos, normas oficiales mexicanas, circulares relacionadas a la creación de entes públicos, establecimiento de niveles permisibles de emisión de ciertos contaminantes (incluso por actividad), prohibiciones de circulación de vehículos auto- 
Esta obra forma parte del acervo de la Biblioteca Jurídica Virtual del Instituto de Investigaciones Jurídicas de la UNAM

motores y de sujeción a verificaciones, etcétera, que hacen del derecho atmosférico normativo federal y local un ordenamiento en su conjunto muy extenso. Es interesante señalar que, además, el espacio atmosférico (como espacio aéreo) es regulado - aunque de manera muy acotadabajo la óptica patrimonial de la Ley General de Bienes Nacionales de 2004 que lo considera un bien de uso común. Situación que permite junto con la normativa constitucional (como ya hemos señalado) discutir sobre las implicaciones jurídicas que se derivan del hecho de que la atmósfera como espacio aéreo constituya un bien nacional sujeto al régimen de dominio público de la Federación.

Aunque México sea parte contratante en la mayoría de los principales documentos vinculantes que existen en materia de capa de ozono y cambio climático, las leyes ambientales no se han ocupado mucho de ellos. No obstante el tiempo que ha transcurrido desde que México suscribió dichos instrumentos internacionales, el gobierno mexicano y los legisladores de los últimos años no han incorporado estos temas atmosféricos en la legislación mexicana como se debiera y sin embargo forman parte del ordenamiento jurídico nacional.

\section{DERECHO ATMOSFÉRICO COMO CIENCIA}

El uso de la palabra atmósfera en el argot científico-jurídico es en realidad de reciente adopción. De aquí que la expresión derecho atmosférico sea poco conocida y escasamente utilizada en la literatura jurídica existente. Al igual que para el caso normativo, es conveniente dividir a lo atmosférico por periodos, regiones geográficas y grupos humanos, para poder comprender y explicar con mayor facilidad sus orígenes y desarrollo desde la óptica científica. Por lo que nuevamente señalamos a la Revolución industrial y a la crisis ambiental moderna como momentos clave para entender el inicio y evolución en la construcción científica de lo atmosférico. Es posible entonces hablar si no de un derecho atmosférico propiamente dicho, sí de un conjunto de estudios jurídicos que durante esos años dedicaban algunos espacios a analizar aunque de manera dispersa y desde la óptica de la salud pública el objeto de estudio a que se refiere esta disciplina. No lo hacían desde luego con la idea de construir jurídicamente un todo alrededor de las instituciones atmosféricas existentes y mucho menos bajo la denominación de un derecho atmosférico. 
Esta obra forma parte del acervo de la Biblioteca Jurídica Virtual del Instituto de Investigaciones Jurídicas de la UNAM

Como tampoco se incluían los recientes temas globales de la capa de ozono y el cambio climático.

Si partimos de la idea de un derecho atmosférico universal o general (como se hizo para la cuestión normativa) veremos que el estudio científico atmosférico también se ha presentado en tiempos y lugares diferentes. El análisis jurídico de la problemática atmosférica ha sido fiel acompañante de la normatividad respectiva desde un enfoque primordialmente de la salud pública. Los primeros ensayos científicos nacen como respuestas al hecho atmosférico y a la prevención y control sanitarios en la regulación. Si bien el antecedente analítico (aunque no necesariamente jurídico) más remoto sobre contaminación atmosférica apunta a la Inglaterra del siglo XVII con la obra de John Evelyn en 1661 —intitutlada Fumi Fugium - estudios subsecuentes han incluido algunas aproximaciones de carácter jurídico que incluso han servido como base para la elaboración de leyes posteriores; tal ha sido el caso en ese mismo país de las recomendaciones hechas por alguna comisión real (Royal Commission) o comité gubernamental que han dado origen, respectivamente, a leyes como la Alkali Act de 1863 y de 1874 y años más tarde a la Clean Air Act de 1956 (y posteriores de 1968 y 1993). ${ }^{18}$

Los esfuerzos por sistematizar jurídicamente algunas instituciones atmosféricas como ahora las conocemos, han transcurrido por lógica en un periodo muchísimo más corto pero en el que se han incluido nuevas formas de explicar dicha problemática y en el que han aparecido los nuevos temas globales. Aun así, siguen siendo escasas las obras (incluyendo artículos) que han intentado revisar ese conjunto de reglas, principios, teorías y conceptos fundamentales que ordenadamente y relacionadas entre sí contribuyan a una explicación amplia y detallada de las instituciones atmosféricas desde la perspectiva jurídica según la definición que hemos propuesto.

Cualquier inicio en el análisis de la cuestión atmosférica desde la óptica científica debe tener presente que el objeto de estudio de nuestra disciplina jurídica se consolida a partir de la crisis ambiental moderna (aunque ya existiera la contaminación atmosférica urbana que es, en todo caso, sólo una parte del todo atmosférico como hoy se entiende). Desde el comienzo de este proceso de consolidación, los temas atmosféricos

18 Véase para mayor detalle, Thornton, Justine y Beckwith, Silas, op. cit., nota 11, pp. 238 y 239 . 
Esta obra forma parte del acervo de la Biblioteca Jurídica Virtual del Instituto de Investigaciones Jurídicas de la UNAM

han sido revisados dentro de lo que se conoce como el derecho ambiental; esta revisión se ha hecho generalmente bajo capítulos o rubros denominados "contaminación atmosférica", "contaminación del aire", "protección de la atmósfera", "protección del aire" o "control y prevención de la contaminación atmosférica". Una mirada rápida a la literatura jurídica existente al respecto nos señala que, efectivamente, la mayoría de las obras de derecho ambiental (o de derecho de los recursos naturales) han dedicado al menos algunas líneas a las cuestiones atmosféricas, pareciera una especie de "trámite" o "requisito" necesario el que todo libro que aborde esta disciplina jurídica toque aunque sea de manera superficial este tema.

De esta manera, diversas obras sobre derecho ambiental —algunas clásicas, otras de reciente aparición - han dedicado espacio a la cuestión atmosférica. Sin que sea necesariamente una lista exhaustiva y consciente de cometer gravísimas omisiones se pueden dar algunos ejemplos en este sentido si los dividimos por países. Así, en Inglaterra: Simon Ball y Stuart Bell, ${ }^{19}$ y Justine Thornton y Silas Beckwith; ${ }^{20}$ en Francia: Michael Despax, ${ }^{21}$ y Jean Lamarque, ${ }^{22}$ en España: Carlos de Miguel Perales, ${ }^{23}$ Silvia Jaquenod, ${ }^{24}$ y Ramón Martín Mateo; ${ }^{25}$ en Estados Unidos de América: Thomas J. Schoenbaum et al.; $; 6$ en Argentina: Carlos Alfredo Botassi, ${ }^{27}$ Jorge Bustamante Alsina, ${ }^{28}$ y Guillermo J. Cano; ${ }^{29}$ en Colombia: Efraín Pérez, ${ }^{30}$ etcétera. Vale la pena señalar que en ciertos países, como en Es-

19 Ball, Simon y Bell, Stuart, Environmental Law, 2a. ed., Londres, Blackstone, 1994.

20 Thornton, Justine y Beckwith, Silas, op. cit., nota 11.

21 Despax, Michael, Droit de l'environnement, París, Librairies Techniques, 1980.

22 Lamarque, Jean, Droit de la protection de la nature et de l'environnement, París, Librairie Générales de Droit et de Jurisprudence, 1973.

23 Miguel Perales, Carlos de, Derecho español del medio ambiente, 2a. ed., Madrid, Civitas, 2002.

24 Jaquenod, Silvia, Derecho ambiental, Madrid, Dykinson, 2002.

25 Martín Mateo, Ramón, op. cit., nota 10.

26 Schoenbaum, Thomas J. et al., Environmental Policy Law, 4a. ed., Nueva York, Foundation Press, 2002.

27 Botassi, Carlos Alfredo, Derecho administrativo ambiental, La Plata, Librería Editora Platense, 1997.

28 Bustamante Alsina, Jorge, Derecho ambiental, Buenos Aires, Abeledo-Perrot, 1995.

29 Cano, Guillermo J., Derecho, política y administración ambientales, Buenos Aires, Ediciones Depalma, 1978.

30 Pérez, Efraín, Derecho ambiental, Santa Fe de Bogotá, McGraw-Hill, 2000. 
Esta obra forma parte del acervo de la Biblioteca Jurídica Virtual del Instituto de Investigaciones Jurídicas de la UNAM

paña, se han hecho trabajos muy interesantes (a modo de artículos) como lo son el de Ramón Martín Mateo, ${ }^{31}$ el de Demetrio Loperena Rota, ${ }^{32}$ y el de Fernando López Ramón. ${ }^{33}$ México ha hecho lo suyo en el mismo sentido, es decir, las obras que se han publicado sobre derecho ambiental, también han dedicado algo de espacio al tratamiento de la cuestión atmosférica. Destacan, por ejemplo, las de Carla D. Aceves Ávila, ${ }^{34}$ Edgard Baqueiro Rojas, ${ }^{35}$ Raúl Brañes Ballesteros, ${ }^{36}$ María del Carmen Carmona Lara, ${ }^{37}$ y Raquel Gutiérrez Nájera, ${ }^{38}$ sólo por mencionar algunos de ellos. Desde luego, existen algunos, muy pocos, artículos en revistas o en obras conjuntas que se han ocupado del tema, como por ejemplo la excelente contribución que hace Miguel Ángel Cancino Aguilar ${ }^{39}$ sobre la prevención y el control de la contaminación atmosférica en una obra conjunta de derecho ambiental editada por la Universidad Autónoma Metropolitana.

Como toda rama del derecho, el atmosférico también analiza y estudia conceptos, principios o reglas enlazados entre sí. Como ya se dijo en el primer apartado de este trabajo, nuestra disciplina se apoya en criterios o figuras jurídicas desarrolladas en otras disciplinas; sin embargo, muchos de estos conceptos, principios o figuras consagradas en el derecho administrativo, ambiental, internacional o urbano, han nacido a partir de planteamientos atmosféricos. Diríamos que algunos de ellos se explican y son propios de la problemática atmosférica. Por ejemplo, los conceptos de capa de ozono, gases de efecto invernadero, lluvia ácida, sumideros, cap-

31 Martín Mateo, Ramón, "El derecho de la atmósfera", Revista de Administración Pública, núm. 121, enero-abril de 1990, pp. 89-148.

32 Loperena Rota, Demetrio, op. cit., nota 12.

33 López Ramón, Fernando, op. cit., nota 7.

34 Aceves, Carla D., Bases fundamentales de derecho ambiental mexicano, México, Porrúa, 2002.

35 Baqueiro Rojas, Edgard, Introducción al derecho ecológico, México, Oxford University Press-Harla, 1997.

36 Brañes, Raúl, op. cit., nota 8.

37 Carmona Lara, María del Carmen, "Derecho ecológico", El derecho en México. Una visión de conjunto, México, UNAM, Instituto de Investigaciones Jurídicas, t. III, 1991.

38 Gutiérrez Nájera, Raquel, Introducción al estudio del derecho ambiental, 2a. ed., México, Porrúa, 1999.

39 Cancino Aguilar, Miguel Ángel, "El marco jurídico para la prevención y control de la contaminación atmosférica”, en González Márquez, José Juan (coord.), Derecho ambiental, México, Universidad Autónoma Metropolitana, 1994. 
Esta obra forma parte del acervo de la Biblioteca Jurídica Virtual del Instituto de Investigaciones Jurídicas de la UNAM

tura de carbono, contingencias atmosféricas, episodios críticos, fuentes fijas y móviles, centros de verificación, etcétera. Asimismo, hay principios que tienen una explicación en torno a un fenómeno atmosférico aunque hayan sido recogidos científicamente por el derecho ambiental o el derecho internacional. Tal es el caso del principio de precaución consagrado por vez primera en un instrumento internacional vinculante de corte atmosférico como lo es el Convenio de Viena para la Protección de la Capa de Ozono de 1985, e incorporado posteriormente en otros instrumentos atmosféricos (y no atmosféricos) también vinculantes como el protocolo de Montreal sobre capa de ozono de 1987 o la Convención Marco de las Naciones Unidas sobre el Cambio Climático de 1992). ${ }^{40}$ Otros principios tienen una lógica constitutiva a partir de un cuestionamiento atmosférico aunque no son excluyentes de aplicarse a otras materias, como es el principio sobre responsabilidades comunes pero diferenciadas en torno al tema del cambio climático y consagrado en el artículo 3o., párrafo 1, de la Convención Marco sobre Cambio Climático. Desde luego, muchas figuras jurídicas son, como actos jurídicos, ampliamente exploradas dentro del derecho administrativo, como licencias, permisos, infracciones, multas, etcétera.

Por último, es importante insistir en que más que discutir sobre el tronco propio o autónomo del derecho atmosférico, se debe atender a las relaciones que guarda con las demás disciplinas jurídicas. Es clara, por ejemplo, la relación que guarda no sólo con las ramas jurídicas arriba señaladas, sino también con el derecho forestal (i. e. en cuanto a la captura de bióxido de carbono), el derecho del mar ( $i$. e. por la influencia que tienen mares y océanos con los ciclos climáticos), con el derecho tributario o fiscal (i. e. en la creación de incentivos fiscales para el uso de energías amigables a la atmósfera), derecho civil (i. e. en materia de responsabilidades), derecho mercantil o corporativo (i. e. para el establecimiento de seguros y fianzas), derecho agrario ( $i$. e. por el uso de agroquímicos), etcétera.

40 Véase Nava Escudero, César, "El principio de precaución en el derecho internacional ambiental", Derecho Ambiental y Ecología, año 1, núm. 2, agosto-septiembre de 2004, pp. 5-7. 
Esta obra forma parte del acervo de la Biblioteca Jurídica Virtual del Instituto de Investigaciones Jurídicas de la UNAM

\section{CONCLUSIÓN: ¿DERECHO ATMOSFÉRICO AMBIENTAL?}

En principio, toda conclusión debe reflejar de algún modo lo que se dijo en los capítulos o secciones desarrolladas. Pues bien, así lo haremos y habremos de resaltar cuatro puntos.

Primero, es ya conveniente contar con una disciplina jurídica a la que llamemos derecho atmosférico no sólo por razones de abundancia normativa (e incipiente presencia científico-jurídica aunque poco ordenada), sino por la trascendencia jurídica y enriquecimiento que tendría hacia otras ramas jurídicas, así como por su contribución al desarrollo interdisciplinario con otras ciencias: química, sociología, urbanismo, economía, etcétera. Un planteamiento sistemático desde la óptica jurídica es primordial ante un fenómeno que ha removido conciencias a nivel global y acercado posiciones de política pública entre países del norte y del sur.

Segundo, aunque la discusión sobre si la autonomía del derecho atmosférico sea indispensable para establecer el contenido o delimitación de su objeto de estudio (aspecto ontológico), sus fines (aspecto teleológico), sus procesos de investigación (aspecto metodológico) y sus principios o valores (aspecto axiológico), se requiere de un mayor espacio con el que aquí se cuenta para ello. Es preferible en este contexto referirnos a sus aspectos normativo y científico que no le quitan en lo absoluto la posibilidad de su existencia. Y con ello se explican - aunque no de manera lineal- los orígenes y desarrollo de las instituciones atmosféricas. En los hechos, el ser humano comenzó a modificar la atmósfera hace quizá más de 700000 años cuando aprendió a utilizar el fuego y sobre el que tuvo marcado control hacia el término de la última glaciación hace aproximadamente 10000 años; ${ }^{41}$ sin embargo, cualquier acercamiento jurídico que se haga a esta disciplina por vía de su regulación o su estudio obliga a considerar dos hechos de vital importancia: la Revolución industrial del siglo XVIII y la crisis ambiental de finales del siglo XX.

Tercero, el derecho atmosférico cubre principalmente cuatro grandes áreas: la contaminación atmosférica urbana, la lluvia ácida, el adelgazamiento de la capa de ozono y el cambio climático. Sin embargo, hay que

41 Brom, Juan, Para comprender la historia, 2a. ed., México, Grijalbo, 2003, p. 70, y Mannion, Antoinette M., "Environmental Change: Lessons from the Past", en Mannion, Antoinette M. y Bowlby Sophia R. (comps.), Environmental Issues in the 1990s, Chichester, Wiley, 1992, p. 55. 
Esta obra forma parte del acervo de la Biblioteca Jurídica Virtual del Instituto de Investigaciones Jurídicas de la UNAM

considerar que otros temas o fenómenos tienen cabida en esta disciplina según la hemos definido, ya que ocurren asimismo en la atmósfera las radiaciones electromagnéticas o la contaminación por olores o ruido. Independientemente de esto, cada tema ha desarrollado sus propios conceptos y principios, muchos de los cuales han tenido su origen precisamente dentro de la cuestión atmosférica (ya sea global, regional, metropolitana o local).

Cuarto, México ha desarrollado una considerable legislación atmosférica pero no ha incorporado a su ordenamiento doméstico los temas globales de mayor importancia (no obstante haber suscrito los instrumentos jurídicos internacionales que los regulan): capa de ozono y cambio climático. Mientras que la regulación interna de todas las instituciones atmosféricas está dispersa y es insuficiente, los estudios que se han elaborado al respecto en los últimos años incluyen principalmente apartados o capítulos dentro de obras de derecho ambiental. Hace falta una visión sistémica de lo atmosférico a partir de la óptica jurídica.

Hasta aquí lo dicho en las secciones intermedias. Ahora quisiera referirme al título que lleva este artículo "Hacia un derecho atmosférico ambiental" y que no fue abordado explícitamente en esas secciones. Lo que explicaré a continuación se infiere de la lectura de todo el artículo y lo dejamos, precisamente y para ponerlo en términos musicales, para la coda de esta conclusión.

Con la expresión derecho atmosférico ambiental lo que se quiere es simplemente enfatizar la conveniencia de insertar en el derecho atmosférico la dimensión ambiental y referirse así al estudio de la cuestión atmosférica en este milenio que comienza. Esto porque el nuevo enfoque ambiental le da un giro impresionante a la regulación y estudio de lo relativo a la atmósfera. En efecto, antes del surgimiento del movimiento ambientalista en las décadas de los sesenta y setenta del siglo pasado, tanto la normativa como el análisis de las cuestiones atmosféricas tenían un enfoque fundamentalmente de salud pública o sanitaria, se concretaban a tratarlas como un problema local y/o metropolitano y estaban constreñidas principalmente a la llamada contaminación atmosférica urbana. No obstante lo anterior, a partir de la crisis ambiental moderna se le da un nuevo enfoque al tratamiento de la contaminación urbana y la incorpora de inmediato a la normativa y estudio ambientales sin que se deje 
Esta obra forma parte del acervo de la Biblioteca Jurídica Virtual del Instituto de Investigaciones Jurídicas de la UNAM

por completo el enfoque de la salud pública, al que por cierto habrá de llamársele salud ambiental.

Al mismo tiempo, la crisis ambiental incorpora al menos dos temas importantísimos: capa de ozono y cambio climático por dos razones fundamentales. Primero porque se hacen descubrimientos científicos que dan cuenta de su presencia y desarrollo precisamente durante esos años, y segundo, porque paralelamente se produjo una suerte de conciencia ambiental global alrededor de ellos. Estos dos temas ahora se discuten en foros ambientales, los instrumentos jurídicos internacionales son parte del derecho internacional ambiental, su tratamiento a nivel normativo se incorpora en la legislación ambiental doméstica y se han creado unidades administrativas casi siempre dentro del ámbito o sector ambiental a nivel gubernamental.

Con todo lo anterior, es posible concluir diciendo que el templo del derecho atmosférico se constituye por un basamento, naves, columnas, capiteles y dinteles anteriores a la crisis ambiental moderna. Los frisos, metopas, figuras y frontones ocurren a partir de una crisis ambiental que no ha dejado de existir. A todo ese templo se le denomina derecho atmosférico ambiental. 
Esta obra forma parte del acervo de la Biblioteca Jurídica Virtual del Instituto de Investigaciones Jurídicas de la UNAM

DE HOMO SAPIENS A HOMO AUTOMOBILIS: REVISITANDO LA GESTIÓN DE LA CALIDAD DEL AIRE EN LA CIUDAD DE MÉXICO*

Me encanta el coche. Con él he pasado las horas más hermosas de mi vida. ${ }^{1}$

\section{INTRODUCCIÓN}

A lo largo de las últimas décadas la Ciudad de México ha experimentado, al igual que otras grandes ciudades en el mundo, un proceso de motorización masiva. Winfried Wolf acuñó hacia finales del siglo pasado una frase para explicar este fenómeno global: "La primera reivindicación de una sociedad de automóviles es que el automóvil es para todos: todos tienen uno o al menos lo desean". 2

Aunque la frase de Wolf podría describir lo que ocurre actualmente en la Ciudad de México, una gran mayoría de quienes habitan en ella y sus zonas conurbadas aún no poseen ni tienen, paradójicamente, acceso a un automóvil. Pero esto no ha sido óbice para que tanto los que conducen un vehículo como los que no lo hacen, sufran de las mismas consecuencias: aire contaminado, impactos negativos en la salud, congestionamientos viales, accidentes de tránsito, etcétera. No es aventurado afirmar que el disparatado aumento en el número y uso de vehículos automotores ha convertido a la capital de nuestro país en un prototipo de centro urbano diseñado para automóviles.

* Título original: "From homo sapiens to homo automobilis. Revisiting Air Quality Management in Mexico City", publicado en Boletín Mexicano de Derecho Comparado, México, nueva serie, año XLI, núm. 121, enero-abril de 2008.

1 Palabras de Adolfo Hitler. En inglés, la cita se lee: I love the car. It has given me the most beautiful hours of my life. Véase Wolf, Winfried, Car Mania. A Critical History of Transport, Londres, Pluto, 1996, p. 65.

2 Ibidem, p. 150. En inglés, la cita se lee: The first claim of the car society is that the car is for everyone: everyone either has a car o wants to have one. 
Esta obra forma parte del acervo de la Biblioteca Jurídica Virtual del Instituto de Investigaciones Jurídicas de la UNAM

Este trabajo tiene por objeto revisitar quince años (1990-2005) de gestión de calidad del aire en la Ciudad de México. A partir de un análisis sobre el crecimiento urbano y poblacional a nivel metropolitano, se examina la respuesta que durante este periodo han tenido las autoridades mexicanas en el control y combate de la contaminación atmosférica. Mientras que la preocupación actual de la contaminación del aire en la Ciudad de México está básicamente relacionada con los niveles de concentración que rebasan los parámetros recomendados para la salud, este artículo hace hincapié en que dichos niveles han sido el resultado de emisiones que provienen de vehículos automotores, principalmente de autos particulares. De modo que pretendemos señalar que si bien se han alcanzado algunas metas a través de diversas estrategias de gestión de la calidad del aire (vinculadas primordialmente al uso de tecnologías limpias y a la implementación de ciertas medidas de tránsito vehicular), el crecimiento absurdo en el número y uso de autos privados podría obstaculizar seriamente los esfuerzos del gobierno para alcanzar y mantener una calidad de aire urbano saludable en la Ciudad de México.

\section{LA CIUDAD DE MÉXICO EN 2000:}

\section{LA SEGUNDA MEGA-CIUDAD EN EL MUNDO}

Al comenzar el nuevo milenio, la Ciudad de México se ubicó como una de las tres ciudades más grandes en el mundo: con sus 18.1 millones de habitantes comparte con Bombay (India) el segundo lugar de una lista de 30 mega-ciudades. Como se observa en la tabla 1, la Ciudad de México se encuentra por debajo de Tokio (Japón) que cuenta con 26.4 millones de habitantes, y ligeramente por encima de Sao Paulo (Brasil) y de Nueva York (Estados Unidos de América) con 17.8 y 16.6 millones de habitantes respectivamente. Aunque para 2010 Tokio permanecerá en el primer lugar de dicha lista de mega-ciudades y Bombay ascenderá al segundo sitio seguido de Lagos (Nigeria) en tercero, es muy probable que la Ciudad de México se mantenga de cualquier manera dentro de las 7 ciudades más pobladas del planeta. ${ }^{3}$

3 Para más detalles, véase United Nations Centre for Human Settlements, The State of the World's Cities Report 2001, United Nations Centre for Human SettlementsHABITAT, 2001, http://www.unchs.org. 
Esta obra forma parte del acervo de la Biblioteca Jurídica Virtual del Instituto de Investigaciones Jurídicas de la UNAM

TABLA 1

Las ciudades más grandes del mundo (millones de habitantes)

\begin{tabular}{|c|r|r|r|}
\hline Rango & \multicolumn{1}{|c|}{1990} & \multicolumn{1}{c|}{2000} & \multicolumn{1}{c|}{2010} \\
\hline 1 & Tokio 25.1 & Tokio 26.4 & Tokio 26.4 \\
\hline 2 & Nueva York 16.1 & Ciudad de México 18.1 & Bombay 23.6 \\
\hline 3 & Ciudad de México 15.1 & Bombay 18.1 & Lagos 20.2 \\
\hline 4 & Sao Paulo 15.1 & Sao Paulo 17.8 & Sao Paulo 19.7 \\
\hline 5 & Shangai 13.3 & Nueva York 16.6 & Ciudad de México 18.7 \\
\hline 6 & Bombay 12.2 & Lagos 13.4 & Dhaka 18.4 \\
\hline 7 & Los Ángeles 11.5 & Los Ángeles 13.1 & Nueva York 17.2 \\
\hline
\end{tabular}

Fuente: Adaptada de United Nations Centre for Human Settlements, 2001.

Ahora bien, debemos aclarar que el número de habitantes que se señala en la tabla 1 para el caso mexicano, es un indicador estadístico que no corresponde a lo que hoy se considera propiamente como Ciudad de México. En efecto, desde 1993 la Ciudad de México es el Distrito Federal, sede de los poderes de la Unión y capital de los Estados Unidos Mexicanos tal y como se establece en el artículo 44 de la Constitución Política de los Estados Unidos Mexicanos. De modo que el espacio territorial de la Ciudad de México coincide con los límites físicos del Distrito Federal que cuenta con una población de 8.6 millones de habitantes y que comprende una extensión de $1486 \mathrm{kms}^{2}$ de los cuales el $41 \%$ es urbano y el restante 59\% rural (suelo de conservación, pastoreo y agricultura).

Desde un punto de vista histórico, el área geográfica de la Ciudad de México se había identificado tradicionalmente, por lo menos hasta antes de 1993, con el espacio ocupado por el área urbana contigua independientemente de los límites territoriales del Distrito Federal. Este último fue creado en 1824 con un área de $8.8 \mathrm{kms}^{2}$ (un radio de cinco millas alrededor del perímetro central de la ciudad) y por razones de tipo político se le ubicó en el corazón de la Ciudad de México la cual ocupaba en aquel entonces una extensión territorial de $390 \mathrm{kms}^{2}$. A lo largo del siglo XIX y debido a los disturbios políticos y sociales ocurridos en el país durante ese periodo, tanto el Distrito Federal como la Ciudad de México sufrieron un sinnúmero de cambios tanto en sus límites territoriales como en 
Esta obra forma parte del acervo de la Biblioteca Jurídica Virtual del Instituto de Investigaciones Jurídicas de la UNAM

las estructuras locales de gobierno. No fue sino hasta 1898 que se llevó a cabo una enorme reorganización del Distrito Federal en la que se ampliaron sus fronteras físicas a como existen en la actualidad; hacia finales de ese mismo siglo, la Ciudad de México había quedado confinada a lo que se conoce como "primer cuadro de la ciudad" con una extensión de 20 $\mathrm{kms}^{2}$ y dentro de la nueva demarcación territorial del Distrito Federal. ${ }^{4}$

Aunque los actuales límites del Distrito Federal no se han modificado desde su creación en 1898, los de la Ciudad de México sí. En efecto, poco después de terminada la Revolución mexicana, el área urbana de la ciudad comenzó a expandirse y se observó un rápido crecimiento para el periodo 1917-1950 que permaneció dentro del territorio del Distrito Federal. Sin embargo, a partir de la década de los cincuenta, la mancha urbana de la Ciudad de México empezó a extenderse hacia la vecina entidad federativa del Estado de México, con lo que comenzó el proceso de conurbación de diversos municipios cercanos al Distrito Federal. Como se observa en la tabla 2, durante las cuatro primeras décadas que comprende este fenómeno (i. e. 1950-1990), la población aumentó sorprendentemente de 3.1 a 14.5 millones de habitantes con un extensión urbana de más de $1250 \mathrm{kms}^{2}$ para $1990 .^{5}$

Iniciada la década de los noventa, a la Ciudad de México y a su zona conurbada se le identificaba con las siguientes expresiones: Zona Metropolitana de la Ciudad de México (ZMCM), Zona Metropolitana del Valle de México (ZMVM) y Área Metropolitana de la Ciudad de México (AMCM); cada una de ellas utilizada indistintamente según el número de municipios conurbados. ${ }^{6}$ Por ejemplo, mientras que la ZMCM se refería a un espacio físico de $3399 \mathrm{kms}^{2}$ con un población total de 14.5 millones de habitantes, el AMCM abarcaba una extensión de $4650 \mathrm{kms}^{2}$ con una

4 Nava Escudero, César, Urban Environmental Governance: Comparing Air Quality Management in London and Mexico City, Aldershot, Ashgate, 2001, y Ward, Peter, Mexico City, Londres, Belhaven, 1990.

5 Véase, para una descripción más detallada, Gamboa de Buen, Jorge, Ciudad de México, una visión, México, Fondo de Cultura Económica, 1994, y Nava Escudero, César, op. cit., nota anterior.

6 Instituto Nacional de Estadística, Geografía e Informática, Estadísticas del Medio Ambiente. México 1997, México, Instituto Nacional de Estadística, Geografía e Informática, 1998. 
Esta obra forma parte del acervo de la Biblioteca Jurídica Virtual del Instituto de Investigaciones Jurídicas de la UNAM

población total de 15.0 millones de habitantes (estas últimas cifras correspondían a la definición estadística de metrópolis). ${ }^{7}$

TABLA 2

Crecimiento poblacional y urbano en la $Z M C M^{*}$

\begin{tabular}{|c|c|c|c|c|}
\hline Año & $\begin{array}{c}\text { ZMCM } \\
\text { Población } \\
\text { (millones) }\end{array}$ & $\begin{array}{c}\text { Área urbana } \\
\text { dentro del } \\
\text { Distrito } \\
\text { Federal }\left(\mathrm{kms}^{2}\right)\end{array}$ & $\begin{array}{c}\text { Área urbana } \\
\text { dentro y fuera } \\
\text { del Distrito } \\
\text { Federal }\left(\mathrm{kms}^{2}\right)\end{array}$ & $\begin{array}{l}\text { Área total de } \\
\text { la } \mathrm{ZMCM} \\
\text { (urbana y } \\
\text { rural) }\left(\mathrm{kms}^{2}\right)\end{array}$ \\
\hline 1917 & .9 & 62 & - & \\
\hline 1928 & 1.2 & 62 & - & \\
\hline 1941 & 1.7 & 99 & - & \\
\hline 1950 & 3.1 & 151 & - & \\
\hline 1953 & & & inicia conurbación & \\
\hline 1959 & 4.8 & 210 & 223 & \\
\hline 1970 & 6.8 & 309 & 384 & \\
\hline 1980 & 8.8 & - & 750 & \\
\hline 1990 & 14.5 & 634 & 1250 & 3399 \\
\hline 1995 & 17.0 & - & 1325 & - \\
\hline 2000 & 18.1 & 625 & 1450 & 3540 \\
\hline 2010 & 18.7 a $20.5 ?$ & - & 1626 & - \\
\hline 2020 & $22.5 ?$ & - & 1748 & - \\
\hline
\end{tabular}

* Los datos para 1990 y 2000 corresponden a la ZMCM que abarca 16 delegaciones del Distrito Federal y 17 y 18 municipios conurbados del Estado de México, respectivamente.

Fuente: Adaptada de Gamboa de Buen, 1994; Nava Escudero, 2001; Comisión Ambiental Metropolitana et al., 2002; United Nations Centre for Human Settlements, 2001.

7 La información sobre estos datos históricos puede obtenerse en publicaciones gubernamentales del Instituto Nacional de Estadística, Geografía e Informática como lo son Ciudad de México (Area Metropolitana). Resultados definitivos. Tabulados básicos, Aguascalientes, XI Censo General de Población y Vivienda 1990, Instituto Nacional de Estadística, Geografía e Informática, 1992, y Estadísticas históricas de México, 3a. ed., Aguascalientes, Instituto Nacional de Estadística, Geografía e Informática, vols. I y II, 1994. 
Esta obra forma parte del acervo de la Biblioteca Jurídica Virtual del Instituto de Investigaciones Jurídicas de la UNAM

Hacia la segunda mitad de la década de los noventa, los límites territoriales metropolitanos de la Ciudad de México y las cifras del aumento poblacional se volvieron a modificar ante el creciente fenómeno de conurbación. Por ejemplo, para 1995 se cambió el concepto de AMCM (a veces llamada zona metropolitana) para referirse a una misma extensión física (es decir, $4650 \mathrm{kms}^{2}$ ) pero ahora con 16.6 millones de habitantes y abarcando 16 delegaciones del Distrito Federal y 28 municipios del Estado de México (situación por demás confusa). ${ }^{8}$

Para 2000, se adoptó una nueva definición metropolitana (para efectos de transporte y vialidad) y por consiguiente la extensión territorial de la Ciudad de México y su zona conurbada aumentó a más de $7410 \mathrm{kms}^{2}$ con una población total de 18.3 millones abarcando 16 delegaciones del Distrito Federal, 58 municipios conurbados del Estado de México y 1 municipio de otra entidad federativa cercana: el estado de Hidalgo. ${ }^{9}$ Mientras que esta definición es la que se sigue utilizando en estos primeros años del siglo XXI, un nuevo término empieza a acuñarse para describir un espacio mucho más grande para la Ciudad de México y que es el de "megalópolis". Este vocablo se refiere a la idea de un área como ciudad-región con un total de 26.8 millones de habitantes en un espacio geográfico que abarca alrededor de 265 unidades locales de gobierno comprendidas en el Distrito Federal y 5 entidades federativas. Hablamos aquí de 16 delegaciones del Distrito Federal, 99 municipios del Estado de México, 31 de Hidalgo, 31 de Morelos, 36 de Puebla y 52 de Tlaxcala. ${ }^{10}$

No obstante todo lo anterior, es fundamental precisar que el término que la mayoría de los documentos gubernamentales han utilizado en relación con la gestión de la calidad del aire es el de zona metropolitana. Al hacerlo, se han referido a las expresiones ZMCM y/o ZMVM. De hecho, los últimos tres (y más importantes) programas oficiales que han sido elaborados específicamente para combatir el problema urbano-ambiental de la contaminación atmosférica en la ciudad capital —nos referimos a: $i$ ) Programa Integral Contra la Contaminación Atmosférica de la Zona Metropolitana de la Ciudad de México (PICCA) de 1990; ii) Programa para

8 Instituto Nacional de Estadística, Geografía e Informática, op. cit., nota 6 .

9 Véase Gobierno del Distrito Federal, "Programa Integral de Transporte y Vialidad 2001-2006 (Pitvi 2001-2006)", Gaceta Oficial del Distrito Federal, México, Gobierno del Distrito Federal, 2002.

10 Idem. 
Esta obra forma parte del acervo de la Biblioteca Jurídica Virtual del Instituto de Investigaciones Jurídicas de la UNAM

Mejorar la Calidad del Aire en el Valle de México (Proaire 1995-2000) de 1996, y iii) Programa para Mejorar la Calidad del Aire de la Zona Metropolitana del Valle de México (Proaire 2002-2010) de 2002 - han usado esas dos categorías conceptuales. Al mismo tiempo, también es indispensable precisar que los documentos oficiales vinculados a los temas de transporte y vialidad en la ciudad se refieren generalmente a espacios metropolitanos mucho más extensos, y de aquí que utilicen la expresión de AMCM y/o una versión ampliada del concepto de ZMCM. ${ }^{11}$ Aunque por esta razón algunos datos estadísticos no coinciden a nivel metropolitano, los porcentajes que se manejan desde los programas atmosféricos para determinar la contribución del sector transporte al problema de la contaminación atmosférica en la ZMCM, son los que se aplican para el análisis en el diseño de políticas públicas. ${ }^{12}$

Por lo tanto, a pesar del gran número de documentos gubernamentales (federales y/o locales) que proporcionan valiosísima información estadística para el análisis del desarrollo social, económico y ambiental de la Ciudad de México, aún no existe una definición única sobre lo que realmente constituye la ZMCM. De manera que para los fines de este trabajo y siguiendo lo que al efecto menciona el último programa sobre gestión de la calidad del aire (i. e. Proaire 2002-2010), preferimos utilizar el término de ZMCM (también aceptamos indistintamente el de ZMVM) que se refiere a un extensión territorial de $3540 \mathrm{kms}^{2}$ con un total de $18.1 \mathrm{mi}-$ llones de habitantes conformada por 16 delegaciones del Distrito Federal y 18 municipios del Estado de México (véase la tabla 3).

11 Por un lado, el Programa Integral de Transporte y Vialidad de 1995 (Pitvi 19952000) establece que el AMCM comprende las 16 delegaciones del Distrito Federal y 28 municipios conurbados del Estado de Mexico. Por el otro, el Programa Integral de Transporte y Vialidad de 2002 (Pitvi 2001-2006), señala que la ZMCM abarca las 16 delegaciones del Distrito Federal, 58 municipios conurbados del Estado de Mexico, y 1 municipio de Hidalgo. Véanse, respectivamente, Departamento del Distrito Federal, Programa Integral de Transporte y Vialidad 1995-2000 (Pitvi 1995-2000), México, Departamento del Distrito Federal, 1995, y Gobierno del Distrito Federal, op. cit., nota 9.

12 Hacemos notar que incluso en trabajos académicos se utilizan términos distintos con contenidos diferentes. En este sentido, véase por ejemplo a Molina, Luisa T. y Molina, Mario J. (coords.), La calidad del aire en la megaciudad de México. Un enfoque integral, trad. de Dulce María Ávila, Bárbara Córcega y Silvia Ruiz de Chávez, México, Fondo de Cultura Económica, 2005. Aquí, los autores y coordinadores de la obra prefieren utilizar el término de AMCM. 
Esta obra forma parte del acervo de la Biblioteca Jurídica Virtual del Instituto de Investigaciones Jurídicas de la UNAM

TABLA 3

La Zona Metropolitana de la Ciudad de México

\begin{tabular}{|l|l|}
\hline $\begin{array}{c}\text { Distrito Federal } \\
16 \text { delegaciones }= \\
1486.4 \mathrm{kms}^{2}\end{array}$ & $\begin{array}{c}\text { Estado de México } \\
\text { municipios conurbados }= \\
2054.3 \mathrm{kms}^{2}\end{array}$ \\
\hline 1. Álvaro Obregón & 1. Atizapán de Zaragoza \\
\hline 2. Azcapotzcalco & 2. Cuautitlán Izcalli \\
\hline 3. Benito Juárez & 3. Coacalco \\
\hline 4. Coyoacán & 4. Cuautitlán \\
\hline 5. Cuajimalpa & 5. Chalco \\
\hline 6. Cuauhtémoc & 6. Chicoloapan \\
\hline 7. Gustavo A. Madero & 7. Chimalhuacán \\
\hline 8. Iztacalco & 8. Ecatepec \\
\hline 9. Iztapalapa & 9. Huixquilucan \\
\hline 10. Magdalena Contreras & 10. Ixtapaluca \\
\hline 11. Miguel Hidalgo & 11. La Paz \\
\hline 12. Milpa Alta & 12. Nicolás Romero \\
\hline 13. Tláhuac & 13. Naucalpan \\
\hline 14. Tlalpan & 14. Nezahualcóyotl \\
\hline 15. Venustiano Carranza & 15. Tecámac \\
\hline 16. Xochimilco & 16. Tlalnepantla \\
\hline & 17. Tultitlán \\
\hline & 18. Valle de Chalco \\
\hline
\end{tabular}

Fuente: Comisión Ambiental Metropolitana et al., 2002.

Por último, cabe señalar que los datos sobre crecimiento poblacional establecidos en el Proaire 2002-2010 muestran que el número total de habitantes en la ZMCM podría alcanzar los 20.5 millones para 2010 y 22.5 millones para 2020. Estas cifras toman en cuenta el hecho de que ciertos municipios habrán de incorporarse a la ZMCM en los próximos 20 años. Llama la atención tal y como se observa en la tabla 4, que el aumento de la población en el Distrito Federal se haya estancado en los últimos años. 
Esta obra forma parte del acervo de la Biblioteca Jurídica Virtual del Instituto de Investigaciones Jurídicas de la UNAM

TABLA 4

Crecimiento poblacional (miles) en la ZMCM (1950-2020)

\begin{tabular}{|c|c|c|}
\hline Año & $\begin{array}{c}\text { Población } \\
\text { en el Distrito Federal }\end{array}$ & $\begin{array}{c}\text { Población en los } \\
\text { municipios conurbados }\end{array}$ \\
\hline 1950 & 2924 & 29 \\
\hline 1960 & 4879 & 246 \\
\hline 1970 & 6934 & 1882 \\
\hline 1980 & 8029 & 4304 \\
\hline 1990 & 8235 & 6812 \\
\hline 1995 & 8489 & 8600 \\
\hline 2000 & 8796 & 9444 \\
\hline 2010 & 8084 & 11449 \\
\hline 2020 & 9330 & 12923 \\
\hline
\end{tabular}

Fuente: Comisión Ambiental Metropolitana et al., 2002.

\section{LA GESTIÓN DE LA CALIDAD DEL AIRE EN LA CIUDAD DE MÉXICO REVISITADA}

A pesar de que la presencia de aire contaminado en la Ciudad de México fue detectada por vez primera durante las décadas de los cincuenta y sesenta, no fue sino hasta 1986 que este problema se convirtió en una prioridad para el gobierno mexicano. Para ese entonces, los niveles de contaminantes urbanos tradicionales como el bióxido de azufre $\left(\mathrm{SO}_{2}\right)$, el material particulado suspendido, el plomo $(\mathrm{Pb})$ y los óxidos de nitrógeno $\left(\mathrm{NO}_{\mathrm{x}}\right)$ se encontraban ya muy por encima de los límites permisibles establecidos por la Organización Mundial de la Salud (OMS). Ante esta situación, y por el hecho de que hacia finales de la década de los ochenta la capital de México era considerada como la ciudad más contaminada de América Latina por diversos contaminantes, el gobierno mexicano impulsó en 1986 y 1987 ciertas medidas para enfrentar dicho problema.

Sin embargo, el verdadero combate a la contaminación atmosférica se inició años más tarde con la expedición de un programa mucho más estricto: el PICCA de 1990, al cual le siguieron el Proaire 1995-2000 de 
Esta obra forma parte del acervo de la Biblioteca Jurídica Virtual del Instituto de Investigaciones Jurídicas de la UNAM

1996 y el vigente Proaire 2002-2010 de 2002. Cada uno de estos tres programas estableció en su momento y con base en información de tipo estadístico, una serie de acciones políticas, objetivos gubernamentales y estrategias a seguir (en lo político-administrativo, social y legal) relativas a los niveles de contaminación, el tipo de contaminantes y sus efectos en la salud, el funcionamiento de los sistemas de monitoreo atmosférico, etcétera (véase la tabla 5).

$$
\begin{gathered}
\text { TABLA } 5 \\
\text { Programas de gestión de calidad del aire } \\
\text { para la ZMCM (1986-2010) }
\end{gathered}
$$

\begin{tabular}{|c|c|c|}
\hline Año & Nombre del programa: & Estrategias principales: \\
\hline 1987 & $\begin{array}{l}21 \text { Acciones para Reducir } \\
\text { la Contaminación del Aire } \\
100 \text { Medidas Necesarias }\end{array}$ & $\begin{array}{l}\text { - } \text { Programa de reubicación industrial } \\
\text { - } \text { Sistema de control de emisiones vehiculares } \\
\text { - } \quad \text { Red automática de monitoreo atmosférico } \\
\text { - Sustitución a gas natural en plantas termoeléctricas }\end{array}$ \\
\hline 1990 & PICCA & $\begin{array}{l}\text { - Mejoramiento en la calidad de las gasolinas } \\
\text { - Transporte } \\
\text { - Expansión del transporte público } \\
\text { - Sistema de control de emisiones vehiculares } \\
\text { - Industria y establecimiento vehicular } \\
\text { - Mejoramiento de procesos de combustión } \\
\text { - Control de emisiones y uso de gas natural (80\%) } \\
\text { - Ren plantas termoeléctricas } \\
\text { - Restauración y educación ecológicas }\end{array}$ \\
\hline 1996 & Proaire 1995-2000 & $\begin{array}{l}\text { - Industria (limpia) y establecimientos de servicio } \\
\text { - Reducción de emisiones, nuevas tecnologías } \\
\text { - Transporte y vehículos (limpión de energéticos } \\
\text { - Reducción de emisiones, nuevas tecnologías } \\
\text { - Medidas de tránsito vehicular } \\
\text { - Expansión del transporte público } \\
\text { - Recuperación ecológica y educación ambiental }\end{array}$ \\
\hline 2002 & Proaire 2002-2010 & $\begin{array}{l}\text { - Transporte y vehículos } \\
\text { - Reducción de emisiones, nuevas tecnologías } \\
\text { - Medidas de tránsito vehicular } \\
\text { - Uso de gas natural y vehículos eléctricos } \\
\text { - Expansión del transporte público } \\
\text { - } \quad \text { Nuevas vialidades (red primaria, anillos, etcétera) } \\
\text { - Reducción de emisiones, nuevas tecnologías } \\
\text { - Conso de energías renovables } \\
\text { - Conservación ecológica y educación ambiental }\end{array}$ \\
\hline
\end{tabular}

Fuente: Comisión Ambiental Metropolitana et al., 2002; Secretariado Técnico Intergubernamental, 1990, y Secretaría de Medio Ambiente, Recursos Naturales y Pesca et al., 1996. 
Esta obra forma parte del acervo de la Biblioteca Jurídica Virtual del Instituto de Investigaciones Jurídicas de la UNAM

Los resultados obtenidos durante quince años (i. e. 1990-2005) de esfuerzos gubernamentales por implementar los tres programas arriba mencionados, indican que los niveles actuales de contaminación atmosférica no son tan graves como los observados hacia finales de la década de los ochenta y principios de los noventa. La información presentada sobre el total de emisiones a la atmósfera en la ZMCM en este periodo deja entrever un escenario optimista (véase la tabla 6). En efecto, al comparar los niveles actuales de ciertos contaminantes con lo experimentado durante la década de los noventa encontramos, por un lado, que las concentraciones de plomo $(\mathrm{Pb})$, bióxido de azufre $\left(\mathrm{SO}_{2}\right)$, monóxido de carbono $(\mathrm{CO})$, o bióxido de nitrógeno $\left(\mathrm{NO}_{2}\right)$ han disminuido, y por el otro, que las concentraciones de ozono $\left(\mathrm{O}_{3}\right)$ han dejado de aumentar (véase la tabla 7).

\section{TABLA 6}

\section{Emisiones atmosféricas totales* en la ZMCM}

(millones de toneladas/año)

\begin{tabular}{|c|c|c|c|c|c|}
\hline Año & Toneladas & Año & Toneladas & Año & Toneladas \\
\hline 1972 & 2.6 & 1982 & 3.7 & 1994 & 4.0 \\
\hline 1974 & 3.3 & 1983 & 3.8 & 1996 & 3.1 \\
\hline 1976 & 3.4 & 1988 & 4.9 & 1998 & 2.4 \\
\hline 1978 & 3.4 & 1989 & 4.3 & 2004 & 3.4 \\
\hline 1980 & 3.6 & 1991 & 4.3 & 2010 & 2.7 \\
\hline
\end{tabular}

* Incluye bióxido de azufre, óxidos de nitrógeno, monóxido de carbono, hidrocarburos, material particulado suspendido como partículas suspendidas totales (PST). A partir de 1996, las PST se substituyen por partículas menores a $10 \mu \mathrm{m}$. Los datos de 2004 incluyen bióxido de azufre, óxidos de nitrógeno, monóxido de carbono, partículas menores a 10 y $2.5 \mu \mathrm{m}$, compuestos orgánicos totales, metano, compuestos orgánicos volátiles, amoníaco. La cifra estimada para 2010 está basada en la misma metodología que se usó para el inventario de emisiones de 1998 por lo que dicha cifra no considera los beneficios de reducción de la contaminación por la implementación del Proaire 2002-2010.

Fuente: Comisión Ambiental Metropolitana et al., 2002; Gobierno del Distrito Federal, 2004; Nava Escudero, César 2001; Secretaría de Medio Ambiente, Recursos Naturales y Pesca et al., 1996, y Secretaría de Medio Ambiente, Recursos Naturales y Pesca, 2000.

En síntesis, es posible afirmar sobre cada uno de estos contaminantes lo siguiente: ${ }^{13}$ i) los niveles de concentración del $\mathrm{Pb}$ han estado desde

13 Comisión Ambiental Metropolitana et al., Programa para Mejorar la Calidad del Aire de la Zona Metropolitana del Valle de México 2002-2012 (Proaire 2002-2012), México, Secretaría de Medio Ambiente y Recursos Naturales-Secretaría de Salud-Gobierno del Distrito Federal-Gobierno del Estado de México, 2002. 
Esta obra forma parte del acervo de la Biblioteca Jurídica Virtual del Instituto de Investigaciones Jurídicas de la UNAM

hace varios años por debajo de la norma mexicana de calidad del aire; ii) los niveles de contaminación del $\mathrm{SO}_{2}$ y del $\mathrm{CO}$ han rebasado la norma mexicana respectiva sólo en algunas ocasiones en los últimos años; iii) aunque se ha observado que el $\mathrm{NO}_{2}$ continúa en ocasiones por arriba de los estándares mexicanos de calidad del aire, los niveles pico ya no son tan frecuentes como lo eran en años anteriores, y iv) si bien la contaminación por $\mathrm{O}_{3}$ rebasó la norma de calidad del aire en un $80 \%$ a $90 \%$ de todos 10 s días por año durante la década de los noventa, en la actualidad no ha alcanzado los mismos niveles de concentración máxima como en ese entonces; en términos generales, dichos niveles de concentración máxima han disminuido en alrededor de un 40\% para el periodo 1990-2004. ${ }^{14}$

\section{TABLA 7}

Concentraciones por arriba de las normas de calidad del aire por contaminante (dias y trimestres para el periodo 1990-2004)

\begin{tabular}{|c|c|c|c|c|c|}
\hline Año & $\begin{array}{c}\mathrm{O}_{3} \\
\text { dias }\end{array}$ & $\begin{array}{c}\mathrm{CO} \\
\text { dias }\end{array}$ & $\begin{array}{c}\mathrm{SO}_{2} \\
\text { dias }\end{array}$ & $\begin{array}{c}\mathrm{NO}_{2} \\
\text { dias }\end{array}$ & $\begin{array}{c}\mathrm{Pb} \\
\text { trimestres }\end{array}$ \\
\hline 1990 & 325 & 141 & 11 & 31 & 4 \\
\hline 1991 & 335 & 93 & 8 & 16 & 2 \\
\hline 1992 & 317 & 56 & 29 & 8 & 1 \\
\hline 1993 & 320 & 17 & 0 & 29 & 0 \\
\hline 1994 & 340 & 11 & 0 & 28 & 0 \\
\hline 1995 & 319 & 4 & 0 & 32 & 0 \\
\hline 1996 & 317 & 6 & 0 & 84 & 0 \\
\hline 1997 & 311 & 1 & 0 & 38 & 0 \\
\hline 1998 & 305 & 4 & 0 & 30 & 0 \\
\hline 1999 & 286 & 2 & 0 & 19 & 0 \\
\hline 2000 & 308 & 1 & 1 & 23 & 0 \\
\hline 2001 & 273 & 0 & 8 & 1 & 0 \\
\hline 2002 & 280 & 0 & 0 & 0 & 0 \\
\hline 2003 & 253 & 0 & 0 & 6 & 0 \\
\hline 2004 & 225 & 0 & 0 & 3 & n.d. \\
\hline
\end{tabular}

n.d. $=$ no disponible

Fuente: Gobierno del Distrito Federal, 2004

A pesar de los datos anteriores, la Ciudad de México no ha alcanzado una calidad del aire urbana saludable. Ciertamente, la zona metropolitana

14 Gobierno del Distrito Federal, "Presentación", Medio ambiente y transporte sustentable, México, Gobierno del Distrito Federal, s.f.; http://www.sma.df.gob.mx/trans portesustentable/. 
Esta obra forma parte del acervo de la Biblioteca Jurídica Virtual del Instituto de Investigaciones Jurídicas de la UNAM

sufre todavía de concentraciones de ozono, partículas - específicamente las menores a $10 \mu \mathrm{m}\left(\mathrm{PM}_{10}\right)$ - e hidrocarburos que se encuentran por encima de los parámetros de protección de la salud (i. e. los niveles permisibles para cada uno de ellos aún se encuentran por arriba de valores internacionales). Así, por ejemplo, mientras que la OMS recomienda una concentración máxima de 0.05 a $0.10 \mathrm{ppm} 1$ hora una vez al año para ozono, el índice de calidad del aire en México - i. e. Índice Metropolitano de la Calidad del Aire (Imeca) - permite concentraciones de más de 0.23 ppm 1 hora una vez al año antes de que se tomen las medidas de emergencia necesarias para disminuir tales niveles de contaminación.

Efectivamente, la implementación del programa de emergencia para la ZMCM por la ocurrencia de episodios críticos de contaminación - antes Programa de Contingencias Ambientales ahora Programa de Contingencias Ambientales Atmosféricas (PCAA) - ${ }^{15}$ ha sido desde sus orígenes característicamente tolerante. Durante sus primeros años de existencia, el programa de emergencia para el caso del ozono se activaba en su fase I cuando los niveles de contaminación alcanzaban los 250 puntos Imeca, lo que significaba un nivel permisible de tolerancia para la protección a la salud equivalente a 0.29 ppm 1 hora una vez al año.

15 El PCAA tiene tres fases de activación: fase de pre-contingencia (para $\mathrm{O}_{3}$ o $\mathrm{PM}_{10}$ ), fase I (para $\mathrm{O}_{3}$ o $\mathrm{PM}_{10}$ o una combinación de ambos) y fase II (para $\mathrm{O}_{3}$ o $\mathrm{PM}_{10}$ ). A partir de agosto de 2006 la fase de pre-contingencia es activada para el $\mathrm{O}_{3}$ a los 170 (o más) puntos Imeca y para las $\mathrm{PM}_{10}$ a los 160 (o más) puntos Imeca. La fase I se activa para el $\mathrm{O}_{3}$ a los 200 (o más) puntos Imeca y para las PM10 a los 175 (o más) puntos Imeca; para cuando existe una combinación de ellos, la fase I se activa para el $\mathrm{O}_{3}$ a los 180 (o más) puntos Imeca y para las $\mathrm{PM}_{10}$ a los 125 (o más) puntos Imeca. La fase II se activa para el $\mathrm{O}_{3}$ a los 250 (o más) puntos Imeca y para las $\mathrm{PM}_{10}$ a los 250 (o más) puntos Imeca. Las acciones que se llevan a cabo según se trate de pre-contingencia, fase I y/o fase II incluyen, entre otras, cancelar las actividades al aire libre en las escuelas y suspender las actividades de pavimentación y/o mantenimiento (bacheo), ampliación del programa "Hoy no circula", reducción en el uso de vehículos de gobierno, diversas medidas de tránsito vehicular para disminuir los congestionamientos viales, reducción de actividades en la industria y las plantas termoeléctricas, etcétera. Para mayor detalle sobre la implementación de este programa para $\mathrm{O}_{3}$ y $\mathrm{PM}_{10}$ véase Gobierno del Distrito Federal, "Manual para la aplicación del Programa para Contingencias Ambientales Atmosféricas en el Distrito Federal", México, 2000, http://www.sma.df.gob.mx, y del mismo ente público, "Decreto por el que se reforma y adiciona el Programa para Contingencias Ambientales Atmosféricas en el Distrito Federal”, México, Gaceta Oficial del Distrito Federal, Gobierno del Distrito Federal, 2006. 
Esta obra forma parte del acervo de la Biblioteca Jurídica Virtual del Instituto de Investigaciones Jurídicas de la UNAM

En mayo de 1998 se acordó bajar el límite de tolerancia, por lo que la activación del programa para ese contaminante iniciaría su fase I cuando se alcanzaran los 241 puntos Imeca equivalente a un nivel permisible de $0.28 \mathrm{ppm} 1$ hora una vez al año. Aunque se redujeron los niveles permisibles para la implementación del programa de contingencias, de 1995 a 2000 los niveles de concentración por ozono estuvieron por encima de las recomendaciones internacionales para la protección de la salud en casi $85 \%$ de todos los días por año (i. e. $0.11 \mathrm{ppm} 1$ hora una vez al año que corresponden a 100 puntos Imeca). Para 2000, si bien los niveles de concentración máxima alcanzaron más de 200 puntos Imeca sólo en 19 ocasiones, fueron alrededor de 323 días los que se registraron por encima de las recomendaciones de la OMS; sólo se contabilizaron para ese mismo año 23 días en los que dichos niveles de concentración estuvieron por debajo de los 100 puntos Imeca. ${ }^{16}$

En 2004, seis de cada diez días estuvieron por encima de esas recomendaciones y durante los primeros seis meses de 2005 (enero-julio) la cifra se incrementó a siete de cada diez días. ${ }^{17}$ Aunque la fase I del programa de contingencias para ozono se activa en la actualidad cuando se alcanzan los 200 puntos Imeca (lo que equivale a $0.23 \mathrm{ppm} 1$ hora una vez al año), dicho nivel permisible para proteger la salud sigue siendo demasiado tolerante.

Es de suma importancia señalar que si bien la información estadística presentada por diversos documentos gubernamentales nos permiten analizar la tendencia que ha tenido la calidad del aire en la Ciudad de México para el periodo 1990-2005, esta no es del todo confiable, algunos ejemplos dan cuenta de ello.

Primero, existe cierta confusión sobre el número de ocasiones en las que el programa de emergencia ha sido activado en su fase I. En efecto, datos oficiales de principios de la década de los noventa ${ }^{18}$ señalan que el programa fue implementado 63 ocasiones en 1991, 41 en 1992 y 11 en 1993, cifras que no concuerdan con las presentadas en publicaciones gubernamentales más recientes tal y como se observa en la tabla 8 .

16 Véase, también, Comisión Ambiental Metropolitana et al., nota 13.

17 Gobierno del Distrito Federal, op. cit., nota 14.

18 Nos referimos a Comisión Metropolitana para la Prevención y Control de la Contaminación Ambiental en el Valle de México, La contaminación atmosférica en el Valle de México, México, Comisión Metropolitana para la Prevención y Control de la Contaminación Ambiental en el Valle de México, 1994. 
Esta obra forma parte del acervo de la Biblioteca Jurídica Virtual del Instituto de Investigaciones Jurídicas de la UNAM

TABLA 8

Activación del programa de contingencias ambientales (1988-2005)

\begin{tabular}{|c|c|c|c|}
\hline Año & $\begin{array}{l}\text { Pre-contingencia } \\
\text { Número de veces }\end{array}$ & $\begin{array}{c}\text { Contingencia } \\
\text { Fase } I^{*} \\
\text { Número de veces }\end{array}$ & $\begin{array}{c}\text { Contingencia } \\
\text { Fase II** } \\
\text { Número de veces }\end{array}$ \\
\hline 1988 & $\longrightarrow$ & 2 & 2 \\
\hline 1989 & $\longrightarrow$ & $\longrightarrow$ & $\longrightarrow$ \\
\hline 1990 & $\longrightarrow$ & $\longrightarrow$ & $\longrightarrow$ \\
\hline 1991 & $\square$ & 3 & 2 \\
\hline 1992 & $\longrightarrow$ & 8 & 4 \\
\hline 1993 & $\longrightarrow$ & 12 & $\longrightarrow$ \\
\hline 1994 & $\longrightarrow$ & 1 & $\longrightarrow$ \\
\hline 1995 & $\longrightarrow$ & 5 & $\longrightarrow$ \\
\hline 1996 & $\longrightarrow$ & 3 & $\longrightarrow$ \\
\hline 1997 & $\longrightarrow$ & 3 & $\longrightarrow$ \\
\hline 1998 & 77 & 5 & $\longrightarrow$ \\
\hline 1999 & 38 & 3 & $\longrightarrow$ \\
\hline 2000 & 24 & 1 & $\longrightarrow$ \\
\hline 2001 & 14 & - & $\longrightarrow$ \\
\hline 2002 & 9 & 1 & 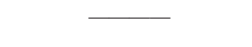 \\
\hline 2003 & 2 & 1 & $\longrightarrow$ \\
\hline 2004 & n. d. & $\longrightarrow$ & $\longrightarrow$ \\
\hline 2005 & n. d. & 1 & $\longrightarrow$ \\
\hline
\end{tabular}

* Los datos de la fase I comprenden $\mathrm{O}_{3}$ y $\mathrm{PM}_{10}$. La norma de calidad del aire para las $\mathrm{PM}_{10}$ (175 puntos Imeca) fue rebasada sólo en tres ocasiones (una vez al año): 1998, 2000 y 2003, respectivamente.

** Los datos de la fase II corresponden todos a niveles de $\mathrm{O}_{3}$.

n.d. $=$ no disponible

Fuente: Comisión Ambiental Metropolitana et al., 2002 y Gobierno del Distrito Federal, 2000 y 2007.

Segundo, los datos de las emisiones atmosféricas totales se basan en diversos inventarios de los cuales los tres más relevantes por su trascen- 
Esta obra forma parte del acervo de la Biblioteca Jurídica Virtual del Instituto de Investigaciones Jurídicas de la UNAM

dencia para la elaboración de la política de gestión de calidad del aire para el periodo que aquí se examina son los producidos en 1989, 1994 y 1998;19 estos tres inventarios de emisiones han servido de sustento estadístico para la elaboración del PICCA, el Proaire 1995-2000 y el Proaire 2002-2010, respectivamente. El problema que aquí se presenta deriva del hecho de que el inventario de emisiones de 1994 no puede compararse con su antecesor en términos absolutos (i.e. el inventario de emisiones de 1989) porque no se aplicaron los mismos supuestos y metodologías de cálculo tal y como lo reconoce abiertamente el propio Proaire 1995-2000. Algo semejante ocurre para el caso del inventario de emisiones de 1998 respecto a su antecesor inmediato (i. e. el inventario de emisiones de 1994): el Proaire 20022010 ha reconocido manifiestamente que el inventario de 1994 no es tan confiable como el de 1998.

Tercero y último, las estadísticas muestran que mientras las emisiones atmosféricas totales en un periodo de tres años bajaron de un total de 4.9 millones de toneladas al año en 1988 a 4.3 millones en 1991, en un periodo similar (menos de cuatro años) bajaron sorprendentemente de 4.0 millones en 1994 a 2.4 millones en 1998. Si esto es así, nos encontramos ante la paradoja de que mientras los niveles de contaminación atmosférica declinaban, el número y uso de vehículos (particulares) en ese mismo periodo aumentaban constantemente y el consumo de gasolinas se incrementaba gradualmente (de 1990 a 2004 dicho consumo ha subido a más del 30\%). ${ }^{20}$ ¿Cómo explicarnos que el total de emisiones disminuyó al doble sólo en unos cuantos años durante mediados de la década de los noventa?

Por lo tanto, no debemos pasar por alto el hecho de que si bien los datos y estadísticas de los tres programas gubernamentales nos permiten

19 El último de estos inventarios, el de 1998, se revisa, amplía y actualiza cada dos años. Están disponibles para consulta en este momento tres inventarios más para 2000, 2002 y 2004. La información estadística contenida en el inventario de emisiones de 2004 tiene como base todavía los mismos límites territoriales de lo que aquí hemos definido por ZMCM y que es el que maneja el Proaire 2002-2010, es decir, se trata de una extensión de $3540 \mathrm{kms}^{2}$ conformada por 16 delegaciones del Distrito Federal y 18 municipios del Estado de México. Más información sobre este inventario puede obtenerse de Gobierno del Distrito Federal, Inventario de Emisiones de la Zona Metropolitana del Valle de México, 2004, México, Gobierno del Distrito Federal, 2004, http://www.sma.df.gob.mx/sma/mo dules.php? name $=$ Aire.

20 Más detalles en idem, así como en Comisión Ambiental Metropolitana et al., op. cit., nota 13 . 
Esta obra forma parte del acervo de la Biblioteca Jurídica Virtual del Instituto de Investigaciones Jurídicas de la UNAM

comprender el desarrollo de la contaminación atmosférica en la Ciudad de México, en cada uno de ellos existen cierto tipo de imprecisiones (tal y como ha quedado demostrado a través de los tres ejemplos anteriores). Nos guste o no esta situación, confiemos o no en la información disponible, lo cierto es que esos datos y estadísticas han sido la base para el diseño e implementación de las políticas públicas en la materia. De aquí se desprende que así como ciertos contaminantes como el CO, $\mathrm{O}_{3}, \mathrm{PM}_{10}$, $\mathrm{NO}_{2}, \mathrm{SO}_{2}$ y $\mathrm{HC}$ representan en la actualidad cierto grado de preocupación — cada uno de ellos ha estado durante el periodo 1990-2005 por arriba de lo establecido por la norma mexicana de calidad del aire (algunos más que otros y con diversas niveles de concentración)—, el gobierno mexicano ha enfatizado que los contaminantes que todavía son un problema serio para la ZMCM y que se erigen como una amenaza para la salud humana, son el $\mathrm{O}_{3}$ y las $\mathrm{PM}_{10}{ }^{21}$

De manera que es posible sostener que aun cuando ya no se experimentan los alarmantes niveles de contaminación de finales de la década de los ochenta y de principios de los noventa, la calidad del aire en la ZMCM continúa siendo mala, y por lo tanto los indicadores de morbilidad y mortandad todavía son un asunto de mucha preocupación.

Para el caso de $\mathrm{O}_{3}$, las principales consecuencias en la salud humana incluyen una gran variedad de enfermedades respiratorias, ausentismo escolar en la niñez, visitas de emergencias a hospitales por asmáticos, irritación de ojos, naríz y garganta, tos, dolores de cabeza, etcétera. Los grupos más vulnerables a los impactos de este contaminante son los niños, los adultos de la tercera edad y/o todos aquellos que padezcan asma o enfermedades cardiovasculares. Para el caso de las $\mathrm{PM}_{10}$, los actuales niveles de contaminación afectan los pulmones, producen crecientes síntomas de enfermedades respiratorias, aumentan el número de visitas a hospitales por bronquitis en niños y adultos, etcétera.

Los elevados niveles de contaminación atmosférica en la ZMCM también han contribuido a un incremento de muertes prematuras. En efecto, no debemos olvidar que algunos estudios han señalado que existe una

21 De hecho, esto ha sido reconocido por el gobierno desde 2000 según los siguientes documentos oficiales: Secretaría de Medio Ambiente, Recursos Naturales y Pesca, Gestión de la Calidad del Aire en México, México, Secretaría de Medio Ambiente, Recursos Naturales y Pesca, 2000, y también Comisión Ambiental Metropolitana et al., op. cit., nota 13. Algunos científicos han manifestado asimismo sus preocupaciones por esos dos contaminantes: véase Molina, Luisa T. y Molina, Mario J. (coords.) op. cit., nota 12, p. 89. 
Esta obra forma parte del acervo de la Biblioteca Jurídica Virtual del Instituto de Investigaciones Jurídicas de la UNAM

correlación entre altas concentraciones de ciertos contaminantes en la atmósfera y un aumento en los índices de mortalidad.

Un estudio realizado para el Banco Mundial en 1992, estimó que según cálculos conservadores existe una relación significativa entre las partículas suspendidas totales (PST) y los índices de mortandad. Basado en los niveles de contaminación de PST en la Ciudad de México durante 1990, el número total estimado (estadísticamente) en vidas que pudieron haberse salvado fue de 6400: cifra equivalente a 3.8 vidas por cada 10000 habitantes. ${ }^{22}$

Aunado a lo anterior, estudios recientes sobre análisis de índices de mortandad realizados por la Universidad de Harvard, han concluido que alrededor de 1000 vidas por año podrían salvarse si sólo el $10 \%$ de los actuales niveles de $\mathrm{PM}_{10}$ disminuyeran; la misma reducción de un 10\% en los niveles de $\mathrm{O}_{3}$ podrían salvar cientos de vidas por año en la capital del país. ${ }^{23}$

\section{HACIA UNA MEGA-CIUDAD DE AUTOMÓVILES}

Es excesivamente desmedido — sin que esto sea una exageración-el incremento en el número de automóviles (vehículos automotores) que en las últimas décadas ha experimentado la Ciudad de México. En verdad que son escalofriantes las cifras oficiales sobre este disparatado crecimiento que comprende desde autos particulares hasta taxis, combis y microbuses, pick ups, motocicletas y vehículos a gasolina, diesel y gas LP (camiones de carga, tractocamiones, autobuses y vehículos de diverso tonelaje: de 3 y de menos o más toneladas).

Al momento de escribir (principios de 2007), el número total de vehículos de superficie se estima en poco más 4.5 millones para la ZMCM

22 Nava Escudero, César, op. cit., nota 4, p. 35. En inglés, la cita se lee: In another study, carried out for the World Bank in 1992, conservative calculations suggested that there was a significant relation between total suspended matter (TSP) and mortality rates. Based on the levels of TSP pollution in Mexico City during 1990, the estimated total number of (statistical) lives saved would have been 6,400-equivalent to 3.8 lives per 10000 people. Información obtenida de Margulis, Sergio, "Back-of-the-Envelope Estimates of Environmental Damage Cost in Mexico", Working Papers, Washington, Banco Mundial, enero de 1992, p. 13.

23 Comisión Ambiental Metropolitana et al., op. cit., nota 13. 
Esta obra forma parte del acervo de la Biblioteca Jurídica Virtual del Instituto de Investigaciones Jurídicas de la UNAM

con un crecimiento anual de alrededor de $5.9 \%$ (con un retiro de la circulación de $3.9 \%$ ). Se calcula por lo tanto que en la actualidad ingresan cada año a la zona metropolitana cerca de 175000 vehículos nuevos. Sólo para la presente década los datos y estimaciones sobre el proceso de crecimiento de la flota vehicular - que representa el $47 \%$ del consumo total de energía para toda la zona metropolitana - son impresionantes: de 3.5 millones de vehículos para 2000 y de 4.5 millones para 2006, se llegará a un total de 5.4 millones para $2010 .^{24}$

Como se observa en la tabla 9 , de todos los automóviles que circulan en la ZMCM los autos particulares son los de mayor número y son los que tienen el porcentaje de mayor crecimiento. El propio gobierno del Distrito Federal ha documentado recientemente el rápido crecimiento de los autos particulares en el Distrito Federal para el periodo 1940-2000. Fue a partir de la década de los sesenta que el crecimiento masivo de vehículos privados comenzó en la capital del país (véase la tabla 10).

\section{TABLA 9}

Número total de vehículos en la ZMCM (2000-2010)

\begin{tabular}{|c|r|r|r|}
\hline Tipo of vehículo & \multicolumn{1}{|c|}{2000} & \multicolumn{1}{c|}{2006} & \multicolumn{1}{c|}{2010} \\
\hline Autos particulares & 2556378 & 3435498 & 4266399 \\
\hline Taxis & 109654 & 110456 & 111046 \\
\hline Combis y microbuses & 34586 & 27990 & 25069 \\
\hline Pick ups & 356547 & 425763 & 479170 \\
\hline Motocicletas & 72704 & 72704 & 72704 \\
\hline Otros* & 383579 & 451565 & 504069 \\
\hline TOTAL & 3513448 & 4523976 & 5458457 \\
\hline
\end{tabular}

* Incluye vehículos a gasolina, diesel y gas LP (camiones de carga, tractocamiones, autobuses y vehículos de diverso tonelaje: de 3 y de menos o más toneladas)

Fuente: Comisión Ambiental Metropolitana et al., 2002.

Si bien se estima que para la presente década estas cifras no aumentarán de la manera tan desproporcionada como lo hicieron durante décadas anteriores, las ventas de automóviles continúan en el Distrito Federal. El

\footnotetext{
24 Idem.
} 
Esta obra forma parte del acervo de la Biblioteca Jurídica Virtual del Instituto de Investigaciones Jurídicas de la UNAM

incremento en el número de vehículos dentro de la ZMCM se reflejará en las zonas conurbadas que será hasta de tres veces mayor que lo que habrá de registrarse en el Distrito Federal en los próximos años.

TABLA 10

Crecimiento poblacional y vehicular en el Distrito Federal (1940-2000)

\begin{tabular}{|c|c|c|}
\hline Año & Población & Vehículos \\
\hline 1940 & 1757530 & 47980 \\
\hline 1960 & 4870876 & 248414 \\
\hline 1980 & 8831079 & 1118771 \\
\hline 1990 & 8235744 & 1372624 \\
\hline 2000 & 8605239 & 1532533 \\
\hline
\end{tabular}

Fuente: Gobierno del Distrito Federal, 2002.

Referirnos al incremento en el número de automóviles cuando abordamos el problema de la contaminación atmosférica en esta o cualquier otra ciudad tiene un sustento lógico: está reconocido mundialmente ${ }^{25}$ que el aumento de vehículos automotores en grandes centros urbanos en expansión deriva en una mala calidad del aire para todo el aglomerado urbano, y la Ciudad de México no es una excepción a ello. Sin embargo, sería demasiado simplista señalar que para el caso específico de la ZMCM el incremento en los niveles de contaminación atmosférica ha sido resultado sólo del aumento en el número y uso de automóviles en la misma proporción. Al mismo tiempo, sería demasiado inocente creer que se puede aspirar a tener una atmósfera saludable (cualesquiera que sean las estrategias de gestión de la calidad del aire) cuando el crecimiento de vehículos automotores es monumental en una zona metropolitana cuya expansión descontrolada (urbana y poblacional) continúa sin que existan los incentivos económicos o sociales para usar modos de transporte menos contaminantes.

25 Véase, por ejemplo, United Nations Centre for Human Settlements, An Urbanizing World: Global Report on Human Settlements, Oxford, United Nations Centre for Human Settlements-HABITAT, Oxford University Press, 1996. 
Esta obra forma parte del acervo de la Biblioteca Jurídica Virtual del Instituto de Investigaciones Jurídicas de la UNAM

Es por ello que debemos tomar en cuenta que el crecimiento de la propiedad y uso del automóvil ha dado como resultado dos fenómenos urbanoambientales que están incidiendo en la gestión de la calidad del aire en la ZMCM. En primer lugar, el aumento de vehículos ha producido mayor número de congestionamientos viales, lo que a su vez ha derivado en que los promedios de velocidad hayan disminuido dramáticamente. Circular a baja velocidad tiene un impacto en la calidad del aire debido a que los automóviles que transitan por debajo de un rango de $50-90 \mathrm{~km} / \mathrm{h}$ consumen más gasolina y producen más emisiones. ${ }^{26}$ Durante la década de los noventa, aunque la velocidad promedio en la $\mathrm{ZMCM}$ era de $36 \mathrm{~km} / \mathrm{h}$, el $30 \%$ de los vehículos automotores circulaba en promedio a $10-20 \mathrm{~km} / \mathrm{h} .{ }^{27}$ En la actualidad, mientras que el promedio de velocidad de los vehículos por día en las principales vías rápidas como el Periférico y el Viaducto es de 13-20 $\mathrm{km} / \mathrm{h}$, durante las horas pico el promedio en estas mismas vialidades disminuye absurdamente a $7-15 \mathrm{~km} / \mathrm{h} .{ }^{28}$ Esta situación es por demás ridícula si recordamos que en la primera carrera de automóviles —organizada en 1894 por dos compañías francesas (Panhard-Lavassor y Peugeot) entre París y Rouen - la velocidad alcanzada fue de alrededor de $20 \mathrm{~km} / \mathrm{h} .{ }^{29}$

Ciertamente, se han elaborado diversas estrategias de tránsito vehicular con el objeto de agilizar las vialidades y lograr con ello velocidades promedio (ni muy bajas ni muy altas) para así incidir de manera más efectiva en la disminución de emisiones contaminantes. Una de estas estrategias se ha enfocado a reducir el uso del automóvil a través de la implementación del Programa Hoy no Circula, obligatorio a partir de noviembre de 1989. En sus orígenes, este programa estableció que todos los vehículos que transitaran en la zona metropolitana dejarían de circular un día a la semana según el último número (o color del engomado) de la placa del vehículo respectivo con lo que se lograría mitigar la saturación vial y bajar las emisiones; sin embargo, este programa no fue desde sus inicios lo

26 Véase Elsom, Derek, Smog Alert: Managing Urban Air Quality, Londres, Earthscan, 1996, pp. 143-145.

27 Secretaría de Medio Ambiente, Recursos Naturales y Pesca et al., Programa Integral Contra la Contaminación Atmosférica de la Zona Metropolitana de la Ciudad de México (Proaire 1995-2000), México, Secretaría de Medio Ambiente, Recursos Naturales y Pesca-Secretaría de Salud-Gobierno del Distrito Federal-Gobierno del Estado de México, 1996.

28 Gobierno del Distrito Federal, op. cit., nota 9.

29 Wolf, Winfried, op. cit., nota 1, p. 69. 
Esta obra forma parte del acervo de la Biblioteca Jurídica Virtual del Instituto de Investigaciones Jurídicas de la UNAM

suficientemente efectivo porque al implementarlo se generó el efecto secundario de que muchas familias adquirieran un segundo automóvil para usarlo precisamente el día en que no circulaba su otro vehículo.

Si bien el programa ha sido modificado con el paso del tiempo y en la actualidad los automóviles con una antigüedad de 5 o menos años están exentos de la prohibición de no circular un día a la semana bajo el supuesto argumento de que los vehículos más nuevos son menos contaminantes, no es del todo claro que se hayan alcanzado sus primigenios, pero todavía vigentes, objetivos. Al momento de su creación, este programa permitía retirar diariamente de la circulación alrededor de 500000 autos particulares; para 2000 se retiraban por día cerca de 350000 autos (los de mayor edad).

Otra de las estrategias diseñadas con el propósito de aliviar el caos vehicular y con ello alcanzar límites de velocidad amigables con el ambiente ha sido la construcción de nuevas vialidades (i. e. anillos, libramientos y vías rápidas). Un caso que ha llamado mucho la atención en este sentido, ha sido la reciente construcción por parte del gobierno del Distrito Federal de vías rápidas llamadas "segundos pisos". Más allá de los fines políticos que puedan existir para la construcción de este tipo de obra pública gigantesca, la razón que se ha esgrimido para llevarla a cabo es la de disminuir el tránsito vehicular tanto en intersecciones o cruceros viales conflictivos como en las ya existentes vialidades rápidas. Sin embargo, mientras el número de vehículos continúe su desmedido crecimiento, será difícil que con estas nuevas vialidades se incremente significativamente el promedio de velocidad de los automóviles en la ZMCM y que por lo tanto se logre una efectiva reducción de los niveles de contaminación. Ante todo, y como bien lo señala Derek Elsom:

Muchos países intentan resolver los problemas de congestionamiento vial en sus ciudades a través de la construcción de más vialidades para enfrentar el tránsito vehicular. Sin embargo, esta política puede ser contraproducente. Nuevas vialidades, incluyendo anillos o libramientos, incentiva que más vehículos las utilicen. La construcción de más vialidades prolonga el ciclo del crecimiento vehicular constante en el que los automovilistas exigen a su vez nuevas vialidades. ${ }^{30}$

30 Elsom, Derek, op. cit., nota 26, p. 148. En inglés, la cita se lee: Many countries attempt to solve traffic congestion problems in cities by building more roads to cope with the traffic. This policy can be self-defeating, however. New roads, including bypasses, en- 
Esta obra forma parte del acervo de la Biblioteca Jurídica Virtual del Instituto de Investigaciones Jurídicas de la UNAM

El segundo fenómeno urbano-ambiental relacionado con el crecimiento de automóviles es que a pesar de la introducción de nuevas tecnologías en la ZMCM (gasolinas más limpias, convertidores catalíticos, control de emisiones más estrictas, etcétera) las emisiones contaminantes a la atmósfera continúan inevitablemente: algunas incluso por encima de las normas de calidad del aire. Si bien algunas medidas tecnológicas han sido exitosas (como por ejemplo con la disminución del plomo), esas y otras estrategias vehiculares para reducir significativamente otros contaminantes (i.e. el ozono), pueden ser contrarrestadas por los niveles diarios de emisiones del transporte de superficie en una ciudad que, en muchos sentidos, ha sido diseñada desde hace ya algunos años para privilegiar el uso de automóviles.

Con lo dicho hasta aquí, es posible referirnos a cuatro puntos de importancia singular respecto al vínculo que existe entre vehículos automotores y contaminación del aire en la ZMCM:

i) Después de quince años de gestión de la calidad del aire en la Ciudad de México (1990-2005), el transporte de superficie continúa siendo la mayor fuente de contaminación atmosférica. Como se observa en las tablas 11, 12 y 13 las emisiones del sector transporte han sido por mucho (y para la mayoría de los contaminantes) la causa principal de la mala calidad del aire en la zona metropolitana. Como se mencionó anteriormente, los tres inventarios de emisiones no pueden ser propiamente comparados entre sí ya que los supuestos y metodologías utilizados para calcular las emisiones atmosféricas por sector fueron distintos para cada inventario. A pesar de esto, es de hacerse notar que independientemente de cómo se haya elaborado cada uno de ellos, el transporte de superficie aparece en los tres como la fuente principal de emisiones totales a la atmósfera incluyendo las estimaciones para 2010 (véase la tabla 14).

courage more cars to use them. New roads continue the cycle of continual traffic growth whose drivers demand new roads. 
Esta obra forma parte del acervo de la Biblioteca Jurídica Virtual del Instituto de Investigaciones Jurídicas de la UNAM

TABLA 11

Inventario de emisiones (1989) por sector (\% en peso)

\begin{tabular}{|c|r|r|r|r|r|r|}
\hline Sector & $\mathrm{SO}_{2}$ & \multicolumn{1}{c|}{$\mathrm{NO}_{x}$} & \multicolumn{1}{c|}{$\mathrm{HC}$} & \multicolumn{1}{c|}{$\mathrm{CO}$} & $\mathrm{PST}$ & Total \\
\hline Energía & 35.5 & 5.6 & 5.6 & 1.8 & 1.0 & 4.0 \\
\hline Industria y servicios & 42.7 & 18.5 & 7.0 & 0.6 & 2.8 & 4.4 \\
\hline Transporte & 21.8 & 75.4 & 52.5 & 96.7 & 2.1 & 76.7 \\
\hline Degradación ecológica & 0.1 & 0.5 & 34.9 & 0.9 & 94.0 & 15.0 \\
\hline Total & 100.0 & 100.0 & 100.0 & 100.0 & 100.0 & 100.0 \\
\hline
\end{tabular}

Fuente: Secretariado Técnico Intergubernamental, 1990.

TABLA 12

Inventario de emisiones (1994) por sector (\% en peso)

\begin{tabular}{|c|r|r|r|r|r|r|}
\hline Sector & \multicolumn{1}{|c|}{$\mathrm{SO}_{2}$} & \multicolumn{1}{c|}{$\mathrm{NO}_{x}$} & \multicolumn{1}{c|}{$\mathrm{HC}$} & \multicolumn{1}{c|}{$\mathrm{CO}$} & $\mathrm{PST}$ & Total \\
\hline Industria & 57.3 & 24.5 & 3.2 & 0.4 & 1.4 & 3.0 \\
\hline Servicios & 15.9 & 4.2 & 38.9 & 0.1 & 0.2 & 10.0 \\
\hline Transporte & 26.8 & 71.3 & 54.1 & 99.5 & 4.2 & 75.0 \\
\hline Vegetación y suelos & 0.0 & 0.0 & 3.8 & 0.0 & 94.2 & 12.0 \\
\hline Total & 100.0 & 100.0 & 100.0 & 100.0 & 100.0 & 100.0 \\
\hline
\end{tabular}

Fuente: Secretaría de Medio Ambiente, Recursos Naturales y Pesca et al, 1996 
Esta obra forma parte del acervo de la Biblioteca Jurídica Virtual del Instituto de Investigaciones Jurídicas de la UNAM

TABLA 13

Inventario de emisiones (1998) por sector (\% en peso)

\begin{tabular}{|c|c|c|c|c|c|c|}
\hline Sector & $\mathrm{SO}_{2}$ & $\mathrm{NO}_{\mathrm{x}}$ & $\mathrm{HC}$ & $\mathrm{CO}$ & $\mathrm{PM}_{10} *$ & Total \\
\hline $\begin{array}{c}\text { Fuentes fijas } \\
\text { (industria) }\end{array}$ & 55.0 & 13.0 & 5.0 & 0.5 & 16.0 & 1.0 \\
\hline $\begin{array}{c}\text { Fuentes fijas } \\
\text { (servicios) }\end{array}$ & 24.0 & 5.0 & 52.0 & 1.5 & 8.0 & 12.0 \\
\hline $\begin{array}{c}\text { Fuentes móviles } \\
\text { (transporte) }\end{array}$ & 21.0 & 80.0 & 40.0 & 98.0 & 36.0 & 84.0 \\
\hline Vegetación y suelos & n. d. & 2.0 & 3.0 & n. d. & 40.0 & 1.0 \\
\hline Total & 100.0 & 100.0 & 100.0 & 100.0 & 100.0 & 100.0 \\
\hline
\end{tabular}

* Sustituye a las PST de inventarios anteriores

n. d. $=$ no disponible

Fuente: Comisión Ambiental Metropolitana et al., 2002.

TABLA 14

Inventario de emisiones (para 2010) por sector (\% en peso)*

\begin{tabular}{|c|r|r|r|r|r|l|}
\hline Sector & $\mathrm{SO}_{2}$ & $\mathrm{NO}_{\mathrm{x}}$ & $\mathrm{HC}$ & $\mathrm{CO}$ & $\mathrm{PM}_{10}$ & Total \\
\hline $\begin{array}{c}\text { Fuentes fijas } \\
\text { (industria) }\end{array}$ & 63.0 & 16.0 & 7.0 & 1.0 & 21.0 & n. d. \\
\hline $\begin{array}{c}\text { Fuentes fijas } \\
\text { (servicios) }\end{array}$ & 16.0 & 5.0 & 50.0 & 1.0 & 7.0 & n. d. \\
\hline $\begin{array}{c}\text { Fuentes móviles } \\
\text { (transporte) }\end{array}$ & 21.0 & 78.0 & 40.0 & 98.0 & 40.0 & n. $d$. \\
\hline Vegetación y suelos & n. d. & 1.0 & 3.0 & n. d. & 32.0 & n. d. \\
\hline Total & 100.0 & 100.0 & 100.0 & 100.0 & 100.0 & n. d. \\
\hline
\end{tabular}

* Cálculos basados en la misma metodología usada para el Inventario de Emisiones de 1998 sin considerar los beneficios de reducción de la contaminación obtenidos después de implementar el Proaire 2002-2010.

n. d. = no disponible

Fuente: Comisión Ambiental Metropolitana et al., 2002.

ii) Según la información disponible, el transporte de superficie es la principal fuente de contaminación de al menos dos de los diversos contaminantes de mayor preocupación en la Ciudad de México: CO 
Esta obra forma parte del acervo de la Biblioteca Jurídica Virtual del Instituto de Investigaciones Jurídicas de la UNAM

y $\mathrm{NO}_{x}$. Aunado a esto, aunque el sector transporte no es la fuente más importante de contaminación de las $\mathrm{PM}_{10}$, se constituye como el segundo causante más alto de este contaminante con el $36 \%$ del total de emisiones, sólo por debajo del causante principal (vegetación y suelos) que genera el $40 \%$ de ese total. De igual manera, no obstante que el sector transporte no es la fuente principal de los $\mathrm{HC}$, se constituye como el segundo causante más alto con un $40 \%$ del total de emisiones por debajo del sector servicios (como fuentes fijas) que contribuye con un $52 \%$. Ya que la combinación de una elevada radiación solar con $\mathrm{NO}_{\mathrm{x}} \mathrm{y} \mathrm{HC}$ favorece la formación del $\mathrm{O}_{3}$, es el sector transporte, una vez más, quien contribuye de manera significativa a los altos niveles que sufre la ZMCM por este contaminante secundario.

iii) No todos los tipos de automóviles contaminan de la misma manera. En efecto, los autos particulares se encuentran en primer lugar de la lista de todos los contaminadores dentro del sector transporte y lo están además por diversos contaminantes. Según datos y estadísticas del inventario de emisiones de 1998 del Proaire 2002-2010, las emisiones de los autos particulares eran mayores que las de otros tipos de vehículos automotores para los casos de $\mathrm{SO}_{2}, \mathrm{HC}$ y $\mathrm{CO}$ (véase la tabla 15). En el inventario de emisiones del 2004, la fuente principal de emisiones para contaminantes como $\mathrm{SO}_{2}, \mathrm{NO}_{x}$, y $\mathrm{CO}$ también lo eran los autos particulares (véase la tabla 16).

TABLA 15

Inventario de emisiones (1998) por vehículo (tons/año)

\begin{tabular}{|c|r|r|r|r|r|}
\hline Fuente & \multicolumn{1}{|c|}{$\mathrm{SO}_{2}$} & $\mathrm{NO}_{x}$ & $\mathrm{HC}$ & $\mathrm{CO}$ & $\mathrm{PM}_{10}$ \\
\hline Autos particulares & 2000 & 47380 & 81705 & 822477 & 701 \\
\hline Taxis & 567 & 11093 & 15310 & 131453 & 199 \\
\hline Combis y microbuses & 194 & 10454 & 21706 & 237188 & 69 \\
\hline Pick ups & 522 & 18961 & 24599 & 255503 & 183 \\
\hline Motocicletas & 63 & 215 & 4742 & 22729 & 22 \\
\hline Otros* & 1324 & 77735 & 39711 & 264313 & 5959 \\
\hline
\end{tabular}

* Incluye vehículos a gasolina, diesel y gas LP (camiones de carga, tractocamiones, autobuses y vehículos de diverso tonelaje: de 3 y de menos o más toneladas).

Fuente: Comisión Ambiental Metropolitana et al., 2002. 
Esta obra forma parte del acervo de la Biblioteca Jurídica Virtual del Instituto de Investigaciones Jurídicas de la UNAM

TABLA 16

Inventario de emisiones (2004) por vehículo (tons/año)

\begin{tabular}{|c|r|r|r|r|r|}
\hline Fuente & $\mathrm{SO}_{2}$ & $\mathrm{NO}_{\mathrm{x}}$ & $\mathrm{HC}$ & $\mathrm{CO}$ & $\mathrm{PM}_{10}$ \\
\hline Autos particulares & 1719 & 57456 & n. d. & 890602 & 860 \\
\hline Taxis & 312 & 11062 & n. d. & 118709 & 144 \\
\hline Combis y microbuses & 167 & 13486 & n. d. & 220750 & 66 \\
\hline Pick ups & 149 & 8572 & n. d. & 106338 & 63 \\
\hline Motocicletas & 62 & 1057 & n. d. & 98399 & 76 \\
\hline Otros* & 912 & 56338 & n. d. & 343109 & 3559 \\
\hline
\end{tabular}

* Incluye vehículos a gasolina, diesel y gas LP (camiones de carga, tractocamiones, autobuses y vehículos de diverso tonelaje: de 3 y de menos o más toneladas)

Fuente: Gobierno del Distrito Federal, 2004.

iv) Por último, mientras que los autos particulares constituyen en la actualidad la principal fuente de la mayoría de los contaminantes de mayor preocupación en la Ciudad de México, representan por modo de transporte menos de un cuarto del total de viajes en toda la ZMCM. Efectivamente, los autos particulares abarcan sólo el 16\% de los viajes en tanto que todos los otros medios de transporte como el autobús, el tren ligero, el trolebús, el metro, combis, microbuses y taxis (excluyendo al nuevo sistema de transporte conocido como metrobús) se distribuyen el restante $84 \%$. Como se observa en la tabla 17, la participación modal de transporte se ha divido en tres grandes áreas de acuerdo al número estimado de viajes: alta, mediana y baja capacidad. Al utilizar esta clasificación para entender las tendencias de la contaminación atmosférica debemos tomar en cuenta que mientras la participación de alta y mediana capacidad asociada al transporte eléctrico (i.e. metro, tren ligero y trolebús) ha ido a la baja, el transporte de superficie ha ido incrementándose. $\mathrm{Si}$ bien es cierto que aquél modo de transporte requiere de cualquier manera plantas de energía, en su conjunto produce menos emisiones contaminantes por persona por viaje que el transporte de superficie que incluye a los autos particulares y los taxis o los microbuses que son todos ellos de baja capacidad. 
Esta obra forma parte del acervo de la Biblioteca Jurídica Virtual del Instituto de Investigaciones Jurídicas de la UNAM

TABLA 17

Participación modal de transporte en la ZMCM (1986-2000)

\begin{tabular}{|c|c|c|c|c|c|c|c|c|}
\hline $\begin{array}{l}\text { Capa- } \\
\text { cidad }\end{array}$ & $\begin{array}{c}1986 \\
(\%)\end{array}$ & $\begin{array}{c}1989 \\
(\%)\end{array}$ & $\begin{array}{c}1992 \\
(\%)\end{array}$ & $\begin{array}{c}1994 \\
(\%)\end{array}$ & $\begin{array}{c}1995 \\
(\%)\end{array}$ & $\begin{array}{c}1998 \\
(\%)\end{array}$ & $\begin{array}{c}2000 \\
(\%)\end{array}$ & $\begin{array}{l}\text { Modo de } \\
\text { transporte }\end{array}$ \\
\hline Alta & 19 & 21 & 13 & 16 & 12 & 14 & 14 & Metro \\
\hline \multirow{2}{*}{$\begin{array}{l}\text { Medi- } \\
\text { ana }\end{array}$} & 3 & 3 & 1 & 1 & 1 & 1 & 1 & $\begin{array}{l}\text { Tren ligero } \\
\text { / Trolebús }\end{array}$ \\
\hline & 42 & 19 & 9 & 10 & 8 & 2 & 9 & Autobús \\
\hline \multirow{3}{*}{ Baja } & 6 & 35 & 51 & 53 & 48 & 59 & 55 & $\begin{array}{c}\text { Microbuses } \\
\text { y combis }\end{array}$ \\
\hline & 5 & 6 & 8 & 3 & 9 & 4 & 5 & Taxis \\
\hline & 25 & 16 & 18 & 17 & 22 & 20 & 16 & $\begin{array}{c}\text { Autos } \\
\text { particulares }\end{array}$ \\
\hline
\end{tabular}

Fuente: Comisión Ambiental Metropolitana et al., 2002, y Gobierno del Distrito Federal, 2002.

Aunado a lo anterior, es importante referirnos de manera muy breve a dos modos de transporte en lo particular: el sistema de transporte colectivo comúnmente llamado "metro", y el recientemente creado "metrobús". Para el primer caso señalamos que, aun cuando se haya reiniciado su expansión desde mediados y finales de la década de los noventa, los datos oficiales muestran que su uso no obstante emitir menos emisiones que otros modos de transporte no se ha incrementado notablemente. Cualesquiera que sean las razones para ello, debemos tomar nota que con el acelerado crecimiento de habitantes en la ZMCM y la expansión del auto particular no se espera un cambio significativo en ese sentido; es muy probable que en el futuro la participación en el modo de baja capacidad (especialmente los autos particulares) aumente. ${ }^{31}$ Esta situación es de suma importancia debido a que se prevé que la demanda de movilidad urbana (i.e. número de desplazamientos o viajes) habrá de incrementarse. Para el segundo caso, debemos ser cautelosos y esperar algunos años más para conocer si la instrumentación de los corredores de transporte

31 Comisión Ambiental Metropolitana et al., op. cit., nota 13, pp. 2/20-21. 
Esta obra forma parte del acervo de la Biblioteca Jurídica Virtual del Instituto de Investigaciones Jurídicas de la UNAM

colectivo en ciertas avenidas —en la actualidad opera sólo a lo largo de la Avenida de los Insurgentes direcciones norte y sur-, habrá de significar menores emisiones de contaminantes del sector transporte y menos uso de los autos particulares.

\section{CONCLUSIÓN}

Este trabajo ha tenido por objeto demostrar que el aumento en el número y uso de los automóviles (especialmente los autos particulares) podrían obstaculizar los esfuerzos gubernamentales para alcanzar una calidad del aire urbana saludable en la ZMCM. Para ello, hemos examinado tres aspectos fundamentales: $i$ ) el crecimiento poblacional y urbano; $i$ ) la actual situación de la calidad del aire, y iii) las emisiones de los vehículos de superficie, como fuente principal de la contaminación atmosféricaque nos han permitido llegar a las siguientes conclusiones.

La información estadística presentada en este trabajo nos lleva a señalar que el crecimiento urbano y poblacional en la ZMCM habrá de continuar. Será en las zonas conurbadas del Distrito Federal donde habrá de registrarse principalmente dicha expansión física y aumento de habitantes. Al mismo tiempo, el número de vehículos de superficie se ha incrementado a tal grado que los niveles de velocidad han disminuido considerablemente. De aquí que a lo largo y ancho de toda la ZMCM los vehículos circulen a bajas velocidades y se presenten congestionamientos viales: paradójicamente, estos dos fenómenos ocurren constantemente en aquéllas vías que fueron creadas precisamente para circular a alta velocidad.

En términos generales, la información disponible sobre transporte y contaminación atmosférica señala que la fuente principal de la mayoría de los contaminantes que más preocupan para la calidad del aire en la Ciudad de México, son los automóviles, especialmente los autos particulares. Si bien el número de autos privados se ha incrementado de manera irracional y exponencial (siendo por tanto la causa de la emisión de la mayoría de los contaminantes de los últimos años), los niveles de ciertos contaminantes se han reducido considerablemente. De modo que el mejoramiento de la calidad del aire en la Ciudad de México sólo ha sido moderado y eso gracias fundamentalmente a la introducción de nuevas tecnologías y a la implementación de ciertas medidas vinculadas al tránsito vehicular. 
Esta obra forma parte del acervo de la Biblioteca Jurídica Virtual del Instituto de Investigaciones Jurídicas de la UNAM

Aunque las emisiones de los vehículos automotores no son la única causa de la contaminación del aire en la capital del país, la principal meta para su control y combate debe incluir no sólo la introducción de tecnologías más limpias sino medidas para desincentivar el uso del automóvil. En este sentido, uno de los muchos retos que el gobierno mexicano (federal y local) enfrenta al comienzo de esta centuria (y por muchos años más) es el de garantizar la movilidad urbana sin comprometer casi dos décadas de gobernabilidad urbano-ambiental en la que se han obtenido algunos resultados favorables en la calidad del aire. Del mismo modo, deberá enfrentar a través de diversas estrategias la reducción de aquellos contaminantes cuyos elevados niveles representan una amenaza para la salud, como es el caso del $\mathrm{O}_{3}$ y las $\mathrm{PM}_{10}$.

Desafortunadamente, la respuesta del gobierno a estos dos casos se ha enfocado por mucho a la adopción de medidas tecnológicas (i. e. combustibles y automóviles más limpios). En efecto, debemos enfatizar que si bien ya se ha iniciado la expansión del metro y se ha comenzado a instrumentar el programa de corredores de transporte como el metrobús, el gobierno mexicano no ha cambiado su política de seguir construyendo más vialidades para automóviles (permitiendo además un crecimiento urbano desproporcionado) lo que ha favorecido el uso indiscriminado de autos particulares en lugar de un modo de transporte menos contaminante.

Como ya lo habíamos advertido desde hace algunos años, ${ }^{32}$ los automovilistas en la Ciudad de México siguen sin utilizar otros modos de transporte y por consiguiente no han contribuido a que los niveles de aquéllos contaminantes que están impactando en los índices de mortandad y morbilidad en la Ciudad de México, disminuyan.

El homo sapiens mexicano que padece a diario caos viales y que sufre de mala calidad del aire en la Ciudad de México, no está dispuesto a dejar su auto en casa y usar el transporte público. Por si fuera poco, aquéllos que aún no son propietarios de un automóvil, desean adquirir uno; de hecho, están ansiosos por comprar no sólo uno sino dos o más. Pesan como razones para comprar y usar automóviles el estatus social, el consumismo, la comodidad, la falta de transporte público y la inseguridad, todos ellos liderados de manera muy especial por los créditos y paquetes financieros diseñados por las compañías automovilísticas que permiten adquirir (la mayoría de las veces a través de endeudamientos) un auto-

32 Véase Nava Escudero, César, op. cit., nota 4, p. 234. 
Esta obra forma parte del acervo de la Biblioteca Jurídica Virtual del Instituto de Investigaciones Jurídicas de la UNAM

móvil a precio muy bajo. Aplica sin duda alguna a la Ciudad de México aquella famosa idea que Henry Ford utilizó hace cien años respecto a la creación de "un auto para las masas":

Construiré un vehículo automotor para las grandes multitudes. Será lo suficientemente grande para la familia pero lo suficientemente pequeño para el individuo quien podrá circularlo y cuidarlo. Estará hecho de los mejores materiales, por los hombres mejor capacitados, como resultado de los diseños más simples que la ingeniería moderna pueda lograr. Pero será tan bajo en precio que ningún hombre con buen salario dejará de adquirirlo y así podrá disfrutar con su familia la bendición de horas de placer en los grandes espacios abiertos creados por Dios. ${ }^{33}$

Manejar un auto en la Ciudad de México, lugar de constantes embotellamientos viales, bajas velocidades y altos niveles de aire contaminado, no es lo que podríamos llamar precisamente una bendición. Lamentablemente, el uso del transporte público no se ha convertido en una opción viable para miles y miles de automovilistas que no tienen, o acaso apenas, un incentivo para cambiar la forma en la que se mueven dentro de la ciudad capital. Mientras esto ocurre, el número de vehículos de superficie - especialmente los autos particulares - continúa en aumento.

Si la información estadística gubernamental resulta correcta, en un corto periodo de diez años — de 2000 a 2010 - el número de vehículos automotores nuevos se habrá incrementado estrepitosamente en casi 2.0 millones. Esto que por sí solo ya es grave, adquiere un mayor grado de preocupación por el hecho de que detrás de esta cifra el incremento más significativo se dará en sólo un modo de transporte, los autos particulares, cuyo descocado crecimiento se estima en cerca de 1.7 millones del total.

Ante esta situación, difícilmente podrá negarse que los habitantes de la Ciudad de México han iniciado un nuevo proceso de evolución: de homo sapiens a homo automobilis.

33 Citada en Wolf, Winfried, op. cit., nota 2, p. 70. En inglés, la cita se lee: I will build a motorcar for the great multitude. It Hill be large enough for the family but small enough for the individual to run and care for. It will be constructed of the best materials, by the best men to be hired, after the simplest designs that modern engineering can devise. But it will be so low in price that no man making a good salary will be unable to own one - and enjoy with his family the blessing of hours of pleasure in God's great open spaces. 
Esta obra forma parte del acervo de la Biblioteca Jurídica Virtual del Instituto de Investigaciones Jurídicas de la UNAM

\section{EXCLUSIÓN AMBIENTAL EN LA ZONA METROPOLITANA DEL VALLE DE MÉXICO. VISIONES ANTROPOCÉNTRICAS PARA MEJORAR LA CALIDAD DEL AIRE**}

Que el aire vuelva a ser respirable y de todos Mario BENEDETTI

\section{INTRODUCCIÓN}

El régimen atmosférico de la Zona Metropolitana del Valle de México (en adelante, ZMVM) ha estado orientado fundamentalmente a la protección ambiental de los seres humanos en cuanto a su salud, bienestar y calidad de vida. Si bien los programas y las disposiciones jurídicas que al efecto se han elaborado reconocen los efectos adversos que la contaminación atmosférica puede generar al medio natural, éste no ha sido tomado en cuenta para desarrollar los mecanismos que permitan la aplicación y operación de la regulación político-jurídica ambiental. Esto se debe a que la idea de mejorar la calidad del aire en la Ciudad de México y su zona conurbada está fundamentada en una visión de tipo antropocéntrico que no es, sin embargo, necesariamente antiambientalista.

El presente trabajo tiene por objeto demostrar que el diseño de programas y la expedición de normas para mejorar la calidad del aire en la ZMVM ha provocado un fenómeno que se conoce con el nombre de exclusión ambiental. Este proceso de no inclusión surge como resultado de adoptar una postura científica y ético-filosófica a la que se le denomina, dentro del pensamiento ambientalista, antropocentrismo. Dicha postura se apoya en la idea de que los seres humanos se encuentran en el centro del universo y de que son superiores a la naturaleza, i. e. no existe igual-

* Publicado en Varios autores, Sin derechos. Exclusión y discriminación en el México actual, México, UNAM, Instituto de Investigaciones Jurídicas, 2014. 
Esta obra forma parte del acervo de la Biblioteca Jurídica Virtual del Instituto de Investigaciones Jurídicas de la UNAM

dad. Por lo tanto, el régimen atmosférico ha privilegiado la protección ambiental de los seres humanos excluyendo al medio natural y a todo aquello que lo conforma.

Este artículo puntualiza que las normas de calidad del aire (que son las que establecen los límites máximos permisibles de concentración de contaminantes atmosféricos), el índice de valores (que es el que identifica la calidad del aire a través de números, colores y calificativos), y los programas de contingencias ambientales (cuya función es la de informar sobre los riesgos por contaminación atmosférica y las actividades sugeridas) están todos encauzados a la protección ambiental sólo de la salud de la población de la ZMVM.

\section{AMBIENTE Y EXCLUSIÓN}

El vocablo ambiente se ha equiparado erróneamente al de ecología. No son términos equivalentes porque sus acepciones primigenias son distintas. Mientras que la ecología es una ciencia que tiene por objeto de estudio las interrelaciones de los seres vivos y el hábitat que les rodea, ${ }^{1}$ el ambiente es una idea cuyo significado es mucho más amplio y se refiere no sólo a una relación de organismos vivos entre sí, sino a lo "que rodea o cerca". ${ }^{2}$ El mismo equívoco se ha cometido con el de naturaleza. Se dice que lo natural es "la sustancia o factor que ocurre o se produce como parte normal de la naturaleza, aparte de cualquier actividad o intervención de los seres humanos. Se distingue de lo artificial o sintético". ${ }^{3}$ En cambio, ambiente representa tanto a lo natural como a lo artificial, e incluso, a lo humano y a otras cosas más.

Ciertamente, se han elaborado muchas definiciones de ambiente, unas más flexibles o restrictivas que otras, sin que hasta nuestros días se tenga una delimitación conceptual precisa. Habremos de insistir que si algún

1 Ecología proviene del griego oikos $=$ casa, y logía $=$ tratado, estudio, ciencia. El término fue acuñado por Ernst Haeckel hacia finales del siglo XIX.

2 Así se ha establecido literalmente desde 1884, según lo establecido por la duodécima edición del Diccionario de la Real Academia Española. Véase Real Academia Española, Nuevo Tesoro Lexicográfico de la Lengua Española, 2010, http://buscon-rae. es/ntlle/SrvltGUILoginNtlle.

3 Nebel, Bernard J. y Wright, Richard T., Ciencias ambientales. Ecología y desarrollo sostenible, 6a. ed., trad. de Francisco Javier Dávila, México, Prentice Hall, 1999, p. 678. 
Esta obra forma parte del acervo de la Biblioteca Jurídica Virtual del Instituto de Investigaciones Jurídicas de la UNAM

consenso se ha logrado en este sentido es que se trata de una idea que puede abarcar cualquier cosa y que a su vez puede tener significados diferentes para áreas de conocimiento o saberes distintos. Por ejemplo, al insertar la dimensión ambiental en la sociología, ambiente podrá designar el nexo que existe entre sociedad y naturaleza; ${ }^{4}$ si es en la economía, será el costo-beneficio actual y futuro del bienestar humano y la biodiversidad, ${ }^{5}$ y si es en el derecho, se tratará del bien o valor jurídico a protegerse por la normatividad correspondiente. ${ }^{6}$ Así, aparecen disciplinas como la sociología ambiental, la economía ambiental, o el derecho ambiental, respectivamente.

Al combinar los vocablos ambiente y derecho - lo que origina la existencia del derecho ambiental - se hace indispensable determinar el contenido y alcance de lo que es el concepto jurídico de ambiente. Para ello, debemos adoptar una visión que permita abarcar, si bien no todo el universo, sí todo aquello que pueda referirse a "lo que rodea o cerca". De manera que podemos señalar que ambiente comprende las nociones esenciales siguientes: ${ }^{7}$

i) El medio natural, que se refiere a los procesos naturales, a lo natural, a los recursos naturales, a la flora y la fauna, a sus interrelaciones, al equilibrio o desequilibrio ecológicos, a los ecosistemas, etcétera;

ii) El medio construido, que comprende los procesos sociales o culturales, lo artificial o sintético, lo creado por el ser humano, las ciudades y megaciudades, etcétera;

4 López Ramírez, Alfonso, "Medio ambiente, desarrollo sustentable y pobreza rural en América Latina. Modelo teórico-metodológico”, en López Ramírez, Alfonso y Hernández, Pedro F., (coords.), Sociedad y medio ambiente: contribuciones a la sociología ambiental en América Latina, México, Asociación Latinoamericana de Sociología-Benemérita Universidad Autónoma de Puebla-La Jornada Ediciones, 1996, p. 40.

5 Park, Chris, Dictionary of Environment and Conservation, Oxford, Oxford University Press, 2008, p. 150.

6 Jaquenod de Zsögön, Silvia, Derecho ambiental, Madrid, Dykinson, 2002, p. 21.

7 La clasificación que aquí presentamos es el resultado de una serie de reflexiones científicas y ético-filosóficas que realizamos en años recientes, y que tuvieron como objeto primordial dotar de significado al concepto de crisis ambiental contemporánea, al vocablo ambiente, y a la disciplina jurídica que se conoce con el nombre de derecho ambiental. Para una mejor comprensión sobre estas discusiones y debates, remitimos a Nava Escudero, César, Ciencia, ambiente y derecho, México, UNAM, Instituto de Investigaciones Jurídicas, 2012, passim. 
Esta obra forma parte del acervo de la Biblioteca Jurídica Virtual del Instituto de Investigaciones Jurídicas de la UNAM

iii) Los seres humanos, particularmente por lo que hace a su salud, bienestar y calidad de vida, y

iv) Las relaciones de interdependencia recíproca que existen entre los propios seres humanos, y entre éstos y los medios natural y construido, cuyo entendimiento y explicación se basa en diversos factores o cuestiones éticas y científicas no jurídicas.

De aquí que se pueda afirmar que la protección ambiental en su dimensión normativa (esto es, el conjunto de normas jurídicas ambientales) deriva de un concepto que comprende las cuatro nociones arriba descritas. Bajo esta circunstancia, y para comprender el argumento que se esboza en el presente trabajo, partimos de la aseveración de que el ordenamiento jurídico ambiental relativo al régimen atmosférico debe proteger no sólo la salud, el bienestar y la calidad de vida de los seres humanos, sino también el medio natural.

Ahora bien, aunque parezca obvio, no está por demás enfatizar que la esencia de la regulación ambiental, debe estar orientada a establecer normas jurídicas que estén a favor del ambiente, y esto no significa otra cosa más que elaborar legislación para proteger las cuatro nociones del contenido mismo del concepto jurídico previamente aludido. Por supuesto que el alcance de la palabra protección en la legislación ambiental tiene ciertas semejanzas con el contenido y alcances de otros vocablos, pero todos ellos deben estar - o al menos deberían estarlo - encaminados a la defensa de su objeto de regulación. ${ }^{8}$ Se trata de expresiones como conservación, preservación, mejoramiento, restauración, remediación, reparación,

8 Parecería un tanto innecesario tener que precisar que la esencia de una norma ambiental es la de proteger el ambiente y no la de desprotegerlo. Sin embargo, la realidad que se vive en nuestro país nos permite señalar que existen fenómenos a los que podemos llamar paradojas de la legislación ambiental, expresión que encierra la idea de que hay disposiciones ambientales antiambientales. Esto es, normas jurídicas que aparentan estar a favor del ambiente pero que en realidad están en su contra provocando alteraciones, contaminación, destrucción o daño, como sucedió con una norma oficial mexicana (la NOM-022-SEMARNAT-2003) en su especificación 4.43, relativa a los humedales costeros a través de engañosas "medidas de compensación" para justificar su destrucción. El análisis de este tipo de paradojas lo desarrollamos en "Tres frases para la construcción de argumentos legales en la aplicación de la legislación ambiental”, en Nava Escudero, César (ed.), Legislación ambiental en América del Norte / Environmental Legislation in North America, Québec, Canadá-México, Comisión para la Cooperación AmbientalUNAM, Instituto de Investigaciones Jurídicas, 2011. 
Esta obra forma parte del acervo de la Biblioteca Jurídica Virtual del Instituto de Investigaciones Jurídicas de la UNAM

reconstrucción, vigilancia, inspección, custodia, etcétera. También las referentes a la prevención, el combate y el control de la contaminación.

Con base en la explicación conceptual anterior, se presentó ante la Línea de Investigación Institucional denominada Derechos, conflictos socio-ambientales y política (espacio académico de discusión multidisciplinaria) una propuesta para discusión respecto a qué sucedería si el concepto jurídico de ambiente, como lo hemos descrito, se amalgamara con ciertas nociones, específicamente con la de exclusión. Y esto fue lo que aconteció.

En principio se planteó la idea de que, independientemente de su significado, la combinación entre el concepto jurídico de ambiente y otras nociones provenientes de diversos campos del derecho y las ciencias sociales es analítica y conceptualmente viable. Por ejemplo, se discutió que al combinarlo con derechos permite la expresión derechos ambientales, con conflictos la de conflictos ambientales, y con marginación la de marginación ambiental. Por lo que, ¿habría razón alguna para dudar sobre la fusión de este concepto con el de exclusión como parte de un proceso de enriquecimiento multidisciplinario, y así referirnos a la expresión exclusión ambiental?

Cuando se procedió a formular tal interrogante, resultó que si bien la propuesta de unión terminológica tuvo una halagadora recepción por el grupo de investigadores (titulares y asociados) y estudiantes (becarios, de posdoctorado y de licenciatura) que conforman la línea de investigación, su significado comenzó a generar un arduo debate en dos sentidos. Primero, que la exclusión estaba ligada consustancialmente a lo social de aquí el uso común de la expresión exclusión social_- por lo que una aleación como la propuesta sólo podía aceptar del concepto jurídico de ambiente lo relativo a los seres humanos. Segundo, que aparte de que se pudiera "ampliar" la definición de exclusión a lo no social, debido a que era difícil concebir que la regulación ambiental no incluyera las cuatro nociones ya descritas — particularmente la del medio natural—, en caso de que así sucediera no estaríamos frente a un fenómeno de exclusión sino frente a uno de omisión u olvido de parte de autoridades y legisladores.

Sobre el primer punto del debate, estaba claro que la polémica radicaba en que la exclusión había sido concebida desde sus orígenes (allá por las décadas de los sesenta y setenta del siglo pasado) para describir 
Esta obra forma parte del acervo de la Biblioteca Jurídica Virtual del Instituto de Investigaciones Jurídicas de la UNAM

situaciones de individuos, comunidades o grupos humanos dentro y fuera de una sociedad: "la noción de 'exclusión social', en sus inicios estuvo ligada a un pequeño sector social que se encontraba ubicado fuera del sistema social". ${ }^{9}$ Pero no así para referirse a grupos no humanos o a situaciones o fenómenos no sociales, como lo podría ser el medio natural. Por consiguiente, el equilibrio ecológico y otras formas de vida, como la flora y la fauna, no podrían constituirse como categorías o unidades de análisis del concepto mismo de exclusión ambiental.

En este sentido, las lecturas que se llevaron a cabo en nuestras reuniones académicas periódicas, consistentemente confirmaron que, en efecto, la idea de exclusión está ligada a especies humanas y sus relaciones en sociedad, y no a especies no humanas o a cualquier otro ente o cosa no humana. Por ejemplo, en una de estas lecturas, Fernando Cortés aborda y discute los dilemas que conlleva precisar el significado de dicho concepto pero explicitando que sus reflexiones están vinculadas invariablemente a cuestiones sólo de tipo social, ya sean las personas, los procesos laborales o las relaciones de trabajo.

En los hechos, el concepto exclusión intenta describir el proceso a través del cual una serie de actores sociales que habían sido incluidos en los frutos del desarrollo y del bienestar en los años de bonanza económica, emergencia y consolidación del Estado benefactor son excluidos - especialmente del mercado laboral-, debido a los cambios inducidos directa o indirectamente por la globalización.

La categoría exclusión social no parece tener una clase de referencia claramente establecida, en efecto, en ocasiones se refiere a individuos; en otras, a procesos de trabajo, y a veces, a relaciones de trabajo. ${ }^{10}$

De modo que siempre fue sumamente controvertible argumentar que debía aceptarse que tanto políticas públicas como normas jurídicas ambientales pueden generar procesos de exclusión del medio natural o de otras formas de vida que no fueran humanas, como ¡las iguanas!

9 Véase Enríquez, Pedro Gregorio, "De la marginalidad a la exclusión social: un mapa para recorrer sus conceptos y núcleos problemáticos", Fundamentos en Humanidades, Argentina, Universidad Nacional de San Luis, año VIII, núm. I (15/2007), p. 75.

10 Cortés, Fernando, "Consideraciones sobre la marginación, la marginalidad, marginalidad económica y exclusión social”, Papeles de Población, México, Universidad Autónoma del Estado de México, núm. 047, enero-marzo de 2006, p. 78. 
Esta obra forma parte del acervo de la Biblioteca Jurídica Virtual del Instituto de Investigaciones Jurídicas de la UNAM

Con el paso del tiempo, entre opositores y adherentes, y ante mi insistencia — que no terquedad - sobre la posibilidad de construir y darle sentido a la expresión "exclusión ambiental" a partir del concepto jurídico de ambiente, se logró por lo menos que se admitiera y reconociera su existencia. Sin embargo, sobre su significado y alcances, no se alcanzó consenso alguno.

Así, la amalgama conceptual quedó explícitamente mencionada en el texto de uno de los trabajos publicados en esta obra colectiva: nos referimos al ensayo del doctor Mauricio Padrón. ${ }^{11}$ En su artículo, a propósito de la descripción que realiza sobre lo que debe de entenderse por exclusión social, se refiere de manera puntual a que existen, junto a ésta, dimensiones conceptuales más generales del pensamiento social contemporáneo, como la exclusión económica, la política, la de género, la étnica, la jurídica y, por supuesto, la ambiental. Todas son, a decir del autor citado, "distintas formas, grados o tipos de exclusión".

Respecto al segundo punto, es decir, por lo que corresponde a lo difícil de creer que la regulación ambiental no incluya al medio natural, y que si así fuera, no sería exclusión sino omisión u olvido, se presentó como contrargumento el ejemplo del régimen atmosférico de protección ambiental, específicamente el caso del mejoramiento de la calidad del aire en la Ciudad de México y su zona conurbada. ${ }^{12} \mathrm{El}$ análisis de este sector dentro del ordenamiento jurídico ambiental, no sólo buscaría persuadir a mis colegas de la línea de investigación sobre la viabilidad de referirse a un concepto de exclusión ambiental con un alcance más allá de lo estrictamente social, sino que permitiría una explicación puntual sobre el hecho de que, en muchos sentidos, el régimen atmosférico para la capital del país ha excluido al medio natural.

Con este caso se puede demostrar que en el sector ambiental atmosférico existen ciertos mecanismos dentro de programas y normas jurídicas que están orientados fundamentalmente a la protección de los seres humanos. Nos referimos, en específico, a las normas de calidad del aire

11 Véase de este autor en Varios autores, Sin derechos..., cit., pp. 69-101, el artículo intitulado "Acceso a la justicia, vulnerabilidad y exclusión: aproximación a las dimensiones relacionales subyacentes".

12 En ocasión de la Semana de las Líneas de Investigación realizada durante el mes de septiembre de 2011 en el Instituto de Investigaciones Jurídicas de la UNAM, se presentó para su discusión y análisis la ponencia intitulada "Conflictos atmosféricos. Exclusión ambiental y grupos vulnerables". 
Esta obra forma parte del acervo de la Biblioteca Jurídica Virtual del Instituto de Investigaciones Jurídicas de la UNAM

(donde se establecen los límites máximos permisibles de concentración de contaminantes atmosféricos), al índice de valores (que identifica la calidad del aire a través de números, colores y calificativos) y a los programas de contingencias atmosféricas ambientales (donde se informa sobre los riesgos por contaminación y acciones sugeridas). Si bien el medio natural, como noción del concepto jurídico de ambiente, se menciona expresamente en algunos cuerpos jurídicos y políticas públicas ambientales, no ha sido considerado para determinar los límites máximos permisibles, ni el índice de valores, como tampoco para formar parte de la activación de los planes de emergencias atmosféricas.

La razón de que esto haya sucedido así se debe a que el régimen atmosférico de protección ambiental ha sido edificado bajo una ética antropocéntrica. Esto significa que los seres humanos han sido el foco de atención y de regulación en dicho régimen.

\section{LA ÉTICA ANTROPOCÉNTRICA}

Dentro del pensamiento ambientalista han existido por tradición dos posturas ético-filosóficas que han tratado de explicar los orígenes y las alternativas de respuesta a la actual crisis ambiental: el antropocentrismo y el ecocentrismo. ${ }^{13}$ Aunque en ocasiones es posible detectar cierto tipo de convergencias entre ellas, cada una conserva sus propias y muy definidas características. Por un lado, la ética antropocéntrica postula que los seres humanos somos el centro del universo y que la naturaleza (que no tiene valor intrínseco ni derechos) existe sólo para beneficio de nosotros mismos. Por el otro, la ética ecocéntrica sostiene que la naturaleza (que sí tiene valor intrínseco y derechos) es el centro del universo y existe para sí misma y para los propios seres humanos.

13 A estas dos se han agregado recientemente el ambiocentrismo, que ha sido adoptada desde el pensamiento complejo y a partir de ello el uso de la expresión complejidad ambiental, y el de la sabiduría ancestral-sagrada, que se ha fundamentado en el pensamiento de grupos y comunidades ancestrales (o indígenas). Hacemos un recuento de éstas en Nava Escudero, César, Ciencia, ambiente..., cit. 
Esta obra forma parte del acervo de la Biblioteca Jurídica Virtual del Instituto de Investigaciones Jurídicas de la UNAM

\section{TABLA 1}

\section{El pensamiento ambientalista antropocéntrico según Foladori}

\begin{tabular}{|c|c|c|c|}
\hline Ética & Grupos & Causas de la crisis ambiental & Soluciones a la crisis ambiental \\
\hline $\begin{array}{l}\mathrm{A} \\
\mathrm{N} \\
\mathrm{T} \\
\mathrm{R} \\
\mathrm{O}\end{array}$ & $\begin{array}{l}\text { Tecnocen } \\
\text { tristas }\end{array}$ & $\begin{array}{l}\text { Cornucopianos: } \\
\text { - No hay crisis ambiental } \\
\text { - Problemas falsos o no graves } \\
\text { Ambientalistas moderados: } \\
\text { - Uso excesivo de recursos na- } \\
\text { turales por no ser propiedad } \\
\text { privada y/o por precios inade- } \\
\text { cuados } \\
\text { - Pobreza y consumo de los ricos }\end{array}$ & $\begin{array}{l}\text { Cornucopianos: } \\
\text { - Libre mercado sin o muy limi- } \\
\text { tada participación estatal } \\
\text { - Se encargan tecnología y mer- } \\
\text { cado } \\
\text { Ambientalistas moderados: } \\
\text { - Políticas que internalicen cos- } \\
\text { tos } \\
\text { - Crecimiento económico } \\
\text { - Tecnologías eficientes y lim- } \\
\text { pias } \\
\text { - Disminución de la pobreza }\end{array}$ \\
\hline $\begin{array}{l}\mathrm{P} \\
\mathrm{O} \\
\mathrm{C} \\
\mathrm{E} \\
\mathrm{N} \\
\mathrm{T} \\
\mathrm{R} \\
\mathrm{I} \\
\mathrm{S} \\
\mathrm{M} \\
\mathrm{O}\end{array}$ & Críticos & $\begin{array}{l}\text { Ecodesarrollistas: } \\
\text { - Producción y consumo im- } \\
\text { puesto por países hegemónicos } \\
\text { en un mundo históricamente } \\
\text { desigual } \\
\text { - Tecnologías inapropiadas } \\
\text { - Dominación cultural } \\
\text { Ecologistas sociales: } \\
\text { - Relaciones de dominación en- } \\
\text { tre humanos y naturaleza } \\
\text { - Lógica de mercado } \\
\text { Marxistas: } \\
\text { - Relaciones sociales de produc- } \\
\text { ción y explotación a la natura- } \\
\text { leza } \\
\text { - Relaciones capitalistas: pro- } \\
\text { ducción ilimitada y desempleo }\end{array}$ & $\begin{array}{l}\text { Ecodesarrollistas: } \\
\text { - Producción y consumo alter- } \\
\text { nativo basado en recursos na- } \\
\text { turales locales, conocimiento y } \\
\text { tecnologías locales, equilibrio } \\
\text { e integración rural-urbana } \\
\text { Ecologistas sociales: } \\
\text { - Expandir comunidades auto- } \\
\text { gerenciadas: producción a pe- } \\
\text { queña escala y relaciones de } \\
\text { cooperación } \\
\text { Marxistas: } \\
\text { - Cambio relaciones de produc- } \\
\text { ción capitalistas por otras no } \\
\text { clasistas y solidarias, basadas } \\
\text { en propiedad y gestión so- } \\
\text { cial de medios de producción }\end{array}$ \\
\hline
\end{tabular}

Fuente: Adaptada de Foladori, Guillermo, "Una tipología del pensamiento ambientalista", en Foladori, Guillermo y Pierri, Naína (coords.), ¿Sustentabilidad? Desacuerdos sobre el desarrollo sustentable, México, Cámara de Diputados-Universidad Autónoma de Zacatecas, Miguel Ángel Porrúa, 2005.

Tanto el antropocentrismo como el ecocentrismo están conformados por diferentes corrientes de pensamiento y se han elaborado diversas ti- 
Esta obra forma parte del acervo de la Biblioteca Jurídica Virtual del Instituto de Investigaciones Jurídicas de la UNAM

pologías en torno a ello. ${ }^{14}$ Siguiendo a Guillermo Foladori, ${ }^{15}$ bajo la égida del antropocentrismo se identifican dos grandes grupos. Primero, los antropocentristas tecnocentristas cuyas corrientes de pensamiento incluyen a cornucopianos y ambientalistas moderados; segundo, los antropocentristas críticos, que abarcan a ecodesarrollistas, ecologistas sociales, y marxistas (véase la tabla 1).

En el caso del ecocentrismo, para Foladori existe un solo grupo: los ecocentristas. Éstos están conformados por dos corrientes de pensamiento a las que se les conoce como ecologistas profundos y ecologistas verdes (véase la tabla 2).

\section{TABLA 2}

El pensamiento ambientalista ecocéntrico según Foladori

\begin{tabular}{|c|c|c|c|}
\hline Ética & Grupo & Causas de la crisis ambiental & Soluciones a la crisis ambiental \\
\hline $\begin{array}{l}\mathrm{E} \\
\mathrm{C} \\
\mathrm{O} \\
\mathrm{C} \\
\mathrm{E}\end{array}$ & \multirow[b]{2}{*}{ Ecocentristas } & $\begin{array}{l}\text { Ecologistas profundos: } \\
\text { - Ética antropocéntrica } \\
\text { - Desarrollo tecnológico, } \\
\text { industrial y urbano } \\
\text { - Explosión demográfica } \\
\text { (neo-malthusianismo) }\end{array}$ & $\begin{array}{l}\text { Ecologistas profundos: } \\
\text { - Igualitarismo biosférico } \\
\text { - Detener el crecimiento indus- } \\
\text { trial, urbano y poblacional } \\
\text { - "Vuelta al campo" } \\
\text { - Preservar la naturaleza }\end{array}$ \\
\hline $\begin{array}{l}\mathrm{N} \\
\mathrm{T} \\
\mathrm{R} \\
\mathrm{I} \\
\mathrm{S} \\
\mathrm{M} \\
\mathrm{O}\end{array}$ & & $\begin{array}{l}\text { Ecologistas verdes: } \\
\\
\text { - Industrialismo y crecimien- } \\
\text { to económico ilimitado: } \\
\text { consumismo } \\
\text { - Crecimiento poblacional } \\
\text { - Tecnologías sucias } \\
\text { - Uso excesivo de recursos } \\
\text { energéticos no renovables }\end{array}$ & $\begin{array}{l}\text { Ecologistas verdes: } \\
\text { - Disminuir consumo } \\
\text { - Detener el crecimiento po- } \\
\text { blacional } \\
\text { - Tecnologías verdes } \\
\text { - Energías limpias con recursos } \\
\text { renovables } \\
\text { - Conservar la naturaleza }\end{array}$ \\
\hline
\end{tabular}

Fuente: Adaptada de Foladori, Guillermo, op. cit.

14 Una tipología clásica se encuentra en O’Riordan, Timothy, "The Challenge for Environmentalism”, en Peet, Richard y Thift, Nigel, New Models in Geography, Londres, Unwin, 1989.

15 Véase Foladori, Guillermo, "Una tipología del pensamiento ambientalista", en Foladori, Guillermo y Pierri, Naína (coords.), ¿Sustentabilidad? Desacuerdos sobre el desarrollo sustentable, México, Cámara de Diputados-Universidad Autónoma de Zacatecas-Miguel Ángel Porrúa, 2005. 
Esta obra forma parte del acervo de la Biblioteca Jurídica Virtual del Instituto de Investigaciones Jurídicas de la UNAM

Desde el punto de vista político-ideológico, y en términos muy generales, se vinculan a la ética antropocéntrica las izquierdas (con ciertas excepciones), los centros, y las derechas (incluida la extrema derecha). A la ética ecocéntrica se asocian posiciones político-ideológicas que no están ni a la izquierda (salvo algunos radicales), ni al centro, ni a la derecha; su posición es estar al frente, esto es, constituir y buscar un nuevo paradigma ideológico.

Por lo anterior, es el antropocentrismo y no el ecocentrismo el que se ha caracterizado por tener el mayor número de seguidores en el discurso ambientalista. En él se encuentran prácticamente todos los gobiernos del planeta; los organismos internacionales (incluyendo a la ONU); una enorme cantidad de científicos, académicos, intelectuales, burócratas, políticos y abogados; ciertas organizaciones no gubernamentales; los partidos políticos (excluyendo a la mayoría de los partidos verdes); las empresas privadas y las grandes trasnacionales; los medios de comunicación in genere y, por último, las principales religiones del mundo (en especial las que provienen de la tradición judeo-cristiana que incluye prácticamente a todas sus escisiones o ramificaciones).

Como los antropocentristas forman parte del grupo mayoritario y dominante en la toma de decisiones (a nivel social, político, gubernamental, jurídico, científico, filosófico, mediático, etcétera), es característico en ellos no buscar nuevos paradigmas ni reformas radicales. Es decir, defienden el status quo y preferentemente buscan adaptarse y responder a tal o cual demanda, problema u oportunidad ambiental. Mientras tanto, los ecocentristas, como grupo minoritario y reactivo al antropocentrismo, proponen cambios trascendentalísimos que confrontan los principios esenciales de la postura ético-filosófica antropocéntrica y plantean con ello nuevos estilos de vida y concepciones vinculadas a un posible igualitarismo biosférico. ${ }^{16}$

16 Es evidente que ni la ética antropocéntrica ni la ética ecocéntrica son puras, como tampoco lo son sus respectivas corrientes de pensamiento. De manera que si bien existen claras diferencias de pensamiento entre unos y otros, también es posible detectar ciertos postulados que convergen y conducen a respuestas similares. Por ejemplo, tanto los antropocentristas ambientalistas moderados como los ecocentristas verdes coincidirían en enfrentar la crisis ambiental a través de tecnologías limpias, con la diferencia de que para éstos dichas tecnologías tendrían que ser de pequeña escala, y para aquéllos, independientemente de su escala, lo importante es que sean efectivas. 
Esta obra forma parte del acervo de la Biblioteca Jurídica Virtual del Instituto de Investigaciones Jurídicas de la UNAM

No debemos perder de vista que adoptar una postura antropocéntrica deriva en admitir la existencia de cierta superioridad humana sobre la naturaleza, una naturaleza que en lo biótico y lo abiótico debe dominarse y utilizarse para un fin último que es el bienestar humano. Un árbol, una iguana, o la atmósfera (todos ellos sin valor intrínseco ni derechos) existen sólo para beneficio nuestro. Pero debe quedar claro que tal concepción universal no es per se una visión antiambientalista puesto que los antropocentristas y su discurso ético-filosófico (con excepción de los cornucopianos) están a favor de proteger el ambiente.

Con esta brevísima explicación sobre la esencia de la ética antropocéntrica, corresponde ahora formularnos la siguiente interrogante: ¿pueden regir en el antropocentrismo las cuatro nociones que conforman el concepto jurídico de ambiente, particularmente la del medio natural? La respuesta en este sentido es afirmativa. Es decir, es correcto aseverar que bajo la ética antropocéntrica la política pública y el ordenamiento jurídico ambientales, según la explicación conceptual que hemos venido desarrollando, tendrían que proteger tanto a los seres humanos (su salud, bienestar y calidad de vida) como al medio natural.

Sin embargo, debido a que tal objeto de protección ostenta el rasgo distintivo de que primero están los intereses humanos y luego los de la naturaleza, ${ }^{17}$ puede ocurrir que a ésta no se le tome en cuenta. Desde el momento en que en alguno de los sectores o regímenes de regulación del cuerpo jurídico ambiental no se incluya al medio natural para su protección se configura el fenómeno de la exclusión ambiental.

El no tomar en consideración tal noción del concepto jurídico de ambiente significa que el diseño de una política pública o la elaboración de una norma jurídica busca favorecer primordialmente a los seres humanos. El argumento de que protegiendo a los humanos se protege a la naturaleza (al menos de manera indirecta) no tiene sentido alguno puesto que no siempre es factible determinar si una política o norma en esta dirección conducirá (y en qué medida y bajo qué parámetros) a beneficiar todo aquello que compone el medio natural. De cualquier manera, proceder así, constataría la preminencia de una visión meramente antropocéntrica, y esto redundaría de nueva cuenta en la presencia del fenómeno de exclusión ambiental.

17 Ello supone también que, en caso de conflicto entre unos y otros, prevalecerán los intereses humanos. 
Esta obra forma parte del acervo de la Biblioteca Jurídica Virtual del Instituto de Investigaciones Jurídicas de la UNAM

El escenario anterior se presenta precisamente dentro del régimen sectorial ambiental atmosférico para el caso de la Ciudad de México y su zona conurbada. Como se demostrará más adelante, el régimen atmosférico de protección ambiental (inmerso como lo está en la ética antropocéntrica) busca proteger la atmósfera o mejorar la calidad del aire, no por el valor intrínseco que pudiera tener la propia atmósfera como parte integrante del medio natural; ni por la igualdad que pudiera tener frente a los humanos; mucho menos porque tenga derechos; tampoco porque se quiera con ello proteger todo lo que conforma el medio natural (i.e. flora y fauna, equilibrio ecológico, ecosistemas, etcétera). En realidad, se protege la atmósfera o se mejora la calidad del aire porque de esta manera se obtiene un beneficio para los seres humanos: disminuir el riesgo de la salud en una población determinada, en este caso, la que reside en la ZMVM.

Con esta reflexión podemos mencionar el ejemplo siguiente. La cubierta vegetal (i.e. bosques o áreas verdes) que se ubica dentro y fuera (alrededor) de un conglomerado urbano tiene importancia porque para sus residentes, su existencia y conservación contribuye a mitigar la generación de ciertos contaminantes atmosféricos, específicamente las partículas, que son nocivas para la salud humana. Es decir, si se desarrollan políticas públicas y legislación ambiental para crear áreas con vegetación (a través de plantación de árboles) o proteger las ya existentes, no es necesariamente por razón de su belleza intrínseca o debido a que otras especies necesiten de ellas para su subsistencia, sino porque, en primerísimo lugar, acarrean beneficios de tipo atmosférico a sus habitantes. Y esta es la situación que prevalece en la ZMVM.

\section{LA CALIDAD DEL AIRE EN LA ZMVM}

La Zona Metropolitana del Valle de México se refiere a una extensión territorial de 7,732 $\mathrm{km}^{2}$ con un total de 19.7 millones de habitantes. Está conformada por 16 delegaciones del Distrito Federal — que es formalmente la Ciudad de México, sede de los Poderes de la Unión y capital de los Estados Unidos Mexicanos-y por 59 municipios del Estado de México (véase la tabla 3). Corresponde al Distrito Federal 19\% de dicha área geográfica con una superficie de $1,495 \mathrm{~km}^{2}$, así como $45 \%$ de la población con 8.8 millones de habitantes. Al Estado de México pertenece 
Esta obra forma parte del acervo de la Biblioteca Jurídica Virtual del Instituto de Investigaciones Jurídicas de la UNAM

el restante $81 \%$ con una superficie de $6,237 \mathrm{~km}^{2}$ y $55 \%$ de la población conformada por 10.9 millones de habitantes.

TABLA 3

Zona Metropolitana del Valle de México

\begin{tabular}{|c|c|c|}
\hline $\begin{array}{c}\text { Distrito Federal } \\
\text { Delegaciones: } 16 \\
\text { Superficie: } 1,495 \mathrm{kms}^{2} \\
\text { Población: } 8.8 \text { millones }\end{array}$ & \multicolumn{2}{|c|}{$\begin{array}{l}\text { Estado de México } \\
\text { Municipios conurbados: } 59 \\
\text { Superficie: } 6,237 \mathrm{kms}^{2} \\
\text { Población: } 10.9 \text { millones }\end{array}$} \\
\hline Álvaro Obregón & Acolman & Melchor Ocampo \\
\hline Azcapotzcalco & Amecameca & Naucalpan de Juárez \\
\hline Benito Juárez & Apaxco & Nextlalpan \\
\hline Coyoacán & Atenco & Nezahualcóyotl \\
\hline Cuajimalpa & Atizapán de Zaragoza & Nicolás Romero \\
\hline Cuauhtémoc & Atlauta & Nopaltepec \\
\hline Gustavo A. Madero & Axapusco & Otumba \\
\hline Iztacalco & Ayapango & Ozumba \\
\hline Iztapalapa & Coacalco de Berriozábal & Papalotla \\
\hline Magdalena Contreras & Cocotitlán & San Martín de las Pirámides \\
\hline Miguel Hidalgo & Coyotepec & Tecámac \\
\hline Milpa Alta & Cuautitlán & Temamatla \\
\hline Tláhuac & Cuautitlán Izcalli & Temsacalapa \\
\hline Tlalpan & Chalco & Tenango del Aire \\
\hline Venustiano Carranza & Chiautla & Teoloyucan \\
\hline \multirow[t]{15}{*}{ Xochimilco } & Chicoloapan & Teotihuacan \\
\hline & Chiconcuac & Tepetlaoxtoc \\
\hline & Chimalhuacán & Tepetlixca \\
\hline & Ecatepec de Morelos & Tepotzotlán \\
\hline & Ecatzingo & Tequixquiac \\
\hline & Huehuetoca & Texcoco \\
\hline & Hueypoxtla & Tezoyuca \\
\hline & Huixquilucan & Tlamanalco \\
\hline & Isidro Fabela & Tlalnepantla de Baz \\
\hline & Ixtapaluca & Tonanitla \\
\hline & Jaltenco & Tultepec \\
\hline & Jilotzingo & Tultitlán \\
\hline & Juchitepec & Valle de Chalco Solidaridad \\
\hline & $\mathrm{La} \mathrm{Paz}$ & Villa del Carbón \\
\hline & & Zumpango \\
\hline
\end{tabular}

Fuente: Comisión Ambiental Metropolitana et al., 2011. 
Esta obra forma parte del acervo de la Biblioteca Jurídica Virtual del Instituto de Investigaciones Jurídicas de la UNAM

Para conocer los niveles de contaminación atmosférica en la ZMVM, se han elaborado desde hace ya algunos años (específicamente a partir de 1972) instrumentos denominados inventarios de emisiones, que a su vez han sido utilizados en el desarrollo de programas para el mejoramiento de la calidad del aire. ${ }^{18}$ A través de estos inventarios (que desde 1998 se actualizan cada dos años) se presenta información que permite - entre otros objetivos-identificar las fuentes de emisión por categoría o sector (esto es, industria, transporte, etcétera); distinguir el tipo de contaminantes criterio, tóxicos y recientemente de efecto invernadero; describir los niveles de concentración y la distribución espacial y temporal de los principales contaminantes, así como establecer las tendencias y comportamientos de las emisiones.

Los datos y estadísticas sobre la situación atmosférica en la Ciudad de México y su zona conurbada que se han utilizado para la elaboración del programa gubernamental más reciente, i. e. el Programa para Mejorar la Calidad del Aire de la Zona Metropolitana del Valle de México 2011-2020 (en adelante, Proaire 2011-2020), provienen del inventario de emisiones de 2008.

Al indagar sobre la situación que guarda la calidad del aire en la ZMVM es indispensable referirnos a tres cuestiones muy específicas dentro del amplio régimen atmosférico de protección ambiental: $i$ ) la concentración máxima permisible de contaminantes; ii) el índice de valores; y iii) el programa de contingencias ambientales. Estos tres aspectos son, a su vez, mecanismos fundamentales para poner en marcha tanto los objetivos diseñados en las políticas públicas como los mandatos establecidos en las normas jurídicas ambientales.

\section{Limites máximos permisibles de concentración}

Existe para ciertos contaminantes atmosféricos un nivel permisible o aceptable de concentración. Los límites máximos permitidos se plasman en lo que comúnmente se conoce como normas de calidad del aire, a las que formalmente llamamos, según nuestra legislación, Normas Oficiales Mexicanas (en adelante, NOMs). Hasta el momento, se han expedido

18 Véase, para mayor detalle, Secretaría del Medio Ambiente del Gobierno del Distrito Federal, Inventario de emisiones de contaminantes criterio de la ZMVM 2008, México, Secretaría de Medio Ambiente, 2010, pp. 15 y ss. 
Esta obra forma parte del acervo de la Biblioteca Jurídica Virtual del Instituto de Investigaciones Jurídicas de la UNAM

normas a nivel federal para ocho contaminantes atmosféricos, que son conocidos con el nombre de contaminantes criterio: plomo $(\mathrm{Pb})$, bióxido de azufre $\left(\mathrm{SO}_{2}\right)$, monóxido de carbono $(\mathrm{CO})$, bióxido de nitrógeno $\left(\mathrm{NO}_{2}\right)$, ozono $\left(\mathrm{O}_{3}\right)$, partículas menores a 10 micrómetros $\left(\mathrm{PM}_{10}\right)$, partículas menores a 2.5 micrómetros $\left(\mathrm{PM}_{2.5}\right)$, y partículas suspendidas totales (PST). ${ }^{19}$

Todas estas NOMs han sido expedidas por el gobierno federal a través de la Secretaría de Salud con el objeto de establecer criterios para evaluar la calidad del aire. Se trata de valores normados para la concentración máxima (i. e. límites permisibles de concentración) de cada uno de los contaminantes atmosféricos arriba señalados como medida de protección a la salud de la población. ${ }^{20}$ Los límites permisibles pueden cambiar con el transcurso de los años según los niveles de tolerancia que establezcan las autoridades correspondientes.

Pongamos un par de ejemplos para comprender la esencia y el desarro1 lo de estas normas. Primero, la anterior Norma Oficial Mexicana relativa al $\mathrm{SO}_{2}$ (i. e. la NOM-022-SSA1-1993) establecía en sus orígenes como nivel máximo permisible una concentración de $0.130 \mathrm{ppm}$ promedio de 24 horas y de $0.030 \mathrm{ppm}$ promedio anual, lo que se consideraba en su momento el límite máximo para la protección a la salud humana. Debido a que se reportó que durante el periodo 2003-2009 las concentraciones de este contaminante en la ZMVM no rebasaron dichos niveles - lo que significaba que, al menos por lo que hace al $\mathrm{SO}_{2}$, se cumplía con los estándares normativos mexicanos - se "bajaron" los límites permisibles de concentración para proteger, aún más, la salud de la población. Así, la norma fue modificada por la vigente NOM-022-SSA1-2010 y se es-

19 Corrobórese en Comisión Ambiental Metropolitana et al., Programa para Mejorar la Calidad del Aire de la Zona Metropolitana del Valle de México (2011-2020), México, Secretaría de Medio Ambiente y Recursos Naturales-Secretaría de Salud-Secretaría de Medio Ambiente del Gobierno del Distrito Federal-Secretaría del Medio Ambiente del Gobierno del Estado de México, 2011, p. 61.

20 Cabe señalar que el gobierno federal ha expedido desde hace algunos años a través de la hoy Secretaría de Medio Ambiente y Recursos Naturales, y paralelamente a las expedidas por la Secretaría de Salud, un número considerable de NOMs en materia atmosférica. Aunque algunas de estas normas se refieren a concentraciones y/o límites máximos permisibles de distintos contaminantes para fuentes fijas o fuentes móviles, calibración de equipos de medición, diversos procesos de producción, etcétera, ninguna de ellas se toma en cuenta como punto de referencia para establecer los niveles permisibles para la elaboración del índice de valores o el programa de contingencias que se aplican en la ZMVM. Más adelante abordaremos esta situación. 
Esta obra forma parte del acervo de la Biblioteca Jurídica Virtual del Instituto de Investigaciones Jurídicas de la UNAM

tableció un valor menos tolerante en donde la concentración máxima no deberá rebasar de 0.110 ppm promedio en 24 horas y de 0.025 ppm promedio anual. ${ }^{21}$

Segundo, en el caso del $\mathrm{O}_{3}$, la Norma Oficial Mexicana respectiva (i.e. la NOM-020-SSA1-1993) establece un máximo de $0.110 \mathrm{ppm}$ promedio de 1 hora y de $0.080 \mathrm{ppm}$ promedio de 8 horas anual. Estos límites han sido superados cada año (con porcentajes diversos) desde que empezó el monitoreo sistemático de la contaminación atmosférica en $1986 .{ }^{22}$ En consecuencia, y a diferencia de lo sucedido con el $\mathrm{SO}_{2}$, no se ha hecho modificación alguna. Se considera que al estar los niveles de concentración constantemente violando los límites máximos permisibles, la población ha estado expuesta a riesgos en su salud a lo largo de todos estos años.

De manera que el criterio principal que se utiliza para determinar la calidad del aire que se respira en la ZMVM (como en todo el país) se refiere a que los niveles de concentración de los contaminantes no rebasen los límites máximos establecidos. Y esto tiene un fin específicamente determinado: proteger la salud de la población. Hay que subrayar que no existen, en ninguna de estas normas, valores de concentración máxima permisible para la protección al medio natural.

\section{2. Índice de valores}

Con el objeto de difundir entre la población de la ZMVM la información de los niveles de contaminación del aire se creó un índice de valores - conocido como Índice Metropolitano de la Calidad del Aire (IMECA) - en donde el límite permisible de concentración establecido en la norma tiene el equivalente a una escala de 100 puntos. ${ }^{23}$ De esta manera, es fácil comprender que, si tomamos el ejemplo del ozono, 100

21 Esta norma fue publicada en el Diario Oficial de la Federación del 8 de septiembre de 2010 .

22 Comisión Ambiental Metropolitana et al., Programa para..., cit., pp. 61 y 62.

23 Aunque el Índice Metropolitano de la Calidad del Aire data de 1982 (su antecedente inmediato es el Índice Mexicano de Calidad del Aire o IMEXCA de 1977), no fue sino hasta noviembre de 2006 que se expidió por la Secretaría del Medio Ambiente del Distrito Federal una norma para definir su significado y utilidad, así como establecer los lineamientos de su cumplimiento. Para mayor información sobre esto, véase Secretaría del Medio Ambiente, "Norma Ambiental para el Distrito Federal NADF-009-AIRE-2006, 
Esta obra forma parte del acervo de la Biblioteca Jurídica Virtual del Instituto de Investigaciones Jurídicas de la UNAM

puntos IMECA equivalen al límite máximo de 0.110 ppm en 1 hora según lo establecido por la NOM-020-SSA1-1993 relativa a ese contaminante en particular.

Si bien existen en la actualidad normas de calidad del aire (NOMs) para ocho contaminantes atmosféricos, sólo seis de ellos se utilizan para obtener el IMECA. Se trata de los contaminantes criterio siguientes: el $\mathrm{O}_{3}$, el CO, el $\mathrm{SO}_{2}$, el $\mathrm{NO}_{2}$, las $\mathrm{PM}_{10}$ y las $\mathrm{PM}_{2.5}$. Para facilitar el entendimiento de las equivalencias mencionadas, los puntos IMECA se identifican de esta manera: $i$ ) a través de una escala de números que aumenta cada 50 puntos; $i$ ) por color, siendo el verde el más bajo y el morado el más alto; y iii) por calificativos de la calidad del aire en donde "buena" es la más baja y "extremadamente mala" es la más alta (véase la tabla 4).

TABLA 4

El IMECA por escala, color, contaminante y calificativo

\begin{tabular}{|l|l|l|l|l|l|l|l|l|}
\hline $\begin{array}{c}I M E- \\
\mathrm{CA}\end{array}$ & Color & $\begin{array}{c}\mathrm{O}_{3} \\
(\mathrm{ppm})\end{array}$ & $\begin{array}{c}\mathrm{NO}_{2} \\
(\mathrm{ppm})\end{array}$ & $\begin{array}{c}\mathrm{SO}_{2} \\
(\mathrm{ppm})\end{array}$ & $\begin{array}{c}\mathrm{CO} \\
(\mathrm{ppm})\end{array}$ & $\begin{array}{c}\mathrm{PM}_{10} \\
\left(\mu \mathrm{g} / \mathrm{m}^{3}\right)\end{array}$ & $\begin{array}{l}\mathrm{PM}_{2.5} \\
\left(\mu \mathrm{g} / \mathrm{m}^{3}\right)\end{array}$ & $\begin{array}{l}\text { Calificativo de } \\
\text { la calidad del } \\
\text { aire }\end{array}$ \\
\hline 50 & Verde & 0.055 & 0.105 & 0.065 & 5.50 & 60 & 15.4 & Buena \\
\hline 100 & Amarillo & 0.110 & 0.210 & 0.130 & 11.00 & 120 & 40.4 & Regular \\
\hline 150 & Naranja & 0.165 & 0.315 & 0.195 & 16.50 & 220 & 65.4 & Mala \\
\hline 200 & Rojo & 0.220 & 0.420 & 0.260 & 22.00 & 320 & 150.4 & Muy mala \\
\hline$>200$ & Morado & $>0.220$ & $>0.420$ & $>0.260$ & $>22.00$ & $>320$ & $>150.4$ & $\begin{array}{l}\text { Extremada- } \\
\text { mente mala }\end{array}$ \\
\hline
\end{tabular}

Fuente: Adaptado de Secretaría del Medio Ambiente, 2006.

Son precisamente los calificativos de la calidad del aire el referente formal para describir el estado que guarda la atmósfera. Así, stricto sensu la manera apropiada para referirse a la situación atmosférica en la ZMVM no es a través del uso de vocablos como "limpia", "saludable", "sana" o "adecuada", sino a través de los calificativos indicados en la tabla 4. De modo que es la calidad del aire - y no la atmósfera - la que puede ser buena, regular, mala, muy mala, o extremadamente mala.

El objeto fundamental de los calificativos de la calidad del aire tiene dos fines claramente identificables. Primero, determinar el riesgo que implica la concentración de un contaminante atmosférico para la po-

que establece los requisitos para elaborar el Índice Metropolitano de la Calidad del Aire", Gaceta Oficial del Distrito Federal, 29 de noviembre de 2006. 
Esta obra forma parte del acervo de la Biblioteca Jurídica Virtual del Instituto de Investigaciones Jurídicas de la UNAM

blación, lo que se produce a través de mensajes de riesgos; y segundo, especificar las actividades que la propia población puede llevar a cabo para su protección, se trata de acciones de prevención y protección (véase la tabla 5).

\section{TABLA 5}

El IMECA por escala y calificativo. Mensajes de riesgo y acciones

\begin{tabular}{|l|l|l|}
\hline IMECA & $\begin{array}{l}\text { Calificativo de la } \\
\text { calidad del aire }\end{array}$ & \multicolumn{1}{c|}{ Mensajes de riesgo / acciones sugeridas } \\
\hline $0-50$ & Buena & $>$ Adecuada para llevar a cabo actividades al aire libre \\
\hline $100-150$ & Regular & $\begin{array}{l}>\text { Se pueden llevar a cabo actividades al aire libre. Po- } \\
\text { sibles molestias en niños, adultos mayores y personas con } \\
\text { enfermedades }\end{array}$ \\
\hline $150-200$ & $\begin{array}{l}\text { Evite las actividades al aire libre, esté atento a la in- } \\
\text { formación de calidad del aire. "Acuda al médico si pre- } \\
\text { senta sintomas respiratorios o cardiacos". Causante de } \\
\text { efectos adversos a la salud en la población, en particular } \\
\text { los niños y los adultos mayores con enfermedades cardio- } \\
\text { vasculares y/o respiratorias como el asma. }\end{array}$ \\
\hline Muy mala & $\begin{array}{l}>\text { Evite salir de casa y mantenga las ventanas cerradas, } \\
\text { esté atento a la información de la calidad del aire. "Acuda } \\
\text { al médico si presenta síntomas respiratorios o cardiacos". } \\
\text { Causante de mayores efectos adversos a la salud en la po- } \\
\text { blación en general, en particular los niños y los adultos ma- } \\
\text { yores con enfermedades cardiovasculares y/o respiratorias } \\
\text { como el asma. }\end{array}$ \\
\hline Extemadamente \\
mala
\end{tabular}

Fuente: Adaptado de Secretaría del Medio Ambiente, 2006.

La norma ambiental respectiva que establece los requisitos para elaborar el IMECA, esto es, la NADF-009-AIRE-2006 expedida por la Secretaría del Medio Ambiente del Distrito Federal, hace puntual referencia a 
Esta obra forma parte del acervo de la Biblioteca Jurídica Virtual del Instituto de Investigaciones Jurídicas de la UNAM

estos dos fines al señalar que el propósito del índice de valores es el de "informar a la población de manera clara, oportuna y continua, sobre los niveles de contaminación atmosférica, los probables daños a la salud que ocasiona y las medidas de protección que puede tomar". ${ }^{24} \mathrm{Y}$ puntualiza lo siguiente:

5.3.2 La difusión del IMECA por medio de un color y un calificativo deberá incorporar información sencilla de los riesgos a la salud humana y las acciones de prevención y protección que puede realizar la población. Los mensajes son breves y consideran que si un contaminante atmosférico criterio tiene concentraciones cuyo riesgo es bajo para la salud, no es necesario preocupar a la población; de lo contrario, es necesario señalarle que el contaminante atmosférico criterio puede ocasionar un efecto negativo a la salud, que esté pendiente y atenta a las recomendaciones sobre medidas de protección y que en su caso las adopte. ${ }^{25}$

En suma, debemos subrayar que el IMECA tiene como propósito fundamental la protección de la población y no la del medio natural, puesto que el índice de valores se adapta a los límites de protección a la salud que establecen las NOMs expedidas por la Secretaría de Salud respecto de los contaminantes criterio arriba señalados.

\section{Programa para contingencias ambientales atmosféricas}

Cuando los niveles de concentración de un contaminante comienzan a rebasar los 100 puntos IMECA, se implementan programas de emergencia o contingencia con el objeto de llevar a cabo todas aquellas acciones de mitigación o reducción de las emisiones correspondientes. Como las normas ambientales y el índice de valores tienen como objeto primordial la protección de la salud humana, tales programas están orientados a la prevención y alerta inmediata a la población en general, y particularmente a los grupos vulnerables, como son niños, asmáticos o personas con problemas respiratorios y cardiovasculares.

La Ciudad de México y su zona conurbada han contado con este tipo de planes desde finales de la década de los ochenta del siglo pasado, to-

\footnotetext{
24 Idem.

25 Idem.
} 
Esta obra forma parte del acervo de la Biblioteca Jurídica Virtual del Instituto de Investigaciones Jurídicas de la UNAM

dos con el propósito principal de proteger a los seres humanos a través de la activación de fases de precontingencia y contingencia. ${ }^{26}$

El plan de emergencia para la ZMVM, el Programa para Contingencias Ambientales Atmosféricas en el Distrito Federal (en adelante, PCAA), 27 al igual que sus antecesores, contempla disposiciones relativas a su activación (ya sea para precontingencia o contingencia en fases I y II) sólo respecto de dos contaminantes: el $\mathrm{O}_{3}$ y las $\mathrm{PM}_{10}$. Asimismo, establece la activación de la fase I del programa por una combinación de ambos según sean sus niveles de concentración (véase la tabla 6).

En un principio, la activación del programa de contingencias por $\mathrm{O}_{3}$ en su fase I, iniciaba cuando los niveles de concentración rebasaban los 250 puntos IMECA, y en su fase II, al rebasar los 350 puntos. Con el paso de los años la determinación para activar el programa se fue modificando. En nuestros días, la fase I se pone en marcha cuando se rebasan los 180 puntos IMECA y la fase II cuando los niveles son mayores a 230 puntos. La determinación para las pre-contingencias por este contaminante también se han ajustado: en agosto de 2006 la fase de pre-contingencia se activaba al llegar a los 170 puntos IMECA, y ahora se hace cuando se alcanzan los 150 puntos.

26 Desde la creación del Programa de Contingencias Ambientales en 1988 se ha producido información sobre el número de veces en que se han activado las fases de pre-contigencia (a partir de 1998) y de contingencia para la reducción de emisiones y de prevención a la salud de la población. Ya hemos advertido en otras ocasiones sobre la confusión que generan los informes gubernamentales en este sentido, puesto que las cifras que se han manejado a lo largo de casi 25 años no siempre concuerdan. Para mayor información sobre este punto y sobre los niveles de activación a través de un cuadro comparado para el período 1988-2005, véase lo que al respecto hemos señalado en Nava Escudero, César, Estudios ambientales, 2a. ed., UNAM, Instituto de Investigaciones Jurídicas, 2011, pp. 318 y ss. Aunado a lo anterior, acúdase para obtener datos respecto del período 19982011 sobre la activación de este programa — que por cierto tampoco concuerdan del todo con cifras publicadas en documentos gubernamentales anteriores - a la página web de la Secretaría de Medio Ambiente del Distrito Federal, www.sma.df.gob.mx

27 Tal y como se establece en el artículo 3o. transitorio del decreto que crea este programa, se abrogaron tanto el Decreto por el que se expidió el Programa para Contingencias Ambientales Atmosféricas en el Distrito Federal según Gaceta Oficial del Distrito Federal del 30 de octubre de 1998, así como los decretos respectivos que reformaron, adicionaron y derogaron diversas disposiciones del mismo, publicadas en la propia $G a-$ ceta Oficial del Distrito Federal del 22 de diciembre de 1999 y 30 de agosto de 2006. Jefatura de Gobierno, "Decreto por el que se expide el Programa para Contingencias Ambientales Atmosféricas en el Distrito Federal", Gaceta Oficial del Distrito Federal, México, 30 de junio de 2008. 
Esta obra forma parte del acervo de la Biblioteca Jurídica Virtual del Instituto de Investigaciones Jurídicas de la UNAM

\section{TABLA 6}

Valores IMECA para la activación y desactivación del Programa de Contingencias Ambientales Atmosféricas

(a partir de julio de 2011)

\begin{tabular}{|c|c|c|c|}
\hline & Precontingencia & Contingencia Fase I & Contingencia Fase II \\
\hline \multirow[b]{2}{*}{$\mathrm{O}_{3}$} & Inicio: mayor a 150 & Inicio: mayor a 180 & Inicio: mayor a 230 \\
\hline & $\begin{array}{l}\text { Suspensión: menor } \\
\text { a } 150\end{array}$ & Suspensión: menor a 150 & Suspensión: menor a 150 \\
\hline \multirow[b]{2}{*}{$\mathrm{PM}_{10}$} & Inicio: mayor a 150 & Inicio: mayor a 175 & Inicio: mayor a 230 \\
\hline & $\begin{array}{l}\text { Suspensión: menor } \\
\text { a } 150\end{array}$ & Suspensión: menor a 150 & Suspensión: menor a 150 \\
\hline \multirow{2}{*}{$\begin{array}{l}\mathrm{O}_{3} \\
\mathrm{y} \\
\mathrm{PM}_{10}\end{array}$} & \multirow[t]{2}{*}{ No aplica } & $\begin{array}{l}\text { Inicio: } \mathrm{O}_{3} \text { mayor a } 160 \mathrm{y} \\
\mathrm{PM}_{10} \text { mayor a } 125\end{array}$ & \multirow[t]{2}{*}{ No aplica } \\
\hline & & Suspensión: menor a 150 & \\
\hline
\end{tabular}

Fuente: Adaptado de Jefatura de Gobierno, 2008.

Algo similar ha pasado con las $\mathrm{PM}_{10}$. Actualmente, la precontingencia se pone en marcha cuando se alcanzan los 150 puntos IMECA, la contingencia en su fase I al llegar a los 175, y la fase II a los 230. En agosto de 2006 la precontingencia se activaba a los 160 puntos IMECA, la fase I de contingencia a los 175 y la fase II a los 250.

Es interesante comentar que el decreto de 2008 por el que se expide el PCAA establece lo que se entiende por precontingencia, contingencia, y contingencia combinada, y todos ellos se refieren a la afectación a la salud que pueda sufrir la población. Aunque en la definición de contingencia ambiental se hace mención a un posible riesgo ecológico o afectación al medio ambiente para la activación del PCAA, tal situación de emergencia se habrá de declarar de acuerdo con las normas oficiales respectivas, las cuales, como ya señalamos anteriormente, sólo establece límites permisibles de concentración de ciertos contaminantes atmosféricos en relación con la protección a la salud humana.

Tomando en cuenta el contenido y alcances de estos tres mecanismos - la concentración máxima permisible de contaminantes, el índice de valores y el programa de contingencias ambientales - nos formulamos las siguientes preguntas. ¿Es la calidad del aire en la ZMVM buena, regular, mala, muy mala, extremadamente mala? Dado que el régimen atmosféri- 
Esta obra forma parte del acervo de la Biblioteca Jurídica Virtual del Instituto de Investigaciones Jurídicas de la UNAM

co está orientado a la protección ambiental sólo de los seres humanos ¿en verdad existe tal protección?

Si analizamos los resultados que se han obtenido en más de 25 años de gestión de la calidad del aire en la ZMVM (1986-2012), se podría afirmar que los niveles actuales de contaminación atmosférica (por contaminante criterio) no son tan graves ni alarmantes como los observados durante finales de las décadas de los ochenta y principios de los noventa del siglo pasado. En efecto, contaminantes como el $\mathrm{CO}$ o el $\mathrm{SO}_{2}$ muestran en los últimos quince años una tendencia descendente. Incluso, en el caso de contaminantes como el $\mathrm{O}_{3}$ que continúan rebasando los límites permisibles establecidos por la NOM (según cifras oficiales, de 1986 a 2009 no se registró un solo año en que se cumpliera con dichos límites) los picos más altos de concentración han desaparecido. ${ }^{28}$

Sin embargo, la calidad del aire en términos generales está lejos de estar exenta de riesgos para la salud humana. En este sentido, hay por lo menos cuatro factores que no permiten escenarios autocomplacientes o demasiado optimistas aunque la tendencia de los contaminantes sea la de ir a la baja y cumplir con ello lo establecido en la normatividad mexicana.

Primero, los límites máximos permitidos de concentración de ciertos contaminantes en las Normas Oficiales Mexicanas son todavía muy flexibles, particularmente cuando son comparados con estándares internacionales. Es decir, la norma mexicana establece límites que son altos frente a los valores que se utilizan o recomiendan en otras partes del mundo, como los adoptados o sugeridos por la Unión Europea (UE), la Agencia de Protección Ambiental de los Estados Unidos de América (por sus siglas en inglés, USEPA), o la Organización Mundial de la Salud (OMS), respectivamente.

Por ejemplo, si comparamos los límites de las normas de calidad del aire mexicanas con las de la OMS para el caso del $\mathrm{O}_{3}$, encontramos que mientras que en México se establece un máximo de $157 \mu \mathrm{g} / \mathrm{m}^{3}$ para un promedio diario de ocho horas (que significa $0.08 \mathrm{ppm}$ ), ${ }^{29}$ las guías de valores de la OMS según su última actualización, ${ }^{30}$ señalan un máximo

28 Los datos y estadísticas al detalle pueden obtenerse en Comisión Ambiental Metropolitana et al., Programa para Mejorar..., cit., pp. 61 y ss.

29 Ibidem, p. 31.

30 Nos referimos a Organización Mundial de la Salud, Guías de calidad del aire de la OMS relativas al material particulado, el ozono, el dióxido de nitrógeno y el dióxido de azufre. Actualización mundial 2005, Ginebra, OMS, 2006. 
Esta obra forma parte del acervo de la Biblioteca Jurídica Virtual del Instituto de Investigaciones Jurídicas de la UNAM

de $100 \mu \mathrm{g} / \mathrm{m}^{3}$ para ese mismo promedio (que significa $0.05 \mathrm{ppm}$ ). Para el caso del material particulado, específicamente para partículas menores a 10 micrómetros (o sea, las $\mathrm{PM}_{10}$ ) existe también una diferencia importante. La norma mexicana establece $120 \mu \mathrm{g} / \mathrm{m}^{3}$ promedio de 24 horas y $50 \mu \mathrm{g} / \mathrm{m}^{3}$ promedio anual, ${ }^{31}$ pero la OMS establece una guía de $50 \mu \mathrm{g} / \mathrm{m}^{3}$ promedio de 24 horas y $20 \mu \mathrm{g} / \mathrm{m}^{3}$ promedio anual, lo que permite advertir fácilmente lo flexible de la norma en nuestro país. Y así para otros casos más. ${ }^{32}$

Segundo, y aunado a lo anterior, la activación del actual programa de emergencias (el PCAA) para la ZMVM no es, como tampoco lo han sido sus antecesores, lo estricto que se requiere, por el contrario, es característicamente tolerante. Dicho de otro modo, el PCAA debería ponerse en marcha - al menos para la activación de la precontingencia- cuando los niveles máximos de concentración tanto del $\mathrm{O}_{3}$ como de las $\mathrm{PM}_{10}$ alcanzaran los 100 puntos IMECA; de hecho, según lo analizado hasta aquí, la activación del programa se inicia cuando las concentraciones de estos dos contaminantes están todavía muy por encima de los límites máximos permitidos por las normas ambientales. Con ello, apenas tendríamos una calidad del aire regular, pero ciertamente preferible a la situación en la que en la actualidad se encuentra, que es mala o muy mala.

Debemos recordar que si el plan de contingencias ambientales está diseñado para prevenir y proteger la salud, su activación a los 180 puntos IMECA para el caso del ozono y de 175 para las partículas menores a 10 micrómetros para la fase I, tolera demasiado riesgo para la población. Ya analizamos (véase la tabla 5) que de 100 a 150 puntos, que es cuando se activa la precontingencia, se causan efectos adversos a los seres humanos (en su salud), específicamente a niños y adultos mayores con enfermedades cardiovasculares y/o respiratorias. Y peor aún, entre los $150 \mathrm{y}$ los

31 Secretaría de Salud, "Modificación a la Norma Oficial Mexicana NOM-025SSA1-1993, Salud ambiental. Criterios para evaluar el valor límite permisible para la concentración del material particulado. Valor límite permisible para la concentración de partículas suspendidas, totales PST, partículas menores a 10 micrómetros $\mathrm{PM}_{10}$ y partículas menores de 2.5 micrómetros $\mathrm{PM}_{2.5}$ de la calidad del aire ambiente. Criterios para evaluar la calidad del aire", Diario Oficial de la Federación, México, 26 de septiembre de 2005.

32 Mayores datos de referencia respecto a esos y otros contaminantes, se pueden encontrar en Comisión Ambiental Metropolitana et al., Programa para..., cit., p. 31, y Organización Mundial de la Salud, Guías de calidad..., cit., passim. 
Esta obra forma parte del acervo de la Biblioteca Jurídica Virtual del Instituto de Investigaciones Jurídicas de la UNAM

200 puntos, que es cuando se activa la fase I, los efectos adversos a la salud son mayores.

Tercero, el diseño político-jurídico para combatir la contaminación atmosférica en la ZMVM no parece cubrir en su totalidad la labor esencial de prevenir los riesgos a la salud humana. Lo anterior, porque las medidas establecidas para la activación del PCAA se enfocan sólo a dos contaminantes: el $\mathrm{O}_{3}$ y las $\mathrm{PM}_{10}$. Es necesario que se incluyan otros contaminantes (si no todos, por lo menos aquellos que son de preocupación) que evidentemente también tienen consecuencias negativas.

Cuarto, con independencia de los tres aspectos anteriores, las concentraciones de ciertos contaminantes siguen contribuyendo a un número estimado de muertes prematuras. Las cifras que se han manejado en este sentido han sido variables pero escandalosas. ${ }^{33}$ En el más reciente de los programas para mejorar la calidad del aire, el ya mencionado Proaire 2011-2020, se proporcionan datos sobre las muertes que se podrían evitar si se cumpliese con los límites que establece la NOM respectiva; que de cualquier manera es muy tolerante. Este documento gubernamental establece, incluso, las muertes que se evitarían si los límites máximos permisibles se ajustaran a estándares internacionales.

...si el promedio anual de $\mathrm{PM}_{10}$ cumpliera cabalmente la norma actual mexicana de $50 \mu \mathrm{g} / \mathrm{m}^{3}$, se evitarían 400 muertes de corto plazo en la ZMVM. Si se cumpliera con la norma europea de $40 \mu \mathrm{g} / \mathrm{m}^{3}$ se evitarían cerca de 1,000 muertes en la ZMVM. Y, si la reducción de los contaminantes llegase hasta los niveles establecidos por la OMS y la EPA, esto es, a $\operatorname{los} 20 \mu \mathrm{g} / \mathrm{m}^{3}$, se podrían evitar 2,300 muertes. ${ }^{34}$

También se han hecho estimaciones para el $\mathrm{O}_{3}$ a través de estudios epidemiológicos que presentan cierta evidencia en la que se asocia a este contaminante con un incremento en las tasas de mortalidad. Si se hiciera una reducción en la concentración de $\mathrm{O}_{3}$ a $50 \mathrm{ppb}$, se evitarían cerca de 400 muertes en la ZMVM al año. ${ }^{35}$

Todas estas consideraciones están, por supuesto, vinculadas a la información que se tiene sobre los riesgos que los niveles de concentración

33 Algunas referencias pueden consultarse en Nava Escudero, César, Estudios ambientales..., cit., pp. 312-322.

34 Comisión Ambiental Metropolitana et al., Programa para..., cit., p. 19.

35 Ibidem, pp. 24 y ss. 
Esta obra forma parte del acervo de la Biblioteca Jurídica Virtual del Instituto de Investigaciones Jurídicas de la UNAM

acarrean para la salud humana. Pero no es así respecto de los riesgos o daños que se pudieran causar al medio natural.

Como veremos a continuación, la regulación para la protección ambiental y el control y reducción de emisiones de los niveles de contaminación atmosférica en la ZMVM, está compuesta de políticas y normas que siempre se refieren a los seres humanos y ocasionalmente al medio natural. Sin embargo, dicha regulación en realidad sólo se actualiza para los seres humanos porque los mecanismos que permiten su aplicación - y operatividad y que son los que hemos explicado en este apartado (i. e. los límites permisibles de concentración, el índice de valores, y los programas de contingencias) - han sido confeccionados únicamente para nosotros los humanos y no para el medio natural.

\section{RÉGIMEN ATMOSFÉRICO DE PROTECCIÓN AMBIENTAL: ¿Y DÓNDE QUEDÓ EL MEDIO NATURAL?}

Como señalamos en el primer apartado de este trabajo, el régimen atmosférico de protección ambiental (en cuanto a sus programas y normas jurídicas) parte de una ética antropocéntrica y, por lo tanto, su foco de atención ha sido los seres humanos. Esto tiene una implicación de enorme trascendencia en relación con las cuatro nociones del concepto de ambiente, particularmente con la del medio natural. Simple y sencillamente, al ser la salud humana lo primordial, ha quedado excluido el medio natural de la protección ambiental.

La aseveración anterior no significa en lo absoluto que las políticas públicas y que las normas jurídicas hayan dejado de reconocer que la contaminación atmosférica no tenga efectos adversos en el medio natural. En efecto, por un lado, los programas atmosféricos más importantes para la ZMVM se han referido a esta noción de manera puntual. El primer programa integral para la ZMVM, el Programa Integral Contra la Contaminación Atmosférica de la Zona Metropolitana de la Ciudad de México (PICCA) de 1990, señaló en su momento que "los contaminantes presentes en el aire tienen distintos grados de toxicidad en el ser humano, los animales o vegetales. A la vez, y dependiendo de las condiciones de humedad, son agresivos a los materiales, edificaciones y monumentos de 
Esta obra forma parte del acervo de la Biblioteca Jurídica Virtual del Instituto de Investigaciones Jurídicas de la UNAM

la ciudad". ${ }^{36}$ Algo semejante sucedió con el programa que lo sustituyó, el Programa para Mejorar la Calidad del Aire en el Valle de México 19952000 (Proaire 1995-2000) de 1996, que estableció

los contaminantes atmosféricos también causan daños en la vegetación... Hace más de diez años que se cuenta con evidencia científica sobre los daños causados por gases oxidantes, como el ozono a las coníferas y a otros tipos de vegetación en la zonas del Ajusco... y del Desierto de los Leones... al sur de la Ciudad de México. ${ }^{37}$

Dos ejemplos más. Entrado el siglo XXI, se expidió el Programa para Mejorar la Calidad del Aire de la Zona Metropolitana del Valle de México 2002-2010 (Proaire 2002-2010) de 2002, y nuevamente incluyó al medio natural a propósito de la lluvia ácida: "entre más ácida es la 1luvia, mayores daños ocasiona a los suelos, la vegetación, los cultivos, los cuerpos de agua superficial, los materiales de construcción y el mobiliario urbano". ${ }^{38}$ Y el vigente Proaire 2011-2020, que especificó respecto al medio natural que a veces las plantas no presentan síntomas visibles y a veces es clara la evidencia de que son dañadas: "se han detectado en los últimos años efectos negativos de los gases oxidantes en algunos cultivos en parcelas experimentales y especies ornamentales en jardines, como soya, frijol, dalia... en la zona del Desierto de los Leones se han detectado daños por ozono en árboles de cereza negra". 39

Por lo que hace a la normatividad y, en este mismo sentido, los cuerpos jurídicos más relevantes en materia ambiental vinculados a la calidad del aire, también se han referido al medio natural. Por ejemplo, en la parte relativa a la prevención y control de la contaminación atmosférica, la Ley

36 Secretariado Técnico Intergubernamental, Programa Integral Contra la Contaminación Atmosférica de la Zona Metropolitana de la Ciudad de México, México, Secretariado Técnico Intergubernamental, 1990, p. 16.

37 Departamento del Distrito Federal et al., Programa para Mejorar la Calidad del Aire en el Valle de México 1995-2000, México, Departamento del Distrito FederalGobierno del Estado de México-Secretaría de Medio Ambiente, Recursos Naturales y Pesca-Secretaría de Salud, marzo de 1996, p. 41.

38 Comisión Ambiental Metropolitana et al., Programa para Mejorar la Calidad del Aire de la Zona Metropolitana del Valle de México 2002-2010, México, Secretaría de Medio Ambiente y Recursos Naturales-Secretaría de Salud-Gobierno del Distrito Federal-Gobierno del Estado de México, 2002, pp. 3-19.

39 Comisión Ambiental Metropolitana et al., Programa para..., cit., pp. 85 y 86. 
Esta obra forma parte del acervo de la Biblioteca Jurídica Virtual del Instituto de Investigaciones Jurídicas de la UNAM

General del Equilibrio Ecológico y la Protección al Ambiente (LGEEPA) de 1988 se refiere a esta noción al principio del artículo 113 al establecer que "No deberán emitirse contaminantes a la atmósfera que ocasionen o puedan ocasionar desequilibrios ecológicos o daños al ambiente".

El propio reglamento de esta Ley (i. e. el Reglamento de la Ley General del Equilibrio Ecológico y la Protección al Ambiente en materia de Prevención y Control de la Contaminación de la Atmósfera de 1988) lo incluye como un criterio para la protección a la atmósfera:

Artículo 13. Para la protección a la atmósfera se considerarán los siguientes criterios:

I. La calidad del aire debe ser satisfactoria en todos los asentamientos humanos y las regiones del país; y

II. Las emisiones de contaminantes a la atmósfera, sean de fuentes artificiales o naturales, fijas o móviles, deben ser reducidas o controladas, para asegurar una calidad del aire satisfactoria para el bienestar de la población y el equilibrio ecológico.

En el plano local, la Ley Ambiental para el Distrito Federal de 2000 previene, en lo que corresponde a la contaminación atmosférica, criterios para la protección a la atmósfera semejantes a los del Reglamento de la LGEEPA arriba mencionado.

Artículo 131. Para la protección a la atmósfera se considerarán los siguientes criterios:

I. Las políticas y programas de las autoridades ambientales deberán estar dirigidas a garantizar que la calidad del aire sea satisfactoria en el Distrito Federal; y

II. Las emisiones de todo tipo de contaminantes a la atmósfera, sean de fuentes fijas o móviles, deben ser prevenidas, reguladas, reducidas y controladas, para asegurar una calidad del aire satisfactoria para la salud y bienestar de la población y el mantenimiento del equilibrio ecológico.

Entonces, si estos programas e instrumentos jurídicos hacen alusión al medio natural, ¿cómo es posible hablar de su exclusión en el régimen atmosférico de protección ambiental?

La respuesta está sustentada en el hecho de que si bien la regulación programático-jurídica atmosférica se ocupa de mencionarlo, el medio natural y todo aquello que lo conforma en realidad no ha sido considerado 
Esta obra forma parte del acervo de la Biblioteca Jurídica Virtual del Instituto de Investigaciones Jurídicas de la UNAM

un factor para elaborar enunciados programáticos y normas de calidad del aire que permita la debida implementación de dicha regulación. Los enunciados y normas jurídicas a los que nos referimos son aquellos mecanismos que sirven para aplicar y hacer operativos — es decir, poner en marcha- los programas e instrumentos jurídicos. Estos mecanismos, a los que ya hemos hecho referencia en el apartado anterior, comprenden los límites permisibles de concentración establecidos en las NOMs, el índice de valores según lo establecido en el IMECA, así como los mensajes de riesgos y acciones sugeridas contenidas en el PCAA. Todos ellos, habremos de repetir una vez más, están orientados sólo a proteger la salud humana.

El punto clave para corroborar lo anterior se encuentra plasmado precisamente en diversas disposiciones jurídicas que al efecto se han elaborado y que sujetan la protección ambiental de la atmósfera a las normas de calidad del aire, i. e. a la NOMs que expide la Secretaría de Salud. Éstas, a su vez, han sido diseñadas para establecer los niveles permisibles de concentración con el objeto de proteger a los seres humanos.

Así, cuando la LGEEPA se refiere a las facultades que a nivel federal tiene la Secretaría de Medio Ambiente y Recursos Naturales en materia de prevención y control de la contaminación atmosférica, se hace hincapié en los valores máximos permisibles para la salud pública que determine la Secretaría de Salud.

Artículo 111. Para controlar, reducir o evitar la contaminación de la atmósfera, la Secretaría tendrá las siguientes facultades:

I. Expedir las normas oficiales mexicanas que establezcan la calidad ambiental de las distintas áreas, zonas o regiones del territorio nacional, con base en los valores de concentración máxima permisible para la salud pública de contaminantes en el ambiente, determinados por la Secretaría de Salud;

El reglamento de la LGEEPA en esta materia reitera la importancia de sujetar aquellas normas que al efecto se expidan para regular las emisiones de olores, gases y partículas a la atmósfera, a las normas previamente expedidas por la Secretaría de Salud según los valores de concentración máxima para los seres humanos. Lo anterior, tanto para fuentes fijas como para fuentes móviles, según lo establecen respectivamente los artículos 16 y 18 del Reglamento en cuestión. 
Esta obra forma parte del acervo de la Biblioteca Jurídica Virtual del Instituto de Investigaciones Jurídicas de la UNAM

Artículo 16. Las emisiones de olores, gases, así como de partículas sólidas y líquidas a la atmósfera que se generen por fuentes fijas, no deberán exceder los niveles máximos permisibles de emisión e inmisión, por contaminantes y por fuentes de contaminación que se establezcan en las normas técnicas ecológicas que para tal efecto expida la Secretaría en coordinación con la Secretaría de Salud, con base en la determinación de los valores de concentración máxima permisible para el ser humano de contaminantes en el ambiente que esta última determina.

Artículo 28. Las emisiones de olores, gases, así como de partículas sólidas y líquidas a la atmósfera que se generen por fuentes móviles, no deberán exceder los niveles máximos permisibles de emisión que se establezcan en las normas técnicas ecológicas que expida la Secretaría en coordinación con la Secretaría de Comercio y Fomento Industrial y de Energía, Minas e Industria Paraestatal, tomando en cuenta los valores de concentración máxima permisible para el ser humano de contaminantes en el ambiente determinados por la Secretaría de Salud.

Dada la importancia que tienen las NOMs que ha expedido la Secretaría de Salud, hemos elaborado un cuadro comparativo con cada una de las normas de calidad del aire que hemos venido mencionando (véase la tabla 7). En él, se observa claramente que en el numeral relativo a las Especificaciones de cada una de ellas, lo que se protege es la población y no el medio natural. ${ }^{40}$ Recordemos que estas NOMs se refieren a contaminantes criterio que sirven de base para conocer los niveles máximos de concentración para el ser humano.

Como ya lo explicamos, las NOMs son el sustento de la elaboración del índice de valores, el IMECA, en donde el límite permisible de concentración establecido en la norma tiene el equivalente a una escala de 100 puntos. El IMECA permite identificar si la calidad del aire a través de tal escala de puntos, y por color o con calificativos, es buena, regular, mala, muy mala o extremadamente mala.

Resulta que la intención del IMECA no está orientada a determinar los posibles daños al medio natural de la ZMVM y con ello conocer sobre la calidad del aire. En efecto, no hay que olvidar que en la ya referida norma NADF-009-AIRE-2006 relativa a los requisitos para elaborar el IMECA,

40 Sugerimos al lector revisar las NOMs que aquí presentamos para una información completa de su contenido. Esta tabla comprende algunas partes relativas a las Especificaciones de cada una. 
Esta obra forma parte del acervo de la Biblioteca Jurídica Virtual del Instituto de Investigaciones Jurídicas de la UNAM

se establece manifiestamente que el propósito de este índice de valores es informar a la población no sólo de los niveles de contaminación atmosférica sino también de los probables daños a la salud humana que ésta ocasiona y de las medidas de protección que se pueden tomar.

\section{TABLA 7}

\section{Especificaciones por contaminante según Norma Oficial Mexicana}

\begin{tabular}{|c|c|}
\hline NOM & Especificaciones por contaminante \\
\hline NOM-020-SSA1-1993 & $\begin{array}{l}\text { 4. Especificaciones. Para efectos de protección a la salud } \\
\text { de la población más susceptible se establece una norma que } \\
\text { contempla: la concentración de ozono como contaminante } \\
\text { atmosférico debe ser menor o igual a } 0.110 \text { ppm, promedio } \\
\text { horario, para no ser rebasado una vez al año. }\end{array}$ \\
\hline NOM-021-SSA1-1993 & $\begin{array}{l}\text { 4. Especificaciones. La concentración de monóxido de carbo- } \\
\text { no como contaminante atmosférico no debe rebasar el valor } \\
\text { permisible de } 11.00 \mathrm{ppm} \text { o lo que es equivalente a } 12,595 \mu \mathrm{g} / \\
\mathrm{m}^{3} \text { en promedio móvil de } 8 \text { hs una vez al año, como protec- } \\
\text { ción a la salud de la población susceptible. }\end{array}$ \\
\hline NOM-022-SSA1-2010 & $\begin{array}{l}\text { 4. Especificaciones. La concentración de dióxido de azufre } \\
\text { como contaminante atmosférico no debe rebasar el límite } \\
\text { máximo normado de } 288 \mu \mathrm{g} / \mathrm{m}^{3} \text { o } 0,110 \text { ppm promedio en } 24 \\
\text { hs, una vez al año, para protección a la salud de la población. }\end{array}$ \\
\hline NOM-023-SSA1-1993 & $\begin{array}{l}\text { 4. Especificaciones. La concentración de bióxido de nitróge- } \\
\text { no, como contaminante atmosférico, no debe rebasar el límite } \\
\text { máximo normado de } 0.21 \mathrm{ppm} \text { o lo que es equivalente a } 395 \\
\mu \mathrm{g} / \mathrm{m}^{3} \text {, en una hora una vez al año, como protección a la salud } \\
\text { de la población susceptible. }\end{array}$ \\
\hline NOM-025-SSA1-1993 & $\begin{array}{l}\text { 5. Especificaciones. Para efectos de protección a la salud de la } \\
\text { población más susceptible, se establecen los valores de con- } \\
\text { centración máxima para PST, PM } \text { y }_{10} \mathrm{PM}_{2.5} \text { en el aire ambien- } \\
\text { te... Partículas Suspendidas Totales PST: } 210 \mu \mathrm{g} / \mathrm{m}^{3} \text { prome- } \\
\text { dio de } 24 \mathrm{hs} \ldots \text { Partículas menores a } 10 \text { micrómetros PM } \\
120 \mu \mathrm{g} / \mathrm{m}^{3} \text { promedio de } 24 \text { hs... Partículas menores a } 2.5 \text { mi- } \\
\text { crómetros PM } \\
\text { ch.5 } 65 \mu \mathrm{g} / \mathrm{m}^{3} \text { promedio de } 24 \text { hs. }\end{array}$ \\
\hline NOM-026-SSA1-1993 & $\begin{array}{l}\text { 4. Especificaciones. La concentración de plomo como conta- } \\
\text { minante atmosférico no debe rebasar el valor permisible de } \\
1.5 \mu \mathrm{g} / \mathrm{m}^{3} \text { en un periodo de tres meses promedio aritmético, } \\
\text { como protección a la salud de la población susceptible. }\end{array}$ \\
\hline
\end{tabular}

Fuente: Adaptado de las Normas Oficiales Mexicanas que se citan. 
Esta obra forma parte del acervo de la Biblioteca Jurídica Virtual del Instituto de Investigaciones Jurídicas de la UNAM

Finalmente, el mecanismo que reafirma la idea de que la regulación atmosférica está edificada sólo para los seres humanos, aunque en ella se haga alusión al medio natural, es el propio Programa de Contingencias Ambientales. El objeto del PCAA señala lo siguiente:

El presente Programa tiene por objeto determinar, atendiendo a la concentración de contaminantes atmosféricos en las 16 delegaciones del Distrito Federal, las fases de contingencia ambientales, las bases de la declaración respectiva, así como las medidas aplicables para prevenir y controlar las emisiones contaminantes generadas por fuentes fijas y móviles, sus efectos en la salud de la población o en los ecosistemas. ${ }^{41}$

¿Por qué sostenemos que sólo cuenta la salud de los humanos y no los ecosistemas tal y como lo menciona el Programa? Porque la activación del PCAA está sujeta a valores o puntos IMECA (según se trate de $\mathrm{O}_{3} \mathrm{y} / \mathrm{o}$ de las $\mathrm{PM}_{10}$ ) cuyas equivalencias se obtienen de los límites máximos permisibles de concentración por contaminante según lo establecido en las NOMs. Y como ya precisamos, en las Especificaciones de estas normas de calidad del aire se deja en claro que el objeto principal en cada una de ellas es la protección de la población.

\section{REFLEXIÓN FINAL}

Dos cuestiones finales. Primero, a lo largo de este trabajo hemos tratado de demostrar que el régimen atmosférico para la ZMVM tiene un objetivo fundamental: proteger la salud de la población. Esto se debe a que los mecanismos que permiten la implementación de la regulación político-jurídica de protección ambiental para mejorar la calidad del aire están fundamentados en una ética antropocéntrica, lo que significa privilegiar a los seres humanos por encima del medio natural o de cualquiera de los factores que lo componen, como la flora o la fauna. Este razonamiento, a manera de hipótesis como parte de una línea de investigación propia, permite afirmar que semejante circunstancia bien podría configurar un fenómeno al que podemos denominar exclusión ambiental. Si queremos evitar que acontezcan este tipo de procesos excluyentes, es indispensable reflexionar sobre la necesidad de incluir al medio natural en los mecanis-

41 Jefatura de Gobierno, "Decreto por...", cit. 
Esta obra forma parte del acervo de la Biblioteca Jurídica Virtual del Instituto de Investigaciones Jurídicas de la UNAM

mos que permiten la operatividad de programas y normas jurídicas ambientales. Es tiempo ya de dejar de pensar sólo en los seres humanos y de buscar beneficios sólo para nosotros mismos; es menester hacerlo también para la naturaleza, el equilibrio ecológico, los ecosistemas, etcétera.

Segundo, gracias a la posibilidad de debatir una serie de temas afines con colegas universitarios de diversas disciplinas al interior de una línea de investigación institucional creada ex profeso, se han asimilado dos cosas fundamentales. Por un lado, que el desarrollo de la investigación científica y el crecimiento personal de cada académico se fortalece exponencialmente al compartir y discutir proyectos de investigación propios en contextos interdisciplinarios. Las posibilidades de expansión intelectuales en este sentido son infinitas. Por el otro, que espacios que permiten el debate abierto y plural de ideas y conceptos, aunque con ello no se llegue a consensos sobre la diversidad de temas explorados, representan la consolidación de los procesos de formación de recursos humanos, particularmente de investigadores jóvenes y de estudiantes de licenciatura y posgrado. 
Esta obra forma parte del acervo de la Biblioteca Jurídica Virtual del Instituto de Investigaciones Jurídicas de la UNAM

\section{EL HOY NO CIRCULA*}

\section{PRIMER ENGOMADO}

Primer engomado: orígenes y desmemoria. En México está comprobado que la desmemoria conduce, casi irremediablemente, a la ignorancia. El ignorante, si tiene un cargo público es neófito e inepto a la vez, y si tiene poder, seguramente se vuelve autoritario y corrupto. Quizá por esta sencilla razón conviene recordar qué es, para qué surgió y qué tan eficaz ha sido el Hoy No Circula (HNC), obligatorio desde el 20 de noviembre de 1989.

Hacia finales de la década de los ochenta y principios de los noventa del siglo pasado, la Ciudad de México y su zona conurbada (ZMVM) eran consideradas de las áreas urbanas con mayor contaminación atmosférica en el mundo. La pésima calidad del aire que se llegó a experimentar durante esos años, llevó a que se le caracterizara como "la antesala de un Hiroshima ecológico", cuando no de un "ecosistema urbano negativo" o "anti-ecosistema". Fueron muchos los contaminantes de preocupación en aquellos años, específicamente el plomo, las partículas suspendidas (principalmente las $\mathrm{PM}_{10}$ ), el bióxido de azufre, los óxidos de nitrógeno $\mathrm{y}$, desde luego, el ozono.

Hacia mediados de los ochenta se elaboraron una serie de medidas para combatir diversos contaminantes, entre ellas, un programa de emergencias, el Plan de Contingencias Ambientales de 1986, y el programa de verificación obligatoria de vehículos a gasolina, en enero de 1989. Pero no fue sino hasta 1990 que la lucha contra la contaminación atmosférica se formalizó con el Programa Integral Contra la Contaminación Atmosférica (PICCA). A partir de él se fueron creando y sustituyendo, uno tras otro, diversos programas para mejorar la calidad del aire

* Los cinco apartados aparecieron en Hechos y Derechos, revista electrónica, núm. 32, marzo-abril de 2016, UNAM, Instituto de Investigaciones Jurídicas, publicados el 29 de abril de 2016. 
Esta obra forma parte del acervo de la Biblioteca Jurídica Virtual del Instituto de Investigaciones Jurídicas de la UNAM

conocidos como Proaire, para los periodos de 1995-2000, 2002-2010 y 2011-2020. Una de las medidas que se incorporó, respectivamente, tanto a estos cuatro programas (el PICCA y los tres Proaire), como a los diversos planes de contingencias ambientales que han existido, fue precisamente el HNC.

Originalmente, el HNC (retiro de vehículos un día de la semana laboral) se diseñó como una medida transitoria para combatir la contaminación atmosférica. Su propósito era doble: $i$ ) reducir lo niveles alarmantes de contaminación atmosférica, y ii) reducir el tránsito vehicular en $20 \%$ aproximado del total de vehículos. Era, por lo tanto, un programa temporal y excepcional; en consecuencia, se trataba de una medida correctiva más que preventiva.

Meses después de su puesta en marcha, los políticos — que no son otra cosa más que políticos-, hicieron del HNC un monstruo híbrido y desvirtuaron su esencia. El error consistió en hacer del HNC original un programa permanente, transformándolo en una medida tanto correctiva como preventiva. El HNC aplicaría con o sin contingencias ambientales: en condiciones no críticas persistió un día laboral sin auto, pero ante una contingencia se decretaba su ampliación. Al activarse la Fase I (más de 250 puntos IMECA) se procedía (entre otras) a la reducción del $50 \%$ de vehículos gubernamentales, y con la Fase II (más de 350 puntos IME$\mathrm{CA})$, los vehículos particulares tendrían restricción de dos días a la semana (el doble HNC). La Fase III (más de 450 puntos IMECA) con medidas sumamente severas, nunca se activó.

Con el tiempo, el HNC comenzó a demostrar su ineficacia debido a que no cumplía con los dos propósitos para los que había sido diseñado. Lo anterior, porque se generó un problema que no fue advertido (o quizá fue ignorado) por las autoridades: los habitantes de la ZMVM empezaron a adquirir un segundo vehículo más para no dejar de circular un día a la semana. Este fenómeno trajo consigo dos contratiempos atmosféricos. Por un lado, en unos cuantos años se incrementó el parque vehicular, lo que derivó en mayores congestionamientos viales. Por el otro, el segundo vehículo era generalmente antiguo, estaba en malas condiciones y no contaba con la tecnología adecuada para circular.

Así, con todo y HNC, los niveles más críticos históricamente registrados por ozono se presentaron durante 1991 y 1992 con 8 y 11 días por arriba de los 300 puntos IMECA respectivamente. En 1992 se alcanzó la 
Esta obra forma parte del acervo de la Biblioteca Jurídica Virtual del Instituto de Investigaciones Jurídicas de la UNAM

concentración más alta que se recuerde por ozono: 398 puntos IMECA. Si bien en años posteriores las concentraciones de ozono disminuyeron ligeramente, éstas siguieron rebasando los 100 puntos IMECA: en 1990 se rebasó la norma por 325 días al año, en 1991 por 335 días, en 1992 por 317 días, en 1993 por 320 días, en 1994 por 340 días, en 1995 por 319 , y en 1996 por 317 días. Al mismo tiempo, el parque vehicular creció de manera persistente, pasando de más de 2.0 millones en 1990, a casi 2.5 millones para 1995. Hacia mediados de la década de los noventa, la velocidad promedio de los vehículos en la ZMVM era de $36 \mathrm{kms} / \mathrm{hora}$, y el $30 \%$ de esos vehículos circulaba en promedio a $10-20 \mathrm{kms} / \mathrm{hora}$.

En la segunda mitad de la década de los noventa, las autoridades tuvieron que modificar el HNC, e introdujeron hologramas para diferenciar, a través de las verificaciones vehiculares, qué vehículos podían circular todos los días y cuáles no, beneficiando a los modelos más recientes. Por lo tanto, el renovado esquema incluyó un tercer propósito: incentivar la compra de vehículos nuevos (supuestamente menos contaminantes) para lograr la "descarcachización" en la ZMVM y con ello mejorar la calidad del aire.

Desde entonces, el HNC se ha "modernizado" en diversas ocasiones. Ha sido un programa permanente tanto preventivo (restricción según holograma un día de la semana laboral, inclusive sábados, a vehículos más antiguos o contaminantes), como temporal y excepcional, es decir, correctivo (restricción sin importar holograma un día a la semana laboral, inclusive sábados y, en su caso, doble HNC ante contingencias ambientales según fase de activación).

A la fecha no existen estudios suficientes y confiables que demuestren que el HNC en sus cambiantes esquemas haya sido determinante para mejorar la calidad del aire o para disminuir el tránsito vehicular. De cualquier modo, los eventuales beneficios del HNC han sido seguramente neutralizados por el crecimiento exponencial de vehículos en la ZMVM.

\section{SEGUNDO ENGOMADO}

Segundo engomado: de H. sapiens sapiens a H. automobilis automobilis. En 2008 se publicó en el Boletín Mexicano de Derecho Comparado, revista indexada al Conacyt, un artículo de mi autoría al que intitulé 
Esta obra forma parte del acervo de la Biblioteca Jurídica Virtual del Instituto de Investigaciones Jurídicas de la UNAM

"From Homo sapiens to Homo automobilis. Revisiting Air Quality Management in Mexico City". Intuyo - presunción iuris tantum- haber acuñado la frase de la primera parte de este título. Pero para nuestros días, 2016, estoy convencido que tal expresión ya evolucionó, y lo hizo en tiempo real. Ahora la forma correcta de referirse al descocado crecimiento vehicular en la ZMVM de los últimos años es: From Homo sapiens sapiens to Homo automobilis automobilis.

Sin duda, los vehículos de superficie o el transporte (autos privados, taxis, camiones de carga, motocicletas, etcétera) continúan siendo la principal causa de emisiones de la mayoría de contaminantes. Su contribución al ozono y a las partículas (únicos contaminantes vinculados al plan de contingencias) es casi del 50\% del total de emisiones. Para el ozono, contribuye con $90 \%$ de los óxidos de nitrógeno $\left(\mathrm{NO}_{\mathrm{X}}\right)$ y con $35 \%$ de los compuestos orgánicos volátiles (COVs), que son sus precursores. En conjunto, autos particulares, taxis y autobuses, emiten 53\% de los $\mathrm{NO}_{\mathrm{X}}$ y para el caso de los COVs, los autos particulares contribuyen con $10 \%$ y las motocicletas con $8 \%$. De todas las fuentes móviles, son los autos particulares (seguidos de taxis y autobuses para $\mathrm{NO}_{\mathrm{x}}$, y motocicletas y taxis para COVs) los que más contribuyen a la formación del ozono.

Por tanto, no debe sorprendernos que el ozono (junto a las partículas) siga siendo uno de los principales problemas atmosféricos en la ZMVM. Si bien los niveles de concentración han estado marcados por cierta tendencia a la baja a partir del nuevo milenio, han rebasado constantemente, en días variables, por año, los 100 puntos IMECA. Para el año 2000 la concentración por ozono superó la norma en 308 días; en 2002 fue en 280 días; en 2004 de 225 días; 2007 de 220 días; 2009, 181 días; 2013, 126 días y en 2014, de 123 días.

Mientras tanto, el parque vehicular en la ZMVM ha crecido y crecido. En 1990 había poco más de 2.0 millones de vehículos, y de 2.7 millones en 1996 pasó a 3.0 en 2000; a 3.4 en 2002; a 3.8 en 2004; y a más de 4.1 en 2006. Para estos últimos años se calculaba que la velocidad promedio en las principales vías rápidas como Periférico y Viaducto era de 13 a $20 \mathrm{kms} /$ hora, y durante las horas pico de 7 a $15 \mathrm{kms} /$ hora. El crecimiento vehicular continuó para los siguientes años: en 2008 era de más de 4.6 millones, y para 2012 alcanzó la cifra de los 5.0 millones de vehículos. Para esta fecha se calculó una velocidad promedio para la Ciudad de México (que ya contaba con la mayoría de los segundos pisos de nuestros días, 
Esta obra forma parte del acervo de la Biblioteca Jurídica Virtual del Instituto de Investigaciones Jurídicas de la UNAM

diversos libramientos, y otras obras viales) de aproximadamente $17 \mathrm{kms} /$ hora en un día normal. En el 2016, se ha alcanzado la nada honrosa cifra de casi 5.5 millones de vehículos, de la cual el 75\% corresponde a autos privados.

Si desde hace muchos años se sabe que el parque vehicular es el que más contribuye al ozono, ¿porqué las autoridades encargadas de la gestión ambiental en la ZMVM (federales y locales) de las últimas dos décadas han dejado que crezca sin control alguno? ¿Qué han hecho y dejado de hacer para que ocurra esta situación? ¿El HNC ha tenido algo que ver en todo esto?

Tres respuestas puntuales. Primera, y la más importante, es que si hay algo que se debe de hacer para evitar el incremento del parque vehicular, es detener el crecimiento urbano y poblacional. Pero quienes han gobernado la ZMVM (niveles federal y local) en los últimos cuatro sexenios no han podido, sabido, o querido, controlar tal situación. Si bien la tasa de crecimiento poblacional se ha reducido, hemos transitado de unos 14.5 millones de habitantes en 1990 a alrededor de 21 millones en la actualidad. En lo urbano, la ZMVM ha crecido tanto vertical como horizontalmente (un ejemplo absurdo es Santa Fe al poniente de la CDMX). Todos sabemos, aunque paradójicamente no lo podamos comprobar, que la expansión urbana (por vialidades, condominios, centros comerciales, vivienda, etcétera) enriquece las cuentas bancarias de funcionarios federales y locales, ya sea de sus parientes o amigos. Permisos, licencias, autorizaciones, tráfico de influencias, amiguismo: la corrupción e impunidad en su esplendor. Encima, ya se construye el nuevo aeropuerto de la CDMX (NAICM) que traerá consigo más población, más urbanismo, más vialidades, más autos privados y, por ende, mala calidad del aire. Desde ahora afirmamos: el NAICM es inviable atmosféricamente hablando.

Segunda. la compra de vehículos particulares está asociada a una mal lograda identidad cultural y socioeconómica en la ZMVM. Las principales razones para adquirir un vehículo (o por lo menos soñar con uno) son el consumismo, la comodidad, el estatus social, y la falta de un transporte público limpio, rápido, seguro, accesible, cómodo, no contaminante, funcional y suficiente. Uno de los más grandes errores de las administraciones locales (CDMX y EdoMex) ha sido incentivar el uso del vehículo con la construcción de vialidades, segundos pisos y libramientos en lugar de 
Esta obra forma parte del acervo de la Biblioteca Jurídica Virtual del Instituto de Investigaciones Jurídicas de la UNAM

invertir a mayor escala y velocidad en la expansión del transporte público. Las vialidades están saturadas porque se venden indiscriminadamente camionetas y coches con enganches bajísimos y a mensualidades. En el escenario actual, el ideal del car users switch to public transportation mode recomendado desde hace tanto tiempo a las sordas e insulsas autoridades de la ZMVM, está muy lejos de convertirse en una realidad. Las aportaciones del metrobús en este sentido, todavía son menores.

Tercera. el HNC ha estado relacionado con la restricción al uso de los vehículos, pero no al de su propiedad. Por lo tanto, y como ya señalamos, cuando se hace permanente el retirar un vehículo un día a la semana laboral, el aumento de vehículos particulares es previsible. Los hologramas para circular todos los días es un incentivo para comprar un auto nuevo, pero el auto por el que es sustituido, no necesariamente sale de la circulación en la ZMVM.

\section{TERCER ENGOMADO}

Tercer engomado: Poncio Pilatos. Si la expansión urbana y el crecimiento poblacional continúan, si el transporte público no mejora, y si el número y uso de vehículos (particularmente, autos privados) sigue incrementándose, la calidad del aire no será saludable y el riesgo de que se sigan presentando episodios críticos estará latente. Esto se confirmó en marzo de 2016 al presentarse una de esas contingencias que creíamos ya no sucederían en la ZMVM.

En efecto, la mala calidad del aire durante algunos días de la segunda semana de marzo llevó a las autoridades a activar — el día 14- la Fase I del Programa de Contingencias Ambientales Atmosféricas (PCAA). Esto se debió a que los niveles de ozono rebasaron los 180 puntos IMECA, alcanzando ese día una concentración de 203 puntos. Se implementó el $\mathrm{HNC}$ restringiendo el martes 15 la circulación a vehículos con holograma de verificación 1, 2 y permisos, con terminación de placa de circulación impar, y vehículos con engomado rosa. Para días subsecuentes, todavía en Fase I, se intensificaron las medidas: restricción de todos los vehículos sin importar el holograma (1, 2, 0 y 00) según el color del engomado o la terminación de placa. Para el miércoles 16 descansaron todos los vehículos con engomado rojo y terminación de placas 3 y 4, y para el jueves 17 todos los de color verde y terminación de placas 1 y 2 . 
Esta obra forma parte del acervo de la Biblioteca Jurídica Virtual del Instituto de Investigaciones Jurídicas de la UNAM

Hacía ya algunos años que las concentraciones por ozono no llegaban a ese nivel, y esto llamó poderosamente la atención de la sociedad y de los medios de comunicación. No sólo no se habían rebasado los 200 puntos IMECA en más de doce años - la última vez fue un 10 de mayo (Día de las Madres) de 2003 con registro de 204 puntos IMECA-, sino que tampoco se habían rebasado desde 2011 los 180 puntos IMECA, que es cuando se activaba la Fase I del PCCAA. De hecho, la última vez que se activó la Fase I por ozono, si bien con un índice de valor distinto al de marzo, fue el 18 de septiembre de 2002 (en temporada de lluvias) con una concentración de 232 puntos IMECA.

A diferencia de otras ocasiones, las reacciones de diversos actores involucrados en la activación de la Fase I, fueron insólitas. Con grescas verbales y deslindes esquivos, se adoptaron posturas y se emitieron declaraciones absurdas - histéricas e infantiles, dirían algunos. En la tragicomedia atmosférica participaron el Jefe de Gobierno de la CDMX, el Gobernador del Estado de México, el titular de la Secretaría de Medio Ambiente y Recursos Naturales (Semarnat), y el Coordinador Ejecutivo de la Comisión Ambiental de la Megalópolis (CAMe). A éstas se sumó la Suprema Corte de Justicia de la Nación (SCJN). En esos días, cada uno se deslindó con palabras o silencios, buscando en algo o en alguien distinto a ellos una explicación del incremento de los niveles de ozono.

Recordemos lo que los medios de comunicación reportaron en esos primeros días de crisis. El Jefe de Gobierno de la CDMX tuvo la ocurrencia de decir que los índices de contaminación eran ajenos a la CDMX, que todo se debía a los vientos que venían de norte a sur, y que los estados de la megalópolis hacían poco para reducir las emisiones de vehículos automotores. Aunque reconoció la contribución de la CDMX a la contaminación y que el problema era de todos, señaló que la CAMe era la que tenía que actuar y enfrentar el problema. Al gobernador del Estado de México le incomodaron tales comentarios y decidió cerrar los basureros mexiquenses para la CDMX. Nadie sabe ni ha sabido cuál es la relación científica entre cerrar basureros y reducir los niveles de ozono. La $\mathrm{CAMe}$, frágil en su interlocución, se refugió en la naturaleza. Su titular explicó que la situación se debió al paso de una tormenta invernal, a los cielos despejados, a la ausencia de viento y a la alta radiación solar.

En esos días, circuló la versión de que una de las causas de tanto ozono en la atmósfera era el aumento de vehículos por una resolución de la 
Esta obra forma parte del acervo de la Biblioteca Jurídica Virtual del Instituto de Investigaciones Jurídicas de la UNAM

SCJN. En julio de 2015, el máximo tribunal había resuelto a favor de que un juez pudiera otorgar una suspensión a quienes cumpliendo las normas de verificación, pudieran obtener un holograma que les permitiera circular todos los días, atendiendo al nivel de contaminantes del automóvil sin importar el año del mismo. En un comunicado del 17 de marzo señaló que su decisión "no tuvo como finalidad ni alcance, permitir indiscriminadamente la circulación de vehículos automotores en el Valle de México"... fue..."en protección del principio de igualdad, como valor primordial en todo Estado de derecho". No se imaginaron los ministros que su resolución abriría la puerta, precisamente, para que las autoridades tomaran la decisión errónea de suspender tal regulación, lo que derivó en un aumento del número de vehículos en circulación. La Corte aventó la piedra y escondió la mano.

Cuando los niveles de contaminación ya no representaban mayor problema, apareció en escena el siempre ausente titular de la Semarnat, cuya comunicación ha sido por costumbre austera y tímida. Envió un tweet, el 17 de marzo que decía: "continuando trabajo conjunto a favor de habitantes del Valle de México, hoy tendremos reunión de trabajo". Ese día, se erigió como árbitro en la disputa entre las autoridades del CDMX y del Estado de México. En su calidad de juez y parte (la Semarnat es autoridad involucrada en la crisis atmosférica), frente a cámaras, y estrechando manos con el jefe de gobierno de la CDMX y el gobernador del Estado de México, él mismo anunció el levantamiento de la Fase I, la reapertura de los basureros y la modificación del PCAA. Qué curioso: el PCAA había sido modificado un mes antes, el 5 de febrero de 2016.

Ante la crisis, las autoridades et al. se lavaron las manos. La aplicación del HNC con la restricción de vehículos un día a la semana laboral por contingencia durante esos pocos días, confirmó su esencia temporal y excepcional y, por lo tanto, correctiva, como ha sido en los últimos años. Pero gracias a la desmemoria, la CAMe, con la anuencia de la Semarnat, la CDMX y el Estado de México, anunció el 30 de marzo que a partir del 5 de abril y hasta el 30 de junio todos los vehículos, sin importar holograma, dejarían de circular un día de la semana laboral, incluyendo los sábados. Otra vez la desmemoria. De nueva cuenta la medida draconiana. Y ahora como justificación, los discursos a la vieja usanza de la propaganda nazi. 
Esta obra forma parte del acervo de la Biblioteca Jurídica Virtual del Instituto de Investigaciones Jurídicas de la UNAM

\section{CUARTO ENGOMADO}

Cuarto engomado: las medidas draconianas estériles y el principio de orquestación. Joseph Goebbels concibió, como parte de la propaganda nazi, el llamado principio de orquestación, que consiste en escoger un número reducido de ideas, repetirlas una y otra vez, y presentarlas constantemente desde diferentes perspectivas pero siempre convergiendo sobre el mismo concepto, para no dejar lugar a dudas. De aquí la famosa frase de que si una mentira se repite lo suficiente, acaba por convertirse en verdad. Esto es lo que precisamente nos quieren hacer creer las autoridades federales y locales al imponer la ampliación del HNC (del 5 de abril al 30 de junio) en el que todos los vehículos, sin importar holograma, descansen un día de la semana laboral, incluyendo los sábados, con la justificación de que con ello se habrá de proteger la salud. Esta forma de actuar es de las preferidas por gobernantes ignorantes y/o autoritarios que buscan justificar la imposición de medidas draconianas irracionales: éstas no sólo no resuelven de fondo el asunto que les dio origen, sino que se vuelven estériles e intrascendentes.

Recordemos que el HNC bajo el esquema de que los vehículos descansen, sin importar holograma, un día de la semana laboral, incluyendo los sábados, es una medida esencialmente temporal y excepcional (se refiere a unos cuantos días, cuando mucho una semana, y su aplicación es exclusiva para el tiempo de la contingencia, $i$. e. cuando se rebasen los puntos IMECA señalados, que hace unos días era de 180, y ahora de 150), y por tanto correctiva (con lo que se pretende reducir los altos niveles de contaminación y disminuir eventualmente la circulación del parque vehicular). Pero las autoridades federales y locales cambiaron las reglas del juego. Volvieron a retorcer (ellos le llaman "ampliar") y a tergiversar (ellos le llaman "endurecer") el HNC para el periodo del 5 de abril al 30 de junio. Y para justificar todo esto, crearon discursos mentirosos, que repiten y repiten, para hacernos creer que son verdaderos. Veamos de qué se trata.

Primero, no respetaron la idea de que una medida drástica, como lo es retirar de la circulación, sin importar holograma, todos los vehículos un día de la semana laboral, incluyendo sábados, sólo puede ser transitoria, amén de reproducir errores del pasado y crear algunos nuevos. Una medida draconiana, transitoria, no puede durar casi dos meses y medio, pero engañosamente nos repiten que esta medida es temporal: una mentira que busca ser verdad. El HNC ampliado para éste periodo no tiene nada 
Esta obra forma parte del acervo de la Biblioteca Jurídica Virtual del Instituto de Investigaciones Jurídicas de la UNAM

de temporal conforme lo hemos explicado en éste y en los engomados anteriores. En todo caso, se trataría de una medida estacional, particularmente por lo que mencionaremos a continuación.

Segundo, tampoco se respetó la circunstancia de excepcionalidad en la ampliación del HNC bajo un esquema drástico, el cual corresponde sólo a una situación en la que se rebasan los niveles permisibles de contaminación. Lo retorcido de la decisión del pasado 30 de marzo es que al momento de anunciarse no se sabía si tendríamos esos episodios críticos, ya que sólo se pronosticaron escenarios de poca dispersión de contaminantes vinculados a una alta radiación solar, intensa estabilidad atmosférica y poca humedad. La excepcionalidad se volvió normalidad profética para el periodo anunciado, pero como veremos en el quinto y último engomado, el oráculo no correspondió a la realidad.

Tercero, el carácter correctivo del HNC es, por lógica, ex-post (una vez que ha ocurrido la contingencia) y no ex-ante (no es una medida preventiva). Sin embargo, la imposición del HNC bajo el esquema ya aludido, rompió con su esencia correctiva y se transformó en una medida para evitar o prevenir los altos niveles de contaminación. Así, la decisión "correctiva" enfrentará una situación que todavía no ha ocurrido, que es inexistente, y que es, según las autoridades, la que protegerá la salud de la población. Lo que ahora será correctivo para el periodo del 5 de abril al 30 de junio, es el doble HNC siempre y cuando se rebase la concentración máxima, lo que ocurrió el miércoles 6 de abril con más de 150 puntos IMECA originando la activación de la "modernizada" Fase I del PCAA.

Cuarto, otra mentira que busca ser verdad es que la razón principal por la que se amplió el HNC es la protección a la salud. No dudo que esto sí les preocupe a algunas autoridades federales y locales, pero si verdaderamente les importara - como repiten y repiten- ¿por qué no han actuado los últimos años para evitar (o sea, prevenir) los episodios críticos atmosféricos? Nadie niega los logros alcanzados, pero ahí sigue el crecimiento urbano desmedido (Santa Fe); los megaproyectos (NAICM); el aumento de vehículos (5.5 millones); los incentivos para usar automóviles (segundos pisos en CDMX y Estado de México); el parsimonioso "mejoramiento" del transporte público; entre otros. ¿Entonces?

Por último, ¿por qué razón no se han deslindado responsabilidades para el episodio atmosférico de mediados de marzo? Insistimos: las auto- 
Esta obra forma parte del acervo de la Biblioteca Jurídica Virtual del Instituto de Investigaciones Jurídicas de la UNAM

ridades federales y locales repiten engañosamente que la salud es lo que se debe cuidar, que es, como dijo el presidente de la República, "un bien mayor." Sin embargo, no hay responsables por los daños ocasionados a la salud de los habitantes de la ZMVM, ni por las muertes prematuras ocurridas, como tampoco los ha habido en contingencias anteriores. Los estudios de morbilidad y mortandad desde hace años son alarmantes, pero a nadie se le castiga, a nadie se le destituye.

Entre medidas draconianas estériles y discursos basados en el principio de orquestación, las autoridades inducen directa e indirectamente a los jueces a no otorgar suspensiones provisionales a los particulares que interpongan amparo en contra de la restricción de circular, un día de la semana laboral, incluyendo los sábados (particularmente vehículos con holograma 0 y 00 ). Ahora resulta que quienes interponen amparos son irresponsables porque "con la salud no se juega", cuando los irresponsables son las autoridades por imponer medidas draconianas con endebles bases científicas y sin fundamentos legales. Si existen responsables por los daños causados a la salud, y por las muertes prematuras ocurridas durante las contingencias (o incluso sin ellas), han sido las autoridades federales y locales que no han garantizado ni nuestro derecho de protección a la salud ni nuestro derecho al medio ambiente sano para nuestro desarrollo y bienestar, según lo dispone el artículo 4o. constitucional, párrafos cuarto y quinto, respectivamente.

\section{QUINTO ENGOMADO}

Quinto engomado: lo más absurdo y el recuerdo de Sir Winston Churchill. Lo más absurdo que he escuchado en las poco más de dos semanas que llevamos de ampliación del HNC (del 5 al 21 de abril), es que esta medida "está dando los resultados" esperados. Lo dijo precisamente el titular de la Semarnat en una entrevista por Radio Fórmula con Ciro Gómez Leyva el miércoles 20 de abril por la mañana. ¿Quién le pudo haber aconsejado que dijera semejante cosa? ¿Alguno de sus asesores o científicos orgánicos?

Al parecer, el parámetro que utilizó el titular de la Semarnat para decretar el éxito del HNC (en el que se restringe la circulación de todos los vehículos un día de la semana laboral, incluyendo los sábados, sin importar el holograma) es que en los quince días que lleva su aplicación (con 
Esta obra forma parte del acervo de la Biblioteca Jurídica Virtual del Instituto de Investigaciones Jurídicas de la UNAM

excepción del 5 de abril en el que se rebasaron los 150 puntos IMECA) "no se ha vuelto a presentar ningún episodio de más de 150 IMECAS...". Y para el secretario, eso "era justo de lo que se trataba este nuevo plan, de prevenir estos altos picos de ozono y hasta ahorita lo hemos realizado".

Lo que quizá ya olvidó nuestro desmemoriado secretario, es que según la información disponible de los máximos diarios de concentración por ozono, esos "picos" se han presentado de manera muy esporádica últimamente. Por ejemplo, durante todo 2015 sólo se rebasaron los 150 puntos IMECA por ozono en 12 días, y eso sin tener HNC ampliado. O dicho de otro modo, de los 365 días de 2015, durante 353 días no ocurrió ningún episodio de más de 150 IMECAS, es decir, no se necesitó de un HNC draconiano para evitar o prevenir que se presentaran esos niveles de contaminación, que ocurrieron excepcionalmente sólo en doce ocasiones.

Precisando la información anterior, de esos doce días de 2015, sólo cinco rebasaron ligeramente los niveles de concentración de 150 puntos IMECA. Así, los días y meses en los que se presentaron en alguna de las casetas atmosféricas tales niveles fueron el 3 de marzo con una concentración máxima de 160 puntos; el 8 de abril con 162; el 9 de abril con 169; el 4 de mayo con 153; el 5 de mayo con 160; el 9 de mayo con 165; el 10 de mayo con 153; el 19 de mayo con 152; el 10 de junio con 179; el 11 de junio con 154; el 14 de julio con 155, y el 4 de octubre con 176 . Cabe mencionar que durante 2015 sólo se activó en seis ocasiones la ahora extinta fase de precontingencia por ozono, y nunca se activó la Fase I del PCCA que comenzaba cuando se rebasaban los 180 puntos IMECA.

De manera tal, que no hay relación alguna entre el supuesto beneficio del HNC ampliado y la reducción del ozono por debajo de lo que ahora se considera un episodio crítico: más de 150 puntos IMECA.

Adicionalmente, se antoja sumamente extraño que el titular de la Semarnat hiciera un comentario como lo hemos descrito, con apenas unos cuantos días de implementado el programa. Es anticipado, meramente político. En todo caso, lo que verdaderamente resalta de la implementación del HNC ampliado es que, en sus escasos 16 o 17 días de vida, se ha observado que el mismo día de su inicio, el martes 5 de abril, se rebasaron los 150 puntos IMECA y se tuvo que activar para el miércoles 6 de abril la Fase I del PCAA. Aún más, en los días subsecuentes, en diversas ocasiones se alcanzaron niveles mucho muy cercanos a los 150 puntos 
Esta obra forma parte del acervo de la Biblioteca Jurídica Virtual del Instituto de Investigaciones Jurídicas de la UNAM

IMECA, y casi todos por encima de los 140 puntos. Así, por ejemplo, en alguna caseta atmosférica se alcanzaron para el jueves 7 los 148 puntos; el viernes 8 los 149; y el sábado 9 los 145. El domingo 10 bajó a 130, pero para el miércoles 13 fue de 144 puntos. El domingo 17 se incrementó a 148, y los días 19, 20 y 21 comenzaron a caer lluvias muy fuertes (en algunas partes con granizo), y por lo tanto los niveles de contaminación disminuyeron considerablemente. No ha habido en estos últimos días esa poca humedad que los profetas de la CAMe predijeron.

De la disminución del tránsito vehicular, las autoridades federales y locales han hablando poco, pero se supone que al día dejan de circular 1.2 millones de vehículos. Si se estima que en la actualidad existen poco menos de 5.5 millones de vehículos, con la ampliación del HNC estarían circulando unos 4.2 millones. Este es más o menos el mismo número de vehículos que circulaban entre 2006 y 2008, cuando la velocidad promedio en las principales vías rápidas como Periférico y Viaducto era de 13 a $20 \mathrm{kms} /$ hora. Con el reglamento de tránsito actual, y no obstante el incremento de segundos pisos y otras obras viales, es difícil pensar que el tránsito en la ZMVM haya mejorado con el HNC. De hecho, y como lo han venido informando los diferentes espacios noticieros, los congestionamientos viales continúan.

Las propuestas para mejorar verdaderamente la calidad del aire y permitir una mejor movilidad en la ZMVM han sido — y seguirán siendolas mismas de siempre en muchos sentidos: detener el crecimiento urbano y poblacional; mejorar el transporte público ampliando las líneas del metro, los autobuses eléctricos y el metrobús; desincentivar el uso y propiedad de los autos particulares; restringir la circulación a camionetas; proteger el suelo de conservación; sustituir vehículos gubernamentales a gasolina por vehículos híbridos; dar estímulos fiscales a particulares para adquirir vehículos híbridos y eléctricos; combatir la corrupción y la impunidad; fortalecer las verificaciones ambientales $\mathrm{y}$, ciertamente, hacer del HNC un programa tanto temporal y excepcional (sólo el tiempo que dura la contingencia y no ridículamente de varias semanas) y, por ende, correctivo.

No sólo es la salud lo que ahora preocupa o debe preocupar, sino la imposición de medidas draconianas y el autoritarismo florecientes de algunas autoridades federales y locales. Parece que con sus discursos, mensajes, acusaciones y actos de autoridad, quieren acallar las voces críticas, 
Esta obra forma parte del acervo de la Biblioteca Jurídica Virtual del Instituto de Investigaciones Jurídicas de la UNAM

descalificar a quienes interponen amparos, excluir a expertos y científicos no gobiernistas, y orillarnos a claudicar y rendirnos en la búsqueda de una ZMVM sin tanto megaproyecto ni tanto funcionario público ignorante, neófito, inepto y corrupto.

Aprendimos desde hace mucho tiempo, algunos, es decir, los que aún tienen memoria, que la propaganda nazi tuvo un contrincante letal que acabó por derrotarla. Me refiero a una frase de Sir Winston Churchill pronunciada en uno de sus discursos en 1940: we shall never surrender. 
Esta obra forma parte del acervo de la Biblioteca Jurídica Virtual del Instituto de Investigaciones Jurídicas de la UNAM

\section{INDICADORES Y RETOS PARA EL DESARROLLO URBANO SUSTENTABLE*}

\section{INTRODUCCIÓN}

Desde el inicio de la década de los noventa del siglo pasado y hasta nuestros días, el tema de la sustentabilidad urbana ha cobrado particular interés dentro del debate ambiental sobre el desarrollo sustentable. Lo anterior ha sido consecuencia de la creciente aceptación de que los centros urbanos son parte fundamental del deterioro ambiental como consumidores y destructores del medio natural y, sin embargo, lo son también en la búsqueda misma de alternativas sustentables (locales, regionales y globales) ya que en estos se desarrollan un gran número de actividades económicas, comerciales, culturales, artísticas, etcétera. ${ }^{1}$ El escenario actual de la problemática ambiental en los centros urbanos no debe concebirse bajo un esquema donde se cuestione la existencia o no de la ciudad sustentable. Aceptar esto implicaría suponer al desarrollo urbano sustentable como un fin en sí mismo, lo que irremediablemente llevaría a una discusión bizantina sobre su conceptualización. Contrario sensu, el desarrollo urbano sustentable debe entenderse como un proceso en el que se haga necesario distinguir, primero, los indicadores que permitirán se lleve a cabo este proceso de desarrollo, y segundo, los obstáculos o retos a los que habrá de enfrentarse.

* Publicado en Bien Común y Gobierno, México, año 6, núm. 72, noviembre de 2000

1 Breheny, Michael J., "Towards Sustainable Urban Development”, en Mannion, Antoinnette M. y Bowlby, Sophia R. (comps.), Environmental Issues in the 1990s, Chichester, Wiley, 1992, pp. 277-290. 
Esta obra forma parte del acervo de la Biblioteca Jurídica Virtual del Instituto de Investigaciones Jurídicas de la UNAM

\section{INDICADORES O CRITERIOS PARA UN DESARROLLO URBANO SUSTENTABLE}

Para identificar y elaborar criterios o indicadores que contribuyan a la construcción de un proceso de desarrollo urbano sustentable en las grandes áreas metropolitanas se requiere de dos aspectos fundamentales. Primero, es indispensable distinguir y localizar de manera específica áreas o actividades que formen parte de la problemática urbano-ambiental dentro de las ciudades, por ejemplo, es necesario identificar si existe o no un problema de contaminación de agua, aire, ruido, desechos tóxicos, o bien, la falta de actividades socioculturales, artísticas e incluso violación a los derechos humanos. Segundo, cada una de las cuestiones arriba mencionadas debe analizarse de manera conjunta o sistémica dentro de todo el espacio urbano, sin que por esto se excluyan áreas contiguas o interdependientes a éste. Así, del estudio combinado de estos dos grandes aspectos se crean indicadores que permiten una adecuada gestión ambiental a través de una instrumentación jurídica, política e institucional. Esto es, con la promulgación de leyes y/o la creación de tribunales; la planeación, implementación y evaluación de las políticas públicas, y finalmente, con la creación, fusión o abolición de estructuras gubernamentales.

Son tres las áreas que engloban los diversos indicadores de sustentabilidad urbana, sin que esto signifique una lista exhaustiva: ${ }^{2}$

1. La salud ambiental. Importante es en este rubro determinar y establecer criterios que, según los tipos de contaminantes y los niveles permisibles de contaminación (aire, agua, ruido, etcétera), no tengan un efecto dañino en la salud de los seres humanos, la flora y fauna existentes o bien impacten de manera negativa al medio construido.

2. La calidad de vida de los habitantes. Se caracteriza por la consecución de actividades sociales, culturales y económicas que garanticen la convivencia, recreación, desarrollo individual y colectivo a través de espacios deportivos, respeto a los derechos humanos y diversidad de creencias religiosas, creación de empleos, protección al patrimonio histórico y cultural de la ciudad, etcétera.

2 Véase Satterthwaite, David, "Sustainable Cities or Cities that Contribute to Sustainable Development?”, Urban Studies, vol. 34, núm. 10, 1997, pp. 1667-1691. 
Esta obra forma parte del acervo de la Biblioteca Jurídica Virtual del Instituto de Investigaciones Jurídicas de la UNAM

3. Minimizar el costo ambiental. Debe procurarse que el accionar urbano-ambiental orientado a los indicadores de salud ambiental y calidad de vida no implique un enorme costo ambiental para ciudadanos y ecosistemas de localidades o regiones circundantes y de otros países o continentes, en fin, del mundo entero.

\section{EL ESCENARIO: LOS RETOS Y DILEMAS}

Si es posible aceptar un intento de identificación de indicadores para el desarrollo urbano sustentable, es menester preguntarse cómo llegar a ellos. Dicho de otra manera, no se trata de plantear soluciones a los problemas ambientales y, por ende, iniciar un proceso de sustentabilidad urbana. Las cuestiones ambientales, en estricto rigor, no ofrecen soluciones, sino retos, dilemas; cada uno de estos, a su vez, parte de un cuestionamiento que atiende a una necesidad urbano-ambiental. De los diversos retos que existen, se mencionan los siguientes: ${ }^{3}$

a) Ético-teológico. Los principios de evolución o co-evolución de la especie humana deben cuestionarse para determinar si este mundo es sagrado o natural. Esta delimitación conduce a discernir entre la creencia ortodoxa de la supremacía del ser humano sobre la naturaleza y, por ende, su legitimidad ética para el uso y explotación de ésta por designio divino; o por el contrario, la aceptación del origen natural del ser humano y por lo tanto su relación en armonía con la naturaleza.

b) Equitativo. Ante cualquier accionar ambiental, es imprescindible preguntarse quién se beneficia y quién pierde. La búsqueda de equidad intra e intergeneracional no debe permanecer estática.

c) Libertario. Los objetivos trazados en el ámbito legal y de políticas públicas sobre la preservación y restauración del equilibrio ecológico y protección al ambiente urbano, conllevan el análisis y evaluación de cuánto se puede restringir la libertad de la conducta individual y/o colectiva para lograr dichos fines.

3 Véase, en este sentido, Bennett, Graham, Dilemmas: Coping with Environmental Problems, Londres, Earthscan, 1992. 
Esta obra forma parte del acervo de la Biblioteca Jurídica Virtual del Instituto de Investigaciones Jurídicas de la UNAM

d) Ideológico. Los procesos de globalización inciden necesariamente en el cambio ideológico y político de las naciones. En la geografía política existente, el cuestionamiento se orienta a la doctrina filosófico-económica que debe prevalecer en el contexto urbano (ya sea capitalismo, socialismo o incluso la llamada tercera vía).

e) Democrático. Ante el avance democratizador de los centros urbanos, ¿puede la democracia mejorar las condiciones ambientales de las ciudades? Sin una respuesta definitiva o universal a esta disyuntiva, deben identificarse las ventajas y desventajas sobre las virtudes y fallas de la democracia, según sea entendida y vivida por cada nación.

f) Educativo. Dado que la educación ambiental es fundamental para el proceso de concienciación de las sociedades urbanas, surge el dilema sobre el tipo de educación a impartirse, esto es, si será meramente informativa, participativa o una combinación de ambas. Es necesario, asimismo, cuestionar el papel de la universidad pública y privada (planes y programas) como actores fundamentales en el proceso educativo urbano-ambiental.

g) Valorativo. La viabilidad y continuidad en los procesos de sustentabilidad urbana deben evitar que la problemática ambiental en las ciudades surja a partir de intereses puramente electorales o, peor aún, por cuestiones de moda en el discurso político.

Así, en tanto cada uno de estos obstáculos sea analizado y confrontado, podrá iniciarse un verdadero proceso de desarrollo sustentable en los grandes centros urbanos.

\section{LAS TENDENCIAS: EL HOY Y EL MAÑANA}

Insertar el crecimiento y desarrollo de las ciudades a un proceso de sustentabilidad urbana, basado en la óptica de enfrentar retos ambientales $\mathrm{y}$, por ende, identificar y construir indicadores adecuados para ello, no es sencillo. Se requiere no sólo de estudios profundos en materia ambiental 
Esta obra forma parte del acervo de la Biblioteca Jurídica Virtual del Instituto de Investigaciones Jurídicas de la UNAM

y disciplinas o saberes afines, sino del entendimiento y respeto por tradiciones, identidad, cultura, en fin, del hacer valer el derecho irrenunciable a disfrutar la vida en la ciudad. ${ }^{4}$

Estar atentos al dinamismo de las ciudades permite allegarse de las mejores herramientas para evaluar el desempeño ambiental en los centros urbanos y sus alrededores y, al mismo tiempo, definir los avances de la sustentabilidad urbana como proceso. Ante todo, es fundamental el impulso de una conciencia urbano-ambiental y la voluntad política de quienes son generadores de cambios sustanciales en las metrópolis para la gestión ambiental del desarrollo. Los beneficios o pérdidas que experimente cada citadino y toda la comunidad urbana en su conjunto dentro de cinco, diez, veinte o treinta años dependerán en mucho de los esfuerzos realizados en este siglo que comienza. Sólo nos explicamos el ahora ambiental con el ayer histórico, lleno y falto de acciones ambientales. Definir desde ahora el mañana ambiental de las ciudades a través de un proceso de sustentabilidad urbana dignifica a sus futuros habitantes.

4 Legorreta, Jorge, "Todos tenemos derecho a la ciudad", La América que queremos: 32 ensayos en defensa de la vida, México, Programa de las Naciones Unidas para el Medio Ambiente-Programa de las Naciones Unidas para el Desarrollo-Fondo de Cultura Económica, 1998, pp. 85-87. 
Esta obra forma parte del acervo de la Biblioteca Jurídica Virtual del Instituto de Investigaciones Jurídicas de la UNAM

\section{VISITA A LAGUNA VERDE*}

Alrededor de Laguna Verde giran historias y relatos diversos, algunos a favor y otros en contra sobre las bondades y perjuicios energéticos y ambientales que produce la generación de electricidad a través de un sistema nuclear. En varias ocasiones se alerta sobre sus consecuencias ecológicas por radiación o uso de agua salada para su funcionamiento.

Por ello y para motivar a los alumnos a no emitir juicios sin conocimiento de causa, se ofrece dentro de la Universidad Iberoamericana (plantel Santa Fe) la materia Mecanismos de Protección Ambiental. Ésta se imparte en el Departamento de Ciencias Sociales y Políticas a estudiantes del Departamento de Relaciones Internacionales dentro del Subsistema de Medio Ambiente. Los objetivos de este curso son dos: promover una conciencia ambiental entre los alumnos y revisar de manera genérica los instrumentos jurídicos (nacionales e internacionales) para la protección del ambiente.

Como parte de la concienciación ambiental, se llevan a cabo durante el semestre diferentes prácticas de campo dentro y fuera de la Ciudad de México. El otoño pasado, la práctica de campo de los alumnos inscritos en la materia Mecanismos de Protección Ambiental consistió en realizar una visita a la central nucleoeléctrica de Laguna Verde, Veracruz, para conocer de cerca las consecuencias ambientales que ocasiona la puesta en operación de una planta nuclear para la generación de electricidad. A continuación se expondrán algunas de sus reflexiones:

1) La visita a Laguna Verde me gustó. En el Centro de Información nos proyectaron dos videos los cuales explicaban el funcionamiento de la central, nos dieron una amplia explicación por medio de maquetas y diagramas. Al finalizar nos trasladamos al edificio del reactor donde todos bien equipados con lentes, casco y botas de

* Publicado en Nuestra Comunidad, México, año VIII, núm. 145, enero de 2005. 
Esta obra forma parte del acervo de la Biblioteca Jurídica Virtual del Instituto de Investigaciones Jurídicas de la UNAM

hule entramos a conocerlo. Fue una experiencia realmente impresionante, divertida y enriquecedora.

\section{Luisa VIZCARRA}

2) Antes de entrar al edificio pasamos por el detector de drogas y explosivos. Una vez dentro a tres compañeros del grupo se les asignó un radiómetro en donde se indicó la radiación que recibimos. Antes de salir fuimos nuevamente inspeccionados por unos aparatos para ver que no tuviéramos ninguna partícula radioactiva en la ropa, así como en los zapatos. El trabajo que se realiza es de suma importancia para la generación de electricidad en México. Pero los temas de impacto ambiental no fueron puntualizados ni profundizados.

Leonor SÁENZ

3) Para mí fue una experiencia inolvidable porque nunca pensé poderlo conocer. Desde el principio del recorrido nos explicaron a detalle el funcionamiento de cada una de las partes que forman Laguna Verde. Lo que más me gustó y aprendí es que la radiación forma parte del mundo en que vivimos, todos estamos expuestos a ella.

Fernanda R. MORENO

4) La mayoría de nosotros salimos muy impresionados, con una excelente opinión de la planta nucleoeléctrica; sin embargo, esta experiencia me obligó a investigar un poco más. Lo que encontré no fue de mi agrado, después de tener la mejor impresión acerca de Laguna Verde, descubrí varios reportes y artículos en los que se asegura que las instalaciones y las repercusiones entre los habitantes cercanos a la planta son realmente desfavorecedoras.

Ana Lucía AgUiLAR

5) Fue una gran experiencia que muchos tal vez no hubiéramos vivido si no es por este viaje. La seguridad, aunque tediosa por todas las veces que tuvimos que pasar las tarjetas, es muy buena. Me da la impresión que no cuentan todo ni toda la verdad: un lugar tan peligroso, considerado de seguridad nacional no concuerda con que todo sea tan simple y tan seguro. Bueno, tal vez sea sólo desconfianza propia de mexicana.

Ana Cecilia MONDRAGÓN 
Esta obra forma parte del acervo de la Biblioteca Jurídica Virtual del Instituto de Investigaciones Jurídicas de la UNAM

6) No podemos olvidar que es importante la generación de energía eléctrica pero que, por obtener nuestros beneficios y cubrir nuestras necesidades, hemos estado dañando nuestro planeta: por ejemplo, el agua de mar que sirve para enfriar el generador regrese a éste con 10 grados centígrados más de temperatura puede dañar de gran manera la fauna que está en la zona. Aunque lo queramos negar, se está olvidando que la Tierra es de todos.

Ana Paula SÁNCHEZ

En conclusión, el principal resultado de una visita como la realizada a Laguna Verde es sin duda de alto impacto para el proceso de concienciación de los alumnos. En la medida en que cada uno de ellos haya asimilado la importancia del debate que gira en torno a la generación de energía a través de procesos nucleares se habrá cumplido una de las metas del curso. Desde luego, seguirá existiendo por años la confrontación de ideas en cuanto a si Laguna Verde o futuras plantas nucleoeléctricas deben operar en el país. 
Esta obra forma parte del acervo de la Biblioteca Jurídica Virtual del Instituto de Investigaciones Jurídicas de la UNAM

\section{LA REGULACIÓN JURÍDICA DE LA DESALACIÓN DE AGUA EN MÉXICO: LO BUENO, LO MALO Y LO MÁS MALO DEL PERIODO 2001-2006*}

\section{INTRODUCCIÓN}

Ante los grandes retos y oportunidades que mundialmente ofrece la creciente complejidad del agua dulce por su distribución inequitativa, su escasez y su contaminación, la idea de desalar agua de mar y agua salobre se ha convertido en una propuesta global de acción alterna. Con mayor frecuencia, aquéllos países en cuyo territorio (o partes de él) existe una situación crítica de disponibilidad de agua, optan por llevar esta idea a la práctica y desarrollar procesos de desalación: Arabia Saudita, Argelia, Australia, Bahrein, China, Emiratos Árabes Unidos, España, Estados Unidos de América, Irán, Israel, Kuwait, Libia, Omán y Qatar por mencionar sólo algunos. ¿Es acaso el agua desalada "la opción" a considerar para aquéllas naciones que empiezan a quedar envueltas en la misma complejidad que se observa a nivel global?

México enfrenta ya las mismas complicaciones que en muchos otros países se han detectado: una consistente distribución inequitativa de agua dulce, condiciones de escasez (estrés hídrico) y contaminación, deterioro o modificación en extensas áreas de su territorio. Dentro de un par de décadas, algunas regiones del país alcanzarán niveles extremadamente preocupantes de disponibilidad de agua como se prevé suceda en las regiones de la Península de Baja California y del Río Bravo. Ambas se unirán a la situación alarmante de disponibilidad de agua dulce que existe actualmente en la región del valle de México. Este amenazante escenario, llevó al actual presidente de la República a declarar al agua como recurso estratégico de seguridad nacional en 2001. Tras esta declaración, y después de casi seis años de gobierno, la idea de la desalación como opción

* Publicado en Fernández Ruiz, Jorge y Santiago Sánchez, Javier (coords.), Régimen jurídico del agua, México, UNAM, Instituto de Investigaciones Jurídicas, 2007. 
Esta obra forma parte del acervo de la Biblioteca Jurídica Virtual del Instituto de Investigaciones Jurídicas de la UNAM

alterna y viable para la adecuada gestión del recurso agua, sufre inexplicablemente de una regulación jurídica insuficiente y dispersa.

Este trabajo tiene por objeto analizar de manera breve la idea de la desalación en un contexto tanto internacional como nacional. Al realizar una sucinta explicación sobre la situación actual de México en materia de agua dulce y desalación, examinaremos de esta última su regulación jurídica (programática y legal). Nuestro estudio comprende el periodo 2001-2006 y se enfoca a los aspectos más importantes de lo bueno, lo malo y lo más malo de dicha regulación. Como veremos a lo largo de este trabajo, existe cierta contradicción al considerar al agua como un asunto de seguridad nacional y a la vez no contar con sustento programático ni con legislación precisa y adecuada que impulse y regule la ya establecida —aunque todavía incipiente- desalación en México.

\section{LA IDEA DE LA DESALACIÓN}

Si las estadísticas son frías y reveladoras, también lo pueden ser engañosas. Veamos por qué. En la actualidad, se estima que $97.5 \%$ del total del agua en el mundo es salada, el restante $2.5 \%$ es agua dulce. Del total de ésta, menos del $1 \%$ se encuentra en las principales fuentes para consumo humano como son lagos, ríos, humedad del suelo y cuencas de aguas subterráneas relativamente poco profundas. Esto es, el agua aprovechable para la especie humana representa apenas $0.01 \%$ del total del agua en el planeta. ${ }^{1}$ A primera vista, este pequeñísimo porcentaje de agua dulce para consumo de los seres humanos podría significar en sí mismo una preocupación, reto o desafío para preservar nuestra especie. Pero esto no es así. En primer lugar, porque si bien se estima que existe una pérdida natural de agua dulce en la Tierra, dicha pérdida es prácticamente insignificante. Es decir, es un mito sostener desde un punto de vista natural que el agua nos va a hacer falta porque cada vez hay menos para su consumo. La cantidad de agua dulce en el planeta en términos absolutos ha sido casi la misma de siempre. ${ }^{2}$ En segundo lugar, porque si bien

1 Véase Programa de las Naciones Unidas para el Medio Ambiente, Perspectivas del medio ambiente mundial 2002 (GEO-3), trad. de Raquel Arévalo de Azrak, Madrid, Ediciones Mundi-Prensa, 2002.

2 Programa de las Naciones Unidas para el Medio Ambiente, "Problems Related to Freshwater Resources", Vital Water Graphics, An Overview of the State of the World's 
Esta obra forma parte del acervo de la Biblioteca Jurídica Virtual del Instituto de Investigaciones Jurídicas de la UNAM

continúa el crecimiento poblacional en el mundo y con ello la demanda del recurso, es una falacia sostener que ese menos del 1\% del agua para consumo humano, por muy pequeño que sea, es globalmente insuficiente o hará falta para la humanidad. ${ }^{3}$

El centro de atención y preocupación que existe sobre este recurso natural, se desprende de una combinación de tres factores estrechamente vinculados entre sí. El primero de ellos es la llamada distribución inequitativa del agua en el contexto mundial por razón de su ubicación con respecto al lugar donde se asientan poblaciones enteras: lo que se traduce en un difícil y complejo sistema de acceso y disponibilidad del recurso, el segundo es la denominada escasez de agua que existe en diversas regiones del mundo por el "estrés hídrico" que sufren aquéllos lugares donde el consumo de agua es superior al 10\% de los recursos renovables de agua dulce, y el tercero es la amenazante y creciente contaminación, deterioro y/o modificación del recurso por causas humanas y naturales, respectivamente.

Las preocupaciones sobre el agua en el ámbito mundial comenzaron a tomar forma en 1977 durante la Conferencia de las Naciones Unidas sobre el Agua celebrada en Mar del Plata, Argentina, en la que diversos países acordaron que todos los pueblos tienen derecho al acceso a agua potable para satisfacer sus necesidades básicas. Este acuerdo habría de fortalecerse y expandirse algunos años después en la Conferencia de las Naciones Unidas sobre el Medio Ambiente y el Desarrollo celebrada en Río de Janeiro, Brasil, en 1992. En uno de los cinco documentos emanados de esta conferencia - la Agenda 21, específicamente en su capítulo 18- se hizo hincapié en la importancia de mantener un suministro suficiente de agua de buena calidad para toda la población del planeta y preservar a la vez las funciones hidrológicas, biológicas y químicas de los ecosistemas. Para ello, sería preciso contar con tecnologías innovadoras que permitieran aprovechar plenamente los recursos hídricos limitados y protegerlos de la contaminación. De modo que en este documento se propusieron áreas de programas para la consecución de dicho objetivo general a través de una serie de acciones, objetivos, actividades

Fresh and Marine Waters, United Nations Environment Programme, 2002, http://www. unep.org/vitalwater/resources/htm.

3 Marsily, Ghislain de, El agua, trad. de Juan José Utrilla Trejo, México, Siglo XXI, 2001, pp. 99 y 100. 
Esta obra forma parte del acervo de la Biblioteca Jurídica Virtual del Instituto de Investigaciones Jurídicas de la UNAM

y medios de ejecución. Dentro de las áreas denominadas "Ordenación y aprovechamiento integrados de los recursos hídricos" y "Repercusiones del cambio climático en los recursos hídricos", se mencionó de manera expresa la necesidad de que los Estados llevaran a cabo (entre muchas otras) acciones vinculadas a la desalación o desalinización de agua tanto para lograr esa ordenación como para evitar dichas repercusiones. ${ }^{4}$

La desalación consiste en un proceso técnico-industrial por el que se separa la sal del agua. Se puede desalar tanto agua de mar como agua salobre ya sea superficial o subterránea con el objetivo principal de obtener agua dulce para consumo. Aunque algunos países cuenten ya con esta tecnología y hayan instalado plantas de este tipo, la idea de la desalación encierra un dilema fundamental en el que es conveniente advertir las ventajas y desventajas que implica su impulso y puesta en operación.

Por un lado, la desalación está orientada a resolver problemas de suministro y abastecimiento de agua que no sólo se destina para consumo humano. Mundialmente, se cuenta cada vez más con experiencias en las que a través de este proceso se dota de agua dulce a ciudades costeras (para fines que nada tienen que ver con usos para consumo humano), a ciertos sectores como el industrial, e incluso a sistemas de riego de cultivos. En algunas regiones del planeta donde existe una situación crítica de escasez de agua (como es el caso de la cuenca del Río Jordán que afecta principalmente a Israel, Jordania, Gaza y Siria) se estima que a través de esta tecnología se podría obtener para 2020 hasta un 50\% adicional del agua dulce disponible en la zona. ${ }^{5}$

Por otro lado, los costos para obtener agua dulce a través de esta innovadora medida pueden ser muy altos. Aunque los precios para ello hayan disminuido en los últimos años, no todos los países poseen los recursos financieros suficientes para invertir en la tecnología o en las energías que habrán de utilizarse. En efecto, el proceso de desalación consume mucha energía que de no ser renovable como la solar o la eólica requiere de

4 Véase Organización de las Naciones Unidas, “18. Protección de la calidad y el suministro de los recursos de agua dulce: aplicación de criterios integrados para el aprovechamiento, ordenación, y uso de los recursos de agua dulce", Programa 21, capítulo 18, División para el Desarrollo Sostenible, 15 de diciembre de 2004, http://www.un.org/ esa/sustdev/documents/agenda21/spanish/agenda21spchapter18.htm,

5 Allan, J. A., "Virtual Water Eliminates Water Wars? A Case Study from the Middleast”, en Hoekstra, A. Y. (ed.), Virtual Water Trade, Delft, núm. 12, febrero 2003, http://www.ihe.nl/downloads/projects/report12-hoekstra.pdf. 
Esta obra forma parte del acervo de la Biblioteca Jurídica Virtual del Instituto de Investigaciones Jurídicas de la UNAM

grandes cantidades de combustibles fósiles. Esto implica, desde luego, un costo altísimo para su implementación. Adicionalmente, la desalación de agua ha sido cuestionada en tres aspectos esenciales. Primero, no garantiza del todo resolver uno de los grandes problemas que enfrentan muchas naciones: la demanda que existe para regadío de largas extensiones de cultivo. Segundo, si no se utilizan energías renovables, se podría generar (según sea la cantidad de quema de combustibles fósiles) un efecto negativo en el ambiente, particularmente en lo relativo a la estabilización de las concentraciones de gases de efecto invernadero en la atmósfera con posibles afectaciones al sistema climático mundial. Tercero, no todo el volumen de agua procesado se convierte en agua dulce sino que se genera como resultado de ello una solución altamente salina. ${ }^{6} \mathrm{Al}$ parecer, este residuo - conocido como salmuera - no puede destinarse a algún otro uso ni puede tampoco reciclarse, por lo que es común que sea devuelto al propio mar. Aunque no se tenga la certeza absoluta de que la salmuera genere contaminación o produzca un impacto negativo en el ambiente, es probable que ciertos ecosistemas marinos o costeros se vean afectados según las cantidades que de ella se viertan al mar (sobre todo tratándose de un área limitada), el tipo de proceso de desalación que se utilice, y la propia fragilidad marina y/o costera del lugar donde se arroje. Si bien la salmuera puede ser depositada en algún confinamiento en la parte terrestre, si éste no cuenta con las medidas de prevención y protección necesarias podría contaminar el suelo, el subsuelo y consecuentemente modificar o deteriorar el agua dulce subterránea que se encuentre en dicho lugar. A todo lo anterior, habría que agregar la contaminación visual (paisaje) y la acústica (ruido) generada por las propias plantas desaladoras. ${ }^{7}$

La desalación de agua no es, en efecto, una panacea para enfrentar los problemas de distribución inequitativa, escasez y contaminación del agua; pero tampoco habría que satanizarla ni mucho menos descartarla. Debemos asimilar el hecho de que existen argumentos a favor y en contra para su desarrollo. Sin embargo, para su implementación e impulso tecno-

6 Barlow, Maude y Clarke, Tony, Oro azul, trad. de Isidro Arias, Barcelona, España, Paidós, 2004, pp. 324 y 325.

7 Para mayor detalle sobre los efectos ambientales que se pudieran generar por el establecimiento de plantas desaladoras, se recomienda acudir a Jiménez Shaw, Concepción, "Agua y desarrollo sostenible. Trascendencia ambiental de la desalación", en Piñar Mañas, José Luis (dir.) y Utrera Caro, Sebastián F. (coord.), Desarrollo sostenible y protección del medio ambiente, Madrid, Civitas, 2002, pp. 125 y 156. 
Esta obra forma parte del acervo de la Biblioteca Jurídica Virtual del Instituto de Investigaciones Jurídicas de la UNAM

lógico es menester atender a las particularidades propias de cada región o país según los problemas que tengan de suministro y abastecimiento, así como a otras variables sociales, económicas, políticas o ambientales. Los casos de Turquía, Israel y España son ilustrativos en este sentido. Según estadísticas del Programa de las Naciones Unidas para el Medio Ambiente, la disponibilidad de agua medida en términos de $1000 \mathrm{~m}^{3}$ por habitante al año es considerada baja para los dos primeros casos $;^{8} \sin$ embargo, cada uno de ellos ha respondido de manera diferente a esta situación. Por un lado, en el reporte que presentó la República de Turquía a propósito de la celebración del Tercer Foro Mundial del Agua celebrado en marzo de 2003 en Japón, se informó que con el objeto de abastecer de agua a las ciudades establecidas a lo largo de la costa mediterránea de Turquía, se prefirió desarrollar un proyecto en el Río Manavgat de almacenamiento y tratamiento del recurso en lugar de impulsar la desalación de agua a la que consideran de menor calidad que la del río y porque el proceso para desalar no es ambientalmente amigable. ${ }^{9}$ Por otro lado, Israel decidió instalar dos plantas desaladoras cuya construcción empezó en 2002. Al parecer, el gobierno de Israel habría retrasado el inicio de este proceso por considerar que las mejores circunstancias para anunciar semejante programa se darían después de que se acordara la paz con Palestina. Debido a que las relaciones entre israelíes y palestinos empeoraron al inicio de este milenio, Israel decidió poner en marcha su programa. ${ }^{10}$ Por cuanto hace a España, la situación de escasez del recurso en zonas aisladas como los archipiélagos Canario y Balear impulsaron el desarrollo de estas tecnologías. Así, el proceso de desalación en ese país comenzó desde la década de los setenta (mayoritariamente en las islas orientales del archipiélago canario) y desde entonces ha ido creciendo hasta encontrarse entre los seis países más importantes del mundo en cuanto a capacidad de producción de agua de este tipo. ${ }^{11}$

8 Programa de las Naciones Unidas para el Medio Ambiente, op. cit., nota 1, p. 152. Existen 6 niveles para determinar la disponibilidad de agua por $1000 \mathrm{~m}^{3}$ por habitante al año: muy alta $(20,0)$, alta $(10,0$ a 20,0$)$, media $(5,0$ a 10,0$)$, baja $(2,0$ a 5,0$)$, muy baja $(1,0$ a 2,0$)$ y extremadamente baja $(1,0)$.

9 World Water Council-Republic of Turkey, Turkey Country Report. Prepared for the 3rd. World Water Forum March 2003, World Water Council, 2003, http://www.world watercouncil.org/fileadmin/wwc/Library/Publications_and_reports/country_reports/re port_Turkey.pdf.

10 Allan, J. A., op. cit., nota 5, p. 143.

11 Jiménez Shaw, Concepción, op. cit., nota 7, pp. 126 y 127. 
Esta obra forma parte del acervo de la Biblioteca Jurídica Virtual del Instituto de Investigaciones Jurídicas de la UNAM

Por lo pronto, los países del Golfo Pérsico son actualmente los mayores productores de agua desalada (principalmente para uso industrial y municipal). Sólo Arabia Saudita representa un cuarto de la capacidad mundial de desalación y el centro más grande para ello se encuentra precisamente en Al-Jubail en una provincia al este de ese país. En términos generales, Arabia Saudita, Kuwait y los Emiratos Árabes Unidos ocupan el primero, tercero y cuarto lugares respectivamente, en capacidad para desalar agua. ${ }^{12}$

Así pues, el desarrollo de la tecnología para desalar es un hecho y no una mera hipótesis. Con todo, le asiste la razón a Mr. Loïc Faouchon (presidente del Consejo Mundial del Agua) quien en su discurso de apertura en el controvertido Cuarto Foro Mundial del Agua celebrado en marzo de 2006 en la Ciudad de México insistió sobre la importancia de contar y exigir una distribución justa del progreso tecnológico a propósito de que toda contribución de inteligencia humana, como lo es la desalación, debe compartirse entre las naciones. Lamentablemente, muchos países que sufren de una disponibilidad de agua dulce baja, muy baja o extremadamente baja, son pobres y carecen de la tecnología adecuada para impulsar este tipo de proyectos desaladores. Al mismo tiempo, cualesquiera que sean las oportunidades para el desarrollo de la desalación, éstas deberán estar orientadas a evitar que se produzca contaminación ambiental.

\section{AGUA Y DESALACIÓN EN MÉXICO}

México enfrenta la misma combinación de factores en torno al agua, tal y como sucede internacionalmente. Es decir, a lo largo y ancho del territorio mexicano se observa una distribución inequitativa del recurso por razón de su ubicación vis à vis asentamientos humanos, escasez del mismo derivado del estrés hídrico por sobreexplotación de acuíferos y finalmente altos grados de contaminación, deterioro o modificación en algunas regiones. ${ }^{13}$

12 World Water Council-Comisión Nacional del Agua, Medio Oriente y Norte de África, Documentos regionales, WWC-CNA, 2006, http://www.worldwaterforum4.org.mx/ uploads/TBL_DOCS_114_50.pdf.

13 Las estadísticas y mapas que se presentan sobre la situación actual del agua en México fueron obtenidas de la Comisión Nacional del Agua, Estadísticas del Agua en México, Comisión Nacional del Agua, 2005, en su versión impresa y electrónica: http:/www.cna. gob.mx/eCNA/Español/Organismos/Central/Estadisticas/EstadisticasAgua_CNA/htm, así como de la Secretaría de Medio Ambiente y Recursos Naturales, Programa Nacio- 
Esta obra forma parte del acervo de la Biblioteca Jurídica Virtual del Instituto de Investigaciones Jurídicas de la UNAM

La distribución inequitativa del agua se refleja en el hecho de que existen dos grandes zonas que dividen la disponibilidad del recurso respecto a la ubicación de diversas poblaciones. La primera de ellas corresponde al norte, centro y noroeste en la que la disponibilidad natural media es apenas del $32 \%$ con una población del 77\%; mientras que para la segunda que abarca el sur y sureste es de siete veces mayor, con $68 \%$ de disponibilidad y sólo $23 \%$ de la población. Si bien el promedio nacional es de $4505 \mathrm{~m}^{3}$ por habitante al año, lo que ubica a nuestro país como una nación con disponibilidad baja, la primera zona se considera como muy baja, pero la segunda como alta (véase mapa 1).

MAPA 1

Disponibilidad de agua, población y producto interno bruto

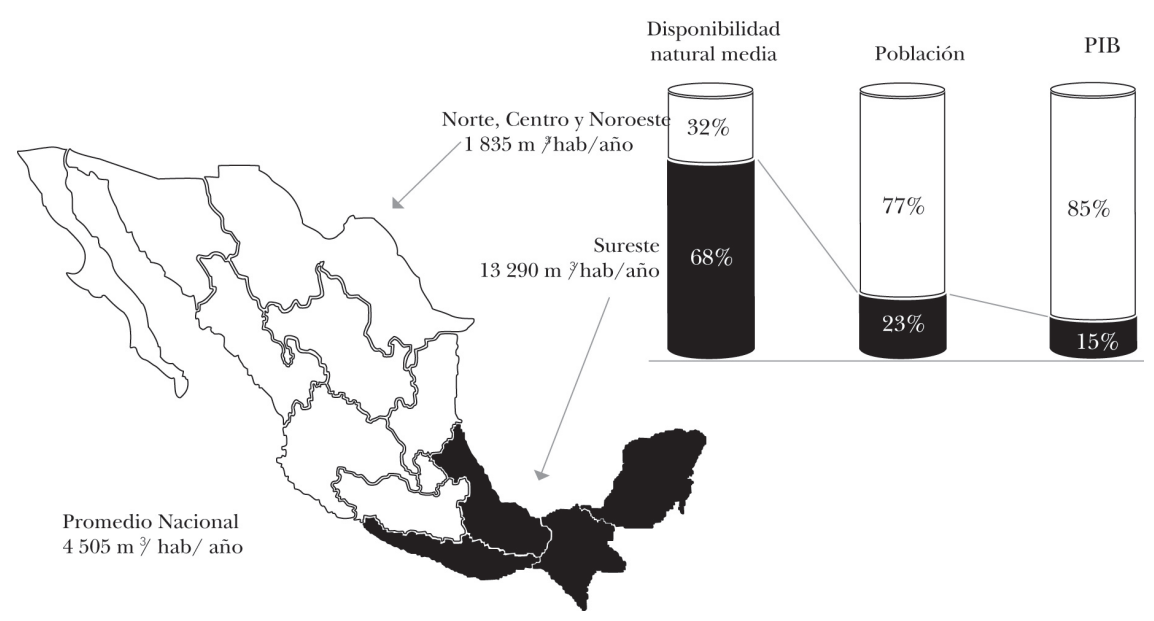

Fuente: Comisión Nacional del Agua, 2005.

Respecto al problema de escasez de agua, existen en el país más de 100 acuíferos sobreexplotados de un total de 653; esto es, existe para ese centenar de casos mayor extracción que recarga. En los últimos treinta

nal del Medio Ambiente y Recursos Naturales 2001-2006, Secretaría de Medio Ambiente y Recursos Naturales, 2001, en su versión impresa y electrónica: http://portal.semarnat. gob.mx/programas/documentos/archivo/pnmarn.pdf. 
Esta obra forma parte del acervo de la Biblioteca Jurídica Virtual del Instituto de Investigaciones Jurídicas de la UNAM

años se ha observado que el estrés hídrico ha aumentado de manera considerable puesto que en 1975 existían 32 acuíferos sobreexplotados, para 1985 aumentó su número a 80, y para 2003 se contabilizaron 104 (véase mapa 2).

\section{MAPA 2}

Acuíferos sobreexplotados y con intrusión salina (2004)

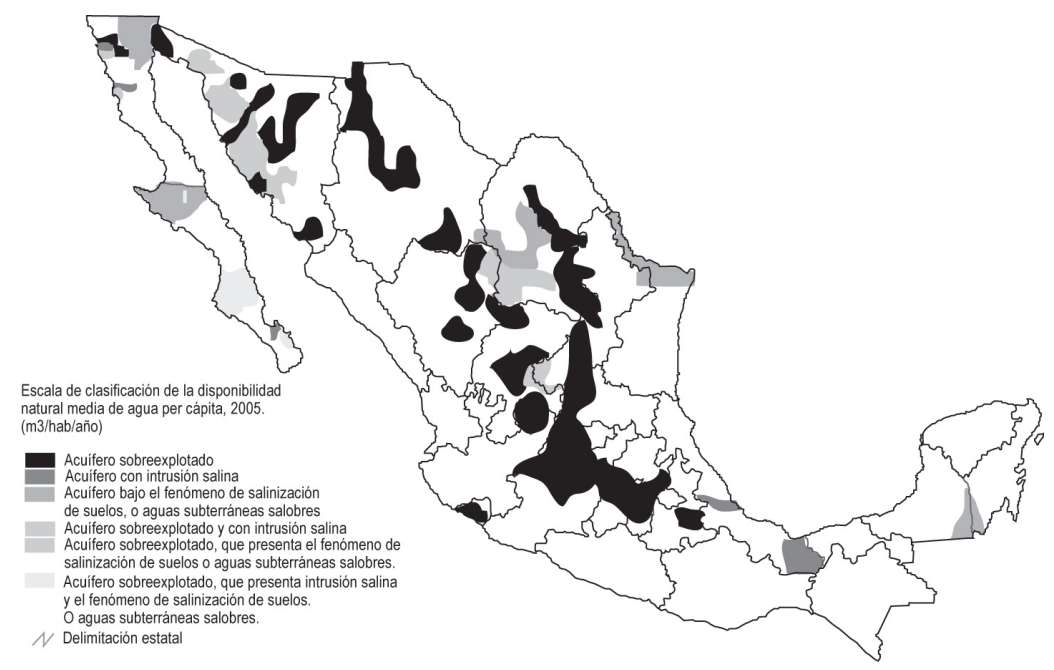

Fuente: Comisión Nacional del Agua, 2005.

De las 13 regiones hidrológico-administrativas en las que se encuentra dividida la República para efectos de manejo del agua, esta sobreexplotación (i. e. extracción superior a la recarga al menos en un $10 \%$ ) es evidente en regiones como la península de Baja California o la del valle de México y el sistema de Cutzamala. Al mismo tiempo, el grado de presión sobre el recurso hídrico (i. e. volumen total de agua concesionado/ disponibilidad natural media de agua) es muchísimo mayor en el norte y en la zona comprendida por la Ciudad de México y algunas partes de las entidades federativas vecinas como son el Estado de México y el estado de Hidalgo, que en el sur del territorio mexicano (véase mapa 3). 
Esta obra forma parte del acervo de la Biblioteca Jurídica Virtual del Instituto de Investigaciones Jurídicas de la UNAM

MAPA 3

Grado de presión sobre el agua (2004)

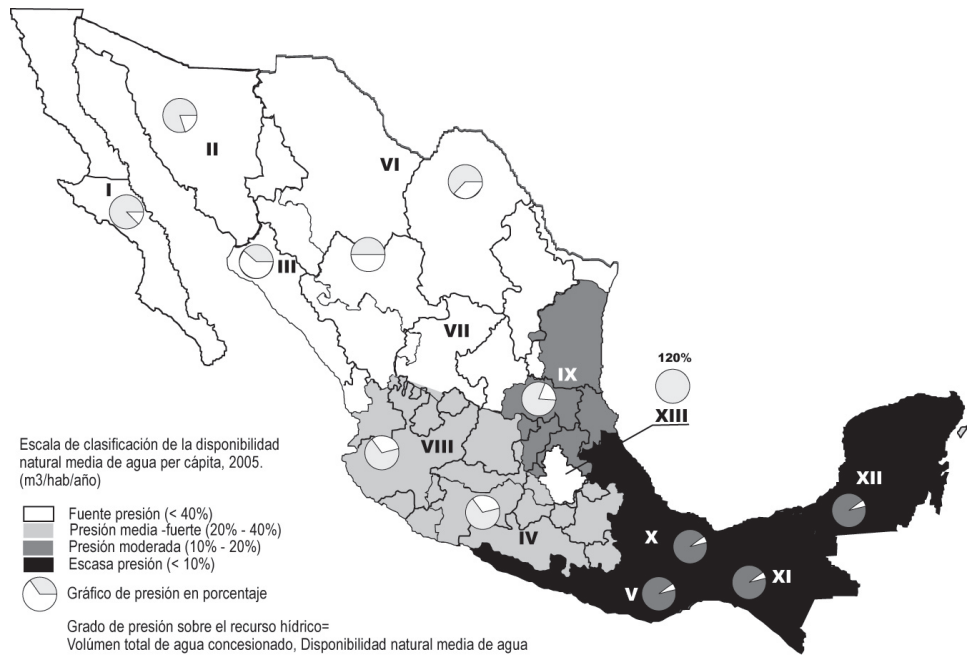

Fuente: Comisión Nacional del Agua, 2005.

Por lo que hace al problema de la contaminación, deterioro o modificación del agua, hay que señalar que un gran porcentaje de los cuerpos de agua existentes en el país y muchos acuíferos sufren de contaminación generada primordialmente en ciudades y zonas agrícolas. Así, por ejemplo, mientras que sólo $27 \%$ de las aguas superficiales presenta calidad satisfactoria (i.e. posibilita su uso para prácticamente cualquier actividad), $49 \%$ se encuentra poco contaminado (i. e. restringe su uso directo para ciertas actividades) y $24 \%$ se encuentra contaminado o altamente contaminado (i. e. es difícil su uso directo en casi cualquier actividad). A ello debe sumarse que existen al menos diecisiete acuíferos deteriorados o modificados por intrusión salina principalmente en las entidades federativas del norte del país como son Baja California, Baja California Sur y Sonora; a éstas se les unen los estados de Colima y Veracruz (véase mapa 2).

Los escenarios a futuro para el país no son nada alentadores. En 1970 la disponibilidad natural media de agua era de $9880 \mathrm{~m}^{3}$ por habitante al año, lo que se consideraba como disponibilidad media (muy cercana a la alta); sin embargo, para 2000 esta disponibilidad bajó a $4708 \mathrm{~m}^{3}$ por habitante al año lo que es considerado como disponibilidad baja. Si bien 
Esta obra forma parte del acervo de la Biblioteca Jurídica Virtual del Instituto de Investigaciones Jurídicas de la UNAM

para 2025 seguiremos en un rango de disponibilidad baja, se prevé que ésta se reduzca a $3822 \mathrm{~m}^{3}$ por habitante al año, cifra que encierra el hecho de que en algunas de las regiones del país esa disponibilidad alcanzará niveles cercanos e incluso inferiores a $\operatorname{los} 1000 \mathrm{~m}^{3}$ por habitante al año lo que es considerado como muy baja o extremadamente baja, respectivamente.

De manera tal que las regiones hidrológico-administrativas I de la península de Baja California y VI del Río Bravo brincarán de una clasificación en 2004 de muy baja a una clasificación extremadamente baja para 2025. Al mismo tiempo, la zona con mayor disponibilidad de agua también se verá afectada, pues la Región X Golfo Centro irá de una clasificación alta en 2004 a una media para 2025, y la XI Frontera Sur de una muy alta a una alta para el mismo 2025. La Región XIII Aguas del Valle de México y Sistema Cutzamala mantendrá su actual y alarmante status de extremadamente baja para 2025 (véanse mapas 4 y 5).

MAPA 4

Disponibilidad natural media de agua (2004)

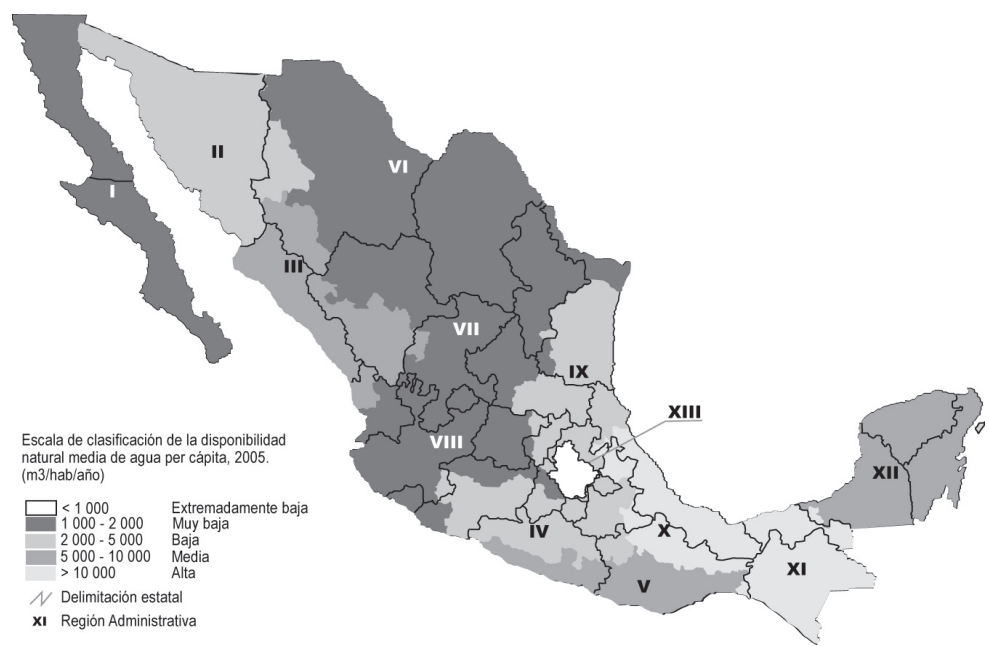

Fuente: Comisión Nacional del Agua, 2005. 
Esta obra forma parte del acervo de la Biblioteca Jurídica Virtual del Instituto de Investigaciones Jurídicas de la UNAM

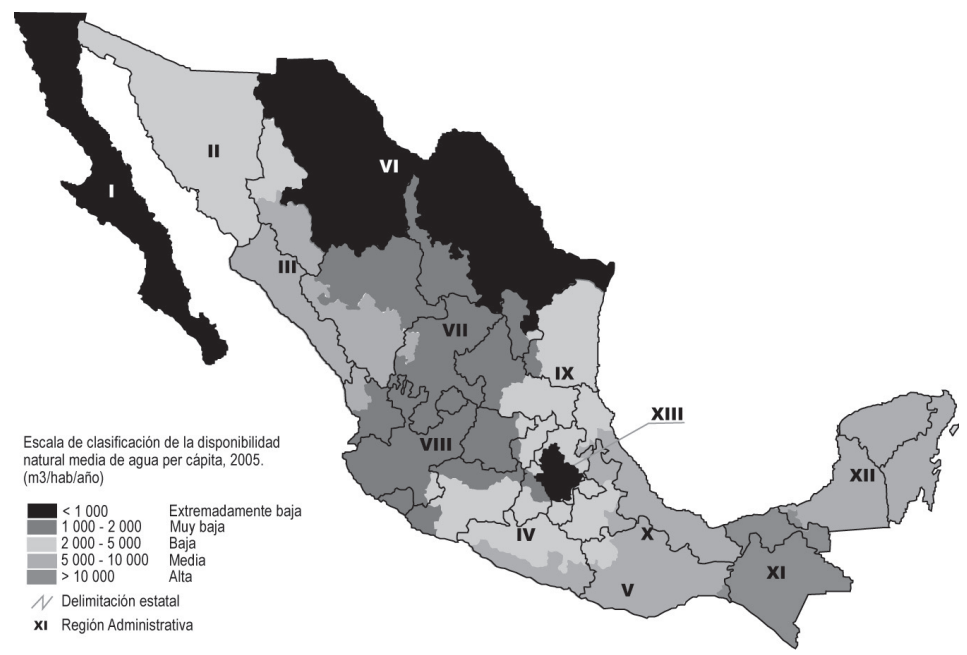

Fuente: Comisión Nacional del Agua, 2005.

Ante el incremento y/o continuidad de esa combinación de factores - distribución inequitativa, escasez y contaminación - la idea de desalar agua de mar y salobre parecería una alternativa lo suficientemente seductora para contrarrestar algunos de los retos y dilemas que presenta la actual situación del agua en México. ¿Estaremos muy lejos de explorar esta posibilidad?

En los hechos, la desalación en México es ya toda una realidad. A principios del siglo que comienza, se estimaban aproximadamente un total de 171 plantas de este tipo, de las cuales 120 se encontraban en operación. Los usos que se dan en los procesos existentes de desalación son principalmente el industrial (generación de energía eléctrica), el turístico (en hoteles) y el municipal (servicio de limpieza).

Sin embargo, la idea misma de desalar agua de mar para consumo humano ha empezado a concretarse por dos caminos distintos. El primero de ellos, a través de la construcción de una planta desaladora en la ciudad de Los Cabos San Lucas, en Baja California Sur, como resultado de una licitación gubernamental derivada de los problemas que enfrenta el estado en esa zona. Ha sido Inima, filial de gestión de agua y medio ambiente de la empresa OHL (uno de los mayores grupos de constructores 
Esta obra forma parte del acervo de la Biblioteca Jurídica Virtual del Instituto de Investigaciones Jurídicas de la UNAM

y servicios de España) quien se adjudicó en 2004 un contrato para la construcción de una planta que buscará beneficiar a una población de más de 50000 habitantes a través de un proceso conocido como ósmosis inversa. Esta empresa (formalmente conocida como Inima OHL, Servicios Europeos de Medio Ambiente S. A.), que tiene instalaciones en Brasil, Chile, Estados Unidos e Israel tendrá a su cargo la gestión de este proyecto por veinte años. ${ }^{14} \mathrm{El}$ segundo, se trata de un mega-proyecto que realiza la máxima casa de estudios del país, la Universidad Nacional Autónoma de México (UNAM), denominado Desalación de Agua de Mar con Energías Renovables como parte del Programa IMPULSA (Programa Investigación Multidisciplinaria Proyectos Universitarios de Liderazgo y Superación Académicas). Este proyecto, encabezado por uno de sus institutos - el Instituto de Ingeniería con la participación de otros institutos y centros de investigación de la propia UNAM, entre ellos el Instituto de Investigaciones Jurídicas - busca aportar soluciones al problema del suministro y abastecimiento del agua en el país a través del uso de energías renovables para la desalación de agua. El proyecto en cuestión se presentó a finales de 2004 e inició sus actividades a mediados del año siguiente. Se estima que para 2007 se tengan dos pequeñas plantas desaladoras en Baja California Sur (una operando con energía eólica y otra con energía termosolar). ${ }^{15}$ Es probable que para años posteriores a 2007, se instalen plantas en otros estados de la República utilizando energías renovables como las arriba señaladas o también la geotérmica, la de mareas o la de olas.

\section{LO BUENO, LO MALO Y LO MÁS MALO}

DE LA REGULACIÓN JURÍDICA EN EL PERIODO 2001-2006

Ante el avance en el desarrollo de la desalación en México, debemos preguntarnos si durante los seis años de gobierno del presidente Vicente Fox Quesada (2001-2006) se elaboraron tanto en lo programático (el Ejecutivo Federal) como en lo legal (ya sea el Ejecutivo Federal o el Congre-

14 Para mayor información, véanse los sitios electrónicos: www.loscabos.gob.mx en la sección comunicados anteriores de fecha 22 de marzo de 2006 y www.finanzas.com/ id.6429200/noticias/noticia.htm. Para conocer sobre la empresa Inima OHL se recomien-

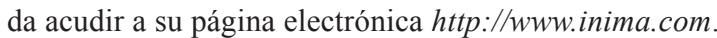

15 Para mayor detalle véase Universidad Nacional Autónoma de México, "Investigan la desalación de agua de mar con energías renovables", Gaceta UNAM, México, núm. 3,900, Ciudad Universitaria, 1o. de junio de 2006. 
Esta obra forma parte del acervo de la Biblioteca Jurídica Virtual del Instituto de Investigaciones Jurídicas de la UNAM

so de la Unión) normas para su regulación. En este sentido, la regulación jurídica correspondería a disposiciones relativas a la desalación de agua de mar y agua salobre (superficial o subterránea) así como a la salmuera. Sobre esto creemos que existen algunos aspectos buenos, otros malos, y algunos más, muy malos. Aquí presentamos lo más relevante de cada uno de los tres.

\section{Lo bueno}

Durante el primer año de gobierno se declaró al recurso natural agua como un tema estratégico y de seguridad nacional. Esta idea quedó plasmada en diversos documentos de carácter programático fundamentales para el país, como lo son, por ejemplo, el Plan Nacional de Desarrollo 2001-2006, el Programa Nacional del Medio Ambiente y Recursos Naturales 2001-2006 y el Programa Nacional Hidráulico 2001-2006. En el mensaje que diera el presidente de la República a propósito de este último programa señaló lo siguiente: "El agua es un tema particularmente delicado. Como fuente de vida, su disponibilidad condiciona el desarrollo de muchas regiones del país. Por ello, su manejo y preservación son asuntos estratégicos de seguridad nacional".

El principio en el que se fundamenta la idea de declarar al agua como tema estratégico y de seguridad nacional comprende fundamentalmente el considerarlo como uno de los recursos principales para el crecimiento económico y elemento indispensable para la renovabilidad de muchos otros recursos también indispensables en la transformación productiva y la vida misma. Una de las bases del desarrollo es la administración sustentable del recurso agua. ${ }^{16}$ En términos programáticos, en el propio Programa Nacional Hidráulico 2001-2006 se establece dentro de uno de los seis objetivos principales - el objetivo 2, fomentar la ampliación de la cobertura y los servicios de agua potable, alcantarillado y saneamientoel uso de técnicas en zonas de baja disponibilidad del recurso, fomentando el desarrollo tecnológico a través de métodos de desalación.

En términos legales, durante los primeros años de este periodo se discutió en el Congreso de la Unión una iniciativa de ley para reformar di-

16 Comisión Nacional del Agua, Programa Nacional Hidráulico 2001-2006, México, Secretaría de Medio Ambiente y Recursos Naturales, Comisión Nacional del Agua, 2001. 
Esta obra forma parte del acervo de la Biblioteca Jurídica Virtual del Instituto de Investigaciones Jurídicas de la UNAM

versos artículos de la Ley de Aguas Nacionales de 1992. El 29 de abril de 2004 se publicó en el Diario Oficial de la Federación el decreto que reforma a dicha ley y se incluye por vez primera en este contexto una disposición sobre la desalación, en particular sobre agua de mar. Establece el actual artículo 17 en su párrafo segundo lo siguiente: "No se requerirá concesión para la extracción de aguas marinas interiores y del mar territorial, para su explotación, uso o aprovechamiento, salvo aquellas que tengan como fin la desalinización, las cuales serán objeto de concesión".

Adicionalmente, el Ejecutivo Federal mantuvo una disposición en materia ambiental relativa a las obras o actividades que estén relacionadas con plantas desaladoras en un reglamento expedido por la administración anterior a la del presidente Vicente Fox. Se trata del Reglamento de la Ley General del Equilibrio Ecológico y la Protección al Ambiente en Materia de Evaluación de Impacto Ambiental expedido en mayo de 2000 y que señala en su artículo 5o., inciso A, fracción XII lo siguiente:

Artículo 5. Quienes pretendan llevar a cabo alguna de las siguientes obras o actividades, requerirán previamente la autorización de la Secretaría en materia de impacto ambiental:

A) HIDRÁULICAS:

XII. Plantas desaladoras.

Esta disposición reglamentaria busca someter las obras o actividades relacionadas con dichas plantas a un procedimiento ante la Secretaría de Medio Ambiente y Recursos Naturales, quien será la encargada de establecer las condiciones a las que éstas se sujetarán para proteger el ambiente, y preservar y restaurar los ecosistemas a fin de evitar o reducir al mínimo los efectos negativos que pudieran generarse.

Por último, vale la pena mencionar que las reformas hechas en 2004 a la Ley de Aguas Nacionales insertaron de manera expresa los pilares del desarrollo sustentable (i. e. los elementos social, económico y ecológico). En efecto, en su artículo 14 bis 5 se señaló como principio que sustenta la política nacional sobre este recurso, que el agua es un bien de dominio público federal, vital, vulnerable y finito, con valor social, económico y ambiental cuya preservación en cantidad, calidad y sustentabilidad es tarea fundamental del Estado y la sociedad. 
Esta obra forma parte del acervo de la Biblioteca Jurídica Virtual del Instituto de Investigaciones Jurídicas de la UNAM

\section{Lo malo}

Desde un punto de vista programático, no existe lineamiento u objetivo específico respecto a la desalación de agua de mar o salobre que permita conocer la política pública que se establece para su regulación. En primer lugar, el Programa Nacional de Medio Ambiente y Recursos Naturales 2001-2006 no hace mención expresa sobre la desalación. En segundo lugar, si bien el Programa Nacional Hidráulico 2001-2006 menciona, como ya señalamos, a la desalación como una de varias actividades de fomento para mejorar la calidad del agua, lo hace de manera extremadamente limitada. En tercer lugar, al referirse de manera expresa al agua salobre como un problema, este programa tampoco señala de forma consistente cuál deberá ser su tratamiento. Por último, en la Cruzada Nacional por los Bosques y el Agua ${ }^{17}$ creada a partir del gobierno foxista, se omite de la misma manera hacer referencia a la desalación de agua, así como al tratamiento de la salmuera.

Desde un punto de vista legal, la Ley de Aguas Nacionales aparece como un instrumento jurídico insuficiente para su regulación pues, como ya se mencionó, sólo existe un artículo al respecto. En este sentido, el reglamento de la propia Ley de Aguas Nacionales no establece nada relativo a la desalación. Ante esta situación, y en tanto no se expidan los nuevos reglamentos a los que se refiere el decreto que reformó la Ley de 1992, se estará en lo conducente a lo dispuesto en ella. Por su lado, la Ley General del Equilibrio Ecológico y la Protección al Ambiente no se refiere expresamente ni a la desalación ni a la salmuera, aunque como ya vimos, dicha ley remite al reglamento correspondiente en materia de evaluación de impacto ambiental que sí contiene una disposición al respecto.

Finalmente, la ley encargada de velar por la prevención de la generación, la valorización y la gestión integral de los residuos peligrosos, de los residuos sólidos urbanos y de manejo especial, así como de prevenir la contaminación de sitios con estos residuos y llevar a cabo su remediación, no establece nada relativo al tratamiento del principal producto derivado de la desalación. La ley de que se trata - Ley General para la Prevención y Gestión Integral de los Residuos publicada en el Diario Oficial

17 Este documento se encuentra en la página electrónica de la Secretaría de Medio Ambiente y Recursos Naturales en http://portal.semarnat.gob.mx/programas/documen tos/archivo/curzada_ba.pdf. 
Esta obra forma parte del acervo de la Biblioteca Jurídica Virtual del Instituto de Investigaciones Jurídicas de la UNAM

de la Federación el 8 de octubre de 2003- sólo establece de manera general algunos lineamientos para lograr la protección y evitar la contaminación del agua, pero sin mencionar expresamente a la salmuera.

\section{Lo más malo}

La idea de desarrollar proyectos para desalar agua de mar para consumo humano, no ha sido debidamente incluida en los programas respectivos. Simplemente, el tema no ha sido insertado como parte de un objetivo general fundamental de la política pública del agua en nuestro país, no obstante el hecho de que los retos a los que nos enfrentamos fueran conocidos incluso antes de que iniciara este sexenio. Peor aún, no hay líneas claras sobre si proyectos de este tipo son deseables o no, y de serlos, si el gobierno federal estaría dispuesto a invertir en ellos de manera consistente o si buscaría (como al parecer sucede en el caso de Inima) inversión privada y/o mixta.

Igual de grave es la ausencia de alguna dirección sobre el tratamiento y forma de enfrentar las consecuencias ambientales que generan los proyectos de desalación al utilizar energía contaminante (i.e. uso de combustibles fósiles) y el tratamiento que se daría a la salmuera o materiales producto de ese proceso en cuanto a su disposición final (ya sea el mar o algún sitio terrestre). No existe claridad sobre el rumbo político respecto a la posibilidad de utilizar para este tipo de proyectos energías renovables y contribuir de esta manera a la estabilización de gases de efecto invernadero causantes del cambio climático.

En términos legales, las muy pocas disposiciones existentes sobre la desalación están dispersas y son francamente insuficientes. Esta situación ha provocado ciertas inconsistencias jurídicas en la incipiente regulación de esta innovadora tecnología, como es el caso de que si bien las obras o actividades de plantas desaladoras se someten a una evaluación de impacto ambiental, no queda claro si las descargas que se hagan de salmuera deberán asimismo someterse a dicho procedimiento de impacto ambiental.

Por otro lado, han pasado ya más de dos años desde que se publicó el decreto de reformas a la Ley de Aguas Nacionales, y más de uno de la fecha límite que se determinó para la publicación del reglamento correspondiente, y éste no ha sido aún expedido. Al momento de escribir, 
Esta obra forma parte del acervo de la Biblioteca Jurídica Virtual del Instituto de Investigaciones Jurídicas de la UNAM

el reglamento en cuestión continúa siendo analizado y comentado por las diversas unidades administrativas (o áreas técnicas) de la Comisión Nacional del Agua y de la Secretaría de Medio Ambiente y Recursos Naturales. Lamentable tardanza.

\section{REFLEXIONES FINALES}

Conviene preguntar si existe o no crisis de agua en México. Cualquier intento de respuesta a ello deberá comprender el análisis y evaluación de la combinación de tres aspectos fundamentales: 1) distribución del recurso; 2) extracción y recarga, y 3) calidad del agua. Dentro de este esquema, ha quedado señalado que el país vive una distribución inequitativa del recurso frente a la ubicación de diversos asentamientos humanos, escasez de agua por la sobreexplotación de acuíferos, y crecientes niveles de contaminación por causas artificiales o naturales.

La situación actual del agua en México, exige seguir explorando medidas adecuadas para su gestión. Entonces, es menester incluir en este proceso la idea de si la desalación de agua de mar y/o salobre es una opción viable y alterna incluso para consumo humano. Conocer la experiencia que otros países han tenido en este sentido constituye un punto de referencia obligado para evaluar de manera objetiva la viabilidad de este tipo de proyectos. De impulsar su desarrollo, debemos tener presente (y determinar) los beneficios y costos que el Estado y la sociedad habrán de recibir y pagar por la instalación de plantas desaladoras. Beneficios que podrían traducirse en mejor y mayor suministro y abastecimiento de agua en zonas que lo requieren, y costos que terminarían en posibles daños ambientales de no utilizar la energía adecuada, ni dar tratamiento responsable a los residuos que se generen.

El doble discurso creado por el gobierno de Vicente Fox al declarar al agua como un recurso estratégico y de seguridad nacional, y a la vez no regular de manera precisa y amplia el desarrollo de la desalación, deriva en una contradicción elemental y provoca incertidumbre jurídica. La elaboración de una política pública se antoja ya indispensable ante tres procesos evidentes en el país: primero, el hecho de que en la actualidad se desala agua; segundo, que no es ajena la posibilidad de desarrollar o invertir en ese tipo de tecnología, y tercero, que los costos para impulsar y operar dichos proyectos están a la baja. Si bien existe suficiente espacio 
Esta obra forma parte del acervo de la Biblioteca Jurídica Virtual del Instituto de Investigaciones Jurídicas de la UNAM

para el análisis sobre las ventajas o desventajas en este tipo de proyectos en cualquiera de sus variables (e. $g$. inversión pública y/o privada o ambas, tipo de energías, disposición final de residuos, etcétera), lo que no es viable es permitir que continúe el desarrollo de plantas desaladoras - como actualmente sucede - sin un marco regulatorio adecuado. Si en verdad se quiere ver al agua como un asunto de seguridad nacional, es contradictorio que el Estado mexicano no tenga objetivos nacionales trazados ante el avance evidente de estas tecnologías en al ámbito internacional, ni estricta participación en su control y vigilancia, ni que invierta adecuadamente para el desarrollo de infraestructura.

La regulación de la desalación de agua de mar y salobre deberá incluirse en la agenda jurídico-ambiental y energética del sexenio 2007-2012. No aconsejaríamos a la nueva administración ni a los entrantes legisladores que dejaran sólo en manos privadas la instalación, operación y demás actividades relacionadas a los procesos de desalación. En todo caso, cualquier intento de regulación deberá tener como punto de partida el desarrollo sustentable.

Desconocemos las razones por las que durante el periodo 2001-2006 actores gubernamentales y legislativos que debieron al menos debatir con profundidad su viabilidad y así poder fortalecer su regulación no lo hicieron. Quizá haya sido la ignorancia, el miedo, la incapacidad, la falta de decisión, o todas ellas. Cualquiera que sea la respuesta a esta grave omisión, es totalmente inaceptable. 
Esta obra forma parte del acervo de la Biblioteca Jurídica Virtual del Instituto de Investigaciones Jurídicas de la UNAM

\title{
AGUA Y DESALACIÓN EN MÉXICO: DEL ENGAÑO AL OSCURANTISMO JURÍDICO*
}

\begin{abstract}
El agua, como regalo y merecimiento de los dioses, se concede a los humanos desde que nacen. Con ésta habrán de vivir y fortalecerse. El agua además es la que limpia y hace resplandecer al corazón en la gente. ${ }^{1}$
\end{abstract}

\section{INTRODUCCIÓN}

En el comienzo de su mandato constitucional (2000-2006) como presidente de la República, Vicente Fox Quesada declaró al agua como un asunto de seguridad nacional. Su declaración política quedó plasmada en el mensaje que diera al país en 2001 a propósito de la expedición del Programa Nacional Hidráulico 2001-2006. Esta idea fue recogida por la entonces LVIII legislatura (2000-2003) del Senado de la República que propuso establecerla por ley, para lo cual habría de presentar a finales de 2001 una iniciativa de decreto de reformas a la Ley de Aguas Nacionales vigente desde 1992. Esta adición legal, entre muchas otras reformas propuestas, se hizo realidad tres años después, en 2004, al entrar en vigor dicho decreto.

* Publicado en Nava Escudero, César e Hiriart Le Bert, Gerardo (coords.), Desalación de agua con energías renovables, México, UNAM, Instituto de Ingeniería-Instituto de Investigaciones Jurídicas, 2008.

1 Explicación que da el historiador Miguel León Portilla a propósito de las palabras (procedentes de los huehuehtlahtolli, testimonios de la "antigua palabra") que se pronunciaban en los momentos en que se iniciaba el ciclo de vida humana entre los pueblos nahuas del México antiguo. Véase para mayor detalle León-Portilla, Miguel, Literaturas indígenas de México, 2a. ed., México, Fondo de Cultura Económica, 1992, p. 209. 
Esta obra forma parte del acervo de la Biblioteca Jurídica Virtual del Instituto de Investigaciones Jurídicas de la UNAM

No obstante lo anterior, a cinco años de que el agua adquiriera su nuevo status y a más de dos de que éste se estableciera por ley del Congreso de la Unión, los resultados obtenidos a la fecha difieren mucho de lo que verdaderamente implica el significado de elevar a rango de seguridad nacional éste o cualquier otro tema.

En efecto, la propuesta de considerar política y jurídicamente al agua como asunto de seguridad nacional conlleva necesariamente la idea de aceptar que existe un riesgo o amenaza que el Estado mexicano debe atender prioritariamente sobre otros temas y que lo hará a través de la adopción de medidas excepcionales: desde el uso de las Fuerzas Armadas hasta el diseño de estrategias con medidas urgentes a través de políticas públicas nuevas, creación de instituciones o elaboración de un marco jurídico adecuado para ello. Sin negar la creciente y preocupante situación de agua que enfrentamos en la actualidad, haber declarado al agua como asunto de seguridad nacional no ha sido más que un discurso retórico de quienes impulsaron y apoyaron esta idea.

El marco jurídico continúa siendo en mucho el mismo desde que se inició el sexenio, y una de las medidas excepcionales que como opción viable debió haberse tomado para enfrentar dicha problemática fue prácticamente ignorada programática y legalmente: la desalación de agua de mar y/o salobre.

Analizamos en este artículo la declaración del agua como asunto de seguridad nacional y lo vinculamos al tema de la desalación de agua. El objetivo central de este trabajo es argumentar que semejante declaración se trató de un engaño pues no se han llevado a cabo las acciones que se requieren para ser congruentes con el significado de lo que implica la seguridad nacional. Para ello, nos basamos en el hecho de que las reformas legales para enfrentar la problemática del agua tardaron mucho tiempo (i. e. casi tres años en cristalizarse), además de que muchas de ellas todavía no pueden entrar en vigor por falta de reglamentación, así como en el hecho de que ciertas actividades que pudieran haber sido establecidas como medidas de emergencia - como es el caso de la desalación de agua de mar y/o salobre - carecen de un referente de política pública y de regulación jurídica. 
Esta obra forma parte del acervo de la Biblioteca Jurídica Virtual del Instituto de Investigaciones Jurídicas de la UNAM

\section{EL AGUA: ¿ASUNTO DE SEGURIDAD NACIONAL?}

\section{Problemática}

La problemática del agua que ha enfrentado México en los últimos años puede sintetizarse en tres grandes rubros: $i$ ) la consistente distribución inequitativa del recurso por razón de su ubicación vis à vis asentamientos humanos; ii) las condiciones de escasez (estrés hídrico) por sobreexplotación de acuíferos, y iii) los altos niveles de contaminación, deterioro o modificación localizados en extensas áreas del territorio mexicano. ${ }^{2}$

\section{A. Distribución inequitativa}

Este rubro se refiere al hecho de que existen dos grandes zonas en las que se divide la disponibilidad del agua frente a la ubicación de diversas poblaciones. Mientras que en la primera de ellas - que comprende el norte, centro y noroeste del país - la disponibilidad natural media de este recurso es del $32 \%$ con una población del $77 \%$ y con un producto interno bruto (PIB) del 85\%, en la segunda — que comprende el sureste- la disponibilidad natural media es de $68 \%$ con una población del $23 \%$ y un PIB del 15\%. En términos generales, a la primera zona corresponde una disponibilidad de $1835 \mathrm{~m}^{3}$ por habitante al año ( $\mathrm{m}^{3} / \mathrm{hab} / \mathrm{año}$ ) y a la segun-

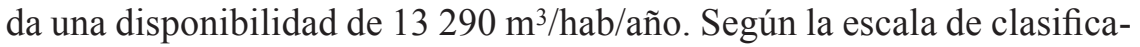
ción de la disponibilidad natural media de agua per cápita $\left(\mathrm{m}^{3} / \mathrm{hab} / \mathrm{año}\right)$ la zona norte, centro y noroeste pertenece a la categoría de muy baja y la zona sureste pertenece a la categoría alta.$^{3}$

2 Véase Nava Escudero, César, "La regulación jurídica de la desalación de agua en México: lo bueno, lo malo y lo más malo del periodo 2001-2006", Documento de Trabajo, México, UNAM, Instituto de Investigaciones Jurídicas, núm. 82, julio de 2006, p. 6.

3 La escala de clasificación de disponibilidad natural media de agua ( $\left.\mathrm{m}^{3} / \mathrm{hab} / \mathrm{año}\right)$ abarca los siguientes parámetros: extremadamente baja de $<1000$, muy baja de 1000 a 2000, baja de 2000 a 5000, media de 5000 a 10 000, y alta de $>10000$. Las cifras y porcentajes aquí presentados fueron obtenidas de la Comisión Nacional del Agua, Estadisticas del agua en México, México, Comisión Nacional del Agua, 2005. Remitimos a esta publicación para mayores detalles. 
Esta obra forma parte del acervo de la Biblioteca Jurídica Virtual del Instituto de Investigaciones Jurídicas de la UNAM

\section{B. Escasez}

Aquí la problemática hace alusión al llamado "estrés hídrico" provocado fundamentalmente por la sobreexplotación de acuíferos, concepto que se refiere a que la extracción del líquido es superior al de la recarga al menos en un $10 \%$. Según datos de la Comisión Nacional del Agua, ${ }^{4}$ el país se ha dividido para fines de administración del agua en 653 acuíferos. De estos, 104 se encuentran sobreexplotados y de ellos se extrae casi el $60 \%$ del agua subterránea para todos los usos. En los últimos 30 años, dicha sobreexplotación ha aumentado considerablemente: 32 acuíferos en esta situación en 1975, 36 en 1981, 80 en 1985, 97 en 2001 y 104 en 2003.

\section{Contaminación, deterioro o modificación}

Por último, nuestro país se enfrenta al problema de que un creciente porcentaje de cuerpos de agua existentes y muchos acuíferos sufren de contaminación, generada primordialmente por ciudades y zonas agrícolas. Mientras que $27 \%$ de las aguas superficiales presenta calidad satisfactoria (i. e. posibilita su uso para prácticamente cualquier actividad), $49 \%$ se encuentra poco contaminado (i. e. restringe su uso directo para ciertas actividades) y $24 \%$ se encuentra contaminado o altamente contaminado (i.e. es difícil su uso directo en casi cualquier actividad). Sólo el 5\% de los cuerpos de agua presenta excelente calidad (i.e. los hace aptos para cualquier uso). Por lo que toca a la calidad del agua subterránea, más de $80 \%$ de los acuíferos contienen agua de buena calidad; a nivel nacional se han identificado 40 acuíferos con cierta degradación por actividades antropogénicas o por causas de origen natural. ${ }^{5}$ Existen al menos 17 acuíferos deteriorados o modificados por intrusión salina, principalmente en las entidades federativas del norte del país como son Baja California, Baja California Sur y Sonora; a éstas se les unen los estados de Colima y Veracruz. ${ }^{6}$

4 La Comisión Nacional del Agua es un órgano desconcentrado de la Secretaría de Medio Ambiente y Recursos Naturales, encargado de la gestión de las aguas nacionales y sus bienes públicos inherentes.

5 Véase Comisión Nacional del Agua, Programa Nacional Hidráulico 2001-2006, México, Comisión Nacional del Agua, 2001, pp. 29-31, y Nava Escudero, César, "La regulación jurídica de la desalación de agua en México...", cit., nota 2.

6 Comisión Nacional del Agua, op. cit., nota 3, p. 56, y Nava Escudero, César, "La regulación jurídica de la desalación de agua en México...”, cit., nota 2. 
Esta obra forma parte del acervo de la Biblioteca Jurídica Virtual del Instituto de Investigaciones Jurídicas de la UNAM

TABLA 1

Disponibilidad natural media de agua per cápita a nivel nacional(1970-2025) y escala de clasificación

\begin{tabular}{|c|c|c|}
\hline $\begin{array}{c}\text { Disponibilidad } \\
\left(m^{3} / \text { hab/año }\right)\end{array}$ & Año & Escala de clasificación \\
\hline 9880 & 1970 & Media \\
\hline 7128 & 1980 & Media \\
\hline 5864 & 1990 & Media \\
\hline 4708 & 2000 & Baja \\
\hline 4250 & 2010 & Baja \\
\hline 3936 & 2020 & Baja \\
\hline 3822 & 2025 & Baja \\
\hline
\end{tabular}

Fuente: Comisión Nacional del Agua, 2005.

Los escenarios a futuro no son del todo alentadores. La disponibilidad natural media de agua per cápita ha ido disminuyendo en los últimos 30 años: tendencia que se mantendrá una vez alcanzado el 2025 (véase tabla 1). Durante todo este primer cuarto de siglo nuestro país mantendrá un rango de disponibilidad bajo, y conforme transcurran los años hacia 2025, algunas regiones alcanzarán niveles cercanos e incluso inferiores a $\operatorname{los} 1000 \mathrm{~m}^{3} / \mathrm{hab} / \mathrm{año}$, lo que es considerado dentro de la escala de clasificación como una disponibilidad muy baja o extremadamente baja, respectivamente. Como se observa en la tabla 2, regiones hidrológicoadministrativas $^{7}$ como la de la Península de Baja California y la del Río

7 Las regiones administrativas abarcan, en su totalidad o en porciones, diferentes entidades federativas: Región I Península de Baja California (totalidad de Baja California y Baja California Sur), Región II Noroeste (totalidad de Sonora y porciones de Chihuahua), Región III Pacífico Norte (totalidad de Sinaloa y porciones de Durango, Chihuahua, Nayarit y Zacatecas), Región IV Balsas (totalidad de Morelos y porciones de Tlaxcala, Puebla, Estado de México, Oaxaca, Guerrero, Michoacán y Jalisco), Región V Pacífico Sur (porciones de Oaxaca y Guerrero), Región VI Río Bravo (porciones de Chihuahua, Coahuila, Durango, Nuevo León y Tamaulipas), Región VII Cuencas Centrales del Norte (porciones de Durango, Zacatecas, Coahuila, San Luis Potosí, Nuevo León y Tamaulipas), Región VIII Lerma-Santiago-Pacífico (totalidad de Aguascalientes y Colima y porciones de Nayarit, Querétaro, Estado de México, Jalisco, Guanajuato, Michoacán y Zacatecas), 
Esta obra forma parte del acervo de la Biblioteca Jurídica Virtual del Instituto de Investigaciones Jurídicas de la UNAM

Bravo brincarán de la clasificación muy baja de 2004 a una clasificación de extremadamente baja para 2025. Aun las regiones con mayor disponibilidad de agua se verán afectadas, como son los casos de la región del Golfo Centro que irá de una clasificación alta en 2004 a una media para el 2025, y de la región de la frontera sur que irá de muy alta en 2004 a alta para 2025. La región conocida como Aguas del Valle de México y Sistema Cutzamala mantendrá su actual rango de extremadamente baja para 2025.

\section{TABLA 2}

Disponibilidad natural media per cápita 2004 y 2025: escala de clasificación por región administrativa

\begin{tabular}{|c|c|c|}
\hline Región administrativa & $\begin{array}{c}\text { Escala de clasificación } \\
2004 \\
\text { disponibilidad } m^{3} / h a b / a \tilde{n} o\end{array}$ & $\begin{array}{c}\text { Escala de clasificación } \\
2025 \\
\text { disponibilidad } m^{3} / \text { hab/año }\end{array}$ \\
\hline I. Península de Baja California & Muy baja & Extremadamente baja \\
\hline II. Noroeste & Baja & Baja \\
\hline III. Pacífico Norte & Media & Media \\
\hline IV. Balsas & Baja & Baja \\
\hline V. Pacífico Sur & Media & Media \\
\hline VI. Río Bravo & Muy Baja & Extremadamente baja \\
\hline VII. Cuencas Centrales del Norte & Muy Baja & Muy baja \\
\hline VIII. Lerma-Santiago-Pacífico & Muy Baja & Muy baja \\
\hline IX. Golfo Norte & Baja & Baja \\
\hline X. Golfo Centro & Alta & Media \\
\hline XI. Frontera Sur & Muy Alta & Alta \\
\hline XII. Península de Yucatán & Media & Media \\
\hline $\begin{array}{l}\text { XIII. Aguas del Valle de México } \\
\text { y Sistema Cutzamala }\end{array}$ & Extremadamente baja & Extremadamente baja \\
\hline
\end{tabular}

Fuente: Comisión Nacional del Agua, 2005.

Región IX Golfo Norte (porciones de Hidalgo, San Luis Potosí, Tamaulipas, Veracruz, Querétaro, Guanajuato, Estado de México y Nuevo León), Región X Golfo Centro (porciones de Veracruz, Oaxaca, Puebla e Hidalgo), Región XI Frontera Sur (totalidad de Chiapas y Tabasco y porciones de Campeche y Oaxaca), Región XII Península de Yucatán (totalidad de Yucatán y Quintana Roo y una gran porción de Campeche) y Región XIII Aguas del Valle de México y Sistema Cutzamala (totalidad del Distrito Federal y porciones del Estado de México, Hidalgo y Tlaxcala). 
Esta obra forma parte del acervo de la Biblioteca Jurídica Virtual del Instituto de Investigaciones Jurídicas de la UNAM

\section{Seguridad nacional}

Con los datos y cifras hasta aquí expuestos, es indudable advertir que el tema del agua para nuestro país supone un reto, dilema o problema. Sin embargo, esta situación per se no lo convierte necesariamente en un asunto de seguridad nacional. El que sea o no declarado así dependerá en mucho de la percepción que se tenga del problema, de la idea de cómo se quiera enfrentarlo y de la definición que se quiera adoptar del propio concepto de seguridad nacional.

De esta manera, así como el agua se declaró asunto de seguridad nacional, bien pudo haberse declarado sólo como asunto grave, prioritario, estratégico o de seguridad pública. En este sentido, se han creado diversas clasificaciones que han buscado asignar un rango y dar un significado a cada una de estas y otras categorías. Así por ejemplo, Salazar Slack ${ }^{8}$ identifica diferentes categorías o maneras en las que se pueden resolver ciertos problemas (según la intervención de los actores) y así poder determinar la naturaleza de un asunto en particular. Las maneras de solución a los conflictos o problemas son los ámbitos siguientes: no político (i. e. la sociedad los resuelve sin intervención gubernamental), politico (i. e. el gobierno interviene y resuelve a través de canales diplomáticos o aplicación del Estado de derecho y pueden involucrarse diversos actores políticos y sociales antes de que se conviertan en una amenaza), seguridad pública (i.e. última instancia para resolverlos sin "quebrantar" el Estado de derecho, aunque en ocasiones esto llegue a pasar por uso de la fuerza pública: se trata de un problema grave), seguridad nacional (i. e. es tan evidente que pone en riesgo o amenaza el bienestar o futuro del país y en ocasiones se incluye a actores extranjeros; la solución supone medidas excepcionales donde el Estado le da prioridad al problema, de no actuar enfrentaría amenazas a la integridad de ciudadanos, degradación general de su calidad de vida o incluso la desaparición del Estado).

Otro ejemplo es Rodríguez Zúñiga ${ }^{9}$ quien no sólo se refiere a diversas categorías sino a un esquema conceptual por el que un problema (a través de un proceso determinado) se convierte en seguridad nacional. Así, este

8 Salazar Slack, Ana María, Seguridad nacional hoy. El reto de las democracias, México, Nuevo Siglo, Aguilar, 2002, pp. 62-70.

9 Rodríguez Zúñiga, Joel, "Retórica de los bosques y el agua como asunto de seguridad nacional: evaluación de sus políticas públicas", Derecho Ambiental y Ecología, México, núm. 14, año 3, agosto-septiembre de 2006, pp. 44-47. 
Esta obra forma parte del acervo de la Biblioteca Jurídica Virtual del Instituto de Investigaciones Jurídicas de la UNAM

autor identifica tres tipos de problemas nacionales: no graves (se atienden con políticas públicas ya existentes), graves (fortalecimiento de políticas públicas), y de seguridad nacional (reingeniería o creación de nuevas políticas públicas extraordinarias). Para que un problema adquiera el carácter de seguridad nacional debe seguir este proceso: $i$ ) pronunciamiento por parte del presidente de la República; ii) ratificación del mismo por actores políticos y grupos empresariales; iii) aval de la sociedad, y $i v$ ) reingeniería y nuevas políticas públicas extraordinarias.

Pero independientemente de la clasificación de que se trate, lo cierto es que el concepto de seguridad nacional entraña la existencia de intereses que habrán de salvaguardarse dentro de un cuerpo normativo ante una amenaza que hoy en día no sólo se asocia a la de tipo externo sino también interno. Como señala Enrique Rojo Stein, ${ }^{10}$ la seguridad nacional la procuran sociedad y gobierno, bajo un sistema que necesariamente debe incluir un marco jurídico que defina alcances y establezca responsabilidades. Ante todo, semejante idea implica, a decir de Leonardo Curzio, la detección de aquellos factores que habrán de obstaculizar un objetivo nacional así como la percepción para determinar la jerarquización de la amenaza respectiva. ${ }^{11}$ Garantizar la seguridad nacional sobre algún tema implica establecer acciones políticas, económicas, jurídicas, sociales, etcétera.

Por lo que tratando de hacer una síntesis de lo anterior, cuando un tema sea declarado como asunto de seguridad nacional se deberá entender lo siguiente:

- Existe riesgo o amenaza al bienestar, integridad o calidad de vida de los ciudadanos, el futuro del país o la consecución de los objetivos nacionales. Esta situación se deriva del hecho de que Estado y sociedad fracasaron en políticas y marco jurídico anteriores para resolver el problema.

- Adquiere prioridad sobre los demás problemas que enfrenta el Estado; aún así requiere de cierto "consentimiento" de la población y de otros actores políticos y sociales.

10 Rojo Stein, Enrique, "Palabras del lic. Enrique Rojo Stein", Praxis 103. La formación de cuadros de seguridad nacional, México, Instituto Nacional de Administración Pública (INAP), 1999, http://www.bibliojuridica.org/libros/libro.htm?l=1309.

11 Véase Curzio, Leonardo, "La seguridad nacional en México: balance y perspectivas”, Revista de Administración Pública, México, número 98, 1998, http://www.juridicas. unam.mx/publica/li-brev/rev/rap/cont/98/pr/pr3.pdf. 
Esta obra forma parte del acervo de la Biblioteca Jurídica Virtual del Instituto de Investigaciones Jurídicas de la UNAM

- Se adoptan medidas excepcionales y se diseñan e implementan estrategias (como acciones urgentes) que trasciendan reglas normales: políticas públicas nuevas, instituciones y/o regulación normativa adecuada, etcétera.

De modo que considerar como asunto de seguridad nacional a un tema conforma la idea de la existencia de un riesgo o amenaza que el Estado atenderá y dará prioridad sobre otras situaciones, y en el que se adoptarán medidas excepcionales para enfrentarlo. Es discrecional, habremos de insistir, el que un asunto sea o no considerado así y en el plano discursivo (incluso con evidente apoyo científico) se pueden establecer criterios o parámetros a favor o en contra para sustentar una declaración de tal magnitud.

No obstante lo anterior, lo que debemos tener por cierto es que, una vez tomada la decisión de elevar cualquier tema a rango de seguridad nacional, el Estado deberá tomar las medidas excepcionales suficientes para enfrentarlo.

\section{EL CAMINO QUE SE RECORRIÓ PARA QUE EL AGUA SE CONVIRTIERA EN UN ASUNTO DE SEGURIDAD NACIONAL}

Recién nacido el siglo XXI — para ser más precisos, en 2001—el entrante presidente constitucional de los Estados Unidos Mexicanos para el periodo 2000-2006, Vicente Fox Quesada, se refirió sin más al tema del agua como un asunto estratégico de seguridad nacional: "El agua es un tema particularmente delicado. Como fuente de vida, su disponibilidad condiciona el desarrollo de muchas regiones del país. Por ello, su manejo y preservación son asuntos estratégicos de seguridad nacional". ${ }^{12}$

Secundó esta idea el Poder Legislativo quien la adoptó considerando igualmente al agua como un asunto de seguridad nacional — aunque optó por referirse a dicho recurso natural como prioritario en lugar de estratégico-.${ }^{13}$ En efecto, transcurridos algunos meses de la declaración presi-

12 Este párrafo se incluye en el mensaje del presidente de la República a propósito de la expedición del Programa Nacional Hidráulico 2001-2006. Véase Comisión Nacional del Agua, op. cit., nota 5, p. vii.

13 La aceptación de considerar al agua como asunto de seguridad nacional abarcó las dos legislaturas correspondientes a los seis años de gobierno foxista: la quincuagésima 
Esta obra forma parte del acervo de la Biblioteca Jurídica Virtual del Instituto de Investigaciones Jurídicas de la UNAM

dencial, el entonces senador de la República y presidente de la Comisión de Recursos Hidráulicos de la Cámara Alta, Ulises Ruíz Ortiz (ahora gobernador del estado de Oaxaca) presentó el 15 de diciembre de 2001 una iniciativa de decreto que buscaba reformar, adicionar y derogar diversas disposiciones de la Ley de Aguas Nacionales (vigente desde 1992). En su discurso de presentación, recogió la idea de considerar al agua como un tema se seguridad nacional: "Senadoras y senadores, el tema del agua es reconocido por todos como un asunto de seguridad nacional, esto no es una simple clasificación, por lo que ello implica es el riesgo que corre el país como Nación si no somos capaces de preservar para las futuras generaciones este vital líquido".

En la propia exposición de motivos del decreto citado, el senador mencionado (perteneciente al grupo legislativo del Partido Revolucionario Institucional), volvió a enfatizar de dos maneras diferentes la categoría de seguridad nacional que adquiría el agua:

... las autoridades federales y locales, así como la ciudadanía en general, consideraron el problema del agua como de seguridad nacional, en armonía con lo planteado por el Ejecutivo Federal, manifestándose en el sentido de que de no resolverse de manera inmediata dicha problemática, se pondría en peligro al propio Estado... las aguas nacionales, de ser un problema de prioridad nacional, se han convertido en tema de seguridad nacional...

En su iniciativa de decreto se proponía adicionar - entre otros - un nuevo artículo en el que se estableciera el fomento al uso racional del agua considerando su conservación como un tema de seguridad nacional.

No fue sino hasta el 24 de abril de 2003, que la minuta con proyecto de decreto que habría de reformar, adicionar y derogar diversas disposiciones de la Ley de Aguas Nacionales se sometió a consideración del pleno de la Cámara de Senadores, y se procedió a su votación siendo aprobada por 94 votos y ninguno en contra. ${ }^{14}$ Ese mismo día fue turnada

octava y la quincuagésima novena. La información que se presenta en este rubro relativa al Poder Legislativo se obtuvo del portal de la Suprema Corte de Justicia de la Nación que permite dar seguimiento a lo sucedido con la iniciativa de decreto de reformas a la Ley de Aguas Nacionales tanto en la Cámara de Senadores y la de Diputados como en el Ejecutivo Federal. Para mayor abundancia sobre este tema en particular, remitimos a http://200.38.86.53/PortalSCJN/RecJur/Legislación/.

14 Vale la pena comentar que el 11 de abril de 2002 se presentó otro proyecto de reformas, modificaciones y adiciones a la Ley de Aguas Nacionales por el senador panista 
Esta obra forma parte del acervo de la Biblioteca Jurídica Virtual del Instituto de Investigaciones Jurídicas de la UNAM

para su estudio y dictamen a la Comisión de Recursos Hidráulicos de la cámara revisora, i. e. la Cámara de Diputados. Días después, la comisión dictaminadora sometió a consideración del pleno de la propia cámara el proyecto de decreto en el que se establecían tres aspectos fundamentales relacionados al tema de la seguridad nacional: $i$ ) se consideró la gestión integrada de los recursos hídricos (a partir de las cuencas hidrológicas en el territorio nacional) como prioridad y asunto de seguridad nacional; ii) se propuso que la conservación, preservación, protección y restauración del agua en cantidad y calidad es asunto de seguridad nacional, por lo que debía evitarse el aprovechamiento no sustentable y los efectos ecológicos adversos, y iii) conservó la idea de fomentar el uso racional y la conservación del agua como tema de seguridad nacional. En la sesión plenaria de la colegisladora celebrada el 29 de abril de 2003, se presentó en segunda lectura el dictamen de la minuta y una vez agotado el turno de los oradores, se procedió a la votación del dictamen siendo aprobado por 413 votos a favor, 1 abstención y ninguno en contra, y se remitió al Ejecutivo Federal para sus efectos constitucionales.

El 5 de junio de 2003 la Secretaría de Gobernación recibió para sus comentarios y observaciones el proyecto de decreto a través de un oficio suscrito por la senadora Lydia Madero García y por la diputada Adela Cerezo Bautista. El 1o. de septiembre del mismo año el Ejecutivo Federal a través de la dependencia arriba citada, lo envió de regreso a la Cámara de Senadores. Entre las diversas observaciones realizadas, se hizo hincapié nuevamente en considerar al agua un tema de seguridad nacional a propósito de la importancia y naturaleza jurídica de la Comisión Nacional del Agua: "Ninguna precaución es superficial cuando se trata de la autoridad encargada de regular, administrar y vigilar el aprovechamiento de un recurso considerado ahora como de seguridad nacional".

Las Comisiones Unidas de Recursos Hidráulicos y de Estudios Legislativos del Senado de la República emitieron el 12 de diciembre de 2003 su dictamen respecto a las observaciones del Ejecutivo Federal. En él se vuelve a hacer hincapié en tratar al agua como un asunto de seguridad nacional quedando asentado en el texto del proyecto de decreto dos aspectos fundamentales: $i$ ) la idea de declarar como utilidad pública la gestión inte-

Víctor Manuel Torres Herrera. El dictamen de abril de 2003 por la Comisiones Unidas de Recursos Hidráulicos y de Estudios Legislativos incluye el análisis y estudio tanto de la iniciativa de Ulises Ruíz como la de Torres Herrera. 
Esta obra forma parte del acervo de la Biblioteca Jurídica Virtual del Instituto de Investigaciones Jurídicas de la UNAM

grada de los recursos hídricos, superficiales y del subsuelo, a partir de las cuencas hidrológicas en el territorio nacional, como prioridad y asunto de seguridad nacional, y ii) considerar al agua dentro de los principios que sustentan la política hídrica nacional como un bien de dominio público federal, vital, vulnerable y finito, con valor social, económico y ambiental, cuya preservación en cantidad, calidad y sustentabilidad es tarea fundamental del Estado y la sociedad, así como prioridad y asunto de seguridad nacional. Con la aprobación unánime de 98 votos se turnó la minuta respectiva a la Cámara de Diputados el 15 de diciembre de ese mismo año.

Algunos días después, el 22 de diciembre, la Cámara de Diputados a través de la Comisión de Recursos Hidráulicos emitió dictamen con proyecto de decreto para reformar, adicionar y derogar diversas disposiciones de la Ley de Aguas Nacionales una vez realizada la discusión correspondiente. Nuevamente, en el texto del proyecto de decreto se confirmó la idea de darle tratamiento de seguridad nacional al recurso agua. Fueron las mismas dos ideas que comentamos arriba para el caso del dictamen del Senado las que permanecieron intactas: $i$ ) se declara de utilidad pública la gestión integrada de los recursos hídricos, superficiales y del subsuelo a partir de las cuencas hidrológicas en el territorio nacional, como prioridad y asunto de seguridad nacional tal y como se había propuesto en el proyecto de decreto enviado por la cámara alta, y ii) queda establecido que dentro de los principios que sustentan la política hídrica nacional, el agua es un bien de dominio público federal, vital, vulnerable y finito, con valor social, económico y ambiental, cuya preservación en cantidad y calidad y sustentabilidad es tarea fundamental del Estado y la sociedad, así como prioridad y asunto de seguridad nacional.

Finalmente, el decreto por el que se reforman, adicionan y derogan diversas disposiciones de la Ley de Aguas Nacionales se publicó en el Diario Oficial de la Federación el 29 de abril de 2004. Quedaron así establecidos por ley del Congreso de la Unión dos preceptos que se refieren de manera contundente al recurso agua como seguridad nacional:

Artículo 7o. Se declara de utilidad pública:

I. La gestión integrada de los recursos hídricos, superficiales y del subsuelo, a partir de las cuencas hidrológicas en el territorio nacional, como prioridad y asunto de seguridad nacional;

Artículo 14 BIS. 5. Los principios que sustentan la política hídrica nacional son: 
Esta obra forma parte del acervo de la Biblioteca Jurídica Virtual del Instituto de Investigaciones Jurídicas de la UNAM

I. El agua es un bien de dominio público federal, vital, vulnerable y finito, con valor social, económico y ambiental, cuya preservación en cantidad y calidad y sustentabilidad es tarea fundamental del Estado y la Sociedad, así como prioridad y asunto de seguridad nacional;

En el artículo segundo transitorio de dicho decreto se estableció que en tanto no se expidieran los reglamentos derivados de la ley, quedarían vigentes las disposiciones del reglamento respectivo (de 1994) en todo lo que no contraviniera lo dispuesto en el propio decreto y la ley que contiene. Dichos reglamentos habrían de expedirse en un plazo no mayor de doce meses a partir de la entrada en vigor del decreto, es decir, en un plazo no mayor a abril de 2005. Al momento de escribir, agosto de 2006, es decir, a más de dos años de distancia de publicado el decreto, ningún reglamento se ha expedido dejando sin posibilidad de implementar infinidad de artículos reformados y adicionados que tuvieron como sustento la idea de que el agua es un tema de seguridad nacional.

\section{LA DESALACIÓN: \\ ¿MEDIDA URGENTE DE SEGURIDAD NACIONAL?}

En párrafos anteriores hemos señalado que al momento en que se declare algún tema como asunto de seguridad nacional, es indispensable la elaboración de medidas excepcionales para enfrentarlo. El Ejecutivo Federal así declaró al agua y por lo tanto debió haber establecido de inmediato las medidas urgentes suficientes para contrarrestar el problema que, como ya hemos también señalado, se resume en: $a$ ) distribución inequitativa; $b$ ) escasez, y c) contaminación, deterioro o degradación. ¿Podría acaso la desalación de agua de mar y salobre haberse convertido en una de las varias medidas urgentes de seguridad nacional para contrarrestar esta combinación de factores que presenta la actual situación del agua en México?

En los hechos, la desalación en México viene operando desde hace ya algunos años. Durante las últimas tres décadas se han instalado pequeñas plantas desaladoras con fines fundamentalmente turísticos (en hoteles), municipales (servicio de limpieza) y para uso industrial (generación de energía eléctrica). A principios de este siglo se calculaban alrededor de 
Esta obra forma parte del acervo de la Biblioteca Jurídica Virtual del Instituto de Investigaciones Jurídicas de la UNAM

171 plantas, de las cuales 120 se encontraban en operación. ${ }^{15}$ Uno de los más grandes proyectos que hemos tenido en nuestro país en los últimos años fue sin duda el de la eventual instalación de una planta de este tipo para suministrar agua desalada a la ciudad de Hermosillo, Sonora. Aunque por razones de tipo político-partidista no se concluyera con el mismo, la experiencia obtenida desde su autorización (en 1999) hasta su suspensión (en 2002) demuestra que la desalación en México es ya una opción real para enfrentar los problemas de agua que sufren ciertas regiones dentro del territorio mexicano. ${ }^{16}$

De cualquier manera, la idea de desalar agua de mar para consumo humano a escala mayor está en proceso de consolidarse ahora a través de la instalación de una planta de este tipo en la ciudad de Los Cabos San Lucas, en Baja California Sur. Ante los graves problemas de escasez de agua que enfrenta ese estado de la República, la empresa española Inima, filial de gestión de agua y medio ambiente de la empresa OHL (uno de los mayores grupos de constructores y servicios de España) se adjudicó en 2004 (a través de una licitación gubernamental) un contrato para la construcción de una planta que buscará beneficiar a una población de más de 50000 habitantes. Adicionalmente a este caso, existe un mega-proyecto que realiza nuestra máxima casa de estudios, la Universidad Nacional Autónoma de México, denominado Desalación de Agua de Mar con Energías Renovables como parte del Programa IMPULSA (Programa Investigación Multidisciplinaria Proyectos Universitarios de Liderazgo y Superación Académicas) el cual busca aportar soluciones al problema del suministro y abastecimiento del agua en el país a través precisamente del uso de energías renovables para la desalación de agua. Este proyecto inició sus actividades a mediados de 2005 y se estima que para 2007 se instalen dos pequeñas plantas desaladoras en Baja California Sur: una operando con energía eólica y otra con energía termo-solar. ${ }^{17}$

Desde luego, es discutible si conviene o no impulsar el desarrollo de la desalación, puesto que ésta, como proceso técnico-industrial por el que

15 Comisión Nacional del Agua, op. cit., nota 3, p. 85.

16 Ha sido uno de los proyectos más ambiciosos en el país por el volumen de agua potable que se destinaría a Hermosillo.

17 Universidad Nacional Autónoma de México, "Investigan la desalación de agua de mar con energías renovables”, Gaceta UNAM, México, núm. 3900, Ciudad Universitaria, 1o. de junio de 2006. Más detalles en Nava Escudero, César, "La regulación jurídica de la desalación de agua en México...”, cit., nota 2, passim. 
Esta obra forma parte del acervo de la Biblioteca Jurídica Virtual del Instituto de Investigaciones Jurídicas de la UNAM

se separa la sal del agua, deriva en consecuencias de tipo social, económico y ambiental no siempre aceptables. Debemos partir de la idea de que desalar tanto agua de mar como agua salobre ya sea superficial o subterránea tiene el objetivo principal de obtener agua dulce para diferentes usos: desde los turísticos y para regadío, hasta los industriales y para consumo humano; ${ }^{18}$ sin embargo, su obtención pudiera acarrear altos costos por el gran consumo de energía que se requiere (i. e. quema de grandes cantidades de combustibles fósiles).

Pero más preocupante aún, es que de no utilizar energías renovables se podría generar un efecto negativo en el ambiente, particularmente en lo relativo a la estabilización de las concentraciones de gases de efecto invernadero en la atmósfera con posibles afectaciones o alteraciones al sistema climático mundial. Y por si fuera poco, al procesar el agua de mar o salobre se generaría un residuo conocido como salmuera, el cual no puede destinarse a algún otro uso ni puede tampoco reciclarse, por lo que se tendría que devolver al propio mar. Aunque no se tenga la certeza absoluta de que este residuo genere contaminación o produzca un impacto negativo en el ambiente, es probable que ciertos ecosistemas marinos o costeros se vean de cualquier manera afectados según las cantidades que de ella se viertan al mar (sobre todo tratándose de un área limitada), el tipo de proceso de desalación que se utilice y la propia fragilidad marina y/o costera del lugar donde se arroje. ${ }^{19}$

En el caso de México, habría que reflexionar sobre el hecho de que algunas de las zonas donde se ha pensado instalar estas plantas están cerca o forman parte de importantes áreas naturales; en particular, nos referimos a las llamadas islas y áreas protegidas del Golfo de California que abarca los estados de Baja California, Baja California Sur, Sonora, Sinaloa y Nayarit y que fue declarada por la Organización de las Naciones Unidas para la Educación, la Ciencia y la Cultura (UNESCO) en 2005 como Patrimonio Mundial Natural de la Humanidad. Es posible que

18 Nava Escudero, César, "La regulación jurídica de la desalación de agua en México...", cit., nota 2, p. 4.

19 Para mayores detalles sobre los posibles efectos ambientales, véase Jiménez Shaw, Concepción, "Agua y desarrollo sostenible. Trascendencia ambiental de la desalación", en Piñar Mañas, José Luis (dir.) y Utrera Caro, Sebastián F. (coord.), Desarrollo sostenible y protección del medio ambiente, Madrid, Civitas, 2002, pp. 125-156. También, Nava Escudero, César, "La regulación jurídica de la desalación de agua en México...", cit., nota 2, passim. 
Esta obra forma parte del acervo de la Biblioteca Jurídica Virtual del Instituto de Investigaciones Jurídicas de la UNAM

la salmuera pueda depositarse en confinamientos terrestres, pero de no contar con medidas preventivas y de protección se podría contaminar el suelo y subsuelo y modificar o deteriorar el agua dulce subterránea que se encuentre en dicho lugar.

De modo que la idea de desalar agua de mar y/o salobre para enfrentar los problemas de distribución inequitativa, escasez y contaminación, degradación o deterioro de agua, es una alternativa viable en tanto se consideren prevenibles las posibles consecuencias negativas ambientales aquí descritas.

No podemos soslayar la experiencia de otros países como han sido Arabia Saudita, Kuwait o los Emiratos Árabes Unidos (primero, tercero y cuarto lugares a nivel mundial respectivamente en capacidad para desalar agua)..$^{20}$ Otro caso relevante, sin duda alguna, lo constituye España que inició el desarrollo de la desalación en el archipiélago de las Canarias para luego extenderse a otras zonas de ese país y las comunidades autónomas Balear, de Valencia, Murcia y Andalucía y encontrarse ahora entre los seis países más importantes del mundo en cuanto a capacidad de producción de agua por este medio. ${ }^{21}$

Derivado de lo anterior, y ante su evidente crecimiento en México, nos parece que la desalación podría haberse incluido como una de las muchas medidas excepcionales que se requieren para hacer frente a un problema que ha sido declarado tema de seguridad nacional. Evidentemente, estas medidas se enfocarían en la elaboración de nuevas políticas públicas en la materia, la creación de la regulación jurídica pertinente y, en su caso, la instauración, ajuste o acomodo de los diversos arreglos institucionales para ello. Ciertamente, impulsar y desarrollar la desalación produciría costos políticos, sociales y ambientales, pero como ya lo hemos señalado anteriormente, tratándose de una medida excepcional derivada de la urgencia para contrarrestar una problemática — la del agua — que ha sido elevada a rango de seguridad nacional, tanto el Estado como la sociedad (aunque ésta en menor medida) tendrían que absorber dichos costos que, desde luego y en ningún caso, deberían ser mayores al problema que se trata de resolver.

20 Véase en este sentido World Water Council y Comisión Nacional del Agua, Medio Oriente y Norte de África, Documentos regionales, WWC-CNA, 2006, http://www. worldwaterforum4.org.mx/uploads/TBL_DOCS_114_50.pdf.

21 Para conocer más a fondo la situación de la desalación en España se recomienda acudir a Jiménez Shaw, Concepción, Régimen jurídico de la desalación del agua marina, Valencia, Tirant Lo Blanch, 2003. 
Esta obra forma parte del acervo de la Biblioteca Jurídica Virtual del Instituto de Investigaciones Jurídicas de la UNAM

\section{EL CAMINO QUE SE RECORRIÓ PARA QUE LA DESALACIÓN NO SE CONVIRTIERA EN UNA MEDIDA URGENTE \\ DE SEGURIDAD NACIONAL}

No cabe la menor duda: la mejor forma o camino a recorrer para que una acción de Estado no se convierta en una medida excepcional para enfrentar un asunto de seguridad nacional, es no incluirla o apenas mencionarla tanto en los programas gubernamentales como en la legislación respectiva. Y éste fue precisamente el camino que tanto el Poder Ejecutivo como el Poder Legislativo, en el ámbito de sus respectivas competencias y facultades, recorrieron para que la desalación no se convirtiera en medida urgente de seguridad nacional.

En términos programáticos, no existe lineamiento u objetivo claro y preciso respecto a la desalación que permita conocer la política pública a seguir. En primer lugar, el principal programa del sector medio ambiente y recursos naturales - el Programa Nacional de Medio Ambiente y Recursos Naturales 2001-2006- simple y sencillamente ignoró por completo hacer mención de la posibilidad y/o conveniencia de obtener agua dulce a través de este proceso técnico. ${ }^{22}$

En segundo lugar, el documento denominado Cruzada Nacional por los Bosques y el Agua, programa creado a partir del gobierno foxista y presentado como una iniciativa presidencial, omitió de la misma manera hacer referencia a la desalación de agua de mar y/o salobre. ${ }^{23}$

Por último, el programa sobre asuntos del agua por excelencia - el Programa Nacional Hidráulico 2001-2006 - apenas y lo menciona refiriéndose a él a propósito de dos situaciones en particular: $i$ ) en el análisis que hace sobre la situación del agua en cada una de las regiones hidrológicas que conforman el país, advierte que el problema de escasez que se presenta en la Región I Península de Baja California requerirá desalar agua de mar empleando innovaciones tecnológicas a bajo costo para incrementar la oferta y no limitar el desarrollo socioeconómico de esa región; sin embargo, inexplicablemente deja de hacer mención de ella para

22 Secretaría de Medio Ambiente y Recursos Naturales, Programa Nacional de Medio Ambiente y Recursos Naturales 2001-2006, México, Secretaría de Medio Ambiente y Recursos Naturales, 2001.

23 Este documento se puede consultar en la página electrónica de la Secretaría de Medio Ambiente y Recursos Naturales en http://portal.semarnat.gob.mx/programas/ documentos/archivo/cruzada_ba.pdf. 
Esta obra forma parte del acervo de la Biblioteca Jurídica Virtual del Instituto de Investigaciones Jurídicas de la UNAM

la Región II Noroeste que corresponde, entre otros, al estado de Sonora que cuenta, como lo hemos visto, con cierta experiencia en el tema, y ii) se establecen seis objetivos nacionales dentro de los cuales el dos se refiere de manera general al fomento de la ampliación de la cobertura y la calidad de servicios de agua potable, alcantarillado y saneamiento: es aquí que de manera particular y a propósito de promover el tratamiento de las aguas residuales e impulsar el intercambio de agua tratada por agua de primer uso, se establece que se usarán técnicas en zonas de baja disponibilidad fomentando el desarrollo tecnológico en áreas como las relativas a los métodos para la desalación. ${ }^{24}$

En resumen, ninguno de los dos primeros programas arriba mencionados se ocuparon de hablar sobre la desalación; el tercero sí lo hace, pero de manera limitada y particularizándolo a una zona territorial del país y para un objetivo específico que está confinado a la competencia de los municipios. De la lectura de estos tres documentos oficiales no se desprende atisbo alguno de que la desalación hubiera podido convertirse en una medida excepcional o urgente para enfrentar los problemas del agua en el país.

En términos legales, el panorama que se presenta no es nada alentador. Las escasísimas disposiciones que existen sobre la desalación están dispersas y son francamente insuficientes. Lo más rescatable, en este ámbito, es una disposición en materia ambiental relativa a las obras o actividades que estén relacionadas con plantas desaladoras que se encuentra en el Reglamento de la Ley General del Equilibrio Ecológico y la Protección al Ambiente en materia de Evaluación de Impacto Ambiental de 2000 que señala en su artículo 5o., inciso A, fracción XII, lo siguiente: “Artículo 5. Quienes pretendan llevar a cabo alguna de las siguientes obras o actividades, requerirán previamente la autorización de la Secretaría en materia de impacto ambiental: A) Hidráulicas:... XII Plantas desaladoras".

Esta disposición reglamentaria de la ley ambiental mencionada (ley que tampoco hace mención expresa de la desalación) somete las obras o actividades relacionadas con dichas plantas a un procedimiento (e.g. la evaluación de impacto ambiental) ante la Secretaría de Medio Ambiente y Recursos Naturales, que será la encargada de establecer las condiciones a las que se sujetarán para proteger al ambiente y preservar y restaurar

24 Comisión Nacional del Agua, op. cit., nota 5, pp. 49 y 92, respectivamente. 
Esta obra forma parte del acervo de la Biblioteca Jurídica Virtual del Instituto de Investigaciones Jurídicas de la UNAM

los ecosistemas a fin de evitar o reducir al mínimo los efectos negativos que pudieran generarse.

Aunada a esta aislada disposición, incluimos el ya multicitado decreto por el que se reforman, adicionan y derogan diversas disposiciones de la Ley de Aguas Nacionales que fue publicado en el Diario Oficial de la Federación el 29 de abril de 2004. En dicho decreto se incluyó, si bien por vez primera, una única disposición sobre desalación, en particular sobre agua de mar. Lo que ahora es el artículo 17 establece en su párrafo segundo lo siguiente: "No se requerirá concesión para la extracción de aguas marinas interiores y el mar territorial, para su explotación, uso o aprovechamiento, salvo aquellas que tengan como fin la desalinización, las cuales serán objeto de concesión".

Como hemos mencionado con anterioridad, en el artículo segundo transitorio de este decreto se estableció que en tanto no se expidieran los reglamentos derivados de la ley, quedarían vigentes las disposiciones del reglamento respectivo (de 1994) en todo lo que no contraviniera lo dispuesto en el propio decreto y la ley que contiene. En este sentido, conviene mencionar que el reglamento de aplicación vigente, el de 1994, no establece nada relativo a la desalación.

\section{REFLEXIÓN FINAL:}

DEL ENGAÑO AL OSCURANTISMO JURÍDICO

El interés que demostraron el Poder Ejecutivo y el Poder Legislativo en los albores de este siglo al declarar el tema del agua como asunto de seguridad nacional se convirtió con el paso de los años en un engaño o mentira con apariencia de verdad. Ambos poderes sabían que sería redituable en términos políticos inducir a la sociedad mexicana a creer y tener por cierto que la problemática del agua se habría de enfrentar al más alto nivel y que la mejor forma de hacerlo era elevando este tema a ese rango en particular; sin embargo, los pocos y tardados resultados que se derivaron de esto evidencian fehacientemente que los discursos gubernamental y legislativo no eran más que retórica mexicana, o, en el mejor de los casos, sofisterías a la mexicana.

Debemos enfatizar lo siguiente: si realmente se quería decir y hacer lo que se declaró, entonces ni el Ejecutivo Federal ni el Legislativo se hubieran tardado tanto tiempo en reformar la disposiciones legales co- 
Esta obra forma parte del acervo de la Biblioteca Jurídica Virtual del Instituto de Investigaciones Jurídicas de la UNAM

rrespondientes, ni tampoco hubieran ignorado la posibilidad de incluir a la desalación de agua de mar y/o salobre como una medida excepcional para enfrentar la problemática del agua. Si se hubiera actuado en consecuencia, se tendrían a la fecha avances significativos con la implementación de acciones substanciales para cambiar el estado que guardaban las cosas hace seis años. Pero no se hizo así.

El oscurantismo jurídico en el que nos dejan tanto los seis años de gobierno del presidente Vicente Fox, como los seis años acumulados de dos legislaturas del Congreso de la Unión, es por demás evidente. La noche que cae sobre la regulación del agua se manifiesta respectivamente en lo siguiente: la tardanza de casi tres años para reformar y adicionar la ley de aguas respectiva, la falta de expedición de reglamentos de dicha ley que ha obstaculizado la posibilidad de implementar una infinidad de artículos reformados y adicionados que tuvieron como sustento la idea de que el agua es un tema de seguridad nacional, la inclusión de sólo un párrafo en tan solo un artículo sobre desalación de agua sin mayores consideraciones de tipo ambiental, y en lo programático, la falta de una política pública que hubiera permitido vincular el tema del agua con el de la desalación como estrategia nacional.

En lo hechos, mientras tanto, la problemática del agua se agudiza y los proyectos de desalación (con todo y su exiguo sustento legal y programático) se expanden. 
Esta obra forma parte del acervo de la Biblioteca Jurídica Virtual del Instituto de Investigaciones Jurídicas de la UNAM

\section{TRES FRASES PARA LA CONSTRUCCIÓN DE ARGUMENTOS LEGALES EN LA APLICACIÓN DE LA LEGISLACIÓN AMBIENTAL*}

Antes de iniciar con la plática del día de hoy quisiera agradecer a los organizadores de este evento el haberme invitado a participar en este seminario. Es de aplaudirse y reconocerse la oportunidad que se les brinda a los académicos de este país para discutir y reflexionar de manera conjunta con jueces, magistrados y autoridades gubernamentales de los tres países que conforman el bloque de América del Norte sobre diversos aspectos de la legislación ambiental. Quienes nos dedicamos a investigar y producir ciencia jurídico-ambiental, tenemos mucho qué decir en foros como estos, sobre todo si hemos sido en el pasado, como es mi caso, parte de la burocracia ambiental.

Esta presentación tiene por objeto examinar lo que significa la idea de una construcción de argumentos legales para la aplicación de la legislación ambiental con base en tres frases del pensamiento humano. Estas tres frases corresponden a un consejo de Don Quijote, una vieja paradoja relativa a Dios, y una verdad incómoda acerca de México.

\section{SOBRE UNO DE LOS CONSEJOS DE DON QuiJote}

De la obra Don Quijote de la Mancha de Miguel de Cervantes Saavedra (1547-1616) proviene la primera frase. Se trata de un consejo que a través de una carta dirige Don Quijote a su fiel escudero, Sancho Panza, cuando éste ocupaba el puesto de gobernador de la ínsula Barataria. Dice

* Publicado en Nava Escudero, César (ed.), Legislación ambiental en América del Norte. Experiencias y mejores prácticas para su aplicación e interpretación jurisdiccional. Environmental Legislation in North America. Experiences and best Practices for its Implementation and Adjudication, Montreal, Canadá-México, Comisión para la Cooperación Ambiental-UNAM, Instituto de Investigaciones Jurídicas, 2010. 
Esta obra forma parte del acervo de la Biblioteca Jurídica Virtual del Instituto de Investigaciones Jurídicas de la UNAM

textualmente la primera parte de este consejo: "No hagas muchas pragmáticas, y si las hicieres, procura que sean buenas $\mathrm{y}$, sobre todo que se guarden y se cumplan, que las pragmáticas que no se guardan lo mismo es que si no lo fuesen....".

De esta trascripción hemos de rescatar no tanto la recomendación de no hacer muchas pragmáticas o la de procurar que sean buenas (enunciados que son bastante ambiguos, o si se quiere, subjetivos), sino la advertencia de que una vez elaboradas, se cumplan, puesto que de lo contrario es como si no existieran. De modo que si seguimos esta última parte del consejo de Don Quijote, debemos tener por cierto que la única manera de empezar a discutir la idea de una construcción de argumentos legales en la aplicación de la legislación ambiental es cerciorarnos de que exista la posibilidad de que las pragmáticas ${ }^{2}$ puedan aplicarse. Esto supone, antes que nada, determinar si se cuenta o no tanto con las leyes ambientales correspondientes como con los instrumentos y/o mecanismos jurídicos que así lo permitan.

Nuestro país cuenta con una legislación ambiental muy amplia (aunque algo dispersa), que es de aplicación en los tres órdenes de gobierno, el federal, el estatal y el municipal; de ella, el bloque de ordenamientos legales ambientales que nos interesa abordar en este trabajo son los que han emanado del Congreso de la Unión. A partir de esta precisión, es posible señalar que la legislación ambiental está conformada por una ley integral o en su conjunto, ${ }^{3}$ seis leyes por sector, ${ }^{4}$ poco más de treinta leyes

1 Cervantes, Miguel de, Don Quijote de la Mancha, Edición del IV Centenario, España-México, Real Academia Española-Asociación de Academias de la Lengua Española, Alfaguara, 2004, segunda parte, capítulo LI, p. 941.

2 Para los fines de esta ponencia, con el vocablo pragmáticas habremos de referirnos a aquéllos cuerpos legales aprobados por el Congreso de la Unión y promulgados y publicados por el Ejecutivo Federal de este país, por ejemplo, aquéllos a los que nosotros conocemos comúnmente a nivel federal como "leyes" vis à vis el de reglamentos, decretos, acuerdos, etcétera.

3 Se trata de la Ley General del Equilibrio Ecológico y la Protección al Ambiente (de 1988).

4 Nos referimos a la Ley de Aguas Nacionales (de 1992), la Ley General de Vida Silvestre (de 2000), la Ley General de Desarrollo Forestal Sustentable (de 2003), la Ley General para la Prevención y Gestión Integral de los Residuos (de 2003), la Ley de Bioseguridad de los Organismos Genéticamente Modificados (de 2005) y la Ley de Promoción y Desarrollo de los Bioenergéticos (de 2008). 
Esta obra forma parte del acervo de la Biblioteca Jurídica Virtual del Instituto de Investigaciones Jurídicas de la UNAM

por materias relacionadas, ${ }^{5} \mathrm{y}$ unas cuantas iniciativas y/o proyectos de leyes que se encuentran pendientes de aprobación, promulgación y/o discusión en los poderes legislativo y ejecutivo respectivamente. No existe un código ambiental como tal, por lo que la gran mayoría de los temas ambientales están plasmados para su regulación en esta clasificación, ya sea de manera integral, por sector, o de manera dispersa en leyes por materias relacionadas con lo ambiental.

Frente a este collage de leyes jurídico-ambientales, los abogados ambientalistas sabemos que hay disposiciones jurídicas contempladas en ellas que no pueden implementarse por falta de instrumentos y/o mecanismos jurídicos para que así suceda. Es decir, existe la ley respectiva (i. e. la pragmática), pero no aquello que permita su debida y completa aplicación. Para fundamentar lo anterior, habré de apoyarme en el paradigmático caso de la vigente Ley de Aguas Nacionales (en adelante, LAN) de 1992, que fuera ampliamente reformada y adicionada en 2004. El problema que se presenta en este caso es que en la actualidad la LAN se aplica con base en un reglamento anterior a las reformas y adiciones de 2004, lo que está impidiendo la aplicación de una gran cantidad de las disposiciones jurídicas recientes.

De entrada, esta ley es una ley difícil de entender. En días pasados, se llevó a cabo en esta universidad nacional el Segundo Encuentro Universitario del Agua, donde participaron científicos de diversas disciplinas: químicos, físicos, geólogos, geógrafos, ingenieros, economistas, abogados, etcétera. El objeto de este encuentro fue el de abordar desde distintos enfoques disciplinarios el tema del agua y analizar, entre otros, el de su regulación jurídica. Habría quedado claro desde el principio que las reformas y adiciones realizadas en 2004 a la LAN hicieron de un asunto tan complejo como lo es el del agua, un tema verdaderamente difícil y complicado de entender. Pero una de las críticas fundamentales en la que los universitarios estuvimos de acuerdo consistió precisamente en el absurdo que representa el hecho de que la no aplicación de muchas disposiciones

5 Como lo son, por ejemplo, la Ley de Expropiación (de 1936), la Ley que declara Reservas Mineras Nacionales los Yacimientos de Uranio, Torio y las demás Sustancias de las cuales se obtengan Isótopos Hendibles que puedan Producir Energía Nuclear (de 1950), la Ley Federal sobre Monumentos y Zonas Arqueológicos, Artísticos e Históricos (de 1972), la Ley de Puertos (de 1993), la Ley de Desarrollo Rural Sustentable (de 2001), la Ley de Energía para el Campo (de 2002), o la Ley General de Pesca y Acuacultura Sustentables (de 2007). 
Esta obra forma parte del acervo de la Biblioteca Jurídica Virtual del Instituto de Investigaciones Jurídicas de la UNAM

de la LAN se debe a la falta de expedición de diversos reglamentos para ello. Independientemente de que esta ley hubiera sido o no del agrado del Ejecutivo Federal, por mandato de ley éste tiene "el deber" de expedir tales instrumentos jurídicos, lo que debió haber realizado en un plazo no mayor de doce meses a partir de la entrada en vigor del decreto que reformó y adicionó la LAN (esto es, el 29 de abril de 2005 como último día).

Estamos a punto de finalizar el 2008 y todavía no se ha expedido el reglamento de la Ley de Aguas Nacionales que habría de abrogar el que está vigente (que es de 1994). Resulta de esto que muchas de las disposiciones jurídicas que se insertaron en las reformas y adiciones del 2004 a esta ley, no se están aplicando por falta de un instrumento jurídico que así lo permita.

Recuerdo que en el encuentro universitario arriba mencionado, me acerqué a un representante de la Comisión Nacional del Agua (órgano desconcentrado de la Secretaría de Medio Ambiente y Recursos Naturales y quien ejerce la autoridad y administración de las aguas nacionales y de sus bienes públicos inherentes en este país), y le pregunté sobre el motivo de la no expedición del reglamento de la ley. Ésta fue nuestra muy corta conversación:

«Mire» — me confesó — «la respuesta es muy sencilla: no conviene.» Bueno -insistí-y ¿por qué no conviene? ¿qué opciones tenemos?

«No insista» - me recalcó-. «En realidad, no debe preocuparse, estamos trabajando en una nueva reforma a la ley, es decir, estamos por ahí elaborando un proyecto de iniciativa de ley para modificar lo del 2004... quisiera poder decirle más pero basta con que le diga que es así como estaremos lidiando con esta situación...»

Tomé aire unos minutos y reflexioné sin decirlo en voz alta: ¡vaya genial idea! Ahora resulta que para enfrentar el problema de la no aplicación de la LAN por no tener reglamento para ello, se habrá de reformar y adicionar lo que hace algunos años se reformó y adicionó pero que nunca se aplicó. De manera tal que muchas de las disposiciones de la "nueva" regulación jurídica que entró en vigor en 2004 seguramente nunca habrán de aplicarse.

Me pregunto, ¿no acaso la construcción de argumentos legales en la aplicación de la legislación ambiental presupone la voluntad de expedir 
Esta obra forma parte del acervo de la Biblioteca Jurídica Virtual del Instituto de Investigaciones Jurídicas de la UNAM

los instrumentos jurídicos correspondientes que permitan la aplicación de las disposiciones de un texto jurídico? ¿Qué propósito oscuro persigue el Ejecutivo Federal al promulgar y publicar leyes que no tiene la intención de aplicar?

Y pensar que en su momento se consideró al objeto de regulación de esta ley sectorial - las aguas nacionales - como una prioridad y asunto de seguridad nacional. ${ }^{6}$

\section{SOBRE EINSTEIN, DiOS Y UNA VIEJA PARADOJA}

Es previsible que una biblioteca que pertenezca al mundo del derecho carezca de libros que aborden desde las ciencias exactas - particularmente desde la física - cuestiones como la existencia de Dios, la relación entre ciencia y religión, o el dilema sobre la vieja paradoja de la omnipotencia. Los nombres de Planck, Einstein, Heisenberg, Schrödinger, Bohr, Eddington o Hawking supondrían poco o nulo interés al investigador de la ciencia jurídica, a menos que la rama de su especialización lo llevara (como lo hizo el derecho ambiental conmigo) a reflexionar sobre el comienzo y el final de todas las cosas.

Gracias a las horas maravillosas que me ha brindado la academia para pensar e investigar sobre mi materia, he podido adentrarme con firmeza autodidacta a indagar sobre el universo entero, desde su comienzo (el big bang o la gran explosión) hasta su posible final (el big crunch o la gran implosión). Para mi fortuna y regocijo universitario, en esta aventura académica me he encontrado - muchos otros ya lo habrán hecho- con el pensamiento de uno de los físicos más importantes del siglo pasado: Albert Einstein (1879-1955). Al examinar sus aportaciones científicas sobre el universo, me di cuenta de su interés por hablar de diversas cuestiones relacionadas con el concepto de Dios. Así, en su búsqueda por comprender el significado de los movimientos espirituales y en su intento por conceptuar ciencia y religión, Einstein reflexiona sobre los

6 Así se señala en la fracción primera del artículo 14 BIS 5 de la vigente Ley de Aguas Nacionales que al efecto establece: "El agua es un bien de dominio público federal, vital, vulnerable y finito, con valor social, económico y ambiental, cuya preservación en cantidad y calidad y sustentabilidad es tarea fundamental del Estado y la Sociedad, así como prioridad y asunto de seguridad nacional", traducción de Pedro de Casso, Barcelona, Kairós, 2007 
Esta obra forma parte del acervo de la Biblioteca Jurídica Virtual del Instituto de Investigaciones Jurídicas de la UNAM

misterios que encierra la idea misma de la existencia de Dios. Delibera sobre ese Dios personal omnipotente, justo y providente, idea que "lleva añejos una serie de puntos débiles decisivos, que se han dejado sentir dolorosamente a lo largo de la historia". ${ }^{7}$ Es fácil advertir una paradoja en la reflexión de Einstein cuando señala:

...si ese ser es omnipotente, entonces todo cuanto ocurre - incluyendo todo pensamiento, toda acción y todo sentimiento y deseo humanos- es también obra Suya; ¿cómo es posible seguir considerando a los hombres responsables de sus pensamientos y acciones en presencia de un Ser todopoderoso? En cierta medida, al distribuir premisos y castigos se estaría juzgando a Sí mismo. ¿Cómo puede esto conciliarse con la bondad y justicia que se le atribuyen? ${ }^{8}$

La reflexión einsteiniana sobre Dios se vincula a una paradoja semejante, también sobre la omnipotencia, que ha sido discutida desde hace muchos años y que algunos físicos de nuestros días — como ha sido el caso del inglés Stephen W. Hawking - la han utilizado para complementar sus explicaciones sobre la viabilidad de encontrar una teoría unificada del universo. ${ }^{9}$ Se trata de una vieja paradoja a la que también se le conoce como la paradoja de la piedra: ¿puede Dios hacer una piedra tan pesada que él no pueda levantarla?

7 Einstein, Albert, "El sentimiento cósmico religioso" y "Ciencia y religión”, en Wilber, Ken (ed.), Cuestiones cuánticas. Escritos místicos de los físicos más famosos del mundo, 10a. ed., traducción de Pedro de Casso, Barcelona, Kairós, 2007, passim.

8 Ibidem, p. 167.

9 La búsqueda de una teoría unificada del universo - a la que se le conoce en ocasiones como "la unificación de la física"- supone encontrar una teoría que sea consistente y completa, que incluya todas las otras teorías parciales que se han elaborado para describir diversos aspectos sobre el universo, como lo han sido por ejemplo la teoría parcial para explicar la gravedad o las teorías parciales para comprender las fuerzas débil, fuerte y electromagnética (las cuales dependen de la mecánica cuántica). El físico Hawking comenta en este sentido que existen tres posibilidades para responder a la pregunta de si puede o no haber tal teoría unificada, y una de esas posibilidades consiste en que simplemente no la hay: "los acontecimientos no pueden predecirse más allá de cierto punto, ya que ocurren de una manera aleatoria y arbitraria". Quienes suscriben esta tercera posibilidad, explica el autor, se han basado en la idea de que si hubiera un conjunto consistente y completo de leyes, iría en contra de la libertad de Dios de cambiar de opinión e intervenir en el mundo, lo que se parece precisamente a la vieja paradoja de la piedra. Véase Hawking, Stephen W., Historia del tiempo. Del big bang a los agujeros negros, traducción de Miguel Ortuño, Barcelona, Crítica, 2005, pp. 201 y ss. 
Esta obra forma parte del acervo de la Biblioteca Jurídica Virtual del Instituto de Investigaciones Jurídicas de la UNAM

A partir de ella, se me ha ocurrido presentar para este seminario mi propia paradoja con el único objeto de apoyar mis reflexiones sobre la idea de lo que significa construir argumentos legales para aplicar la legislación ambiental. La he denominado la paradoja de la legislación ambiental y consiste en preguntarnos: ¿puede la legislación ambiental establecer disposiciones jurídicas que desprotejan el ambiente?

Parecería ocioso tener que enfatizar que la legislación ambiental tiene como objetivo esencial el de llevar a cabo acciones y establecer mecanismos a favor del ambiente. Este propósito se traduce, en general, en una serie de actividades que comprenden - entre otras - el de la conservación, la preservación, el mejoramiento, la restauración, el aprovechamiento sustentable y la protección de lo que es el ambiente, y/o el equilibrio ecológico, y/o los recursos naturales, y/o los ecosistemas (cualesquiera que sean las acepciones que adoptemos para estos conceptos), así como la prevención, el combate y el control de la contaminación. Esta lista no es exhaustiva pero permite convenir en que todas estas actividades van encaminadas hacia la defensa del ambiente. Esto para el diseño de instrumentos y/o mecanismos jurídicos implica que la legislación ambiental no supone el establecimiento de disposiciones jurídicas para fomentar, promover, desarrollar o generar actividades contrarias a su propia esencia. Qué tanto el derecho ambiental normativo podría "radicalizarse" hasta el punto de regular conductas de los seres humanos que induzcan a la consecución de emisiones cero, contaminación cero, aprovechamiento cero, descarga cero, etcétera, es un tema de análisis de mucha discusión que no está resuelto y que no habremos de abordar en esta ocasión.

La paradoja que hemos elaborado surge a partir de la existencia de casos lamentables donde se puede presentar una situación en la que una disposición ambiental vaya en contra de realizar acciones a favor del ambiente. Para ejemplificar lo anterior, habré de referirme a un caso muy concreto que es el de la regulación jurídica de los humedales costeros con mangle en este país. Se trata de un instrumento que forma parte de la legislación ambiental nacional: la Norma Oficial Mexicana NOM-022SEMARNAT-2003, que establece las especificaciones para la preservación, conservación, aprovechamiento sustentable y restauración de los humedales costeros en zonas de manglar, publicada en el Diario Oficial de la Federación el 10 de abril de 2003.

El objeto de esta norma (en adelante, NOM-022-SEMARNAT-2003) consiste en establecer una serie de especificaciones técnicas para regular 
Esta obra forma parte del acervo de la Biblioteca Jurídica Virtual del Instituto de Investigaciones Jurídicas de la UNAM

el aprovechamiento sustentable de los humedales costeros (a los que define para efectos de la propia norma como "unidades hidrológicas integrales que contengan comunidades vegetales de manglares") para prevenir su deterioro, fomentar su conservación y, en su caso, su restauración. ${ }^{10}$ Lo maravilloso de la norma (y que cualquier ambientalista comprometido habría de celebrar) es que al momento de su expedición contenía toda una serie de enunciados tanto en sus considerandos como en sus numerales introductorios que permitían no sólo convencer a cualquier neófito en la materia de la importancia que tienen los humedales costeros, sino que no contravenía en lo general la idea esencial de que la legislación ambiental habrá de elaborarse para proteger el ambiente, en este caso, el humedal costero en zona de mangle.

Sin embargo, al ser publicada el 7 de mayo de 2004 en el Diario Oficial de la Federación una infame adición a la NOM-022-SEMARNAT-2003, surgió la incongruencia de que una disposición ambiental desprotegía el ambiente. Esta adición — se trató de la especificación 4.43- estableció en su momento un sistema de excepción a través del cual todas aquellas obras y actividades prohibidas o con límites (así reguladas por la propia NOM-022-SEMARNAT-2003) que fueran a realizarse sobre estas zonas costeras, podían estar exentas de tales prohibiciones o limitantes si se llevaban a cabo medidas de compensación en beneficio de los propios humedales. Aquí el texto de dicha especificación:

4.43 La prohibición de obras y actividades estipuladas en los numerales 4.4 y 4.22 y los límites establecidos en los numerales 4.14 y 4.16 podrán exceptuarse siempre que en el informe preventivo o en la manifestación de impacto ambiental, según sea el caso se establezcan medidas de compensación en beneficio de los humedales y se obtenga la autorización de cambio de uso de suelo correspondiente. ${ }^{11}$

10 Véanse los numerales $0.2,1.1$ y 1.2 de la norma oficial mexicana de referencia. Cabe mencionar que la propia norma establece una definición detallada de humedales costeros en una especificación posterior, la 3.36, donde se señala que se trata de "ecosistemas costeros de transición entre aguas continentales y marinas, cuya vegetación se caracteriza por ser halófita e hidrófita, estacional o permanente, y que dependen de la circulación continua del agua salobre y marina. Asimismo, se incluyen las regiones marinas de no más de $6 \mathrm{~m}$. de profundidad en relación al nivel medio de la marea más baja”.

11 Descripción técnica tomada textualmente del Acuerdo que adiciona la especificación 4.43 a la Norma Oficial Mexicana NOM-022-SEMARNAT-2003, que establece las especificaciones para la preservación, conservación, aprovechamiento sustentable y res- 
Esta obra forma parte del acervo de la Biblioteca Jurídica Virtual del Instituto de Investigaciones Jurídicas de la UNAM

La inclusión en la redacción de un "beneficio de los humedales" era engañosa puesto que la adición misma permitía llevar a cabo ciertas obras y actividades sobre las áreas costeras en cuestión con tan sólo establecer medidas de compensación (nada difíciles de solventar) incluso aún con impactos ambientales negativos. De manera que al hacerse efectiva la compensación se podía: 1) establecer infraestructura fija (diques, rompeolas, muelles, marinas y bordos) y llevar a cabo cualquier otra obra que ganara terreno a la unidad hidrológica en zonas de manglar (según el numeral 4.14);2) construir infraestructura acuícola en áreas cubiertas de vegetación de manglar (según el numeral 4.22); 3) construir vías de comunicación aledañas, colindantes o paralelas al flujo del humedal costero sin que se tomara en cuenta las franjas y/o límites de protección correspondientes (según el numeral 4.14), y 4) realizar actividades agropecuarias, acuícolas intensivas o semi-intensivas, de infraestructura urbana, u otras aledañas o colindantes con la vegetación del humedal costero sin que se respetara la distancia mínima (de 100 metros) respecto al límite de la vegetación (según el numeral 4.16).

Es evidente que con tales excepciones se abrió la puerta a los desarrolladores turísticos - entre otros - en detrimento de los humedales costeros en zonas de manglar. En ese año (2004) muchas organizaciones ambientalistas hicieron pública la denuncia del retroceso que semejante adición significaba ante el consenso logrado por científicos y ambientalistas en un proceso previo de siete años de discusión de la norma oficial mexicana en cuestión. ${ }^{12}$ Esta adición fue sin duda alguna un golpe certero y mortífero a la esencia misma de la NOM-022-SEMARNAT-2003 de protección a los manglares. ${ }^{13}$

tauración de los humedales costeros en zonas de manglar, publicado en el Diario Oficial de la Federación del 7 de mayo de 2004.

12 Véase Nava Escudero, César, "La privatización de las zonas costeras en México", en López Olvera, Miguel Alejandro (coord.), Estudios en homenaje a don Alfonso Nava Negrete. En sus 45 años de docencia, México, UNAM, Instituto de Investigaciones Jurídicas, 2006, p. 163.

13 Hacemos notar al lector que este letal escenario jurídico cambió a partir de un decreto publicado en el Diario Oficial de la Federación, el 1o. de febrero de 2007, por el que se adicionó un artículo 60 ter a la Ley General de Vida Silvestre. El texto vigente de este artículo señala en su primer párrafo lo siguiente: “Artículo 60 ter. Queda prohibida la remoción, relleno, transplante, poda, o cualquier obra o actividad que afecte la integralidad del flujo hidrológico del manglar; del ecosistema y su zona de influencia; de su productividad natural; de la capacidad de carga natural del ecosistema para los proyectos 
Esta obra forma parte del acervo de la Biblioteca Jurídica Virtual del Instituto de Investigaciones Jurídicas de la UNAM

De modo que me pregunto, ¿cómo pensar en la construcción de argumentos legales en la aplicación de una legislación ambiental cuando ésta puede paradójicamente contemplar entre sus disposiciones la no protección de aquello que trata de proteger?

\section{SOBRE LA VERDAD INCÓMODA DE CARLOS FUENTES}

Quienes nos dedicamos a las cuestiones ambientales sabemos que uno de los motivos que llevó al ex vicepresidente de los Estados Unidos de América, Al Gore, a obtener del Comité Nobel Noruego el Premio Nobel de la Paz de 2007, fue el crear y difundir conocimiento sobre el cambio climático a través de un documental conocido lisa y llanamente como Una verdad incómoda (en inglés, An Inconvenient Truth). ${ }^{14}$ El título principal de este documental ha sido utilizado para describir y/o denunciar las muchas verdades incómodas de los funcionarios públicos, los programas o políticas gubernamentales, o la humanidad misma, sean o no en torno al cambio climático. ${ }^{15}$

turísticos; de las zonas de anidación, reproducción, refugio, alimentación y alevinaje; o bien de las interacciones entre el manglar, los ríos, la duna, la zona marítima adyacente y los corales, o que provoque cambios en las características y servicios ecológicos". El segundo párrafo del mismo artículo señala: "Se exceptuarán de la prohibición a que se refiere el párrafo anterior las obras o actividades que tengan por objeto proteger, restaurar, investigar o conservar las áreas de manglar". De manera que con esta reforma y según el artículo segundo de este decreto quedaron derogadas todas las disposiciones que contravinieran al decreto de referencia desde su entrada en vigor.

$14 \mathrm{El}$ documental en video producido por Al Gore llevó por título An Inconvenient Truth. A Global Warning.

15 Como ejemplos en este país recordemos que precisamente el día de la presentación del libro de Al Gore en su versión en español (junio de 2007), Patricia Arendar, Directora Ejecutiva de Greenpeace México señaló: “... en México también tenemos nuestras verdades incómodas... pese a que en los documentos oficiales se menciona el tema del calentamiento como de seguridad nacional, el gobierno no ha traducido sus buenas intenciones en recursos económicos para emprender esta lucha". En ésa misma ocasión, Alejandro Nadal, investigador de El Colegio de México comentó al respecto “... pero la verdad más incómoda de todas es que vamos a tener que cambiar nuestro estilo de vida, ya que se trata del reto (el cambio climático) más grande que hemos enfrentado como humanidad". Cita de Planeta Azul. Periodismo ambiental, Critican estrategia de cambio climático, México, 2007, consultable en http://www.planetaazul.com.mx/www/2007/06/02/criticanestrategia-de-cambio-climatico/. 
Esta obra forma parte del acervo de la Biblioteca Jurídica Virtual del Instituto de Investigaciones Jurídicas de la UNAM

En mi propia búsqueda de alguna verdad incómoda, que pudiera incidir de manera directa en mis reflexiones para indagar sobre la construcción de argumentos legales para la aplicación de la legislación ambiental, descubrí una derivada de unas palabras pronunciadas hace algunos años por el gran escritor mexicano Carlos Fuentes. Durante la entrega en el 2001 de los premios a la comunicación del Fondo de Naciones Unidas para la Infancia (UNICEF), el ganador del Premio Príncipe de Asturias 1994 y egresado de la Facultad de Derecho de esta máxima casa de estudios, señaló lo siguiente: "La diferencia entre América Latina, frente a Europa y Estados Unidos, es que allá la corrupción es investigada, se descubre, se denuncia y los responsables pueden ser llevados a juicios y eventualmente, a la cárcel...". ${ }^{16}$

¡Vaya verdad incómoda la de Carlos Fuentes! Decimos en México que aunque las mentiras matan, las verdades duelen, y esta no es la excepción. Y bien, ¿tienen alguna vinculación los temas de corrupción e impunidad — que dicho sea de paso, están hundiendo a este país — en la construcción de argumentos legales para la implementación de la legislación ambiental?

Para dar respuesta a tal pegunta habré de apoyarme en la experiencias burocráticas que tuve como funcionario público durante casi tres años en lo que antes era la Coordinación General Jurídica (hoy Unidad Coordinadora de Asuntos Jurídicos) de la Secretaria de Medio Ambiente y Recursos Naturales. Mi reflexión se fundamenta a partir de dos textos legales que contenían las sanciones respectivas en materia de uso y aprovechamiento de zonas costeras de aquéllos bienes sujetos al régimen de dominio público de la entonces Ley General de Bienes Nacionales de 1982, abrogada por una ley con el mismo nombre en 2004. En aquél entonces el artículo 96 (hoy artículo 149) establecía lo siguiente:

Artículo 96. Se sancionará con prisión de dos años a doce años y multa de trescientas a quinientas veces el salario mínimo general diario vigente para el Distrito Federal a quien, vencido el término señalado en la concesión, permiso o autorización que se haya otorgado para la explotación, uso o aprovechamiento de un bien de dominio público, no lo devolviere a la autoridad correspondiente dentro del término de treinta días siguientes a la fecha del requerimiento administrativo que le sea formulado. ${ }^{17}$

16 Cita textual tomada de López, Jaime, Corrupción presidencial en América Latina, consultable en http://www.offnews.info/downloads/corrupcion_presidencial.pdf.

${ }^{17}$ Los cambios que se le hicieron a este artículo en la vigente ley de 2004 son mínimos y no modifican en lo absoluto el razonamiento que aquí exponemos relativo a la corrupción e impunidad existentes en nuestro país. Para que el lector pueda advertir 
Esta obra forma parte del acervo de la Biblioteca Jurídica Virtual del Instituto de Investigaciones Jurídicas de la UNAM

Dentro de los bienes sujetos al régimen de dominio público que establecía la ley de 1982 (como ahora lo está también en la ley de 2004) se encontraban los terrenos o zonas costeras siguientes: las playas marítimas, por tratarse de un bien de uso común según el artículo 29, fracción IV (hoy artículo 7o., fracción IV), la zona federal marítimo terrestre, por tratarse igualmente de un bien de uso común según el artículo 29, fracción V (hoy artículo 7o. fracción $\mathrm{V}$ ), y los terrenos ganados natural o artificialmente al mar, según el artículo 2o., fracción VIII (hoy artículo 6o., fracción IX).

Una de las formas que existían en ese tiempo para la explotación, uso o aprovechamiento por particulares de la zona federal marítimo terrestre y de los terrenos ganados al mar - pero que en la actualidad funciona idénticamente-, era a través del otorgamiento de una concesión (o permiso, según fuera el caso) por parte de la Secretaría de Medio Ambiente y Recursos Naturales. Las concesiones sobre estos dos bienes podían otorgarse por un plazo de hasta cincuenta años, prorrogables hasta por plazos equivalentes a los señalados originalmente según lo señalaba el segundo párrafo del artículo 20 de la ley de $1982 .{ }^{18}$ Esto es, si a un particular se le otorgaba el plazo de diez años para el uso y aprovechamiento de un terreno determinado de zona federal marítimo terrestre, el concesionario podía solicitar prórroga de hasta otros diez años más.

Ahora bien, de manera muy puntual la ley de 1982 establecía que el titular de una concesión gozaba de un plazo de cinco años, previo al vencimiento de la concesión, para solicitar la prórroga correspondiente, y que al término del plazo de la concesión, o de la última prórroga según fuera el caso, las obras e instalaciones adheridas de manera permanente a la zona federal marítimo terrestre revertirían en favor de la Nación (último párrafo del artículo 20). La ley también era muy clara en señalar que

lo anterior, transcribimos el texto del artículo 149 de la ley de 2004: "Artículo 149. Se sancionará con prisión de dos a doce años y multa de trescientas a mil veces el salario mínimo general diario vigente para el Distrito Federal a quien, vencido el término señalado en la concesión, permiso o autorización que se haya otorgado para la explotación, uso o aprovechamiento de un bien sujeto al régimen de dominio público de la Federación, no lo devolviere a la autoridad correspondiente dentro del término de treinta días naturales siguientes a la fecha de notificación del requerimiento administrativo que le sea formulado".

18 La idea de prorrogar concesiones hasta por el mismo plazo se conservó en la ley de 2004, aunque con una redacción diferente y enfatizando que las prórrogas podían otorgarse una o varias veces. En la actualidad, el primer párrafo del artículo 73 establece que "las concesiones... podrán otorgarse por un plazo de hasta cincuenta años, el cual podrá ser prorrogado una o varias veces sin exceder el citado plazo...". 
Esta obra forma parte del acervo de la Biblioteca Jurídica Virtual del Instituto de Investigaciones Jurídicas de la UNAM

el vencimiento del término por el que se hubiera otorgado la concesión causaría su extinción (artículo 21, fracción I).

De manera que, de la lectura adminiculada de estos artículos con el artículo 96 de la ley de 1982, quedaba claro a nuestro entender que si el concesionario no solicitaba su prórroga antes del vencimiento, cuando éste se produjera y tras ser requerido, el titular de la concesión tendría que devolver a la autoridad administrativa correspondiente dicho bien, puesto que de lo contrario sería sancionado con prisión y multa. Asimismo, sosteníamos el criterio de que si el concesionario solicitaba su prórroga en tiempo, es decir, antes de su vencimiento, pero la autoridad no resolvía antes de que éste ocurriera, entonces sucederían tres cosas: 1) la concesión se extinguía, ya que es causal de extinción el vencimiento del término otorgado; 2) no se podía proceder a la prórroga correspondiente, porque simple y sencillamente ¡no se puede prorrogar lo que está extinto!, y 3) la autoridad ambiental respectiva incurriría en responsabilidad.

Recuerdo perfectamente bien que de todos los casos que en materia de zona federal marítimo terrestre y terrenos ganados al mar llegaban a mi escritorio para su respectiva opinión jurídica, los relativos a las prórrogas de concesiones (estuvieran en tiempo o no) eran llamativos por su cantidad. Nuestras opiniones trataban de alertar a la autoridad correspondiente (particularmente a la que ahora es la Dirección General de Zona Federal Marítimo Terrestre y Ambientes Costeros) sobre las anomalías que a nuestro juicio considerábamos evidentes según lo que hemos explicado en párrafos anteriores. Pocas veces conocíamos de alguna devolución en favor de la Federación por esta situación y tristemente nos enterábamos que las concesiones, ya extintas, se prorrogaban en contravención a lo establecido en la legislación correspondiente.

Aunado a lo anterior, habíamos descubierto que la propia autoridad ambiental era omisa para imponer las mismas sanciones contenidas en el artículo 96 de la ley de 1982 cuando se realizaba la explotación, uso o aprovechamiento de la zona federal marítimo terrestre sin que se hubiera obtenido previamente una concesión (tal y como lo señalaba el artículo 97 de esa abrogada ley, hoy artículo 150 de la ley de 2004):

Artículo 97. La misma pena se impondrá a quien, a sabiendas de que un bien pertenece a la nación, lo explote, use o aproveche sin haber obtenido previamente, concesión, permiso, autorización, o celebrado contrato con la autoridad competente. 
Esta obra forma parte del acervo de la Biblioteca Jurídica Virtual del Instituto de Investigaciones Jurídicas de la UNAM

Las obras e instalaciones que sin concesión o permiso se realicen en los bienes de propiedad federal, se perderán en beneficio de la Nación. En su caso, la Secretaría de Desarrollo Urbano y Ecología (sic) ordenará que las obras o instalaciones sean demolidas por cuenta del infractor, sin que proceda indemnización o compensación alguna.

Los argumentos que en aquellos tiempos exponían las autoridades respectivas al área jurídica para explicar por qué "no aplicaban” la ley según los dos textos legales aquí transcritos, merecen ser reproducidas:

...usted bien sabe que tenemos un rezago desde la administración pasada... ¿cómo nos pide que no prorroguemos las concesiones cuando los solicitantes lo hicieron en tiempo y nosotros no hemos respondido porque no contamos con el personal suficiente?... lo invitamos a que nos visite a la dirección general para que vea los paquetes y paquetes que tenemos para prorrogar solicitudes... tenemos un caso en el que no podemos ser más papistas que el papa: se trata de un palapero, jefe de familia, pobre y con muchos hijos qué mantener... no tenemos la certeza de que haya sabido, o no, que tenía que solicitar concesión. El hecho es que construyó una palapita pequeña...es un restaurancito y de eso sobreviven... díganos usted qué hacemos, ¿considera justo que el palapero pierda su restaurante en beneficio de la nación? ¿Y si mejor lo regularizamos y le otorgamos la concesión respectiva?... usted no se da cuenta que el solicitante es un gran empresario que provee de empleos y es factor de impulso al turismo, ¿quiere usted gente en las calles?

En las reuniones de trabajo que llegamos a sostener con las autoridades de la zona federal marítimo terrestre y con algunos inspectores de la Procuraduría Federal de Protección al Ambiente para ventilar estos y otros asuntos, discutíamos ampliamente los criterios utilizados para determinar un posible incumplimiento de la legislación, pero no la forma en la que finalmente se habrían de resolver los asuntos. Nuestra visión de las cosas apuntaba a que la no implementación de las disposiciones jurídicas respectivas no se debía sólo a una diferencia de criterios jurídicos. Desde las oficinas centrales de donde dictaminábamos diversos asuntos (sólo hacíamos eso, dictaminar y opinar) nos era punto menos que imposible contar con pruebas contundentes sobre las prácticas que llevaban a cabo funcionarios e inspectores para "solucionar" los problemas presentados en nuestras zonas costeras. La falta de aplicación de la ley por la autori- 
Esta obra forma parte del acervo de la Biblioteca Jurídica Virtual del Instituto de Investigaciones Jurídicas de la UNAM

dad competente, estuviera o no adecuada a nuestra realidad, ¿no es acaso en sí misma una forma de corrupción e impunidad?

Ha pasado algo de tiempo desde aquéllas experiencias burocráticas (dejé de laborar para el gobierno federal hacia finales de 2003), y a la fecha no he detectado por ningún lado señales que me permitan afirmar que el comportamiento de quienes ahora están encargados de otorgar concesiones (con todo y sus prórrogas) y de realizar los actos de inspección y vigilancia para el cumplimiento de la ley sea diferente al de entonces.

Es difícil decirlo en voz alta, y más aún reconocerlo como mexicanos, pero nuestros niveles de corrupción son muy elevados, y es algo que tenemos que combatir. Ante tal verdad incómoda, ¿de qué tipo de argumentos legales queremos hablar en un seminario como estos, si al fin y al cabo la aplicación de la legislación ambiental está sujeta presumiblemente a componendas de tipo económico?

\section{CONCLUSIÓN}

Quiero terminar mi presentación con una última reflexión. En estos días de seminario, se estarán analizando diversos temas para el fortalecimiento de la aplicación y la administración de la legislación ambiental en América del Norte. Si los mexicanos queremos verdaderamente aprender de las experiencias que en este sentido han tenido nuestros socios comerciales canadienses y estadounidenses, requerimos y demandamos apertura plena en la discusión y difusión de las ideas de quienes participen en un evento como estos. No tengamos miedo.

Aprovechemos la participación sincera de los tres países, y su buena disposición en la conformación de un grupo de panelistas expertos, para manifestarnos con plena libertad de pensamiento. La Universidad Nacional Autónoma de México es territorio propicio para ello porque somos un espacio universitario y por consiguiente un espacio para la irreverencia intelectual. Hemos de decir las cosas tal y como han de decirse, con puntos y comas.

Muchas gracias. 
Esta obra forma parte del acervo de la Biblioteca Jurídica Virtual del Instituto de Investigaciones Jurídicas de la UNAM

\section{INSTITUCIONALIZAR LA CAPACITACIÓN JURÍDICO-AMBIENTAL EN MÉXICO*}

\section{INTRODUCCIÓN}

Con atinada presencia regional, la Comisión para la Cooperación Ambiental (CCA) de América del Norte ha planteado como base de la cooperación entre Canadá, Estados Unidos y México, el fortalecimiento y desarrollo de capacidades en materia jurídico-ambiental en los tres países. Para ello, la CCA se embarcó en la ardua pero gratificante tarea de organizar tres eventos - el Simposio internacional sobre el poder judicial y la legislación ambiental en Canadá, Estados Unidos y México; el Simposio sobre legislación ambiental para jueces, y el Seminario para el fortalecimiento de la aplicación y administración de la legislación ambiental en América del Norte-, celebrados en la ciudad de México en 2005, 2007 y 2008, respectivamente. Diferentes instituciones mexicanas participaron en la coorganización de cada una de dichas reuniones: en la primera, la Universidad Panamericana; luego, el Tribunal Federal de Justicia Fiscal y Administrativa, y finalmente, el Instituto de Investigaciones Jurídicas de la Universidad Nacional Autónoma de México (UNAM).

Tras realizar un balance de las actividades realizadas durante los tres eventos, documentar las experiencias comparadas que ahí se vertieron, y compilar las participaciones escritas, la CCA se aproximó al Instituto de Investigaciones Jurídicas de la máxima casa de estudios de México para difundir los resultados obtenidos. Al mismo tiempo, el organismo tripartito invitó a esta dependencia universitaria a reflexionar sobre las áreas de opor-

* Publicado en Nava Escudero, César (ed.), Legislación ambiental en América del Norte. Experiencias y mejores prácticas para su aplicación e interpretación jurisdiccional. Environmental Legislation in North America. Experiences and best Practices for its Implementation and Adjudication, Montreal, Canadá-México, Comisión para la Cooperación Ambiental-UNAM, Instituto de Investigaciones Jurídicas, 2010. 
Esta obra forma parte del acervo de la Biblioteca Jurídica Virtual del Instituto de Investigaciones Jurídicas de la UNAM

tunidad para institucionalizar la capacitación jurídico-ambiental en México. Toca a mi persona aceptar tan significativa responsabilidad académica.

\section{CAPACITACIÓN JURÍDICO-AMBIENTAL: SIGNIFICADO Y ALCANCES}

El concepto de capacitación jurídico-ambiental o fortalecimiento de capacidades en materia ambiental en el mundo del derecho tiene, en un sentido amplio, un significado puntual: "hacer aptos" a quienes realizan actividades jurídicas relacionadas con el ambiente. Tal afirmación conduce a una serie de reflexiones vinculadas fundamentalmente a dos interrogantes: primero, ¿qué herramienta debe utilizarse para hacer apto a alguien?, y segundo, ¿quiénes son los sujetos a capacitar y qué formación profesional deberán tener los sujetos que capacitan?

El punto de partida para el análisis de estas dos preguntas supone aceptar la idea de que la capacitación jurídico-ambiental tiene como objeto contribuir a la creación o mejoramiento del conocimiento de quienes están en contacto con lo que se conoce como derecho ambiental. Esta rama del derecho se refleja en tres fases que son comunes a todo sistema jurídico nacional: 1) la elaboración de la normatividad ambiental a cargo de los órganos legislativos o parlamentarios correspondientes; 2) la aplicación (o implementaciòn) e interpretación de la misma por las autoridades ambientales en los distintos órganos de gobierno (ya sea centrales y locales, o bien federales, estatales y municipales), así como la elaboración de instrumentos jurídicos reglamentarios, y 3) la interpretación jurisdiccional de todo el ordenamiento jurídico ambiental por juzgados, tribunales y cortes.

De manera tal que institucionalizar la capacitación jurídico-ambiental supone indiscutiblemente contar con una herramienta - el derecho ambiental-, procurar el entrenamiento de tres sujetos distintos - los legisladores, los burócratas, y los jueces y magistrados- y, por último, establecer el perfil de los capacitadores. En efecto, para lograr que la capacitación cumpla con el objetivo de "hacer aptos" en sus diferentes quehaceres públicos a los sujetos identificados, es indispensable determinar si existe el personal adecuado para llevarla a cabo e identificar qué formación profesional - ¿sólo abogados?, ¿con trayectoria teórica o práctica, legislativa, burocrática, judicial, etcétera? — deberán tener los capacitadores. 
Esta obra forma parte del acervo de la Biblioteca Jurídica Virtual del Instituto de Investigaciones Jurídicas de la UNAM

Es importante insistir, desde ahora, que si no se logra responder adecuadamente a las dos interrogantes planteadas, los resultados de la capacitación serán parciales y la actividad jurídica de los sujetos a capacitar estará incompleta. Pero aún más importante, no se habrá alcanzado el objetivo último de la capacitación que es el de establecer o mejorar el conocimiento sobre el derecho ambiental a fin de contribuir a la elaboración de leyes que recojan en sus textos la cuestión ambiental, a la instrumentación y vigilancia del cumplimiento de la normatividad correspondiente, y a la interpretación jurisdiccional de los cuerpos y disposiciones normativas.

Cabe preguntarse en este momento si la capacitación es realmente necesaria o no. Parte de la respuesta puede encontrarse en la misma legislación ambiental de un país (que bien puede no sólo recoger y definir el concepto de capacitación, sino incluirlo como un derecho u obligación de quienes llevarán a cabo una actividad jurídica ambiental), o al menos en las propuestas de quienes se ocupan de esta materia. De manera tal que la capacitación jurídico-ambiental puede concebirse, por ejemplo, como parte de la educación jurisdiccional, tal y como entusiastamente lo señaló Sandra Oxner (en su ponencia escrita, publicada en este libro) al referirse a las áreas de oportunidad de entrenamiento ambiental. ${ }^{1}$ También puede ser concebida como un aspecto fundamental del adiestramiento de servidores públicos en ciertos entes públicos, como lo afirmó en su presentación el director general del Instituto de Estudios sobre Justicia Fiscal y Administrativa, Eugenio Arriaga Minko: "la capacitación está orientada a los empleados, ejecutivos y funcionarios de nivel que por sus funciones, realizan un trabajo técnico calificado". ${ }^{2}$ Finalmente, la capacitación jurídico-ambiental puede constituirse en un criterio indispensable para la elaboración de la política pública a nivel nacional, como se refleja en la ley integral ambiental de México, la Ley General del Equilibrio Ecológico y la Protección al Ambiente, que incluye la capacitación en el capítulo relativo a "Instrumentos de la Política Ambiental"y la vincula a los temas de investigación y educación ecológicas. En el artículo 40 de esta ley se establece lo siguiente:

Artículo 40. La Secretaría de Trabajo y Previsión Social promoverá el desarrollo de la capacitación y adiestramiento en y para el trabajo en materia

1 Más información puede encontrarse en la ponencia presentada por esta autora "Areas of opportunity for environmental training for the judiciary. Steps forward".

2 Véase la ponencia "Intercambio de experiencias y capacitación judicial en la materia ambiental”, publicada en la presente compilación. 
Esta obra forma parte del acervo de la Biblioteca Jurídica Virtual del Instituto de Investigaciones Jurídicas de la UNAM

de protección al ambiente, y de preservación y restauración del equilibrio ecológico, con arreglo a lo que establece esta Ley de conformidad con los sistemas, métodos, y procedimientos que prevenga la legislación especial...

Pero otra parte de la respuesta también puede ubicarse en el plano internacional, en instrumentos jurídicos que no sólo reafirman la importancia de la capacitación jurídico-ambiental sino que proponen a las naciones el camino que habrán de seguir en este sentido. Ejemplo de lo anterior son los Principios de Johannesburgo sobre el Papel del Derecho y el Desarrollo Sostenible, un instrumento internacional no vinculante - $\mathrm{O}$ soft law - que fuera adoptado en agosto de 2002 en el Simposio Global de Jueces, pocos días antes de la Conferencia de las Naciones Unidas sobre el Desarrollo Sostenible (también conocida como Río + 10) celebrada en Johannesburgo, Sudáfrica. En este documento se señala lo siguiente respecto a la capacitación:

Apoyamos firmemente la opinión de que reviste carácter de urgencia fortalecer la capacidad de los magistrados, fiscales, legisladores y todas las personas que desempeñan un papel prominente a nivel nacional en el proceso de la ejecución, el desarrollo y la aplicación coercitiva del derecho ambiental, incluidos los acuerdos ambientales multilaterales, especialmente por conducto de procesos judiciales.

Al establecer como uno de sus principios la idea de desarrollar la educación, formación y diseminación de la información en el ámbito del derecho ambiental, se propuso un programa de trabajo para la realización de éste y otros principios que incluya:

La mejora de la capacidad de quienes participan en el proceso de promover, ejecutar, desarrollar y aplicar coercitivamente la ley, tales como magistrados, fiscales, legisladores y otras personas, para que realicen sus funciones sobre una base bien fundamentada con la especialización, la información y los materiales necesarios.

Otro ejemplo, pero ahora de un instrumento jurídico regional vinculante - hard law -, es el propio Acuerdo de Cooperación Ambiental de América del Norte (ACAAN), suscrito entre los gobiernos de Canadá, Estados Unidos y México y a veces conocido simplemente como "acuer- 
Esta obra forma parte del acervo de la Biblioteca Jurídica Virtual del Instituto de Investigaciones Jurídicas de la UNAM

do paralelo ambiental", en el que también se aborda el tema de la capacitación en materia ambiental. A propósito de la implementación de la legislación ambiental, este tratado internacional establece lo siguiente:

Artículo 5. Medidas gubernamentales para la aplicación de leyes y reglamentos ambientales

1. Con el objeto de lograr altos niveles de protección del ambiente y de cumplimiento con sus leyes y reglamentos ambientales, cada una de las Partes aplicará de manera efectiva sus leyes y reglamentos ambientales a través de medidas gubernamentales adecuadas, conforme al Artículo 37, tales como:

(a) nombrar y capacitar inspectores...

En suma, para ser eficaz, la capacitación jurídico-ambiental deberá institucionalizarse en las esferas legislativa o parlamentaria, administrativa o burocrática, y jurisdiccional. En cada una de ellas existen oportunidades y retos semejantes y a la vez distintos, pero el punto de arranque será el entrenamiento a partir de lo que se conceptualice como derecho ambiental.

\section{EL DERECHO AMBIENTAL EN MÉXICO}

Es común que se afirme que la expresión derecho ambiental se refiere sólo a un conjunto de normas jurídicas (cuyo objeto es regular lo que tiene que ver, por ejemplo, con el ambiente, con la naturaleza, o con los medios natural y construido), y que el sentido de lo jurídico-ambiental sólo está presente en el proceso de elaboración de una ley, en la implementación de la misma por una autoridad ambiental, pero sobre todo, en la interpretación judicial. En muchos sentidos ha estado vigente la idea de que en cualquier rama jurídica, el derecho - al menos el derecho positivo - es lo que los jueces y magistrados (y ministros de la Corte, para el caso mexicano) dicen que es, y no lo que está en el texto jurídico respectivo.

Existe un adagio jurídico norteamericano que reza: "La Constitución es lo que los jueces dicen que es"... En términos generales, podría recogerse el aforismo anterior y afirmarse: al final, lo que se determine por los órganos jurisdiccionales, será lo que en realidad vendrá a ser derecho positivo; la Constitución y las leyes no dicen lo que se expresa en su texto, sino lo que 
Esta obra forma parte del acervo de la Biblioteca Jurídica Virtual del Instituto de Investigaciones Jurídicas de la UNAM

los jueces establecen. De lo anterior se desprende que el conocimiento de cualquier rama del derecho sin su interpretación por el Poder Judicial se convierte en una bella exposición de filosofía del derecho, pero no de derecho positivo. ${ }^{3}$

La reflexión arriba transcrita resulta bastante convincente para comprender "el derecho positivo", pero insuficiente para explicar lo que hemos aprendido durante los seminarios organizados por la CCA. Y es que pensar el derecho sólo de ésa manera significaría para nuestro propósito dos cosas a la vez: 1) que la capacitación jurídico-ambiental sólo debiera darse en la esfera judicial, y 2) que, derivado de lo anterior, pareciera que las autoridades ambientales no llevan a cabo interpretación alguna para la implementación de la normatividad ambiental.

Respecto de la primera suposición, es mejor referirnos en todo caso a una esfera jurisdiccional y no sólo a un Poder Judicial, de manera que podamos incluir a otras instancias de impartición de justicia que no están "dentro" de ése poder, como los tribunales administrativos, particularmente el Tribunal Federal de Justicia Fiscal y Administrativa en México, donde se ventilan asuntos relacionados con el ambiente. Para la segunda suposición, debemos aceptar que la interpretación de los textos jurídicoambientales no es tarea exclusiva de jueces y magistrados, sino que las autoridades ambientales están también constantemente interpretando (si bien para fines administrativos de aplicación) un sinnúmero de disposiciones contenidas en leyes ambientales, las cuales no siempre alcanzan a ser analizadas o interpretadas por los tribunales de este país, por la simple y sencilla razón de que su contenido nunca es impugnado por la vía procesal, aunque probablemente sí por la procedimental.

Si en principio aceptamos la idea de que el derecho ambiental es un conjunto de normas jurídicas, la capacitación jurídico-ambiental deberá abarcar a los sujetos involucrados con ellas, ya sea en su elaboración, en su implementación o en su interpretación. Entonces, ¿qué ordenamientos jurídicos integran ese conjunto de normas ambientales que a su vez deberá conformar el contenido mismo de cualquier programa de capacitación?

Responder esta pregunta sugiere cuestionar la idea de que el derecho ambiental es únicamente un conjunto de normas jurídicas. En efecto, si

3 Véase en este sentido, Rojas Caballero, Ariel Alberto, La jurisprudencia del Poder Judicial de la Federación. Manual para su consulta y aplicación, México, Porrúa, 2008, p. 1. 
Esta obra forma parte del acervo de la Biblioteca Jurídica Virtual del Instituto de Investigaciones Jurídicas de la UNAM

deseamos llevar a cabo una capacitación que explique el contenido del ordenamiento jurídico ambiental, requerimos por motivos pedagógicos de una tipología de la normatividad en esta materia que sólo podemos obtener si llevamos a cabo un proceso de sistematización de lo que es el derecho ambiental normativo. Para ello, además de conceptos, definiciones y principios que expliquen bajo qué criterios tal o cual ley, tratado o disposición es ambiental, se necesita un método que facilite su estudio y comprensión. Cuando nos referimos a que ciertos sujetos se dedican a estudiar, analizar y sistematizar dicho conjunto de normas jurídicoambientales entonces decimos que el derecho ambiental es algo más que un simple conjunto de normas; es decir, el derecho ambiental puede tener - y de hecho tiene - una naturaleza eminentemente científica. Así lo explica, en sus propias palabras, Raúl Brañes:

...[L]a expresión "derecho ambiental" puede asumir, por lo menos, un doble significado. En general, cuando el sustantivo "derecho" se presenta adjetivado con otra palabra que designa un sector del sistema jurídico — v.gr. "derecho civil" o "derecho penal"-, la expresión así compuesta puede referirse precisamente a aquel sector del sistema jurídico de que se trata y, en consecuencia, designar al conjunto de normas jurídicas que integran ese sector, pues la expresión "derecho", en este caso estará siendo empleada en el sentido de "derecho positivo". Pero la misma palabra puede referirse a un conjunto de proposiciones que se formulan respecto de dichas normas, cuando con ella se quiere designar una determinada "ciencia jurídica"...

...[L]a expresión "derecho ambiental" se utiliza indistintamente para denominar el conjunto de las normas jurídicas que regulan cuestiones ambientales y la ciencia jurídica que se ocupa de tales normas. ${ }^{4}$

Acudir a la ciencia del derecho ambiental permite sustentar la capacitación en el quehacer cuidadoso y de esmero reflexivo por parte de juristas que se dedican a estudiar cada ley, cada norma, cada precepto. Con la dogmática jurídico-ambiental el diseño del contenido de la capacitación puede ser más preciso, posibilitando una delimitación conceptual y una tipología confiable que fortalezca el entrenamiento o proceso de enseñanza-aprendizaje de los sujetos a capacitar.

4 Brañes, Raúl, Manual de derecho ambiental mexicano, 2a. ed., México, Fundación Mexicana para la Educación Ambiental-Fondo de Cultura Económica, 2000, p. 28. 
Esta obra forma parte del acervo de la Biblioteca Jurídica Virtual del Instituto de Investigaciones Jurídicas de la UNAM

Combinar la doble naturaleza del derecho ambiental —es decir, la norma y la ciencia - conduce a establecer con mayor certidumbre la base de nuestra capacitación. Asistidos por esta reflexión, procedamos a delinear el contenido normativo del derecho ambiental tomando en consideración que una parte del ius ambientalismo mexicano ha reconocido esta doble naturaleza de nuestra disciplina jurídica. ${ }^{5}$

\section{TIPOLOGÍA DEL DERECHO AMBIENTAL NORMATIVO}

Una clasificación que me parece de enorme utilidad para delinear el contenido del derecho ambiental como conjunto de normas jurídicas en cualquier proceso de capacitación tiene como punto de arranque, por un lado, un segmento internacional, y por el otro, uno nacional o doméstico.

\section{Lo internacional}

Dentro del segmento internacional debemos considerar una lista de instrumentos jurídicos que regulan diversas materias, desde temas atmosféricos o del mar, hasta los relativos a la flora y la fauna o a la diversidad biológica en general. Estos instrumentos bien pueden ser multilaterales, regionales o bilaterales, y tener naturaleza vinculante (instrumentos o disposiciones de derecho rígido o duro - hard law-) o no vinculante (instrumentos o disposiciones derecho flexible, suave, blando o quasiderecho - soft law-).

¿Qué es lo que hace que estos instrumentos internacionales puedan considerarse derecho ambiental y, por lo tanto, incluirse en los contenidos de la capacitación respectiva? Esta situación no es fácil de resolver porque así como hay instrumentos internacionales cuya "naturaleza ambiental" se antoja más que obvia, como es el caso del Convenio sobre la Diversidad Biológica (CDB), de 1992, hay otros en los que tal naturaleza no es del todo clara, como el Tratado sobre Prohibición de Emplazar Armas Nucleares y otras Armas de Destrucción en Masa en los Fondos Marinos y Oceánicos y su Subsuelo, de 1971, que podría tener vincula-

5 Cfr. Brañes, Raúl, Manual de derecho ambiental mexicano, cit., nota anterior; Gutiérrez Nájera, Raquel, Introducción al estudio del derecho ambiental, 2a. ed., México, Porrúa, 1999, y Carbonell, Miguel et al., Compendio de derecho ambiental, México, Porrúa, 2010. 
Esta obra forma parte del acervo de la Biblioteca Jurídica Virtual del Instituto de Investigaciones Jurídicas de la UNAM

ción con temas ambientales pero que, a su vez, se considera un tratado clasificado bajo el rubro de desarme. Aún más, ¿qué sucede con tratados internacionales como la Convención de las Naciones Unidas sobre el Derecho del Mar, de 1982, que pertenece a un área jurídica denominada derecho del mar pero cuyo texto comprende, entre muchas otras, disposiciones relativas a la protección y preservación del medio marino y la conservación de sus recursos vivos?

En alguna otra ocasión señalamos que para responder a estas interrogantes ${ }^{6}$ podíamos auxiliarnos de ciertos criterios con el objeto de acotar en lo posible lo que pertenece a lo jurídico internacional ambiental. Tales criterios son los siguientes:

a. Serán temas internacionales ambientales para incluirse en toda capacitación aquellos que pertenezcan al ámbito de la discusión internacional en foros considerados o llamados propiamente foros ambientales, como los del cambio climático o los de la biodiversidad. La obviedad que esto implica facilita la identificación clara de ciertos instrumentos jurídicos y disposiciones ambientales. Se consideran foros ambientales aquellos que se han llevado a cabo a partir de finales de la década de los sesenta y principios de los setenta del siglo pasado (periodo en el que se habría de consolidar - particularmente en 1972, con la celebración de la Conferencia de las Naciones Unidas sobre el Medio Humano en Estocolmo, Suecia - el proceso de internacionalización de los temas ambientales) y hasta nuestros días. Para muchos autores, tal periodo se considera como el nacimiento del derecho internacional ambiental, ${ }^{7}$ el cual se desarrolla de la siguiente manera: una primera fase, de 1972 a 1992, cuando se celebra la Conferencia de las Naciones Unidas sobre el Medio Ambiente y el Desarrollo, en Río de Janeiro, Brasil; la segunda que abarca de 1992 a 2002, con la celebración de la Conferencia de las Naciones Unidas sobre el Desarrollo Sostenible de Johannesburgo, Sudáfrica, y la tercera, de 2002 a la fecha.

$b$. También serán parte de un proceso de capacitación aquellos temas internacionales que, aun sin pertenecer a foros considerados o llamados propiamente ambientales, se discutan en otros foros internacionales con repercusiones ambientales evidentes, como sucede en los relativos a mu-

6 Véase para mayor detalle, Nava Escudero, César, Estudios ambientales, México, UNAM, Instituto de Investigaciones Jurídicas, 2009, pp. 126 y ss.

7 Idem. 
Esta obra forma parte del acervo de la Biblioteca Jurídica Virtual del Instituto de Investigaciones Jurídicas de la UNAM

jeres, comercio, cuestiones urbanas o indígenas. En efecto, existen ciertos temas en foros de discusión - por ejemplo, en el marco de la Organización Mundial del Comercio-que tienen un vínculo o repercusión evidente con la cuestión ambiental, como es el caso de las actividades de importación y exportación de organismos genéticamente modificados.

c. Aunados a los dos anteriores, existen temas que han pertenecido tradicionalmente a otros foros de discusión internacional, ciertamente anteriores al proceso de internacionalización de los temas ambientales, pero que con el paso del tiempo se han ido incorporando a la lógica ambiental, como es el caso del derecho del mar.

\section{A. Tratados (globales y regionales) anteriores a 1972}

- Convención para la Protección de la Flora, de la Fauna y de las Bellezas Escénicas Naturales de los Países de América (Washington D.C., 12 de octubre de 1940).

- Convenio Interamericano de Lucha contra la Langosta (Montevideo, 19 de noviembre de 1946).

- Convención Internacional para la Reglamentación de la Caza de la Ballena con Reglamento Anexo (Washington D.C., 2 de diciembre de 1946).

- Protocolo a la Convención Internacional para la Reglamentación de la Caza de la Ballena, del 2 de septiembre de 1946 (Washington D.C., 19 de noviembre de 1956).

- Convenio Internacional para la Conservación del Atún del Atlántico (Río de Janeiro, 14 de mayo de 1966).

- Convenio Internacional relativo a la Intervención en Alta Mar en casos de Accidentes que causen una Contaminación por Hidrocarburos (Bruselas, 29 de noviembre de 1969).

- Convención sobre los Humedales de Importancia Internacional especialmente como Hábitat de Aves Acuáticas (Ramsar, 2 de febrero de 1971; véase la enmienda en los tratados de la fase 19721992). 
Esta obra forma parte del acervo de la Biblioteca Jurídica Virtual del Instituto de Investigaciones Jurídicas de la UNAM

B. Tratados (globales y regionales), fase 1972-1992

- Convenio sobre la Prevención de la Contaminación del Mar por Vertimiento de Desechos y otras Materias (Londres-México- Moscú-Washington D.C., 29 de diciembre de 1972).

- Convención sobre el Comercio Internacional de Especies Amenazadas de Fauna y Flora Silvestres (CITES) (Washington D.C., 3 de marzo de 1973).

- Convenio Internacional para Prevenir la Contaminación por los Buques (véanse Protocolo de 1978 y enmiendas) (Londres, 2 de noviembre de 1973).

- Protocolo relativo a la Intervención en Alta Mar en casos de Contaminación del Mar por Sustancias distintas de los Hidrocarburos (Londres, 2 de noviembre de 1973)

- Protocolo de 1976 al Convenio Internacional sobre Responsabilidad Civil por Daños Causados por la Contaminación de las Aguas del Mar por Hidrocarburos, 1969 (Londres, 19 de noviembre de 1976)

- Protocolo correspondiente al Convenio Internacional sobre la Constitución de un Fondo Internacional de Indemnización de Daños Causados por la Contaminación de Hidrocarburos, 1971 (Londres, 19 de noviembre de 1976).

- Protocolo de 1978 relativo al Convenio Internacional para Prevenir la Contaminación por los Buques, 1973 (marpol 1973/1978) (Londres, 17 de febrero de 1978).

- Anexo V del Protocolo de 1978 relativo al Convenio Internacional para Prevenir la Contaminación por los Buques, 1973, y enmiendas de 1989, 1990 y 1991 a dicho Anexo, así como enmiendas de 1994 (Londres, 17 de febrero de 1978).

- Protocolo que Modifica la Convención sobre los Humedales de Importancia Internacional Especialmente como Hábitat de Especies Acuáticas (París, 3 de diciembre de 1982).

- Convenio para la Protección y el Desarrollo del Medio Marino de la Región del Gran Caribe y Protocolo relativo a la Cooperación para Combatir los derrames de Hidrocarburos en la Región del Gran Caribe (Cartagena de Indias, 24 de marzo de 1983).

- Enmiendas de 1984 al Anexo del Protocolo de 1978 relativo al Convenio Internacional para Prevenir la Contaminación por los Buques, 
Esta obra forma parte del acervo de la Biblioteca Jurídica Virtual del Instituto de Investigaciones Jurídicas de la UNAM

1973, mediante la Resolución MEPC 14(20) del Comité de Protección del Medio Marino de la Organización Marítima Internacional (Londres, 7 de septiembre de 1984).

- Convenio de Viena para la Protección de la Capa de Ozono (Viena, 22 de marzo de 1985)

- Enmiendas de 1985 al Anexo del Protocolo de 1978 relativo al Convenio Internacional para Prevenir la Contaminación por los Buques, 1973 (referentes al Anexo II del Convenio Internacional para Prevenir la Contaminación por los Buques, 1973, en su forma modificada por el correspondiente protocolo de 1978) mediante la Resolución MEPC 16(22) del Comité de Protección del Medio Marino de la Organización Marítima Internacional (Londres, 5 de diciembre de 1985).

- Enmiendas de 1985 al Protocolo de 1978 relativo al Convenio Internacional para Prevenir la Contaminación por los Buques, 1973 (referentes al Protocolo I del Convenio Internacional para Prevenir la Contaminación por los Buques, 1973, en su forma modificada por el correspondiente Protocolo de 1978), mediante la Resolución MEPC 21(22) del Comité de Protección del Medio Marino de la Organización Marítima Internacional (Londres, 5 de diciembre de 1985).

- Enmienda a los artículos 6o. y 7o. de la Convención relativa a los Humedales de Importancia Internacional Especialmente como Hábitat de Aves Acuáticas (Regina, 28 de mayo de 1987).

- Protocolo de Montreal relativo a las Sustancias Agotadoras de la Capa de Ozono (Montreal, 16 de septiembre de 1987) (véanse las enmiendas).

- Enmiendas de 1987 al Anexo del Protocolo de 1978 relativo al Convenio Internacional para Prevenir la Contaminación por los Buques, 1973 (asignación del carácter de zona especial al Golfo de Aden) mediante la Resolución MEPC 29(25) del Comité de Protección del Medio Marino de la Organización Marítima Internacional (Londres, 1o. de diciembre de 1987).

- Enmienda de 1989 al Anexo del Protocolo de 1978 relativo al Convenio Internacional para Prevenir la Contaminación por los Buques, 1973 (Apéndices II y III del Anexo II del Marpol 1973/1978), mediante la Resolución MEPC 34(27) del Comité de Protección del 
Esta obra forma parte del acervo de la Biblioteca Jurídica Virtual del Instituto de Investigaciones Jurídicas de la UNAM

Medio Marino de la Organización Marítima Internacional (Londres, 17 de marzo de 89).

- Enmiendas de 1989 al Código para la Construcción y el Equipo de Buques que Transporten Productos Químicos Peligrosos a Granel (Código CIQ) mediante la Resolución MEPC 32(27) del Comité de Protección del Medio Marino de la Organización Marítima Internacional (Londres, 17 de marzo de 1989).

- Enmiendas de 1989 al Código para la Construcción y el Equipo de Buques que Transporten Productos Químicos Peligrosos a Granel (Código CGrQ), aprobadas en Londres, Gran Bretaña, el 17 de marzo de 1989, mediante Resolución MEPC 33 (27) del Comité de Protección del Medio Marino de la Organización Marítima Internacional (Londres, 17 de marzo 1989).

- Convención de Basilea sobre el Control de los Movimientos Transfronterizos de los Desechos Peligrosos y su Eliminación (Basilea, 22 de marzo de 1989).

- Enmiendas al Protocolo de Montreal relativo a las Sustancias que agotan la Capa de Ozono del 16 de septiembre de 1987 (Londres, 29, de junio de 1990).

- Enmiendas de 1990 al Anexo del Protocolo de 1978 relativo al Convenio Internacional para Prevenir la Contaminación por los Buques, 1973, mediante la Resolución MEPC 42(30) del Comité de Protección del Medio Marino de la Organización Marítima Internacional (Londres, 16 de noviembre de 1990).

- Convenio Internacional sobre Cooperación, Preparación y Lucha contra la Contaminación por Hidrocarburos (Londres, 30 de noviembre de 1990).

- Enmiendas de 1991 al Anexo del Protocolo de 1978 relativo al Convenio Internacional para Prevenir la Contaminación por los Buques, 1973 (nueva regla 26 y otras enmiendas al Anexo I del MARPOL73/78), mediante resolución MEPC 47(31) del Comité de Protección del Medio Marino de la Organización Marítima Internacional (Londres, 4 de julio de 1991).

- Enmiendas de 1992 al Anexo del Protocolo de 1978 relativo al Convenio Internacional para Prevenir la Contaminación por los Buques, 1973 (criterios relativos a las descargas del Anexo I del marpol 73/78), mediante la resolución MEPC 51(32) del Comité de Protec- 
Esta obra forma parte del acervo de la Biblioteca Jurídica Virtual del Instituto de Investigaciones Jurídicas de la UNAM

ción del Medio Marino de la Organización Marítima Internacional (Londres, 6 de marzo de 1992).

- Enmiendas de 1992 al Anexo del Protocolo de 1978 relativo al Convenio Internacional para Prevenir la Contaminación por los Buques, 1973 (nuevas reglas 13F y 13G y enmiendas conexas al Anexo I del marpol 1973/1978), mediante la resolución MEPC 52(32) del Comité de Protección del Medio Marino de la Organización Marítima Internacional (Londres, 6 de marzo de 1992).

C. Tratados (globales y regionales), fase 1992-2002

- Convención Marco de las Naciones Unidas sobre el Cambio Climático (Nueva York, 9 de mayo de 1992).

- Convenio sobre la Diversidad Biológica (Río de Janeiro, 5 de junio de 1992).

- Modificaciones al Protocolo de Montreal relativo a las Sustancias que Agotan la Capa de Ozono del 16 de septiembre de 1987 (Copenhague, 25 de septiembre de 1992).

- Protocolo de 1992 que enmienda el Convenio Internacional sobre Responsabilidad Civil nacida de Daños Debidos a Contaminación por Hidrocarburos, 1969 (Londres, 27 de noviembre de 1992).

- Protocolo de 1992 que enmienda el Convenio Internacional sobre la Constitución de un Fondo Internacional de Indemnización de Daños Debidos a Contaminación por Hidrocarburos, 1971 (Londres, 27 de noviembre de 1992).

- Acuerdo de Cooperación Ambiental de América del Norte entre el Gobierno de los Estados Unidos Mexicanos, el Gobierno de Canadá y el Gobierno de los Estados Unidos de América, 1993 (Ciudad de México- Ottawa-Washington D.C., 14 de septiembre de 1993).

- Convención de las Naciones Unidas de Lucha contra la Desertificación en los Países Afectados por Sequía Grave o Desertificación, en particular en África (París, 17 de junio de 1994).

- Protocolo de 1996 relativo al Convenio sobre la Prevención de la Contraminación del Mar por Vertimiento de Desechos y otras Materias, 1972 (Londres, 7 de noviembre de 1996).

- Convención Interamericana para la Protección y Conservación de las Tortugas Marinas (Venezuela, 1o. de diciembre de 1996). 
Esta obra forma parte del acervo de la Biblioteca Jurídica Virtual del Instituto de Investigaciones Jurídicas de la UNAM

- Enmiendas del Protocolo de Montreal relativo a las Sustancias que Agotan la Capa de Ozono, 1987 (Montreal, 15 al 17 de septiembre de 1997).

- Protocolo de Kioto a la Convención Marco de las Naciones Unidas sobre Cambio Climático (Kioto, 11 de diciembre de 1997).

- Acuerdo sobre el Programa Internacional para la Conservación de los Delfines (Washington, D.C., 21 de mayo de 1998).

- Convenio de Róterdam para la Aplicación del Procedimiento de Consentimiento Fundamentado Previo a ciertos Plaguicidas y Productos Químicos Peligrosos objeto de Comercio Internacional (Róterdam, 10 de septiembre de 1998).

- Enmienda de Beijing que modifica el Protocolo de Montreal relativo a las Sustancias que Agotan la Capa de Ozono, adoptada el 3 de diciembre de 1999 por la XI Conferencia de las Partes (Beijing, 3 de diciembre de 1999).

- Protocolo de Cartagena sobre Seguridad de la Biotecnología del Convenio sobre la Diversidad Biológica (Montreal, 29 de enero de 2000).

- Convenio de Estocolmo sobre Contaminantes Orgánicos Persistentes (Estocolmo, 22 de mayo de 2001).

- Convenio Internacional sobre el Control de los Sistemas Antiincrustantes Perjudiciales de los Buques (Londres, 5 de octubre de 2001).

Tomando en cuenta estos criterios, es posible entonces clasificar los instrumentos internacionales ambientales en cuatro fases: instrumentos anteriores al año de 1972 que, aunque contenían ya disposiciones vinculadas a nuestra materia, no pueden llamarse ambientales, pues ello sería un anacronismo (véase A. Tratados [globales y regionales] anteriores a 1972); instrumentos suscritos de 1972 a 1992, en el llamado periodo Estocolmo-Río (véase B. Tratados [globales y regionales], fase 19721992); instrumentos suscritos entre 1992 y 2002, en el periodo Río-Johannesburgo (véase C. Tratados [globales y regionales] fase 1992-2002), y finalmente, instrumentos de 2002 a la fecha (no se incluyen en este trabajo).

La importancia de incorporar en la capacitación jurídico-ambiental el segmento internacional del derecho ambiental normativo tiene como fundamento tres cuestiones muy puntuales. Primero, que la legislación ambiental mexicana, al igual que muchas legislaciones de otros países 
Esta obra forma parte del acervo de la Biblioteca Jurídica Virtual del Instituto de Investigaciones Jurídicas de la UNAM

del sur, ha evolucionado en parte debido a la influencia de la normativa internacional.

El derecho internacional ha desempeñado en las últimas décadas un papel muy importante en el desarrollo del derecho ambiental nacional de todos los países del mundo. La naturaleza internacional: global, regional y subregional de los problemas ambientales ha determinado que muchas iniciativas jurídicas se hayan canalizado hacia el derecho internacional, cuya evolución en las últimas décadas es verdaderamente sorprendente...

Esto ha determinado, a su vez, que el derecho internacional haya pasado a ser en muchos sentidos, metafóricamente hablando, la locomotora que conduce el tren del derecho ambiental. Muchas de las iniciativas que hoy se están discutiendo en el interior de los países tienen que ver con compromisos internacionales asumidos por los Estados en materia de cambio climático, protección de la capa de ozono, conservación y uso racional de la diversidad biológica, lucha contra la desertificación, movimientos transfronterizos de desechos peligrosos y su eliminación, y comercio internacional de flora y fauna silvestres amenazadas para citar algunos de los casos más conocidos, tienen que ver con las transformaciones que está impulsando el derecho internacional. En este sentido, es posible afirmar que se está construyendo un orden jurídico internacional para una sociedad mundial ambientalmente sostenible y que el derecho interno tiene un papel importante en la construcción de ese orden, pero cada vez más complementario de iniciativas que son adoptadas en escenarios internacionales. ${ }^{8}$

Así, al regular ciertos temas ambientales, México no ha escapado a la influencia proveniente del exterior. Por ejemplo, nuestro país comenzó a desarrollar una legislación amplia y ordenada - aunque no aceptada por todos los sectores involucrados - en materia de bioseguridad de los organismos genéticamente modificados sólo hasta después de que el Protocolo de Cartagena sobre la Seguridad de la Biotecnología del Convenio sobre la Diversidad Biológica entrara en vigor internacionalmente, el 11 de septiembre de 2003. Fue en 2005 que se promulgó y publicó la ley respectiva, y en 2009 se expidió su reglamento. Para conocer la esencia de nuestra legislación, es indispensable conocer sus orígenes, de dónde vie-

8 Programa de las Naciones Unidas para el Medio Ambiente, El desarrollo del derecho ambiental latinoamericano y su aplicación. Informe sobre los cambios jurídicos después de la Conferencia de las Naciones Unidas sobre el Medio Ambiente y el Desarrollo (Río 1992), México, Oficina Regional para América Latina y el Caribe, 2001, p. 20. 
Esta obra forma parte del acervo de la Biblioteca Jurídica Virtual del Instituto de Investigaciones Jurídicas de la UNAM

ne, cómo se gestó, cuál es el propósito de su existir, de manera que podamos entender el sentido de la aplicación de tal o cual disposición jurídica.

Segundo, que determinada normatividad internacional ambiental busca - $\mathrm{y}$ de hecho tiene - el efecto de armonizar la legislación nacional de los países que intervienen como partes contratantes en dicha normatividad.

... uno de los propósitos, o por lo menos el efecto, de ciertos acuerdos internacionales ambientales es armonizar las leyes nacionales, ya sea global o regionalmente. Los tratados sobre responsabilidad civil por accidentes nucleares o por daños al mar derivados de contaminación con petróleo, representan buenos ejemplos de tal armonización: la ley nacional tendrá que reproducir en buena medida las disposiciones de estos tratados y tendrá que ser básicamente la misma en cada parte contratante. En este caso el objetivo es facilitar el acceso a la justicia de los litigantes que hayan sufrido pérdidas ocasionadas por accidentes internacionales de gran escala. Al procurar armonizar el derecho normativo nacional, los tratados normativos contemplan diferentes objetivos: el impacto económico de implementar medidas de protección ambiental podría ser de tal envergadura que los propios estados estén dispuestos a participar en estos tratados siempre y cuando se les pueda garantizar que los mismos estándares reglamentarios habrán de prevalecer para las partes involucradas. ${ }^{9}$

Claro está que si ello fuera el caso para todas las materias ambientales en la legislación mexicana, poco tendríamos que preocuparnos por la parte internacional, ya que todo estaría plasmado en los instrumentos y disposiciones nacionales. Pero esto no sucede así. Dicho de otro modo, el proceso de capacitación jurídico-ambiental deberá establecer con precisión dos cosas a la vez: 1) que no toda ley nacional sobre un tema deter-

9 Birnie, Patricia et al., International Law and the Environment, 3a. ed., Oxford, Oxford University Press, 2009, p. 10. Traducción de Cesar Nava Escudero. Cita textual en Ingles: “ $\ldots$ an additional purpose, or at least effect, of some international environmental agreements is to harmonize national laws, either globally or regionally. Treaties on civil liability for nuclear accidents or oil-pollution damage at sea afford good examples of such harmonization: in effect national law will largely have to replicate the provisions of these treaties and will essentially be the same in each state party. Here the objective is to facilitate access to justice for litigants who have suffered loss in large-scale international accidents. Regulatory treaties have different objectives in mind when seeking to harmonize national law: the economic impact of implementing environmental protection measures may be such that states are willing to participate in such treaties once they can be assured that the same regulatory standards will prevail in competitor states". 
Esta obra forma parte del acervo de la Biblioteca Jurídica Virtual del Instituto de Investigaciones Jurídicas de la UNAM

minado reproduce el contenido de un tratado internacional (aunque presumiblemente tal ley no iría en contra del tratado mismo, sí podría incluir o regular cuestiones no establecidas en él), y 2) que no es de trámite el que, una vez que un tratado del que México sea parte entre en vigor a nivel internacional, necesariamente hayan de elaborarse una ley o establecerse los instrumentos jurídicos para lograr su implementación interna.

Tercero, que nuestra legislación interna hace constantes referencias a cuestiones internacionales que conviene tener en cuenta al momento de elaborar una nueva ley (o reformar o adicionar alguna disposición) vinculada a lo ambiental, aplicarla para efectos administrativos, o interpretarla desde la función jurisdiccional. Baste como ejemplo lo que al respecto señala la ley que regula las cuestiones ambientales en su conjunto en este país (la Ley General del Equilibrio Ecológico y la Protección al Ambiente, LGEEPA) al establecer los principios para la formulación de la política ambiental y la expedición de instrumentos jurídicos:

Artículo 15. Para la formulación y conducción de la política ambiental y la expedición de normas oficiales mexicanas y demás instrumentos previstos en esta Ley, en materia de preservación y restauración del equilibrio ecológico y la protección al ambiente, el Ejecutivo Federal observará los siguientes principios:

XVII. Es interés de la nación que las actividades que se lleven a cabo dentro del territorio nacional y en aquellas zonas donde ejerce su soberanía y jurisdicción, no afecten el equilibrio ecológico de otros países o de zonas de jurisdicción internacional;

XVIII. Las autoridades competentes en igualdad de circunstancias ante las demás naciones, promoverán la preservación y restauración del equilibro de los ecosistemas regionales y globales...

Otras leyes más, de las que hablaremos en el siguiente rubro, hacen referencia de igual manera a cuestiones internacionales, por ejemplo, en materia de vida silvestre o de bioenergéticos.

\section{Lo nacional o doméstico}

El contenido del segmento nacional (ordenamiento jurídico nacional) para la capacitación jurídico-ambiental comprende dos bloques de dis- 
Esta obra forma parte del acervo de la Biblioteca Jurídica Virtual del Instituto de Investigaciones Jurídicas de la UNAM

posiciones jurídicas. El primero se refiere a la Constitución Política de los Estados Unidos Mexicanos, en la que encontramos diversos preceptos que: 1) de manera expresa se refieren a los vocablos ambiente/ambiental o equilibrio ecológico; 2) sin referirse de manera expresa a tales vocablos, se encuentran íntimamente vinculados a su significado; 3) se refieren a los recursos naturales, ya sea de manera genérica o específica, y 4) se refieren a materias relacionadas con el ambiente, o que tienen evidentes repercusiones ambientales, en el equilibrio ecológico o en los recursos naturales.

El segundo bloque alude a lo que en sentido amplio se conoce como legislación ambiental y que puede categorizarse por tipos de leyes: 1) una ley conocida y comúnmente referenciada como "ley integral" o "ley en su conjunto"; 2) seis leyes sectoriales o por sector; 3) diversas leyes por materias relacionadas, y 4) ciertas leyes que se encuentran pendientes en el Congreso de la Unión o en el Ejecutivo federal, es decir, en discusión en cualquiera de los dos poderes, o bien listas ya para su promulgación y consecuente publicación en el Diario Oficial de la Federación. Desde luego, hay asimismo todo un caudal de instrumentos jurídicos que permiten la implementación de las leyes: reglamentos, acuerdos, decretos, normas oficiales mexicanas, circulares, etcétera (véase el cuadro 1). En este mismo bloque se encuentran adicionalmente todas las disposiciones ambientales locales. Aparte, aunque no se les puede considerar propiamente dentro del conjunto del ordenamiento jurídico ambiental, hay un sinfín de actos de autoridad provenientes de las autoridades ambientales como concesiones, licencias, autorizaciones, etcétera. 
Esta obra forma parte del acervo de la Biblioteca Jurídica Virtual del Instituto de Investigaciones Jurídicas de la UNAM

\section{CUADRO 1}

Tipología propia del derecho ambiental

\begin{tabular}{|c|c|c|}
\hline \multirow{2}{*}{$\begin{array}{l}\text { Ordenamiento } \\
\text { jurídico ambien- } \\
\text { tal nacional }\end{array}$} & Constitución & $\begin{array}{l}\text { - Preceptos que de manera expresa se refieren } \\
\text { a los vocablos ambiente/ambiental o equili- } \\
\text { brio ecológico } \\
\text { - Preceptos que, sin referirse de manera ex- } \\
\text { presa a tales vocablos, se encuentran íntima- } \\
\text { mente vinculados a su significado } \\
\text { - Preceptos que se refieren a materias relacio- } \\
\text { nadas con el ambiente, o que tienen eviden- } \\
\text { tes repercusiones en el equilibrio ecológico } \\
\text { o en los recursos naturales }\end{array}$ \\
\hline & $\begin{array}{l}\text { Legislación (le- } \\
\text { yes y otros ins- } \\
\text { trumentos jurídi- } \\
\text { cos) }\end{array}$ & $\begin{array}{l}\text { - Ley integral o "ley en su conjunto" } \\
\text { - Leyes sectoriales o por sector } \\
\text { - Leyes por materias relacionadas } \\
\text { - Leyes que se encuentran pendientes en el } \\
\text { Congreso de la Unión o en el Ejecutivo Fe- } \\
\text { deral } \\
\text { - Diversos reglamentos, acuerdos, decretos, } \\
\text { normas oficiales mexicanas, convenios, cir- } \\
\text { culares } \\
\text { - Disposiciones ambientales locales }\end{array}$ \\
\hline
\end{tabular}

En nuestra carta magna, los preceptos constitucionales que de manera expresa se refieren a ambiente/ambiental o a equilibrio ecológico abarcan los siguientes temas: prevención y combate a la contaminación ambiental (artículo 73, fracción XVI, base cuarta); la sujeción del uso de los recursos productivos por parte de los sectores social y privado a la idea de cuidar tanto su conservación como el ambiente (artículo 25, párrafo sexto); las medidas necesarias que se habrán de dictar para la preservación y restauración del equilibrio ecológico en materia de aprovechamiento — para beneficio social - de los recursos naturales susceptibles de apropiación (artículo 27, párrafo tercero); la distribución de competencias en materia de protección al ambiente y de preservación y restauración del equilibrio ecológico (artículo 73, fracción XXIX-G); la preservación del medio ambiente y la protección ecológica como facultades para legislar del órgano local legislativo, esto es, la Asamblea Legislativa del Distrito Federal (artículo 122, apartado $\mathrm{C}$, base primera, fracción $\mathrm{V}$, inciso j); la suscripción de convenios para la creación de comisiones metropolitanas en materia de 
Esta obra forma parte del acervo de la Biblioteca Jurídica Virtual del Instituto de Investigaciones Jurídicas de la UNAM

protección al ambiente y preservación y restauración del equilibrio ecológico (artículo 122, apartado G, párrafo primero), y el derecho de las personas a un medio ambiente adecuado para su desarrollo y bienestar (artículo 4o., párrafo cuarto).

Respecto a los preceptos constitucionales que aun sin referirse de manera expresa a los vocablos ambiente/ambiental o equilibrio ecológico, se encuentran íntimamente vinculados a ellos, destacan los siguientes temas: el derecho de las personas a la protección de la salud (artículo 4o., párrafo tercero y otros artículos relacionados); la garantía para que el desarrollo nacional - cuya rectoría corresponde al Estado - sea integral y sustentable (artículo 25, párrafo primero); la conservación y mejoramiento del hábitat de y por los pueblos y comunidades indígenas (artículo 2o., apartado A, fracción V), y la obligación de las autoridades correspondientes a apoyar las actividades productivas y el desarrollo sustentable de las comunidades indígenas (artículo 2o., apartado B, fracción VII).

En relación con los preceptos constitucionales que se refieren a los recursos naturales, con tratamiento ya sea genérico o específico, se incluyen materias como: la conservación de los recursos naturales y las medidas para evitar su destrucción (artículo 27, párrafo tercero); la explotación, uso o aprovechamiento de los recursos naturales por particulares o sociedades mediante concesiones (artículo 27, párrafo sexto); el acceso al uso y disfrute preferente de los recursos naturales por los pueblos y comunidades indígenas (artículo 2o., apartado A, fracción VI), y lo relativo a tierras, aguas continentales (superficiales y del subsuelo), aguas marinas, atmósfera, bosques, minerales, salinas, etcétera (disperso en diversos artículos constitucionales).

Por último, los preceptos constitucionales que se refieren a materias relacionadas con el ambiente o que tienen evidentes repercusiones ambientales, en el equilibrio ecológico o en los recursos naturales incluyen temas que van desde lo relacionado con monopolios y concesiones para la prestación de servicios públicos y el aprovechamiento de bienes sujetos al régimen de dominio público de la Federación, hasta cuestiones como los asentamientos humanos, la pesca y la acuacultura o las obligaciones de los mexicanos para contribuir a los gastos públicos de la Federación, el Distrito Federal, los estados y municipios de manera proporcional y equitativa.

Por lo que toca al rubro de la legislación, sólo existe una ley integral o en su conjunto en nuestro país: la Ley General del Equilibrio Ecológico y 
Esta obra forma parte del acervo de la Biblioteca Jurídica Virtual del Instituto de Investigaciones Jurídicas de la UNAM

la Protección al Ambiente (LGEEPA) de 1988. Cuenta con diversos reglamentos en diversas materias tales como áreas naturales protegidas, auditoría ambiental, evaluación del impacto ambiental, ordenamiento ecológico, prevención y control de la contaminación atmosférica, y registro de emisiones y transferencia de contaminantes. Esta ley contiene en seis títulos un gran número de temas ambientales. Mientras que los títulos primero, quinto y sexto de la ley abordan aspectos genéricos, los títulos segundo, tercero y cuarto abordan cuestiones específicas sobre cada tema o sector ambiental.

De manera genérica, el título primero contiene el fundamento constitucional de la ley: conceptos; definiciones; principios; distribución de competencias entre la Federación, los estados, los municipios y el Distrito Federal, e instrumentos de la política ambiental. El título quinto se refiere a todo lo relativo a la participación social e información ambiental (derechos de acceso), y el título sexto incluye una serie de disposiciones en materia de procedimiento, como son las concernientes a inspección y vigilancia, medidas de seguridad, sanciones administrativas (multas, clausuras, arresto administrativo, decomisos, etcétera), recursos administrativos y denuncia popular. Aunque en un principio se contemplaban en esta parte de la LGEEPA disposiciones en materia penal ambiental, a partir de la reforma que sufrió la ley en 1996, es el Código Penal Federal el que contempla ahora en su título vigésimo quinto (bajo el nombre de delitos contra el ambiente y la gestión ambiental) este tipo cuestiones.

De manera específica, el título segundo contiene diversas disposiciones relativas a la biodiversidad identificadas con los temas de: áreas naturales protegidas (tipos y características, declaratorias para su establecimiento, administración y vigilancia, integración del sistema nacional), flora y fauna silvestres y, en particular, recursos biológicos y biotecnología. El título tercero regula lo relativo al aprovechamiento sustentable de los recursos naturales, incluidos el agua y los ecosistemas acuáticos, el suelo y sus recursos, y la exploración y explotación de los recursos no renovables. Finalmente, el título cuarto de la LGEEPA se refiere a la protección al ambiente, abarcando cuestiones sobre prevención y control de la contaminación de la atmósfera, del agua y los ecosistemas acuáticos, y del suelo, así como algunas disposiciones sobre actividades altamente riesgosas, materiales y residuos peligrosos, energía nuclear, ruido, vibraciones, energía térmica y lumínica, olores y contaminación visual. 
Esta obra forma parte del acervo de la Biblioteca Jurídica Virtual del Instituto de Investigaciones Jurídicas de la UNAM

Además, la legislación ambiental también comprende seis leyes sectoriales en materia de aguas nacionales, vida silvestre, bosques, residuos, bioseguridad de los organismos genéticamente modificados y bioenergéticos (véase el cuadro 2). Estas leyes son ambientales sectoriales en tanto que, para efectos administrativos, su aplicación e interpretación corresponde a la Secretaría de Medio Ambiente y Recursos Naturales (Semarnat): sea a través de sus unidades administrativas o de sus organismos públicos descentralizados y órganos desconcentrados, según corresponda. Cabe señalar que en el caso de las últimas dos materias también intervienen para estos efectos otras secretarías de Estado. Cada ley sectorial tiene su propio reglamento.

Junto a las leyes sectoriales existe un gran número de leyes por materias relacionadas cuya aplicación e interpretación corresponde a secretarías distintas de la Semarnat, pero que tienen cierta relación con la actividad de las autoridades ambientales. Se trata de instrumentos jurídicos que complementan el quehacer de la Semarnat, la cual encuentra en las reuniones intersecretariales o en los convenios de coordinación las herramientas necesarias para apoyarse en tales instrumentos y cumplir con lo que la ley en su conjunto y las leyes sectoriales determinan. Las leyes y otros instrumentos jurídicos que conforman la legislación ambiental de México por materias relacionadas son numerosos y muy diversos, por lo que en el cuadro 2 se presentan sólo de manera enunciativa más no exhaustiva, algunos de los más importantes. 
Esta obra forma parte del acervo de la Biblioteca Jurídica Virtual del Instituto de Investigaciones Jurídicas de la UNAM

CUADRO 2

Tipología propia de la legislación ambiental (leyes)

\begin{tabular}{|c|c|}
\hline & Leyes \\
\hline & $\begin{array}{l}\text { - Ley General del Equilibrio Ecológico y la Protección al Am- } \\
\text { biente, } 1988\end{array}$ \\
\hline Por sector & $\begin{array}{l}\text { - Ley de Aguas Nacionales, } 1992 \\
\text { - Ley General de Vida Silvestre, } 2000 \\
\text { - Ley General de Desarrollo Forestal Sustentable, } 2003 \\
\text { - Ley General para la Prevención y Gestión Integral de los Re- } \\
\text { siduos, } 2003 \\
\text { - Ley de Bioseguridad de los Organismos Genéticamente Mo- } \\
\text { dificados, } 2005 \\
\text { - Ley de Promoción y Desarrollo de los Bioenergéticos, } 2008\end{array}$ \\
\hline $\begin{array}{l}\text { Por materias } \\
\text { relacionadas }\end{array}$ & $\begin{array}{l}\text { - Ley de Expropiación, } 1932 \\
\text { - Ley Federal sobre Monumentos y Zonas Arqueológicas, Ar- } \\
\text { tísticos e Históricos, } 1972 \\
\text { - Ley Orgánica de la Administración Pública Federal, } 1976 \\
\text { - Ley de Planeación, } 1983 \\
\text { - Ley General de Salud, } 1984 \\
\text { - Ley Federal del Mar, } 1986 \\
\text { - Ley Agraria, } 1992 \\
\text { - Ley sobre la Celebración de Tratados, } 1992 \\
\text { - Ley General de Asentamientos Humanos, } 1993 \\
\text { - Ley de Desarrollo Rural Sustentable, 2001 } \\
\text { - Ley para el Aprovechamiento Sustentable, } 2001 \\
\text { - Ley de Bienes Nacionales, 2004 } \\
\text { - Ley de Vivienda, 2006 } \\
\text { - Ley General de Pesca y Acuacultura Sustentables, } 2007 \\
\text { - Ley para el Aprovechamiento Sustentable de la Energía, } 2008 \\
\text { - Ley para el Aprovechamiento de las Energías Renovables y el } \\
\text { Financiamiento para la Transición Energética, } 2008 \\
\text { - Ley General de Turismo, } 2009 \\
\text { - Legislación tributaria } \\
\text { - Legislación procedimental } \\
\text { - Legislación procesal } \\
\text { - Código Civil Federal } \\
\text { - Código Penal Federal }\end{array}$ \\
\hline
\end{tabular}


Esta obra forma parte del acervo de la Biblioteca Jurídica Virtual del Instituto de Investigaciones Jurídicas de la UNAM

Por último, además de toda la normatividad local, existen algunos proyectos de ley que todavía están pendientes de discutirse o de aprobarse en los poderes legislativo o ejecutivo, como ocurre con los relativos a acceso a recursos biológicos y genéticos, responsabilidad civil por daño ambiental, zonas costeras, calidad del aire y protección atmosférica, entre otros.

\section{CAPACITADO Y CAPACITADOR, ¿POR DÓNDE EMPEZAR?}

Es importante dedicar unas cuantas líneas de reflexión al asunto de los sujetos que participan en la capacitación: los que la reciben y los que la imparten.

\section{El sujeto a capacitar}

Al principio de este artículo identificamos tres sujetos distintos a quienes la capacitación jurídico-ambiental va dirigida: legisladores, burócratas o funcionarios públicos, y jueces y magistrados.

Sobre el primer grupo, los legisladores, advertimos que la capacitación tiene importancia debido a que son ellos los responsables de elaborar la legislación correspondiente. Entre los aspectos a reflexionar en torno a nuestros legisladores se encuentran los siguientes:

- No todos los diputados y senadores aceptarían fácilmente algún tipo de capacitación, entrenamiento o adiestramiento en materia jurídico-ambiental puesto que alegarían que para eso existen comisiones específicamente establecidas para ciertos temas.

- Independientemente de lo anterior, muchos diputados y senadores dedican pocas o nulas horas de su tiempo a entrenarse legislativamente, lo que significa adquirir cierta capacitación no sólo en técnica legislativa sino en el entendimiento de ciertos temas de la agenda política nacional, como algunos temas ambientales de gran impacto mediático, político o electoral para las carreras de los propios legisladores, por ejemplo, el cambio climático a nivel global o la persistente amenaza y extinción de especies a escala nacional.

- Es bien sabido por todos en este país que, en vez de elaborar leyes o perfeccionar las ya existentes (en numerosas ocasiones son los asesores u otros sectores sociales, gubernamentales o privados los que 
Esta obra forma parte del acervo de la Biblioteca Jurídica Virtual del Instituto de Investigaciones Jurídicas de la UNAM

realmente redactan las iniciativas), diputados y senadores se dedican a hacer lo que en México se suele conocer rústicamente como "grilla". La "grilla" o "el hacer política" al interior y exterior de las cámaras (algunos le llaman a veces equivocadamente lobbying) no siempre se traduce en resultados legislativos.

- Se ha puesto en tela de juicio el hecho de que los diputados duran tan sólo tres años en funciones (los senadores duran seis años) y, por lo tanto, cualquier capacitación "se antoja" poco duradera. Pero este argumento es una cortina de humo por dos razones: es un hecho incontrovertible que muchos diputados al término de su periodo se mueven a la cámara de senadores o a otro órgano legislativo local, y en ocasiones repiten como diputados (con los senadores ocurre algo semejante). Además, cada vez tiene mayor aceptación en ciertos círculos políticos y sociales la propuesta de llevar a cabo reformas legales para que se permita la reelección. En este sentido, la capacitación no es un desperdicio ni de tiempo ni de dinero.

Respecto al segundo de los sujetos identificados, es decir, los burócratas, la importancia de la capacitación jurídico-ambiental radica en que son ellos quienes implementan la ley, en ocasiones la interpretan, y también elaboran instrumentos jurídicos sobre temas previstos en las leyes, como es el caso de los reglamentos. Entre las reflexiones en torno a la capacitación de los burócratas figuran:

- Es común -y lo afirmo por experiencia propia como exfuncionario público federal de la secretaría ambiental respectiva y como capacitador externo hacia funcionarios de esa secretaría- que los burócratas que acuden a los centros de capacitación y adiestramiento no son quienes ostentan lo cargos más altos (directores generales, subsecretarios, procuradores, subprocuradores, titulares de unidades coordinadoras, y mucho menos el propio secretario en turno) sino sólo los que conforman lo que graciosamente se ha dado por llamar la "tropa burocrática". Entonces ¿qué sentido tiene capacitar a los servidores públicos menores, que aunque son los que "rayan el lápiz" para elaborar los documentos y darles forma y vida a las opiniones jurídicas, los actos de autoridad, las contestaciones a demandas u otros, no son quienes toman las decisiones y más bien siguen órdenes de los servidores públicos mayores, es decir, sus jefes? 
Esta obra forma parte del acervo de la Biblioteca Jurídica Virtual del Instituto de Investigaciones Jurídicas de la UNAM

- Con lo dicho anteriormente no queremos menoscabar la importancia de la función de la tropa burocrática. La capacitación desde luego abona en su desarrollo profesional (a nivel personal) y quizá sirva para mejorar su quehacer funcional. Sin embargo, es de cuestionarse que, de no ascender a puestos mayores, o de salirse de la dependencia en que trabajan para buscar mejores opciones de ingreso en algún otro lugar, la inversión en tal capacitación no rendirá los frutos deseados por estar sujeta a vaivenes característicos de una decisión económica o política (en ocasiones ajena al propio servidor público, con todo y el servicio civil de carrera).

- Resulta también, que debido a la movilidad gubernamental del personal de alta jerarquía burocrática (por cierto, en ocasiones deseable), a menudo los funcionarios públicos entrantes no tienen idea de los temas ambientales. Sabemos quienes nos dedicamos a cuestiones ambientales que últimamente la gran mayoría de los puestos de mayor nivel han sido ocupados por funcionarios del sector privado o político que nada tienen que ver con la cuestión ambiental y que están, por tanto, alejados de cualquier noción de lo que significa "lo público-ambiental" (me refiero al fenómeno de "empresarialización" de la burocracia). Repitamos lo que ya conocemos: muchos de ellos están ahí por razones políticas, favores políticos o el prevaleciente amiguismo de nuestros gobiernos federales. ¡A este tipo de funcionarios no les vendría nada mal una capacitación!

- Las unidades administrativas jurídicas a lo largo y ancho de la secretaría ambiental federal han experimentado constantemente la llegada de abogados carentes de la más pequeña noción de lo que es el derecho ambiental. Ellos necesitan, en definitiva, una capacitación, pero difícilmente (por no decir nunca) la aceptan.

- La capacitación jurídico-ambiental debería abarcar - como en ocasiones lo hace - no sólo a los abogados de la secretaría ambiental respectiva, sino a también a quienes cuentan con profesiones distintas a la jurídica, como biólogos o economistas. Toda capacitación ambiental (sea jurídica o no) tendrá éxito sólo si es interdisciplinaria.

Finalmente, la importancia del tercero de los sujetos identificados jueces, magistrados y ministros - radica en el simple pero fundamental hecho de que son ellos quienes, ante una controversia presentada ante un órgano jurisdiccional, interpretan y deciden lo que tal o cual disposición 
Esta obra forma parte del acervo de la Biblioteca Jurídica Virtual del Instituto de Investigaciones Jurídicas de la UNAM

jurídica realmente dice (es decir, juzgan su correcta aplicación). Algunas reflexiones al respecto:

- No resulta fácil convencer a jueces y magistrados - menos a los ministros de la Corte - sobre la necesidad y conveniencia de capacitarse en lo jurídico ambiental; más bien, son sus secretarios (particulares o de estudio y cuenta) quienes, a veces de manera gustosa y comprometida, pero otras de manera un tanto obligada, acudirían a los cursos de capacitación.

- Jueces, magistrados y ministros corren el riesgo de ser demasiado "legalistas" en la interpretación de la legislación al no contar con una visión amplia e integral — con conciencia de la mutua reciprocidad entre seres humanos y ambiente- sobre lo que significa la crisis ambiental y los posibles alcances (no jurídicos, sino ambientales) de tomar tal o cual decisión. Cuántas veces no hemos detectado en foros ambientales - como sucedió en los organizados por la CCA - que los participantes del poder judicial, ante su falta de conocimiento jurídico-ambiental, confunden o tergiversan conceptos esenciales del derecho ambiental que han sido ampliamente discutidos y concertados en reuniones internacionales o en el medio académico.

- Salvo excepciones contadísimas, ni jueces ni magistrados (ya no se diga ministros) han tenido a bien inscribirse en alguna universidad para tomar algún diplomado en derecho ambiental (qué decir de un curso de capacitación).

- Todo lo anterior ha provocado, desde mi punto de vista, que las pocas decisiones provenientes de nuestros tribunales revistan un limitado o nulo carácter ambiental. Muchas de ellas se basan en argumentaciones o razonamientos propios de las áreas procedimentales o procesales, pero finalmente la esencia misma de la resolución está muy alejada de las circunstancias que en los foros internacionales y académicos se discuten.

\section{El sujeto que capacita}

El éxito de la capacitación jurídico-ambiental (como me imagino habrá de ocurrir en todo proceso de capacitación) depende muchísimo del sujeto encargado de impartir la capacitación. Es válido preguntarse: 
Esta obra forma parte del acervo de la Biblioteca Jurídica Virtual del Instituto de Investigaciones Jurídicas de la UNAM

¿puede un mismo sujeto capacitar a los tres sujetos a capacitar identificados (legisladores, burócratas, jueces y magistrados)? O por el contrario, ¿requerimos de un capacitador para cada uno de los tres tipos de sujetos que serán capacitados? Y más aún, tomando en cuenta que el derecho ambiental como conjunto de normas jurídicas, según la tipología presentada en el apartado anterior, tiene por objeto regular una amplísima gama de cuestiones, desde lo relacionado con la atmósfera y los residuos hasta lo que atañe al agua y los bosques, ¿necesitamos de un abogado ambientalista "sabelotodo"? Reflexionemos en lo siguiente:

1. En principio, parecería lógico suponer que el capacitador idóneo debería ser un abogado, pero sostener tal situación tendría como consecuencia natural negar el carácter eminentemente interdisciplinario del derecho ambiental. ¿Hay biólogos que sean abogados? y ¿abogados que sean biólogos? En este sentido habría que pensar en dos modelos distintos: uno que permitiera la concurrencia de capacitadores con antecedentes profesionales diversos (ecólogos, biólogos, químicos, abogados) o bien, uno que permitiera la participación de abogados ambientalistas especializados: en atmósfera, en residuos, en aguas, etc., con conocimientos sobre los aspectos técnicos no jurídicos relacionados con su área de especialización.

2. Por lo anterior, resulta muy delicada la designación de los capacitadores en el curso respectivo. Como no soy partidario de creer que existen los "sabelotodo" en el derecho ambiental, jes necesario revisar cuidadosamente el curriculum vitae del capacitador antes de contratarlo! Pensemos tan sólo, por ejemplo, en la materia atmosférica. El abogado encargado de dar la capacitación jurídica tendría no sólo que conocer la legislación nacional al respecto, sino también comprender cuestiones no jurídicas como el significado de los contaminantes primarios y secundarios; la formación y dispersión (al igual que su nomenclatura química) de óxidos de nitrógeno, ozono, bióxido de azufre, compuestos orgánicos volátiles, etcétera los distintos tipos de enfermedades respiratorias, o bien las redes de monitoreo atmosférico, ya sean manuales o automáticas. Además, el abogado capacitador tendría que conocer sobre temas afines a la contaminación atmosférica urbana, incluidas las preocupaciones globales respecto al cambio climático y la capa de ozono, y manejar conocimientos sobre instrumentos jurídicos internacionales de derecho duro y de derecho suave en estos temas, a la vez que poder explicar lo que es un mercado de carbono, lo que es un glaciar, o lo que son los clorofluorocarbonos (CFC), etcétera. 
Esta obra forma parte del acervo de la Biblioteca Jurídica Virtual del Instituto de Investigaciones Jurídicas de la UNAM

3. Si logramos establecer claramente el perfil por materia de especialidad del sujeto que capacita, y — en la misma línea del ejemplo anteriortomando en cuenta que no habríamos de requerir algún especialista en ciencias de la atmósfera sino a un abogado atmosférico, nos enfrentamos a otro problema. ¿Qué queremos: un teórico o un práctico? Podríamos pensar en escenarios tales como optar por un académico (que maneje teoría y que tenga práctica de campo) o un abogado litigante, juez o magistrado, o incluso un servidor público con experiencia en la materia. En cualquiera de los casos se tienen ventajas y desventajas. Por un lado, es posible que el académico oriente su capacitación al conocimiento de materiales y fórmulas para mejor entender-investigar la problemática ambiental específica, imprimiendo un toque ético-filosófico y científico a su exposición, pero quizá sin contar con experiencia práctica. Por el otro, es posible que el litigante/juez/magistrado/servidor público ignore conceptos, definiciones, principios, teorías, etcétera, pero a cambio privilegie en su capacitación el análisis-respuesta de casos concretos. Asimismo, podría advertirse que quizás el académico, el litigante y el juez/magistrado sean más críticos y analíticos que el servidor público. De cualquier modo, la libertad de pensamiento y de cátedra siempre será un bonus en la capacitación.

4. Suponiendo resuelto el dilema anterior, ahora la duda es la siguiente: ya sea académico o litigante/juez/magistrado/servidor público, ¿conviene que el capacitador tenga carrera como docente? Esta pregunta se liga al hecho de que una capacitación que funcione debe tener como resultado que los sujetos capacitados aprendan, y para ello se requiere un capacitador que enseñe o que logre transmitir los conocimientos respectivos. En principio, podríamos pensar que un docente (de nivel licenciatura o, qué mejor, de nivel posgrado) tendría la experiencia y la carrera profesional adecuadas para ello, aunque esto no siempre será una garantía. De cualquier manera, podría apostarse al hecho de que un profesor con ciertos años de experiencia probablemente obtenga mejores resultados para capacitar que alguien que no suele dictar conferencias, no trata con alumnos, o no se expresa en público. Esto que podría parecer trivial, es esencial para la transmisión de conocimientos. ¡La buena capacitación no puede basarse tan sólo en una charla amena de un caso concreto o en la exhibición de un montón de diapositivas en power point!

5. Por último, el capacitador habría de elaborar una especie de evaluación a los sujetos capacitados. No hacerlo no ayuda ni al sujeto que se capacita ni al capacitador. 
Esta obra forma parte del acervo de la Biblioteca Jurídica Virtual del Instituto de Investigaciones Jurídicas de la UNAM

\section{CuATro BREVES CONCLUSIONES}

1. La capacitación jurídico-ambiental es indispensable en este país y requiere como condición sine qua non el determinar una tipología del derecho ambiental normativo. ${ }^{10}$ Tal capacitación abarca a los sujetos que elaboran los instrumentos jurídicos (legisladores y burócratas), a quienes los implementan (burócratas), y a los que los interpretan administrativa o jurisdiccionalmente (burócratas y jueces, magistrados y ministros).

2. Está claro que existen suficientes resistencias políticas, sociales, laborales y de vanidad o petulancia que impiden que los sujetos identificados lleguen realmente a capacitarse. Dentro del conjunto de los sujetos a capacitar se distinguen, por un lado, los que casi nunca aceptan la capacitación (en general, diputados y senadores, altos funcionarios y la mayoría de los jueces y magistrados), y por el otro, los que acaban siendo capacitados "voluntariamente" (en general, la tropa burocrática, los asesores de legisladores y los secretarios abogados, o de estudio y cuenta en los órganos jurisdiccionales).

3. El sujeto que capacita debe tener una carrera profesional probada en el ámbito del derecho ambiental. No todos los capacitadores han de ser abogados, sino que pueden provenir de disciplinas distintas, como biólogos o ecólogos. Una combinación entre el abogado teórico y el práctico (sea académico, juez o servidor público, aunque preferentemente docente) conforma un escenario aceptable. Los tres eventos organizados por la CCA incluyeron ponentes de diversos sectores y antecedentes profesionales y constituyen un buen ejemplo de esto.

4. La institucionalización de la capacitación jurídico-ambiental no tiene un ideal de sujetos capacitados (lo que podría significar la inclusión de todos los sujetos en cuestión) ni tampoco un ideal de sujeto capacitador (ello tendría que suponer un irreal y ficticio abogado sabelotodo). Sin embargo, no queda duda de que, en esta institucionalización, el mensaje de la capacitación jurídico-ambiental como oportunidad para quien elabora la ley, la implementa y la interpreta jurisdiccionalmente, deberá ser siempre el mismo: actus iustitiae est reddere debitum (el acto de justicia consiste en dar lo debido).

${ }^{10}$ Hemos propuesto aquí una tipología propia. 
Esta obra forma parte del acervo de la Biblioteca Jurídica Virtual del Instituto de Investigaciones Jurídicas de la UNAM

\title{
LA PRIVATIZACIÓN DE LAS ZONAS COSTERAS EN MÉXICO*
}

\author{
I. NOTA INTRODUCTORIA: \\ ¿SE PRIVATIZAN NUESTRAS ZONAS COSTERAS?
}

Inicio este trabajo con una cita. Se lee en la página 26 del Derecho administrativo mexicano del maestro Alfonso Nava Negrete lo siguiente:

Privatización de la administración es, en la hora actual, pasar la propiedad de las empresas públicas a los particulares o empresarios privados; es también abandonar actividades o servicios atendidos por organismos públicos para que sean los particulares los que carguen con ellos. Traspasar el poder público, propiedades y servicios a los dominios del poder privado. El cambio lo crea y registra el derecho, y el otrora fenómeno de publicización que transformó campos del derecho privado en esferas del derecho público, ahora se sustituye por el de privatización; vuelven a su antiguo régimen de derecho privado las actividades y servicios que el Estado adquirió, retuvo o monopolizó. ${ }^{1}$

Si bien se desprende de esta idea la existencia de diversas formas de privatización, para los fines de este trabajo nos enfocamos en dos en particular que son ya clásicas para el entendimiento de este concepto. ${ }^{2}$ Se trata,

* Publicado en López Olvera, Miguel Alejandro (coord.), Estudios en homenaje a don Alfonso Nava Negrete. En sus 45 años de docencia, México, UNAM, Instituto de Investigaciones Jurídicas, 2006.

1 Nava Negrete, Alfonso, Derecho administrativo mexicano, 2a. ed., México, Fondo de Cultura Económica, 2001, p. 26.

2 El significado del término privatización es en verdad amplio y puede manifestarse de diversas formas que no sólo se refieren a la venta de bienes del sector público. En este sentido véase, por ejemplo, Nava Escudero, César, Privatisation in the UK and Latin America: a Political Decisión. British Telecom (BT): a Case-Study, Exeter, 1993, p. 8, tesis presentada para optar por el grado de maestro en administración pública por la Universidad de Exeter. John R. Greenwood y David J. Wilson citan un artículo de Young, S. 
Esta obra forma parte del acervo de la Biblioteca Jurídica Virtual del Instituto de Investigaciones Jurídicas de la UNAM

en primer lugar, de actividades que realizan los particulares sobre bienes públicos en lugar de que las realice el Estado, y en segundo término, de bienes que siendo propiedad de la nación pasan a propiedad privada. Estas dos formas típicas de hacer privado aquello que es público sirven como marco de referencia para evaluar el proceso de privatización en el que se encuentran inmersas las zonas costeras en México.

Es entonces el propósito de este artículo, con el que pretendemos rendir un justo homenaje al maestro Alfonso Nava Negrete, examinar $i$ ) de qué manera el Estado mexicano está abandonando su actuar público en las zonas costeras, y ii) cómo traspasa la propiedad de las mismas (o una porción de ellas) a favor de los particulares. Por aquélla entendemos el abandono de una actividad pública por el otorgamiento de concesiones a particulares para el uso y aprovechamiento (o explotación) de bienes que son propiedad del Estado, y por ésta el traspaso a manos privadas de esos mismos bienes a través de un acto de desincorporación y su posterior enajenación. En ambos casos, estos bienes públicos conforman lo que doctrinalmente identificamos como zonas costeras que en su acepción jurídica más simple comprenden las playas marítimas, la zona federal marítimo terrestre y los terrenos ganados al mar. ${ }^{3}$

La razón de abordar el tema de las zonas costeras - por cierto, escasamente explorado en la literatura jurídica mexicana - se debe a la falta de atención e inclusión en las agendas políticas del Ejecutivo Federal y del Poder Legislativo para su adecuada regulación. Mucho se discute sobre las ventajas y desventajas de privatizar o no temas relacionados con la energía eléctrica o el petróleo, pero casi nada se dice de aquellos bienes públicos, como las zonas costeras del país, sobre los que se ha iniciado e incluso consolidado ya un proceso privatizador.

(1986) quien identifica al menos siete tipos diferentes de privatización: $i$ ) venta de bienes del sector público; ii) apertura de monopolios públicos para permitir la competencia; iii) contratación de servicios públicos; iv) concesión de servicios públicos; $v$ ) inversión privada en proyectos públicos; $v i$ ) inclusión de prácticas privadas en el sector público, y vii) reducción de subsidios e incremento de precios de servicios del sector público para que los consumidores paguen una mayor proporción de su costo real; véase Greenwood, John R. y Wilson, David J., Public Administration in Britain Today, 2a. ed., Londres, Unwin Hyman, 1989, p. 246.

3 Como se verá más adelante, a estos tres conceptos se unen otros dos que se encuentran escasamente regulados en nuestra legislación pero que forman parte integral de un concepto más amplio de zona costera: los ambientes costeros y las formaciones rocosas y acantilados. 
Esta obra forma parte del acervo de la Biblioteca Jurídica Virtual del Instituto de Investigaciones Jurídicas de la UNAM

\section{NOTA CONCEPTUAL PRIMERA: DELIMITACIÓN Y TERMINOLOGÍA}

Lo costero o costera es lo perteneciente o relativo a la costa. En una de sus acepciones, la palabra costa proviene del gallego o del catalán y se constituye a partir de dos características fundamentales: la orilla del mar y la porción de tierra cercana a ella. ${ }^{4}$ Si por zona entendemos superficie, extensión, o mejor aún espacio, entonces la expresión "zona costera" se refiere de manera conjunta a un espacio de tierra (lo terrestre), a un espacio de mar (lo marino) y a la constante interacción que existe entre ellos. A esta definición se agregan, aunque por tradición no se haya hecho, tanto el espacio situado por encima de las porciones terrestre y marina (es decir, el aire, aquello que forma la atmósfera), como el espacio situado por debajo de éstas.

Existen otras expresiones que se utilizan indistintamente para referirse a ese espacio terrestre-marino (o sólo al terrestre o al marino) y su interacción. Hay así combinaciones terminológicas entre diversos vocablos. Las más comunes (sin que sea una lista exhaustiva) son: costa marina, costas marítimas, costa del mar, costa terrestre, costa marítimo-terrestre, franja costera, orla costera, borde costero, medio costero, medio ambiente costero, litoral costero, perfil costero, ecosistema costero, ordenación costera, ordenación de las zonas costeras, ordenamiento territorial costero, ordenamiento (ecológico) costero, etcétera.

Si bien la expresión zona costera apunta hacia una idea de interacción espacial tierra-mar y mar-tierra, es común que se le diferencie de la llamada "zona marina". La palabra marino o marina es lo perteneciente al mar, y la noción mar proviene del latín mare que en una de sus acepciones significa masa de agua salada que cubre la mayor parte de la superficie de la Tierra. ${ }^{5}$ Mientras que la zona marina pudiera referirse estrictamente sólo a la porción marina (y a la porción terrestre por debajo de ella), la zona costera lo haría a una porción terrestre y a una porción marina y sus interacciones (incluyendo los espacios situados por encima y por debajo de ambas porciones y sus interacciones). Esta distinción no es siempre así aceptada y en ocasiones se presentan significados más amplios o más

4 De esto da cuenta la Real Academia de la Lengua Española en su diccionario de la lengua al definirla - entre muchos otros significados - como orilla del mar, de los ríos, lagos, etcétera, y tierra que está cerca de ella; véase Real Academia de la Lengua Española, Diccionario de la Lengua Española, 21a. ed., Madrid, 1992.

\section{Idem.}


Esta obra forma parte del acervo de la Biblioteca Jurídica Virtual del Instituto de Investigaciones Jurídicas de la UNAM

reducidos en los que incluso uno de estos vocablos es el género del otro. Esto es posible detectarlo, por ejemplo, en diferentes foros internacionales, como sucedió en la Conferencia de las Naciones Unidas sobre el Medio Ambiente y Desarrollo celebrada en Río de Janeiro, Brasil, en 1992, en donde el capítulo 17 de la denominada Agenda 21 - documento emanado de dicha conferencia- establece que por "medio marino" se entiende los océanos, los mares y las zonas costeras adyacentes. El citado texto hace una distinción expresa, por un lado de las zonas marinas y por el otro de las zonas costeras, enfatizando la necesidad de contar con un enfoque integral para su entendimiento y regulación. ${ }^{6}$

La separación terminológica de ambas zonas también encontró eco en la reciente Conferencia Global sobre los Océanos y las Costas, celebrada en la sede de la Organización de las Naciones Unidas para la Educación, la Ciencia y la Cultura, en París, en 2001 (en torno a la cumbre mundial sobre desarrollo sostenible, Río +10 , celebrada en Johannesburgo, Sudáfrica, en 2002), en la que se señaló que el desarrollo sostenible y la reducción de la pobreza no podrían ser alcanzados sin océanos y costas saludables. ${ }^{7}$ En clara alusión a la protección ambiental, en esta conferencia se hizo referencia a cada una de ellas - áreas costeras y marinasaunque, desde luego, bajo un enfoque ecosistémico.

Conforme a la definición y delimitación conceptual que hasta ahora se ha hecho de la zona costera, podemos identificar las siguientes variables para el caso mexicano:

a) La expresión zonas costeras y los vocablos costa o costero, aparecen de manera esporádica y aislada en nuestra legislación.

b) No obstante su breve mención en diferentes leyes, no existe una definición que permita identificar sus componentes espaciales.

c) El espacio terrestre de la zona costera no sólo se refiere a "tierra firme" sino a "porciones acuáticas" que no son, sin embargo, conside-

6 Organización de las Naciones Unidas, "17. Protección de los océanos y de los mares de todo tipo, incluidos los mares cerrados y semicerrados, y de las zonas costeras, y protección, utilización racional y desarrollo de sus recursos vivos", Programa 21, capítulo 17, División para el Desarrollo Sostenible, 23 de enero de 2003, http://www. un.org./esa/sustdev/documents/agenda21spchapter17.htm.

7 Organización de las Naciones Unidas para la Educación, la Ciencia y la Cultura, "Proclama UNESCO urgente necesidad de proteger áreas oceánicas y costeras", Noticias, 2001, http://www.unesco.org.-cu/Noticias/noticia121201.htm. 
Esta obra forma parte del acervo de la Biblioteca Jurídica Virtual del Instituto de Investigaciones Jurídicas de la UNAM

radas jurídicamente como espacios marinos. ${ }^{8}$ Este espacio terrestre se identifica con cinco conceptos: playas marítimas, zona federal marítimo terrestre, terrenos ganados al mar, ambientes costeros y formaciones rocosas y acantilados.

d) El espacio marino de la zona costera se identifica con la expresión zonas marinas, las cuales se conforman por: mar territorial, aguas marinas interiores, zona contigua, zona económica exclusiva, plataforma continental e insular y cualquiera otra permitida por el derecho internacional.

De estas variables se desprende que en México, desde un punto de vista estrictamente jurídico, se distingue una zona marina de una zona costera. En la primera, se regula la parte relativa al mar que comprende seis partes o espacios marinos; en la segunda se regula la parte relativa a la tierra y a porciones acuáticas no marinas adyacentes al mar que comprenden cinco partes o espacios terrestres. Así, es jurídicamente correcto asociar en la actualidad el concepto de zona costera a un espacio terrestre que comprende tanto una porción de tierra firme como una porción acuática no marina, ambas cercanas al mar.

\section{NOTA CONCEPTUAL SEGUNDA: CONCEPTOS JURÍDICOS COSTEROS}

Según lo señalado en el apartado anterior, desde un punto de vista jurídico las zonas costeras en México comprenden cinco conceptos: $i$ ) playas marítimas; $i$ i) zona federal marítimo terrestre; iii) terrenos ganados al mar; $i v$ ) ambientes costeros, y $v$ ) formaciones rocosas y acantilados. Los tres primeros se encuentran regulados fundamentalmente en la Ley General de Bienes Nacionales $(\mathrm{LGBN})^{9}$ y su reglamento denominado Reglamento para el Uso y Aprovechamiento del Mar Territorial, Vías Navegables, Playas, Zona Federal Marítimo Terrestre y Terrenos Ganados al Mar (Ruazofemat); ${ }^{10}$ el cuarto lo está como una categoría conceptual

8 Estos espacios acuáticos no marinos incluyen, por ejemplo, desde porciones de tierra firme con humedad constante (como los pantanos) hasta porciones de transición entre aguas continentales y marinas (como los humedales), aguas salobres o planicies con inundaciones temporales de aguas marinas (como las marismas).

9 Publicada en el Diario Oficial de la Federación el 20 de mayo de 2004.

10 Publicado en el Diario Oficial de la Federación el 21 de agosto de 1991. 
Esta obra forma parte del acervo de la Biblioteca Jurídica Virtual del Instituto de Investigaciones Jurídicas de la UNAM

de reciente creación en el reglamento interior ${ }^{11}$ de la Secretaría de Medio Ambiente y Recursos Naturales y se relaciona con otras disposiciones de la LGBN y su reglamento, y el último se encuentra regulado en el propio reglamento de la LGBN. ${ }^{12}$

\section{Playas maritimas}

Define la fracción IV del artículo 7o. de la LGBN a las playas marítimas de la siguiente manera (véase figura 1):

Artículo 7. Son bienes de uso común:

IV. Las playas marítimas, entendiéndose por tales las partes de tierra que por virtud de la marea cubre y descubre el agua, desde los límites de mayor reflujo hasta los límites de mayor flujo anuales;

Las playas marítimas son bienes de uso común y por lo tanto se consideran bienes nacionales. Los bienes de uso común están sujetos al régimen de dominio público de la Federación y por lo tanto son inalienables, imprescriptibles e inembargables. Aunque la LGBN establezca la posibilidad de que ciertos bienes - o inmuebles federales, como también los llama - sujetos al régimen de dominio público de la Federación puedan desincorporarse de dicho régimen y se autorice su enajenación (según se determine) a particulares, no es el caso de las playas marítimas. Lo anterior, en virtud de que sólo podrán ser objeto de actos de administración y disposición (enajenaciones, ventas, donaciones, etcétera) los bienes que no sean útiles para destinarlos al servicio público o que no sean de uso común (según lo señala el artículo 84, párrafo primero, de la LGBN), supuesto jurídico, este último, que le es propio a las playas marítimas. Esto se traduce en que en México no existen playas (marítimas) privadas desde un punto de vista estrictamente jurídico.

11 Publicado en el Diario Oficial de la Federación el 21 de enero de 2003.

12 Es importante señalar que tanto los conceptos de ambientes costeros como el de formaciones rocosas y acantilados se encuentran escasamente regulados y se mencionan en reglamentos y no en leyes, lo que se traduce en que sean inconstitucionales (véase más adelante); sin embargo, los mencionamos como dos categorías conceptuales por su trascendencia para la regulación de las zonas costeras. 
Esta obra forma parte del acervo de la Biblioteca Jurídica Virtual del Instituto de Investigaciones Jurídicas de la UNAM

\section{FIGURA 1}

Delimitación de las playas marítimas
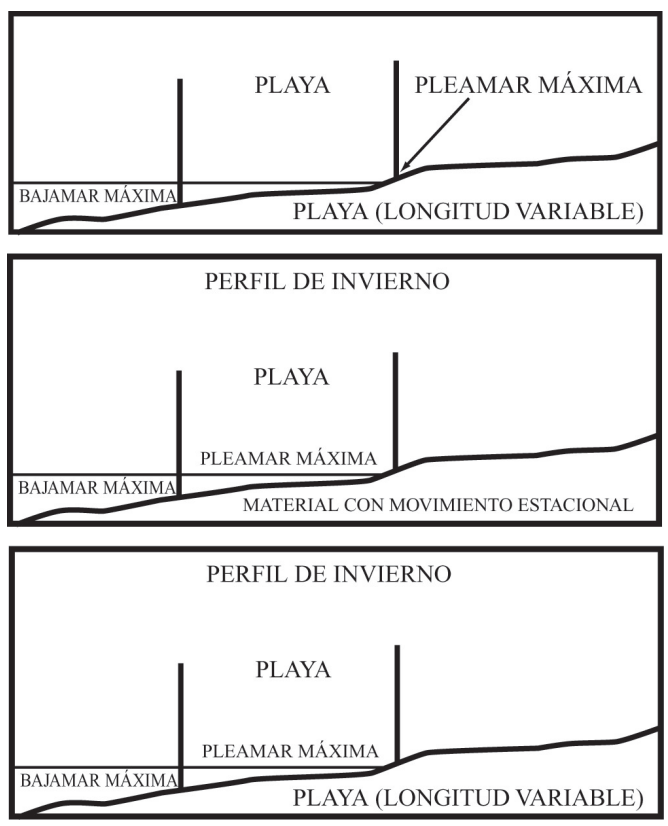

Fuente: Dirección General de Zona Federal Marítimo Terrestre y Ambientes Costeros, $2005 .{ }^{13}$

Aunque se discute si las playas marítimas son susceptibles de ser materia de concesión en virtud de que el párrafo segundo del artículo $8 \mathrm{o}$. de la LGBN considera que los bienes de uso común son concesionables para aprovechamientos especiales, ni la propia LGBN ni su reglamento contemplan expresamente la posibilidad de que estos espacios puedan concesionarse, como sí lo hace para la zona federal marítimo terrestre y los terrenos ganados al mar. Se otorgan, eso sí, permisos, por ejemplo, para ejercer el comercio ambulante.

En este sentido, se ha querido argumentar - cuestión que no compartimos - que el fundamento de que las playas marítimas sean susceptibles de concesionarse se encuentra en la fracción XXXIX del artículo 32-bis

13 Todas las imágenes que se presentan en este trabajo fueron obtenidas de http:// portal.semarnat.gob.mx. 
Esta obra forma parte del acervo de la Biblioteca Jurídica Virtual del Instituto de Investigaciones Jurídicas de la UNAM

de la Ley Orgánica de la Administración Pública Federal, ${ }^{14}$ en la que de manera genérica se establecen los actos de autoridad que podrá emitir la Secretaría de Medio Ambiente y Recursos Naturales (Semarnat) en diversas materias, entre otras, sobre las playas marítimas. Establece este artículo en la fracción referida lo siguiente:

Artículo 32-bis. A la Secretaría de Medio Ambiente y Recursos Naturales, corresponde el despacho de los siguientes asuntos:

XXXIX. Otorgar contratos, concesiones, licencias, permisos, autorizaciones, asignaciones, y reconocer derechos, según corresponda, en materia de aguas, forestal, ecológica, explotación de la flora y fauna silvestres, y sobre playas, zona federal marítimo terrestre y terrenos ganados al mar;

Como bienes de uso común, cualquier persona puede usar, disfrutar y gozar las playas marítimas sin más restricciones que las establecidas por las leyes y reglamentos respectivos. Por lo que cometerá una infracción a la normatividad aplicable quien obstruya o impida el libre acceso o tránsito a las playas marítimas; en todo caso, la construcción e instalación de obras estarán sujetas a lo que apruebe la Semarnat conforme a las excepciones establecidas en la legislación correspondiente. Desde luego, está prohibida la realización de actos o hechos que contaminen las playas marítimas.

\section{Zona federal maritimo terrestre}

Existen diferentes formas para delimitar la superficie que abarca este concepto. Tanto para la parte continental como para las islas, la pauta nos la da el artículo 119 de la LGBN en sus diversas fracciones. Señala la primera parte de la fracción I lo siguiente (véase figura 2):

Artículo 119. Tanto en el macizo continental como en las islas que integran el territorio nacional, la zona federal marítimo terrestre se determinará:

I. Cuando la costa presente playas, la zona federal marítimo terrestre estará constituida por la faja de veinte metros de ancho de tierra firme, transitable y contigua a dichas playas...

14 Publicada en el Diario Oficial de la Federación el 29 de diciembre de 1976. 
Esta obra forma parte del acervo de la Biblioteca Jurídica Virtual del Instituto de Investigaciones Jurídicas de la UNAM

Este punto de partida se ve acotado por el artículo 4o. del Ruazofemat al señalar que dicha faja de veinte metros únicamente se determinará en aquellas zonas que en un plano horizontal presenten un ángulo e inclinación de treinta grados o menos. Desafortunadamente, la LGBN y su reglamento son omisos respecto a aquellas superficies con una inclinación mayor a treinta grados. Como se verá más adelante, al tratarse de formaciones rocosas y acantilados, el Ruazofemat señala que se determinará la faja de veinte metros de zona federal marítimo terrestre únicamente cuando la inclinación sea de treinta grados o menor en forma continua.

La segunda forma de delimitar la zona federal marítimo terrestre se encuentra en la segunda parte de la propia fracción I del mismo artículo 119 al incluir a las riberas de los ríos en su desembocadura con el mar (véase figura 3). Señala esta parte lo siguiente:

Artículo 119. Tanto en el macizo continental...

I... la zona federal marítimo terrestre estará constituida por la faja de veinte metros de ancho de tierra firme, transitable y contigua... a las riberas de los ríos desde la desembocadura de éstos en el mar, hasta cien metros río arriba;

Lamentablemente, el párrafo tercero del artículo 4o. del reglamento de la LGBN crea confusión respecto a este tipo de delimitación, pues establece que para el caso de los ríos la zona federal marítimo terrestre se determinará desde la desembocadura de estos en el mar hasta el punto río arriba donde llegue el mayor flujo anual, lo que no excederá en ningún caso los 200 metros. No está claro si esta disposición se refiere a la última parte de la fracción I del artículo 119, arriba citado, que de ser así estaría contraviniendo lo establecido por ley, o si está estableciendo alguna nueva forma de delimitación, que de ser así estaría rebasando los límites de la propia ley.

Otra forma para determinar la zona federal marítimo terrestre se refiere a los lagos, lagunas, esteros o depósitos naturales de agua marina conectados directa o indirectamente con el mar (véanse figuras 3 y 4). Así lo señala la fracción III del multicitado artículo 119:

Artículo 119. Tanto en el macizo continental...

III. En el caso de lagos, lagunas, esteros o depósitos naturales de agua marina que se comuniquen directa o indirectamente con el mar, la faja de 
Esta obra forma parte del acervo de la Biblioteca Jurídica Virtual del Instituto de Investigaciones Jurídicas de la UNAM www.juridicas.unam.mx

veinte metros de zona federal marítimo terrestre se contará a partir del punto a donde llegue el mayor embalse anual o límites de la pleamar, en los términos que determine el reglamento;

\section{FIGURA 2}

Delimitación de la zona federal marítimo terrestre (playas)

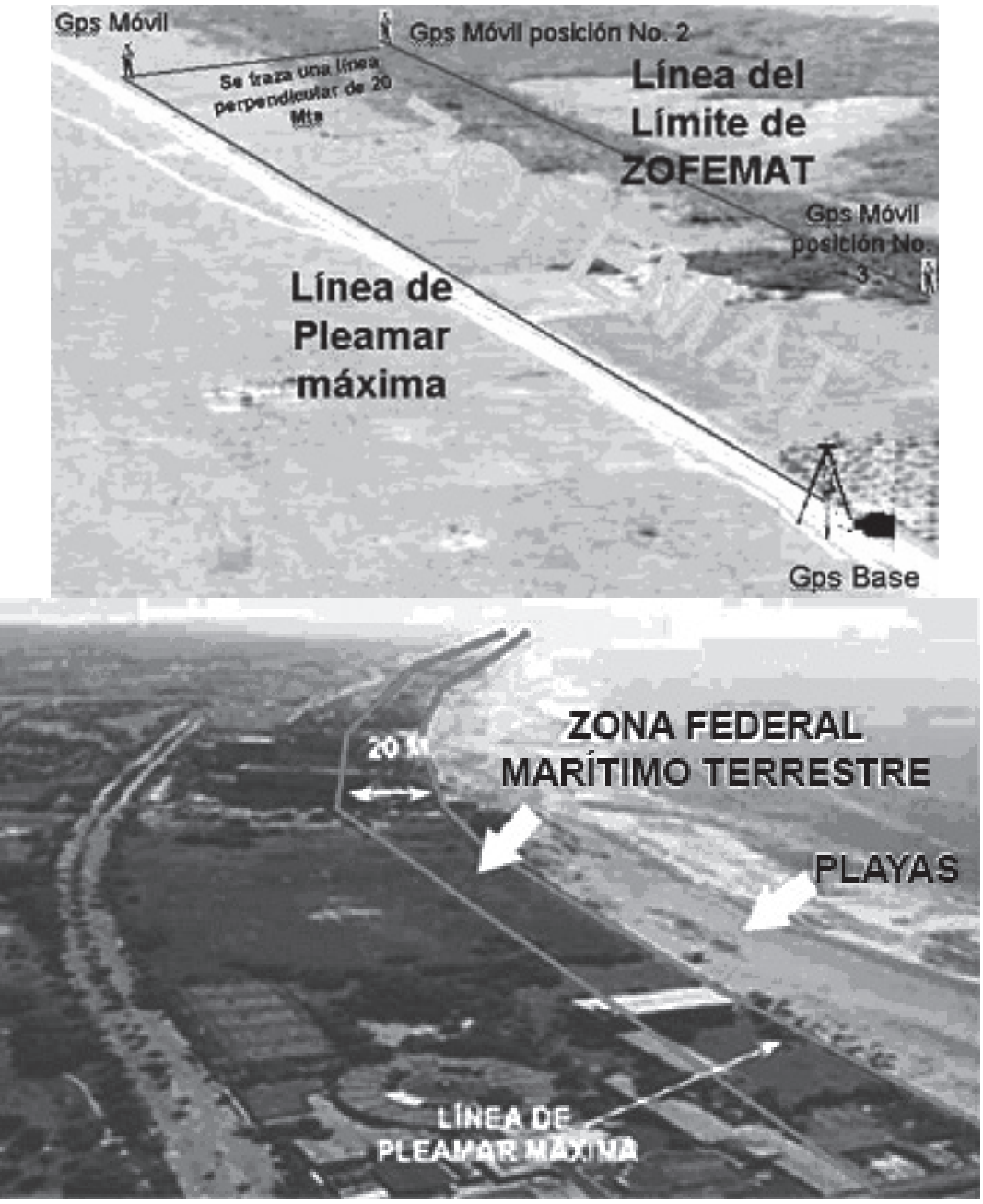

Fuente: Dirección General de Zona Federal Marítimo Terrestre y Ambientes Costeros, 2005 . 
Esta obra forma parte del acervo de la Biblioteca Jurídica Virtual del Instituto de Investigaciones Jurídicas de la UNAM www.juridicas.unam.mx

\section{FIGURA 3}

\section{Delimitación de la zona federal marítimo terrestre (rios)}

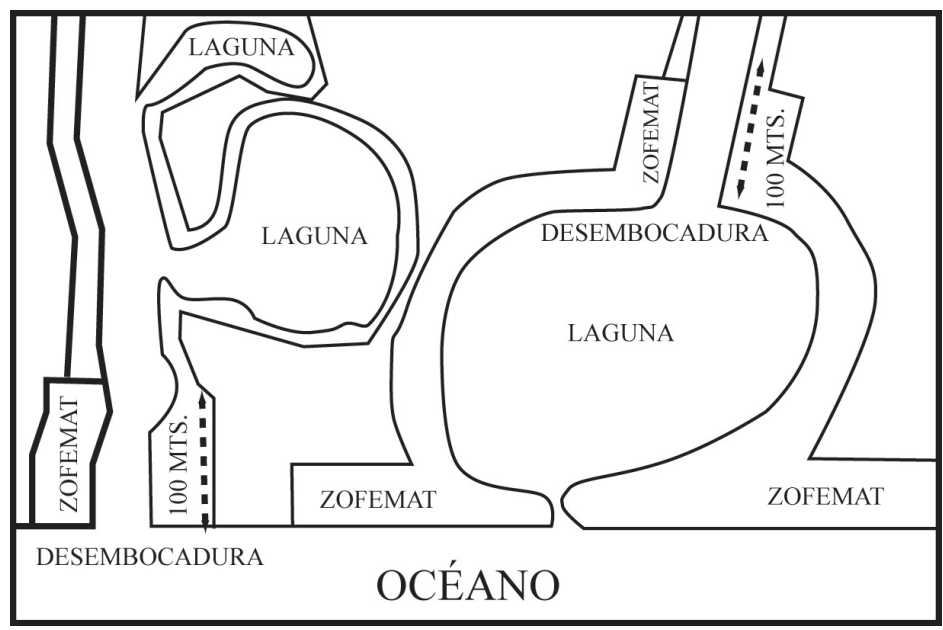

Fuente: Dirección General de Zona Federal Marítimo Terrestre y Ambientes Costeros, 2005.

\section{FIGURA 4}

\section{Delimitación de la zona federal marítimo terrestre (lagos y lagunas)}

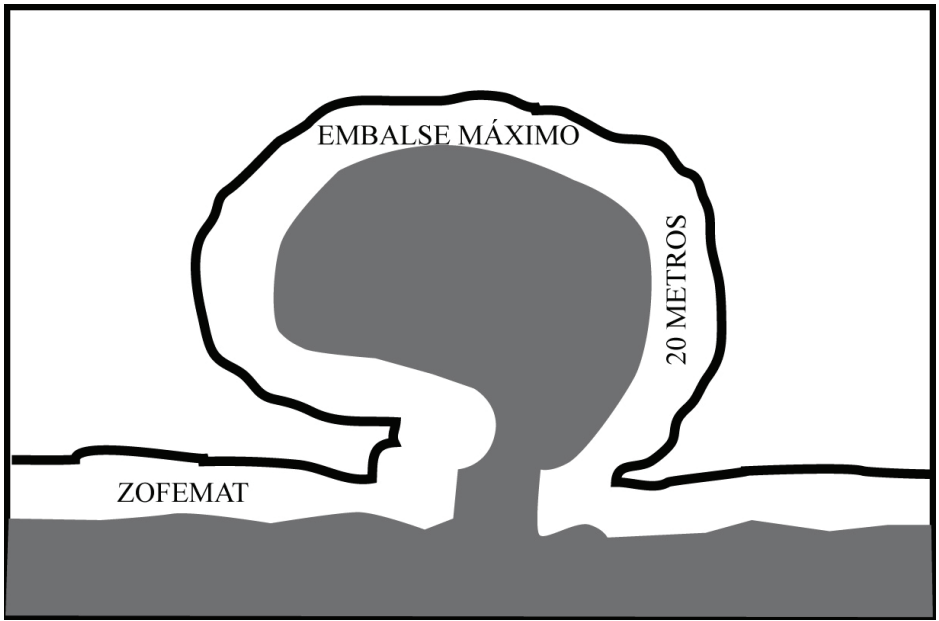

Fuente: Dirección General de Zona Federal Marítimo Terrestre y Ambientes Costeros, 2005. 
Esta obra forma parte del acervo de la Biblioteca Jurídica Virtual del Instituto de Investigaciones Jurídicas de la UNAM

La fracción II del artículo 119 establece una cuarta forma para delimitar este concepto. En esta ocasión se trata de los cayos y arrecifes:

Artículo 119. Tanto en el macizo continental...

II. La totalidad de la superficie de los cayos y arrecifes ubicados en el mar territorial, constituirá zona federal marítimo terrestre;

Finalmente, existe una quinta manera para conocer de la zona federal marítimo terrestre y tiene que ver con las llamadas "marinas". En este caso, cuando se construye una marina la zona federal marítimo terrestre se reducirá de veinte a tres metros y, como veremos más adelante, los diecisiete metros restantes serán ahora terrenos ganados al mar. Señala la segunda parte de la fracción IV del artículo 119 de la LGBN:

Artículo 119. Tanto en el macizo continental...

IV. La zona federal marítimo terrestre correspondiente a las marinas... no excederá de tres metros de ancho y se delimitará procurando que no interfiera con el uso o destino de sus instalaciones;

La propia LGBN exceptúa la delimitación de la zona federal marítimo terrestre para el caso de marinas artificiales o esteros dedicados a la acuacultura, cuando entre dichas marinas o esteros y el mar medie una zona federal marítimo terrestre (véase figura 5).

Al igual que las playas marítimas, la zona federal marítimo terrestre es un bien de uso común y por lo tanto se considera un bien nacional. Como hemos dicho anteriormente, los bienes de uso común están sujetos al régimen de dominio público de la Federación y por lo tanto son inalienables, imprescriptibles e inembargables. Al tratarse de un bien de uso común, la zona federal marítimo terrestre no está sujeta a actos de desincorporación y su posterior autorización a enajenarse. Es decir, desde un punto de vista jurídico, ni las playas (marítimas) ni esa faja de veinte metros de ancho adyacente a estas podrán estar en manos de propietarios privados.

Contrariamente a lo que sucede con las playas marítimas, la zona federal marítimo terrestre sí es susceptible de concesionarse para su uso y aprovechamiento, pues así se señala explícitamente en la LGBN y su reglamento. El objeto de las concesiones para usar, ocupar y aprovechar esta superficie puede ser muy variado, pero como bienes de uso común, cualquier habitante de la República puede usar, disfrutar y gozar de ella 
Esta obra forma parte del acervo de la Biblioteca Jurídica Virtual del Instituto de Investigaciones Jurídicas de la UNAM

sin más restricciones que las establecidas por las leyes y reglamentos respectivos. De esta manera, los concesionarios deben abstenerse de construir obras o realizar actos que impidan el libre acceso a dicha superficie, con las excepciones que al efecto señale la legislación correspondiente.

\section{FIGURA 5 \\ No delimitación de la zona federal marítimo terrestre (marinas)}

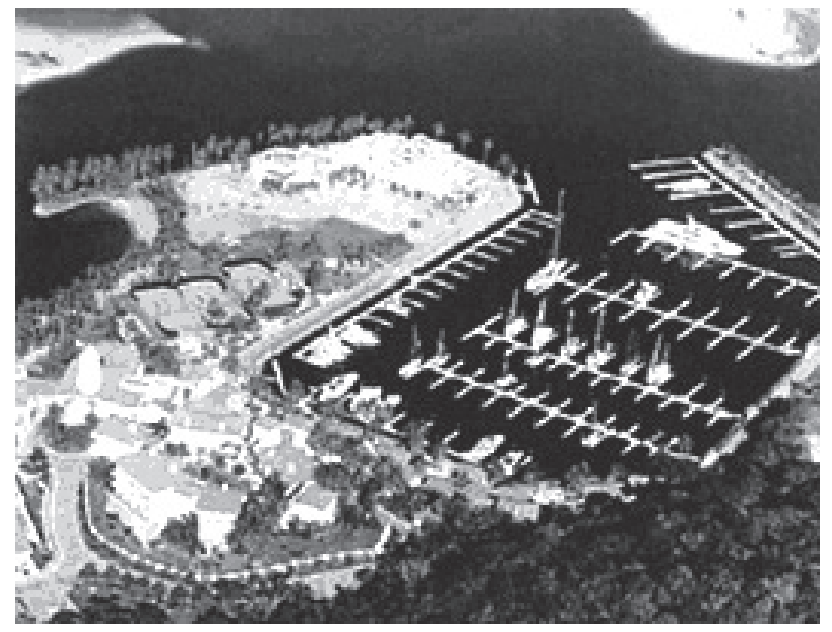

Fuente: Dirección General de Zona Federal Marítimo Terrestre y Ambientes Costeros, 2005 .

Si bien está prohibida la realización de actos o hechos que contaminen la zona federal marítimo terrestre, los concesionarios — si así se estipula como parte de sus obligaciones - deberán coadyuvar en la preservación del equilibrio ecológico y la protección al ambiente.

\section{Terrenos ganados al mar}

La LGBN establece en su artículo 125 las dos formas por las que se ganan terrenos al mar: causas naturales y causas artificiales. Cuando esto sucede se llevará a cabo una nueva delimitación de la zona federal marítimo terrestre (véase figura 6). La nueva configuración de la zona federal 
Esta obra forma parte del acervo de la Biblioteca Jurídica Virtual del Instituto de Investigaciones Jurídicas de la UNAM

marítimo terrestre y terrenos ganados al mar (i. e. su identificación y deslinde) correrá a cargo de la Semarnat. Señala este artículo lo siguiente:

Artículo 125. Cuando por causas naturales o artificiales, se ganen terrenos al mar, los límites de la zona federal marítimo terrestre se establecerán de acuerdo con la nueva configuración física del terreno, de tal manera que se entenderá ganada al mar la superficie de tierra que quede entre el límite de la nueva zona federal marítimo terrestre y el límite de la zona federal marítimo terrestre original.

Por un lado, se ganan terrenos al mar de manera natural por fenómenos meteorológicos como los ciclones tropicales (cuya etapa de mayor afectabilidad es la del huracán). ${ }^{15}$ Por el otro, se pueden ganar artificialmente terrenos al mar a través de la construcción de los llamados rompeolas o escolleras que son obras realizadas con piedras (u otros materiales) echadas al fondo del mar para formar verdaderas barreras o diques de defensa en contra del oleaje. Estas obras (que también sirven para la construcción de muelles) tienen el efecto de "alejar" al mar y con ello descubrir nuevas superficies que formarán parte de una nueva delimitación de la zona federal marítimo terrestre. Lo mismo sucede para el caso de ganar artificialmente terrenos al mar a través de obras de relleno o azolve tal y como se muestra en la figura 7. En uno u otro caso se requiere de la autorización de la Semarnat, con la intervención, según corresponda, de la Secretaría de Comunicaciones y Transportes, mismas que determinarán la forma y términos para ejecutar dichas obras.

Aunado a lo anterior, existe una tercera forma en la que se generan terrenos ganados al mar aunque en estricto sentido no estemos necesariamente en presencia de un "alejamiento" del mar. Es decir, se trata de una superficie a la que se le denomina terrenos ganados al mar con todas las consecuencias jurídicas que ello implica, pero su formación no se deriva de una obra que forzosamente "aleje" al mar al descubrir (e. g. rompeolas) o aumentar (e. g. rellenos) nuevas superficies terrestres, sino de la

15 La evolución de un ciclón tropical puede dividirse en cuatro etapas: nacimiento (depresión tropical) con vientos de hasta 62 kilómetros por hora o menos, desarrollo (tormenta tropical) con vientos de hasta 117 kilómetros por hora, madurez (huracán) con vientos de hasta 370 kilómetros por hora, divididas en cinco categorías y disipación (fase final). Véase Instituto Nacional de Estadística, Geografía e Informática, Estadísticas del Medio Ambiente. México 1997, México, Instituto Nacional de Estadística, Geografía e Informática, 1998, pp. 83-85. 
Esta obra forma parte del acervo de la Biblioteca Jurídica Virtual del Instituto de Investigaciones Jurídicas de la UNAM

construcción de una marina artificial. Por mandato expreso de la LGBN, cuando se construye una marina, la faja original de veinte metros de zona federal marítimo terrestre no excederá de tres metros de ancho y los diecisiete metros restantes se considerarán terrenos ganados al mar.

Contrarios a la naturaleza jurídica de sus dos antecesoras - las playas marítimas y la zona federal marítimo terrestre-, los terrenos ganados al mar no son bienes de uso común. Por lo que estos bienes inmuebles son susceptibles de desincorporarse del régimen de dominio público de la Federación y autorizar su enajenación a particulares. Esta situación —así establecida en la LGBN — nos lleva al cuestionamiento siguiente: si los terrenos ganados al mar están sujetos al régimen de dominio público de la Federación, lo que a su vez significa que se trata de bienes inalienables, ¿cómo es entonces que se pueden enajenar? Creemos que la respuesta subyace en una excepción que hace la ley a esta aseveración en el sentido de que si los bienes sujetos al régimen de dominio público de la Federación son inalienables, habrá ciertos bienes que de manera excepcional sí puedan venderse. Este es el caso por excepción de aquellos bienes que estando sujetos a dicho régimen no sean ni de uso común ni tampoco útiles para destinarlos al servicio público. La LGBN señala que los bienes inmuebles que se encuentren en esta situación (i.e. se desincorporen del régimen del dominio público) perderán únicamente su carácter de inalienables. ${ }^{16}$ En otras palabras, desde un punto de vista jurídico, una porción de zona costera que es denominada "terreno ganado al mar" podrá estar en manos de propietarios privados.

16 Existe cierta duda sobre la verdadera naturaleza jurídica de los terrenos ganados al mar una vez que han sido desincorporados para que se autorice su enajenación. Por un lado, se argumenta que por el hecho de que son bienes sujetos al régimen de dominio público de la Federación, y que por lo tanto son inalienables, la desincorporación de ese régimen provoca, por ese solo hecho, que estos bienes dejen de ser terrenos ganados al mar, puesto que los particulares no pueden ser propietarios de bienes sujetos a dicho régimen. Por otro lado, al establecer la $\mathrm{LGBN}$ en su artículo 95 párrafo segundo, que los bienes inmuebles que se desincorporen del régimen del dominio público perderán únicamente su carácter de inalienables, hace pensar que esos bienes continúan siendo verdaderos bienes sujetos al régimen del dominio público aun desincorporados, es decir, su naturaleza no varía, por lo que los particulares adquieren bienes del dominio público que son por excepción establecida en ley, enajenables. Es decir, en esta última idea desincorporación no significa en estricto sentido separación del régimen al que están sujetos. En este sentido, y como se verá más adelante, los acuerdos administrativos de desincorporación se refieren lisa y llanamente a superficies de terrenos ganados al mar. 
Esta obra forma parte del acervo de la Biblioteca Jurídica Virtual del Instituto de Investigaciones Jurídicas de la UNAM www.juridicas.unam.mx
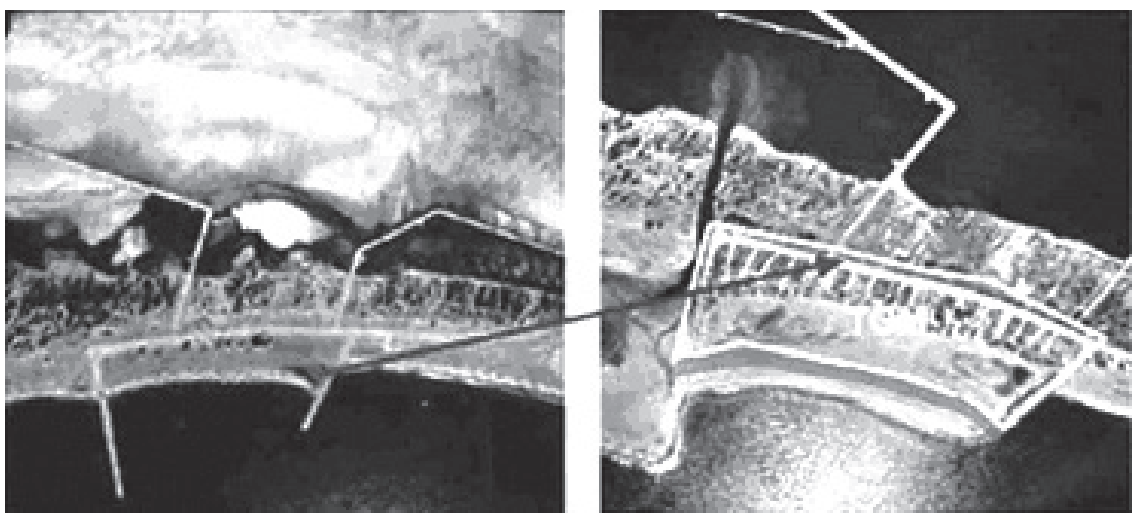

Fuente: Dirección General de Zona Federal Marítimo Terrestre y Ambientes Costeros, 2005.

\section{FIGURA 7}

Delimitación de los terrenos ganados al mar (rellenos o azolve)

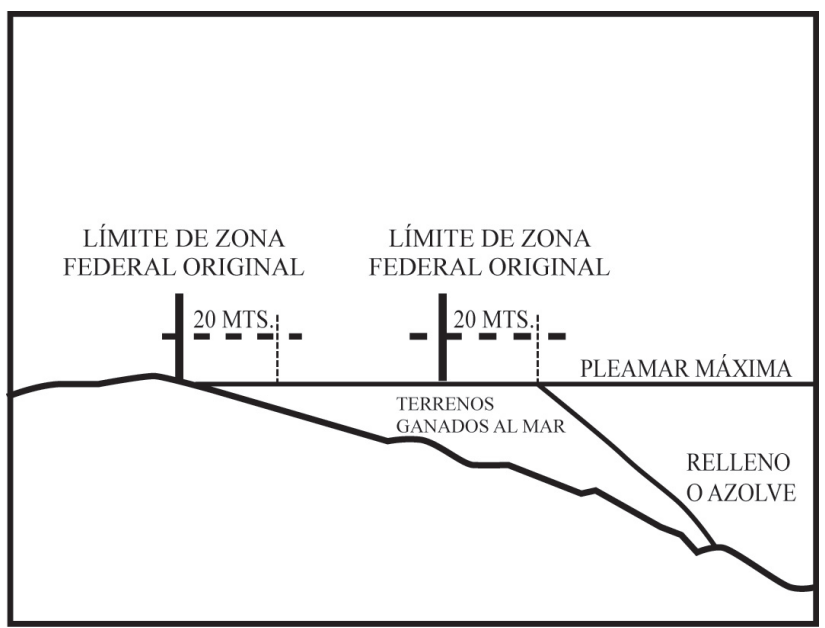

Fuente: Dirección General de Zona Federal Marítimo Terrestre y Ambientes Costeros, 2005. 
Esta obra forma parte del acervo de la Biblioteca Jurídica Virtual del Instituto de Investigaciones Jurídicas de la UNAM

Al igual que la zona federal marítimo terrestre, los terrenos ganados al mar son susceptibles de concesionarse para su uso y aprovechamiento conforme a lo que se señala de manera explícita tanto en la LGBN como en su reglamento. El objeto de las concesiones para usar, ocupar y aprovechar esta superficie puede ser de la misma manera muy variado. Al tratarse de bienes sujetos al régimen de dominio público de la Federación, se podrá estipular en las concesiones que los concesionarios se obligan a garantizar el libre tránsito sobre ellos, así como el deber de coadyuvar en la preservación del equilibrio ecológico y la protección al ambiente.

También se pueden "perder terrenos al mar" aunque la ley no distingue si esto será por causas naturales o artificiales. Cuando se pierden terrenos al mar por invasión de aguas a la zona federal marítimo terrestre o incluso a los terrenos adyacentes (aun de propiedad privada), se delimitará una nueva zona federal marítimo terrestre. La situación patrimonial de los propietarios que se encuentren bajo este supuesto normativo cambia y entonces las propiedades privadas pierden ese carácter y se convierten ahora por disposición legal en zona federal marítimo terrestre. Esta situación genera, desde luego, que los antiguos propietarios privados podrán solicitar - si bien con un derecho de preferencia_ concesión para el uso, ocupación y aprovechamiento de la nueva zona federal marítimo terrestre (antes terrenos suyos) con el pago de derechos sobre dicho espacio, según corresponda. Señala el artículo 122 de la LGBN lo siguiente:

Artículo 122. En el caso de que la zona federal marítimo terrestre sea invadida total o parcialmente por las aguas, o de que éstas lleguen inclusive a invadir terrenos de propiedad particular colindantes con la zona federal marítimo terrestre, ésta se delimitará nuevamente en los términos de esta ley y sus reglamentos. Las áreas de los terrenos que pasen a formar parte de la nueva zona federal marítimo terrestre perderán su carácter de propiedad privada, pero sus legítimos propietarios tendrán derecho de preferencia para que se les concesione, conforme a lo establecido por esta ley.

Es común que se pierdan terrenos al mar de manera natural por la presencia de los comentados fenómenos meteorológicos conocidos como ciclones tropicales. Típico ejemplo de ello han sido las costas en el estado de Quintana Roo (ubicado en la Península de Yucatán), que han experimentado en los últimos años, al menos en dos ocasiones, la invasión de aguas de mar. En septiembre de 1988 con el huracán Gilberto y más 
Esta obra forma parte del acervo de la Biblioteca Jurídica Virtual del Instituto de Investigaciones Jurídicas de la UNAM

recientemente en octubre de 2005 con el huracán Wilma, la existente zona federal marítimo terrestre se ha ido recorriendo tierra adentro hasta alcanzar como en el caso de Cancún las construcciones que forman la zona hotelera. ${ }^{17}$

El Ruazofemat establece algunos lineamientos para determinar cuándo se está en presencia de un terreno perdido al mar. El artículo 18 del mismo señala en sus párrafos primero y segundo lo siguiente:

Artículo 18. Cuando de manera definitiva y permanente algún terreno quede invadido por el agua del mar, la secretaría realizará el deslinde, identificación topohidrográfica y amojonamiento de la nueva zona federal marítimo terrestre. Los terrenos que integren la nueva zona federal marítimo terrestre pasarán por ese hecho a ser propiedad de la nación, de acuerdo con la legislación en la materia, pero sus antiguos propietarios tendrán derecho de preferencia para que se les concesionen, conforme a las disposiciones aplicables.

Se entiende que un terreno ha quedado invadido de manera definitiva y permanente cuando haya permanecido invadido por el agua del mar por un lapso ininterrumpido mayor a los ciento ochenta días naturales y del estudio que se realice no se prevea su retiro gradual.

\section{Ambientes costeros}

Los llamados "ambientes costeros" no se encuentran regulados expresamente ni por la LGBN (ni por su reglamento) ni tampoco por la Ley General del Equilibrio Ecológico y la Protección al Ambiente (LGEEPA). ${ }^{18}$ La creación de esta nueva expresión descriptiva como uno de los componentes de las zonas costeras se concibe en el reglamento interior de la Semarnat de principios de 2003 y la considera como un concepto asociado a las playas marítimas, la zona federal marítimo terrestre y los terrenos ganados al mar. La redacción del texto en el artículo relativo a las atribuciones de la Dirección General de Zona Federal Marítimo Terrestre y

17 Las preocupaciones de los inversionistas en esta zona turística por la pérdida de superficies con playas de arena tiene ya varios años. Se ha especulado que durante los últimos años (anteriores al huracán Wilma) se habrían perdido entre 30 y 40 metros de playa y/o zona federal marítimo terrestre. Véase Becerra Gallo, Mauricio, "La zona federal marítimo-terrestre", El Mundo del Abogado, México, año 3, núm. 22, febrero de 2001, pp. 53 y 54.

18 Publicada en el Diario Oficial de la Federación el 28 de enero de 1988. 
Esta obra forma parte del acervo de la Biblioteca Jurídica Virtual del Instituto de Investigaciones Jurídicas de la UNAM

Ambientes Costeros es más que desafortunada puesto que no queda claro cuáles son los ambientes costeros. Transcribimos las tres primeras fracciones del artículo 30 del reglamento interior de la ya citada dependencia del Ejecutivo Federal:

Artículo 30. La Dirección General de Zona Federal Marítimo Terrestre y Ambientes Costeros tendrá las atribuciones siguientes:

I. Ejercer los derechos de la nación sobre los bienes nacionales siguientes: zona federal marítimo terrestre, playas marítimas y terrenos ganados al mar o a cualquier otro depósito natural de aguas marítimas;

II. Conservar, restaurar y proteger el desarrollo sustentable de los bienes nacionales citados en la fracción I de este artículo, y de los ambientes costeros asociados a éstos;

III. Llevar a cabo los programas para la protección ambiental, manejo integral y el desarrollo sustentable de los bienes nacionales y ambientes costeros a que se refieren las fracciones I y II de este artículo, así como participar en la formulación de normas oficiales mexicanas para su regulación ambiental;

Es así que el reglamento interior de la Semarnat de 2003 es un reglamento inconstitucional puesto que rebasa el contenido tanto de la LGBN como el de la LGEEPA, en virtud de que aquél crea una situación jurídica que ninguna de estas dos leyes recoge —incluyendo además en este mismo supuesto a la Ley Orgánica de la Administración Pública Federal-. En contra de esta aseveración, no aceptamos el argumento de que la creación de la expresión ambientes costeros (por muy necesaria que ésta sea) sirve para llenar un vacío legal o para complementar la ley. Transcribimos lo que al respecto señala el maestro Nava Negrete:

El reglamento no complementa la ley, porque entonces estaría legislando el presidente de la República; lo que hace es desarrollar y particularizar las situaciones ya legalmente previstas. Esto significa que el reglamento no puede prever mandatos que rebasen el contenido natural de la ley; está subordinado siempre al texto de la ley; su expresión, en extensión numérica de palabras, puede ser mayor que la ley pero no puede exceder el contenido de la misma. ${ }^{19}$

19 Nava Negrete, Alfonso, op. cit., nota 1, p. 84. 
Esta obra forma parte del acervo de la Biblioteca Jurídica Virtual del Instituto de Investigaciones Jurídicas de la UNAM

De manera informal y si se tienen los medios informáticos para ello, es posible conocer a lo que se refieren los ambientes costeros, pues según se establece en la página de Internet de la Dirección General de Zona Federal Marítimo Terrestre y Ambientes Costeros, ${ }^{20}$ éstos comprenden a los humedales, marismas, manglares, lagunas, ríos, lagos y esteros conectados con el mar y de sus litorales o zonas federales (véase figura 8). Es fácil advertir que algunos de estos términos encuadran en uno de los componentes del concepto de zonas costeras que hemos analizado aquí: se trata en su mayoría de porciones acuáticas no marinas adyacentes al mar. Sin embargo, la concepción que hace la dirección general citada en su página electrónica crea confusión con ciertos términos como es el caso de las lagunas que estén conectadas al mar, en virtud de que la fracción $\mathrm{V}$ del artículo 36 de la Ley Federal del $\mathrm{Mar}^{21}$ considera a las lagunas comunicadas (permanente o intermitentemente) con el mar como aguas marinas interiores. Luego, no es claro si las lagunas de las que habla la página de Internet citada son espacios diferentes a los mencionados en la Ley Federal del Mar o si se trata en realidad de una zona marina, y por lo tanto, estarían sujetas a disposiciones legales diferentes.

No obstante las obligaciones que México ha adquirido en el concierto internacional de las naciones para regular, por ejemplo, humedales y manglares, no se tiene un sustento jurídico apropiado en la legislación nacional. ${ }^{22}$ Lo poco que se ha regulado está disperso y causa confusión. Así, por ejemplo, si bien la Ley de Aguas Nacionales ${ }^{23}$ establece lo que debe entenderse por humedales, no deja en claro cuál es su naturaleza jurídica y desde luego no menciona que éstos formen parte de algo llamado ambientes costeros. ${ }^{24}$ Por su lado, la LGEEPA sólo se refiere a los humedales cuando se trata de la evaluación del impacto ambiental; esto es, somete al procedimiento de evaluación de impacto ambiental a las obras y actividades que se realicen sobre ellos. Mientras tanto, y

20 Véase Dirección General de Zona Federal Marítimo Terrestre y Ambientes Costeros, Conceptos Básicos, Secretaría de Medio Ambiente y Recursos Naturales, mayo de 2005, http://portal.semarnat.gob.mx.

21 Publicada en el Diario Oficial de la Federación el 8 de enero de 1986.

22 Para mayor abundamiento, véase Aceves, Carla D., Bases fundamentales de derecho ambiental mexicano, México, Porrúa, 2003, pp. 348-350.

23 Publicada en el Diario Oficial de la Federación el 1o. de diciembre de 1992.

24 Véase Comisión Nacional del Agua, Ley de Aguas Nacionales y su Reglamento, México, Comisión Nacional del Agua, 2004, p. 5. 
Esta obra forma parte del acervo de la Biblioteca Jurídica Virtual del Instituto de Investigaciones Jurídicas de la UNAM

para mayor confusión, el reglamento de la propia LGEEPA, en materia de evaluación del impacto ambiental, ${ }^{25}$ considera a los humedales como ecosistemas. La situación es aún peor para el caso de los manglares puesto que no se les menciona en leyes donde podrían estar regulados como la LGBN o la Ley General de Desarrollo Forestal Sustentable. ${ }^{26}$ La LGEEPA y su reglamento, en materia de evaluación del impacto ambiental, tratan a los manglares igual que a los humedales. Es decir, se refieren a los manglares, a propósito de someter al procedimiento de evaluación del impacto ambiental las obras y actividades que se realicen sobre ellos como ecosistemas.

FIGURA 8

\section{Delimitación de ambientes costeros}

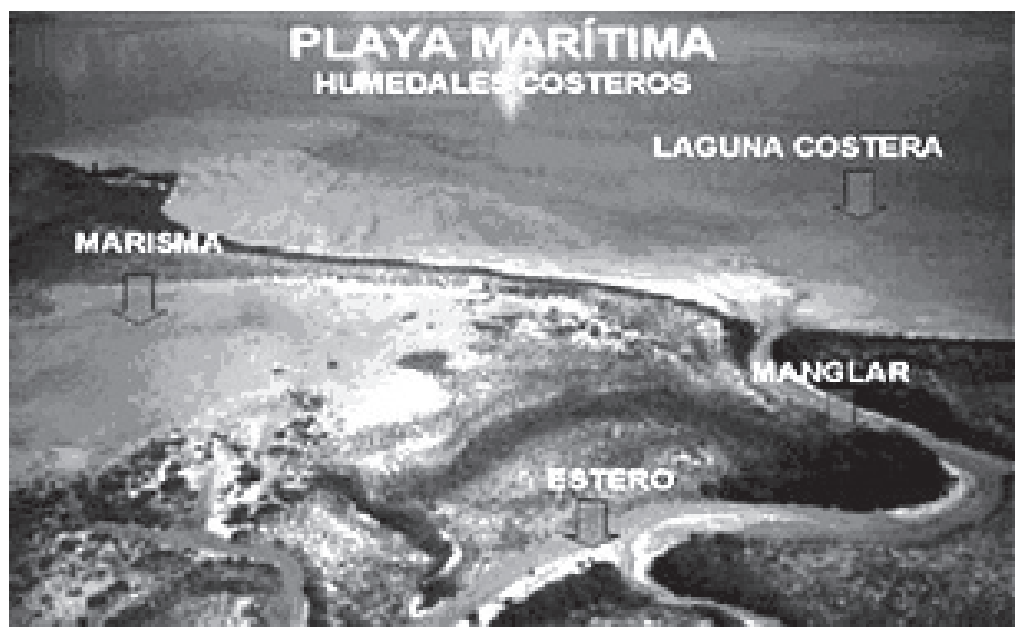

Fuente: Dirección General de Zona Federal Marítimo Terrestre y Ambientes Costeros, 2005.

Como una práctica que parece ya común en la administración pública federal, la Semarnat ha intentado regular a través de normas oficiales mexicanas situaciones no previstas o confusamente previstas en leyes y reglamentos, como es el caso de humedales y manglares. Es así que

25 Publicado en el Diario Oficial de la Federación el 30 de mayo de 2000.

26 Publicada en el Diario Oficial de la Federación el 25 de febrero de 2003. 
Esta obra forma parte del acervo de la Biblioteca Jurídica Virtual del Instituto de Investigaciones Jurídicas de la UNAM

la NOM-022-SEMARNAT-200327 establece que el humedal costero es la unidad hidrológica que contiene comunidades vegetales de manglar. Siendo uno género y el otro especie, aumenta irremediablemente la confusión sobre cada concepto y su consiguiente naturaleza jurídica.

Pero más allá de problemas conceptuales, el querer gobernar a través de instrumentos jurídicos como las normas oficiales mexicanas (para llenar vacíos jurídicos que no contemplan las leyes ni sus reglamentos) conlleva riesgos de aplicación, interpretación, certidumbre a los particulares, y sobre todo, de posible abuso regulatorio por parte del Ejecutivo $\mathrm{Fe}$ deral. Así sucedió con la norma que aquí mencionamos y que se refiere al establecimiento de las especificaciones para la preservación, conservación, aprovechamiento sustentable y restauración de los humedales costeros en zonas de manglar. En mayo de 2004 se le hizo a esta norma una modificación $^{28}$ a la que cerca de treinta organizaciones no gubernamentales se opusieron por contrariar, según afirman, un consenso logrado por científicos y ambientalistas en un proceso de siete años de elaboración de la misma. La inconformidad radica en que dicha modificación, al decir de estas organizaciones, favorece a desarrolladores turísticos, pues establece indebidas excepciones a la prohibición de actividades con alto impacto ambiental en humedales costeros, siempre y cuando se establezcan, en el informe preventivo o en la manifestación de impacto ambiental, medidas de compensación en beneficio de los humedales. ${ }^{29}$

\section{Formaciones rocosas y acantilados}

El último concepto que abarca la noción de zonas costeras se refiere a las llamadas formaciones rocosas y acantilados, cuya existencia en nuestra legislación es patéticamente limitada.

Irrumpe este concepto en la legislación mexicana vigente, a propósito de la delimitación y determinación de la zona federal marítimo terrestre. El segundo párrafo el artículo 4o. del reglamento de la LGBN señala lo siguiente:

27 Publicada en el Diario Oficial de la Federación el 10 de abril de 2003.

28 Publicada en el Diario Oficial de la Federación el 7 de mayo de 2004.

29 Véase Centro Mexicano de Derecho Ambiental, Greenpeace e IFAW, “¡Ya basta Alberto Cárdenas!", La Jornada, México, 23 de mayo de 2005. 
Esta obra forma parte del acervo de la Biblioteca Jurídica Virtual del Instituto de Investigaciones Jurídicas de la UNAM

Artículo $4 o$. La zona federal marítimo terrestre se determinará...

Tratándose de costas que carezcan de playas y presenten formaciones rocosas o acantilados, la secretaría determinará la zona federal marítimo terrestre dentro de una faja de veinte metros contigua al litoral marino, únicamente cuando la inclinación en dicha faja sea de treinta grados o menor en forma continua.

Al igual que sucede con los ambientes costeros, al no existir disposición alguna en la LGBN sobre la delimitación de la zona federal marítimo terrestre en estas formaciones rocosas y acantilados, debe entenderse que dicha disposición es inconstitucional al ir más allá de lo que establece el texto de la ley citada.

Para fines de asignación de derechos de propiedad, las formaciones rocosas y acantilados no son considerados como bienes nacionales que estén sujetos al régimen de dominio público de la Federación. El lamentable vacío respecto a la definición sobre la naturaleza jurídica de este concepto se traduce en que grandes superficies de zona costera son susceptibles de pertenecer a particulares. ${ }^{30}$

Vale la pena comentar que la Ley General de Bienes Nacionales de 1982 habría tratado en un principio de llenar semejante vacío al incluir en su texto aquellos casos en los que si la costa carecía de playas y presentaba formaciones rocosas o acantilados, la faja de veinte metros se contaría a partir del punto en la parte superior de dichas formaciones rocosas o acantilados en los que se pudiera transitar libremente y en forma continua; ${ }^{31} \sin$ embargo, esta disposición que recogería la fracción II del artículo 49 fue duramente criticada (y considerada de dudosa constitucionalidad), por lo que fue modificada en dos ocasiones. Y es que no sólo se cuestionaba lo problemático que sería delimitar la zona federal marítimo terrestre en zonas topográficas irregulares (donde el transitar libremente y de forma continua podría estar kilómetros tierra adentro), sino que

30 En este sentido, véase Cortina Segovia, Sofía y Quiñones Valadez, Leticia, Análisis y recomendaciones del marco jurídico aplicable a océanos y costas, México, Dirección General de Investigación en Política y Economía Ambiental, Instituto Nacional de Ecología, mayo de 2005, p. 80, http://www.ine.gob.mx/down-load/anal_recom_marco_jur.pdf.

31 La fracción II del artículo 49 de la LGBN de 1982 al momento de ser abrogada señalaba lo siguiente: “Artículo 49. II: Cuando la costa carezca de playas y presente formaciones rocosas o acantilados, la faja de veinte metros de zona federal marítimo terrestre se contará desde el punto de la parte superior de dichos acantilados o formaciones rocosas en que pueda transitarse libremente y en forma continua...". 
Esta obra forma parte del acervo de la Biblioteca Jurídica Virtual del Instituto de Investigaciones Jurídicas de la UNAM

equivalía a una expropiación de terrenos de particulares, lo que inhibía los proyectos de inversión - particularmente los turísticos, en los que los inversionistas no aceptaban que sus construcciones pasaran a propiedad federal y que vencido el plazo de la concesión pagaran derechos sobre sus propias construcciones y por el uso de los ahora terrenos de propiedad federal—. ${ }^{32}$ Pocos años después se intentó solucionar este problema con una modificación a la ley, en 1987, que eliminó los requisitos de que fuera transitable (libremente) y de que para medir los veinte metros se iniciara en el punto superior de acantilados y formaciones rocosas. Finalmente, en 1992 se reformó nuevamente la ley en comento y se suprimió cualquier referencia de regulación a estos dos conceptos.

Diez años más tarde, en las mesas de discusión de la entonces Secretaría de Contraloría y Desarrollo Administrativo - hoy Secretaría de la Función Pública - para la elaboración de lo que sería la LGBN de 2004, se intentó incluir la idea de regular y definir la naturaleza jurídica de las formaciones rocosas y los acantilados; sin embargo, dicho intento fracasó ante el temor por parte de los redactores de la ley, que la discusión y eventual oposición respecto a un reformulación de estos conceptos afectaran los tiempos diseñados para su conclusión so pretexto de tratarse de un proyecto de ley sexenal.

\section{NOTA BREVE QUE DESCRIBE LA SITUACIÓN ACTUAL: IMPORTANCIA, LEGISLACIÓN Y ADMINISTRACIÓN PÚBLICA}

México cuenta con más de 11000 kilómetros de litoral. De éstos, el $70 \%$ pertenece a las vertientes del Océano Pacífico, el Golfo de California y el Mar de Cortés. El otro 30\% pertenece a las vertientes del Golfo de México y el Mar Caribe. Si todo el litoral mexicano reuniera las características de presentar playas de tierra firme, transitable y contigua a dichas playas y estuvieran en un plano horizontal, que presentaran un ángulo e inclinación de treinta grados o menos y quisiéramos de manera muy simplista multiplicar esos 11000 kilómetros por los veinte metros que representan la faja de zona federal marítimo terrestre, obtendríamos una gran extensión de alrededor de 220000 kilómetros cuadrados por

32 Sempé Minvielle, Carlos, Técnica legislativa y desregulación, 2a. ed., México, Porrúa, 1998, pp. 80 y 81 . 
Esta obra forma parte del acervo de la Biblioteca Jurídica Virtual del Instituto de Investigaciones Jurídicas de la UNAM

este concepto. ${ }^{33}$ Como es lógico suponer, sin embargo, no todo el litoral mexicano reúne esas características. Tener un dato aproximado de la superficie que comprende la zona costera como aquí se ha definido, tendría que tomar en cuenta no sólo el espacio donde se pudiera delimitar la zona federal marítimo terrestre y multiplicarlo por la longitud correspondiente, sino sumar los espacios que abarcan los otros cuatro conceptos: playas marítimas, algunos terrenos ganados al mar, los ambientes costeros (o en su caso, las porciones acuáticas no marinas) y las formaciones rocosas y los acantilados.

De cualquier manera, el país cuenta con 16000 kilómetros cuadrados de superficie estuarina y más de 12000 kilómetros cuadrados de lagunas costeras que permiten la existencia de ecosistemas costeros impresionantemente ricos en biodiversidad marina y terrestre. De la amplia gama de recursos y ecosistemas costeros en el país, se traduce que, en términos de litorales (junto a superficie marina), México sea uno de los doce países mejor dotados a nivel mundial. ${ }^{34}$ Con todo, la contaminación y el deterioro ambientales amenazan seriamente su existencia y su destrucción irreversible.

Por lo anterior, es necesario hacer hincapié en la situación actual de nuestras zonas costeras respecto a tres temas fundamentales: $i$ ) importancia; ii) legislación, y iii) administración pública.

\section{Importancia}

Son tres los pilares del desarrollo sustentable: economía, sociedad y ambiente. Los tres se reflejan de manera precisa en las zonas costeras y de aquí su trascendencia para nuestro país.

a) Importancia económica. Variadas son las actividades que contienen una dimensión económica y que representan un sustento para las comunidades costeras y no costeras de nuestro país. Aquí mencionamos

33 Mauricio Becerra Gallo calcula en 260000 kilómetros cuadrados esta zona al considerar en 13000 kilómetros los litorales mexicanos; op. cit., nota 17, p. 52. La propia Secretaría del Medio Ambiente y Recursos Naturales estima los litorales en 11122 kilómetros. Secretaría del Medio Ambiente y Recursos Naturales, Programa Nacional de Medio Ambiente y Recursos Naturales 2001-2006, México, 2001, p. 27. Las aproximaciones que se tienen sobre el tema irremediablemente varían.

34 Instituto Nacional de Estadística, Geografía e Informática, op. cit., nota 15, pp. 69 y 70 . 
Esta obra forma parte del acervo de la Biblioteca Jurídica Virtual del Instituto de Investigaciones Jurídicas de la UNAM

sólo algunas de ellas: ingente flujo comercial a través de importación y exportación de mercancías, derrama de divisas extranjeras, inversión turística, ingresos por concepto de contribuciones para el gasto público, extracción de minerales, comunicaciones y transportes, generación de energía, pesca, acuacultura, pastoreo y silvicultura.

b) Importancia social. Representan estas zonas un espacio para una gran cantidad de manifestaciones artísticas, culturales, deportivas y científicas. Es así que se desarrollan presentaciones teatrales, cinematográficas, festivales de danza, carnavales, conciertos de música, concursos y eventos recreativos, torneos y campeonatos deportivos, congresos o seminarios científicos. Son, asimismo, lugares de diversidad cultural donde aún se asientan comunidades indígenas y en los que a la vez se localiza un patrimonio arqueológico e histórico invaluables. Desde un punto de vista sociopolítico son áreas estratégicas y de seguridad nacional. Lamentablemente, son también zonas para el tráfico de órganos, droga, indocumentados, etcétera.

c) Importancia ambiental. Fundamental para la viabilidad de nuestro país (su medio natural y su medio construido) es lo que ocurre y lo que significan las zonas costeras. Son el hábitat de todo tipo de flora y fauna (terrestre y acuática), hábitat también de especies endémicas, ahí se encuentran centros de reproducción de especies migratorias y por tanto son lugares de una enorme diversidad biológica con un vasto patrimonio genético, se localizan también bosques y aguas (continentales o dulces, salobres y marinas), proveen de servicios ambientales como el paisaje, y mantienen y permiten la continuidad de los ciclos hidrológico y climático.

Enfatizamos que el gran reto o dilema, a la vez que oportunidad, con la que se debieran percibir (y regular) nuestras zonas costeras, consiste en la combinación de estos tres pilares del desarrollo sustentable. En otras palabras, de nada serviría al país fortalecer las actividades económicas y fomentar las actividades sociales si éstas generan - los ya de por sí muy evidentes - altos niveles de contaminación y degradación ambientales y sobreexplotación de recursos naturales (costeros y marinos). ${ }^{35}$ De tal

35 En este sentido, y a propósito de un análisis sobre la gestión de la zona costera en España, Mercedes Ortiz García señala que al caracterizarse esta zona por una intensa actividad humana y una gran riqueza ecológica se hace imprescindible algo que deno- 
Esta obra forma parte del acervo de la Biblioteca Jurídica Virtual del Instituto de Investigaciones Jurídicas de la UNAM

manera, que cualquier intento por diseñar una estrategia jurídica para una gestión integral de la zona costera deberá tomar en cuenta los espacios terrestre y marino (incluyendo los espacios por encima y por debajo de ellos), a la vez que encontrar un punto de equilibrio entre factores económicos, sociales y ambientales.

\section{Legislación}

Como bien señalan Donna R. Christie y Richard G. Hildreth, ${ }^{36}$ las interacciones naturales de los espacios terrestre y marino y sus recursos naturales son complejas, y por lo tanto producen consecuencias legales igual de complicadas. Esto ha provocado que se generen conflictos jurídicos de todo tipo, relacionados con derechos de propiedad (públicos vs. privados) y con la asignación de competencias y atribuciones entre entes públicos. Toda esta situación es aún más confusa y problemática si estamos, como en el caso de México, ante la presencia de un mare mágnum de leyes, reglamentos, acuerdos, decretos, normas oficiales mexicanas y demás normatividad administrativa federal, estatal y municipal que se entrelazan, yuxtaponen e incluso contradicen. Esta situación de dispersión legislativa ha generado en muchas ocasiones una verdadera sobreregulación ${ }^{37}$ para el uso, ocupación y aprovechamiento de estos bienes públicos, creando costos innecesarios e incertidumbre jurídica a los particulares. Intricado es pues identificar la participación de diversas dependencias del Ejecutivo Federal (y de los estados y los municipios) en el ámbito de sus respectivas competencias y el cuerpo legal que habrá de aplicarse (y que habrá de prevalecer frente a los demás cuerpos legales) según el supuesto jurídico del que se trate.

Lamentablemente, nuestra carta magna no establece de manera expresa la regulación de las zonas costeras, ni como concepto ni en su con-

mina una relación fluida entre el uso antrópico y el medio natural que ahí se desarrolla. Para lograr un desarrollo armónico y sustentable es necesario según afirma, diseñar una estrategia coordinada de los aspectos económicos, sociales, ecológicos, etcétera. García Ortiz, Mercedes, La gestión eficiente de la zona costera. Los parques marinos, Valencia, Tirant lo Blanch, 2003, pp. 32 y 33.

36 Christie, Donna R. y Hildreth, Richard G., Coastal and Ocean Management Law, 2a. ed., St. Paul, West Group, 1999, p. 1.

37 Compartimos en este mismo sentido la opinión de Cortina Segovia, Sofía y Quiñones Valadez, Leticia, op. cit., nota 30, p. 79. 
Esta obra forma parte del acervo de la Biblioteca Jurídica Virtual del Instituto de Investigaciones Jurídicas de la UNAM

junto. Tampoco lo hace nuestra legislación, pues no se encuentra la expresión zonas costeras regulada de manera integral. En todo caso, nos encontramos frente a una legislación dispersa que regula de manera separada ciertos espacios o porciones (como es el caso de los humedales mencionados) de lo que conforma el concepto de zona costera.

Las ventiún leyes que consideramos más importantes de aplicación directa o indirecta en las zonas costeras (agregando la porción marina) son:

— Ley Orgánica de la Administración Pública Federal.

- Ley de Planeación.

- Ley General de Bienes Nacionales.

- Ley General del Equilibrio Ecológico y la Protección al Ambiente.

- Ley General de Desarrollo Forestal Sustentable.

- Ley General de Vida Silvestre.

- Ley de Aguas Nacionales.

- Ley General para la Prevención y Gestión Integral de los Residuos.

- Ley de Bioseguridad de Organismos Genéticamente Modificados.

- Ley de Pesca.

- Ley de Puertos.

- Ley de Navegación.

- Ley Federal del Mar.

- Ley Minera.

- Ley Federal de Turismo.

- Ley Federal sobre Monumentos y Zonas Arqueológicos, Artísticos e Históricos.

- Ley General de Asentamientos Humanos.

- Ley Federal de Vivienda.

- Ley de Desarrollo Rural Sustentable.

- Ley Federal de Derechos.

- Ley sobre la Celebración de Tratados.

Es fundamental señalar que todas estas leyes cohabitan con leyes estatales y con la legislación municipal; por si fuera poco, lo hacen también con planes y programas federales, estatales y municipales. 
Esta obra forma parte del acervo de la Biblioteca Jurídica Virtual del Instituto de Investigaciones Jurídicas de la UNAM

\section{Administración pública}

Según la Ley Orgánica de la Administración Pública Federal corresponde a la Secretaría de Medio Ambiente y Recursos Naturales ejercer la posesión y propiedad de la nación en las playas (marítimas), la zona federal marítimo terrestre y los terrenos ganados al mar (artículo 32-bis, fracción VIII). A su vez, la LGBN considera a dicha secretaría como una dependencia administradora de inmuebles (que son definidos por la propia ley como terrenos con o sin construcciones de la Federación, así como aquéllos en que ejerza la posesión, control o administración a título de dueño). Debido al gran número de actividades que se realizan en las zonas costeras, intervienen en ellas en menor o mayor medida al menos trece secretarías de Estado, incluyendo, desde luego, a la del medio ambiente y recursos naturales:

- Secretaría de Medio Ambiente y Recursos Naturales.

- Secretaría de Gobernación.

- Secretaría de Educación Pública.

- Secretaría de Comunicaciones y Transportes.

- Secretaría de Turismo.

- Secretaría de Marina.

- Secretaría de Hacienda y Crédito Público.

- Secretaría de Energía.

- Secretaría de Agricultura, Ganadería, Desarrollo Rural, Pesca y Alimentación.

- Secretaría de Economía.

- Secretaría de Desarrollo Social.

- Secretaría de la Función Pública.

- Secretaría de Relaciones Exteriores.

También participan organismos públicos descentralizados como Petróleos Mexicanos, la Comisión Federal de Electricidad o la Comisión Nacional Forestal, y órganos desconcentrados como la Comisión Nacional del Agua o el Instituto Nacional de Antropología e Historia. 
Esta obra forma parte del acervo de la Biblioteca Jurídica Virtual del Instituto de Investigaciones Jurídicas de la UNAM

A esta amalgama de dependencias, organismos y órganos federales, se unen diecisiete estados costeros distribuidos en las vertientes arriba mencionadas:

- Baja California.

- Baja California Sur.

- Campeche.

- Chiapas.

- Colima.

- Guerrero.

- Jalisco.

- Michoacán.

- Nayarit.

- Oaxaca.

- Quintana Roo.

- Sinaloa.

- Sonora.

- Tabasco.

- Tamaulipas.

- Veracruz.

- Yucatán.

A dependencias, entidades del Ejecutivo Federal y a entidades federativas, se unen de igual manera 166 municipios costeros y la participación de los sectores social y privado.

\section{NOTA QUE IDENTIFICA DOS PROCESOS PRIVATIZADORES: CONCESIONES Y DESINCORPORACIONES}

Identificamos al menos seis actos administrativos que realiza la dependencia del Ejecutivo Federal — la Semarnat—, encargada por ley de ejercer la posesión y propiedad de la nación en las playas marítimas, la zona federal marítimo terrestre y los terrenos ganados al mar para el uso y aprovechamiento de las zonas costeras. Éstos son: i) las concesiones; ii) los permisos (o autorizaciones); iii) los acuerdos de destino; iv) los acuerdos 
Esta obra forma parte del acervo de la Biblioteca Jurídica Virtual del Instituto de Investigaciones Jurídicas de la UNAM

administrativos de desincorporación; $v$ ) los acuerdos intersecretariales, y vi) los convenios de colaboración o coordinación y de concertación.

De estas seis maneras en las que la administración pública federal expresa su voluntad dirigida a producir efectos de derecho, se identifican principalmente a las concesiones y a las desincorporaciones como parte de un proceso de privatización de las zonas costeras en el país. ${ }^{38}$ Como dijimos al principio de este artículo, las primeras se refieren a una actividad, que es el uso y aprovechamiento (o explotación) de bienes del dominio público de la Federación, y las segundas a un acto de enajenación de dichos bienes.

\section{Concesiones}

La reina de todos los actos administrativos en las zonas costeras de México es la concesión administrativa. Lo es así por el número que se otorga a particulares y por las extensiones territoriales que abarcan para el uso, aprovechamiento o explotación de ciertos bienes sujetos al dominio público de la Federación.

Las concesiones se definen como actos que crean en un particular el derecho para explotar un bien propiedad del Estado, con una prestación a favor de éste. ${ }^{39}$ Es claro que el concesionario particular no adquiere la propiedad del bien concesionado, simplemente se crea a su favor un derecho para realizar una actividad que consiste en usar, aprovechar o explotar bienes inmuebles que están sujetos al régimen de dominio público de la Federación. La contraprestación común que recibe el Estado es el pago de derechos correspondientes. Si bien las concesiones no crean derechos reales a favor de los concesionarios, éstos podrán obtener de la secretaría otorgante - en este caso la Semarnat - autorización, tanto para dar en arrendamiento o comodato fracciones de los bienes inmuebles concesionados, como para ceder los derechos y obligaciones derivados de las propias concesiones.

38 Desde luego, forman parte de un acto de privatización según lo hemos referido anteriormente, los convenios de concertación que se celebren con el sector privado. En esta ocasión sólo analizamos concesiones y desincorporaciones.

39 Nava Negrete, Alfonso, op. cit., nota 1, p. 383. Recordamos que las concesiones no sólo se otorgan para la explotación de un bien público, sino también para la prestación de servicios públicos. 
Esta obra forma parte del acervo de la Biblioteca Jurídica Virtual del Instituto de Investigaciones Jurídicas de la UNAM

La mera solicitud de un particular para que se le otorgue una concesión con todo y que reúna los requisitos previstos para ello, según lo establecido en la LGBN y su reglamento o en las leyes específicas respectivas, no obliga por ese solo hecho a la Semarnat a otorgar el título de concesión. Debemos insistir en que el otorgamiento de las concesiones es potestativo, no obligatorio. En este sentido, es más que contundente el artículo 72 de la LGBN en su primer párrafo:

Artículo 72. Las dependencias administradoras de inmuebles podrán otorgar a los particulares derechos de uso o aprovechamiento sobre los inmuebles federales, mediante concesión, para la realización de actividades económicas, sociales o culturales, sin perjuicio de leyes específicas que regulen el otorgamiento de concesiones, permisos o autorizaciones sobre inmuebles federales. ${ }^{40}$

Para el otorgamiento de las concesiones, la Semarnat deberá atender una serie de requisitos establecidos por la LGBN, entre los que se encuentran el que no sea posible o conveniente que emprenda ella misma la explotación directa de los bienes inmuebles respectivos. El hecho de que esta dependencia del Ejecutivo Federal decida no explotar el bien inmueble del que se trate por no ser posible o conveniente, no significa que tenga la obligación de otorgar la concesión a un particular. De aquí se desprende que si la secretaría otorga concesiones para el uso y aprovechamiento de zona federal marítimo terrestre y terrenos ganados al mar, es porque ha decidido (pues nadie la obliga) abandonar su actuar público respecto de estos bienes y dejar dicha actividad a los particulares; es decir, hace de una actividad pública una actividad privada, que es el uso y aprovechamiento (o explotación) por particulares de ciertas superficies de la zona costera.

El abandono de la actividad pública que se manifiesta a través del otorgamiento de títulos de concesión se acompaña de otras resoluciones administrativas, tales como las prórrogas, las cesiones de derechos y obligaciones, las modificaciones a las bases y condiciones de las concesiones, o los derechos de preferencia o de prelación. Desde luego, las concesiones y sus resoluciones administrativas podrán, según corresponda, estar sujetas al rescate, negativa o extinción de las mismas.

40 Énfasis del autor para destacar la naturaleza potestativa en el otorgamiento de concesiones. 
Esta obra forma parte del acervo de la Biblioteca Jurídica Virtual del Instituto de Investigaciones Jurídicas de la UNAM

Las estadísticas que se reportan mes con mes respecto al otorgamiento de concesiones, permite darnos una idea del grado de privatización de nuestras zonas costeras a través de estos actos administrativos. Tomamos como ejemplo información disponible relativa sólo a seis meses (de abril a septiembre) de 2005, puesto que un estudio más amplio y comparado de los últimos años rebasa, con mucho, el espacio con el que contamos en este artículo.

Sólo por nuevos títulos de concesión (sin contar prórrogas, cesiones de derechos y obligaciones, o modificación a las bases) se contabilizan para este periodo más de 500 resoluciones otorgadas; el mes en el que mayor número de nuevas concesiones se otorgaron en este periodo - junioabarcó casi 3 millones de metros cuadrados de superficie, mientras que el de menor número - agosto - abarcó más de 250 mil metros cuadrados de superficie (véase tabla 1).

\section{TABLA 1}

Títulos de concesión (de abril a septiembre de 2005)

\begin{tabular}{|c|c|c|c|}
\hline Mes & Concesiones: 579 & Volumen & Superficie (m2) \\
\hline Abril & 97 & & \\
\hline Mayo & 109 & & \\
\hline Junio & 162 & Mayor & 2788994 \\
\hline Julio & 102 & & \\
\hline Agosto & 47 & Menor & 260500 \\
\hline Septiembre & 62 & & \\
\hline
\end{tabular}

Fuente: Dirección General de Zona Federal Marítimo Terrestre y Ambientes Costeros, 2005.

El número de concesiones y de metros cuadrados de superficie no depende de algún parámetro preestablecido por la Semarnat. Es decir, en un mes se pueden identificar mayor número de concesiones, con las superficies más grandes pero también con las superficies más pequeñas, y viceversa, en un mes se pueden identificar superficies enormes o verdaderamente insignificantes pero con un número reducido de concesiones.

Esta variabilidad se observa en el periodo analizado. Retomamos los ejemplos de los meses con mayor y menor número de concesiones. En 
Esta obra forma parte del acervo de la Biblioteca Jurídica Virtual del Instituto de Investigaciones Jurídicas de la UNAM

efecto, en el mes de mayor número de concesiones (junio) se otorgaron las concesiones de mayor y de menor extensión en metros cuadrados en comparación al de menor número de concesiones (agosto). Así, en el mes de junio se otorgó un nuevo título de concesión a favor de Crustamar, SCL, en el municipio de Elota, Sinaloa, con la superficie de 1408868.35 metros cuadrados y con una vigencia de quince años para uso de acuacultura, y un nuevo título de concesión a favor de José Julián y/o David Martínez y/o Martínez Cruz y/o Cruz en el municipio de Acapulco de Juárez, Guerrero, con la superficie de 5.84 metros cuadrados y con una vigencia de quince años para uso de local comercial para la venta de artesanías en general y cocteles de frutas tropicales. En tanto que en agosto se otorgó un nuevo título de concesión a favor de Desarrollo Marina Vallarta, S. A. de C. V. en el municipio de Puerto Peñasco, Sonora, con la superficie de 106529.23 metros cuadrados y con una vigencia de quince años para uso de ornato, y un nuevo título de concesión a favor de Mario Enrique Hernández Aguilar en el municipio de Ciudad Madero, Tamaulipas, con la superficie de 18.38 metros cuadrados, con una vigencia de quince años para uso de venta de artesanías y artículos de playa. ${ }^{41}$

\section{Desincorporaciones}

Se les conocía como decretos presidenciales de desincorporación antes de la entrada en vigor (en mayo de 2004) de la vigente LGBN; ahora son acuerdos administrativos de desincorporación. Aquéllos tenían la distintiva característica de que la decisión última para desincorporar un bien sujeto al dominio público de la Federación y autorizar su enajenación recaía en el primer burócrata de la administración pública: el titular del Ejecutivo Federal. En cambio, ahora quien decide si se desincorporan y autorizan para su enajenación es el titular de la dependencia: se trata de un verdadero acuerdo secretarial.

El cambio de un decreto presidencial a un acuerdo secretarial se sustenta en el "absurdo" argumento de pretender simplificar los trámites para llevar a cabo el acto de desincorporación y autorización para la enajenación correspondiente, tal y como se desprende de la lectura de la ex-

41 Esta información está disponible en la página de Internet de la Dirección General de Zona Federal Marítimo Terrestre y Ambientes Costeros, a la que se llega por la dirección electrónica: http://portal.semarnat.gob.mx. 
Esta obra forma parte del acervo de la Biblioteca Jurídica Virtual del Instituto de Investigaciones Jurídicas de la UNAM

posición de motivos de la iniciativa de la LGBN presentada por el Ejecutivo Federal ante la Cámara de Diputados el 14 de diciembre de 2002.42 En efecto, el razonamiento de los creadores de esta ley para utilizar ahora acuerdos secretariales en lugar de decretos presidenciales se fundamenta en motivos de simplificación administrativa. Razonamiento que es ilógico e incomprensible, puesto que básicamente se elimina con la nueva ley - como si esto hubiera excesivamente alargado o complicado una desincorporación - la opinión de la Consejería Jurídica de la Presidencia para determinar si procede o no dicho acto. Lo que creemos subyace en esta reforma, es abrir las puertas para una fácil y expedita privatización de bienes inmuebles y evitar el desgaste político del presidente de la República de ser acusado con la frase popular de ser un "vende patrias". El foco de atención se traslada así al titular de la Semarnat en turno.

En las zonas costeras, el único bien que está sujeto por ley a que se desincorpore del régimen del dominio público de la Federación y se autorice su enajenación, son los terrenos ganados al mar. La LGBN señala que los bienes inmuebles podrán ser enajenados (previa desincorporación del régimen de domino público) cuando no sean útiles para destinarlos a un servicio público o no sean de uso común. El hecho de que los terrenos ganados al mar se encuentren en el supuesto jurídico de no considerarse por ley bienes de uso común y que además la Semarnat determine que estos no son susceptibles de destinarse preferentemente a la prestación de servicios públicos, no significa que deba procederse a su desincorporación y enajenación a particulares. Los terrenos ganados al mar pueden desincorporarse o no y, al igual que la zona federal marítimo terrestre, pueden concesionarse o no. Establece claramente el segundo párrafo del artículo 124 de la LGBN lo siguiente:

Artículo 124. Sólo podrán realizarse obras para ganar artificialmente terrenos al mar...

A la Secretaría de Medio Ambiente y Recursos Naturales corresponderá la posesión, delimitación, control y administración de los terrenos ganados al mar, debiendo destinarlos preferentemente para servicios públicos, atendiendo a las disposiciones de esta ley y sus reglamentos. Sin embargo, cuando sea previsible que no se requieran para la prestación de servicios públicos, podrán desincorporarse del régimen de dominio público de la

42 Véase para mayor detalle, Secretaría de la Función Pública, Ley General de Bienes Nacionales, México, julio de 2004, pp. 13 y 24. 
Esta obra forma parte del acervo de la Biblioteca Jurídica Virtual del Instituto de Investigaciones Jurídicas de la UNAM

Federación para disponer de ellos conforme a lo señalado en los artículos 84 y 95 de esta ley. ${ }^{43}$

Utilizamos el mismo razonamiento que para las concesiones: las desincorporaciones son actos potestativos, no obligatorios. Esto es, aunque la LGBN establezca la posibilidad de que los terrenos ganados al mar puedan desincorporarse, no se traduce en que exista la obligación por parte de la Semarnat para hacerlo y luego autorizar su enajenación. Cuando se ganen terrenos al mar ya sea por causas naturales (como huracanes) o por causas artificiales (rellenos, rompeolas o marinas), esta secretaría decidirá si procede o no a desincorporarlas tomando en cuenta, como ya hemos señalado, que estos terrenos no sean susceptibles a la prestación de servicios públicos, y que además determine la conveniencia de llevar a cabo la enajenación. Luego, si la secretaría decide (pues nadie la obliga) desincorporar los terrenos ganados al mar del dominio público de la Federación y autorizar su enajenación a particulares, es porque ha querido o determinado pasar la propiedad de un bien que es público a manos privadas.

Quienes tienen un derecho de preferencia para adquirir terrenos ganados al mar (o según el caso, para que se les concesione), son aquellos particulares que tengan concesionada la superficie que ha dejado de ser zona federal marítimo terrestre. Para los casos en los que el particular cuente con una concesión para la construcción y operación de una marina o granja acuícola y solicite a la secretaría la enajenación de los terrenos ganados al mar, en caso de que dicha dependencia desincorpore y autorice la enajenación de terrenos ganados al mar, ésta será a título oneroso a favor del solicitante. Antes de que entrara en vigor la vigente LGBN de 2004 existía la duda de si a dicha solicitud de desincorporación y su respectiva autorización para enajenación debía dársele trámite una vez concluidas las obras respectivas; sin embargo, la nueva ley facilitó a los particulares la adquisición de estos bienes inmuebles al establecer que la solicitud (y debe por tanto entenderse que su tramitación respectiva) podrá presentarse antes o durante la construcción y operación de la marina o granja de que se trate.

Durante los primeros años del sexenio del licenciado Vicente Fox - periodo en el que todavía era vigente la anterior LGBN de 1982no se expidió ni uno de los entonces decretos presidenciales de desin-

43 Énfasis del autor para destacar la naturaleza potestativa de las desincorporaciones. 
Esta obra forma parte del acervo de la Biblioteca Jurídica Virtual del Instituto de Investigaciones Jurídicas de la UNAM

corporación. A partir de la entrada en vigor de la LGBN de 2004 (que abrogara a su homóloga de 1982), y ya como titular de la Semarnat el ingeniero Alberto Cárdenas Jiménez — quien substituyera en su cargo al licenciado Víctor Lichtinger Waisman (de diciembre de 2000 a septiembre de 2003) - , se inició el proceso de privatización de los terrenos ganados al mar a través de enajenaciones a particulares. Proceso que por cierto ha continuado con el tercer secretario designado al frente de esta secretaría en menos de cinco años de gobierno foxista: el ingeniero José Luis Luege Tamargo, quien sustituyó a Cárdenas Jiménez en junio de 2005.

El falso argumento de la simplificación administrativa para sustituir a los decretos presidenciales por los acuerdos secretariales, ha logrado su objetivo principal: tener una forma ágil de privatizar una porción importante de las zonas costeras en México. En efecto, sólo en los primeros nueve meses de este año (de enero a septiembre de 2005) se han expedido once acuerdos por los que se desincorpora del régimen del dominio público de la Federación diversas superficies de terrenos ganados al mar (estero y/o laguna) con autorización para enajenarlos a título oneroso a particulares.

Estas superficies desincorporadas suman casi un total de 350000 metros cuadrados (véase tabla 2). Las dos porciones territoriales más extensas corresponden, primero, a una superficie de 157595.75 metros cuadrados de terrenos ganados al Estero Veinticinco (así como sus instalaciones y construcciones) ubicados en un lugar conocido como predio Higueras de Abuya, cerca de la población de Nicolás Bravo, frente al Estero Veinticinco (Agua Amarga), municipio de Culiacán, Sinaloa, a favor de Cimarrón Paraíso Natural, S. C., para que la continúe utilizando como Centro de Investigación y Aprovechamiento del Recurso Fauna Silvestre, y segundo, a una superficie de 123276.02 metros cuadrados de terrenos ganados al mar (así como sus instalaciones y construcciones) ubicados en el predio conocido como La Salina, municipio de Ensenada, Baja California, a favor de Banco Mercantil del Norte, S. A., Institución de Banca Múltiple, Grupo Financiero Banorte, Institución Fiduciaria del Fideicomisario "B" Puerto Salina, S. A. de C. V., para que se utilice como un desarrollo náutico turístico residencial. La más pequeña porción de estas desincorporaciones corresponde a una superficie de 124.53 metros cuadrados de terrenos ganados al mar (así como sus instalaciones y construcciones) ubicados frente al boulevar costero Lázaro Cárdenas, local 3 del 
Esta obra forma parte del acervo de la Biblioteca Jurídica Virtual del Instituto de Investigaciones Jurídicas de la UNAM

lote 7, manzana 1, sección primera del centro comercial y turístico Todos Santos, S. A., municipio de Ensenada, Baja California, a favor de Antojitos Peninsulares de Baja California, S. A. de C. V., con el objeto de que la utilice para servicios turísticos recreativos. ${ }^{44}$

TABLA 2

Acuerdos de desincorporación (de enero a septiembre de 2005)

\begin{tabular}{|c|c|c|c|}
\hline Estado & Municipio & Superficie (m2) & Objeto \\
\hline Baja California & Ensenada & 124.53 & $\begin{array}{c}\text { Servicios turísticos } \\
\text { recreativos }\end{array}$ \\
\hline Baja California & Ensenada & 229.04 & $\begin{array}{l}\text { Local comercial/ } \\
\text { estacionamiento }\end{array}$ \\
\hline Baja California & Ensenada & 724.53 & Restaurante \\
\hline Baja California & Ensenada & 123276.02 & $\begin{array}{l}\text { Desarrollo náutico- } \\
\text { turístico residencial }\end{array}$ \\
\hline Baja California Sur & Loreto & 9164.03 & Protección \\
\hline Campeche & Ciudad del Cármen & 8229.11 & $\begin{array}{c}\text { Taller, oficina y } \\
\text { patio de maniobras }\end{array}$ \\
\hline Nayarit & San Blas & 400.00 & $\begin{array}{l}\text { Casa-habitación/ } \\
\text { venta artesanías }\end{array}$ \\
\hline Nayarit & San Blas & 400.00 & Casa-habitación \\
\hline Quintana Roo & Benito Juárez & 1505.45 & Estacionamiento \\
\hline Quintana Roo & Benito Juárez & 47181.57 & $\begin{array}{c}\text { Actividades } \\
\text { turísticas }\end{array}$ \\
\hline Sinaloa & Culiacán & 157595.75 & $\begin{array}{l}\text { Investigación y } \\
\text { aprovechamiento }\end{array}$ \\
\hline
\end{tabular}

Fuente: Diario Oficial de la Federación, diversas fechas, 2005.

Por último, es importante señalar que aun cuando el número y la cantidad de metros cuadrados por superficie que se desincorpora no pareciera significativa, si se compara con el número de concesiones otorgadas o

44 Curiosamente, estos tres ejemplos de los once aquí citados pueden ubicarse en el mismo Diario Oficial de la Federación del 12 de enero de 2005. 
Esta obra forma parte del acervo de la Biblioteca Jurídica Virtual del Instituto de Investigaciones Jurídicas de la UNAM

con la superficie de zona federal marítimo terrestre concesionada, sorprende que en tan poco tiempo se hayan enajenados ya estas porciones de tierra a particulares.

\section{NOTA QUE CONCLUYE Y SE PREGUNTA: LEGISLAR Y PRIVATIZAR, ¿ES ESA LA CUESTIÓN?}

Dos reflexiones finales. La primera tiene que ver con la necesidad o no de contar con una ley específica en materia costera (e. g. ley de costas o ley de zonas costeras); la segunda, con la de examinar si queremos o no, si nos conviene o no, privatizar nuestras zonas costeras.

\section{1. ¿Ley de costas?}

Hemos insistido en varios foros de discusión — burocráticos y universitarios - sobre la necesidad de contar con una ley en esta materia. La razón principal es muy simple y peca de obviedad: se requiere de una regulación integral, sistematizada y coherente de las zonas costeras en este país. Esto no quiere decir que sea sencillo de lograr. Quizá los tres retos a los que nos enfrentamos con semejante aseveración sean los siguientes:

a) Desinterés y apatía: aquél adjetiviza perfectamente al Ejecutivo Federal, ésta lo hace de la misma manera al Congreso de la Unión. Es necesario que ambos poderes lleven al más alto nivel de sus agendas políticas la necesidad y la conveniencia de crear una ley costera. La iniciativa de Ley de Zonas Costeras presentada ante la Cámara de Diputados el 6 de octubre de 2005 no es precisamente el mejor ejemplo de lo que se desea para regular las zonas costeras. Sólo tres aspectos de la ley evidencian su desaseo: primero, se omite señalar qué dependencia del Ejecutivo Federal será la encargada de realizar los actos administrativos sobre un nuevo concepto de zonas costeras (como convenios de colaboración o acuerdos de destino, a los que por cierto ignora). En este sentido, la iniciativa de ley establece la creación de una Unidad Técnica de Zonas Costeras dependiente de la Semarnat, pero no especifica su naturaleza jurídica y mucho menos establece si será ésta la competente para la emisión de actos de autoridad. Segundo, se ignora por completo la nueva situación patri- 
Esta obra forma parte del acervo de la Biblioteca Jurídica Virtual del Instituto de Investigaciones Jurídicas de la UNAM

monial (incluyendo terminología) de los bienes inmuebles regulados por la vigente LGBN, de la que no se hace mención alguna. Tercero, en ninguno de sus artículos transitorios (a los que por cierto denomina incorrectamente disposiciones transitorias) señala si se derogan o no todas aquellas disposiciones que se opongan a lo que establece esa ley, como tampoco señala si, en tanto se expide el o los reglamentos y demás disposiciones derivadas de la misma, se continuarán aplicando las disposiciones reglamentarias (como es el caso del Ruazofemat) y administrativas vigentes en lo que no se opongan a ella.

b) Dispersión normativa: tarea de romanos será armonizar en una sola ley la legislación que actualmente se aplica; sin embargo, no se requiere de una ley extensa y con ello abrumar y confundir a los gobernados. No se trata de diseñar una ley más a las ya existentes, sino de hacerla lógica, comprensible e integral, enfocándose desde luego a resolver la yuxtaposición de competencias entre entes públicos y determinar con claridad, en su caso, las atribuciones que la ley otorgará a estados y municipios.

c) Oscilación de prioridades: hay quienes dan mayor importancia a lo económico, otros a lo social, otros a lo ambiental. Hermanar a estos tres aspectos es intentar alcanzar la sustentabilidad en el desarrollo de una zona llena de oportunidades para el país. Las leyes no son perfectas, son perfectibles. Una ley para el manejo integral de las zonas costeras en el país no resolvería todos los problemas que se presentan en nuestro litoral pero sí facilitaría la resolución de acertijos y dilemas actuales.

\section{Privatizar o no privatizar, ¿es esa la cuestión?}

Si dicha pregunta no figura en el debate político y/o legislativo, habrá que incluirla. No es la única cuestión a discutir, pero debe advertirse que la tendencia de la regulación existente es la de privatizar estas zonas. Entonces, debemos reflexionar en lo siguiente:

a) Abandono de actividades. Es verdad que el Estado no puede intervenir en todas las actividades que puedan desarrollarse para el uso y aprovechamiento de playas marítimas, zona federal marítimo terrestre y terrenos ganados al mar. Sería absurdo sugerir que actividades 
Esta obra forma parte del acervo de la Biblioteca Jurídica Virtual del Instituto de Investigaciones Jurídicas de la UNAM

como las que llevan palaperos o vendedores de artesanías sobre bienes costeros no fueran susceptibles de concesionarse. Por la misma razón, sería absurdo pensar que el Estado no puede o no debe llevar a cabo actividades para el uso y aprovechamiento de las zonas costeras y destinarlas a servicios públicos u ocuparse de ellas por razones de interés público. Si bien es enorme el número de ocupaciones irregulares en nuestras zonas costeras, esto no es justificación para que la Semarnat otorgue a diestra y siniestra concesiones. Ayudarse o auxiliarse del sector privado no es malo, al contrario, en muchas ocasiones es deseable y necesario. Sin embargo, se percibe la falta de una política nacional costera que pudiera establecer claramente la labor pública de quien ejerce la posesión y la propiedad de la nación en estas zonas. Dejar en el olvido la regulación, por ejemplo, de formaciones rocosas y acantilados, es una forma de aceptar sin más la participación de particulares y una forma de hacer patente el desgobierno ocasionado por la falta de rumbo hacia una sustentabilidad costera.

b) Enajenación de bienes. Los bienes públicos no son mercancías que debieran someterse al mejor postor. Nos cuestionamos ¿el Estado no puede ejercer la posesión y propiedad de ciertos bienes y por eso vende? ¿no será que el Estado ya no quiere ejercer dicha posesión y propiedad y por eso vende? Permitir que los sectores privado y social intervengan en las zonas costeras para su uso y aprovechamiento sustentable no significa que el Estado tenga que dejar de ser propietario de sus bienes. Si nada garantiza que el Estado sepa usar y aprovechar mejor o explotar playas marítimas, zona federal marítimo terrestre y terrenos ganados al mar (tomando en cuenta ambientes costeros y formaciones rocosas y acantilados) tampoco lo es que el particular sí lo sepa hacer. En principio, pensamos que no existe justificación económica, social o ambiental suficientes para que los terrenos ganados al mar se desincorporen de su régimen de dominio público y se enajenen a particulares. Hay numerosísimos ejemplos de cómo los particulares han podido invertir, luego llevar a cabo sus actividades de lucro, y por lo tanto, recuperar su inversión y más, sin necesidad de que sean propietarios de estos bienes. Por lo que no es el Estado quien debe preocuparse por encontrar razones de peso o justificaciones éticas o sustentables para no llevar 
Esta obra forma parte del acervo de la Biblioteca Jurídica Virtual del Instituto de Investigaciones Jurídicas de la UNAM

a cabo dichas enajenaciones; en todo caso, es el sector privado - es decir, los interesados en comprar- quien debe encontrar razones suficientes para justificar el porque sí habría que enajenar éstos u otros bienes. Habrá que recordar que ahí donde hay bienes, hay patria (ubi bene, ibi patria).

\section{NOTA QUE ES ADICIONAL A LA NOTA QUE CONCLUYE}

Inicié este trabajo con una cita, lo acabo con otra. Se trata ahora del último párrafo de un artículo intitulado "Un hogar... mi biblioteca", publicado el 22 de junio de 1956 - hace casi cincuenta años-. Gracias a la relación y la intimidad familiar, sabemos que ese es el primer artículo de a quien ahora se le rinde homenaje:

¡Imaginación sublime y conciencia plena de grandezas y maravillas son necesarias para comprender que, desde este hogar tapizado de libros y horizontes se contempla a la naturaleza en absoluto reposo, que sin mirar su belleza y sin tocar su rostro se siente el influjo divino de su presencia!

Por tus cuarenta y cinco años de docencia, querido maestro, tu hijo te felicita. Enhorabuena. 
Esta obra forma parte del acervo de la Biblioteca Jurídica Virtual del Instituto de Investigaciones Jurídicas de la UNAM

\section{PALABRAS DE RECONOCIMIENTO AL DOCTOR HÉCTOR FIX-ZAMUDIO POR SUS CINCUENTA AÑOS DE LABOR CIENTÍFICA (1956-2006)*}

\section{Estimado doctor Héctor Fix-Zamudio:}

Quisiera confesarle que no soy un asiduo lector de haikus (forma poética originariamente japonesa compuesta comúnmente de sólo 17 sílabas y con severa pauta silábica, 5-7-5). Pero sí lo soy en cambio de la obra del nostálgico y en ocasiones festivo escritor uruguayo Mario Benedetti a quien debo mi limitadísimo conocimiento de tan singular poesía oriental. En un intento por latinoamericanizar lo primigeniamente japonés, Benedetti escribe sus propios haikus y se aventura a publicar hacia finales del milenio anterior (puntualmente en 1999) la obra Rincón de haikus. El poeta y también cuentista uruguayo inicia su obra con una frase que pertenece a Matsuo Bashoo (1644-1694), maestro y creador de haikus, y que ahora me permito reproducirla por considerarla apropiada en ocasión de sus 50 años como investigador jurídico: "No sigas las huellas de los antiguos busca lo que ellos buscaron".

Admito que me tomó por sorpresa la atenta invitación del doctor Eduardo Ferrer Mac-Gregor a participar en una obra colectiva que ha de recoger ensayos sobre diversos aspectos de una disciplina en la que no soy un especialista, el derecho procesal constitucional. Al recibir la invitación y leerla con cuidado, me percaté que la gran mayoría de los temas sugeridos para elaborar un trabajo con ese objetivo guardan una considerable distancia con los temas (fundamentalmente sustantivos y no adjetivos) de la disciplina jurídica a la cual me he dedicado desde hace

* Publicado en Ferrer Mac-Gregor, Eduardo y Zaldívar Lelo de Larrea, Arturo (coords.), La ciencia del derecho procesal constitucional. Estudios en homenaje a Héctor Fix-Zamudio en sus cincuenta años como investigador del derecho, México, Marcial Pons-Instituto Mexicano de Derecho Procesal Constitucional-UNAM, Instituto de Investigaciones Jurídicas, 2008, t. I. 
Esta obra forma parte del acervo de la Biblioteca Jurídica Virtual del Instituto de Investigaciones Jurídicas de la UNAM

ya algunos años tanto por la vía de la práctica profesional como servidor público, como por la de la gratificante carrera docente y la estimulante actividad de la investigación: el derecho ambiental. El palmario hecho (que no por mera casualidad) de mi circunstancia ius-ambientalista, me llevó a reflexionar lo siguiente: ¿en qué se vincularán el debido proceso constitucional con el eco-etiquetado de productos transgénicos? ¿cuál será la cercanía entre el análisis jurídico de las pruebas en los procesos constitucionales y el de la emisión de bonos de carbono para combatir el cambio climático? ¿acaso tienen algo en común la justicia constitucional y la conservación de humedales costeros? ¿tendrán alguna relación las discusiones sobre la jurisdicción constitucional estadual o provincial con las discusiones sobre establecer una contribución para el aprovechamiento no extractivo (por actividades de observación y acercamiento) de ciertos ejemplares silvestres como el de las ballenas grises?

Con aliviante tino académico - iy político! — la carta-invitación convoca asimismo a escribir ya sea junto al ensayo o por separado, una carta en la que se expresen anécdotas, vivencias, experiencias personales, expresiones de gratitud, etcétera. Qué mejor —-pensé inmediatamenteque optar por esta alternativa (que a su vez privilegio) y atreverme a redactar una carta con todo y el espacio tan reducido con el que se cuenta para ello y no obstante el dato de nunca haber sido su alumno.

Desde luego, su andar científico y trayectoria académica llegó por vez primera a mi conocimiento (recuerdo que aún en mis años adolescentes) por razón de la relación de amistad que siempre ha guardado con mi señor padre. Más adelante, su labor se hizo aún más patente en mi persona a partir de mi ingreso a la Facultad de Derecho en 1987, año en el que por cierto lo habrían de designar investigador emérito del Instituto de Investigaciones Jurídicas de nuestra máxima casa de estudios. Recuerdo que durante mi carrera, su obra en los cursos respectivos era siempre sugerida como lectura indispensable para el entendimiento de las difíciles (para mí) materias procesales. Después, cuando ingresé al propio Instituto en 1991 como técnico académico, mis colegas y yo (la mayoría aún sin titularse) nunca vacilábamos en reconocer que "Jurídicas" no podía entenderse sin la obra ni las aportaciones del doctor Fix-Zamudio; ese mismo año recibía usted el Premio Universidad Nacional. Luego, un avión me arrancó de estas tierras mexicanas y me llevó a la costumbrista Inglaterra para realizar estudios de posgrado; regresé después de más de seis años 
Esta obra forma parte del acervo de la Biblioteca Jurídica Virtual del Instituto de Investigaciones Jurídicas de la UNAM

con maestría y doctorado y me enlisté en el gobierno federal para servir a México durante casi tres años como funcionario público. El mismo año que regresé al Instituto ahora como investigador de tiempo completo, i. e. 2004, le era otorgado merecidamente el Premio Internacional Justicia en el Mundo. Han transcurrido ya tres años desde mi conversión a académico universitario y he tenido la fortuna de conocerlo un poco más. Quizá por eso me he animado a escribirle estas líneas y comentarle que el propósito central de esta carta no es otro sino el de manifestarle mi profundo reconocimiento por lo que ha hecho para la ciencia jurídica de este país.

El sendero de la vida universitaria es largo y para no claudicar es preciso contar con el ejemplo de quienes nos preceden, como es el de usted. Pero así como le he confesado que poco sé de haikus quisiera paralelamente confesarle que es muy probable que yo no vaya a dar un giro en mis investigaciones para abandonar el derecho ambiental y dedicarme de lleno al procesal constitucional. Sin embargo, y parafraseando a Matsuo Bashoo, el ejemplo que sigo en usted no es la huella del procesal constitucional, sino aquello que buscó y lo llevó a ocupar el sitio que tiene por su aportación al avance del pensamiento jurídico mexicano.

Felicidades por sus 50 años de labor científica.

César NAVA ESCUDERO 
Esta obra forma parte del acervo de la Biblioteca Jurídica Virtual del Instituto de Investigaciones Jurídicas de la UNAM

\section{EL QUIJOTE Y SANCHO PANZA EN LA LEGISLACIÓN AMBIENTAL MEXICANA}

\section{PRELIMINAR: UN MAESTRO Y DOS PERSONAJES FICTICIOS}

Si hay algo que conozco bien del maestro Alfonso Nava Negrete es que a lo largo de su vida no ha contado con amigos. Pero hago una aclaración: no me refiero a amigos como los que ahora han aceptado gustosamente participar en esta obra-homenaje para celebrar sus 50 años como docente en la Facultad de Derecho de la UNAM, sino a ese tipo de amistades con las que él podría reunirse permanentemente en algún restaurante a discutir sobre lo mal que andan algunos tribunales administrativos en el país — ¡incluyendo a algunos de sus magistrados! —, a platicar sobre cuál debe ser la táctica a seguir para adquirir a buen precio algún libro en las librerías de viejo de esta ciudad, o a criticar las nefastas andadas de algún político o funcionario público corrupto e inepto al que seguramente lo calificaría de "etcétera". Sin temor a equivocarme, agregaría que tampoco ha tenido de esos amigos con los que podría encontrarse frecuentemente los fines de semana y conversar (con sus respectivas esposas) sobre hijos, viajes y otros menesteres domésticos.

Ya habría confesado él mismo en 2007 la ausencia de este tipo de amigos a través de su testimonio en la colección Voz de Nuestros Juristas, editada por el Instituto de Investigaciones Jurídicas de nuestra máxima casa de estudios:

Una de las cosas simpáticas que me han sucedido [en mi vida] es que no tengo amigos. ¿En qué sentido no tengo amigos? En que no tengo de esos

* Publicado en Nava Escudero, César y Nava Escudero, Oscar (coords.), Administración pública contemporánea. Derecho, politica y justicia. Estudios en homenaje a Alfonso Nava Negrete, México, Porrúa-UNAM, Instituto de Investigaciones Jurídicas y Facultad de Derecho, 2010, t. I. 
Esta obra forma parte del acervo de la Biblioteca Jurídica Virtual del Instituto de Investigaciones Jurídicas de la UNAM

amigos que uno se reúne los sábados, o los domingos, con las esposas... tengo muchos amigos sí, pero no de ése tipo...Entonces, yo cuando me reúno o hago alguna reunión en mi casa invito a ex-alumnos o amigos, y van, y nos reunimos y nos tratamos muy bien con mucho afecto... [adicionalmente] he guardado una amistad muy bella con Héctor Fix y con Diego Valadés y con muchos otros académicos...pero no de reuniones frecuentes.

No puedo yo decir que tengo un grupo de amigos; no tengo grupos de amigos así, permanentes. ${ }^{1}$

No obstante su falta de "amigos permanentes", quienes han tenido oportunidad de convivir con el maestro en su arbolada casa de Coyoacán, saben que esa ausencia lo es sólo en apariencia, porque en realidad vaya que guarda una relación de amistad permanente con dos singulares personajes: Don Quijote de la Mancha y Sancho Panza.

En efecto, basta un recorrido por las diversas habitaciones de su casa (todas ellas llenas de libreros) para descubrir que el maestro sí ha tenido amigos permanentes que lo han acompañado en su larga trayectoria académica incluso los fines de semana. Por ejemplo, desde hace muchos años que en la sala principal de la casa se puede distinguir al caballero de la triste figura reposando en una silla, quien amable, da la bienvenida a cuanto invitado o visitante haya cruzado la puerta de entrada (hecha de vidrio y herrería forjada) que conduce a esa habitación. La escultura, no muy grande ni pesada, descansa llamativamente (y sobre una carpeta) en un Steinway \& Sons horizontal que el maestro habría adquirido hace algunos años en una de esas ventas de casonas viejas a las que le encanta asistir; sólo al Quijote y a un par de retratos familiares se les ha permitido "subirse" a la tapa de este maravilloso instrumento de cuerdas percutidas.

Si el invitado es observador, podrá advertir que en esa misma habitación cuelga de una de sus paredes un óleo del pintor mexicano Mondragón con el rostro del Quijote. Es más, si el invitado deja de ser observador y se convierte en un fisgón, se dará cuenta que en el librero principal de la sala aparecen en un entrepaño unas bellísimas figuras del Quijote y de Sancho Panza resguardando, como es debido, libros de literatura, historia y arte mexicanos, así como los primeros diecisiete tomos de esa obra maravi-

1 Instituto de Investigaciones Jurídicas, “Alfonso Nava Negrete”, Voz de Nuestros Juristas, entrevista de la maestra Eugenia M. de Lizalde, México, UNAM, Instituto de Investigaciones Jurídicas, enero, 2007. 
Esta obra forma parte del acervo de la Biblioteca Jurídica Virtual del Instituto de Investigaciones Jurídicas de la UNAM

llosa que es la Summa Artis. Historia General del Arte de José Pijoán, editada por la casa Espasa Calpe. ${ }^{2}$

La relación permanente con ambos personajes no se agota en dicha habitación. Apartada de la construcción principal y separada por un jardín de rosas, plantas y árboles frutales, se avizora la biblioteca del maestro que es al mismo tiempo fuente de su saber administrativo y búnker contra exalumnos o familiares que sueñan despiertos creyendo ingenuamente que podrán introducirse en ella y apoderarse de alguna obra. Cerca de la puerta de entrada, en la pared exterior, y acompañado por una reproducción de la piedra de los soles (mal llamada "calendario azteca") cuelga otra vez el rostro de un Quijote pero ahora tallado sobre un trozo de madera.

Aún hay más: en el interior de la biblioteca se aprecian en libreros o cerca de las ventanas una gran variedad de figuras de diversos tamaños y de materiales distintos tanto del caballero manchego como de su fiel ayudante. Aunque es fácil advertir que estos dos personajes ficticios resguardan más libros de historia, arte y literatura (mexicanos y universales) y ahora también de filosofía y poesía así como obras excelentísimas sobre nuestros antepasados, lo que realmente custodian es la enorme colección de libros jurídicos que tiene el maestro en español y en francés (los que están en italiano, portugués e inglés son sólo unos cuantos). Desde luego, destacan las obras de derecho administrativo representadas por autores diversos, nacionales y extranjeros. Por ejemplo, ahí se encuentra su bien conservada colección de "Fragas", ${ }^{3}$ de la que pudo contar con la primera edición solo hasta hace muy poco tiempo. En lugar especial están los libros de su mentor don Andrés Serra Rojas con quien mantuvo una estrecha relación académica, profesional y de amistad por muchos años. A

2 Los tomos restantes de esta obra se encuentran distribuidos en otros libreros de la casa.

3 Antes de 2008, sólo era posible conocer la relación que tuvo el maestro Nava $\mathrm{Ne}$ grete con don Gabino Fraga a través de sus propias narraciones verbales. Pero fue en ese preciso año que a propósito de la inauguración del Auditorio "Gabino Fraga Magaña" en la Facultad de Derecho de la UNAM, quedaron por escrito las palabras que ahí pronunciara respecto a sus vivencias con el maestro Fraga. Lo que dijo en aquella ocasión puede consultarse en Suprema Corte de Justicia de la Nación, "Versión estenográfica de las palabras pronunciadas por el Dr. Alfonso Nava Negrete, durante la inauguración del Auditorio “Gabino Fraga Magaña” en la Universidad Nacional Autónoma de México. 29 de febrero de 2008", Semblanzas. Vida y Obra de los Ministros de la Suprema Corte de Justicia de la Nación. Ministro Gabino Fraga Magaña, México, SCJN, 2008, pp. 163174. 
Esta obra forma parte del acervo de la Biblioteca Jurídica Virtual del Instituto de Investigaciones Jurídicas de la UNAM

este último le dedica algunas palabras de homenaje en la tercera y más reciente de sus ediciones del Derecho administrativo mexicano: “...mi recuerdo y mi reconocimiento al jurista, al científico de la ciencia política $\mathrm{y}$, sobre todo, al maestro siempre ejemplar y al amigo inolvidable. Maestro, siempre seré su alumno". ${ }^{4}$

Al recorrer con la vista todos sus libreros, nuestra mirada se topa con muchos otros autores no sólo de México sino de otras naciones, sería una locura tratar de citar a todos, ya que seguramente cometeríamos el error de omitir a algún destacado administrativista. Basta con mencionar sólo a los que se encuentran cerca de Fraga y de Serra Rojas: Renato Alessi, Jean-Marie Auby y Robert Ducos-Ader, H. Berhtélemy, Rafael Bielsa, José María Boquera Oliver, Roger Bonnard, Allan R. BrewerCarías, José Canasi, Juan Carlos Cassagne, Jesús González Pérez, André de Laubadere, Manuel Ma. Díez, José Roberto Dromi, Charles Eisenmann, Rafael Entrena Cuesta, Bartolomé A. Fiorini, Fritz Fleiner, Eduardo García de Enterría, José Antonio García-Trevijano Fos, Fernando Garrido Falla, Francisco Eladio Gómez Mejía, Agustín Gordillo, Maurice Hauriou, Gastón Jèze, Miguel S. Marienhoff, Ramón Martín Mateo, Otto Mayer, Adolfo Merkl, Jorge Olivera Toro, Luciano Parejo Alfonso, Jean Rivero, Enrique Rojas Franco, Antonio Royo-Villanova, Enrique Sayagués Laso, Jaime Vidal Perdomo, Benjamín Villegas Basavilbaso.

¡Qué gran deleite para los ojos de don Quijote (no estaría tan seguro que así lo fuera para los de Sancho Panza) ver reunidos a tantos administrativistas latinoamericanos y europeos!

El hecho de que el profesor Nava Negrete haya permitido que el Quijote y que Sancho lo sigan acompañando en su vida, me invita a recordar algunos párrafos de la gran obra de Miguel de Cervantes relacionados con el quehacer legislativo de un gobierno. Transcribo estos párrafos y luego los comento para relacionar su contenido con el estado que guarda la legislación ambiental mexicana en nuestros días.

4 Nava Negrete, Alfonso, Derecho administrativo mexicano, 3a. ed., México, Fondo de Cultura Económica, 2007, p. 16. 
Esta obra forma parte del acervo de la Biblioteca Jurídica Virtual del Instituto de Investigaciones Jurídicas de la UNAM

\section{El CONSEJO DEL QuiJOte, LA RESPUESTA DE SANCHO PANZA, Y LO QUE DEBEMOS SABER SOBRE LAS PRAGMÁTICAS ${ }^{5}$}

En ocasión de una carta dirigida a Sancho Panza (entonces gobernador de la ínsula Barataria) don Quijote de la Mancha le aconsejó lo siguiente:

No hagas muchas pragmáticas, y si las hicieres, procura que sean buenas y, sobre todo que se guarden y cumplan, que las pragmáticas que no se guardan lo mismo es que si no lo fuesen, antes dan a entender que el príncipe que tuvo discreción y autoridad para hacerlas no tuvo valor para hacer que se guardasen; y las leyes que atemorizan y no se ejecutan, vienen a ser como la viga, rey de las ranas, que al principio las espantó, y con el tiempo la menospreciaron y se subieron sobre ella. ${ }^{6}$

Al recibir la carta, Sancho Panza ordenó a su secretario leerla en voz alta. Habiendo escuchado lo escrito por Don Quijote, el gobernador se aprestó a encerrarse en su estancia con su ayudante para responder a la misiva de su amo y señor. Despachada su respuesta en el correo, procedió esa misma tarde a elaborar algunas pragmáticas relativas al buen gobierno, las cuales se hicieron guardar en el lugar para el que gobernaba y se les nombró Las constituciones del gran gobernador Sancho Panza.

Transcurridos apenas diez días como gobernador, Sancho Panza abandonó la ínsula y dejó el gobierno antes de que el gobierno acabase con él. Tomó camino de regreso no sólo para encontrarse con su amo don Quijote sino para ver a los duques que le mandaron gobernar y comentarles que ya no era más el gobernador de la ínsula Barataria. Puesto de rodillas y frente a sus señores el duque y la duquesa, Sancho diría entre otras cosas lo siguiente:

5 En la edición que hemos consultado (véase nota siguiente), se asocia la expresión "pragmáticas" con la de "ordenanzas". Ahí mismo, en su glosario, se define a las pragmáticas como "decretos". Pensamos que la intención en el uso de ese vocablo es la de referirse a todo instrumento legal dentro de un ordenamiento jurídico. Para los fines de este trabajo asociamos la expresión pragmáticas al de leyes, esto es, nos referimos en un sentido amplio a instrumentos jurídicos generales, abstractos, obligatorios, coercibles independientemente de cómo los llame nuestro ordenamiento jurídico mexicano.

6 Cervantes, Miguel de, Don Quijote de la Mancha, Edición del IV Centenario, España-México, Real Academia Española, Asociación de Academias de la Lengua Española, Alfaguara, 2004, segunda parte, capítulo LI, pp. 941-942. 
Esta obra forma parte del acervo de la Biblioteca Jurídica Virtual del Instituto de Investigaciones Jurídicas de la UNAM

Yo, señores, porque lo quiso así vuestra grandeza, sin ningún merecimiento mío, fui a gobernar vuestra ínsula Barataria, en la cual entré desnudo, y desnudo me hallo: ni pierdo ni gano. Si he gobernado bien o mal, testigos he tenido delante, que dirán lo que quisieren. He declarado dudas, sentenciado pleitos...y aunque pensaba hacer algunas ordenanzas provechosas, no hice ninguna, temeroso que no se habían de guardar, que es lo mismo hacerlas que no hacerlas. ${ }^{7}$

Al final de su plática, el duque lo abrazó y le dijo que le pesaba en el alma que hubiera dejado tan pronto el gobierno, pero que le daría otro oficio de menos carga y de más provecho. La duquesa también lo abrazó, y conmovida por el estado en que se encontraba después de su camino al castillo, mandó a que lo atendieran. En realidad, ninguno de los duques quedó arrepentido de la burla que hicieron a Sancho Panza, sobre todo porque el mayordomo de éste les habría contado finalmente sobre sus palabras y acciones durante su gestión como gobernador de la ínsula.

Es de esta manera que Miguel de Cervantes dejó en la pluma de su ingenioso hidalgo un consejo a Sancho Panza conformado por tres ideas fundamentales que no han de ignorarse por juristas, políticos, administradores y legisladores cuando de hacer leyes se trate: (i) que no sean demasiadas; (ii) que si se hacen sean buenas; y (iii) que ya hechas se cumplan. Aunque todas ellas en verdad invitan a la reflexión, la primera y segunda ideas son harto subjetivas, ciertamente más que la tercera que se presenta un tanto más precisa que sus predecesoras. Analicemos cada una de éstas y demos nuestra propia opinión al respecto.

\section{Primera idea}

Se trata de no hacer demasiadas leyes. Es clara la subjetividad en esta primera idea de las tres que conforman el consejo de don Quijote: ¿cuántas pragmáticas son "muchas" o "demasiadas"? La ambigüedad de tal pregunta supone una primera aproximación igual de ambigua para intentar responderla: no serán demasiados instrumentos jurídicos si son los necesarios según lo determinen aquéllos a quienes van dirigidos, es decir, no son muchas las leyes, reglamentos, decretos o acuerdos siempre y cuando surjan de las necesidades de los gobernados. Pero creer en que

7 Ibidem, p. 974. 
Esta obra forma parte del acervo de la Biblioteca Jurídica Virtual del Instituto de Investigaciones Jurídicas de la UNAM

los gobernantes (legisladores y administradores públicos) se acercan a sus gobernados para conocer verdaderamente sus necesidades - situación que podría ayudarnos a fijar el criterio anterior- suena un poco a ingenuidad ciudadana.

No podemos ignorar el hecho de que las leyes rara vez toman en cuenta $\mathrm{o}$ atienden cabalmente las necesidades de todos sus destinatarios. Y cuando sí lo hacen pueden pecar, no obstante sus características innatas de generalidad y abstracción, de llevar dedicatoria, es decir, de beneficiar sólo a unos cuantos (que en la mayoría de las veces son lo que ostentan el poder político y económico) en detrimento de la mayoría de los gobernados. Por esto, aunque los gobernados (o administrados como se les llama dentro del derecho administrativo) deben ser el centro de todo sistema de gobierno, ${ }^{8}$ el quehacer normativo se manifiesta a veces de manera selectiva, sin atender las necesidades comunes de todos sus destinatarios y generalmente "sin previo aviso". Esto último, que es propio de todo sistema jurídico, no debe sin embargo soslayarse: "puede ciertamente ser deseable que las normas jurídicas sean puestas en conocimiento de aquellos a quienes se aplican, inmediatamente después de ser dictadas". 9

De manera que atender la primera idea del consejo de Don Quijote de la Mancha basándonos en el supuesto de que bastará con conocer las necesidades de los destinatarios para no incurrir en el error de hacer demasiadas pragmáticas, no nos ayuda del todo para responder a la pregunta inicial. Es así que una segunda aproximación a este dilema podría tener por lo tanto su punto de partida en el hecho de que son los propios hacedores de las leyes quienes deciden sobre cuáles y cuántas habrán de elaborarse, independientemente de que con ellas se atiendan o no las necesidades que surjan de los gobernados.

La subjetividad permanece bajo esta segunda aproximación y la pregunta sigue siendo la misma: ¿cuántas pragmáticas son "muchas" o "demasiadas"? Sabemos que las razones que impulsan a legisladores y administradores para elaborar cuerpos normativos se fundamentan en un sinnúmero de situaciones de todo tipo. Las hay porque a veces lo manda

8 Véase en este sentido lo que al respecto comenta el catedrático don Jesús González Pérez a propósito de su estudio sobre el administrado. González Pérez, Jesús, El administrado, México, Fundación Universitaria de Derecho, Administración y Política (FUNDAP), 2003, pp. 21 y ss.

9 Hart, H.L.A., El concepto de derecho, 2a. ed., trad. de Genaro R. Carrio, México, Editora Nacional, 1980, p. 28. 
Esta obra forma parte del acervo de la Biblioteca Jurídica Virtual del Instituto de Investigaciones Jurídicas de la UNAM

un precepto constitucional, un tratado internacional o una ley o reglamento, o bien porque en ocasiones también se busca amparar demandas de los gobernados para satisfacer necesidades colectivas o de interés general. Sin embargo, es común encontrarse, por ejemplo, con iniciativas de ley supuestamente fundadas en el ideal de atender demandas sociales cuando lo que en realidad buscan es satisfacer las aspiraciones políticas, económicas o electorales personales de quienes precisamente elaboran el texto jurídico. En este mismo sentido, no faltan situaciones que responden a intereses ideológicos partidistas o de grupo y las que complacen la voracidad económica de empresas nacionales y extranjeras. Cada una de estas circunstancias o la combinación de todas nos hace pensar que el consejo de no hacer demasiadas pragmáticas habrá de quedar sin efecto: siempre se presentará alguna razón para hacer alguna ley en tal o cual sentido.

Una tercera y última aproximación para saber cómo responder al llamado del Ingenioso Hidalgo podría apoyarse en la opción de enfocarnos al tema o la materia de la que se trate. Es decir, una vez tomada la decisión para iniciar un texto normativo sobre una determinada materia (cualquiera que haya sido la razón para ello y se haya o no atendido a una necesidad de sus destinatarios), la cuestión se centra en la idea de elaborar una y no muchas leyes para regular dicha materia. Cuando el sistema jurídico de un país está conformado por una abundante legislación, proceder a reagrupar cuerpos normativos preexistentes en una sola ley nos conduce a un fenómeno que supone "recoger los principios generales rectores comunes" del tema o materia en cuestión; a este proceso jurídicamente le llamamos codificación. ${ }^{10}$ Por lo que quizá la respuesta a la primera idea del consejo del Quijote sea la de codificar y no la de elaborar diversos instrumentos jurídicos.

Lo anterior, empero, puede ser tramposo puesto que la codificación no siempre significa recoger todos esos principios generales comunes plasmados en una normatividad preexistente y reunirlos en un solo texto jurídico; tampoco significa que por sí sola impida que a futuro se vayan a elaborar leyes en torno a esa misma materia. En cualquiera de los dos casos podrían coexistir junto al código una o más leyes sobre el mismo tema. Encima de todo esto, puede suceder que en un sistema jurídico

10 Nava Negrete, Alfonso, Derecho administrativo mexicano, cit., nota 4, p. 80. 
Esta obra forma parte del acervo de la Biblioteca Jurídica Virtual del Instituto de Investigaciones Jurídicas de la UNAM

existan leyes a las que no se les adjetive de códigos, pero que en el fondo sí lo sean. ${ }^{11}$

Resulta de estas tres aproximaciones que por su evidente ambigüedad no podríamos del todo adentrarnos a resolver el enigma de cuántas son muchas pragmáticas: más bien podemos estar ciertos de que es poco claro cuándo se estará frente a muchos o pocos cuerpos legales. Por consiguiente, la idea de no hacer demasiadas pragmáticas podría tener mayor precisión si la vinculamos con la siguiente idea del consejo de don Quijote: una vez hechas, hay que procurar que sean buenas.

\section{Segunda idea}

Nos encontramos inmersos nuevamente en un mundo subjetivo: ¿cuándo una pragmática es "buena"? Para intentar alguna respuesta a esta interrogante tendríamos necesariamente que averiguar a qué se refiere el término "bueno" y enseguida interpretar el sentido que le habría querido dar el Quijote al traducirlo como consejo a Sancho Panza.

De manera que para facilitar nuestra búsqueda sobre lo que significa la noción bueno, es conveniente acudir sin más al Diccionario de la Real Academia. Ahí encontraremos definiciones como estas: "que tiene bondad en su género"; "gustoso, apetecible, agradable, divertido"; "dicho de una persona: simple, bonachona, o chocante"; $y$ "dicho de una cosa: no deteriorada y que puede servir". ${ }^{12}$ Francamente, ninguna de ellas nos ayuda a cumplir con nuestro objetivo.

Sin embargo, el diccionario consultado aporta otra acepción que nos parece bastante cercana a lo que andamos buscando: "útil y a propósito para algo". Si por un momento adoptamos este significado, entonces la pregunta ya no es cuándo una pragmática es buena, sino cuándo sirve para algo y cuándo cumple su propósito. Esto en el mundo jurídico podría traducirse en indagar su característica esencial. Por tanto, es posible que don Quijote de la Mancha al aconsejar a Sancho Panza sobre su go-

11 Ibidem, p. 81.

12 Real Academia Española, Diccionario de la lengua española, 22a. ed., España, 2001, http://buscon.rae.es/draeI/SrvltConsulta?TIPO_BUS=3\&LEMA=bueno. 
Esta obra forma parte del acervo de la Biblioteca Jurídica Virtual del Instituto de Investigaciones Jurídicas de la UNAM

bierno, le estuviera diciendo que cuando hiciere leyes procurara no olvidar su esencia, esto es, la razón de ser del derecho. ${ }^{13}$

Ciertamente se ha escrito mucho, muchísimo, sobre el concepto y la naturaleza del derecho. Nos viene a la mente en este sentido aquélla reflexión que hiciera en 1961 el inglés H.L.A. Hart en su libro The Concept of Law en el que hace hincapié sobre lo prolífico que ha sido preguntarse lo que es el derecho:

Pocas preguntas referentes a la sociedad humana han sido formuladas con tanta persistencia y respondidas por pensadores serios de maneras tan diversas, extrañas, y aun paradójicas, como la pregunta “¿qué es derecho?”. Aunque limitemos nuestra atención a la teoría jurídica de los últimos ciento cincuenta años, y dejemos a un lado la especulación clásica y medioeval acerca de la "naturaleza" del derecho, nos daremos con una situación que no encuentra paralelo en ningún otro tema estudiado en forma sistemática como disciplina académica autónoma. ${ }^{14}$

Si bien se ha repetido hasta el cansancio la falta de consenso que existe en torno a un significado común sobre la noción de derecho, quienes hacen los textos legales no podrán jamás nunca quejarse de la ausencia de significados o de discusiones sobre su contenido y alcances. Tomemos como ejemplo las explicaciones que desde el siglo XVIII esgrimía Montesquieu al señalar que las leyes se establecen para regular las relaciones entre los pueblos, que es el Derecho de gentes y que se funda en el principio de que "todas las naciones deben hacerse en la paz el mayor bien posible y en la guerra el menor mal posible". ${ }^{15}$ También se establecen leyes — según este autor - tanto para regular las relaciones entre gobernantes y gobernados (le llama derecho político) así como para regular las relaciones de todos los ciudadanos (le llama derecho civil), y hace la siguiente precisión:

La ley, en general, es la razón humana en cuanto se aplica al gobierno de

13 Para nosotros los dos sentidos en que se utiliza el vocablo "derecho" comprenden tanto el de su naturaleza científica como el de su naturaleza normativa. Hacemos la aclaración de que en este trabajo nos referimos al segundo ya que creemos que el consejo del Quijote alude precisamente al de la parte normativa del derecho.

14 Hart, H. L. A., El concepto de derecho, cit., nota 9, p. 1.

15 Montesquieu, Del espíritu de las leyes, 14a. ed., trad. de Nicolás Estévanez, México, Porrúa, 2001, colección Sepan Cuantos, número 191, p. 7. 
Esta obra forma parte del acervo de la Biblioteca Jurídica Virtual del Instituto de Investigaciones Jurídicas de la UNAM

todos los pueblos de la Tierra; y las leyes políticas y civiles de cada nación no deben ser otra cosa sino casos particulares en que se aplica la misma razón humana.

Deben ser estas últimas tan ajustadas a las condiciones del pueblo para el cual se hacen, que sería una rarísima casualidad si las hechas para una nación sirvieran para otra.

Es preciso que esas leyes se amolden a la naturaleza del gobierno establecido o que se quiere establecer, bien sea que ellas lo formen, como lo hacen las leyes políticas, bien sea que lo mantengan, como las leyes civiles.

Deben estar en relación con la naturaleza física del país, cuyo clima puede ser glacial, templado o tórrido; ser proporcionadas a su situación, a su extensión, al género de vida de sus habitantes, labradores, cazadores o pastores; amoldadas igualmente al grado de libertad posible en cada pueblo, a su religión, a sus inclinaciones, a su riqueza, al número de habitantes, a su comercio y a la índole de sus costumbres. Por último, han de armonizarse unas con otras, con su origen, y con el objeto del legislador. Todas estas miras han de ser consideradas. ${ }^{16}$

¿Será suficiente considerar que las pragmáticas son útiles y que además cumplen el propósito de serlo (es decir, son pragmáticas buenas) si seguimos al pie de la letra cada uno de los puntos contenidos en estos párrafos transcritos textualmente? Contrastemos estas ideas (publicadas en 1748 durante los tiempos de la Francia del Rey Luis XV) con las de Bodenheimer y las de Kelsen (publicadas respectivamente en 1940 y 1944 durante los tiempos de la Alemania de Adolf Hitler). Respecto a la naturaleza misma del derecho en general, Edgar Bodenheimer escribía en aquella época lo siguiente:

Por su propia naturaleza el derecho es un término medio entre la anarquía y el despotismo. Trata de crear y mantener un equilibrio entre esas dos formas extremas de la vida social. Para evitar la anarquía, el Derecho limita el poder de los individuos particulares; para evitar el despotismo enfrena (sic) el poder del gobierno. La limitación legal del poder de las autoridades públicas se denomina Derecho público. La función general de ambas

\footnotetext{
16 Ibidem, pp. 7 y 8.
} 
Esta obra forma parte del acervo de la Biblioteca Jurídica Virtual del Instituto de Investigaciones Jurídicas de la UNAM

ramas del Derecho es esencialmente la misma; consiste en la creación de restricciones al ejercicio arbitrario e ilimitado del poder. ${ }^{17}$

A su vez, Hans Kelsen advertía que lo que caracteriza esencialmente al derecho - asumiendo que se trata de un orden coercitivo - es el establecimiento de un monopolio de la fuerza común, y que cuando el ejercicio de éste se centraliza, cuando el derecho de usar la fuerza es transferido a un órgano central, cuando se crea un Poder Ejecutivo centralizado, la comunidad (a la que llama jurídica) se convierte en un Estado. Y dentro de éste se alcanza el mayor grado de pacificación de las relaciones entre individuos: la paz nacional. ${ }^{18}$ Para la construcción de una paz internacional el autor alemán afirmaba que

Cuando se plantea la cuestión de cómo puede asegurarse la paz internacional, de cómo puede eliminarse el empleo más terrible de la fuerza - a saber, la guerra - de las relaciones entre los Estados, ninguna respuesta puede ser más evidente por sí misma que ésta: uniendo a todos los Estados individuales, o por lo menos al mayor número de ellos posible, en un Estado mundial; concentrando todos sus medios de poder, sus fuerzas armadas, y poniéndolos a disposición de un gobierno mundial de acuerdo con leyes creadas por un parlamento mundial. Si a los Estados se les permite seguir existiendo únicamente como miembros de una poderosa federación mundial, entonces la paz entre ellos quedará asegurada con la misma eficacia que entre los Estados que componen los Estados Unidos de América o los Cantones de la República Suiza. Tal es la idea principal de las numerosas sugestiones que se han hecho para el mantenimiento de la paz al discutirse la reconstrucción de la posguerra. ${ }^{19}$

Años más tarde, en 1949, el mismo Kelsen habría de insistir en la característica esencial de coacción que posee el derecho; se trata de una técnica social específica que permite distinguir el orden jurídico de otros órdenes sociales. De hecho, argumenta que "en cuanto problema científico, el del derecho es un problema de técnica social, no un problema éti-

17 Bodenheimer, Edgar, Teoría del derecho, 2a. ed., trad. de Vicente Herrero, México, Fondo de Cultura Económica, 2004, p. 28.

18 Kelsen, Hans, La paz por medio del derecho, trad. de Luis Echávarri, Buenos Aires, Editorial Losada, 1946, pp. 28 y 29.

19 Ibidem, pp. 29 y 30. 
Esta obra forma parte del acervo de la Biblioteca Jurídica Virtual del Instituto de Investigaciones Jurídicas de la UNAM

co", es decir, no se está frente a un juicio moral donde un orden jurídico es bueno o justo. ${ }^{20}$

Algo de lo que se ha dicho en México sobre el concepto del derecho lo encontramos en los textos de dos juristas que a través de sus libros han "educado" por generaciones a estudiantes y estudiosos del derecho en México. Comencemos por don Eduardo García Máynez quien en su libro introductorio sobre el estudio del derecho nos advierte que el punto central sobre el significado del derecho en su género próximo es determinar el carácter normativo de sus preceptos. En su análisis sobre lo que son las normas nos indica la relevancia de la bilateralidad en el derecho en cuanto que en las relaciones entre individuos existe un obligado y un facultado: "Frente al jurídicamente obligado encontramos siempre a otra persona, facultada para reclamarle la observancia de lo prescrito". ${ }^{21}$ Define al derecho (en sentido objetivo) como un conjunto de normas, de preceptos imperativo-atributivos, reglas que imponen deberes y facultades, que son creadas y reconocidas por el Estado.22

Por su lado, Miguel Villoro Toranzo en su libro también introductorio sobre el estudio del derecho, define al derecho como "un sistema racional de normas sociales de conducta, declaradas obligatorias por la autoridad, por considerarlas soluciones justas a los problemas surgidos de la realidad histórica". ${ }^{23}$ Es además contundente cuando se refiere a la esencia del derecho como "un sistema racional de normas sociales de conducta" 24 y cita a Santo Tomás de Aquino: "La Ley...no es más que un ordenamiento de la razón, en orden al bien común, promulgado por aquel que tiene a su cuidado la comunidad". ${ }^{25}$ Villoro Toranzo, quien asocia la voz "comunidad" del Aquinate con la de "autoridad", señala que no es suficiente la voluntad del legislador para hacer leyes sino que éstas deben encontrar cierto acatamiento entre sus destinatarios. Esto será otorgado si ellos

20 Kelsen Hans, Teoría general del derecho y del estado, 2a. ed., trad. de Eduardo García Máynez, México, UNAM, 1983, Textos universitarios, p. 6.

21 García Máynez, Eduardo, Introducción al estudio del derecho, 31a. ed., México, Porrúa, 1980, p. 15.

22 Ibidem, pp. 97 y ss.

23 Villoro Toranzo, Miguel, Introducción al estudio del derecho, 9a. ed., México, Porrúa, 1990, p. 151.

24 Idem.

25 Ibidem, p. 152. 
Esta obra forma parte del acervo de la Biblioteca Jurídica Virtual del Instituto de Investigaciones Jurídicas de la UNAM

mismos consideran que el contenido de las normas jurídicas es justo y si están conformes con la forma o procedimiento para su promulgación. ${ }^{26}$

Si pudiéramos juntar algunas de las ideas de todos estos pensadores ¿podríamos sostener que en sus explicaciones se encuentra la clave para saber si una pragmática es buena?

\section{Tercera idea}

En las reflexiones anteriores nos hemos enfrentado al dilema de discernir cuándo una ley es buena en el entendido de que bueno es aquello que es útil y que lo es a propósito para algo, y que en el mundo de lo jurídico esto último supone indagar sobre la característica esencial del derecho normativo. Para todo lo anterior nos hemos apoyado en autores de diversas nacionalidades que pertenecieron a épocas distintas; de aquí aprendimos que existen diversos enfoques de juristas y filósofos del derecho para confrontar el aprieto al que nos ha sometido en su carta el Caballero de la Triste Figura. Detectamos de todas estas formas de pensamiento ciertos elementos en común, como lo son la regulación de comportamientos y/o las reglas imperativas, pero no deja de intranquilizarnos el hecho de que se incluyen en cada una de ellas vocablos o expresiones difíciles de acotar y que son igual de ambiguas que el calificativo bueno. Por ejemplo ¿Qué es la razón humana? ¿Cuáles son los límites entre anarquía y despotismo? ¿Cómo delimitar lo que es el monopolio de la fuerza común? ¿Qué es lo racional en un sistema de normas sociales de conducta que son obligatorias por que se consideran justas?

Es en este contexto que debemos analizar la tercera idea del consejo del Quijote que es, como ya hemos dicho, mucho más clara que sus antecesoras. Se trata ahora de que las leyes -independientemente de que sean demasiadas o de que puedan considerarse como buenas- se guarden y se cumplan, por lo que la pregunta a responder es ¿cuándo una pragmática se cumple?

Quizá la forma más simple de abordar semejante interrogante es la de estar ciertos que el cumplimiento de las leyes está asociado a la existencia de la posibilidad de su aplicación, $i$. e. la posibilidad de hacer efectivo su contenido. Para sustentar lo anterior, es indispensable recordar que las

26 Ibidem, p. 154. 
Esta obra forma parte del acervo de la Biblioteca Jurídica Virtual del Instituto de Investigaciones Jurídicas de la UNAM

leyes tienen como características esenciales las de ser generales, abstractas y obligatorias, pero sobre todo, coercibles. De manera que la coercibilidad supone la posibilidad (abstracta si se quiere) de hacer efectiva la aplicación de una pragmática. Junto a este concepto, existe la idea del uso de la fuerza física (si fuera el caso) para lograr ese cumplimiento y se conoce con el nombre de coacción. Si bien es fundamental para el cumplimiento de una ley contar con un gobernante que tenga la capacidad de imponer algo como obligatorio a sus gobernados, también lo es que tenga la posibilidad de hacer que se cumpla. Debido a que la característica de obligatoriedad en las leyes no es suficiente para su cumplimiento, es menester que se establezcan órganos que en última instancia puedan aplicar el uso de la fuerza en caso de incumplimiento. ${ }^{27} \mathrm{El}$ Quijote fue cuidadoso en hacer énfasis en el cumplimiento de las pragmáticas, seguramente con la idea de confrontar aquélla vieja fórmula "obedézcase, pero no se cumpla". ${ }^{28}$

En el contexto de las relaciones entre gobernantes y gobernados, la idea de cumplimiento no sólo alude a los segundos, sino también a los primeros y lo hace en su calidad no de destinatarios pero sí de sujetos, o mejor dicho, de autoridades que han de hacer sólo lo que las leyes les permitan hacer. Esto es lo que conocemos como principio de legalidad y que ha sido definido como "la faceta más valiosa del régimen del Estado de derecho": 29

Reza el principio: las autoridades públicas sólo pueden hacer lo que la ley les autorice. En consecuencia, ninguna autoridad legislativa, judicial o administrativa puede realizar actividad alguna si no está prevista y au-

27 Véase para mayor información en este sentido, Atienza, Manuel, Introducción al derecho, México, Fontamara, 1998, pp. 29 y ss.

28 Nos explica Osterc a propósito de su estudio sobre el pensamiento social y político del Quijote, que las leyes y prescripciones en tiempos de Felipe II (1527-1598) eran cumplidas precisamente a la letra e interpretadas según el sentido de que la ley se obedece, pero no se cumple. Durante ese gobierno proliferó una excesiva reglamentación sobre la vida nacional y sobre la conducta de sus gobernados hasta en los actos más íntimos de la vida. El autor aclara en este sentido que "Los códigos de aquel tiempo están repletos de disposiciones de esta naturaleza, fundadas en la noción de que el gobierno es omnisciente y que los subordinados son incapaces de conducirse debidamente por sus propios esfuerzos". Véase Osterc, Ludovik, El pensamiento social y político del Quijote, 2a. ed., México, UNAM, 1975, pp. 231 y 232.

29 Nava Negrete, Alfonso, Derecho administrativo mexicano, cit., nota 4, p. 161. 
Esta obra forma parte del acervo de la Biblioteca Jurídica Virtual del Instituto de Investigaciones Jurídicas de la UNAM

torizada por la ley. Es la autolimitación que consiente la autoridad dentro de ese régimen. ${ }^{30}$

Aunque los gobernantes han de sujetarse a lo que una ley les faculte, no siempre aplican la ley y/o algunas de las normas contenidas en ella. Un ejemplo de esto apunta a aquélla idea vinculada a lo que se ha descrito como los límites del derecho, que no es otra cosa más que aceptar que en un país determinado pueden existir "circunstancias en que los órganos del Estado optan por la no aplicación de la norma como una forma de preservar el Estado de derecho". ${ }^{31}$ La no aplicación de ciertas normas jurídicas puede también derivarse de actos que si bien no suponen un incumplimiento por parte del gobernante, sí son el resultado de facultades discrecionales que permiten optar por una norma en lugar de otra o incluso por ninguna de ellas. ${ }^{32}$ Es el caso del otorgamiento de concesiones o de la emisión de acuerdos de desincorporación cuya aplicación depende de la voluntad del gobernante. Ambas figuras jurídicas pueden estar reguladas en una o más leyes pero si el gobernante (con su facultad discrecional) decide no hacer uso de ellas entonces una parte de las leyes quedará sin aplicarse. Un tercer ejemplo sobre la no aplicación de leyes es aquél donde los ordenamientos jurídicos están "incompletos". En otras palabras, hay pragmáticas que no se pueden aplicar o que tienen una aplicación parcial porque una o muchas de sus normas están condicionadas a la creación de otras normas jurídicas que son las que harán posible el funcionamiento de esa misma ley o de toda una parte de la legislación respectiva. Se entiende así que la aplicación de muchos cuerpos legales ocurre por etapas: "la creación de una norma que está regulada por otra norma constituye una aplicación de esta última. La aplicación del derecho es, a la vez, creación del derecho: acto que continúa la creación gradual y sucesiva del orden jurídico". ${ }^{33}$

Si es el caso en efecto de que las pragmáticas no se guardan ni se cumplen, don Quijote nos advierte sobre las tres consecuencias que habrán

\footnotetext{
30 Idem.

31 Valadés, Diego, Problemas constitucionales del Estado de derecho, 2a. ed., Buenos Aires, Astrea, 2004, p. 12.

32 Véase para mayor detalle Nava Negrete, Alfonso, Derecho administrativo mexicano, cit., nota 4, pp. 568-570.

33 Tamayo y Salmorán, Rolando, “Aplicación del derecho”, Diccionario Jurídico Mexicano, 8a. ed., México, Porrúa-UNAM, Instituto de Investigaciones Jurídicas, p. 186, t. I.
} 
Esta obra forma parte del acervo de la Biblioteca Jurídica Virtual del Instituto de Investigaciones Jurídicas de la UNAM

de presentarse i) es como si no existiesen, ii) denota la falta de valor de quien las hizo, y iii) son despreciadas e ignoradas por sus destinatarios. Esta advertencia - particularmente la que se refiere a la primera consecuencia - tuvo un efecto profundo en Sancho Panza al momento en que explicaba a los duques su salida del gobierno de la ínsula Barataria, puesto que esgrimió como razón de no haber hecho ninguna "ordenanza provechosa" su temor a que no se fueran a guardar. Habría de seguir al pie de la letra la idea de su señor y amo en sus explicaciones de que no hacer guardar y cumplir las pragmáticas es como si no existieran.

\section{Nuestra opinión}

Si bien el consejo del Quijote comprende tres ideas fundamentales (esto es, que no se hagan demasiadas pragmáticas, pero que si se hacen sean buenas, y que además se cumplan) su análisis ha de realizarse de manera integral pero tomando en cuenta el peso que tiene la tercera de ellas sobre las otras dos. Esto debe ser así porque derivado de la lectura de los párrafos de la obra cervantina arriba transcritos, se desprende que el Quijote da mayor importancia a la tercera idea ya que por encima del no hacer demasiadas pragmáticas y del que éstas sean buenas, enfatiza que sobre todo estas habrán de guardarse y cumplirse. Aún más, mientras que el caballero manchego sí le advierte a su escudero que de no cumplirse con las pragmáticas se entenderá que es como si no existiesen, que denotará la falta de valor de quien las hizo y que serán despreciadas e ignoradas por sus destinatarios, no le advierte de igual manera lo que habrá de suceder si las pragmáticas son demasiadas o no, o si no son buenas o no.

La intención de Don Quijote en este sentido es corroborada y puesta en acción posteriormente por el propio Sancho Panza al dar cuenta a los duques sobre su salida como gobernador. Explica Sancho a sus señores que la razón fundamental por no haber hecho pragmáticas no fue por temor a que fueran demasiadas o a que no fueran buenas, sino a que éstas no se fueran a cumplir. De las tres consecuencias que según el Quijote han de derivarse por el no cumplimiento de las pragmáticas, Sancho se escuda en la primera de ellas al señalar que si las pragmáticas no se cumplen es lo mismo hacerlas que no hacerlas.

Del posterior análisis que hemos hecho sobre el consejo de Don Quijote y de lo que al respecto hizo y dijo Sancho Panza podemos señalar lo siguiente. Con todo y las ambigüedades que rodean a la idea de no hacer 
Esta obra forma parte del acervo de la Biblioteca Jurídica Virtual del Instituto de Investigaciones Jurídicas de la UNAM

demasiadas leyes (porque no es claro si se atienden o no las necesidades de sus destinatarios, si son claras o no las razones para elaborarlas, o si es mejor codificar) así como a la idea de que una vez hechas sean buenas (porque no hay consenso para determinar la esencia del derecho), es fundamental que las pragmáticas se cumplan. Hemos llegado a esta conclusión porque al formularnos las preguntas ¿cuántas pragmáticas son "muchas" o "demasiadas"? y ¿cuándo una pragmática es "buena"? nos enfrentamos a un elemento de subjetividad enorme. Ni ha sido posible identificar qué indicadores son determinantes y concluyentes para saber cuándo un gobierno ya está haciendo demasiadas leyes, como tampoco ha sido factible esclarecer con toda precisión cuáles son los criterios y definiciones para elaborar un consenso sobre cuándo el derecho normativo nos es útil y cuándo habrá cumplido con su propósito, y de aquí saber si la ley es buena o no.

Con lo anterior no queremos decir que no ha de importarnos revisar las aproximaciones que hemos llevado a cabo sobre la vaguedad que supone el no hacer demasiadas leyes y el que ya hechas sean buenas. En realidad, cuando se hace una ley, lo importante será que se cumpla, puesto que de lo contrario, se habrá de actualizar la advertencia del Quijote. Obviamente, un aserto como el anterior solo es aceptable si existen las instancias jurisdiccionales adecuadas para que los gobernados puedan combatir la ley y su aplicación.

Por último, hay que enfatizar que cualquiera de las tres consecuencias - o las tres - que se deriven de la advertencia del Quijote por el no cumplimiento de las leyes, se traduce en un mensaje poco alentador para todos aquellos gobernados que busquen convivir dentro de un Estado de derecho. ¿Para qué hacer leyes que ni gobernantes ni gobernados han de cumplir? La consecuencia última en una nación donde las leyes no se aplican es que se crea un riesgo enorme para ambos: acostumbrarse a vivir en una cultura de ilegalidad sustentada en la corrupción y la impunidad.

\section{EL LEGADO CERVANTINO}

\section{EN LA LEGISLACIÓN AMBIENTAL MEXICANA}

Inciden en la legislación ambiental mexicana del siglo XXI el consejo de Don Quijote de la Mancha y la reacción de Sancho Panza por una sencilla razón. independientemente de que a la fecha existan o no de- 
Esta obra forma parte del acervo de la Biblioteca Jurídica Virtual del Instituto de Investigaciones Jurídicas de la UNAM

masiadas leyes en materia ambiental, o de que éstas sean buenas porque cumplen con su propósito fundamental, lo cierto es que un buen número de normas jurídicas contenidas en ellas no se cumplen. A la luz de lo que ahora sabemos en la obra cervantina sobre las pragmáticas, es posible crear un marco conceptual de referencia para analizar la situación que priva en la legislación ambiental de nuestro país.

\section{La legislación ambiental mexicana}

- Nuestro punto de partida es que el derecho ambiental en su naturaleza normativa está compuesto por un segmento internacional (conformado por tratados y acuerdos interinstitucionales ambientales) y por un segmento nacional (conformado por dos bloques: a) preceptos constitucionales ambientales y $b$ ) legislación ambiental).

- La legislación ambiental, que es el bloque que habremos de abordar en este trabajo, comprende todas las disposiciones que en esta materia emanan de los poderes Legislativo y Ejecutivo (federal, estatal y municipal, según corresponda). La parte que nos interesa analizar es la de la legislación ambiental que emana del Congreso de la Unión (leyes federales, generales, o que no lleven ninguno de estos dos apellidos) y la que emana del Poder Ejecutivo Federal (reglamentos, decretos, acuerdos, etcétera).

- La legislación ambiental así descrita puede clasificarse en cuatro grandes rubros por tipos de leyes: i) legislación en su conjunto, ${ }^{34}$ ii) legislación sectorial, ${ }^{35}$ iii) legislación por materias relacionadas, ${ }^{36}$

34 La única es la Ley General del Equilibrio Ecológico y la Protección al Ambiente (de 1988).

35 Comprende seis leyes que son: Ley de Aguas Nacionales (de 1992), Ley General de Vida Silvestre (de 2000), Ley General de Desarrollo Forestal Sustentable (de 2003), Ley General para la Prevención y Gestión Integral de los Residuos (de 2003), Ley de Bioseguridad de los Organismos Genéticamente Modificados (de 2005) y Ley de Promoción y Desarrollo de los Bioenergéticos (de 2008).

36 En este rubro se encuentran leyes con disposiciones jurídicas dispersas que están relacionadas con diversos temas o sectores ambientales. Aquí encontramos desde el Código Penal Federal (que dedica un título completo a los delitos contra el ambiente y la gestión ambiental) hasta leyes como la Ley General de Bienes Nacionales (que contiene disposiciones dispersas sobre zonas costeras), la Ley Federal del Mar (que regula la conservación de los recursos marinos vivos) o la Ley Agraria (cuyas disposiciones son 
Esta obra forma parte del acervo de la Biblioteca Jurídica Virtual del Instituto de Investigaciones Jurídicas de la UNAM

y iv) legislación que está pendiente en los poderes Legislativo o Ejecutivo. ${ }^{37}$

- Sólo podemos hablar de una legislación en materia ambiental a partir de que el vocablo "ambiente" y su significación actual (como problemática, crisis, cuestión, situación, reto, dilema u oportunidad) fueron insertados en el orden jurídico mexicano. Esto ocurrió hacia principios de la década de los setenta del siglo pasado, particularmente en el año de $1971 .^{38}$ Toda la normatividad existente antes de esta fecha y que se haya referido a los diversos temas o sectores que ahora consideramos parte de la regulación del derecho ambiental (como bosques, aguas, atmósfera, etcétera) conforman los antecedentes de la legislación ambiental. Sostener que antes de 1971 las disposiciones relativas a los recursos naturales (u otros temas relacionados) eran disposiciones ambientales, es un anacronismo.

\section{2. ¿Existen demasiadas pragmáticas ambientales?}

- De las diversas aproximaciones a las que hemos acudido para abordar la idea relativa a no hacer demasiadas leyes, habremos de referirnos a la tercera de ellas. Recordemos que esta aproximación se centra en la discusión de elaborar sólo una y no muchas leyes sobre

fundamentales para que las autoridades ambientales respectivas en el cumplimiento de sus atribuciones expidan por causas de utilidad pública decretos de expropiación de bienes ejidales).

37 Nos referimos a diversos temas que se encuentran en "discusión" ya sea en el Ejecutivo Federal, en el Senado o en la Cámara de Diputados. Algunos temas ambientales que se encuentran en este estado son el del acceso a los recursos genéticos y el de la contaminación atmosférica y la calidad del aire.

38 La inserción de aquello que es lo ambiental a nuestro sistema jurídico — es decir, la juridificación de lo que se ha descrito como problemática ambiental, crisis ambiental, cuestión ambiental, situación ambiental, reto ambiental, dilema ambiental u oportunidad ambiental - se produce en nuestra legislación a partir de la Ley Federal para Prevenir y Controlar la Contaminación Ambiental del 12 de marzo de 1971. A nivel constitucional, la primera vez que de manera expresa nuestra carta magna incorpora este término fue el 6 de julio de ese mismo año a través de una reforma a la fracción XVI, base cuarta del artículo 73 en la que se otorgan atribuciones legislativas y ejecutivas a una entidad administrativa denominada Consejo de Salubridad General para legislar y establecer medidas en materia de prevención y combate a la contaminación ambiental. 
Esta obra forma parte del acervo de la Biblioteca Jurídica Virtual del Instituto de Investigaciones Jurídicas de la UNAM

una misma materia. Si se procediera de esta manera en materia ambiental se estaría frente a lo que los especialistas llaman codificación ambiental. ¿Es esto lo que ha ocurrido en nuestro país?

- Para responder a la pregunta anterior es fundamental entender que la legislación ambiental (en su desarrollo y evolución) ha estado sujeta a "un vaivén entre las tendencias integradoras y las tendencias a la dispersión en leyes con temas específicos". ${ }^{39}$ Si tomamos en cuenta la clasificación de la legislación ambiental que hemos propuesto, el rubro que nos dará la pauta para saber si se ha optado por un proceso de codificación o no es el de la legislación en su conjunto que habría de suponer que, en principio, existe una ley o código que ha recogido los principios generales rectores comunes a toda la materia ambiental.

- En este sentido nos referimos a la vigente Ley General del Equilibrio Ecológico y la Protección al Ambiente (en adelante, LGEEPA) cuya intención habría sido desde su entrada en vigor en 1988 la de reunir en su texto los aspectos rectores sobre la materia ambiental. Antes de este año, las disposiciones ambientales se encontraban dispersas en diversas leyes sectoriales (como la de aguas o la de bosques), en leyes por materias relacionadas (como la de aguas marinas), y en dos pequeñas leyes ambientales que habrían sido el antecedente directo de la LGEEPA. ${ }^{40}$

- La expedición de la LGEEPA ha sido el paso más importante que se ha dado para lograr una codificación ambiental, ya que desde su entrada en vigor ha contemplado disposiciones generales y específicas ambientales propias de toda codificación. Nos referimos a principios, definiciones, distribución de competencias entre los tres órdenes de gobierno, instrumentos de política ambiental, regulación sobre temas específicos (como aguas, bosques, biodiversidad, atmósfera, ruido, vibraciones, etcétera), recursos administrativos, sanciones y hasta delitos ambientales.

39 Azuela, Antonio, Visionarios y pragmáticos. Una aproximación sociológica al derecho ambiental, México, Fontamara-UNAM, Instituto de Investigaciones Sociales, 2006, p. 108 y 109.

40 Nos referimos a dos leyes federales, la Ley Federal de Protección al Ambiente (de 1982) abrogada por la LGEEPA, y la ya mencionada Ley Federal para Prevenir y Controlar la Contaminación Ambiental (de 1971) abrogada por la ley de 1982. 
Esta obra forma parte del acervo de la Biblioteca Jurídica Virtual del Instituto de Investigaciones Jurídicas de la UNAM

- Sin embargo, ni en su momento inicial ni en el de sus posteriores adiciones y reformas ha recogido u ordenado toda la normatividad preexistente que está contenida en leyes sectoriales y por materias relacionadas. Como lo señala el fundador de la ciencia del derecho ambiental mexicano, el doctor Raúl Brañes, aunque la LGEEPA ha significado la homogeneidad del sistema jurídico en materia ambiental por contener un enfoque globalista y transectorial, no ha sido un verdadero código en el sentido de recoger integral y adecuadamente a toda la legislación ambiental preexistente. ${ }^{41}$

- A lo largo de sus más de veinte años de vida, la LGEEPA ha estado acompañada paradójicamente de un desarrollo y fortalecimiento tanto de la legislación sectorial como de la legislación por materias relacionadas preexistentes.

- En el primer caso, la legislación sectorial nunca acabó por incorporarse a la LGEEPA. Por el contrario, ha seguido su desarrollo, por un lado, insertando en el texto de las leyes que la conforman nuevas cuestiones ambientales a través de reformas y adiciones, y por el otro, a través de la sustitución de una ley por otra. Dos ejemplos de leyes sectoriales que evidencian lo anterior son: la vigente Ley de Aguas Nacionales (de 1992) que fue ampliamente modificada en 2004, y la Ley Forestal (también de 1992) que fue abrogada por la actual Ley General de Desarrollo Forestal Sustentable (de 2005).

- En el segundo caso, la legislación por materias relacionadas tampoco ha permitido que un sinnúmero de disposiciones ambientales que se encuentran dispersas en los ordenamientos que la conforman, se integren a la LGEEPA. Un claro ejemplo de esto es la Ley General de Bienes Nacionales (de 2004) que tiene contenido en materia ambiental por sus disposiciones en relación con las zonas costeras. $\mathrm{Si}$ bien la LGEEPA ha ido incorporado algunas disposiciones costeras, la ley de bienes nacionales mencionada (que abrogó a su similar de 1982) ha conservado prácticamente la totalidad de las normas jurídicas que abordan temas propios de lo ambiental-costero.

- Aunado a todo lo anterior, se han ampliado tanto la legislación sectorial como la de materias relacionadas en cuanto al número de le-

41 Brañes, Raúl, Manual de derecho ambiental mexicano, 2a. ed., México, Fundación Mexicana para la Educación Ambiental-Fondo de Cultura Económica, 2000, pp. 698 y 699. 
Esta obra forma parte del acervo de la Biblioteca Jurídica Virtual del Instituto de Investigaciones Jurídicas de la UNAM

yes. Este crecimiento se debe al surgimiento de una serie de temas novedosos que han tomado relevancia para nuestro país y que han requerido de un marco jurídico de regulación. Lejos de integrarse a la LGEEPA, los nacientes objetos de estudio han acabado por plasmarse en leyes específicas.

- Ejemplos de lo anterior dentro de la legislación sectorial son: (i) la conservación y el aprovechamiento sustentable de la vida silvestre y su hábitat con la Ley General de Vida Silvestre (de 2000) que abrogó la Ley Federal de Caza (de 1952); (ii) la protección al ambiente en materia de prevención y gestión integral de los residuos con la Ley General para la Prevención y Gestión Integral de los Residuos (de 2004); (iii) la regulación de actividades de utilización confinada, liberación experimental, liberación en programa piloto, liberación comercial, comercialización, importación y exportación de organismos genéticamente modificados con la Ley de Bioseguridad de los Organismos Genéticamente Modificados (de 2005) y (iv) la promoción y desarrollo de los bioenergéticos para la diversificación energética y el desarrollo sustentable con la Ley de Promoción y Desarrollo de los Bioenergéticos (de 2008).

- Ejemplos dentro de la legislación por materias relacionadas podemos citar los siguientes: (i) la promoción del desarrollo rural sustentable y el medio ambiente adecuado con la Ley de Desarrollo Rural Sustentable (de 2001) que abrogó la Ley de Fomento Agropecuario (de 1981) y la Ley de Distritos de Desarrollo Rural (de 1988); (ii) la regulación, fomento y administración del aprovechamiento de los recursos pesqueros y acuícolas con la Ley General de Pesca y Acuacultura Sustentables (de 2007) que abrogó la Ley de Pesca (de 1992); (iii) el aprovechamiento sustentable de la energía con la Ley para el Aprovechamiento Sustentable de la Energía (de 2008) y (iv) el aprovechamiento de fuentes de energías renovables y tecnologías limpias con la Ley para el Aprovechamiento de las Energías Renovables y el Financiamiento para la Transición Energética (también de 2008).

- En suma, coexisten con la LGEEPA distintas pragmáticas que regulan aspectos diversos de todo lo que conforma la materia ambiental. Proceder a una codificación ambiental será, como es lógico suponer, una labor sumamente complicada no sólo porque el número de 
Esta obra forma parte del acervo de la Biblioteca Jurídica Virtual del Instituto de Investigaciones Jurídicas de la UNAM

leyes y de normas jurídicas ambientales ha aumentado, sino porque ciertas leyes como la de aguas nacionales es considerada a su vez como un verdadero código. ${ }^{42}$

\section{3. ¿Son buenas las pragmáticas ambientales?}

- Sobre la pregunta de cuándo las pragmáticas han de ser buenas (que corresponde a la segunda idea del consejo de don Quijote) hemos tratado de darle respuesta a través del argumento de que una ley es buena en la medida en que sea útil y cumpla su propósito, es decir, se apegue a lo que es la característica esencial de una ley. Para ello, acudimos al pensamiento de varios autores y nos llama la atención lo que en este sentido ha razonado Montesquieu. Recordemos que este pensador francés señala que las leyes deben estar en relación con la naturaleza física del país, tomando en cuenta cuestiones como el clima, su extensión geográfica, el tipo de vida y número de sus habitantes, las inclinaciones de éstos, su comercio, etcétera. Por lo que nos preguntamos ¿acaso la legislación ambiental ha recogido los razonamientos y propuestas de Montesquieu?

- Para responder a esta última interrogante debemos retomar lo ya señalado respecto a que la tendencia de nuestra legislación ambiental no es la de codificar, sino la de regular por sector y la de incluir disposiciones en la legislación por materias relacionadas. Derivado de esto, y teniendo presente el fortalecimiento y expansión particularmente de las leyes sectoriales, tendríamos que analizar si la legislación ambiental de este tipo se ha desarrollado a tal grado que está cumpliendo con el propósito de regular por sector temas ambientales que estén relacionados — como decía Montesquieu- con las condiciones físico-geográficas y poblacionales de este país.

- Aclarado el punto anterior, nos viene a la mente un tema que por su importancia se ajusta a lo que aquí pretendemos exponer, que no es otra cosa que determinar si la legislación ambiental sectorial ha plasmado en sus leyes lo razonado por Montesquieu. Se trata de un sector que hemos abordado en otras ocasiones y desde diversos en-

42 Nava Negrete, Alfonso, Derecho administrativo mexicano, cit., nota 4, p. 81. 
Esta obra forma parte del acervo de la Biblioteca Jurídica Virtual del Instituto de Investigaciones Jurídicas de la UNAM

foques: lo relativo a las zonas costeras. ${ }^{43} \mathrm{Y}$ sobre este tema debemos comenzar por señalar que aún no existe en la legislación ambiental sectorial una ley sobre costas, lo que nos parece verdaderamente lamentable por varias razones.

- En primer lugar, es fundamental hacer hincapié en que nuestro país es una nación privilegiada por su extensión costera y superficie marina. Cuenta con más de 11,000 kilómetros de litoral (i. e. longitud de la línea de costa) que pertenece en un $70 \%$ a las vertientes del Océano Pacífico, el Golfo de California y el Mar de Cortés y en un $30 \%$ a las del Golfo de México y el Mar Caribe, y con más de 3, $149,920 \mathrm{~km}^{2}$ de superficie marina (incluye al mar territorial y a la zona económica exclusiva). Por su ubicación geográfica y por su extensión, México goza de diversas "regiones ecológicas" en las partes costeras que incluyen desde selvas cálido-húmedas y cálidosecas hasta grandes planicies y desiertos. ${ }^{44}$

- En segundo lugar, el litoral mexicano (en su parte terrestre, es decir, lo propiamente costero) es verdaderamente rico en diversidad natural (y cultural) con climas secos, cálidos y templados. La importancia ambiental que tiene es enorme: representa el hábitat de varias especies endémicas y de reproducción de especies migratorias, al mismo tiempo que se erige como uno de los principales lugares donde se localiza un vasto patrimonio genético además de ser el motor para mantener y permitir la continuidad de los ciclos hidrológico y climático para el país y otras regiones del planeta. ${ }^{45}$

- En tercer lugar, el potencial económico-productivo por el atractivo turístico que representan nuestras playas se ve reflejado en el

43 Hacemos alusión a los siguientes artículos: Nava Escudero, César "La privatización de las zonas costeras en México", en López Olvera, Miguel Alejandro (coord.), Estudios en homenaje a don Alfonso Nava Negrete. En sus 45 años de docencia, México, UNAM, Instituto de Investigaciones Jurídicas, 2006, pp. 143-185 y del mismo autor "Turismo internacional de playa y cambio climático", Revista de la Facultad de Derecho de México, México, tomo LVIII, núm. 250, julio-diciembre de 2008, pp. 201-231.

44 Véase para mayor referencia Instituto Nacional de Estadística, Geografía e Informática, México hoy. Edición 2007, México, Instituto Nacional de Estadística, Geografía e Informática, 2008.

45 Véase para mayor información Nava Escudero, César "La privatización de las zonas costeras en México", en López Olvera, Miguel Alejandro (coord.), Estudios en homenaje a don Alfonso Nava Negrete..., cit., nota 43, pp. 165 y ss. 
Esta obra forma parte del acervo de la Biblioteca Jurídica Virtual del Instituto de Investigaciones Jurídicas de la UNAM

número de divisas extranjeras que entran al país por la internación de visitantes de otras naciones (sobre todo de Estados Unidos y de Canadá) a centros como Cancún y Cozumel en Quintana Roo y Los Cabos en Baja California Sur. Los turistas de internación, ${ }^{46}$ que son los más importantes para el sector turístico mexicano por razón del tiempo de estancia, uso de servicios turísticos y derrama económica, han tenido como preferencia los destinos de playa. ${ }^{47}$

- Si bien contamos con una ley que regula la parte marina de nuestros litorales, que es la Ley Federal del Mar, no así una que regule la parte terrestre. Lo que existe en la actualidad es una dispersión considerable de normas jurídicas en más de veinte leyes donde destaca de todas ellas la Ley General de Bienes Nacionales y su reglamento (Reglamento para el Uso y Aprovechamiento del Mar Territorial, Vías Navegables, Playas, Zona Federal Marítimo Terrestre y Terrenos Ganados al Mar). Hay que mencionar que esa dispersión legislativa incluye a la LGEEPA, a algunas leyes ambientales por sector, y a otras leyes por materias relacionadas. Esto claramente se ha visto reflejado en una situación de yuxtaposición y contradicción de ordenamientos que a fin de cuentas generan incertidumbres sobre si se estará cumpliendo o no con el propósito de una regulación ambiental de las zonas costeras en México.

- En suma, pensamos que la legislación ambiental sectorial no puede considerarse como buena porque aún faltan por expedirse pragmáticas que cumplan con el propósito de regular temas que están apegados a nuestras condiciones naturales y sociales, como bien lo advirtió en su momento Montesquieu. Una ley de costas deberá estar orientada a regular la zona territorial costera pero idealmente deberá incluir y de manera integrada tanto la zona marina como la atmosférica.

46 La Secretaría de Turismo ha definido a estos visitantes como "aquéllos que rebasan la franja fronteriza o que directamente llegaron al país a cualquiera de las ciudades o destinos turísticos del interior". Véase Secretaría de Turismo, Visitantes internacionales hacia México, el turismo de internación 2000-2005, México, Secretaría de Turismo, noviembre de 2006.

47 Más información en Nava Escudero, César, "Turismo internacional de playa y cambio climático", cit., nota 43, pp. 210-213. 
Esta obra forma parte del acervo de la Biblioteca Jurídica Virtual del Instituto de Investigaciones Jurídicas de la UNAM

\section{4. ¿Se cumplen las pragmáticas ambientales?}

- Llegamos finalmente a la tercera idea que, como recordaremos, consiste en que las leyes han de cumplirse, porque de lo contrario, es como si no existiesen. En el análisis que efectuamos para determinar cuándo una ley habrá de cumplirse, incluimos un aspecto fundamental que es el de que la no aplicación de una ley o de ciertas disposiciones jurídicas tiene que ver no sólo con los gobernados sino con los gobernantes. Al explorar las posibles causas de la no aplicación de normas por los gobernantes dijimos que una de ellas es que los ordenamientos jurídicos están incompletos. Es esta razón la que nos interesa rescatar para vincularla a la tercera idea del consejo del Quijote y habremos de tomar como ejemplo una ley ambiental sectorial, la Ley de Aguas Nacionales (en adelante, LAN).

- Debemos comenzar por preguntarnos, ¿la legislación ambiental en su conjunto, sectorial o por materias relacionadas en nuestro país no se cumple porque está incompleta? Me parece que uno de los muchos desafíos que enfrenta el ius-ambientalismo mexicano en la actualidad es que una de las principales razones por las que las leyes ambientales no se cumplen es por falta de reglamentos, por reglamentos que están incompletos, o porque no se expiden o emiten otros ordenamientos jurídicos indispensables que permitan su aplicación, como lo podrían ser acuerdos, decretos o normas oficiales mexicanas (conocidas por sus siglas como NOM). Sería impreciso sostener que esto sucede en toda la legislación ambiental, pero sí es inequívoco que muchas de las disposiciones ambientales contenidas en diversas leyes que conforman toda esa legislación ambiental simplemente no tienen aplicación, i. e. es como si no existieran.

- Este es el caso de una ley ambiental sectorial, la LAN, cuya aplicación actual es parcial. Esto es así porque el decreto que se publicó en el Diario Oficial de la Federación el 29 de abril de 2004 para reformar, adicionar y derogar diversas disposiciones de esta ley, sujetó la aplicación de muchas de sus normas jurídicas a una serie de reglamentos que todavía no han sido expedidos.

- En efecto, en el artículo tercero transitorio del decreto arriba mencionado, se establece que en un plazo que no será mayor de doce meses a partir de su entrada en vigor se habrían de expedir los re- 
Esta obra forma parte del acervo de la Biblioteca Jurídica Virtual del Instituto de Investigaciones Jurídicas de la UNAM

glamentos a los que alude el propio texto de la ley, lo que permitiría la aplicación de un gran número de disposiciones jurídicas. Este decreto de reformas, adiciones y derogaciones entró en vigor al día siguiente de su publicación, por lo que los reglamentos debieron haberse expedido a más tardar a finales de abril de $2005.48 \mathrm{~A}$ la fecha, no se ha procedido en total consecuencia y por lo tanto no ha sido posible el cumplimiento completo de la ley.

- Sabemos que no existe obligación constitucional para que el Ejecutivo Federal expida el o los reglamentos correspondientes aunque exista una ley, ya que se trata de una atribución discrecional del propio presidente de la República. ${ }^{49}$ Pero esta situación ha llevado a que una parte importante de lo reformado y adicionado de la LAN no se haya implementado en los casi cinco años de vida que ya tienen las disposiciones insertadas desde 2004. ¿No es absurdo promulgar y publicar una ley que no se tiene la intención de aplicar?

- Una de las posibles razones por las que no hay todavía un reglamento de la LAN radica en que las reformas y adiciones a ésta nunca fueron del beneplácito del Ejecutivo Federal. Recordemos que las modificaciones a dicha ley fueron propuestas originalmente desde el Congreso de la Unión - la Comisión Nacional del Agua tuvo poca participación - pero fueron rechazadas desde un principio por las autoridades ambientales correspondientes. ${ }^{50}$

- La falta de pericia y experiencia del entonces "gobierno del cambio" (nos referimos a la administración del ex-presidente Vicente Fox Quesada) seguramente orilló al Ejecutivo Federal a publicar ese decreto de reformas y adiciones por presiones y conveniencias de tipo político-electorales. Independientemente de que las modificaciones a la LAN no hubieran sido las mejores para muchos sectores involucrados en el tema como lo fue la de minimizar el ideal

48 Es interesante hacer notar que el Reglamento Interno de la Comisión Nacional del Agua fue expedido posteriormente a esa fecha límite: su publicación en el Diario Oficial de la Federación es de 30 de noviembre de 2006.

49 Nava Negrete, Alfonso, Derecho administrativo mexicano, cit., nota 4, p. 137.

50 Rodríguez Briceño, Emiliano, “Agua y saneamiento en México: avances, errores y alternativas", en Olivares, Roberto y Sandoval, Ricardo (coords.), El agua potable en México. Historia reciente, actores, procesos y propuestas, México, Asociación Nacional de Empresas de Agua y Saneamiento de México A.C. (ANEAS), 2008, p. 53. 
Esta obra forma parte del acervo de la Biblioteca Jurídica Virtual del Instituto de Investigaciones Jurídicas de la UNAM

de gobiernos estatales y municipales por vivir un proceso fortalecido de descentralización a través de transferencia de atribuciones y coadyuvancia, ${ }^{51}$ o que se hubieran incluido principios inoperables $a$ priori como la idea de decretar el agua un "asunto estratégico de seguridad nacional", 52 lo cierto es que las autoridades de la Comisión Nacional del Agua encontraron la forma de detener la aplicación de la LAN a través de la atribución discrecional en materia de expedición de reglamentos arriba señalada.

- Con todo, es inadmisible la idea de que se hayan hecho tantas modificaciones a la LAN y que no se hayan establecido los mecanismos jurídicos para el cumplimiento de la nueva normatividad. Lamentablemente, el actual "gobierno del cambio, segunda parte" (nos referimos a la administración en manos de Felipe de Jesús Calderón Hinojosa) no parece tener la intención de expedir los reglamentos derivados de la ley.

- Es interesante advertir que de 2006 a 2008 se han presentado en el Congreso de la Unión un buen número de proyectos de iniciativas para reformar diversos artículos de la LAN. Algunos de estos proyectos han sido desechados, otros aprobados y otros más se encuentran aún pendientes de discusión.

- En suma, con el ejemplo de las aguas nacionales aquí analizado, nos encontramos ante un grotesco escenario en el que se busca reformar $\mathrm{y}$ adicionar una serie de reformas y adiciones que aunque hayan sido publicadas en el Diario Oficial de la Federación, nunca han existido simple y sencillamente porque nunca se han aplicado.

51 Véase para un análisis sobre esta cuestión a Jardines Moreno, José Luis, "La infraestructura hidráulica municipal y la participación en su creación y operación de los gobiernos federal y estatal", en Olivares, Roberto y Sandoval, Ricardo (coords.), El agua potable en México..., cit., nota anterior, pp. 93 y ss.

52 Los razonamientos sobre este punto en particular pueden encontrarse en Nava Escudero, César “Agua y desalación en México: del engaño al oscurantismo jurídico", en Nava Escudero César e Hiriart Le Bert, Gerardo (coords.), Desalación de agua con energías renovables, México, UNAM, Instituto de Investigaciones Jurídicas, 2008. 
Esta obra forma parte del acervo de la Biblioteca Jurídica Virtual del Instituto de Investigaciones Jurídicas de la UNAM

\section{EPÍLOGO: DICE UN REFRÁN ANÓNIMO QUE "DE NECIOS ES HUIR DEL CONSEJO”}

Necio es el ignorante, el que no sabe lo que podía o debía saber. Así podríamos adjetivar a todos aquellos gobernantes que huyen del consejo de Don Quijote y que se dedican sin mayor seriedad a hacer o aprobar demasiadas pragmáticas que luego resultan no ser tan buenas, pero que sobre todo, no se llegan a cumplir. Lo que pueden y deben hacer nuestros gobernantes se sabe (aunque no siempre se practica) desde 1651, año en que se publicó la segunda parte de la obra de Miguel de Cervantes de donde hemos obtenido el consejo del caballero manchego y la respuesta de Sancho.

Como hemos visto en los apartados anteriores, lo escrito en la obra cervantina desde aquellos tiempos sigue teniendo vigencia. Aún transcurridos tantos años, no es obsoleta la presencia de esos dos personajes ficticios en la legislación ambiental mexicana de nuestros días.

Así como juristas, políticos, administradores y legisladores debieran poner atención a lo aconsejado por Don Quijote de la Mancha y aprender lo que al respecto hizo y dijo Sancho Panza, los estudiantes y estudiosos del derecho debiéramos hacer lo mismo respecto a los consejos que nos han dado algunos profesores de la Facultad de Derecho de la UNAM. Especialmente, cuando han provenido de maestros que tienen la experiencia profesional (teórica y práctica), la carrera docente, y los años de vida transcurridos que les da la autoridad moral para hacerlo.

En este sentido, quienes hemos sido alumnos del profesor Alfonso Nava Negrete, debemos recordar sus consejos de clase y ponerlos en práctica en nuestros quehaceres profesionales. Inmediatamente surge un dilema: más allá de que sus recomendaciones hayan sido muchas o no, de que sean buenas o no, ¿hemos de aplicarlas?

Como ex alumno, me atrevería a señalar que son cuatro los consejos que de mi maestro de derecho administrativo he tratado de poner en práctica, aunque creo que todavía me falta mucho camino por recorrer para seguirlos al pie de la letra. El primero de ellos lo heredó de su maestro de literatura mexicana, de ése poeta a quien conoció desde la secundaria y que fue para él un modelo en su vida, su maestro de maestros, Carlos Pellicer, quien le aconsejó que hay que viajar mucho. El segundo deviene como circunstancia natural de su amor a los libros y del gusto por la cultura: un buen abogado debe ser culto. El tercero, que él mismo ha puesto 
Esta obra forma parte del acervo de la Biblioteca Jurídica Virtual del Instituto de Investigaciones Jurídicas de la UNAM

en práctica día a día y que no se cansa de repetirlo a sus estudiantes radica en que hay que estudiar siempre y mucho. Finalmente, un consejo que trato de seguir cada vez que entro a un salón de clases y que es lo que lo ha caracterizado a lo largo de sus 50 años como docente: hay que entregarse a la cátedra.

Por lo que has dejado a tantas generaciones de abogados de universidades públicas y privadas, por tus cincuenta años de docencia y de entrega verdadera e ininterrumpida a tus alumnos de la Facultad de Derecho de la UNAM, querido maestro, igracias! y ¡muchas felicidades! 
Esta obra forma parte del acervo de la Biblioteca Jurídica Virtual del Instituto de Investigaciones Jurídicas de la UNAM

\section{DIÁLOGOS EN CRONOLOGÍA. A 75 AÑOS DE LA FUNDACIÓN DEL INSTITUTO DE INVESTIGACIONES JURÍDICAS*}

\section{DiÁlogo 1. Con Luis Ponce De LeÓn ARMEnTA}

El primer trabajo de tiempo completo que tuve en mi vida profesional fue en el Instituto de Investigaciones Jurídicas de la UNAM como técnico académico. Recuerdo con gran cariño aquellos tiempos.

Transcurrían los primeros días de enero de 1991 y me presenté ante el doctor Ponce de León Armenta, quien fungía en aquel entonces como titular del ahora extinto Centro de Documentación, Legislación y Jurisprudencia. María Antonia Bello Mendieta (conocida en nuestro medio como Toñita) era su secretaria y a ella me dirigí.

- Toñita, buenos días ¿se encontrará el doctor?

-Usted es el de nuevo ingreso ¿verdad? Pase, ya le espera - me dijo sonriente mientras se levantaba y abría la puerta del cubículo de mi nuevo jefe.

Entré, y sin mayor preámbulo, lo saludé.

- Me vengo a presentar, soy César Nava, estudiante de la Facultad de Derecho, y estaré trabajando con usted. Creo que ya estaba enterado.

- Sí, ya sé quién eres. Bienvenido. ¿Ya sabes cuáles serán tus labores?

—No, todavía no. ¡Pero ya tengo cubículo! —respondí con entusiasmo, puesto que yo ya me sentía en todos los sentidos miembro del Instituto.

- Te adelanto que estarás apoyándonos en diversos proyectos que se realizan en el Centro. Uno de ellos es el Sistema UNAM-JURE. Seguro lo conoces.

- Creo que no doctor, la verdad no - respondí titubeante y al mismo tiempo un tanto sonrojado, ya que era la primera vez que escuchaba sobre

* Publicado en Bernal, Beatriz et al. (coords.), Testimonios y remembranzas acerca del Instituto de Investigaciones Jurídicas. 75 aniversario, México, UNAM, Instituto de Investigaciones Jurídicas, 2015. 
Esta obra forma parte del acervo de la Biblioteca Jurídica Virtual del Instituto de Investigaciones Jurídicas de la UNAM

la existencia de semejante proyecto y a mí no me sonaba en aquel instante; seguramente era importantísimo y conocido por todos.

— ¿Conoces a Alberto Real? —continuó preguntándome el doctor. idea.

- No - le respondí, y volví a sonrojarme porque no tenía la menor

-Él te explicará en lo que consiste. El proyecto es muy interesante, ya lo verás. Pronto conocerás a todos tus demás compañeros. Mientras tanto ¿qué te parece si vas a tu cubículo para establecerte? Más adelante tendremos oportunidad de platicar con calma.

Al entender que se trataba de una plática corta, le agradecí sus palabras de bienvenida y me despedí. Ambos nos levantamos, me extendió la mano, y muy cordialmente me deseó la mejor de las suertes.

A los pocos días, el doctor Ponce de León dejó de ser mi jefe; su lugar lo ocupó el doctor Juan José Ríos Estavillo.

\section{DiÁlogo 2. Con José Luis SoBerANES FERnÁNDEZ}

En febrero de 1991 se festejaron los 75 años de la promulgación de la Constitución Política de los Estados Unidos Mexicanos. Algunos eventos se realizaron en el estado de Querétaro y el Instituto tuvo una participación singular en ellos. El gobernador de esa entidad federativa era Enrique Burgos (hoy senador por el PRI), y el director del Instituto era el doctor José Luis Soberanes Fernández.

Algunos técnicos académicos fuimos invitados a participar en dichos festejos y recuerdo haber sostenido en aquella ocasión una brevísima conversación con el entonces director del Instituto y con el gobernador arriba mencionado. Lo distintivo de esa plática fue, por un lado, lo impensable de que llegara a suceder, y por el otro, el que hubiera tenido la "fortuna divina" de no haberme caído en una fuente del patio del recinto colonial donde se llevó a cabo el encuentro.

Repaso en mi mente lo ocurrido. Me encontraba al pie de la ya referida fuente colonial, y por razones meramente circunstanciales, tanto José Luis Soberanes como Enrique Burgos (quienes caminaban juntos, seguidos de una copiosa comitiva) se dirigieron hacia donde yo estaba para retirarse del lugar.

-Buenas tardes doctor — saludé primero al director del Instituto, quien se encontraba dos pasos adelante de Enrique Burgos. 
Esta obra forma parte del acervo de la Biblioteca Jurídica Virtual del Instituto de Investigaciones Jurídicas de la UNAM

-Qué tal César — me respondió.

De manera inesperada, el doctor Soberanes se dirigió al ahora ex gobernador con el objeto de presentarme con él.

- Mire — le dijo - le presento a uno de nuestros académicos... por cierto, de reciente ingreso.

- Hola, un gusto - expresó de manera escueta y me extendió su mano.

Después de saludarnos pensé en felicitarlo por la organización de los festejos, cuestión que no sucedió porque me percaté que tenía que ceder el paso para que él, y quienes les acompañaban, pudieran seguir avanzando.

Fue entonces, al hacerme a un lado, que perdí el equilibrio al meter el talón del pie derecho en una especie de surco o canal que rodeaba la fuente. En lo que un ser divino salido de la nada me detenía para no caer, la mirada enfática del doctor Soberanes me decía (creo yo): "no te caigas, no queremos show...".

\section{DiÁlogo 3. CON RAÚl PANTOJA BARANDA}

Regresando del periodo vacacional en el verano de 1992, me topé con mi querido compañero de generación y colega en el Instituto, Raúl Pantoja. Aquel encuentro fue propicio para presumirle que en definitiva sí me iba a estudiar la maestría a Inglaterra, a la Universidad de Exeter.

— ¿Qué onda mi buen Raúl! ¿Qué cuentas de nuevo?

-Nada mi querido César, sólo que sigo con lo de irme a estudiar a Inglaterra. ¿Tú cómo vas con eso?

-Pues te presumo que, finalmente, sí me voy a mediados de septiembre, y será a Exeter, la universidad con el campus más bello del sur de Inglaterra. Y te prometo una cosa — agregué tras una breve pausa- ¡allá voy a promocionar el UNAM-JURE!

Ambos empezamos a reír y Raúl, como era su costumbre, me tomó del antebrazo y con una sonrisa sincera me dijo:

- César qué gusto me da, te visitaré algún día, pero prométeme que no te vas a olvidar de todos nosotros.

- Raúl — le comenté con cara seguramente de despedida- es difícil olvidar a Jurídicas y a nuestros compañeros. Créemelo.

En ese mismo instante empecé a recordar (como ahora lo hago) las caras y nombres de aquellos con quienes más llegué a convivir como téc- 
Esta obra forma parte del acervo de la Biblioteca Jurídica Virtual del Instituto de Investigaciones Jurídicas de la UNAM

nico académico durante 1991 y 1992: Alberto Real, Rocío Ovilla, Judith Camacho, Juan José Ríos, Raúl Plascencia, Laura Ortiz, Ismael Eslava, Edgar Corzo, Arturo Anzures, Flora Bustillos, Marcia Muñoz, María del Pilar Hernández, Emma Riestra, Karla Acosta, Gilda Bautista, Susana Pedroza, Rocío García, María Eugenia Vázquez Laslop.

Años más tarde, en el verano de 1994, Raúl Pantoja me visitó en Londres. Yo vivía en el snobby y classy Hampstead, y estaba terminando mi primer año de doctorado en la Universidad de Londres. Ahí, en algún $p u b$, con un par de pints encima, recordamos y recortamos a los colegas del periodo 1991-1992.

\section{Diálogo 4. Con Diego VAladÉs Ríos}

Fue a principios de junio de 2004 que me entrevisté con el entonces director del Instituto, el doctor Diego Valadés, para analizar la posibilidad de incorporarme como investigador a mi antiguo hogar universitario. Nuestra plática duró unos 25 minutos o quizá 30 (no lo recuerdo con exactitud) pero hablamos de muchos temas, todos relacionados con mi eventual ingreso y con mis áreas de especialización. De todo lo hablado, recuerdo que se abordó una cuestión un tanto inusual para mí pero de la mayor trascendencia relacionada con las percepciones económicas de los investigadores de recién ingreso.

- Hay algo que quisiera preguntarle César —me comentó el doctor Valadés con ese tono ceremonioso pero siempre amigable que le caracteriza.

-Algo que es relevante, creo yo, para usted.

- Sí doctor, dígame.

- ¿Está casado?

He de confesar que la pregunta me tomó por sorpresa puesto que jamás habría imaginado que el estado civil importara para ser investigador. Le respondí que no, y me atreví a preguntar el porqué de tal situación.

Al verme sorprendido o extrañado, Diego Valadés me aclaró las cosas con un elegante toque de realismo universitario.

-No se asuste... lo que pasa es que al principio ise gana muy mal!

Y, en efecto, me asusté por un instante.

- Pero con el paso del tiempo - continuó- se gana mejor. Hay que hacer carrera académica, y pensar en el futuro. 
Esta obra forma parte del acervo de la Biblioteca Jurídica Virtual del Instituto de Investigaciones Jurídicas de la UNAM

—Entonces doctor — contesté- ya me casaré cuando llegue ese futuro.

Ambos sonreímos, nos despedimos, y un 15 de junio de 2004 comencé a trabajar en el Instituto como Investigador Ordinario de Carrera Asociado "C" de Tiempo Completo (a contrato).

Semanas más tarde, cuando recibí mi primer talón de pago, me acordé de aquel diálogo con Diego Valadés. Tenía toda la razón.

\section{DiÁlogo 5. CON LOS Vigilantes DE LA CASETA}

Hay diálogos que se han repetido cientos y cientos de veces (quizá millones de veces) dentro de las instalaciones del Instituto. El que creo que gana es el que yo, seguramente al igual que mi colegas, hemos sostenido con los vigilantes de la caseta.

- Que tal, buenos días - digo cuando llego al Instituto.

-Buenos días, doctor - me responden.

- Hasta luego, buenas tardes - digo cuando me voy del Instituto.

- Hasta luego, que le vaya bien doctor - me responden.

Y así per secula seculorum.

Para mí que estas frases son ya Patrimonio Cultural Intangible del Instituto.

\section{DiÁlogo 6. Con DANIEl MÁRQuez GÓMEZ}

Lograr el ingreso, permanencia y, en su caso, promoción en los diversos niveles del Sistema Nacional de Investigadores (en adelante, SNI) es como aventar una moneda al aire. A veces cae sol, a veces cae águila, a veces no cae.

Es natural que los investigadores aspiren a los niveles más altos del SNI, particularmente, el nivel III. Daniel Márquez y yo siempre hemos aspirado al nivel IX, $\mathrm{X}$ o a alguno más alto.

- Mi estimado Daniel, ¿cómo estás?

- Cesare, caro amico, fratelo, ti saluto. Yo bien ¿y tú?

-Aquí ando. Para no variar estoy armando mi expediente para el SNI. Ahora voy por el nivel IX, y si los dioses andan de buen humor, me dan el nivel X.

Entre broma y broma, Daniel siempre me da esperanzas: 
Esta obra forma parte del acervo de la Biblioteca Jurídica Virtual del Instituto de Investigaciones Jurídicas de la UNAM

— ¿Cesare, qué bueno! Algún día lo lograrás... o lograremos, pero intentemos el nivel XV ¿sale?

\section{DiÁlogo 7. CON HÉCTOR FiX-FierRo}

Algún día, no recuerdo cuál, me visitó Héctor Fix-Fierro en mi cubículo. Terminaba la gestión de Diego Valadés (hacia mediados de 2006), y Héctor se perfilaba para sustituirlo en el honorabilísimo cargo de director del Instituto.

Su visita fue inesperada para mí, pero nuestra plática fue muy cordial. Hablamos de muchas cosas: de la UNAM, de su estancia en Alemania y de la mía en Inglaterra, de nuestros proyectos, del personal académico.

También hablamos de un libro suyo que tenía poco de haberse publicado.

-Héctor, me enteré por ahí que se publicó un libro tuyo... es la versión en español de tu tesis de doctorado ¿no es así?

- Sí, y acaba de salir. Se publicó aquí, en el Instituto. ¿Ya lo tienes?

- Creo que no... ¿acaso no lo repartieron a los investigadores?

Guardó silencio unos segundos y me dijo:

- Si me esperas, te traigo un ejemplar.

Héctor se levantó y se fue.

$\mathrm{Al}$ cabo de unos cuantos minutos me visitó nuevamente en mi cubículo y, en efecto, traía en la mano un ejemplar de su libro.

- Caray Héctor - le dije estrechando su mano mientras me entregaba el ejemplar y leía en ese instante Tribunales, justicia y eficiencia - te agradezco el detalle. Muchas gracias.

Aquel día, no recuerdo cuál, pude descubrir (y conocer) a un Héctor amigable y generoso.

\section{DiÁlogo 8. CON HÉCTOR FiX-ZAMUdio}

Tuve el gran honor y privilegio de presentar, hacia finales de octubre de 2013, una ponencia sobre el derecho al agua en el Aula Mayor de El Colegio Nacional en el marco de los Actos Conmemorativos por los 70 años (1943-2013) de existencia de tan prestigiada institución en nuestro país. 
Esta obra forma parte del acervo de la Biblioteca Jurídica Virtual del Instituto de Investigaciones Jurídicas de la UNAM

Ofrecieron, en esos días, una comida a los participantes en las propias instalaciones del recinto mencionado (ubicado allá por Donceles, en el Centro Histórico de la Ciudad de México), y a la cual asistí gustosamente.

La mesa (custodiada a todo lo largo por retratos de diversos miembros de El Colegio Nacional) estaba exquisitamente adornada y dispuesta para unas 60 personas o quizá más. De un lado nos sentamos, en línea, los abogados. Yo me situé a la derecha del doctor Héctor Fix-Zamudio, y junto a mí, a mi derecha, se sentaron Ingrid Brena, después Arturo Oropeza y, finalmente, Alfredo Sánchez Castañeda. Del lado izquierdo de don Fix-Zamudio se sentaron un par de académicos, entre ellos, el doctor Fausto Kubli. Frente a nosotros, se ubicaron otros cuatro invitados, escritores, tres de los cuales reconocí inmediatamente: Enrique Krauze, Guillermo Sheridan y Christopher Domínguez.

Así sentados, y con tan poquitos comensales, comenzó la comida.

- Oiga doctor - le pregunté en voz baja a don Fix-Zamudio — ¿nos va a acompañar el doctor Diego Valadés?

- No - me respondió- pero se disculpó por no poder asistir.

— ¡Ah! ya veo- exclamé.

- Somos muy poquitos ¿verdad? — pregunté nuevamente. Y anticipándome a su respuesta, agregué nuevamente en voz baja:

- Por lo menos somos más que los de enfrente.

Don Fix-Zamudio movió afirmativamente la cabeza y me miró a los ojos como queriendo adivinar mi próxima pregunta.

- O de plano doctor estos literatos son entre fresas y alzados.

- Bueno, mire - me contestó - no lo sé. Pero a veces así son las cosas. Algunos son así...

Sin que nos hubieran escuchado los de enfrente, cambiamos de tema y seguimos comiendo.

Minutos más tarde, Guillermo Sheridan rompió el silencio entre ellos y nosotros (o entre nosotros y ellos). Nos hizo varias preguntas, y antes de que empezara a fumar, curioseó para saber si alguien de los investigadores llevaba la voz cantante o de representación del Instituto, particularmente refiriéndose a aquellos que tienen alguna columna en algún periódico de circulación nacional.

El diálogo que específicamente tuvieron él y el doctor Fix-Zamudio sobre ese y otros temas me pareció de lo más interesante; algunas frases en francés de ambos enriquecieron la plática. 
Esta obra forma parte del acervo de la Biblioteca Jurídica Virtual del Instituto de Investigaciones Jurídicas de la UNAM

Hacia el final de la comida, con coincidencias y antinomias de los temas abordados, acabamos tranquilamente nuestro postre, nos levantamos y nos tomamos (aunque no todos) una foto grupal.

Dialogar con don Héctor Fix-Zamudio siempre será una exquisitez intelectual. Sólo hay que esperar o, mejor dicho, pedir al destino que haga lo suyo para poder sentarse en una comida a platicar con él.

\section{DiÁlogo 9. CON JORGE WitKer VELÁZQUEZ}

Hacia finales de 2014 recibí una carta firmada por el director entrante, Pedro Salazar Ugarte, en la que se me invitaba a participar en una publicación de testimonios y remembranzas de la vida cotidiana del Instituto a propósito del cumpleaños 75 de esta dependencia universitaria. En ella, se designaba a la doctora Beatriz Bernal y a los doctores Ricardo Méndez Silva y Jorge Witker como coordinadores de la obra. Muchos otros investigadores, actuales y no, recibieron también esta carta-invitación.

La extensión de las colaboraciones, tal y como lo especificaba la carta mencionada, aludía a un mínimo de tres cuartillas y un máximo de doce. La misiva señalaba que los escritos enviados tendrían como objeto algo poco común en las obras de tipo conmemorativo. Cito textualmente: "...me complace invitar a Usted a participar con una colaboración sobre un tema libre de su elección relacionada con sus vivencias como miembro del Instituto".

De entrada, la idea me pareció genial por su originalidad y trascendencia personal, pero la duda que esto generó en mi persona sobre lo que se debía escribir, fue inmediata.

Poco tiempo después, hacia principios de 2015, los coordinadores designados enviaron una carta colectiva para aclarar algunas cuestiones relativas a las colaboraciones para semejante obra recordatoria. Cito textualmente: “...se trata de una visión sobre el acontecer del día a día, sobre nuestras experiencias particulares y las anécdotas que reflejan la vitalidad de nuestras convivencias".

Enviada esta carta, la duda permanecía.

Entonces, decidí preguntarle al doctor Jorge Witker sobre lo que podíamos escribir y lo que no.

—Doctor, buenos días, ¿está ocupado? - le pregunté a sabiendas de que un jurista de su talla siempre lo está. 
Esta obra forma parte del acervo de la Biblioteca Jurídica Virtual del Instituto de Investigaciones Jurídicas de la UNAM

—No, pásale — me respondió a sabiendas de que siempre está ocupado, pero que aún así tiene algún tiempecito para recibir a sus colegas.

-Doctor, vengo a verlo porque sé que usted es uno de los coordinadores de la obra conmemorativa por los 75 años del Instituto, pero no entiendo bien a bien el alcance de lo que se desea que nosotros escribamos.

- Sí claro. No se trata de ensayos o trabajos académicos propiamente, sino de cuestiones sobre lo que has vivido en el Instituto, tus experiencias. Cualquier cosa que sea una remembranza.

El doctor Witker hizo una pausa y le pregunté de manera un poco bromista: — ¿en verdad puede ser cualquier vivencia? ¿Incluso las que nos han sacado canas verdes?

- Bueno - me aclaró riéndose - no necesariamente las cosas malas o negativas, sino los recuerdos gratos, lo que tú consideres propio de un festejo.

—Entonces —enfaticé acompañándolo con algunas risas - dejaré los ratos incómodos o desagradables para otro momento, porque todo investigador los ha tenido ¿verdad doctor?

Ambos nos miramos asintiendo.

— ¿Y puedo utilizar cualquier forma de texto? —volví a preguntar.

- Sí, la que tú quieras, hay completa libertad.

-Entonces doctor - comenté inmediatamente — quizá elabore algo con ciertos tintes literarios. Puede ser en prosa o en verso, puede tratarse de una novela o un cuento. Ya veré.

El doctor Witker consintió y me despedí de él.

Saliendo de su cubículo me dije a mí mismo "quizá escriba algo así como unos diálogos con algunos miembros del Instituto, pero serán en cronología. Voy a releer a Eduardo Galeano o a Mario Benedetti, seguro me darán ideas de cómo hacer diálogos.

Y empecé a escribir lo que estoy escribiendo.

\section{Diálogo 10. Con Pedro Salazar Ugarte}

La primera semana de actividades conmemorativas de los 75 años del Instituto comenzó el martes 10 de marzo de 2015 con un evento llamado Conversatorio: retrospectiva del Instituto de Investigaciones Jurídicas. En él participaron los cinco ex directores actuales: los doctores Héctor 
Esta obra forma parte del acervo de la Biblioteca Jurídica Virtual del Instituto de Investigaciones Jurídicas de la UNAM

Fix-Zamudio, Jorge Madrazo, José Luis Soberanes, Diego Valadés y Héctor Fix-Fierro. Moderó el evento el director en turno, Pedro Salazar.

Cada cual comentó sobre sus experiencias como directores, a veces con comentarios-respuesta a las preguntas formuladas por el moderador, a veces con comentarios-vivencias a modo de mundología personal. Unos nos hicieron reír más que otros: afloraron anécdotas y recuerdos. También se asomaron, chismosas y reveladoras como casi siempre lo son, una que otra lágrima.

Después de una oleada de aplausos y de acostumbradas salutaciones al final del evento, se ofreció en el mismo auditorio (el Auditorio "Héctor Fix-Zamudio") un recital de cello: el intérprete fue, nada más y nada menos, que Carlos Prieto.

Antes de que comenzara el recital, yo me acerqué lo más que pude a las primeras filas de asientos, y me senté junto a la doctora Carla Huerta. En la plática le ofrecí una pastilla Halls de hierbabuena que inmediatamente aceptó.

En ese preciso instante se acercó Pedro Salazar, quien presenció el acto de ofrecimiento de pastilla, y pidió una.

-Yo también quiero una - expresó el director dirigiendo su mirada hacia mí y hacia las pastillas. Y continuó — no sé de quién sean, pero ¿puedo?

—Son mías Pedro... pero por supuesto que sí - le contesté.

Extendí el paquete de pastillas y tomó una.

- Gracias, César.

- No hay de qué Pedro... así podremos disfrutar mejor el recital.

A su lado se encontraba la doctora Mónica González, quien presenciaba esta fabulosa danza de pastillas, y me percaté de que ella, asimismo, quería la suya. Amigablemente me solicitó una, la tomó, y tanto Pedro como Mónica se sentaron exactamente enfrente de donde estábamos sentados Carla y yo. Minutos después, el sonido de las notas musicales inundó el auditorio.

Con un genuino conversatorio, unas refrescantes pastillas Halls, y un magnífico recital, comenzó, para mí, el 75 aniversario del Instituto. 
Esta obra forma parte del acervo de la Biblioteca Jurídica Virtual del Instituto de Investigaciones Jurídicas de la UNAM

\section{HISTORIAS ANTI-AMBIENTALES DE UN PASADO RECIENTE. EL SEXENIO 2006-2012 QUE SE FUE*}

\section{INTRODUCCIÓN}

Al doctor Jorge Witker no le son ajenos los temas ambientales. En su larga trayectoria como investigador ha escrito - si bien desde la óptica del derecho económico - sobre cuestiones que son propias del derecho ambiental como los recursos naturales, ${ }^{1}$ el agua, ${ }^{2}$ y el cambio climático. ${ }^{3}$ Por esta sencilla razón, estoy convencido de que el artículo que he elaborado a propósito de su merecido homenaje por sus 40 años como universitario ejemplar, no le será ni extraño ni distante.

Primero como su alumno en la Facultad de Derecho (en 1990), y luego como colega en el Instituto de Investigaciones Jurídicas (desde 2004), he aprendido de él lo trascendente que es conducirse con honestidad científica y rectitud académica. Si se quiere indagar sobre la verdad de las cosas, estos dos pilares son indispensables, y me parece que todo

* Publicado en Godínez Méndez, Wendy A. y García Peña, José Heriberto (coords.), Derecho económico y comercio exterior. 40 años de vida académica. Homenaje a Jorge Witker, México, Tecnológico de Monterrey-UNAM, Posgrado Derecho e Instituto de Investigaciones Jurídicas, 2015.

1 Le dedica todo un capítulo a este tema desde la primera edición de una de sus obras clásicas, Witker, Jorge, Curso de derecho económico, México, UNAM, Instituto de Investigaciones Jurídicas, 1989, pp. 71 y ss.

2 Véase Witker, Jorge, "El agua como recurso natural desde la perspectiva del derecho económico", en Nava Escudero, César e Hiriart LeBert, Gerardo, Desalación de agua con energías renovables, México, UNAM, Instituto de Ingeniería e Instituto de Investigaciones Jurídicas, 2008, pp. 205-215.

3 En un artículo reciente sobre cambio climático aborda específicamente el tema de los bonos de carbono. Véase Witker, Jorge, "El derecho económico y los bonos de carbono", en Nava Escudero, César y Nava Escudero, Oscar (coords.), Administración pública contemporánea. Derecho, política y justicia. Estudios en homenaje a Alfonso Nava Negrete, México, Porrúa-UNAM, Facultad de Derecho e Instituto de Investigaciones Jurídicas, 2010, pp. 685-709. 
Esta obra forma parte del acervo de la Biblioteca Jurídica Virtual del Instituto de Investigaciones Jurídicas de la UNAM

trabajo de investigación de mi querido maestro está estructurado de esta manera. Percibir y corroborar esto en la obra de un académico inspira y motiva para andar el mismo camino.

Por ello, este ensayo tiene por objeto inquirir sobre la veracidad de dos hechos históricos ocurridos durante el sexenio 2006-2012 a la luz del pensamiento ambientalista contemporáneo: la existencia de la llamada "guerra" contra el crimen organizado, y la afición del entonces presidente de la República por la "fiesta" taurina. Si bien la administración pasada tenía una agenda ambiental, estas dos historias — que aquí describimos como anti-ambientales - permiten comprobar el perfil incongruente y contradictorio de un gobierno y de su jefe máximo al mostrar lo que fue en su momento un discurso quimérico fabricado desde el poder para hacernos creer que el tema de la protección ambiental se encontraba en el nivel más alto de la agenda presidencial.

\section{HiSTORIAS ANTI-AMBIENTALES}

Relatar lo que ha ocurrido a través de la investigación (que es ciencia) y de la narración (que es arte) ha sido, al menos en un sentido clásico, una forma de describir la labor que realiza el historiador. ${ }^{4}$ El contar una historia, o muchas, no es quehacer ficticio o infecundo en tanto se busque con ello el conocimiento y la verdad de las cosas que se relatan. Quien escribe una o varias historias, les da sentido y las dota de utilidad y credibilidad si parte de hechos consumados o difíciles de negar, lo que seguramente lo aleja del mito o la novela. En palabras de Luis Villoro:

El historiador tiene que partir de una realidad actual, nunca de una situación imaginaria; esto es lo que separa su indagación de la del novelista, quien también, a menudo, escudriña en el pasado. Quiere esto decir que, a la vez que el pasado permite comprender el presente, el presente plantea los interrogantes que incitan a buscar el pasado. De allí que la historia pueda verse en dos formas: como un intento de explicar el presente a partir del sus antecedentes pasados, o como una empresa de comprender el pasado desde el presente. ${ }^{5}$

4 Cfr. Shotwell, James T., Historia de la historia en el mundo antiguo, trad. de Ramón Iglesia, México, Fondo de Cultura Económica, 1940, pp. 40 y ss.

5 Villoro, Luis, "El sentido de la historia”, Historia, ¿para qué?, 19a. ed., México, Siglo XXI, 2002, p. 38. 
Esta obra forma parte del acervo de la Biblioteca Jurídica Virtual del Instituto de Investigaciones Jurídicas de la UNAM

Las historias que se relatan en este artículo están basadas en hechos reales cuya existencia es prácticamente innegable — por lo menos a los ojos de quienes nos hemos dedicado por muchos años a los temas ambientales - . Por consiguiente, nuestro punto de partida fáctico no es incierto. Aunque es altamente probable que se genere cierta polémica respecto a la interpretación de dichas historias, estamos convencidos de que la interpretación que hemos llevado a cabo de los hechos históricos relatados se apoya en el conocimiento de los mismos, ${ }^{6}$ de que hemos buscado con ello la verdad de lo que ha acontecido, ${ }^{7} \mathrm{y}$ de que su análisis a la luz del pensamiento ambientalista está debidamente fundamentado. Nuestros relatos difieren de las versiones que han sido maliciosamente elaboradas por quienes trataron de falsear la realidad y de crear al mismo tiempo una imagen engañosa en torno a lo que representa proteger el ambiente y a lo que significa actuar de manera consecuente para alcanzar tal protección. Se ha realizado una labor legítima y sobre todo útil para comprender el pasado desde el presente. ${ }^{8}$

Para proceder en consecuencia, es indispensable reflexionar en lo siguiente. En lenguaje común se dice que hacer crítica desde "afuera" es muy fácil, y con esto se ha querido enfatizar que cualquier análisis sólo es correcto y verdadero si la crítica se hace desde "adentro". Pero no está del todo claro a qué se refiere eso de estar adentro o, en su caso, estar afuera, particularmente para cuando se pretende desarrollar el arte y la ciencia de escribir e interpretar historias que han ocurrido.

Preocuparía en demasía creer que el historiador debiera ubicarse en un espacio y tiempo determinados para que su relato fuera fidedigno. ¿Sólo es creíble la narración del escritor que está espacialmente "dentro" de un grupo o clase dominante vis à vis la narración de quien está "fuera" de ese círculo? ¿Sólo es verosímil el relato de quien temporalmente tiene

6 Se ha dicho correctamente que todo aquel que escribe historia "deberá tener presente siempre que la base de toda interpretación seria es el conocimiento de los hechos; sobre todo, [de] aquellos datos que parezcan contradecir sus opiniones previas". Brom, Juan, Para comprender la historia, México, Grijalbo, 2003, p. 56.

7 La importancia que tiene la idea de buscar la verdad de las cosas pasadas, sin farsa ni disimulo, tiene antecedentes remotos, y quizá el más conocido de ellos en occidente es el que encontramos en la principal obra de Tucídides: Historia de la Guerra del Peloponeso.

8 Una excelente reflexión sobre la legitimidad y utilidad del saber histórico se puede obtener en Pereyra, Carlos, Historia, ¿para qué?, cit., pp. 11-18. 
Esta obra forma parte del acervo de la Biblioteca Jurídica Virtual del Instituto de Investigaciones Jurídicas de la UNAM

una experiencia directa con hechos que le son contemporáneos y no el relato de quien indaga en un pasado que no vivió personalmente o que le es distante?

Es científicamente insostenible querer descalificar o desacreditar historias y/o sus interpretaciones por el simple hecho de que éstas hayan sido escritas desde un subjetivísimo "estar afuera" espacial y temporalmente. Agregaríamos, incluso, que tal intento de desaprobación se vuelve irrelevante, como lo demuestran los innumerables casos de grandes historiadores cuyas obras son el resultado indistinto de narrar hechos que les fueron contemporáneos a la vez que remotos. Además, hay obras que no siempre se escribieron desde una posición privilegiada o desde una élite determinada. Todo lo contrario: se hicieron desde la exclusión social o política, desde el destierro mismo.

Historias monumentales han adquirido ese estatus con fuentes de información muy variadas: vivencias directas, encuestas o entrevistas con testigos presenciales, documentos de diversa índole (antiguos y coetáneos), crónicas basadas en la tradición oral, entre otros. Ahí están, por ejemplo, esos grandes historiadores griegos de la antigüedad, como Heródoto, Tucídides, Jenofonte o Polibio, que si bien "tendían en realidad a escribir exclusiva o principalmente sobre hechos del pasado inmediato", 9 en ciertas ocasiones fueron testigos presenciales y en otras más fueron simples receptores de relatos antiguos.

Heródoto, Padre de la Historia para los países occidentales, hizo historia moderna pero también historia antigua; sus fuentes de información las obtenía de documentos antiguos para su época, de encuestas con sabios y sacerdotes de los lugares que visitaba, y como buen religioso que era ¡hasta de los oráculos de Delfos! ${ }^{10}$ Es sabido que Tucídides escribió parte de su principal obra, i. e. las guerras entre atenienses y espartanos, en el destierro. Paradójicamente, el haber estado alejado de los primeros

9 Heródoto (ca. 484-425 a. de C.) escribió sobre las Guerras Médicas (499-449 a. de C.), que habrían acontecido antes de su nacimiento y durante su vida; Tucídides (ca. 460-396 a. de C.) relató las guerras del Peloponeso (431-404 a. de C.), de las que fue su contemporáneo; Jenofonte (ca. 431-354 a. de C.) fue testigo de las historias sobre las hegemonías de Esparta y Tebas (404-362 a. de C.); Polibio (ca. 200-118 a. de C.) describió las tres Guerras Púnicas (264-146 a. de C.) pero sólo fue coetáneo de la última. Véase Momigliano, Arnaldo, Ensayos de historiografia antigua y moderna, trad. de Stella Mastrangelo, México, Fondo de Cultura Económica, 1993, pp. 141 y ss.

10 Shotwell, James T., Historia de..., cit., pp. 200 y ss. 
Esta obra forma parte del acervo de la Biblioteca Jurídica Virtual del Instituto de Investigaciones Jurídicas de la UNAM

le ayudó a comprender aún más el conflicto que relató por tener relación precisamente con los segundos. ${ }^{11}$

Por lo que más allá de preocuparnos por determinar si estuvimos dentro o fuera de los hechos que narramos, hemos sido cautelosos en la selección y depuración de nuestras fuentes de información procurando corroborar su autenticidad, buscando con ello acercarnos a la realidad de las cosas. Nos hemos allegado de documentos oficiales; opinión de expertos en los temas que se abordan (a través de notas periodísticas, artículos, ensayos, libros u otros trabajos científicos); entrevistas o charlas informales con diferentes actores o testigos presenciales (esto es, académicos, funcionarios públicos, litigantes, miembros de organizaciones no gubernamentales, etcétera). ${ }^{12}$ Las fuentes son muy variadas, pero gracias a ello hemos logrado sustentar nuestros puntos de vista.

Ahora bien, el título de este artículo utiliza la expresión historias anti-ambientales y no la de historias ambientales porque los hechos que se narran en este artículo han de considerarse contrarios a lo que es la protección ambiental. ¿Y qué significa proteger el ambiente? Bueno, sobre esto se ha escrito muchísimo, y nos atreveríamos a sostener que en realidad no hay un razonamiento concluyente sobre lo que tal expresión representa. Pero es importante puntualizar dos cosas. Primero, que el objeto que se quiere proteger, es decir, lo ambiental, comprende (al menos desde el punto de vista jurídico) el medio natural, el medio construido, así como la salud, el bienestar y la calidad de vida de los seres humanos. ${ }^{13}$

11 Tucídides vivió un poco de ambos mundos en la guerra entre atenienses y espartanos, aunque no siempre bajo las mismas condiciones de privilegio. Durante algún tiempo tuvo una elevada posición en los asuntos públicos de Atenas, conoció personajes destacados de la guerra, e incluso fue elegido como jefe militar. Sin embargo, desde el 424 al 404 a. de C. (cerca de 20 años) estuvo desterrado, fuera de esa cúpula ateniense, y sus fuentes de información comenzaron a provenir de relatos de testigos espartanos. Más información en ibidem, pp. 211-213.

12 Por su supuesto, se han retomado investigaciones propias publicadas como capítulos de libros y artículos en revistas arbitradas, así como de libros de mi autoría debidamente dictaminados.

13 Para un análisis del concepto jurídico de ambiente, acúdase a Nava Escudero, César, Ciencia, ambiente y derecho, México, UNAM, Instituto de Investigaciones Jurídicas, 2012, pp. 267 y ss. 
Esta obra forma parte del acervo de la Biblioteca Jurídica Virtual del Instituto de Investigaciones Jurídicas de la UNAM

La idea de protección bien podría referirse a evitar, minimizar, eliminar o revertir el daño a lo ambiental. ${ }^{14}$

TABLA 1

El pensamiento ambientalista: principales posturas y corrientes

\begin{tabular}{|c|c|c|c|}
\hline & $\begin{array}{c}\text { Criterio de } \\
\text { distinción inicial }\end{array}$ & $\begin{array}{c}\text { Posturas cientificas } \\
\text { y ético- } \\
\text { filosóficas }\end{array}$ & $\begin{array}{l}\text { Corrientes de } \\
\text { pensamiento }\end{array}$ \\
\hline $\begin{array}{l}\text { Pensamiento } \\
\text { ambientalista } \\
\text { (Eje Norte- } \\
\text { Sur) }\end{array}$ & $\begin{array}{l}\text { Existen dos entes: } \\
\text { lo humano } \\
\text { vis à vis } \\
\text { lo no humano } \\
\text { Existe una relación } \\
\text { entre ambos entes }\end{array}$ & $\begin{array}{l}\text { Antropocentrismo } \\
\text { Ecocentrismo } \\
\text { Ambiocentrismo } \\
\text { Sabiduría } \\
\text { ancestral-sagrada }\end{array}$ & $\begin{array}{l}\text { Cornucopianos } \\
\text { Intervencionistas } \\
\text { Acomodaticios } \\
\text { Tecnocentristas } \\
\text { Ambientalistas moderados } \\
\text { Eco-desarrollistas } \\
\text { Eco-feministas } \\
\text { Marxistas } \\
\text { Eco-comunalistas } \\
\text { Gaianistas } \\
\text { Anarquistas } \\
\text { Neo-malthusianos } \\
\text { Verdes } \\
\text { Conservacionistas } \\
\text { Ultradarwinistas } \\
\text { Ecologistas cosmogénicos } \\
\text { Ecologistas profundos } \\
\text { Ecologistas chamánicos } \\
\text { Cosmopercepcionistas } \\
\text { Saberes ancestrales-sagrados }\end{array}$ \\
\hline
\end{tabular}

Fuente: Nava Escudero, César, Ciencia, ambiente y derecho, cit.

Segundo, que bajo la égida del pensamiento ambientalista, y en el contexto de un eje discursivo entre países del norte y del sur, se han desarrollado diversas posturas científicas y ético-filosóficas con el objeto de darle orientación (mediante distintas corrientes de pensamiento) a los de-

14 Hemos tomado este ejemplo de Park, Chris, Dictionary of Environment and Conservation, Oxford, Oxford University Press, 2008, p. 154. Alertamos al lector que existen una infinidad de definiciones respecto a lo que es la protección en el contexto ambiental. 
Esta obra forma parte del acervo de la Biblioteca Jurídica Virtual del Instituto de Investigaciones Jurídicas de la UNAM

bates que giran alrededor de lo que significa la protección ambiental. En un sentido amplio, esto mismo equivale a explicar y puntualizar las causas y respuestas a la crisis ambiental de nuestros días (véase la tabla 1). ${ }^{15}$

Así, es posible identificar sin que existan fronteras exactas, a qué corriente de pensamiento pertenecen los discursos ambientalistas que se construyen por los diferentes actores políticos. Consciente o inconscientemente, tales discursos están basados en argumentos, postulados, valores, convicciones, preocupaciones, oportunidades, entre otros, de cada postura (o de algunas partes de ellas) y de sus corrientes de pensamiento.

La presencia de valores ambientales se ha generalizado en todos los ámbitos y penetrado en todos los discursos políticos a lo largo y ancho del planeta, por lo que es importante desagregar, por un lado, los distintos discursos y, por el otro, sus usos políticos concretos, incluso las distintas filosofías que subyacen en esos discursos ambientalistas que encierran valores e identidades. ${ }^{16}$

No cabe duda que prácticamente todas las posturas y corrientes de pensamiento son ambientalistas. Es decir, sus postulados y discusiones buscan desde diversas ópticas e ideologías — donde algunas contrastan y otras concuerdan entre sí- el objetivo común de proteger el ambiente. De manera relevante, todas ellas coinciden fundamentalmente en una

${ }^{15}$ En un trabajo de investigación anterior identificamos cuatro grandes posturas científicas y ético-filosóficas con base en un criterio inicial de distinción entre lo humano ( $i$. $e$ c cultura, mente, sustancia pensante, proceso social, medio construido, etcétera) y lo no humano (i.e. cuerpo, sustancia extensa, proceso natural, recursos naturales, medio natural, etcétera). Éstas son: $i$ ) el antropocentrismo, donde el ser humano aparece como un sujeto que domina a lo no humano, este último aparece como el objeto dominado; ii) el ecocentrismo, donde se reconoce la igualdad entre el sujeto y el objeto, pero existe cierto predominio de éste sobre aquél; iii) el ambiocentrismo, donde no importa tanto el sujeto o el objeto y su relación jerárquica, sino la relación de interdependencia que existe entre ellos, y se basa primordialmente en el concepto de complejidad; y $i v$ ) la sabiduría ancestral-sagrada, donde hay una relación entre el ser humano y el cosmos, y se caracteriza por la existencia de fenómenos reciprocantes y el interés por la percepción de ese mismo cosmos a través de una relación que utilice todos los sentidos. Para mayor detalle, véase Nava Escudero, César, Ciencia, ambiente..., cit., pp. 200 y ss.

16 Antal, Edit, "Redes y discursos de las ong ambientalistas en la zona de TijuanaSan Diego", en Antal, Edit (ed.), Nuevos actores en América del Norte, México, UNAM, Centro de Investigaciones sobre América del Norte (CISAN), 2005, vol. I, p. 194. 
Esta obra forma parte del acervo de la Biblioteca Jurídica Virtual del Instituto de Investigaciones Jurídicas de la UNAM

cuestión sobre lo que esto implica: no poner en tela de juicio la crisis ambiental contemporánea.

Sin embargo, dentro de la postura científica y ético-filosófica de mayor aceptación (i.e. el antropocentrismo) ${ }^{17}$ figura una corriente de pensamiento alejada de todas sus homónimas al no reconocer la existencia misma de la crisis ambiental o, en todo caso, no considerarla grave. Tiene muchos nombres pero el vocablo con el que más se le asocia es el de cornucopia, y se le ha descrito - incluso por sus propios seguidores - como una corriente anti-ambientalista. Por esto a sus partidarios se les llama anti-ambientalistas, o simplemente, cornucopianos. Este apodo surge de la palabra cornucopia, que significa cuerno de la abundancia, y de aquí el que no estén a favor de establecer límites al crecimiento económico puesto que no reconocen la finitud de la naturaleza. ${ }^{18}$ Entonces, se puede decir que los cornucopianos no defienden lo mismo que los ambientalistas, lo que en sentido estricto se traduce en no tener como objetivo último proteger el ambiente.

Los cornucopianos se autotitulan antiambientalistas para diferenciarse de lo que los ambientalistas defienden. Alegan que los análisis y proyecciones catastrofistas hechos por ambientalistas y ecologistas carecen de fundamentos científicos. Estarían basadas en modelos de previsión muy rígidos, equivocados en los elementos de partida utilizados para la proyección...

17 Es el antropocentrismo la postura científica y ético-filosófica que ha prevalecido por la cantidad de correligionarios que tiene, además del número creciente de políticas públicas, legislación, instrumentos internacionales, etcétera. En ocasiones, y con ciertos matices, también se le ha identificado con el concepto de tecnocentrismo. Por definición, el tecnocentrismo apuesta a la ciencia y a la tecnología para dar una explicación de cómo debe protegerse el ambiente y, en su caso, cómo enfrentar la crisis ambiental. Véase Park, Chris, Dictionary of ..., cit. Evidentemente, su significado es amplio y para una revisión ya clásica (a la vez que profunda) sobre esto recomendamos a O'Riordan, Timothy, "The Challenge for Environmentalism", en Peet, Richard y Thift, Nigel, New Models in Geography, Londres, Unwin, 1989, pp. 84 y ss. La idea misma de que el tecnocentrismo es antropocentrismo ha cobrado fuerza incluso entre diversas disciplinas desde hace algunos años, como ha sido en el caso de la geografía humana. Para esto último véase Castree, Noel, "Environmental Movement", en Johnston, R. J. et al. (eds.), The Dictionary of Human Geography, 4a. ed., Estados Unidos de América, Blackwell, 2000, p. 221.

18 Véase Yu Chang, Man, “Cornucopianos: los ultraneoliberales", en Foladori, Guillermo y Pierri, Naína (coords.), ¿Sustentabilidad? Desacuerdos sobre el desarrollo sustentable, México, Cámara de Diputados-Universidad Autónoma de Zacatecas-Miguel Ángel Porrúa, 2005, pp. 163. 
Esta obra forma parte del acervo de la Biblioteca Jurídica Virtual del Instituto de Investigaciones Jurídicas de la UNAM

produciendo escenarios precarios que no retratan la dinámica económica en su perspectiva histórica. Rechazan las ideas del ecologismo de limitar el crecimiento, porque eso restringiría los efectos positivos del progreso económico y del avance tecnológico. ${ }^{19}$

De manera que los anti-ambientalistas, siendo optimistas respecto a la abundancia de los recursos naturales, desconfían en lo que todos los demás ambientalistas concuerdan si bien en grados diferentes: la elaboración de políticas estatales. Es decir, los cornucopianos son anti-intervención estatal por excelencia. ${ }^{20}$

Ubicados en la parte más radical del espectro político-ideológico del antropocentrismo, los cornucopianos consideran la protección ambiental como algo secundario, tangencial a otros temas, y sujeto a una composición o arreglo vinculados a las fuerzas del mercado: son el ala más conservadora de la economía ambiental. Se caracterizan por tener posiciones parciales que favorecen los intereses de los empresarios y las grandes trasnacionales. Además, apoyan la productividad de alimentos con el uso de pesticidas y químicos, por lo que estarían a favor de la biotecnología agrícola. Al mismo tiempo, sostienen que la pobreza es la que provoca la degradación de la naturaleza, y dejan a un lado los temas de justicia social. Si bien defienden la preservación de parques y paisajes por ser atractivos estéticos, minimizan la importancia de proteger la diversidad biológica. De manera relevante, apuestan por la tecnología y utilizan la expresión "crecimiento verde" para defender la idea de que el crecimiento económico (a ultranza) es la mejor forma de enfrentar una supuesta crisis ambiental. ${ }^{21}$

De todas estas características debemos rescatar dos cuestiones puntuales para los propósitos de este artículo. Primero, por estar inmersos en un capitalismo extremo que apuesta al crecimiento in genere, los cornucopianos o anti-ambientalistas tienden a no oponerse al uso y expansión de

19 Ibidem, pp. 164-166.

20 Vale la pena mencionar que algunos autores considerarían a los cornucopianos como ambientalistas; sin embargo, es amplia la aceptación de que se encuentran distanciados de todas las demás corrientes ambientalistas, incluso y con ciertos matices, de los marxistas. Para mayor precisión, acúdase a Foladori, Guillermo, "Una tipología del pensamiento ambientalista”, en Foladori, Guillermo y Pierri, Naína (coords.), ¿Sustentabilidad?..., cit., pp. 105-107 y 110-114.

21 Para mayor profundidad sobre esas y otras características del cornucopianismo, recomendamos al lector Yu Chang, Man, "Cornucopianos:...", cit., passim. 
Esta obra forma parte del acervo de la Biblioteca Jurídica Virtual del Instituto de Investigaciones Jurídicas de la UNAM

las armas, sean de destrucción masiva o no. Esto los coloca en contra de una enorme mayoría de ambientalistas que sostienen que los gastos militares deben redirigirse hacia objetivos socio-ambientales (como lo propuso Wangari M. Maathai, Premio Nobel de la Paz 2004), y que no debe permitirse ni fomentarse la violencia (como ha sido enfatizado, entre otros, por el Movimiento Verde Internacional). ${ }^{22}$ Segundo, es contradictorio que se preocupen por preservar o defender parques, reservas y paisajes por considerarlos atractivos, bellos o estéticos y al mismo tiempo "negar la validez de proteger la biodiversidad" y "resistirse a dar la debida importancia a la protección de las especies en extinción". ${ }^{23} \mathrm{De}$ esto último se infiere que, si no se preocupan por los animales silvestres tampoco lo harían por los domésticos, estén o no amenazados o en peligro de extinción.

Las dos características cornucopianas a las que hemos aludido en el párrafo anterior, describen nítidamente las dos historias anti-ambientales que examinamos en este artículo. Por un lado, nos referimos a la estrategia de seguridad nacional de la administración pasada definida como una "guerra" o lucha (militar) contra la delincuencia organizada. Y por el otro, se trata de la posición presidencial respecto a las corridas de toros al ignorar la crueldad y la violencia a las que son sometidos estos animales en la mal llamada "fiesta" taurina.

Por definición, la guerra y las corridas de toros tienen una esencia anti-ambientalista, es decir, ambas son contrarias a cualquier idea de protección ambiental. Y sin embargo, esto no fue reconocido como tal por el entonces titular del Ejecutivo federal. Por el contrario, y más allá de esto, se difundió de muchas maneras y con el uso de distintos medios de comunicación masivos (especialmente los televisivos) una equívoca imagen de un gobierno comprometido con el ambiente y de un presidente que era ambientalista. ${ }^{24}$ Se hizo mucha publicidad de los galardones

\footnotetext{
22 Sobre este punto en particular puede revisarse lo que al respecto se señala en Broswimmer, Franz J., Ecocidio. Breve historia de la extinción en masa de las especies, trad. de Francisco Páez de la Cadena, Pamplona-México, Laetoli-Océano, 2005, pp. 166170 .

${ }^{23}$ Véase Yu Chang, Man, “Cornucopianos:...”, cit., p. 170.

24 Debemos recordar que ya desde su campaña el entonces candidato a la Presidencia se refería a su "compromiso con el medio ambiente", lo que puede corroborarse en Calderón, Felipe, El hijo desobediente. Notas en campaña, México, Nuevo Siglo-AguilarSantillana, 2006, pp. 114 y 115.
} 
Esta obra forma parte del acervo de la Biblioteca Jurídica Virtual del Instituto de Investigaciones Jurídicas de la UNAM

internacionales otorgados al gobierno y al mandatario mexicano por su presunto "liderazgo ambiental", particularmente en materia climática y energética, ${ }^{25}$ pero esto contrasta diametralmente con el saldo negativo en este tema al final del sexenio. ${ }^{26}$ Como si los premios contaran para medir los logros del actuar de un gobierno; como si no se supiera que la mayoría de ellos son otorgados por circunstancias diplomáticas y políticas.

\section{GUERRA Y AMBIENTE: INCONGRUENCIA PRESIDENCIAL}

Incongruencia inconfundible hacer la guerra y querer proteger el ambiente. Todo ambientalista, si es auténtico, sabe o al menos intuye que una guerra tiene efectos directos e indirectos contra el medio natural, el medio construido y los seres humanos. Los costos económicos, sociales y

25 Por ejemplo, el Premio Globe (de la Organización Global de Legisladores) otorgado al ex presidente en 2009 de manos del ex primer ministro británico Gordon Brown; el Premio Campeones de la Tierra (de la Organización de las Naciones Unidas) otorgado en 2011; o el premio de Ecología y Medio Ambiente Miguel Alemán Valdés (galardón que otorga la Fundación Miguel Alemán, A. C.) entregado también en 2011.

26 Son muchas las historias anti-ambientales por relatar, todas debidamente documentadas. Pero no tenemos espacio suficiente en este ensayo para referirnos a ellas en detalle. Sólo por mencionar algunas por rubro: $i$ ) en bosques y selvas el fracaso de los tan anunciados programas Proárbol; ii) en materia de zonas costeras, la destrucción de playas, manglares, humedales con el consabido desplazamiento por la fuerza de comunidades locales (como sucedió en Tenacatita, Jalisco) o la construcción de muelles (como en El Revolcadero, en Acapulco, Guerrero), así como los permisos otorgados para la construcción de megaproyectos turísticos y comerciales altamente destructivos, como Cabo Cortés (después Los Pericúes) en Baja California Sur, y Dragon Mart en Quintana Roo; iii) en minería, la gran cantidad de conflictos socio-ambientales registrados por el otorgamiento de concesiones sin la consulta y/o participación de grupos y comunidades afectadas, como sucedió con el pueblo wixárika; $i v$ ) en aguas, los proyectos impulsados para la construcción de presas u otras obras hidráulicas, como el caso del Acueducto Independencia y la afectación del pueblo yaqui en Sonora; $v$ ) en justicia social, la cantidad alarmante de más de 40 asesinatos de defensores ambientales (campesinos, indígenas, ambientalistas) y de secuestrados o desaparecidos a lo largo y ancho del país (con impunidad en la mayoría de los casos) que estuvieron vinculados precisamente con asuntos forestales, mineros, de aguas, costeros, etcétera. La Secretaría de Medio Ambiente y Recursos Naturales a través de la Subsecretaría de Gestión para la Protección Ambiental y sus Direcciones Generales (encargadas, entre otras, de otorgar las autorizaciones en materia de impacto ambiental y las concesiones y permisos respectivos sobre los bienes nacionales costeros) fueron los que se encargaron principalmente de encubrir y fomentar una enorme cantidad de arbitrariedades y actos de corrupción relacionados con los temas descritos con antelación. 
Esta obra forma parte del acervo de la Biblioteca Jurídica Virtual del Instituto de Investigaciones Jurídicas de la UNAM

ambientales derivados de ella y de otras actividades militares (incluyendo la de su preparación) tienden a ser altísimos y devastadores. De aquí la trascendencia de evitarla y detener el crecimiento de la milicia.

La desmilitarización nos brinda una oportunidad especialmente obvia para eliminar un derroche importante de recursos financieros y físicos al tiempo que eliminamos una gran causa — quizá la mayor- de destrucción ecológica y sufrimiento humano de nuestro mundo moderno. De toda la degradación medioambiental del mundo, se calcula que del 10 al 30\% se debe a actividades relacionadas con las actividades militares...27

Claro está que hay de guerras a guerras y de armas a armas. Hay guerras entre naciones y dentro de ellas, ${ }^{28}$ y hay armas convencionales y nucleares. ${ }^{29}$ Por lo que es lógico suponer que las alteraciones al ambiente pueden tener manifestaciones distintas en cuanto a su magnitud, peligrosidad, irreversibilidad, daño, reparación, etcétera. Las consecuencias de conflictos armados en los que han intervenido militares como las ocurridas en Vietnam (durante la década de los sesenta y setenta del siglo pasado) y en Libia (hace un par de años), no son ciertamente las mismas. Pero en términos ambientales — y de esto no debe caber la menor dudalas operaciones militares en cualquiera de sus formas siempre producirán efectos perjudiciales a nivel local o regional, y serán según su potencial, una amenaza a la seguridad ambiental global. ${ }^{30}$

27 Broswimmer, Franz J., Ecocidio. Breve..., cit., p. 141.

28 Un ejemplo para entender su significado: "La guerra se define convencionalmente como un conflicto armado entre naciones. El término también se utiliza para denotar conflictos armados dentro de las naciones (guerras civiles o guerras de liberación) y de acciones armadas de grupos clandestinos o rebeldes contra los gobiernos o las fuerzas de ocupación (guerras de guerrillas, insurrecciones o intifadas)...". Levy, Barry S. y Sidel, Victor W., "La guerra", en Frumkin, Howard, Salud ambiental. De lo global a lo local, trad. Magali Amiela Lavinge et al., Washington D. C., Organización Panamericana de la Salud, 2010, p. 291.

29 Las armas convencionales existen en forma de explosivos, incendiarias y de varios tamaños, desde armas pequeñas y ligeras, hasta la artillería. Los países que con certeza tienen armas nucleares son los Estados Unidos de América, Rusia, Reino Unido, Francia, China, Israel, India y Pakistán. Existen otros tipos de armas como las radiológicas, las químicas o las biológicas. Mas información en íbidem, pp. 293 y ss.

30 Véase Bowlby, S. R. y Mannion, A. M., "Perspective and Prospect", en Mannion, Antoinette M. y Bowlby, Sophia R. (comps.), Environmental Issues in the 1990s, Chich- 
Esta obra forma parte del acervo de la Biblioteca Jurídica Virtual del Instituto de Investigaciones Jurídicas de la UNAM

Si el presidente de la República del sexenio pasado se decía ambientalista, ¿cómo fue que decidió utilizar a las fuerzas armadas de este país para combatir al crimen organizado? ¿Pensó el mandatario mexicano que podía enarbolar la causa del ambientalismo al tiempo de movilizar miles de efectivos del ejército y la marina para enfrentar en una "guerra" a la delincuencia organizada?

Hay quienes al responder estas interrogantes seguramente argumentarían en su favor dos cosas en concreto. Primero, que el conflicto armado que presenciamos millones de mexicanos fue un asunto de seguridad nacional y fue tan sólo una lucha o combate, pero nunca una guerra. Segundo, que no había otra forma de enfrentar al crimen organizado en el país sino con ayuda del ejército mexicano: se trató en todo caso - enfatizarían sus seguidores - de una acción de gobierno necesaria. Combinadas, estas dos respuestas contribuirían a no poner en tela de juicio la vocación ambientalista del entonces primer mandatario y a confirmar el compromiso del gobierno mexicano por los temas ambientales.

Sin embargo, lejos de consolidar la imagen de un jefe de Estado preocupado por el ambiente, tales razonamientos destruirían precisamente dicha pretensión. Esto es así porque independientemente de que se haya definido a la estrategia de seguridad nacional en términos de una lucha y no de una guerra, y de que el uso del ejército mexicano hubiese sido la única opción que tenía el propio gobierno, es científica y éticamente indefendible que un mandatario se erija como un protector del ambiente y al mismo tiempo trate de resolver problemas de Estado (cualesquiera que éstos sean) de la mano de los militares.

Hay que precisar que fue el propio ex presidente quien en repetidas ocasiones durante los primeros años de su sexenio señaló que nos encontrábamos en una guerra, aunque después lo hubiera negado. En efecto, es un hecho verídico que en los discursos al comienzo de su gobierno utilizaba palabras o expresiones refiriéndose a la existencia de una guerra contra la delincuencia o el crimen organizado, lo que es fácilmente demostrable. ${ }^{31}$ También es completamente verificable que en la agonía

ester, Wiley, 1992, p. 333; Calvert, Peter y Susan, The South, the North, and the Environment, Londres-Nueva York, Pinter, 1999, p. 198.

${ }^{31}$ Existen muchos ejemplos sobre esto. Aquí presento dos citas textuales obtenidas de la propia página de la Presidencia de la República de aquel entonces (hoy todavía consultables). Primero, a menos de un año de que tomara posesión como presidente de la República, en 2007, al conmemorar el 97 Aniversario de la Revolución Mexicana, 
Esta obra forma parte del acervo de la Biblioteca Jurídica Virtual del Instituto de Investigaciones Jurídicas de la UNAM www.juridicas.unam.mx

de su sexenio comenzó a negar que él se hubiera referido al problema del narcotráfico como tal, desmentido que puede corroborarse fehacientemente en una entrevista televisiva ${ }^{32}$ llevada a cabo en 2011 y que contó con un amplio auditorio.

Llámesele guerra o lucha contra el crimen organizado, lo cierto es que la decisión que tomó el ex mandatario mexicano de involucrar a la milicia trajo como consecuencia diversas alteraciones de tipo ambiental, siendo las más visibles las relacionadas con los seres humanos por cuanto hace a su vida, integridad física, salud, desarrollo, bienestar, entre otros. Una de las mejores y más confiables fuentes de periodismo en este país, la de Aristegui Noticias, describió hacia finales del 2012 lo ocurrido en el sexenio pasado en relación con este tema:

expresó lo siguiente: “...La inquebrantable lealtad y vocación patriótica de las Fuerzas Armadas, su firmeza y decisión, han sido y seguirán siendo fundamentales en esta guerra...”. Presidencia de la República, El Presidente Calderón en la ceremonia de entrega de condecoraciones de perseverancia, mérito deportivo y ascensos, Ciudad de México, Campo Militar Marte, 20 de noviembre de 2007, fecha de acceso 3 de agosto de 2013. Segundo, en 2008, al encabezar la Ceremonia de Clausura y Apertura de Cursos del Sistema Educativo Militar sostuvo lo siguiente: "En esta guerra contra la delincuencia, contra los enemigos de México, no habrá tregua ni cuartel...”. Presidencia de la República, En la guerra contra la delincuencia no habrá tregua ni cuartel: Presidente Felipe Calderón, nota informativa, 12 de septiembre de 2008, fecha de acceso 17 de agosto de 2013. Ambas citas pueden obtenerse de http://calderon.presidencia.gob.mx Si el lector desea conocer más frases en las que el ex presidente utilizó este término, recomendamos acudir al blog de la redacción de la Revista Nexos bajo el nombre de "Una ayudadita de memoria para Felipe Calderón", 28 de enero de 2011, en http://redaccion.nexos.com.mx En este mismo sentido, puede acudirse a la siguiente fuente periodística: Fernández de Mendoza, Jr., Erasmo, “Calderón uso la palabra 'guerra' desde el 2006", Política a la mexicana, 9 de diciembre de 2011, disponible en $w w w$.periodistasenlinea.org.

32 Es de conocimiento público la entrevista que el entonces presidente de la República diera a Noticieros Televisa en 2011 (entrevista realizada por Joaquín López Dóriga) transmitida en dos partes a través del Canal 2. En la segunda parte, el ex presidente señaló: “...hay una expresión que a mí $[s i c]$ no me gusta que dice: la guerra de Calderón. Esta ni es guerra, es simplemente el cumplimiento de la ley es la seguridad de los ciudadanos la que está en juego ni es mía. Ni es mía exclusivamente, es la seguridad, la seguridad es un compromiso que constitucionalmente nos compete a los alcaldes, a los gobernadores, al presidente, al Legislativo en el ámbito de formulación de leyes, al propio Poder Judicial en el ámbito de juicio a los criminales, es una tarea de Estado y es una equivocación preocupante que se piense que es una asignación personal". Esta información todavía puede consultarse en Presidencia de la República, Entrevista al presidente Calderón en el noticiero con Joaquín López Dóriga, segunda parte, 8 de diciembre de 2011, disponible en http://calderon.presidencia.gob.mx (acceso: 17 de agosto de 2013). 
Esta obra forma parte del acervo de la Biblioteca Jurídica Virtual del Instituto de Investigaciones Jurídicas de la UNAM

El saldo de muertos, desaparecidos y desplazados es el más visible de seis años de "guerra" contra el crimen organizado, emprendida por el gobierno de Felipe Calderón en diciembre de 2006.

No hay una cifra exacta de muertos civiles por las batallas entre grupos delictivos, pero existen acercamientos de diferentes instituciones oficiales y grupos de la sociedad civil que han intentado cuantificar la atrocidad del sexenio.

La irregularidad de la forma en que se presentaron las cifras y la falta de transparencia son señales de la carencia de una estrategia y la incapacidad de las autoridades para organizar la información de tantas estadísticas mortales, antes de limpieza de cuerpos policiacos y la implementación de un sistema de justicia penal acusatorio. ${ }^{33}$

En la tabla 2 se pueden apreciar las diferencias entre el número de muertos contabilizados según la fuente y los periodos que abarcan. Sin información disponible, a éstas cifras deberán sumarse un número desconocido de heridos o con lesiones (posiblemente de invalidez); de refugiados, desplazados y emigrantes; sensaciones de miedo y ansiedad; traumas sicológicos; incremento de violencia entre la población; etcétera.

\section{TABLA 2}

Número de muertos durante el sexenio de Felipe Calderón Hinojosa

\begin{tabular}{|l|l|l|}
\hline \multicolumn{1}{|c|}{ Fuente de información } & Muertos & \multicolumn{1}{|c|}{ Periodo } \\
\hline $\begin{array}{l}\text { Base de Datos de Fallecimientos } \\
\text { Ocurridos por Presunta Rivalidad }\end{array}$ & 47,515 & Diciembre 2006 a septiembre 2011 \\
$\begin{array}{l}\text { Delincuencial y Procuraduría Ge- } \\
\text { neral de la República (fuente ofi- } \\
\text { cial) }\end{array}$ & 46,015 & Durante todo el sexenio \\
\hline $\begin{array}{l}\text { Comisión Nacional de los Dere- } \\
\text { chos Humanos }\end{array}$ & 70,000 & Entre 2006 y 2012 \\
\hline $\begin{array}{l}\text { Movimiento por la Paz con Justicia } \\
\text { y Dignidad }\end{array}$ & 44,412 & Diciembre 2006 a agosto 2012 \\
\hline Diario Reforma & 88,361 & Diciembre 2006 a marzo 2012 \\
\hline Revista Proceso & 57,449 & Diciembre 2006 a octubre 2012 \\
\hline Diario Milenio & 71,000 & Enero 2007 a abril 2012 \\
\hline Revista Semanario Zeta & \multicolumn{2}{|l}{} \\
\hline
\end{tabular}

Fuente: Aristegui Noticias, 2012.

33 Aristegui Noticias, “Los 'daños colaterales' y el costo social del combate al narcotráfico”, Redacción Aristegui Noticias 2012, México, 26 de noviembre de 2012, disponible en www.aristeguinoticias.com (acceso: 17 de agosto de 2013). 
Esta obra forma parte del acervo de la Biblioteca Jurídica Virtual del Instituto de Investigaciones Jurídicas de la UNAM

Más complicado aún resulta contabilizar los daños ocasionados al medio natural y al medio construido, pero se deberán tomar en cuenta entre otros: la quema de combustibles fósiles para transportar a cientos de militares y marinos a las zonas de conflicto, y con ello su contribución al cambio climático; los residuos generados (peligrosos, tóxicos u otros) por la preparación de la "guerra" y durante la "guerra" (incluyendo equipos, uniformes, armamento); la contaminación atmosférica, visual y auditiva con afectación a la flora y la fauna; el destrozo de casas, edificios, comercios, etcétera.

Bajo estas circunstancias, no es difícil de imaginar la cantidad de veces que la violación del derecho fundamental al ambiente de un número considerable de mexicanos y extranjeros habrá estado presente. Nuestra carta magna establece en su artículo 4o., párrafo quinto, lo siguiente: "Toda persona tiene derecho a un medio ambiente sano para su desarrollo y bienestar. El Estado garantizará el respeto a este derecho. El daño y deterioro ambiental generará responsabilidad para quien lo provoque en términos de lo dispuesto por la ley". ${ }^{34}$

Cuando se le cuestionaba su estrategia militar, el entonces presidente de México respondía señalando que no había otra forma de enfrentar al crimen organizado. Siempre con mucha firmeza - aunque a veces con cierto grado de enojo - resaltaba que hasta el último minuto de su gobierno combatiría a los delincuentes de esa manera. ${ }^{35}$ Muchos recursos económicos se invirtieron en programas transmitidos por radio y televisión que destacaban los avances en materia de seguridad.

No nos corresponde en este artículo discutir si tal estrategia presidencial fue la correcta o no, es decir, si esta "guerra" fue necesaria o innecesaria, justa o injusta, legítima o ilegítima, constitucional o anticonsti-

34 Es un tanto irónico que el texto así redactado se incorporara a nuestra Constitución durante el periodo sexenal respectivo (reforma publicada en el Diario Oficial de la Federación del 8 de febrero de 2012). Antes de esta reforma, la Constitución establecía en su artículo 4o. párrafo quinto lo siguiente: "Toda persona tiene derecho a un medio ambiente adecuado para su desarrollo y bienestar". Este precepto aparece por vez primera en nuestra carta magna hacia finales del siglo pasado (reforma publicada en el Diario Oficial de la Federación el 28 de junio de 1999).

35 Como es lógico suponer, el entonces primer mandatario criticaba a quienes se oponían a su política de seguridad nacional. Millones de mexicanos fuimos testigos a través de las transmisiones televisivas que cuando en alguno de sus discursos se le criticaba de manera pública por tal estrategia, él respondía - de manera un tanto agresiva - que precisamente por ese tipo de críticas o actitudes México no avanzaba. 
Esta obra forma parte del acervo de la Biblioteca Jurídica Virtual del Instituto de Investigaciones Jurídicas de la UNAM

tucional. Tampoco nos atañe evaluar si hubo logros durante su gestión y en qué consistieron. Lo que hemos tratado de puntualizar es que el presidente de la República del sexenio pasado consintió e impulsó un conflicto armado con la intervención de un gran número de militares en donde los enfrentamientos entre éstos (incluyendo cuerpos policiacos) y la delincuencia organizada generaron múltiples impactos ambientales.

$\mathrm{Su}$ actitud pro-militarista fue completamente contraria a la imagen ambientalista que él y su gobierno pretendieron difundir a nivel nacional e internacional. Trataron de convencernos de que su preocupación por la crisis ambiental era real. Pero una buena parte de la sociedad civil, incluyendo por supuesto a un gran número de abogados ambientalistas, jamás creyeron en tal montaje.

Hay que remarcar que la gestión del presidente pasado acabó precisamente por ignorar e incumplir con dos principios fundamentales del derecho internacional ambiental que todo ius-ambientalista conoce y respeta. Se trata de los principios 24 y 25 de la trascendentalísima Declaración de Río sobre Medio Ambiente y Desarrollo de 1992, emanada de la Conferencia de las Naciones Unidas sobre el Medio Ambiente y el Desarrollo celebrada en Río de Janeiro, Brasil (también conocida como Cumbre de la Tierra) y que a la letra señalan:

\section{PRINCIPIO 24}

La guerra es, por definición, enemiga del desarrollo sostenible. En consecuencia, los Estados deberán respetar las disposiciones de derecho internacional que protegen al medio ambiente en épocas de conflicto armado, y cooperar en su ulterior desarrollo, según sea necesario.

\section{PRINCIPIO 25}

La paz, el desarrollo y la protección del medio ambiente son interdependientes e inseparables. ${ }^{36}$

En suma, no dejaremos de insistir en que las audacias castrenses de cualquier jefe de Estado siempre habrán de coincidir con la esencia del anti-ambientalismo como lo hemos explicado con anterioridad. De manera directa o indirecta se estimula con ellas el uso y expansión de las armas, los gastos militares aumentan y generalmente no son redirigidos a

36 Véase el texto completo en www.un.org/spanish/esa/susdev/agenda21/riodeclaration.html. 
Esta obra forma parte del acervo de la Biblioteca Jurídica Virtual del Instituto de Investigaciones Jurídicas de la UNAM

cuestiones ambientales, y ciertamente se exacerba y se hace más visible la violencia en todas sus formas.

\section{Si SE ES AFICIONADO A LOS TOROS, NO SE PUEDE SER AMBIENTALISTA}

Contradicción evidente ser un aficionado a las corridas de toros y pretender al mismo tiempo ser un ambientalista. Desde hace muchos años que el discurso de animalistas (protección de los animales) y de ambientalistas (protección de las especies, conservación de la biodiversidad, etcétera) se encontraron para ser parte de un mismo debate. Su acercamiento se debió en mucho al trascendentalísimo objetivo común — con todo y las diferencias subyacentes con ciertos grupos ecologistas - de discutir el comportamiento de los seres humanos respecto a otros seres vivos y de reducir la violencia en contra de ellos.

Aunque ambas [éticas de los animales y éticas de la naturaleza] comparten unas inquietudes comunes frente al deterioro del planeta, la deforestación, la extinción de especies y, en general, la manera profundamente egoísta como el ser humano se comporta con el resto de seres vivos; y aunque ambas se proponen el mismo objetivo de reducir la violencia contra las otras especies y de enseñar al ser humano a convivir con ellas, es innegable que sus ideales y sus fines, así como sus métodos para alcanzarlos, no sólo son distintos, sino en algunos aspectos incluso divergentes, lo que ha llegado a provocar profundas discusiones entre ambas. ${ }^{37}$

Pero tales diferencias, si bien aún existentes, lejos de distanciar a ambos movimientos han enriquecido el debate en su totalidad. Más importante aún, temas como el de los derechos de los animales o el de la liberación animal, se han insertado reiteradamente en diversos saberes o disciplinas ambientales ${ }^{38}$ y forman parte inseparable de lo que se concibe

37 Tafalla, Marta, "Introducción: un mapa del debate", en Tafalla, Marta (ed.), Los derechos de los animales, Barcelona, Idea Books, 2004, p. 38.

38 Existe una infinidad de libros ambientales que abordan estos temas. De los últimos años podemos mencionar, por ejemplo, la excelente obra sobre ética ambiental donde se presentan artículos relacionados para su lectura y discusión, particularmente relativos a extractos del pensamiento de Immanuel Kant (seres racionales), Peter Singer (liberación animal), Tom Regan (derechos de los animales) Mary Ann Warren (crítica a la teoría de los derechos de los animales) y Dale Jamieson (en contra de los zoológicos). Véase Poj- 
Esta obra forma parte del acervo de la Biblioteca Jurídica Virtual del Instituto de Investigaciones Jurídicas de la UNAM

como crisis ambiental contemporánea. ${ }^{39}$ De aquí que de algún modo todo animalista tenga su parte de ambientalista, y viceversa, todo ambientalista tenga su parte de animalista.

Argumentos a favor o en contra de la tauromaquia han existido desde hace mucho tiempo, ${ }^{40}$ ciertamente muchísimo antes de que el ambientalismo apareciera y se consolidara en un movimiento global como ahora lo conocemos. Sin embargo, el rechazo de los ambientalistas a las corridas de toros recoge reflexiones de épocas pasadas y recientes. Por un lado, desarrollan razonamientos no muy distintos a los que se han elaborado por ciertos individuos o grupos (intelectuales, filósofos, artistas o asociaciones protectoras de animales) que han luchado por la abolición de dicha actividad, y por el otro, invocan principios y valores que se han desarrollado dentro del propio ambientalismo.

De manera tal, que una parte importante del discurso ambientalista critica a las corridas de toros por diversas razones. Algunas de ellas podemos resumirlas de la siguiente manera. Primero, son crueles, ${ }^{41}$ lo que fue debidamente señalado en su momento por los precursores del movimiento ambientalista. En efecto, las raíces o antecedentes del ambientalismo global están vinculados a las campañas que desde la primera mitad

man, Louis P. (ed.), Environmental Ethics. Readings in Theory and Application, 4a. ed., Thomson Wadsworth, Belmont, 2005, passim. Otro ejemplo indiscutible también sobre ética ambiental en el que se incluye para su análisis el asunto de la protección de los animales es el de Jamieson, Dale, Ethics and the Environment, Cambridge, Cambridge University Press, 2008, pp. 102 y ss. Un buen ejemplo desde las ciencias políticas es la obra de Carter, Neil, The Politics of the Environment. Ideas, activism, policy, 2a. ed., Cambridge, Cambridge University Press, 2007, pp. 26 y ss., en donde también se discute la cuestión de la protección de los animales desde el moral extensionism. En la ciencia jurídica destaca la gran contribución para este tema de Ost, François, Naturaleza y derecho. Para un debate ecológico en profundidad, Bilbao, Mensajero, 1996, pp. 195 y ss. Nosotros hemos hecho lo propio en Nava Escudero, César, Ciencia, ambiente..., cit., pp. 113-126.

39 Cualquier discusión en torno a la actual crisis ambiental incluye el debate sobre la protección de los animales, argumento que hemos tratado de posicionar a través de una serie de reflexiones científicas y ético-filosóficas de tipo ambiental. Para conocer sobre esto acúdase a nuestros análisis en Nava Escudero, César, ibidem, passim.

40 Un buen número de ejemplos en Mosterín, Jesús, "La tortura como espectáculo", en Tafalla, Martha (ed.), Los derechos de..., cit., pp. 239-248.

41 Del latín, crudẽlis, que significa: 1. Que se deleita en hacer sufrir o se complace en los padecimientos ajenos. 2. Insufrible, excesivo. 3. Sangriento, duro, violento. Véase Real Academia Española, Diccionario de la Lengua Española, 21a. ed., Madrid, Real Academia Española, 2001. 
Esta obra forma parte del acervo de la Biblioteca Jurídica Virtual del Instituto de Investigaciones Jurídicas de la UNAM

del siglo XIX (particularmente en Inglaterra) se iniciaron en contra de la crueldad hacia los animales domésticos y silvestres. En aquel tiempo se fundó, en 1824, la Society for the Protection of Animals que se convirtió, en 1840, en la Royal Society for the Prevention of Cruelty to Animals. Se consideraba que la crueldad en contra de los animales era la más primitiva y salvaje de todas las acciones humanas. ${ }^{42}$

Segundo, exhiben la tortura pública, puesto que se presentan como espectáculos en plazas creadas en muchas ocasiones específicamente para ello. En un contexto histórico, las corridas de toros forman parte de muchos otros "entretenimientos" populares de humanos y animales con semejantes grados de tortura.

Durante la mayor parte de la historia la tortura más espeluznante ha sido aplicada rutinariamente y con la mayor naturalidad. Los procedimientos penales tendían a que el condenado no muriese de golpe, sino que su agonía fuese lo más atroz y prolongada posible. Descoyuntar sus miembros y despellejar o quemar viva a la víctima eran prácticas habituales, y no las más crueles. Gran parte de estas truculencias se efectuaban en público, como espectáculo para las masas. De hecho no había espectáculos más populares que las ejecuciones públicas y las quemas de herejes, delincuentes o sediciosos...

No sólo la pública tortura de los hombres era un espectáculo popular, sino también la de los animales. Aunque menos multitudinaria, también la tortura de osos, toros, gallos, perros y otros animales tenía su público soez y apasionado. Las peleas de gallos y de perros siguen practicándose de forma más o menos legal o clandestina en diversos países. En los siglos XVI y XVII muchos miles de gatos -identificados con el diablo y la brujeríaeran quemados vivos en público, en general en cestos sobre el fuego, a la altura justa para alargar al máximo su agonía. Sus gritos agónicos hacían reír a carcajadas al público. En algunas ciudades de Bélgica se arrojaban gatos desde las torres de los ayuntamientos al suelo en las fiestas. En el siglo XIX los gatos de verdad fueron sustituidos por muñecos de trapo con forma de gato, que todavía hoy siguen arrojándose..$^{43}$

Tercero, enaltecen la superioridad humana a través de la violencia, lo que va en detrimento de la relación ser humano-naturaleza. Una de las

\footnotetext{
42 Véase McCormick, John, The Global Environmental Movement, 2a. ed., Chichester, Wiley, 1995, p. 4.

43 Mosterín, Jesús, "La tortura...", cit., pp. 239 y 240.
} 
Esta obra forma parte del acervo de la Biblioteca Jurídica Virtual del Instituto de Investigaciones Jurídicas de la UNAM

principales posturas ético-filosóficas dentro del pensamiento ambientalista - el ecocentrismo - otorga valores intrínsecos a los procesos naturales donde los humanos no tenemos derecho a reducir o deteriorar la riqueza y variedad de otras formas de vida (salvo para satisfacer nuestras necesidades básicas). Esto implica que no somos superiores a otras especies (algunos lo llaman igualitarismo biosférico), ni somos el centro del universo: la propuesta es de armonía y de equilibrio ecológico, por lo que de plano se rechaza cualquier intento de predominio humano. Pero aun la postura contraria al ecocentrismo - el antropocentrismo- que no asigna valores intrínsecos al medio natural y que propone que éste existe para servir a nuestra propia especie, tampoco aceptaría el uso de la violencia recreativa para glorificar nuestro señorío e imperio hacia los animales. Desde luego, habría algunas corrientes de pensamiento antropocéntrico, como la de los cornucopianos, que decididamente no apoyarían tal postura al no considerar grave o significativo el dilema de discutir la trascendencia de la reconciliación, solidaridad, respeto, inclusión o consideración moral de las especies no humanas, como lo serían los toros. ${ }^{44}$ Adicionalmente, al tiempo que no se aprecia nuestra relación con la naturaleza, tampoco la relación que existe entre nosotros mismos.

... [el tecnocentrismo, antropocentrismo] no toma en cuenta las relaciones entre los seres humanos en el proceso y en la forma como éstos se relacionan con la naturaleza. Es como si la relación hombre-naturaleza fuese independiente de las relaciones ser humano-ser humano (las relaciones sociales). La exclusión de las relaciones sociales y políticas en el análisis de la cuestión ambiental redunda en la parcialidad de las tesis defendidas por los cornucopianos. ${ }^{45}$

Cuarto, contradicen toda idea de preservación y protección de especies y subespecies. El concepto de biodiversidad se utiliza comúnmente para describir su diversidad, ${ }^{46}$ esto es, el número y abundancia de espe-

44 Más sobre esto en Nava Escudero, César, Ciencia, ambiente..., cit., passim.

45 Yu Chang, Man, "Cornucopianos:...", cit., p. 171.

46 Se ha definido a la biodiversidad como "La diversidad en el mundo natural de los seres vivos. Por lo común se refiere a las especies, pero también comprende los ecosistemas y las variaciones genéricas [sic]". Nebel, Bernard J. y Wright, Richard T., Ciencias ambientales. Ecología y desarrollo sostenible, 6a. ed., trad. de Francisco Javier Dávila, México, Prentice Hall, 1999, p. 667. 
Esta obra forma parte del acervo de la Biblioteca Jurídica Virtual del Instituto de Investigaciones Jurídicas de la UNAM

cies diferentes dentro de un área en particular (biodiversidad local) o en el mundo (biodiversidad global). ${ }^{47}$ Sin embargo, preservar y proteger es una tarea que no sólo incluye a animales que se consideren stricto sen$s u$ especies y que se encuentren en peligro de extinción o amenazados, sino también a los que no lo son y no lo están, a sus ecosistemas, y a sus hábitat naturales (o incluso inducidos). ${ }^{48}$ Ante todo, hay algo de malo e incorrecto en la destrucción o deterioro de la vida no humana. ${ }^{49}$ Esto incluye a los toros de lidia (sean categorizados como especies, subespecies, animales mestizos o seudorrazas). Por consiguiente, es ilógico e inmoral sostener que la fiesta taurina (donde se practica la crueldad, la tortura, el dolor, la violencia y la muerte) sea indispensable para la subsistencia del toro bravo y de la dehesa, como equívocamente lo han llegado a afirmar los que apoyan estas actividades.

Quinto, son antagónicas al valor y alcance científicos de la teoría de la evolución. En efecto, las corridas de toros arremeten contra la ciencia al desdeñar las aportaciones de la genética y la biología molecular (podríamos agregar a la geología y la paleontología) en relación con el origen y evolución de todas las especies — incluyendo la nuestra-. Esto se traduce en despreciar la trascendencia que tiene el significado sobre el descubrimiento del último antepasado común universal ${ }^{50}$ para todos los seres vivos y para sus relaciones de interdependencia recíproca en este planeta.

...los estudios que se basan en la comparación de secuencias de moléculas portadoras de información de diferentes organismos vivos (i.e. los ácidos desoxirribonucleicos o $\mathrm{ADN}$, los ácidos ribonucleicos o ARN y las proteínas) en los que las moléculas desempeñan la misma función, han cobrado

47 Véase para mayor precisión Park, Chris, Dictionary of..., cit., p. 47.

48 Véase en este sentido lo que ya hemos señalado con antelación.

49 Para una explicación más profunda desde una reflexión para encontrar una ética ambiental no antropocéntrica que proporcione un valor intrínseco a los seres vivos no humanos, recomendamos ampliamente al lector acudir a Callicott, J. Baird, "Teoría del valor no antropocéntrica y ética ambiental", en Valdés, Margarita M. (coord.), Naturaleza y valor, México, Fondo de Cultura Económica, 2004, pp. 99-117.

50 Christian de Duve, Premio Nobel de Medicina 1974, habría señalado en este sentido que “.... ahora existen pruebas abrumadoras de que todos los seres vivos conocidos descienden de una única forma de vida ancestral. Dicha afirmación se apoya en muchas razones convincentes. Su prueba más persuasiva la proporcionan los resultados de secuenciación molecular...”. Véase de Duve, Christian de, La vida en evolución, trad. de Joandomènec Ros, Barcelona, Crítica, 2004, p. 22. 
Esta obra forma parte del acervo de la Biblioteca Jurídica Virtual del Instituto de Investigaciones Jurídicas de la UNAM

mucha importancia... Es posible que una de las aportaciones más trascendentales que hasta el momento haya arrojado este tipo de investigación sea la de corroborar la idea primigenia de Darwin de que todos los seres vivos actuales descendemos por medio de la evolución de una única forma de vida ancestral: el último antepasado común (UAC) o último antepasado común universal (UACU). ${ }^{51}$

Si genéticamente hablando los seres humanos estamos emparentados por un antepasado común con otras especies - como sucede con los toros_- ${ }^{52}$ ¿cuál sería la explicación o justificación científica de realizar una "fiesta" para aniquilar a estos animales con violencia por mera diversión? Ninguna.

Estos cinco razonamientos son prueba suficiente de que no hay manera de que un ambientalista se declare en favor de las corridas de los toros. ${ }^{53}$ Hacerlo es ignorar lo que verdaderamente significa ser un ambientalista.

Existen diferentes fuentes de información que documentan fehacientemente que el jefe del Ejecutivo federal del sexenio pasado disfrutaba y era un aficionado de las corridas de toros. Por ejemplo, dando seguimiento de lo que ocurría en la Plaza de Toros México a principios de 2010, felicitó por teléfono a Hilda Tenorio, matadora de toros, por haberse convertido en la primera mujer en tomar la alternativa en dicha plaza el 28 de febrero de ese año. ${ }^{54}$

Otro ejemplo lo constituye una entrevista que le realizara el periodista Javier Moreno en la residencia oficial de Los Pinos en 2011. En ésta, el ex presidente, al referirse a los objetivos que aún tenía pendientes hacia

51 Nava Escudero, César, Ciencia, ambiente..., cit., p. 30.

52 Como se sabe ya universalmente, nuestros parientes más cercanos son los chimpancés pigmeos del África central, los bonobos, con quienes compartimos poco más del 98\% de nuestro ácido desoxirribonucleico.

53 A estos razonamientos se agrega que la "fiesta" taurina no sea un arte ni se equipare a un deporte.

54 Esta información puede corroborarse a través de diversas notas periodísticas de la época, como lo son los periódicos Reforma de 1o. de marzo de 2010 en su página www.reforma.com, así como Crónica con esa misma fecha, específicamente en www. cronica.com.mx/notas/2010/491363.html. Más evidencia sobre esto puede encontrarse en los portales de algunas páginas o medios de comunicación taurinos existentes en la red, como "Al Toro México" www.altoromexico.com/2010/index. php? acc=noticia\&id=4142 y también Toriles.com, página de Alfredo Florez, que con fecha 2 de marzo de 2010 hace referencia a tal felicitación presidencial (nota obtenida del blog En los medios Revista Taurina, y consultable en www.toriles.com/noticia.php?recordID $=1975$. 
Esta obra forma parte del acervo de la Biblioteca Jurídica Virtual del Instituto de Investigaciones Jurídicas de la UNAM

finales de su sexenio, respondió invocando su conocimiento taurino: “... yo estoy en mi tarea, en mis metas y en mis objetivos. En términos taurinos lo que viene es el tercer tercio, en lo que estamos es el de la faena y es precisamente la audacia y es el de más cosas". ${ }^{55}$ Recordemos que el tercer tercio en una corrida de toros es en la que precisamente se da muerte al animal y de ahí el nombre de tercio de muerte (el primero es el de varas y el segundo el de banderillas). El filósofo español Jesús Mosterín lo describe de la siguiente manera:

...en el último tercio llega por fin el momento de matar al toro, que si se hace bien, de una estocada limpia que le alcance el corazón, será el único momento de piedad de la corrida, poniendo fin al sufrimiento del animal. Por desgracia, los "matadores" suelen ser unos carniceros patosos, que con frecuencia fallan sus estocadas, teniendo que repetir una y otra vez la introducción del estoque (una espada de un metro) y perforando los pulmones del toro, que se van encharcando de sangre. Si el torero sigue sin acertar, otro matarife le clavará un cuchillo (la puntilla) tantas veces como sea necesario. ${ }^{56}$

Siguió a esa entrevista un artículo publicado en el periódico La Jorna$d a$ (el 28 de marzo de 2011) por el periodista José Cueli, en el que afirmó que si el entonces presidente prefería el tercer tercio, a él le gustaba más el primero.

Aunque al [sic] presidente Felipe Calderón prefiera el tercer tercio en una corrida de toros, según se desprende de la espléndida entrevista que le hace Javier Moreno en el periódico El País el día de ayer, a algunos como el que escribe, nos gusta más el primer tercio que suele ser el de la verónica en que se marcan los tres tiempos de lance fundamental, que es la verónica y en la puya se mide la bravura de los toros. En el tercer tercio el presidente Calderón registra la audacia de las granes faenas, seguramente como continuación en el pase natural rematado con el de pecho, de la verónica y posteriormente el volapié que se realizan en contadas ocasiones. ${ }^{57}$

55 Dicha entrevista puede leerse en la página de El País del 27 de marzo de 2011, disponible en www.elpais.com/diario/2011/03/27/domingo/1301201553_850215.html.

56 Mosterín, Jesús, "La tortura...", cit., p. 244.

57 Véase Cueli, José, “A mi me gusta el primer tercio”, La Jornada, artículo publicado el 28 de marzo de 2011 y disponible en www.jornada.unam.mx/2011/03/28/opinion/ a42aldep (acceso el 24 de agosto de 2013). 
Esta obra forma parte del acervo de la Biblioteca Jurídica Virtual del Instituto de Investigaciones Jurídicas de la UNAM

Pero el ejemplo más contundente de su afición por los toros es una confesión por escrito que él mismo hace en su libro El hijo desobediente. Notas en campaña, publicado en 2006. En él, reconoce su gusto y afición por lo toros. Aquí la cita textual correspondiente cuando se refiere a su esposa:

Tenemos aficiones muy normales. Las veladas bohemias, la política, la "vibra" que da poder hablar con la gente y fortalecer su esperanza, nuestros hijos, las corridas de toros, a las cuales me aficioné precisamente por acompañar a la familia a la plaza, donde mi suegro tiene cuatro lugares. Nos gusta el toreo de Enrique Ponce, y de los mexicanos, el del Zotoluco y de todos los paisanos: Paco Dóddoli, que fue mi compañero en el "Valladolid”, y más recientemente Fernando Ochoa, sobrino nieto de mi querido maestro Ramón Sánchez Medal. Me tocó ver a unos cuantos metros la última faena inmortal de David Silvetti. ${ }^{58}$

Habremos de insistir que si se es aficionado a los toros, no se puede ser ambientalista. Es incompatible, es contradictorio, es irracional, porque siempre prevalecerá en tales actividades el disfrutar del dolor, el sufrimiento, la crueldad, la violencia y la muerte. Después de todo, "la fiesta de los toros representa una compleja transacción sicológica, resultado de compromisos entre los gustos sádicos de la afición y su cambiante sensibilidad a la crueldad y a la muerte". 59

Que quede en nuestra memoria como mexicanos a propósito de esta historia anti-ambiental del sexenio pasado lo siguiente:

...un ciudadano que goza del sacrificio jubilar de un toro sin que semejante carnicería le revuelva el estómago también asume con secreta naturalidad que un magnate, sin necesidad de jugarse la femoral, le estafe ante el notario: eso es una verónica; que un mandamás entre a saco en sus derechos: eso es un trincherazo; que un empresario declare una quiebra frau-

58 Calderón, Felipe, El hijo..., cit., p. 136. Esta misma información fue adicionalmente difundida por el periódico El Universal el 9 de septiembre de 2006 (cuatro días después de que el entonces candidato fuera declarado presidente electo de México por el Tribunal Electoral del Poder Judicial de la Federación el 5 de ese mes y año). La nota periodística puede localizarse bajo el rubro "Buscarán dialogar con Calderón", disponible en www.eluniversal.com.mx/deportes/84668.html.

59 Paniagua, Cecilio, "Psicología de la afición taurina", Revista de Humanidades, Dendra Médica, vol. 7, núm. 2, noviembre de 2008, pp. 155 y 156. 
Esta obra forma parte del acervo de la Biblioteca Jurídica Virtual del Instituto de Investigaciones Jurídicas de la UNAM

dulenta y deje en la calle a miles de trabajadores: eso es un pase por alto; que un obrero en paro se dedique a la chapuza y la cobre como si fuera ingeniero: eso es un quite por chicuelitas; que un aparato represor cargue contra una manifestación pacífica: eso es una suerte de varas; que un fanático asesino vacíe el cargador de la pistola en la nuca de un guardia: eso son unas banderillas de fuego, o que una sociedad comience a degollarse por las esquinas: eso es el tercio de muerte. ${ }^{60}$

\section{REFLEXIÓN FINAL}

La guerra y las corridas de toros nunca serán buenas noticias para el ambientalismo de nuestros días. Las dos se oponen a la definición primigenia de lo que significa proteger el ambiente y ninguna de ellas es aceptada por las principales y más importantes corrientes del pensamiento ambientalista. Impulsar una lucha con la participación de militares y ser un aficionado a la "fiesta" taurina es negar o ignorar la trascendencia que tiene en el mundo contemporáneo la crisis ambiental que todos padecemos. Quien piensa y actúa de esta manera es axiomáticamente un antiambientalista o cornucopiano.

Las dos historias ocurridas en el sexenio pasado que se han relatado en este ensayo -i.e. la estrategia gubernamental de combatir con militares al crimen organizado, y la afición del entonces primer mandatario a las corridas de toros - muestran a la luz del quehacer ambientalista una imagen incongruente y contradictoria del gobierno y del primer mandatario de aquel entonces.

No se puede ser ambientalista y al mismo tiempo pasar por alto los daños ambientales causados a los seres humanos (en su vida, desarrollo y bienestar), al medio natural (alteración a la flora y la fauna), y al medio construido (casas, edificios y comercios) por la movilización de miles de efectivos del ejército en una "guerra" contra la delincuencia organizada. No se puede ser ambientalista y al mismo tiempo menospreciar los fundamentos científicos y ético-filosóficos que explican lo inmoral, incorrecto y acientífico de actividades en las que se permite y fomenta el dolor, el sufrimiento, la tortura, la violencia, la crueldad y la muerte de

60 Vicent, Manuel, “Antitauromaquia (tres pasajes)”, en Tafalla, Martha (ed.), Los derechos..., cit., p. 251. 
Esta obra forma parte del acervo de la Biblioteca Jurídica Virtual del Instituto de Investigaciones Jurídicas de la UNAM

una o muchas especies por mera recreación, como es el caso de los toros de lidia.

Esperemos que en el presente sexenio 2012-2018, el gobierno y el actual presidente de la República, reconozcan la existencia de la crisis ambiental contemporánea y tengan la inteligencia y sensibilidad suficientes para actuar de manera congruente con lo que significa proteger el ambiente. Es urgente contar con el menor número posible de historias anti-ambientales. 
Esta obra forma parte del acervo de la Biblioteca Jurídica Virtual del Instituto de Investigaciones Jurídicas de la UNAM

\section{CAMBIO CLIMÁTICO (MARCO JURÍDICO INTERNACIONAL)*}

La expresión cambio climático se utiliza comúnmente para describir dos fenómenos en el clima del planeta Tierra. Primero, los cambios climáticos naturales que pueden ser cortos o no muy cortos (entre estaciones, ciclos regulares anuales, algunas décadas, unos cuantos cientos de años), o los muy largos (fases glaciales e interglaciales). Segundo, el cambio climático inducido por los seres humanos como resultado de las crecientes concentraciones de gases de efecto invernadero que alteran la composición natural de la atmósfera provocando una variación en el clima y que abarca de los últimos 150 a 100 años hasta los próximos 50 a 100 años o más. Este segundo fenómeno es el que ha llamado la atención de la comunidad internacional que ha derivado en la creación de un régimen jurídico climático.

Aunque se atribuye al sueco Svante Arrhenius haber publicitado en 1896 que los gases de efecto invernadero producidos por los seres humanos tendrían una repercusión en el calentamiento del clima (lo que él asumía favorable), fue hasta la década de los setenta del siglo pasado que el cambio climático formó parte de las discusiones ambientales entre las naciones. A partir de la celebración de la Primera Conferencia Mundial sobre el Clima en Ginebra, Suiza, en 1979, ha prosperado un marco jurídico internacional conformado por normas e instrumentos vinculantes (derecho duro o hard law) y no vinculantes (derecho suave o soft law).

El primer tratado de importancia global (vinculante pero con alto contenido soft) fue adoptado en mayo de 1992, se abrió a la firma en junio del mismo año en la Cumbre de la Tierra (Río de Janeiro, Brasil) y entró en vigor en marzo de 1994. Se trata de la Convención Marco de las Na-

* Publicada en Ferrer Mac-Gregor, Eduardo et al. (coords.), Diccionario de derecho procesal constitucional y convencional, Poder Judicial de la Federación, Consejo de la Judicatura Federal-UNAM, Instituto de Investigaciones Jurídicas, 2014, t. I. Véase infra, "Derecho del cambio climático". 
Esta obra forma parte del acervo de la Biblioteca Jurídica Virtual del Instituto de Investigaciones Jurídicas de la UNAM

ciones Unidas sobre el Cambio Climático (en adelante, la Convención) cuyo objetivo último es el de lograr

la estabilización de las concentraciones de gases de efecto invernadero en la atmósfera a un nivel que impida interferencias antropógenas peligrosas en el sistema climático. Ese nivel debería lograrse en un plazo suficiente para permitir que los ecosistemas se adapten naturalmente al cambio climático, asegurar que la producción de alimentos no se vea amenazada y permitir que el desarrollo económico prosiga de manera sostenible.

La Convención inserta en su texto principios fundamentales del derecho internacional ambiental (e. g. el de responsabilidades comunes pero diferenciadas, el de precaución, el de desarrollo sustentable, etcétera) y establece dos tipos de compromisos para las partes contratantes. Primero, los compromisos genéricos, que aplican a todas las partes pero que son mínimos, y que bien podrían caracterizarse como disposiciones soft law por su contenido político, programático y de cooperación. Segundo, los específicos, que aplican, por un lado, a las partes enumeradas en el anexo I de la Convención que son tanto los países desarrollados como los que están en proceso de transición a una economía de mercado y, por el otro, a los países desarrollados y a los países que figuran en el anexo II.

La Convención establece la Conferencia de las Partes (en adelante, $\mathrm{COP}$ ) que en su calidad de órgano supremo examina la implementación de la Convención y de cualquier otro instrumento jurídico conexo adoptado por la propia COP, y toma las decisiones necesarias relativas a su aplicación eficaz. Siguiendo lo establecido por la Convención, el Mandato de Berlín de 1995 (COP-1) y la Declaración Ministerial de Ginebra de 1996 (COP-2), se adoptó en Japón, en diciembre de 1997 (COP-3) el Protocolo de Kyoto de la Convención Marco de las Naciones Unidas sobre el Cambio Climático (en adelante, PK). El PK, que precisa y desarrolla las disposiciones de la Convención y lo establecido en las COPs anteriores, entró en vigor en febrero de 2005 y es el segundo tratado multilateral de importancia global en materia climática.

Destacan dos cuestiones jurídicas en el PK. Primero, se establecen compromisos cuantificados de limitación y reducción de las emisiones de los gases de efecto invernadero enumerados en el anexo A (emisiones agregadas expresadas en bióxido de carbono). Lo anterior, para los países desarrollados, la entonces Comunidad Europea y sus miembros, y los de 
Esta obra forma parte del acervo de la Biblioteca Jurídica Virtual del Instituto de Investigaciones Jurídicas de la UNAM

economías en transición según el listado del anexo B del propio PK. El fin de estos compromisos, vinculantes, es el de reducir individual o conjuntamente el total de las emisiones por lo menos en 5\% para un primer periodo que abarca de 2008 a 2012 tomando como referencia los niveles de emisión de 1990. Algunos países pueden aumentar sus emisiones, otros quedarse en el nivel establecido, y otros reducirlas.

Segundo, se determinan tres mecanismos flexibles para lograr el cumplimiento de los compromisos asumidos: $a$ ) proyectos de aplicación conjunta (joint implementation); b) mecanismos para un desarrollo limpio (clean development mechanism); y c) comercio de los derechos de emisión (emissions trading). Con estos mecanismos se ha creado un marco jurídico de aplicación regional y bilateral en el que pueden participar las partes incluidas o no - según sea el caso - en el anexo I de la Convención. Por ejemplo, en el caso del comercio de derechos de emisión destaca a nivel regional la expedición de la Directiva 2003/87/CE, del Parlamento Europeo y del Consejo, que se aprobó en octubre de 2003 y entró en vigor en ese mismo mes y año. En el mecanismo para un desarrollo limpio, cuyo número de instrumentos bilaterales es muy amplio e incluye tanto tratados internacionales como tratados en forma simplificada, se puede hablar del acuerdo celebrado entre el gobierno de los Estados Unidos Mexicanos y el gobierno de la República Francesa (junio de 2005). Para el de aplicación conjunta, un buen ejemplo es el proyecto de protección forestal y de especies en peligro de extinción Bikin Tiger Carbon Project (enero 2013) ubicado en Primorsky Krai al sureste de Rusia.

En 2007, en Bali, Indonesia (COP-13), se acordó iniciar las negociaciones y una ruta crítica para un segundo periodo de cumplimiento. Se tendría un documento final en 2009 en Copenhague, Dinamarca (COP15), pero ni en esta ni en la siguiente conferencia donde también se tenía cierta expectativa en este sentido, i. e. la de Cancún, México (COP-16), se logró adoptar un régimen climático vinculante para después de 2012. No obstante, y tras la celebración de las conferencias siguientes, en Durbán, Sudáfrica en 2011 (COP-17), y en Doha, Qatar en 2012 (COP-18), la comunidad internacional ha logrado ciertos acuerdos importantes. Entre ellos: a) el compromiso de las partes para mantener el aumento de la temperatura media mundial respecto a niveles preindustriales por debajo de $2{ }^{\circ} \mathrm{C}$; b) la creación y funcionamiento del Fondo Verde para el Clima; c) alcanzar el objetivo conjunto de los 100,000 millones de dólares de 
Esta obra forma parte del acervo de la Biblioteca Jurídica Virtual del Instituto de Investigaciones Jurídicas de la UNAM

los Estados Unidos de América anuales para 2020 de las partes que son países desarrollados; $d$ ) la extensión por ocho años más (a partir de enero de 2013) del régimen vinculante existente para un segundo periodo de cumplimiento, y e) la adopción de un nuevo acuerdo climático universal hard para el 2015, con aplicación (entrada en vigor) en 2020. 
Esta obra forma parte del acervo de la Biblioteca Jurídica Virtual del Instituto de Investigaciones Jurídicas de la UNAM

\section{CONFLICTOS SOCIO-AMBIENTALES*}

La palabra conflicto proviene del latín conflictus y según el Diccionario de la Lengua Española significa — entre diversas acepciones- combate, lucha, pelea, enfrentamiento armado, apuro, problema, cuestión, materia de discusión. Diversos autores lo describen como un proceso o una situación donde intervienen diferentes entes (dos o más) que están opuestos o que se confrontan. Paralelamente, una considerable cantidad de trabajos académicos que abordan esta noción se enfocan a analizar la participación del Estado como el ente que: $i$ ) crea directa o indirectamente el conflicto o simplemente no lo previene al interior de su territorio; $i$ ) participa en la resolución de los mismos a través de diferentes figuras jurídicas e instancias diversas, ya sea desde el gobierno mismo o desde sus instituciones u órganos jurisdiccionales (administrativos o judiciales); iii) defiende su territorio y soberanía ante confrontaciones o agresiones externas; y $i v$ ) coopera o colabora con otros Estados para enfrentar conflictos derivados de temas globales o regionales de interés común para la humanidad en el ámbito internacional.

Aunque en la expresión compuesta de conflicto socio-ambiental también se examina la participación del Estado, no siempre se alude a éste último. Es lógico suponer que por definición todo conflicto social esté constituido por un elemento de este tipo que le es inseparable y cuya materialización tiene lugar sólo en el ámbito de lo público. Sin embargo, cuando se agrega la dimensión ambiental, además de la controversia entre dos o más actores sociales y de la participación del Estado si es el caso, también se incluye un componente de tipo privado: disputa entre particulares o empresas privadas. Así, el objeto de la confrontación socio-ambiental se refiere a la naturaleza, a los recursos naturales, o en general, al medio natural, en la que pueden intervenir todos los prota-

* Publicada en en Ferrer Mac-Gregor, Eduardo et al. (coords.), Diccionario de derecho procesal constitucional y convencional, Poder Judicial de la Federación, Consejo de la Judicatura Federal-UNAM, Instituto de Investigaciones Jurídicas, 2014, t. I. 
Esta obra forma parte del acervo de la Biblioteca Jurídica Virtual del Instituto de Investigaciones Jurídicas de la UNAM

gonistas arriba mencionados. De aquí que se haya argumentado que la disciplina jurídica que regula los conflictos ambientales -i.e. el derecho ambiental - pertenezca al mismo tiempo al derecho público, al derecho privado y al derecho social.

Independientemente del número de tipologías o aproximaciones que se han elaborado desde distintas disciplinas (e. g. ciencia política, sociología política, economía ecológica, etcétera) para comprender el significado y alcance de lo que representan los conflictos socio-ambientales, es fundamental que éstos se inserten en un concepto más amplio que es el de crisis ambiental. Éste se define como una situación crítica del ambiente derivada de una serie de alteraciones producidas por los homo sapiens sapiens al medio natural, al medio construido y a la salud, bienestar y calidad de vida de los seres humanos como consecuencia de ciertos acontecimientos ocurridos a partir de la relación de interdependencia recíproca que guardan con el ambiente. Tanto la crisis ambiental como el conflicto socio-ambiental poseen una doble naturaleza: son idea y fenómeno a la vez.

Derivado de lo anterior, las controversias o disputas entre diversos actores pueden ser, por un lado, ideológicas o conceptuales, donde prevalecen cuestiones científicas y ético-filosóficas contrapuestas, y por el otro, por sucesos que han ocurrido y que impactan en el ambiente. De modo que, según corresponda, el Estado, los partidos políticos, las organizaciones, los grupos, las comunidades, los pueblos, las naciones, las instituciones públicas, los particulares, las empresas privadas, los individuos, etcétera, pueden actuar como entes exógenos y también como entes endógenos ante las alteraciones al ambiente que se pudieran producir (idea) o las ya producidas (fenómeno). Por ejemplo, para el primer caso - entes exógenos - un grupo ambientalista puede oponerse al interés de un gobierno por elaborar políticas públicas que impulsen los desarrollos turísticos en zonas costeras (idea), o bien, luchar junto a una comunidad indígena por las aguas a las que ya no tienen acceso ante la construcción de una presa hidroeléctrica (fenómeno). Para el segundo caso - entes endógenos - las familias de una zona urbana de tipo habitacional pueden objetar o impugnar a un gobierno local un programa en el que se pretenda construir en dicha zona vías rápidas para "agilizar" el tránsito vehicular como única opción al problema de congestionamientos viales (idea), o bien, pueden combatir los permisos otorgados por 
Esta obra forma parte del acervo de la Biblioteca Jurídica Virtual del Instituto de Investigaciones Jurídicas de la UNAM

un gobierno local por la construcción de un rascacielos dentro de esa misma zona habitacional que está ocasionando contaminación visual, auditiva, por olores, vibraciones, tránsito vehicular, cortes de agua, etcétera, afectando directamente a los habitantes de dicha área urbana y zonas contiguas (fenómeno). 
Esta obra forma parte del acervo de la Biblioteca Jurídica Virtual del Instituto de Investigaciones Jurídicas de la UNAM

\section{DERECHO AL MEDIO AMBIENTE*}

Es común que en la doctrina y en la normatividad interna de muchos países, el denominado derecho al medio ambiente o derecho al ambiente sea descrito y precisado como un derecho humano. Bajo esta tesitura, se ha considerado (aunque no de manera unánime) que el derecho al ambiente pertenece a los derechos de solidaridad o de la tercera generación, como el derecho al desarrollo, la paz o la libre determinación de los pueblos. Esto permite distinguirlos de los derechos civiles y políticos (de la primera generación) y de los derechos económicos, sociales y culturales (de la segunda generación).

Los autores que apoyan el planteamiento de que se trata de un derecho de tercera generación habrían de coincidir en que este tipo de derechos - a diferencia de los de primera y segunda generación- establecen al mismo tiempo deberes estatales positivos (i.e. de hacer) a la vez que negativos (i.e. de no hacer). Esto significa que el Estado deberá, por ejemplo, mejorar, restaurar o lograr la conservación del ambiente y evitar su deterioro y contaminación; asegurar que sus titulares puedan ejercer este derecho (legitimación procesal), ya sea como acción ambiental individual o colectiva; establecer normas procesales e instancias jurisdiccionales para garantizar su cumplimiento; delimitar la responsabilidad subjetiva y objetiva por daño ambiental, etcétera.

En toda discusión relativa al reconocimiento de un derecho al ambiente subsisten, entre otras, tres ideas para un análisis jurídico: $i$ ) el ambiente como objeto de protección; ii) la titularidad y legitimación procesal; y iii) las garantías procesales para el cumplimiento efectivo del derecho. Respecto a la primera, como no existe una definición única o universal sobre el concepto de ambiente, es muy complejo delimitar el significado del bien que se pretende tutelar. ¿Están incluidos todos los componentes

* Publicada en en Ferrer Mac-Gregor, Eduardo et al. (coords.), Diccionario de derecho procesal constitucional y convencional, Poder Judicial de la Federación, Consejo de la Judicatura Federal-UNAM, Instituto de Investigaciones Jurídicas, 2014, t. I. 
Esta obra forma parte del acervo de la Biblioteca Jurídica Virtual del Instituto de Investigaciones Jurídicas de la UNAM

esenciales de la noción ambiente, es decir, seres humanos, medio natural, medio construido y las relaciones de interdependencia recíproca que hay entre ellos? Aunque en un principio se ha señalado que el bien jurídico tutelado (i.e. el ambiente) se refiere a la salud, el bienestar, la calidad de vida, el desarrollo de la personas (entre otros), es claro que tanto la naturaleza como el medio artificial los condicionan, por lo que éstos deberán protegerse para que el derecho al ambiente tenga sentido. Precisar o acotar el contenido de lo que es el bienestar o la calidad de vida, así como lo que abarcan los medios natural y construido, es tarea de quienes inciden en la elaboración de la normatividad respectiva. En esta labor debe tomarse en cuenta que existen bienes jurídicos conexos (si bien independientes) a lo ambiental, lo que supone que el derecho al ambiente está vinculado a otros derechos (reconocidos constitucionalmente o no) como el derecho a la salud, el derecho al desarrollo sustentable, el derecho al agua, el derecho a la atmósfera, el derecho al patrimonio cultural, etcétera. Además, se discute si los calificativos frecuentemente asignados al ambiente son los idóneos: sano, saludable, adecuado o equilibrado. Lo anterior, porque se ha criticado que todos ellos son muy ambiguos. Sin embargo, hay que señalar que precisamente su inherente flexibilidad permite que este derecho pueda adaptarse o expandirse bajo los principios ambientales de equidad inter-generacional e intra-generacional. El ambiente, cualquiera que sea su adjetivo, beneficia a todos, y de aquí su característica colectiva.

En relación con la segunda idea, se debaten dos cuestiones muy puntuales. Por un lado, si la titularidad del derecho es individual o colectiva y, por el otro, si la potestad legal para acudir a las instancias jurisdiccionales competentes (legitimación procesal) es exclusiva de la persona física o jurídica que ha sufrido (o podría sufrir) el agravio de manera personal y concreta por lo que se requiera acreditar un interés directo (derecho subjetivo en sentido clásico), o bien de una persona en donde el agravio no haya sido como el mencionado con antelación y sólo tenga un interés legítimo o un interés difuso (afectación a la esfera jurídica de la persona por su especial situación frente al orden jurídico). En la primera, se debe aceptar que la titularidad del derecho al ambiente es individual: se trata de un derecho subjetivo, de un derecho humano, de un derecho de las personas (el bien protegido es individual). Al mismo tiempo debe admitirse que la titularidad es colectiva: se trata de un grupo de personas, de una 
Esta obra forma parte del acervo de la Biblioteca Jurídica Virtual del Instituto de Investigaciones Jurídicas de la UNAM

colectividad, de una clase de individuos (el bien tutelado corresponde a todos, es decir, es un bien colectivo). En la segunda cuestión, se acepta que cualquier persona, grupo de personas, comunidades, pueblos está(n) legitimado(s) para presentar acciones ambientales individuales o colectivas (según corresponda) que tengan interés directo o difuso.

En la tercera idea jurídica se plantea que no es suficiente que el derecho al ambiente se mencione en preceptos constitucionales y/o en textos legales sustantivos, sino que existan disposiciones jurídicas procesales que permitan su cumplimiento. Esto supone dos cosas a la vez. En primer lugar, que se elaboren normas en las que se otorgue a la(s) persona(s) agraviada(s), por interés directo o difuso, medidas tanto de prevención para evitar posibles daños ambientales, como de reparación o resarcimiento en caso de que se hubiere actualizado el daño o afectación respectivos. Así, la prevención y la reparación vinculadas al bien jurídico tutelado podrá ser individual o colectiva. En segundo lugar, es imprescindible que existan las instancias jurisdiccionales competentes donde se ventilen las controversias que se pudieran suscitar por la violación de este derecho. El legal y efectivo cumplimiento del derecho al ambiente puede sustanciarse ante instituciones $\mathrm{u}$ órganos del Poder Ejecutivo $(i$. $e$. las autoridades que emiten actos de autoridad y tribunales administrativos), o del Poder Judicial (i. e. juzgados, tribunales y cortes). Aunque algunos tribunales (administrativos y judiciales) cuentan con salas o jurisdicciones especiales en materia ambiental, debería generalizarse la existencia de tribunales ambientales.

Por último, hay que señalar que la postura claramente antropocéntrica de caracterizar el derecho al ambiente como un derecho humano, ha excluido la posibilidad de que se reconozca que la naturaleza - representada en su conjunto tanto por la comunidad biótica (árboles, plantas, animales, microbios) como por los factores abióticos que la determinan (elementos químicos y físicos, por ejemplo el agua, la temperatura, el suelo) y que configuran los ecosistemas - también pueda ser considerada titular o sujeto de este derecho. Son pocos los ejemplos de juristas que discuten y que eventualmente están a favor de asignar derechos a la naturaleza, y menos aún los casos de textos constitucionales y legales que así lo determinan (excepcionalmente, en América Latina, la Constitución del Ecuador destina todo un capítulo, el séptimo, a desarrollar explícitamente el tema de "los derechos de la naturaleza"). Asimismo, 
Esta obra forma parte del acervo de la Biblioteca Jurídica Virtual del Instituto de Investigaciones Jurídicas de la UNAM

existe resistencia doctrinal y normativa para que se reconozcan derechos al medio construido, representado por las obras realizadas por los humanos (el patrimonio cultural, tangible e intangible) y que forma parte, al igual que la naturaleza, de la noción ambiente. Si existe un desarrollo paralelo y conveniente de un ordenamiento jurídico de protección de los medios natural y construido, no se debe a que se les haya reconocido derechos, sino a que tal protección acarrea beneficios directos e indirectos a los seres humanos $y$, en última instancia, a que facilita el poder ejercer el derecho al ambiente.

En síntesis, desde el punto de vista jurídico, el derecho al ambiente es simultáneamente un derecho individual y colectivo, que genera deberes de acción y de abstención del Estado. Es un derecho que complementa, pero que a su vez se complementa con otros derechos. Su constitucionalización debe generalizarse en todos los países del mundo. 
Esta obra forma parte del acervo de la Biblioteca Jurídica Virtual del Instituto de Investigaciones Jurídicas de la UNAM

\section{DERECHO ATMOSFÉRICO*}

I. Dice el Diccionario de la Lengua Española de la Real Academia Española que atmosférico es lo "perteneciente o relativo a la atmósfera", y que atmósfera (del lat. cient. atmosphaera, y éste del gr. atmós "vapor, aire" y sphaîra "esfera") significa "capa gaseosa que rodea la Tierra y otros cuerpos celestes". El mismo Diccionario señala que aire (del lat. aer, -ěris, y éste del gr. $a \bar{e} r$ ) es el "gas que constituye la atmósfera terrestre, formado principalmente de oxígeno y nitrógeno, y con otros componentes como el dióxido de carbono y el vapor de agua". El aire es, técnicamente hablando, un "fluido, formado por una serie de gases, que constituye la atmósfera". ${ }^{1}$

La atmósfera está compuesta por "una mezcla de gases, vapor de agua, partículas sólidas y pequeñas gotas de líquido", ${ }^{2}$ y está divida en varias capas en función de su temperatura y composición. Aunque no haya consenso al respecto, se dice que las capas que constituyen la atmósfera generalmente incluyen la troposfera (que se eleva desde el nivel de mar hasta unos $17 \mathrm{kms}$ desde la zona del Ecuador), la estratosfera (que alcanza una altitud de $50 \mathrm{kms}$.), la mesosfera (que se extiende hasta los $80 \mathrm{kms}$.), y la termosfera (hasta $1,000 \mathrm{kms}$. de altura). A este bloque de capas se le conoce en lenguaje común como "atmósfera terrestre", "espacio atmosférico" o "espacio aéreo". La siguiente capa, la exosfera, es el límite de la atmósfera y, por lo tanto, constituye una región de transición entre la atmósfera y el espacio exterior (al que se le denomina también "espacio ultraterrestre" o "espacio sideral"). Por ello, en ocasiones se considera que la exósfera es parte de la atmósfera terrestre y en otras del espacio ultraterrestre.

* Esta voz también se publica en el Diccionario jurídico mexicano, México, PorrúaUNAM, Instituto de Investigaciones Jurídicas, 2018.

1 Arenas Muñoz, José Antonio, Diccionario técnico y jurídico del medio ambiente, Madrid, McGraw Hill, 2000, p. 55.

2 Rivero Serrano, Octavio et al., Contaminación atmosférica y enfermedad respiratoria, México, Biblioteca de la Salud-Secretaría de Salud-Fondo de Cultura EconómicaUNAM, 1993, p. 27. 
Esta obra forma parte del acervo de la Biblioteca Jurídica Virtual del Instituto de Investigaciones Jurídicas de la UNAM

II. Se define al derecho atmosférico como una rama del derecho cuyo objeto de estudio y regulación son las conductas humanas que afectan el conjunto de gases, líquidos o sólidos que componen la atmósfera. Nuestros comportamientos o actividades en relación con la atmósfera pueden tener efectos negativos o positivos. Son negativos los que causan un daño al medio natural (que incluye a la propia atmósfera), al medio construido, y a la salud, bienestar y calidad de vida de los seres humanos. Esto ocurre cuando se introducen gases y partículas que alteran la composición natural de la atmósfera, y entonces se dice que existe contaminación atmosférica o contaminación del aire. A tales gases y partículas se les denomina contaminantes. La vigente Ley General del Equilibrio Ecológico y la Protección al Ambiente establece que contaminante es "toda materia o energía en cualesquiera de sus estados físico y formas, que al incorporarse o actuar en la atmósfera, agua, suelo, flora, fauna o cualquier elemento natural, altere o modifique su composición y condición natural" (artículo 3o., fracción VIII), y que contaminación es "la presencia en el ambiente de uno o más contaminantes o de cualquier combinación de ellos que cause desequilibrio ecológico" (artículo 3o., fracción VI). Son positivos, si los efectos de nuestros comportamientos o actividades mantienen un equilibrio atmosférico natural o permiten el proceso natural de autodepuración que en su conjunto son necesarios para la vida en el planeta Tierra.

III. No debe confundirse derecho atmosférico con derecho aéreo. Aquél está orientado a la protección jurídica de la atmósfera y de aquí su estrecha relación con el derecho ambiental (aunque por extensión también con otros campos del derecho como el administrativo y el internacional). En cambio, el derecho aéreo se ha identificado tradicionalmente con la navegación aérea, y por lo tanto su vínculo es principalmente con el derecho internacional (se extiende a otros derechos como el mercantil, el administrativo y el de las telecomunicaciones). De igual manera, y por lo dicho en los apartados anteriores, tampoco debe confundirse con derecho ultraterrestre, cuyo objeto de estudio y regulación son las actividades de exploración y explotación del espacio exterior teniendo una relación fundacional con el derecho internacional.

IV. Son cuatro las áreas de estudio y regulación del derecho atmosférico. Primero, la contaminación atmosférica urbana, que se refiere a la contaminación producida en los grandes centros urbanos proveniente particularmente de industrias y vehículos automotores por la quema de 
Esta obra forma parte del acervo de la Biblioteca Jurídica Virtual del Instituto de Investigaciones Jurídicas de la UNAM

combustibles fósiles. Elevadas concentraciones de contaminantes atmosféricos pueden no sólo alterar la salud humana (con efectos agudos y crónicos) y provocar muertes prematuras, sino producir daños en la flora, la fauna y la naturaleza, así como en monumentos y edificios históricos o artísticos. Los contaminantes de mayor preocupación son los contaminantes criterio (que incluyen el monóxido de carbono, el bióxido de azufre, el bióxido de nitrógeno, el material particulado, el plomo y el ozono) y los contaminantes tóxicos (como el butadieno, el benceno o el formaldehído, entre otros). La normatividad jurídica para enfrentar este problema es doméstica, aunque muchos países, como es el caso de México, han adoptado una legislación atmosférica basada en guías, lineamientos o estándares internacionales. Esto incluye normas relativas a los niveles máximos permisibles de concentración por contaminante (i. e. normas de calidad del aire); índices de valores (para efectos de conocer y difundir a la población los niveles de contaminación y riesgos asociados y acciones a seguir); sistemas de monitoreo de los contaminantes (que incluye tanto los métodos de referencia o equivalente como las verificaciones de las estaciones o casetas de monitoreo), etcétera.

Segundo, la lluvia ácida, expresión que describe la existencia de precipitaciones o deposiciones ácidas (húmedas y secas) como resultado de transformaciones químicas en la atmósfera ante la presencia de ciertos gases, como el dióxido de azufre y los óxidos de nitrógeno (que producen, respectivamente, ácido sulfúrico y ácido nítrico) o de ciertos compuestos orgánicos volátiles, como el amoniaco. Los efectos de la lluvia ácida son: la acidificación de cuerpos de agua (ríos, lagos) afectando la composición misma del agua y la vida de la flora y la fauna acuáticas; la acidificación de suelos y la alteración de ecosistemas terrestres (específicamente los forestales); los impactos negativos en el sector agrícola (reducción de cosechas); el deterioro y corrosión de edificios y monumentos (llamado "mal de la piedra") y, desde luego, las posibles afectaciones en la salud humana. Cuando la fuente y los efectos de la lluvia ácida se presentan en zonas urbanas, agrícolas o de conservación que están bajo la jurisdicción de una sola nación, se trata de un problema de contaminación atmosférica doméstica. Sin embargo, cuando la fuente de la lluvia ácida se produce en zonas que se encuentran bajo la jurisdicción de un Estado pero los efectos se resienten en zonas bajo la jurisdicción de otro Estado distinto al de la fuente y que sea a larga distancia, entonces 
Esta obra forma parte del acervo de la Biblioteca Jurídica Virtual del Instituto de Investigaciones Jurídicas de la UNAM

se trata de un problema de contaminación transfronteriza. Desde el punto de vista convencional, el instrumento internacional más importante a nivel multilateral para este último caso es el Convenio sobre la Contaminación Atmosférica Transfronteriza a Larga Distancia, adoptado en 1979 en Ginebra, Suiza, que cuenta con diversos protocolos específicos. Nuestro país no es parte contratante de este tratado.

Tercero, el agotamiento de la capa de ozono, fenómeno que se atribuye a la presencia en la atmósfera de clorofluorocarbonos y de otras sustancias o compuestos como los halones o los hidroclorofluorocarbonos. La capa de ozono se encuentra situada entre los 20 y los 40 kilómetros de altura aproximadamente (es el ozono estratosférico vis à vis el ozono troposférico, que es un gas contaminante) y es fundamental para la vida en el planeta Tierra porque actúa como una esponja o escudo que absorbe la radiación ultravioleta (proveniente de los rayos solares) impidiendo que ésta llegue a la superficie terrestre. El deterioro o destrucción de esta capa trae consigo efectos como quemaduras solares, cáncer de piel, envejecimiento (cutis de campesino), muerte de ciertas especies, modificaciones genéticas, alteraciones climáticas, etcétera. Las preocupaciones a nivel global por la ocurrencia de tal fenómeno, llevó a la comunidad internacional a adoptar el Convenio de Viena para la Protección de la Capa de Ozono en 1985 (que es un convenio marco para proteger la salud humana y el ambiente de efectos adversos por la modificación del ozono), y posteriormente el Protocolo de Montreal Relativo a las Sustancias Agotadoras de la Capa de Ozono en 1987 (instrumento que establece metas específicas para reducir y eliminar el consumo y producción de sustancias que destruyen el ozono); México es parte contratante en ambos tratados. La implementación de estos dos instrumentos (y los posteriores ajustes y enmiendas al Protocolo de Montreal en donde se incluyeron adicionalmente otras sustancias) está consiguiendo, al parecer, un efecto positivo para detener o revertir el proceso de adelgazamiento de la capa de ozono.

Cuarto, el cambio climático, que indica la existencia de un fenómeno inducido por los seres humanos debido a las crecientes concentraciones de gases de efecto invernadero (GEI) que están alterando la composición natural de la atmósfera. Los GEI que forman parte de la regulación internacional son el dióxido de carbono, el metano, el óxido nitroso, los hidrofluorocarbonos, los perfluorocarbonos, el hexafluoruro de azufre y el trifluoruro de nitrógeno. La esencia del problema es el aumento de la 
Esta obra forma parte del acervo de la Biblioteca Jurídica Virtual del Instituto de Investigaciones Jurídicas de la UNAM

temperatura media global, lo que está acarreando muy diversos y nocivos efectos en todo el mundo, como el derretimiento de la nieve y el hielo; la elevación del nivel del mar; mayores sequías; tormentas más intensas; extinción de especies; desaparición de corales, etcétera. Los cuatro instrumentos internacionales vinculantes fundamentales para enfrentar el cambio climático son: la Convención Marco de las Naciones Unidas sobre el Cambio Climático, adoptada en 1992; el Protocolo de Kioto de la Convención Marco de las Naciones Unidas sobre el Cambio Climático, adoptado en 1997; la Enmienda de Doha al Protocolo de Kioto, adoptada en 2012 (y que aún no entra en vigor); y el Acuerdo de París, adoptado en 2015 (que entrará en vigor en 2016). Nuestro país ha suscrito todos ellos. 
Esta obra forma parte del acervo de la Biblioteca Jurídica Virtual del Instituto de Investigaciones Jurídicas de la UNAM

\section{DERECHOS DE LOS ANIMALES*}

I. Según el Diccionario de la Lengua Española de la Real Academia Española, la voz animal (del lat. anǐmal, -ālis.) significa en su primera acepción "ser orgánico que vive, siente y se mueve por propio impulso". El contenido de este concepto forma parte del discurso enarbolado por movimientos como el animalista y el ambientalista, y se atribuye al jurista y filósofo inglés Jeremy Bentham el haber asociado por vez primera hacia finales del siglo XVIII el vocablo animales con el de derechos en su obra An Introduction to the Principles of Morals and Legislation.

II. La expresión derechos de los animales tiene un doble significado. En una primera acepción designa, lato sensu, todas aquellas ideas, teorías, criterios, perspectivas o formas de pensamiento (científicas o religiosas) que plantean mediante argumentos diversos la consideración moral de los animales. Dentro de ellas pueden incluirse - entre muchas más - la postura de Pitágoras de respeto a los animales basada en la teoría de la transmigración de las almas, los cánticos de San Francisco de Asís de alabanza a las demás criaturas, el rechazo de Voltaire a la costumbre de comer carne, el amor de Chamalú hacia los animales en el chamanismo andino, o el reclamo del Papa Francisco en su encíclica Laudato Si respecto al ensañamiento contra cualquier criatura por ser contrario a la dignidad humana. Éstos y otros planteamientos en defensa de los animales suelen agruparse bajo diversas denominaciones, cuyos contenidos en algunas ocasiones coinciden y en otras divergen. Entre las más importantes mencionamos las siguientes: abolicionismo; contractualismo; teorías emotivistas, del sentimiento o de la compasión; utilitarismo; liberación animal; ética kantiana; derechos (para o de los) animales; antiespecismo; vegetarianismo; igualdad animal, etcétera.

* Esta voz también se publica en el Diccionario jurídico mexicano, México, PorrúaUNAM, Instituto de Investigaciones Jurídicas, 2018. 
Esta obra forma parte del acervo de la Biblioteca Jurídica Virtual del Instituto de Investigaciones Jurídicas de la UNAM

De todas ellas, una de las que más ha tenido difusión es la del utilitarismo, cuyo antecedente principal se encuentra en el pensamiento del ya mencionado J. Bentham, y cuyo máximo representante en la actualidad es el filósofo australiano Peter Singer. En esencia, esta postura radica en que el principio ético de igualdad entre los seres humanos deberá de extenderse a los animales. Ellos y nosotros merecemos igualdad de consideración, aunque no de trato: "el principio básico de la igualdad no exige un tratamiento igual o idéntico, sino una misma consideración". ${ }^{1}$ A esta idea se unen, entre otros, dos argumentos fundamentales. Primero, que lo que hace que los animales tengan estatus moral es que son seres sintientes, o sea, pueden sentir dolor o sufrimiento, placer o bienestar, y esto es razón suficiente para que tengan intereses que deban ser moralmente considerados. Segundo, que el mejor escenario o el más útil es el de maximizar la satisfacción de intereses morales; deberá causarse el mayor bienestar posible al mayor número posible de animales.

En una segunda acepción, la expresión derechos de los animales designa, stricto sensu, una teoría que propone el reconocimiento de derechos a los animales (en inglés, the rights view) bajo la premisa de que éstos pueden $\mathrm{y}$, de hecho, tienen derechos. Esta teoría, criterio o visión, es considerada por muchos como una postura radical para la defensa de los animales; por lo tanto, ha sido rechazada por un buen número de filósofos, sociólogos y juristas que conocen sobre el tema. Si bien autores como J. Bentham o Henry S. Salt (en su obra Animals' Rights: Considered in Relation to Social Progress de finales del siglo XIX) aludieron a los derechos de los animales, lo hicieron más respecto a la igualdad o el trato hacia ellos que a sus derechos como individuos. Por lo que la idea de reconocer derechos a los animales como sujetos descansa fundamentalmente en la obra The Case for Animal Rights del filósofo estadounidense Tom Regan. A él se atribuye en realidad la articulación y la sistematización de esta teoría.

La propuesta de T. Regan establece que todo aquel individuo que tenga un valor inherente lo tendrá en igualdad, sea animal humano o no. Tal valor pertenece a aquellos individuos que experimenten ser sujetos de una vida. Por lo tanto, lo animales no deben ser tratados como meros receptáculos de valores intrínsecos (como el placer o la satisfacción), sino

1 Singer, Peter, Liberación animal, ed. actualizada, trad. de ANDA, Madrid, Taurus, 2011, p. 18. 
Esta obra forma parte del acervo de la Biblioteca Jurídica Virtual del Instituto de Investigaciones Jurídicas de la UNAM

que debe reconocérseles el poseer un valor inherente de igualdad precisamente por ser sujetos de una vida. En relación con esto, sostiene que son falsas la tres proposiciones siguientes: $i$ ) "comparadas con cualquier otro y con cualquier otra cosa, las personas tienen un estatus moral único y superior"; ii) "todas las personas, y sólo las personas, pueden tener derechos"; y iii) "todas las personas, y sólo las personas, tienen derechos". ${ }^{2}$ A lo largo de los años, este autor ha considerado que todos los mamíferos y las aves, así como otros vertebrados (particularmente los peces), son animales no humanos capaces de poseer derechos. Los derechos que deben reconocérseles son los derechos morales básicos, en específico el de la vida, la integridad corporal y la libertad; todos ellos unificados en el derecho a ser tratados con respeto.

III. En nuestra opinión, las diversas perspectivas de los derechos de los animales, tanto en sentido amplio como estricto, convergen hacia un mismo objetivo: la protección o defensa in genere de los animales. Aunque no sean unánimes ni unificadas, todas son válidas y éticamente defendibles. Sin embargo, enfrentan por sí solas o en su conjunto un dilema insalvable: la supervivencia del ser humano. Esto es, si se pretende extender la esfera de lo moral hacia los animales, es indispensable tener en cuenta que cualquier ética, incluyendo la que se basa en el reconocimiento de sus derechos, será indefendible ante un escenario en el que la vida misma de los humanos esté comprometida y en donde al mismo tiempo éstos no tengan alguna otra alternativa para sobrevivir.

Esta postura - a la que llamamos el criterio entre la supervivencia y la alternativa $-{ }^{3}$ nos conduce a afirmar que no toda actividad humana relacionada con un animal es necesariamente condenable y por ende contraria a los derechos de los animales. Así, no puede justificarse éticamente la prohibición de la caza y la pesca de animales si los humanos que las realizan para consumirlos no cuentan con otras opciones para alimentarse. El vegetarianismo (y sus diferentes grados) se practica no sólo por razones éticas, de salud, ambientales o espirituales, sino porque se tiene la alternativa, según sea el caso, de ingerir productos que no pertenecen a algún tipo de carne ni se derivan de animales. Tal alternativa permite que

2 Regan, Tom, "Poniendo a las personas en su sitio", en Tafalla, Marta (ed.), Los derechos de los animales, Barcelona, Idea Books, 2004, p. 55.

3 Nava Escudero, César, Ciencia, ambiente y derecho, México, UNAM, Instituto de Investigaciones Jurídicas, 2012. 
Esta obra forma parte del acervo de la Biblioteca Jurídica Virtual del Instituto de Investigaciones Jurídicas de la UNAM

por ejemplo veganos, ovovegetarianos, lactovegetarianos u ovolactovegetarianos puedan alimentarse, es decir, sobrevivir y, según se afirma, no poner en riesgo su salud.

De manera tal que es rechazable cualquier comportamiento en el que se mate o dañe al animal en donde no esté involucrada nuestra supervivencia. Pero si ésta lo estuviera, entonces deberá buscarse alguna otra alternativa para evitar la muerte del animal o cualquier tipo de sufrimiento, dolor, tortura o crueldad, logrando de este modo respetar su vida, integridad corporal, libertad y al mismo tiempo garantizar su propia supervivencia y bienestar. Es bajo este esquema, y en estas circunstancias, que condenamos actividades como el esparcimiento, la diversión, el lucro, el uso para experimentación con fines farmacéuticos y cosméticos, entre otras. Por consiguiente, nos oponemos a las corridas de toros, las peleas de gallos y de perros, la cacería y pesca deportivas, los circos, los zoológicos y acuarios (a menos que fueran reservas naturales), etcétera.

IV. No debe confundirse la expresión derechos de los animales (la primera palabra está en plural) con la de derecho de los animales (la primera palabra está en singular). Esta última indica que estamos frente a una rama del derecho y, como tal, tiene una doble naturaleza: científica y normativa. Como ciencia, se refiere al conjunto de conceptos, definiciones, perspectivas, criterios, teorías o posturas que estudian la protección o defensa de los animales. Como norma, es el conjunto de normas jurídicas que regulan la protección o defensa de los animales.

En México, no está claramente determinada la situación jurídica del animal (que incluye su terminología y naturaleza jurídicas) puesto que el lenguaje y contenido que se utiliza es muy diverso. Por un lado, el Código Civil Federal los considera bienes susceptibles de apropiación y, por lo tanto, tienen dueños o propietarios. No son sujetos de derecho sino objetos de derecho. La Ley General de Vida Silvestre, sin definirlos, los describe mayormente como ejemplares, y admite la existencia de mascotas y animales de compañía. Al mismo tiempo, se refiere al trato digno y respetuoso hacia ellos (expresamente se les refiere como ejemplares de fauna silvestre) "para evitar o disminuir la tensión, sufrimiento, traumatismo y dolor" que se llegara a ocasionar "durante su aprovechamiento, traslado, exhibición, cuarentena, entrenamiento, comercialización y sacrificio" (artículo 29). Asimismo, esta Ley prohíbe estrictamente todo acto de crueldad en contra de ellos. Por el otro, la Ley de Protección a los 
Esta obra forma parte del acervo de la Biblioteca Jurídica Virtual del Instituto de Investigaciones Jurídicas de la UNAM

Animales del Distrito Federal los considera objeto de tutela y protección, y define al animal como un "ser orgánico, no humano, vivo, sensible, que posee movilidad propia y capacidad de respuesta a los estímulos del medio ambiente perteneciente a una especie doméstica o silvestre (artículo 4o., fracción I). Dicha Ley, al establecer obligaciones de los habitantes de la Ciudad de México y deberes de las propias autoridades locales respecto a ellos, también establece un listado de derechos, como: vivir libre en su ambiente natural, terrestre, aéreo o acuático; reproducirse; vivir y crecer al ritmo y condiciones de vida y libertad de su propia especie; que la duración de su vida sea según su longevidad natural; alimentación reparadora; reposo, etcétera. Desde luego, esta Ley también se refiere al trato digno y respetuoso a los animales para evitar dolor o angustia, y de forma muy pertinente establece un listado de prohibiciones como la de celebrar peleas entre ellos o realizar espectáculos en la vía pública. Lamentablemente, la Ley exceptúa de tal prohibición a las corridas de toros y a las peleas de gallos, entre otras. 
Esta obra forma parte del acervo de la Biblioteca Jurídica Virtual del Instituto de Investigaciones Jurídicas de la UNAM

\section{DERECHO DEL CAMBIO CLIMÁTICO*}

I. Indica el Diccionario de la Lengua Española de la Real Academia Española que la voz climático es "lo perteneciente o relativo al clima", y que clima (del lat. tardío clima "latitud, región", y éste del gr. klíma) es "conjunto de condiciones atmosféricas que caracterizan una región". Por cambio (del lat. tardío cambium, y éste del galo cambion), se entiende "Acción y efecto de cambiar". En una combinación de palabras, el Diccionario dice que cambio climático es "cambio previsible en el clima terrestre provocado por la acción humana que da lugar al efecto invernadero y al calentamiento global".

Técnicamente, la expresión cambio climático se refiere a dos fenómenos distintos. Primero, a los cambios climáticos de tipo natural que pueden ser cortos y no muy cortos (entre estaciones, ciclos regulares anuales, algunas décadas, unos cuantos cientos de años), así como muy largos (fases glaciales e interglaciales). Segundo, al cambio climático (en singular) inducido por los seres humanos debido a las crecientes concentraciones de gases de efecto invernadero (en adelante, GEI) que alteran la composición natural de la atmósfera, lo que está provocando una variación en el clima del planeta Tierra (a esto mismo se refiere la expresión calentamiento global). Es en el contexto de la segunda acepción que se habla de un derecho del cambio climático o régimen climático, el cual se constituye como uno de los diversos regímenes internacionales de protección al ambiente. De aquí que la doctrina lo haya incluido persistentemente como un sector o capítulo de estudio del derecho internacional ambiental.

Por lo anterior, se define al derecho del cambio climático como una rama del derecho internacional ambiental cuyo objeto de estudio y regulación es el cambio climático inducido por los seres humanos.

* Esta voz también se publica en el Diccionario jurídico mexicano, México, PorrúaUNAM, Instituto de Investigaciones Jurídicas, 2018. Véase supra, "Cambio climático (marco jurídico internacional)". 
Esta obra forma parte del acervo de la Biblioteca Jurídica Virtual del Instituto de Investigaciones Jurídicas de la UNAM

II. El derecho del cambio climático o régimen climático está conformado por una serie de conferencias, reuniones, normas e instrumentos jurídicos (vinculantes y no vinculantes) en torno al fenómeno del cambio climático inducido. El sustento normativo vinculante de dicho régimen lo componen fundamentalmente cuatro tratados.

Primero, la Convención Marco de la Naciones Unidas sobre el Cambio Climático (en adelante, la Convención) de 1992, cuyo objetivo según el artículo 2o. es el de lograr

la estabilización de las concentraciones de gases de efecto invernadero en la atmósfera a un nivel que impida interferencias antropógenas peligrosas en el sistema climático. Ese nivel debería lograrse en un plazo suficiente para permitir que los ecosistemas se adapten naturalmente al cambio climático, asegurar que la producción de alimentos no se vea amenazada y permitir que el desarrollo económico prosiga de manera sostenible.

La Convención establece dos tipos de compromisos: los genéricos, que son mínimos y que en realidad no son vinculantes, y los específicos, que aplican por un lado a los países desarrollados y los que están en proceso de transición a una economía de mercado (según anexo I), y por el otro a los países desarrollados y otros países (que figuran en anexo II). En esencia, es un tratado de derecho duro (hard law) con alto contenido de normatividad suave (soft law). Muy relevante, la Convención establece la Conferencia de las Partes (en adelante, COP), que es el órgano supremo de la Convención y es el encargado de examinar su implementación y la de cualquier otro instrumento jurídico conexo adoptado por la COP, además de tomar las decisiones necesarias para promover su aplicación eficaz (artículo 7o.). A la fecha se han realizado 21 COPs en diferentes sedes: COP-1 en Berlín, en 1995; COP-2 en Ginebra, en 1996; COP-3 en Kioto, en 1997; COP-4 en Buenos Aires, en 1998; COP-5 en Bonn, en 1999; COP-6 en La Haya y Bonn, en 2000; COP-7 en Marruecos, en 2001; COP-8 en Nueva Delhi, en 2002; COP-9 en Milán, en 2003; COP-10 en Buenos Aires, en 2004; COP-11 en Montreal, en 2005; COP-12 en Nairobi, en 2006; COP-13 en Bali, en 2007; COP-14 en Poznan, en 2008; COP-15 en Copenhague, en 2009; COP16 en Cancún, en 2010; COP-17 en Durban, en 2011; COP-18 en Doha, en 2012; COP-19 en Varsovia, en 2013; COP-20 en Lima, en 2014; por último, la COP-21 en París, en 2015. 
Esta obra forma parte del acervo de la Biblioteca Jurídica Virtual del Instituto de Investigaciones Jurídicas de la UNAM

Segundo, el Protocolo de Kyoto de la Convención (en adelante, PK) adoptado en la COP-3 en Kioto, Japón, en 1997. El PK, a diferencia de la Convención, es un tratado que contiene una mayor normatividad vinculante, si bien parte de su texto no lo es. Destaca en este instrumento el establecimiento de obligaciones vinculantes para los países anexo I de la Convención relativa a compromisos cuantificados de limitación y reducción de emisiones para un primer periodo específico: de 2008 a 2012. Las partes contratantes obligadas (según el anexo B del Protocolo) se comprometieron a reducir ya sea de manera individual o conjuntamente, el total de sus emisiones de un número determinado de gases (son seis los enumerados en el anexo A del protocolo) a un nivel inferior en no menos de 5\% tomando como referencia los niveles de emisión de 1990. Adicionalmente, es de suma relevancia mencionar que el PK establece tres mecanismos flexibles para lograr el cumplimiento de compromisos asumidos por las partes contratantes: $a$ ) los proyectos de aplicación conjunta; $b$ ) los mecanismos de desarrollo limpio, y $c$ ) el comercio de derechos de emisión.

Tercero, la Enmienda de Doha al PK, adoptada en la COP-18 en Doha, Qatar, en 2012. Este instrumento jurídico (que enmienda al PK para que la continuidad de éste quede garantizada sin interrupción) estableció, entre otras cosas, un segundo periodo de compromisos por ocho años a partir del 1o. de enero de 2013 y hasta el 31 de diciembre de 2020, en donde el compromiso de las partes anexo I para reducir el total de sus emisiones es "a un nivel inferior en no menos del 18\% al de 1990 en el periodo de compromiso comprendido entre los años 2013 y 2020" (artículo 3.1 bis). Asimismo, da continuidad a los mecanismos flexibles del PK, sustituye el cuadro del anexo B del PK por uno nuevo que establece renovados compromisos cuantificados de limitación o reducción de emisiones para el segundo periodo, y agrega un GEI a la lista original del anexo A del PK. A septiembre de 2016 no se habían depositado aún los instrumentos de ratificación necesarios para que este tratado entrara en vigor.

Cuarto, el Acuerdo de París (en adelante AP), adoptado en la COP-21 en París, Francia, en 2015. Distinto a lo establecido en el PK, este instrumento contiene mucha normatividad no vinculante y se aleja de los compromisos cuantificados de limitación o reducción de emisiones para transitar hacia enunciados basados en promesas voluntarias a través de las llamadas contribuciones determinadas a nivel nacional. El AP busca 
Esta obra forma parte del acervo de la Biblioteca Jurídica Virtual del Instituto de Investigaciones Jurídicas de la UNAM

mejorar la aplicación de la Convención (incluido el logro de su objetivo) y tiene por objeto "reforzar la respuesta mundial a la amenaza del cambio climático, en el contexto del desarrollo sostenible y de los esfuerzos por erradicar la pobreza" (artículo 2.1). Para conseguir lo anterior, el AP establece en una norma meramente aspiracional el "mantener el aumento de la temperatura media mundial muy por debajo de los $2{ }^{\circ} \mathrm{C}$ con respecto a niveles preindustriales" así como esforzarse para "limitar ese aumento de la temperatura a $1.5^{\circ} \mathrm{C}$ " respecto a esos mismos niveles. En este sentido se agrega "aumentar la capacidad de adaptación a los efectos adversos del cambio climático" promoviendo la resiliencia al clima y un desarrollo con bajas emisiones de GEI, ambas vinculadas a lo que el AP llama "corrientes financieras".

Si bien el AP entrará en vigor a partir del 4 de noviembre de 2016 (habrán transcurrido 30 días contados a partir del 5 de octubre, fecha en la que se depositaron los instrumentos de ratificación, aceptación, aprobación o adhesión que suman al menos 55 partes en la Convención y que rebasan el umbral del $55 \%$ del total de las emisiones mundiales de GEI), existe cierta preocupación entre la comunidad internacional de que los niveles estimados de emisiones agregadas de GEI para 2025 y 2030 resultantes de las contribuciones previstas determinadas a nivel nacional (según informe de síntesis de octubre de 2015) no son compatibles con los escenarios de niveles por debajo de $\operatorname{los} 2{ }^{\circ} \mathrm{C}$ de temperatura media global. 
Esta obra forma parte del acervo de la Biblioteca Jurídica Virtual del Instituto de Investigaciones Jurídicas de la UNAM

\section{DERECHO INTERNACIONAL AMBIENTAL*}

I. Señala el Diccionario de la lengua española de la Real Academia Española, que internacional (de inter-y nacional) es lo "perteneciente o relativo a dos o más naciones", y que ambiental es lo "perteneciente o relativo al ambiente". El propio diccionario dice que ambiente (del lat. ambiens, -entis "que rodea o cerca") es, en su primera acepción, aquello "que rodea algo o a alguien como elemento de su entorno".

II. Se define al derecho internacional ambiental como una rama del derecho internacional cuyo objeto de estudio y regulación son las relaciones entre los sujetos de derecho internacional (Estados, organizaciones internacionales, y otros entes que tienen incidencia en el orden internacional) relativas a la protección ambiental. Sobre este concepto, es importante puntualizar tres cuestiones. Primero, una parte importante de la doctrina considera que el derecho internacional ambiental es un desprendimiento o rama específica del derecho internacional. Si bien no se le otorga aún el estatus de una disciplina jurídica autónoma, se sostiene que es pública y privada a la vez. De aquí que se afirme que su contenido abarca el corpus entero del derecho internacional relativo a la protección del ambiente. Segundo, debido a que estamos frente a una rama específica del derecho internacional, los destinatarios de las normas jurídicas internacionales ambientales son muchos y muy diversos, por lo que deben incluirse no sólo a los sujetos del derecho internacional general (fundamentalmente los Estados y las organizaciones internacionales), sino a otros más que pueden aparecer en el escenario internacional ambiental, como individuos o empresas privadas. Tercero, la regulación jurídico internacional sobre la protección ambiental es fundamentalmente sectorial. Esto es, comprende diversos regímenes convencionales ambientales, como lo son el régimen de cambio climático o régimen climático,

* Esta voz también se publica en el Diccionario jurídico mexicano, México, PorrúaUNAM, Instituto de Investigaciones Jurídicas, 2018. 
Esta obra forma parte del acervo de la Biblioteca Jurídica Virtual del Instituto de Investigaciones Jurídicas de la UNAM

el régimen de la capa de ozono, el régimen de la diversidad biológica, etcétera. Por ende, no existe en realidad un régimen convencional de protección ambiental en su conjunto. Adicionalmente, el contenido de la regulación internacional ambiental incluye normas de otros regímenes o sectores que tienen vínculos y/o repercusiones ambientales evidentes, como el comercial, el nuclear o el del derecho del mar.

III. En el contexto doctrinal, los primeros usos de la expresión derecho internacional ambiental (y también la de derecho ambiental internacional que tiene una connotación un poco distinta) comenzaron a realizarse hacia principios o mediados de la década de los setenta del siglo pasado.

En el contexto normativo, los primeros antecedentes se ubican hacia la segunda mitad del siglo XIX con la celebración de tratados y acuerdos en materia pesquera y de protección de varias especies de flora. Sin embargo, las primeras normas e instrumentos jurídicos que en realidad pueden considerarse derecho internacional ambiental surgen hacia finales de la década los sesenta (particularmente en 1968), y con mayor claridad hacia principios de los años setenta (específicamente en 1972) a partir de la llamada "internacionalización de los temas ambientales" con la celebración en ese año de la Conferencia de las Naciones Unidas sobre el Medio Humano en Estocolmo, Suecia. Desde entonces y hasta la fecha se han realizado, entre otras, un sinnúmero de conferencias y reuniones - de partes contratantes, ministeriales, preparatorias - para tratar los más diversos temas ambientales.

Las conferencias más importantes después de la de Estocolmo son, en orden cronológico, la Conferencia de las Naciones Unidas sobre el Medio Ambiente y el Desarrollo, también conocida como "Cumbre de la Tierra", celebrada en Río de Janeiro, Brasil, en 1992; la Cumbre Mundial sobre el Desarrollo Sostenible, también conocida como "Cumbre de Johannesburgo" o "Río+10", celebrada en Johannesburgo, Sudáfrica, en 2002; y la Conferencia de las Naciones Unidas sobre el Desarrollo Sostenible, conocida como "Río+20", celebrada nuevamente en Río de Janeiro, Brasil, en 2012.

IV. El derecho internacional ambiental normativo está conformado por disposiciones jurídicas contenidas en diversos instrumentos internacionales. Es común que la doctrina divida a estos instrumentos en dos grandes categorías. 
Esta obra forma parte del acervo de la Biblioteca Jurídica Virtual del Instituto de Investigaciones Jurídicas de la UNAM

Primero, aquellos que son de carácter no vinculante o soft (es el derecho flexible, blando, suave o cuasiderecho), y que generalmente se les conoce como declaraciones, lineamientos, resoluciones, programas, agendas, estrategias, cartas, memoranda de entendimiento, etcétera. Los instrumentos soft más importantes contienen una serie de principios que en ocasiones son definidos y dotados de significado concreto en tratados internacionales o en la propia jurisprudencia. Entre los principios más relevantes se encuentran el de la cooperación internacional para la protección ambiental, el de prevención, el de precaución, el de quien contamina paga, el de desarrollo sustentable (equidad intergeneracional y equidad intrageneracional), y el de responsabilidades comunes pero diferenciadas.

Segundo, los de carácter vinculante o hard (es el derecho rígido, fuerte, duro), los cuales reciben diversas denominaciones como tratados, acuerdos, convenciones, convenios o protocolos. Si bien el contenido normativo en estos instrumentos es en principio de naturaleza vinculante, es característico en el derecho internacional ambiental que dichos instrumentos contengan disposiciones que no tienen dicha naturaleza, es decir, se trata de disposiciones que carecen de obligatoriedad. Son normas (compromisos u obligaciones) que no son propiamente jurídicas o legales, y a las que se le denomina declarativas, políticas, programáticas, exhortativas, aspiracionales, no autoejecutables, vagas e imprecisas, menos vinculantes o simplemente normas que generan obligaciones mínimas, obligaciones de comportamiento u obligaciones generales (i. e. normas de carácter general).

V. Es común que México forme parte de una buena cantidad de instrumentos en los diversos regímenes internacionales ambientales, sean vinculantes o no, y sean a nivel multilateral, regional o bilateral. Nuestro derecho interno llama a todos estos instrumentos respectivamente tratados internacionales (que requieren de la aprobación del Senado, su posterior ratificación por el Ejecutivo federal, y su publicación en el Diario Oficial de la Federación para su entrada en vigor a nivel nacional), o bien acuerdos interinstitucionales (que no requieren de la aprobación del Senado, tampoco de un acto de ratificación, y generalmente no se publican en el Diario Oficial de la Federación para que entren en vigor). 
Esta obra forma parte del acervo de la Biblioteca Jurídica Virtual del Instituto de Investigaciones Jurídicas de la UNAM

\section{BIBLIOGRAFÍA}

\section{LIBROS Y REVISTAS}

ACEVES, Carla D., Bases fundamentales de derecho ambiental mexicano, México, Porrúa, 2003.

ADEDE, Andrónico O., Digesto de derecho internacional ambiental, trad. de Diana Lucero Ponce-Nava, México, Secretaría de Relaciones Exteriores, 1995.

AnTAL, Edit, Cambio climático: desacuerdo entre Estados Unidos y Europa, México, Plaza y Valdés-UNAM, Centro de Investigaciones sobre América del Norte, 2004.

ANTAL, Edit, "Redes y discursos de las ong ambientalistas en la zona de Tijuana-San Diego", en ANTAL, Edit (ed.), Nuevos actores en América del Norte, México, UNAM, Centro de Investigaciones sobre América del Norte, vol. I, 2005.

AREnas MuÑoz, José Antonio, Diccionario técnico y jurídico del medio ambiente, Madrid, McGraw Hill, 2000.

Arellano García, Carlos, Primer curso de derecho internacional público, 7a. ed., México, Porrúa, 2013.

ARrietA LERDO DE TEJADA, Gustavo, "La descentralización o federación ambiental en México", Derecho ambiental y ecología, México, año 1, núm. 3, octubre-noviembre de 2004.

AsCENCIO, Alfonso, "The Transboundary Movement of Living Modified Organisms: Issues Relating to Liability and Compensation", Reciel, Oxford, núm. 3, vol. 6, 1997.

Ashby, E. y Anderson, M., The Politics of Clean Air, Oxford, Clarendon, 1981.

ATIENZA, Manuel, Introducción al derecho, México, Fontamara, 1998.

AtKinson, A., "Environment and Development: Concepts and Practices in Transition", Public Administration and Development, vol. 11, 1991. 
Esta obra forma parte del acervo de la Biblioteca Jurídica Virtual del Instituto de Investigaciones Jurídicas de la UNAM

Ávalos GómEz, Montserrat, "Panel Intergubernamental sobre el Cambio Climático, PICC", en MARTÍNEZ, Julia y FERNÁNDEZ, Adrián (comps.), Cambio climático: una visión desde México, México, Instituto Nacional de Ecología, 2004.

AzUEla, Antonio, Visionarios y pragmáticos. Una aproximación sociológica al derecho ambiental, México, Fontamara-UNAM, Instituto de Investigaciones Sociales, 2006.

BALL, Simon y BeLL, Stuart, Environmental Law, 2a. ed., Londres, Blackstone, 1994.

BALl, Simon y Bell, Stuart, Environmental Law, 3a. ed., Londres, Blackstone, 1995.

BAQUeIRo Rojas, Edgard, Introducción al derecho ecológico, México, Oxford University Press-Harla, 1997.

Barlow, Maude y Clarke, Tony, Oro azul, trad. de Isidro Arias, Barcelona, España, Paidós, 2004.

BARRAGÁN BARRAGÁN, José, "Concurrencia de facultades en materia de medio ambiente entre la Federación y los estados", en CARMONA LARA, María del Carmen y HeRnández MeZA, Lourdes (coords.), Temas selectos de derecho ambiental, México, Procuraduría Federal de Protección al Ambiente-UNAM, Instituto de Investigaciones Jurídicas, 2006.

BAXTER, R. R., "International Law in «Her Infinite Variety»", The International and Comparative Law Quarterly, vol. 29, núm. 4, octubre de 1980.

BeCERRA GALlo, Mauricio, "La zona federal marítimo-terrestre", El Mundo del Abogado, México, año 3, núm. 22, febrero de 2001.

BennetT, Graham, Dilemmas: Coping with Environmental Problems, Londres, Earthscan, 1992.

BEURIER, Jean-Pierre, Droit international de l'environnement, 4a. ed., París, Pedone, 2010.

BEYERLIN, Ulrich y MARAUHN, Thilo, International Environmental Law, Oxford, Hart-CH Beck-Nomos, 2011.

BIDART CAMPOS, Germán J., Teoría general de los derechos humanos, Buenos Aires, Astrea, 1991.

BIRNIE, Patricia W. y BOYLE, Alan E., International Law and the Environment, 2a. ed., Oxford, Oxford University Press, 2002. 
Esta obra forma parte del acervo de la Biblioteca Jurídica Virtual del Instituto de Investigaciones Jurídicas de la UNAM

Birnie, Patricia, Boyle, Alan E. y RedGwell, Catherine, International Law and the Environment, 3a. ed., Oxford, Oxford University Press, 2009.

BLOWERS, A. "Pollution and Waste - A Sustainable Burden?", en Blowers, A. (comp.), Planning for a Sustainable Environment, Londres, Town and Country Planning Association-Earthscan, 1993.

BoDANSKy, Daniel, The Art and Craft of International Environmental Law, Cambridge-Londres, Harvard University Press, 2010

BODENHEIMER, Edgar, Teoría del derecho, 2a. ed., trad. de Vicente Herrero, México, Fondo de Cultura Económica, 2004.

BorRás PENTINAT, Susana, Los regímenes internacionales de protección del medio ambiente, Valencia, Tirant lo Blanch, 2011.

BotASSI, Carlos Alfredo, Derecho administrativo ambiental, La Plata, Librería Editora Platense, 1997.

Bowlby, S. R. y Mannion, A. M., "Perspective and Prospect", en ManNION, Antoinette M. y BOwLBY, Sophia R. (comps.), Environmental Issues in the 1990s, Chichester, Wiley, 1992.

BRAÑES, Raúl, Manual de derecho ambiental mexicano, México, Fundación Mexicana para la Educación Ambiental-Fondo de Cultura Económica, 1994.

BRAÑES, Raúl, Manual de derecho ambiental mexicano, 2a. ed., México, Fundación Mexicana para la Educación Ambiental-Fondo de Cultura Económica, 2000.

Bravo Álvarez, Humberto, La contaminación del aire en México, México, Universo Veintiuno, 1987.

BREHENY, Michael J., "Sustainable Development and Urban Form: An Introduction", en BREHENY, Michael J. (comp.), Sustainable Development and Urban Form, Londres, Pion, 1992.

BREHENY, Michael J., "Towards Sustainable Urban Development", en MANNION, Antoinette M. y BowlbY, Sophia R. (comps.), Environmental Issues in the 1990s, Chichester, Wiley, 1992.

BreHENY, Michael J., y RoOKWOOD, R., "Planning the Sustainable City Region", en Blowers, A. (comp.), Planning for a Sustainable Environment, Londres, Town and Country Planning Association-Earthscan, 1993.

BrimblecomBe, P., The Big Smoke, Londres, Routledge, 1987.

Brom, Juan, Para comprender la historia, 2a. ed., México, Grijalbo, 2003. 
Esta obra forma parte del acervo de la Biblioteca Jurídica Virtual del Instituto de Investigaciones Jurídicas de la UNAM

Broswimmer, Franz J., Ecocidio. Breve historia de la extinción en masa de las especies, trad. de Francisco Páez de la Cadena, Pamplona-México, Laetoli-Océano, 2005.

Brownlie, Ian, Principles of Public International Law, 7a. ed., Oxford, Oxford University Press, 2008.

Bustamante Alsina, Jorge, Derecho ambiental, Buenos Aires, AbeledoPerrot, 1995.

CABAllero OchOA, José Luis, "Comentario sobre el Artículo 1o., segundo párrafo de la Constitución (la cláusula de interpretación conforme al principio pro persona)", en FERRER MAC-GREGOR, Eduardo et al. (coords.), Derechos humanos en la Constitución: comentarios de jurisprudencia constitucional e interamericana, México, Suprema Corte de Justicia de la Nación-Fundación Konrad Adenauer-UNAM, Instituto de Investigaciones Jurídicas, t. I, 2013.

CABAllero OchOA, José Luis, La interpretación conforme. El modelo constitucional ante los tratados internacionales sobre derechos humanos y el control de convencionalidad, México, Porrúa-Instituto Mexicano de Derecho Procesal Constitucional, 2013.

CABRERA ACEVEDO, Lucio, El derecho de protección al ambiente, México, UNAM, Instituto de Investigaciones Jurídicas, 1981.

CAlderón, Felipe, El hijo desobediente. Notas en campaña, México, Nuevo Siglo-Aguilar-Santillana, 2006.

CALDERÓN-GARCidUEÑAS, Lilian et al., "Histopathologic Changes of the Nasal Mucosa in Southwest Metropolitan Mexico City Inhabitants", American Journal of Pahtology, vol. 140, núm. 1, enero de 1992.

CALlicotT, J. Baird, "Teoría del valor no antropocéntrica y ética ambiental”, en VALDÉs, Margarita M. (coord.), Naturaleza y valor, México, Fondo de Cultura Económica, 2004.

CALVERT, Peter y Susan, The South, the North, and the Environment, Londres-Nueva York, Pinter, 1999.

CAMPUZANO, Raúl F., "El concepto de desarrollo sustentable en la jurisprudencia y en otras fuentes de derecho internacional", Revista de Derecho de la Universidad Católica de Valparaíso, Chile, núm. XXIII, 2002.

CANCINO Aguilar, Miguel Ángel, "El marco jurídico para la prevención y control de la contaminación atmosférica", en GONZÁLEZ MÁRQUEZ, 
Esta obra forma parte del acervo de la Biblioteca Jurídica Virtual del Instituto de Investigaciones Jurídicas de la UNAM

José Juan (coord.), Derecho ambiental, México, Universidad Autónoma Metropolitana, 1994.

Cano, Guillermo J., Derecho, política y administración ambientales, Buenos Aires, Ediciones Depalma, 1978.

CARbonell, Miguel, Los derechos fundamentales en México, México, Comisión Nacional de los Derechos Humanos-Porrúa-UNAM, Instituto de Investigaciones Jurídicas, 2005.

Carbonell, Miguel et al., Compendio de derecho ambiental, México, Porrúa, 2010.

CÁRdenas CAStañedA, Fabián Augusto, "A Call for Rethinking the Sources of International Law: Soft Law and the Other Side of the Coin", Anuario Mexicano de Derecho Internacional, vol. XIII, 2013.

CARLSON, E., "The Legacy of Habitat II", The Urban Age, Washington D. C., vol. 4, núm. 2, Banco Mundial, agosto de 1996.

CARMONA LARA, María del Carmen, "Derecho ecológico", El derecho en México. Una visión de conjunto, México, UNAM, Instituto de Investigaciones Jurídicas, t. III, 1991.

CARMOna LaRA, María del Carmen, Derechos en relación con el medio ambiente, 2a. ed., México, Cámara de Diputados, LVIII LegislaturaUNAM, 2001.

Carmona lara, María del Carmen, Derechos del medio ambiente, 3a. ed., México, Secretaría de Educación Pública, Instituto Nacional de Estudios Históricos de las Revoluciones de México-UNAM, Instituto de Investigaciones Jurídicas, 2015.

CARMONA TINOCO, Jorge Ulises, "La reforma y las normas de derechos humanos previstas en los tratados internacionales", en CARBONELL, Miguel y SALAZAR, Pedro (coords.), La reforma constitucional de derechos humanos: un nuevo paradigma, México, UNAM, Instituto de Investigaciones Jurídicas, 2011.

CARMONA TINOCO, Jorge Ulises, "La reforma constitucional en derechos humanos de junio de 2011 y su relación con los derechos universitarios", en CARMONA TINOCO, Jorge Ulises (coord.), La vinculación entre los derechos humanos y los derechos universitarios. Obra en homenaje al Dr. Jorge Carpizo Mac Gregor, México, UNESCO-UNAM, Defensoría de los Derechos Universitarios, 2013.

CARTER, Neil, The Politics of the Environment. Ideas, Activism, Policy, 2a. ed., Cambridge, Cambridge University Press, 2007. 
Esta obra forma parte del acervo de la Biblioteca Jurídica Virtual del Instituto de Investigaciones Jurídicas de la UNAM

CASESE, Antonio, International Law, 2a. ed., Oxford, Oxford University Press, 2005.

CAStells, Manuel, "The Power of Identity", The Information Age: Economy, Society and Culture, 2a. ed., Oxford, Blackwell, vol. II, 2004.

CAstree, Noel, "Environmental movement", en Johnston, R. J. et al. (eds.), The Dictionary of Human Geography, 4a. ed., Malden, Blackwell, 2000.

Cervantes Ahumada, Raúl, Derecho marítimo, México, Herrero, 1970.

Cervantes, Miguel de, Don Quijote de la Mancha, Edición del IV Centenario, España-México, Real Academia Española, Asociación de Academias de la Lengua Española, Alfaguara, 2004.

CERVANTES RAmíREZ, Francisco F., "De la propiedad de las aguas nacionales", Lex, México, suplemento Ecología, enero de 1999.

Chinkin, C. M., "The Challenge of Soft Law: Development and Change in International Law", The International and Comparative Law Quarterly, vol. 38, núm. 4, octubre de 1989.

Christie, Donna R. y Hildreth, Richard G., Coastal and Ocean Management Law, 2a. ed., Minnesota, West Group, 1999.

CoHen, M., "Habitat II: A Critical Assessment", The Urban Age, Washington D. C., vol. 4, núm. 2, Banco Mundial, agosto de 1996.

Collins, Charles O. y ScotT, Steven L., "Air Pollution in the Valley of Mexico", Geographical Review, vol. 38, núm. 2, abril de 1993.

Corzo Sosa, Edgar, "Derecho al medio ambiente adecuado, reconocimiento jurídico y acceso a la justicia (protección). Un esbozo”, en CARMONA Tinoco, Jorge Ulises y Hori FoJACO, Jorge M. (coords.), Derechos humanos y medio ambiente, México, Secretaría de Medio Ambiente y Recursos Naturales-UNAM, Instituto de Investigaciones Jurídicas, 2010.

Cossío DíAz, José Ramón, Los problemas del derecho indígena en México, México, Comisión Nacional de los Derechos Humanos, 2002.

DAly, H. E., "The Perils of Free Trade", Scientific American, noviembre de 1993.

Delhoste, Marie-France, 'L'environnement dans les Constitutions du monde", Revue du Droit Public, LGDJ, núm. 2, marzo-abril de 2004.

Despax, Michael, Droit de l'environnement, París, Librairies Techniques, 1980. 
Esta obra forma parte del acervo de la Biblioteca Jurídica Virtual del Instituto de Investigaciones Jurídicas de la UNAM

DíAz DíAz, D. y Perló Cohen, M., Retos y propuestas: Ciudad de México, México, Fundación Mexicana Cambio XXI Luis Donaldo Colosio, 1994.

DÍAZ Y DÍAZ, Martín, Ensayos sobre la propiedad, México, UNAM, Instituto de Investigaciones Jurídicas, 2014.

DIEZ DE VELASCO, Manuel, Instituciones de derecho internacional público, 16a. ed., Madrid, Tecnos, 2007.

DiXON, Martin et al., Cases \& Materials on International Law, 5a. ed., Oxford, Oxford University Press, 2011.

DuPuY, Pierre-Marie, "Soft Law and the International Law of the Environment", Michigan Journal of International Law, vol. 12, núm. 420, invierno de 1991.

DuvE, Christian de, La vida en evolución, trad. de Joandomènec Ros, Barcelona, Crítica, 2004.

EHRlich, P. R., The Population Bomb, Nueva York, Ballantine Books, 1969.

Ehrlich, P. R. y Ehrlich, A. H., Population, Resources, Environment: Issues in Human Ecology, San Francisco, Freeman, 1970.

EINSTEIN, Albert, "El sentimiento cósmico religioso" y "Ciencia y religión”, en WILBER, Ken (ed.), Cuestiones cuánticas. Escritos místicos de los físicos más famosos del mundo, 10a. ed., trad. de Pedro de Casso, Barcelona, Kairós Editorial, 2007.

Elkin, T. et al., Reviving the City: Towards Sustainable Urban Development, Londres, Friends of the Earth, 1991.

Elsom, Derek, Atmospheric Pollution: A Global Problem, 2a. ed., Oxford, Blackwell, 1992.

Elsom, Derek, Smog Alert: Managing Urban Air Quality, Londres, Earthscan, 1996.

ENRÍQUEZ, Pedro Gregorio, "De la marginalidad a la exclusión social: un mapa para recorrer sus conceptos y núcleos problemáticos", Fundamentos en Humanidades, Argentina, Universidad Nacional de San Luis, año VIII, núm. I, (15/2007).

ESPINOZA, Luis (Chamalú), Ecología chamánica, 3a. ed., Barcelona, Ediciones Obelisco, 1994.

Ezcurra, Ezequiel, "The Basin of Mexico City”, en TURner II, B. L. (coord.), The Earth as Transformed by Human Action, Cambridge, University of Cambridge, 1990. 
Esta obra forma parte del acervo de la Biblioteca Jurídica Virtual del Instituto de Investigaciones Jurídicas de la UNAM

FARÍAS, Urbano, Derecho mexicano de aguas nacionales, México, Porrúa, 1993.

FERREY, S., Environmental Law, 3a. ed., Nueva York, Aspen, 2004.

FERRER MAC-GREGOR, Eduardo, "Interpretación conforme y control difuso de convencionalidad. El nuevo paradigma para el juez mexicano", en CARBonell, Miguel y SAlazAr, Pedro (coords.), La reforma constitucional de derechos humanos: una nuevo paradigma, México, UNAM, Instituto de Investigaciones Jurídicas, 2011.

FIX-ZAMUdio, Héctor y VALENCIA CARMONA, Salvador, Las reformas en derechos humanos, procesos colectivos y amparo como nuevo paradigma constitucional, 3a. ed., México, Porrúa-UNAM, Instituto de Investigaciones Jurídicas, 2015.

FLORES LIERA, Socorro, "El cambio climático, ¿un reto que rebasa a la comunidad internacional?", en GoNZÁLEZ G., Guadalupe et al. (eds.), México y el multilateralismo del siglo XXI. Reflexiones a los 70 años de la $O N U$, México, Siglo XXI Editores-ITAM-Senado de la República, 2015.

FOLADORI, Guillermo, "Una tipología del pensamiento ambientalista", en FOLADORI, Guillermo y PIERRI, Naína (coords.), ¿Sustentabilidad? Desacuerdos sobre el desarrollo sustentable, México, Cámara de Diputados-Universidad Autónoma de Zacatecas-Miguel Ángel Porrúa, 2005.

Fraga, Gabino, Derecho administrativo, 22a. ed., México, Porrúa, 1982.

FrANCE, Lesley, "Introduction”, en FrANCE, Lesley (ed.), The Earthscan Reader in Sustainable Tourism, Londres, Earthscan, 1997.

Fried, R. C., "Mexico City", en Robson W. A. y Regan D. E. (comps.), Great Cities of the World, Londres, Allen and Unwin, vol. II, 1972.

GALlEGOS GARCíA, Artemio, "Clima oceánico: los mares mexicanos ante el cambio climático global", en MARTíNEZ, Julia y FERNÁNDEZ, Adrián (comps.), Cambio climático: una visión desde México, México, Instituto Nacional de Ecología, 2004.

Gamboa de Buen, Jorge, Ciudad de México, una visión, México, Fondo de Cultura Económica, 1994.

GANDY, M., Recycling and Waste: An Exploration of Contemporary Environmental Policy, Aldershot, Avebury, 1993.

GARCÍA, R. et al., "Aldehídos: contaminantes atmosféricos", Teorema, México, año 4, núm. 16, marzo-mayo de 1998. 
Esta obra forma parte del acervo de la Biblioteca Jurídica Virtual del Instituto de Investigaciones Jurídicas de la UNAM

García GuAdilla, M. P. (comp.), Ambiente, Estado y sociedad, Caracas, Universidad Simón Bolívar-Centro de Estudios del Desarrollo, 1991.

GARCÍA MÁYNEZ, Eduardo, Introducción al estudio del derecho, 31a. ed., México, Porrúa, 1980.

GARVEY, James, The Ethics of Climate Change. Right and Wrong in a Warming World, Londres, Continuum, 2008.

Gilbert, Richard et al., Making Cities Work, Londres, Earthscan, 1996.

Gómez, Teo y Romanillos, Pere, El cambio climático, Barcelona, Océano, 2012.

Gómez-RoBledo Verduzco, Alonso, Temas selectos de derecho internacional, 2a. ed., México, UNAM, Instituto de Investigaciones Jurídicas, 1994.

Gómez-Robledo Verduzco, Alonso, Derecho del mar, México, McGraw-Hill-UNAM, Instituto de Investigaciones Jurídicas, 1997.

GonzÁlez GALVÁN, Jorge A., "La validez del derecho indígena en el derecho nacional", en CARBOnell, Miguel y PÉrez Portilla, Karla (coords.), Comentarios a la reforma constitucional en materia indígena, México, UNAM, Instituto de Investigaciones Jurídicas, 2002.

GonzÁlez GALVÁN, Jorge A., "La reforma constitucional en materia indígena", Cuestiones Constitucionales, México, núm. 7, julio-diciembre de 2002.

GonzÁlez Galván, Jorge A., "La Corte y los indígenas", Boletín Mexicano de Derecho Comparado, México, nueva serie, año XXXVI, núm. 107, mayo-agosto de 2003.

GONZÁlEZ MÁRQUEZ, José Juan, La responsabilidad por el daño ambiental en México, México, Universidad Autónoma Metropolitana, 2002.

GonzÁlez MÁrquez, José Juan y CAncino Aguilar, Miguel Ángel, "La distribución de competencias en materia ambiental", en GONZÁLEZ MÁrqueZ, José Juan (coord.), Derecho ambiental, México, Universidad Autónoma Metropolitana, 1994.

GonzÁlez PÉREZ, Jesús, El administrado, México, Fundación Universitaria de Derecho, Administración y Política, 2003.

Gossop, Ch. y WeBB, A., "Getting Around: Public and Private Transport", en Blowers, A. (comp.), Planning for a Sustainable Environment, Londres, Town and Country Planning Association-Earthscan, 1993.

Greenwood, John R. y Wilson, David J., Public Administration in Britain Today, 2a. ed., Londres, Unwin Hyman, 1989. 
Esta obra forma parte del acervo de la Biblioteca Jurídica Virtual del Instituto de Investigaciones Jurídicas de la UNAM

Grossman, M. R. y Endres, A. B., "Regulation of Genetically Modified Organisms in the European Union", American Behavioral Scientist, Estados Unidos de América, vol. 44, núm. 3, noviembre de 2000.

GrubB, Michael et al., The Earth Summit Agreements: a Guide and Assessment, Londres, The Royal Institute of International Affairs-Earthscan, 1993.

GuRUSWAMY, Lakshman D., International Environmental Law, 2a. ed., St. Paul, Minnesota, Thomson-West, 2003.

GUTIÉRREZ NÁJERA, Raquel, Introducción al estudio del derecho ambiental, 2a. ed., México, Porrúa, 1999.

HARDIE, R. Wayne et al., "Development of a Methodology for Evaluating Air Pollution Options for Improving the Air Quality in Mexico City", The Science of the Total Environment, vol. 1, 1995.

HARDOY, J. E. et al., Environmental Problems in Third World Cities, Londres, Earthscan, 1992.

HART, H. L. A., El concepto de derecho, 2a. ed., trad. de Genaro R. Carrio, México, Editora Nacional, 1980.

HATCHER, R. Lee, "Local Indicators of Sustainability: Measuring the Human Ecosystem", en NATH, Bhaskar et al., (comps.), Sustainable Development, Bruselas, Vubpress, 1996.

Haughton, Graham y Hunter, Colin, Sustainable Cities, Londres, Kingsley-Regional Studies Association, 1994.

Hawking, Stephen W., Historia del tiempo. Del big bang a los agujeros negros, trad. de Miguel Ortuño, Barcelona, Crítica, 2005.

HENS, Luc, "The Rio Conference and Thereafter", en NATH, Bhaskar et al., (comps.), Sustainable Development, Bruselas, Vubpress, 1996.

Herdegen, Matthias, Derecho internacional público, trad. de Marcela Anzola, México, Fundación Konrad Adenauer-UNAM, Instituto de Investigaciones Jurídicas, 2005.

HERNÁNDEZ-MENDIBLE, Víctor Rafael, "La regulación de la actividad turística”, en FERnÁNDEZ RuIZ, Jorge y SANTIAGo SÁncheZ, Javier (coords.), Régimen jurídico del turismo y de la zona marítimo-terrestre. Memoria del Congreso Internacional de Derecho Turístico, México, UNAM, Instituto de Investigaciones Jurídicas, 2009.

HERNÁNDEZ NAVARRO, Luis, "Constitución y derecho indígena: el alcance de la norma”, Revista del Senado de la República, México, vol. 4, núm. 11, abril-junio de 1998. 
Esta obra forma parte del acervo de la Biblioteca Jurídica Virtual del Instituto de Investigaciones Jurídicas de la UNAM

Hernández NaVArro, Luis y Vera Herrera, Ramón (comps.), Acuerdos de San Andrés, México, Era, 1998.

Hernández NAVARro, Luis y Vera Herrera, Ramón, "Al margen y en el centro", en HERnÁndEZ NAVARro, Luis y VERA HERrERA, Ramón (comps.), Acuerdos de San Andrés, México, Era, 1998.

Herrera Molina, Pedro M., Derecho tributario ambiental, Madrid-Barcelona, Ministerio de Medio Ambiente-Marcial Pons, 2000.

HuERTA OCHOA, Carla, "Ecoturismo y protección ambiental", en FERNÁNDEZ RUIZ, Jorge y SANTIAGO SÁNCHEZ, Javier (coords.), Régimen jurídico del turismo y de la zona marítimo-terrestre. Memoria del Congreso Internacional de Derecho Turístico, México, UNAM, Instituto de Investigaciones Jurídicas, 2009.

Hundsalz, M., "The Habitat Debate: Goals, Commitments and Action Plans", Habitat Debate, Nairobi, vol. 2, núms. 3 y 4, United Nations Conference for Human Settlements-HABITAT, septiembre-diciembre de 1996.

JACOBS, M., The Green Economy, Londres, Pluto, 1991.

JAMIESON, Dale, Ethics and the Environment, Cambridge, Cambridge University Press, 2008.

JAQUENOD DE ZSÖGÖN, Silvia, Derecho ambiental, Madrid, Dykinson, S. L., 2002.

JiMÉNEZ SHAW, Concepción, “Agua y desarrollo sostenible. Trascendencia ambiental de la desalación”, en PIÑAR MAÑAS, José Luis (dir.), y UTRERA CARO, Sebastián F. (coord.), Desarrollo sostenible y protección del medio ambiente, Madrid, Civitas, 2002.

JimÉNEZ SHAW, Concepción, Régimen jurídico de la desalación del agua marina, Valencia, España, Tirant lo Blanch, 2003.

JoRDANO FRAGA, Jesús, La protección del derecho a un medio ambiente adecuado, Barcelona, José María Bosch, 1995.

Juste RuIZ, José, Derecho internacional del medio ambiente, Madrid, McGraw-Hill, 1999.

Kandell, J., La capital: the Biography of Mexico City, Nueva York, Random House, 1988.

Kelsen, Hans, La paz por medio del derecho, trad. de Luis Echávarri, Buenos Aires, Editorial Losada, 1946.

KeLSEN, Hans, Teoría general del derecho y del Estado, 2a. ed., trad. de Eduardo García Máynez, México, UNAM, 1983. 
Esta obra forma parte del acervo de la Biblioteca Jurídica Virtual del Instituto de Investigaciones Jurídicas de la UNAM

KISS, Alexandre Ch. y SHELTON, Dinah, International Enviornmental Law, Nueva York, Trasnational Publishers, 1991.

KISS, Alexandre Ch. y SHELTON, Dinah, International Enviornmental Law, 3a. ed., Ardsley, Nueva York, Trasnational Publishers, 2004.

KlabBers, Jan, "Reflections on Soft International Law in a Privatized World”, Lakimies, vol. 104, 2006.

KLEIN, Naomi, Esto lo cambió todo. El capitalismo contra el clima, trad. de Albino Santos Mosquera, Barcelona, Paidós, 2015.

KRÄMER, Ludwig, Derecho ambiental y Tratado de la Comunidad Europea, 3a. ed., trad. de Luciano Parejo Alfonso y Ángel Manuel Moreno Molina, Madrid, Marcial Pons, 1999.

LAMARque, Jean, Droit de la protection de la nature et de l'environnement, París, Librairie Générale de Droit et de Jurisprudence, 1973.

LÁzAro CAlvo, Trinidad, Derecho internacional del medio ambiente, Barcelona, Atelier, 2005.

LEFF, Enrique, "Análisis sociológico del movimiento ambientalista en América Latina", en García Guadilla, M. P. (comp.), Ambiente, Estado y sociedad, Caracas, Universidad Simón Bolívar-Centro de Estudios del Desarrollo, 1991.

LefF, Enrique, Green Production: Toward an Environmental Rationality, Nueva York, Guildford, 1995.

LEFF, Enrique, Saber ambiental: sustentabilidad, racionalidad, complejidad, poder, México, Siglo XXI-PNUMA-UNAM, 1998.

LEGORRETA, Jorge, "Todos tenemos derecho a la ciudad", La América que queremos: 32 ensayos en defensa de la vida, México, Programa de las Naciones Unidas para el Medio Ambiente-Programa de las Naciones Unidas para el Desarrollo-Fondo de Cultura Económica, 1998.

LeÓN-PorTILla, Miguel, Literaturas indigenas de México, 2a. ed., México, Fondo de Cultura Económica, 1992.

LEVY, Barry S. y SIDEL, Victor W., "La guerra", en FrUMKIN, Howard, Salud ambiental. De lo global a lo local, trad. Magali Amiela Lavinge et al., Washington D. C., Organización Panamericana de la Salud, 2010.

Lezama DE la TORRe, José Luis, Aire dividido. Crítica a la politica del aire en el Valle de México, 1979-1996, México, El Colegio de México, 2000. 
Esta obra forma parte del acervo de la Biblioteca Jurídica Virtual del Instituto de Investigaciones Jurídicas de la UNAM

LOPERENA RotA, Demetrio, "Tratamiento jurídico de la protección de la atmósfera", Revista Española de Derecho Administrativo, núm. 81, enero-marzo de 1994.

LÓPEZ-BASSOLS, Hermilo, Los nuevos desarrollos del derecho internacional público, 3a. ed., México, Porrúa, 2008.

LÓPEZ MATA, Rosendo, "Notas para el análisis sobre la constitucionalidad de algunas disposiciones contenidas en la Ley sobre la Celebración de Tratados", Jurídica, Anuario del Departamento de Derecho de la Universidad Iberoamericana, México, núm. 24, 1995-I.

LÓPEZ RAMíREZ, Alfonso, "Medio ambiente, desarrollo sustentable y pobreza rural en América Latina. Modelo teórico-metodológico", en López RAMÍrez, Alfonso y Hernández, Pedro F. (coords.), Sociedady medio ambiente: contribuciones a la sociología ambiental en América Latina, México, Asociación Latinoamericana de Sociología-Benemérita Universidad Autónoma de Puebla-La Jornada Ediciones, 1996.

LÓPEZ RAMÓN, Fernando, "Régimen jurídico de la protección del aire", Revista Española de Derecho Administrativo, núm. 84, octubre-diciembre de 1994.

Lovell, L. y JoHnson, D. L., "The Environmental Crisis and Direct Social Work Practice", en HofF, M. D. y McNuTT, J. G. (comps.), The Global Environmental Crisis, Aldershot, Avebury, 1994.

LUGO RoDRÍGUEZ, José, "La biotecnología y la propiedad intelectual", Memorias del Primer Encuentro Internacional de Derecho Ambiental, México, Secretaría de Medio Ambiente y Recursos Naturales, Instituto Nacional de Ecología, 2003.

MAGAÑA RUEDA, Víctor O., "El cambio climático global: comprender el problema”, en MARTíNEZ, Julia y FERNÁNDEZ, Adrián (comps.), Cambio climático: una visión desde México, México, Instituto Nacional de Ecología, 2004.

MALJEAN-DuBOIS, Sandrine, "The Making of International Law Challenging Environmental Protection”, en KERBRAT, Yann y MALJEANDuBoIs, Sandrine (eds.), The Transformation of International Environmental Law, Oxford-París, A. Pedone \& Hart, 2011.

Mangas Martín, Araceli, Tratado de la Unión Europea, Tratados constitutivos de las Comunidades Europeas, 6a. ed., Madrid, Tecnos, 1998. MANNION, Antoinette M., "Biotechonology and Genetic Engineering: New Environmental Issues”, en MANNION, Antoinette M. y BowlBY, 
Esta obra forma parte del acervo de la Biblioteca Jurídica Virtual del Instituto de Investigaciones Jurídicas de la UNAM

Sophia R. (comps.), Environmental Issues in the 1990s, Chichester, Wiley, 1992.

MANNION, Antoinette M., "Environmental Change: Lessons from the Past", en MAnnion, Antoinette M. y Bowlby, Sophia R. (comps.), Environmental Issues in the 1990s, Chichester, Wiley, 1992.

MANNION, Antoinette M. y BOWLBY, Sophia R., "Introduction", en MANNION, Antoinette M. y BowlBY, Sophia R. (comps.), Environmental Issues in the 1990s, Chichester, Wiley, 1992.

MARISCAL URETA, Karla Elizabeth, Medio ambiente sano. Derecho colectivo global, México, Porrúa, 2015.

MARSILY, Ghislain de, El agua, trad. de Juan José Utrilla Trejo, México, Siglo XXI, 2001.

MARTín MATEO, Ramón, Derecho ambiental, Madrid, Instituto de Estudios de Administración Local, 1977.

MARTÍN MATEO, Ramón, "El derecho de la atmósfera", Revista de Administración Pública, Madrid, núm. 121, enero-abril de 1990.

MARTÍN MATEO, Ramón, Nuevo derecho energético, Madrid, Instituto de Estudios de Administración Local, 1982

MARTÍNEZ AliER, Joan y RoCA JUSMET, Jordi, Economía ecológica y política ambiental, México, Programa de las Naciones Unidas para el Medio Ambiente-Fondo de Cultura Económica, 2000.

MARTíneZ, Julia y FERNÁNDEZ, Adrián (comps.), Cambio climático: una visión desde México, México, Instituto Nacional de Ecología, 2004.

MCCORMICK, John, British Politics and the Environment, Londres, Earthscan, 1991.

MCCORMICK, John, The Global Environmental Movement, 2a. ed., Chichester, Wiley, 1995.

Mcmanus, Phil, "Contested Terrains: Politics, Stories and Discourses of Sustainability", Environmental Politics, Londres, vol. 5, núm. 1, primavera de 1996.

MCManus, Phil, "Conservation", en Johnston, R. J. et al. (eds.), The Dictionary of Human Geography, 4a. ed., Malden, Blackwell, 2000.

MCMAnus, Phil, "Sustainable Development", en Johnston, R. J. et al. (eds.), The Dictionary of Human Geography, 4a. ed., Malden, Blackwell, 2000.

Meadows, D. H. et al. (comps.), The Limits to Growth, Nueva York, Potomac Associates Books, 1972. 
Esta obra forma parte del acervo de la Biblioteca Jurídica Virtual del Instituto de Investigaciones Jurídicas de la UNAM

Miguel Perales, Carlos de, Derecho español del medio ambiente, $2 \mathrm{a}$. ed., Madrid, Civitas, 2002.

Moguel, Julio, "Legislar sobre el tema indígena: ¿callejón sin salida?”, Revista del Senado de la República, México, vol. 4, núm. 11, abril-junio de 1998.

MolinA, Luisa T. y MolinA, Mario J. (coords.), La calidad del aire en la megaciudad de México. Un enfoque integral, trad. de Dulce María Ávila, Bárbara Córcega y Silvia Ruiz de Chávez, México, Fondo de Cultura Económica, 2005.

Momigliano, Arnaldo, Ensayos de historiografia antigua y moderna, trad. de Stella Mastrangelo, México, Fondo de Cultura Económica, 1993.

Montemayor, Carlos, Los pueblos indios de México. Evolución histórica de su concepto y la realidad social, México, Debolsillo, 2008.

Montesquieu, Del espíritu de las leyes, 14a. ed., versión castellana de Nicolás Estévanez, México, Porrúa, 2001.

Mosterín, Jesús, "La tortura como espectáculo", en TAFALlA, Marta (ed.), Los derechos de los animales, Barcelona, Idea Books, 2004.

MotA Flores, Ventura Enrique, "Apuntes sobre la ordenación jurídica del turismo”, en FERnÁndEZ RuIZ, Jorge y SANTIAGo SÁNCHEZ, Javier (coords.), Régimen jurídico del turismo y de la zona marítimo-terrestre. Memoria del Congreso Internacional de Derecho Turístico, México, UNAM, Instituto de Investigaciones Jurídicas, 2009.

Motavalli, Jim (comp.), El cambio climático, trad. de Yolanda Fontal, Barcelona, Paidós, 2005.

Munson, Abby, "The United Nations Convention on Biological Diversity", en GruBB, Michael et al., The Earth Summit Agreements: A Guide and Assessment, Londres, The Royal Institute of International AffairsEarthscan, 1993.

MUÑOZ BARRET, Jorge, "Los recursos naturales y su protección jurídica en México", en Varios autores, La industria petrolera ante la regulación jurídico-ecológica en México, México, UNAM, Instituto de Investigaciones Jurídicas, 1992.

MuÑoz RAmíREZ, Gloria, EZLN: 20 y 10, el fuego y la palabra, México, La Jornada-Revista Rebeldía, 2005. 
Esta obra forma parte del acervo de la Biblioteca Jurídica Virtual del Instituto de Investigaciones Jurídicas de la UNAM

NATH, Bhaskar y TALAY, Ilkden, "Man, Science, Technology and Sustainable Development", en NATH, Bhaskar et al. (comps.), Sustainable Development, Bruselas, Vubpress, 1996.

NAVA Escudero, César, Urban Environmental Governance: Comparing air Quality Management in London and Mexico City, Aldershot, Inglaterra, Ashgate, 2001.

NAVA EsCuDERO, César, "El principio de precaución en el derecho internacional ambiental", Derecho Ambiental y Ecología, México, año 1, núm. 2, agosto-septiembre de 2004.

NAVA ESCUDERO, César, "La seguridad de la biotecnología: la normatividad internacional vis à vis la regulación nacional mexicana", Memorias del Segundo Encuentro Internacional de Derecho Ambiental, México, Secretaría de Medio Ambiente y Recursos Naturales-Instituto Nacional de Ecología-Programa de las Naciones Unidas para el Medio Ambiente, diciembre de 2004.

NAVA ESCUDERO, César, "Hacia un derecho atmosférico ambiental", Derecho Ambiental y Ecología, México, año 1, núm. 4, diciembre 2004-enero 2005.

NAVA EsCUDERO, César, "Guía mínima para la enseñanza del derecho internacional ambiental en México", Boletín Mexicano de Derecho Comparado, nueva serie, año XXXVIII, núm. 113, México, UNAM, Instituto de Investigaciones Jurídicas, mayo-agosto de 2005.

NAVA Escudero, César, "La privatización de las zonas costeras en México", en LóPez OlverA, Miguel Alejandro (coord.), Estudios en homenaje a don Alfonso Nava Negrete. En sus 45 años de docencia, México, UNAM, Instituto de Investigaciones Jurídicas, 2006.

NAVA EsCudERO, César, "La primera reforma constitucional ambiental del nuevo milenio: el acceso de los pueblos indios a los recursos naturales", en SERNA DE LA GARZA, José María (coord.), Derecho comparado Asia-México, México, UNAM, Instituto de Investigaciones Jurídicas, 2007.

NAVA Escudero, César, "Agua y desalación en México: del engaño al oscurantismo jurídico", en NAVA ESCUDERO, César e HIRIART LE BERT, Gerardo (coords.), Desalación de agua con energías renovables, México, UNAM, Instituto de Ingeniería e Instituto de Investigaciones Jurídicas, 2008. 
Esta obra forma parte del acervo de la Biblioteca Jurídica Virtual del Instituto de Investigaciones Jurídicas de la UNAM

NAVA Escudero, César, "Turismo internacional de playa y cambio climático", Revista de la Facultad de Derecho de México, México, t. LVIII, núm. 250, julio-diciembre de 2008.

NAVA Escudero, César, Estudios ambientales, México, UNAM, Instituto de Investigaciones Jurídicas, 2009.

NAVA ESCUDERO, César, "Institucionalizar la capacitación jurídicoambiental en México", en NAVA EscudERO, César (ed.), Legislación ambiental en América del Norte. Environmental Legislation in North America, Quebec, México, Comisión para la Cooperación AmbientalUNAM, Instituto de Investigaciones Jurídicas, 2011.

NAVA Escudero, César, "México ante la COP-16. Entre la simulación climática y la incertidumbre jurídica", Revista del Posgrado en Derecho de la UNAM, México, núm. 13, julio-diciembre, 2011.

NAVA EscudERO, César, "Tres frases para la construcción de argumentos legales en la aplicación de la legislación ambiental", en NAVA ESCUDERO, César (ed.), Legislación ambiental en América del Norte. Environmental Legislation in North America, Québec-México, Comisión para la Cooperación Ambiental-UNAM, Instituto de Investigaciones Jurídicas, 2011.

NAVA Escudero, César, Estudios ambientales, 2a. ed., México, UNAM, Instituto de Investigaciones Jurídicas, 2011.

NAVA Escudero, César, Ciencia, ambiente y derecho, México, UNAM, Instituto de Investigaciones Jurídicas, 2012.

NAVA Escudero, César, "El turismo sustentable en la Constitución", Revista de la Facultad de Derecho de México, México, t. LXIII, núm. 260, julio-diciembre de 2013.

NAVA EscuDERO, César, "Derecho al medio ambiente", en FERRER MACGREGOR, Eduardo et al. (coords.), Diccionario de derecho procesal constitucional y convencional, México, Poder Judicial de la Federación-UNAM, Instituto de Investigaciones Jurídicas, t. I, 2014.

NAVA Escudero, César, Debates jurídico-ambientales sobre los derechos de los animales. El caso de tlacuaches y cacomixtles versus perros y gatos en la Reserva Ecológica del Pedregal de San Ángel de Ciudad Universitaria, México, UNAM, Coordinación de la Investigación Científica-SEREPSA-Instituto de Investigaciones Jurídicas, 2015.

NaVA NeGRete, Alfonso, Derecho administrativo mexicano, 2a. ed., México, Fondo de Cultura Económica, 2001. 
Esta obra forma parte del acervo de la Biblioteca Jurídica Virtual del Instituto de Investigaciones Jurídicas de la UNAM

NAVA Negrete, Alfonso, Derecho administrativo mexicano, 3a. ed., México, Fondo de Cultura Económica, 2007.

NAVA Negrete, Alfonso, "Derecho de los energéticos", en Fernández RuIZ, Jorge (coord.), Derecho administrativo. Memoria del Congreso Internacional de Culturas y Sistemas Jurídicos Comparados, México, UNAM, Instituto de Investigaciones Jurídicas, 2005.

NAVA Negrete, Alfonso, "El turismo en las zonas arqueológicas de México", en Fernández Ruiz, Jorge y SANTIAGo SÁnChez, Javier (coords.), Régimen jurídico del turismo y de la zona marítimo-terrestre. Memoria del Congreso Internacional de Derecho Turístico, México, UNAM, Instituto de Investigaciones Jurídicas, 2009.

NAVA Negrete, Alfonso, "Enmiendas a la Constitución de 1917”, Revista de la Facultad de Derecho de México, México, t. LXIV, núm. 262, julio-diciembre de 2014.

NAVARro, B., El metro y sus usuarios, México, Universidad Autónoma Metropolitana, 1993.

Nebel, Bernard J. y Wright, Richard T., Ciencias ambientales. Ecología y desarrollo sostenible, 6a. ed., trad. de Francisco Javier Dávila, México, Prentice Hall, 1999.

Nuccio, R. A. et al., "Mexico's Environment: Securing the Future", en Bagley, B. M. y Aguayo QuezadA, Sergio (coords.), Mexico: In Search of Security, Miami, North-South Centre, University of Miami, 1993.

O'Riordan, Timothy, Environmentalism, 2a. ed., Londres, Pion, 1981.

O'RIORDAN, Timothy "The Challenge for Environmentalism", en PEET, Richard y THIFT, Nigel, New Models in Geography, Londres, Unwin, 1989.

ORTIZ GARCÍA, Mercedes, La gestión eficiente de la zona costera. Los parques marinos, Valencia, Tirant lo Blanch, 2003.

Ost, François, Naturaleza y derecho. Para un debate ecológico en profundidad, Bilbao, Mensajero, 1996.

OSTERC, Ludovik, El pensamiento social y político del Quijote, 2a. ed., México, UNAM, 1975.

Palacios Treviño, Jorge, Tratados. Legislación y práctica en México, 3a. ed., México, Secretaría de Relaciones Exteriores, 2001. 
Esta obra forma parte del acervo de la Biblioteca Jurídica Virtual del Instituto de Investigaciones Jurídicas de la UNAM

Palacios Treviño, Jorge, Tratados. Legislación y práctica en México, 4a. ed., México, Secretaría de Relaciones Exteriores-Universidad Iberoamericana, 2007.

Paniagua, Cecilio, "Psicología de la afición taurina", Revista de Humanidades, Dendra Médica, vol. 7, núm. 2, noviembre de 2008.

Paoletti, Maurizio G. y Pimentel, David, "Genetic Engineering and Agricultural: Limits and Options for Maintaining Biodiversity and Sustainability", en NATH, Bhaskar et al. (comps.), Sustainable Development, Bruselas, Vubpress, 1996.

PEARCE, David et al., Blueprint for a Green Economy, Londres, Earthscan, 1989.

Pearson, Ch. S. y PrYor, A., Environment: North and South, Nueva York, Wiley, 1978.

Pereyra, Carlos, "Historia, ¿para qué?”, Historia, ¿para qué?, 19a. edición, México, Siglo XXI Editores, 2002.

PÉrEZ, Efraín, Derecho ambiental, Santa Fe de Bogotá D. C., Colombia, McGraw-Hill, 2000.

PÉREZ SALOM, José Roberto, Recursos genéticos, biotecnología y derecho internacional, Navarra, Aranzadi, 2002.

PÉREZ VÁZQUEZ, Carlos (coord.), El camino para la reforma constitucional de derechos humanos, México, Suprema Corte de Justicia de la Nación-UNAM, Instituto de Investigaciones Jurídicas, 2013.

Pezzoli, K., "Environmental Conflicts in the Urban Milieu: the Case of Mexico City", en Goodman D. y RedCLIFT M. (comps.), Environment and Development in Latin America, Manchester, Manchester University, 1991.

POCAR, Valerio, Los animales no humanos: por una sociología de los derechos, trad. de Laura N. Lora, Buenos Aires, Ad-Hoc, 2013.

PoJman, Louis P. (ed.), Environmental Ethics. Readings in Theory and Application, 4a. ed., Thomson Wadsworth, Belmont, 2005.

PRIEUR, Michel, Droit de l'environnement, 4a. ed., París, Dalloz, 2001.

Pujol Rosas, Rebeca F. y TORRES MALDONADO, Eduardo J., "El sistema constitucional, legal y reglamentario del turismo en México: una radiografía de la evolución institucional y la política legislativa turística", Anales de Jurisprudencia, México, Sexta Época, Segunda Etapa, núm. 247, septiembre-octubre de 2000. 
Esta obra forma parte del acervo de la Biblioteca Jurídica Virtual del Instituto de Investigaciones Jurídicas de la UNAM

QUADRI, Gabriel, "Economía, sustentabilidad y política ambiental", en YúNEZ-NAUDE, A. (comp.), Medio ambiente: problemas y soluciones, México, El Colegio de México, 1994.

RABASA GAMBOA, Emilio, "Las falacias sobre la reforma indígena: sus aciertos y desaciertos", Derecho y Cultura, México, vol. 1, núm. 3, primavera-verano de 2001.

RABASA, Emilio O., "Génesis de la materia ambiental en nuestra Constitución”, en RABASA, Emilio O. (coord.), La Constitución y el medio ambiente, México, UNAM, Instituto de Investigaciones Jurídicas, 2007.

RedClift, M., Development and the Environmental Crisis, Londres, Methuen, 1984.

Redclift, M. y Goodman, D., "Introduction", en Goodman D. y ReDCLIFT, M. (comps.), Environment and Development in Latin America: the Politics of Sustainability, Manchester, University of Manchester, 1991.

Redclift, M. y Sage, C., "Introduction", en Redclift, M. y Sage, C. (comps), Strategies for Sustainable Development: Local Agendas for the Southern Hemisphere, Chichester, Wiley, 1994.

REES, A., The Pocket Green Book: the Environmental Crisis in a Nutshell, Londres-Nueva Jersey, Zed Books, 1991.

RegAn, Tom, The Case for Animal Rights, 2a. ed., Berkeley-Los Ángeles, University of California Press, 2004.

Regan, Tom, "Poniendo a las personas en su sitio", en TAFAlla, Marta (ed.), Los derechos de los animales, Barcelona, Idea Books, 2004.

REGAN, Tom, "Derechos animales y ética medioambiental", en HERRERA Guevara, Asunción (ed.), De animales y hombres. Studia Philosophica, España, Biblioteca Nueva, Universidad de Oviedo, 2007.

RESTREPO, Iván (comp.), La contaminación atmosférica en México, sus causas y efectos en la salud, México, Comisión Nacional de los Derechos Humanos, 1992.

REY CARO, Ernesto J., Temas de derecho internacional ambiental, Córdoba, Marcos Lerner Editora Córdoba, 1998.

Richardson, N. G., "Canada", en StREN, Richard et al. (comps.), Sustainable Cities: Urbanisation and the Environment in International Perspective, Oxford, Westview, 1992. 
Esta obra forma parte del acervo de la Biblioteca Jurídica Virtual del Instituto de Investigaciones Jurídicas de la UNAM

Rivero Serrano, Octavio et al., Contaminación atmosférica y enfermedad respiratoria, México, Biblioteca de la Salud-Secretaría de SaludFondo de Cultura Económica-UNAM, 1993.

Rodiles, Alejandro, "El Acuerdo de París: un empujoncito hacia la justicia climática", Nexos, 25 de febrero de 2016.

RODRÍGUEZ ZÚÑIGA, Joel, "Retórica de los bosques y el agua como asunto de seguridad nacional: evaluación de sus políticas públicas", Derecho Ambiental y Ecología, México, núm. 14, agosto-septiembre de 2006.

Rojas CABAllero, Ariel Alberto, La jurisprudencia del Poder Judicial de la Federación. Manual para su consulta y aplicación, México, Porrúa, 2008.

SADELEer, Nicolas de, "The Precautionary Principle in International Law", en Kerbrat, Yann y Maljean-Dubois, Sandrine (eds.), The Transformation of International Environmental Law, Oxford-Paris, A. Pedone \& Hart, 2011.

Salazar Slack, Ana María, Seguridad nacional hoy. El reto de las democracias, México, Nuevo Siglo, Aguilar, 2002.

SAlAZAR UGARTE, Pedro (coord.), La reforma constitucional sobre derechos humanos. Una guía conceptual, México, Senado de la RepúblicaInstituto Belisario Domínguez, 2014.

SANDBROOK, R., "Opening the Environmental Debate", en Wilson, D. (comp.), The Environmental Crisis. A Handbook for All Friends of the Earth, Londres-Exeter, Inglaterra, Heinemann, 1984.

SANDS, Philippe, "International Environmental Law: an Introductory Overview", en SANDS, Philippe (comp.), Greening International Law, Nueva York, The New Press, 1994.

SANDS, Philippe, Principles of International Environmental Law, 2a. ed., Cambridge, Cambridge University Press, 2003.

SANTOS-BurgOA, Carlos y Rojas Bracho, Leonora, "Los efectos de la contaminación atmosférica en la salud", en RESTREPO, Iván (comp.), $L a$ contaminación atmosférica en México, sus causas y efectos en la salud, México, Comisión Nacional de los Derechos Humanos, 1992.

SARASÍBAR IRIARTE, Miren, El derecho forestal ante el cambio climático: las funciones ambientales de los bosques, Navarra, Thomson-Aranzadi, 2007.

Satterthwaite, David, "Sustainable Cities or Cities that Contribute to Sustainable Development?”, Urban Studies, vol. 32, núm. 10, 1997. 
Esta obra forma parte del acervo de la Biblioteca Jurídica Virtual del Instituto de Investigaciones Jurídicas de la UNAM

SchoenBaum, Thomas J. et al., Environmental Policy Law, 4a. ed., Nueva York, Foundation Press, 2002.

SCHTEINGART, Martha, "The Environmental Problems Associated with Urban Development in Mexico City", Environment and Urbanization, vol. 1, núm. 1, abril de 1989.

SCHWARTZ, J. y MARCUS, A., "Mortality and Air Pollution in London: a Time Series Analysis", American Journal of Epidemiology, vol. 131, núm. 1, The Johns Hopskins University School of Hygiene and Public Health, 1990.

SEARA VÁzQuez, Modesto, Derecho internacional público, 24a. ed., México, Porrúa, 2012.

Sempé Minvielle, Carlos, Técnica legislativa y desregulación, 2a. ed., México, Porrúa, 1998.

SePúlvedA, César, Derecho internacional, 20a. ed., México, Porrúa, 2000.

SEPÚlVEDA IGUINIZ, Ricardo J., "Análisis constitucional de la Ley sobre la Celebración de Tratados", Revista de Investigaciones Jurídicas, México, núm. 18, año 18, 1994.

SERNA DE LA GARZA, José María, El sistema federal mexicano. Un análisis jurídico, México, UNAM, Instituto de Investigaciones Jurídicas, 2008.

SHAW, Malcolm N., International Law, 7a. ed., Cambridge, Cambridge University Press, 2014.

SHELTON, Dinah, "Comments on the normative challenge of environmental «soft law»", en KerbRAT, Yann y MALJEAN-DubOis, Sandrine (eds.), The Transformation of International Environmental Law, Oxford-París, A. Pedone \& Hart, 2011.

SHERLOCK, H., Cities are Good for Us, Londres, Paladin, 1991.

Shotwell, James T., Historia de la historia en el mundo antiguo, trad. de Ramón Iglesia, México, Fondo de Cultura Económica, 1940.

Simental Franco, Víctor Amaury, Derecho ambiental, México, Limusa, 2010.

SINGER, Peter, Liberación animal, ed. actualizada, trad. de ANDA, Madrid, Taurus, 2011.

Soto Flores, Armando, "Bases constitucionales del derecho ambiental mexicano y derecho comparado", en CARMONA LARA, María del Carmen y HERnÁNDEZ MEZA, Lourdes (coords.), Temas selectos de dere- 
Esta obra forma parte del acervo de la Biblioteca Jurídica Virtual del Instituto de Investigaciones Jurídicas de la UNAM

cho ambiental, México, Procuraduría Federal de Protección al Ambiente-UNAM, Instituto de Investigaciones Jurídicas, 2006.

Soussan, John G., "Sustainable Development", en MANnion, Antoinette M. y BowlBY, Sophia R. (comps.), Environmental Issues in the 1990s, Chichester, Wiley, 1992.

STERN, Nicholas, El Informe Stern. La verdad del cambio climático, trad. de Albino Santos (1a. parte) y Joan Vilaltella (2a. parte), Barcelona, Paidós, 2007.

Strauss, J. y Mainwaring, S. J., Air Pollution, Baltimore, Edward Arnold, 1984.

STREN, Richard, "A Comparative Approach to Cities and the Environment", en STREN, Richard et al. (comps.), Sustainable Cities: Urbanisation and the Environment in International Perspective, Oxford, Westview, 1992.

SubCOMANDANTE InSURGENTE MARCOS, "Unas palabras sobre nuestro pensamiento", Crónicas Intergalácticas: EZLN. Primer Encuentro Intercontinental por la Humanidad y contra el Neoliberalismo, México, Planeta Tierra, 1996.

Sustein, Cass R. y Nussbaum, Martha C. (eds.), Animal Rights. Current Debates and New Directions, Nueva York, Oxford University Press, 2006.

SzÉKELY, Francisco (comp.), El medio ambiente en México y América Latina, México, Nueva Imagen, 1978.

SzÉKELY, Alberto, "El medio ambiente: derecho internacional", Revista de la Facultad de Derecho de México, México, t. XXVI, núms. 103 y 104, julio-diciembre de 1976.

SzÉKELY, Alberto, Derecho del mar, México, UNAM, Instituto de Investigaciones Jurídicas, 1991.

SzÉKELY, Alberto y PonCE-NAVA, Diana, "La Declaración de Río y el Derecho Internacional Ambiental", en GLENDER, Alberto y LICHTINGER, Víctor (comps.), La diplomacia ambiental, México, Secretaría de Relaciones Exteriores-Fondo de Cultura Económica, 1994.

TAFALlA, Marta, "Introducción: un mapa del debate", en TAFALLA, Marta (ed.), Los derechos de los animales, Barcelona, Idea Books, 2004.

Thomas, C., The Environment in International Relations, Londres, The Royal Institute of International Affairs-Earthscan, 1992. 
Esta obra forma parte del acervo de la Biblioteca Jurídica Virtual del Instituto de Investigaciones Jurídicas de la UNAM

ThORnton, Justine y BECKWITH, Silas, Environmental Law, Londres, Sweet \& Maxwell, 1997.

Tena RAMíREz, Felipe, Derecho constitucional mexicano, 33a. ed., México, Porrúa, 2000.

TORO HuERTA, Mauricio Iván del, "El fenómeno del soft law y las nuevas perspectivas del derecho internacional", Anuario Mexicano de Derecho Internacional, vol. VI, 2006.

TRIGUEROS GAISMAN, Laura, "Comentarios en torno a la ley sobre la celebración de tratados”, Alegatos, núm. 21, mayo-agosto de 1992.

TudelA, Fernando, "México y la participación de países en desarrollo en el régimen climático", en MARTínEZ, Julia y FERNÁNDEZ, Adrián (comps.), Cambio climático: una visión desde México, México, Instituto Nacional de Ecología, 2004.

Turner, R. K. "Sustainability: Principles and Practice", en TURnER, R. K. (comp.), Sustainable Environmental Economics and Management: Principles and Practice, Londres, Belhaven, 1993.

VAladÉS, Diego, Constitución y política, 2a. ed., México, UNAM, Instituto de Investigaciones Jurídicas, 1994.

VALADÉS, Diego, "Los derechos indígenas y la renovación constitucional en México", en GonzÁlez GAlván, Jorge Alberto (coord.), Constitución y derechos indígenas, México, UNAM, Instituto de Investigaciones Jurídicas, 2002.

VAlADÉS, Diego, Problemas constitucionales del Estado de derecho, 2 a. ed., Buenos Aires, Astrea, 2004.

VALENCIA MulKaY, Miguel, "Hacia otra perspectiva jurídica del agua", Derecho ambiental y ecología, México, año 2, núm. 11, febrero-marzo de 2006.

VAllarta MARrón, José Luis, Derecho internacional público, 2a. ed., México, Porrúa, 2014.

VALlARTA PlatA, José Guillermo, "Turismo y desarrollo sustentable", en FERnÁndez Ruiz, Jorge y SANTIAgo SÁnCHEZ, Javier (coords.), Régimen jurídico del turismo y de la zona marítimo-terrestre. Memoria del Congreso Internacional de Derecho Turístico, México, UNAM, Instituto de Investigaciones Jurídicas, 2009.

VÁZQUEZ, Luis Daniel y SERRANO, Sandra, "Los principios de universalidad, interdependencia, indivisibilidad y progresividad. Apuntes para su aplicación práctica”, en CARBOnEll, Miguel y SAlazAR, Pedro 
Esta obra forma parte del acervo de la Biblioteca Jurídica Virtual del Instituto de Investigaciones Jurídicas de la UNAM

(coords.), La reforma constitucional de derechos humanos: un nuevo paradigma, México, UNAM, Instituto de Investigaciones Jurídicas, 2011.

VÁZQUEZ GARCÍA, Aquilino, "El federalismo en materia ambiental", Memorias del Primer Encuentro Internacional de Derecho Ambiental, México, Instituto Nacional de Ecología-Secretaría de Medio Ambiente y Recursos Naturales-Programa de las Naciones Unidas para el Medio Ambiente, 2003.

VÁzQuez Montalbán, Manuel, Marcos: El señor de los espejos, México, Aguilar, 1999.

Vázquez Pando, Fernando, "Notas para el estudio del sistema jurídico mexicano en materia de contaminación del ambiente", Jurídica, Anuario del Departamento de Derecho de la Universidad Iberoamericana, núm. 6, julio de 1974.

Vega CÁnovas, Gustavo et al., México, Estados Unidos y el Canadá: resolución de controversias en la era post-TLCAN, México, UNAM, Instituto de Investigaciones Jurídicas-Programa Interinstitucional de Estudios sobre la Región de América del Norte, 2004.

VICENT, Manuel, "Antitauromaquia (tres pasajes)", en TAFALlA, Marta (ed.), Los derechos de los animales, Barcelona, Idea Books, 2004.

Villalobos, V. M., "Transgénicos: la ciencia superó a la ficción”, Desarrollo Sustentable, México, año 1, vol. 1, núm. 5, 1999.

VILloro, Luis, "El sentido de la historia”, Historia, ¿para qué?, 19a. ed., México, Siglo XXI Editores, 2002.

Villoro Toranzo, Miguel, Introducción al estudio del derecho, 9a. ed., México, Porrúa, 1990.

Villoro Toranzo, Miguel, Introducción al estudio del derecho, 21a. ed., México, Porrúa, 2012.

WARD, Peter, Mexico City, Londres, Belhaven, 1990.

WARD, Peter, Mexico City, 2a. ed., Chichester, Wiley, 1998.

WEIL, Prosper, "Towards Relative Normativity in International Law?", The American Journal of International Law, vol. 77, núm. 3, julio de 1983.

WheELler, Brian, “Tourism's Troubled Times. Responsible Tourism is Not the Answer", en FrAnCE, Lesley (ed.), The Earthscan Reader in Sustainable Tourism, Londres, Earthscan, 1997. 
Esta obra forma parte del acervo de la Biblioteca Jurídica Virtual del Instituto de Investigaciones Jurídicas de la UNAM

White, R. R., North, South and the Environmental Crisis, Toronto, University of Toronto, 1993.

WiLliamson, Richard L. Jr., "Hard Law, Soft Law, and Non-Law in Multilateral Arms Control: Some Compliance Hypotheses", Chicago Journal of International Law, vol. 4, núm. 1, Article 7, 2003.

Wilson, D., "The Environmental Crisis", en WILSON D. (comp.), The Environmental Crisis. A Handbook for All Friends of the Earth, LondresExeter, Heinemann, 1984.

WITKER, Jorge, Curso de derecho económico, México, UNAM, Instituto de Investigaciones Jurídicas, 1989.

WITKER, Jorge, "El agua como recurso natural desde la perspectiva del derecho económico", en NAVA ESCUDERO, César e HIRIART LEBERT, Gerardo, Desalación de agua con energías renovables, México, UNAM, Instituto de Ingeniería e Instituto de Investigaciones Jurídicas, 2008.

Wolf, Winfried, Car Mania. A Critical History of Transport, Londres, Pluto, 1996.

Yu CHANG, Man, "Cornucopianos: los ultraneoliberales", en FOLADORI, Guillermo y PIERRI, Naína (coords.), ¿Sustentabilidad? Desacuerdos sobre el desarrollo sustentable, México, Cámara de Diputados-Universidad Autónoma de Zacatecas-Miguel Ángel Porrúa, 2005.

\section{FUENTES ELECTRÓNICAS}

ACEDO, Alfredo, "Con el Acuerdo de París arderá el planeta", Agencia Latinoamericana de Información (ALAI), 10 de diciembre de 2015, disponible en: www.alainet.org/es/articulo/174215.

ADLER, J. H., "The Cartagena Protocol and Biological Diversity: Biosafe or Biosorry?", Georgetown International Environmental Law Review, versión electrónica, Washington, vol. 12, núm. 3, primavera de 2000.

Al TORO MÉXICO, página electrónica, disponible en www.altoromexico. com/2010/index.php? acc $=$ noticia\&id $=4142$.

Allan, J. A., "Virtual Water Eliminates Water Wars? A Case Study from the Middleast", en HoekstrA, A. Y. (ed.), Virtual Water Trade, Delft, núm. 12, febrero de 2003, http://www.ihe.nl/downloads/projects/report12hoekstra.pdf. 
Esta obra forma parte del acervo de la Biblioteca Jurídica Virtual del Instituto de Investigaciones Jurídicas de la UNAM

ARISTEGUi Noticias, "Los 'daños colaterales' y el costo social del combate al narcotráfico”, Redacción Aristegui Noticias 2012, México, 26 de noviembre de 2012, disponible en: www.aristeguinoticias.com.

Auditoría Superior de la Federación, "X. Sector Medio Ambiente y Recursos Naturales", Informe de la Cuenta Pública, México, 2009, disponible en: http://www.asf.gob.mx/Trans/Obliga/Resumenejec07. $p d f$.

CECEÑA, Ana Esther, "El reconocimiento de los derechos y cultura indígenas y la incompetencia del sistema político mexicano", Derechos indigenas y los Acuerdos de San Andrés, México, s. f., disponible en: http://www.ezln.org/san_andres/.

Centro de Derechos Humanos "Miguel Agustín Pro Juárez", Cronología narrativa. Proceso de la reforma constitucional en materia indigena, México, s. f., disponible en: http://www.centroprodh.org.mx/ especiales/cronologia_indigena/cronologiaindigena.htm.

Centro de Documentación sobre Zapatismo, Acuerdos de San Andrés-Reforma Aprobada en el 2001, México, Documentación histórica, CEDOZ, s. f., www.cedoz.org/site/content.php?doc $=720$.

COMISIÓN INTERSECRETARIAL DE BIOSEGURIDAD Y ORGANISMOS GENÉTICAMENTE ModifiCAdos, Normatividad, México, 2002, http://www. cibiogem.gob.mx/.

Comisión Nacional del Agua, Estadísticas del agua en México, Comisión Nacional del Agua, 2005, disponible en: http://www.cna.gob. mx/CNA/Español/Organismos/Central/Estadisticas/EstadisticasAgua CNA/htm.

Comisión Nacional Del Agua, Resumen de la temporada de ciclones tropicales 2006, México, CNA, s. f., disponible en: http://smn.cna.gob. $m x /$ ciclones/tempo2006/crt2006.pdf.

COMité Clandestino REVOluCiONARIO IndíGENA, COMANDANCIA GENERAL DEL EJÉRCITO ZAPATISTA DE LIBERACIÓN NACIONAL, Comunicado, México, 2 de diciembre de 2000, disponible en: htpp://www.ezln. org/documentos/2000/20001202c.es.htm.

Comité Clandestino Revolucionario IndíGENA, Comandancia GeNERAL DEL EJÉRCITO ZAPATISTA DE LIBERACIÓN NACIONAL, Comunicado, México, 29 de abril de 2001, disponible en: htpp://www.ezln.org/ documentos/2001/ezln010429b.es.htm. 
Esta obra forma parte del acervo de la Biblioteca Jurídica Virtual del Instituto de Investigaciones Jurídicas de la UNAM

Comité Clandestino Revolucionario Indígena, Comandancia GeNERAL DEl EjÉRCITO ZAPATISTA DE LiBERACión NACIONAL, Sexta Declaración de la Selva Lacandona, México, junio de 2005, disponible en: http://www.ezln.org/documentos/2005/sexta.es.htm.

Cortina SEgovia, Sofía y QuiÑones VALADEZ, Leticia, Análisis y recomendaciones del marco jurídico aplicable a océanos y costas, México, Dirección General de Investigación en Política y Economía Ambiental, Instituto Nacional de Ecología, mayo de 2005, diponible en: http:// www.ine.gob.mx/download/anal_re-com_marco_jur.pdf.

CuEli, José, "A mí me gusta el primer tercio", La Jornada, 28 de marzo de 2011, disponible en www.jornada.unam.mx/2011/03/28/opinion/ a42aldep.

CURZIO, Leonardo, "La seguridad nacional en México: balance y perspectivas", Revista de Administración Pública, México, núm. 98, 1998, disponible en: http://www.juridicas.unam.mx/publica/li-brev/rev/rap/ cont/98/pr/pr3.pdf.

Dirección General de Zona Federal Marítimo Terrestre y AMBientes Costeros, Conceptos básicos, Secretaría de Medio Ambiente y Recursos Naturales, mayo de 2005, disponible en: http://portal.semarnat.gob.mx.

EJÉRCITO ZAPATISTA DE LIBERACIÓN NACIONAL, Reformas constitucionales propuestas de la Comisión de Concordia y Pacificación, 29 de noviembre de 1996, México, Ejército Zapatista de Liberación Nacional, s. f., disponible en: http://www.ezln.org/san_andres/cocopa961129-sp. html.

ESPINOZA SAUCEDA, Guadalupe, Los pueblos indigenas ante la coyuntura de las controversias constitucionales y posibles escenarios, México, 14 de mayo de 2002, disponible en: http://www.ciepac.org/procesodepaz/ contges0502.htm.

FERNÁNDEZ DE MENDOZA, Jr., Erasmo, "Calderón usó la palabra 'guerra' desde el 2006", Politica a la mexicana, 9 de diciembre de 2011, disponible en: www.periodistasenlinea.org.

FLOREZ, Alfredo, blog En los medios Revista Taurina, 2 de marzo de 2010, disponible en: www.toriles.com/noticia.php? recordID $=1975$.

FresnedA, Carlos, "El Acuerdo de París: ¿éxito o fraude?", El Mundo, 13 de diciembre de 2015, disponible en: www.elmundo.es/ciencia/2015/12 /13/566dcldfee2704ece3d8b4614.html. 
Esta obra forma parte del acervo de la Biblioteca Jurídica Virtual del Instituto de Investigaciones Jurídicas de la UNAM

GABČIKOvo-NAgymaros Project (Hungary/Slovakia), Judgement, I. C. J. Reports, 1997, disponible en: www.icj-cij.org/docket/files/92/7375. $p d f$.

Gobierno Del Distrito Federal, Manual para la aplicación del Programa de Contingencias Ambientales Atmosféricas en el Distrito Federal, México, 2000, disponible en: http:/www.sma.df.gob.mx.

GobiERno DEL Distrito FEDERAL, "Inventario de Emisiones de la Zona Metropolitana del Valle de México, 2004", México, Gobierno del Distrito Federal, 2004, disponible en: http://www.sma.df.gob.mx/sma/modules.php? name=Aire.

Gobierno DEL Distrito Federal, "Presentación”, en Medio ambiente y transporte sustentable, México, Gobierno del Distrito Federal, s. f., disponible en: http://www.sma.df.gob.mx/transportesustentable/.

Gobierno Del Distrito Federal, Fechas de activación del Programa de Contingencias Ambientales Atmosféricas, México, Gobierno del Distrito Federal, 2007, disponible en: http://www.sma.df.gob.mx/sma/ modules.php? name=Aire.

GONZÁLEZ, Dolores, "Implicaciones de la reforma sobre derechos indígenas aprobada en el Congreso", Cuadro comparativo entre los derechos del Convenio 169 de la OIT, la iniciativa Cocopa, los Acuerdos de San Andrés y el dictamen de reforma constitucional aprobado por el Senado de la República el 25 de abril de 2001, México, Centro de Derechos Humanos Miguel Agustín Pro Juárez, A.C.-SERAPAZ, 17 de mayo de 2001, disponible en: http://www.centroprodh.org.mx.

InSTITUTO DE INVESTIGACIONES JURÍDiCAS, Legislación Federal, México, UNAM, Instituto de Investigaciones Jurídicas, 2004, disponible en: http://www.juridicas.unam.mx/inst/.

Korstanje, Maximiliano, Tratado turístico, versión electrónica, 2007, disponible en: www.eumed.net./libros/2007c/321/.

LÓPEZ, Jaime, Corrupción presidencial en América Latina, 2001, disponible en: http://www.offnews.info/downloads/corrupcion_presidencial. $p d f$.

M2 PRESSWIRE, UN: Entry into force of Cartagena Protocol on Biosafety "Landmark for Sustainable Development", says Secretary-General, versión electrónica, 10 de septiembre de 2003. 
Esta obra forma parte del acervo de la Biblioteca Jurídica Virtual del Instituto de Investigaciones Jurídicas de la UNAM

Moreno, Javier, entrevista con Felipe Calderón Hinojosa, El País, 27 de marzo de 2011, disponible en: www.elpais.com/diario/2011/03/27/domingo/1301201553_850215.html.

ORGANIZACIÓN DE LAS NACIONES UNIDAS, Informe de la Cumbre Mundial sobre el Desarrollo Sostenible, Johannesburgo (Sudáfrica), 26 de agosto a 4 de septiembre de 2002, Naciones Unidas, 2002, disponible en: www.un.org/spanish/conferences/wssd/doconf.htm.

ORGANIZACIÓN DE LAS NACIONES UNIDAS, Declaración de Río sobre Medio Ambiente y Desarrollo, disponible en: www.un.org/spanish/esa/ susdev/agenda21/riodeclaration.html.

ORGANIZACIÓN DE LAS NACIONES UNIDAS, "16. Gestión Ecológicamente Racional de la Biotecnología”, Programa 21, capítulo 16, División de Desarrollo Sostenible, 24 de marzo de 2003, disponible en: http://www. un.org/esa/sustdev/documents/agenda21/spanish/agenda21spchapter 16. htm.

Organización de las Naciones Unidas, "17. Protección de los océanos y de los mares de todo tipo, incluidos los mares cerrados y semicerrados, y de las zonas costeras, y protección, utilización racional y desarrollo de sus recursos vivos", Programa 21, capítulo 17, División para el Desarrollo Sostenible, 23 de enero de 2003, disponible en: http:// www.un.org./esa/sustdev/do-cuments/agenda21spchapter-17.htm.

ORGANIZACIÓN DE LAS NACIONES UNIDAS, “18. Protección de la calidad y el suministro de los recursos de agua dulce: aplicación de criterios integrados para el aprovechamiento, ordenación, y uso de los recursos de agua dulce", Programa 21, capítulo 18, División para el Desarrollo Sostenible, 15 de diciembre de 2004, disponible en: http://www.un.org/ esa/sustdev/documents/agenda21/spanish/agenda21schapter18htm.

ORGANIZACIÓN DE LAS NACIONES UNIDAS, Resolución aprobada por la Asamblea General, 66/288. El futuro que queremos, Naciones Unidas, 2012, disponible en: www.un.org/es/comun/docs/?symbol=A/ RES/66/288.

OrganizACIÓn DE LAS NACIONES UnidAs, Programa 21, Departamento de Asuntos Económicos y Sociales, División de Desarrollo Sustentable, s. f., www.un.org/spanish/esa/sustdev/agenda21/agenda21toc.htm.

OrganiZACIÓn DE LAS NACIONES UNIDAS, ¿Qué es el Consejo de Seguridad?, Organización de las Naciones Unidas, s. f., http://www.un.org/ spanish/docs/sc/unsc_infoBasica.html. 
Esta obra forma parte del acervo de la Biblioteca Jurídica Virtual del Instituto de Investigaciones Jurídicas de la UNAM

ORGANIZACIÓN DE LAS NACIONES UNIDAS PARA LA EDUCACIÓN, LA CIENCIA Y LA CULTURA, "Proclama UNESCO urgente necesidad de proteger áreas oceánicas y costeras", Noticias, 2001, disponible en: http://www. unesco. org.cu/Noticias/noticia121201.htm.

Organización Meteorológica Mundial y Programa de las NACIONES UNIDAS PARA EL MEDIO AMBIENTE, Introducción, Grupo Intergubernamental sobre el Cambio Climático, Organización Meteorológica Mundial-Programa de las Naciones Unidas para el Medio Ambiente, disponible en: http://www.ipcc.ch/about/faq/IPCC\%20Introduction\%20S.pdf.

Organización Mundial Del Turismo, Barómetro OMT del Turismo Mundial, vol. 5, núm. 2, junio de 2007, disponible en: www.unwto.org/ facts/menu/.html.

OrganizAción Mundial del Turismo, Acerca de la OMT, s. f., www2. unwto.org/es/content/acera-de-la-omt.

Organización Mundial Del Turismo, Definición, Sustainable Development of Tourism, UNWTO, s. f., disponible en: sdt.unwto.org/ex/ content/definicion.

OrganizACIÓn Mundial DEL TuRISMO, Entender el turismo: Glosario Básico, s. f., disponible en: http://media.unwto.org/es/content/entender-el-turismo-glosario-basico.

Ortiz PÉREz, Mario Arturo y MÉndez LinAREs, Ana Patricia, Repercusiones por ascenso del nivel del mar en el litoral del Golfo de México, México, UNAM, s. f., disponible en: http://www.atmosfera.unam.mx/ editorial/libros/cambio_climatico/cos-tas.pdf.

PARTIDO DE LA REVOluCiÓn DEMOCRÁTICA, Conclusiones de los Foros para el Análisis de la Minuta del Proyecto de Decreto de Ley de Bioseguridad de Organismos Genéticamente Modificados, México, Área de Desarrollo Rural y Medio Ambiente, Cámara de Diputados, 10 de marzo de 2004, disponible en: http://prdleg.camara.gob.mx/otros/bioseguridad.htm.

Peters, Anne y PAgotto, Isabella, "Soft Law as a New Mode of Governance: A Legal Perspective", NEWGOV: New Modes of Governance, 28 de febrero de 2006, disponible en: http://dx.doi.org/10.2139/ ssm. 1668531. 
Esta obra forma parte del acervo de la Biblioteca Jurídica Virtual del Instituto de Investigaciones Jurídicas de la UNAM

Planeta Azul. Periodismo Ambiental, Critican estrategia de cambio climático, México, 2007, disponible en: http://www.planetaazul.com. $m x / w w w / 2007 / 06 / 02 /$ critican-estrategia-de-cambio-climatico/.

PRESIDENCIA, Discursos. Diversas intervenciones en la celebración del Día Mundial del Medio Ambiente, México, 5 de junio de 2008, disponible en: http://calderon.presidencia.gob.mx.

Presidencia De LA RepúblicA, "2.8 Turismo", Plan Nacional de Desarrollo, 2007, disponible en: pnd.calderon.presidencia.gob.mx/economia-competitiva-y-generadora-de-empleos/turismo.html.

PRESIDENCIA DE LA REPÚBLICA, El presidente Calderón en la ceremonia de entrega de condecoraciones de perseverancia, mérito deportivo y ascensos, Ciudad de México, Campo Militar Marte, 20 de noviembre de 2007, disponible en: http://calderon.presidencia.gob.mx.

PRESIDENCIA DE LA REPÚBLICA, En la guerra contra la delincuencia no habrá tregua ni cuartel: presidente Felipe Calderón, nota informativa, 12 de septiembre de 2008, disponible en: http://calderon.presidencia. gob.mx.

PRESIDENCIA DE LA REPÚBLICA, Entrevista al presidente Calderón en el noticiero con Joaquín López Dóriga, segunda parte, 8 de diciembre de 2011, disponible en: http://calderon.presidencia.gob.mx (consultada el 17 de agosto de 2013).

Programa de las Naciones Unidas PARA El Medio Ambiente, Protocolo de Montreal relativo a las sustancias que agotan la capa de ozono en su forma ajustada y/o enmendada en Londres, 1990; Copenhague, 1992; Viena, 1995; Montreal, 1997; Beijing 1999; Programa de las Naciones Unidas para el Medio Ambiente-Secretaría del Ozono, 2000, disponible en: http://www.unep.org/ozone.

Programa de las Naciones Unidas para El Medio Ambiente, "Declaración de Río sobre el Medio Ambiente y el Desarrollo 1992", Hitos ambientales, Oficina Regional para América Latina y el Caribe, 19952001, disponible en: http://www.rolac.unep.mx/docamb/esp/dr1992. htm.

Programa de las NaCiOnes UnidAs PARA EL MEdio AmBIENTE, "Problems Related to Freshwater Resources", Vital Water Graphics, An Overview of the State of the World's Fresh and Marine Waters, United Nations Environment Programme, 2002, disponible en: http://www. unwp.org/vitalwater/resources/htm. 
Esta obra forma parte del acervo de la Biblioteca Jurídica Virtual del Instituto de Investigaciones Jurídicas de la UNAM

REAL ACADEMIA ESPAÑOLA, Diccionario de la lengua española, 22a. ed., España, 2001, disponible en: http://buscon.rae.es/draeI/ SrvltConsulta? TIPO BUS=3\&LEMA=bueno.

REAL ACADEMIA ESPAÑOLA, Nuevo tesoro lexicográfico de la lengua española, 2010, disponible en: http://buscon-rae.es/ntlle/SrvltGUILoginNtlle.

REVISTA NEXOS, "Una ayudadita de memoria para Felipe Calderón", 28 de enero de 2011, disponible en: http://redaccion.nexos.com.mx.

Rojo Stein, Enrique, "Palabras del Lic. Enrique Rojo Stein", Praxis103. La formación de cuadros de seguridad nacional, México, Instituto Nacional de Administración Pública, 1999, disponible en: http://www. bibliojuridica.org/libros/libro.htm? $l=1309$.

SAFRIN, S., "Treaties in Collision? The Biosafety Protocol and the World Trade Organization Agreements", The American Journal of International Law, Washington, versión electrónica, Estados Unidos de América, vol. 96, núm. 3, julio de 2002.

SÁNDEZ ARANA, Juan Diego, "La fracturación hidráulica en la Unión Europea: estado de la cuestión", Documento Marco, Instituto Español de Estudios Estratégicos, Ministerio de Defensa, Gobierno de España, Boletín electrónico, núm. 18, 3 de noviembre de 2014, disponible en: www.ieee.es.

Secretaría de Medio Ambiente Del Distrito Federal, www.sma. df.gob.mx.

Secretaría de Medio Ambiente y Recursos NATurales, Cruzada Nacional por los Bosques y el Agua, Secretaría de Medio Ambiente y Recursos Naturales, 2001, disponible en: http://portal.semarnat.gob. mx/programas/documentos/archivo/curzada_ba.pdf.

SeCretaría de Medio Ambiente y ReCursos NATURAles, Programa Nacional del Medio Ambiente y Recursos Naturales 2001-2006, Secretaría de Medio Ambiente y Recursos Naturales, 2001, disponible en: http://portal.semarnat.gob.mx/programas/documentos/archivo/pnmarn.pdf.

SecretaríA de Medio Ambiente y Recursos NATURAles, "Cuarta Comunicación Nacional", Biosfera. Sala de prensa. Noticias del medio ambiente, México, 2009, disponible en: http://www.semarnat.gob.mx

SECRETARÍA DE MEDIO AMBIENTE Y RECURSOs NATURALES, Inventarios forestales y tasas de deforestación, México, s. f., disponible en: http:// 
Esta obra forma parte del acervo de la Biblioteca Jurídica Virtual del Instituto de Investigaciones Jurídicas de la UNAM

app1.semarnat.gob.mx/dgeia/informe_04/02_vegetacion/recuadros/c_ rec3_02.htm.

SeCretaría de Relaciones Exteriores, Convenio de Viena para la Protección de la Capa de Ozono, México, Secretaría de Relaciones Exteriores, disponible en: $h t t p: / / w w w . s r e . g o b . m x$.

SECRETARÍA DE TURISMO, La inversión privada en el sector turístico, México, Secretaría de Turismo, 2006a, disponible en: http://datatur.sectur. gob.mx/pubyrep/cargas_manuales/docext/Invturmay.pdf.

Secretaría de Turismo, Boletín cuatrimestral de Turismo, México, Secretaría de Turismo, núm. 19, enero-abril de 2007, disponible en: $h t t p: / /$ datatur.sectur.gob.mx/pubyrep/bol/2007/m01/bol12007.pdf.

SeCretaría del Convenio sobre la Diversidad BiológiCa, Cartagena Protocol on Biosafety. About the Protocol, febrero de 2004, disponible en: http://www.biodiv.org/biosafety/background.asp\#.

Secretaría del Convenio sobre la Diversidad Biológica, Cartagena Protocol on Biosafety. Home, febrero de 2004, disponible en: http:// www.biodiv.org/biosafety/default.aspx.

SolÓN, Pablo, "COP21: A New Disguise for an Old Agreement", noviembre de 2015, disponible en: https://pablosolon.wordpress.com.

Suprema Corte de Justicia DE LA NACión, Legislación, México, Suprema Corte de Justicia de la Nación, 2006, disponible en: http://200.38.86.53/ PortalSCJN/Rec-Jur/Legislacion/.

SzÉKELY, Alberto, Comentarios al artículo de Vargas, Jorge A., "Terminología sobre el derecho del mar", Boletín Mexicano de Derecho Comparado, México, nueva serie, año XIII, núm. 39, septiembre-diciembre de 1980, disponible en: http://www.juridicas.unam.mx/publica/librev/rev/ bo letin/cont/39/bib/bib26.pdf.

United Nations Centre For Human Settlements, The State of the World's Cities Report 2001, United Nations Centre for Human Settlements-HABITAT, disponible en: 2001, http://www.unchs.org.

United Nations Framework Convention On Climate Change, Synthesis Report on the Aggregate Effect of INDCs, UNFCC, 2015, disponible en: unfccc.int/focus/indc portal/items/9240.php.

United Nations Organization, "Definitions of Key Terms Used in the UN Treaty Collection, United Nations, Treaty Collection, disponible en: https://treaties.un.org/Pages/overview.aspx?path=overview/definition/page1_en.xml. 
Esta obra forma parte del acervo de la Biblioteca Jurídica Virtual del Instituto de Investigaciones Jurídicas de la UNAM

VIÑUALES, Jorge, "The Paris Climate Agreement: An Initial Examination (Part II of III)", EJIL: Talk!, Blog of the European Journal of International Law, 8 de febrero de 2016, disponible en: www.ejiltalk,org/the-pariclimate-agreement-an-initial-examination-part-ii-of-iii/.

ViÑuALES, Jorge, "The Paris Climate Agreement: An Initial Examination (Part III of III)", EJIL: Talk!, Blog of the European Journal of International Law, 8 de febrero de 2016, disponible en: www.ejiltalk,org/thepari-climate-agreement-an-initial-examination-part-iii-of-iiil.

World TOURISM Organisation, Djerba Declaration on Tourism and Climate Change, World Tourism Organisation (WTO), abril de 2003, disponible en: http://www.world-tourism.org/sustainable/climate/decdjerba-eng.pdf.

World TOURISM ORGANISATION, About UNWTO, World Tourism Organisation (WTO), 2006, disponible en: http://www.unwto.org/aboutwto/ index.php.

World TOURISM OrganisATION et al., Davos Declaration, WTOUNEP-WEF-WM0-Confederación Suiza, octubre de 2007, disponible en: http://www.unwto.org/pdf/pr071046.pdf.

WOrld TOURISM ORGANiSATION, WORLD WATER COUNCIL y COMISIÓN NACIONAL DEL AGUA, "Medio Oriente y Norte de África", Documentos regionales, WWC-CNA, 2006, disponible en: http://www.world-waterforum4.org.mx/uploads/TBL_DOCS_114_50.pdf.

WORld WATER COUNCIL Y REPUBliC OF TURKEY, Turkey Country Report, Prepared for the 3rd.,World Water Forum March 2003, World Water Council, 2003, disponible en: http://www.worldwatercouncil. org/fileadmin/wwc/Library/Publications_and_reports/country_re ports/report_Turkey.pdf.

\section{OTRAS FUENTES}

Alponte, Juan María, Alimentación mundial y desigualdad productiva. Nuevos conceptos de salud en el mundo. Transformación de la producción de alimentos. Revolución de los transgénicos, México, séptima conferencia del profesor Juan María Alponte, Secretaría de Medio Ambiente y Recursos Naturales, agosto de 2003.

BARTOne, C. et al., Toward Environmental Strategies for Cities: Policy Considerations for Urban Environmental Management in Developing 
Esta obra forma parte del acervo de la Biblioteca Jurídica Virtual del Instituto de Investigaciones Jurídicas de la UNAM

Countries, Washington, D. C., Urban Management Programme-United Nations Development Programme-United Nations Conference on $\mathrm{Hu}-$ man Settlements-World Bank, 18, 1994.

BARRAGÁn, José, "Derecho pesquero", Diccionario jurídico mexicano, 8a. ed., México, Porrúa-UNAM, Instituto de Investigaciones Jurídicas, t. D-H, 1995.

BAUER, M. y Quintanilla, J., "Emissions of the Energy Chaings in the Mexican Energy System", ponencia presentada en Seminario Internacional sobre Sustentabilidad Urbana y el Manejo de la Cuenca Atmosférica en la Zona Metropolitana del Distrito Federal y del Estado de México, México, 22-25 de mayo de 1995.

Bell, Sandra, Capital Killer II: Still Fuming over London's Traffic Pollution, Londres, London Boroughs Association, 1993.

Bravo Álvarez, Humberto y Torres Jardón, Ricardo, "Prioridades en contaminación atmosférica en la ciudad de México: ozono y partículas respirables", Foro de Consulta Popular Medio Ambiente y Desarrollo Sustentable en el Valle de México, México, s. e., 1995.

Button, J., A Dictionary of Green Ideas: Vocabulary for a Sane and Sustainable Future, Londres, Routledge, 1988.

CABALlero OCHOA, José Luis, "Cláusula de interpretación conforme", en Ferrer MAC-Gregor, Eduardo et al. (coords.), Diccionario de derecho procesal constitucional y convencional, Poder Judicial de la Federación, Consejo de la Judicatura Federal-UNAM, Instituto de Investigaciones Jurídicas, t. I, 2014.

CALvillo, Alejandro, "Seminario el Transporte y la Contaminación en la Ciudad de México", El transporte y la contaminación, México, Greenpeace México, 1993.

CÁmara de Senadores, "Exposición de Motivos de la Ley sobre la Celebración de Tratados", Diario de los Debates, México, Cámara de Senadores del Congreso de los Estados Unidos Mexicanos, núm. 20, 6 de diciembre de 1991.

CAMPOS RuIZ, H. et al., "Políticas para la revención y control de la contaminación: el caso de la Ciudad de México", Diagnóstico de los países centroamericanos en torno a la implementación de los problemas de la politica ambiental, Berlín, ZöV Zentralstelle für Öffentliche Verwaltung, 1993. 
Esta obra forma parte del acervo de la Biblioteca Jurídica Virtual del Instituto de Investigaciones Jurídicas de la UNAM

Carbonell, Miguel et al., Compendio de derecho ambiental, México, Porrúa, 2010.

CARMona LARA, María del Carmen, Ley General del Equilibrio Ecológico y la Protección al Ambiente. Comentarios y concordancias, México, Procuraduría Federal de Protección al Ambiente-UNAM, Instituto de Investigaciones Jurídicas, 2003.

CARPIZO, Jorge, "Nación”, Diccionario jurídico mexicano, 8a. ed., México, Porrúa-UNAM, Instituto de Investigaciones Jurídicas, t. I-O, 1995.

Centro MexicAno De Derecho Ambiental, Grado de cumplimiento de los tratados ambientales internacionales por parte de la República de México a 1999, México, IDEADS, 2000.

Centro Mexicano de Derecho Ambiental, Greenpeace e Ifaw, "¡Ya basta Alberto Cárdenas!", La Jornada, México, 23 de mayo de 2005.

CheErs, Gordon (ed.), Geographica. El Gran Atlas Mundial Ilustrado, trad. de Gemma Deza, Guil et al., Colonia, Könemann, 2000.

ColÁs GIL, Jaume (coord.), Diccionario ilustrado de ecología y medio ambiente, Barcelona, SPES Editorial, 2002, t. 2.

COMISIÓn INTERSECRETARIAL DE CAMBIo ClimÁtico, Estrategia Nacional del Cambio Climático, México, CICC, Comisión Intersecretarial de Cambio Climático, Secretaría de Medio Ambiente y Recursos Naturales, 2007.

Comisión Ambiental Metropolitana et al., Programa para Mejorar la Calidad del Aire de la Zona Metropolitana del Valle de México 20022010 (PROAIRE 2002-2010), México, Secretaría de Medio Ambiente y Recursos Naturales-Secretaría de Salud-Gobierno del Distrito FederalGobierno del Estado de México, 2002.

Comisión Ambiental Metropolitana et al., Programa para Mejorar la Calidad del Aire de la Zona Metropolitana del Valle de México (20112020), México, Secretaría de Medio Ambiente y Recursos NaturalesSecretaría de Salud-Secretaría de Medio Ambiente del Gobierno del Distrito Federal-Secretaría del Medio Ambiente del Gobierno del Estado de México, 2011.

COMisión METROPOlitana PARA LA PREVEnCIÓN Y CONTROL DE LA CONTAMINACIÓN AMBIENTAL EN EL VALlE DE MÉXICO, ¿Qué estamos haciendo para combatir la contaminación del aire en el Valle de México?, México, Comisión Metropolitana para la Prevención y Control de la Contaminación Ambiental en el Valle de México, 1992. 
Esta obra forma parte del acervo de la Biblioteca Jurídica Virtual del Instituto de Investigaciones Jurídicas de la UNAM

COMisión METROPOlitana PARA LA PREVEnCión Y CONTROL DE LA Contaminación Ambiental en el VAlle de MÉXICO, Avances a junio de 1994 del Programa Integral Contra la Contaminación Atmosférica, México, Comisión Metropolitana para la Prevención y Control de la Contaminación Ambiental en el Valle de México, 1994.

COMisión METROPOLITANA PARA LA PREVENCIÓn Y CONTROL DE LA Contaminación Ambiental en el Valle de México, Air Pollution in Mexico City. Present Situation, México, Comisión Metropolitana para la Prevención y Control de la Contaminación Ambiental en el Valle de México, 1994.

Comisión MEtropolitana PARA LA PREVEnCión y CONTROL DE LA Contaminación AMBIEnTAl EN El VAlle de MÉXICO, La contaminación atmosférica en el Valle de México, México, Comisión Metropolitana para la Prevención y Control de la Contaminación Ambiental en el Valle de México, 1994.

Comisión MEtropolitana para la PrEVEnción y CONTROL DE LA Contaminación Ambiental en el Valle de México, Medidas de invierno 1994-1995: Informe final, México, Comisión Metropolitana para la Prevención y Control de la Contaminación Ambiental en el Valle de México, abril de 1995.

COMISIÓN METROPOLITANA PARA LA PREVENCIÓN Y CONTROL DE LA Contaminación Ambiental en el VAlle DE MÉXICO, Informe Mensual de la Calidad del Aire, México, Comisión Metropolitana para la Prevención y Control de la Contaminación Ambiental en el Valle de México, mayo de 1995.

Comisión Nacional del Agua, Programa Nacional Hidráulico 20012006, México, Secretaría de Medio Ambiente y Recursos NaturalesComisión Nacional del Agua, 2001.

Comisión Nacional del AguA, Ley de Aguas Nacionales y su Reglamento, México, Comisión Nacional del Agua, 2004.

Comisión Nacional del AguA, Estadísticas del agua en México, México, Comisión Nacional del Agua, 2005.

Comisión Nacional del AguA, Estadísticas del agua en México. Edición 2014, México, Secretaría de Medio Ambiente y Recursos Naturales, Comisión Nacional del Agua, diciembre de 2014. 
Esta obra forma parte del acervo de la Biblioteca Jurídica Virtual del Instituto de Investigaciones Jurídicas de la UNAM

Commission of the European Communities, Green Paper on the Urban Environment, Luxemburgo, Commission of the European Communities, 1990.

CORTÉS, Fernando, “Consideraciones sobre la marginación, la marginalidad, marginalidad económica y exclusión social", Papeles de Población, Universidad Autónoma del Estado de México, núm. 047, eneromarzo de 2006.

DEPARTAMENTO DEL DistRITO FEDERAL, Programa Integral de Transporte y Vialidad 1995-2000 (PITVI 1995-2000), México, Departamento del Distrito Federal, 1995.

Departamento Del Distrito Federal et al., Programa para Mejorar la Calidad del Aire en el Valle de México 1995-2000, México, Departamento del Distrito Federal-Gobierno del Estado de México-Secretaría de Medio Ambiente, Recursos Naturales y Pesca-Secretaría de Salud, marzo de 1996.

Department of HeAlth, Ozone, Londres, First Report, Advisory Group on the Medical Aspects of Air Pollution Episodes, Department of Health, Her Majesty's Stationery Office, 1991.

DePartment of HeAlth, Sulphur Dioxide, Londres, Second Report, Advisory Group on the Medical Aspects of Air Pollution Episodes, Department of Health, Her Majesty’s Stationery Office, 1992.

DEPARTMENT OF HEALTH, Oxides of Nitrogen, Londres, Third Report, Advisory Group on the Medical Aspects of Air Pollution Episodes, Department of Health, Her Majesty's Stationery Office, 1993.

DePARTMENT OF HeAlth, Health Effects of Exposures to Mixtures of Air Pollutants, Londres, Fourth Report, Advisory Group on the Medical Aspects of Air Polllution Episodes, Department of Health, Her Majesty's Stationery Office, 1995.

Department of Health, Handbook on Air Pollution and Health, Londres, Committee on the Medical Effects of Air Pollutants, Department of Health, The Stationery Office, 1997.

DePARTMENT OF THE ENVIRONMENT, Sustainable Development: The UK Strategy, Londres, Department of the Environment, Her Majesty's Stationery Office, 1994.

Department of the EnVIROnMent, Air Quality: Meeting the Challenge, Londres, Departament of the Environment, enero de 1995. 
Esta obra forma parte del acervo de la Biblioteca Jurídica Virtual del Instituto de Investigaciones Jurídicas de la UNAM

Department of HeAlth, The United Kingdom National Air Quality Strategy-Consultation Draft, Londres, Department of the Environment, agosto de 1996.

DePARTMENT OF HEALTH, The United Kingdom National Air Quality Strategy, Londres, Cm 3587, Department of the Environment, The Stationery Office, marzo de 1997.

DEPARTMENT OF THE ENVIRONMENT, TRANSPORT AND THE REGIONS, Keeping Buses Moving, Londres, Local Transport Note 1/97, Department of the Environment, Transport and the Regions, The Stationery Office, 1997.

DEPARTMENT OF TRANSPORT, A Transport Strategy for London, Londres, Department of Transport and Government Office for London, Her Majesty's Stationery Office, 1996.

DoBSON, Frank, Creating a Bad Atmosphere: the Tory threat to Britain's air quality, Londres, Informe de Frank Dobson MP (miembro del parlamento), Shadow Environment Secretary, Labour, s. f.

EzCURRA, Ezequiel, "Reunión sobre el Manejo de la Cuenca Atmosférica de la Ciudad de México: el marco histórico-urbano", ponencia presentada en el Seminario Internacional sobre Sustentabilidad Urbana y el Manejo de la Cuenca Atmosférica de la Zona Metropolitana del Distrito Federal y del Estado de México, México, 22-25 de mayo de 1995.

FRIENDS OF THE EARTH, Transport-Related Atmospheric Pollution in London: Summary of Evidence from Friends of the Earth, Londres, Friends of the Earth, 1994.

Gobierno Del Distrito Federal, "Programa Integral de Transporte y Vialidad 2001-2006 (PITVI 2001-2006)", Gaceta Oficial del Distrito Federal, México, Gobierno del Distrito Federal, 2002.

GOBIERNO DEL DISTRITO FEDERAL, "Decreto por el que se reforma y adiciona el Programa para Contingencias Ambientales Atmosféricas en el Distrito Federal", Gaceta Oficial del Distrito Federal, México, Gobierno del Distrito Federal, 2006.

GreIG, A. D., "Urban Sustainability: An Annotated Bibliography", Research Papers, Londres, Department of Geography, London School of Economics, 1993.

Hernández Ávila, M., Producción bibliográfica en el área de salud ambiental, Cuernavaca, México, Centro de Investigaciones de Salud Pública, s. f. 
Esta obra forma parte del acervo de la Biblioteca Jurídica Virtual del Instituto de Investigaciones Jurídicas de la UNAM

Instituto DE InVESTIGACIONES JuRídiCAS, “Alfonso Nava Negrete”, Voz de Nuestros Juristas, entrevista de la maestra Eugenia M. de Lizalde, México, UNAM, Instituto de Investigaciones Jurídicas, enero de 2007. Instituto NACIONAL DE ESTADÍSTICA, GEOGRAFÍA E INFORMÁTICA, Ciudad de México (Área Metropolitana). Resultados Definitivos. Tabulados Básicos, México, XI Censo General de Población y Vivienda 1990, Instituto Nacional de Estadística, Geografía e Informática, 1992.

InSTITUTO NACIONAL DE ESTADÍSTICA, GEOGRAFÍA E INFORMÁTICA, Estadísticas del Medio Ambiente, México, Instituto Nacional de Estadística, Geografía e Informática, 1994.

InstituTO NACIONAL DE ESTADÍSTICA, GEOGRAFÍA E INFORMÁTICA, Estadísticas históricas de México, 3a. ed., México, Instituto Nacional de Estadística, Geografía e Informática, vols. I y II, 1994.

InstituTO NACIONAL DE EstAdístiCA, GEOGRAFÍA E INFORMÁTICA, Estadísticas del Medio Ambiente. México 1997, México, Instituto Nacional de Estadística, Geografía e Informática, 1998.

Instituto NACIONAL DE ESTAdísticA, GEOGRAFÍA E INFORMÁTICA, México Hoy. Edición 2007, México, Instituto Nacional de Estadística, Geografía e Informática, 2008.

InTERGOVERNMENTAL PANEL ON ClimATE CHANGE, "Summary for Policymakers", en Solomon, S. et al. (eds.), Climate Change 2007: The Physical Science Basis. Contribution of Working Group I to the Fourth Assessment Report of the Intergovernmental Panel on Climate Change, Cambridge-Nueva York, Cambridge University Press, 2007.

Intergovernmental Panel On Climate Change, "Summary for Policymakers", en PARry, M. L. et al. (eds.), Climate Change 2007: Impacts, Adaptation and Vulnerability. Contribution of Working Group II to the Fourth Assessment Report of the Intergovernmental Panel on Climate Change, Cambridge-Nueva York, Cambridge University Press, 2007.

IPCC, Cambio climático 2014: Informe de síntesis. Contribución de los Grupos de trabajo I, II y III al Quinto Informe de Evaluación del Grupo Intergubernamental de Expertos sobre el Cambio Climático, Ginebra, [Equipo principal de redacción, R. K. Pachauri y L. A. Meyer (eds.)], IPCC, 2015.

JARDINES MORENO, José Luis, “La infraestructura hidráulica municipal y la participación en su creación y operación de los gobiernos federal 
Esta obra forma parte del acervo de la Biblioteca Jurídica Virtual del Instituto de Investigaciones Jurídicas de la UNAM

y estatal", en Olivares, Roberto y SANDOVAL, Ricardo (coords.), El agua potable en México. Historia reciente, actores, procesos y propuestas, México, Asociación Nacional de Empresas de Agua y Saneamiento de México A. C., 2008.

Jefatura DE GobieRno, "Decreto por el que se expide el Programa para Contingencias Ambientales Atmosféricas en el Distrito Federal", México, Gaceta Oficial del Distrito Federal, 30 de junio de 2008.

JeFATURA DE GOBIERnO, "Decreto por el que se expide el Programa para Contingencias Ambientales Atmosféricas en el Distrito Federal", México, Gaceta Oficial del Distrito Federal, 9 de agosto de 2012.

Keating, Michael, Agenda for Change, Ginebra, Centre for Our Common Future, 1993.

KEMP, David D., The Environment Dictionary, Londres, Routledge, 1998. KISS, Alexandre Ch., Survey of Current Developments in International Environmental Law, Morges, IUCN Environmental Policy and Law Paper, núm. 10, 1976.

Levinson, A. y ShetTy, S., "Efficient Environmental Regulation: Case Studies of Urban Air Pollution", Working Papers, Washington, D. C., Banco Mundial, agosto de 1992.

LONDON ReSEARCh CENTRE, London Energy Study, Londres, documento elaborado en el marco del programa Commission of the European Communities' Urban and Regional Energy Management Programme, Londres, London Research Centre, septiembre de 1993.

MARGULIS, Sergio, "Back-of-the-Envelope Estimates of Environmental Damage Cost in Mexico", Working Papers, Washington, D. C., Banco Mundial, enero de 1992.

Medina S. y Quenel, P. (comps.), Technical Report: Air Pollution and Health in large Metropolises, París, Observatoire regional de sante d'Ile-de-France, junio de 1993.

MÉNDEZ SILVA, Ricardo, "Tratados internacionales", Diccionario jurídico mexicano, 8a. ed., México, Porrúa-UNAM, Instituto de Investigaciones Jurídicas, 1995.

Murley, Loveday (comp.), Pollution Handbook 1994, Brighton, National Society for Clean Air and Environmental Protection, 1994.

National GeOgRaPhic, "Tragedia en el Golfo de México. Lo que no sabemos del vertido", Revista National Geographic, España, octubre de 2010 . 
Esta obra forma parte del acervo de la Biblioteca Jurídica Virtual del Instituto de Investigaciones Jurídicas de la UNAM

National Society For Clean AIr, Pollution Handbook, 1991, Brighton, National Society for Clean Air and Environmental Protection, 1991.

NAVA EsCuDERO, César, El derecho de las concesiones y permisos en los servicios y obras públicas en México. Estudio constitucional y administrativo, México, tesis presentada para optar por el grado de licenciatura en derecho, UNAM, Facultad de Derecho, 1992.

Nava Escudero, César, Privatisation in the UK and Latin America: a Political Decision. British Telecom (BT): a Case-Study, Exeter, tesis presentada para optar por el grado de maestro en administración pública por la Universidad de Exeter, 1993.

NAVA Escudero, César, "From Homo Sapiens to Homo Automobilis: Revisiting Air Quality Management in Mexico City", ponencia presentada en el seminario Urban Governance in Global Perspective International Workshop, University of Southern California, Los Angeles, septiembre 17-18 de 2004.

NAVA Escudero, César, "La regulación jurídica de la desalación de agua en México: lo bueno, lo malo y lo más malo del periodo 2001-2006", Documento de Trabajo, México, UNAM, Instituto de Investigaciones Jurídicas, núm. 82, julio de 2006.

NAVA Escudero, César, "Derecho al medio ambiente", en FERRER MACGREGOR, Eduardo et al. (coords.), Diccionario de derecho procesal constitucional y convencional, Poder Judicial de la Federación, Consejo de la Judicatura Federal-UNAM, Instituto de Investigaciones Jurídicas, t. I, 2014.

NAVA NeGrete, Alfonso, "Aguas", Diccionario jurídico mexicano, 8a. ed., México, Porrúa-UNAM, Instituto de Investigaciones Jurídicas, t. A-CH, 1995.

OrganisATION FOR ECONOMIC COOPERATION AND DEVELOPMENT, Environmental Policies for Cities in the 1990s, París, Organisation for Economic Cooperation and Development, 1990.

Organisation for ECONOMIC COOPERATION AND DEVElopMEnT, Control of Hazardous Air Pollutants in OECD Countries, París, Organisation for Economic Cooperation and Development, 1995.

ORGANISATION FOR ECONOMIC COOPERATION AND DEVELOPMENT, Innovative Policies for Sustainable Urban Development: The Ecological City, París, Organisation for Economic Cooperation and Development, 1996. 
Esta obra forma parte del acervo de la Biblioteca Jurídica Virtual del Instituto de Investigaciones Jurídicas de la UNAM

ORgANIZACIÓN DE LAS NACIONES UNIDAS PARA LA AGRICULTURA Y LA AlimentACIÓN, Evaluación de los Recursos Forestales Mundiales 2005. Hacia la ordenación forestal sustentable, Roma, Estudio FAO: Montes, 147, FAO, 2006.

Organización Mundial DE LA SAlud, Guías de calidad del aire de la OMS relativas al material particulado, el ozono, el dióxido de nitrógeno y el dióxido de azufre. Actualización mundial 2005, Ginebra, Organización Mundial de la Salud, 2006.

Ostro, B. et al., "Air Pollution and Mortality: Results from Santiago, Chile", Working Papers, Washington D. C., Banco Mundial, mayo de 1995.

PARK, Chris, Dictionary of Environment and Conservation, Oxford, Oxford University Press, 2008.

Poder Ejecutivo Federal, Programa Especial de Cambio Climático 2008-2012, México, versión consulta pública del 24 de marzo de 2009.

Programa de Desarrollo del Sector Turismo 1995-2000 (México). Programa de las Naciones Unidas para el Medio Ambiente, El desarrollo del derecho ambiental latinoamericano y su aplicación. Informe sobre los cambios jurídicos después de la Conferencia de las Naciones Unidas sobre el Medio Ambiente y el Desarrollo (Río 1992), México, Oficina Regional para América Latina y el Caribe, 2001.

Programa de las NaCiOnes UnidAs PARA EL MEdio AmBIENTE, Perspectivas del Medio Ambiente Mundial 2002 (GEO-3), trad. de Raquel Arévalo de Azrak, Madrid, Ediciones Mundi-Prensa, 2002.

Programa de las Naciones Unidas Para el Medio Ambiente, Perspectivas del Medio Ambiente Mundial Geo4, Madrid, Grupo MundiPrensa, 2007.

Programa NACIONAL DE MODERnizACIÓN DEL TURISMO 1991-1994 (México).

QUALITY OF URBAN AIR REVIEW GROUP, Urban Quality in the United Kingdom, Londres, First Report of the Quality of Urban Air Review Group, Quality of Urban Air Review Group, enero de 1993.

REAL ACADEMIA DE LA LENGUA EsPañola, Diccionario de la lengua española, 21a. ed., Madrid, 1992.

REAl ACADEMia DE LA Lengua EsPañola, Diccionario de la lengua española, 22a. ed., Madrid, 2001. 
Esta obra forma parte del acervo de la Biblioteca Jurídica Virtual del Instituto de Investigaciones Jurídicas de la UNAM

Red Ecologista Autónoma de la Cuenca de MÉxico, Hacia otra visión del agua, México, Red Ecologista Autónoma de la Cuenca de México, Tercera Declaración, 2005.

RODRÍGUEZ BRICEÑO, Emiliano, "Agua y saneamiento en México: avances, errores y alternativas", en OLIVARES, Roberto y SANDOVAL, Ricardo (coords.), El agua potable en México. Historia reciente, actores, procesos y propuestas, México, Asociación Nacional de Empresas de Agua y Saneamiento de México A. C., 2008.

ROMIEU, Isabel et al, "Air Pollution and School Absenteeism Among Children in Mexico", en MedinA, S. y Quenel, P. (comps.), Technical Report: Air Pollution and Health in Large Metropolises, París, Observatoire regional de sante d'Ile-de-France, junio de 1993.

ROMIEU, Isabel et al., "Effect of Urban Air Pollutants on Emergency Visits for Childhood Ashtma in Mexico City", en Hernández ÁvilA, M., Producción bibliográfica en el área de salud ambiental, Cuernavaca, México, Centro de Investigaciones de Salud Pública, s. f.

Royal COMmission on EnVIRONMENTAL Pollution, First Report, Londres, Cmnd 4585, Her Majesty’s Stationery Office, 1971.

Royal Commission on Environmental Pollution, Fourth Report, Londres, Cmnd 5780, Her Majesty’s Stationery Office, 1974.

Royal COMmission on Environmental Pollution, Fifth Report, Londres, Cmnd 6371, Her Majesty's Stationery Office, 1976.

Royal COMmission on EnviROnMEntal Pollution, Tenth Report, Londres, Cmnd 9149, Her Majesty’s Stationery Office, 1984.

Royal COMmission on Environmental Pollution, Eighteenth Report, Londres, Cm 2674, Her Majesty's Stationery Office, 1994.

SAlGADO Y SAlGADO, José Eusebio, "Derecho marítimo", Nuevo diccionario jurídico mexicano, México, Porrúa-UNAM, Instituto de Investigaciones Jurídicas, t. D-H, 2000.

SECRETARÍA DE DeSARrollo Social, Informe de la Situación General en Materia de Equilibrio Ecológico y Protección al Ambiente 1991-1992, México, Secretaría de Desarrollo Social-Instituto Nacional de Ecología, 1993.

SECRETARÍA de DeSARRollo Social, Informe de la Situación General en Materia de Equilibrio Ecológico y Protección al Ambiente 1993-1994, México, Secretaría de Desarrollo Social-Instituto Nacional de Ecología, 1994. 
Esta obra forma parte del acervo de la Biblioteca Jurídica Virtual del Instituto de Investigaciones Jurídicas de la UNAM

SECRETARÍA DE GOBERNACIÓn, Guía de tratados promulgados y otros instrumentos internacionales vigentes suscritos por México, México, Secretaría de Gobernación, 2003.

SECRETARÍA DE LA FUnCIÓN PÚBLICA, Ley General de Bienes Nacionales, México, julio de 2004.

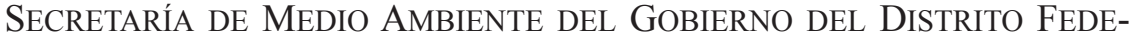
RAL, Inventario de emisiones de contaminantes criterio de la ZMVM 2008, México, Secretaría de Medio Ambiente, 2010.

Secretaría de Medio Ambiente y Recursos Naturales, Programa de Medio Ambiente y Recursos Naturales 2001-2006, México, Secretaría de Medio Ambiente y Recursos Naturales, 2001.

SeCretaría de Medio Ambiente y Recursos Naturales, Política Ambiental Nacional para el Desarrollo Sustentable de Océanos y Costas de México, México, Secretaría de Medio Ambiente y Recursos Naturales, junio de 2006.

Secretaría de Medio Ambiente y Recursos Naturales, Programa Sectorial de Medio Ambiente y Recursos Naturales, México, Secretaría de Medio Ambiente y Recursos Naturales, enero de 2008.

SeCretaría de Medio Ambiente, Recursos NATurales y PescA, Gestión de la calidad del aire en México, México, Secretaría de Medio Ambiente, Recursos Naturales y Pesca, 2000.

Secretaría de Medio Ambiente, Recursos NATURAles Y PescA et al., Programa Integral Contra la Contaminación Atmosférica de la Zona Metropolitana de la Ciudad de México (PROAIRE 1995-2000), México, Secretaría de Medio Ambiente, Recursos Naturales y PescaSecretaría de Salud-Gobierno del Distrito Federal-Gobierno del Estado de México, 1996.

SECRETARÍA DE RELACIONES EXTERIORES, Guía para la conclusión de tratados y acuerdos interinstitucionales en el ámbito internacional según la Ley sobre la Celebración de Tratados, México, Secretaría de Relaciones Exteriores, 1999.

SECRETARÍA DE SALUD, Acciones desarrolladas para evaluar el efecto en la salud por la contaminación atmosférica en el Valle de México, México, Sistema Nacional de Salud, 1993.

SeCRETARÍA DE SALUD, "Modificación a la Norma Oficial Mexicana NOM-025-SSA1-1993, Salud ambiental. Criterios para evaluar el valor límite permisible para la concentración del material particulado. Valor 
Esta obra forma parte del acervo de la Biblioteca Jurídica Virtual del Instituto de Investigaciones Jurídicas de la UNAM

límite permisible para la concentración de partículas suspendidas, totales PST, partículas menores a 10 micrómetros $\mathrm{PM}_{10}$ y partículas menores de 2.5 micrómetros $\mathrm{PM}_{2.5}$ de la calidad del aire ambiente. Criterios para evaluar la calidad del aire", México, Diario Oficial de la Federación, 26 de septiembre de 2005.

SeCRETARÍA DE TURISMO, Visitantes internacionales hacia México, el turismo de internación 2000-2005, México, Secretaría de Turismo, noviembre de 2006.

SeCretaría del Medio Ambiente, "Norma Ambiental para el Distrito Federal NADF-009-AIRE-2006, que establece los requisitos para elaborar el Índice Metropolitano de la Calidad del Aire", Gaceta Oficial del Distrito Federal, 29 de noviembre de 2006.

SECRETARIAdo TÉCNICO InTERgubernAmental, Programa Integral Contra la Contaminación Atmosférica de la Zona Metropolitana de la Ciudad de México, México, Secretariado Técnico Intergubernamental, 1990.

Serageldin, I. y Cohen, M. A. (comps.), The Human Face of the Urban Environment: a Report to the Development Community, Washington, D. C., Second Annual World Bank Conference on Environmentally Sustainable Development, Environmentally Sustainable Development Proceedings Series núm. 5, septiembre 10-21 de 1994, 1995.

South East Institute of Public Health, Air Quality in London: the First Report of the London Air Quality Network, Londres, South East Institute of Public Health, 1994.

Suprema CORTE DE JuSTiCIA DE LA NACión, "Versión estenográfica de las palabras pronunciadas por el Dr. Alfonso Nava Negrete, durante la inauguración del Auditorio 'Gabino Fraga Magaña' en la Universidad Nacional Autónoma de México. 29 de febrero de 2008”, Semblanzas. Vida y Obra de los Ministros de la Suprema Corte de Justicia de la Nación. Ministro Gabino Fraga Magaña, México, SCJN, 2008.

SZÉKELY, Alberto, "Aguas marinas interiores", Diccionario jurídico mexicano, 8a. ed., México, Porrúa-UNAM, Instituto de Investigaciones Jurídicas, t. A-CH, 1995.

TAMAYO y SAlmorÁn, Rolando, "Aplicación del derecho", Diccionario Jurídico Mexicano, 8a. ed., México, Porrúa-UNAM, Instituto de Investigaciones Jurídicas, t. A-CH, 1995. 
Esta obra forma parte del acervo de la Biblioteca Jurídica Virtual del Instituto de Investigaciones Jurídicas de la UNAM

TAMAYO Y SALMORÁN, Rolando, "Estado", Enciclopedia jurídica mexicana, 2a. ed., México, Porrúa-UNAM, Instituto de Investigaciones Jurídicas, t. III, D-E, 2004.

ThE ENVIRONMENT ENCYClOPEDIA, The Environment Encyclopedia and Directory: a World Survey, Londres, Europa Publications, 1994.

United Nations Centre for Human SetTlements, An Urbanising World: Global Report on Human Settlements, Oxford, Oxford University, United Nations Centre for Human Settlements-HABITAT, 1996.

United NATIONS CONFERENCE FOR Human SeTtlements, "Habitat II Spells out Road Map to the Future", Habitat Debate, Nairobi, vol. 2, núm. 3/4, United Nations Conference for Human Settlements-HABITAT, septiembre-diciembre de 1996.

United Nations Environment Programme, Environmental Data Report 1993-1994, Oxford, United Nations Environment Programme, World Resources Institute, Global Environmental Monitoring System, Monitoring and Assessment Research Centre, Blackwell, 1993.

United Nations Framework Convention On Climate Change, Decisión 2/CP.15 Acuerdo de Copenhague, Informe de la Conferencia de las Partes sobre su 15o. periodo de sesiones, celebrado en Copenhague del 7 al 19 de diciembre de 2009, marzo de 2010.

UnIVERSIDAD NACIONAL AUTÓNOMA DE MÉXICO, "Investigan la desalación de agua de mar con energías renovables", Gaceta UNAM, México, núm. 3,900, Ciudad Universitaria, 1o. de junio de 2006.

VAN LIEROP, Robert F. y SZÉKELY, Alberto, "Compliance with Environmental Treaties: The Empirical Evidence A Commentary on the Softening of International Environmental Law", Proceedings of the Annual Meeting (American Society of International Law), American Society of International Law, vol. 91, 9-12 de abril de 1997.

WEIR, F., A Critique of UK Air Quality Strategy, Inglaterra, Friends of the Earth Paper to the IEHO Congress, The Institution of Environmental Health Officers, septiembre 13-16 de 1993.

World BANK, Making Development Sustainable, Washington D. C., Environment Department of the World Bank, 1994.

World COMmission on Environment And Development, Our Common Future, Oxford, World Commission on Environment and Development-Oxford University Press, 1987. 
Esta obra forma parte del acervo de la Biblioteca Jurídica Virtual del Instituto de Investigaciones Jurídicas de la UNAM

World HeAlth ORGANiSATION y UNITED NATIONS ENVIRONMENT PROGRAMME, Urban Air Pollution in Megacities of the World, Oxford, Blackwell, 1992.

World Resources Institute, World Resources 1992-93, Nueva YorkOxford, United Nations Environment Programme-United Nations Development Programme-Oxford University, 1992. 
Esta obra forma parte del acervo de la Biblioteca Jurídica Virtual del Instituto de Investigaciones Jurídicas de la UNAM

\section{APÉNDICE}

\section{TRATADOS Y OTROS INSTRUMENTOS INTERNACIONALES}

- Acta Constitutiva del Grupo de Trabajo para la Cooperación Bilateral en Materia Forestal, Vida Silvestre y Áreas Naturales Protegidas entre México y Guatemala.

- Acuerdo de Cooperación Ambiental de América del Norte entre el Gobierno de los Estados Unidos Mexicanos, el Gobierno de Canadá y el Gobierno de los Estados Unidos de América.

- Acuerdo de Copenhague.

- Acuerdo Internacional sobre la Conservación de Osos Polares y su Hábitat.

- Acuerdo sobre el Programa Internacional para la Conservación de los Delfines.

- Agenda 21.

- Anexo V del Protocolo de 1978 relativo al Convenio Internacional para Prevenir la Contaminación por los Buques, 1973, y enmiendas de 1989, 1990 y 1991 a dicho Anexo, así como enmiendas de 1994.

- Carta Mundial del Turismo Sostenible.

- Código Ético Mundial para el Turismo.

- Constitución Europea.

- Convención de Basilea sobre el Control de los Movimientos Transfronterizos de los Desechos Peligrosos y su Eliminación.

- Convención de las Naciones Unidas de Lucha contra la Desertificación en los Países Afectados por Sequía Grave o Desertificación, en particular en África.

- Convención de las Naciones Unidas sobre el Derecho del Mar.

- Convención de Viena sobre el Derecho de los Tratados.

- Convención Interamericana para la Protección y Conservación de las Tortugas Marinas. 
Esta obra forma parte del acervo de la Biblioteca Jurídica Virtual del Instituto de Investigaciones Jurídicas de la UNAM

- Convención Internacional para la Reglamentación de la Caza de la Ballena con Reglamento Anexo.

- Convención Marco de las Naciones Unidas sobre el Cambio Climático.

- Convención para la Protección de la Flora, de la Fauna y de las Bellezas Escénicas Naturales de los Países de América.

- Convención sobre el Comercio Internacional de Especies Amenazadas de Fauna y Flora Silvestres.

- Convención sobre los Humedales de Importancia Internacional especialmente como Hábitat de Aves Acuáticas.

- Convenio de Estocolmo sobre Contaminantes Orgánicos Persistentes.

- Convenio de Ginebra sobre la Contaminación Atmosférica Transfronteriza a Larga Distancia (y sus protocolos adicionales).

- Convenio de Rótterdam para la Aplicación del Procedimiento de Consentimiento Fundamentado Previo a ciertos Plaguicidas y Productos Químicos Peligrosos objeto de Comercio Internacional.

- Convenio de Viena para la Protección de la Capa de Ozono.

- Convenio Interamericano de Lucha contra la Langosta.

- Convenio Internacional para la Conservación del Atún del Atlántico.

- Convenio Internacional para Prevenir la Contaminación por los Buques.

- Convenio Internacional relativo a la Intervención en Alta Mar en casos de Accidentes que causen una Contaminación por Hidrocarburos.

- Convenio Internacional sobre Cooperación, Preparación y Lucha contra la Contaminación por Hidrocarburos.

- Convenio Internacional sobre el Control de los Sistemas Antiincrustantes Perjudiciales de los Buques.

- Convenio para la Protección y el Desarrollo del Medio Marino de la Región del Gran Caribe y Protocolo relativo a la Cooperación para Combatir los derrames de Hidrocarburos en la Región del Gran Caribe.

- Convenio sobre la Diversidad Biológica. 
Esta obra forma parte del acervo de la Biblioteca Jurídica Virtual del Instituto de Investigaciones Jurídicas de la UNAM

- Convenio sobre la Prevención de la Contaminación del Mar por Vertimiento de Desechos y otras Materias.

- Convenio 169 sobre Pueblos Indígenas y Tribales en Países Independientes.

- Declaración Autorizada, sin Fuerza Jurídica Obligatoria, de Principios para un Consenso Mundial respecto de la Ordenación, la Conservación y el Desarrollo Sostenible de los Bosques de Todo Tipo.

- Declaración de Bergen sobre Desarrollo Sustentable.

- Declaración de Estocolmo sobre el Medio Humano.

- Declaración de Johannesburgo sobre el Desarrollo Sostenible.

- Declaración de La Haya sobre Turismo.

- Declaración de las Naciones Unidas sobre los Derechos de los Pueblos Indígenas.

- Declaración de Río sobre el Medio Ambiente y el Desarrollo.

- Enmienda a los Artículos 6 y 7 de la Convención relativa a los Humedales de Importancia Internacional Especialmente como Hábitat de Aves Acuáticas.

- Enmienda de Beijing que modifica el Protocolo de Montreal relativo a las Sustancias que Agotan la Capa de Ozono, adoptada el 3 de diciembre de 1999 por la XI Conferencia de las Partes.

- Enmienda de 1989 al Anexo del Protocolo de 1978 relativo al Convenio Internacional para Prevenir la Contaminación por los Buques, 1973 (Apéndices II y III del Anexo II del Marpol 73/78), mediante la Resolución MEPC 34(27) del Comité de Protección del Medio Marino de la Organización Marítima Internacional.

- Enmiendas al Protocolo de Montreal relativo a las Sustancias que agotan la Capa de Ozono del 16 de septiembre de 1987.

- Enmiendas de 1984 al Anexo del Protocolo de 1978 relativo al Convenio Internacional para Prevenir la Contaminación por los Buques, 1973, mediante la Resolución MEPC 14(20) del Comité de Protección del Medio Marino de la Organización Marítima Internacional.

- Enmiendas de 1985 al Anexo del Protocolo de 1978 relativo al Convenio Internacional para Prevenir la Contaminación por los Buques, 1973 (referentes al Anexo II del Convenio Internacional para Prevenir la Contaminación por los Buques, 1973, en su forma modificada 
Esta obra forma parte del acervo de la Biblioteca Jurídica Virtual del Instituto de Investigaciones Jurídicas de la UNAM

por el correspondiente Protocolo de 1978) mediante la Resolución MEPC 16(22) del Comité de Protección del Medio Marino de la Organización Marítima Internacional.

- Enmiendas de 1985 al Protocolo de 1978 relativo al Convenio Internacional para Prevenir la Contaminación por los Buques, 1973 (referentes al Protocolo I del Convenio Internacional para Prevenir la Contaminación por los Buques, 1973, en su forma modificada por el correspondiente Protocolo de 1978), mediante la Resolución MEPC 21(22) del Comité de Protección del Medio Marino de la Organización Marítima Internacional.

- Enmiendas de 1987 al Anexo del Protocolo de 1978 relativo al Convenio Internacional para Prevenir la Contaminación por los Buques, 1973 (asignación del carácter de zona especial al Golfo de Aden) mediante la Resolución MEPC 29(25) del Comité de Protección del Medio Marino de la Organización Marítima Internacional.

- Enmiendas de 1989 al Código para la Construcción y el Equipo de Buques que Transporten Productos Químicos Peligrosos a Granel (Código CIQ) mediante la Resolución MEPC 32(27) del Comité de Protección del Medio Marino de la Organización Marítima Internacional.

- Enmiendas de 1989 al Código para la Construcción y el Equipo de Buques que Transporten Productos Químicos Peligrosos a Granel (Código CGrQ), aprobadas en Londres, Gran Bretaña, el 17 de marzo de 1989, mediante Resolución MEPC 33 (27) del Comité de Protección del Medio Marino de la Organización Marítima Internacional.

- Enmiendas de 1990 al Anexo del Protocolo de 1978 relativo al Convenio Internacional para Prevenir la Contaminación por los Buques, 1973, mediante la Resolución MEPC 42(30) del Comité de Protección del Medio Marino de la Organización Marítima Internacional.

- Enmiendas de 1991 al Anexo del Protocolo de 1978 relativo al Convenio Internacional para Prevenir la Contaminación por los Buques, 1973 (nueva regla 26 y otras enmiendas al Anexo I del MARPOL73/78), mediante resolución MEPC 47(31) del Comité de Protección del Medio Marino de la Organización Marítima Internacional. 
Esta obra forma parte del acervo de la Biblioteca Jurídica Virtual del Instituto de Investigaciones Jurídicas de la UNAM

- Enmiendas de 1992 al Anexo del Protocolo de 1978 relativo al Convenio Internacional para Prevenir la Contaminación por los Buques, 1973 (criterios relativos a las descargas del Anexo I del MARPOL 73/78), mediante la resolución MEPC 51(32) del Comité de Protección del Medio Marino de la Organización Marítima Internacional.

- Enmiendas de 1992 al Anexo del Protocolo de 1978 relativo al Convenio Internacional para Prevenir la Contaminación por los Buques, 1973 (nuevas reglas 13F y 13G y enmiendas conexas al Anexo I del MARPOL 73/78), mediante la resolución MEPC 52(32) del Comité de Protección del Medio Marino de la Organización Marítima Internacional.

- Enmiendas del Protocolo de Montreal relativo a las Sustancias que Agotan la Capa de Ozono, 1987.

- Estrategia Mundial de la Conservación.

- Modificaciones al Protocolo de Montreal relativo a las Sustancias que Agotan la Capa de Ozono del 16 de septiembre de 1987.

- Principios de Johannesburgo sobre el papel del derecho y el desarrollo sostenible.

- Protocolo a la Convención Internacional para la Reglamentación de la Caza de la Ballena, del 2 de septiembre de 1946.

- Protocolo correspondiente al Convenio Internacional sobre la Constitución de un Fondo Internacional de Indemnización de Daños Causados por la Contaminación de Hidrocarburos, 1971.

- Protocolo de Cartagena sobre Seguridad de la Biotecnología del Convenio sobre la Diversidad Biológica.

- Protocolo de Kyoto de la Convención Marco de las Naciones Unidas sobre el Cambio Climático.

- Protocolo de Montreal relativo a las Sustancias que Agotan la Capa de Ozono (y sus ajustes y enmiendas).

- Protocolo de Nagoya sobre Acceso y a los Recursos Genéticos y Participación Justa y Equitativa en los Beneficios derivados de su Utilización al Convenio sobre la Diversidad Biológica.

- Protocolo de 1976 al Convenio Internacional sobre Responsabilidad Civil por Daños Causados por la Contaminación de las Aguas del Mar por Hidrocarburos, 1969. 
Esta obra forma parte del acervo de la Biblioteca Jurídica Virtual del Instituto de Investigaciones Jurídicas de la UNAM

- Protocolo de 1978 relativo al Convenio Internacional para Prevenir la Contaminación por los Buques, 1973 (MARPOL 73/78).

- Protocolo de 1992 que enmienda el Convenio Internacional sobre Responsabilidad Civil nacida de Daños Debidos a Contaminación por Hidrocarburos, 1969.

- Protocolo de 1992 que enmienda el Convenio Internacional sobre la Constitución de un Fondo Internacional de Indemnización de Daños Debidos a Contaminación por Hidrocarburos, 1971.

- Protocolo de 1996 relativo al Convenio sobre la Prevención de la Contaminación del Mar por Vertimiento de Desechos y otras Materias, 1972.

- Protocolo que Modifica la Convención sobre los Humedales de Importancia Internacional Especialmente como Hábitat de Especies Acuáticas.

- Protocolo relativo a la Intervención en Alta Mar en casos de Contaminación del Mar por Sustancias distintas de los Hidrocarburos, 1973.

- Tratado Constitutivo de la Comunidad Europea de texto consolidado con las modificaciones insertadas hasta el Tratado de Ámsterdam.

- Tratado entre los Estados Unidos Mexicanos y los Estados Unidos de América relativo a la Utilización de las Aguas de los Ríos Colorado y Tijuana, y del Río Bravo (Grande), desde Fort Quitman, Texas, hasta el Golfo de México.

- Tratado sobre Prohibición de Emplazar Armas Nucleares y otras Armas de Destrucción en Masa en los Fondos Marinos y Oceánicos y su Subsuelo.

\section{LEGISLACIÓN NACIONAL}

- Acuerdo que adiciona la especificación 4.43 a la Norma Oficial Mexicana NOM-022-SEMARNAT-2003.

- Acuerdos de desincorporación (enero a septiembre de 2005).

- Alkali Act (Inglaterra).

- Código Civil Federal. 
Esta obra forma parte del acervo de la Biblioteca Jurídica Virtual del Instituto de Investigaciones Jurídicas de la UNAM

- Código Penal Federal.

- Constitución Política de los Estados Unidos Mexicanos.

- Environment Act (Inglaterra).

- Environmental Protection Act (Inglaterra).

- Greater London Authority Act (Inglaterra).

- Ley Agraria.

- Ley Ambiental de Protección a la Tierra en el Distrito Federal.

- Ley Ambiental para el Distrito Federal.

- Ley de Aguas de Jurisdicción Federal.

- Ley de Aguas de Propiedad Nacional (1929 y 1934).

- Ley de Aguas Nacionales.

- Ley de Bioseguridad de Organismos Genéticamente Modificados.

- Ley de Contribución de Mejoras por Obras Públicas Federales de Infraestructura Hidráulica.

- Ley de Cooperación para Dotación de Agua Potable en Municipios.

- Ley de Desarrollo Rural Sustentable.

- Ley de Distritos de Desarrollo Rural.

- Ley de Energía Geotérmica.

- Ley de Energía para el Campo.

- Ley de Expropiación.

- Ley de Fomento Agropecuario.

- Ley de Hidrocarburos.

- Ley de la Agencia Nacional de Seguridad Industrial y de Protección al Medio Ambiente del Sector Hidrocarburos.

- Ley de la Comisión Nacional para el Desarrollo de los Pueblos Indígenas.

- Ley de la Industria Eléctrica.

- Ley de Navegación.

- Ley de Navegación y Comercio Marítimos.

- Ley de Pesca.

- Ley de Planeación.

- Ley de Promoción y Desarrollo de los Bioenergéticos.

- Ley de Protección a los Animales del Distrito Federal. 
Esta obra forma parte del acervo de la Biblioteca Jurídica Virtual del Instituto de Investigaciones Jurídicas de la UNAM

- Ley de Puertos.

- Ley de Riegos.

- Ley de Transición Energética.

- Ley de Vertimientos en las Zonas Marinas Mexicanas.

- Ley de Vivienda.

- Ley Federal de Aguas.

- Ley Federal de Caza.

- Ley Federal de Derechos.

- Ley Federal de Ingeniería Sanitaria.

- Ley Federal de Procedimiento Administrativo.

- Ley Federal de Protección al Ambiente.

- Ley Federal de Sanidad Animal.

- Ley Federal de Sanidad Vegetal.

- Ley Federal de Turismo.

- Ley Federal de Variedades Vegetales.

- Ley Federal de Vivienda.

- Ley Federal del Mar.

- Ley Federal para Prevenir y Controlar la Contaminación Ambiental.

- Ley Federal sobre Metrología y Normalización.

- Ley Federal sobre Monumentos y Zonas Arqueológicos, Artísticos e Históricos.

- Ley Forestal (1992).

- Ley General de Asentamientos Humanos.

- Ley General de Bienes Nacionales (1942, 1969, 1982 y 2004).

- Ley General de Cambio Climático.

- Ley General de Desarrollo Forestal Sustentable.

- Ley General de Pesca y Acuacultura Sustentables.

- Ley General de Salud.

- Ley General de Turismo.

- Ley General de Vida Silvestre.

- Ley General del Equilibrio Ecológico y la Protección al Ambiente.

- Ley General para la Prevención y Gestión Integral de los Residuos.

- Ley Minera. 
Esta obra forma parte del acervo de la Biblioteca Jurídica Virtual del Instituto de Investigaciones Jurídicas de la UNAM

- Ley Orgánica de la Administración Pública Federal.

- Ley Orgánica de la Armada de México.

- Ley para el Aprovechamiento de las Energías Renovables y el Financiamiento para la Transición Energética.

- Ley para el Aprovechamiento Sustentable de la Energía.

- Ley para Prevenir y Controlar la Contaminación Ambiental.

- Ley que declara Reservas Mineras Nacionales los Yacimientos de Uranio, Torio y las demás Sustancias de las cuales se obtengan Isótopos Hendibles que puedan Producir Energía Nuclear.

- Ley Reglamentaria del Párrafo Octavo del Artículo 27 Constitucional, relativo a la Zona Económica Exclusiva.

- Ley Reglamentaria del Párrafo Quinto del Artículo 27 Constitucional en Materia de Aguas del Subsuelo.

- Ley sobre Irrigación con Aguas Federales.

- Ley sobre la Celebración de Tratados.

- Ley sobre Producción, Certificación y Comercio de Semillas.

- Modificación a la Norma Oficial Mexicana NOM-025-SSA1-1993.

- Norma ambiental para el Distrito Federal NADF-009-AIRE-2006.

- Norma Oficial Mexicana NOM-056-FITO-1995.

- Norma Oficial Mexicana NOM-022-SEMARNAT-2003.

- Norma Oficial Mexicana NOM-020-SSA1-1993.

- Norma Oficial Mexicana NOM-021-SSA1-1993.

- Norma Oficial Mexicana NOM-022-SSA1-1993.

- Norma Oficial Mexicana NOM-022-SSA1-2010.

- Norma Oficial Mexicana NOM-023-SSA1-1993.

- Norma Oficial Mexicana NOM-025-SSA1-1993.

- Norma Oficial Mexicana NOM-026-SSA1-1993.

- Reglamento de la Ley de Aguas Nacionales.

- Reglamento de la Ley General del Equilibrio Ecológico y la Protección al Ambiente en materia de Evaluación de Impacto Ambiental.

- Reglamento de la Ley General del Equilibrio Ecológico y la Protección al Ambiente en materia de Prevención y Control de la Contaminación de la Atmósfera. 
Esta obra forma parte del acervo de la Biblioteca Jurídica Virtual del Instituto de Investigaciones Jurídicas de la UNAM

- Reglamento de la Ley General del Equilibrio Ecológico y la Protección al Ambiente para la Prevención y Control de la Contaminación generada por los Vehículos Automotores que circulan por el Distrito Federal y los Municipios de su Zona Conurbada.

- Reglamento Interior de la Secretaría de Medio Ambiente y Recursos Naturales.

- Reglamento Interior de la Secretaría de Relaciones Exteriores.

- Reglamento Interno de la Comisión Nacional del Agua.

- Reglamento para el Uso y Aprovechamiento del Mar Territorial, Vías Navegables, Playas, Zona Federal Marítimo Terrestre y Terrenos Ganados al Mar.

- Reglamento para los Establecimientos Molestos, Insalubres o Peligrosos.

- Reglamento para la Prevención y Control de la Contaminación Atmosférica Originada por la Emisión de Humos y Polvos. 
Estudios ambientales, tercera edición, editado por el Instituto de Investigaciones Jurídicas de la UNAM, se terminó de imprimir el 11 de junio de 2018 en los talleres de Gráfica Premier, S. A. de C. V., 5 de febrero 2309 , colonia San Jerónimo Chicahualco, Metepec, 52170 Estado de México, tel. 01722199 1345. Se utilizó tipo Times New Roman en 9, 10 y 11 puntos. En esta edición se usó papel cream book de 70 x 95 de 60 gramos para las páginas interiores y cartulina couché de 250 gramos para los forros, consta de 1,000 ejemplares (impresión offset). 